Universidad deValladolid

PROGRAMA DE DOCTORADO EN EUROPA Y EL MUNDO ATLÁNTICO: PODER, CULTURA Y SOCIEDAD

TESIS DOCTORAL:

\title{
Adolfo Suárez y el Centro Democrático y Social (1982-1991)
}

Presentada por Darío Díez Miguel para optar al grado de Doctor por la Universidad de Valladolid

Dirigida por:

José-Vidal Pelaz López 



\section{Agradecimientos}

Ejercer la tutela de una tesis doctoral no es tarea fácil. Durante el prolongado período que dura este proceso, el doctorando acumula dudas, genera -muchas veces de la nadaproblemas de difícil resolución y en ocasiones, aun avanzada la investigación parece víctima de una desorientación casi absoluta. La labor del tutor de tesis doctoral trasciende la mera orientación académica, la recomendación de bibliografía o la facilitación de fuentes, ejerciendo de mentor y amigo, imprescindible punto de apoyo con el que afrontar una tarea que a veces centellea y en otros momentos, obnubila, el horizonte personal y profesional del investigador. En esta ocasión, el doctorando ha tenido la suerte de poder contar con la tutela del Doctor José-Vidal Pelaz López, Profesor Titular de la Universidad de Valladolid. Su absoluta dedicación al presente trabajo de tesis doctoral ha sido una ayuda -más que una ayuda- imprescindible sin la que hubiera sido imposible llevarlo a cabo. Toda la gratitud que pueda expresar será insuficiente para compensar las horas dedicadas a hacer posible la culminación de este doctorado, a pesar de lo cual, sólo puedo decir una vez más, muchas gracias.

Cuatro años de doctorado, de colaboración y de trabajo, han forjado amistades de sólidos lazos y de muchas horas de cafetería. Por ello, no puedo dejar pasar esta ocasión para agradecer su amistad a: Itziar, Iris, Lucía, Alberto, María, Álvaro, Daniel, Ana, Carlos, Rodrigo y Matteo. Y a quienes me acompañan desde mucho antes, por senderos paralelos y cercanos: Luis, Jorge, Cristina y Roberto. $\mathrm{Y}$ por supuesto, mi agradecimiento más especial a Diego, compañero de viaje desde que llegara a Valladolid en 2006.

Del mismo modo, quiero agradecer al Departamento de Historia Moderna, Contemporánea, América, Periodismo y CAP de la Facultad de Filosofía y Letras, el excepcional marco brindado para la realización de mi trabajo, especialmente a Rosa María González, Guillermo Pérez-Sánchez, Rafael Serrano, José Ramón Díez, Juli Rodríguez y Francisco Javier Criado. De otra parte, mi agradecimiento al Instituto de Historia Simancas: Maribel del Val, Elena Maza y Mercedes Sebastián. Y, no puedo olvidarme de Olatz y Juan Carlos. Por último, mi sincero agradecimiento al grupo de trabajo que ha dado sentido a la presente investigación, encabezado por Pablo Pérez 
López, catedrático de Historia Contemporánea de la Universidad de Navarra junto a: Jaime, Carlos, Jorge, Gema, Santiago, Jesús María, Javier, Ana, Mariano y Pedro Pablo. Asimismo, estamos en deuda con el personal del Centro Documental de la Comunicació de la Universitat Autònoma de Barcelona, Antonio Muñoz Sánchez y los miembros del Instituto de Ciencias Sociáis de la Universidad de Lisboa, donde el doctorando ha realizado sendas estancias de investigación en este período. Del mismo modo, queremos agradecer la atención prestada por los integrantes del Archivo del Consejo General de Castilla y León, el Archivo Histórico Provincial de Zamora y la Hemeroteca de la Biblioteca Nacional.

Finalmente, esta tesis doctoral no hubiera sido posible sin la generosa colaboración y atención proporcionada por muchos miembros del Centro Democrático y Social, responsables de archivos y bibliotecas, cuya ayuda ha sido indispensable en nuestro empeño. Aun a riesgo de olvidos y omisiones, que por adelantado queremos disculpar, consideramos ineludible señalar algunas de estas valiosas contribuciones. En primer lugar, estamos particularmente agradecidos a Antonio Garrosa, Diputado Nacional del CDS y quien, pacientemente, nos ha ayudado canalizar el impulso inicial en un fructuoso recorrido por la trayectoria del CDS y de la política española de los años 80', transformando en amistad, lo que en un principio se circunscribía a un mero proyecto de tesis doctoral. Gracias a él, ha sido posible entrar en contacto con otras personalidades políticas con las que nos sentimos igualmente en deuda: Daniel de Fernando, Carlos Sánchez-Reyes, Jaime Hernando, Jorge Poliz y José Luis Sagredo de Miguel. De forma especial, agradecemos la atención brindada por Aurelio Delgado y José Ramón Caso, quien se ha mostrado siempre presto a resolver las múltiples dudas surgidas durante la investigación. De otra parte, ha sido inestimable la ayuda de Manuel de Sárraga Gómez, Xavier Latorre, José Luis Graullera, Tomás Martín Tamayo, Gerardo Muñoz Lorente, Rafael Martínez-Campillo y José Luis González Quirós. Asimismo, siempre recordaremos los entrañables encuentros con José Antonio Pérez González y Laura Morso, quien nos ha hecho posible la puesta en contacto con Abel Cádiz, Fernando Lanzaco y José Luis Garro, a quien estamos especialmente agradecidos por su generosa colaboración al poner en nuestras manos una valiosísima documentación de cara a la realización del presente trabajo. Del mismo modo, agradecemos el interés por los frutos de esta investigación a Adolfo Suárez Illana y Eduard Punset. 


\section{ADOLFO SUÁREZ Y EL CENTRO DEMOCRÁTICO Y SOCIAL (1982-1991)}

\section{Índice}

RESUMEN

SUMMARY .2

INTRODUCCIÓN

PARTE 1. EL REGRESO DE ADOLFO SUÁREZ: CREACIÓN DEL CDS, “TRAVESÍA DEL DESIERTO” Y ELECCIONES GENERALES DE 1986

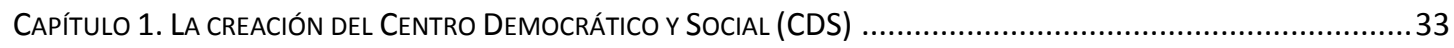

1. 1. El suarismo en la Unión de Centro Democrático (1979-1981) .....................................................34

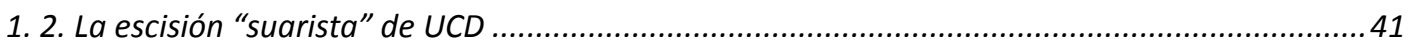

1. 3. La fundación del Centro Democrático y Social .........................................................................50

1. 4. La LOAPA y la OTAN: hacia una diferenciación política de UCD ...........................................55

1. 5. El "Manifiesto del Ritz" y la reacción mediática …....................................................................6

1. 6. Un estudio de caso: de la UCD al CDS en la provincia de Zamora............................................ 70

CAPítUlo 2. "HACER PARTIDO” Y “HACER CAMPAÑA”: EL CDS Y LAS EleCCIONES LEGISLATIVAS DE 1982 .....................81

2. 1. La estructuración del partido: del "goteo" al Congreso Constituyente ......................................81

2. 2. Competencia electoral y espectro ideológico en el verano de 1982 .........................................95

2. 3. El programa electoral del CDS: España Como Debe Ser............................................................ 106

2. 4. La campaña de las elecciones generales del 28 octubre de 1982 ...........................................109

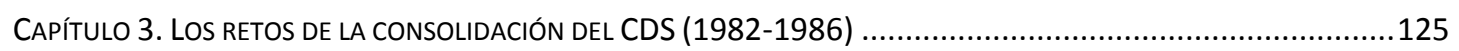

3. 1. El análisis y las consecuencias de los resultados electorales (28-O) .....................................125

3. 2. Formalización y dinámica de los órganos de gobierno del CDS (1982-1986)............................136

3. 3. Un intento de consolidación fallida: de CC-UCD al CDS (Cataluña)........................................149

3. 4. Las elecciones municipales y autonómicas de 1983 ............................................................160

3. 5. La "travesía del desierto": Suárez recorre el país.................................................................173

CAPÍTULO 4. EL CDS EN LA VIDA PoLítICA ESPAÑola dURANTE LA II LEGISLATURA (1982-1986) .............................185

4. 1. El CDS y el gobierno socialista: los Debates sobre el Estado de la Nación .................................186

4. 2. La actividad parlamentaria: desarrollo autonómico y economía ............................................199

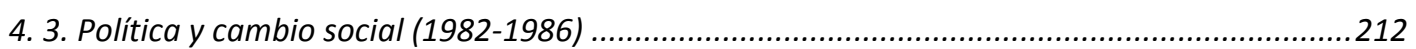

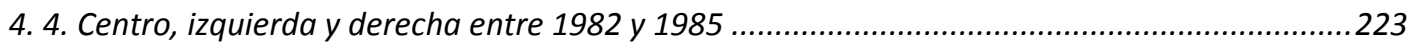

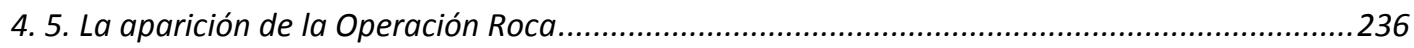

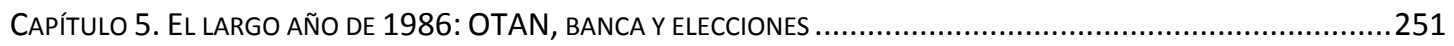

5. 1. Del impasse de los comicios gallegos a la convocatoria de las elecciones generales de 1986251

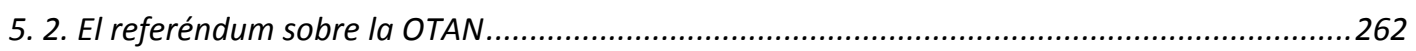

5. 3. Un programa electoral "moderadamente radical" (1986) .......................................................25 
5. 4. El reto de la campaña del CDS para las elecciones generales de 1986 ..................................287

5. 5. El discurso de campaña de Adolfo Suárez: felipismo y Transición ........................................301

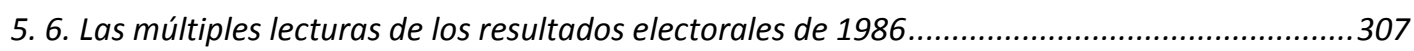

\section{PARTE 2. APOGEO Y AGONÍA DEL CDS: OPOSICIÓN, PACTOS Y OCASO POLÍTICO DE ADOLFO SUÁREZ}

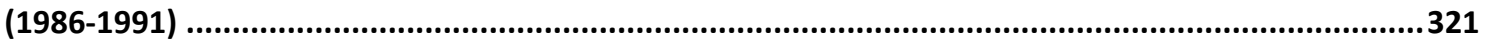

CAPÍTULO 6. EL CDS EN LA CUMBRE: UNA OPOSICIÓN QUE BUSCA SER ALTERNATIVA...........................................323

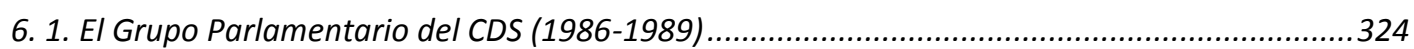

6. 2. El CDS y la crisis de la derecha española (1986-1987) ..........................................................332

6. 3. El Debate sobre el Estado de la Nación de 1987 y la Moción de Censura de Hernández Mancha.

6. 4. Las elecciones autonómicas, municipales y europeas de 1987 .............................................349

6. 5. Los resultados electorales de 1987: presencia institucional y política de pactos......................360

6. 6. El Grupo Parlamentario CDS en la oposición: líneas de actuación y principales debates políticos

CAPÍTULO 7. REESTRUCTURACIÓN Y RENOVACIÓN EN EL CDS: ORGANIZACIÓN E IDEOLOGÍA...................................391

7. 1. El Il Congreso del CDS y el crecimiento del partido (1986-1989)..............................................392

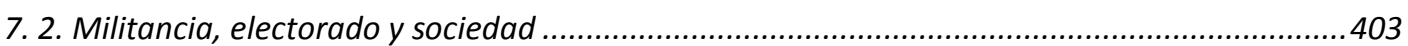

7. 3. Pensamiento e ideología en el CDS (1985-1993) ..............................................................413

7. 4. Un análisis prosopográfico: Dictadura, oposición y UCD ...................................................424

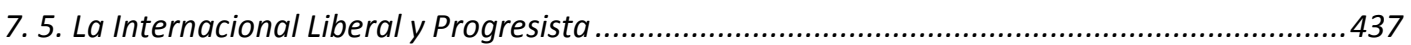

7. 6. La proyección europea del Centro Democrático y Social ..........................................................446

7. 7. La consolidación democrática y la aparición de nuevos partidos políticos: el caso del Partido Renovador Democrático de Portugal y del Centro Democrático Social en España .........................455

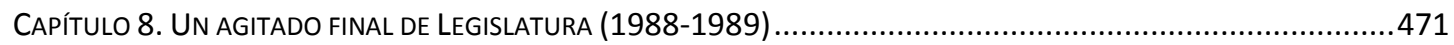

8. 1. El Debate sobre el Estado de la Nación de 1988.....................................................................472

8. 2. Las elecciones catalanas de 1988. La política autonómica del CDS (1988-1993) ...................477

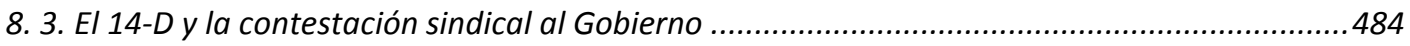

8. 4. Entre Mario Conde y la refundación de Alianza Popular. .....................................................494

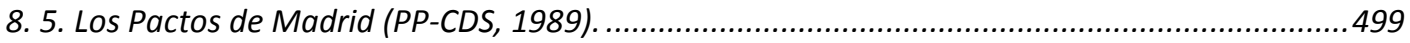

8. 6. Las elecciones generales de 1989: programa y campaña electoral.........................................514

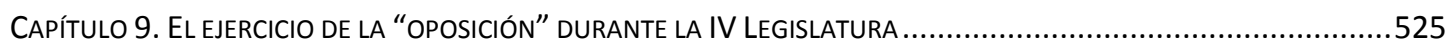

9. 1. Los resultados de las elecciones generales de 1989. ......................................................525

9. 2. Del Debate de Investidura (1989) al caso "Juan Guerra". Los críticos. .................................534

9. 3. El III Congreso del CDS (Torremolinos, 1990). .....................................................................542

9. 4. El Grupo Parlamentario del CDS durante Ia IV Legislatura .......................................................552

9. 5. La experiencia del "bloque constitucional" ............................................................................558

CAPÍTULO 10. El FINAL PoLítICO de Adolfo SUÁREZ ..................................................................................5 
10. 1. Las elecciones municipales y autonómicas de 1991

10. 2. El punto de inflexión de los resultados electorales de 1991 ..............................................584

10. 3. La dimisión de Adolfo Suárez como Presidente del CDS...................................................590

10. 4. La celebración del IV Congreso: Adolfo Suárez abandona la política ...................................595

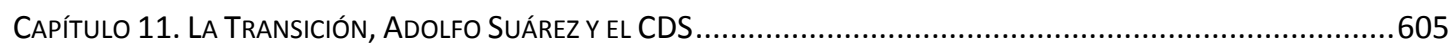

11. 1. Visión mediática del Suárez de la Transición ..................................................................606

11. 2. La mirada en el espejo: la Transición vista desde el CDS ..................................................621

11. 3. El peso de la Historia: Il República, Dictadura y Transición .................................................630

11. 4. Exportando la Transición: la proyección internacional de Adolfo Suárez (1982-1991)..........634

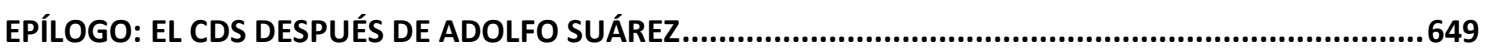

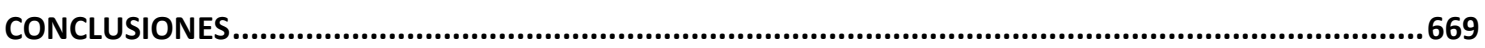

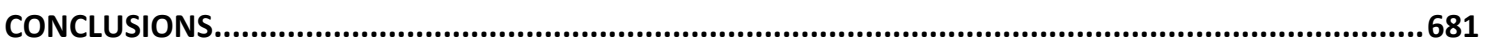

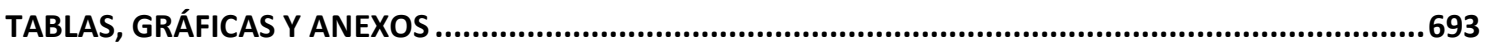

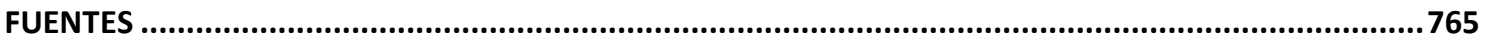

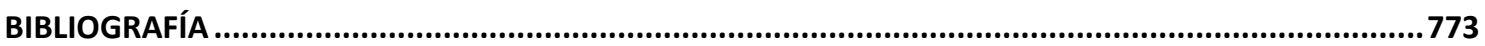





\section{ADOLFO SUÁREZ AND THE DEMOCRATIC AND SOCIAL CENTER (1982-1991)}

\section{Index}

SUMMARY

PART 1. THE RETURN OF ADOLFO SUÁREZ: THE BIRTH OF CDS IN 1982, THE ‘CROSSING THE DESERT’

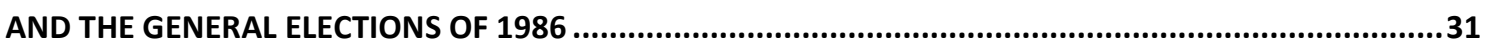

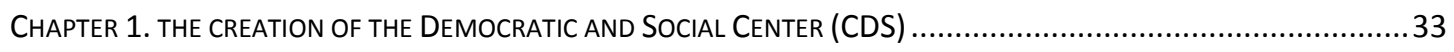

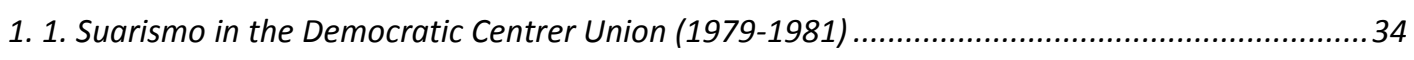

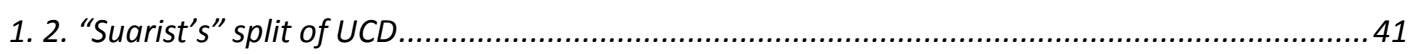

1. 3. The founding of the Democratic and Social Center .............................................................50

1. 4. LOAPA and OTAN: towards the political differenciation of UCD .........................................55

1. 5. The "Ritz Manifest" and mediatic recreation...................................................................60

1. 6. A Case Study: from UCD to CDS in the provinde of Zamora ................................................. 70

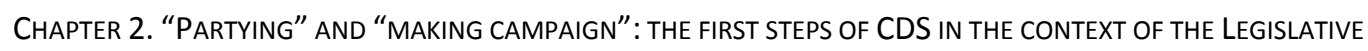

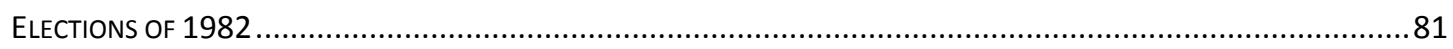

2. 1. The structuring of the Party: From the "drip"to the Constituent Congress..............................81

2. 2. Electoral competence and ideological spectrum in the summer of 1982 ...............................95

2. 3. The CDS electoral program: Spain, As It Shoulld Be ............................................................... 106

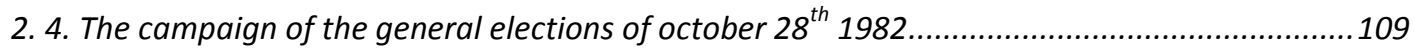

CHAPTER 3. THE CHALLENGES OF THE CONSOLIDATION OF CDS (1983-1985) .................................................125

3. 1. Analysis and consequences of electoral results $(28-0)$................................................... 125

3. 2. Formalization and Dynamics of the governing bodies of CDS (1982-1986) ........................... 136

3. 3. A failed consolidation attempt: from CC-UCD to CDS (Catalonia) ......................................... 149

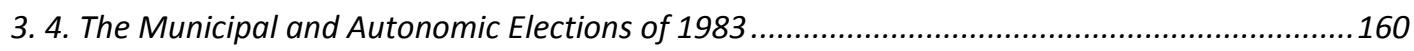

3. 5. The "crossing the desert ": Suárez travels the country .....................................................173

CHAPTER 4. CDS IN THE SPANISH POLITICAL LIFE DURING THE II LEGISLATURE (1982-1986) ................................185

4. 1. CDS and the socialist government: Debates on the State of the Nation ................................ 186

4. 2. The parliamentary activity: autonomic development and economy .....................................199

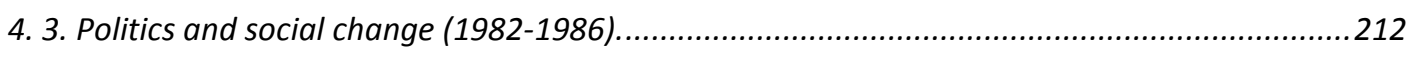

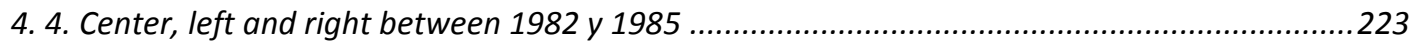

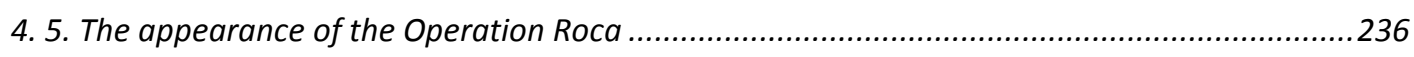

CHAPTER 5. THE LONG YEAR OF 1986: OTAN, BANKING Y ELECTIONS ..........................................................251 
5. 1. From the impasse of the galician elections to the convocation of the General Elections of 1986

251.

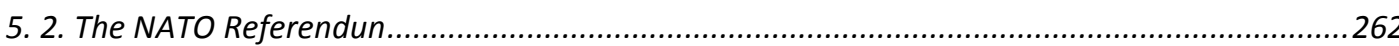

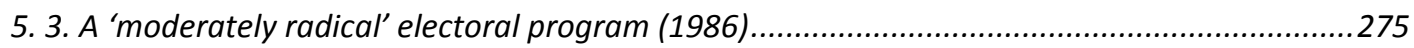

5. 4. The challenge of the CDS campaign for the 1986 General ELections.....................................287

5. 5. Adolfo Suárez's campaign speech: "felipism" and Transition ..............................................301

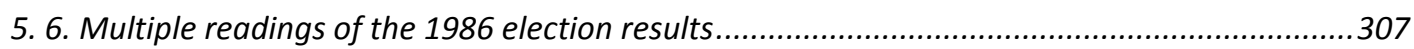

PART 2. APOGEMENT AND AGONY OF THE CDS: OPPOSITION, COVENANT AND POLITICAL TWILIGHT

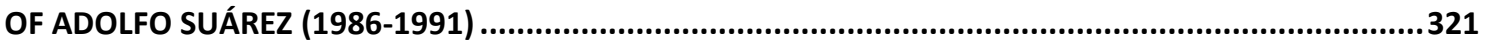

CHAPTER 6. THE POLIOTICAL SUCCESS OF CDS: OPPOSITION AND SEARCH FOR THE ALTERNATIVE .............................323

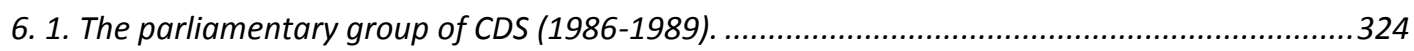

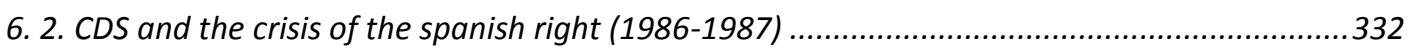

6. 3. The Debate on the State of the Nation and the Motion of Censorship of Hernández Mancha (1987)

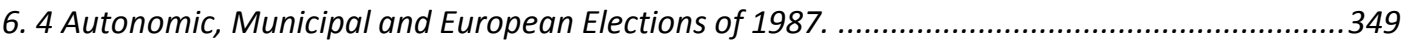

6. 5. The electoral results of 1987: institutional presesnce and political pacts ..............................360

6. 6. The Parliamentary Group of CDS in the oposition:lines of action and main political debates. 371

CHAPTER 7. RESTRUCTURING AND RENEWING IN CDS: ORGANIZATION AND IDEOLOGY ........................................391

7. 1. The Second Congress of CDS and the growth of the party (1986-1989)............................392

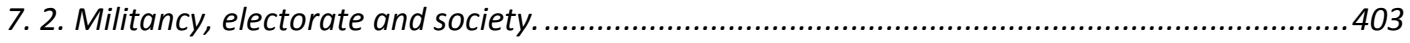

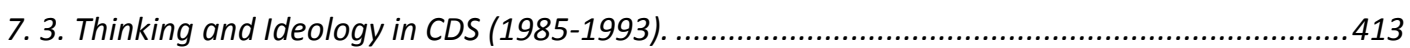

7. 4. A prosopographic analysis: Dictatorship, Oppsosition and UCD........................................424

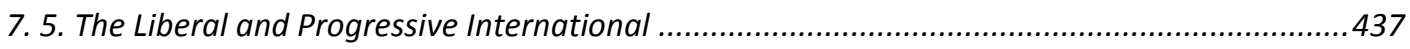

7. 6. The european proyection of the Democratic and Social Center..........................................446

7. 7. The consolidation of democracy and the emergence of new political parties: the case of the Renovative Democratic Party of Portugal and the Democratic and Social Center .........................455

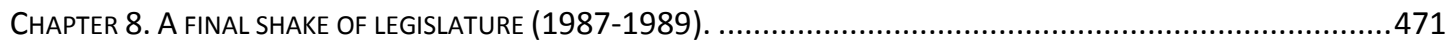

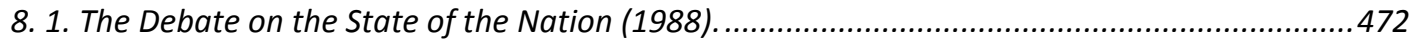

8. 2. The catalonian elections of 1988. The autonomic policies of CDS (1988-1993)....................477

8. 3. 14-D and the trades union's answer to the Government .....................................................484

8. 4. Between Mario Conde and the refoundation of Alianza Popular. .........................................494

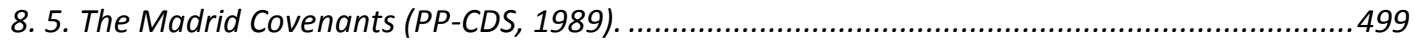

8. 6. General Elections 1989: program and electoral campaign..............................................514

CHAPTER 9. THE EXERCISE OF THE “OPPosition” DURING THE IV LEGISLATURE.................................................55

9. 1. The results of the 1989 General Elections...........................................................................525

9. 2. From the Investiture Debate (1989) to the case "Juan Guerra". The critics.............................534

9. 3. The III Congress of the CDS (Torremolinos, 1990).........................................................542 
9. 4. The CDS Parliamentary Group during the IV Legislature .................................................552

9. 5. The experience of the "constitutional bloc" ...................................................................558

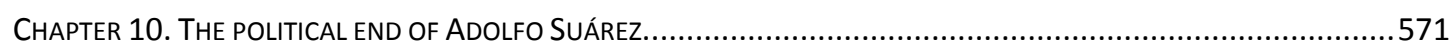

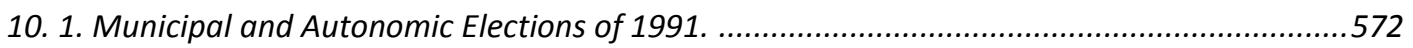

10. 2. The turning point of the 1991 election results ....................................................................584

10. 3. The resignation of Adolfo Suárez as Presidente of the CDS .............................................590

10. 4. The celebration of the IV Congress: Adolfo Suárez leaves politics ........................................595

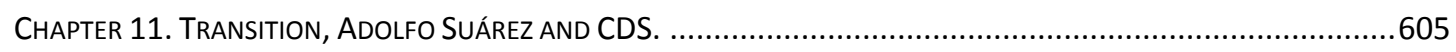

11. 1. Media Vision of the Tansition Suárez.......................................................................606

11. 2. The look in the mirror: the transition seen from CDS.................................................621

11. 3. The weight of History: // Republic, Dictatorship and Transition .....................................630

11. 4. Exporting the Transition: the international projection of Adolfo Suárez (1982-1991)...........634

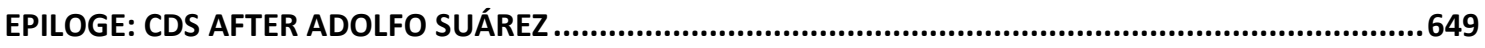

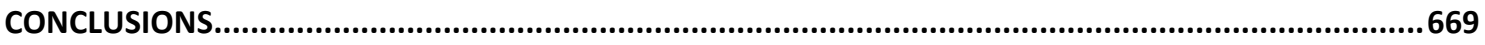

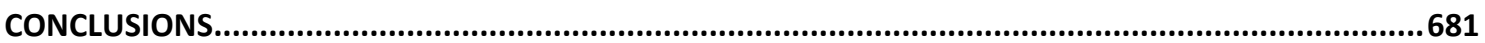

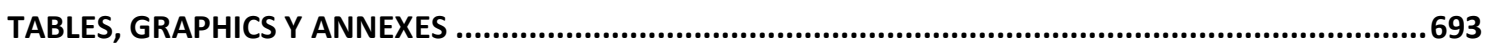

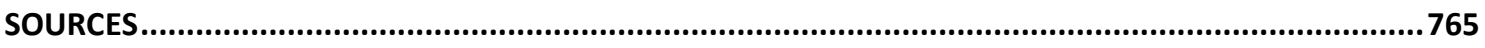

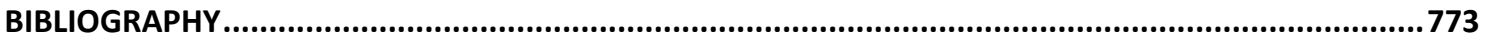





\section{RESUMEN}

A lo largo de la presente Tesis Doctoral, se analiza la trayectoria del Centro Democrático y Social (CDS) entre 1982 y 1991. La historia del CDS constituye un nexo fundamental dentro de la Historia Reciente de España entre la Transición democrática y la inmediatamente posterior Época Socialista, eslabón encarnado en la figura de Adolfo Suárez, quien fundara esta formación en 1982 y la presidiera hasta 1991.

Tras su dimisión como Presidente del Gobierno en 1981, Adolfo Suárez pudo prorrogar de la mano del CDS una fértil actividad política durante toda la década de los 80 '. En una época marcada por el recuerdo de sus antiguas responsabilidades políticas, su actuación al frente del CDS se desvela imprescindible para una comprensión global de su pensamiento y trayectoria política.

El CDS ejerció un decisivo papel en el proceso de reestructuración del centroderecha español tras el ocaso y desaparición de UCD, protagonista hegemónico de los ejecutivos de la Transición. El rol del CDS se puso de manifiesto en sus actuaciones parlamentarias, los comicios electorales y la formación de alianzas y fue objeto de un interesante y permanente debate mediático espoleado a su vez por la aparición de la Operación Reformista y las diferentes estrategias desplegadas por el PSOE y AP/PP

De este modo, el presente trabajo de investigación recupera y aborda a un protagonista central de la Historia Reciente de España desde un punto de vista interdisciplinar y a partir del manejo y análisis de copiosas fuentes archivísticas, hemerográficas y orales.

Palabras claves: CDS, Adolfo Suárez, Época Socialista, centro, partidos políticos. 


\section{SUMMARY}

Throughout the present Doctoral Thesis, the trajectory of the Democratic and Social Center (CDS) between 1982 and 1991is analyzed. The history of CDS constitutes a fundamental nexus within the Recent History of Spain between the democratic Transition and the immediately following Socialist Stage, incarnated link in the figure of Adolfo Suárez, who founded this formation in 1982 and presided it until 1991.

After his resignation as President of the Government in 1981, Adolfo Suárez was able to prolong a fertile political activity throughout the 1980s. In an era marked by the memory of his former political responsibilities, his performance at the head of CDS proves essential for a comprehensive understanding of his thinking and political trajectory.

CDS played a decisive role in the process of restructuring of the Spanish centre-right after the decline and disappearance of $\mathrm{UCD}$, the hegemonic protagonist of the Transition executives. The role of CDS was manifested in its parliamentary activities, the electoral elections and the formation of alliances and was the subject of an interesting and permanent media debate spurred by the appearance of the Reform Operation and the different strategies deployed by PSOE and AP / PP

In this way, the present work of investigation recovers and approaches a fundamental protagonist of the Recent History of Spain from an interdisciplinary point of view and from the handling and analysis of copious archival, hemerographic and oral sources.

Key words: CDS, Adolfo Suárez, Socialist Era, center, political parties. 


\section{INTRODUCCIÓN}



"Diez años, toda una década, y hoy apenas parece un incidente en la biografía de Adolfo Suárez"1.

\section{Justificación}

Preguntado en una ocasión sobre su opinión acerca del Centro Democrático y Social, Leopoldo Calvo-Sotelo contestó que, con esa iniciativa, Adolfo Suárez había pretendido alcanzar casi lo imposible: "entrar dos veces consecutivas en la historia"2. Es evidente que el papel de Suárez como artífice de la Transición ha sido estudiado y revisado con frecuencia y abundancia desde que abandonara el poder en 1981. Pero otra cosa muy diferente ha sido esa "segunda salida quijotesca" que supuso la fundación del CDS. La presente tesis doctoral aborda el estudio de la última aventura política de Adolfo Suárez desde que se produjera su marcha de UCD y la fundación del Centro Democrático y Social (1982) hasta su posterior abandono de la política, una década después (1991) ${ }^{3}$.

Nuestro trabajo se ha incardinado en dos amplios proyectos de investigación enfocados al estudio y análisis de la Historia Actual de España, que han prestado una particular atención al período de Transición y de consolidación democrática. Nos referimos al Grupo de Investigación de Historia Reciente de España (GIRHE) dirigido por Pablo Pérez López y al proyecto de investigación "El Gobierno de Leopoldo CalvoSotelo (1981-1982)" (Ministerio de Economía y Competitividad, HAR 2010-20762) bajo la dirección de José-Vidal Pelaz López. Fértiles líneas de investigación que, desde el principio, han orientado nuestra labor y nos han permitido, en la medida en la que hemos sido capaces, ser partícipes de una dinámica y fértil actividad historiográfica en revistas y congresos.

\footnotetext{
1 “Su invención política más genuina [...] un tiempo cargado de densidad política que va a ser trascendental en su vida pero que empalidece tanto la figura, empequeñece tanto el icono en el que se convertirá más tarde, que lo común es dedicarle unas líneas, como si se tratara de una aventura intrascendente [...] nadie se interesa por ese Suárez renacido, autosuficiente, seguro de sí mismo, como en sus mejores tiempos presidenciales, que tiene conciencia vaga de que va a iniciar una travesía del desierto. La enésima de su vida" en MORÁN, Gregorio: Ambición y destino, Barcelona, Debate, 2009, pp. 541-3.

S. a.: "Calvo-Sotelo critica a Suárez por querer imponer a Raúl Morodo", El País, 02 de octubre de 1991.

${ }^{3}$ Un proyecto que ha contado con el respaldo de las Ayudas para la Formación del Personal Investigador de la Universidad de Valladolid y el Banco Santander (2012-2013) y del Programa de Formación del Profesor Universitario desarrollado del Ministerio de Educación, Cultura y Deportes del Gobierno de España (2012-2016) -convocatoria de 2012 (Referencia 12/02682)-. Asimismo, se ha inscrito en el Programa de Doctorado de Europa y Mundo Atlántico del Instituto de Historia Simancas (2012-2017), programa interuniversitario coordinado por la Universidad de Valladolid y la Universidad del País Vasco.
} 
Los estudios sobre Historia Actual de España viven en los últimos años un fecundo período en el plano investigador. Si en un comienzo se puede afirmar que la importancia nacional e internacional a nivel historiográfico, sociológico y politológico de la Transición canalizó buena parte de las propuestas en este ámbito, lentamente se están abriendo paso los análisis del período inmediatamente posterior, que podemos denominar como Época socialista -siguiendo la obra de referencia actual sobre esta etapa: Historia de la Época Socialista. España: 1982-1996, dirigida por Abdón Mateos López y Álvaro Soto Carmona (2013)-.

Publicaciones como Historia Actual Online y Tiempo Presente y congresos como los organizados periódicamente por numerosos grupos de trabajo se afanan en reconstruir las últimas décadas de la Historia de nuestro país. Sin afán de exhaustividad queremos destacar: Historia de Nuestro Tiempo (Universidad de La Rioja), Historia Actual de España (Universidad de Cádiz) o Estudios del Tiempo Presente (Universidad de Almería). Asimismo, dentro de espacios temáticos y cronológicos más amplios, como los propuestos por la Asociación de Historia Contemporánea en sus congresos bianuales y en su publicación - la revista $A Y E R-$ o los encuentros, patrocinados por dicha institución, de Jóvenes Investigadores en Historia Contemporánea, resulta evidente el peso cada vez mayor que la Historia Actual de España está encontrando en el mundo académico y hemos de añadir, el público no especializado, en lo que es una tendencia en aumento. El final del reinado de Juan Carlos I permite a su vez dotar de cierta coherencia a las cuatro décadas transcurridas desde la muerte del dictador en 1975, dentro de las cuales la llamada Transición democrática comenzaría a ser vista tan solo como una etapa inicial.

De este modo, al cobijo de estas y otras reuniones científicas, el estudio de la España Democrática se ha consolidado como un interesante e incipiente campo con todavía numerosas líneas temáticas por explorar y como veremos, no exento de retos metodológicos. En este contexto, situamos nuestro objeto de estudio, ya que si el ámbito de trabajo por excelencia de la Historia Actual de España ha sido la Transición, uno de sus protagonistas fundamentales es Adolfo Suárez. Sin embargo, como hemos advertido con anterioridad -motivando en buena medida nuestro trabajo- las biografías y estudios sobre Adolfo Suárez presentan en la actualidad fuertes desequilibrios entre el prolijo análisis de su etapa como Presidente del Gobierno y los escasas páginas dedicadas a su experiencia al frente del Centro Democrático y Social. 


\section{Estado de la cuestión}

Si en política hablamos del centro, la reflexión de partida no puede ser otra que la famosa aserción del politólogo Maurice Duverger: "el centro no existe" -Los partidos políticos, 1992-. En cierto modo, los análisis posteriores han supuesto intentos de confirmación o refutación de la misma. Los estudios clásicos sobre partidos políticos y sistemas de partidos constituyen así el marco teórico en el que se desarrolla nuestro trabajo. Esta idea, enunciada por Duverger, en el contexto de un análisis sobre el bipartidismo merece algunas líneas más. Para Duverger, el "centro" se reduce al espacio geométrico donde se reúnen los "moderados de tendencias opuestas" (derecha e izquierda). Puede haber un partido de centro, pero nunca una doctrina, una tendencia. Su aspiración a la síntesis ideológica es imposible en una praxis política dominada por la acción y los posicionamientos. A finales de los 90' cuando algunos anticipaban el final de las ideologías y la emergencia de la transversalidad, todavía Norberto Bobbio defendía la virtualidad de las categorías políticas de izquierda y derecha apelando a los valores clásicos de igualdad y libertad respectivamente, reafirmando en buena medida la vieja tesis de Duverger. Aun considerando plausible la emergencia de terceras opciones, siempre estarían subordinadas a esta dicotomía fundamental-Derecha e izquierda: razones y significados de una distinción política, 1995-.

Esta tensión, firmemente arraigada en la opinión pública, los trabajos académicos y las obras de divulgación va a ejercer una influencia decisiva, aunque en ocasiones esquiva y sutil, sobre nuestra tesis doctoral, que no deja de aspirar a la comprensión de una trayectoria personal y un proyecto político -Adolfo Suárez y el CDS-, autoubicados en el llamado espacio de centro ${ }^{4}$.

Nuestro estado de la cuestión presenta, al menos, dos grandes áreas diferenciadas. Por un lado, nos detendremos en la copiosa aunque desigual bibliografía generada sobre la figura política de Adolfo Suárez. En segundo lugar, ha sido preciso recorrer la situación historiográfica de la Historia Actual de España y concretamente de la época democrática, con especial atención a la evolución de los "partidos políticos" e incluyendo trabajos propios del área de la sociología electoral y la politología.

\footnotetext{
${ }^{4}$ Para el conjunto de referencias bibliográficas nos remitiremos al apartado de Bibliografía, salvo en aquellas aclaraciones que se consideren necesarias.
} 
La figura de Adolfo Suárez (1932-2014) ha sido centro de atención permanente para el conjunto de la sociedad española desde que alcanzase de forma sorprendente e inesperada la Presidencia de Gobierno en 1976. El notable éxito con el que condujo un ágil y trepidante proceso de democratización, culminado con la aprobación de la Carta Magna en 1978, acrecentó la dimensión histórica de su figura. En poco más de tres años, Adolfo Suárez había pasado de vice-ministro Secretario General del Movimiento en los estertores del régimen dictatorial a convertirse en uno de los grandes estadistas de la Historia Contemporánea de España, simbolizando un tiempo marcado por la democracia y las libertades. Sin embargo, su popularidad se desvaneció con la misma celeridad con la que había conseguido desmontar el férreo entramado de poder franquista. Su dimisión, su actuación en el 23-F y la fundación del CDS, en medio de la crisis interna del partido del Gobierno (UCD), completaron un perfil épico no exento de claroscuros. Se inició así una época marcada por la distancia existente entre las críticas y los reproches mediáticos y partidistas, y un carisma popular que parecía permanecer intacto cuando recorría la geografía española al frente del CDS, pero que no se traducía en votos. Finalmente, tras casi una década cómo líder de este nuevo proyecto, en 1991, decía adiós a la política. Una vez más, daba comienzo una etapa marcada por el contraste, en este caso, entre la tragedia personal y el merecido y sincero homenaje público e institucional de todo un país.

En una fecha tan temprana como 1979, había aparecido un polémico libro publicado por el periodista Gregorio Morán -Adolfo Suárez: historia de una ambición-, que recogía, gracias a la recopilación de múltiples testimonios, copiosa información sobre los episodios más desconocidos de la trayectoria política de Adolfo Suárez. Si bien con notable pericia retrataba este complejo recorrido que le había conducido a la Presidencia, con no menos intensidad, asentaba muchos de los tópicos y clichés que iban a marcar análisis posteriores -ambición, escasa preparación, etc.-. Sea como fuere, la obra de Gregorio Morán se convirtió en un referente para el estudio de la figura de Adolfo Suárez desde su publicación, hasta el punto de que el propio autor llevó a cabo una reedición en 2009 en la que se incluían ulteriores episodios de su vida política como la dimisión, el 23-F y el CDS y en los que ha mantenido intacto su tono crítico e incisivo -Adolfo Suárez: ambición y destino-. Gregorio Morán ha subrayado el oportunismo y el carácter errático del partido suarista, herramienta de Adolfo Suárez 
para la satisfacción de su ambición personal y consecuencia directa de un resentimiento espoleado durante su etapa final en la Presidencia de Gobierno.

Hasta 1995 fueron apenas un puñado las obras que abordaron al personaje y lo hicieron siempre centradas en aspectos puntuales, particularmente su dimisión. En ningún caso, podemos hablar de auténticas biografías políticas. Antonio Navalón y Francisco Guerrero publicaron a finales de los $80^{\prime}$ un libro referido a sus últimos meses en la Presidencia del Gobierno -Objetivo Adolfo Suárez: 1980, el año de la agonía (1987)-, cuestión ya trabajada por periodistas como José Oneto o quien fuera portavoz del Gobierno, Josep Meliá, en Los últimos días de un Presidente: de la dimisión al golpe de estado (1981) y Así cayó Adolfo Suárez (1981), respectivamente ${ }^{5}$. A comienzos de la década de 90', Antxón Sarasqueta publicó La agonía del Duque: el enigma de Adolfo Suárez (1991), a propósito de su abandono de la política. Sarasqueta elogiaba su actuación durante la Transición no sin reprocharle sus pretensiones progresistas durante su etapa en el CDS, que le habían convertido en un aliado inesperado de Felipe González; discurso similar al vertido por el también periodista Ángel del Río en la única biografía actualmente disponible de Agustín Rodríguez Sahagún (1991), mano derecha de Adolfo Suárez desde finales de los 70'. En 1997, el historiador Ricardo de la Cierva publicaba un libro disonante en el contexto de homenajes y celebraciones que estaban teniendo lugar en torno al ex presidente: $E l$ suicidio político de Adolfo Suárez; una obra muy personal que prorrogaba la literatura anteriormente señalada.

En la segunda parte de la década de los 90' se intensificó el interés público por la figura de Adolfo Suárez. Si la obra de Gregorio Morán suponía una crítica a lo que se consideraban las visiones más oficialistas y edulcoradas de la Transición, la obra del escritor y periodista Carlos Abella Adolfo Suárez (1997) se incorporaba a la corriente de revisión de la dimensión histórica y política que se estaba haciendo de la figura de Adolfo Suárez desde 1995, parejo por otra parte, a la recuperación del pasado transicional entre la sociedad española. En esta ocasión, el objeto central de estudio se desplazaba de una sinuosa trayectoria no exenta de contradicciones a su decisiva contribución en el proceso de edificación y estructuración del nuevo estado democrático. Casi una década después el mismo autor publicó un volumen más

\footnotetext{
${ }^{5}$ En 2006, José Oneto publicó: Conspiración contra un Presidente: de la dimisión al golpe de estado, Barcelona, Zeta, 2006.
} 
completo titulado Adolfo Suárez: el hombre clave de la Transición (2006). En esta nueva mirada a la Transición se embarcaron los dos principales periódicos nacionales El País y El Mundo-, así como TVE de la mano de la excelente serie documental La Transición, narrada por la periodista Victoria Prego. De esta última autora debemos citar su libro sobre Adolfo Suárez -en una serie sobre los ex Presidentes de Gobierno-, trufada de testimonios y valoraciones del propio político abulense, aparecida en el año 2000 y reeditada poco después con el título de Adolfo Suárez: la apuesta del rey (19761981).

En esta línea se sitúa el trabajo del también periodista José García Abad, quien en 2005 realizó un acercamiento a Adolfo Suárez que aunque no pretendía ser sistemático, sí constituía una interesante visión para conocer la compleja personalidad del personaje adentrándose en sus vivencias durante la década de los 80' -Adolfo Suárez: Una tragedia griega-. Su benévola visión del CDS subraya la tenacidad del suarismo en su empeño por sacar adelante este nuevo proyecto hasta convertirlo en la única "oposición constructiva" al gobierno del PSOE.

Desde un punto de vista complementario, Federico Quevedo ha llevado a cabo, en Pasión por la libertad. El pensamiento político de Adolfo Suárez (2007), un análisis de los fundamentos teóricos e ideológicos que directa o indirectamente habrían podido inspirar la actuación política de Adolfo Suárez en UCD y el CDS. Un ejercicio, que partiendo de textos y discursos del propio Suárez, le lleva al autor a citas de los padres del liberalismo político y económico ${ }^{6}$.

Paralelamente, desde finales de los 90' y comienzos de la década siguiente las obras, entre muchos otros, de Javier Tusell, Álvaro Soto Carmona o Charles Powell lograron poner en pie un sólido discurso sobre la Transición que ordenaba y hacía inteligible el conjunto de sucesos, protagonistas y datos relativos a este proceso de cambio político. En este contexto, Charles Powell publicó junto al periodista Pere Bonnin Adolfo Suárez

\footnotetext{
${ }^{6}$ Frente a esta propuesta, el profesor de Ciencias Políticas, Pedro C. González Cuevas experto en la evolución de la ideología conservadora española contemporánea ha defendido la tesis contraria definiendo a Adolfo Suárez como lo contrario de un "doctrinario político [...] hombre en el que primaba de modo absoluto la praxis sobre la teoría. De hecho, inauguró en España la etapa de los políticos de 'imagen', característicos de la era televisiva...", GONZÁLEZ CUEVAS, Pedro C.: El pensamiento político de la derecha española en el siglo XX. De la Restauración al Estado de partidos (1898-2000), Madrid, Tecnos, 2005, p. 232. Véase, la reseña de González Cuevas a Federico Quevedo en el contenido web, ÍD.: "Reseña. Pasión por la libertad. El pensamiento político de Adolfo Suárez", El Catoblepas: revista crítica del presente, 76, 2008, disponible en http://www.nodulo.org/ec/2008/n076p16.htm Fecha de consulta: 12 de diciembre de 2012 .
} 
(2004) una obra en la que Powell combinaba con acierto su trayectoria política y la reflexión sobre los rasgos más característicos de su personalidad -en el que la audacia era el motor principal-, sobre un contexto, el de la Transición, perfilado rigurosamente. Sin embargo, no ha sido hasta el año 2011 cuando ha aparecido el recorrido más completo realizado sobre Adolfo Suárez como personaje histórico desde el punto de vista académico. En esta fecha salió a la luz Adolfo Suárez: la historia que no se contó del profesor Juan Francisco Fuentes Aragonés; un trabajo que aportaba una copiosa y nueva documentación de archivo, junto al más habitual uso, en este caso, de la prensa y las fuentes orales.

La aparición de este notable trabajo de investigación coincidió en el tiempo con la publicación de multitud de obras que, generalmente escritas por amigos, colaboradores y periodistas, que han rememorado con nostalgia y emoción su relación con el personaje; un recuerdo que su fallecimiento, en marzo de 2014, ha revivido con mayor intensidad. Merece la pena destacar los trabajos de Manuel Ortiz y Javier González de Vega, amigos y colaboradores de Suárez desde 1976, ambas, elocuentes miradas a los entresijos del entorno presidencial, Adolfo Suárez y el bienio prodigioso (1976-1977) y Adolfo Suárez. España 1976-1977: el año milagroso, publicados en 2006; el de los periodistas y amigos de Adolfo Suárez, Luis Herrero, Los que le llamábamos Adolfo (2007), Abel Hernández, Suárez y el Rey (2009), y Fernando Ónega, Puedo prometer y prometo (2013), así como la obra de Carmen Laviña sobre la campaña electoral de 1982 -Adolfo Suárez: recuerdos prestados (2010)-,o el trabajo del periodista Manuel Campo Vidal, titulado: Adolfo Suárez: El presidente inesperado de la Transición (2012). Una mención aparte merece la publicación de La Sombra de Suárez (2014), escrito por quien fuera su mano derecha desde que abandonara la política, Eduardo Navarro y recopilado por Jorge Trías Sagnier, depositario de su archivo. Debemos concluir este recorrido citando, la única obra firmada por el propio Adolfo Suárez sobre su trayectoria que con el título de Fue posible la concordia apareció en 1996 y fue editada junto a Abel Hernández, periodista y amigo del abulense.

En esta larga lista bibliográfica, las referencias al CDS son circunstanciales y tienen un carácter absolutamente secundario, siendo una etapa considerada menor en la vida

\footnotetext{
${ }^{7}$ González de Vega había publicado previamente, en 1996, una obra titulada A la sombra de Adolfo Suárez.
} 
política de Adolfo Suárez. El CDS no hacía “justicia”, de acuerdo con la mayoría de los autores, a las brillantes gestas políticas de Suárez.

Queremos terminar este recorrido con cuatro testimonios de singular importancia. Por un lado, las memorias del político leonés Luis Aznar, que constituyen a día de hoy, la única publicación de estas características realizada por un miembro del CDS, ya que otras obras como las de Manuel Jiménez de Parga o Ramón Tamames han otorgado a esta etapa un protagonismo secundario. En segundo lugar, el reciente libro de Pilar Urbano, La gran desmemoria: lo que Suárez olvidó y el Rey prefiere no recordar (2014), que ha supuesto la reavivación pública de algunas de las polémicas más arraigadas en torno a la vida de Suárez como fue su relación con el rey y en la que el 23F centra la mitad de la investigación. Como contrapunto a este trabajo, debemos citar el ensayo novelado y éxito editorial publicado por Javier Cercas, Anatomía de un instante (2009), que usando como leitmotiv la actuación de Adolfo Suárez durante el golpe de estado desgranaba con profundidad tanto los múltiples perfiles del personaje como los del ya citado 23-F. En último lugar, destacamos la reciente obra del periodista Emilio Contreras, Suárez acoso y derribo (2016), que sustentada en valiosos testimonios de amigos y colaboradores del abulense aborda el ocaso político de Suárez.

Podemos afirmar que el tratamiento historiográfico del CDS ha sido prácticamente nulo hasta el momento, aparte del breve recorrido que realizan sobre él los biógrafos de Suárez destacando la obra del profesor Juan Francisco Fuentes Aragonés, y los trabajos pioneros sobre la trayectoria del partido realizados por Rafael Quirosa-Cheyrouze y Muñoz y Mónica Amador Fernández, ambos incluidos en obras colectivas dedicadas a la Transición y la etapa democrática. Asimismo, en el campo del derecho político se realizaron a lo largo de las décadas de los 80 ' y 90' artículos monográficos por parte de María Victoria García-Atance y Pilar Mellado Prado a propósito de la celebración del I, III y IV Congreso del CDS. Por último, se ha defendido recientemente un Trabajo Fin de Máster (UNED) a cargo de Luis de Castro Redondo, sobre la historia del partido suarista: El Centro Democrático y Social y la derecha española.

La explicación más plausible a estas ausencias, no sólo tiene que ver con lo reciente de estos fenómenos, también nos habla de que las fuentes primarias para el análisis de esta realidad no son muy abundantes y las existentes no han sido objeto de un estudio 
sistemático hasta el momento. Una situación que se extiende al conjunto de los partidos políticos, herméticos en cuanto a la disponibilidad de sus archivos.

Otro aspecto decisivo en nuestro trabajo, es el recorrido bibliográfico de los últimos compases de la Transición española, centrándonos en la trayectoria final del partido político en el gobierno. La UCD fue un conglomerado heterogéneo de familias ideológicas y políticas que aglutinaba bajo el mismo techo a democristianos, socialdemócratas, liberales y con una fuerza singular, a los sectores reformistas del régimen franquista. A pesar de los éxitos electorales de 1977 y 1979, no se consiguió lograr la consolidación de este partido político, que desapareció en 1983 tras un largo período de tensiones internas, recrudecidas al hilo de la dimisión de Suárez a comienzos de 1981 y su abandono definitivo del partido apenas un año después para fundar el CDS. A través de la exposición de este trabajo esperamos contribuir también, aunque de forma menor, a la comprensión de este complejo proceso, -la crisis de UCD-, que afectó sensiblemente a la consolidación del sistema de partidos español.

A día de hoy, el debate historiográfico acerca de la entidad de UCD como partido político permanece abierto. Si para investigadores como Carlos Huneeus o Silvia Alonso Castrillo, la UCD fue ante todo una herramienta política imprescindible para llevar a cabo la Transición -véase respectivamente, La Unión del Centro Democrático y la transición a la democracia en España (1985) y La apuesta del centro: historia de la UCD (1996) -, para otros, caso de Jonathan R. Hopkin -El partido de la transición: ascenso y caída de la UCD (2000)-, o Richard Gunther (1989) la consolidación hubiera sido posible si el comportamiento político de sus miembros hubiese sido distinto. Con el fin de completar nuestro recorrido debemos citar los imprescindibles trabajos de periodistas como Javier Figuero (UCD. La empresa que creó Adolfo Suárez, 1981), Manuel Soriano y Fernando Jáuregui (La otra historia de UCD, 1980) o Eduardo Chamorro (Viaje al centro de UCD, 1981), sin olvidar testimonios de políticos centristas, convertidos hoy en referentes clásicos para el estudio de la Transición, como los Leopoldo Calvo-Sotelo o Emilio Attard en Memoria Viva de la Transición (1990) y Vida y muerte de UCD (1983), respectivamente.

Sin embargo, a pesar de la cantidad de estudios referentes a UCD, no es exagerado afirmar que su análisis ha recibido un tratamiento historiográfico desigual. Aunque el papel político de UCD ha sido espléndidamente sintetizado por los autores antes 
mencionados, persiste cierto vacío, en el estudio de la intrahistoria del partido por la ausencia de fuentes directas ${ }^{8}$. Además, los partidos surgidos a raíz de la descomposición centrista, como el CDS, el PDP o el PAD, apenas han suscitado el interés de los investigadores.

Las reflexiones sobre el centro político son inseparables de las trayectorias políticas de algunos de sus promotores en UCD y su posterior evolución. En este sentido, el estudio y el análisis de las memorias de los protagonistas ha sido fundamental para nuestro trabajo; un ejercicio no exento de riesgos como certera y premonitoriamente señalaba El País en un editorial firmado en 1985:

Este es un país, donde no se escriben memorias ni diarios, se pierden los papeles, se contrastan poco las informaciones y se tienen razonables dudas acerca del testimonio de los otros. Cuando alguien recuerda, su memoria es selectiva y, cuando escribe o habla, la selección actúa aún más vertiginosamente sobre sus palabras 9 .

Más allá de la parcialidad o subjetividad presente en estas obras, debemos enfrentarnos a la realidad de que sólo tangencialmente han afectado a nuestro trabajo. En el espacio de derecha y centro-derecha, destacamos las publicaciones de Marcelino Oreja, Fernando Álvarez de Miranda, Jorge Verstrynge, Manuel Fraga, J. Antonio DíazAmbrona, Jaime Mayor Oreja, José María Aznar, Miguel Herrero de Miñón, Antonio Garrigues-Walker, Manuel Jiménez de Parga, Ramón Tamames y, la ya citada, de Eduardo Navarro. Desde una perspectiva diferente, debemos citar las aportaciones de Santiago Carrillo, José Barrionuevo, Joaquín Almunia, Pablo Castellano, Alfonso Guerra, Julio Feo o Raúl Morodo. Igualmente interesante ha sido la lectura de las memorias de políticos nacionalistas como Xabier Arzallus, Carlos Garaikoetxea o Jordi Pujol o de personajes que sin pertenecer al ámbito de la política establecieron contacto con Adolfo Suárez a lo largo de este período como Mario Conde, Fernando Jáuregui, Alfredo Fraile o Juan Jesús Armas Marcelo. Especial atención merecen los ejercicios que entre el periodismo y el ensayo han tratado de recoger el testimonio de los principales protagonistas políticos de nuestra época democrática: Julia Navarro, María Antonia Iglesias o Tom Burns Marañón. Por último, la proliferación de diccionarios biográficos y atlas electorales, en muchos casos en proyectos sufragados por las distintas instituciones territoriales -Comunidades Autónomas, Diputaciones

\footnotetext{
${ }^{8}$ En cuanto a los estudios locales y provinciales debemos citar la reconstrucción de la vida interna del partido en Soria realizada por RUIZ DÍEZ, Manuel: Formación y desarrollo de un partido en la Transición, Trabajo Fin de Máster, Universidad de Zaragoza, 2013.

9 “Aviso a los historiadores futuros", El País, 12 de septiembre de 1985.
} 
Provinciales, Ayuntamientos, etc.-, ha sido particularmente útil a la hora de poder sistematizar el estudio biográfico de los miembros del $\mathrm{CDS}^{10}$.

Es interesante señalar también, como la década de los años 90' vivió numerosos éxitos editoriales sobre temas de investigación y análisis periodístico que en clave política analizaron la actualidad nacional, caso paradigmático de las colecciones publicadas por Temas de Hoy y la obra de profesionales como Ernesto Ekaizer, Graciano Palomo, Jesús Cacho, Mariano Guindal, etc. La crítica al felipismo, la corrupción, el mundo empresarial o el 23-F centraron la atención de gran número de lectores y nos han sido realmente útiles para acercarnos al período analizado ${ }^{11}$.

De uso imprescindible han sido los trabajos que desde las Ciencias Políticas y la Sociología Electoral han contribuido al estudio de la España democrática. En el terreno de la sociología electoral siguen siendo fundamentales las obras de Richard Gunther, Giacomo Sani y Goldie Shabada sobre las claves de la evolución del incipiente sistema de partidos español -El sistema de partidos políticos en España. Génesis y evolución, 1989-, obra complementada por la edición a cargo de Pilar del Castillo de un exhaustivo análisis de las elecciones acaecidas en España desde 1977 hasta mediados de la década de los 90' - Comportamiento político y electoral, 1998-. En el terreno del estudio de pactos y coaliciones electorales queremos destacar por la importancia que ha tenido en el presente trabajo el artículo pionero de Germán y Rubén Sánchez Medero “PP-CDS. Pactos y alternativas de gobierno de centro-derecha en 1989", publicado en Política y Sociedad, 2003-, que se inserta en un ámbito de investigación ya asentado en nuestro país gracias a obras monográficas como la editada por Josep María Reniu Pactar para gobernar. Dinámicas coalicionales en la España multinivell, 2013-. De otra parte, ha sido imprescindible una amplia consulta de las series de la Revista Española de Investigaciones Sociológicas (CIS) y la Revista de Derecho Político (UNED).

\footnotetext{
${ }^{10}$ Debido al abundante número de autores nos remitimos a la Bibliografía temática aportada al final del presente trabajo para la consulta del título y del año de publicación de las distintas obras.

11 Sobre este fenómeno, véase, DÍAZ GÜELL, Luis: Periodismo y periodistas de investigación en España, 1975-2000: contribución al cambio político, jurídico, económico y social, Tesis Doctoral, UCM, 2003, pp. 34-5. Disponible en: http://www.biblioteca.ucm. Fecha de consulta: 02 de marzo de 2015.
} 


\section{Hipótesis y objetivos}

El corpus bibliográfico anteriormente descrito nos ha proporcionado una firme base desde la que construir nuestra investigación permitiéndonos recrear el contexto histórico en el que se desenvolvió nuestro objeto de estudio y aportándonos el armazón teórico imprescindible para nuestra argumentación. Además y no menos importante, nos ha planteado sugerentes interrogantes que, conectando con el conjunto de la Historia Contemporánea de España, han espoleado de forma decisiva nuestra labor investigadora.

Nos referimos a la noción, reiterada en nuestra contemporaneidad, acerca de las condiciones de posibilidad de un "tercer" proyecto político, capaz de trascender la idea de las dos Españas enfrentadas y ejercer como mediadora entre ambas, una idea presente desde la irrupción del liberalismo en España. Un tercer partido -o quizá una tercera España-, defensor de los seculares proyectos de modernización y europeización recurrentes desde el siglo XIX y alejado a su vez de la ambigüedad o de la demagogia y en última instancia, de las acusaciones de populismo. Nuestra hipótesis es que la experiencia política de la Transición, las vivencias familiares y personales de Adolfo Suárez, su trayectoria y su intento de dar continuidad a un partido de centro reformista en un momento en el que todavía había una considerable distancia ideológica y programática entre los principales partidos políticos (AP-PSOE) constituyeron un ocasión excepcional para llevar a cabo un proyecto de este tipo en un contexto de democracia consolidada.

El papel de Adolfo Suárez en la recomposición del espacio de centro-derecha, es decir, en la reestructuración del sistema de partidos tras el ocaso de UCD se presenta como un sugerente objeto de estudio. En este caso, la habitual lucha política discernida en la prensa, en la televisión, en los ámbitos socio-profesionales y en las urnas adquirió matices absolutamente genuinos derivados de la presencia del ex Presidente de Gobierno durante la Transición. Y es que, el papel jugado por el recuerdo de su gestión al frente del Ejecutivo y los usos subsiguientes usos del pasado constituyeron un hándicap para el afianzamiento del CDS en el sistema de partidos español. Esta interpretación, inaugurada por H. M. Enzesberger, quien acuñó el concepto de "héroe de la retirada" y magistralmente proseguida por Javier Cercas en Anatomía de un instante, 
se desvelará como un prisma excepcionalmente complejo en el que la memoria se mezclará con el ritmo de los acontecimientos políticos más mundanos y cotidianos.

La puesta de largo de estos planteamientos en nuestro estudio, sintéticamente, quedan formulados del siguiente modo. Por un lado, ¿era realmente posible la existencia de un tercer partido en España después de los trágicos episodios vividos a lo largo del s. XX y el considerable éxito que supuso la Transición bajo el liderazgo de una fuerza autoproclamada centrista abierta al pacto y al diálogo? De otra parte, ¿por qué no fue capaz Adolfo Suárez de rentabilizar con el CDS el enorme capital político conseguido durante la Transición y qué factores influyeron en ello?

De este modo, el objetivo del presente trabajo es el estudio de la trayectoria política de Adolfo Suárez y su partido, el Centro Democrático y Social entre 1982 y 1991, es decir, la búsqueda de una definición del suarismo como proyecto político dotado de contenidos propios y diferenciados.

\section{Fuentes}

Después de más de cuatro años de investigación, podemos afirmar que no existe un archivo del CDS, ni un fondo documental organizado del partido centrista. Tampoco tenemos constancia, más allá de las referencias de unos u otros autores, de un archivo o unas memorias inéditas elaboradas por Adolfo Suárez. Todo ello nos ha llevado, como veremos más adelante, a considerar la prensa como hilo conductor de nuestro trabajo ${ }^{12}$.

Quien fuera el Presidente Nacional del CDS (1991-1998), Rafael Calvo Ortega, asegura que no se ha conservado la documentación generada por el partido ${ }^{13}$. Los principales dirigentes en la década de los 80', caso de José Ramón Caso (Secretario General, 1982-1991) o Laura Morso (Comité Nacional, 1982-1991), al abandonar el CDS a comienzos de los 90' desconocen también la suerte corrida por la abultada documentación generada en este período ${ }^{14}$. Podemos afirmar que la tumultuosa historia

\footnotetext{
${ }^{12} \mathrm{El}$ análisis de la documentación generada por los partidos políticos -actas, informes, análisis internos o registros de afiliación-, supone a día de hoy un reto historiográfico todavía abierto e irresuelto. Especialmente llamativos han sido los casos del CDS y UCD, cuyo apresurado final nos ha desprovisto de valiosos testimonios históricos.

${ }^{13}$ Entrevista con Rafael Calvo Ortega, 18 de febrero de 2015 (Madrid).

${ }^{14}$ Entrevista con Laura Morso, 11 de febrero de 2015 (Madrid) y con José Ramón Caso, 19 de noviembre de 2014 (Madrid).
} 
de esta formación vivida durante esta década - cambios de sede incluidos-, provocó la pérdida paulatina de documentación. José Moreira, Secretario General en el año 2005, momento en el que el CDS bajo la Presidencia de María Teresa Gómez-Limón se integró en el Partido Popular, nos ha podido confirmar cómo los últimos archivadores y cajas conservados fueron depositados en la sede de este último partido ${ }^{15}$.

Este hecho ha orientado nuestra investigación en dos caminos complementarios. Por un lado, hemos realizado un exhaustivo vaciado de toda la documentación generada por el CDS conservada en archivos y registros de acceso público, análisis que hemos extendido a todo el espectro político de centro-derecha (UCD, PDP, PP). En primer lugar, hemos trabajado con los fondos conservados en el Registro de Partidos Políticos (Ministerio del Interior) en el que se depositaron los estatutos, designación de cargos y otras notificaciones del partido ${ }^{16}$. Una aportación imprescindible han sido las más de doscientas entrevistas realizadas por Richard Gunther a políticos de la Transición, de las que hemos consultado aproximadamente una decena, toda ellas llevadas a cabo entre 1982 y 1986 y cuyas transcripciones están depositadas en el Archivo Linz de la Transición del Centro de Estudios Avanzados en Ciencias Sociales de la Fundación March; siguiendo las normas de citación, hemos respetado el anonimato de las fuentes.

Un valioso testimonio sobre el pálpito del centro-derecha nacional durante la década de los años 80' nos lo han proporcionado los archivos personales depositados en el Archivo General de la Universidad de Navarra por destacados políticos de la Transición Española como José Luis Álvarez o Marcelino Oreja. El Archivo Diario 16: MAST-Fundación San Pablo CEU nos ha aportado una interesante documentación relativa a la relación del CDS con la Internacional Liberal y Progresista.

Asimismo, hemos dirigido nuestra mirada a archivos de ámbito territorial. Destacamos los fondos de UCD conservados en los Archivos Provinciales de Zamora y

\footnotetext{
${ }^{15}$ Discurso de integración del CDS en el PP, José Moreira, 2005, Documentación de José Moreira. La documentación mencionada fue solicitada por vía postal al Partido Popular mediante carta fechada el día 11 de junio de 2015 y firmada por el autor, con pleno acuerdo y consentimiento adscrito del depositario de la documentación -José Moreira-, sin obtener respuesta.

16 Para el cómputo de cargos institucionales (concejales, alcaldes y diputados provinciales) se han consultado los datos de la Dirección General de Coordinación con las Comunidades Autónomas y las Entidades Locales del Ministerio de Hacienda y Administraciones Públicas (AMINHAP).
} 
Soria que nos han proporcionado una valiosa información sobre el momento de constitución del partido suarista ${ }^{17}$.

Finalmente, nos ha sido de gran utilidad la serie histórica de los Diarios de Sesiones parlamentarios conservada en la web del Congreso de los Diputados, así como del Boletín Oficial del Estado, de cara al análisis de las candidaturas electorales ${ }^{18}$. Asimismo, la información electoral ha sido elaborada gracias a la consulta de la base de datos online del Ministerio del Interior -http://www.infoelectoral.mir.es/-, y el completo y exhaustivo repositorio online: http://www.historiaelectoral.com/.

Por otro lado, hemos intentado recomponer la trayectoria del CDS gracias a la documentación aportada por los militantes del partido. En este sentido, ha sido imprescindible la ayuda de Antonio Garrosa Resina, Presidente Provincial del CDS en Valladolid, Secretario General del CDS en Castilla y León y Diputado Nacional (19861989). Del mismo modo, debemos citar a José Luis Garro, quien nos ha proporcionado una abundante documentación generada por el Gabinete de Presidencia del CDS, del que fuera máximo responsable entre los años 1982 y 1987 (Archivo Gabinete de Presidencia, AGP). En este mismo sentido, debemos agradecer la colaboración de José Antonio Pérez González -activo militante del CDS madrileño-, Jaime Hernando dirigente del partido en Soria-, Daniel de Fernando -Presidente Federal del CDS en Castilla y León-, José Moreira -Secretario General del CDS desde finales de la década de los 90’- y José Luis Gómez-Calcerrada -Secretario General en 1992-. Una mención especial merece Jorge Trías Sagnier quien amablemente nos permitió el acceso y consulta al fondo de Archivo Eduardo Navarro-Jorge Trías Sagnier (ENA), imprescindible para comprender la concepción política de España presente en Adolfo Suárez.

De forma paralela y como se ha señalado con anterioridad, se han llevado a cabo “entrevistas personales" con numerosos dirigentes del CDS. Debemos destacar la colaboración recibida de todas las personas con las que hemos contactado, accediendo sin reservas a colaborar con el presente proyecto. La recopilación de "fuentes orales" se

\footnotetext{
${ }^{17}$ En el marco de esta investigación, el autor ha elaborado el instrumento de control de la documentación de este fondo colaborando así con el AHPZ: "ES-CYL-AHPZa-49001 02.03.01.02. Unión de Centro Democrático (UCD)", Certificado del AHPZ, 20 de febrero de 2015.

18 Las fuentes parlamentarias y las publicaciones oficiales han sido consultadas en http://www.congreso.es y http://www.boe.es. Con el fin de facilitar la lectura del texto, se omitirán en adelante estas referencias.
} 
ha convertido de este modo en un pilar imprescindible para el desarrollo de la presente tesis doctoral, que al margen de su uso en el cuerpo de texto, ha permitido al autor completar de manera vívida una previa e imprescindible "composición de lugar" en un trabajo de esta magnitud. En las transcripciones se ha evitado la alusión a "terceros", y aunque se ha preferido la cita indirecta, se han usado las "citas textuales" cuando podían resultar significativas, sobre todo, a la hora de rescatar las vivencias y sentimientos de los protagonistas.

Como hemos señalado anteriormente, la prensa y concretamente, El País y $A B C$, han sido empleados para seguir cronológica y sistemáticamente la trayectoria del partido. Tres razones nos han llevado a esta decisión. En primer lugar y ya adelantada, la inexistencia de un archivo del CDS. En segundo lugar, el ser los periódicos más leídos y de mayor difusión en España durante el marco cronológico delimitado en la investigación. En tercer lugar, la manifiesta contraposición ideológica entre ambos, que convirtió al histórico rotativo monárquico, bajo la dirección de Luis María Anson en el, en expresión coloquial aunque elocuente de Antonio Alférez, "órgano campeón de la derecha española" y a El País, en el indiscutible órgano de información de la sensibilidad política progresista. No va a ser casual la basculación hacia el primero de los medios en cuanto al número de referencias totales a lo largo de la Tesis, debido en buena medida, a la confusa y polémica ubicación del CDS en el espectro de partidos. Nuestro análisis, que ha perseguido la exhaustividad en estos dos casos, ha sido complementado con la consulta de otros medios nacionales, Ya, Diario 16 o La Vanguardia, durante episodios electorales, debates sobre el estado de la nación u otros momentos considerados significativos durante el transcurso de la investigación ${ }^{19}$.

Asimismo, es preciso mencionar otros medios, como el semanario El Independiente o el diario El Mundo, fundados en 1987 y 1989, respectivamente; El Noticiero Universal, con unos cincuenta mil ejemplares de tirada media y concentrado mayoritariamente en la zona de Barcelona -clausurado en 1985- o el periódico de información económica Cinco Días. Completan nuestro análisis revistas y semanarios de información general entre las que destacamos ofreciendo datos de su tirada total

\footnotetext{
${ }^{19}$ El País, ABC y La Vanguardia han sido consultados en el período 2012-2016, salvo anotación expresa, a través de sus hemerotecas digitales omitiéndose con el fin de facilitar la lectura la alusión a las mismas a lo largo del texto. La prensa se ha citado incluyendo el nombre del periódico y la fecha, añadiéndose el autor y titular de la noticia siempre y cuando se ha considerado relevante para la investigación. El archivo de estos periódicos está disponible en: http://www.elpais.es/archivo; http://www.hemeroteca.abc.es; http://www.lavanguardia.com/hemeroteca.
} 
media: Cambio 16 (142.957, datos de 1987), Tiempo (150.311, 1987), Interviú (392.682, 1984) y Época (106.267, 1986). Asimismo, se ha recurrido cuando ha sido preciso a casi cuarenta títulos de prensa local pertenecientes a toda la geografía nacional.

La prensa ha sido consultada gracias a los siguientes archivos y hemerotecas: Hemeroteca de la Biblioteca Nacional de España, Hemeroteca de la Biblioteca de la Facultad de Ciencias de la Información de la Universidad Autónoma de Barcelona, Hemeroteca de la Caixa de Tarragona, Archivo Diario 16: Museo Adolfo Suárez y Transición-Fundación San Pablo CEU (Cebreros, Ávila) ${ }^{20}$, Archivo Linz de la Transición $^{21}$ y Archivo del Consejo General de Castilla y León (Valladolid). Debemos señalar también, la consulta de numerosos archivos digitales de prensa local a raíz de la proliferación de entrevistas o recordatorios de la figura de Adolfo Suárez por políticos y colaboradores en los últimos años.

Esta información ha sido complementada decisivamente gracias a boletines y periódicos, editados para su difusión entre la militancia por el Centro Democrático y Social. El más importante ha sido el Boletín de Participación y Difusión Cultural (1984-1985), rebautizado como Órgano de Información del Centro y Democrático y Social (1986-1991), de periodicidad mensual aunque irregular, editado por la dirección nacional y del que no se conserva, a día de hoy, en ningún archivo o biblioteca pública la serie completa. De forma complementaria hemos consultado boletines emitidos por las secretarías, provinciales o locales; todos ellos de carácter disperso, intermitente y discontinuo y en algunos lugares de aparición significativamente tardía ${ }^{22}$.

Por último, debemos señalar la producción estrictamente electoral del partido, desde programas a propaganda emitida en el contexto de elecciones. En este apartado han sido imprescindibles los fondos documentales, bibliográficos y hemerográficos de: Centre Documental de la Comunicació (CEDOC, UAB), Hemeroteca de la Biblioteca Nacional de España, Biblioteca del Pavelló de la República (UB), Bibliotecas Públicas de Castilla-La Mancha, Cantabria, Cataluña, Asturias, Castilla y León y Andalucía e Instituto Bibliográfico Aragonés. Para la documentación relativa al sistema de partidos

\footnotetext{
${ }^{20}$ De forma abreviada será citado como MAST.

${ }^{21}$ Archivo Linz de la Transición del Centro de Estudios Avanzados en Ciencias Sociales del Instituto Juan March de Estudios e Investigaciones. De forma abreviada será citado como Archivo Linz.

${ }^{22}$ Un catálogo completo de las publicaciones periódicas utilizadas se puede encontrar en el epígrafe dedicado a la relación de "Fuentes".
} 
portugués, trabajado en el sub-epígrafe 7.7. se ha abordado con los fondos de la Biblioteca Nacional de Portugal, Hemeroteca Municipal de Lisboa (Laranjeiras), Biblioteca-Museu Resistencia y Arquivo Nacional Torre da Tombo.

\section{Metodología}

El presente trabajo está académica y metodológicamente ligado a las investigaciones de Historia Actual y es deudor de una perspectiva multidisciplinar que nos ha llevado más allá de los estudios estrictamente históricos para valernos de herramientas propias de otras Ciencias Sociales como las Ciencias Políticas -análisis y estudio de los “partidos políticos"-, la Sociología -perfiles socio-profesionales y sociología electoraly las Ciencias de la Información -análisis de la "opinión publicada"_23.

La tesis doctoral ha precisado de una metodología de trabajo eminentemente cualitativa y ha tenido que lidiar con una paradójica situación, característica de las investigaciones circunscritas al ámbito de la Historia Actual. Por un lado, ha hecho frente a una sobreabundancia de fuentes generada por la "prensa de información general" y que ha sido abordada mediante la estrategia metodológica del análisis de contenido. Por otro lado, se ha topado con la escasez de fuentes producida por el objeto de estudio; nos referimos fundamentalmente a documentos de archivo. Esto nos ha obligado desde un principio a recurrir a "entrevistas personales", con las exigencias metodológicas ulteriores que ha implicado.

Las más de veinte mil referencias relativas a prensa de información general y publicaciones periódicas del CDS revisadas nos han impelido a dotarnos de una técnica de recogida de información que reuniera todos los requisitos científicos necesarios. Se ha buscado la mensurabilidad y la posibilidad de contrastar la información mediante la creación de un sistema de categorías que al emplearlo dentro del esquema general de una investigación permitiera “obtener información numérica y cuantificable a través del

\footnotetext{
${ }^{23}$ Como ha señalado Julio Aróstegui: "historiar lo coetáneo ha sido hasta ahora una tarea tomada con exagerada cautela por los historiadores, quedando ocupado, con mucha más dedicación, el espacio histórico presente por el 'periodismo de investigación' y sus sucedáneos, por los sociólogos empiristas y los analistas de la nueva cultura [...], los encuestadores, los economistas, los politólogos y los antropólogos y, a veces, por los políticos en ejercicio", ARÓSTEGUI, Julio: Historia vivida. Sobre la Historia del Presente, Madrid, Alianza Editorial, 2004, p. 23.
} 
contenido manifiesto de un documento" 24 . Esta información nos ha servido de base para la inferencia del desarrollo de determinados acontecimientos históricos y la secuenciación lineal y cronológica de la vida del partido. De otra parte, ha permitido la búsqueda del "sentido latente" presente en los textos -es decir, las tendencias de los mismos- y en consecuencia, la reconstrucción más fiel de las dinámicas políticas y opiniones de la época -siguiendo a N. Patricia Bautista en Proceso de la investigación cualitativa. Epistemología, metodología y aplicaciones (2011)-. La frecuencia de las noticias, la temática de las referencias, la aparición en portada o los editoriales han sido indicadores fundamentales para el trabajo con medios de comunicación.

Los medios de comunicación escritos se han tratado como fuentes de información histórica, pero también como decisivos agentes partícipes de la transformación de las actitudes y percepciones políticas. Hemos entendido de este modo, la prensa como un elemento decisivo en el proceso de "construcción de la realidad", determinación para la que desde las Ciencias de la Información se han desarrollado dos conceptos de enorme utilidad: agenda setting y framing - de acuerdo con las obras de Federico Boni, Teoría de los medios de comunicación (2008), Mar de Fontcuberta, La noticia. Pistas para aprender a percibir el mundo (1993), C. Rodríguez-Maribona y S. Berrocal, Análisis básico de la prensa diaria. Manual para aprender a leer periódicos (1998) y J. Guillamet y F. Salgado, El periodismo en las transiciones políticas: de la Revolución Portuguesa y la Transición Española a la Primavera Árabe (2014)-. Si el término de agenda setting hace alusión a la capacidad de los medios para, de forma jerarquizada, “poner en el orden del día” los asuntos que centrarán el debate y la opinión de los ciudadanos, el framing responde a la capacidad de los medios para seleccionar o enfatizar una u otra perspectiva, enfoque en sus publicaciones.

De acuerdo con los objetivos marcados y la estructura perfilada en los inicios de nuestra investigación, hemos elaborado una base de datos usada fundamentalmente para el análisis de la prensa en la que hemos consignado las siguientes categorías. En un plano general: fecha, publicación, autor, título, comentario/notas, página (portada) lugar y personaje (aludidos). Notas de identificación general que han sido acompañadas de dos subcategorías que nos han facilitado la interrelación de los datos recogidos. Las primeras se han agrupado en: CDS, Transición, Adolfo Suárez, AP, PSOE y PRD. En el

\footnotetext{
${ }^{24}$ BLANCO LEAL, Ma del Mar: Modelos de análisis para el estudio crítico de la prensa, Madrid, E.I.U., 2008, p. 77.
} 
segundo grupo se han identificado como subcategorías principales: Iglesia, Ejército, Financiación, Campaña Electoral, Programa Electoral, Dimisión, OTAN, Terrorismo, Política Comparada, Educación/Sanidad, Parlamento, Mociones de Censura, Pactos, Opinión, Congresos/Estructura, Altas/Bajas e Ideología. Del mismo modo, se ha trabajado con información cruzada de militantes y miembros del CDS que ha contenido datos relativos a su identificación personal -apellidos y nombre, fecha de nacimiento, profesión- con otros de carácter estrictamente político: trayectoria y militancia en otros partidos, cargos en el CDS, cargos institucionales y candidaturas.

Junto al análisis de la prensa y de los medios de comunicación, nos hemos servido también de conceptos propios de la politología. La categorización de los partidos políticos ha sido un ejercicio recurrente en el terreno de las Ciencias Políticas desde comienzos del s. XX. Un fértil terreno desde el punto de vista conceptual que nos ha guiado de forma decisiva en el desarrollo de nuestro trabajo aportándonos capacidad relacional. Caracterizaciones sobre la tipología de los partidos políticos como la de catch-all party o partidos-cartel, las reflexiones sobre el "centro político" o los análisis sobre el origen y desarrollo de los partidos político realizado por Angelo Panebianco Los partidos políticos, 1990-, han influido en los enfoques y la estructura del trabajo.

Si atendemos a estos estudios, el concepto de catch all-party nos ha proporcionado una sugerente categoría de análisis, ajustándose a nuestro objeto de estudio en su interrelación con las contiendas electorales, los grupos sociales y las instituciones públicas - marcos esenciales de nuestro trabajo-. Las características de este modelo de partido radican en la:

Drástica reducción del bagaje ideológico [...] incremento de la importancia otorgada a los recursos comunicacionales como consecuencia del fortalecimiento del liderazgo personalizado [...] disminución del papel y la influencia de los afiliados [...] pretensión de ganar votos en todos los grupos de población configuración de programas ambiguos y generalistas $^{25}$.

Estos partidos apelan a las "clases medias", ideológicamente enarbolan la eficacia y calidad de la gestión, generan tendencias centrípetas, y organizativamente se subordinan a la presencia e importancia del grupo parlamentario. Si seguimos los análisis de Van Biezen el conjunto de los partidos españoles posteriores a 1977, adquieren estas características e incluso encajarían con la categoría de partidos-cartel debido a su

\footnotetext{
25 RUIZ CONTERRAS, Marta: La imagen de los partidos políticos: el comportamiento electoral en España durante las Elecciones generales de 1993 y 1996, Madrid, CIS, 2007, p. 30.
} 
absoluta dependencia de fondos públicos y en consecuencia su búsqueda de puestos institucionales, como clave de supervivencia; una realidad que les hace estar en permanente campaña electoral (José María Magone, Contemporary Spanish Politics, 2009). Igualmente útiles, nos han sido los estudios comparados de Angelo Panebianco sobre los procesos de génesis e institucionalización de los partidos políticos y las categorizaciones llevadas a cabo, para el caso español por C. R. Aguilera de Prat (1988) y Manuel Ramírez, este último, en su obra El sistema de partidos en España (19311990) (1991).

Desde el punto de vista conceptual, también la noción de "memoria" ocupa un lugar central, especialmente, en la mirada que vamos a efectuar sobre el proceso de Transición. A lo largo del trabajo, se hará manifiesta de manera recurrente la forma en que la Transición, como acontecimiento histórico, ha sido "elaborado, transmitido y percibido" por la sociedad durante la década de los 80', materializándose en un discurso en constante transformación hasta nuestros días, como ha puesto de manifiesto entre otro, Josefina Cuesta Bustillo. Un proceso en el que ha sido fundamental el análisis del discurso presente en editoriales, columnas de opinión y crónicas de dos de las principales cabeceras periodísticas de la época, El País y $A B C$.

El acontecimiento y la memoria encuentran un punto de contacto en el recurso a las fuentes orales, abordadas mediante la técnica de investigación basada en entrevistas personales. Como han señalado diversos autores -Julio Aróstegui, Historia vivida: sobre la Historia del Presente (2004), Pilar Folguera, Cómo se hace historia oral (1994) o V. Núñez, D. Jorge y J. C. Pereira, "Les sources orales pour l'étude de la dimension internationale de la transition espagnole" en la Revue d'Histoire Diplomatique, (2013)-, aunque se convierten en un recurso fundamental para completar lagunas generadas por la documentación escrita, éstas deben estar sometidas a criterios de verificabilidad mediante el recurso a otras fuentes -orales o no-. Guiados por estas indicaciones, hemos considerado imprescindible metodológicamente el empleo de un cuestionario común, abierto a preguntas en todo caso complementarias

En nuestro caso, las entrevistas se han realizado siempre que ha sido posible de forma presencial y presentando previamente el cuestionario empleado en el encuentro; guión que no ha ejercido de modelo cerrado siendo ante todo marco y orientador de la conversación. El desarrollo propuesto en cada una de las entrevistas ha contemplado dos 
fines principales. En primer lugar, atesorar experiencias personales, vivencias y datos que nos ayudasen a completar la secuencia histórica del CDS e interpretar los acontecimientos ya registrados. En segundo lugar, recoger -gracias a las opiniones personales y valoraciones de los entrevistados-, tendencias y puntos de contacto entre la militancia del CDS acerca del significado del proyecto político representado por Adolfo Suárez.

Los cuestionarios seguidos en las entrevistas han recorrido los siguientes ítems: proceso de creación del CDS, ideología del CDS, proyecto político para España, funcionamiento interno durante la travesía del desierto y en el período posterior a 1986 (II Congreso), OTAN, Operación Roca, campaña electoral de 1986, alternativa de gobierno, política de pactos, descontento y división interna (III Congreso), dimisión de Adolfo Suárez (elecciones municipales y autonómicas de 1991 y IV Congreso) y acontecimientos posteriores (V-VI Congreso).

\section{Estructura}

La estructura de la presente tesis doctoral es eminentemente cronológica. En este sentido nos alejamos del análisis longitudinal de categorías aislables y definibles ex tempore, para adentrarnos en un enfoque que pretende ser ante todo histórico. Debemos explicitar esta intención debido al carácter poliédrico que presenta el estudio de un partido político, en este caso, el Centro Democrático y Social. Nuestro trabajo aspira a complementar desde el punto de vista de la disciplina histórica un camino que actualmente presenta un recorrido más intenso y fructífero en terrenos como el de la Ciencia Política. De ahí que nuestro análisis haya puesto el acento en el acto de emisión de los discursos políticos y la materialidad de los mismos, -es decir, las decisiones, estrategias y políticas concretas de los diferentes grupos-, así como las reacciones que han generado dando forma a los distintos acontecimientos históricos. Las categorías de izquierda, derecha y centro o las diferentes teorías sobre el voto son perfectamente útiles y válidas en nuestro análisis, — como se observa en la realidad histórica—, sin embargo, hemos trabajado con estos conceptos asumiendo su volubilidad en manos de los distintos agentes históricos. Fruto de este marco teórico general, hemos procedido a la estructuración cronológica de la Tesis Doctoral en dos grandes partes, que concuerdan 
con dos etapas netamente diferenciadas de la vida del partido ${ }^{26}$. El punto de inflexión es la importancia que adquiere el partido a partir de 1986, pasando de dos a diecinueve diputados, episodio que transformó radicalmente la experiencia política del CDS. Cada una de estas etapas ha sido dividida en capítulos, cinco y seis respectivamente, y estos a su vez en subepígrafes que oscilan entre los cuatro y los siete por capítulo.

En el primer capítulo nos sumergimos en las primeras manifestaciones del suarismo como corriente política organizada, todavía en el seno de UCD, hasta la formación de una opción netamente diferenciada, el CDS. Para ello, nos acercaremos a su ideario político y algunos de sus posicionamientos públicos más significativo. En segundo lugar, abordaremos las decisivas elecciones generales de 1982, en las que la campaña y la presentación del programa electoral se van a interrelacionar con la definitiva estructuración del partido en un agitado contexto de competencia política. En tercer lugar, y sin perder de vista los diferentes comicios electorales -caso de las elecciones municipales y autonómicas de 1983- describiremos las claves, tanto teóricas como prácticas, que explican la vida interna del CDS desde 1983 hasta 1986, período conocido como "travesía del desierto". El cuarto capítulo está dedicado a la descripción y análisis de la actuación del CDS en la vida política española durante la II Legislatura (1982-1986). Nos referimos, de una parte, a sus actuaciones y posicionamientos parlamentarios y de otra, a la competencia por el espacio de centro con el PSOE, la CP y la Operación Roca. El capítulo quinto está dedicado al año 1986, especialmente a dos hechos decisivos: el referéndum sobre la OTAN y las elecciones generales de junio 1986, analizadas estas últimas por su decisiva importancia de forma pormenorizada.

La segunda parte de la presente tesis doctoral arranca en el verano de 1986. El capítulo sexto traza el nuevo emplazamiento del CDS como partido de oposición. De este modo, nos detendremos en sus principales actuaciones parlamentarias y su papel en el proceso de reordenación del centro y la derecha española -en el contexto de crisis de AP y fracaso de la Operación Reformista-. Tras el éxito electoral de 1986, el CDS vivió un profundo proceso de reestructuración y renovación que afectó a su órganos de

\footnotetext{
${ }^{26}$ De acuerdo con el análisis del secretario general del partido José Ramón Caso en conversaciones con el autor en Madrid, 19 de noviembre de 2014. De cualquier forma, resulta igualmente elocuente la clasificación del profesor Quirosa-Cheyrouze generando otro punto de inflexión en 1989, a raíz de la política de pactos centrista y el comienzo de su declive electoral, QUIROSA-CHEYROUZE y MUÑOZ, Rafael: "El Centro Democrático y Social. Auge y caída de un proyecto político (1982-1996)" en MATEOS LÓPEZ, Abdón y SOTO CARMONA, Álvaro (dirs.): Historia de la época socialista: 19821996, Madrid, Ed. Sílex, 2013, pp. 405-430.
} 
gobierno, su dimensión internacional y su búsqueda de definición ideológica; aspectos que veremos a lo largo del capítulo séptimo. A continuación -capítulo octavo-, recorreremos el final de la III Legislatura. Una vez más, seguiremos el ritmo de las diferentes citas con las urnas y particularmente las consecuencias de los resultados de las elecciones municipales y autonómicas de 1987. Las dificultades del CDS para su consolidación como alternativa - como puso de manifiesto el 14-D (1988)-, y los pactos con el PP firmados en 1989 son los ejes de nuestra argumentación que se cierra con las elecciones generales de 1989. En el capítulo noveno, abordamos la nueva correlación de fuerzas generada en la IV Legislatura en la que el CDS, que condujo al acercamiento de los "suaristas" al PSOE y numerosas fracturas internas, puestas de manifiesto en el III Congreso. El capítulo décimo está dedicado al análisis del final político de Adolfo Suárez (1991) y el fin de la representación institucional, al menos a nivel nacional, del CDS. Todo ello, condujo a un prolongado periodo de decaimiento y la definitiva desaparición del partido en 2005 -periodo que recorreremos en el epílogo final-.

En el capítulo undécimo se ha seguido una estrategia de análisis transversal en la que se ha caracterizado a Adolfo Suárez desde el punto de vista histórico, en un momento en el que todavía permanecía en la política activa, con todos los condicionantes que ello suponía. De este modo, se ha analizado el tratamiento mediático de su papel en la Transición, su influencia en el ámbito internacional y la capacidad del CDS y Adolfo Suárez para elaborar un discurso coherente y cohesionado sobre la Transición y el conjunto de la Historia Contemporánea de España.

Como hemos podido ver, las circunstancias que rodean todos estos episodios tienen que ver tanto con la propia dinámica interna del CDS, como con la influencia de factores externos, especialmente, el proceso de reestructuración del sistema de partidos a la derecha del PSOE tras el ocaso de UCD.

De este modo, cada de una de estas etapas analizamos aspectos que tienen que ver con la creación, organización y estructuración del partido (capítulos: 1, 2, 3, 7 y 10). En estos capítulos ha ejercido una poderosa influencia el enfoque del politólogo italiano Angelo Panebianco (1990) que en su modelo genético identificaba la formación de los partidos políticos a partir tres factores: su implantación por el territorio (difusión/penetración), la ausencia o presencia de elementos institucionales externos y la presencia de liderazgos carismáticos. Igualmente determinante es el concepto de 
"institucionalización” por el cual el partido logra asentar una estructura firme, independiente y autosuficiente capaz de trascender el impulso original de su creación; tensión que ha permanecido latente en nuestro trabajo.

De otra parte, se han estudiado los rasgos ideológicos y programáticos del partido, tomando como sustrato teórico la noción de "espectro ideológico" y competencia espacial; teoría clásica desarrollada por Anthony Downs y actualizada por autores como Giovanni Sartori -Partidos y sistemas de partidos: marco para un análisis, 1998-. En este sentido, hemos analizado la caracterización ideológica del CDS y Adolfo Suárez en el centro político a propósito de las contiendas electorales, sus posicionamientos parlamentarios -en cuestiones decisivas, cleavages, de la contemporaneidad españolay el ejercicio de la oposición, entre los partidos hegemónicos de derecha e izquierda, Alianza Popular y PSOE (capítulos: 2, 4, 5, 7, 8 y 9).

Hemos comenzado la presente introducción reflexionando, junto a Gregorio Morán, sobre el contraste existente entre la escasa atención dedicada a esta etapa de la vida de Adolfo Suárez y la magnitud de la misma. Sin embargo, en agosto 1984, intelectuales de signo tan opuesto como Manuel Vázquez Montalbán y Ricardo de la Cierva desde la tribuna del diario El País y $Y a$ respectivamente, aventuraban para un futuro próximo una copiosa retahíla de "tesis doctorales" centradas en el personajes. A sus antiguas responsabilidades políticas durante la Dictadura, su inesperado nombramiento como Presidente del Gobierno en 1976, su indiscutible éxito en la conducción de la Transición democrática o su sorprendente dimisión en enero de 1981 había que añadir la fundación del Centro Democrático y Social en 1982, aspecto este último que terminaba por conformar un rompecabezas que se les antojaba a los autores cada vez más complejo e indescifrable. Un desafío lanzado entre bromas y veras y ante al cual, humildemente, hemos decidido recoger el guante. 

PARTE 1:

EL REGRESO DE ADOLFO SUÁREZ: CREACIÓN DEL CDS, “TRAVESÍA DEL DESIERTO” Y ELECCIONES GENERALES DE 1986 



\title{
Capítulo 1:
}

\section{La creación del Centro Democrático y Social (CDS)}

\author{
"Suárez stands to the left of most of the party [UCD] \\ $[\ldots]$ has been negotiating to keep the right wing from \\ defecting [...] Suárez can be very persuassive when \\ dealing with individuals but has trouble being so \\ convincing with groups [...] Suárez does not appear to \\ be firmly wed to any political philosophy, ideology, or \\ concrete set of ideas, but he is a political infighter par \\ excellance" .
}

A lo largo del año 1982, el sistema de partidos español sufrió una profunda transformación como consecuencia de la interrelación de dos factores: el proceso de descomposición de UCD y la apabullante victoria socialista en las elecciones generales de 1982. En el plazo de apenas seis meses surgieron, con mayor o menor fortuna, numerosos proyectos políticos al hilo de sucesivas escisiones del partido en el gobierno: el Partido Demócrata Popular (PDP), liderado por el democristiano Óscar Alzaga, el Partido Demócrata Liberal (PDL) de Antonio Garrigues Walker y el Partido de Acción Democrático (PAD) del socialdemócrata Francisco Fernández Ordóñez, sin mencionar los diferentes partidos regionales que fueron creados a lo largo de toda la geografía española, caso del Partido Riojano Progresista $(\mathrm{PRP})^{2}$. El hito más significativo de aquel prolongado episodio de descomposición, -"the most crushing blow"3- fue la formación del CDS por parte de Adolfo Suárez. Según J. R. Hopkin: "la partida de Adolfo Suárez para formar el Centro Democrático y Social en julio de 1982 puede considerarse el acontecimiento emblemático del desplome de UCD”4 . Con esta decisión,

\footnotetext{
${ }^{1}$ Informe de julio de 1982: "Spain and a Weakened UCD: Downhill Toward an Election", CIA-RDP83, Archivo CIA. Disponible en: http://www.cia.gov. Fecha de consulta: 25 de enero de 2017.

${ }^{2} \mathrm{Si}$ la formación e integración en un nuevo partido fue la opción seguida por algunos miembros de UCD, la mayor parte de políticos centristas, especialmente en sus cargos autonómicos, provinciales y locales, decidieron pasar a formar parte de Alianza Popular, partidos regionales de centro-derecha (UPN, PAR, UV) o crear plataformas políticas de independientes cercanas a ésta.

${ }^{3}$ NIELSEN, John: "Spain' socialists on the move", Time, 25 de octubre de 1982.

${ }^{4}$ HOPKIN, Jonathan Richard: El partido de la transición. Ascenso y caída de la Unión de Centro Democrático, Madrid, Acento, 2000, p. 282.
} 
Adolfo Suárez, "clavillo del abanico" de UCD en palabras de Leopoldo Calvo-Sotelo", parecía condenar a muerte la plataforma política con la que había conseguido la presidencia en 1977 y 1979.

La creación del CDS, en el verano de 1982, fue el resultado de un complejo proceso de "decantación" de los diversos grupos y sectores de la UCD conocidos en los medios y en el seno del partido como "suaristas", Para comenzar, primero perfilaremos y definiremos lo que en la época se conocía como suarismo: su génesis, sus miembros y sus posicionamientos. En segundo lugar, abordaremos las principales causas de ruptura de este "grupo" con la dirección política de UCD, así como con el resto de familias?. Por último, es preciso describir las acciones que dieron forma al CDS en las últimas semanas de julio del 82': desde las primeras reuniones informales del entorno personal de Adolfo Suárez hasta la presentación oficial en el Hotel Ritz de Madrid el día 31 de julio.

Junto a esta exposición cronológica (suarismo/ruptura/formación), analizaremos luego las líneas maestras del nuevo proyecto político, -el "Manifiesto del Ritz" o "Manifiesto Político" y su lectura de algunos de los hitos del ejecutivo de Calvo-Sotelo (LOAPA y OTAN)- y la subsiguiente reacción mediática a su puesta en escena. Finalmente, complementaremos la visión de conjunto, con el estudio detallado del tránsito de UCD al CDS en una provincia castellano y leonesa.

\section{1. El suarismo en la Unión de Centro Democrático (1979-1981)}

El término suarismo fue acuñado en el argot periodístico durante la época de gobierno de Suárez y usado con profusión desde 1979. Ha sido empleado para aludir a diversos aspectos, no siempre coincidentes, cuyas similitudes podemos reducir a las connotaciones peyorativas del vocablo. Por un lado, se ha hecho mención, de forma general, a los continuismos y herencias existentes del régimen anterior. El periodista

\footnotetext{
5 “Adolfo Suárez, artífice de la transición e insigne fundador de UCD; Adolfo Suárez, máximo, último cismático tránsfuga de UCD”, CALVO-SOTELO, Leopoldo: Memoria Viva de la Transición, Barcelona, Plaza \& Janés, Barcelona, 1991, p. 90.

${ }^{6}$ La expresión "decantación" ha sido usado por un alto cargo del CDS, Interview undertaken by Richard Gunther in 1983 (june), Archivo Gunther (AG).

7 Sobre la disolución centrista los estudios más exhaustivos, desde un punto de vista general, corresponden a ALONSO CASTRILLO, Silvia: La apuesta del centro: una historia de UCD, Madrid, Alianza Editorial, 1996; HOPKIN, Jonathan Richard: El partido de la transición...; HUNEEUS, Carlos: La Unión de Centro Democrático y la Transición a la Democracia en España, Madrid, CIS, 1985.
} 
Javier Figuero definía el suarismo como "democracia post-franquista", una práctica política que capitalizaba muchos de los elementos de la dictadura, -como se vio en el control burocrático de las elecciones del 77' o en la formación de $\mathrm{UCD}^{8}$ - y basaba su discurso electoral en el "miedo" a una nueva Guerra Civil y el comunismo ${ }^{9}$. Por otra parte y en estrecha relación con la definición precedente, el suarismo servía para referirse a la manera autoritaria de ejercer el liderazgo político por parte de Suárez, es decir, al margen de las estructuras propias del partido: "evocador sin duda de actitudes mucho más próximas al personalismo autoritario que al teórico distanciamiento del líder democrático" ${ }^{\prime 10}$. Finalmente, podemos hablar del suarismo como corriente diferenciada dentro de UCD, siendo esta la significación del término que centrará nuestra atención y que vamos a exponer a continuación.

Las primeras referencias al suarismo como grupo o facción nacen en el mismo momento en el que se produjo la disolución en UCD, de todos los partidos y grupúsculos que lo habían dado forma, en diciembre de $1977^{11}$; Suárez ejercía desde su fundación la presidencia, tanto del partido como del gobierno. Desde 1979, la progresiva contestación interna que vivió Suárez por parte de los barones de las distintas familias fue haciéndose cada vez más permeable al partido y al gobierno y obligó a muchos líderes centristas, hasta ese momento ajenos a estas disputas, a posicionarse. A mediados de 1980, el suarismo encuadraba en la dirección centrista a: José Pedro PérezLlorca, Agustín Rodríguez Sahagún, Rafael Arias-Salgado, Jaime García Añoveros, Félix Pérez Miyares y Enrique Lamo de Espinosa ${ }^{12}$. Podemos añadir a Rafael Calvo Ortega, secretario general de UCD desde mayo de 1980, a Fernando Abril Martorell, -a pesar del distanciamiento producido durante el verano de ese año ${ }^{13}-$, y a multitud de

\footnotetext{
${ }^{8}$ FIGUERO, Javier: UCD, la empresa que creó Adolfo Suárez, Barcelona, Grijalbo, 1981, p. 298 y ss.

${ }^{9}$ Figuero lo pone en relación con el "franquismo sociológico". El papel de la Guerra Civil durante la Transición, -destacar la fecha de edición de la obra de Figuero, el año 1981-, ha generado un debate con un recorrido muy amplio en la historiografía española desde la publicación de AGUILAR FERNÁNDEZ, Paloma: Memoria y olvido de la Guerra Civil, Madrid, Alianza, 1996.

${ }^{10}$ FIGUERO, Javier: $U C D \ldots$... p. 21. Sobre la creación, con objeto de descalificación política del término "felipismo", véase, COTARELO, Ramón: La Conspiración. El golpe de estado difuso, Barcelona, Ediciones B, 1995, p. 234 y ss.

${ }^{11}$ Pilar Urbano escribía a propósito de la disolución de los partidos fundacionales en UCD en URBANO, Pilar: "Suárez ya tiene suarismo", $A B C, 04$ de diciembre de 1977.

12 CABELlOS, Carmelo: “Acoso y caída de Adolfo Suárez" en SINOVA, Justino, (ed.): Historia de la Transición, Madrid, Grupo 16, 1984, p. 640.

${ }^{13}$ Antonio Lamelas sitúa la "verdadera" dimisión de Abril hacia mayo de 1980, a propósito de la moción de censura del PSOE, tras la que Suárez le atribuyó algunas deslealtades, según el autor injustificadas. Lamelas entrevé la causa de este distanciamiento en la enemistad tanto de los "barones" como de los "fontaneros" hacia Abril Martorell en LAMELAS, Antonio: La Transición en abril: Una biografía política de Fernando Abril Martorell, Madrid, Ariel, 2004. En palabras de Abril Martorell: "las cosas no
} 
líderes regionales desde Enrique Sánchez de León a Lorenzo Olarte ${ }^{14}$. El nexo entre todos ellos era la defensa del liderazgo de Suárez y el hecho de no estar integrados en ninguna de las familias más o menos diferenciadas con que contaba el partido, socialdemócratas, liberales, azules y democristianos- $-{ }^{15}$, y se asimilaba habitualmente, hasta bien entrado el año 1981, al llamado "aparato" del partido u "oficialismo"16.

A lo largo de 1980, se recrudecieron las tensiones en el seno de UCD ocasionando un significativo descenso de la aceptación del partido, y particularmente, del presidente de gobierno en la opinión pública. En un contexto de tremenda tensión política como consecuencia del terrorismo de ETA y los rumores sobre posibles golpes de estado se generó una fuerte campaña mediática y política, liderada por el PSOE y dirigida contra el presidente de gobierno, -la operación "de acoso y derribo" ${ }^{\prime 1}$-. Las pugnas políticas entre los líderes de UCD desembocaron en dos crisis ministeriales, llegándose a contestar abiertamente el liderazgo de Suárez en la reunión de la Comisión Permanente

se rompen de golpe, poco a poco van dejando de ser estrechas. Algunos le calentaron la cabeza y, como yo estaba realmente agotado, no tuve interés en defenderme. No tenía excesivo interés en continuar en el Gobierno y dejé que la situación se resolviese por sí misma... estaba saturado y muy cansado. Por todo esto presenté la dimisión en julio de 1980", entrevista a Fernando Abril Martorell, en JULIÁ DÍAZ, Santos, PRADERA, Javier y PRIETO, Joaquín (eds.): Memoria de la Transición, Madrid, Taurus, 1996, p. 210 .

${ }^{14}$ En cualquier caso, no debemos olvidar que Adolfo Suárez formaba parte del llamado grupo de los “independientes" en las Cortes Orgánicas de 1976, una expresión un tanto equívoca para referirse a los miembros del aparato estatal franquista. En este sentido, resulta prácticamente imposible vincular una ideología a este grupo, al margen de su formación burocrática y administrativa durante la Dictadura y las realizaciones concretas llevadas a cabo durante la Transición como veremos en páginas posteriores. Comenta Alfonso Guerra, en el prólogo a la biografía de Fernando Abril que su filosofía política respondía al "posibilismo [...] más de una vez me dijo: lo que no esté en tus manos resolver debe dejar de preocuparte, para dedicar tus esfuerzos a lo que puedas solucionar" en LAMELAS, Antonio: $L a$ Transición en abril..., p. 15.

15 Al margen de las estructuras políticas de UCD, bajo el término suarismo, cabe incluir a los colaboradores más estrechos de Suárez, que prestaban sus servicios en presidencia de gobierno, -los llamados "fontaneros" de la Moncloa-, entre los que podemos citar a: José Luis Graullera, Manuel Ortiz, Josep Melià, José Coderch o Aurelio Delgado, Lito. Asimismo, en un plano más político e intelectual y algo distanciado de Suárez durante los años centrales de la Transición debemos añadir a Eduardo Navarro. NAVARRO, Eduardo: La Sombra de Adolfo Suárez, Barcelona, Plaza \& Janés, 2014; ORTIZ, Manuel: Adolfo Suárez y el bienio prodigioso, Barcelona, Planeta, 2006; GONZÁLEZ DE VEGA, Javier: A la sombra de Adolfo Suárez, Barcelona, Plaza \& Janés, 1996. Sin embargo, la relación que van a mantener todos ellos con Adolfo Suárez a lo largo de los años posteriores va a ser más personal y profesional que política, excediendo los límites de este trabajo, aunque no por ello su interés académico, véase, CONTRERAS, Emilio: Suárez. Acoso y derribo, Madrid, La Esfera de los Libros, 2016, p. 314 y ss.

${ }^{16}$ En el contexto del I Congreso de UCD, octubre de 1978: "el naciente suarismo aparece representado por Abril, Calvo Ortega Calvo-Sotelo, Pérez-Llorca, Rodríguez-Sahagún, Sánchez Terán, Sánchez de León, Carlos Sentís y Jesús Viana. Repasando estos nombres, José Luis Graullera y yo llegamos a la conclusión de que, de todos ellos, no se sacaban ni cuatro suaristas de verdad" en NAVARRO, Eduardo: La sombra..., p. 248.

17 Sobre la incidencia de estos aspectos en el "alejamiento" de Suárez de UCD puede leerse, FERNÁNDEZ AMADOR, Mónica y QUIROSA-CHEYROUZE Y MUÑOZ, Rafael: "La creación del Centro Democrático y Social en 1982" en QUIROSA-CHEYROUZE Y MUÑOZ, Rafael, (ed.): Los partidos en la Transición, Madrid, Biblioteca Nueva, 2013, pp. 201-219. 
del partido celebrada en julio de aquel año, -la célebre reunión de "La Casa de la Pradera"- ${ }^{18}$. Para la mayor parte de investigadores y biógrafos de Suárez, 1980 fue el año más crítico de su presidencia ${ }^{19}$. Junto a los graves problemas nacionales, entre los que sobresalía el recrudecimiento del terrorismo de ETA, Suárez debía hacer frente al hostigamiento de prácticamente todos los poderes del país - la fuerte oposición socialista, el acoso mediático, la presión de los llamados "poderes fácticos"- incluido, su partido (crisis de gobierno y elecciones de portavoz del grupo parlamentario) ${ }^{20}$.

A partir de ahí, los acontecimientos se precipitaron con inusitada celeridad: dimisión de Suárez en enero de 1981, celebración del II Congreso de UCD en Palma de Mallorca (del 6 al 8 de febrero) y golpe de estado del 23-F. En este contexto de vertiginosa transformación del protagonismo político de Suárez, -que abandonaba simultáneamente la presidencia del gobierno y del partido-, se dio un nuevo paso en el proceso de delimitación del llamado suarismo. Por ello, siguiendo el testimonio y la interpretación de políticos cercanos al CDS, nos vamos a referir a algunos episodios que tuvieron lugar en este período y que consideramos particularmente relevantes para comprender la futura formación del CDS: la desestabilización del Grupo Parlamentario, la posición de Suárez tras su dimisión y la situación de UCD tras la celebración del Congreso de Palma ${ }^{21}$.

Quizá el episodio más sobresaliente en la larga crisis de UCD, se vivió en la elección de portavoz del Grupo Parlamentario (GP-UCD) en el otoño de 1980, en la que el candidato de Suárez, Santiago Rodríguez Miranda, fue derrotado por Miguel Herrero de Miñón, diputado del sector "crítico" con la gestión presidencial"22. La votación, celebrada el 14 de octubre de 1980, deparó el contundente resultado de 105 frente a 41

\footnotetext{
${ }^{18}$ Durante aquel encuentro cuestionaron abiertamente la autoridad de Suárez: Fernández Ordóñez, Martín Villa, Lavilla, Garrigues Walker y Álvarez de Miranda, mostrándose más ambiguo Cabanillas. Por su parte le apoyaron, Arias-Salgado, Calvo Ortega y Pérez Llorca, FUENTES ARAGONÉS, Juan Francisco: Adolfo Suárez. La historia que no se contó, Barcelona, Planeta, 2011, p. 338.

${ }^{19}$ Charles Powell se refiere a este como "el más duro en la vida política de Suárez" en POWELL, Charles T.: "Adolfo Suárez. El presidente que se hizo a sí mismo" en BONNIN, Pere y POWELL, Charles T.: Adolfo Suárez, Barcelona, Ediciones B, 2004, p. 168.

${ }^{20}$ Sobre la evolución psicológica de Suárez en este período, véase, CERNUDA, Pilar: El síndrome de la Moncloa, Barcelona, Espasa, 2001, pp. 26-41.

${ }^{21}$ No contamos con nueva documentación sobre este episodio, para el que según Aurelio Delgado, "queda poco más que decir", Entrevista con Aurelio Delgado, 19 de diciembre de 2014 (Ávila). En cualquier caso, hemos constatado ciertas constantes en militantes y cargos del CDS que nos parecen bastante significativas y vamos a exponer en las siguientes páginas; es necesario tener en cuenta que el CDS surge, entre otras razones, por una determinada interpretación de los acontecimientos políticos recientes.

${ }^{22} \mathrm{La}$ elección del portavoz parlamentario desde el punto de vista de los "críticos" puede verse en HERRERO DE MIÑ́́N, Miguel: Memorias de estío, Madrid, Temas de Hoy, 1993, p. 216-7.
} 
$\operatorname{votos}^{23}$. Numerosos miembros de la dirección del CDS han insistido en la importancia de la pérdida del control del Grupo Parlamentario a la hora de comprender la dimisión de Adolfo Suárez; un acontecimiento que debilitaba enormemente su posición al frente de la Presidencia de Gobierno: "si yo siempre les digo: si Uds. no eligen un presidente en unas elecciones; eligen unos diputados, que a su vez eligen un presidente, líder de un partido" ${ }^{24}$. La persona que mejor conocía UCD en aquellos momentos, Rafael AriasSalgado, comenta:

Por la base se estaba haciendo un partido [...] que no se estaba haciendo en el grupo parlamentario [...] y ahí es donde estaba el conflicto interno de UCD. Adolfo Suárez tuvo una ocasión de controlar en mayor medida el grupo parlamentario [elecciones de 1979] y él en un acto de generosidad les respetó a todos ${ }^{25}$.

Desde el punto de vista del propio Suárez el problema fundamental de UCD era el grupo parlamentario, "compuesto por personas muy preparadas, con grandes ambiciones, convencidas de que su dedicación política les ocasionaba perjuicios económicos -básicamente por el lucro cesante-" ${ }^{26}$; Suárez era consciente de que "sin el control del grupo parlamentario no se tenía poder”27. Para José Antonio Pérez González, miembro de UCD y CDS en Madrid, un síntoma de esta preocupación fue el hecho de

\footnotetext{
${ }^{23}$ El País, 15 de octubre de 1980.

${ }^{24}$ Alto cargo nacional del CDS, Interview undertaken by Richard Gunther in 1983 (june), AG. Se ha barajado un ulterior paso en esta hipótesis; una supuesta iniciativa, gestada en el sector crítico del partido, que permitió la recopilación de firmas de parlamentarios de UCD que se adherirían al PSOE en una próxima moción de censura, ABELLA, Carlos, Adolfo Suárez. El hombre clave de la Transición, Madrid, Espasa-Universidad, 2005. Algunos líderes posteriores del CDS corroboraron esta idea, al parecer transmitida por el propio Suárez: "la versión [sobre su dimisión] que él da es que Felipe González le dijo que un grupo de 40, 50 diputados de UCD votarían a favor de una moción de censura, esa es la versión que da Suárez", en Interview undertaken by Richard Gunther in 1983 (june), AG. El propio Suárez en 1984, en Belmonte reveló que su dimisión se debió al descenso de popularidad, la presión del Ejército, la banca y las grandes empresas y "haber temido el triunfo de una moción de censura con el apoyo de un sector hostil hacia él dentro de la UCD", según informaba EFE, "Suárez propone un nuevo Pacto de la Moncloa", $A B C, 02$ de abril de 1984.

${ }^{25}$ Entrevista con Rafael Arias-Salgado, 09 marzo de 2015 (Madrid). Esta opinión fue comunicada por el propio Arias-Salgado en el Comité Ejecutivo Nacional de UCD el 02 de julio de 1982, quien tras realizar un análisis de la dimensión histórica del partido y rechazar tajantemente el alineamiento con posiciones conservadoras concluía: "el planteamiento precedente [...] no es hoy compartido, sin embargo, por un sector del partido que, a juzgar por los últimos resultados electorales internos, es minoritario pero tiene especial incidencia en el Grupo Parlamentario cuya composición no refleja adecuadamente la voluntad mayoritaria del Congreso de Palma ni de las Asambleas Provinciales del Partido. Ahí radica, sin duda, una de las principales causas de la actual crisis interna", Caja 257, Legajo 101, Archivo General Consejo Castilla y León (AGCYL).

26 "Transcripción del encuentro con Adolfo Suárez", 07 de mayo de 1981, Archivo de José Antonio Pérez González. Para Aurelio Delgado la pérdida del control sobre el Grupo Parlamentario fue "el punto de inflexión en su caída", CONTRERAS, Emilio: Suárez..., p. 240 y ss.

${ }^{27}$ Ibid.
} 
"[hacer] firmar [una] [...] renuncia sin fecha" a todos los candidatos electorales de 1979, "que aunque no era exigible, suponía un compromiso ético"28.

A finales de enero de 1981, Suárez decidía dimitir como presidente del gobierno y de UCD, y tras ponerlo en conocimiento de su familia, los líderes de su partido y la Casa Real, lo anunció en TVE el día 29. Para Aurelio Delgado y José Ramón Caso su dimisión fue un ejercicio de responsabilidad, propia de un hombre estado, y añade Caso, ante las tensiones que se vivían en UCD, "la dimisión es un intento de que subsista UCD, un partido de centro [...] Leopoldo Calvo-Sotelo era un hombre bien visto por los poderes económicos" 29 . Y es que, para muchos de los que recalaron posteriormente en el CDS, las presiones sobre Suárez y sobre UCD habían partido del mismo impulso: recomponer políticamente el espacio de centro-derecha. En el plano psicológico, Aurelio Delgado recuerda como desde hacía unos meses Adolfo Suárez se encontraba profundamente cansado, -un cansancio acumulado por el exigente ritmo de trabajo impuesto desde 1976-, y en cierto modo, triste y decepcionado por el reguero de desencuentros y maniobras producidas en su entorno. Abel Hernández transcribe un significativo comentario de Fernando Alcón, amigo íntimo de Suárez, cuando le comunicó su intención de dimitir: "has tardado mucho en hacerlo"30. A propuesta de Suárez, la dirección del partido eligió a Leopoldo Calvo-Sotelo como sucesor en la presidencia del gobierno, quien fue ratificado en el II Congreso de UCD. No existía en ese momento, recuerda Aurelio Delgado, ninguna perspectiva o proyecto concreto de futuro $^{31}$.

\footnotetext{
${ }^{28}$ Ibid.

${ }^{29}$ Entrevista con José Ramón Caso, 19 de noviembre 2014 (Madrid).

30 "Al presidente Suárez no lo echan ni el Rey, ni los militares; lo echan los "barones" de UCD y el tremendo acoso de los socialistas [...] Entonces fue acribillado y destrozado por todos: la banca, la Iglesia, la prensa, los militares, la oposición y los mandarines de su propio partido [...] Y el Rey le quitó la mano del hombro. En el origen de su dimisión influye no poco el cambio de posición de su amigo Fernando Abril Martorell”, HERNÁNDEZ, Abel: Suárez y el rey, Madrid, Espasa, 2011, p. 162 y ss.

${ }^{31}$ Entrevista con Aurelio Delgado, 19 de diciembre de 2019 (Ávila). La afirmación de A. Delgado está en abierta polémica con una hipótesis que ha contado con un fuerte eco mediático y que alude a una "solución temporal" de Suárez. Según esta teoría, la dimisión habría sido un paso más dentro de un "jugada política" de amplia envergadura, cuya estrategia era la de retornar tiempo después por petición de su propio partido y con un mayor respaldo de la opinión pública. Carlos Abella sostiene que la idea de Suárez era hacer pública su dimisión en la inauguración del II Congreso de Palma, el cual a priori, se iba a desarrollar desde el 29 de enero, el mismo día de la emisión en RTVE del famoso discurso de Suárez; una estrategia finalmente frustrada, véase, ABELLA, Carlos: Adolfo Suárez.... La hipótesis de la "solución temporal" puede verse también en HOPKIN, Jonathan R.: El partido de la transición...; ALONSO CASTRILLO, Silvia: La apuesta... La idea de que Calvo-Sotelo era un "hombre de paja" o de "transición" usado por Suárez para una posible vuelta a la política en 1983 es sostenida por autores tan dispares como MORÁN, Gregorio: Ambición... o HERRERO DE MIÑÓN, Miguel: Memorias... Javier Cercas ve en la dimisión un gesto ético conducente a la obtención de una nueva legitimidad moral con la
} 
La celebración del II Congreso de UCD en Palma de Mallorca sirvió para escenificar nuevamente la fractura abierta en el partido. Se presentaron dos candidaturas en la elección de la mesa del congreso, de presidencia del partido y de vocales de la ejecutiva: los "críticos" frente a los "oficialistas" 32 . Los "críticos" eran democristianos, liberales y otros sectores, liderados por Landelino Lavilla, y descontentos con el estilo presidencialista de Suárez. Los "oficialistas" se correspondían con el "aparato del partido", es decir, "suaristas", socialdemócratas e independientes/azules. El triunfo del "aparato" u "oficialismo", con aproximadamente un 60\% de los votos en cada una de las votaciones, permitió a Agustín Rodríguez Sahagún alcanzar la presidencia del partido y a Rafael Calvo Ortega continuar en la Secretaría General ${ }^{33}$. Por primera vez, los cargos de presidente del gobierno y del partido quedaban en manos distintas. Asimismo, el "aparato" controlaba el comité ejecutivo y buena parte de las asambleas provinciales, incluso después del proceso de renovación de cargos en las mismas en julio de $1981^{34}$. La división de UCD no ocultaba sin embargo, el apoyo mayoritario de las bases a Adolfo Suárez, quien fue el vocal de la ejecutiva elegido con el mayor número de votos, en un congreso, en el que también fue designado Presidente de Honor.

En este contexto, la profunda reestructuración que sufrió el secretariado del partido permite entrever la primera manifestación de cohesión u organización entre algunos de los futuros cuadros dirigentes del CDS (incluidos el presidente y el secretario general) $(\text { Anexo I })^{35}$. Sin embargo, el particular peso específico adquirido por el suarismo, indica uno de los más cercanos colaboradores de Suárez, no implicó su organización como

que algún día volver a optar al poder, CERCAS, Javier: Anatomía de un instante, Madrid, Debolsillo, 2014.

32 Dice Javier Moral que evitó ser así "derrotado" en el Congreso de Palma, aunque añade, "ni el mismo Suárez ha explicado a estas alturas las razones de su salida", MORAL, Javier: El centro de la derecha, Madrid, Eudema, 1991, p. 107.

33 "Dentro de las instancias del partido, el Comité Ejecutivo y el Consejo Político, el aparato suarista no necesitaba desencadenar una purga contra los críticos ya que con el sistema mayoritario adoptado en el Congreso de Palma estaban neutralizados desde el punto de vista numérico", ALONSO CASTRILLO Silvia: La apuesta..., pp. 506-7.

${ }^{34}$ El "oficialismo" triunfó en la mayoría de las provincias donde se presentaron dos candidaturas, salvo en Madrid. Fue el caso de: Alicante (Luis Gamir), Huesca (León Buil), Salamanca (Salvador Sánchez Terán), Castellón (Manuel Tarancón), Álava (Jesús Viana), Ciudad Real (Blas Camacho), Burgos (Juan Manuel Reol Tejada), Zaragoza (Gaspar Castellanos), Soria (Gabriel Cisneros), Asturias, (García Pumariño), Valencia (Manglano), El País, 07 de julio de 1981 y 13 de julio de 1981. Suárez no asistió a la reunión de la Ejecutiva encargada de analizar los resultados de estas elecciones, El País, 13 de julio de 1981.

${ }^{35}$ Por el contrario, en el Comité Ejecutivo sólo nos encontramos con tres futuros miembros fundadores del CDS, al margen de Suárez, Chus Viana, Lorenzo Olarque [sic, Lorenzo Olarte] y Manuel de Zárraga [sic, Manuel de Sárraga] junto a otros destacados "suaristas" como Reol Tejada, Lamo de Espinosa, García Añoveros, etc. Datos extraídos de HUNEEUS, Carlos: La Unión..., p. 331. 
grupo o facción diferenciada en el seno del partido o en el grupo parlamentario a pesar de que la división existente era palpable ${ }^{36}$.

Ha sido frecuente, tanto en la prensa de la época -especialmente, Diario 16- como en ensayos y memorias posteriores, interpretar la situación de UCD en 1981 como un intento por parte de Suárez de mantener, incluso lejos del gobierno, su control sobre el partido, mientras de forma paulatina y premeditada, en declaraciones y conversaciones privadas, desgastaba al nuevo ejecutivo ${ }^{37}$. Otros, por su parte, han considerado que el peso y la influencia del aparato del partido, aunque reales, fueron sobredimensionados por determinados medios de comunicación para desacreditar al gobierno ${ }^{38}$. En opinión del secretario de organización de UCD en 1981, José Ramón Caso, este estado de cosas no se concibió como un golpe de mano dirigido contra el gobierno:

Leopoldo en aquel momento renuncia a ser presidente del partido [...] para gestionar con eficacia el gobierno [...] Entonces se elige a Agustín, más identificado con Adolfo, pero no es una imposición de Adolfo [...] es una renuncia voluntaria de Leopoldo, que de ninguna manera quería hacerse cargo del partido ${ }^{39}$.

\section{2. La escisión "suarista" de UCD}

El 25 de febrero de 1981 Suárez abandonaba definitivamente la presidencia del gobierno, y ese mismo día, se embarcaba en un viaje de más de mes y medio de duración por Estados Unidos y Panamá ${ }^{40}$. En aquellas semanas, Suárez comenzó a

\footnotetext{
${ }^{36}$ Cada uno, recuerda Laura Morso, hacía campaña "por su lado" durante las elecciones gallegas de noviembre del 81', Entrevista con Laura Morso. 11 de febrero de 2015.

${ }^{37}$ Como el propio Calvo-Sotelo, véase, entrevista en El País, 19 de diciembre de 1982.

${ }^{38}$ Para Hopkin, la bicefalia de UCD era parte de una estrategia política de mayores dimensiones, orquestada por Adolfo Suárez: "para mantener su dominio de UCD sin tener que enfrentarse a las presiones de un papel de líder visible", HOPKIN, Jonathan R.: El partido de la Transición..., p. 247. Según Silvia Alonso Castrillo o el diputado de UCD Emilio Attard, las diferencias ideológicas fueron artificialmente exageradas por los suaristas y el papel de Suárez en UCD a partir de este momento se limitó a dificultar la labor de gobierno de Calvo-Sotelo; "frustrado por verse apartado del poder tan joven, Adolfo Suárez se pierde en un laberinto de politiquería [...] El papel ambiguo, por no decir negativo, que Adolfo Suárez desempeñó en la UCD después de su dimisión del 29 de enero hasta el abandono de un partido del que había sido fundador y presidente [...] Los argumentos ideológicos pueden aparecer como la cobertura de una estrategia de control de la UCD y después del fracaso de ésta... como un pretexto para excusar lo inexcusable: el abandono de la UCD por parte de Suárez y la fundación de un partido competidor" en ALONSO CASTRILLO, Silvia: Una apuesta de..., p. 509.

${ }^{39}$ Entrevista con José Ramón Caso, 19 de noviembre 2014. Sobre la negativa de Calvo-Sotelo a hacerse con el control del partido, véase, CALVO-SOTELO BUSTELO, Leopoldo: Memoria viva...

${ }^{40}$ Aunque excede los límites de nuestro trabajo, nuevamente, se ha reabierto la polémica sobre la posibilidad de que Suárez intentase revocar su dimisión como presidente de gobierno tras el 23-F, cuando todavía era "presidente en funciones". Cabe añadir, que Suárez fue el gran ausente de la manifestación en defensa de la democracia del 27-F, véase, URBANO, Pilar: La gran desmemoria. Lo que Suárez olvidó y el rey prefiere no recordar, Barcelona, Planeta, 2014, p. 706 y ss.
} 
pergeñar el futuro de su vida política y personal, mientras en Madrid, algunos de sus más cercanos colaboradores se encargaban de realizar las gestiones pertinentes para abrir un bufete de abogados. Una vez de vuelta en España, Suárez manifestó por primera vez la posibilidad de formar un partido totalmente nuevo, tanteando en conversaciones informales la viabilidad del mismo con personas de su entorno más inmediato como Rodríguez Sahagún. En un análisis a medio y largo plazo, Suárez consideraba que en las siguientes elecciones generales se iba a producir, con muchas posibilidades, una mayoría del PSOE, un fracaso de UCD y un ascenso de AP. Por lo tanto, era necesaria la existencia de un partido que moderase la previsible polarización política y contribuyera a la gobernabilidad del país ${ }^{41}$. Mientras, la relación entre Suarez y Leopoldo Calvo-Sotelo distaba mucho de ser fluida y el alejamiento de Suárez de UCD era cada vez más perceptible ${ }^{42}$.

En noviembre de 1981, a propósito de las elecciones autonómicas gallegas, se produjo un nuevo punto de inflexión en el precario equilibrio entre la $\mathrm{UCD}$, dirigida por Rodríguez Sahagún, y el ejecutivo controlado por Calvo-Sotelo. Para José Ramón Caso, responsable de la campaña electoral, la presión de los sectores más conservadores del partido, proclives a una futura alianza con M. Fraga, -con el objetivo de poner en marcha la llamada "mayoría natural" ${ }^{3}$, estaba desvirtuando desde hacía tiempo "la

\footnotetext{
${ }^{41}$ Entrevistas con Aurelio Delgado y José Ramón, 19 de diciembre y 19 de noviembre de 2014, respectivamente. Para autores como Gregorio Morán "desde mayo de 1981...ya hay pruebas incontestables de que está organizando un nuevo partido". Además, cobró cuerpo al parecer en una asesoría llamada Esfinge organizada por hombres de confianza de Suárez durante la primavera de ese año. En este sentido, opinaban numerosos columnistas políticos de la época, que incluso lo bautizaron como Operación Duque, en CABELLOS, Carmelo: “Arias, Abril y Lito preparan la vuelta de Suárez al poder", Diario 16, 06 de abril de 1981.

${ }^{42}$ Calvo-Sotelo lamentaba en sus memorias el escaso esfuerzo de Suárez, apenas veinte minutos, por analizar con él algunos aspectos de la transmisión de poderes; lo que Felipe González denominó la espantá de Suárez, en CALVO-SOTELO BUSTELO, Leopoldo: Memoria Viva... El 25 de junio tuvo lugar uno de los escasos encuentros entre Suárez y Calvo-Sotelo. Supuestamente, Suárez señaló que UCD se había "derechizado" y al parecer Calvo-Sotelo expresó su intención de hacerse con el partido, ABELLA, C.: Adolfo Suárez..., p. 561. El 24 de septiembre de 1981 se produjo un nuevo encuentro entre ambos para apaciguar tensiones, FRAGA, Manuel: En busca del tiempo servido, Barcelona, Planeta, 1988 , p. 264.

${ }^{43}$ Con el objetivo de alcanzar un pacto de cara a las elecciones de 1983, CONTRERAS, Emilio: Suárez..., p. 321. La "mayoría natural” fue una tesis electoral desarrollada desde AP que señalaba que existía una mayoría cualitativa de centro-derecha o conservadora real en términos sociológicos, que necesitaba de un correlato electoral mediante la convergencia de AP y UCD. Tuvo notable eco en el partido centrista, como demostró la fundación de la Plataforma Moderada durante el verano de 1981 con la adhesión de 39 diputados, HUNEEUS, Carlos: La Unión..., pp. 353-55.
} 
esencia centrista" de $\mathrm{UCD}^{44}$; en plena campaña, el propio Suárez admitía en conversaciones privadas: "no me va a quedar otro remedio que irme" 45 .

Las elecciones gallegas depararon un sonoro fracaso electoral de UCD, incapaz de resistir el empuje de $\mathrm{AP}^{46}$. Calvo-Sotelo consideró necesario ocupar la presidencia del partido y designó al democristiano Íñigo Cavero como su secretario general en detrimento de Calvo Ortega. El director de la campaña centrista explica así aquellos días:

Como secretario de organización y director de la campaña presento ante la ejecutiva de UCD un análisis demoledor de las causas de la derrota desde la inhibición de parte del gobierno [...] hasta la traición de diputados y senadores democristianos de UCD [...] después de presentar yo el informe, Leopoldo [...] pide tiempo muerto [para tomar decisiones] [...] y la Comisión Ejecutiva no se vuelve a reunir. Se exige a Agustín que renuncie. Y toma el control los sectores democristianos y liberales afines a la mayoría natural ${ }^{47}$.

La reacción de Adolfo Suárez, que había acudido hasta ese momento a actos y organismos de UCD, fue la de inhibirse de cualquier participación en UCD, dejando de intervenir en mítines y dimitiendo del Comité Ejecutivo y del Consejo Nacional ${ }^{48}$. La situación de Suárez en el partido era, cuanto menos, comprometida: “deja de hablar con Leopoldo porque lo considera una traición [...] porque considera que las presiones que está recibiendo UCD y el equipo que ha puesto Leopoldo van hacia la mayoría natural

\footnotetext{
44 "Adolfo Suárez había identificado su posición con el centro-izquierda, pero los sectores menos avanzados de UCD intentaron torpedear esos planteamientos con la descalificación de pseudoprogresismo y con el argumento sorprendente de que UCD había ganado las elecciones con los votos de la derecha" en RODRÍGUEZ SAHAGÚN, Agustín: "De la división a la desnaturalización", en SINOVA, Justino (ed.) Historia..., pp. 708-710.

${ }^{45}$ Entrevista con Laura Morso, 11 de febrero de 2015. "Suárez había dejado traslucir sus intenciones de desvincularse de la UCD, según la constancia que de ello dejó impresa (sin que Suárez la desmintiera) el semanario Tiempo del 12 de agosto de 1981", VILAR, Sergio: La década sorprendente, Barcelona, Planeta, 1986, p. 118. Según Carlos Abella, "Suárez le previno de las operaciones de sectores económicos y financieros, con la complicidad de sectores de la propia UCD, para desintegrar UCD y del peligro de derechización que estaba sufriendo. También Suárez le reiteró que quien controlaba el partido era Rodríguez Sahagún y no él"; Calvo-Sotelo tenía dos opciones: disolver las cámaras o hacerse con el control de UCD y concluir la legislatura (juicio del 23-F, OTAN) en ABELLA, Carlos: Adolfo Suárez..., p. 550.

${ }^{46}$ Los resultados fueron: Alianza Popular (26 diputados autonómicos), UCD (24), PSOE (16), PSG-EG (1), PCG (1), BNG (3).

${ }^{47}$ Entrevista con José Ramón Caso, 19 de noviembre 2014.

${ }^{48}$ Se produjo entre el 13/14 de noviembre, coincidente con el abandono de la presidencia de Rodríguez Sahagún, ABELlA, Carlos: Adolfo..., p. 564; El País, 08 de agosto de 1982. Desde este momento, Suárez consideraba inevitable el proceso de ruptura de UCD, "yo creo que hay una inflexión en UCD que para Adolfo, en términos estratégicos-políticos es crucial, que es lo que se llamó la reunificación de la presidencia" en Entrevista con José Ramón Caso, 19 de noviembre 2014.
} 
inequívocamente" ${ }^{\text {49 }}$. Aunque Calvo-Sotelo en su discurso ante el Consejo Político se esforzó por transmitir una imagen de unidad, - "quiero dejar especial testimonio de la lucidez y de la generosidad con las que Agustín Rodríguez Sahagún condujo las conversaciones" distancia entre ambos no hacía sino crecer. Incluso, colaboradores de Calvo-Sotelo pidieron que se incorporara en su gabinete personal Caso, hombre de confianza de Suárez, con el objetivo de mantener un último canal de comunicación entre ambos:

Me piden que me incorpore y yo lo interpreto, y Adolfo me lo dice así, de correo, cuando Leopoldo quiere que le llegue un mensaje a Adolfo, para no romper; se mantiene como un vínculo último ${ }^{51}$.

Un nuevo impasse se vivió con motivo de las elecciones andaluzas de mayo de 1982 en las que, sin éxito, Calvo-Sotelo puso a prueba su liderazgo. El fracaso electoral le llevó a tomar la decisión de abandonar la presidencia del partido, mientras, democristianos y liberales aceleraban su salida de UCD en vista de las escasas expectativas electorales ${ }^{52}$. Desde noviembre, Suárez había permanecido en un segundo plano, sin hacer apenas declaraciones más allá de su vida personal, y esquivando cualquier compromiso político ${ }^{53}$. Laura Morso, quien le comunicó su intención de darse de baja de UCD en los primeros meses de 1982, recuerda como Suárez le pidió continuar en el partido por lo menos hasta la celebración de las elecciones andaluzas y la resolución del juicio sobre el 23-F, finalmente, el día 3 de junio ${ }^{54}$. Si en el primer caso, esquivaba la posibilidad de imputar al suarismo la derrota electoral, en el segundo, estimaba que el riesgo de desestabilización era todavía considerable.

En este contexto y como respuesta inmediata a la derrota en Andalucía, acontecieron dos episodios inéditos en UCD: uno en la cúpula y otro en las bases del partido. En un postrer intento por salvar el partido, -y encarar la inexorable reducción de su cuota de

\footnotetext{
${ }^{49}$ Entrevista con José Ramón Caso, 19 de noviembre 2014. En cualquier caso, y con cierta sorpresa en el suarismo, Calvo-Sotelo siempre se negó a cualquier alianza con Fraga, ALONSO CASTRILLO, Silvia: Una apuesta...

50 "Discurso de Leopoldo Calvo-Sotelo en el Consejo Político de UCD: 21 de noviembre de 1981", Caja 3336, Archivo Histórico Provincial de Soria (AHPS).

${ }^{51}$ Entrevista con José Ramón Caso, 19 de noviembre 2014.

${ }^{52}$ Resultados: AP (17), UCD (15), PSA (3), PSOE (66), PCA (8).

${ }^{53}$ Portada y reportaje principal: "Primeras Navidades en su nuevo hogar del ex presidente Suárez con su familia", Hola, 16 de enero de 1982; "Los duques de Suárez y sus hijos, de vacaciones en la estación invernal de Astún”, Hola, 05 de mayo de 1982.

${ }^{54}$ Entrevista con Laura Morso, 11 de febrero de 2015. “A estas alturas ya están: J. Ramón Caso, Jesús Viana, Calvo Ortega y Rodríguez Sahagún... [en la preparación del nuevo partido]”Adolfo, por su parte, se adentra en uno de sus períodos taciturnos que le valdrán el apodo de la "Esfinge". Por tanto, la Esfinge hace como que no se entera, disimula porque sabe que cuanto más demore su marcha, más posibilidades tendrá de aumentar su partido", MORÁN, Gregorio: Ambición ..., pp. 548-564.
} 
poder político-, se produjo una negociación entre los tres grandes líderes del partido, "trilateral"-, recordemos, tras unos meses de ostensible distanciamiento: Landelino Lavilla (líder del sector crítico), Leopoldo Calvo-Sotelo (presidente de UCD y del Gobierno) y Adolfo Suárez (presidente de honor). Paralelamente, se vivió una contestación abierta por parte de las bases, -nos referimos a dirigentes locales y provinciales-, demandando el regreso de Suárez.

Los días 7 y 12 de junio de 1982 se celebraron las dos primeras de las reuniones de la “trilateral” de UCD. La propuesta de Adolfo Suárez se basaba en la asunción del control del partido y de la confección de las listas electorales, "sin cortapisas" 55 , mientras se hacía todo lo posible para que Calvo-Sotelo terminase la legislatura y Lavilla fuera designado candidato presidencial. Según Abella, Calvo-Sotelo comprendió en ese momento que Suárez buscaba un partido totalmente nuevo, pero con las siglas de UCD, lo que en cierto modo no difería mucho de las perspectivas generadas en el entorno de Suárez desde su dimisión y especialmente, las elecciones gallegas, es decir: emprender un proyecto político desde cero ${ }^{56}$. Además, su distanciamiento respecto al gobierno se había incrementado durante este tiempo. El día 4 de junio había publicado en El País un artículo titulado "Yo disiento", -recordando el célebre "Yo acuso" de E. Zola en defensa de Alfred Dreyfus-, en el que lamentaba la indulgente sentencia del 23-F y argumentaba "es preciso dejar muy claro que en España no existe un poder civil y un poder militar. El poder es sólo civil" ${ }^{\prime 57}$. Como se ha señalado, Suárez hacía visible de este modo "su autonomía política", respaldado por el recuerdo de su actuación durante el $23-\mathrm{F}^{58}$.

\footnotetext{
${ }^{55}$ MORÁN, Gregorio: Ambición..., p. 561. E incluso, la supresión de los órganos de gobierno del partido, ABELLA, Carlos: Adolfo..., pp. 576-7; YÁRNOZ, Carlos: "El ocaso de UCD" en JULIÁ DÍAZ, Santos, PRADERA, Javier y PRIETO, Joaquín (eds.): Memoria ..., p. 517.

${ }^{56}$ ABELLA, Carlos: Adolfo... p. 575.

${ }^{57}$ Aunque no aludió explícitamente a investigar la trama civil del golpe, apuntó: "el rigor no consiste en concentrar las responsabilidades, sino en castigar adecuadamente a todos los culpables. La ejemplaridad no se produce si quedan sin castigar comportamientos intolerables. La justicia penal también debe ser disuasoria, y no se disuade a los que puedan participar en una rebelión militar si se personalizan las penas en los promotores y se libra a quienes las secundan y actúan fuera de la ley. Nunca puede ser aceptable que quede un amplio margen de irresponsabilidad para quienes intervienen en un golpe de Estado y con su actuación provocan amenazas que ponen en crisis la democracia en España”, SUÁREZ GONZÁLEZ, Adolfo: "Yo disiento", El País, 04 de junio de 1982. A propósito del golpe de estado abortado a comienzos de octubre de 1982, en plena campaña electoral, Suárez manifestaba: "hay que descubrir dijo- a los colaboradores directos e indirectos, civiles y militares", Diario 16, 06 de octubre de 1982.

${ }^{58}$ FERNÁNDEZ AMADOR, Mónica y QUIROSA-CHEYROUZE Y MUÑOZ, Rafael: "La creación del...", p. 203. A lo largo de junio, fue perceptible la autonomía del suarismo en numerosos debates parlamentarios: la votación del defensor del pueblo y la polémica sobre el director de RTVE Robles Piquer, véase, El País y ABC, junio y julio de 1982.
} 
Finalmente, el día 5 de julio en el transcurso de una cena en el restaurante Zalacaín se dirimieron las propuestas definitivas. Suárez se negaba a aceptar cualquier otro compromiso y rechazaba la creación de una "comisión permanente" o una dirección colegiada junto a Lavilla ${ }^{59}$. Para Calvo-Sotelo, quien además debía ser en calidad de presidente del partido, el encargado de convencer a los líderes centristas, la postura de Suárez era inasumible: "el plan de Suárez era eliminar a los barones de la élite del partido y "renovar UCD bajo su liderazgo"60. La negativa de Calvo-Sotelo ponía "a Suárez en el disparadero" "61 y conducía definitivamente a Lavilla a asumir la presidencia de UCD en la reunión del Consejo Político convocada el 10 de julio.

Para el suarismo, la estrategia de Calvo-Sotelo y Lavilla era revitalizar la UCD, a través de la imagen y el liderazgo de Suárez (sin ser siquiera candidato presidencial) y sin perder el control ni del gobierno, ni del partido ${ }^{62}$. Según Caso:

Se le contesta que esto no puede ser [la propuesta de Suárez] y no puede ser porque hay sectores que no lo tolerarían [...] y Adolfo dice si hay gente que dice lo que es posible o no es posible hacer dentro de mi partido, ése no es mi partido y ya se siente desligado, totalmente desligado ${ }^{63}$.

En la prensa, El País en su análisis de la crisis de UCD, era hasta cierto punto condescendiente con Suárez y consideraba que "la tentativa de endosar la catástrofe centrista a la obcecación personal de Adolfo Suárez no resiste un análisis somero"64. Asimismo, subrayaba la imperiosa necesidad de UCD, -confirmada en los últimos comicios-, por usar su figura para detener la caída en las urnas. Por su parte, $A B C$ veía con buenos ojos la marcha de Suárez al concluir que los males del partido eran: los personalismos, la ausencia de una ideología definida, la desconfianza del electorado y recomendaba la concurrencia de una amplia coalición electoral para hacer frente al PSOE (es decir, en la línea de la tesis de la "mayoría natural") ${ }^{65}$. En otro medio de tirada nacional, Diario 16, José Luis Gutiérrez criticaba la ambición desmedida de

\footnotetext{
${ }^{59}$ HERNÁNDEZ, Abel: Suárez ..., p. 184.

${ }^{60}$ HOPKIN, Jonathan R.: El partido..., p. 281.

61 YÁRNOZ, Carlos: "El ocaso de UCD” en JULIÁ DÍAZ, Santos, PRADERA, Javier y PRIETO, Joaquín (eds.): Memoria..., p. 517.

${ }^{62}$ Entrevista con José Ramón Caso, 19 de noviembre 2014. Según el politólogo R. Gunther, la postura de Suárez pretendía suprimir dos fuentes de inestabilidad generadas en el partido: las ambiciones personales de los líderes centristas y las presiones externas (poderes fácticos), GUNTHER, Richard: "Electoral Laws, Party Systems, and Elites: The Case of Spain", American Political Science Review, Vol. 83, 3, september 1989, pp. 835-858.

63 Entrevista con José Ramón Caso, 19 de noviembre 2014. La invocación de presiones “fácticas” en aquellas reuniones ha sido siempre negada por Calvo-Sotelo, véase, HOPKIN, Jonathan R.: El partido...

${ }^{64}$ En el editorial: "Réquiem por un parado", El País, 08 de julio de 1982.

${ }^{65}$ En el editorial: "Cirugía o muerte natural”, $A B C, 02$ de julio de 1982.
} 
Suárez en estas negociaciones y consideraba la posibilidad de un eventual apoyo al PSOE:

Porque la idea que Suárez siempre acarició, desde el mismo momento en que Leopoldo ocupó el despacho presidencial, es la de volver donde solía, a la jefatura del Gobierno. Y ¿qué piensa el duque? Baraja varias hipótesis, todas ellas en función de los resultados electorales, al margen de sus veleidades jacobinas, de su firme determinación de decapitar a los que considera desleales, el ex presidente no descarta la variante de tener que ocupar los escaños de la oposición ante un triunfo incuestionable de los socialistas de Felipe González. Y en este proyecto no puede desdeñarse la idea de gobernar en coalición con el partido del puño y la rosa ${ }^{66}$.

Un análisis de Agencia Central de Inteligencia de EE.UU. (CIA) fechado en julio de 1982 sobre la situación de UCD todavía consideraba la posibilidad de que Suárez triunfase en su intento de controlar el partido, ya que mantenía el apoyo de buena parte del aparato provincial. Si esto ocurría preveía una eventual alianza con los Socialistas tras las elecciones, y la ruptura del ala derecha del partido favorable a una coalición conservadora y que no estaba en condiciones de aceptar el control de UCD por Suárez. De otra parte, mantenía la puerta abierta a la formación de un "partido bisagra", que no obstante encontraría graves problemas de financiación. En cualquier caso, no se dudaba de su retorno a la política ${ }^{67}$.

De forma paralela a la discusión en la cúpula y los órganos ejecutivos, emergían voces discordantes desde otros sectores del partido que, de alguna manera, azuzaban estos últimos intentos de negociación de la "trilateral". Poco después de la consulta andaluza, algunos líderes regionales comenzaron a distanciarse abierta y públicamente de la dirección nacional, generando una atmósfera de fuerte contestación interna en todos los comités provinciales. En una reunión entre Leopoldo Calvo-Sotelo y el grupo de UCD en el Senado a finales de mayo, "Luis Rodríguez San León [Zamora] apuntaba que queríamos haberle dicho que se marchara y lo dejara"; otro dirigente, "[Francisco Villodres, Málaga] señalaba que "se han repetido cosas conocidas y no se ha dado la palabra a ningún andaluz"',68. En otro sentido, las espontáneas declaraciones de lealtad a los órganos de dirección de algunas ejecutivas provinciales, no hacían sino evidenciar el mismo ambiente de división: "se hizo una valoración de los resultados obtenidos por

\footnotetext{
66 "Portazo suarista a la ejecutiva de UCD”, Diario 16, 03 de julio de 1982. En esta línea GUTIÉRREZ, José Luis: "Los planes del duque", Diario 16, 16 de junio de 1982.

67 "Spain and a Weakened UCD: Downhill Toward an Election", julio 1982, CIA-RDP83, Archivo CIA. Disponibles en: http://www.cia.gov. Fecha de consulta: 25 de enero de 2017.

${ }^{68}$ Tanto Rodríguez San León, en el caso de Zamora, como Francisco Villodres, en Málaga, en apenas dos meses ingresaron en el Centro Democrático y Social, dando forma a dichos partidos en sus provincias respectivas. La cita corresponde a ABC Córdoba, 28 de mayo de 1981.
} 
UCD [...] quedó de manifiesto la adhesión de la Ejecutiva al Partido, apoyándose la idea de la necesidad de un partido de Centro para el futuro desarrollo de la política nacional" $"$ 69.

Las bases irritadas y descontentas del partido lograron coordinarse a lo largo de las primeras semanas de junio, en un proceso en el que tuvo un papel destacado el antiguo secretario general de UCD y "suarista", Rafael Calvo Ortega, junto con la dirección de UCD-Asturias $^{70}$. El objetivo era ejercer una presión eficaz sobre la cúpula. En una reunión celebrada en Madrid con treinta secretarios provinciales, se mantuvo la propuesta de la búsqueda de una alternativa integradora en el seno de UCD, -“expresión de voz"71-, buscando la mediación entre Leopoldo Calvo-Sotelo y Adolfo Suárez. El resultado de aquella reunión fue un breve documento, remitido a todas las direcciones provinciales, que contenía cinco demandas de índole programática y estratégica. En primer lugar, se exigía la concreción de un programa acorde con los principios ideológicos aprobados en los Congresos del Partido, un debate real en el seno del Consejo Político y "la afirmación inequívoca de una posición política de centro, con vocación progresista y reformista" ${ }^{, 72}$. Asimismo, se reafirmaba en la necesidad de constituir un partido unitario (sin permitirse tendencias ni "asociaciones parapolíticas"), "rechazándose todo tipo de coalición política electoral" (probablemente, una alusión implícita a la "mayoría natural") y finalmente, "[la necesidad de establecer] un claro liderazgo en el mismo, que, consideramos, debe recaer en la persona del Fundador del

\footnotetext{
69 "Acta del Comité Ejecutivo Provincial de Soria”, 28 de mayo de 1982, Fondo UCD, Caja 3335, AHPS.

70 "El revuelo en las bases, la inquietud de las bases, de los secretarios provinciales y [...] los diputados es la preocupación de que esto va mal [y se] fuerza un intento, que ahí trabajó mucho yo creo Rafael Calvo Ortega [...] porque tenía muy buena relación con los secretarios provinciales [...] de que entre las bases haya una reclamación de que se entienda la cúpula", Entrevista con José Ramón Caso, 19 de noviembre 2014. Por ejemplo, contamos con el testimonio de movimientos de estas características en Aragón donde el 13 de junio se publicó un documento con el fin de: "contrarrestar con toda claridad los intentos que puedan producirse, encaminados a conducir a nuestro partido hacia las tesis de la mayoría natural o gran derecha", suscrito por futuros miembros del CDS como Rafael Martínez Campillo y Bernardo Baquedano, en BUIL GIRAL, León: "La Unión de Centro Democrático en Aragón”, en VV.AA.: Memoria de los partidos: crónica de los partidos políticos aragoneses en la época de la Transición, Zaragoza, Asoc. de Exparlamentarios de la Cortes de Aragón, 2003, p. 114.

${ }^{71}$ Aludiendo a la terminología usada por Hopkin, como recurso alternativo a la "opción de salida". Jonathan Hopkin ha puesto en relación el desarrollo de fórmulas alternativas de integración política que den respuesta al descontento interno, -ejercicios de "voz" -, con la existencia de "opciones de salida", que se negocian y ejecutan cuando fracasa la primera vía, "la incapacidad para aumentar su influencia en las decisiones [...] incrementó indudablemente el atractivo de la estrategia de salida". Hopkin utilizó este modelo para explicar las "deserciones" de los sectores conservadores del partido centrista y subrayar que "los desacuerdos sobre objetivos ideológicos no constituyen una explicación suficiente para la gravedad del conflicto interno del partido", HOPKIN, Jonathan R.: Un partido..., p. 292 y ss.

${ }^{72}$ Fondo UCD, Caja 5, Archivo Histórico Provincial de Zamora (AHPZ).
} 
Partido, Adolfo Suárez González"73. Esta iniciativa surgida al margen de la dirección nacional demostraba la inclinación suarista de buena parte de las provincias, entre $25 \mathrm{y}$ 30, destacando: Álava, Albacete, Asturias, Sevilla, Cantabria, La Rioja, Toledo, Lérida, Gerona, Tarragona o Barcelona. Una de las demostraciones de fuerza del suarismo, promovida con el fin de poner de manifiesto la existencia de opciones diferenciadas en el seno de UCD lo constituyó la presentación de una candidatura alternativa a la oficial en la Asamblea Provincial de Madrid, liderada por Abel Cádiz frente al cuñado de Calvo-Sotelo, Miguel Domenech ${ }^{74}$.

A comienzos de julio, la dirección asturiana tomaba nuevamente la iniciativa y remitía a (algunas) direcciones provinciales las resoluciones del Comité Ejecutivo Provincial celebrado el 7 de julio de 1982; si bien, en esta ocasión no se incluía ninguna referencia a Adolfo Suárez y todavía se mostraban defensores de la búsqueda de soluciones en el seno de UCD, "los problemas existentes en nuestro Partido tienen solución si se les aplica un adecuado y enérgico tratamiento" ${ }^{\text {"75 }}$. Sin embargo, el proceso de ruptura era irreversible.

Chus Viana fue quien escenificó la ruptura del suarismo con UCD durante su intervención en el Consejo Político del día 10 de julio de 1982 reunido en el Hotel Convención de Madrid en el que salió elegido como presidente del partido Lavilla, diciendo: "la tumba de Adolfo Suárez fue hecha desde fuera, pero lo enterramos desde dentro"76. Los suaristas Manuel de Sárraga (UCD-Lérida), Viana y Calvo Ortega se abstuvieron en la votación y "Rodríguez Sahagún ni siquiera asistió [...] porque quería dejar bien claro, que "ni apoyamos ni obstaculizamos la candidatura de Lavilla como presidente del partido"',77. La decisión de abandonar la UCD, como comenta Delgado

\footnotetext{
${ }^{73}$ Fondo UCD, Caja 5, AHPZ. La prensa cifraba en 32 los secretarios y apuntaba que una comisión de dichos secretarios, en su mayoría suaristas, quiere reunirse con Calvo-Sotelo, Lavilla y Suárez en "32 secretarios provinciales de UCD quieren a Suárez como líder”, El País, 24 de junio de 1982; "Empleados del partido centrista piden la vuelta de Suárez", El País, 26 de junio de 1982.

${ }^{74}$ En este grupo estaban: Abel Cádiz, José Vicente Cebrián, Eugenio Nasarre, el liberal Pedro Pérez, José Luis González Quirós o José Antonio Pérez González, cuatro de ellos, futuros miembros de CDS, de los que tres se integraron en el Comité Nacional, véase, "Los suaristas se oponen a la renovación de cargos", El País, 09 de junio de 1982. La presentación de una candidatura alternativa, que no tenía opciones reales de victoria, fue solicitada por el propio Adolfo Suárez, Entrevistas con José Antonio Pérez González, mayo y junio de 2013.

75 “Ante la crisis de UCD”, Actas Comité Ejecutivo Regional de Asturias, 07 de julio de 1982, Fondo UCD, Caja 3350, AHPS.

${ }^{76}$ HERNÁNDEZ, Abel: Suárez..., p. 187. En ese Consejo Político Chus Viana, básicamente, “expone que ese ya no es el partido de Suárez", entrevista con Laura Morso, 11 de febrero de 2015.

77 PRADES, Joaquina y JÁUREGUI, Fernando: "Fuerte contestación de suaristas y azules a la presidencia de Lavilla en Unión de Centro Democrático”, El País, 11 de julio de 1982.
} 
no fue ni mucho menos una decisión fácil para Suárez, y como apunta Caso, "tampoco queríamos plantearlo como un sabotaje de la UCD”78.

Sin embargo, muchos de los que se quedaron en UCD, vieron en los últimos movimientos políticos de Adolfo Suárez un cuidadoso intento, premeditadamente dilatado en el tiempo, por socavar al máximo la estructura del partido en el gobierno. Un informe del 12 de julio de 1982 con la intención de revitalizar el espacio de centroderecha explicaba así la demora de Suárez en abandonar UCD: "deben excluirse suaristas y socialdemócratas [en este proyecto de revitalización], cuya única finalidad es 'dinamitar' UCD, para que sus restos puedan ser heredados y asumidos por sus líderes respectivos"

\section{3. La fundación del Centro Democrático y Social}

Cuando se produjo el fracaso de las negociaciones con Calvo-Sotelo y Lavilla la decisión última de Suárez no estaba tomada. En las primeras semanas del verano de 1982, recuerda José Ramón Caso, se discutió entre los "íntimos" del presidente (Agustín Rodríguez Sahagún, Chus Viana, Fernando Abril y Rafael Arias) el camino a seguir en un futuro inmediato. Rodríguez Sahagún y Caso eran decididos partidarios de la creación de un nuevo partido ${ }^{80}$, postura compartida por el propio Suárez ${ }^{81}$. La tesis de Arias-Salgado y Abril Martorell se inclinaba por mantener su influencia política en el seno de UCD.

\footnotetext{
${ }^{78}$ Entrevistas con Aurelio Delgado y José Ramón Caso, 19 de diciembre y 19 de noviembre de 2014, respectivamente.

${ }^{79}$ Documento de José Luis Álvarez, "Algunos principios programáticos mínimos", p. 3, 12 de julio de 1982, Caja 9, 45-374, Archivo General de la Universidad de Navarra, Fondo José Luis Álvarez $(A G U N / J L A)$. En el campo de la politología ha sido habitual aludir a la concepción "instrumental" del liderazgo partidista por parte de Suárez, "nunca consideró al partido una institución por derecho propio y tenía pocos vínculos con él aparte de su papel de apoyo al liderazgo [...] poco entendía o apreciaba al partido político como institución democrática”, HOPKIN, Jonathan R.: El partido..., p. 286.

80 "La necesidad de ser fiel a unas convicciones ideológicas y a unos principios antes que a unas siglas y el deseo de salvar para el futuro los planteamientos de centro progresista, llevaron a Suárez (y con él a cuantos decidimos acompañarle en su empeño) a la creación del Centro Democrático y Social, (como opción diferenciada de la derecha y del socialismo) y como un partido claramente comprometido con la defensa de las libertades y la modernización de España [...] Para salvar ese espíritu de centro nació el CDS, consciente Adolfo Suárez de que elegía un largo y difícil camino, pero, al mismo tiempo, una tarea apasionante y decisiva para el futuro", RODRÍGUEZ SAHAGÚN, Agustín: "El fin de UCD" en SINOVA, Justino (ed.): Historia ..., pp. 709-712.

${ }^{81}$ Suárez estuvo ausente cinco días aproximadamente por un viaje a Venezuela invitado por Luis Herrera Campins (del 14 al 18 de julio), del que tuvo que regresar precipitadamente por un accidente de moto de su hijo menor.
} 
Arias-Salgado, -ministro de Administración Territorial con Calvo-Sotelo-, explica, como durante el mes de julio, Adolfo Suárez le convocó a una reunión en su domicilio, en la que se encontraba Rodríguez Sahagún, y a la que acudió junto a Abril Martorell ${ }^{82}$. Aquel día, Suárez les manifestó su intención definitiva de abandonar UCD y su decisión de fundar un partido nuevo, llamado Centro Democrático y Social, ofreciéndoles participar en el mismo. Para Abril Martorell y Arias-Salgado aquella era una decisión desacertada, -“si él se hubiera quedado en UCD, hubieran sacado 40 diputados"-, e "injusta" con muchos de sus colaboradores. Por ejemplo, Arias-Salgado, como Secretario General, había realizado un considerable esfuerzo entre 1978-80 estructurando las bases del partido; unas bases que por otra parte apoyaban mayoritariamente a Suárez y eran ajenas a las intrigas gestadas en el grupo parlamentario. Arias-Salgado declinó la oferta de Suárez, -suponía desarticular todo lo construido hasta ese momento-, y se inició un período de distanciamiento entre $\operatorname{ambos}^{83}$. Según Caso, la estrategia política de Abril Martorell y Arias-Salgado, muy razonable desde el punto de vista táctico, consistía en:

Que pasaran las elecciones con la UCD de Landelino que iba a haber [...] un gran fracaso electoral y que mucha gente vendría a reclamarle que volviera al cabo de un par de años o algo así [...] habría un movimiento en España para que el retomara la bandera del centro, pero que tenía que estarse en casa dos, cuatro años, que se pasara la cantidad de connotaciones negativas que [en la prensa, por ej.] había acumulado [...] un período de saneamiento ${ }^{84}$.

Ambas posturas, diferenciadas en función de la continuidad o no en UCD, originaron la primera fractura en el suarismo ${ }^{85}$. Finalmente, y con el decidido impulso de Adolfo Suárez, se celebraron en las primeras semanas de julio numerosas reuniones informales con la intención de dar forma al nuevo partido. En aquellos encuentros participaron de

\footnotetext{
${ }^{82}$ Véase, CONTRERAS, Emilio: Suárez..., p. 323. El apoyo de Abril Martorell se vio siempre como improbable, lo que fue en perjuicio de la capacidad de atracción del nuevo partido, "existe el convencimiento de que las elecciones generales están a la vuelta del verano. Y sus mesnadas incondicionales han quedado reducidas o menoscabades [sic] con la decisión de Abril Martorell. El antiguo número dos de UCD y ex vicepresidente del Gobierno ha decidido jugar políticamente dentro del partido centrista. Ya es elocuente que las relaciones personales entre Suárez y Abril se hayan deteriorado en profundidad" en CONTRERAS, Lorenzo: "Suárez y Garrigues: grandes perdedores" en Cinco días, 03 de junio de 1982.

83 Entrevista con Rafael Arias-Salgado, 09 de marzo de 2015. Asimismo, otros "suaristas" como Jaime Lamo de Espinosa o Salvador Sánchez-Terán declinaron participar en el CDS, al entender que su tiempo político había pasado, GONZÁLEZ MARTÍNEZ, Carlos: Salvador Sánchez-Terán. Una biografía política, Tesis Doctoral, Universidad de Valladolid, 2014, p.462.

${ }^{84}$ Entrevista con José Ramón Caso, 19 de noviembre 2014.

85 "Ninguno de los más cercanos colaboradores de Suárez durante la Transición lo acompañaron; su soledad no podía ser más dramática” en HUNEEUS, Carlos: La Unión de Centro..., p. 384.
} 
forma decisiva Caso, Rodríguez Sahagún, Viana ${ }^{86}$, persona de la máxima confianza de Suárez y hombre fuerte del suarismo en el País Vasco, Rafael Calvo Ortega ${ }^{87}$ y algunos de sus colaboradores como José Luis González Quirós o Gerardo Harguindey ${ }^{88}$, y finalmente, León Buil Giral y Alejandro Rebollo ${ }^{89}$. El nombre del partido surgió en el seno de estas reuniones, jugando con la premisa e idea del "centro" como eje primordial $^{90}$. Recuerda Caso, "al final dimos con el Centro Democrático, por mayor continuidad con la UCD, volver a hablar de unión era... [...] Y democrático social era una forma inversa de decir social demócrata [...] pero estábamos jugando con esos conceptos, cómo vender centro progresista"91. En otro sentido, el nombre remitía al artículo 1.1 de la Constitución Española de 1978 que define el Estado español como “social y democrático de Derecho".

El "Manifiesto Político" (Manifiesto del Ritz) escrito durante aquellos días fue ideado por Adolfo Suárez, cuyo pensamiento probablemente estuvo mediado por la pluma de Eduardo Navarro y en cuya redacción tuvieron un papel destacado los políticos anteriormente citados, y particularmente, Rodríguez Sahagún ${ }^{92}$.

El siguiente paso, una vez perfilado el proyecto en sus rasgos más elementales (nombre, miembros fundacionales, texto programático), era oficializarlo en el registro

\footnotetext{
${ }^{86}$ Entrevista con Laura Morso, febrero 2015.

${ }^{87}$ Quien tenía ciertas sobre reservas sobre si constituía o no el momento oportuno, entrevista con José Ramón Caso, 19 de noviembre 2014.

${ }^{88}$ Ricardo De la Cierva se refiere a estos últimos como el Clan de Molinoviejo, véase, DE LA CIERVA, Ricardo: El suicidio político de Suárez, Madrid, ARC Editores, 1997.

${ }^{89}$ León Buil era diputado de UCD por Huesca y Alejandro Rebollo, presidente de RENFE. León Buil sitúa el 21 de julio su primera entrevista con Suárez en Madrid quien le presentó el borrador con los principios de la nueva formación "todavía sin nombre". Las razones de su marcha de UCD eran dos: la deriva conservadora del partido y la tramitación del Estatuto de Autonomía de Aragón -votado el 20 de julio en el Senado- "sin tener en cuenta nuestras enmiendas [del Comité Regional de UCD]", en BUIL GIRAL, León: "La Unión de Centro...", en VV.AA.: Memoria de los partidos: crónica de los partidos políticos aragoneses en la época de la Transición, Zaragoza, Asoc. de Exparlamentarios de la Cortes de Aragón, 2003, p. 116.

${ }^{90}$ Con ironía comentaba Lorenzo López Sancho, "Suárez, al quitar la U de Unión prefiere lo seguro a lo dudoso. No le ha salido ni medio bien lo de la unión estos últimos años y, como el Cid machadiano al destierro se va con veinte de los suyos que todavía no sabe si serán veinte, aunque sí que deberán ser cabales" en "Madrigalejos y no madridejos", ABC, 30 de julio de 1982.

${ }^{91}$ El nombre aparece ya en la prensa, al menos, desde el 11 de julio de 1982 (El País) si bien todavía surgieron otras hipótesis en los días siguientes; Luisa Palma desde $A B C$ barajaba dos opciones: "CDS o UCP [Unión Centrista Popular] posibles nombres del proyecto suarista" en $A B C, 29$ de julio de 1982. Esta incertidumbre puede guardar una estrecha relación con lo que le sucedió apenas unas semanas antes al Partido Demócrata Popular de Óscar Alzaga (PDP), quienes por poco vieron usurpado el nombre de su proyecto político por parte de un grupo de personas, quizá vinculado al sector azul de la UCD, como expusieron PRADES, Joaquina y JÁUREGUI, Fernando: "Los promotores del Partido Demócrata Popular consideran que se intentó boicotear su inscripción", El País, 09 de julio de 1982.

${ }_{92}$ Carlos Santos le considera "el 'ideólogo' del suar [sic], esa singular ideología que quiere ser el suarismo", Diario 16, 26 de septiembre de 1982.
} 
de partidos políticos y presentarlo públicamente ante los medios; aunque era vox populi, no se conocían datos fiables sobre el CDS. El 28 de julio Suárez enviaba una carta a Lavilla manifestándole su deseo de abandonar UCD y en la que no profundizaba en las razones de su marcha "porque [Lavilla] de sobra las conocía"93.

En la inscripción en el registro de partidos políticos tuvo un papel destacado Laura Morso, encargada de llevar la documentación (estatutos y composición de órganos) al Ministerio del Interior. Morso, en ese momento miembro de UCD, recuerda como, con apenas un día de antelación y en absoluto secreto, se la encomendó realizar este trámite. El primer obstáculo era darse de baja en UCD, lo que debía hacer en un puñado de horas y siempre, antes de formalizar la inscripción del CDS, problema que resolvió gracias a la ayuda de UCD-Madrid. Cuando llamaran los medios o dirigentes de UCD buscando información, se debía confirmar que no militaba en el partido.

A continuación, el 29 de julio se firmaron las actas notariales constituyentes en las que figuraban como promotores del nuevo partido la propia Laura Morso, Ignacio Roch i Rovira y Rosa María de Castro Martín ${ }^{94}$, con arreglo al artículo $2^{\circ}$ de la Ley 54/78 y fijándose la primera sede en el $n^{\circ} 2$ de la calle Maestro Guerrero de Madrid, una trasera de Plaza de España ${ }^{95}$. Finalmente, poco antes del mediodía:

Me fui al Ministerio del Interior, pedí ver al Director General de Política Interior, estuve con él, [...] no se podía creer [...] Llamó al ministro y le dijo: está aquí Laura Morso para registrar el partido del presidente. Me dijo que me pusiera al teléfono, hablé con Rosón [...]: ¿esto no hay marcha atrás? No, no. ¿Cómo se enteró la prensa? Yo no lo sé, lo que sí te puedo decir es que yo salí por una puerta de atrás [...] sin hacer ninguna declaración [...] Todo el mundo sabía que era el partido de Suárez ${ }^{96}$.

\footnotetext{
${ }^{93}$ Horas después, en la sede central de Unión de Centro Democrático, se emitía un comunicado oficial en el que se decía: "no se ven auténticas razones objetivas que justifiquen la decisión adoptada por Adolfo Suárez de abandonar UCD", al tiempo que le reprochaban el "no colaborar a la consecución de los ideales de integración que dieron aliento al proyecto inicial de UCD ni a la opción política de centro recientemente reafirmada por Landelino Lavilla", en PRADES, Joaquina y JÁUREGUI, Fernando, "Suárez confirma su abandono de UCD y prepara un nuevo partido", El País, 29 de julio de 1982.

${ }^{94}$ Todos ellos, vinculados a UCD: Ignacio Roch i Rovira había trabajado en la Secretaría de Información de UCD y era miembro del Comité Ejecutivo Provincial de Ávila (vinculado al grupo de trabajo de José Ramón Caso, junto a Rosa María de Castro Martín); Laura Morso había sido Directora General de Servicios Sociales, Entrevista con Laura Morso, 11 de febrero de 2015; Registro de Partidos Políticos (Ministerio del Interior), -de ahora en adelante, $R P P-$, Registro de Entrada $n^{\circ} 170,29$ de julio de 1982, 12:00 (Acta Notarial, 1771. José Luis Martínez Gil. 29 de julio de 1982) y ABC, 30 de julio de 1982.

${ }^{95}$ Unas oficinas propiedad del presidente de CNTE (Telefónica, Salvador Sánchez-Terán), Entrevista con Laura Morso, 11 de febrero de 2015.

${ }^{96}$ Entrevista con Laura Morso, 11 de febrero de 2015.
} 
Una vez realizados los trámites administrativos, sólo quedaba culminar los preparativos de la presentación pública ${ }^{97}$. Siguiendo el testimonio de Morso,

Del Ministerio del Interior yo fui a Serrano, al despacho de Agustín y en el despacho de Agustín estaban Alejandro Rebollo, Rafael Calvo, José Ramón y Chus Viana y cuando entro, no sé cómo decirte, [....] [muchísima] emoción, llamaron a Adolfo Suárez, [...] “iya está aquí Laura!" [...]

El sábado 31 de julio se celebró en el Hotel Ritz la presentación oficial del Centro Democrático y Social ${ }^{98}$. En el acto comparecieron únicamente Adolfo Suárez, Jesús María Viana, José Ramón Caso e Ignacio Roch, en calidad de jefe de prensa, quienes dieron a conocer el "Manifiesto Político" del partido. Suárez, y en un segundo nivel, Viana, eran los únicos conocidos por la opinión pública. Se concentraron en torno a medio centenar de periodistas y "fueron excluidos fotógrafos y periodistas extranjeros como los corresponsales del New York Times y el Washington Post"99. Aunque el CDS nacía en ese momento, no había lista de militancia y no estaba diseñado siquiera el $\operatorname{logotipo~}^{100}$. Dos ideas fuerza impulsaban al nuevo partido suarista: defender los logros de Suárez como presidente de gobierno y alertar sobre los peligros existentes de cara a la consolidación democrática, defendiendo ante todo, la "supremacía del poder civil"101. Sin duda, la actitud de Suárez durante el golpe de estado suponía el mayor aval del nuevo partido. En este sentido, los fines del CDS señalados en los estatutos eran:

1) El pleno respeto a los derechos fundamentales de la persona y la defensa de su dignidad, de su libertad y de su igualdad y la consecución mediante la acción política del pluralismo social y cultural.

\footnotetext{
${ }^{97}$ La inscripción definitiva se produjo el 23 de agosto, mediante confirmación de la dirección del Registro de Partidos Políticos a Ignacio Roch i Rovira y una escueta nota firmada por Adolfo Suárez en la que atestiguaba la recepción de la documentación: "he recibido en mano un sobre con correspondencia oficial enviada por el registro de partidos políticos del Ministerio del Interior, a nombre de d. Ignacio Roch Rovira". La notificación decía: "En cumplimiento de lo establecido en el artículo $3^{\circ}$ del Real Decreto 2281/1.976, de 16 de septiembre, se comunica a Vd. Formalmente el acto de inscripción del denominado partido "CENTRO DEMOCRATICO Y SOCIAL", en el Registro de Partidos Políticos del Ministerio del Interior, que ha tenido lugar el día 23 de agosto de 1.982, en el Tomo I, folio 409 del Libro de Inscripciones, determinando la referida inscripción el goce de todos los efectos jurídicos y legales que señalan las leyes", documento del $R P P$, Documento de Salida, $\mathrm{n}^{\circ} 183$.

98 Como señala J. L. Gutiérrez, al celebrarse en sábado podía "irrumpir ante la opinión pública" en domingo "el día de mayor venta y circulación de periódicos", en "El duque ya no fuma "ducados", Diario 16, 01 de agosto de 1982.

${ }^{99}$ Siguiendo la crónica de Fernando Jáuregui para El País, 01 de agosto de 1982.

100 "El diseño del logotipo corrió a cargo de un profesional que colaboró desinteresadamente", Entrevista con José Ramón Caso, 19 de noviembre 2014. "El portavoz suarista, asimismo, dio a conocer oficialmente el logotipo del DCS [sic] aprobado por la gestora nacional, que figura en la fotografía de Efe, y en el que -dijo- se ve claramente que el mensaje de lo social también está en el centro", ENRIQUE, Melchor: $Y a, 09$ de septiembre de 1982, Gabinete de Información, Caja 243, Informe Diario $\mathrm{n}^{\circ} 317, A G C Y L$.

${ }^{101}$ Véase, el editorial: "Un partido para el duque”, El País, 02 de agosto de 1982.
} 
2) La defensa de la Democracia y del Estado Social y democrático de Derecho definido en el orden constitucional vigente, y de la soberanía nacional que reside en el pueblo español $^{102}$.

En palabras de Suárez, en el curso de una conversación con la periodista Carmen Laviña, (octubre de 1982):

[La creación del CDS] Puede ser un órdago si consideras que, después de mi dimisión y del 23-F, muchos creían que ya estaba fuera de la política. Sé que muchos se frotaron las manos. Me veían derrotado, pero he demostrado que no era así. Sin embargo, el CDS no lo creé por tirarme un farol, sino porque creo que España necesita una tercera fuerza política para no caer en el bipartidismo político [...] que hiciera de mediador, que supiera acercar posturas de unos y otros ${ }^{103}$.

\section{4. La LOAPA y la OTAN: hacia una diferenciación política de UCD}

Algunos de los rasgos del discurso del CDS se fueron gestando a raíz de críticas, más o menos veladas, a la gestión gubernamental de Calvo-Sotelo. Fundamentalmente, hacían referencia a dos aspectos: la firma de la LOAPA y la adhesión a la OTAN. De este modo, ambos episodios sirvieron al suarismo para marcar distancias con UCD -la UCD que representaba Calvo-Sotelo y Lavilla-, y orientar programáticamente las directrices de su nuevo proyecto político.

La firma de los pactos autonómicos de julio de 1981, entre la UCD y el PSOE, desembocó en la aprobación parlamentaria de la Ley Orgánica de Armonización del Proceso Autonómico (LOAPA), supuesto cierre definitivo del marco sobre el que iba a producirse el desarrollo autonómico ${ }^{104}$. La irrupción de la LOAPA ponía en peligro desde el punto de vista de Suárez el precario equilibrio construido durante la Transición $^{105}$. En el plano teórico constituía una medida centralizadora en la que se

\footnotetext{
${ }^{102}$ Estatutos CDS (julio 1982), artículo $2^{\circ}$, Registro de Partidos Políticos, Registro de Entrada n ${ }^{\circ} 170,29$ de julio de 1982.

${ }^{103}$ Carmen Laviña fue jefa de prensa del CDS entre el verano de 1982 y julio de 1984, LAVIÑA, Carmen: Recuerdos prestados, Madrid, Laberinto, 2010, p. 138.

${ }^{104}$ Dicha ley, elaborada cuando no se había culminado la aprobación de todos los estatutos autonómicos, ha sido interpretada por la comunidad historiográfica como el acicate definitivo para estabilizar y consolidar el Estado de las Autonomías en DÍAZ GIJON, José Ramón: Historia de la España actual, 1939-2000, autoritarismo y democracia, Madrid, Marcial Pons, 2001, p. 273; SOTO CARMONA, Álvaro: La transición a la democracia, España 1975-1982, Madrid, Alianza, 1998, p. 175. O como una concesión a los golpistas "destinada a apaciguar los ánimos del patriotismo centralista", opinión compartida por los partidos nacionalistas, véase MUNIESA, Bernat: La España Lampedusiana: Dictadura y Transición II. La monarquía parlamentaria, Barcelona, UAB, 2005, p. 136.

105 Suárez explicaba del siguiente modo, en 1982, las claves de la estructuración territorial del Estado: “Cuando dije aquello de 'puedo prometer y prometo', sobre lo que tantos chistes se han hecho prometí cuatro o cinco cosas solamente y todas se hicieron [...] ¿Qué no tenía un modelo autonómico? Claro que
} 
hacía prevalecer la legislación estatal sobre la autonómica. Desde un punto de vista pragmático, traía consigo la marginación de dos actores políticos fundamentales durante la Transición como eran el PNV y CiU. Significativamente, en la primera rueda de prensa que acompañó a la presentación del nuevo partido Adolfo Suárez lamentó los “insuficientes contactos” con los nacionalistas en la elaboración de la nueva legislación autonómica $^{106}$.

De este modo, su crítica a la LOAPA guardaba una estrecha relación con la naturaleza de su proyecto político, que en última instancia, aspiraba a contribuir a la consolidación del sistema democrático desde la búsqueda de equilibrios, moderación y pactos. El CDS asumía a diferencia de otros partidos y sin matizaciones retóricas, el articulado constitucional ${ }^{107}$. En este sentido, mientras que en el programa electoral de 1982, el CDS apelaba tanto a la autonomía de las distintas "nacionalidades y regiones" como a la unidad de España, AP se cuidaba de no incluir el término nacionalidades ${ }^{108}$, UCD hablaba de "comunidades"109 y el PSOE se mostraba remiso a una declaración explícita de españolismo, tras señalar la necesidad de "autogobierno" de las distintas nacionalidades y regiones ${ }^{110}$. En palabras de un dirigente suarista: "se potencia y

lo tenía. Lograr que todas las regiones y nacionalidades tuvieran su autogobierno. ¿Alcance y dimensiones? Calibrar milimétricamente las competencias de cada uno era prácticamente imposible de determinar, entre otras cosas porque yo no podía ni siquiera imponer un modelo, debía hacerlo en colaboración con todas las fuerzas representativas, y negociarlo después con los parlamentarios de las regiones. Tropecé, sin embargo, con que el tiempo, lógico del proceso, que se debía respetar, no tenía nada que ver con el tiempo político, con algunas fuerzas actuando en determinada dirección en algunas regiones y provocando una situación de urgencia", en GUTIÉRREZ, José Luis: "La entrevista del año [entrevista a Suárez]”, Diario 16, 26 de septiembre de 1982.

106 JÁUREGUI, Fernando: “Adolfo Suárez defiende la primacía del poder civil”, El País, 01, agosto, 1982.

${ }^{107}$ Sobre el caso catalán, en un mitin celebrado en Barcelona el 25 de octubre Suárez se mostró crítico con la LOAPA e incluso, según la crónica, en su ardor autonomista hizo comentarios que excedían el texto constitucional, "no le preocupa nada que Cataluña se llame a sí misma nación" en: "En España caben todas las nacionalidades como son", El Noticiero Universal, 26 de octubre de 1982; el parlamentario Planas[demunt] en Gerona señalaba que "Suárez nos trajo el Estatuto de Autonomía y Calvo-Sotelo, en cambio, nos trae la LOAPA", El País, 26 de octubre de 1982.

${ }^{108}$ Alianza Popular, junto con UV, UPN, PDP y PL en Es hora de soluciones. Programa electoral, 1982. Disponible en http://www.pp.es/sites/default/files/documentos/1146-20090908160947.pdf Fecha de consulta: 16 de junio de 2015.

109 "La unidad de España y la solidaridad entre todas las comunidades [sic] que integran la Nación española", en SÁNCHEZ CORNEJO, David: "La Unión de Centro Democrático y la idea de España", Historia del Tiempo Presente, 13, 2009, p. 13. Disponible en: http://historiadelpresente.es/sites/default/files/revista/articulos/13/13.2davidsanchezcornejo.launiondecent rodemocraticoylaideadeespana.laproblematicareelaboraciondeundiscursonacionalistaparauncontextodemo cratico.pdf. Fecha de consulta: 13 de mayo de 2015.

110 PSOE: Por el cambio. Programa electoral, 1982. Disponible en: http://www.psoe.es/ambito/ideasyvalores/docs/index.do?action=Print\&id=695589. Fecha de consulta: 16 de junio de 2015. Una visión más amplia sobre el discurso "patriótico" del PSOE y del PP en NUÑEZ SEIJAS, Xosé M.: "La cuestión nacional en la época socialista: entre la armonización autonómica y el 
profundiza la unidad de España, potenciando y reconociendo su propia pluralidad y haciendo una distribución del poder político horizontal, sin miedo"111.

Por otro lado, el CDS exigía la vuelta de los grandes consensos, en un intento por defender y capitalizar la obra política de Adolfo Suárez bajo cuyos ejecutivos se había articulado el modelo territorial, "surgió además la LOAPA desestabilizadora y descomponedora [sic] de lo que con tanta paciencia había conseguido Adolfo Suárez en el terreno de las autonomías [recuérdese la negociación del Estatuto de Guernica con Garaikoetxea o la vuelta de Tarradellas]"112. De este modo, junto a la necesidad de armonizar los intereses estatales con los autonómicos sobre la base irrenunciable del texto constitucional había de darse siempre "una política flexible y concertada con todas las fuerzas políticas, evitando una dialéctica de enfrentamiento" ${ }^{113}$.

Finalmente, el énfasis autonomista de los suaristas tenía mucho que ver con el acelerado proceso de descomposición de UCD. A mediados de 1982, era perceptible en el llamado "sector suarista" la búsqueda de unas señas de identidad que les permitiesen estructurar un discurso diferenciado y competitivo electoralmente tanto con UCD como con los nuevos partidos que estaban surgiendo a nivel estatal y regional ${ }^{114}$. En este último caso, parte de las elites locales o regionales de UCD se constituyeron como partidos políticos en diversas autonomías adoptando una retórica regionalista con el fin, primordial, de mantener sus "cuotas de poder" 115 . El CDS, que mantuvo negociaciones con muchos de estos líderes, constituyó otro cauce más, en este caso a nivel estatal, para canalizar el protagonismo de buena parte de los sectores más "progresistas" o con mayor "compromiso" autonomista de estas elites, desafectas tanto con la línea política

patriotismo constitucional" en SOTO CARMONA, Álvaro y MATEOS LÓPEZ, Abdón (eds.): Historia ..., pp. 105-127.

111 "La LOAPA ha sido un intento de embridar el proceso de autonomías. Es decir, ha sido una mala solución o una solución, [...] excesivamente nerviosa, probablemente por presiones también de poderes facticos", Interview undertaken by Richard Gunther in 1986 (june), AR.

112 Comentario en precampaña del dirigente del CDS en Ávila, Fernando Alcón, recogido en MAXIMILIANO: “Centrismo, moderación y liderazgo de Suárez, razones del paso al CDS", Diario de Ávila, 16, septiembre, 1982, Gabinete de Presidencia, Caja 317, Dossier CDS, AGCYL.

${ }^{113}$ CDS: Programa electoral. España como debe ser, 1982, p. 20.

114 El auge de los regionalismos en la Transición, GRANJA, José Luis, BERAMENDI, Justo y ANGUERA, Pere: La España de los nacionalismos y las autonomías, Madrid, Síntesis, 2001, p. 205.

115 NAVAJAS ZUBELDIA, Carlos: "Desconcierto y zozobra en la segunda transición autonómica en La Rioja, 1982-1983" en NAVAJAS ZUBELDIA, Carlos (ed.): Actas del III Simposio de Historia Actual. Logroño, 26-28 de octubre de 2000, Logroño, Gobierno de La Rioja, Instituto de Estudios Riojanos, 2002, pp. 285-320. 
del gobierno como con la dirección de $\mathrm{UCD}^{116}$. Este episodio se dio en toda la geografía española desde La Rioja ${ }^{117}$, Canarias ${ }^{118}$, País Vasco a Cataluña.

En relación a la OTAN, debemos remontarnos, aunque sea brevemente, a la etapa presidencial de Adolfo Suárez, con el fin de contextualizar los distintos posicionamientos del CDS. Cuando llegó a la presidencia del ejecutivo, Suárez mantuvo abierta la perspectiva de una posible inserción de España en el Tratado del Atlántico Norte, si bien, el clima de consenso previo a la Constitución hacía más prudente la posposición de un debate en materia de política exterior, debido al rechazo que provocaba la OTAN tanto en el PSOE como el PCE. Sin embargo, con el paso del tiempo y como puso de manifiesto su evasivo discurso de investidura en 1979, se fue haciendo perceptible que esta postergación tenía un carácter indefinido. Paradójicamente, la renuente actitud de Adolfo Suárez no contaba con las simpatías de buena parte de su partido, siendo incluso ajena a la de sus propios ministros de exteriores $^{119}$. Su política internacional mostraba cierta fijación por el relanzamiento de las relaciones hispanoamericanas e hispanoárabes; fijación, exagerada en los medios de comunicación y en buena medida, consecuencia de las dificultades y complejidades técnicas existentes en las negociaciones con las instituciones europeas, principal objetivo del gobierno en materia de política exterior ${ }^{120}$.

Las dudas de Adolfo Suárez sobre la adhesión a la OTAN han sido objeto de una fuerte controversia y han sido ampliamente comentadas. Por un lado, para Suarez existía una preocupación real respecto a posibles represalias soviéticas ante una hipotética

\footnotetext{
${ }^{116}$ Para José Luis Merino la vocación autonomista del CDS nacía de tres factores: su aceptación plena de la Constitución -señalando, de forma un tanto sorprendente, "sin renunciar, para el futuro, a un posible tránsito hacia un Estado federal"-, el doble nacimiento del partido desde el centro y la posterior adhesión de núcleos de la periferia, "donde sus integrantes, en su mayor parte, estábamos seriamente comprometidos con el proceso autonómico" y el papel de mediador en el mapa político español, en MERINO HERNÁNDEZ, José Luis: "Los partidos centristas en la formación de la Comunidad Autónoma de Aragón" en VV.AA.: Memorias de los partidos..., pp. 129-130.

${ }^{117}$ El CDS al vetar el ingreso a un sector considerable de "ucedistas" de la comunidad riojana propició indirectamente la fundación del Partido Riojano Progresista, NAVAJAS ZUBELDIA, Carlos: "Desconcierto y zozobra...", pp. 285-320.

${ }^{118}$ La principal diferencia entre las AIC y el CDS en Canarias fue, en origen, su fuerza territorial en unas u otras islas, en función de la influencia social y política de sus respectivos líderes, GARCÍA ROJAS, José Adrián: "Pactos Electorales y coaliciones en Canarias (1977-2002)", Política y Sociedad, 2 (Volumen 40), 2003, pp. 137-156. Disponible en: http://www.revistas.ucm.es/index.php/POSO/article /viewFile/POSO0303110137A/23812 Fecha de consulta: 16 de enero de 2014.

${ }_{119}$ Véase, OREJA, Marcelino: Memoria y esperanza: relatos de una vida, Madrid, La Esfera de los Libros, 2010.

${ }^{120}$ Véase, POWELL, Charles T.: El amigo americano. España y Estados Unidos: de la dictadura a la democracia, Barcelona, Círculo de Lectores, 2001, pp. 525-6. Véase también, VIÑAS, Ángel: En las garras del águila: Los pactos con Estados Unidos, de Francisco Franco a Felipe González (1945-1995), Barcelona, Crítica, 2003; URBANO, Pilar: La gran ..., pp. 416-431.
} 
vinculación defensiva de España al bloque occidental ${ }^{121}$. En segundo lugar, el ejecutivo deseaba conseguir una posición negociadora fuerte que le permitiese obtener ciertas contrapartidas, por ejemplo, la entrada en la CEE. Finalmente, se ha argumentado la existencia de un sentimiento antiamericano en Adolfo Suárez, que recogía a su vez una considerable inercia histórica heredada de la Dictadura franquista (tradicionalmente vinculada al mundo árabe e Iberoamérica). Sin obviar la impronta que dejó su paso y formación en las filas del Movimiento, no debemos olvidar tampoco, la creciente incomodidad de Suárez ante el intervencionismo norteamericano en América Latina u Oriente Próximo $^{122}$. Una última pregunta queda en el aire, ¿modificó sus planteamientos durante sus últimos meses de presidencia? Según algunos testimonios de miembros de la UCD, Suárez dio su visto bueno al inicio de los trámites de adhesión a finales de 1980, fuentes que aunque han contado con bastante eco en la producción historiográfica todavía permanecen envueltas en un halo de incertidumbre.

Finalmente, la decisión del gobierno de Leopoldo Calvo-Sotelo, en 1981, de llevar a cabo la entrada de España en la OTAN fue respaldada en el Parlamento por Adolfo Suárez y quienes iban a engrosar en escasos meses las filas de su nuevo partido, caso del diputado Agustín Rodríguez Sahagún quien aludía en la tribuna del Congreso al ineludible proceso de modernización español, al fin del aislamiento y a la mejora en el posicionamiento sobre aspectos claves de seguridad interior y exterior (caso de Ceuta/Melilla o Gibraltar) ${ }^{123}$.

Apenas un año después, durante la presentación oficial del CDS, Adolfo Suárez matizaba su voto favorable a la adhesión a la OTAN. No se cuestionaba la pertenencia de España en la Alianza, sino la precipitación con la que se había realizado: no hubo consenso parlamentario (como había sucedido en el resto de los grandes debates políticos durante la Transición), ni se gozaba de la suficiente estabilidad democrática (inexistente debido a las intentonas golpistas) y ni siquiera se había garantizado ninguna contrapartida ${ }^{124}$. Todo ello implicaba que, al menos, "él no hubiera entrado en la OTAN

\footnotetext{
${ }^{121}$ POWELL, Charles T.: El amigo..., pp. 519-522.

122 En relación al 23-F, todavía en 1991 Suárez calificaba la actuación norteamericana de "poco amigable" en ASENSI, Juan: "Adolfo Suárez afirma que no sería benévolo con Tejero", $A B C, 09$ de febrero de 1991. Desde el punto de vista de la investigación histórica, hoy en día se ha matizado documentalmente el papel de EE.UU. en el golpe de estado, LÓPEZ ZAPICO, Misrael A.: "Anatomía de un asunto interno", Ayer, 84, 2011, pp. 183-205.

${ }^{123}$ Diario de sesiones del Congreso de Diputados (DSCD), Sesión Plenaria, 29 de octubre de 1981, $\mathrm{n}^{\circ}$ 193, p. 11428.

${ }^{124}$ DE PABLO, F. L.: "Me fui de UCD porque es incapaz de dar respuesta a los problemas del país", $Y a$, 02 de agosto de 1982, Archivo Linz.
} 
como [se] ha hecho". En 1984, llegó a afirmar en el Congreso que si había votado favorablemente había sido por disciplina de voto ${ }^{125}$.

La postura del CDS se profundizó en su I Congreso. En relación a la OTAN, escamoteó un debate dicotómico basado en el "sí o no" y se centró en valorar la necesidad de mejorar la posición de España dentro de la organización defensiva ${ }^{126}$. No obstante, se postulaba a favor de articular una política internacional no subordinada a EE.UU., ni en el ámbito nacional, ni europeo: "lo que no puede exigir EE.UU. a un país como España, es que le secunde en sus errores"127.

En julio de 1982, un informe de la inteligencia norteamericana señalaba que un posible triunfo electoral del PSOE aliado con Adolfo Suárez llevaría a España, aun manteniendo su deseo de integración en Europa, a un mayor énfasis en sus relaciones con países del Tercer Mundo y en relación a la OTAN: "Spain could become a less cooperative NATO member and would be more independent of Washington"128.

\section{5. El “Manifiesto del Ritz" y la reacción mediática}

El manifiesto fundacional del CDS constituyó el primer documento de referencia del proyecto suarista y en cierto modo, era una síntesis de las lecturas políticas y personales que Suárez había hecho de la realidad española desde que abandonara la presidencia del gobierno $^{129}$.

A lo largo de sus páginas, se solapaban dos líneas argumentales convergentes: una, referente a los últimos años de historia de España, y otra, una declaración de intenciones en términos programáticos (expresada, debemos añadir, con bastante más ambigüedad).

\footnotetext{
125 "Suárez apoyó la necesidad de alcanzar un consenso sobre cuestiones de Estado", $A B C, 26$ de octubre de 1984.

126 "Respecto de la integración española en la Alianza Atlántica, ya iniciada, es necesaria una negociación de las condiciones concretas de la misma [...] y vinculando, nuestra plena integración, a la satisfacción, por parte de los futuros aliados de una serie de demandas pendientes [...]", en CDS: Programa Electoral: España..., p. 16

127 "Nuestra política exterior" en Órgano de Información del Centro Democrático y Social (OICDS), 1, marzo de 1986.

128 "Spain and a Weakened UCD: Downhill Toward an Election", julio 1982, CIA-RDP83, Archivo CIA. Disponibles en: https://www.cia.gov. Fecha de consulta: 25 de enero de 2017.

129 A lo largo de este epígrafe, estudiaremos la "ideología institucional" del CDS, siguiendo la clasificación de Alan Ware quien contempla dos enfoques a la hora de abordar la ideología de un partido político: el de la competencia espacial y de la ideología institucional, véase, WARE, Alan: Partidos Políticos y Sistemas de partidos, Madrid, Istmo, 2000.
} 
El punto de convergencia de ambas era el análisis de los riesgos existentes en el país para la consolidación de la democracia; contexto en el que se justificaba políticamente la escisión del CDS de UCD: “en una democracia consolidada quizá deberíamos haber defendido nuestras tesis en los órganos del Partido del Gobierno [...] Pero en una democracia consolidada no sentiríamos la urgencia de salir en su defensa porque no existirían los riesgos que nos acosan"130.

Por un lado, el "Manifiesto Político" enunciaba los episodios fundamentales de la etapa reformista de la Transición, resaltando por su importancia los siguientes: la Constitución, los Pactos Autonómicos, la Reforma Fiscal y el Acuerdo Social (Pactos de la Moncloa). A continuación, propugnaba la superación de la división secular de España, como se había demostrado durante la Transición, mediante la práctica del diálogo y la ulterior búsqueda de pactos.

En segundo lugar y conectando con lo anterior, describía una realidad española asediada por numerosos peligros que ponían en riesgo la consolidación y estabilidad democrática. Desde el inicio del segundo mandato de Suárez, el reformismo característico de la Transición había encontrado numerosos obstáculos: "los ataques internos y externos a la unidad del proyecto político, -iniciados en 1979- adquirieron una violencia inusitada [en 1981]"131. En este epígrafe, titulado "La Democracia amenazada", el tono se endurecía y no es difícil entrever veladas críticas a las fuerzas conservadoras consideradas culpables de la situación generada en $\mathrm{UCD}^{132}$. Denunciaba: “es preciso poner de relieve ante la opinión pública, con serenidad y valor, que en España existen personas que pretenden utilizar estructuras económicas e incluso poderes institucionales" para tergiversar la soberanía del pueblo en lo que suponía una alusión a la presión de los "poderes fácticos” (sectores militares y económicos,

\footnotetext{
${ }^{130}$ CDS: Manifiesto Político, 1982, p. 8.

${ }^{131}$ Ibid., p. 7.

${ }^{132} \mathrm{Al}$ hablar sobre los argumentos esgrimidos habitualmente por estos sectores, se usó un ejemplo muy significativo, el de la "defensa de los valores tradicionales", en la que eran incluidos "desde una concepción sui generis de las creencias religiosas hasta determinadas y patriarcales concepciones de la familia o de la moral. No se trata naturalmente de averiguar cuáles son las exigencias de los valores auténticos que deben presidir la vida de una moderna comunidad política occidental. Esto obligaría sin duda a realizar unos cambios sociales, económicos y políticos que ciertos grupos no están dispuestos a consentir [...] Hay que denunciar la gravísima responsabilidad en que incurren quienes pretenden resucitar el fuego destructor que ha acompañado nuestras discordias civiles en los últimos doscientos años", Manifiesto..., pp. 7-8.
} 
fundamentalmente) $)^{133}$. Esta amenaza se solapaba con la injerencia de algunos de estos sectores en el debate político en favor del bipartidismo a costa del espacio político de centro,

Mito reaccionario de la clarificación política, en virtud del cual, los españoles, divididos eternamente en bandos antagónicos, deberían destruirse mutuamente [...] privando por la manipulación de las conciencias primero y si fuera preciso por la fuerza después a media España de la posibilidad de participar en las tareas de Gobierno ${ }^{134}$.

Con estas palabras expresaban su temor a la bipolarización del país, concepto vinculado al pasado de Guerra Civil, y motivo muy presente a lo largo del texto ${ }^{135}$.

Finalmente, se explicaba la propuesta del CDS, consistente en establecer: la "supremacía del poder civil" -ante posibles golpes de estado involucionistas-, un "estado social de derecho", -basado en el mérito y la libertad individual, en la igualdad "real" de oportunidades y en la justicia social-y la integración plena, aunque no a cualquier precio, en Occidente (crítica, por lo tanto, con el precipitado proceso de adhesión a la OTAN iniciado por Calvo-Sotelo). Las prioridades políticas del país ante las próximas elecciones, a las que acudían con "vocación de gobernar", nuevamente situaban como "prioridad esencial" la defensa de la supremacía del Poder Civil y del principio de soberanía nacional, y con una redacción bastante confusa, la necesidad de articular una política basada en el pacto en tres grandes áreas: el desarrollo autonómico, la superación de la crisis económica y la política exterior. Concluía asumiendo como un postulado irrenunciable la defensa del sistema democrático y de la consolidación de la Monarquía, "felizmente encarnada hoy en la persona del Rey Don Juan Carlos".

\footnotetext{
${ }^{133}$ La referencia a los "poderes fácticos" es un concepto interesante para comprender el pensamiento y la trayectoria de Suárez desde 1981. Creemos necesario insertar en este momento, una última lectura sobre la dimisión, que va a conectar este episodio con la fundación del CDS y el nuevo discurso político suarista. Señala J. R. Caso, que junto a la inestabilidad política general había una "presión muy fuerte de determinados poderes por la famosa mayoría natural, que es una de las causas de que él se vaya o una de las causas que él ve están más incidiendo en intentar fragmentar UCD”, entrevista con José Ramón Caso, 19 de noviembre 2014.

${ }^{134}$ Esta frase, que alude a la posibilidad de un golpe de estado, es susceptible de dos interpretaciones: o bien se refiere a los votantes de centro (en ese momento, lejos de futuras responsabilidades de gobierno fuera con UCD o el CDS) que se dividirían entre el PSOE y AP o a los votantes del PSOE; el propio Suárez señaló en diversas ocasiones que resultaba intolerable la intoxicación y presión ejercida por algunos sectores con el fin de evitar un gobierno socialista, Manifiesto Político, CDS, p. 7.

${ }^{135}$ Las primeras palabras del "Manifiesto" eran: "La crisis que ha sufrido la vida política española en los últimos tiempos se ha caracterizado por la tensión -en muchas ocasiones y expresada en guerras civiles..." Dicha idea aparecía explícitamente en 10 de los 33 párrafos de esta obra, Manifiesto Político, s.l., CDS, s.a. (1982). El recuerdo de la Guerra Civil entre los políticos de la Transición aparece subrayado en la biografía histórica sobre Adolfo Suárez de FUENTES ARAGONÉS, Juan Francisco: Adolfo Suárez..., pp. 538-555. Véase por ejemplo, el epílogo de Adolfo Suárez a la obra de ONETO, José: Anatomía de un cambio de régimen, Barcelona, Plaza \& Janés, 1985.
} 
Las dos líneas argumentales contenidas en el "Manifiesto Político" son susceptibles de un análisis más pormenorizado. Por ello, vamos a ahondar a continuación en la lectura de la Transición contenida en la propuesta del "Manifiesto Político", -la continuación del reformismo transicional y el constitucionalismo-, y por otro lado, en las principales implicaciones ideológicas del mismo, -el modelo de sociedad del CDS y el personalismo comunitario-.

Como decíamos al principio, en este texto parecía condensarse toda la trayectoria política de Suárez, y especialmente, su experiencia posterior a 1979: "la peripecia personal [...] durante su última etapa de gobierno parece haber marcado una profunda huella en su manera de entender la acción política"136. Adolfo Suárez recorría en este breve ideario las responsabilidades de los distintos sectores político-sociales en la desestabilización de la democracia española, -como sucedió durante su dimisión y el 23-F-, en lo que constituía una visión nada complaciente de la Historia Reciente de España. Suárez en una entrevista concedida a Miguel Ángel Aguilar, para El País, y publicada en portada con el titular, "No vuelvo para vindicar ofensas sino por los intentos de coartar la supremacía del poder civil”, señalaba:

A mi juicio, existen dos [riesgos] fundamentales. En primer lugar, la sensación creciente de que existen intentos reales para coartar la supremacía del poder civil y, por tanto, en último término, para acabar con el principio fundamental de que la soberanía nacional reside en el pueblo español [y en segundo lugar, la bipolarización política] ${ }^{137}$.

Al considerar que el gobierno de Leopoldo Calvo-Sotelo se había "derechizado", en parte debido a la presión de los poderes fácticos favorables a la "mayoría natural", muchos de quienes recalaron en el partido de Suárez provenientes de UCD aducían proseguir así el proyecto iniciado durante la Transición ${ }^{138}$. El distanciamiento del gobierno de Calvo-Sotelo se basaba en dos argumentos: la crítica a la LOAPA y a la precipitación en la adhesión a la OTAN, ambas medidas llevadas a cabo sin el consenso necesario. Manuel de Sárraga, ex diputado por Lérida, opina que el CDS recogía la continuidad ideológica de lo que había significado UCD, ante el sector liderado por

\footnotetext{
${ }^{136}$ Editorial: "El proyecto político de Suárez", La Vanguardia, 01 de agosto de 1982.

${ }^{137}$ El País, 08 de agosto de 1982.

138 Sobre el papel de algunos medios, especialmente El País, en magnificar la "derechización” del gobierno y el distanciamiento entre Suárez y Calvo-Sotelo es revelador, MARTíNEZ SÁNCHEZ, Santiago: "La opinión publicada y el gobierno Calvo-Sotelo" en NAVAJAS ZUBELDIA, Carlos e ITURRIAGA BARCO, Diego (eds.): España en democracia. Actas del IV Congreso de Historia de Nuestro Tiempo, Logroño, Universidad de la Rioja, 2014, pp. 209-221.
} 
Lavilla cercano a Alianza Popular ${ }^{139}$. Un diputado autonómico catalán que pasó al CDS en aquel verano justificaba su decisión con estas palabras: "la verdad es que el país había votado en 1979 una mayoría de centro y se encuentra hoy un Gobierno de derechas [...] La derecha controla el Gobierno y desde allí controla la UCD [...] dar el cambiazo para frenar los cambios" ${ }^{140}$. Perfecto Yebra, que ingresó en el CDS en agosto, manifestaba que había militado en UCD "con idea de llevar a cabo un programa de cambio, de reforma, un planteamiento progresista para una sociedad española distinta. Eso ha quedado en el camino, embarrancado"141. Rodríguez Sahagún hablaba de la “desnaturalización” del proyecto político de $\mathrm{UCD}^{142}$. Por citar un último ejemplo:

Es cierto, reconoce el representante del CDS, que tales presupuestos [de modernización que propone el CDS] figuran en el programa ideológico que fue aprobado en el primer Congreso de UCD, pero no es menos cierto que han sido negados por la práctica política en el último año y medio ${ }^{143}$.

La vinculación del CDS con la etapa reformista de la Transición (1976-1979), sus logros y sus valores le caracterizaban: "como partido constitucionalista, defensor del modelo de libertades del 78"144. El "constitucionalismo" del CDS tenía dos implicaciones ulteriores. Por un lado, la idea de culminar las reformas económicosociales (iniciadas con medidas como la Reforma Fiscal), una vez llevadas a cabo las principales transformaciones políticas (Constitución de 1978), en lo que se interpretaba como un intento por desarrollar íntegramente los preceptos de una Constitución que se había definido como "democrática y social" $" 145$ y que no había podido ser finalizado debido a la resistencia de los sectores privilegiados ${ }^{146}$.

\footnotetext{
${ }^{139}$ Entrevista con Manuel de Sárraga, 23 de julio de 2014 (Lérida).

${ }^{140}$ GUILLÉN, Santiago: "Dar el cambiazo", El Noticiero Universal, 03 de septiembre de 1982.

${ }^{141} A B C, 14$ de agosto 1982.

${ }^{142}$ El Noticiero Universal, 15 de septiembre de 1982.

${ }^{143}$ ABC, 19 de agosto de 1982.

144 Entrevista con José Ramón Caso, 19 de noviembre 2014. En este sentido, UCD y Adolfo Suárez parecían condensar a ojos de la opinión pública las fórmulas de mediación política, -el "consenso" como caso paradigmático-, desarrolladas en la Transición e identificadas con el discurso político del centro, y en última instancia su ideología, véase, en la obra clásica de DEL ÁGUILA TEJERINA, Rafael: El discurso político de la Transición, Madrid, CIS, 1984.

${ }^{145}$ Véase, MORODO, Raúl: La transición política, Madrid, Tecnos, 1984. La idea de llevar a cabo la “transición económica" se le atribuye a ÓNEGA, Fernando: Puedo prometer y prometo, Barcelona, Mondadori, 2013, p. 318.

${ }^{146}$ En propaganda electoral del CDS Madrid se explicaba el fin de Adolfo Suárez como el fruto de una “operación tenaza" entre el PSOE y las elites económicas ("\$ Club”). Asimismo, incluía una reproducción de la obra de Francisco de Goya Duelo a garrotazos, como condensación de la Historia Contemporánea de España, basada en la división y el enfrentamiento. El panfleto propagandístico se titulaba: "Aclarando historias, para evitar retrocesos", Archivo UB-Biblioteca Pavelló de la República, CDS, F.F.U. 1982/1.
} 
Por otra parte, el "consenso" constitucional era la antítesis de la bipolarización política que estaba viviendo el país y que ponía en peligro las reformas realizadas. Por ello, era necesaria la formación de un "Partido de Centro"147, el CDS, como factor moderador y equilibrador que garantizase la estabilidad democrática. Siguiendo la postura de Suárez,

En segundo lugar, existen intentos manifiestos de radicalizar el país y enfrentar a los españoles en dos bandos antagónicos. Estos intentos se fomentan desde las posiciones más conservadoras, como medio de evitar el temido triunfo socialista. Algunas personas además vierten veladas amenazas de involución para imposibilitar esa opción. A mí esa postura me parece, en cuanto a estrategia electoral, peligrosa y nociva para la convivencia española, y en cuanto al chantaje que se pretende ejercer sobre la libertad de voto, claramente intolerable ${ }^{148}$.

El CDS era fruto de unas circunstancias políticas, y cabe decir, históricas, muy concretas. Su principal “capital político" lo constituía la presidencia de Adolfo Suárez y su identificación con la fase central de la Transición y recordemos, la concatenación de episodios excepcionales (dimisión, 23-F, desintegración de UCD, etc.) que habían sucedido en los últimos meses ${ }^{149}$. Todo ello, generó increíbles dificultades al partido en su búsqueda de una ideología qué trascendiese las singulares causas de su origen. Montserrat Roig, en una ronda de entrevistas con los candidatos en las elecciones de 1982 en TVE, preguntaba sin rodeos al político abulense: “¿Usted cree en algo señor Suárez?"150.

No era extraño que, desde fuera, se subrayase el componente personalista sobre el que pivotaba el nuevo partido y del que derivaba primordialmente su cohesión, es decir, el suarismo. El periodista J. L. Gutiérrez en una entrevista realizada en Diario 16 a Suárez, en la precampaña del 82', enmarcaba una de sus preguntas sobre el CDS del siguiente modo: "hablemos ahora del CDS. Si un partido en democracia es el encuentro de unas personas con coincidencias ideológicas $[\ldots]$ ¿el CDS no es más un grupito de amigos, un ropero, un club para jugar al mus y practicar las ceremonias y los ritos de la

\footnotetext{
${ }^{147}$ Según fórmula empleada en el Manifiesto..., p. 7.

${ }^{148}$ Edición dominical de El País, 08 de agosto de 1982.

${ }^{149}$ El propio Adolfo Suárez ha reflexionado en numerosos artículos, entrevistas y discursos sobre las características básicas del momento histórico que protagonizó y perfiló una imagen bastante nítida de la Transición, imagen que se trasladó, como proyecto político de futuro al CDS. En sus análisis de la Transición, se refirió a ella como el período histórico que va desde 1976 a 1978, en el que destacaba ante todo tres hechos: la Ley para la Reforma Política, las elecciones del 15 de junio de 1977 y la Constitución, según publicó en el no 1000 de Cambio 16 en 1991, SUÁREZ GONZÁLEZ, Adolfo: "La transición española", Cambio 16, 7 de abril de 2014. La misma idea en CASO, José Ramón: "El centro sigue vivo", $A B C, 02$ de diciembre de 1982.

${ }_{150}$ "Suárez no convenció anoche en la pequeña pantalla", Diario 16, 28 de septiembre de 1982, Gabinete de Presidencia, Caja 317, Dossier CDS, AGCYL.
} 
más fervorosa e inquebrantable 'adolfolatría'?"151. El excesivo peso de Suárez en el liderazgo del partido, -conocido en los ambientes políticos o periodísticos como "centro de Suárez" o "casa de Suárez"-, era usado para subrayar su ausencia de ideología y caricaturizar, como se había hecho con profusión desde 1979, la ambición política del fundador $^{152}$. Al margen de las intenciones electoralistas de estos comentarios, resultaba evidente que el CDS constituía, ante todo el vehículo de afirmación política de Suárez. Recuerda el presidente provincial del CDS en Valladolid, Antonio Garrosa, la confusión que a veces provocaba el fuerte liderazgo de Adolfo Suárez en el CDS. No era extraño en este sentido que surgieran militantes que confundieran, de forma en ocasiones interesada, la admiración por la figura y obra de Suárez con comportamientos más cercanos al auténtico culto a la personalidad ${ }^{153}$.

Las escasas dimensiones del CDS, tanto representativas como organizativas, permitieron generar la idea en la opinión pública de que el partido y Adolfo Suárez eran indiscernibles. De este modo, no era difícil sostener que la ocupación del espacio de centro por parte de Adolfo Suárez respondía a un voto desideologizado, avalado únicamente por la "volatilidad" política de su fundador y, stricto sensu, susceptible de ser analizado en términos de adhesión personal. Los medios de comunicación y el resto de partidos políticos subrayaban la indefinición del nuevo "invento" suarista, cuyo manifiesto resultaba excesivamente abstracto y general. La única explicación que se encontraba, tanto a derecha como izquierda, a la formación del CDS era el triunfo de las ambiciones personales en el espacio político del centro-derecha: "en fin, cerrada la crisis [de UCD] es cuando mejor se ve su sentido y su radical personalismo"154.

El prurito por buscar un corpus ideológico estable y también, coherente con los principios del CDS, condujo a proclamar en el "Manifiesto Político" al "personalismo comunitario" como doctrina inspiradora del sistema de valores defendido por el nuevo partido, una corriente filosófica del s. XX con poderosos, aunque lejanos ecos políticos ${ }^{155}$. Esta teoría subrayaba la centralidad política de la persona siempre dentro de

\footnotetext{
${ }^{151}$ Diario 16, 26 de septiembre de 1982.

${ }^{152}$ Los ejemplos son muy numerosos, destacamos por su explicitud: "en el CDS Suárez es una institución por encima de la contingencia" en GARCÍA, Laureano: "Turno de la oposición”, ABC Sevilla, 18 de octubre de 1983.

${ }^{153}$ Entrevista con Antonio Garrosa, julio de 2013 (Fuensaldaña, Valladolid).

154 ALTARES, Pedro: "La vuelta de la sopa de letras", El País, 09 de agosto de 1982.

${ }^{155}$ Manifiesto..., p. 9; el "personalismo comunitario" es una corriente filosófica articulada por Emmanuel Mounier en las décadas centrales del s. XX con un fuerte componente ético, político y social e incardinada sobre el pensamiento cristiano. Aunque en abierta polémica con el marxismo, no renunciaba
} 
la comunidad y la sociedad en oposición al individualismo contemporáneo. Debido a la estrecha vinculación entre la libertad y la dignidad del hombre y la vida en comunidad, sólo el desarrollo de la justicia y la solidaridad podían ser garantías de las primeras. Sin embargo, las personas y las sociedades debían estar en constante transformación evitando la "cristalización definitiva e inamovible de la organización política"156. El estado era una herramienta más al servicio del desarrollo del ser humano, y no al revés. El modelo de sociedad que intentaba aunar esta dualidad, en la que se encontraba la sociedad contemporánea, era la "sociedad de mérito":

Las libertades ciudadanas y los derechos individuales han de poder ser ejercidos por todos los españoles sin que lo impida o entorpezca la situación económica o la clase social de cada uno [...] es necesario, por tanto, desarrollar una actividad compensatoria de todas las desigualdades de partida. Defendemos una sociedad de mérito en que el esfuerzo y el trabajo tengan su recompensa [...] nadie, en definitiva, en nombre de la libertad puede defender la injusticia de los privilegios.

En términos económicos intentaba mantener un equilibrio entre los principios de libertad económica y de intervención estatal, sin que se viera mermado o desincentivado el esfuerzo y el trabajo individual, pero no sirviera por ello para la justificación de injusticias:

La libertad, la igualdad y la solidaridad, unidas a los objetivos de calidad de vida y eficacia económica constituyen sus principios esenciales. Defendemos la libertad económica porque sólo con ella es posible la libertad política y la dignidad y realización de la persona. Pero la libertad económica no es un valor absoluto [...] Creemos en las virtualidades de la economía libre de mercado pero entendemos también que el sistema de mercado requiere unos correctivos y la existencia de un sector público que sirva, por un lado, para garantizar la autonomía económica de la Nación y, por otro, para conseguir un reparto más equitativo de la renta, la riqueza y el poder social.

Para Aurelio Delgado el pensamiento político de Suárez giraba en base a la idea de una "sociedad permeable" en la que primase el "mérito", pero siempre manteniendo "un sentido de la justicia" y contando para ello con el papel de un estado equilibrador ${ }^{157}$. En cierto modo, concluye Delgado, el pensamiento de Suárez guardaba una estrecha relación con su trayectoria vital (Anexo II).

a la transformación política, en clave progresista, de la sociedad, distanciándose de este modo del "humanismo cristiano" inspirador de los proyectos políticos democristianos, véase, DÍAZ HERNÁNDEZ, Carlos: Mounier: ética y política, Madrid, Editorial: Cuadernos para el Diálogo (Colección Suplementos: $\left.\mathrm{n}^{\circ} 59\right), 1975$.

${ }^{156}$ MELLADO PRADO, Pilar: "Congreso Constituyente del Centro Democrático y Social”, Revista de Derecho Político, 16, invierno 1982-1983, p. 229.

${ }^{157}$ Entrevista con Aurelio Delgado, 19 de diciembre de 2014. Parece exagerada la genealogía de las inspiraciones teóricas -liberales-, de Suárez (remontándose hasta Adam Smith o F. Hayek) descrita pormenorizadamente en QUEVEDO, Federico: Pasión por la libertad. El pensamiento político de Adolfo Suárez, Barcelona, Altera, 2007. 
La apelación al "personalismo comunitario" sirvió en última instancia para enmarcar el cariz "ético" y social del que quiso imbuir Suárez a sus intervenciones en este período, sin embargo no cuajó ni en el seno del partido, ni en el electorado ${ }^{158}$. Se convirtió en un enigma para la mayoría de los militantes que desconocían tanto el porqué de esta adscripción como sus implicaciones ${ }^{159}$. También intelectuales y comentaristas políticos acogieron con escepticismo la adscripción filosófica del CDS en la obra de E. Mounier, que sí tenía relevancia en el "comunitarismo" político latinoamericano, ámbito donde quizá, en uno de sus múltiples viajes y contactos con líderes hispanohablantes, fuera conocida por Suárez ${ }^{160}$.

La reacción de los medios de comunicación a la presentación pública del CDS centrándonos en la "opinión publicada"-, fue amplia y exhaustiva, aunque en su mayor parte hostil -sobre las cifras de difusión de estos medios, véase gráfica 1-. La prensa hizo amplios resúmenes del mismo, e incluso, el CDS lo publicó en El País de forma íntegra $^{161}$. Para $A B C$, el nacimiento del CDS se basaba en dos argumentos: una opción estrictamente personal de Suárez, cuya trayectoria por otra parte estaba totalmente condicionada por la incógnita de su dimisión, y la indefinición de un proyecto basado en el "personalismo comunitario", sin homologación en Europa ${ }^{162}$. El columnista Carlos Dávila enfatizaba el despropósito estratégico (para el centro-derecha en su conjunto) e ideológico que suponía la decisión de $S u a ́ r e z{ }^{163}$. Desde las páginas del $Y a$ se realizaba una crítica sin paliativos al nuevo proyecto suarista, que no era ni necesario, ni original:

\footnotetext{
158 “Aureola de moralidad y fuertes principios éticos”, La Hoja del Lunes, 02 de agosto de 1982.

159 Todavía en 1987, en una publicación del partido en Albacete se decía: "todos los que militamos en el CDS sabemos que el PERSONALISMO, es nuestra fuente de inspiración doctrinal, pero ¿qué es? Muy brevemente y para no ser pesados diremos [...]", SANTOS, Ángel: "Personalismo y C.D.S." en Eslabón Boletín Informativo del Centro Democrático y Social, 2, febrero de 1987, 6.

160 "Precisamente una de las características de dicha ideología es su conciencia de no constituir un cuerpo doctrinal de carácter dogmático, sino una serie de principios flexibles que deberán adaptarse a cada país en la práctica política, y el mismo autor que venimos citando así lo hace al detenerse en el examen de los distintos países donde esa filosofía política ha tenido cierta influencia. Habrá que esperar, pues, para saber algo más concreto, al congreso constituyente del partido y a conocer las bases que allí se establezcan" en ABELLÁN, José Luis: "El personalismo comunitario", El País, 18 de septiembre de 1982. Las dudas razonadas del profesor Abellán eran la excepción frente a la ironía de muchos columnistas a derecha e izquierda que lo usaron para sacar a relucir el cliché sobre la pobre formación intelectual de Suárez, "la única sorpresa, grande, por cierto, en los manifiestos de intenciones es lo del personalismo humanista [sic] del CDS. No es para menos eso de que Suárez se supone que en sus años mozos haya leído a Maritain y Mounier. Claro que como diferenciación no le va a servir de mucho" en ALTARES, Pedro: "La vuelta de la sopa de letras", El País, 09 de agosto de 1982. P. Urbano ironizaba diciendo que los principios del CDS eran tan generales y abstractos que podían ser los de la Marsellesa, URBANO, Pilar: "Algo más que spray", $A B C, 09$ de septiembre de 1982.

${ }_{161}^{1}$ Publicado a doble página, El País, 01 de agosto de 1982.

${ }^{162}$ Editorial: "El personalismo comunitario", $A B C, 01$ de agosto de 1982.

${ }^{163}$ DÁVILA, Carlos: "Contra las luces de la razón", $A B C, 01$ de agosto de 1982.
} 
"nos parece más un pulso a la UCD que un nuevo partido"164. La Vanguardia situaba a un CDS nacido con "cierto aroma justiciero", en la frontera electoral del PSOE, exigía una mayor concreción en cuanto a pactos políticos (en relación al PSOE) y achacaba la escisión de Suárez a "enfrentamientos personales"165. Adolfo Suárez ocupaba la portada de Diario 16 bajo el titular, "Si un militar hubiera pedido mi dimisión, estaría encarcelado"166, y Pedro J. Ramírez le dedicaba un duro artículo que comenzaba reconociendo su papel en la llegada de la democracia para añadir inmediatamente después: "en algún lugar de su subconsciente surgen extrañas barreras mentales que le impiden actuar en la vida pública de acuerdo con los usos y exigencias del sistema"167. Finalmente, El País ironizaba sobre la decisión de Suárez de crear un partido personalista y populista -"Un partido para el Duque"168-, elogiando, aunque caracterizándola de frívola, la nueva "aventura” de un político que parecía abocado a la "jubilación forzosa"169.

Gráfica 1: Difusión total de la prensa de información general nacional (1982-1991).

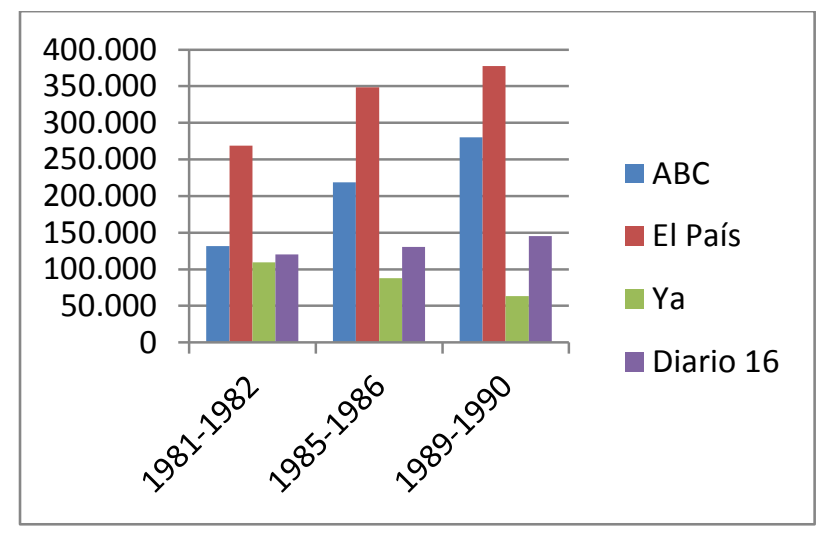

Elaboración propia a partir de los datos del Boletín de la Oficina de Justificación de la Distribución (no: 203-302).

\footnotetext{
${ }^{164}$ Editorial: “¿Un nuevo partido o un pulso?”, Ya, 01 de agosto de 1982.

165 Editorial: "El proyecto político de Suárez", La Vanguardia, 01 de agosto de 1982. Lorenzo Contreras subrayaba las similitudes entre el PAD y el CDS en Informaciones, 02 de agosto de 1982. Sobre la cercanía al PSOE, ABASCAL, Federico: Cinco Días, 02 de agosto de 1982. Pedro Hernández escribía: "Suárez abandona su casa y establece un campamento en las cercanías [del PSOE]" en Tiempo, 02 de agosto de 1982.

${ }^{166}$ Diario 16, 01 de agosto de 1982.

${ }^{167}$ El autor llamaba la atención sobre la incapacidad o ausencia de interés por parte de Suárez de imponer democráticamente sus posicionamientos en el seno de UCD y tildaba de "extravagante[s]" los motivos defendidos para la fundación del CDS y marcha de UCD, RAMÍREZ, Pedro. J.: "El duque y las uvas", Diario 16, 02 de agosto de 1982. J. L. Gutiérrez se mostraba más benévolo al subrayar la nueva imagen y discurso mostrados por Suárez, "El duque ya no fuma 'Ducados", Diario 16, 01 de agosto de 1982.

${ }^{168}$ Editorial: "Un partido para el duque”, El País, 02 de agosto de 1982.

${ }^{169}$ El 01 de agosto ocupaba la portada de El País con el titular, "Adolfo Suárez defiende la primacía del poder civil". Asimismo, fue en El País en el medio donde concedió su primera entrevista desde su reaparición política, con el periodista Miguel Ángel Aguilar, titulada: "La hostilidad de sectores privilegiados es el precio a pagar por mi independencia como presidente", El País, 08 de agosto de 1982.
} 
Junto con algunos comentaristas políticos afines a Suárez, como Abel Hernández candidato del CDS por Soria en $1982^{170}$ - o el historiador Carlos Seco Serrano ${ }^{171}$ el decano del periodismo barcelonés El Noticiero Universal fue el único medio que saludó con entusiasmo el nacimiento del CDS: "El CDS un partido necesario"172. El CDS suponía un proyecto decisivo para la consolidación del régimen democrático debido a su oposición a grupos desestabilizadores y a la polarización política, y el intento más plausible de proseguir el rumbo modernizador iniciado en la Transición. Cabe concluir, con el conciso titular de Pueblo "Vuelve Suárez", quien podía ser centro-progresista, centro-izquierdista, pero ante todo era "la política".

\section{6. Un estudio de caso: de la UCD al CDS en la provincia de Zamora}

Hasta ahora hemos analizado el nacimiento del CDS atendiendo a su dimensión nacional. Nos parece sugerente complementar esta visión, analizando estas dinámicas desde una perspectiva más reducida, que nos permita observar con mayor detalle algunos de los comportamientos políticos existentes durante esta convulsa fase de la historia del sistema de partidos español. El interés reside en dos aspectos: en la singularidad de las fuentes con las que contamos, -"Fondo UCD” del Archivo Histórico Provincial de Zamora-, y en lo paradigmático de un caso que resulta, como veremos, extrapolable a otras provincias.

La UCD había resultado vencedora indiscutible en los procesos electorales de 1977 y 1979 celebrados en Zamora, con unos porcentajes que superaban holgadamente la media nacional, erigiéndose en el grupo político más poderoso de la provincia. En 1977, UCD obtuvo en Zamora un 46,59\%, frente a un 34,44\% a nivel nacional; en 1979, alcanzó el 50,57\% frente a un 34,84\%. Incluso, en las elecciones de 1982, Zamora fue una de las pocas provincias donde UCD obtuvo representación, gracias a la elección

\footnotetext{
170 "El Manifiesto del Ritz", Ya, 02 de agosto de 1982.

171 "Suárez y el centro", El País, 05 de agosto de 1982.

172 El Noticiero Universal, 02 de agosto de 1982. En el plano mediático, El Noticiero Universal fue el principal medio afín al CDS existente en España, a pesar de mantener en materia socio-económica una línea editorial más escorada al centro-derecha. En la campaña de 1982 escribía diariamente el candidato por Barcelona, Antonio de Senillosa, y aparecían habitualmente artículos de los centristas Josep Pujadas y, algo después, de Federico Ysart. El día 22 de octubre, El Noticiero Universal organizó a Suárez una cena-coloquio en Barcelona -en un viaje relámpago en plena campaña electoral-, copando la portada y tres páginas completas en la siguiente edición. La estrecha relación de Adolfo Suárez con El Noticiero Universal se remontaba a la participación accionarial de Aurelio Delgado en el vespertino catalán desde 1976, véase, GARCÍA ABAD, José: Una tragedia ..., p. 163.
} 
como diputado de Luis Ortiz González. Los diputados y senadores electos por Zamora en 1977 y 1979 fueron:

Tabla 1 a): Diputados y senadores electos en la provincia de Zamora $(1977)^{173}$.

\begin{tabular}{|l|l|l|l|}
\hline \multicolumn{2}{|l|}{ DIPUTADOS 1977} & \multicolumn{2}{l|}{ SENADORES 1977} \\
\hline UCD & JOSE A.OTERO MADRIGAL & UCD & VALERIANO ENRÍQUEZ GONZÁLEZ \\
\hline UCD & MODESTO ALONSO PELAYO & UCD & VICTOR M. CARRASCAL FELGUEROSO \\
\hline AP & FEDERICO SILVA MUÑOZ & UCD & LUIS RODRÍGUEZ SAN LÉON * \\
\hline PSOE & DEMETRIO MADRID LOPEZ & PSOE & MANUEL ALONSO NOVO \\
\hline
\end{tabular}

Elaboración propia a partir de http://www.historiaelectoral.com/e1977d.html y http://www.historiaelectoral.com/e1977s.html ${ }^{174}$

Tabla 1 b): Diputados y senadores electos en la provincia de Zamora (1979).

\begin{tabular}{|l|l|l|l|}
\hline \multicolumn{2}{|l|}{ DIPUTADOS 1979 } & \multicolumn{2}{l|}{ SENADORES 1979 } \\
\hline UCD & VICTOR M. CARRASCAL FELGUEROSO & UCD & LUIS RODRÍGUEZ SAN LÉON * \\
\hline UCD & CESAR MARTIN MONTES * & UCD & RICARDO RODRÍGUEZ CASTANÓN \\
\hline UCD & JESUS PEREZ LOPEZ * & UCD & ONÉSIMO LÓPEZ CHILLÓN \\
\hline PSOE & DEMETRIO MADRID LOPEZ & AP & CARLOS PINILLA TURIÑO \\
\hline
\end{tabular}

Elaboración propia a partir de http://www.historiaelectoral.com/e1979d.html y http://www.historiaelectoral.com/e1977s.html

Tabla 1 c): Diputados y senadores electos en la provincia de Zamora (1982).

\begin{tabular}{|l|l|l|l|}
\hline \multicolumn{2}{|l|}{ DIPUTADOS 1982 } & \multicolumn{2}{|l|}{ SENADORES 1982 } \\
\hline PSOE & DEMETRIO MADRID & PSOE & ANDRÉS LUIS CALVO \\
\hline PSOE & JOSÉ LUIS GARCÍA RAYA & PSOE & DOMINGO MAÑANES \\
\hline UCD & LUIS ORTIZ & AP-PDP & CARLOS PINILLA TURIÑO \\
\hline AP-PDP & JOSÉ MARÍA RUIZ GALLARDÓN & AP-PDP & SANTOS MISOL \\
\hline
\end{tabular}

Elaboración propia a partir de http://www.historiaelectoral.com/e1982d.html y http://www.historiaelectoral.com/e1982comp.html

Fue precisamente en este contexto de éxito político, cuando se gestó el origen de la futura división y descomposición del partido a nivel provincial. El grupo de UCDZamora evidenciaba síntomas de desunión desde 1979, apenas año y medio después de la formalización definitiva de sus órganos de gobierno cuando el diputado Víctor Carrascal Felgueroso fue elegido presidente en la II Asamblea Provincial del partido, con la ausencia de más de la mitad de los convocados y del antiguo presidente

\footnotetext{
${ }^{173}$ Con un asterisco señalamos aquellos parlamentarios de UCD que se integraron en el CDS en agosto de 1982. Es necesario hacer una breve semblanza política y profesional de los que van a ser los protagonistas de este epígrafe. El senador Luis Rodríguez San León era en ese momento un conocido empresario zamorano y director de diversas asociaciones locales; César Martín Montes, palentino, vinculado al Servicio Nacional de Inspección de las Administraciones Locales, trabajaba en la provincia de Zamora desde 1966, y Jesús Pérez López fue asesor jurídico de la UCD provincial desde sus inicios. Por otra parte, Víctor Carrascal Felgueroso era un político oriundo de Madrid, con amplia formación académica y vinculado a Ignacio Camuñas en el tardofranquismo, José Andrés Díez de Ulzurrun Mosquera ( $\mathrm{n}^{\circ} 4$ en la listas al congreso de 1979), zamorano ejercía como ingeniero técnico agrario en el I.R.Y.D.A. desde 1966, y Onésimo López Chillón, zamorano, era agricultor y promotor de la Asociación Independiente de Ganaderos y Labradores de Zamora en Dossier de la Secretaría de Información de UCD, Biografías de Diputados y Senadores, Fondo UCD, caja 21, AHPZ.

${ }^{174}$ Para las tablas 1 a), b) y c) la información fue consultada el 26 de abril de 2015.
} 
provincial, Luis Rodríguez San León ${ }^{175}$. Luis Rodríguez San León había presentado su dimisión el 3 de mayo de 1979, poco después de ser elegido senador por UCD en la circunscripción zamorana ${ }^{176}$. Sobre la nueva dirección política del partido en Zamora comentaba un destacado dirigente centrista:

[Answer] No, no existían [las baronías], curiosamente vinieron a continuación. Es decir, de los que estaban que subieron a la ejecutiva en la asamblea siguiente [1979] [...] es ahí donde comenzó el primer error y la primera caída de la UCD provincial [...] la historia de este país es que todo el mundo quiere ser diputado, pero por ej. los que crearon la UCD, todo el mundo quería ser diputado por Madrid, pero claro, el presidente Suárez decía, bueno, es que en la lista de Madrid son 25, yo lo que no puedo hacer es meter a 48 [...] todo lo que ha ocurrido en UCD es una razón completamente personal [...]

[Question] Entonces en estas luchas no fue muy importante asuntos ideológicos ni de organización. Simplemente la lucha por el poder.

[A.] La lucha por el poder... ${ }^{177}$

La situación de la UCD en Zamora, hacia 1979, estaba atravesada por una fractura política entre el cuadro directivo saliente (encabezado por Luis Rodríguez San León) y el entrante, (con Víctor Carrascal Felgueroso al frente), que asimismo dividió a las bases y cargos electos del partido durante los años siguientes. La lucha por el control del aparato provincial y los problemas en la composición de las listas electorales fueron las causas subyacentes de este distanciamiento. En 1981, las diferentes tensiones existentes dentro de la UCD, más o menos soterradas hasta entonces, estallaron a raíz de la dimisión del presidente y líder centrista, Adolfo Suárez, a finales de enero y la celebración del II Congreso de UCD en Palma de Mallorca.

En el ámbito provincial, a comienzos de julio de 1981, tuvo lugar un proceso de renovación de cargos que repitió en sus formas y enfrentamientos lo sucedido a nivel nacional, si bien, con algunos matices particulares. La preparación de la III Asamblea Provincial de Zamora, celebrada en julio de 1981, ahondó la división existente en la provincia. Los dos bloques que se habían fraguado en 1979 dentro del partido estaban a la altura de 1981 perfectamente perfilados y presentaron sus listas respectivas en abierta oposición $^{178}$. Por un lado, se presentaba una lista apoyada por quienes habían llevado las riendas de la UCD en Zamora desde 1979, entre ellos el presidente provincial Víctor

\footnotetext{
${ }^{175}$ El País, 17 de julio de 1979. Luis Rodríguez San León fue elegido presidente provincial de UCD en Zamora el 09 de diciembre de 1977 en Dossier de la Secretaría de Información de UCD, Fondo UCD, Caja 21, AHPZ.

${ }^{176}$ Carta de Dimisión de Luis Rodríguez San León, Fondo UCD, Caja 2, AHPZ.

177 Interview undertaken by Richard Gunther in 1983 (june), AR.

178 "UCD renueva este fin de semana 12 ejecutivas provinciales [...] también en Zamora se presenta una situación de enfrentamiento", El País, 04 de julio de 1981.
} 
Carrascal Felgueroso ${ }^{179}$. Al frente de esta lista se encontraba el Ministro de Obras Públicas, Luis Ortiz González, uno de los hombres de gobierno más cercanos a Leopoldo Calvo-Sotelo. Frente a ellos, se había constituido una auténtica plataforma opositora auspiciada por aquellos que no participaron en la II Asamblea Provincial. Estaban encabezados por el senador Luis Rodríguez San León, los diputados César Martín Montes y Jesús Pérez López y el Presidente de la Diputación Provincial, José Miguel López Martínez. Entre junio y julio de 1981, los cuatro firmaron una serie de artículos en El Correo de Zamora en los que presentaban sus propuestas de renovación de los órganos de gobierno provinciales:

La lista ahora llamada "oficialista" (observen la paradoja), para la que se obtuvieron refuerzos foráneos mediante el aterrizaje de conocidos políticos madrileños [...] De cara a la asamblea del 5 de julio las posiciones están tomadas. Continuismo o renovación. Colonialismo o autonomía política provincial ${ }^{180}$.

En relación a la candidatura de Luis Ortiz se lanzaba la acusación de "cunero": "no nos dice qué motivaciones de conciencia le indujeron a acordarse de Zamora, precisamente de Zamora, para el ejercicio de su misión salvadora” ${ }^{„ 181}$. Como ocurría en el resto de España, en Zamora, el enfrentamiento político en el seno de la UCD provincial se identificaba sólo parcialmente con "el oficialismo" y con "el sector crítico". Las luchas de poder a nivel local y provincial entre los líderes de la UCD surgieron entre los que se consideraban defensores de los intereses de Zamora frente a los políticos colocados desde Madrid, y sólo a posteriori, desembocaron en la vinculación de los dos bloques a unas u otras de las familias del partido, en función de su afinidad ideológica. El grupo encabezado por Rodríguez San León se posicionaba políticamente en abierta discrepancia con el llamado sector crítico y apostaba por el resurgir, desde la UCD, de una oferta política de centro-centro, en sintonía con los hombres más cercanos de Adolfo Suárez. Sin embargo, su poder no residía tanto en la

\footnotetext{
179 "Soy una de las personas que más ha trabajado en la aproximación [...] desde el principio en el que se planteó la presidencia de Luis Ortiz yo dije que iba a estar a su lado y en este apoyo me mantengo asumiendo los errores que haya podido cometer", "Acta del Comité Ejecutivo Provincial de UCD Zamora", 06 de marzo de 1982, p. 3. Fondo UCD, Caja 64, AHPZ.

${ }^{180}$ Dichos artículos se encontraban como documentos anejos a una de las fichas de expulsión del Comité Disciplinario de UCD, en agosto de 1982: "Desde el Congreso de Palma", en El Correo de Zamora, 30 de junio de 1981; "Contestando al ministro del M. O. P. U.”, El Correo de Zamora, 03 de julio de 1981 y "Ante la Asamblea de UCD", El Correo de Zamora, 04 de julio de 1981 en "Dossier de expulsados", Fondo UCD, caja 65, AHPZ. La cita corresponde a El Correo de Zamora, 30 de junio de 1981, "Dossier de expulsados", Fondo UCD, Caja 65, AHPZ.

${ }^{181}$ El Correo de Zamora, 03 de julio de 1981, "Dossier de expulsados”, Fondo UCD, Caja 65, AHPZ.
} 
presión del aparato suarista del partido, como en la importancia de los cargos que desempeñaban y su capacidad de influencia a nivel local y provincial $^{182}$.

Los resultados de la II Asamblea Provincial de Zamora depararon una apretada victoria, -247 votos frente a $217^{183}$-, de la lista encabezada por Ortiz González, quien se convirtió en el nuevo presidente de la UCD zamorana. Junto a él, José Díez de Ulzurrun Mosquera resultó elegido secretario general. Ambos estaban apoyados por el ex presidente provincial Víctor Carrascal Felgueroso. Asimismo, como miembros con voz pero sin voto de la nueva ejecutiva, -en tanto que parlamentarios de la provincia-, se encontraban Luis Rodríguez San León, Jesús Pérez López y César Martín Montes ${ }^{184}$. A partir de entonces, la situación en la UCD de Zamora se fundió totalmente con la del centrismo nacional y el pulso político del grupo centrista provincial pasó a ser un reflejo sintomático de la convulsa situación de la UCD entre los años 1981 y $1982^{185}$.

En el otoño de 1981, tuvo lugar el abandono del sector socialdemócrata del partido centrista, tanto a nivel nacional, como provincial. Ricardo Rodríguez Castañón ${ }^{186}$, senador socialdemócrata por Zamora, comunicaba oficialmente su renuncia a la militancia centrista indicando explícitamente que la situación del partido en Zamora, "no puede sustraerse a la realidad del Partido a nivel Nacional"187. La marcha de la facción socialdemócrata se solapaba con los cambios en la Presidencia y Secretaría General de UCD de noviembre del ' 81 , tras el fracaso centrista en las elecciones autonómicas gallegas. Leopoldo Calvo-Sotelo se hacía cargo del partido, en lugar de Agustín Rodríguez Sahagún, e Íñigo Cavero recalaba en la Secretaría General sustituyendo a Rafael Calvo Ortega, relegándose así a los “suaristas" del poder ${ }^{188}$.

En la reunión del Comité Ejecutivo Provincial celebrada con posterioridad a estas dimisiones y encabezada por el ministro Luis Ortiz González, consciente de la peligrosa situación que se estaba generando, trató de quitar hierro a los problemas mostrando su

\footnotetext{
${ }^{182}$ Véase, El Correo de Zamora, 30 de junio de 1982 en "Dossier de Expulsados", Fondo UCD, Caja 65, AHPZ.

${ }_{183}$ El País, 07 de julio de 1981.

184 “Dossier de la Secretaría de Información de UCD”, Fondo UCD, Caja 21, AHPZ.

185 "El paradigma de esta nueva fase de la crisis de UCD es la sustitución del recurso a la "voz", por la estrategia de salida", HOPKIN, Jonathan R.: Un partido...

${ }^{186}$ Sobre su participación en el PAD de Francisco Fernández Ordóñez, líder del ala socialdemócrata de UCD y ministro en diversos gobiernos de A. Suárez y L. Calvo-Sotelo, véase, Partido de Acción Democrática. Congreso Constituyente, Madrid, PAD, 1982, pp. 17-42.

187 "Carta de Rodríguez Castañón", 13 de noviembre de 1981 en "Dossier de Expulsados", Fondo UCD, Caja 65, AHPZ.

${ }^{188}$ HUNEEUS, Carlos: Unión de Centro..., p. 373 y ss.
} 
total afinidad con la nueva dirección del partido y transmitiendo "la situación de noramalidad [sic] a todos los sectores de nuestra provincia" ${ }^{\text {"189 }}$. A aquella reunión del Comité Ejecutivo no asistieron ni Jesús Pérez López, ni César Martín Montes; por aquellas fechas, miembros del sector suarista comenzaron a ausentarse también de las reuniones de la ejecutiva nacional. Sin embargo, todavía había una posibilidad de convergencia de intereses entre las dos facciones.

Por un lado, de aquellas reuniones de la ejecutiva provincial se trasluce que la mayor preocupación era evitar que se consumase la división del partido existente en la provincia, con el fin de no perjudicar aún más a UCD y al gobierno estatal ${ }^{190}$. Por otra parte, en la dialéctica entre aumentar su presencia en los órganos directivos del partido o abandonarlo definitivamente, -al hilo de los desarrollos teóricos de J. Hopkin aplicados a UCD-, el grupo del senador Luis Rodríguez San León estaba en condiciones -debido a la importancia de sus cargos y su liderazgo a nivel provincial/local-, de exigir nuevas fórmulas de participación:

Tras largas y extensas conversaciones con los Parlamentarios Luis Rodríguez San León, César Martín Montes y Jesús Pérez López, y con el Presidente de la Diputación, para tratar de llegar a un acuerdo en el que se lograra la plena integración de estos en el seno del Partido, se ha elaborado un documento que se somete a consideración de este Comité Ejecutivo para que adopte los acuerdos correspondientes ${ }^{191}$.

En este documento, se proponía la creación de un Comité de Coordinación y Acción Provincial que contase con la presencia de todos los grandes cargos provinciales y tuviese destacados poderes en la formación de las listas (una de las cláusulas requería la inclusión de los parlamentarios electos en 1979 en las futuras listas de forma automática). Aunque se realizó una votación que resultó favorable a la formación del nuevo Comité, -salvo el apartado referente a la inclusión, por defecto, de los parlamentarios elegidos en 1979 en las nuevas listas-, esta fórmula de integración llegaba demasiado tarde; suponía el último intento, al margen ya de las fórmulas estatutarias, de integración política. Una anotación a mano, junto al acta de aquella reunión resumía el estado de ánimo dentro del partido: "Desde UCD, no podemos permitirnos el lujo de pregonar la democracia, el progreso, la paz. Yo pido a todos,

\footnotetext{
${ }^{189}$ Esta reunión constituyó la última de la que tenemos constancia de la presencia de Luis Rodríguez San León, "Actas de la reunión del Comité Ejecutivo Provincial de U.C.D. de Zamora", 11 de diciembre de 1981, 22 de enero de 1982 y 06 de marzo de 1982 en Fondo UCD, Caja 64, AHPZ.

190 "Actas de la reunión del Comité Ejecutivo Provincial de U.C.D. de Zamora", 11 de diciembre de 1981, 22 de enero de 1982 y 06 de marzo de 1982, Fondo UCD, Caja 64, AHPZ.

191 "Acta de la reunión del Comité Ejecutivo Provincial de U.C.D. de Zamora", 06 de marzo de 1982, Fondo UCD, Caja 64, AHPZ.
} 
generosidad, y que nadie se mire a sí mismo, sino a los demás. Ni vencedores, ni vencidos. No todos los problemas están resueltos"192.

En las semanas siguientes, el bloque de parlamentarios enfrentado a la cúpula provincial acentuó sus actividades como un grupo autónomo ${ }^{193}$, cada vez más abiertamente explícito en sus acusaciones al ejecutivo centrista, identificado con la dirección provincial del partido ${ }^{194}$ :

[...] ha ignorado, marginado, y menospreciado al Presidente del Partido, y a los Parlamentarios, cargos Provinciales y Locales, miembros del Comité Ejecutivo y militantes en general que no forman parte del grupo perdedor en la Asamblea Provincial de 1981, que encabeza el Senador D. Luis Rodríguez San León quien recientemente abandonó UCD para incorporarse al nuevo Partido Centro Democrático y Social [...] Tal connivencia, que ya quedó apuntada en el apartado anterior, se ha materializado en numerosas visitas realizadas por ambos a pueblos de la Provincia; visitas [...] a las que nunca fueron invitados el Presidente o Secretario Provincial del Partido, Parlamentarios del otro grupo, etc. Estas visitas han quedado reflejadas sobradamente, en la radio y prensa local $[\ldots]^{195}$.

De este modo, los posicionamientos de ambos grupos, a la altura de la primavera de 1982 estaban perfectamente clarificados. El Comité Ejecutivo Provincial se identificaba con la política gubernamental y la gestión de UCD por parte de Leopoldo Calvo-Sotelo; por su parte, el grupo encabezado por Luis Rodríguez San León, partidario del centrocentro, agotó definitivamente la búsqueda de una alternativa integradora en el seno de la UCD provincial, -expresión de "voz"-, al encontrar un nuevo cauce de representación política junto a otros cuadros provinciales de UCD, a nivel nacional, a lo largo de junio y julio de 1982, cuya demanda principal era la vuelta de Adolfo Suárez a la presidencia

\footnotetext{
192 "Acta de la reunión del Comité Ejecutivo Provincial de U.C.D. de Zamora", 06 de marzo de 1982, Fondo UCD, Caja 5, AHPZ. De cara a la opinión pública se daba una versión maquillada de los hechos: "Ayer día 5 de julio se cumplió el primer aniversario de la elección de Luis Ortiz González como presidente de UCD en Zamora, [...] La elección fue dura y reñida y provocó un cierto malestar en algunos de los miembros de la candidatura derrotada, origen, quizás, de las discrepancias que, a lo largo del año, se han manifestado, sobre todo por parte de los parlamentarios que quedaron fuera del Comité Ejecutivo [...] El señor Ortiz González considera que sus tres aspiraciones se han visto cumplidas [...]", El Correo de Zamora, 06 de julio de 1982, Gabinete de Información, Caja 243, Informe Diario n ${ }^{\circ}$ 317, AGCYL.

${ }^{193}$ Entre la documentación adjunta a uno de los expedientes de expulsión, se hallaban los siguientes artículos destinados a demostrar las actividades de este grupo: "Los parlamentarios Pérez López, Martín Montes y Rodríguez San León, con el ministro de Trabajo y S. S. Les acompañaban el presidente de la Diputación y el alcalde de Toro", El Correo de Zamora, 27 de marzo de 1982; "Acompañado por el senador Luis Rodríguez San León. El Ayuntamiento de Cubillos, visita al presidente de la Diputación Provincial", El Correo de Zamora, 28 de marzo de 1982; "El presidente de la Diputación y el senador Rodríguez San León, con el subsecretario del ministerio de agricultura", El Correo de Zamora, 19 de junio de 1982, "Dossier de Expulsados", Fondo UCD, Caja 65, AHPZ.

${ }_{194} \mathrm{Si}$ calificaba como "eficiente" a Leopoldo Calvo-Sotelo en junio de 1981 pasaba a solicitar un año después, mayo de 1982, su dimisión en "Desde el Congreso de Palma", El Correo de Zamora, 30 de junio de 1981, "Dossier de Expulsado", Fondo UCD, Caja 65, AHPZ.

${ }_{195}$ Cargos para la incoación de un expediente disciplinario en un informe del 06 de agosto de 1982, "Dossier de Expulsados", Fondo UCD, Caja 65, AHPZ.
} 
del partido ${ }^{196}$. Leopoldo Calvo-Sotelo, tras el fracaso de las elecciones andaluzas de mayo del 82', había cedido la presidencia de UCD a Landelino Lavilla.

La "opción de salida" primó sobre cualquier otra solución cuando el líder centrista, Adolfo Suárez, abandonó UCD y creó el CDS, institucionalizando la corriente "suarista" y parte del malestar político de las bases en el verano de 1982. Así, la creación de este nuevo partido permitió dar una solución razonable a las numerosas luchas de poder enquistadas en el conglomerado centrista, cuyas causas, como estamos viendo se remontaban años atrás:

ANTE LA CRISIS DE UCD [doble subrayado] [...] CONSCIENTES [subrayado] de que las causas originantes de estos hechos son de índole muy diversa, y vienen de tiempo atrás sin que puedan reconducirse a una sola por la heterogeneidad de las mismas ${ }^{197}$.

Cuando se impuso "la opción de salida" sobre la de la negociación, las relaciones en el seno de UCD-Zamora estaban muy deterioradas y es difícil achacarlas a cuestiones meramente ideológicas. Las bajas de Luis Rodríguez San León ${ }^{198}$, César Martín Montes, Jesús Pérez López y José Miguel López Martínez estuvieron acompañadas de dimisiones y expulsiones de UCD a lo largo de toda la provincia ${ }^{199}$, habiéndose identificado más de una decena de incoaciones de expedientes por parte del Comité de Disciplina Provincial, resueltas definitivamente en una reunión mantenida el 9 de agosto de $1982^{200}$. Las acusaciones versaban sobre la pertenencia de los militantes expulsados a la órbita política de Luis Rodríguez San León y por ende, al naciente CDS: "está llevando a cabo una política de desprestigio del actual aparato del Partido [....] y en apoyo, de la política que actualmente está llevando el Presidente de la Diputación y el ex-Senador de UCD [Luis Rodríguez San León]", "recorre la Provincia [...] en nombre del ex-senador de nuestro Partido, añadiendo que es quien manda en la Provincia”,

\footnotetext{
${ }^{196}$ Documentación analizada en el epígrafe: "1. 2. La escisión "suarista" de UCD".

197 "Conclusiones del Comité Ejecutivo Regional de UCD-Asturias, 08 de junio de 1982", Fondo UCD, Caja 3350, AHPS.

${ }^{198}$ Cabe añadir, que Luis Rodríguez San León fue uno de los primeros diputados de UCD que solicitó su baja del partido para integrarse en el CDS y también el primero en exigir públicamente la dimisión de Calvo-Sotelo de la presidencia de UCD tras el fracaso en las elecciones andaluzas, El Periódico de Catalunya, 30 de julio de 1982.

${ }^{199}$ Asimismo hubo muestras de inquebrantable adhesión a la UCD provincial por parte de alcaldes, concejales y militantes centristas, Fondo UCD, Caja 5, AHPZ.

200 "Acta de la reunión del Comité de Disciplina Provincial", 09 de agosto de 1982, en "Dossier de Expulsados", Fondo UCD, Caja 65, AHPZ.
} 
"siempre ha sido un hombre muy adicto a cierto ex-Senador de nuestro partido" 201 o "es persona que sigue totalmente la línea que le marca el nuevo Partido del Duque"202.

El día 7 de agosto tenía lugar el primer acto del CDS en la provincia, en el que estuvieron presentes Luis Rodríguez San León, quien encabezaba el grupo, César Martín Montes y Jesús Pérez López y, como representante a nivel nacional, Agustín Rodríguez Sahagún ${ }^{203}$. El evento se celebró apenas una semana después de la presentación nacional del CDS en el Hotel Ritz de Madrid. La celeridad en la formación del CDS de Zamora confirmaba la existencia de un grupo perfectamente delimitado, homogéneo y clarificado en la UCD zamorana, cuya división era previa a la escisión suarista. Posteriormente, y tras la adhesión al naciente CDS zamorano de José Miguel López Martínez ${ }^{204}$, se creó la comisión gestora del partido a nivel provincial ${ }^{205}$, con el fin de presentar oficialmente las candidaturas para las inminentes elecciones que iban a tener lugar en el otoño de $1982^{206}$.

A modo de recapitulación, debemos señalar como en un primer momento, en el caso de Zamora, la pugna por el control político de las estructuras centristas provinciales se entremezcló con un discurso en el que se oponía a los llamados cuneros con los considerados auténticos defensores de los intereses zamoranos. Sin embargo, al hilo del agudizamiento de la crisis nacional de UCD, dichos grupos hubieron de tomar partido por las distintas familias que operaban en el conglomerado centrista. Si al principio, primó la búsqueda de soluciones políticas o "expresiones de voz" (la presentación de dos listas a la III Asamblea de UCD-Zamora, la propuesta de creación de un Comité de Coordinación, etc.), al producirse la fundación del CDS, fue la salida del partido la fórmula más viable para solventar el enfrentamiento político.

\footnotetext{
201 "Informe de la Secretaría Provincial", 05 de agosto de 1982, en "Dossier de Expulsados", Fondo $\mathrm{UCD}$, Caja 65, AHPZ.

202 "Informe de la Secretaría de Acción Municipal", 05 de agosto de 1982 en "Dossier de Expulsados", Fondo UCD, Caja 65, AHPZ.

203 "Rueda de prensa de Agustín Rodríguez Sahagún”, El Correo de Zamora, 08 de agosto de 1982, Gabinete de Información, Caja 243, Informe Diario no 317, AGCYL.

204 "Baja en UCD y cese en el Ayuntamiento, en la Diputación y en el Consejo de Castilla y León", El Correo de Zamora, 05 de septiembre de 1982, Gabinete de Información, Caja 242, Informe Diario n²25, $A G C Y L$.

${ }^{205}$ Rodríguez San León publicó en la prensa local, "Centro Democrático y Social: una vía de esperanza", El Correo de Zamora, 05 de septiembre de 1982, Gabinete de Información, Caja 243, Informe Diario n³17, AGCYL.

${ }^{206}$ Con la asistencia de Fernando Castedo: "Presentación pública de los candidatos del CDS", El Correo de Zamora, 23 de septiembre de 1982, Gabinete de Información, caja 317, Dossier CDS, AGCYL.
} 
Podemos enunciar, a partir de este estudio de caso, que resulta equívoco afirmar que a nivel provincial fue la diversidad ideológica la principal causa de la descomposición centrista. La mímesis entre el proceso de descomposición nacional y provincial aunque real, lo es más en sus estrategias y ritmos, que en sus motivaciones, pergeñadas de adhesiones personales y clientelares, retóricas localistas, etc. En el caso de la formación del CDS, hemos visto, como la constitución política del suarismo trascendió también la pura discrepancia política e ideológica, solapándose a un proceso de división de las elites políticas locales que lo antecedía temporalmente. Finalmente, a lo largo de este proceso, hemos pretendido resaltar algunos detalles acerca de la vida interna de un partido, que a pesar de gobernar durante más de cinco años, apenas ha dejado testimonios documentales y es que, el precipitado ocaso político de UCD se llevó consigo buena parte de sus vestigios materiales ${ }^{207}$.

\footnotetext{
207 "Probable embargo de la sede de UCD [en Murcia] para cumplir una sentencia por despido", El País, 29 de marzo de 1983. "Entre tanto, la comisión liquidadora de las siglas centristas, [...], ha puesto en venta, en pública subasta, las sedes locales y provinciales propiedad del partido, con el fin de atender las deudas más inmediatas del mismo", El País, 23 de marzo de 1983. "La Telefónica reclama a UCD el pago de una deuda de 11 millones", El País, 10 de abril de 1983, etc.
} 



\section{Capítulo 2:}

\section{"Hacer partido" y "hacer campaña": el CDS y las Elecciones Legislativas de 1982}

Las elecciones generales de octubre de 1982 depararon el mayor triunfo y el mayor fracaso electoral de la Historia de España. En aquella jornada, el PSOE consiguió 202 diputados y algo más de diez millones de votos y UCD agravó su crisis hasta límites insospechados. En una carrera contrarreloj, el CDS, fundado apenas tres meses antes, se vio obligado a acelerar su proceso de estructuración e implantación en el territorio, el diseño de un programa y una campaña electoral y el perfilamiento de su posición en el cambiante sistema de partidos español. El ambiente era poco menos que frenético. Comentaba Rodríguez Sahagún al presentador de La Clave J. L. Balbín a finales del mes de septiembre: "son ya muchas las noches que llevamos sin dormir para afrontar esa triple tarea: del Congreso Constituyente, de la implantación del partido [...] y finalmente, tener que hacer frente a esa situación de campaña electoral"1.

\section{1. La estructuración del partido: del "goteo" al Congreso Constituyente}

A lo largo del presente epígrafe, vamos a abordar la organización del CDS durante los meses de agosto, septiembre y octubre de 1982. Para ello, en primer lugar, aludiremos brevemente a los recursos económicos del partido. En segundo lugar, desarrollaremos la organización oficial del partido y su proceso de implantación territorial. Finalmente, analizaremos el proceso de incorporación de diferentes dirigentes nacionales y provinciales, prestando especial atención al caso de los parlamentarios $^{2}$. Cada uno de estos elementos estuvo condicionado no sólo por la

\footnotetext{
${ }^{1}$ En un debate en La Clave en TVE el 01 de octubre de 1982, Archivo RTVE online. Fecha de consulta: a lo largo del período 2012-2016.

${ }^{2}$ La estructuración de este apartado toma como punto de referencia conceptualizaciones de los elementos organizativos de los partidos políticos efectuadas en el ámbito de la politología. Conceptos, sin duda útiles, pero que hemos empleado de una forma flexible, en función de las características y transformaciones de nuestro objeto de estudio que remiten grosso modo a las categorías definidas por Angelo Panebianco de "reglas formales", "financiación" y "reclutamiento" en PANEBIANCO, Angelo: Los partidos políticos, Madrid, Alianza Editorial, 1990.
} 
reciente fundación del partido, sino, desde finales de agosto, por el anuncio de adelanto electoral realizado por Calvo-Sotelo el día 26. Precisamente, la convocatoria electoral acentuó ciertos desequilibrios en el proceso de implantación centrista y obligó a acelerar, con algunas dosis de improvisación, los pasos ordinarios a dar en todo partido para su definitiva constitución.

La precaria financiación fue una constante del partido centrista desde el mismo momento de su presentación; aquel día comentaba Adolfo Suárez: "si no alcanzamos la financiación suficiente, haremos campaña por el país con un spray en la mano"3. Desde el CDS se informó de un presupuesto inicial de en torno a 100 millones de pesetas conseguidos mediante créditos avalados por un total de 26 personas ${ }^{4}$. No obstante, en las crónicas periodísticas hubo especulaciones sobre el origen de los fondos, vinculándose su disponibilidad a los frecuentes viajes de Suárez a Latinoamérica (el "triángulo Colombia-Panamá-Cuba") o a la generosidad de algunos partidos políticos internacionales ${ }^{5}$. En cualquier caso, el distanciamiento de la patronal bancaria y empresarial respecto de Adolfo Suárez era vox populi, así como el apoyo de ésta a posiciones más conservadoras. Para el propio Suárez, la enemistad de la banca privada española nacía de las medidas liberalizadoras del sector llevadas a cabo bajo su mandato y que permitieron la expansión del capital extranjero en España ${ }^{6}$. En 1983, un empresario y dirigente del CDS identificaba el aumento -súbito- de la presión fiscal a raíz de las reformas económicas de los gobiernos de Suárez como la causa fundamental del alejamiento de estos poderes y ello, a pesar de que en el cómputo de los países desarrollados seguía "siendo la previsión [sic] fiscal más baja que existe"”.

El CDS tuvo sus primeras oficinas en la Calle Maestro Guerrero (Madrid) y a mediados de agosto, comenzó a acondicionar la futura sede, algo más amplia, situada en la Calle Sagasta. El día 26 de agosto, los promotores del partido designaron al primer

\footnotetext{
${ }^{3}$ El País, 01 de agosto de 1982.

${ }^{4} A B C$, 01 de agosto de 1982.

${ }^{5}$ La Vanguardia, 01 de agosto de 1982.

${ }^{6}$ Rueda de prensa de Suárez en Sevilla, El País, 26 de abril de 1983.

${ }^{7}$ El mismo testimonio evidencia, tras constatar el apoyo económico "infinito" de la CEOE a CiU y AP en las elecciones de 1982, la insalvable distancia existente con el proyecto de Suárez: "el resultado [de ese apoyo económico] ha sido la victoria socialista con mayoría absoluta, lo cual demuestra la gran visión de la derecha española, que está muy lejos todavía de la derecha europea. Porque de corazón son golpistas. Esperan, no no, sinceramente creen que si hubiera ganado el golpe del 23F, y me lo han dicho a mí algunos empresarios, el negocio iría mejor [...] No Ferrer Salat evidentemente, Ferrer Salat es un hombre muy culto, y muy europeo, pero todos los demás de la CEOE. Si toman a Jacques Chirac está infinitamente más a la izquierda que Fraga Iribarne y la CEOE en conjunto", Interview undertaken by Richard Gunther 1983 (june), AR.
} 
Comité Provisional del CDS, que hasta la celebración del I Congreso Nacional -órgano supremo del partido-, asumía las funciones del Comité Nacional. Estatutariamente, se salvaguardaba el carácter presidencialista del partido -en detrimento, de otros cargos, como el de la secretaría general, en este momento sin cubrir ${ }^{8}-$, otorgando al presidente funciones de representación, moderación y control de los distintos órganos de dirección. El Comité Nacional era el órgano ejecutivo del partido encargado de perfilar las directrices políticas generales: “determina, desarrolla e impulsa la política del Partido, bajo la dirección del Presidente, dentro del marco de los acuerdos del Congreso"9.

La Junta Gestora Provisional estaba formada, íntegramente, por antiguos dirigentes de UCD y prácticamente todos sus miembros habían sido partícipes de las conversaciones que dieron lugar a la fundación del partido: Adolfo Suárez (presidente), José Ramón Caso, Joaquín Abril Martorell, Gerardo Harguindey, León Buil, Jesús M. Viana -quien hacía las veces de portavoz ${ }^{10}-$, José A. Escudero, Rafael Calvo Ortega y Agustín Rodríguez Sahagún (vocales). Asimismo, en esa época se fue conformando el gabinete o secretaría de Adolfo Suárez para todo lo relacionado con las actividades del partido a cuyo frente estuvieron José Luis Garro -jefe de gabinete de Suárez hasta finales de la década- ${ }^{11}$, Laura Morso, María Antonia Aleñar y Alfonso Íñiguez ${ }^{12}$.

En agosto de 1982, la dirección del CDS se marcó dos objetivos prioritarios: la implantación en todo el territorio nacional y la celebración del Congreso Constituyente. Todo ello, debía a su vez compatibilizarse con el cumplimiento de las exigencias personales de Suárez, que le impedían dedicar todo su tiempo al partido -por ejemplo, en los primeros días de agosto y en calidad de ex presidente, se trasladó a Colombia en compañía de González, Calvo-Sotelo y Fraga-. Finalmente, debía adecuarse a los tiempos que marcaba el nuevo calendario electoral.

\footnotetext{
${ }^{8}$ En cualquier caso, desde el primer momento el futuro secretario general, J. R. Caso, adquiría un papel determinante: “[Disposición cuarta] Facultar a Rosa María de Castro Martín, promotora del Partido, D. José Ramón Caso García, indistintamente para que en nombre y representación del Partido puedan elevar a públicos los anteriores acuerdos, suscribiendo cuantos documentos públicos o privados sean necesarios a tal efecto y lograr su inscripción, si procede, en el Registro competente", $R P P$, Protocolización de acuerdos otorgada por el Centro Democrático y Social, Registro de Entrada ${ }^{\circ}$ 218, 06 de septiembre de 1982 (Acta notarial 1886. José Luis Martínez Gil, 2 de septiembre de 1982).

${ }^{9}$ Título II, De la Organización Nacional, Capítulo III y IV, Comité Nacional, Estatutos del CDS, RPP, Registro de Entrada n $^{\circ}$ 170, 29 de julio de 1982.

${ }^{10}$ El jefe de prensa, en esa primera etapa, era Ignacio Roig, El País, 01 de septiembre de 1982.

${ }^{11}$ Ayudado por Mercedes Polo, amiga del matrimonio Suárez-Illana, Entrevista con José Luis Garro, 06 de mayo de 2015.

${ }^{12}$ En la secretaría personal de Suárez en el bufete de abogados se encontraba $\mathbf{M}^{\mathrm{a}}$ Gador Ongil Cores (1982-1989). Disponible en: http://www.asambleamadrid.es /ES/QueEsLaAsamblea/ Composicion delaAsamblea/ Distribuciondeescanos/Paginas/curriculum.aspx?ID=184 Fecha de consulta: 28 de mayo de 2015 .
} 
El mes de agosto sirvió para establecer los primeros contactos entre los dirigentes nacionales y los encargados de impulsar el partido por todo el territorio: dirigentes de UCD, personalidades públicas o personas de confianza. Esta labor prospectiva permitió establecer "gestoras provisionales" en todas las provincias españolas a lo largo del mes de septiembre ${ }^{13}$. Dichas gestoras, que debían ser ratificadas por el Comité Nacional, se encargaron de afrontar el primer intento de estructuración del partido en su territorio, la búsqueda de una sede y la elaboración de las listas electorales. La presentación ante los medios locales corría a cargo de un miembro del Comité Nacional acompañado por los dirigentes territoriales. El organigrama a nivel provincial se componía, aunque no había cargos oficializados, de al menos: un presidente-portavoz, los miembros de la gestora (vocales), un gerente y un asesor jurídico. La formación de las "gestoras provisionales" respondía a una amplia casuística en la que sin embargo, se aprecian dos tendencias fundamentales, en función, de la mayor o menor importancia de las dinámicas propias de UCD en su surgimiento.

En la mayor parte de las ocasiones, la existencia de una división "de facto" y significativa en UCD a nivel provincial/local, se solapaba con la ruptura acaecida a nivel nacional y aceleraba, o al menos, facilitaba la constitución de las distintas gestoras como sucedió en Madrid y otras provincias, como hemos podido observar en el caso de Zamora $^{14}$. En la provincia de Madrid, se encargó la creación del partido al ex presidente de UCD-Madrid, Abel Cádiz. Rápidamente, el CDS madrileño se convirtió en el organismo territorial con más peso e influencia en el seno del partido, alcanzando más de 800 afiliaciones en las primeras semanas ${ }^{15}$.

Un fenómeno de división interna de UCD, paradigmático por su consistencia, sucedió en Segovia donde las distintas corrientes adquirieron cohesión a raíz del debate sobre la integración o no de la provincia en el ente preautonómico castellano-leonés. Al

\footnotetext{
${ }^{13}$ El Comité Nacional aprobó la creación de gestoras provinciales el 01 de septiembre. Las nuevas gestoras debían ser ratificadas por el Comité Nacional. Los miembros del Comité Nacional fueron allanando este camino las semanas previas: Rodríguez Sahagún estuvo en Salamanca y Zamora el 07 de agosto, el 23 de agosto en Valladolid, en Barcelona junto con Suárez en las primeras semanas de agosto; Viana estuvo el 17 de agosto en Málaga, etc.

${ }^{14} \mathrm{Si}$ bien son procesos que requieren un estudio ex profeso el mismo fenómeno se ha podido apreciar en el caso de Álava, Aragón, Lérida, Segovia, Málaga, Ávila o Navarra. En Aragón, en palabras de Merino Hernández, líder autonómico del CDS: "una serie de militantes centristas de las tres provincias, molestos como nos encontrábamos con la marcha de los acontecimientos en UCD en todo el territorio nacional y muy especialmente en la cúpula madrileña a raíz del último Congreso Regional del partido [...] decidimos voluntariamente pasar a una suerte de 'provisional retiro político', declinando toda participación activa en el partido a la espera de futuros acontecimientos", MERINO HERNÁNDEZ, José Luis: "Los partidos...", p. 128.

${ }^{15}$ Entrevista con Abel Cádiz, 4 de marzo de 2015 (Madrid).
} 
igual que en el caso de Zamora uno de los grupos en liza, en este caso los partidarios de la integración en Castilla y León, dio como resultado en agosto de 1982 la formación del CDS, proceso facilitado si cabe por las numerosas amistades de Adolfo Suárez y Rafael Calvo Ortega en la provincia ${ }^{16}$. En el caso de Álava, desde finales de 1979, -a raíz del nombramiento como delegado de gobierno de Marcelino Oreja-, se vivió una fuerte pugna por el poder en el seno de UCD. Se conformaron dos grandes sectores, por un lado, el de Chus Viana, -amigo íntimo de Adolfo Suárez y uno de los fundadores del CDS-, y por otra parte, el del propio Marcelino Oreja -más tarde, en el $\mathrm{PP}-$. Se barajaba incluso, meses antes de la fundación del CDS, la posibilidad de un desgajamiento de la UCD alavesa. En este caso, el distanciamiento de los hombres de Viana se tiñó de un fuerte discurso autonomista muy crítico con el desarrollo de la LOAPA por el ejecutivo de Calvo-Sotelo. En un análisis de la situación política en el País Vasco, llevado a cabo por el entorno de Marcelino Oreja a finales de 1981 se subrayaban las propias contradicciones del suarismo, en su afán de articular un discurso diferenciador: "en amplios círculos de Álava no se perdona la defensa a ultranza que hizo Viana del Estatuto de Autonomía"; para añadir posteriormente: "el electorado de UCD en el País Vasco no ha comprendido como Viana pretende dar una imagen de izquierdas [...] Ninguno de los Grupos de Intereses que rodean a Viana son ajenos a la derecha"17. En la provincia de Lérida, aunque la raíz del conflicto era distinta, fue también una ruptura previa la que facilitó la rápida y cohesionada estructuración del CDS, partido en el que recalaron todos los diputados nacionales y autonómicos de UCD, con excepción de un parlamentario que pasó a CiU. Como refiere Manuel de Sárraga, la división de UCD era un hecho en Lérida durante el verano de 1982 y precisamente, la creación del CDS permitió la continuidad en política de prácticamente todos los parlamentarios ilerdenses, paulatinamente distanciados de la nueva dirección de Lavilla, que consideraban inclinada hacia posiciones cada vez más conservadoras ${ }^{18}$.

\footnotetext{
${ }^{16}$ Destacaron entre otros Juan Antonio Perteguer, médico y amigo personal de Adolfo Suárez y el alcalde centrista de Segovia J. M. López Arranz, en PÉREZ LÓPEZ, Pablo y GONZÁLEZ CLAVERO, Mariano: La transición en Segovia, Palencia, Cálamo, 2007, pp. 146- 153 y p. 189 y ss. Véase también, SORIANO, Manuel y JÁUREGUI, Fernando: La Otra Historia de UCD, Madrid, Emiliano Escolar D. L., 1980, p. 23.

${ }^{17}$ Archivo Universidad de Navarra (UNAV), Fondo Marcelino Oreja, 97-710, pp. 2-3. Sobre su defensa del Estatuto, todavía en UCD, "Jesús María Viana [...] declaró [...] que, en el caso de que el Parlamento vasco presentase unas resoluciones críticas a la Ley Armonizadora, su grupo parlamentario no iba a estar sometido a una disciplina de voto" En este sentido, el líder centrista se ofreció como "puente de diálogo" entre las posturas enconadas, defendidas entre nacionalistas y socialistas, en relación a la Ley Armonizadora", El País, 23 de julio de 1982.

${ }^{18}$ Entrevista con Manuel de Sárraga Gómez, 23 de julio de 2014.
} 
En otras ocasiones, adquiría un papel más activo la dirección nacional quien se encargaba de contactar y poner en relación a los dirigentes y candidatos provinciales, a veces amigos o personas de confianza de la dirección suarista u otras personas de relieve profesional o político ${ }^{19}$. Recuerda Antonio Garrosa, número uno para el Congreso y máximo dirigente provincial del CDS en Valladolid desde mediados de 1983 hasta comienzos de los 90', como contactaron con él a comienzos de septiembre: “yo nunca había sido afiliado de la UCD, [...] [pero] sabían que estaba más o menos en esa línea". En aquellos días, fue convocado a una reunión en el Parador de Tordesillas a la que acudió Rodríguez Sahagún y tras la que, finalmente, se decidió a afiliarse al nuevo partido de Suárez. Poco después, se constituyó la gestora provincial compuesta por siete miembros cuyo cometido fundamental era confeccionar las listas electorales, presentar la candidatura y hacer campaña ${ }^{20}$. José Luis Sagredo de Miguel, uno de los futuros dirigentes del suarismo en Castilla y León, fue el encargado de organizar el CDS en Salamanca, aunque como afirma, nunca se ha considerado un "hombre de partido". Sagredo de Miguel era amigo íntimo de Adolfo Suárez desde la década de los años 50', y aunque no había militado en UCD, colaboró con el llamado grupo de "fontaneros de la Moncloa", mientras continuaba con su trabajo en la Diputación Provincial de Salamanca. Cuando se creó el CDS, Rodríguez Sahagún se puso en contacto para pedirle que fuera él quien organizara la Gestora Provisional en Salamanca, tarea que hubo de emprender con los escasos medios de que disponía y habilitando como primera sede un local bajo su propio domicilio ${ }^{21}$.

En cierto modo, fue un proceso de dos velocidades. A mediados de 1983, un cargo a nivel nacional del CDS explicaba los fuertes desequilibrios de implantación del siguiente modo:

\footnotetext{
${ }^{19}$ Por ejemplo en la vecina León, donde el CDS se estructuró en torno a Luis Aznar, ex secretario provincial de UCD y "en 1982 el leonés [Martin Villa] seguía siendo presidente del Consejo Político Provincial de UCD [...] Las disensiones de Madrid, llegan tarde a León” en FERNÁNDEZ, Pedro Víctor: La transición en León, León, Instituto Leonés de Cultura, 2008, p. 159. Como recuerda el propio Aznar, en agosto de 1982, se encontraba desvinculado de la política y de la propia UCD, cuando recibió una llamada de Laura Morso, con quien tenía una muy buena relación. Morso mantuvo una reunión con Aznar en la C/ Sagasta para que se "hiciese cargo en León del nuevo proyecto", que a continuación le explicó el propio José Ramón Caso. No sin humor, prosigue: "se trataba de enganchar a mis amigos, los de verdad [...] Iñaqui [Morán] no había tenido ninguna relación con la UCD, mientras que Agustín [Álvarez Nogal] y Plácido [Sánchez] al menos habían participado en el equipo de voleibol", en AZNAR, Luis: Haciendo memoria, León, Ed. Eolas, 2015, pp. 108-110.

${ }^{20}$ Entrevista con Antonio Garrosa, 17 de julio, 31 de julio y 21 de agosto de 2013.

${ }^{21}$ Entrevista con José Luis Sagredo de Miguel, 04 de junio de 2015 (Salamanca).
} 
Vamos un poco viendo donde surgen esos núcleos de personas que se identifican más con ese proyecto político, y que entonces funcionan y van construyendo en las provincias [...] el proyecto más de prisa, con más rapidez [...] Y sin embargo, hoy, en otras zonas, en otras provincias, en las que por no existir este núcleo, o porque el núcleo de personas que supuestamente podrían estar de acuerdo están relativamente desconectados, no les ha llegado suficientemente claro el mensaje, pues están todavía un poco más paralizados ${ }^{22}$.

De forma paralela, numerosos militantes de UCD abandonaban su formación y trataban de darse de alta en el CDS, bien tras haber mantenido algún encuentro con dirigentes suaristas o de forma espontánea. A diario, aparecía en la prensa el caso de algún dirigente centrista, cargo electo o directivo estatal que se había incorporado al CDS. En UCD se minimizaba el impacto que había tenido en sus filas la fundación del nuevo partido y se criticaba la estrategia de Suárez, el llamado "goteo": "su incorporación [...] se realiza a lo largo de todo el mes de agosto en una táctica destinada a prolongar el interés informativo, que la prensa calificó como goteo"23. La dirección del CDS argumentaba que era un intento por impedir la formación de bloques, facciones o corrientes internas en su seno, prohibidas de forma expresa en sus estatutos: "no se permitirá la existencia de grupos o fracciones dentro del Partido"24. Precisamente, una de las responsabilidades que con más celo aplicó la Junta Gestora Provisional en esta primera etapa fue la de dar el visto bueno a los nuevos afiliados:

1. La solicitud de afiliación se presentará por escrito, avalada por dos afiliados, en la sede del Comité Local del lugar de residencia del solicitante. El Comité emitirá informe, que elevará al Comité Provincial. A su vez enviará las solicitudes de afiliación al Secretario General con las observaciones que pueda considerar oportunas.

2. Las solicitudes de afiliación serán aprobadas por el Comité Nacional, teniendo en cuenta los informes recibidos ${ }^{25}$.

A medida que se iba produciendo el pase al CDS de numerosos miembros de UCD, sólo quedaba hacer cábalas sobre el número total de parlamentarios, entre diputados y senadores, que iban a acompañar al ex presidente. El sinfín de rumores, negociaciones y análisis que se hicieron durante el verano dejaban entrever la importancia mediática de estos acontecimientos. A finales de agosto, 23 parlamentarios de UCD se habían pasado

\footnotetext{
${ }^{22}$ Interview undertaken by Richard Gunther in 1983 (june), AG. Estas velocidades coinciden con dos de los conceptos usados por Angelo Panebianco a la hora de abordar el origen de un partido: "la penetración territorial o difusión territorial". Si en un caso hablamos de la creación por parte de la dirección nacional de grupos territoriales, en el otro supone la reunión de elites política dispersas y organizadas (provenientes de UCD), PANEBIANCO Angelo: Modelos..., p. 110.

${ }^{23}$ WERT, José Ignacio: "La campaña electoral de octubre de 1982: el camino del cambio", REIS, 28, 1984, p. 65. Huneeus apunta que esta forma de atraer dirigentes locales y provinciales de UCD era tanto útil para el CDS, como dolorosa para el partido del gobierno, HUNEEUS, Carlos: Unión de ..., p. 382.

${ }^{24}$ Título I. De los afiliados, Capítulo II, "Derechos y deberes de los afiliados", Artículo 12.4. en los estatutos depositados en el RPP, Registro de Entrada n ${ }^{\circ}$ 170, 29 de julio de 1982.

${ }^{25}$ Capítulo II, Artículo 5 ${ }^{\circ}$ Ibid.
} 
a las filas del CDS. De entre ellos, destacaba el amplio número de diputados y senadores catalanes y zamoranos con un total de 7. Como hemos podido ver, las circunstancias particulares de la UCD en las distintas provincias condicionaron en buena medida muchos de estos traspasos (Anexo III). Un alto dirigente del CDS explica la celeridad con la que se produjeron estos acontecimientos:

Yo creo que algunos de los miembros de UCD [...] pensaban ya en CDS [...] y de hecho son aquellos que tan pronto como UCD se rompe [...] y cuando sale CDS dicen: esto es lo que estamos diciendo desde entonces [...] hay gente que en UCD estaba ya tocando la música de CDS, aunque quizás los que los que la recibían desde el otro extremo no la entendiesen $^{26}$.

Suárez y Rodríguez Sahagún, en sus cartas de baja de UCD dirigidas a Lavilla, el 27 y 28 de julio respectivamente, marcaron la pauta a seguir por el resto de parlamentarios salientes de UCD. En primer lugar, Suárez manifestó su intención de renunciar al escaño "ya que no le parece ético integrarse en el Grupo Mixto cuando le debe su acta de diputado a UCD", aunque si "por razones de estado" se considerase necesaria su permanencia decía estar dispuesto a continuar en su puesto y votar junto con el Grupo Parlamentario Centrista. En segundo lugar, Suárez tenía previsto solventar cualquier futura contradicción entre la política de UCD y el manifiesto político de su futuro partido "mediante comunicados oficiales [...] en los que se explique que se vota favorablemente determinado proyecto del Gobierno debido al compromiso contraído, pero se añadirán a continuación pormenorizadas, las discrepancias con dicha ley..."27. Se mantuvo en todo momento, como señala Manuel de Sárraga, el compromiso de disciplina del partido ${ }^{28}$. En cualquier caso, si tenemos en cuenta que las bajas de UCD se produjeron en torno a las primeras semanas de agosto, su actividad parlamentaria como miembros del Centro Democrático y Social fue prácticamente nula, coincidiendo con el cierre estival del Congreso y la disolución anticipada de las Cámaras. En el CDS, se entendió que la decisión de Calvo-Sotelo de adelantar los comicios había sido un intento premeditado de interrumpir su crecimiento y expansión, e injustificado porque los parlamentarios suaristas se habían comprometido públicamente a dar su apoyo a UCD hasta el final de la legislatura ${ }^{29}$. En una reunión entre dirigentes de UCD

\footnotetext{
${ }^{26}$ Interview undertaken by Richard Gunther in 1983 (june), AG.

${ }^{27}$ El País, 29 de julio de 1982. En el mismo sentido, se manifestó Rodríguez Sahagún sólo un día después, El País, 30 de julio de 1982.

${ }^{28}$ Entrevista con Manuel de Sárraga Gómez, 23 de julio de 2014.

29 "El escaso tiempo con que contará el Centro Democrático y Social para concurrir a las urnas puede ser otra componente importante de la decisión tomada...", en el editorial: "Elecciones generales", El País, 28 de agosto de 1982. Por contra, Carlos Dávila, en las páginas de $A B C$, había insinuado días antes que uno
} 
convocada con el fin de valorar el adelanto electoral, uno de los argumentos esgrimidos a favor era precisamente evitar el "engorde del CDS - Casa De Suárez-”“30.

A finales de septiembre según fuentes del CDS, se habían aceptado en torno a 600 solicitudes de afiliación de un total de 14.000, que seguían esperando su tramitación por los órganos dirigente, aunque resulta plausible considerar que las cifras de afiliación eran inferiores a las reales y las solicitudes habían sido exageradas ${ }^{31}$. De cualquier modo, la prudencia se convirtió en una máxima en la construcción del nuevo partido y muchas de las peticiones de ingreso se resolvieron después de las elecciones. Incluso, Suárez bromeaba diciendo que la nueva militancia debía cumplir dos requisitos: el de transparencia y la superación de un test psicológico, para evitar repetir viejos episodios $^{32}$. Asimismo, se enfatizaba el gran número de personas que habían ingresado en el CDS y que no habían tenido militancia política previa, que Viana estimaba en torno al $50 \%^{33}$. Desde el CDS se intentó controlar el número de afiliaciones de militantes de UCD, especialmente de cargos públicos y dirigentes: "tratando de no provocar, de no introducir confusión, y de no hacer simplemente un trasvase de gente de UCD al CDS [...] hay una consigna que circula ahí dentro que no se llame a nadie de UCD"; una idea que significaba evitar generar estructuras similares a UCD con el nombre del $\mathrm{CDS}^{34}$. Además, evitó incorporar a miembros de otros partidos o a políticos más o menos independientes (Anexo IV) ${ }^{35}$. El proceso de estructuración del partido a lo largo del territorio nacional pretendió desde un primer momento trascender la simple

de los pocos beneficiados de un adelanto electoral era el CDS; Adolfo Suárez durante ese verano había alcanzado cotas de popularidad como no se recordaban desde antes de su dimisión, $A B C, 13$ de agosto de 1982. Por parte del CDS se criticó en todo momento esta decisión; crítica que se extendió al intento de instrumentalización por parte de Calvo-Sotelo de la visita de Juan Pablo II a España, finalmente pospuesta, en VILAR, Sergio: "La organización del milagro", El Noticiero Universal, 04 de septiembre de 1982.

${ }^{30}$ Documento de José Luis Álvarez "0046 Documento", p. 4, fechado entre el 01 de mayo de 1982 hasta 20 de julio de 1982, Caja 8, 45-378, 1982, AGUN/JLA. Nota del autor: la fecha puede ser posterior (agosto).

${ }^{31}$ Un carnet de militancia expedido a comienzos de septiembre de 1982 está numerado con el 1.385, divergiendo considerablemente con las cifras aportadas por la dirección centrista, Archivo Antonio Garrosa Resina.

${ }^{32}$ Entrevista con Laura Morso, 11 de febrero de 2015.

${ }^{33}$ El País, 09 de septiembre de 1982. Es la cantidad que se mantuvo en todo este período, GómezCalcerrada mantenía esa cifra en la campaña electoral, entrevista en $A B C, 08$ de octubre de 1982.

${ }^{34}$ Quizá, el episodio paradigmático se vivió en La Rioja donde no se admitió la solicitud de ingreso del presidente autonómico Rodríguez Moroy junto con parte del equipo de gobierno, quienes se encontraban en una posición difícil en el seno de UCD, debido a su distanciamiento de Lavilla y cercanía a los posicionamientos suaristas. Finalmente, este grupo, ante la negativa de Suárez, formó el Partido Riojano Progresista, NAVAJAS ZUBELDIA, Carlos: ““"Desconcierto” y “zozobra”...”.

${ }^{35}$ Sonaron los nombres de algunas personalidades protagonistas junto a Suárez de la Transición, políticos de centro-izquierda o del ala socialdemócrata de UCD, HUNEEUS, Carlos: La Unión ..., p. 382. 
yuxtaposición de grandes personalidades. Como afirmaba el candidato por Barcelona, Antonio De Senillosa, reflejando la percepción de Suárez: "lo que no se debe hacer nunca es una UCD-2"36. UCD se había convertido en una especie de antítesis de lo que pretendía llegar a ser el CDS: no se permitían las facciones (aludiendo a las "familias de UCD”) y se recalcaba la escasez de recursos y la lejanía del poder.

El discurso centrista subrayaba constantemente el punto de inflexión que suponía la fundación del CDS en la carrera de Suárez: "gracias por ayudar a estructurar un partido joven, con pocos medios y muchas dificultades, y en poco tiempo"37. Se subrayaba el hecho de ser un partido creado "desde abajo", "desde el pueblo y no desde el poder [...] no hay arribistas"; en el que las escasas posibilidades electorales se consideraban una garantía contra los oportunismos, "no olemos a poder" 38 . Quizá por ello, desde el primer momento, la estrategia política del CDS se basaba en el largo plazo y pasaba por una sólida implantación territorial -"hacer partido"- constituyéndose en cierto modo como "una iniciativa política diferente al PAD y al PDP, que se habían caracterizado por ser eminentemente de parlamentarios y dirigentes nacionales" 39 . Como un mantra y quizá para amortiguar así, los magros resultados que se preveían en las elecciones se repetía con insistencia: "implantar el CDS es lo prioritario"

Sin embargo, el afán de originalidad centrista contrastaba con la proveniencia de los líderes provinciales y nacionales, en su mayoría, de $\mathrm{UCD}^{41}$. Además, las dimisiones en cascada de cargos nacionales, autonómicos y locales de UCD para integrarse en el CDS y presentarse a las elecciones generaron una impresión bastante negativa de ambos partidos y en conjunto, de la clase política: “[el adelanto] lesiona desde luego las oportunidades de Suárez, pero no las liquida, y consigue, de paso, ofrecer el aire más bien penoso de una estrategia de corto vuelo" $"$.

\footnotetext{
${ }^{36}$ Diario 16, 18 de septiembre de 1982, Archivo Linz.

${ }^{37}$ Diario de Ávila, 21 de septiembre de 1982.

${ }^{38}$ El Correo de Zamora, 23 de septiembre de 1982; El País, 09 de septiembre de 1982.

${ }^{39}$ HUNEEUS, Carlos: La Unión..., p. 382.

${ }^{40}$ En palabras de Rodríguez Sahagún, $A B C$, 06 de septiembre de 1982.

41 "Exclusivo reclutamiento de dirigentes y afiliados de UCD”, HUNEEUS, Carlos: La Unión ..., p. 382.

${ }^{42}$ Editorial: "Dimisiones electorales", El País, 03 de septiembre de 1982. "El famoso goteo hacia el CDS, por el momento, no es más que una levísima llovizna de personajes secundarios", GUTIÉRREZ, José Luis: "Rentrée", Diario 16, 02 de septiembre de 1982.
} 
El día 23 de septiembre ${ }^{43}$, la Gestora fijaba la celebración del Congreso Constituyente para los días 2 y 3 de octubre en el Palacio de Exposiciones Congresos de Madrid y con el slogan "Por una España Como Debe Ser"44. El Congreso Constituyente, al margen de oficializar las estructuras provisionales de gobierno, buscaba la definición del proyecto político y la elaboración del programa electoral del CDS -se entendió como un acto de campaña-. Por su parte, la premura con la que había sido organizado evidenciaba la necesidad del suarismo de diferenciarse de UCD, cuyo congreso fundacional había tenido lugar mucho después de las elecciones del 77', con el partido ya al frente del gobierno.

El Congreso se desarrolló mediante el trabajo de comisiones, las cuales presentaron 31 ponencias, coordinadas bajo la dirección de Rafael Calvo Ortega y en las que participaron casi un centenar de expertos, sirviendo los textos finalmente aprobados de base para la elaboración del programa electoral del partido ${ }^{45}$. Entre los principales redactores de las distintas ponencias destacaron, al margen de la participación de Suárez, Caso y Navarro en la ponencia ideológica y los estatutos ${ }^{46}$ : Agustín Rodríguez Sahagún en Defensa, José Luis González Quirós y José Antonio Escudero en Educación, Alberto Aza en Asuntos Exteriores, colaboradores de Enrique Fuentes Quintana en Economía ${ }^{47}$ o José María Almansa Pastor en Sanidad ${ }^{48}$. Acudieron en torno a quinientos compromisarios, todos ellos, miembros de las diversas gestoras provinciales y en su mayoría, antiguos miembros de $\mathrm{UCD}^{49}$. Junto a ellos, se

\footnotetext{
${ }^{43}$ La última reunión de la Comisión Gestora para la preparación del Congreso se produjo el 29 de septiembre, Teletipo EFE, 23 de septiembre de 1982, Gabinete de Información, Caja 243, Dossier CDS, $A G C Y L$

${ }^{44}$ Un juego de palabras con las siglas del CDS (Como debe ser). El CDS no era el único partido en esta situación, el PDP había celebrado su Congreso Constituyente la semana anterior, los días 26-27 de septiembre. Cabe señalar en lo relativo a los recursos que el CDS, al margen del "Manifiesto Político" y del programa electoral, no editó las ponencias del Congreso a diferencia del PDP o del PAD, cuyas publicaciones constaban de 493 y 220 páginas respectivamente, PDP: Una política joven y europea. Primer Congreso Nacional del Partido Demócrata Popular, Madrid, 1982 y PAD: Un partido para el progreso. Una respuesta socialdemócrata. Congreso Constituyente, Madrid, 1982.

${ }^{45} A B C, 29$ de septiembre de 1982.

${ }^{46}$ Un ejemplo de la precipitación con la que se llevó a cabo el I Congreso era el hecho de que los asistentes conocieran por primera vez el borrador de la ponencia ideológica el sábado 2 de octubre por la mañana. Asimismo, "ninguna enmienda a las ponencias originales [llegó] a prosperar para ser defendida en el pleno lo que prueba los escasos enfrentamientos y la adhesión a la directiva, que fueron la tónica del congreso clausurado", El País, 04 de octubre de 1982.

${ }^{47}$ El equipo del profesor Fuentes Quintana, Diario 16, 04 de octubre de 1982. También, participó en el diseño del programa económico del partido Carlos Sánchez-Reyes, Entrevista con Carlos Sánchez-Reyes, 01 de junio de 2015 (Valladolid). En la ponencia de "Economía Social y Corporativa" participó J. L. Gómez-Calcerrada, Entrevista con J. L. Gómez Calcerrada, 10 de junio de 2015 (Madrid).

${ }^{48}$ Ex Secretario General Técnico con Enrique Sánchez de León, Rovira Tarazona y Alberto Oliart.

${ }^{49}$ Entrevista a Laura Morso publicada en el Órgano de Información del Centro Democrático y Social, 2 , septiembre de 1986.
} 
encontraban presentes cerca de 250 periodistas. La dirección de la organización del I Congreso corrió a cargo de Laura Morso ${ }^{50}$.

Suárez abrió el Congreso el día 2 de octubre, previa presentación de Caso y con los sones del himno del partido de fondo. El cronista de El País, Fernando Jáuregui, describía un ambiente tremendamente efusivo -"medio millar de compromisarios asistentes [...] aplaudieron enfervorecidos a Suárez, mostrando la inequívoca lealtad de todos ellos al creador del CDS" ${ }^{\text {- }}$, que moderó el propio Suárez con un discurso sobrio, sin "aires mitineros", señalando que el auténtico reto iba a comenzar el día 29 de octubre, "vamos a luchar por conseguir un resultado aceptable". Precisamente por esta razón, se decidió posponer la elección de secretario general, presumiblemente José Ramón Caso, hasta noviembre, con el fin de "no" solapar su cometido con el desarrollo de la campaña. El ambiente del Congreso estuvo preñado de despliegues musicales y audiovisuales y de un sentimiento de adhesión incondicional a Suárez.

El Congreso se inició con la lectura del informe de gestión presentado por la Junta Gestora Provisional del CDS que recalcaba la ausencia de apoyos, las dificultades con algunos grupos de presión y el reto que suponía la creación de las gestoras provinciales -e incluso, extranjeras: Francia, Inglaterra, Argentina, USA, Suiza, Ecuador, Alemania y Bolivia- ${ }^{52}$.

El día 3 se eligió al Comité Nacional, la ejecutiva del partido, compuesto por 20 miembros todos ellos designados a propuesta del presidente Suárez ${ }^{53}$, y procedentes de UCD (incluyendo los nueve miembros de la Junta Gestora Provisional), es decir, aquellos con más experiencia política ${ }^{54}$. La lista se aprobó sin votos en contra (sólo algunas abstenciones y votos en blanco) y de acuerdo a criterios mayoritarios ${ }^{55}$.

\footnotetext{
${ }^{50}$ Entrevista con Laura Morso, 11 de febrero de 2015.

51 El País, 03 de octubre de 1982. Una encuesta encargada por la CEOE a la agencia SOFEMASA publicada el día de la apertura del Congreso situaba al CDS como tercera fuerza política.

${ }^{52} A B C, 03$ de octubre de 1982.

${ }^{53}$ Elegido a su vez, el 3 de octubre, con 4 enigmáticos votos en blanco en El País, 04 de octubre de1982.

54 “El CDS es Suárez, y el núcleo central del partido se compone básicamente de amigos, contraparientes -como Agustín Rodríguez Sahagún- y tránsfugas de UCD. Ni un solo miembro del comité nacional ejecutivo se salva de esta regla, y resulta curioso comprobar cómo en algunos casos varios de los miembros de este comité fueron miembros del Opus Dei, aunque hoy ya no lo sean. Esto explicaría algunas tomas de posición (aborto) de un partido que se reclama no confesional", JÁUREGUI, Fernando: El País, 20 de octubre 1982.

${ }^{55}$ Destacándose la ausencia de A. de Senillosa y sobre todo, L. Olarte en el Comité. Véase, QUIROSACHEYROUZE Y MUÑOZ Rafael y FERNÁNDEZ AMADOR, Mónica: "La creación...”; El País, 04 de octubre de 1982.
} 
En el discurso de clausura, ante más de 3.000 asistentes, Suárez mantuvo el tono del día anterior, sin referencias a otros partidos -el cronista de $A B C$, Raúl R. Sáez, comentaba que había sido "un vibrante discurso [...] sin criticar a nadie" propugnando la necesidad de un pacto entre las fuerzas parlamentarias capaz de garantizar la estabilidad del sistema democrático y centrado en dos grandes ámbitos: economía y política exterior.

La intervención de Suárez desgranó las líneas maestras del CDS cuya idea central pasaba por retomar el reformismo que había conducido a la Constitución: "frente a los espectáculos mezquinos de intereses injustos y ambiciones desatadas, existe, como dice Machado, una 'España que alborea",57. Las palabras de Suárez subrayaban, en primer lugar, la distancia con UCD: “en primer lugar creo que la oferta política del C.D.S. es nueva porque constituye un proyecto político homogéneo y coherente [...] es un partido unido". En segundo lugar, proclamaba su compromiso con el pueblo español y su voluntad soberana, añadiendo: "podemos ser todo lo populistas que quieran nuestros adversarios porque sólo con nuestro pueblo queremos comprometernos. Lo que nunca seremos es un partido que sirva a los intereses de un grupo, de una clase, de una casta o de una secta".

A continuación, se ahondaba en el auténtico sentido de la reforma democrática. No suponía una mera "solución parcial y transitoria", sino más bien, debía ser la "solución definitiva y radical con que se encauza una necesidad nacional, sentida por la gran mayoría del pueblo español y que ineludiblemente, al reducir los intereses de los menos en beneficio de las necesidades de la mayoría, transforma la realidad social".

El sentido del progresismo reformista requería de forma continua nuevas transformaciones con el fin de impedir situaciones de monopolio. Apelando a su desempeño presidencial Suárez afirmaba: "la democracia en España se encuentra gravemente amenazada por los mismo [sic] intereses que a ella se opusieron, y que, ahora pretenden utilizarla como medio para mantener unas situaciones de monopolio y de injusticia que la propia Constitución y la realidad misma hacen inadmisibles". En su discurso, recurría al símil con El Gatopardo de Lampedusa. La democracia en España no ha venido "cambiando algo para que todo siga igual". El progresismo del CDS no

\footnotetext{
${ }^{56} A B C, 04$ de octubre de 1982.

${ }^{57}$ Discurso de Clausura del Congreso Constituyente, Carpeta 2, Archivo Gabinete de Presidencia CDS (AGP).
} 
constituía un empeño utópico, ni indefinido, sino una voluntad general de mejora y siempre con perspectiva: "entiendo por ello, que una política de reformas ha de ser fundamentalmente pragmática y no dogmática [...] hay que partir de la situación real de los españoles" ${ }^{, 5}$. Finalmente, apelaba a la solidaridad y esfuerzo común, ante la crisis económica-social.

En el siguiente tramo del discurso desarrollaba su concepción del centro político, rechazando una vez más dogmatismos e "ideologías que tratan de enfrentar a los españoles", basándose en los valores de moderación y tolerancia que hicieron posible la Transición. La desarticulación de una trama golpista aquel fin de semana sirvió para subrayar las dos grandes amenazas existentes en el futuro: el terrorismo "no puede ser tolerante con quienes con el pretexto de supuestos ideales políticos, asesinan y secuestran” y el golpismo, “tampoco con quienes, arrogándose ilegítimamente la representación de una institución básica, como las Fuerzas Armadas [...] atentan contra la soberanía del pueblo español”. El centro político encontraba su electorado en el "centro sociológico", una "serie de sectores sociales que van desde los trabajadores, los empleados y los funcionarios hasta los empresarios y las profesiones liberales. Ellos son los que llevan el peso del país".

La última parte de su intervención, titulada, "La democracia como alternativa", incardinaba el momento histórico español con una visión más global afirmando: "la democracia es la única alternativa posible al subdesarrollo, a la crisis de valores y a la dependencia exterior”. En España, la democracia tenía que ser capaz de garantizar la igualdad de partida de todos los ciudadanos y hacer frente a las grandes injusticias existentes en nuestra sociedad, para "poder hacer real y estable la Democracia" y profundizar en la estructuración autonómica del Estado. En materia económica, y ante el azote de la crisis mundial, se debía buscar una salida consensuada y viable a la política industrial e implementar una respuesta solidaria a la misma, sin dejar de respetar el contexto de economía de libre mercado. Sus últimas palabras defendieron la perentoria necesidad de un pacto de estado en pos de la modernización del país en una triple dimensión: la estabilidad del sistema democrático, la respuesta a la crisis y la posición exterior de España.

\footnotetext{
${ }^{58}$ El progresismo del CDS se encuadraba con las siguientes palabras, algo inconcretas, en la Historia Política de España: "la historia española del progresismo ha sido, hasta ahora, una preocupante relación de 'discontinuos', de paréntesis, entre largos períodos de signo reaccionario", Ibid., p. 10.
} 
En la prensa se resaltó la propuesta de pacto político realizada por Suárez y su discurso en defensa de la democracia ( $A B C$, El País y Cinco Días ${ }^{59}$ ). El día 4 de octubre $A B C$, aprovechando el intento de golpe desarticulado, titulaba con una frase de Suárez: "nada ni nadie impedirá que nos presentemos a las elecciones" 60 . Otros como Carlos Santos, cronista de Diario 16 o Pilar Urbano en $A B C$, sacaban conclusiones de cara a las elecciones de octubre. Por un lado, Carlos Santos veía en el evento la confirmación de la proximidad del CDS con el PSOE, -“el CDS deja la puerta abierta para gobernar con el PSOE"- y el carácter fuertemente personalista del partido, "la apoteosis del duque"61. Pilar Urbano interpretaba la supuesta afinidad entre el PSOE y el CDS, en función del interés de los socialistas en trocear el sistema de partidos y añadir confusión en el espacio de centro - una operación similar a la realizada por Suárez apoyando al PSA de Rojas Marcos-.

\section{2. Competencia electoral y espectro ideológico en el verano de $1982^{62}$}

La irrupción del CDS en el sistema de partidos en un momento de particular euforia electoral espoleó, hasta el mismo día de las elecciones, todo tipo de especulaciones en el seno de los partidos políticos y los medios de comunicación. Por ello, en primer lugar, abordaremos el posicionamiento del CDS en el "espectro ideológico" del sistema de partidos, los perfiles de su electorado y la estrategia política seguida por Suárez. Finamente, recorreremos las complejas relaciones entre los distintos partidos que tuvieron lugar durante aquellos meses.

\footnotetext{
59 "El CDS por unos 'pactos de la Moncloa' bis", Cinco Días, 05 de octubre de 1982. "El ex presidente Adolfo Suárez propondrá un pacto de Estado para la modernización de España", El País, 03 de octubre de 1982. "Suárez propone un pacto entre todos los partidos para estabilizar la democracia", El País, 04 de octubre de 1982. "Llamamiento de Suárez para consolidar el sistema democrático", $A B C, 03$ de octubre de 1982. En relación, a esta proclamación de "garante" de la integridad del sistema político, se le llegó a preguntar en la rueda de prensa posterior sobre las similitudes entre el CDS y el PRI mexicano, El País 04 de octubre de 1982.

${ }^{60} A B C, 04$ de octubre de 1982.

61 "Las luces se apagaron. El vídeo comenzó a emitir estampas de ancianos sonrientes, niños juguetones, atardeceres, amaneceres, campos floridos y naves industriales. Mientras aparecían y desaparecían las siglas del CDS, los congresistas encendían cerillas, daban vivas a Suárez y acompañaban con palmas un himno pegadizo que es pura expresión del culto a la personalidad", Diario 16, 04 de octubre de 1982, Archivo Linz.

${ }^{62}$ En este epígrafe retomamos el segundo de los enfoques ideológicos contemplados por Alan Ware en el estudio de los partidos políticos: la competencia electoral, entendida como el "espectro ideológico", es decir, el continuиm derecha-izquierda en el que se mueven electoralmente los partidos, en WARE, Alan: Partidos políticos...
} 
Desde su presentación pública a finales de julio, el CDS se adscribió a un espacio de "centro progresista", acorde con "una interpretación progresista de la Constitución"63, en definitiva, algo más restringido que el "centrismo" protagonizado por UCD en el que cabían tendencias políticas distantes. Adolfo Suárez, y en general la militancia, consideraban al CDS como un partido de centro-progresista o centro-reformista. En sus estatutos se definía como un "partido político democrático, reformador, popular y progresista" ${ }^{, 64}$. Sin embargo, no era extraño encontrar en declaraciones y propaganda otros términos como centro-izquierda o centro-centro ${ }^{65}$. En ocasiones, las dificultades del CDS a la hora de definir con precisión su ubicación política generaban cierta disparidad de criterios. Durante la presentación de la candidatura del CDS en Burgos: “el Sr. Castedo, se definió como de centroizquierda [...] se le preguntó al Sr. Del Hoyo Aguilera [ex gobernador civil de Burgos y candidato $\mathrm{n}^{\circ} 1$ por el Senado] [quien] respondió taxativamente: "Yo soy de centro-centro",66. En la prensa, se prefería hablar de "social-centrismo" o con cierto sarcasmo, de "neo-centrismo".

Según algunas encuestas realizadas en 1982, las tendencias ideológicas en las que se sentían identificados los votantes del CDS deparaban los siguientes resultados: en primer lugar, destacaba una mayoría identificada con la socialdemocracia, y en el segundo caso (siendo los ítems diferentes) una posición más progresista que la defendida por UCD -tablas 2 y $3-$ :

Tabla 2: Tendencias políticas en los principales partidos (auto-posicionamiento en tendencias ideológicas) (1982).

\begin{tabular}{|l|c|c|c|c|}
\hline Tendencia & PSOE & CDS & UCD & AP $^{67}$ \\
\hline Continuadores del régimen de Franco & 1 & 2 & 4 & 12 \\
\hline Conservadores & 1 & 10 & 13 & 40 \\
\hline Liberales & 2 & 11 & 11 & 9 \\
\hline Demócrata-cristianos & 2 & 22 & 24 & 17 \\
\hline Socialdemócratas & 15 & 34 & 14 & 5 \\
\hline Socialistas & 61 & - & 5 & 1 \\
\hline Comunistas & 2 & - & - & - \\
\hline Ninguna y no respuesta & 15 & 20 & 29 & 16 \\
\hline
\end{tabular}

Elaboración propia a partir de la Encuesta DATA 1982 reproducida en MONTERO, J. R., "Sobre las...", p. 87.

\footnotetext{
${ }^{63}$ Entrevista con José Ramón Caso, 19 de noviembre de 2014.

${ }^{64}$ Estatutos del CDS (julio de 1982), artículo $1^{\circ}, R P P$, Registro de Entrada no 170, 29 de julio de 1982.

65 El término "centro-derecha" apenas era usado en las declaraciones de militantes o dirigentes. La autodefinición como un partido "liberal" o "radical" tuvo más eco en otros períodos del partido.

${ }^{66}$ Diario de Burgos, 01 de octubre de 1982.

${ }^{67}$ Coalición AP-PDP-UL.
} 
Tabla 3 a): Tendencias políticas en los principales partidos (auto-posicionamiento en el continuum izquierda-derecha) (1982).

\begin{tabular}{|l|l|l|l|l|l|l|l|l|l|}
\hline & $\begin{array}{l}\text { Ext. } \\
\text { Izqda. }\end{array}$ & Izqda. & $\begin{array}{l}\text { Centro } \\
\text { izqda. }\end{array}$ & Centro & $\begin{array}{l}\text { Centro } \\
\text { Dcha. }\end{array}$ & Dcha. & $\begin{array}{l}\text { Ext. } \\
\text { Dcha. }\end{array}$ & Ning. & $\begin{array}{l}\text { No } \\
\text { sabe }\end{array}$ \\
\hline CDS & - & 1 & 6 & 34 & 12 & 3 & - & 3 & 40 \\
\hline UCD & - & - & 1 & 40 & 21 & 8 & - & 1 & 26 \\
\hline
\end{tabular}

Elaboración propia a partir de la Encuesta SOFEMASA realizada en diciembre de 1982 en Castilla y León, Gabinete de Información, Dossier n 445 , Archivo General de Castilla y León (AGCYL) ${ }^{68}$.

Tabla 3 b): Tendencias políticas en los principales partidos (auto-posicionamiento en tendencias ideológicas) (1982).

\begin{tabular}{|l|l|l|l|l|l|l|l|l|l|l|l|}
\hline & Marx. & Com. & Soc. & $\begin{array}{l}\text { Social- } \\
\text { democ. }\end{array}$ & Lib. & Centris. & $\begin{array}{l}\text { Crist. } \\
\text { Democ. }\end{array}$ & Conserv. & Dcha & $\begin{array}{l}\text { Nin } \\
\text { g. }\end{array}$ & $\begin{array}{l}\text { No } \\
\text { sabe }\end{array}$ \\
\hline CDS & - & - & - & 6 & 6 & 34 & 2 & 4 & - & 5 & 39 \\
\hline UCD & - & - & - & - & - & 48 & 4 & 11 & 7 & 2 & 26 \\
\hline
\end{tabular}

Elaboración propia a partir de la Encuesta SOFEMASA realizada en diciembre de 1982 en Castilla y León, Gabinete de Información, Dossier n 445, AGCYL.

La auto-ubicación media de los votantes del CDS era de 5,4 dentro de una escala izquierda-derecha (1-10) siendo 5,5 el punto central ${ }^{69}$. Aunque en el caso de UCD, este posicionamiento era de un 5'6, es decir, había una diferencia de apenas 0,2 puntos, existía una impresión generalizada de que el CDS era un proyecto político situado, por expresarlo de alguna manera, más a la izquierda que UCD. La posición media atribuida en una escala izquierda-derecha (1-10) por el electorado al CDS en 1982 era de 5,7 frente a un 6,2 de UCD (en 1979, 6'5) ${ }^{70}$. Las razones de esta lectura eran fundamentalmente dos. Por un lado, en el CDS no militaban los miembros más conservadores de UCD (democristianos, buena parte de los "azules" y liberales), y por otra parte, el propio espacio de centro-derecha estaba sufriendo su propio realineamiento ante el empuje de Alianza Popular. No sin crudeza expresaba un dirigente territorial del partido en 1983 esta sensación: "lo que pasa es que en la CDS [sic] hay mucha menos gente de derechas que las que había en UCD, porque en aquel momento no era honorable ser de derechas, era una vergüenza ser de derechas. Ahora ya no les da vergüenza, y esto ha sido la diferencia"71.

\footnotetext{
${ }^{68}$ Una encuesta realizada en Madrid y publicada en El País, ofrecía los siguientes datos: el total de la población analizada se consideraba en un $47 \%$ y un $15 \%$ progresista moderada y conservadora liberal, mientras que entre los votantes del CDS estos porcentajes eran, respectivamente de un $42,1 \%$ y un 34,4 , El País, 29 de mayo de 1983.

${ }^{69}$ MONTERO, José Ramón: “Sobre las preferencias electorales en España: fragmentación y polarización (1977-1993)" en DEL CASTILLO, Pilar (eds.): Comportamiento político y electoral, Madrid, CIS, 1998.

${ }^{70}$ Ibid., p. 90.

${ }^{71}$ Interview undertaken by Richard Gunther in 1983 (june), AR. Se ha señalado que el CDS ha sido igual que la UCD (socialdemócratas, liberales, independientes, etc.) pero sin democristianos, MORAL, Javier: El centro de la derecha, Madrid, Eudema, 1991, p. 102.
} 
La estrategia política de Suárez pasaba por mantener en el CDS al electorado más progresista de UCD, asimilable al centro-izquierda, y en el contexto de 1982, más cercano al PSOE que a UCD ${ }^{72}$. La postura de Suárez bebía de tres fuentes distintas: entroncaba por un lado con una antigua y frustrada tentativa política que databa de 1976, respondía a la interpretación que había hecho el CDS de la realidad del país y finalmente, se basaba en estudios sociológicos y electorales. Como ha escrito en sus memorias Jiménez de Parga: “[Suárez] me invitó a sumarme a su proyecto, que nacería sin los condicionamientos económicos y sociales que habían frustrado la UCD. Sería un auténtico centro-izquierda",73.

En el primer caso, se ha aludido en numerosas ocasiones al intento por parte de Adolfo Suárez de crear un partido progresista de centro, justo después de la celebración del Referéndum de la Ley para la Reforma Política en diciembre de 1976: "que ideológicamente habría sido mucho menos heterogéneo que la futura UCD"74. La tentativa, rápidamente olvidada, se gestó en torno a la llamada Federación Social Independiente (Grupo Mixto, “azules" e "independientes" liderados por Martín Villa) ${ }^{75}$. El escaso pedigrí democrático de la mayor parte de los miembros de esta coalición, así como la inestabilidad que podía haber originado en el naciente sistema de partidos español impidió la consolidación de esta operación. Un futuro dirigente de UCD admitía: "en diciembre de 1976 [quisimos] fundar un partido político de centroprogresista, digamos, de centro-izquierda, [...] se consideró por diversas personas [...] que no era conveniente fundarlo"

En el segundo caso, debemos volver la vista al "Manifiesto político" y al significado histórico de la fundación del CDS. Siguiendo a José Ramón Caso a Suárez le preocupaban los riesgos que podía generar una mayoría del PSOE en 1982 para el país.

\footnotetext{
${ }^{72}$ Es la opinión de quien con mayor profundidad analizase la historia de UCD, HUNEEUS, Carlos: La Unión... Es interesante recordar, como esta idea era sostenida por los sectores conservadores, especialmente dentro de UCD, desde 1979, BONNIN, Pere y POWELL, Charles T.: Adolfo...

73 JIMÉNEZ DE PARGA, Manuel: Vivir es arriesgarse: memoria de lo pasado y de lo estudiado, Barcelona, Planeta, 2008.

${ }^{74}$ GUNTHER, Richard, SANI, Giacomo y SHABADA, Goldie: El sistema ..., p. 114. El historiador Charles Powell señala: "el CDS, por su parte, lo confió todo al liderazgo carismático de un Suárez que finalmente pudo presentarse ante el electorado con el programa de centro-izquierda que no había tenido ocasión de defender como dirigente de UCD" en POWELL, Charles: España en democracia, 1975-2000, Barcelona, Plaza \& Janes, 2001, p. 324.

${ }^{75}$ Se llegó a pensar en una convergencia con Reforma Social Española (de M. Cantarero del Castillo), y el Partido Socialista Democrático Español (liderado por Antonio García López), JÁUREGUI, Fernando y SORIANO, Manuel: La Otra Historia..., p. 63. Muchos de estos políticos formaron poco después la coalición Alianza Socialista Democrática en 1977 o participaron en la Federación Social Demócrata fundada por José Ramón Lasuén a comienzos de ese mismo año.

${ }^{76}$ Interview undertaken by Richard Gunther in 1983 (june), AR.
} 
Las causas no radicaban tanto en el propio PSOE, más allá de la inexperiencia de gobierno, como en la capacidad -ya demostrada- de determinados poderes fácticos para poner en peligro la estabilidad del sistema; la victoria del socialismo podía constituir una nueva oportunidad ${ }^{77}$. La perspectiva del CDS era compartida por los miembros de asociaciones como la "Fundación para el Progreso y la Democracia (FPD)" o el "Club de los 1000 "78, quienes se mostraban a favor de la creación de un partido o asociación de personalidades independientes que llevara a cabo un papel moderador, "bisagra", en la política española. Uno de los miembros de la FPD, Víctor Ferreres i Pla, pedía desde El País al CDS ejercer el mismo papel que jugó el Partido Radical en 1933 pero con un gobierno de izquierdas: "usted ha fundado su CDS. Seguramente no hará el ridículo en los comicios. Sin embargo, y usted lo sabe, no obtendrá lo necesario para gobernar [...] si Felipe González [...] quiere gobernar, los poderes fácticos harán lo imposible para conseguir un fracaso socialista" ${ }^{, 79}$. Según las hipótesis que se manejaba en el entorno de Suárez, -Caso era quien poseía el perfil más técnico en aspectos de sociología electoral y política-, junto con el fuerte ascenso del PSOE (unos 150 escaños), se iba a producir un aumento considerable de la derecha de Fraga (140, aproximadamente) y un descalabro de la UCD, desembocando en la radicalización y polarización de las opciones políticas, y en última instancia, creando el caldo de cultivo idóneo para la desestabilización democrática ${ }^{80}$. Por ello, la formación del CDS pretendía reproducir un modelo de partidos similar al alemán, -identificando al CDS con el Freie Demokratische Partei (FDP, Partido Liberal Alemán)-:

Estás en un escenario de enorme inestabilidad, en un momento en el que estábamos teniendo cien asesinatos de ETA por año y una crisis económica [...] Una enorme debilidad institucional en el que la alternativa era volver a la derecha pero sin mayoría y muy apoyada por unos sectores muy involucionistas pero no en la Constitución, digamos en cómo gobernar-, y una izquierda absolutamente inexperta y también muy débil [...] Eso es lo que se veía venir en el verano y eso es lo que explica el nacimiento del CDS [...] Eso "lo mata" los 200 escaños [...] una legitimidad tremenda ${ }^{81}$.

Por último, encuestas realizadas entre 1979 y 1982 sobre la "auto-ubicación" del electorado español en escalas izquierda-derecha (1-10) reflejaban una resistencia sociológica a la bipolarización política (el 58\% del electorado se posicionaba entre el 46 en 1979 y el 51\% en 1982) y una inclinación mayoritaria hacia el centro izquierda (la

\footnotetext{
${ }^{77}$ Entrevista con José Ramón Caso, 19 de noviembre de 2014.

78 Algunos de los miembros de estas asociaciones, que en el verano de 1982, "sonaron" para el CDS, HUNEEUS, Carlos: La unión...

${ }^{79}$ FERRERES i PLA, Víctor: “Carta abierta a Adolfo Suárez”, El País, 04 de septiembre de 1982.

${ }^{80}$ Junto con Ignacio Roig, El País, 20 de julio de 1982.

${ }^{81}$ Entrevista con José Ramón Caso, 19 de noviembre de 2014.
} 
media era de 4,8 en 1979 y 1982): "la izquierda y el centro-izquierda superan, en consecuencia a sus opuestos en medida considerable; una superioridad a la que no son ajenas las connotaciones positivas asociadas con la izquierda" ${ }^{\prime 2}$.

Como hemos dicho en más de una ocasión, Adolfo Suárez no fue el único, ni tampoco el primero, en crear en aquel verano de 1982 un nuevo proyecto político a partir de las cenizas de UCD. Junto al CDS debemos hacer referencia al PAD, el PDL o el PDP. La existencia de numerosas opciones políticas, muchas de ellas concomitantes ideológicamente, nutrió las sedes de los partidos y las páginas de los periódicos de numerosas hipótesis y elucubraciones tendentes a optimizar los réditos electorales de las distintas formaciones ${ }^{83}$. Hipótesis e impulsos, de entre los que destacaron, desde el punto de vista de la evolución del CDS: los intentos de reconstitución de una plataforma unitaria del centro, la forja de una gran coalición que abarcara el espacio de centro y derecha y finalmente, los posibles pactos postelectorales.

La relación que se generó entre el CDS y UCD fue bastante confusa hasta la desaparición de este último partido en febrero de 1983. Las diferencias programáticas o apelaciones históricas eran en muchos casos indiscernibles entre ambos: uno era el partido de gobierno de la Transición y el otro, representaba la presidencia del mismo. En El País se decía: "poco es lo que puede encontrarse de original [en] el programa del CDS, excepto, tal vez, mayores reparos en temas de política exterior [...] o autonómicos" $" 84$ y para la línea editorial de $A B C$ constituían "dos programas para un mismo electorado" $" 85$.

\footnotetext{
${ }^{82}$ Los niveles 3 y 4 concentraban al $31 \%$ de los encuestados, frente al $17 \%$ adherido a los niveles 6 y 7 , MONTERO, José Ramón: "Sobre las preferencias...".

${ }^{83}$ Para Javier Moral el nacimiento del CDS impidió al PDL presentar muchas de sus candidaturas, obligó al PAD a abandonar la posición de partido bisagra y acercarse definitivamente al PSOE y a UCD a intentar ejercer esa posición de bisagra, MORAL, Javier: El centro de la derecha, Madrid, Eudema, 1990. ${ }^{84}$ Editorial: "El programa del CDS", El País, 20 de octubre de 1982. Las diferencias entre ambos electorados eran "menos espectaculares de lo que suaristas y leopoldistas afirman de ordinario en su propio beneficio. Lo que no quiere decir que no se aprecien en algunos terrenos claras distinciones de rumbo y actitud entre ambos períodos" en el editorial: "Balance presidencial", El País, 08 de octubre de 1982. Idéntica opinión en el editorial: "Las libertades y la defensa del estado", El País, 30 de septiembre de 1982.

${ }^{85}$ Editorial: "Dos programas, un mismo electorado", $A B C, 08$ de octubre de 1982. Algunos columnistas vieron en el logotipo del CDS un "remedo cuadrangular" del de la UCD, DÁVILA, Carlos: "El festín de las listas", $A B C 12$ de septiembre de 1982; ÍD.: "Suárez se negó a cualquier pacto con UCD", $A B C, 15$ de septiembre de 1982; CÁNDIDO: "Naturaleza y artificio", $A B C$, 09 de septiembre de 1982. Antonio Papell fue muy crítico con la división del centro identificando los nuevos partidos con "grupos de presión privada"; "el CDS y la UCD con el febril objetivo de ver quién obtiene la pírrica victoria sobre el otro"; “ disparatada desagregación [...] causas psicológicas que tienen nombres desagradables tales como irresponsabilidad, oportunismo, ambiciones desmesuradas...", en PAPELL, Antonio: "De nuevo, la sopa
} 
Desde UCD, llegaron algunas ofertas de colaboración con el CDS; los más activos eran aquellos sectores "suaristas" que permanecían en el partido: el comité ejecutivo de Toledo (controlado por Arias-Salgado), el de Cádiz (por García Díez) o Lamo de Espinosa. Incluso Lavilla o Calvo-Sotelo afirmaron ante los medios en las primeras semanas de agosto: "yo estoy trabajando en ello: en una coalición de los diversos partidos centristas, en forma de federación, para concurrir a las elecciones con una clara opción de centro" ${ }^{~} 86$. Suárez rehusó cualquier tipo de oferta o acercamiento y en un principio, sólo reconoció haber mantenido contactos con líderes del $\mathrm{PAD}^{87}$. Precisamente, una opción de centro-izquierda constituida por el CDS, el PAD y plataformas de independientes (Morodo o Tamames) llegó a ser barajada por algunos medios de comunicación ${ }^{88}$ :

P. Se ha especulado con una recomposición del centro mediante una alianza en la que podrían estar presentes, junto a UCD, el nuevo CDS y el PAD de Fernández Ordóñez...

R. [Adolfo Suárez] Respecto del PAD, yo mantuve conversaciones con Luis González Seara. Posteriormente, Javier Moscoso ha manifestado que no desean contactos con el CDS, y a eso me atengo por ahora. En cuanto a UCD, en principio no veo posible ese acuerdo $^{89}$.

En última instancia, las reticencias del CDS a la hora de concretar un pacto o coalición preelectoral se basaban en tres puntos: el partido se había concebido como un proyecto a largo plazo, se buscaba construir un centro diferenciado políticamente de la amalgama de fuerzas que habían constituido la UCD y para Suárez, las expectativas electorales de UCD, así como del resto de partidos (PDL, PAD), eran realmente bajas. No sucedía lo mismo, en lo referente a convergencias postelectorales.

El seguimiento de la prensa a la política de pactos fue in crescendo durante aquel verano y tuvo un punto de inflexión tras una rueda de prensa de Suárez, el 4 de agosto,

de letras", "La productividad del voto", "La derecha invertebrada" en $A B C, 15$ de agosto, 23 de agosto y 16 de septiembre de 1982 respectivamente.

${ }^{86}$ El País, 06 de agosto de 1982. Lavilla se desmarcó a mediados de agosto de la búsqueda de una convergencia política. Hubo, al menos un último intento de coalición, en un encuentro posterior entre Lavilla y Suárez, Diario 16, 09 de septiembre de 1982. Para El País, la negativa de Suárez respondía a la estrategia de arrinconar a la UCD entre dos alternativas: o "subsumirse en el partido de Fraga o dividir entre el CDS y UCD los escasos votos centristas", en el editorial: "Los caminos de UCD", 07 de septiembre de 1982 y CEBRIÁN, Juan Luis: "El pecado y la penitencia", El País, 12 de septiembre de 1982. Distinta opinión se podía leer en El Noticiero Universal, el único medio para el que la diferencia entre ambos partidos era real, editorial: "Clarificación y coherencia política", El Noticiero Universal, 09 de septiembre de 1982.

${ }^{87}$ Aunque fue el PDL, debido a su debilidad política y estructural, quien mostró con mayor claridad su intención de llegar a un pacto de coalición con UCD y el CDS o el PDP, véase, El País, 30 de agosto de 1982.

${ }^{88}$ El País, 22 de agosto de 1982.

${ }^{89}$ El País, 06 de agosto de 1982. 
en la que, presuntamente, mostró su preferencia a un gobierno en coalición con el PSOE. El País, en portada, tituló: "Suárez no apoyará una coalición postelectoral de centro-derecha" "90; $A B C$ agradeció a Suárez la claridad de sus manifestaciones, tras la ambigüedad de su presentación pública ${ }^{91}$. Desde $Y a$ se consideraba al CDS un partido cuyo único interés era el de "aprovecharse" de un hipotético gobierndel PSOE en minoría $^{92}$. El acercamiento del CDS al PSOE fue una tesis también defendida, hasta el mismo día de las elecciones, por Diario 16. Los pactos postelectorales acercaban el CDS al PSOE, pero no descartaban a UCD, y es que, la postura en favor de la “gobernabilidad" del Estado dejaba la puerta abierta a un amplio abanico de coaliciones, entre la que la más remota o acaso la más incómoda era $\mathrm{AP}^{93}$, a quien se reprochó su intento, finalmente no incluido en el programa electoral, de reformar la Constitución: "El CDS no formará gobierno con quien mantenga la más mínima ambigüedad respecto de la Constitución",94.

Para Caso, los análisis electorales de UCD eran totalmente erróneos. La UCD de Lavilla barajaba como hipótesis un resultado de 120-130 escaños para ellos, 120-130 para el PSOE y dos opciones de gobierno: una gran coalición (UCD-PSOE) o un pacto UCD-AP liderado por UCD. Según Caso, "la tesis que tenía Adolfo era que eso era un imaginario [pues Suárez consideraba segura la caída de UCD] y que lo que iba a haber era un ascenso muy fuerte, y más con la experiencia que habían vivido esos años, de la derecha [...] y que íbamos a tener un riesgo serio de dos Españas"95.

\footnotetext{
${ }^{90}$ El País, 05 de agosto de 1982. Sobre la relación entre el PSOE y el CDS: “[Suárez] también negó que hubiese tratado con Felipe González, con quien coincidió en Colombia, el tema de posibles alianzas con el PSOE. En todo caso, el secretario general del PSOE, hablando para la cadena de televisión venezolana Venevisión, aceptó la posibilidad de una colaboración con el CDS: 'Si Suárez está dispuesto a apoyar a un Gobierno socialista sin condiciones ni contrapartidas, estarnos dispuestos a aceptarlo. Un apoyo de esa naturaleza garantizaría la gobernabilidad de España', dijo, confirmando las hipótesis, apuntadas por el mismo Calvo Sotelo, de que los socialistas gobernarán en coalición" en: "Suárez: si los socialistas ganan, el CDS hará que puedan gobernar", El Noticiero Universal, 11 de agosto de 1982.

${ }^{91}$ Editorial: "La oferta de Adolfo Suárez", $A B C, 07$ de agosto de 1982.

92 Editorial: “¿Un nuevo partido o un pulso?”, Ya, 01 de agosto de 1982.

93 Según La Vanguardia "[Suárez] declaró su apoyo "al PSOE aun sin ministros, es decir, aun sin participar en el Gobierno", aunque formaría gobierno tanto con el PSOE como AP, en función del resultado, en editorial: "Coaliciones posibles", La Vanguardia, 19 de octubre de 1982, citado en BAZÁN, Francisco: Análisis crítico de los discursos editoriales de La Vanguardia, El País y Diario 16 durante las elecciones generales (1977, 1979 y 1982) de la transición española (1975-1982), Madrid, Tesis Doctoral, Universidad Complutense, 2014.

94 Teletipo EFE, 08 de septiembre de 1982, Gabinete de Información, Caja 323, Dossier CDS, AGCYL. "La Constitución ante todo. Cualquier pacto postelectoral, menos el que ponga en peligro el propio sistema, afirma Viana", Pueblo, 09 de septiembre de 1982.

${ }^{95}$ Entrevista con José Ramón Caso, 19 de noviembre de 2014.
} 
Paralelamente, desde mediados de julio, habían tenido lugar una serie de movimientos políticos encaminados a forjar una gran coalición electoral de centroderecha, es decir, una alternativa real al socialismo. A comienzos de julio de 1982, algunas personalidades centristas idearon el proyecto (plazos, base programática, etc.) de una "Unión de Centro Independiente"; una suerte de UCD renovada, con personas nuevas y capaz de recomponer una opción electoral de centro-derecha, entonces dispersa en partidos regionalistas (UPN, Convergència, PAR, y "CLAVERO"96) y de ámbito nacional (PDL, UCD y PDP), flexible pero eficaz, es decir, capaz de establecer cuando fuera necesario listas conjuntas con Alianza Popular. Se estimaba que: "con la presencia en el terreno político de Adolfo Suárez y Fernández Ordóñez, el electorado de Centro es, indiscutiblemente, un electorado de Centro-Derecha, progresista, reformista, que no quiere el triunfo de Alianza Popular, pero que no quiere ambigüedades ni "sospechas" de que, con sus votos, pueda apoyarse a un gobierno socialista". El objetivo era constituir en torno a este grupo una alternativa con opciones reales de triunfo frente al socialismo: "es necesario establecer una estrategia política y electoral que permita evitar el triunfo del PSOE y sus 'afines' ${ }^{97}$. En su lectura del sistema de partidos se encargaba de subrayar sus diferencias estratégicas y programáticas con el grupo de Adolfo Suárez -todavía no se había formado como tal el CDS-, al que incluía junto al PAD, en los aledaños del PSOE.

Estos movimientos de convergencia en el "centro-derecha" se vieron finalmente frustrados por la división de criterio en el seno de UCD. La principal línea de fractura nacía del debate sobre la idoneidad de un acercamiento a AP, postura que contaba con un amplio respaldo en la prensa conservadora. Los sectores democristianos, y algunos "azules" consideraban que el futuro político pasaba por trasladar a una gran coalición conservadora el pedigrí centrista -como sucedió en el caso del PDP- y en unión con AP, generar una sinergia capaz de construir una sólida alternativa al socialismo. A finales del verano del 82', una nota escrita por José Luis Álvarez, partidario de esta operación política, decía: "es la única forma de encauzar el centro [...] desaparecen el CDS y UCD. Bipolarización entonces si que se produce [sic]. Existencia de un partido de centro homologable en Europa"98. A pesar de haber contado con la resistencia de

\footnotetext{
${ }^{96}$ En mayúsculas en el original. Referencia a UA (Unidad Andaluza).

${ }^{97}$ Documento de José Luis Álvarez, "Algunos principios programáticos mínimos", 12 de julio de 1982, Caja 9, 45-374, AGUN/JLA. El CDS y PAD estaba llevándose consigo, y acercándolos al PSOE, muchos votos del centro izquierda, en ÁLVAREZ, José Luis: "El Centro hoy", $A B C, 07$ de septiembre de 1982.

${ }^{98}$ Documento de José Luis Álvarez: “0045Documento”, 1982, p. 1, Caja 8, 45-377, AGUN/JLA.
} 
Leopoldo Calvo-Sotelo y Landelino Lavilla ${ }^{99}$, no se puede obviar la importancia de la tesis de la "mayoría natural" en UCD. Muchos de los cuadros nacionales de UCD acabaron integrados en la coalición AP-PDP-UL y finalmente, la mayor parte de sus dirigentes locales y regionales dieron el salto con motivo de las elecciones de mayo de 1983.

Por aquel entonces, en la prensa conservadora se estaba consolidando la idea de que todo aquello que quedaba a la derecha del PSOE era "afín" a una misma concepción política, a un mismo "modelo de sociedad", lo que generaba un fuerte discurso crítico contra la existencia de cualquier partido autónomo entre PSOE y AP. Más allá de la pertinencia sociológica o ideológica de estas tesis, este discurso servía ante todo para amparar operaciones políticas concretas ${ }^{100}$. De acuerdo con Óscar Alzaga, líder del PDP:

Sin emplear términos excesivamente entusiastas, explicó la coalición con Alianza Popular en función de la necesidad de derrotar al Partido Socialista y, una vez más, arremetió contra UCD, que, "al negarse a entrar en una gran coalición, facilita la victoria socialista y se coloca a su vera para disfrutar un puesto al sol de un hipotético Gobierno del PSOE". El CDS de Adolfo Suárez aspira al mismo futuro, dijo después ${ }^{101}$.

Se enfatizaba la necesidad de clarificación del sistema de partidos como paso imprescindible para lograr la estabilidad y consolidación de la democracia española y se relacionaba con una reflexión constantemente espoleada, tanto en la prensa conservadora como progresista, de que la ausencia de una alternativa política real al PSOE constituía un grave déficit para el sistema democrático. La "teoría de los afines" se generalizaba en la especulación política del momento -como reflejaban gráficos y estudios que habitualmente incorporaban al CDS dentro de un espacio indiferenciado de

\footnotetext{
${ }^{99} A B C$ reaccionó así, ante esta decisión: "la suma de votos del centro y la derecha podría constituir hoy la mayoría electoral. Esta es la conclusión en que coinciden varios estudios sociológicos realizados este mismo verano... El socialismo sólo podría vencedor si se enfrentara a unos rivales divididos...", en el editorial: “Decisión histórica en UCD” en $A B C, 07$ de septiembre de 1982.

${ }^{100}$ Con la intención de traslucir el ambiente periodístico, podemos leer el editorial: "Una gran coalición de centro y de derecha [que iría de UCD al PDL y del PDP a AP, no al CDS]", $A B C$, 05 de septiembre de 1982. Llama la atención, este reportaje del $Y a$ partidario de reproducir el mapa político de la II República en su defensa de la "mayoría natural" solicitando la unión de Alzaga, Lavilla, Garrigues Walker y Fraga: "el ejemplo más claro de coaliciones [...] elecciones y nos referimos a la etapa de la Segunda República Española, es el del Frente Popular y la CEDA [...] que constituyeron [...] la expresión clara de la unión entre afines", en $Y a, 24$ de septiembre de 1982. Arturo Moya (UCD, Granada) proponía una gran coalición de centro que iba desde el CDS, PDL, PDP, UCD a AP en ABC, 04 de septiembre de 1982. José Luis Álvarez presionó en UCD hacia el pacto con AP-PDP, al resultar imposible, renunció definitivamente a UCD, GUNTHER, Richard: "Leyes electorales, sistemas de partidos y elites", REIS, 47, Julio-Septiembre 1989, pp. 73-106. Sobre el peso de las presiones externas "conservadoras" en la fragmentación y desaparición de UCD, véase, HOPKIN, Jonathan R.: El partido de la Transición...

${ }^{101}$ El País, 25 de septiembre de 1982.
} 
centro-derecha-, y se debía materializar en una gran coalición postelectoral, pacto preelectoral o partido.

Pero si otros partidos surgidos del fin de UCD se podían proclamar liberales, socialdemócratas o democristianos -incluso a nivel internacional-, el CDS era reducido a un ente populista ${ }^{102}$. El centro político que representaba Adolfo Suárez era considerado un capricho del duque, quien movilizaba a un electorado esencialmente similar al resto de los grupos "afines". Para el suarismo el discurso sobre los "afines" o la "clarificación" política así como los movimientos operados en el centro-derecha, eran la culminación de las presiones de los distintos grupos sociales conservadores, cuyo objetivo último era la subsunción de UCD en AP. Volar el centro había constituido un paso más en la consecución de la llamada "mayoría natural"103. Precisamente, uno de los ejes básicos de la campaña de Suárez se iba a dirigir a criticar estas operaciones políticas y las fuerzas sociales que las habían impulsado: "hay quien dice -grita entre aplausos, Suárez-, que el objetivo de estas elecciones es impedir que gane el PSOE. Eso es un disparate. Nosotros decimos que el objetivo de estas elecciones, gane quien gane, es solucionar los problemas de España" ${ }^{\text {"104. }}$

Resulta revelador completar este análisis con la visión del periódico fundado por Pablo Iglesias, El Socialista, que incluía en uno de sus números de agosto una larga crónica firmada por Julio Bernárdez titulada: "El centro de Suárez". La desintegración de UCD, para el autor, no alejaba necesariamente una futura unión en busca de la "mayoría natural", en defensa de la economía de mercado y con el objetivo de "frenar el socialismo". Una posición que admitía el autor estaba matizada en todos sus puntos por el CDS, "también en este último caso, el CDS se diferencia de los recientemente creados partidos..." ${ }^{105}$. En el editorial, la desintegración de UCD debía servir para la definitiva clarificación política del país, es decir, la consolidación de partidos firmemente asentados en la sociedad - una lectura, que aunque distante de las opiniones más conservadoras, convergía en el resultado final esperado- ${ }^{106}$.

\footnotetext{
${ }^{102}$ El populismo era la tónica en la carrera política de Suárez para el editorial: "Un partido para el Duque", El País, 02 de agosto de 1982.

103 José María Areilza escribía, en una interpretación coincidente con la del CDS: “de pronto se decidió por algunos grupos que era necesario volar el centro [...] la derecha conservadora podía, finalmente, fagocitar esos fragmentos centristas uno a uno [...] una algazara poco disimulada", en AREILZA, José María: "Reflexiones sobre el centrismo", El País, 06 de septiembre de 1982.

${ }^{104}$ Diario 16, 22 de octubre de 1982.

105 BERNÁRDEZ, Julio: "El Centro de Suárez”, El Socialista, 04-10 de agosto de 1982.

${ }^{106}$ Editorial: “Clarificación política”, El Socialista, 04-10 de agosto de 1982.
} 


\section{3. El programa electoral del CDS: España Como Debe Ser}

Los textos de las ponencias defendidas y aprobadas en el I Congreso sirvieron para componer el Programa Electoral de las Elecciones de $1982^{107}$, publicado el 4 de octubre bajo el título de España Como Debe $\operatorname{Ser}^{108}$. La ideología y las razones históricas que habían inspirado la creación del CDS fueron nuevamente utilizadas como punto de partida en el programa electoral y a su vez, preludio a la descripción de las políticas de gobierno centristas perfiladas para las distintas áreas sectoriales.

La introducción del programa electoral -"La estabilidad del sistema político"-, planteaba el reto existente en la nueva legislatura: generar en las instituciones y la ciudadanía hábitos y comportamientos democráticos. Incluso identificaba las causas y los responsables de la fragilidad institucional: "estas situaciones desestabilizadoras no se han producido por azar, por el contrario, su causa se debe buscar en comportamientos inadecuados e irresponsables de buena parte de los protagonistas sociales" ${ }^{\text {109 }}$. Por ello, y con el fin de atenuar estas tensiones, era necesario -“al margen de la natural mudanza que el turno en el poder"110 imponía-, un pacto de estado en materia económica ${ }^{111}$, política exterior y política autonómica ${ }^{112}$, concretado en algún tipo de acuerdo de legislatura a nivel estatal.

La economía española había sufrido con extrema dureza los efectos de la segunda crisis del petróleo, lo que ponía en peligro la posibilidad de alcanzar la tan ansiada convergencia con la Europa desarrollada: "no estamos lejos de recaer en el grupo de

107 Las ponencias han sido analizadas con anterioridad por MELLADO PRADO, Pilar, "Centro...", Revista de Derecho Político, 16, invierno 1982-1983, y QUIROSA-CHEYROUZE Y MUÑOZ, Rafael y FERNÁNDEZ AMADOR, Mónica: "La creación..." en QUIROSA-CHEYROUZE Y MUÑOZ, Rafael, (ed.): Los partidos en la Transición, Madrid, Biblioteca Nueva, 2013, pp. 201-219. El Programa Electoral del CDS se extendía hasta las 79 páginas frente a las 47 páginas del programa electoral del PSOE, "Por el cambio" y las 176 de AP-PDP.

${ }^{108}$ En este sentido, y debido a que no se publicaron las ponencias del I Congreso como tal, hemos decidido llevar a cabo el análisis conjunto de dichas ponencias y del programa electoral, haciendo cuando sea oportuno las matizaciones necesarias.

${ }^{109}$ Lanzaba un mensaje que aludía al desprestigio sufrido por Suárez, "todos ellos tienen derecho a exigir de los políticos un rendimiento de cuentas, pero es preciso recordar que el trabajo político en una democracia aún no arraigada, es necesariamente ineficaz sin el apoyo social en la generación y aceptación de hábitos democráticos de convivencia política", CDS: España. Como debe ser, 1982, p. 6.

${ }^{110}$ CDS: España..., p. 8.

${ }^{111}$ Por ejemplo, en el caso de la economía, CDS, PCE, UCD y PSOE consideraban necesaria la búsqueda de la concertación social. El dirigente del CDS en Madrid, Abel Cádiz abogaba por un modelo sindical, al estilo centro-europeo o alemán que trascendiese la dicotomía capital-trabajo, $A B C, 17$ de septiembre de 1982.

112 Demandado este último explícitamente en el "Manifiesto". La idea de un pacto de estado fue defendida también desde el PCE, fundamentalmente en materia económica, coincidencia que no pasó desapercibida en los medios de comunicación. 
países semi-industrializados de Asia y Sudamérica"" del trabajo" a nivel mundial y la transformación de las estructuras productivas exigía una política económica a largo plazo que implementase la aparición de nuevos sectores. Sin enunciarlo explícitamente, el CDS abogaba por llevar a cabo una "reconversión" del tejido industrial -sostenida por el consenso entre el Estado y las fuerzas sociales- y la reindustrialización del país con tecnologías de vanguardia ${ }^{114}$. El apartado económico del programa electoral era en suma bastante pragmático, eludiendo la retórica electoralista o al menos, cortoplacista. Quizá sea necesario recordar en este punto, la experiencia política de Suárez, así como de Calvo-Ortega y Rodríguez Sahagún en ministerios del área de economía. Para El País el programa económico del CDS, que sus propios líderes consideraban se podía culminar en no menos de diez o quince años incurría "en las habituales fantasías a las que son propensos los discípulos de Toffler [futuristas]"115, e insinuaba que se iba a realizar por medio de la iniciativa privada a costa del presupuesto público ${ }^{116}$; en El Noticiero Universal se afirmaba: “el CDS conjuga el liberalismo económico con la intervención estatal [...] centro liberal" ${ }^{\text {"117 }}$. Respecto a la realidad inmediata (ahorro, inversión, reducción del déficit) no había apenas diferencias entre UCD, CDS y PSOE; en la misma línea, se insertaban las políticas de concertación, de apoyo a pequeñas y medianas empresas, de mejora de la recaudación fiscal, etc. ${ }^{118}$.

En materia exterior, se criticaba la actitud del gobierno de Leopoldo Calvo-Sotelo, "la precisa definición de una política exterior verdaderamente de Estado, que incorpore el acuerdo de la práctica totalidad de las fuerzas políticas [...] carece absolutamente de sentido asumir compromisos internacionales y políticas exteriores que involucren un alto grado de discrepancia interna" ${ }^{\prime 19}$. El CDS apostaba por una renegociación de las condiciones de España dentro de la OTAN con vistas a la recuperación de Gibraltar y la

\footnotetext{
${ }^{113}$ CDS: España..., p. 8.

${ }^{114}$ El programa económico fue presentado por Joaquín Abril Martorell y Chus Viana en Madrid el 08 de octubre de 1982. Destacó en los debates y mesas redondas con otros partidos, José Luis Gómez Calcerrada, candidato del CDS por Ciudad Real.

115 Editorial: "El programa del CDS", El País, 10 de octubre de 1982. Cabe señalar que $A B C, L a$ Vanguardia y Diario 16 no dedicaron un editorial a analizar el programa del CDS, en BAZÁN, Francisco: Análisis crítico...

${ }^{116}$ Una velada referencia al "capitalismo de estado" practicado durante la Dictadura franquista, en la que habían iniciado su carrera política algunos de los miembros más representativos del CDS.

${ }^{117}$ El Noticiero Universal, 22 de octubre de 1982. Asimismo, proponía la inclusión de cierta flexibilidad en la contratación (especialmente en las PYMES), pero se alejaba de los postulados del neoliberalismo, "la política monetaria se articulará de modo que no haga énfasis exclusivo en el control de las tensiones inflacionistas", CDS: España..., p. 28.

${ }^{118}$ Editorial: “El programa del CDS”, El País, 10 de octubre de 1982. En esta línea, la posición del CDS, José Luis Gómez-Calcerrada, en las “mesas de debate” organizadas por $A B C, 20$ de octubre de 1982.

${ }^{119}$ CDS: España ..., p. 10.
} 
entrada en la $\mathrm{CEE}^{120}$. Finalmente, se subrayaba la necesidad de profundizar la cooperación con Iberoamérica y los países del Norte de África ${ }^{121}$. En relación a la defensa nacional, el CDS se mostraba partidario de la reducción del servicio militar, de su prestación en las regiones de origen y de la posibilidad de llevar a cabo servicios sustitutorios $^{122}$. Asimismo, manifestaba la necesidad de reformar el Código de Justicia Militar para hacerlo conciliable con el resto de ordenamientos legales ${ }^{123}$.

El siguiente escalón lo constituían una serie de medidas englobadas bajo el título de “Acción, Política y Sociedad” entre las que se incluía la educación, la cultura, la sanidad o la familia. Se demandaba la escolarización obligatoria y gratuita hasta los 16 años potenciando asimismo la formación profesional, aunque sin abordar la enseñanza en los niveles inferiores. En relación al principio constitucional de libertad de enseñanza enunciaba su intención de: "promover un marco legal que, garantizando la creación de centros docentes privados, establezca las condiciones conforme a las que hayan de otorgarse las subvenciones públicas"124. En el mismo sentido, se manifestaba en política sanitaria, garantizando por un lado, la libertad de elección (y con ello, la red sanitaria privada) y asumiendo el compromiso, en tanto que servicio público, de su completa extensión: "se tenderá a garantizar una asistencia hospitalaria gratuita", ${ }^{25}$. Para Fernando Jáuregui, el programa del CDS presentaba una "ambigüedad general en los planteamientos de temas conflictivos".

\footnotetext{
${ }^{120}$ Aun reconociendo la necesidad de un pacto de estado se criticaba la falta de concreción en el editorial: "El programa del CDS", El País, 10 de octubre de 1982.

${ }^{121}$ Punto en el que difería significativamente de AP: "Pujadas [CDS] se pronunció por un estrechamiento de las relaciones con las naciones democráticas, mientras que Arespacochaga puntualizó que no se puede establecer una cooperación en base a procesos accidentales", $A B C, 17$ de octubre de 1982.

${ }_{122}$ Diario de Ávila, 08 de octubre de 1982; AP-PDP-UL era partidaria de mantenerlo íntegramente y UCD lo omitía, Diario 16, 28 de octubre de 1982.

${ }^{123}$ Esta parte del programa fue presentada públicamente por Agustín Rodríguez Sahagún y Josep Pujadas. ${ }^{124}$ CDS: España ..., p. 44. Una redacción intencionadamente flexible que lo acercaba más al PSOE que a UCD o AP, y que le generó la indiferencia de la "patronal" de los colegios privados-CECE-, El País, 21 de octubre de 1982.

${ }^{125}$ CDS: España ..., p. 50. En la propaganda electoral pontevedresa se podía leer: "una alternativa mixta a la sanidad $[\ldots]$ considera que toda opción política sobre la Sanidad debe partir del respeto a las exigencias del artículo 43 de la Constitución [...] es preciso, recomponer el descoordinado sector público sanitario, del que dependen diferentes organismos de la Administración del Estado hasta entes mutuales como la Seguridad Social, para así alcanzar un sistema sanitario uniforme, capaz de dar cobertura a toda la población [...] El Estado debe permitir la conjunción del sistema sanitario público con la iniciativa privada, sujeta a criterios de interés general en sus concepciones, funciones y rentabilidad. El modelo sanitario del Centro Democrático y Social de Adolfo Suárez, se presenta como una alternativa mixta, que hace necesario partir de la racionalización del sistema público para complementarlo con la iniciativa privada", Vota a Antonio Sieira Pérez, CDS-Pontevedra, 1982.

${ }^{126}$ Esta posibilidad se inclúa asimismo en la propaganda electoral: "La justicia es sin duda, garantía de la
} 
Un tercer bloque agrupaba la relación entre el ciudadano y la administración (libertades públicas, seguridad ciudadana, justicia, etc.). En las medidas referentes a este apartado destacaba la propuesta para la introducción paulatina del jurado e incluso, aunque no fue enunciada dentro del programa, la idea del $\mathrm{n}^{\circ} 1$ por Alicante, el jurista y ex ministro de trabajo Manuel Jiménez de Parga de sustituir el ministerio de Justicia por un Departamento que coordinase las acciones del Gobierno con la judicatura ${ }^{126}$. La lucha contra el terrorismo, incluida en el apartado dedicado a la "Seguridad Ciudadana", no estipulaba ni medidas de excepción, ni un endurecimiento de las acciones punitivas, decantándose por "intensificar la lucha antiterrorista mediante el aislamiento social y político de las organizaciones que promueven y utilizan la violencia”, la búsqueda de la colaboración ciudadana y la mejor dotación de medios policiales ${ }^{127}$.

\section{4. La campaña de las elecciones generales del 28 octubre de 1982}

En la medianoche del 5 al 6 de octubre de 1982 comenzaba oficialmente la campaña electoral en España. Si hasta ahora hemos recorrido los pasos dados por el CDS en su proceso de estructuración como partido político, en las siguientes páginas vamos a ver cómo afrontaron los primeros comicios de su historia, en unas elecciones generales que tuvieron lugar apenas tres meses después de su fundación. Para llevar a cabo nuestro análisis aludiremos, en primer lugar, a la actividad de Adolfo Suárez en las semanas previas al inicio de la campaña. En un segundo momento, desgranaremos las claves del proceso de presentación de candidaturas. A continuación, describiremos los recursos materiales y la organización de la campaña en sus hitos fundamentales. Finalmente, nos detendremos en la caracterización, desde el punto de vista del CDS, de algunos conceptos básicos de sociología electoral particularmente relevantes en el marco de nuestra investigación (mensaje electoral, candidato, posicionamiento).

\footnotetext{
${ }^{126}$ Esta posibilidad se incluía asimismo en la propaganda electoral: "La justicia es sin duda, garantía de la democracia. En el programa del Centro de Adolfo Suárez se da gran importancia a la participación del fiscal en la investigación, la reforma del Código de Justicia Militar, el cambio de denominación del Ministerio -que debería convertirse en un departamento de Relaciones con la Justicia-... Desde la renovación política que el CDS propugna...", Vota a Ángeles Fernández Ferreiro, CDS-Pontevedra, 1982; $A B C, 15$ de octubre de 1982. En la ponencia de Justicia del I Congreso se propuso la reducción del Ministerio de Justicia a labores de mera coordinación y supervisión, con el fín de garantizar la independencia de los organismos judiciales, Diario 16, 04 de octubre de 1982.

${ }^{127}$ Ibid., p. 75.
} 
Durante todo el mes de septiembre, la preparación de las distintas comisiones gestoras provinciales, la presentación de las candidaturas y particularmente, la puesta en marcha del Congreso Constituyente concentraron todos los esfuerzos del partido ${ }^{128}$. En este lapso de tiempo, Adolfo Suárez permaneció en un discreto segundo plano y únicamente acudió a la presentación de una de las gestoras provinciales (Ávila, 20 de septiembre) mientras Chus Viana se convertía en el portavoz oficioso del partido ${ }^{129}$. Nuevamente, la actitud de Suárez era objeto de desconcierto entre la prensa: "A Suárez no lo enseñan. Lo tiene 'tapao'. Te llaman del CDS, 'que hay rueda de Prensa'. Vas. Y sale Chus Viana. Por cierto, que no sé yo de dónde le surge a este vasco la 'escuela de Pío' de decir sin decir, de amagar y no dar, de indefinirse [sic] en la definición..." ${ }^{130}$ La ironía de los medios contrastaba con la gravedad de las noticias que aparecieron desde el 8 de septiembre y que denunciaban un presunto complot internacional para asesinar a Adolfo Suárez, lo que desde su entorno justificaba sus escasas intervenciones públicas ${ }^{131}$. Este episodio, revelado por un agente secreto sirio, fue acumulando nuevas revelaciones con el paso de las semanas ${ }^{132}$, sin llegar a ser en ningún momento confirmado por el Gobierno que aseguraba carecer de datos en este sentido ${ }^{133}$.

No fue hasta la última semana de septiembre, cuando Suárez volvió a ocupar la primera plana de los periódicos gracias a dos entrevistas concedidas en importantes medios de comunicación: el día 26 a Diario 16, a cargo de José Luis Gutiérrez ${ }^{134}$, y el 27 en TVE con la presencia de Pablo Sebastián (Tiempo), José Vicente de Juan (Hoja del Lunes/Ya), Carlos Luis Álvarez $(A B C)$ y Montserrat Roig (La Vanguardia) ${ }^{135}$. Aunque ambos encuentros se inscribían en el contexto de la precampaña electoral y formaban parte de rondas de entrevistas con los distintos candidatos políticos, en el caso de Suárez tuvieron una orientación singular. No sirvieron de plataforma para exponer las líneas maestras del programa de gobierno o la política de pactos del CDS y sí para

\footnotetext{
${ }^{128}$ Diario 16, 26 de septiembre de 1982.

${ }^{129}$ Diario de Ávila, 21 de septiembre de 1982.

${ }^{130}$ URBANO, Pilar: "Algo más que "spray"”, $A B C, 09$ de septiembre de 1982.

131 Un plan en el que supuestamente estaban involucrados ex miembros de los servicios secretos españoles, agentes internacionales y la mafia marsellesa, “Quién quiere asesinar a Suárez?”, Diario 16, 08 de septiembre de 1982 ,

${ }^{132}$ El contacto entre los servicios secretos y la mafia marsellesa apareció muerto en Burdeos durante aquellos días, El País, 24 de septiembre de 1982; Josep Meliá señalaba a instigadores de la extrema derecha tras el complot, en $A B C, 25$ de septiembre de 1982.

${ }^{133}$ El País, 25 de septiembre de 1982.

${ }^{134}$ Fue titulada "La entrevista del año" y ocupaba tres páginas completas en el periódico, Diario 16, 26 de septiembre de 1982.

${ }^{135}$ Se grabó el día 26 y se emitió al día siguiente a las 10:35, curiosamente después de un programa de magia dedicado a David Copperfield, $A B C, 27$ de septiembre de 1982.
} 
recorrer, no sin ciertas dosis de sensacionalismo, los principales episodios de su presidencia y su actividad política, que Suárez con desigual fortuna trataba de reivindicar ${ }^{136}$. En palabras de J. L. Gutiérrez en el encabezamiento de su entrevista: "Adolfo Suárez se ha prestado a responder con absoluta franqueza a todo el interminable catálogo de inquietudes, perplejidades y reproches que ha suscitado su actuación política"137.

A pesar de todo, la pequeña pantalla volvió a constituir un magnífico escaparate para Suárez, siendo acogida con especial interés su intención de renegociar el tratado de adhesión de la OTAN ${ }^{138}$. Una encuesta de Diario 16 realizada a los principales comentaristas políticos españoles le otorgaba en su valoración un aprobado alto, cuya media $(6,39)^{139}$, le situaba en segundo lugar, por detrás de Felipe González y a cierta distancia de Lavilla $(5,93)$ y Fraga $(5,841)^{140}$; incluso, según las encuestas llevadas a cabo por El País, Suárez había logrado el mayor porcentaje de cambios positivos de la opinión pública $^{141}$.

Ese mismo día, el 27 de septiembre, Suárez se trasladó a Galicia donde se reunió en Santiago, Pontevedra, Vigo y Coruña con los miembros del CDS, concediendo dos ruedas de prensa, presentando ante los medios a los candidatos locales e inaugurando de facto los viajes de campaña que le iban a llevar a recorrer todo el país, apenas una semana después.

Como decíamos, uno de los primeros objetivos de las comisiones gestoras, recientemente creadas, fue la configuración de las listas electorales para las elecciones legislativas, cuyo plazo de presentación expiraba el día 19 de septiembre. Se enfatizó no incluir independientes en las candidaturas y la necesidad, conectando así con ese proceso de estructuración que se quería implementar, de presentarse en todas las provincias (véase tabla inferior) ${ }^{142}$. En el discurso centrista, los comicios eran un paso

\footnotetext{
136 Los sub-epígrafes que jalonaban la entrevista eran: "errores", "el mono", "bienio negro", "credibilidad", "mi gran error", "complejos y miedos", "historias de UCD", Calvo-Sotelo", "de provincias", Diario 16, 26 de septiembre de 1982.

${ }_{137}^{137}$ Diario 16, 26 de septiembre de 1982.

${ }^{138}$ Copó los titulares de El País y $A B C$, el día 28 de septiembre.

${ }^{139}$ Distinguiendo entre forma (6,78) y contenido (6), Diario 16, 29 de septiembre de 1982

140 "El impacto televisivo de Suárez, baza del CDS", El Noticiero Universal, 29 de septiembre de 1982.

${ }^{141}$ El País, 13 de octubre de 1982. Sin embargo, renunció a participar en el único debate televisivo que se realizó entre los candidatos en el espacio La Clave, apenas una semana antes del inicio de la campaña y en la víspera de la inauguración del Congreso Constituyente. En su lugar, acudió Rodríguez Sahagún. Tampoco, estuvo presente Felipe González, siendo Alfonso Guerra el representante del PSOE, RTVE, 01 octubre de 1982, Archivo RTVE online.

${ }^{142} Y a, 08$ de septiembre de 1982.
} 
más dentro de su proyecto a largo plazo: "el menosprecio aparente de los temas electorales es tal, que a quienes le hablan de puestos en las listas, escaños y demás, Adolfo Suárez replica: 'Puedes ir de número uno por Madrid, no te preocupes, porque yo me quedo con el número quince",143.

La designación de candidatos y el desarrollo de la campaña electoral transcurrieron en la mayoría de las provincias en unas circunstancias, cuanto menos complejas, caracterizadas por la escasez de medios y la subsiguiente improvisación. Las únicas excepciones fueron Madrid, Ávila, Asturias o Segovia, donde, bien la financiación o la implantación del partido, y por lo tanto, las expectativas de voto, eran mayores. Estas candidaturas estaban copadas por los líderes nacionales del partido. En el siguiente cuadro, mostramos la posición en las listas de todos los miembros de la Junta Gestora Provisional (Comité Nacional):

Tabla 4: Los miembros del Comité Nacional en las listas electorales.

\begin{tabular}{|l|l|}
\hline Madrid & $\begin{array}{l}\text { Congreso: } 1^{\circ} \text { Adolfo Suárez; } 2^{\circ} \text { Rafael Calvo Ortega; } 3^{\circ} \text { Jesús María Viana; } 4^{\circ} \text { Abel Cádiz; } \\
5^{\circ} \text { Joaquín Abril Martorell; } 6^{\circ} \text { José Vicente-Cebrián; } 15^{\circ} \text { Laura Morso; } 25^{\circ} \text { Fernando Castedo } \\
\text { Álvarez }\end{array}$ \\
\hline Asturias & Congreso: $1^{\circ}$ Alejandro Rebollo \\
\hline Segovia & Congreso: $1^{\circ}$ José Ramón Caso \\
\hline Ávila & Congreso: $1^{\circ}$ Agustín Rodríguez Sahagún \\
\hline Lérida & Congreso: $1^{\circ}$ Manuel de Sárraga Gómez \\
\hline Álava & Congreso: $1^{\circ}$ Alfredo Marco Tabar \\
\hline Valencia & Senado: Emilio Pujalte \\
\hline Zaragoza & Congreso: $1^{\circ}$ José Antonio Escudero \\
\hline Huesca & Congreso: $1^{\circ}$ León Buil Giral \\
\hline Cantabria & Congreso: $1^{\circ}$ Federico Ysart \\
\hline Teruel & Congreso: $1^{\circ}$ Miguel Ángel Eced Gómez \\
\hline Alicante & Congreso: $1^{\circ}$ M. Jiménez de Parga \\
\hline Málaga & Congreso: $1^{\circ}$ Francisco Villodres \\
\hline
\end{tabular}

Elaboración propia a partir de $B O E, \mathrm{n}^{\mathrm{o}} 236,02$ de octubre de 1982, p. 27089 y ss.

Debemos destacar la presencia de antiguos colaboradores habituales en presidencia como cabezas de lista de algunas provincias. Algunos de ellos, renunciaron después de las elecciones a cualquier protagonismo en el seno del CDS, en lo que debemos entender, como un último servicio a Suárez. Entre otros, fue el caso de Manuel Ortiz (Sevilla), José Coderch (Gerona), Josep Meliá (Baleares) o Alberto Aza (Huelva).

Citando el testimonio de Antonio Garrosa, cabeza de lista al Congreso por Valladolid y miembro de la Gestora Provincial: “éramos siete miembros [en la Gestora] y el

\footnotetext{
143 "Es, claro está, una forma elegante de decir que no es ese el mejor modo de poner el pie en el partido
} del duque", El País, 05 de septiembre de 1982. 
cometido fue preparar una candidatura, una lista y presentarnos a las elecciones, ni más ni menos. A veces recorrimos los pueblos; [tener] presencia, alguna intervención en la radio que me llamaron y poco más se pudo hacer". En ese momento, en la provincia de Valladolid los afiliados no superaban las cuarenta personas, no había medios, ni ningún apoyo público ${ }^{144}$. En la provincia de Ciudad-Real, José-Luis Gómez-Calcerrada, funcionario del Ministerio de Trabajo y estrecho colaborador del ex ministro Calvo Ortega subraya la rapidez con la que se sucedieron los acontecimientos aquel verano. A pesar de su distanciamiento ideológico de UCD, tras un encuentro personal en el mes de agosto con Suárez, decidió ingresar en el CDS y apenas unos días después, aceptó encabezar la lista al Congreso por Ciudad Real. Uno de los máximos dirigentes del partido concluye: "las listas se cerraron como se pudo""145. La presentación de las candidaturas tuvo lugar en los últimos días de septiembre, ante los medios locales y con el arropamiento de los líderes del partido o miembros del Junta Gestora Provisional (Comité Nacional). Por citar algunos ejemplos: en Ávila se celebró el día 20 con la presencia de Suárez y Rodríguez Sahagún (candidato nº 1 por el Congreso); en Zamora el 22 con Fernando Castedo; en Segovia, el 23 con Rafael Calvo Ortega; en Palencia el 25 con José-Vicente Cebrián -“casi sin organización"146_, etc.

Los medios con los que el CDS encaró las elecciones generales de 1982 estuvieron marcados por numerosas dificultades en la financiación, particularmente, para acceder a los préstamos bancarios ${ }^{147}$. Durante aquellas semanas, consecuencia no sólo de las supuestas enemistades labradas por Suárez durante su etapa presidencial, sino especialmente, debido a la negativa suarista a participar en una amplia coalición de

\footnotetext{
144 "En ese momento, se contaba con una sede absolutamente provisional: un pequeño cuarto de dos habitaciones ubicado en la calle Duque de la Victoria (Valladolid), situado en el último piso y con el techo medio abuhardillado", Entrevista con Antonio Garrosa, 31 de julio de 2013.

${ }^{145}$ Entrevista con José Ramón Caso, 19 noviembre de 2014. Al desglosar la lista de León, el cabeza de lista por aquella provincia, la tilda por la concurrencia de amigos, conocidos y familiares de "lista familiar". Para preparar la campaña, alquilaron y amueblaron un local entre los miembros de la gestora por la ausencia de financiación procedente de Madrid. De los 4.000.000 millones asignados, llegaron 600.000 ptas., AZNAR, Luis: Haciendo ..., p. 113-4.

${ }^{146}$ PÁEZ RENEDO, Pablo: Del Tardofranquismo a la Democracia en Palencia (1968-1982), Palencia, Diputación de Palencia, 2013, p. 278.

${ }^{147}$ Se decía que de los siete grandes, el Banco Bilbao había sido el único en conceder un crédito, $A B C, 04$ de octubre de 1982. "Los acuerdos AP-CEOE habían dado sus frutos y AP concurría a las elecciones con 1800 millones; UCD y PSOE, con 1.500 millones de pesetas cada uno. El Partido Comunista calcula un desembolso de 1.000 millones; mientras que los partidos con una proyección alta de voto no han contado con muchas dificultades a la hora de negociar con los grandes de la Banca, otros -concretamente CDS y PCE- han tenido que recurrir a donaciones personales, los primeros, y a la emisión de bonos de 100 pesetas, los segundos, medidas que también han adoptado los socialistas", PENELLA, Manuel: [Tomo II] Los orígenes y la evolución del Partido Popular: una historia de AP, Salamanca, Caja Duero, 2005, p. 684.
} 
centro o centro-derecha, la hostilidad de la patronal empresarial (CEOE, CEIM y FNT) y de la AEB hacia el CDS fue manifiesta. Este punto de partida estaba agravado por las escasas perspectivas electorales del CDS, que hacían del partido de Suárez una inversión muy arriesgada y escasamente rentable ${ }^{148}$.

Como señala Fuentes Aragonés, fue clave el apoyo crediticio del holding RUMASA, presidido por José María Ruiz Mateos y concedido, gracias a la mediación de Antonio Navalón ${ }^{149}$. Chus Viana confirmó un presupuesto para la campaña electoral de entre 500 y 550 millones, cantidad en la que se incluían aportaciones personales y créditos bancarios y que la prensa elevaba en el mejor de los casos hasta los 600 o 700 millones. Aunque las cifras resultaban bastante bajas para poder llevar a cabo una precampaña y una campaña electoral de ámbito nacional, como era el objetivo del CDS -y más aún en comparación con el resto de grandes partidos- eran más que considerables para una formación fundada escasas semanas antes ${ }^{150}$. En cualquier caso y como testimonio de la escasez de fondos, en Vizcaya se hablaba de un presupuesto de campaña de en torno a 10 millones de pesetas; un líder del CDS en Cataluña afirmaba que en materia crediticia sólo les habían concedido "un crédito en un banco [...] catalán, totalmente mínimo"151 y en Andalucía, un militante exponía el caso de un candidato al senado que, ante la escasez de las dotaciones del partido se había sufragado una campaña a nivel personal con un coste de 16 millones.

El director de campaña del CDS fue Joaquín Abril Martorell, miembro del Comité Nacional y hermano del ex vicepresidente del gobierno, designado para este desempeño

148 "El CDS de Cataluña también ha quedado excluido del lote de los beneficiarios puesto que la evolución 'demasiado progresista' preocupa profundamente a Fomento [Nacional del Trabajo]", $A B C, 07$ de septiembre de 1982. "El presidente de CEIM fue preguntado sobre si el apoyo anunciado por los empresarios a las fuerzas que defiendan su modelo de sociedad abarcaría también al CDS de Adolfo Suárez. Segurado respondió: 'Cuando conozcamos detalladamente el programa del señor Suárez, me pronunciaré. Sin embargo, Adolfo Suárez ha dicho públicamente que gobernaría con el socialismo'", $E l$ País, 09 de septiembre de 1982. Joaquín Estefanía hablaba del PAD y el CDS como de las "dos bestias negras del aparato empresarial", El País, 27 de agosto de 1982 o El País, 01 de octubre de 1982.

${ }^{149}$ Sobre la financiación de Ruiz Mateos al CDS contamos con diversos testimonios, como el del propio Ruiz Mateos y el Ministro de Economía y Hacienda Miguel Boyer en GUINDAL, Mariano, El declive de los dioses, Barcelona, Planeta, 2011, pp. 225-6 y EKAIZER, Ernesto, El último magnate, Barcelona, Plaza \& Janés, 1984, pp. 404-5 y p. 611. Asimismo, era vox populi para todos los militantes del partido. Según un dirigente en Andalucía: "nosotros decimos que sí, que la campaña electoral pasada, no la municipal, sino las generales, estuvo parte de ella financiada, un algo, por el holding Rumasa y por los bancos de Rumasa", Interview undertaken by Richard Gunther in 1983 (june), AR.

${ }^{150}$ Señala Morán, "lo cual pone una cierta sordina a la presunta precariedad inicial del partido" en MORÁN, Gregorio: Ambición..., p. 564. Siguiendo al autor: los fondos en su mayor parte provenían de RUMASA (sus bancos le dan a fondo perdido 350 millones de pesetas); otros fondos eran de Cajas: 150 millones Caja Madrid, 75 la Caixa y 50 las Cajas Rurales; y de Bancos: Bilbao, Popular, Banesto e Hispano-Americano, le aportaron 280 millones.

${ }^{151}$ Interview undertaken by Richard Gunther, in 1983 (june), AR. 
a finales de agosto. Las incertidumbres en torno a la financiación condicionaron la planificación de una campaña plagada de viajes imposibles, improvisación y que en última instancia, dependía del grado de estructuración del partido en las distintas provincias y localidades ${ }^{152}$. Los reportajes periodísticos describían una campaña de mínimos: vuelos en clase turista y línea regular, un Citröen blindado propiedad de la DGSE (Dirección General de la Seguridad del Estado) y otro vehículo en el que se trasladaba la escolta ${ }^{153}$. Durante la campaña electoral Suárez recorrió más de treinta provincias, en total, $50.000 \mathrm{~km}$. Hubo problemas con la cartelería y en multitud de ocasiones, los auditorios -generalmente, teatros o cines- se quedaban pequeños ante la afluencia de gente que acudía a presenciar los mítines de Suárez. Se denunció asimismo, sin éxito, la escasa presencia del partido en TVE ante la Junta Electoral Central, tanto en lo relativo al reparto de espacios electorales como al tratamiento informativo de la campaña suarista; críticas, elevadas por los consejeros del CDS en RTVE: Antonio Del Olmo y J. Antonio Escudero ${ }^{154}$. En parte por este cúmulo de contratiempos, el mayor peso en materia de propaganda electoral lo tuvieron las cuñas radiofónicas, en cualquier caso, el medio más usado por todos los partidos.

Tabla 5: Recorrido de campaña de A. Suárez (1982).

\begin{tabular}{|l|l|}
\hline Madrid & $2,3,4$ octubre \\
\hline País Vasco & 5 de octubre \\
\hline Valencia y Alicante & 6 de octubre (inicio de campaña) \\
\hline Segovia y Ávila & 7 de octubre \\
\hline Asturias & 8 de octubre \\
\hline
\end{tabular}

152 "La corta vida del CDS condiciona su campaña", Diario 16, 21 de octubre de 1982. En palabras de Carlos Santos era "casi demencial", Diario 16, 09 de octubre de 1982". En el mundo rural, donde el partido en la mayor parte de España no contaba con ninguna militancia, la situación era aún más complicada: "Si había que presentar un mitin para un pueblo, había que mandar un compañero del partido al pueblo porque en ese pueblo no había estructura propia del partido [...] Entonces en los pueblos, no teníamos [...] a quien decirle, mira, prepárame el local que mañana va a ir... para un mitin. Tenían que salir dos coches de [capital de provincia andaluza] para ir, pegar carteles durante el día, y el segundo coche tenía que estar dando vueltas por el pueblo con un altavoz anunciando el mitin, y algunos compañeros irse al colegio o al sitio donde se iba a dar el mitin para ordenar un poco" en Interview undertaken by Richard Gunther, in 1983 (june), AR.

${ }^{153}$ SANTOS, Carlos: “A Suárez le da envidia el autobús de Felipe”, Diario 16, 09 de octubre de 1982.

${ }^{154}$ El editorial de El País afirmaba "parece casi evidente la discriminación objetiva de que es objeto el partido de Adolfo Suárez y las formaciones nacionalistas vasca y catalana" en el editorial: "Las batallas de Prado del Rey”, El País, 15 de octubre de 1982. Siguiendo a Rogelio Baón -basándose en El País- los tiempos de cobertura en los informativos fueron: el CDS un 11,8\%. UCD un 17,9\%, PSOE un 17,4\%, PCE un 14,4\% y AP un 14,2 \% y "en RTVE los programas gratuitos fueron distribuidos por el Comité Técnico de Prensa, Radio y Televisión, dependiente de la Junta Electoral Central, según el criterio de importancia parlamentaria de los partidos, y todos éstos, salvo el CDS, difundieron sus spots de un total de treinta minutos por la Primera Cadena en horas de máxima audiencia. El CDS emitió un espacio de diez minutos por la Primera Cadena y dos por la Segunda" en BAÓN, Rogelio: Historia del Partido Popular: del Franquismo a la Refundación, Madrid, Ibersaf, 2001, pp. 418-421. 


\begin{tabular}{|l|l|}
\hline Salamanca y Zamora & 9 de octubre \\
\hline Cantabria & 12 de octubre \\
\hline Extremadura & 12 de octubre \\
\hline Granada & 13 de octubre \\
\hline Aragón, Cuenca y Albacete & 15 de octubre \\
\hline Tenerife & 17 de octubre \\
\hline Las Palmas, Lanzarote y Huelva & 18 de octubre \\
\hline Sevilla y Cádiz & 19 de octubre \\
\hline Navarra & 21 de octubre \\
\hline Soria, Burgos, Logroño y Guadalajara & 22 de octubre \\
\hline Málaga, Granada & 24 de octubre \\
\hline Lérida, Gerona y Barcelona & 25 de octubre \\
\hline Valencia, Ávila y Madrid & 26 de octubre \\
\hline
\end{tabular}

Elaboración propia a partir de la información de prensa y documentación de la Carpeta 1, AGP.

Los primeros días de campaña transcurrieron en el País Vasco y la Comunidad Valenciana, donde Suárez participó en los distintos eventos electorales alejado de los encuentros multitudinarios o actos excesivamente populistas en la calle. La primera excepción fue Ávila donde, apenas una jornada después, recorrió paseando muchos de sus pueblos, entre ellos, su localidad natal, Cebreros. Avanzada la campaña -Zamora, Salamanca- comenzaron a aparecer en sus intervenciones críticas y reproches al gobierno y a UCD, a la par que se consolidaba una alta, y en cierto modo inesperada, afluencia a sus mítines ${ }^{155}$. Tras un pequeño parón los días 10 y 11 para grabar en Madrid los espacios electorales de TVE, retomó la campaña en Badajoz donde grupos de ultraderecha intentaron reventar su intervención y con los que incluso se llegó a carear:

- ¿Qué has hecho durante todos estos años?

- Entre otras cosas, he hecho posible que tú puedas hablarme como lo estás haciendo ahora -lo que desencadenó nuevos aplausos- $-^{156}$.

Su pasado en la presidencia de gobierno le volvió a generar manifestaciones de rechazo en Cantabria, en este caso por parte de seguidores de AP, desencuentros que centraron la atención mediática de sus $\operatorname{actos}^{157}$. La campaña prosiguió en Segovia,

\footnotetext{
${ }^{155}$ En Salamanca congregó a 6.000 personas frente a las 3.000 que había reunido la semana anterior Landelino Lavilla, El País, 11 de octubre de 1982.

156 "Grupos ultraderechistas intentaron reventar el mitin de Suárez en Badajoz", El País, 13 de octubre de 1982. Este episodio no fue una excepción. El líder del ultraconservador Partido Proverista, Maysonauve, pidió la retirada de las listas del CDS declarando: "el Centro Democrático y Social está totalmente fuera de la ley, y no debe existir. Al no haber celebrado un congreso constituyente, el firmante de sus propuestas carece de representación jurídica, según señalan expresamente los estatutos depositados en el Ministerio del Interior" en BÁRBULO, Tomás, El Alcázar, 25 de septiembre de 1982, Archivo Linz. En Guadalajara, se produjo la agresión a un militante de FE de JONS por los servicios de seguridad del CDS durante un mitin, "FE de las JONS se retira de las elecciones", El País, 26 de octubre de 1982. Episodios similares, aunque sin consecuencias, se vivieron en Granada, Málaga o Cantabria.

${ }^{157}$ El País, 14 de octubre de 1982.
} 
donde el despliegue de medios, debido a la notable implantación del partido, fue considerable. En esta provincia, estuvo acompañado de su familia, algo no muy habitual a lo largo de la campaña. Los siguientes días discurrieron en la provincia de Madrid, en Navarra y Canarias, donde mantuvo el tono austero y en cierto modo, anti-mitinero, a pesar de la afluencia de público o de la incorporación de espectáculos en sus intervenciones $^{158}$. A medida que subía el tono de la campaña y se recrudecían los ataques entre los distintos candidatos, los discursos siempre más inflamados de los líderes provinciales y locales llegaron a generar cierta incomodidad a Suárez en más de una ocasión ${ }^{159}$.

Su paso por Andalucía, que en total duró casi tres días, fue quizá el síntoma más palpable de las deficiencias organizativas de la campaña. Si en regiones como Canarias o Castilla y León gozaba todavía de una gran popularidad, en comunidades como la andaluza eran palpables las inmensas dificultades existentes para poder transmitir su mensaje. Todavía se recordaban de forma negativa episodios de su etapa de gobierno, como el referéndum de febrero de 1980. Los últimos días discurrieron en Cataluña, donde volvió a primer plano la inestabilidad democrática generada por la amenaza golpista $^{160}$.

El final de campaña resultó agridulce para las filas suaristas. En Barcelona, la intervención de Suárez estuvo lejos de llenar el aforo del Palau Blaugrana. El mitin de cierre de campaña tuvo lugar en el Cine Salamanca de Madrid donde tomó la palabra junto a la candidata al Senado, Rosa Posada. El discurso de Suárez fue el primero, más breve que de costumbre, y centrado en la defensa de la democracia, la condena al golpismo y su oferta de colaboración en favor de la gobernabilidad de España ${ }^{161}$. En las últimas horas de la campaña, Suárez, en un giro aparentemente imprevisto, se trasladó a Ávila donde desde hacía un par de días se estaban difundiendo octavillas anunciando la retirada del CDS de la contienda electoral.

Nuevamente, en el encuentro que los principales líderes políticos mantuvieron con el rey durante la jornada de reflexión, Suárez insistió en valorar la “coincidencia básica

\footnotetext{
${ }^{158}$ Caso por ejemplo de Las Palmas donde actuó el cantante José Velez, simpatizante del CDS.

${ }^{159}$ El País, 17 de octubre de 1982.

160 El candidato por Lérida José María Mora llegó a recordar las “conversaciones leridanas" entre miembros del PSOE y Armada ante lo que Fernando Jáuregui consideraba una evidente incomodidad de Suárez, El País, 25 de octubre de 1982; "Suárez arrecia sus ataques a los sectores involucionistas", $A B C$, 25 de octubre de 1982.

${ }_{161}$ Para Carlos Santos fue el único discurso mitinero que hizo Suárez en la campaña, Diario 16, 27 de octubre de 1982, Archivo Linz.
} 
que todos mostraron en pro de la consolidación de la democracia y la defensa de la Constitución frente al golpismo y el terrorismo" ${ }^{\prime 162}$.

El mensaje electoral ${ }^{163}$ se articuló en torno a dos grandes ideas en las que se condensaba el discurso del CDS: consolidación de la democracia (supremacía del poder civil) y pacto de estado (crisis económica y política exterior) ${ }^{164}$. El slogan de campaña fue: "España, como debe ser" -acróstico de CDS-. Adolfo Suárez enmarcaba sus propuestas políticas como la conclusión del proyecto histórico iniciado en España años atrás. Todas ellas tenían como fin conseguir la estabilidad democrática y suponían una vuelta al consenso en un sentido amplio, es decir, más allá de una mera reformulación de los Pactos de la Moncloa. Se buscaba un gran Pacto de Estado: "lo que ocurre es que estamos atravesando una crisis muy profunda que le afecta a España doblemente porque la crisis económica incide en un momento en que estamos intentando crear un Estado y generar los hábitos que lo consoliden" ${ }^{\text {165 }}$. Finalmente, planteaba su oferta política como una colaboración desinteresada en favor de la gobernabilidad de España ${ }^{166}$. La presencia del CDS evitaba la escisión de España en dos bloques (izquierda-derecha) y ahondaba en el proceso de modernización económica y social de España ${ }^{167}$.

Los mítines de Suárez eran reiterativos e invariables independientemente del lugar o del auditorio. En sus crónicas, Fernando Jáuregui, quien acompañaba al CDS como enviado de El País ${ }^{168}$, comentaba: "habla de la necesaria reconversión de sectores industriales [...] (algo que no le importó repetir en zonas eminentemente siderúrgicas,

\footnotetext{
${ }^{162}$ El País, 28 de octubre de 1982.

163 "El mensaje electoral [...] contiene ideas, valores, informaciones, palabras clave, eslogan, comportamientos, imagen del Partido, del Candidato, información del Programa, comunicación análoga: (no-verbal, postura, gestos, expresión facial, la inflexión de la voz, la secuencia y el ritmo, y, la cadencia de palabras) y digital (de lenguaje)". Por ello recorreremos, el tono, el lenguaje (emocional o racional) y los principales atributos/valores del candidato. Una sistematización de estos conceptos en SANCHÍS, José Luis: Elementos básicos para una campaña electoral, Madrid, Universidad Complutense, Tesis Doctoral, 2014, p. 141. Disponible en: http://eprints.ucm.es/27652/ 1/T35562.pdf. Fecha de consulta: 10 de marzo de 2016.

${ }^{164}$ SUÁREZ GONZÁLEZ, Adolfo: "Un pacto de Estado", El País, 12 de octubre de 1982. "El pacto de Estado que proponéis, ¿no parece una mera oferta de colaboración al PSOE? - [Rafael Calvo Ortega] No es una oferta al Partido Socialista. Es un pacto, digamos, urbi et orbi. Se trata de un acuerdo abierto a todos, con varias formas posibles de concreción, y referido a puntos esenciales, que para nosotros son tres: terrorismo, grandes líneas de política económica y política exterior”, $A B C, 24$ de octubre de 1982.

${ }^{165}$ El Correo de Zamora, 10 de octubre de 1982.

${ }^{166}$ Desde el punto de vista de la última idea, en defensa de la gobernabilidad, "desde su posición estructural, no dejaba de ser un ejercicio de ironía o de ingenuidad", WERT, José Ignacio: "La campaña electoral de octubre de 1982: el camino del cambio", REIS, 28, 1984, p. 79.

${ }^{167}$ Estas ideas aparecen contenidas en la carta de Adolfo Suárez solicitando el voto entre el electorado (mailing, aunque no se llevó a cabo de forma sistemática), s. t., Madrid, 20 de octubre de 1982, Archivo UB-Pavelló de la Republica.

${ }^{168}$ JÁUREGUI, Fernando: Historia vivida de España: de Franco a Podemos, Almuzara, 2015, p. 261.
} 
como el País Vasco o Asturias)"169. Apenas buscó el ataque personal -“todas las formaciones políticas españolas son igualmente patrióticas" ${ }^{170}-$, y dedicó sus palabras más duras a los militares golpistas -lo que concentraba los mayores aplausos en los auditorios y generaba un evidente malestar en sectores de extrema derecha-. Rafael Calvo Ortega tildaba la campaña de "explicativa”, José Ramón Caso la ha recordado como de corte "institucional" y Laura Morso habla de "conciencia civil"171. En opinión de un alto dirigente suarista: "[hemos] dicho muchas veces que tenía que [habérnosla] pagado el estado, porque era una campaña institucional; una campaña poniendo de relieve los peligros que podríamos esperar, en el terreno económico y en todos los terrenos, del involucionismo de un golpe militar" ${ }^{\prime 17}$.

Debido en parte a la precaria infraestructura, se hubo de renunciar en la mayoría de las localidades a baños de masas y el propio Suárez esquivó los gestos excesivamente populistas. Aparecía un nuevo Suárez que comenzaba su andadura política desde abajo y traía un discurso sencillo, pero claro y reflexivo ${ }^{173}$. Incluso, la valoración personal de Suárez mejoraba en las encuestas electorales y le situaba, generalmente, en segundo lugar por detrás de Felipe González ${ }^{174}$. Aunque el equipo de imagen de Suárez estuvo a cargo de Nicolás de Laurentis, las decisiones fundamentales descansaron en el político abulense; decisiones trascendentales como la renuncia al uso de su imagen en el escaño el 23-F, en un momento que coincidía con el recrudecimiento del ruido de sables y la aparición de una nueva intentona golpista ${ }^{175}$.

\footnotetext{
${ }^{169}$ En relación a la política económica Suárez hablaba de la reconversión de sectores industriales (ruinosos u obsoletas) y de la dependencia económica y energética de España, El País, 20 de octubre de 1982. "Sus mítines fueron deliberadamente monótonos", El País, 28 de octubre de 1982.

${ }^{170}$ El País, 08 de octubre de 1982.

${ }^{171}$ Los cronistas de la campaña del CDS, Raúl Sáez para $A B C$, Fernando Jáuregui, para El País y Carlos Santos desde Diario 16 coincidieron en esta apreciación. El historiador Seco Serrano la calificaba de "ejemplar [...] humildad con que ha asumido sus errores, pero también sus aciertos", El País, 26 de octubre de 1982. Carlos Dávila explicaba "su mensaje de estos días es sobre todo institucional, porque el ex presidente está impresionado por los últimos acontecimientos militares", $A B C, 06$ de octubre de 1982.

${ }^{172}$ Interview undertaken by Richard Gunther, in 1983 (june), AR.

${ }^{173}$ Con bastante ironía Carlos Santos lo llamó: "La sublime obsesión de Suárez: que le crean [...] Adolfo Suárez ha dejado en segundo plano su imagen, ingrediente fundamental de su patrimonio, para dedicarse de lleno a una actividad que lo obsesiona", Diario 16, 22 de octubre de 1982; José Luis Aranguren en El País escribía: "la transformación de Adolfo Suárez desde que cesó en el Gobierno ha sido extraordinaria, y yo diría que se ha reencontrado a sí mismo [...] casi un underdog, un pillete de Cebreros" en "La estampa de los líderes", El País, 24 de octubre de 1982.

${ }^{174}$ Su liderazgo era el segundo tras el de Felipe González en GUNTHER, Richard: "El hundimiento de UCD”, en LINZ, Juan José y MONTERO, José Ramón (eds.): Crisis y cambio: electores y partidos en la España de los años ochenta, Madrid, Centro de Estudios Constitucionales, 1989.

${ }^{175}$ Como pone de manifiesto el editorial: "Elecciones contra el golpismo", El País, 28 de octubre de 1982.
} 
Desde comienzos de agosto, Suárez había hecho explícita su intención de no emplear la imagen del $23-\mathrm{F}$ como reclamo electoral ${ }^{176}$, considerándola parte del patrimonio democrático español; algo que se había barajado seriamente por parte de analistas políticos, politólogos e incluso, miembros de su partido ${ }^{177}$. Recuerda el candidato por Valladolid, Antonio Garrosa,

Nosotros estábamos convencidos de que el cartel electoral del CDS iba a ser la fotografía de Adolfo [...] en su escaño el 23 de febrero mientras todos los diputados estaban [...] agachados con la cabeza escondida en sus asientos [...] Adolfo se negó en redondo, dijo que esa fotografía era propiedad de todo el pueblo español y que de ninguna de las maneras era propiedad de nadie en particular, ni siquiera de él mismo ${ }^{178}$.

A pesar de esta decisión, los componentes de su discurso - las apelaciones al pueblo o la idea de "modernización"-, el heterogéneo público de sus mítines ${ }^{179}$ y el fuerte carácter personalista del partido prolongaron la percepción de la existencia de un fuerte contenido populista en su campaña ${ }^{180}$. Los reportaje sobre la campaña del CDS estaban aderezados de todos los estereotipos que rodeaban la figura de Suárez: café, tabaco -los cohíbas que le regalaba Castro-, frugalidad, gritos de traidor y piropos femeninos. Fernando Jáuregui subrayaba: "quiéralo o no, es el carácter populista que imprime a sus actos el que llena los locales" "181. Para Carlos Santos, incluso los carteles usados en la propaganda electoral de los candidatos provinciales estaban llenos "de tintes tercermundistas: el candidato de turno sonríe complacido junto a un Suárez complaciente, con la cara sombreada por la barba y una chaqueta de cuadros que, probablemente, no se volverá a poner en su vida"182.

\footnotetext{
${ }^{176}$ Entrevista con Aurelio Delgado, 19 de diciembre 2014. Quizá el "atributo" más sobresaliente del candidato era el de la valentía y el coraje. La decisión de Suárez, aunque valiosa desde el punto de vista democrático chocaba con el llamado "packaging", es decir, la campaña de promoción pública del candidato en función de los valores que representa, siguiendo la conceptualización de SANCHÍS, José Luis: Elementos..., p. 121.

177 "El vídeo del 23-F puede recuperar la imagen de Suárez. Su coraje le puede valer muchos votos para él y para su partido", DE RIOJA, Eugenio: "Los partidos políticos ante las elecciones", La Nueva España, 12 de septiembre de 1982.

${ }^{178}$ Entrevistas con Antonio Garrosa, 17 de julio de 2013.

${ }^{179}$ El público que se agolpaba en los mítines era heterogéneo, con la mención inexcusable, al electorado femenino. Como describía Fernando Jáuregui, "clases acomodadas en las primeras filas, más humildes en los asientos traseros, predominio de la mediana edad, sobre todo entre las mujeres", El País, 28 de octubre de 1982.

${ }^{180}$ Se preveía una campaña personalista y populista según $A B C, 22$ de septiembre de 1982.

${ }^{181}$ El País, 09 de octubre de 1982.

${ }^{182}$ Diario 16, 09 de octubre de 1982.
} 
El objetivo básico de la campaña del CDS se basaba en la identificación del partido con Suárez, y en consecuencia, con el liderazgo de la Transición ${ }^{183}$-como hemos dicho, fundamentalmente hasta 1979-; una trayectoria, sin embargo, no exenta de polémica en numerosos sectores del electorado y que presentaba, al menos, tres hándicaps. En primer lugar, el recuerdo de la presidencia de Suárez, para El País o Diario 16 iba a situar en un absoluto segundo plano el programa electoral del CDS en la decisión de los votantes:

Las simpatías y los rechazos del CDS tienen como origen común la controvertida valoración de la figura de Adolfo Suárez. La gran duda es saber qué porcentaje del electorado que votó a Suárez en 1977 y 1979 seguirá fiel a un político que tan decisivamente contribuyó a devolver a los españoles sus libertades y que fracasó, en cambio, por sus propios errores o por las conjuras ajenas, al ejercer su mandato como primer presidente de Gobierno constitucional de la Monarquía parlamentaria ${ }^{184}$.

En segundo lugar, existían bastantes dificultades en el electorado a la hora de identificar a Adolfo Suárez con el CDS y no con UCD -incluso los colores y el logotipo eran en cierto modo parecidos- ${ }^{185}$. Una encuesta de finales de septiembre aclaraba que a los encuestados se les había tenido que definir el CDS como "partido de Suárez" para facilitar su identificación ${ }^{186}$. Según un sondeo realizado por el propio CDS, un $16 \%$ de los participantes creía que Suárez seguía perteneciendo a $\mathrm{UCD}^{187}$.

Por último, su gestión presidencial durante la Transición era objeto de fuertes polémicas con todos los líderes políticos y estaba condicionada por una dimisión incomprendida en la opinión pública y calificada, en el mejor de los casos, como "una peligrosa finta personal" "188. Si Suárez esgrimía el argumento de la derechización del gobierno de UCD y la paralización de las reformas desde 1981, Calvo-Sotelo aducía las dramáticas circunstancias en las que Suárez le había delegado el poder y la complicada herencia recibida; si el CDS reprochaba los obstáculos puestos por el PSOE para la celebración de un debate electoral en TVE, los socialistas le recordaban su anterior

\footnotetext{
183 "No somos un partido personalista, de culto a la personalidad de Suárez, si bien creemos en su proyecto político. No negamos que es un líder en este país y que ha hecho la transición, lo cual es un patrimonio que tenemos que explotar", declaraba Manuel Ortiz (candidato $\mathrm{n}^{\circ} 1$ por Sevilla y ex colaborador en Moncloa de Adolfo Suárez) en ABC, 22 de septiembre de 1982.

${ }^{184}$ Editorial: "El programa del CDS", El País, 10 de octubre de 1982.

${ }^{185}$ Como afirmaba un dirigente centrista: "Si logramos identificar CDS y nuestro líder podemos ganar las elecciones", $A B C, 14$ de septiembre de 1982.

${ }^{186}$ El País, 28 de septiembre de 1982.

${ }^{187}$ El País, 08 de octubre de 1982.

188 "Balance presidencial", El País, 08 de octubre de 1982. Desde las páginas de $A B C$, aunque no se ponía el mismo énfasis se incidía en esta idea. Carlos Dávila escribía: "El CDS de Adolfo Suárez aprovecha cualquier viaje para alumbrar pactos e intentar un objetivo hace días casi imposible: recuperar credibilidad", $A B C, 13$ de octubre de 1982.
} 
etapa por el ejecutivo ya que como señalaba El País: "Suárez nunca aceptó debates en directo con sus adversarios [campañas de 1977 y 1979, así como la ausencia de un debate de investidura este último año]"189. En el caso de Fraga hubo reproches mutuos acerca de la responsabilidad en los sucesos de Montejurra en 1976.

En relación al posicionamiento del CDS entre el resto de partidos, Suárez orientaba sus críticas hacia UCD y el gobierno, Alianza Popular (junto a la CEOE y la "banca") y en último lugar, el $\mathrm{PSOE}^{190}$. Por su parte, los ataques que recibió durante la campaña provinieron básicamente de UCD, así como, de forma tangencial desde AP -Fraga le llamó ‘émulo de Felipe' en varias ocasiones”- y el PSOE ${ }^{191}$. Desde UCD, se criticaba al CDS con dureza por haber abandonado sin explicaciones tanto el partido, como el gobierno $^{192}$. Sobre la rivalidad entre UCD y el CDS a lo largo de la campaña un cargo del CDS en Andalucía certificaba:

En la campaña electoral de octubre el único partido que nos atacó verdaderamente en los mitins [sic] fue UCD [...] fue una campaña cruel la que hicieron ellos. Ellos nos seguían a los pueblos, que donde nosotros teníamos un mitin, mañana lo tenían ellos, o lo tenían media hora antes de nosotros. Con otros partidos, incluso con el partido comunista o AP no hubo ningún tipo de problema ${ }^{193}$.

Las previsiones electorales del CDS desde su fundación hasta la celebración de las elecciones fueron por lo general bastante bajas; se reconocía abiertamente que no se optaba al triunfo electoral y su objetivo principal era contribuir a la gobernabilidad del país. Una encuesta de ALEF para Grupo 16 (Diario 16), publicada el 24 de septiembre, le otorgaba el 5,2\% en intención de voto y un 1,7\% en voto decidido, siendo la segunda fuerza más votada en Castilla y León. En la víspera del I Congreso, en la sede central del CDS se barajaban en torno a 5 o 6 diputados, aunque durante aquel fin de semana aparecieron algunos sondeos en los que alcanzaban incluso una veintena de

\footnotetext{
${ }^{189}$ Editorial: "El debate frustrado", El País, 26 de octubre de 1982. "En caso de que se hubiera celebrado un debate electoral entre primeros candidatos electorales, sólo Suárez, líder entonces del CDS, no habría atacado al socialista Felipe González, en el editorial: "El PSOE rompe la baraja", Diario 16, 25 de octubre, en BAZÁN, Francisco: Análisis crítico..., p. 598.

${ }^{190}$ Curiosamente quienes más coincidieron con la propuesta suarista fueron los miembros del PCE, El País, 13 de octubre de 1982, 17 de octubre, etc. "[Carrillo] quienes entierran políticamente a Suárez se equivocan porque tiene capital político y todavía puede desempeñar un papel en este país", El País, 21 de octubre de 1982.

191 "La tesis de Fraga en este sentido es que en España actualmente sólo existen dos opciones políticas: ellos y los socialistas. Fraga no oculta su desprecio por los partidos de centro y pide a todo el que le escucha que no opte por esos 'partiduchos, partidejos, partidillos y partidúsculos', que dispersan a su juio, el voto no marxista", El País, 11 de octubre de 1982.

${ }_{192}$ El País, 08 de octubre de 1982.

${ }^{193}$ Interview undertaken by Richard Gunther, in 1983 (june), AR.
} 
parlamentarios ${ }^{194}$. Poco después, una encuesta del PSOE le otorgaba nuevamente un $2 \%$ de los votos. Sin embargo, desde el comienzo de la campaña electoral se observó en algunas de las previsiones de resultados una dinámica ascendente por parte del CDS. El 30 de septiembre el CDS contaba con un $3 \%$ en voto decidido y un $8,4 \%$ en tendencia de voto, destacando en Asturias, Cantabria, Castilla y León y Canarias ${ }^{195}$. En cualquier caso, los magros resultados previstos para el CDS lo situaban inevitablemente en el terreno de los pactos postelectorales.

La opción de un pacto con el PSOE era barajada especialmente desde Diario $16^{196}$. Suárez, que no ocultaba su preferencia por tender su mano hacia la izquierda, insistía en que no quería formar parte de ningún gobierno sino "ayudar a la gobernabilidad". Incluso, el editorial de El País publicado en la jornada de reflexión alertaba sobre los riesgos de la bipolarización, "unas elecciones que trajeran como consecuencia añadida la práctica desaparición del centro político, es decir, de la derecha moderada capitaneada por Landelino Lavilla y Adolfo Suárez, y la marginación periférica de Santiago Carrillo podrían tener, a medio o largo plazo, consecuencias profundamente negativas para la estabilidad del sistema democrático" ${ }^{197}$. Por su parte, desde $A B C$, el CDS era una opción orientada claramente al centro-izquierda, al margen de la reconstrucción del espacio de centro-derecha ${ }^{198}$. Según Dávila, la idea de "pacto de estado" del CDS no sólo era irrelevante por la escasas perspectivas electorales, sino que era una forma encubierta de presentar una oferta de coalición al PSOE ${ }^{199}$.

\footnotetext{
${ }^{194}$ El País, 29 de septiembre de 1982; Diario 16, 04 de octubre de 1982.

195 "Baja el PSOE, suben AP y el centro de Suárez", Diario 16, 08 de octubre de 1982.

${ }^{196}$ Se valoraba el tono elogioso que usaban tanto Felipe González como Suárez al referirse entre ellos y concluía que sin duda, Suárez era el favorito de González en caso de necesitar otro partido para formar gobierno, Diario 16, 19 de octubre de 1982.

${ }^{197}$ Editorial: "Una reflexión ante las urnas", El País, 27 de octubre de 1982.

198 "Y el CDS, de don Adolfo Suárez, decidido a navegar en la deriva izquierdista del centro, no sería presumiblemente un amigo de cuenta" en el editorial: "Evitar el debate", $A B C, 26$ de octubre de 1982.

199 "El consenso, que tanto separó a Suárez y González en otras épocas, les vuelve a unir", $A B C, 06$ de octubre de 1982.
} 



\section{Capítulo 3:}

\section{Los retos de la consolidación del CDS (1982-1986)}

Una vez celebradas las elecciones de 1982, la presencia institucional, y con ello, la importancia mediática del CDS cayó a un segundo plano. El CDS sólo había obtenido dos diputados en el Congreso y menos de un 3\% de los votos. Desde entonces, y hasta la celebración de los comicios municipales y autonómicos de 1983, su mayor protagonismo se redujo a aquellos diputados regionales y concejales que habiendo obtenido su puesto en las listas de UCD se habían incorporado al CDS. El partido de Suárez, ignorado definitivamente en la vida política nacional y en los medios de comunicación, se replegó hacia dentro e inició un lento proceso de implantación en todo el territorio. El ex presidente de gobierno y protagonista de la Transición iniciaba así su particular "travesía del desierto".

\section{1. El análisis y las consecuencias de los resultados electorales (28-O)}

Las elecciones de octubre de 1982 depararon una histórica victoria del PSOE, que obtenía en aquella jornada electoral 202 diputados y una incontestable mayoría absoluta. En la oposición, se consolidaba Alianza Popular, partido que había acudido en coalición con el PDP y diversos grupos regionalistas (UV, PAR y UPN) alcanzando la cifra de 107 diputados, mientras UCD lograba únicamente 11 de los 168 escaños conseguidos en 1979, en lo que fue un sonoro fracaso electoral y el preludio de su inminente disolución. La derrota de UCD, que ha despertado un enorme interés por parte de politólogos y sociólogos, estuvo acompañada por los malos resultados del PCE (4) y del CDS (2) ${ }^{1}$. Por su parte, el triunfo socialista ha sido valorado unánimemente en la historiografía como la consolidación del proceso democrático en lo que se conoce como las "las elecciones del cambio"2.

\footnotetext{
${ }^{1}$ CACIAGLI, Mario: “España 1982. Las elecciones del Cambio", REIS, 28, 1984, pp. 85-118.

2 Valoración general, en torno a la cual los distintos autores han subrayado una u otra idea: el fortalecimiento del proceso de modernización, el triunfo del cambio generacional o el fin del golpismo,
} 
A continuación, nos centraremos en el análisis de los resultados electorales y la representación parlamentaria obtenida por el CDS. Después, abordaremos la posición del partido suarista en el debate de investidura de Felipe González y la formación del primer gabinete socialista.

Como hemos señalado con anterioridad, las previsiones suaristas contemplaban un futuro político bastante más equilibrado de lo que habían deparado los comicios, una situación en la que el CDS tuviera un papel relevante desde el punto de vista de la gobernabilidad. Los créditos se habían solicitado barajando una estimación de voto que permitiera la consecución de en torno a 15 o 20 diputados $^{3}$. No cabe duda, de que el resultado electoral suponía un duro golpe para el recién formado partido. Se había conseguido un 2,87\% de los votos (604.309) y tan sólo 2 diputados en el Congreso, y ningún representante en el Senado -tabla 6 a) -:

Tabla 6 a): Diputados conseguidos por el CDS (nombre y circunscripción) en las elecciones generales de 1982

\begin{tabular}{|l|l|l|l|}
\hline Nombre & Provincia & Votos \% & Partidos más votados \\
\hline Agustín Rodríguez Sahagún & Ávila & 22,4 & AP, PSOE, CDS, UCD \\
\hline Adolfo Suárez González & Madrid & 4,1 & PSOE, AP, PCE, CDS, UCD \\
\hline
\end{tabular}

Elaboración propia a partir de http://www.historiaelectoral.com/e1982d.html y http://www.historiaelectoral.com/e1982comp.html Fechas de consulta: 17 de mayo de 2015.

Tabla 6 b): Porcentajes obtenidos por el CDS en las diferentes circunscripciones electorales en las elecciones al Congreso de los Diputados.

\begin{tabular}{|l|l|l|l|}
\hline Galicia & & Murcia & 1,9 \\
\hline La Coruña & 2,7 & Extremadura & \\
\hline Lugo & 2 & Badajoz & 1,4 \\
\hline Orense & 1,9 & Cáceres & 1,9 \\
\hline Pontevedra & 2,9 & Baleares & 5,2 \\
\hline Asturias & 4,3 & Comunidad Valenciana & \\
\hline Cantabria & 5 & Alicante & 2,5 \\
\hline Aragón & & Valencia & 2,3 \\
\hline Zaragoza & 4 & Castellón & 2,7 \\
\hline Teruel & 4,7 & Andalucía & \\
\hline Huesca & 4,9 & Almería & 1,7 \\
\hline País Vasco & & Granada & 1,8 \\
\hline Vizcaya & 1,5 & Jaén & 0,9 \\
\hline Guipúzcoa & 1,6 & Córdoba & 1,2 \\
\hline Álava & 3,8 & Málaga & 1,5 \\
\hline Navarra & 4,1 & Sevilla & 0,7 \\
\hline Cataluña & & Huelva & 1,3 \\
\hline Barcelona & 1,8 & Cádiz & 1,7 \\
\hline Gerona & 2 & Canarias & \\
\hline Lérida & 3,1 & Las Palmas & 5,9 \\
\hline
\end{tabular}

CASANOVA, Julián: Historia de España en el siglo XX, Madrid, Ariel, 2009, p. 393; COMELLAS, José Luis: Historia de España Contemporánea, Madrid, Rialp, 2008, p. 522, etc.

${ }^{3}$ Entrevista con J. R. Caso, 19 de noviembre 2014. 


\begin{tabular}{|l|l|l|l|}
\hline Tarragona & 2,4 & Santa Cruz de Tenerife & 3,9 \\
\hline Castilla y León & & Ceuta & 7,8 \\
\hline León & 2,7 & Melilla & 7,7 \\
\hline Zamora & 4,4 & Madrid & 4,1 \\
\hline Salamanca & 3,8 & Castilla-La Mancha & \\
\hline Ávila & 22,4 & Albacete & 2 \\
\hline Segovia & 7,5 & Cuenca & 1,8 \\
\hline Soria & 4,7 & Guadalajara & 3,2 \\
\hline Valladolid & 4,2 & Ciudad Real & 2 \\
\hline Palencia & 3,9 & Toledo & 1,8 \\
\hline Burgos & 4,9 & La Rioja & 3,7 \\
\hline
\end{tabular}

Elaboración propia a partir de http://www.historiaelectoral.com/e1982.html Fecha de consulta: 17 de mayo de 2015

Los mejores resultados del CDS se concentraban en Madrid, Castilla y León, Canarias ${ }^{4}$, Asturias, Cantabria, Aragón, Ceuta y Melilla y eran especialmente negativos en Castilla-La Mancha, Extremadura y Andalucía, donde en algunas provincias ni siquiera alcanzaba el $1 \%$-tabla 6 b) - . Asimismo, se veía afectado por la consolidación de las fuerzas nacionalistas en el País Vasco y Cataluña. En la lucha por el espacio de centro, el CDS superaba a UCD en las provincias de Barcelona ${ }^{5}$, Madrid, -disputado entre Adolfo Suárez y Landelino Lavilla ${ }^{6}$-, Ceuta y Ávila, provincia donde obtenía el $22,4 \%$ de los voto y se situaba en tercer lugar.

Los retos a los que se había enfrentado el partido de Suárez en aquellas elecciones habían sido fundamentalmente dos. Por un lado, y en parte lo hemos descrito en las páginas precedentes, respondían a los desequilibrios en la implantación producidos por el adelanto electoral y la precipitación con la que había tenido lugar la estructuración del partido a lo largo del territorio, siendo prácticamente inexistente en buena parte de Andalucía, Castilla-La Mancha, Extremadura, Galicia o País Vasco. Quizá por ello, en aquellas provincias donde se habían conseguido porcentajes relevantes las direcciones provinciales matizaban el pesimismo general, conscientes del esfuerzo realizado en apenas unas semanas partiendo prácticamente desde cero. Señala el dirigente del CDSMadrid, Abel Cádiz, "tuvimos que montar deprisa y corriendo una estructura de partido capaz de hacer la campaña" contando con escasos recursos. A pesar de ello y en parte,

\footnotetext{
${ }^{4}$ En Arrecife el CDS era el segundo partido con un $15,7 \%$ de los votos y en Santa Cruz de Tenerife lograba un 7,2\% frente al 3,9\% de UCD, El País, 16 de noviembre de 1982.

5 Provincia en cualquier caso donde se había frustrado una de las grandes bazas electorales del CDS: Antonio de Senillosa. Adolfo Suárez al valorarlo comentó: "los personalismos no son suficientes para obtener un resultado electoral favorable. No creo, por ejemplo, que Antonio de Senillosa haya sido derrotado en Barcelona. Ha sido derrotado el CDS", El País, 13 de noviembre de 1982.

${ }^{6}$ En el análisis electoral de El País se subrayaba: "el haber conseguido más votos que UCD en la provincia madrileña será un pequeño consuelo en su difícil camino", BRAVO, Pilar y ORTIZ, Carmen $E l$ País, 13 de noviembre de 1982.
} 
gracias a la actitud y motivación de la militancia se consiguió un $4 \%$ de los votos en la capital $^{7}$. El propio Suárez, en su comparecencia durante la noche electoral desde el Hotel Gran Versalles declaraba: "[los resultados pueden considerarse un fracaso] si se juzga por los resultados, pero no lo es por el tiempo y el esfuerzo empleado" ${ }^{\text {. }}$

Por otra parte, el capital político de Adolfo Suárez había sido profundamente erosionado desde el año 1980. A los errores en la gestión de gobierno y la campaña de acoso mediático, era necesario añadir una dimisión y un retorno a la política mal explicados o insuficientemente comprendidos por la opinión pública ${ }^{9}$. En numerosos artículos escritos por miembros del CDS posteriores a las elecciones se intentó aclarar de forma plausible estos episodios políticos resaltando la visión de estado de Suárez en estos acontecimientos. El dirigente nacional González Quirós reflexionaba:

Muchos votantes de Suárez en el 77 y el 79 se han preguntado por qué el presidente de Gobierno que fue elegido gracias a sus votos dimitió y por qué ahora ha vuelto a la escena política desde un partido nuevo. Las líneas que siguen constituyen un intento de aportar alguna luz sobre estas dificultades ${ }^{\mathbf{1 0}}$.

A través de las siguientes gráficas reflejamos la percepción y valoración de Adolfo Suárez por parte de la sociedad en este período; datos que subrayan el comentario arriba expuesto y exponen el paulatino descenso que sufrió su popularidad después de enero de 1981 -tablas 7 y 8-. En el primer caso, recogemos la valoración media de Adolfo Suárez en las encuestas del CIS realizadas desde enero de 1981 a octubre de 1982, momento en el que se encontraba en su registro más bajo $(3,84)$ y un período en el que sólo alcanzó el aprobado (5) inmediatamente después del 23-F (marzo de 1981):

Tabla 7: Conocimiento y valoración de la actuación política de Adolfo Suárez.

\begin{tabular}{|l|l|}
\hline Mes & Valoración media (0-10) \\
\hline Enero (1981) & 4,64 \\
\hline Marzo & 5 \\
\hline Abril & 4,71 \\
\hline
\end{tabular}

\footnotetext{
${ }^{7}$ Entrevista con Abel Cádiz, 4 de marzo de 2015, (Madrid).

${ }^{8}$ El País, 29 de octubre de 1982.

${ }^{9}$ Una sensación que expresaba M. A. Aguilar en una entrevista con A. Suárez en el verano del 82': “P. ¿Cuál ha sido la última razón de su vuelta a la escena política para empezar casi como un francotirador, cuando tantos y con tan pesados argumentos -también profesionales y familiares- le han aconsejado prorrogar algún tiempo su retirada en espera de acontecimientos y coyunturas más favorables? ¿Los vetos a que alude el manifiesto fundacional del CDS han sido decisivos para impulsarle a su regreso? ¿Ha calculado la reacción que puede derivarse también en el área personal?”, El País, 08 de agosto de 1982.

${ }^{10}$ En el debate, “Tomas de posición. Proyectos de centro “, GONZÁLEZ QUIRÓS, José Luis: "El porqué de un nuevo partido", $A B C, 02$ de diciembre de 1982. "Muchas críticas se han vertido sobre la figura de Adolfo Suárez por personas que tanto en las elecciones del 77 como del 79 le concedieron su confianza, ya sea primeramente por su no suficientemente razonada dimisión y posteriormente por us [sic] vuelta a la arena política desde un nuevo partido", S/A: "Clarificación", Boletín Informativo Tarragona, 0, enero de 1983 .
} 


\begin{tabular}{|l|l|}
\hline Mayo & 4,35 \\
\hline Julio & 4,46 \\
\hline Septiembre & 4,36 \\
\hline Octubre & 3,99 \\
\hline Noviembre & 4,10 \\
\hline Enero (1982) & 4,34 \\
\hline Febrero & 4,40 \\
\hline Marzo & 4 \\
\hline Abril & 4,31 \\
\hline Junio & 4,36 \\
\hline Julio & 4,01 \\
\hline Agosto & 4,01 \\
\hline Septiembre & 4,14 \\
\hline Octubre & 3,84 \\
\hline
\end{tabular}

Elaboración propia a partir de las fuentes estadísticas del Centro de Investigaciones Sociológicas (CIS, Conocimiento y escala de valoración (0-10) de la actuación política de Adolfo Suárez (nacional), Código: A501010130) ${ }^{11}$.

En la segunda tabla, aportamos los datos de una encuesta de SOFEMASA, realizada en Castilla y León -una comunidad a priori favorable- sobre su valoración media, desglosada por provincias (debido al particular interés de la provincia de Ávila) y en comparación con la de Fraga, González y Lavilla. Los datos arrojan un saldo negativo en todas las provincias salvo en Ávila -donde también "suspende"-, ocupando el último lugar en Burgos, León, Palencia, Salamanca y Zamora.

Tabla 8: Valoración media de Adolfo Suárez y el resto de líderes políticos nacionales en las distintas provincias castellano y leonesas en diciembre de 1982.

\begin{tabular}{|l|l|l|l|l|}
\hline & Adolfo Suárez & Felipe González & Manuel Fraga & Landelino Lavilla \\
\hline ÁVILA & 4,45 & 5,22 & 4,23 & 3,58 \\
\hline BURGOS & 4,28 & 6,05 & 5,71 & 4,45 \\
\hline LEÓN & 3,95 & 5,67 & 5,36 & 4,25 \\
\hline PALENCIA & 3,62 & 5,69 & 5,36 & 4,06 \\
\hline SALAMANCA & 3,33 & 6 & 4,89 & 3,38 \\
\hline SEGOVIA & 4,18 & 5,97 & 5,01 & 4,14 \\
\hline SORIA & 4,88 & 6,21 & 4,71 & 4,85 \\
\hline VALLADOLID & 3,36 & 6 & 4,39 & 3,34 \\
\hline ZAMORA & 3,62 & 5,08 & 4,21 & 3,84 \\
\hline
\end{tabular}

Elaboración propia a partir de una encuesta de SOFEMASA realizada en Castilla y León, Archivo General del Consejo de Castilla y León $(A G C Y L)^{12}$.

Los dirigentes del CDS, conscientes de esta realidad, asumieron como un mal trago necesario los resultados de 1982, es decir, una consecuencia inevitable del desgaste político vivido por Suárez desde 1980 y, sobre todo, el efecto de la dimisión. En

\footnotetext{
${ }^{11}$ Con el fin de facilitar la lectura, de ahora en adelante omitiremos el emplazamiento online donde se ha obtenido la presente encuesta, disponible en http://www.analisis.cis.es/cisdb.jsp

12 "Puede concluirse que el único líder valorado con nota superior a cinco en todas las provincias es Felipe González, le sigue Manuel Fraga, que supera el cinco en otras tantas provincias. El resto de los políticos no alcanza el cinco en ninguna provincia siendo los menos valorados en líneas generales Blas Piñar y Santiago Carrillo", encuesta de SOFEMASA realizada en Castilla y León, Gabinete de Presidencia, Dossier no 445, p. 384, AGCYL.
} 
expresión del propio partido, era preciso “eliminar el 'efecto desodorante' (la sensación de que nos abandonó)"13:

Nosotros en el año 82, como objetivo operativo dentro del plan estratégico queremos superar el rechazo, esto es, nosotros entendemos que cuando el presidente del partido dimite [...] en España no comprende nadie la dimisión [...] era necesario recibir un voto de castigo $[\ldots]^{14}$.

En palabras de José Ramón Caso en ningún momento se barajó la posibilidad de no acudir a las elecciones de octubre de 1982 -o incluso, haber permanecido en UCD hasta los siguientes comicios-. Añade cómo, una vez celebradas las elecciones y avanzada la legislatura, las interpretaciones se volvieron totalmente distintas, especialmente respecto al papel y la estrategia que debía desempeñar el partido suarista: la legitimidad del PSOE era amplísima ${ }^{15}$. Un dirigente regional comentaba en 1983: "sí, yo creo que hubiera sido mucho mejor haber aguantado [en UCD, hasta después de las elecciones]. Pero claro, lo digo esto hoy, no lo decía yo en agosto [de 1982]"”16.

El desconocimiento de muchos de sus candidatos y las características del sistema electoral perjudicaron por lo demás un voto disperso y de amplitud nacional, que debía resistir a su vez la fuerte presión hacia el centro del PSOE - y en menor medida de la coalición liderada por AP-, y la competencia electoral de UCD y diversos partidos nacionalistas y regionalistas. En muchos de los análisis electorales efectuados en los medios durante aquellas jornadas se volvió a ahondar, con fuerte insistencia, en tres aspectos recurrentes desde el verano: las causas de la destrucción del centro político, la asimilación del voto de centro en el nuevo esquema bipartidista y las posibilidades de reconstrucción del centro político. Las diferencias entre unos medios y otros estribaban en la interpretación de los acontecimientos, y sobre todo, en la búsqueda de responsables.

El día 29 de octubre, contando ya con un recuento parcial de los resultados, desde $E l$ País, se reconocía el valor en favor de la consolidación democrática de la campaña de los partidos centristas -que adscribía al espacio de "derechas"- ${ }^{17}$ y días después, se

\footnotetext{
${ }^{13}$ Expresión en “...1986: Objetivo cumplido”, Órgano de Información del Centro Democrático y Social [OICDS], 2, julio 1986.

${ }^{14}$ Interview undertaken by Richard Gunther in 1986 (june), AR.

${ }^{15}$ Entrevista con J. R. Caso, 19 de noviembre de 2014.

${ }^{16}$ Interview undertaken by Richard Gunther, in 1983 (june), AR.

17 "Sectores de la derecha inteligente y del centro-derecha, representados por Suárez y Lavilla, han comenzado en las últimas semanas una campaña de apaciguamiento y de tranquilidad cara a su clientela conservadora, lo mismo para señalarles que el triunfo del socialismo no significa para ellos el fin del mundo que para poner de relieve la necesidad de que la experiencia socialista, avalada por la voluntad
} 
añadía en relación a Adolfo Suárez: "ha dado un ejemplo de convicción casi emocionante al asumir su nuevo papel de outsider, en pugna con las enormes limitaciones económicas y organizativas del recién fundado CDS, perjudicado por esa disolución anticipada de las Cortes Generales"18. Finalmente, se apostaba por la continuidad de un centro independiente que garantizase la existencia de una oposición moderada de derechas:

Los diputados de UCD y CDS también pueden resistirse al liderazgo o el yugo de Fraga, y es más posible que se dediquen a una tarea, lenta y trabajosa, pero necesaria, de reconstruir el centro o de redescubrirlo, en lo que no les faltará el apoyo de los propios socialistas $^{19}$.

En Diario 16, Pedro J. Ramírez achacaba la hecatombe del centrismo, fundamentalmente a Adolfo Suárez y anticipaba los futuros movimientos, -“al principio oscura, labor extraparlamentaria"-, que se iban a producir para conseguir su reconstitución. Señalaba el error, en términos estratégicos, que habían supuesto las candidaturas diferenciadas de UCD y CDS:

Los responsables de tal hecatombe son muchos, pero el principal de ellos se llama Adolfo Suárez. La fría realidad de las cifras es el mayor alegato imaginable frente a la esterilidad de su escisión. La suma del 7,2 por 100 obtenido por UCD y el 2,8 por 100 del CDS hubieran situado al centrismo, -eso sin contar los votos añadidos que se hubieran derivado de la unidad-, en una cota idéntica a la que en 1979 proporcionó al Partido Comunista 23 escaños $^{20}$.

Por el contrario, $A B C$ destacaba positivamente la nueva reconfiguración del sistema de partidos. El electorado de los grupos auto-posicionados en el centro había sido transferido a las dos grandes opciones políticas y a los partidos nacionalistas. El CDS era una "anécdota" en el sistema de partidos español:

Existe una mayoría socialista, un gran partido en el centroderecha liberal y conservador. Y existen dos partidos que encarnan los dos fenómenos periféricos determinantes de nuestra Historia contemporánea. Todo lo demás son anécdotas [...] Es una anécdota la exigüidad de la extrema derecha, el descenso de la coalición política de los votantes de

ciudadana, funcione bien durante estos próximos cuatro años si se quiere proteger lo que es interés de todos: la estabilidad del régimen y la gobernabilidad del país", editorial: "El triunfo del socialismo", El País, 29 de octubre de 1982.

${ }^{18}$ Editorial: "La destrucción del centro y su posible reconstrucción", El País, 31 de octubre de 1982.

${ }^{19}$ Editorial: "El partido de la oposición”, El País, 30 de octubre de 1982 y editorial: "La destrucción del Centro y su posible reconstrucción”, El País, 31 de octubre de 1982.

${ }^{20}$ RAMÍREZ, Pedro J.: “Así se ganaron y perdieron las elecciones", Diario 16, 31 de octubre de 1982. Columnistas como Carmelo Cabellos consideraban ineludible una futura convergencia entre UCD y CDS: "si aún persisten en sus ideas, quizá lo único que les queda es recomponer posiciones y buscar la posibilidad de convertirse, juntos, en un partido bisagra" en CABELLOS, Carmelo: "Las diez respuestas del cambio", Diario 16, 30 de octubre de 1982, Archivo Linz. 
ETA y la inexistencia electoral de don Adolfo Suárez que termina, desde el poder y la gloria, una representación de personaje semitrágico ${ }^{21}$.

La postura de $A B C$, en la que se relacionaban las dos grandes opciones políticas (PSOE-AP) con los dos principales "modelos de sociedad", achacaba a los personalismos y la exageración artificial de diferencias políticas la destrucción de UCD, incapaz de representar los intereses de los sectores conservadores y liberales. Mientras, para El País, los movimientos políticos en el seno de UCD no explicaban suficientemente el derrumbamiento del partido del gobierno y señalaban: "parecen olvidar que la movilización interclasista que logró Adolfo Suárez en provecho de UCD forzosamente obligaba a compatibilizar las expectativas del centroizquierda con las exigencias de la derecha clásica"22. Por último, El Noticiero Universal mantenía su apoyo al proyecto suarista a pesar de la fuerte derrota electoral, haciéndose eco del discurso de la dirección del CDS:

Todo ello no nos hace perder nuestra confianza en un auténtico centro político ni la esperanza de su consolidación aglutinado alrededor de un eje, -el CDS- que sea a la vez reformista y progresista. Don Adolfo Suárez ni ha arrojado la toalla ni ha dicho su última palabra $^{23}$.

Los dos diputados electos del CDS, Adolfo Suárez y Agustín Rodríguez Sahagún, sin posibilidad de constituirse como grupo parlamentario se integraron, en la Legislatura que daba comienzo (II Legislatura) en el Grupo Mixto. No obstante, se plantearon otras opciones. En algunos medios, surgió la posibilidad de integrarse en un grupo de centro liderado por los parlamentarios de UCD, alternativa rápidamente rechazada desde el $\mathrm{CDS}^{24}$. La negativa del CDS fue paralela a los contactos que se produjeron entre CiU y

\footnotetext{
${ }^{21}$ Editorial: "La OTAN: test anticipado", $A B C, 30$ de octubre de 1982. En esta línea, la columna de URBANO, Pilar: "Dos potentes imanes", $A B C, 30$ de octubre de 1982. Jaime Campmany comentaba: "el regreso de don Adolfo Suárez a su tamaño político natural es cosa que sabíamos todos, menos don Agustín Rodríguez Sahagún, don Antonio de Senillosa, don Federico Ysart y el propio interesado, naturalmente como sucede en los vodeviles" en "Las armas de guerra", $A B C, 25$ de noviembre de 1982. Una visión desde "la derecha" de las elecciones de 1982 y coetánea de los acontecimientos en MUÑOZ ALONSO, Alejandro: Las elecciones del cambio, Barcelona, Planeta, 1984.

${ }^{22}$ Editorial: "La destrucción del centro y su posible reconstrucción", El País, 31 de octubre de 1982. Una visión diferente desde la izquierda política en Tierno Galván: "me refiero a la práctica desaparición de los partidos de centro en el ámbito parlamentario. Quizá la causa más honda no esté, en el fraccionamiento de UCD, sino en la valoración de los partidos de centro como proponentes de un cambio tibio, precedido de una historia política tibia frente a las exigencias sociales [...] En estas épocas, en que la sociedad pide sí o no, el papel de centro lo subsume el propio partido que propone el cambio" en "Cambio y madurez social”, El País, 10 de noviembre de 1982.

${ }^{23}$ Editorial: "Un plebiscito para la democracia", El Noticiero Universal, 29 de octubre de 1982. Sobre la necesidad de un centro progresista y reformista que evitase la radicalización de la vida política española, editorial: "Una opción necesaria", El Noticiero Universal, 13 de noviembre de 1982.

${ }^{24}$ El País, 30 de octubre de 1982.
} 
los suaristas con el objetivo de crear una gran plataforma centrista en Cataluña y un grupo de centro y autonomista en el Congreso, ambos, finalmente, descartados ${ }^{25}$.

El CDS pasó a formar parte del Grupo Mixto junto al diputado de EE (Juan María Bandrés), el de ERC (Francesc Vicens i Giralt) y los cuatro del PCE, liderados por Santiago Carrillo. Precisamente, la confluencia de Suárez y Carrillo, en esta nueva situación decididamente secundaria, constituyó una de las anécdotas más comentadas del inicio nueva legislatura ${ }^{26}$. El 18 de noviembre, fecha de apertura de las nuevas cortes, el CDS tomó asiento en la parte superior y central del congreso, detrás de los representantes de las minorías vasca y catalana; con ironía Pilar Urbano transcribía unas palabras de Suárez a Rodríguez Sahagún en aquella jornada: “¡Agustín, no te me pierdas, que rompes el partido!', le decía mientras subían la escalerilla del hemiciclo hacia las gradas altas de la penumbra” ${ }^{, 27}$.

Desde el primer momento, y entroncando así con su postura en favor de la gobernabilidad del país, el CDS ofreció su apoyo al futuro gobierno socialista y contempló como una necesidad histórica la victoria electoral de la izquierda en las elecciones. Los primeros días de noviembre, Adolfo Suárez se entrevistó personalmente con Felipe González, por iniciativa de éste, para intercambiar impresiones sobre el desempeño presidencial $^{28}$.

La primera reunión del Comité Nacional (CN) tras las elecciones se celebró el 12 de noviembre; previamente todos los dirigentes del CDS habían permanecido una semana al margen de la actualidad informativa o del partido, a modo de "semana de descanso".

\footnotetext{
${ }^{25}$ Conversaciones en las que había que tener en cuenta las primeras manifestaciones de la Operación Roca y, sobre todo, la frágil situación de Pujol en la Generalitat, El País, 13 de noviembre de 1982.

26 “[El GM] presenta otra característica aún más sobresaliente: por primera vez, se sientan en sus escaños Suárez y Carrillo, dos auténticos pesos pesados, protagonistas históricos de la transición y líderes durante años de partidos que tuvieron singular importancia en el proceso democrático... Los dos se resisten a abandonar la política activa e intentarán dar al grupo toda la 'marcha' que puedan. Carrillo y Suárez convivirán durante cuatro años en escaños vecinos [...] Ambos [...] se profesan mutuo afecto y se admiran recíprocamente. Los dos lo han reconocido en conversaciones públicas y privadas. Y ambos tienen parecida visión de Estado para ciertos temas", Diario 16, 17 de noviembre de 1982, Archivo Linz. Véase también, MARTÍN PRIETO, J. L.: "Santiago Carrillo, después de la caída", El País, 14 de noviembre de 1982.

${ }^{27}$ URBANO, Pilar: "Savia nuevo en el parlamento", $A B C, 19$ de noviembre de 1982.

${ }^{28}$ La periodista Pilar Urbano aludió posteriormente a una llamada, algo más que de felicitación, en la noche electoral: "Felipe González quería saber esas cosas que no constan en actas: temas y procedimientos de Consejos de Ministros; cuestiones estatales delicadas y secretas; situación "verdad, verdad', del Ejército antes y después del 23-F; espionaje internacional", URBANO, Pilar: "La llave Miterrand", $A B C, 27$ de febrero de 1984. Volvió a tener una larga entrevista con Felipe González el día 25 de noviembre en el Palacio del Congreso, $A B C, 26$ de noviembre de 1982. El día 05 de diciembre hubo una última reunión entre González y Suárez, -dentro de una ronda de contactos con los dos ex presidentes-, en las dependencias privadas del edificio, El País, 06 de diciembre de 1982.
} 
En una reunión que se prolongó más de siete horas, cada miembro del $\mathrm{CN}$ leyó un informe sobre resultados electorales, proyectos de futuro y elección de secretario. En la posterior comparecencia de prensa, la primera de Suárez desde las elecciones, admitió que los resultados no eran particularmente favorables pero estaban dentro de lo previsto, anunció su apoyo a Felipe González - tanto en la investidura, como en calidad de ex presidente-, y expresó su intención de acudir en solitario a las elecciones municipales y autonómicas $^{29}$.

El día 25 tuvo lugar la inauguración oficial de la II Legislatura a cargo del rey Juan Carlos I, cuyo discurso en el Congreso de los Diputados estuvo precedido por el de Gregorio Peces-Barba presidente de la Cámara. Aquella tarde, en la recepción de los distintos líderes políticos se produjo un breve encuentro entre el monarca y Adolfo Suárez, quien alabó las palabras del rey y del presidente del Congreso.

En el debate de investidura, el discurso de Felipe González - día 30 de noviembrefue considerado por el resto de fuerzas parlamentarias como bastante moderado aunque algo vago e inconcreto. Todos los medios de comunicación, destacaron las declaraciones posteriores de Adolfo Suárez quien había realizado "un elogio sin paliativos" a la investidura de Felipe González subrayando: "este tipo de exposiciones programáticas no puede durar siete horas [...] ha sido lo que puede y debe ser un discurso de investidura" 30 .

La intervención de Adolfo Suárez, dentro del Grupo Mixto y contando para la misma, con algo menos de diez minutos, se basó en la exposición de los argumentos que justificaban su "sí" a la investidura de Felipe González. Comenzaba así: "queremos contribuir con nuestro 'sí' a la consolidación de la democracia, al progreso de nuestro pueblo y a la vertebración en solidez y profundidad del Estado de las Autonomías"31. El voto afirmativo del CDS guardaba relación con la sintonía programática que el líder centrista entreveía con las propuestas socialistas:

Es evidente que la raíz que nutre uno y otro programa político es distinta, como distintos son también los planteamientos ideológicos y las propuestas políticas concretas: pero, a mi juicio, existen notables coincidencias en las líneas maestras de la política a desarrollar

\footnotetext{
${ }^{29}$ ABC, 13 de noviembre de 1982; El Noticiero Universal, 13 de noviembre de 1982.

30 "Los grupos parlamentarios critican la falta de medidas concretas y elogian la moderación del discurso del candidato" en ANGULO, Javier y PRADES, Joaquina, El País, 01 de diciembre de 1982; LAFORA, Victoria: "Sólo Suárez elogió el discurso de investidura", Diario 16, 01 de diciembre de 1982, Archivo Linz.

${ }^{31}$ Votaron a favor de Felipe González, PSOE, CDS, EE y PCE, en contra AP y UCD y el resto de fuerzas políticas se abstuvieron.
} 
en los próximos años y, entiendo, también una voluntad política similar para el progreso de nuestro pueblo y la modernización de nuestra sociedad ${ }^{32}$.

En segundo lugar, defendía su compromiso en favor de la gobernabilidad del país aunque la mayoría absoluta socialista transformara notablemente su significado-: "Otras fuerzas políticas pueden pensar, y con toda razón, que su contribución a la gobernabilidad del Estado debe hacerse en este momento desde la crítica y la oposición. Nosotros hacemos hoy real el compromiso adquirido ante el pueblo español, otorgando nuestra confianza inicial [...]". Y finalmente, en base a su concepción de la consolidación democrática:

Entendemos que la democracia en España sólo estará sólidamente asentada en la medida en que se hagan reales y eficaces las necesarias reformas económicas, sociales y culturales, y se consiga hacer realmente operativas la libertad, la igualdad y la justicia para todos los españoles ${ }^{33}$.

Los últimos puntos de su discurso revistieron un mayor interés, al abordar dos aspectos centrales de la campaña electoral y del Manifiesto Político del CDS y firmemente enraizados en su experiencia presidencial. Por un lado, Suárez agradeció la voluntad política de pacto y consenso manifestada por Felipe González en aspectos de política exterior, economía y desarrollo constitucional (autonomías) y tras subrayar su completa independencia política, Suárez se volvió a referir a todos aquellos, que a propósito del descrédito del gobierno intentasen contribuir a la desestabilización política del país:

El Partido Socialista, el 28 de octubre, ha sabido suscitar la ilusión de una importante mayoría del pueblo español y ganar su credibilidad. A mi juicio, en un momento tan delicado no debemos contribuir al desencanto. Por tanto, no nos alegrarán los posibles errores del Gobierno, si los comete no participaremos, ni en la Cámara ni fuera de ella, en operaciones de desestabilización del Gobierno. No somos partidarios del irresponsable y peligroso juego de capitalizar en beneficio propio las dificultades de quien tiene la honrosa carga de gobernar a España ${ }^{34}$.

Felipe González agradeció a Suárez sus palabras y su apoyo, tanto por su oferta de colaboración como por su voto afirmativo en la investidura -más si cabe, al recordar que él nunca lo había hecho-, enunció algunos de los proyectos de ley que se iban a poner en marcha en las próximas fechas resaltando y retomando el hilo de lo dicho por Suárez "cuando hablamos de esas leyes [...] hablamos previamente de una negociación de los modelos fundamentales en los que debe apoyarse un debate parlamentario

\footnotetext{
${ }^{32}$ DSCD, Sesión Plenaria, 01 de diciembre de 1982, nº 4, p. 52.

${ }^{33}$ Cuando Suárez finalizó su discurso, se escuchó un "muy mal" y desde la bancada socialista recibió aplausos, La Vanguardia, 02 de diciembre de 1982.

${ }^{34}$ DSCD, Sesión Plenaria, 01 de diciembre de 1982, no 4, p. 52.
} 
posterior" 35 . Las reacciones a la intervención de Suárez subrayaron su decidido apoyo a la nueva situación que vivía el país. En El País se titulaba: "Queremos contribuir a consolidar la democracia" ${ }^{36}$; Diario 16 recogía: "Coincidencia en los objetivos" ${ }^{, 37}$ La Vanguardia subrayaba “Adolfo Suárez (CDS): 'El gobierno necesita la colaboración de todos"”; finalmente, $A B C$ : “Adolfo Suárez: 'El futuro es cosa del esfuerzo común de todos",38. Sin embargo, la mano tendida de Suárez al recién inaugurado gobierno del PSOE podía ser también interpretada en un sentido opuesto. Fraga dejó escrito en sus memorias: "Adolfo Suárez, en pleno oportunismo"39.

\section{2. Formalización y dinámica de los órganos de gobierno del CDS (1982-1986)}

A lo largo de la II Legislatura fueron cobrando forma e iniciando su andadura los principales órganos de gobierno del partido. En primer lugar, y con el fin de comenzar su estructuración, -en especial de todas esas gestoras provisionales que habían ido dando forma al CDS en las semanas previas a las elecciones- fue prioritario el nombramiento del Secretario General el 11 de noviembre de 1982. Tal y como se había adelantado en la prensa, el Comité Nacional, a propuesta de Suárez, designó a José Ramón Caso. Se habían barajado los nombres de Jesús María Viana o Rafael Calvo Ortega. Sin embargo, y a pesar de la experiencia organizativa de ambos, la situación del partido tras las elecciones les hizo optar por centrarse nuevamente en sus desempeños profesionales, al igual que sucedió con la mayor parte de la dirección excepción hecha de Rodríguez Sahagún y el propio Caso.

José Ramón Caso García conocía a Adolfo Suárez desde mediados de los 70', cuando se embarcaron en un proyecto empresarial en la provincia de Ávila ${ }^{40}$. Posteriormente, al ser Suárez nombrado presidente de gobierno, Caso se ofreció a su

\footnotetext{
${ }^{35}$ Ibid.

${ }^{36}$ El País, 02 de diciembre de 1982.

${ }^{37}$ Diario 16, 02 de diciembre de 1982; GUTIÉRREZ, José Luis: "Las reacciones. El segundo día", Diario 16, 02 de diciembre de 1982.

${ }^{38}$ ABC, 02 de diciembre de 1982;

${ }^{39}$ FRAGA, Manuel: En busca..., p. 298. Véase también, la sátira de FLORENCIO, M. J.: “Suárez: El único político al que escribían los discursos”, ABC Sevilla, 30 de noviembre de 1982.

${ }^{40}$ José Ramón Caso es licenciado en Derecho por la Universidad de Madrid y en Administración de Empresas (ICADE), diplomado en Análisis de Sistemas. En ese momento tenía 36 años, había sido director de varias empresas y había participado como asesor de Acción Democrática en las elecciones portuguesas de 1979 (también había trabajado en comicios en Francia y América), $A B C, 12$ de noviembre de 1982.
} 
equipo, -liderado por Aurelio Delgado-, para realizar tareas de análisis y estudio electoral, pasando a formar parte de lo que se conocía en la época como "fontaneros" de la Moncloa. Al cabo de un tiempo, cuando la colaboración se hizo más estrecha, fue nombrado Director General de Servicios Sociales y de Acción Social ${ }^{41}$. En ese momento, Caso todavía no tenía desempeño alguno en el partido. Fue después del Congreso de Palma, cuando se acordó su inclusión en la ejecutiva de UCD, al frente del secretariado de organización y con el fin de ayudar al, en ese momento, presidente Rodríguez Sahagún. En aquel período de 1981, forjó una estrecha amistad con Calvo Ortega y Rodríguez Sahagún, siendo los tres, quienes informaban a Suárez de la marcha de UCD durante aquellos meses y el círculo donde se barajó la hipótesis de formación de un nuevo partido. Una vez producida la formación del CDS y pasados los comicios, la secretaría general del partido no era un cargo apetecible; fue Suárez, con quien había logrado tener muy "buena química" después de tantos años de colaboración, especialmente desde 1981-, quien creyó necesario su nombramiento ${ }^{42}$.

Durante las semanas siguientes a la designación de Caso, se dio forma al Plan Estratégico del partido, el cual vio finalmente la luz en enero de $1983^{43}$. En el Plan Estratégico se planteaban dos grandes fases en el desarrollo del CDS: 1983-1986 y 1986-1990 ${ }^{44}$. La primera de estas etapas tenía como objetivo fundamental "crecer hacia dentro", mientras la segunda debía servir para proyectarse en la sociedad como auténtica alternativa de gobierno de cara a las elecciones generales de 1990.

Los comicios de 1982 y 1983 fueron útiles para generar una primera estructura partidaria -y aún conscientes de las escasas perspectivas electorales- dar a conocer las siglas/mensaje del CDS logrando identificar a Suárez con el mismo ${ }^{45}$. Si 1982 se había

\footnotetext{
${ }^{41}$ En 1979 y 1980 respectivamente, BOE, no 300, 15 de diciembre de 1979, p. 28812 y BOE, no 158,02 de julio de 1980, p. 15157.

42 Entrevista con J. R. Caso, 19 de noviembre de 2014, Madrid. De acuerdo con los estatutos el nombramiento del Secretario General era llevado a cabo por el Comité Nacional a propuesta del Presidente y debía a su vez, ser miembro de dicho comité, Estatutos CDS (julio, 1982), Capítulo 5, Artículo 25 $5^{\circ}, R P P$, Registro de Entrada ${ }^{\circ} 170,29$ de julio de 1982.

${ }^{43}$ La reunión del 31 de enero de 1983 sirvió al Comité Nacional para intentar canalizar el impulso electoral de las elecciones de mayo de cara a la consolidación de estructuras estables en el partido; junto a aspectos electorales (programa, selección de candidatos) se aprobó el Reglamento de Organización, se analizó el proceso de afiliación y el grado de implantación, así como la situación económica, en las distintas provincias, $A B C, 31$ de enero de 1983. Documento sobre la situación del partido en provincias (1983), AGP.

${ }^{44}$ En base al testimonio de un dirigente centrista en Interview undertaken by Richard Gunther (june 1986).

45 Todavía se indicaba el CDS como "P. Suárez" (al igual que el PDP, PAD o PDL eran denominados aludiendo a sus líderes) en una encuesta de SOFEMASA encargada por al Gobierno del Consejo General
} 
concebido como "un mal trago" necesario, en 1983 se buscó superar la indiferencia mediática y social en la que se hallaban inmersos. El siguiente paso, en 1984, pasaba por lo que se llamó: “despertar simpatía”. Para ello, era preciso conseguir una implantación real, formal y electa democráticamente en las 52 provincias; una implantación que debía ir acompañada de la difusión de la "idea política de España” del CDS (Convención Nacional, monográficos, conferencias, etc.) y un aumento de la presencia pública del Presidente. El año 1985 se relacionó con la idea de "generar adhesión" en la sociedad gracias a la plena identificación del mensaje y el liderazgo del partido. Estos pasos, desembocaban en el afrontamiento del reto de las legislativas de 1986 fijado en la obtención de 2 millones de votos. Objetivos a medio y largo plazo de un partido, todavía, en ciernes.

El CDS había sido una organización surgida exclusivamente en torno a Suárez y su entorno político. A partir de este núcleo poderosamente personalista -compuesto por "hombres de confianza", amistades, etc.- debía generarse una auténtica organización de partido, es decir, órganos de gobierno estables y con mecanismos de funcionamiento democrático. De acuerdo con los estatutos, los órganos de gobierno se estructuraban en cuatro niveles territoriales: nacionales, regionales, provinciales y locales. El núcleo organizativo a nivel nacional se reproducía en los distintos escalones territoriales desde los más amplios hasta los de ámbito municipal ${ }^{46}$. El modelo de afiliación propuesto, como era la tónica general en la mayor parte de los partidos políticos europeos de ese momento, era de tipo "directo" es decir, no estaba mediado por la pertenencia a alguna asociación socio-profesional o sindical ${ }^{47}$. Las solicitudes de afiliación debían estar avaladas por dos afiliados, debiendo contar con la aprobación del Comité Provincial y el visto bueno del Comité Nacional ${ }^{48}$. El grado de compromiso exigido a los afiliados

de Castilla y León en diciembre de 1982, Gabinete de Presidencia, Dossier no 445, Archivo General de Castilla y León,

${ }^{46}$ En el caso del CDS resultó significativamente más operativo el nivel provincial -en parte debido a la dificultad y a veces inconveniencia- de generar agrupaciones locales. En cualquier caso, la estructura coincide con los niveles de poder político generados por los propios mecanismos democráticos e institucionales como ha puesto de manifiesto, entre otros, Van Biezen quien distingue: "local and provincial", "federal" y "national party estructures", VAN BIEZEN, Ingrid: Political parties in new democracies party organization in Southern and East-Central Europe, Hampshire, Palgrave Macmillan, 2003, pp. 77-104. Véase también, HALLIDAY, Ian: "Building a Parties State in a New Democracy" en WEBB, Paul, FARREL, David y HALLIDAY, David (eds.): Political parties in advanced industrial democracias", N. York, Oxford University Press, 2003, p. 248.

47 MELLA MÁRQUEZ, Manuel, ABREU FERNÁNDEZ, Víctor, et al.: Curso de partidos políticos, Madrid, Akal, 1997, p. 100.

${ }^{48}$ En un principio, exclusivamente del Comité Nacional, lo que ponía de manifiesto no sólo el empeño en controlar el proceso de afiliación sino la débil estructura territorial del partido, Estatutos (julio y 
consistía en la aceptación de los principios ideológicos y programáticos del partido, el cumplimiento de los estatutos y decisiones de los órganos directivos, la contribución económica (pago de las cuotas) y la participación en sus "actividades políticas desarrollando una acción constante en los medios en que se desenvuelva"49.

Los órganos de gobierno del CDS con competencia en todo el territorio (Título II) eran, por este orden: el Congreso, la Convención Nacional, el Comité Nacional, el Presidente y el Secretario General. El Congreso, de acuerdo con la legislación ${ }^{50}$, se definía como el órgano supremo del partido. En el Congreso, se fijaba la estrategia política y los perfiles programáticos, se fiscalizaba la actuación de los órganos de Gobierno y se elegía a sus integrantes. Los miembros del Congreso eran los compromisarios electos en las distintas Asambleas Provinciales (hasta un máximo de mil) y del Comité Nacional. El Congreso se debía reunir cada tres años, así como con carácter extraordinario a petición de la Convención Nacional, el Presidente o el CN. Los acuerdos del Congreso se decidían: "por mayoría simple de presentes. Las votaciones serán siempre públicas, excepto cuando se trate de elegir a personas para cubrir los puestos previstos en estos Estatutos, en cuyo caso serán secretas (art. 15.5)”.

El I Congreso o Congreso Constituyente se celebró, como hemos visto, los días 2 y 3 de octubre de 1982, por lo que el II Congreso estaba previsto para el otoño de 1985, pero hubo de posponerse en sucesivas ocasiones. En un principio debido a la coincidencia con las elecciones autonómicas de Galicia (noviembre, 1985) se retrasó hasta comienzos de 1986 y después se fue demorando de forma paulatina con la intención de extraer la máxima rentabilidad electoral -y el menor gasto económico-. Su celebración se postergó hasta el mes de septiembre (1986).

La Convención Nacional era el órgano superior del partido en el período entre congresos y en ella, se debían, aprobar a propuesta del Comité Nacional, los programas

noviembre, 1982), RPP, Registro de Entrada $\mathrm{n}^{\circ}$ 170, 29 de julio de 1982 y Acta Notarial $\mathrm{n}^{\mathrm{o}} 301$, J. L. Martínez Gil, 07 de febrero de 1983 (en base a acuerdos del Comité Nacional del 11 de noviembre de 1982 y la celebración del I Congreso del CDS los días 02 y 03 de octubre de 1982).

${ }^{49}$ No se distinguía entre afiliados, militantes y simpatizantes. El grado de implicación no se concretaba con demasiada profundidad. En octubre de 1982, se modificaron algunas cláusulas de los estatutos en relación a la antigüedad necesaria por parte de los afiliados para ejercer ciertos derechos, Título 1, Artículo $4^{\circ}, R P P$, Registro de Entrada no 170, 29 de julio de 1982 y Acta Notarial n ${ }^{\circ} 301$, J. L. Martínez Gil, 07 de febrero de 1983 (en base a acuerdos del Comité Nacional del 11 de noviembre de 1982 y la celebración del I Congreso del CDS los días 02 y 03 de octubre de 1982).

${ }^{50}$ El artículo 4.2 de la Ley 54/1978 de 04 de diciembre, de Partidos Políticos señala: “el órgano supremo estará constituido por la Asamblea general del conjunto de sus miembros, que podrán actuar directamente o por medio de compromisarios", BOE, no 293, 08 de diciembre de 1978, pp. 27781. 
de actuación del partido. En la Convención Nacional se profundizaba la línea política del partido (desde la actuación general a seminarios y jornadas sobre temas particulares) y se velaba por el cumplimiento de las disposiciones congresuales: "los acuerdos se adoptarán por mayoría de presentes y, en caso de empate, podrá decidir el voto del Presidente. No podrán adoptarse acuerdos sobre temas no incluidos en el Orden del Día" (Art. 18. 2). La Convención estaba formada por: el Presidente, el Secretario General, los miembros del CN, el Secretario de las Juventudes ${ }^{51}$, los Presidentes y Secretarios de Federaciones y Provincias, los representantes del partido en el extranjero y altos cargos públicos del partido ${ }^{52}$. La Convención Nacional se debía reunir, al menos, con una periodicidad de seis meses.

Nuevamente, las dificultades económicas, el reto que suponía la implantación territorial del partido y el escaso desarrollo de las secretarías ejecutivas a nivel nacional demoraron la celebración de la I Convención hasta el año $1985^{53}$. La I Convención Nacional tuvo lugar los días 23 y 24 de marzo en Madrid y sirvió para abordar programáticamente la posición del partido en relación al desarrollo del Estado de las Autonomías. La Convención, en la que estuvieron presentes 129 delegados, fue coordinada por el área de Interior y Administraciones Públicas dirigida por Javier Soto.

No obstante, de cara a la estrategia y la puesta en común de las disposiciones programáticas del partido se habían realizado con anterioridad tres asambleas de presidentes y secretarios provinciales (o en su defecto, representantes de las gestoras provisionales) que ejercieron "de facto", y al margen de la regulación estatutaria, la coordinación a nivel nacional del partido durante este período. La I Asamblea se celebró en Madrid los días 6 y 7 de octubre de 1983 con la participación del Presidente y el Comité Nacional. Durante la misma se trataron tres grandes temas: "la situación política actual y la posición del partido", "la estrategia a seguir" de cara a la consolidación y "el análisis sobre las próximas elecciones autonómicas a celebrar próximamente [País Vasco y Cataluña, en febrero y mayo de 1984, respectivamente]”. Constituyó asimismo, un puente de comunicación entre Rodríguez Sahagún, como diputado y los grupos locales-provinciales sobre los posicionamientos del CDS en los proyectos de ley

\footnotetext{
${ }^{51}$ No se concretó como un Órgano de Gobierno del partido estatutariamente hasta 1991, si bien, su funcionamiento es perceptible desde la III Legislatura.

${ }^{52}$ Los Presidentes del Congreso, del Senado, del Gobierno - junto a sus ministros- y de las CC.AA.

${ }^{53}$ En este lapso de tiempo fue una constante el anuncio de la I Convención Nacional, a la par, que se consideraba necesario multiplicar el esfuerzo de captación de afiliados, CASO GARCÍA, José Ramón: “Carta del Secretario General”, Boletín de Difusión Cultural y Participación (BDCP), 1, enero 1984, p. 1.
} 
socialistas. Finalmente, se abordaron aspectos monográficos sobre Sanidad, Educación, Defensa, Reindustrialización, Administración Local y Organización Interna ${ }^{54}$.

La II Asamblea de portavoces, -presidentes, secretarios o representantes de las gestoras provinciales-, se celebró en Madrid los días 4 y 5 de febrero de $1984^{55}$. Igual que en la ocasión anterior, se hizo un análisis de la situación política general y a continuación se presentaron tres ponencias, a cargo de los distintos responsables de área (economía, educación/cultura/comunicación e interior/administraciones públicas) ${ }^{56}$.

La III Asamblea tuvo lugar el 2 y 3 de junio de 1984 en Madrid. De nuevo, se expuso una visión panorámica de la dinámica política nacional a cargo de la Secretaría General para finalmente analizar con más profundidad los resultados de las elecciones autonómicas catalanas de mayo y particularmente, las opciones y viabilidad de la llamada "Operación Reformista"

La Convención Nacional no se podía asemejar a órganos colegiados de otros partidos como la Junta Directiva Nacional de AP, el Comité Federal del PSOE o por mencionar algunos de creación paralela al CDS, el Consejo Político Federal del PAD o el Consejo Político del PDP (del que emanaba el Comité Ejecutivo). No poseía la capacidad ejecutiva de estos órganos de gobierno, no era, estrictamente, un órgano de representación territorial -como algunos de los citados anteriormente- y estaba enfocada esencialmente a la formación, divulgación y profundización del mensaje político centrista entre sus cuadros y la supervisión, en términos generales de la marcha del partido. No tenía las funciones habituales de los Consejos Políticos o los Consejos Federales.

El Comité Nacional decidía y ejecutaba las decisiones políticas del Partido "bajo la dirección del Presidente" y equivalía a la "ejecutiva". En el Comité Nacional se decidían todos los posicionamientos del CDS en la política nacional. Sus atribuciones eran: el impulso de la acción del Partido en todos los ámbitos, el establecimiento de las directrices políticas generales (labores parlamentarias y de Gobierno), la aprobación de los programas electorales, la fijación de la posición en cuestiones políticas (incluyendo Mociones de Censura o Cuestiones de Confianza, sesiones de investidura), la

\footnotetext{
${ }^{54}$ Boletín Informativo, CDS-Aragón, 1, noviembre 1983, p. 2.

55 El día 14 de febrero se celebraron unas Jornadas de Comunicación del partido, también, con la presencia de Adolfo Suárez, Carpeta 1, AGP.

${ }^{56} A B C$, 05 de febrero de 1984.

${ }^{57}$ Boletín Informativo (CDS-Federación de Madrid), 0, junio 1984, p. 5.
} 
autorización de pactos de Gobierno y alianzas/pactos parlamentarios, las relaciones internacionales (tanto a nivel general como partidista), la supervisión de la gestión patrimonial, económica y financiera y en última instancia, asegurar el cumplimiento de los fines y objetivos del partido. Los acuerdos del CN eran vinculantes para todos los afiliados y órganos de ámbito territorial inferior. Asimismo "el Comité Nacional podrá suspender actos, acuerdos y decisiones de los órganos del Partido que sean contrarios a estos Estatutos o a los acuerdos del Congreso, de la Convención Nacional, del propio Comité Nacional, del Presidente o del Secretario General, siendo su decisión inmediatamente ejecutada" (art. 19.3.). El CN estaba compuesto por el Presidente, el Secretario General y diecinueve vocales. Su elección se llevaba a cabo en el Congreso del partido "con arreglo a criterios mayoritarios" (art. 20, c.) en candidaturas cerradas y bloqueadas y avaladas por al menos el $10 \%$ de los miembros del Congreso ${ }^{58}$. El CN podía elegir, a propuesta del Presidente, una Comisión Permanente ${ }^{59}$ y coordinaba mediante la conformación de una Comisión Nacional Electoral (CNE) todas las cuestiones electorales. Dicha CNE estaba dirigida por el Presidente junto al Secretario General del partido.

El CN se debía reunir con la frecuencia que por sí mismo acordase o por petición expresa de la mitad más uno de sus miembros y convocatoria del presidente. Los acuerdos del CN debían ser adoptados por mayoría simple de votos, decidiendo el voto del Presidente en caso de empate y siempre que estuvieran presentes la mayoría absoluta de sus miembros: "todos los miembros del Comité Nacional serán solidariamente responsables de los acuerdos que se adopten, sin perjuicio de que se haga constar en el acta los votos particulares que hubiere sobre las decisiones adoptadas”.

En esta primera fase del partido, que abarca hasta 1986, las reuniones del Comité Nacional no estaban sujetas a regularidad, -prácticamente la totalidad de los miembros del Comité estaban dedicados a sus obligaciones profesionales personales-, y dependían fundamentalmente del calendario político y electoral. Solían dar inicio hacia las seis o siete de la tarde (lunes y jueves habitualmente), y aproximadamente, con una frecuencia media de dos meses.

\footnotetext{
${ }^{58}$ En este caso, coincidían con los estatutos del PAD a propósito de su Comité Ejecutivo Federal, véase, PAD: Un partido para el progreso...

${ }^{59}$ Intrascendente en la vida política del CDS, pero determinante en la historia de UCD sobre la que han pervivido dos interpretaciones. Para autores como Mario Caciagli había sido una "cesión de Suárez" a los llamados "barones" de UCD, para Alonso Castrillo supuso lo contrario: una demostración de fuerza del político abulense, véase, CACIAGLI, Mario: "España 1982...” y ALONSO CASTRILLO, Silvia: La apuesta de...
} 
Tabla 9: Reuniones del Comité Nacional y principales temas de debate político en el CDS entre las elecciones generales de 1982 y 1986.

\begin{tabular}{|c|c|}
\hline Períodos electorales y/o anuales & Fecha y acontecimiento político principal \\
\hline $\begin{array}{l}\text { Reuniones del Comité Nacional } \\
\text { entre noviembre de } 1982 \text { y mayo } \\
\text { de } 1983 \text {. }\end{array}$ & $\begin{array}{l}\text { - } 11 \text { de noviembre de } 1982 . \text { Valoración resultados electorales. } \\
\text { - } 13 \text { de diciembre de } 1982 \text {. Precampaña y estructuración } \\
\text { territorial. } \\
\text { - } 31 \text { de enero de 1983. Organización y preparación campaña } \\
\text { electoral. } \\
\text { - } \quad 21 \text { de febrero de 1983. Preparación campaña electoral. } \\
\text { - } \quad 15 \text { de marzo de 1983. Ratificación candidaturas electorales. } \\
\text { - } \quad 14 \text { de abril de 1983. Campaña electoral. } \\
\text { - } \quad 9 \text { de mayo de 1983. Análisis de resultados. }\end{array}$ \\
\hline $\begin{array}{l}\text { Reuniones del Comité entre junio } \\
\text { y diciembre de } 1983 \text {. }\end{array}$ & $\begin{array}{l}\text { - } \quad 6 \text { de junio de } 1983 \text { (Ausencia de comunicación a los medios). } \\
\text { - } \quad 12 \text { de septiembre de } 1983 \text {. Reorganización y financiación. } \\
\text { - } \quad 7 \text { de diciembre de } 1983 \text {. Inauguración sede. }\end{array}$ \\
\hline Reuniones del Comité en 1984. & $\begin{array}{l}\text { - } 19 \text { de enero. Elecciones autonómicas País Vasco. } \\
\text { - } 12 \text { de marzo. Elecciones autonómicas P. Vasco y Cataluña. } \\
\text { - } 10 \text { de mayo. Elecciones autonómicas Cataluña. Operación } \\
\text { Roca. } \\
\text { - } 10 \text { de julio. Operación Roca. } \\
\text { - } \quad 24 \text { de septiembre. Inicio curso político. } \\
\text { - } 29 \text { de octubre. Fijación de postura en el DEN (OTAN). } \\
\text { - } 21 \text { de diciembre. - }\end{array}$ \\
\hline Reuniones del Comité en 1985 & $\begin{array}{l}\text { - } 25 \text { de febrero. Plan de Actuación: congreso en octubre y } \\
\text { fortalecer las estructuras del partido. } \\
\text { - } 13 \text { o } 15 \text { de mayo. Convención Nacional. } \\
\text { - } \quad 1 \text { julio. Relanzamiento del partido en Galicia. } \\
\text { - } \quad 11 \text { de octubre. Elecciones autonómicas Galicia. DEN. } \\
\text { - } \quad 19 \text { de diciembre. Elecciones autonómicas Galicia. }\end{array}$ \\
\hline $\begin{array}{l}\text { Reuniones del Comité Nacional } \\
\text { en los primeros meses de } 1986\end{array}$ & $\begin{array}{ll}\text { - } & 17 \text { de marzo. Integración CEE. Resultado referéndum OTAN. } \\
\text { - } & 28 \text { de abril. Elecciones Legislativas Junio. }\end{array}$ \\
\hline
\end{tabular}

Elaboración propia a partir de la ficha "Reuniones del Comité Nacional", Carpeta 1, AGP.

Este período, como destacan algunos miembros del Comité Nacional, fue una etapa políticamente muy cómoda para Adolfo Suárez. Las reuniones solían comenzar con el análisis de la actualidad político-parlamentaria, la exposición de los puntos de vista sobre los temas de debate incluidos en el orden del día - en general, se encargaba de esta apertura José Ramón Caso- y las conclusiones eran cerradas por Suárez, quien siempre expresaba su postura sobre los puntos tratados ${ }^{60}$. A Suárez le gustaba dejar que los miembros del Comité expresaran su opinión; si bien, como también sucede en un órgano colegiado de este tipo, era infrecuente abordar algún tema en el que no hubiera sondeado previamente la inclinación mayoritaria de sus miembros, procurando conocer la "voluntad política" del Comité.

\footnotetext{
${ }^{60}$ Las reuniones del Comité Nacional eran manuscritas por L. Morso quien se encargaba en este período del Libro de Acta, Entrevista con Laura Morso, 11 de febrero de 2015.
} 
Además, en este caso, el Comité era muy dependiente de la intuición y el liderazgo político de Suárez y difícilmente presentaba posiciones antagónicas, adoptando en este sentido, un comportamiento notablemente diferente al de las ejecutivas de UCD. La influencia política de Suárez sobre los miembros del Comité era prácticamente total. Ni siquiera los puntos más polémicos de esta etapa como el posicionamiento respecto a la OTAN o la Operación Roca generaron discrepancias de relieve en el seno de este órgano $^{61}$. En las escasas ocasiones en las que hubo ciertas diferencias primó, como es lógico, la máxima de la discreción. A propósito de una de las escasas divergencias entre miembros del CN que trascendió a los medios, ha concluido su principal protagonista, el jurista Jiménez de Parga: "en la ejecutiva del CDS se dijo, y con razón, que no era conveniente la discrepancia pública entre nosotros en asuntos importantes" ${ }^{\prime 62}$.

De este modo, no era extraño que el Presidente conservara, estatutariamente, unas amplias competencias en la dirección del partido: "el Presidente del Partido es, a todos los efectos de la legislación vigente y de estos Estatutos, el representante legal y político del mismo; vela por el cumplimiento y desarrollo de los acuerdos del Congreso; supervisa la acción de los órganos ejecutivos del Partido y arbitra, en su caso, los conflictos que pudieran suscitarse entre órganos de igual rango" (art. 22.1.). El Presidente era el encargado de establecer las relaciones con el Gobierno, de presidir el Grupo Parlamentario del CDS y promover y coordinar la actividad política y organizativa del partido, "con plenas facultades ejecutivas" (art. 22.2.), siendo políticamente responsable ante el Congreso, órgano donde se efectuaba su elección directa en votación uninominal, secreta y avalada por el 10\% de sus miembros.

El "liderazgo y representación del partido" recaía, igual que en el resto de partidos políticos de ámbito nacional, en un órgano unipersonal, en este caso, el de la Presidencia (al igual que en AP y el PDP o la Secretaría General en el caso del PSOE y el PAD). El cargo de Presidente estaba complementado por la Secretaría General con importantes atribuciones en relación a la organización y coordinación del partido (similar al Vicesecretario General en el PAD o las Vicepresidencias y Secretaría

\footnotetext{
${ }^{61}$ Entrevistas con José Ramón Caso, Abel Cádiz, Laura Morso y Manuel de Sárraga, miembros del Comité Nacional entre 1982 y 1986. Sobre el funcionamiento del Comité Nacional, coincidente con estas líneas, CERNUDA, Pilar: “Así son por dentro las ejecutivas del PRD, el CDS y el PCE”, Cambio 16, 19 de mayo de 1986.

${ }^{62}$ Nos referimos a la publicación de un artículo, -"Cambio constitucional sin reforma del texto", Diario 16, 11 de marzo de 1985-, contrario a la reforma del Consejo General del Poder General y firmado por Jiménez de Parga, el mismo día que Suárez hacía unas declaraciones favorables a la misma, en JIMÉNEZ DE PARGA, Manuel: Vivir es arriesgarse..., pp. 318-9.
} 
General en el PDP y AP, respectivamente). A diferencia de UCD o PAD que poseía una "Presidencia Honorífica" o el cargo de Presidente en el PSOE, el CDS no contemplaba ningún cargo de índole simbólica u honoraria. El fuerte componente carismático que inspiraba el propio partido se traducía, en el CDS, en el carácter presidencialista de su estructura organizativa y el liderazgo de facto de su inspirador ${ }^{63}$.

El Secretario General era el encargado, "por delegación del Presidente", de impulsar y organizar la acción del Partido y dirigir la ejecución de los acuerdos llevados a cabo por los órganos superiores. Coordinaba la acción de los Secretarios Ejecutivos y de los órganos de dirección Federales y Provinciales y controlaba la actuación administrativa y económico-financiera del partido. Era elegido por el Comité Nacional a propuesta del Presidente (art. 26.1-2).

Las "secretarías ejecutivas" del partido, que profundizaban, delineaban y coordinaban la línea política en las distintas áreas sectoriales (encargándose, desde la celebración de conferencias y jornadas a la elaboración de libros blancos), se pusieron en marcha con bastante lentitud ${ }^{64}$. A comienzos de 1984, existían sólo tres grandes áreas de trabajo:

Tabla 10: Principales áreas de trabajo sectorial en el CDS durante la II Legislatura.

\begin{tabular}{|l|l|}
\hline Área & Director de área \\
\hline Economía & Joaquín Abril \\
\hline Educación, Cultura e Información & Fernando Castedo \\
\hline Interior y Administraciones Públicas (Política Municipal) & Javier Soto \\
\hline
\end{tabular}

Elaboración propia a partir del Boletín de Difusión Cultural e Información del CDS, 2, febrero $1984^{65}$.

Otros órganos de carácter nacional correspondían a las Juventudes del CDS (Título VII, arts. 55-57) -que no se formalizaron en este período-, la Comisión Nacional de

\footnotetext{
${ }^{63}$ OLIVER ARAUJO, Joan y CALAFELL FERRÁ, Juan Vicente: Los estatutos de los partidos políticos españoles, Madrid, CEPC, 2007, pp. 42-3.

${ }^{64}$ Sus miembros podían acudir, cuando fuere necesario, a las reuniones del $\mathrm{CN}$ con voz, pero sin voto

${ }^{65}$ José Moreira era el encargado de lo relativo al área de "Cultura", Entrevista con José Moreira, 21 de mayo de 2015 (Madrid). En lo relativo a "Sanidad", desde su ingreso en el partido fue Carlos Revilla quien coordinó y definió la política del partido, $A B C, 18$ de febrero de 1983. El área de organización (por ejemplo, en lo relativo en la elaboración de las publicaciones periódicas, apoyo a gestoras y comités) estaba dirigido por Alfonso Íñiguez, véase, Boletín de Difusión Cultural del CDS y Órgano de Información del CDS, Entrevista con José Ramón Caso, 19 de noviembre de 2014. En palabras de Luis Aznar: "[Íñiguez] era hombre de despacho, colaborador a tiempo total de José Ramón Caso y Adolfo Suárez", AZNAR, Luis: Haciendo..., p. 145. En la Asamblea de Portavoces celebrada en octubre de 1983 se distinguían las siguientes secretarías ejecutivas (sectoriales), aunque algunas no pasaran de ocasionales grupos de trabajo: Sanidad, Educación, Defensa, Reindustrialización, Administración Local y Organización Interna, Boletín de Información, CDS-Aragón, 0, noviembre 1983.
} 
Conflictos (arts. 58-60) ${ }^{66}$ y la Comisión Nacional de Cuentas (CNC) encargada, semestralmente, de supervisar la correcta administración de los recursos económicos ${ }^{67}$. Los miembros de la CNC eran: Fernando Alcón Sáez, Joaquín Borrel Mestre, Jesús Merino Delgado, José Luis Sagredo de Miguel e Ignacio Ansoleaga Deusto.

Un aspecto de interés, que quedaba pendiente de reglamentar por parte del $\mathrm{CN}$, en buena medida por la ausencia de cargos, era el "régimen de incompatibilidades" (disposición adicional $5^{\circ}$ ). Como documentos anejos a los Estatutos aprobados por el Comité Nacional, se consignaban el Reglamento de Organización y el Reglamento de Conflictos (disposición adicional $\left.2^{\circ}\right)^{68}$.

Los estatutos del partido, elaborados en julio de 1982, fueron aprobados y ratificados por el I Congreso el día 3 de octubre con unas modificaciones mínimas, aunque como veremos, significativas, quedando definitivamente registrados en el Ministerio del Interior el 11 de febrero de 1983. En primer lugar, llama la atención la sustitución del adjetivo "regional" por el de "federal" en la denominación de sus órganos de gobiernos territoriales acercándose -al menos, discursivamente- a partidos de corte más progresista, como el PSOE, en oposición a $\mathrm{AP}^{69}$. Sin embargo, el CDS no se constituyó como tal en un partido federal, es decir, integrado por partidos de ámbito territorial con estatutos propios que debieran ser ratificados por un Comité Ejecutivo Federal ${ }^{70}$. La relación de poder intra-partidaria entre los órganos de gobierno estatales y territoriales

\footnotetext{
${ }^{66}$ No podían ser miembros de esta Comisión los integrantes de los comités de dirección (provinciales, federales o nacionales), el Grupo Parlamentario y la administración del partido, estatutos (octubre 1982), Título IX, Artículo 60,$R P P$, Acta Notarial n ${ }^{\circ}$ 301, J. L. Martínez Gil, 07 de febrero de 1983.

${ }^{67}$ a) Las cuotas que establezca el Comité Nacional del Partido; b) Aportaciones voluntarias de afiliados y simpatizantes; c) Herencias, legados y donaciones causadas a su favor; d) La renta de sus bienes y, en su caso, el producto de su enajenación; e) Empréstitos que considere necesario contraer; f) Ingresos procedentes de las actividades y productos del Partido; g) Subvenciones que legalmente le correspondan de los Presupuestos Generales del Estado, estatutos (octubre 1982), Título IX, Artículo 63.2, RPP, Acta Notarial no 301, J. L. Martínez Gil, 07 de febrero de 1983.

${ }^{68}$ Abordado por el Comité Nacional en mayo de 1984, en Gabinete de Presidencia: "Presencia CDS", 1984-5, Carpeta 1, AGP.

69 "Los órganos de cada Federación actuarán dentro del marco de los acuerdos y directrices de los órganos nacionales del Partido, siendo sus acuerdos, en el ámbito de sus competencias, vinculantes para todos los afiliados y órganos del Partido de inferior ámbito territorial. Estos órganos actuarán bajo las siglas de C.D.S. adjetivas con el nombre de la Comunidad Autónoma (región o nacionalidad) de que se trate", estatutos (octubre, 1982), Artículo 27.2. RPP, Acta Notarial n ${ }^{\circ}$ 301, J. L. Martínez Gil, 07 de febrero de 1983. Como señala Van Beizen, y en parte subraya el esfuerzo del CDS por introducir algunos matices en el lenguaje político del centro y centro-derecha al hablar de la estructura federal de los partidos "The Spanish right, on the other hand, has always been more suspicious of Basque and Catalan nationalisms, wchic are traditionally perceived as a threat to the unitary character of the Spanish state. The right, therefore, conventionally tends to be more centralist", VAN BIEZEN, Ingrid: Political parties in new democracies party organization..., p. 93.

${ }^{70}$ Lo que sí sucedió en otro partido de centro-izquierda formado en 1982, el Partido de Acción Democrático (PAD) de Francisco Fernández Ordóñez: "Título Segundo. De los principios generales de la organización. Artículo 13”, PAD: Un partido para el progreso ..., p. 150-1.
} 
era sustancialmente diferente. Uno de los máximos dirigentes del partido en 1983, lo expresaba así:

Pretendemos, eso sí, claramente, en cada ámbito, el ámbito local [...], el ámbito de las comunidades autónomas [que] los órganos correspondiente tengan una enorme autonomía de decisión y no interferir desde los gobiernos centrales ${ }^{71}$. Pero cuando haya problemas nacionales, que corresponda a los órganos centrales decidir, estamos dispuestos a que todo el mundo lo siga, y a no permitir ninguna desviación y creemos que los partidos tienen que ser fuertemente disciplinados [...] tiene que haber algunas determinadas materias en que la unidad de decisión sea muy fuerte. Porque si no todo el esquema tiende a dispersarse. UCD tenía errores en ese aspecto ${ }^{72}$.

En segundo lugar, a diferencia de otros partidos nacidos o escindidos de UCD, merece la pena destacar dos aspectos. Por un lado, en el CDS no se preveía estatutariamente, "la fusión" del partido, lo que si sucedía en el caso del PAD en sus disposiciones finales $^{73}$; por otro lado, apenas se mencionaba la posibilidad de establecer alianzas electorales, como figuraba en el articulado del PDP (art. $\left.2^{\circ}\right)^{74}$.

Aunque ambas ausencias no eran un impedimento ni para la fusión o integración del CDS en otro partido, ni tampoco para la formación de una coalición electoral resultaban significativas como testimonio de las prioridades políticas del bloque suarista y son suficientemente elocuentes vistas desde un punto de vista comparativo ${ }^{75}$. El CDS se concebía como un proyecto político a largo plazo.

Por último y como hemos apuntado a propósito de la estructuración del partido en el verano de 1982, desde un primer momento el CDS trató de marcar distancias respecto a UCD, fijándose como principal objetivo la constitución de un partido homogéneo y cohesionado. Los propios Estatutos, así como, el Reglamento de Organización del partido suarista incluyeron algunas cláusulas que recordaban, -en negativo-, el modelo

\footnotetext{
${ }^{71}$ Tesis que se mantuvo sin dificultades durante la primera etapa del partido, sin apenas representación, por ejemplo, en el caso de Canarias donde sus dirigentes contaron con "libertad de decisión" respecto a la política de pactos autonómica, "El PSOE y el CDS de Canarias preparan un pacto de legislatura", El País, 07 de julio de 1985.

${ }^{72}$ Interview undertaken by Richard Gunther, in 1983 (june), AR. En cierto modo, el dirigente centrista expresaba una idea ratificada, a nivel estatal, en las investigación politológicas: "Spanish parties are chiefly held together from the top, which gives them a rather synthetic character" en HALLIDAY, Ian: "Building a Parties State in a New Democracy" en WEBB, Paul, FARREL, David y HALLIDAY, David (eds.): Political parties..., p. 269. A pesar de la estructura federal/regional de los partidos hay una concentración de poder considerable en manos de "a close circle around the party leadership", VAN BIEZEN, Ingrid: Political parties in new democracies party organization ..., p. 99.

73 "Título Octavo: de la Disolución del Partido y de la fusión", art. 44, en PAD: Un partido para el progreso..., p. 160.

${ }^{74}$ Mientras el CDS sólo lo menciona al enumerar las atribuciones del Comité Nacional, en el caso del PDP lo encontramos en su artículo $2^{\circ}$ : "d) Autorizar los pactos de Gobierno y las alianzas o pactos parlamentarios", PDP: Una politica joven y europea. Primer Congreso...

${ }^{75}$ Una última comparación nos habla de la pormenorización y exhaustividad de los Estatutos del CDS, compuestos de 64 artículos, frente a los 31 del PDP y 44 del PAD.
} 
de partido que había supuesto UCD. Quizá, el hecho más evidente se manifestaba en el art. 11.4 que prohibía expresamente la existencia de grupos o facciones. Al margen de su enunciación teórica, este principio se llevó a la práctica impidiendo la inclusión de "bloques" a nivel nacional y privilegiando la afiliación estrictamente individual. Se insistía en el nacimiento desde "abajo" del partido -no desde el poder, como UCD, lo que para la dirección había dificultado la estructuración del partido y desatado las ambiciones y luchas internas ${ }^{76}$ - y se subrayaba que aproximadamente la mitad de los afiliados no había militado anteriormente en política. Como señalaba José Ramón Caso: "La UCD produjo su hundimiento al hundir a su líder, Adolfo Suárez. Pero hemos corregido aquellos errores de la UCD"77.

El recuerdo de UCD estaba tan presente que incluso en el contexto de su definitiva disolución, el tema era esquivado una y otra vez, y sólo sirvió para reiterar la intención de no aceptar a miembros relevantes de UCD más o menos cercanos a Adolfo Suárez (por ejemplo, aquellos "socialdemócratas" que no se habían integrado en el PAD o no habían "dado el salto" al PSOE) ${ }^{78}$. Cuando en febrero de 1983, la desaparición de UCD dejó sin cobertura política a un gran número de alcaldes y concejales, -tras la decisión del Consejo Político de llevar a cabo la liquidación de UCD (18 de febrero)-, como señala el responsable de acción electoral del CDS en 1983, Abel Cádiz, sólo una minoría recaló en el $\mathrm{CDS}^{79}$.

Si el proceso de admisión de la nueva militancia suponía un salto cualitativo en la formación del nuevo partido respecto de UCD, esta actitud se complementó con las fórmulas aprobadas de elección de los cuadros dirigentes nacionales y territoriales ${ }^{80}$. En

\footnotetext{
${ }^{76}$ La clave era, en palabras de un dirigente del CDS, el escaso compromiso ideológico con UCD de muchos de sus cargos políticos atraídos fundamentalmente por la capacidad de "reparto de poder" del partido, Interview undertaken by Richard Gunther, in 1983 (june), AR.

${ }^{77} A B C, 15$ de abril de 1983. "La destrucción de UCD arrancó de aquellas personas que utilizaron su escaño para derribar un programa y a su líder, Adolfo Suárez'. Sobre la posibilidad de un acercamiento de militantes de UCD a su partido dijo que era un problema de personas, estando claro el pensamiento y liderazgo del partido", El País, 18 de febrero de 1983.

${ }^{78}$ La presidente del Comité Local del CDS en Vélez Málaga se refería así a su pasado político en UCD en el Programa Electoral de 1983: "Queridos velezanos: Estuve en otro tiempo y sigo estando en el partido de Suárez; pero sobre todo me honro en haber podido conseguir un nuevo equipo joven que se presenta con un entusiasmo y ganas de trabajar por el pueblo", CDS-Vélez Málaga [Propaganda Electoral], 1983.

${ }^{79}$ Entrevista con Abel Cádiz, 4 de marzo de 2015. En junio de 1983, un alto dirigente centrista afirmaba que entre 15.000 y 20.000 de los cargos municipales electos de UCD habían pasado a AP, cifra a la que debemos sumar el elevado número de políticos que fueron en listas de independientes y que nos lleva a concluir la excepcionalidad que constituyó el pase al CDS en la mayor parte del territorio, Interview undertaken by Richard Gunther, in 1983 (june), AR.

${ }^{80}$ El mensaje habitual era: "estamos empeñados en hacer un partido unido, homogéneo y solidario, que no surge de estructuras de poder, ni responde a ambiciones personales, ni de grupo [Suárez, en un acto de partido en Cuenca]" ABC, 27 de enero de 1985.
} 
este caso, se optó por el sistema mayoritario con listas cerradas y bloqueadas con el objetivo de impedir la formación de facciones en el seno de las ejecutivas en torno a las listas menos votadas, un factor, que como vimos tuvo particular importancia a nivel provincial en los últimos meses de UCD:

En la propia redacción de los estatutos se ha tenido en cuenta lo que podemos llamar de algún modo errores de UCD. Y de hecho algunos de los elementos, de los cargos, que en UCD se elegían por sistemas proporcionales, se ha ido ahora a un sistema mayoritario [...] [Los sistemas proporcionales] lo que terminan haciendo es produciendo grupos de actuación no suficientemente identificados, que nacen de una especie de compromiso, o de resultado electoral, pero que tenían posiciones a veces relativamente distintos ${ }^{81}$.

\section{3. Un intento de consolidación fallida: de CC-UCD al CDS (Cataluña)}

A finales de 1982, el CDS contaba con presencia institucional proveniente de UCD en nueve parlamentos autonómicos: Canarias (4), Cataluña (8), País Vasco (4), Asturias (3), Navarra (5), Galicia (1), Castilla y León (2), Cantabria (2) y Aragón (1) -Anexo V. En los casos de Cataluña y Navarra, el número de diputados permitió la configuración de grupos parlamentarios propios. En los poderes municipales, aunque se produjeron movimientos semejantes, la legislación electoral concedía menos margen de maniobra a los concejales salidos de UCD. La Gestora del CDS en Tarragona describía del siguiente modo la situación:

Siendo la situación de nuestros Concejales del CDS en los Ayuntamientos, un tanto embarazosa, ya que se ven obligados a actuar como UCD, por así obligarlos la ley electoral, en su artículo 11 apartado 7 [...] En el comité local de Tarragona, habíamos comentado la posibilidad de que nuestros 3 concejales del Ayuntamiento de Tarragona exindidos [sic] de CC-UCD propusieran al Ayuntamiento la creación del grupo CDS, para así tener acceso a todas las comisiones y poder actuar en nombre de nuestro Partido. Se hicieron las gestiones oportunas, pero la legalidad vigente lo prohíbe ${ }^{82}$.

Como recuerda Caso, en 1982, todavía había cierta curiosidad pública por saber qué iba a pasar con la candidatura de Suárez pero tras el fracaso electoral la opinión pública fue perdiendo interés. Por ello, los posicionamientos y actividades de estos diputados sirvieron, durante el período en el que permanecieron en sus cargos, para rescatar al CDS del anonimato en el que había caído a raíz del resultado electoral de octubre. Sin embargo, paradójicamente, la presencia institucional del CDS, heredada de UCD,

\footnotetext{
${ }^{81}$ Interview undertaken by Richard Gunther, in 1983 (june), AR.

${ }^{82}$ Boletín Informativo, CDS-Tarragona, 0, enero 1983.
} 
dificultó en el caso que vamos a ver -el de Cataluña (Anexo VI)- la consolidación del partido y reprodujo las tensiones del antiguo grupo centrista ${ }^{83}$.

El surgimiento del CDS en Cataluña estuvo revestido de notas diferenciales de singular importancia respecto al resto de autonomías: la existencia previa de una fuerza centrista autónoma y relativamente independiente al funcionamiento de UCD, como fue Centristes de Catalunya (CC-UCD) ${ }^{84}$, y el relevante papel que jugó el CDS en la política parlamentaria catalana desde 1982 a 1984. Desde el anuncio de la marcha de Suárez de UCD, en CC-UCD se vivieron momentos de expectación e incertidumbre; un alto número de afiliados, militantes y dirigentes, -las primeras informaciones hablaron de "empate" al ex presidente era tal que durante las primeras semanas se llegó a barajar la idea de una articulación de Centristes, en tanto que partido, en el seno del nuevo grupo político de Adolfo Suárez, trasladando la dinámica entre Centristes con UCD, al CDS. Nada más conocerse la creación del CDS, diversos nombres sonaron como futuros miembros del partido de Suárez: el presidente de CC-UCD en Barcelona, Josep Pujadas Domingo, el vicepresidente, José María Mesa Parra, y el presidente en Lérida, Manuel de Sárraga. En este contexto, el 4 de agosto, se produjeron en el despacho de la Calle Maura, siempre a título personal, las primeras conversaciones entre aquellos miembros de CCUCD que se declaraban "suaristas" con el ex presidente y Agustín Rodríguez Sahagún. Conversaciones que continuaron capitaneadas por el propio Rodríguez Sahagún y Chus Viana, ya en Cataluña, los dos días siguientes y versaron sobre: "el grado de autonomía del partido, la financiación y la forma de establecer las relaciones entre el CDS y las fuerzas políticas catalanas $y$, en concreto, con Convergència i Unió” ${ }^{\prime 86}$.

El diseño de un CDS catalán, como partido autónomo, fue vislumbrado en una reunión del viernes 6 de agosto en un céntrico hotel barcelonés en la que estuvieron

\footnotetext{
${ }^{83}$ Generó asimismo una sobrerrepresentación artificial del CDS como sucedió en el Consejo de RTVE, quizá el caso más flagrante: "este es un Consejo ya fantasmal, en el que algunos de sus miembros son adscritos a un partido, el CDS, inexistente cuando fueron nombrados. No es de extrañar que carezca de autoridad ante la opinión pública", en "El relevo de los consejeros", $A B C, 19$ de marzo de 1983; "Un consejo devaluado", La Vanguardia, 30 de enero de 198.

${ }^{84}$ Aunque la relación seguía siendo estrecha: "CC-UCD, que, independiente formalmente de la UCD, mantenía (incluso estatutariamente) una mayor dependencia respecto del partido de ámbito general español [comparándolo con la relación PSC-PSOE]" en BOTELLA, Joan "Elementos del sistema de partidos en la Cataluña actual", Papers. Revista de Sociología, 21, 1983, p. 21.

85 "Masiva deserción de los miembros de UCD de Cataluña hacia el CDS", El País, 13 de agosto de 1982.

${ }^{86}$ En aquella reunión estuvieron presentes por parte de CC-UCD: Josep Pujadas i Domingo, José María Mesa Parra, Manuel de Sárraga, Jaume Barnola, Pere Roselló y Santiago Guillén, La Vanguardia, 05 de agosto de 1982.
} 
presentes cincuenta miembros de CC-UCD y los dos líderes nacionales del CDS. El eje del proyecto era Josep Pujadas i Domingo, "el hombre de Suárez en Cataluña" ${ }^{87}$ y se intentó estructurar el nuevo partido a partir de la organización provincial de CC-UCD, de la que poder extraer militantes y cuadros para la futura Gestora Provisional, cuyo Congreso Constituyente tenía previsto celebrarse a comienzos de septiembre. El día 16 de agosto se fijaba como fecha para la lectura de un manifiesto ideológico. Incluso, se aventuraba la idea de concurrir en solitario a las elecciones ${ }^{88}$. En cualquier caso, los movimientos y anuncios del futuro CDS catalán se ralentizaron la semana del 9 al 16 de agosto. Una vez lanzado el proyecto, era necesario valorar con mayor prudencia el peso político específico del suarismo en cada provincia catalana.

Por otra parte, desde CC-UCD, aunque la situación era caótica, se intentó contraatacar las iniciativas suaristas con el objetivo de impedir que encauzasen la descomposición del partido desde dentro del mismo. Se decidió destituir automáticamente al Comité Provincial de Lérida, al que pertenecían Pere Roselló y Manuel de Sárraga, y al presidente de CC-UCD en Barcelona Josep Pujadas y su secretario provincial de CC-UCD en Barcelona, Josep Sánchez Llibre, quienes tenían previsto celebrar una reunión del Comité Ejecutivo de CC-UCD el lunes 16, con el fin de explicar su postura política. En otras ocasiones, eran los propios militantes centristas quienes intentaban boicotear los actos de los dirigentes cesados o dimisionarios.

La reunión del Comité Ejecutivo Provincial de Barcelona de CC-UCD convocada por Pujadas y desautorizada por Cañellas constituyó la génesis del grupo promotor del CDS en Barcelona y fue el "banderín de enganche" para el suarismo catalán ${ }^{89}$. Asistieron un total de 20 de los 33 miembros del Comité Ejecutivo y en ella se concretó el plan de creación del Centro Democrático y Social de Cataluña. Desde El País lo describía Carmen Parra de la siguiente manera:

\footnotetext{
87 "Josep Pujadas i Domingo [...] es el típico exponente de la burguesía catalana culta. Viste siempre impecablemente y sus ademanes suaves y comedidos denotan la buena educación recibida en los Jesuitas de Sarriá. Apartidista hasta el año 79, entró en el mundo de la política del brazo de Anton Cañellas [...] Formó parte de la integración centrista que desembocó en el partido de Centristes de Catalunya UCD y con él ganó su escaño de diputado en el Congreso el 1 de marzo del 79", El Periódico de Catalunya, 17 de agosto de 1982.

${ }^{88}$ La Vanguardia, 07 y 08 de agosto de 1982.

89 "El CDS comienza su andadura en Barcelona", El País, 17 de agosto de 1982. En Gerona se repitió este procedimiento convocándose una reunión de la ejecutiva provincial el día 23 de agosto, lo que fue visto como un intento de captación de nuevos afiliados "al parecer varios militantes lanzaron sus carnés sobre el presidente dimisionario, Josep Coderch, y otros pidieron la salida del local de aquellos que se habían dado de baja del partido. En el local de los centristas se sucedieron turnos de militantes para impedir la entrada al mismo de aquellos que han dejado de pertenecer a UCD", $A B C$, 24 de agosto de 1982.
} 
Sus seguidores van a inaugurar en los próximos días la sede de Barcelona, en la calle Tuset, y a continuación invitarán a los militantes y simpatizantes centristas a inscribirse en el nuevo partido. A finales de agosto sus promotores presentarán el Centro Democrático y Social de Cataluña - probable nombre del partido-, y a mediados del próximo mes de septiembre tienen previsto celebrar su congreso constituyente... ${ }^{90}$

Aquella reunión tuvo lugar en el despacho de Josep Sánchez Llibre. El grupo promotor estaba encabezado por Josep Pujadas i Domingo y compuesto por José María Valón, el propio Josep Sánchez Llibre, José María Mesa Parra, Santiago Guillén, Lluís Puyó y Xavier Martí ${ }^{91}$, a quienes días después se unió Ramón Vinyals i Soler ${ }^{92}$. Su objetivo prioritario era la formación del grupo promotor en el resto de las provincias, siendo el caso de Lérida, liderado por Sárraga, el lugar donde este proceso se encontraba más avanzado ${ }^{93}$. Para impulsar este proceso, el jueves 19 de agosto se reunieron en Madrid con Adolfo Suárez, Agustín Rodríguez Sahagún y Gerardo Harguindey, logrando obtener el compromiso de que el líder nacional visitaría todas las provincias catalanas. Desde La Vanguardia se vaticinaron incluso los futuros cargos del partido/grupo regional y sus cabezas de lista ${ }^{94}$. La relación entre el grupo promotor y el CDS nacional era ambigua; no dejaba de ser similar a los creados en otras provincias, sin embargo, aspiraba a estructurarse como un partido autónomo. En palabras de un destacado líder del CDS en Cataluña:

UCD fue siempre un partido centralista y unitario, y por esto no fui miembro. Yo como catalán no podía estar en un partido nacionalista porque de corazón somos separatistas, y por otra parte no podía estar en un partido centralista unitario. Entonces en el momento en

\footnotetext{
90 "El CDS comienza su andadura en Barcelona", El País, 17 de agosto de 1982.

${ }^{91}$ Todos eran miembros de CC-UCD. Los diputados autonómicos catalanes de CC-UCD que se habían pasado al CDS eran en ese momento, los cuatro diputados de Lérida, un tarraconense y un barcelonés: Santiago Guillén, Pere Roselló i Esteban, Joan Besa i Esteve, Joan Manuel Margaleff i Miralles, Josep Mesegué i Utgé y Francesc-Xavier Puig i Andreu, La Vanguardia, 17 de septiembre de 1982. Respecto a los concejales suaristas de CC-UCD se les conminó a permanecer en aquel partido con el fin de que no fuesen expulsado tal como se recogía en La Vanguardia, 20 de agosto de 1982.

${ }^{92}$ El País, 21 de agosto de 1982.

${ }^{93}$ En Gerona, José Coderch, presidente provincial, Martí Manel Díaz Lloret, secretario provincial así como miembro del consejo asesor de RTVE en Cataluña, y el diputado autonómico Albert Planasdemunt anunciaron su pase al CDS, El País, 21 de agosto de 1982. En Tarragona, el proceso cobró forma el día 28 con la marcha al CDS del presidente de CC-UCD, Josep María Oller, y el ex secretario provincial, Xavier Artal. Al igual que en el resto de las provincias, "se espera que varios miembros de comités locales y comarcales pasen al Centro Democrático y Social”. La crisis del centrismo fue paradigmática en Tarragona. El siguiente secretario provincial y presidente en funciones, Lluis Badía, dimitió el día dos de septiembre y poco después ingresó en el Centro Democrático y Social. Hemos de comprender estas “esperas" y posposiciones indefinidas como el estudio de sucesivas ofertas políticas, de unos u otros partidos, que permitiesen garantizar la supervivencia política de las elites centristas, véase, $L a$ Vanguardia, 27 de agosto de 1982.

${ }^{94}$ Presidente: Josep Pujadas; Secretario General: Julián Valón. Cabezas de lista: por Barcelona, Pujadas y Valón; Gerona: Coderch; Lérida: Sárraga; Tarragona: Margaleff.
} 
que Suárez decidió crear Centristas de Cataluna [sic], que tenía autonomía para asuntos catalanes y era uno más en los asuntos espanoles [sic], entonces yo me hice militante ${ }^{95}$.

Las fechas, relativamente tardías, de incorporación al CDS por parte de los parlamentarios catalanes indican una compleja negociación de contrapartidas políticas, así como la probable existencia de otras "ofertas políticas", principalmente de CiU/AP. Sin embargo, el proyecto de crear un partido autónomo en Cataluña perdió rápidamente fuerza y al cabo de unos días la idea simplemente dejó de circular en la prensa. Las dificultades para trasvasar las estructuras de CC-UCD al futuro nuevo partido, la premura existente debido al adelanto electoral y la oposición del suarismo a nivel nacional a esta iniciativa hicieron descartar esta idea que primero se pospuso y finalmente se enterró, aunque las aspiraciones del bloque suarista catalán afloraron posteriormente en otras situaciones ${ }^{96}$.

El siguiente paso se dio el 30 de agosto, en lo que iba a ser la presentación del CDS catalán y se convirtió finalmente en el "primer acto electoral" del partido centrista, a partir de ahora, preocupación fundamental del partido. Se criticó el "viraje a la derecha" del ejecutivo de Calvo-Sotelo y la LOAPA ${ }^{97}$, se anunciaron "fichajes" sorprendentes como el del historiador y periodista -partícipe en la fundación del PSI/PSP ${ }^{98}$-, Sergio Vilar, quien aquel día no tuvo inconveniente en declararse marxista, y circularon rumores sobre la incorporación del gobernador civil, cercano a Rafael Calvo Ortega, Jorge Fernández Díaz ${ }^{99}$-finalmente confirmado-, e incluso el del director de la revista satírica El Papus, Javier Écharri. La plana mayor del suarismo catalán presidía el acto:

Un hotel de cinco estrellas sirvió de marco a la rueda de prensa del CDS, ya que el nuevo local de Vía Layetana todavía está en obras. El parlamentario Santiago Guillén ofició de maestro de ceremonias, asistido en las bandas por un representante de cada una de las circunscripciones: Mesa Parra, de Barcelona; Sárraga, de Lérida; Planasdemunt, de Gerona, y Artal, de Tarragona. El todo suarismo se encontraba entre el público ${ }^{100}$.

Los días iniciales de septiembre se dedicaron a la composición de las listas electorales y fue en este momento cuando tuvieron lugar las primeras fricciones entre

\footnotetext{
95 El modelo, para este dirigente del CDS catalán, era el de un federalismo cooperativo, que según su postura podía ser desarrollado en el marco de las autonomías, Interview undertaken by Richard Gunther, in 1983 (june), $A R$.

${ }^{96}$ Crónicas políticas de Carmen Parra para El País, 21 de agosto de 1982.

${ }^{97}$ Un destacado líder del CDS a nivel autonómico declaraba en 1983: "Yo soy un gran partidario de un federalismo cooperativo...", Interview undertaken by Richard Gunther, in 1983 (june), AR.

98 RUBIO RUBIO, Amalia: Un partido en la oposición. El Partido Socialista Popular, Tesis Doctoral, Universidad Complutense de Madrid, 2001, p. 164.

${ }^{99}$ La Vanguardia, 31 de agosto de 1982.

${ }^{100}$ El Periódico de Catalunya, 31 de agosto de 1982.
} 
los promotores del CDS catalán. Eran días plagados de rumores más o menos fundados, desmentidos y prisas, que en última instancia relanzaban la dimensión pública en los medios del CDS. Se llegó incluso a considerar la inclusión de Gutiérrez Mellado como cabeza de lista por Barcelona ${ }^{101}$, posición que finalmente iba a recaer en Antonio de Senillosa. La designación de Senillosa, a pesar de su atractivo electoral, era cuanto menos sorprendente ya que ni siquiera era miembro de la gestora de Barcelona Si Adolfo Suárez quería evitar la inclusión de independientes en las listas, Senillosa, recién afiliado al partido, era el paradigma de un freelance de la política. En cualquier caso, su elección suponía un golpe de autoridad de la dirección nacional del CDS. Los medios habían destacado el avanzado estado de consolidación del CDS catalán, ¿acaso Suárez temía haber contribuido a crear la primera gran facción dentro del CDS?

Las declaraciones de Senillosa en una entrevista a Diario 16, publicada el mismo 18 de septiembre, resultaban un soplo de aire fresco en el desgarrado panorama político centrista, que él llegaba a tildar de "subpolítica". Baste decir que el título del artículo era: "Me paso al CDS porque es la opción más audaz e imaginativa". En aquella entrevista, Senillosa ofrecía un perfil moderno, desenfadado y un tanto narcisista, rasgos que casaban bastante bien con la nueva imagen de Adolfo Suárez y su partido: "me enternece [...] que un hombre que ha ganado dos elecciones generales [...] quiera salir ahora de la nada y que, además, cuando aún no ha comenzado la campaña electoral, ya recibido [sic] amenazas de muerte. Me enternece, lo encuentro apasionante..."102 . Las listas se presentaron oficialmente en Barcelona el día 22 de septiembre ${ }^{103}$ y desde el CDS de Cataluña se decía que Suárez iba a inaugurar la campaña electoral en la Ciudad Condal $^{104}$. Como vimos, no fue en el inicio, sino en el cierre de campaña, durante los días 24 y 25 de octubre, cuando Suárez visitó Cataluña.

\footnotetext{
${ }^{101}$ En algunos periódicos se pudo leer un rumor finalmente desmentido: "Gutiérrez Mellado puede ser la 'bomba' Suárez en Barcelona”, Diario 16, 03 de septiembre de 1982, Archivo Linz.

102 Diario 16, 18 de septiembre de 1982; "Senillosa: la imaginación al poder"; La Vanguardia, 23 de septiembre de 1982. Antonio de Senillosa, que había participado junto a J. M. Areilza en la formación de la UCD, era, en ese momento, diputado electo por Barcelona dentro de Coalición Democrática, proveniente del pequeño partido de Areilza, Acción Ciudadana Liberal, del que fue su vicepresidente y que fue disuelto después de las elecciones de 1979. A comienzos de 1982, J. M. Areilza y Senillosa se habían desmarcado parcialmente de la dirección del Grupo Parlamentario de CD y el 30 de julio J. M. Areilza había abandonado CD y se había integrado en la UCD.

${ }^{103} A B C, 23$ de septiembre de 1982.

104 "Suárez piensa realizar los primeros actos de la campaña electoral en Cataluña" en Teletipo Efe, 22 de septiembre de 1982, Gabinete de Información. Prensa. Caja 323. Dossier CDS, AGCYL.
} 
Desde el primer momento, en el parlamento catalán, se percibió la importancia que podía tener la creación del CDS en la política autonómica ${ }^{105}$, donde llegó a contar con ocho diputados. Hay que tener en cuenta que el gobierno de Pujol estaba sustentado por $\mathrm{CiU}$ con el necesario apoyo de ERC y CC-UCD. Si damos pábulo a los rumores, el primer contacto que mantuvo Adolfo Suárez con la política catalana fue con Miquel Roca, con quien almorzó el 4 de agosto, incluso antes de reunirse con los sectores suaristas $^{106}$. Las primeras informaciones sobre la actitud que había decidido adoptar el CDS eran confusas y contradictorias, a fin de cuentas, ni siquiera el CDS sabía con certeza la fuerza con la que iba a contar. Desde la Generalitat se tendió la mano al nuevo partido: "el departamento de gobernación de la Generalitat [...] dice que la relación con Adolfo Suárez siempre ha sido buena"107.

Sin embargo, los primeros pasos dados por el CDS fueron erráticos: criticó el exceso de protagonismo de CiU en la marcha de la Diada del 11 de septiembre ${ }^{108}$, tachó de error la eliminación del 12 de octubre como fiesta en Cataluña ${ }^{109}$, anunció su abstención en la votación del programa de gobierno de Jordi Pujol ${ }^{110}$ y mostró sus simpatías hacia la moción de censura presentada por el PSUC, en la que finalmente se abstuvo -junto a CC-UCD-. Episodio, este último, que se encargó de poner de manifiesto algunas carencias estructurales. Como señalaba El País:

Los parlamentarios suaristas tienen previsto reunirse el próximo lunes para estudiar la situación, pero la inexistencia de una dirección del partido en Cataluña -sólo hay gestoras provinciales- hace muy difícil la adopción de una decisión estratégica. Dirigentes del Centro Democrático Social consultados por EL PAIS discrepan en cuanto a la actitud a $\operatorname{adoptar}^{111}$.

El CDS era consciente de que podía ejercer funciones de partido bisagra en la política catalana, si bien, prefirió esperar a la celebración de las elecciones generales. La inclusión de los parlamentarios del CDS en el "grupo de no-adscritos" era una forma de no generar ninguna confusión sobre pactos pre o postelectorales. Sin embargo, fue precisamente con la celebración de los comicios nacionales cuando muchas de las ilusiones y esperanzas generadas se desvanecieron: "La política catalana se bipolariza

\footnotetext{
105 "La atención masiva de dirigentes catalanes centristas a la plataforma de Adolfo Suárez, planteará ciertos problemas en el Grupo parlamentario de la Cámara legislativa autónoma" en $A B C, 08$ de agosto de 1982.

${ }^{106} A B C, 05$ de agosto de 1982.

${ }^{107} A B C, 27$ de agosto de 1982 .

${ }^{108} A B C, 12$ de septiembre de 1982

${ }^{109}$ El País, 13 de octubre de 1982.

${ }^{110}$ El País, 23 de septiembre de 1982.

${ }^{111}$ El País, 25 de septiembre de 1982.
} 
entre Convergència i Unió y el PSC-PSOE" ${ }^{\prime 12}$. Los resultados electorales en Cataluña fueron bastante negativos, más si se tiene en cuenta, que a diferencia de otras provincias, contaban con una estructura que aunque imperfecta, estaba sostenida por cuadros políticos dotados de gran experiencia, tanto en el trabajo de partido como ante el electorado. Si la media nacional del CDS rondó el 2,8\%, en Cataluña se quedó en el $2 \%$, una de las más bajas de España y precisamente los mismos resultados que CC$\mathrm{UCD}^{113}$. El porcentaje más bajo lo obtuvo en Barcelona. No sólo la elección de Antonio de Senillosa para ocupar la lista de la Ciudad Condal parecía haberse demostrado errónea, sino que se reconocía la ausencia de credibilidad de un centro político envuelto en un sinfín de luchas internas y personalismos: "esa falta de credibilidad de nuestra oferta $[. .$.$] de nuestros dirigentes es cosa que debemos tener presente..."114. Los$ resultados, desglosados por provincias, fueron:

Tabla 11: Resultados electorales del CDS en las circunscripciones catalanas.

\begin{tabular}{|l|l|l|l|l|}
\hline Media & LLEIDA & GIRONA & BARCELONA & TARRAGONA \\
\hline $\mathbf{1 , 9 9 \%}$ & $3,1 \%$ & $2 \%$ & $1,8 \%$ & $2,4 \%$ \\
\hline
\end{tabular}

Elaboración propia a partir de la información electoral del Ministerio del Interior ${ }^{115}$.

La inauguración de la II Legislatura mostraba una curiosa situación en el Parlamento de Cataluña. Por un lado, el CDS era consciente de que, en aquellos momentos, no tenía apenas electorado en la región, y por otra parte, conservaba la llave de la gobernabilidad catalana. El CDS arrastraba en Cataluña un protagonismo, debido a la relevancia de sus líderes (nacional, en un primer momento y ahora autonómica), que contrastaba con las dificultades de implantación en el territorio. Según Sárraga, como los principales miembros del CDS en Cataluña eran cargos electos, se había producido en un primer momento un enorme desequilibrio entre la atención despertada en el exterior y la fuerza real del partido ${ }^{116}$.

\footnotetext{
112 El País, 28 de octubre de 1982.

${ }^{113}$ En base a los análisis sociopolíticos realizados inmediatamente después de las elecciones, podemos concluir -siguiendo los ejes derecha-izquierda y centralismo-nacionalismo- que el CDS no supo transmitir al electorado su proceso de diferenciación de AP-CC/UCD, y sobre todo, no lo supo hacer en las ciudades, donde seguía percibiéndose como una fuerza de centro/conservadora. Además, no supo hacer valer su postura autonomista, crítica con los últimos gobiernos de la UCD, ya que finalmente, la mayor parte de los votantes de UCD, transfirieron su voto a CiU, véase, CAÑAIS, Ramón Ma , VALLÉS,

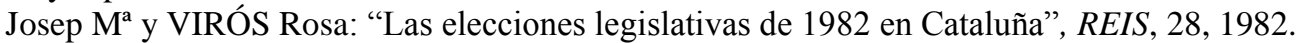

114 Diario de Tarragona, 24 de noviembre de 1982, recogido en BADÍA, L.: Opiniones Diarias, Tarragona, Ed. CDS., 1988, p. 6.

${ }^{115}$ Concretamente los resultados en Cataluña le dieron un total de 68.395 votos.

${ }^{116}$ Entrevista con Manuel de Sárraga, 23 de julio 2014.
} 
El 11 de noviembre $A B C$ rotulaba su apartado sobre la política de Cataluña con unas declaraciones de la vicepresidenta del parlamento autonómico: “Concepción Ferrer: La

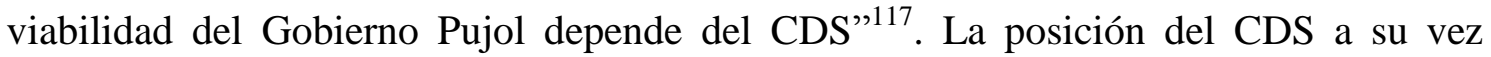
estaba condicionada por nuevas circunstancias. En primer lugar, el resultado electoral de octubre, indirectamente, había transformado la realidad de la política de pactos catalana. En Madrid, habían desaparecido gobiernos minoritarios necesitados del apoyo de CiU, por lo que el centrismo catalán, ahora tenía vía libre para tejer o entretejer aquellos pactos políticos que creyese conveniente. En segundo lugar, tanto Centristes como UCD estaban en pleno proceso de descomposición y desde hacía tiempo habían dejado de ser garantías de futuro. Por si fuera poco, la situación se magnificaba gracias a las declaraciones de Miquel Roca que preludiaban lo que iba a ser la gran novedad política de los siguientes años: el reformismo centrista de la Operación Roca.

El CDS fue el primero en mover ficha votando a favor de la moción de censura del PSUC contra el Conseller de Sanidad, Josep Laporta, y días después, Adolfo Suárez arribó a Barcelona para reunirse con Jordi Pujol y negociar la política de pactos, que $A B C$ veía como una "imposición", mientras El País se centraba en el uso de "la ambigüedad como arma política". Dichos pactos pasaban por una coalición electoral entre CiU y el CDS para las elecciones municipales, como admitió indirectamente el propio Santi Guillén ${ }^{118}$. La presencia del CDS se veía como un elemento desestabilizador para el Parlamento catalán ${ }^{119}$. Ni siquiera el CDS tenía definida su estrategia; con el fin de ejercer una función de coordinación entre el Parlamento y las gestoras provinciales se creó a finales de 1982 la Gestora de Cataluña del CDS.

En enero de 1983, el CDS había rechazado todos los ofrecimientos de Pujol y desde El País se subrayaba su acercamiento a las posturas del PSC, desde donde se sopesaba la idea de plantear una moción de censura. Por su parte, la prensa conservadora ponía el acento en la indeterminación del CDS, a medio camino entre CiU y el PSC ${ }^{120}$. Ciertamente, desde el CDS se insistía en la necesidad de una nueva política de acuerdos por parte de Pujol, pero sin llegar a concretar ni con quién ni cómo ${ }^{121}$.

\footnotetext{
${ }^{117} A B C, 11$ de noviembre de 1982.

${ }^{118}$ El País, 20 de noviembre de 1982 y ABC, 20 de noviembre de 1982.

${ }^{119}$ Un excelente ejemplo de esta opinión la da SOPENA GADANZO, Enric: "Pujol: la soledad de un presidente", Diario 16, 27 de noviembre de 1982, Archivo Linz.

${ }^{120} A B C, 25$ de enero de 1983.

${ }^{121}$ Bulletí de Informació CDS Tarragona, 0, enero 1983, y Diario de Tarragona, 13 de enero de 1982, recogido en BADÍA, Lluis: Opiniones..., p. 21-23.
} 
La sorpresa saltaba el fin de semana del 29-30 de enero de 1983 cuando Suárez decidía cesar a los líderes del CDS en Cataluña ${ }^{122}$. Los deseos de no repetir los errores de la UCD parecían haber fracasado ${ }^{123}$. Los motivos que adujeron unos y otros versaban sobre los acuerdos políticos y electorales que Santi Guillén, a la sazón portavoz del CDS en el Parlamento, estaba intentando alcanzar o bien con CiU o bien con el PSC; negociaciones que no contaban con la aquiescencia de Madrid. Aunque la prensa pusiese el acento en uno u otro partido, coincidía unánimemente en resaltar que fundamentalmente lo que estaba en juego era el grado de autonomía con el que contaba el grupo catalán, autonomía que de la mano del protagonismo político de Santi Guillén iba in crescendo y chocaba frontalmente con los planteamientos de J. Pujadas, presidente de la recién creada Gestora de Cataluña y de la Gestora de Barcelona y fiel a las directrices nacionales ${ }^{124}$. Por ello, fue Josep Pujadas quien ejecutó los ceses de J. Valón, S. Guillén y J. Sánchez Llibre, así como del resto de miembros de la gestora de Barcelona -de todos menos uno-, aduciendo razones de eficacia organizativa ${ }^{125}$. Uno de los cesados declaró que su expulsión estaba originada por "la burocracia centralista dura

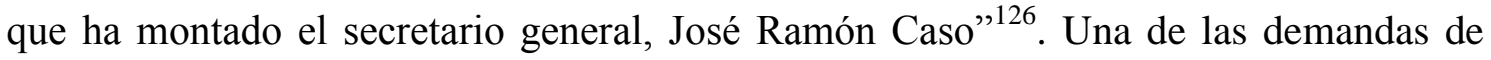
Santi Guillén había sido la constitución, a finales de enero, de la Asamblea Provincial de Barcelona, cuya convocatoria había desestimado J. Pujadas y el propio Comité Nacional:

Las presiones de la secretaría general eran en opinión de los dirigentes cesados "contrarias a la autonomía pactada con Suárez cuando en agosto se creó el partido", toda la gestora, salvo Pujadas, convocó para finales de este mes de enero la asamblea provincial, a fin de elegir los órganos ejecutivos del partido, decisión plenamente estatutaria. Para entonces, los compañeros de Pujadas en la dirección de Barcelona ya le habían hecho saber que no le apoyarían para la presidencia definitiva del $\operatorname{CDS}^{127}$.

La situación era realmente compleja. Un documento para afiliados del CDS, el Boletín de Información del CDS Tarragona, publicaba instantes antes del estallido de la crisis una entrevista a Xavier Artal, líder del partido en Tarragona en la que describía así la situación del partido. En primer lugar, respecto a la elegibilidad de los cargos internos comentaba:

\footnotetext{
${ }^{122}$ En el Diario 16 y La Vanguardia, y al día siguiente en El País y ABC.

${ }^{123}$ Diario de Tarragona, 03 de diciembre de 1982, recogido en BADÍA, L.: Opiniones..., p. 10.

${ }^{124}$ La creación de la Comisión Gestora de Cataluña se produjo a finales de 1982, Boletín de Información CDS Tarragona, 0, enero 1983.

${ }^{125}$ La Vanguardia, 30 de enero de 1983.

${ }^{126}$ MARTÍNEZ IBÁÑEZ, José Luis: "El CDS tiene solamente en Cataluña 600 afiliados”, El País, 01 de febrero de 1983.

${ }^{127}$ Ibid.
} 
[E] ¿Cuándo se celebrarán las elecciones internas del partido en las Provincias y Catalunya? -[XA] Según acuerdo del Comité Nacional después de celebradas las Municipales, se producir [sic] las distintas Asambleas Provinciales, Comarcales y Locales que deberán de dar los auténticos representantes democráticamente elegidos de nuestro partido para los próximos 3 años ${ }^{128}$.

Aquel boletín, pergeñado de forma rudimentaria con máquina de escribir y rotuladores, estaba relatando de forma indirecta las claves de la crisis: "la Gestora de Catalunya [presidida por J. Pujadas] es el máximo organismo decisorio del partido en cuestiones de toda índole que afecten al partido ya sea de política general como de política parlamentaria" ${ }^{229}$. Si la gestora catalana estaba controlada por J. Pujadas y políticos afines a la línea oficialista, la convocatoria de las Asambleas Provinciales o Federales -única vía para sustituir los órganos de gobierno provisionales, es decir, las Gestoras- correspondía estatutariamente al Comité Nacional ${ }^{130}$.

Santi Guillén y otros miembros de la extinta CC-UCD tenían las manos atadas para tomar sus propias decisiones políticas y emplear la fuerza numérica existente en el Parlamento de Cataluña, frente a una dirección nacional celosa de mantener la independencia del partido ${ }^{131}$. La proximidad de las elecciones locales y las escasas perspectivas de futuro que aportaba el CDS aceleraron sus movimientos $y$, en consecuencia, su salida. El desvanecimiento del partido en Cataluña era una realidad. Comentaba uno de los escasos dirigentes del CDS en dicha comunidad, a mediados de 1983:

[Question] To what extent have you been able to attract the infraestructure from UCD in this región.

[Answer] Oh, here it was great, there 4 provincial presidentes, 4 provincial secretaries, and 1 catalan secretary; out of the 10,9 all CDS .

[Question] And still are active within the party?

[Answer] No, out of them, out of the 9, 8 are. We have the feeling that more people will leave each week. It is very difficult...132

\footnotetext{
${ }^{128}$ Boletín de Información CDS Tarragona, 0, enero 1983.

${ }^{129}$ Formaban parte de la Gestora como miembros destacados Manuel de Sárraga, miembro del Comité Nacional del CDS, Albert Planasdemunt, Presidente de la Gestora de Gerona, Pere Rosello, Diputado del Parlamento de Cataluña, Santi Guillen, portavoz de CDS al Parlamento de Cataluña, Julián Valón, Xavier Puig, Diputado del Parlamento de Cataluña, Jacinto Saiz, Josep Ma Mera, Martí Manel y Juan Martín, Ibid., p. 5.

${ }^{130}$ El "Reglamento de Organización" aprobado precisamente en la reunión del Comité Nacional del 31 de enero de 1983, había decidido en su disposición transitoria: "la celebración de las primeras Asambleas Provinciales y Congresos de Federación corresponderá su convocatoria al Comité Nacional”, Reglamento de Organización, CDS, 1983.

${ }^{131}$ Desde La Vanguardia, a lo largo de aquel mes de febrero, se llegó a decir que aspiraba a un cargo de conseller.

${ }^{132}$ Este apartado de la entrevista fue realizado en inglés, Interview undertaken by Richard Gunther in 1983 (june), AR.
} 
El fracaso de octubre de 1982, la provisionalidad inicial, y el relativo peso político en el Parlament truncaron cualquier posibilidad de cohesión en el suarismo catalán. De ahora en adelante, el CDS vivió un deambular "fantasmagórico""133 por la política catalana hasta 1986, a pesar de su importancia parlamentaria (concluida con la celebración de las autonómicas catalanas en abril de 1984). No es exagerado considerar que en la constitución del CDS hubo un exceso de precipitación. Tiempo después hubo que volver a empezar prácticamente desde cero.

\section{4. Las elecciones municipales y autonómicas de 1983}

Apenas medio año después de los comicios de octubre de 1982, el CDS debió encarar una nueva cita con las urnas, en este caso, a nivel municipal y autonómico. Estas elecciones, celebradas en mayo de 1983, supusieron otro rotundo éxito del PSOE que ratificaba así los resultados obtenidos a nivel nacional mientras AP, favorecida por la definitiva disolución de UCD, consolidaba su primacía dentro de las fuerzas de oposición. Desde el punto de vista del CDS, esta nueva contienda electoral constituía un ulterior reto a nivel organizativo: sin haberse repuesto de los resultados de 1982, ni haber podido hacer frente a las deudas generadas y sin haber conseguido una estructura estable y sólida en todo el territorio nacional. Asimismo, la irrupción del PDL y los movimientos políticos que comenzaron a gestarse desde finales de 1982 en torno a Miquel Roca presagiaban una reorganización de fuerzas en el espacio de centro-derecha e incrementaban la competencia en el abigarrado espacio centrista.

La situación generada tras los comicios del 82' no implicó un cambio de planes en la estrategia del CDS. El día 13 de diciembre de 1982, el Comité Nacional aprobaba la decisión, ya anunciada con anterioridad, de acudir en solitario a las próximas elecciones ${ }^{134}$, siendo el único partido de ámbito centrista en defender dicha postura. Sin embargo, a diferencia de las elecciones generales $-\mathrm{y}$ debido a la cantidad de listas que se habían de componer-, se facilitó la entrada de independientes en las candidaturas nombradas por las distintas gestoras: "de cara a las elecciones municipales, nuestra postura es de acudir solos en todos los municipios en que podamos contar con

\footnotetext{
${ }^{133}$ SOPENA DAGANZO, Enric: "Pujol: mil días de soledad", Diario 16, 05 de febrero de 1983, Archivo Linz.

${ }^{134} A B C, 14$ de diciembre de 1982.
} 
posibilidades estando abiertos a la integración de independientes que se vean representados por nuestra oferta electoral" ${ }^{\prime 135}$. El 31 de enero el Comité Nacional concretó sus objetivos: concurrir en todos los municipios mayores de 50.000 habitantes, en la práctica totalidad de todos los superiores de 20.000 y lograr obtener entre 300 y 500 concejales $^{136}$. El CDS esperaba su mayor número de representantes en Castilla y León y Canarias, y en segunda instancia, Madrid, Asturias o Cantabria.

El fracaso de octubre de 1982 había hecho cundir el temor en el seno de la dirección centrista de que se produjera un aluvión de dimisiones y bajas entre los miembros de algunas de las gestoras provinciales y demás afiliados. Especialmente, en aquellos lugares donde la implantación era meramente simbólica ${ }^{137}$. El apresuramiento con el que se habían constituido las candidaturas electorales impidió asimismo a la dirección ejercer el rigor previsto en la admisión de los nuevos miembros del partido. Por ello, uno de los primeros propósitos consignados por la ejecutiva y en el que tuvo un papel protagonista el propio Suárez -junto a algunos miembros del Comité Nacional como Rodríguez Sahagún, Caso García y Calvo Ortega- fue el de recorrer muchas de las provincias españolas con la intención de consolidar la presencia y adaptarla a la normativa estatutaria.

En estos momentos, Asturias, Ávila, Segovia, Madrid y Canarias eran los territorios donde el CDS se encontraba más sólidamente implantado ${ }^{138}$. El 18 de diciembre se celebró en Madrid la reunión de las gestoras provinciales de todo el país. En ella, se explicaron los acuerdos y estrategia del Comité Nacional en los que se concebía el CDS como un proyecto a "cuatro años vista" y la necesidad de acudir "en solitario" a los próximos comicios, con el fin de "no desdibujar los perfiles del partido"139. En las

\footnotetext{
${ }^{135}$ Boletín Informativo de Tarragona, 0, enero de 1983.

${ }^{136}$ El País, 01 de febrero de 1983.

${ }^{137}$ Algunos recalaron en otros partidos - como AP- caso del ex gobernador civil Fernández Díaz, Diario 16, 29 de enero de 1983. La pluma de Carlos Dávila lo describía así: "el cómputo de los votos trajo consigo pequeñas fugas como la del inestable ex gobernador de Barcelona, Jorge Fernández, que, sólo en cuatro meses, pasó de la UCD al CDS y de éste a Alianza. Los galgos de carrera corta no valían para una carrear cuya meta final Suárez fijó, presuntamente, para el 90" en DÁVILA, Carlos: "La larga marcha del centro político", Diario 16, 13 de septiembre de 1986.

${ }^{138}$ El 5 de diciembre tuvo lugar la constitución de la primera asamblea provincial del partido, el I Congreso Federal del CDS-Asturias. El acto se realizó en Oviedo y contó con la presencia de R. Calvo Ortega. Acudieron 250 compromisarios, de entre 400 afiliados, que eligieron por unanimidad como presidente a Alejandro Rebollo y secretario general a Sabino López. Ambos ex miembros de UCD, al igual que otros miembros del Comité Ejecutivo como Serafín Abilio (ex secretario regional de UCD), Adolfo Barthe Aza (concejal del Ayuntamiento de Oviedo con UCD) o Juan Batista Fernández Fidalgo (ex presidente de la Junta del Principado de Asturias), La Nueva España, 07 de diciembre de 1982 y ABC, 05 de diciembre de 1982.

${ }^{139} A B C, 19$ de diciembre de 1982.
} 
semanas siguientes, se celebraron reuniones regionales de las distintas gestoras y en las principales ciudades con el fin de crear comisiones electorales (autonómicas y locales). Como señala Caso, las visitas de los dirigentes del CDS por las provincias, incluido Suárez, intentaban hacer converger dos ideas: la preparación de la campaña (de 1983) y la generación de estructura, "levantar vocaciones" (véase, Tabla 12). Ese fue el motivo por el que se impuso desde el principio, a pesar de los innumerables problemas, la idea de acudir en el mayor número de lugares posibles a las elecciones concluyendo que: "en este sentido, sí funcionó razonablemente" ${ }^{140}$.

Tabla 12: Desplazamientos de Adolfo Suárez entre diciembre (1982) y abril (1983).

\begin{tabular}{|l|l|}
\hline Palma de Mallorca & 03 y 04 de diciembre de 1982 \\
\hline Madrid & 23 de enero de 1982 \\
\hline Reunión del Comité Nacional & 31 de enero de 1983 \\
\hline Ávila & 07 de febrero de 1983 \\
\hline Zaragoza (Calatayud) & 13 de febrero de 1983 \\
\hline Valladolid & 18 de febrero de 1983 \\
\hline Logroño & 19 de marzo de 1983 \\
\hline Canarias & 22 de marzo de 1983 \\
\hline
\end{tabular}

Elaboración propia a partir de información en prensa ${ }^{141}$.

Con el fin de preparar los comicios y marcar los criterios y perfiles del Programa Electoral se desarrollaron actividades contando con la participación de cuadros y candidatos del partido, tanto a nivel territorial -cuando era posible- como de forma general $^{142}$. El 26 de febrero de 1983 se produjo la reunión de las gestoras sobre política municipal presidida por el secretario general, José Ramón Caso, el responsable de política municipal, Javier Soto y el coordinador electoral, Abel Cádiz. La presentación de las listas se fue efectuando desde comienzos de marzo y en la ejecutiva del 15 de este mes se ultimaron las de las principales ciudades, entre ellas, Madrid. El CDS logró presentar mil candidaturas aproximadamente en las elecciones municipales, frente a las más de 6000 de AP-PDP-UL y PSOE, las 1750 del PCE y las 25 del PDL ${ }^{143}$. La

\footnotetext{
${ }^{140}$ Entrevista con José Ramón Caso, 19 de noviembre de 2014.

${ }^{141}$ Baleares, 04 de diciembre de 1982. Reunión con la Comisión Gestora del CDS-Valladolid, El Norte de Castilla, 23 de enero de 1983; Diario de Ávila, 08 de febrero de 1983; La Rioja, 19 de marzo de 1983. Visitó Tenerife, La Gomera y La Palma, Diario de Avisos, 22 de marzo de 1983. Los días siguientes hubo de suspender algunos de los viajes previstos debido a problemas de salud, ABC Sevilla, 26 de marzo de 1983.

${ }^{142}$ Jornada sobre Política Municipal (12 y 13 de febrero de 1983, CDS-Madrid) con alrededor de 200 delegados del partido.

${ }^{143}$ El País, 25 de marzo de 1983. Exactamente el CDS presentaba a las elecciones municipales 1.110 candidaturas con 9.844 candidatos, cubriendo el $60 \%$ del censo electoral. En las elecciones autonómicas se presentaba en 13 comunidades y 31 provincias, con un total de 637 candidatos abarcando el $94 \%$ del censo, $A B C, 10$ de abril de 1983.
} 
elaboración de las candidaturas fue presentada, en sí misma, como un auténtico triunfo. Adolfo Suárez se dirigía con estas palabras en su carta de felicitación a los candidatos:

Independientemente de los resultados, para nosotros ya ha sido un éxito presentarnos en 1.000 municipios con casi 10.000 candidatos [....] Cuento con tu entusiasmo para seguir trabajando para la consolidación de nuestro Partido, que estoy profundamente convencido será una auténtica alternativa en $1.986^{144}$.

En cierto modo, la capacidad organizativa del CDS para estos comicios puso de manifiesto que lo realizado durante el verano del 82' había solidificado e incluso había tenido continuidad. Para Caso la prueba de que aquello "empezaba a fluir" fueron las listas que se presentaron en 1983: "la gente que se ponía en contacto, algún antiguo votante, alguno que había sido concejal [...] te llamaban, yo me iba para allá a verle el fin de semana y decir oye pues venga intenta montar un comité, unas gestoras"145. Abel Cádiz, responsable de Acción Electoral y dirigente del partido en Madrid, corrobora esta impresión: "el partido ya tenía ciertos mimbres"

La campaña de las autonómicas y municipales de 1983 tuvo una menor intensidad y capacidad de movilización que la celebrada en octubre. El slogan del CDS en la campaña fue: "El equilibrio necesario". Un lema que dejaba entender al menos tres ideas: la identificación con el espacio de centro, la asunción del papel de bisagra y la necesidad de evitar la bipolarización ${ }^{147}$. Nuevamente, la presencia, imagen y popularidad de Adolfo Suárez se convirtieron en la base de la estrategia del partido. Suárez aparecía en los carteles y panfletos (en solitario o acompañado de los candidatos locales) y como sucediera en 1982, sus intervenciones se alejaban de la confrontación política.

Suárez comenzó la campaña en Salamanca, iniciando su recorrido por Castilla y León (Zamora y León), mientras los candidatos de Madrid realizaban la pegada de carteles en las proximidades de la sede de Calle Sagasta ${ }^{148}$. La campaña discurrió a lo largo de toda la geografía, con bastante voluntarismo y en general, en pequeños locales y ante audiencias reducidas. El discurso de Suárez se vertebró en base a la idea de evitar la bipolarización del país, y en política municipal atenuar, lo que él consideraba, una

\footnotetext{
${ }^{144}$ Carta de Adolfo Suárez a los candidatos, 02 de mayo de 1983, Carpeta 2, AGP.

${ }^{145}$ Entrevista con José Ramón Caso, 19 de noviembre de 2014.

${ }^{146}$ Entrevista con Abel Cádiz, 4 de marzo de 2015.

${ }^{147}$ En un juego de palabras del candidato a la alcaldía barcelonesa Ramón Vinyals: "el Partido bisagra necesario para que el Ayuntamiento barcelonés conserve el equilibrio necesario", La Vanguardia, 06 de mayo de 1983; en Bilbao por ejemplo, el slogan fue: "Bilbao no es cosa de dos" y "Tu barrio también es el centro", El Correo Vasco, 23 de abril de 1983.

${ }^{148} A B C, 16$ de abril de 1983.
} 
excesiva "politización": "los ayuntamientos no pueden servir de correa de transmisión de consignas o postulados ideológicos" ${ }^{\prime 149}$. Sin embargo, los obstáculos durante la campaña fueron numerosos y actuaron en perjuicio de la información electoral. Desde finales de abril, se hubo de matizar en sucesivas ruedas de prensa la relación del CDS con el holding RUMASA en las legislativas de 1982. En Cataluña, el interés se centró en la posibilidad, en principio lejana, de participar en la llamada Operación Roca y en la víspera de las votaciones se avivaron desde la prensa nuevas polémicas.

Tabla 13: Viajes de campaña de Adolfo Suárez en las elecciones del 8 de mayo de 1983.

\begin{tabular}{|l|l|}
\hline Salamanca & $15-16$ de abril \\
\hline Zamora, León & 16 de abril \\
\hline Valladolid & 17 de abril \\
\hline Alicante & 19 de abril \\
\hline Valencia, Castellón & 20 de abril \\
\hline Mallorca, Menorca & 22 de abril \\
\hline Ávila & 23 de abril \\
\hline Sevilla, Córdoba & 25 de abril \\
\hline Ávila & 27 de abril \\
\hline Gran Canaria, Tenerife & 29 de abril \\
\hline Barcelona & 30 de abril \\
\hline La Coruña, Pontevedra & 2 de mayo \\
\hline Cantabria, Álava & 4 de mayo \\
\hline Burgos, La Rioja, Navarra, Zaragoza & 5 de mayo \\
\hline Madrid, Guadalajara, Cuenca, Toledo, Ciudad Real & 6 de mayo \\
\hline
\end{tabular}

Elaboración propia a partir de Carpeta 4, AGP.

Si $A B C$, centró su atención en la relación entre el CDS con el PSOE y la Operación Roca $^{150}$, fue en El País donde se publicó uno de los titulares más polémicos, el último día de la campaña, a propósito de unas declaraciones del político abulense en Vitoria. Decía así: "Suárez dispuesto a negociar con los terroristas respetando la Constitución"; titular matizado por el propio Suárez al día siguiente quien indicó: "Yo nunca afirmé [...] que había que negociar con terroristas; simplemente dije que cualquier diálogo que estuviera dentro de la Constitución y el Estatuto de Guernika, tendente a la pacificación del País Vasco, me parecería loable"151. En todo caso, el CDS tuvo un seguimiento

\footnotetext{
${ }^{149}$ El País, 18 de abril de 1983.

${ }^{150}$ Comentarios aislados de algunos de sus columnistas: “[Suárez y Garrigues Walker] dispersarán voto liberal-conservador arañando en la coalición aliancista. Dios me libre de apuntar "padrinazgos económicos' aunque puede haberlos", URBANO, Pilar: "El nuevo rostro de la derecha", $A B C, 17$ de marzo de 1983; Campmany, más cáustico, escribía: "la gatita del CDS, que a veces araña", en CAMPMANY, Jaime: "La rosa marchita", $A B C, 26$ de abril de 1983.

${ }^{151}$ El País, 07 de mayo de 1983.
} 
mucho más discreto que en las elecciones de octubre. Ni en El País, ni Diario 16, ni $A B C$ hubo referencias en sus editoriales o reportajes monográficos ${ }^{152}$.

El presupuesto electoral para el conjunto de la campaña se estimaba en 200 millones de pesetas (cien millones en bonos, junto a cien millones en créditos bancarios) ${ }^{153}$. En la mayoría de provincias, hubo aún a limitaciones más severas:

La campaña ha sido una campaña con poquitos medios, hemos gastado aquí en Málaga capital 500 mil pesetas, eso es ridículo comparado con otros partidos, parecido a lo que hemos gastado en todos los sitios. [...] Porque la campaña anterior contratábamos gente, teníamos gente que se le pagaba para pegar carteles en la campaña. Pero yo valoro [una campaña así], claro lo que se ha conseguido ha sido una unión mayor dentro de los militantes, de decirles, mira, no hay dinero para contratar gente [...] ¿A qué horas puedes? Pues yo puedo, mira, me quito unas horas de sueño, uno llega a las 3 , otro se iba a las 5 , se iban turnando ${ }^{154}$.

Las deudas acumuladas a nivel nacional y provincial durante la campaña de octubre impidieron al CDS obtener suficiente financiación mediante los cauces bancarios habituales. Por ello anunció, al igual que hicieron otros partidos, la emisión de bonos de cien pesetas, publicitados en la prensa local y nacional:

CDS INFORMA: Que para la financiación de la campaña se expiden bonos para militantes y simpatizantes, que están a su disposición en nuestros locales en la calle Ángel Terrel [...] a partir de las 7:30 de la tarde. LA COMISIÓN GESTORA [CDS-SORIA] ${ }^{155}$.

Del presupuesto total, entre 10 y 25 millones estaban destinados a la capitalautonomía de Madrid ${ }^{156}$-Rosa Posada la rebajaba a un millón- ${ }^{157}$. Nuevamente, la radio se convirtió en el principal activo de los candidatos centristas -y el medio, por lo general, más utilizado por todos los partidos-. Rosa Posada llegó a pasar seis horas

152 Cabe mencionar el artículo del periodista Carlos Taboada, uno de los escasos testimonios durante la campaña y en la prensa nacional en favor de la continuidad política de Suárez, "dentro de la iniciativa de reconstruir un partido centrista" y reivindicando el reconocimiento de su papel durante la Transición en TABOADA, Carlos: "El bueno de Suárez", Diario 16, 03 de mayo de 1983.

${ }^{153}$ El País, 31 de marzo y 10 de abril de 1983. A modo de contraste: AP-PDP-UL contó con 1000 millones, el PSOE con 900 millones y el PDL con 71 millones, $A B C, 07$ de mayo de 1983;

${ }^{154}$ Interview undertaken by Richard Gunther, in 1983 (june), AR.

155 Soria Semanal, 16 de abril de 1983. Véase también, El País, 28 de febrero de 1983.

${ }^{156}$ Donde se alquilaron 200 vallas publicitarias y se hicieron 10.000 carteles publicitarios, El País, 17 de abril de 1983. Citando otros territorios, en Aragón el presupuesto de campaña fue de 5 millones, $A B C, 05$ de mayo de 1983. En el País Vasco, Jesús María Viana cifraba en un millón de pesetas el presupuesto electoral; en Bilbao contaron con 10.000 carteles y 10.000 tiras, El Correo Español-El Pueblo Vasco, 03 de mayo y 23 de abril de 1983. En Mallorca se barajaban 6 millones de pesetas, Diario de Mallorca, 13 de abril de 1983. Cabe señalar que desde comienzos de año, habían aparecido en la prensa noticias sobre impagos, deudas y embargos que afectaban al CDS, "El CDS tiene deudas electorales en Tenerife", Diario de Avisos, 22 de marzo de 1983; "Una deuda de 97.000 pesetas deja al CDS sin teléfonos", Diario de Mallorca, 13 de abril de 1983.

${ }^{157}$ Rosa Posada usó las mismas fotografías que las empleadas para el Senado en 1982 y señaló, que el gerente de campaña para Madrid era un médico que había dejado su trabajo durante un mes y había puesto a disposición del partido su vehículo y su personal administrativo. Las tareas de seguridad fueron cubiertas por la Policía Nacional, El País, 23 de abril de 1983. 
diarias grabando en locutorios (participó en 45 emisiones) y comenzó su campaña con una entrevista de Jesús Quintero en El Loco de la Colina ${ }^{158}$. Asimismo, la imposibilidad de llevar a cabo grandes actos electorales orientó la campaña hacia el contacto con asociaciones de vecinos, colegios profesionales y otras organizaciones, así como los actos en la calle (mercados, barrios, etc.) ${ }^{159}$; una campaña en palabras del periodista Victorino Ruiz de Azúa "casi silenciosa", en la que la medida más novedosa del programa del CDS para Madrid era la creación de un Estatuto Municipal Vecinal ${ }^{160}$. Un estudio realizado en Madrid señalaba que la campaña del CDS había sido la "más tímida" de los grandes partidos, correlato de los escasos recursos humanos y económicos empleados ${ }^{161}$. El CDS, apelando a la moderación ${ }^{162}$, quería retomar la “ilusión" suscitada en las municipales de 1979 y defraudada como consecuencia de la mala gestión ${ }^{163}$. Rosa Posada basó su discurso en la mejora de la gestión y de la participación ciudadana ${ }^{164}$.

Igual que sucediera en la campaña del 82', el reparto de espacios de propaganda electoral en TV generó las quejas centristas, desestimadas en una primera instancia por el Comité de Radio, TV y Prensa de la Junta Electoral Central ${ }^{165}$. Dicho comité, señaló que el CDS carecía de una implantación superior al 20\% de los municipios en al menos 25 provincias, requisito establecido para su inclusión en la distribución de espacios televisivos. El CDS se presentaba en las 52 provincias, en 16 de las cuales en más de un $20 \%$ de los municipios (cubriendo un $64 \%$ del censo en las municipales y un $90 \%$ en las

\footnotetext{
${ }^{158}$ El País, 23 de abril de 1983 y 06 de mayo de 1983.

${ }^{159}$ Rosa Posada participó en actos electorales con 153 asociaciones, El País, 06 de mayo de 1983.

${ }^{160}$ El País, 04 de mayo de 1983.

${ }^{161}$ El País, 29 de mayo de 1983.

${ }^{162}$ En este sentido, fueron frecuentes los reproches del CDS (Javier Soto, Rosa Posada) a AP-PDP-PL por su manipulación de las cifras sobre el déficit del ayuntamiento madrileño de Tierno Galván: “[desde] el CDS que no oculta sus críticas a la gestión de la izquierda, desmintieron ayer los datos presentados el jueves por los candidatos de Coalición Popular", El País, 30 de abril de 1983. En una entrevista en El País, se preguntaba a Rosa Posada: "Muchos electores pueden tener la sensación de que el CDS mantiene una opinión poco clara sobre los cuatro años de gestión municipal de la izquierda", a lo que esta respondía: "el CDS no es el submarino del PSOE, sino un barco que tiene la quilla orientada hacia la constitución de una alternativa de poder. Pero cuando hacemos crítica queremos ser objetivos", El País, 04 de mayo de 1983.

163 "El CDS entiende que el gobierno socialista-comunista ha merecido un aprobado estricto en las intenciones y un suspenso amplio en las realizaciones", en palabras de Javier Soto, $A B C$, 06 de mayo de 1983. "La izquierda ha conseguido devolver la ilusión a los ciudadanos, hacerles ver que es posible una política de recuperación de la ciudad. Eso es positivo para todos [...] Se ha gestionado mal, terriblemente mal", Rosa Posada en El País, 04 de mayo de 1983.

${ }^{164}$ En $A B C$, Ignacio Ruiz Quintano definió el programa del CDS para Madrid como: "un programa para que lo voten todos aquellos que, sin querer los demás programas, no tienen otro programa que votar", $A B C, 31$ de marzo de 1983.

${ }^{165}$ El CDS estaba representado en dicho Comité por Antonio del Olmo.
} 
autonómicas) ${ }^{166}$. Finalmente, la demanda del CDS fue aceptada gracias al alegato, -en base al artículo 20 de la Constitución que establece el acceso a los grupos sociales y políticos significativos a los Medios de Comunicación Social del Estado-, presentado por Jiménez de Parga. Se fijó un espacio de 10 minutos cuya emisión se encuadró entre las 23:30 y 23:50 de la noche en la primera cadena, el miércoles 4 de mayo.

Si el CDS fue uno de los últimos partidos en presentar sus candidaturas, situación que generó notables dificultades, fue el primero en dar a conocer su programa electoral, diseñándose un Programa marco para las elecciones municipales de 1983 en el que se definían las pautas a seguir, antes de su concreción en las distintas localidades ${ }^{167}$. El programa del CDS se articulaba en torno a tres grandes puntos: dignificación institucional, política de inversiones y solidaridad. El principio rector del programa era la idea de "MODERNIDAD, consistente en considerar como absolutamente necesario el asentamiento de las Corporaciones Locales desde la Constitución, y bajo el lema de la obtención del mayor resultado social para el ciudadano con el mínimo coste, también social, para la comunidad". Asimismo, propugnaba la conquista de los siguientes principios constitucionales: democratización, autonomía y efectiva suficiencia económica. En términos económicos, y en parte, como consecuencia de la situación de crisis vivida y reacción al mayoritario gobierno de izquierdas salido de las elecciones de 1979, acentuaba su discurso liberal fijando diversas políticas de "ajuste"168.

A propósito de la dignificación institucional, el CDS, en una línea eminentemente pragmática, abogaba por atenuar los enfrentamientos políticos mediante: la diferenciación de los actos institucionales de la gestión, la información integral y abierta (participación ciudadana) y la "defensa del ser y de la esencia de cada pueblo de España”. Para ello era necesario mejorar la información entre el Ayuntamiento y la ciudadanía (publicaciones y boletines), dotar de reglamentos internos a los entes locales y crear Estatutos Municipales del Vecino. Se trataba de evitar "la radicalización política de la vida local" y practicar "en posiciones de gobierno [...] respeto para la oposición, en posiciones de oposición, respeto institucional y crítica constructiva". Como había hecho en las elecciones de 1982, alertaba sobre algunas situaciones que ponían en

\footnotetext{
${ }^{166}$ El País, 20 de abril de 1983 y ABC, 20 de abril de 1983.

${ }^{167}$ Programa Municipal C. A. Madrid, CDS, 1983, Carpeta 4, AGP.

168 "CDS: promover la iniciativa privada", sobre la propuesta electoral del CDS para el Ayuntamiento de Barcelona, El Noticiero Universal, 29 de abril de 1983.
} 
peligro, en este caso, la democracia a nivel municipal: "análisis de defectos o ausencias en la vida local".

La política de inversiones se entendía como el desarrollo del conjunto de obras y servicios urbanos que "satisfagan las demandas y las necesidades del vecindario", en tres órdenes de actuación: descentralización, fijación de una banda de prioridades acerca de los servicios a proveer y modernización y mejora de la Administración.

Finalmente, en un contexto de crisis económica propugnaba el reparto de los costes derivados de la misma entre las distintas instancias administrativas, "es preciso aliviar e incluso suprimir los costes adicionales que hoy suponen los atrasos en las disponibilidades de efectivos para los pagos" y se apostaba por la "iniciativa privada" como el instrumento más idóneo para la realización y provisión de los distintos servicios urbanos de competencia local. En definitiva, se pretendía: el aumento de la participación de los municipios en los Presupuestos Generales del Estado, la congelación de los gastos políticos (así como de personal público), la estabilidad fiscal y la mejora de la financiación.

El programa electoral se estructuraba, intentando atender a la pluralidad y variabilidad de situaciones en los municipios españoles, diseñando distintas políticas prioritarias tanto en función de la población como de los sectores implicados. En todos los casos, la nota común fue conseguir mayor eficacia en la gestión: "el nuestro no es un programa para gustar, sino para funcionar" ${ }^{\prime 169}$. En este sentido, el Programa Municipal para Madrid estaba abanderado por el lema, "Con lo que se tiene, se puede"170, en abierta oposición, para los dirigentes centristas, con los excesos ideológicos del anterior consistorio:

Los homenajes verbales a metas vagas y objetivos "ideológicos" deben ser reemplazados por la producción de estructuras y planificaciones, garantía de acciones políticas sin sobresaltos ni desazones ${ }^{171}$.

El final de campaña del CDS fue bastante sobrio. Se celebró en un hotel madrileño la noche del 6 de mayo, con la presencia de Adolfo Suárez y los candidatos al Ayuntamiento de Madrid, Rosa Posada y a la Comunidad Autónoma, Carlos Revilla, con la asistencia de cerca de 400 personas. En Barcelona, se cerró la campaña en los Cines Balmes con una rueda de prensa y la proyección, para todos los candidatos

\footnotetext{
${ }^{169}$ Programa Municipal C. A. Madrid, CDS 1983, Carpeta 4, p. 5, AGP.

${ }^{170}$ Definida como "filosofía posibilista” en El País, 29 de abril de 1983.

${ }^{171}$ Programa Municipal C. A. Madrid, CDS 1983, Carpeta 4, p. 5, AGP.
} 
provinciales de "2001. Una odisea en el espacio" con el lema, izado a lo largo de la campaña, de: "una película de futuro, para un partido de futuro". Las expectativas eran realmente bajas. Rosa Posada comentaba el último día de campaña tras repartir propaganda en el centro de Madrid: "algunos de mis interlocutores [...] me han indicado que no piensan votarme, pero que reconocen nuestro esfuerzo por hacer un partido de centro. Con esto me doy por satisfecha”"172. El propio Adolfo Suárez, al depositar su voto, comentó que el CDS ya había conseguido su objetivo ${ }^{173}$.

Los resultados previstos para el CDS, si se tomaban como referencia los comicios de 1982, le impedían acceder a la práctica totalidad de los gobiernos municipales y autonómicos. Ni siquiera superaba el 5\% necesario en la mayor parte de los casos para formar parte del recuento. Como apuntaba Lorenzo Contreras: "no obtenerlos repite a escala política el mito de Sísifo. Volver a escalar la montaña con la piedra al lado. Algunos no podrán hacerlo"174. En una encuesta realizada en Castilla y León, los resultados no eran particularmente halagüeños. La estimación de voto del CDS era del $2 \%{ }^{175}$. La empresa GALLUP publicaba en El País pocos días antes de las elecciones señalaba que el PDL en la "batalla de Madrid" superaba el 5\% de los votos, mientras el CDS se quedaba en un $0,26 \%{ }^{176}$. En una valoración general en $A B C$, ese mismo día, la Encuesta ARESCO A. S. otorgaba un $0,7 \%$ al PDL y un $1,6 \%$ al $\mathrm{CDS}^{177}$. Las bajas previsiones de voto enrocaban a la dirección centrista en su valoración de las elecciones desde el punto de vista del largo plazo: "Suárez indicó que con independencia de los resultados que logre su partido en las próximas elecciones, el CDS es consciente de que tiene que 'atravesar el desierto’ y anunció que seguirá trabajando para su implantación en toda España" ${ }^{178}$. Un discurso que llegó a ser asociado incluso dentro del partido con cierto derrotismo, hasta el punto de que el CDS-Aragón envió un telegrama al Presidente Nacional demandándole "cariñosamente" "más energía” y "convicción de triunfo en sus intervenciones" ${ }^{\prime 179}$.

En relación a los pactos pre-electorales el CDS mantuvo siempre su negativa a participar en la Operación Roca y descartó, tras una serie de contactos a primeros de

\footnotetext{
${ }^{172}$ El País, 06 de mayo de 1983.

${ }^{173}$ ABC, 09 de mayo de 1983.

${ }^{174}$ CONTRERAS, Lorenzo: "El porcentaje electoral y las compras a Francia”, $A B C, 17$ de abril de 1983.

175 SOFEMASA: "Encuesta. Estudio socio-político", Gabinete de Información, Caja 544, AGCYL.

${ }^{176}$ El País, 02 de mayo de 1983.

${ }^{177}$ En la suma de: intención de voto y voto decidido, $A B C$, 02 de mayo de 1983.

${ }^{178}$ ABC, 03 de mayo de 1983

${ }^{179}$ Heraldo de Aragón, 23 de abril de 1983.
} 
marzo, un pacto con el PDL en municipios como Madrid. En lo que a coaliciones postelectorales se refiere, el CDS se mantuvo abierto a todas las opciones y se subrayó la necesidad de que, en caso de que fueran posibles, deberían ser ratificadas por los comités territoriales del partido ${ }^{180}$.

La dirección centrista, con José Ramón Caso y Adolfo Suárez al frente, siguió los resultados en la sede central del partido. El porcentaje de votos obtenido fue del 1,7\%, una cifra incluso menor que la conseguida el 28-0. Un descenso que se puede atribuir a dos circunstancias: la concurrencia en las grandes ciudades del PDL y el carácter territorial de las elecciones ${ }^{181}$. Aunque el CDS mostró cierta satisfacción a pesar de los escasos votos - una vez asumidas las posibilidades reales del partido el 28-O y resaltando el importante salto cualitativo dado en cuanto a implantación provincial y local ${ }^{182}$-, el resultado en Madrid, donde no se había conseguido ningún concejal suponía un duro contratiempo para el partido. Ni siquiera en Ávila se habían logrado los resultados esperados. En total, el CDS obtuvo más de 1.000 concejales, 10 de ellos en capitales de provincia, 9 diputados autonómicos y 16 diputados provinciales o consejeros en cabildos insulares -todos ellos en Canarias y Castilla y León (Ávila, Segovia y Zamora), donde junto con Ceuta obtuvo sus mejores resultados-:

Tabla 14: Porcentaje de votos y diputados o concejales del CDS en los parlamentos autonómicos y las grandes ciudades españoles en las elecciones de 1983.

\begin{tabular}{|l|l|}
\hline Comunidad Autónoma & Porcentaje \\
\hline Cantabria & 2,45 \\
\hline Madrid & 3,12 \\
\hline La Rioja & 2,43 \\
\hline Extremadura & 0,79 \\
\hline Canarias & 7,14 y 6 diputados \\
\hline Castilla La-Mancha & 3,01 \\
\hline Castilla y León & 5,94 y 2 diputados $^{184}$ \\
\hline Asturias & 3,87 \\
\hline Murcia & 1,14 \\
\hline Comunidad Valenciana & 1,88 \\
\hline Aragón & 3,29 y 1 diputado $^{185}$ \\
\hline
\end{tabular}

${ }^{180}$ El País, 20 de abril de 1983.

181 "El CDS pierde el 1.1 por ciento respecto a las generales del 28-0, que sólo alcanzó el 2,89 por ciento. El PDL, por su parte, ha resultado ser un rotundo fracaso al obtener el 0,80 por ciento de los votos. Ha conseguido quitar votos al CDS pero no 'arañarlos' de AP”, La Vanguardia, 10 de mayo de 1983.

182 "Suárez y Garrigues, entre la satisfacción y la resignación”, El País, 09 de mayo de 1983; "Seriedad y caras largas en la sede del CDS", $A B C, 09$ de mayo de 1983; "CDS: esperanza en el futuro", $L a$ Vanguardia, 09 de mayo de 1983. Esta "satisfacción" aparente suscitó bastantes comentarios satíricos en la prensa; J. L. Gutiérrez lo llamó "Houdini electoral", en GUTIÉRREZ, José Luis: "Noche de samba", Diario 16, 10 de mayo de 1983.

1831 en Gran Canaria, 1 en Tenerife, 2 en Fuerteventura, 1 en Lanzarote y 1 en La Palma.

${ }^{184}$ Daniel de Fernando y José Manuel Hernández - quien abandonó el partido en 1983, sin renunciar al cargo-. 


\begin{tabular}{|l|l|}
\hline Baleares & 2,37 \\
\hline Melilla & 3,55 \\
\hline Ceuta & 9,04 y 2 concejales \\
\hline Navarra & No se presentó \\
\hline Principales ciudades & Porcentaje \\
\hline Madrid & 3,02 \\
\hline Barcelona & 0,94 \\
\hline Zaragoza & 3,14 \\
\hline Sevilla & 1,16 \\
\hline Valencia & 1,93 \\
\hline Bilbao & 0,93 \\
\hline
\end{tabular}

Elaboración propia a partir de la información electoral del Ministerio del Interior y la Dirección General de Coordinación con las Comunidades Autónomas y las Entidades Locales del Ministerio de Hacienda y Administraciones Públicas (AMINHAP).

\section{Gráfica 2: Distribución del total de Diputados Provinciales y Consejeros en Cabildos Insulares (1983-1987).}

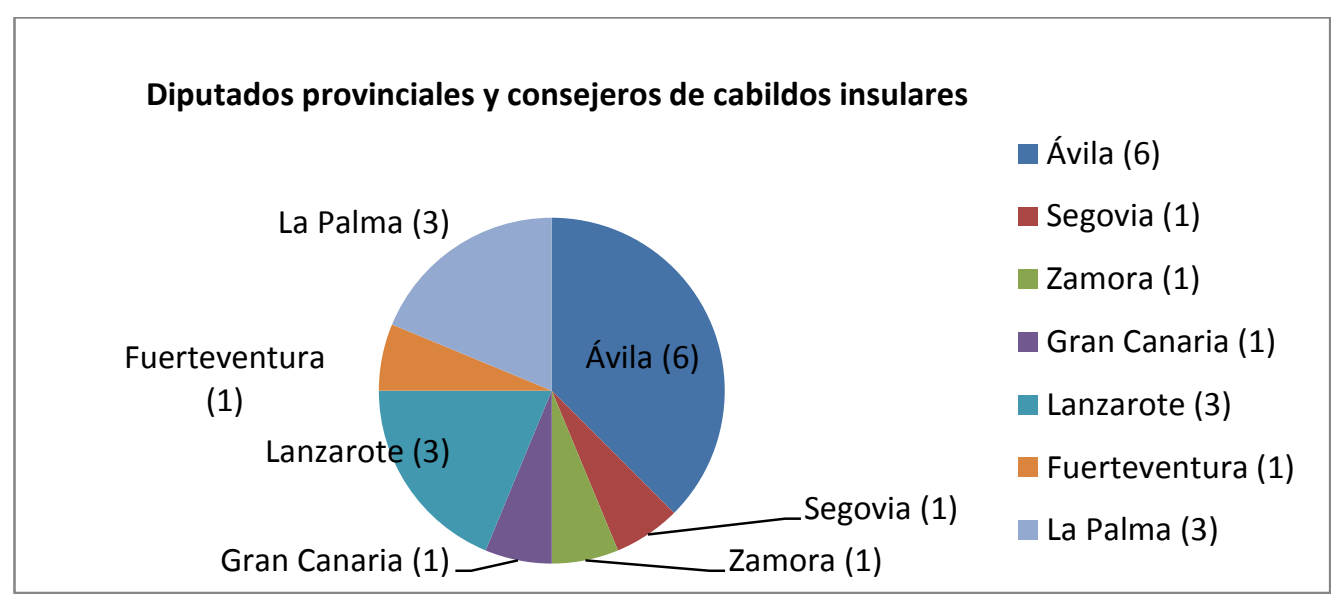

Elaboración propia a partir de la base de datos del $A M I N H A P^{186}$.

Todas las grandes cabeceras nacionales certificaban la defunción del actual centro político, es decir, del CDS y del PDL, en tanto que formaciones autónomas e independientes $^{187}$. La principal diferencia nacía de la lectura que hacían los distintos periódicos sobre quién podía recoger ese electorado. Para $A B C$, las elecciones significaban la consolidación del modelo bipartidista y el reforzamiento de la "coalición liberal-conservadora" confirmada como la "única alternativa capaz de sustituir al socialismo en el plazo de tres años". Subrayaba: "hay que registrar, asimismo, la inexistencia de los partidos con voluntad de intermediación entre los grandes. Ni el grupo liberal del señor Garrigues Walker, ni el CDS, han obtenido un solo puesto de

\footnotetext{
${ }^{185}$ José Luis Merino por Zaragoza, miembro del Comité Nacional y del Comité Nacional de Cuentas.

${ }^{186}$ En 1986, se produjo el pase de un diputado provincial de León del PSOE, Pedro Vizcay, al CDS.

187 "En primer lugar, el CDS de Suárez, había concurrido a las elecciones con muy poco dinero, cuando, por los deprimentes resultados de octubre, ya no era lo que se entiende por un caballo ganador... En esta situación, el derrotado Adolfo Suárez sacó fuerzas de flaqueza para continuar...", PENELLA, Manuel: [Tomo II] Los orígenes..., pp. 698-9.
} 
concejal en la Corporación madrileña"188. En esta línea, se encabezaba la sección de política nacional el día siguiente: "Se consolida el carácter bipartidista del mapa político español"189. Desde Diario 16, no se consideraba que los votos del centrismo hubieran ido a parar a la coalición conservadora, y a la vez admitía que ninguno de los dos partidos existentes -CDS y PDL- habían logrado atraer a ese electorado; concluían, en lo que quizá fuera una alusión velada a la Operación Roca: "los [partidos] actuales que luchan por rehacer ese hueco no tienen fuerza ni atractivo suficiente para ocuparlo. El domingo, la mayoría de esos votos potenciales se fueron al limbo, en la espera de mejores tiempos"190. La crónica de La Vanguardia, en segunda página, titulaba: "Victoria socialista y confirmación del bipartidismo junto a recuperación del PCE"191. El fracaso de las alternativas que "aspiraban a configurarse en bisagras" también era corroborado por el editorial de El País ${ }^{192}$. El Periódico de Catalunya certificaba la práctica "desaparición de las opciones centristas"193.

Desde los principales partidos políticos, Alianza Popular, a través de Jorge Verstrynge, y el PSOE, por medio de Guillermo Galeote, se confirmaba la consolidación del modelo bipartidista. Manuel Fraga, con cierta vehemencia, señaló: "las operaciones, operacioncillas, partídillos, partidejos y partiduchos han quedado aplastados"194.

El Comité Nacional, reunido el 10 de mayo, acordó los criterios básicos para establecer pactos postelectorales (Castilla y León, Ávila, Canarias o Segovia):

\footnotetext{
${ }^{188}$ Editorial: "Los hechos", $A B C, 09$ de mayo de 1983. Para Pilar Urbano, el centro había comenzado a perder su batalla en favor de la coalición AP-PDP-UL y comentaba: "interesante aporte de clientelas, que obligarán a la coalición de derechas a marcar su acento en el qué liberal y en el para qué popular, si se me permite una reducción muy primaria; a modernizarse, a liberalizarse y a desclasarse", en URBANO, Pilar: "Elecciones de inercia", $A B C, 10$ de mayo de 1983.

${ }^{189} A B C, 10$ de mayo de 1983 .

${ }^{190}$ Análisis de los resultados en Diario 16, 10 de mayo de 1983. El día anterior, J. L. Gutiérrez certificaba la práctica desaparición de CDS y PDL, mientras confirmaba la paradoja de la importancia electoral del centro (en términos sociológicos e ideales), como lugar hacia donde se inclinaban tanto PSOE como APPDP-UL, en GUTIÉRREZ, José Luis: "El centro fuera", Diario 16, 09 de mayo de 1983. "El CDS, para qué andarse con cuentos, pierde de todo. Incluso más (a última hora, me entero, le han arrebatado hasta la alcaldía de Lillo). Pero eso no quiere decir que al señor Suárez no le estén saliendo las cosas a pedir de boca, ni mucho menos. Él siempre ha dicho (porque lo ha dicho) que su punto de mira está puesto en 1986, así que todo este tiempo de inactividad expectante le va a venir bien para preparar el desembarco enérgico en las próximas legislativas, para lo cual, se rumorea, ya tiene prevista una campaña mucho más lacrimógena de lo habitual" en MARTÍN AYER: “Todos contentos", El País, 07 de junio de 1983.

${ }^{191}$ La Vanguardia, 09 de mayo de 1983. En esta línea, PI, Ramón: "La bipolarización sustituye al centro", La Vanguardia, 09 de mayo de 1983.

${ }^{192}$ Editorial: "Las elecciones del 8-M: un primer análisis", El País, 09 de mayo de 1983; "Las municipales consolidan el bipartidismo y reducen considerablemente el voto a las opciones minoritarias", El País, 10 de mayo de 1983.

${ }^{193}$ El Periódico de Catalunya, 09 de mayo de 1983, Archivo Linz.

${ }^{194}$ La Vanguardia, 10 de mayo de 1983.
} 
elaboración de un nuevo programa abierto y transparente en el que se contemplasen los principios básicos del $\mathrm{CDS}^{195}$. La decisión corrió a cargo de los órganos territoriales del partido. A continuación mostramos en un cuadro resumen, la política de pactos y posicionamientos del CDS en las CC.AA. y las capitales de provincia:

Tabla 15: Posición del CDS en la formación de gobiernos autonómicos y municipales.

\begin{tabular}{|c|c|c|c|}
\hline Lugar & $\begin{array}{l}\text { Partido } \\
\text { mayoritario }\end{array}$ & Posición CDS & $\begin{array}{l}\text { Formación } \\
\text { de mayorías }\end{array}$ \\
\hline Segovia & PSOE & Abstención & Decisivo \\
\hline Ávila & $\mathrm{CP}$ & $\begin{array}{l}\text { Pacto de gestión municipal. Tras un período de } \\
\text { considerable inestabilidad, en el que el CDS llegó a } \\
\text { algunos acuerdos con AP -(cambios de alcalde } \\
\text { incluidos)-, se llegó a un pacto de gestión municipal } \\
\text { entre todas las fuerzas políticas AP, PSOE y CDS, } \\
A B C, 03 \text { de noviembre de } 1983 \text {. }\end{array}$ & Decisivo \\
\hline Ceuta & PSOE & - & No decisivo \\
\hline Aragón & PSOE & A favor & No decisivo \\
\hline $\begin{array}{l}\text { Castilla } \quad \mathrm{y} \\
\text { León }\end{array}$ & PSOE & Abstención $^{196}$ & Decisivo \\
\hline Canarias & PSOE & En contra & Decisivo \\
\hline
\end{tabular}

Elaboración propia ${ }^{197}$.

\section{5. La "travesía del desierto": Suárez recorre el país}

Desde mayo de 1983, se manifestó crudamente la verdadera situación del partido. Había quedado atrás la efervescencia política provocada por la ruptura de UCD, la fundación del partido y las elecciones del 82', que con intensidad notablemente menor, se había prorrogado hasta los comicios municipales y autonómicos del 83'. Desde este momento, y hasta junio de 1986, el protagonismo político del CDS y de Adolfo Suárez fue absolutamente mínimo: no poseía apenas representación en ninguno de los escalones institucionales, las declaraciones de Suárez eran parcamente comentadas por los medios de comunicación y los posicionamientos políticos del CDS eran una anécdota en la dinámica parlamentaria. El partido trasladó sus prioridades hacia la implantación territorial; a nivel nacional, apenas era requerido.

\footnotetext{
195 Navarra Hoy, 11 de mayo de 1983.

${ }^{196}$ En $A B C$, se instaba a repetir lo sucedido en Ávila, “una vez más, el CDS podría erigirse en árbitro de la situación por más que algunas personalidades del partido de Suárez hayan vaticinado ya su abstención durante la elección de presidente", $A B C, 10$ de mayo de 1983.

197 La categoría de "formación de mayorías" se caracteriza por tener la facultad -en caso de ser "decisiva"- de posibilitar por sí mismo la formación de mayorías absolutas en la cámara, papel que corresponde a lo que denominados "legisladores medianos", RENIU, Josep Ma: "Gobiernos de coalición y dinámicas coalicionales en España” en RENIU, Josep $\mathrm{M}^{\mathrm{a}}$ (Ed.): Pactar para gobernar. Dinámicas coalicionales en la España multinivel, Valencia, Tirant lo Blanch, p. 27.
} 
Esta etapa fue caracterizada en la época como la "travesía del desierto" y asumida rápidamente con esta denominación por la militancia y los medios de comunicación ${ }^{198}$. En todo este tiempo y de acuerdo con el Plan Estratégico (enero, 1983) el CDS estuvo centrado en la primera de sus fases de actuación caracterizada por "crecer hacia dentro", y a su vez subdividida en dos "vectores estratégicos": la infraestructura (maquinaria electoral y militancia) y la formación ${ }^{199}$. Un largo camino que debía apuntalar el proceso de "institucionalización" del $\mathrm{CDS}^{200}$.

En septiembre de 1983, se fijaron los pasos a seguir para reimpulsar el partido e implantarlo en todo el territorio. Por un lado, Suárez debía asumir un papel protagonista -acudiendo a la celebración de Asambleas- y obtener un mayor protagonismo político en esta época, inició, como ex presidente una serie de viajes a América Latina con una importante repercusión mediática-. Por otra parte, era necesario transformar las gestoras provisionales en Asambleas constituidas en base al Reglamento de Organización y los Estatutos, sistematizando las estructuras provisionales existentes y dotando así de una voz complementaria al partido, hasta ese momento, ejercida casi en exclusividad por José Ramón Caso y por Agustín Rodríguez Sahagún. Las sucesivas "derrotas" electorales habían mermado el entusiasmo y, muchos de los liderazgos iniciales, se habían ido apartando progresivamente del partido como refleja la constitución de los nuevos órganos de gobierno provinciales (Anexo VI) ${ }^{201}$.

El modo de constitución de las Asambleas fue fijado en el Reglamento de Organización -aprobado por el Comité Nacional en enero de 1983-. Cuando una gestora o agrupación territorial provisional del partido lograba reunir un número

\footnotetext{
${ }^{198}$ El término "travesía del desierto" fue popularizado por Fraga a finales de los 70' a propósito de la trayectoria de AP, DE LA CIERVA, Ricardo: El suicidio..., p. 108. Siguió siendo habitualmente usado por el político gallego, en referencia a dicha etapa, en los años venideros, El País, 18 de diciembre de 1982 o 25 de abril de 1983. En este contexto, comenzó a emplearse para describir la situación de otros partidos como el PDP, -véase PALMA, L. y S. J.: "Historia de AP", ABC, 22 de enero de 1984-, o especialmente el CDS.

${ }^{199}$ Comité Nacional del CDS: "Plan de Actuación para 1985, 13 de mayo de 1985, Carpeta 2, AGP. Como se ha puesto de manifiesto desde el ámbito de la politología, la importancia de la estructuración a nivel territorial es determinante a dos niveles: el electoral y el de la militancia, véase VAN BIEZEN, I: Political parties..., p. 88.

${ }^{200}$ Siguiendo la terminología de Panebianco y utilizada por autores como Gunther o Hopkin en sus análisis sobre UCD, la consolidación y estabilización del partido pasaba, entre otros aspectos por dotar al partido de un alto grado de autonomía y sistematización (desde el punto de vista organizativo), PANEBIANCO, Angelo: Modelos de partidos: organización y poder en los partidos políticos, Madrid, Alianza, 1990.

${ }^{201}$ El proceso de estructuración del CDS encontraba su correlato en el PRD, el PDP o, en menor medida, el PAL (29 de julio de 1985, I Congreso), siendo habitualmente comparado en los medios de comunicación, véanse los trabajos de Pilar Bravo y Carmen Ortiz en El País.
} 
significativo de militantes -al menos un centenar- y de recursos, -en ocasiones, se abrieron sedes usando instalaciones personales de miembros del partido-, se procedía, por decisión del Comité Nacional, a la convocatoria de la Asamblea Constituyente que procediera a la elección del Presidente, Secretario y Comité Ejecutivo ${ }^{202}$. Rara vez, los miembros del CDS heredaron infraestructuras o personal administrativo de UCD, entre otras razones, porque éste último no desapareció hasta febrero del 83' y las direcciones y secretarías provinciales de UCD existentes en 1982 permanecieron en el partido en prácticamente todos los casos ${ }^{203}$.

Las Asambleas Provinciales -constituyentes, de "seguimiento"204, de elección de compromisarios o de renovación de cargos- debían contar con un máximo de 200 miembros y en caso de ser superior el número de afiliados, debían proceder a su elección los Comités Locales o de Distrito si los hubiere. La elección de compromisarios, sobre el listado de todos los afiliados de la localidad o de la provincia seguía el siguiente criterio: "[la Mesa] fijará el número máximo de compromisarios a elegir por cada elector [...] cada uno de los electores podrá votar como máximo al 80 por 100 de la totalidad de los puestos a elegir". La Mesa de la Asamblea se elegía por mayoría y los acuerdos en el seno de la Asamblea se llevaban a cabo por mayoría absoluta de entre los presentes. El Presidente del Comité Provincial era elegido por votación uninominal y secreta debiendo alcanzar la mayoría absoluta en la primera votación y mayoría simple en la segunda. El Secretario Provincial era elegido entre los miembros del Comité Ejecutivo Provincial por mayoría absoluta. Los miembros del Comité Ejecutivo Provincial debían ser elegidos en listas cerradas y bloqueadas por un sistema mayoritario (art. 20): se debía elegir la candidatura con mayor número de votos. El Comité Provincial debía reunirse al menos una vez al mes y podía, si lo consideraba necesario, crear una Comisión Permanente.

Una vez constituidos los órganos de gobierno provinciales se procedió a la celebración de los Congresos de Federación. La elección de compromisarios a los Congresos de Federación tenía lugar mediante listas cerradas y bloqueadas, debiendo las

\footnotetext{
${ }^{202}$ Recogido en la "Disposición Transitoria" del Reglamento de Organización aprobado por el Comité Nacional el 31 de enero de 1983: "para la celebración de las primeras Asambleas Provinciales y Congresos de Federación corresponderá su convocatoria al Comité Nacional", CDS: "Reglamento de Organización", 31 de enero de 1983, Archivo Jaime Hernando.

${ }^{203}$ Todos los dirigentes nacionales del CDS lo descartaban, salvo quizá en algunas zonas de Ávila o Asturias, Interviews undertaken by Richard Gunther in 1983 (june), AR.

${ }^{204}$ Asambleas de carácter informativo y periodicidad anual.
} 
diferentes candidaturas obtener al menos un $10 \%$ de los miembros de cada una de las Asambleas Provinciales partícipe en el proceso. Se fijaba un número mínimo de compromisarios por provincia (10) que aumentaba proporcionalmente al número de afiliados (sin poder sobrepasar el total 200). Posteriormente, en lo que es un sistema de votación proporcional corregido:

Se dividirá el total de votos obtenidos por cada candidatura por uno, dos, tres, etc., hasta un número igual al de Compromisarios a elegir. Los puestos de compromisarios se atribuirán a las candidaturas que correspondan los mayores cocientes (redondeándose por exceso, las fracciones iguales o superiores a $0{ }^{\prime} 5 \mathrm{y}$, por defecto, las inferiores a $0{ }^{\prime} 5$ ) procediéndose a esta atribución por orden decreciente de éstos ${ }^{205}$.

Los órganos de gobierno federales eran elegidos según los mismos criterios referidos anteriormente a nivel provincial. La renovación de cargos en los órganos de gobierno provinciales o federales se debía llevar a cabo cada tres años. En las Asambleas Constituyentes celebradas entre 1982 y 1986, -salvo el significativo caso de Madrid-, se presentó únicamente una candidatura en las elecciones de los órganos de gobierno ${ }^{206}$.

En este proceso, tuvieron un papel destacado Adolfo Suárez ${ }^{207}$,_“"nuestro Presidente [...] está realizando continuos viajes por la geografía española, coincidiendo con la celebración de las Asambleas, impulsando nuestra implantación"208-, junto a José Ramón Caso y Agustín Rodríguez Sahagún, quienes estuvieron presentes en la mayoría de estos $\operatorname{actos}^{209}$. La presencia de Adolfo Suárez constituía el principal anhelo de los dirigentes y militantes centristas y era el mejor catalizador para aumentar el número de afiliados y atraer la atención de los medios de comunicación, fundamentalmente locales:

Finalmente queda una pregunta. ¿Cuándo tendremos en nuestra comarca nuevamente al Presidente Nacional de CDS D. Adolfo Suárez? Las previsiones eran que estuviese aquí a finales de Enero, pero por diversos problemas relacionados con la labor parlamentaria, parece que el viaje se habrá que aplazar nuevamente.... ${ }^{210}$

\footnotetext{
${ }^{205}$ CDS: "Reglamento de Organización", Art. 11, p. 8, Archivo Jaime Hernando.

${ }^{206}$ En el caso de Madrid, la candidatura electa fue la de Carlos Revilla frente a la encabezada por José Antonio Pérez González, Entrevista con José Antonio Pérez González, 23 de mayo de 2014.

207 "Una silenciosa labor de recorrer España", JÁUREGUI, Fernando: "Reformistas y suaristas preparan sus estrategias para la definitiva batalla por el espacio de centro", El País, 28 de diciembre de 1984.

${ }^{208}$ BDCP, CDS, 2, abril 1984.

209 En el timing de actividades manejado por el gabinete de Suárez y dedicado a la presencia del Presidente y el Secretario General, se incluían los viajes y actos de Rodríguez Sahagún, "Presencia CDS", 1984-5, Carpeta 1, AGP.

${ }^{210}$ Boletín Información, CDS-Tarragona, 0, enero 1983. Véanse por ejemplo, las siguientes "notas de la redacción" de $L a$ Voz de Galicia $(L V G)$ a propósito de las cuatro asambleas provinciales celebradas en Galicia: "Adolfo Suárez asistirá a la asamblea del CDS de Lugo", LVG, 02 de abril de 1985; "Adolfo Suárez presidirá la asamblea del partido en Orense", $L V G, 16$ de septiembre de 1984; "Adolfo Suárez asiste hoy a la asamblea del CDS en Pontevedra", $L V G, 26$ de mayo de 1984; “Adolfo Suárez presidirá
} 
Las intervenciones de Suárez en las distintas provincias, -elaboradas en el seno de su gabinete-, seguían un esquema similar y se basaban en última instancia en la intervención de apertura del Congreso Constituyente. Las partes que las componían eran:

- Felicitación: labor Comisión Gestora, proceso constituyente y nuevos cargos.

- Reafirmación: recordar el papel del CDS en la política española, seguir trabajando en la labor de cohesión (referencias al gobierno, oposición, Operación Reformista).

- Posicionamientos políticos (reconversión, geopolítica, etc.).

- Referencias ideológicas.

- Despedida ${ }^{211}$.

Tras la felicitación a los nuevos cargos electos, desarrollaba los motivos que habían conducido a la creación del partido, "una contestación radical ante la desilusión, la desesperanza y la falta de fé [sic] en la misma democracia y en la libertad", y la apelación al pacto de estado: "el tiempo va demostrando la conveniencia de establecer un acuerdo institucional -llámesele como se quiera- que haga posible una negociación política entre todas las fuerzas representativas" ${ }^{, 212}$. Destacaban las insistentes alusiones a las dificultades que atravesaba el proyecto, en lo que era, una petición de paciencia a los cargos y militantes del partido: “es un proceso largo y lento de búsqueda reflexiva [...] Y somos conscientes de que es necesario tiempo. De ahí, nuestras continuas referencias a esa "travesía del desierto",213. En el I Congreso Federal de Madrid comentaba: "no pretendíamos crear una plataforma electoral. Y, en ese sentido, las elecciones generales

mañana en Santa Cruz (La Coruña) la asamblea provincial del CDS", $L V G$, 09 de febrero de 1984; "El CDS celebrará su congreso gallego los días 15 y 16 con asistencia de Suárez", LVG, 02 de junio de 1985.

${ }^{211}$ Esquema basado en el "Discurso de Clausura de la I Asamblea Provincial de Zamora", noviembre de 1983, Carpeta 2, AGP.

${ }^{212}$ En Palencia, dos años después, desgranaba todos los antagonismos que se estaban originando en la vida nacional: "Es preciso impedir que esa situación continúe. Si sigue así, desde la mezquina y estúpida satisfacción que puede dar la continua crítica al Gobierno y la disolución de la confianza en el Estado, la Sociedad se encerrará en un conjunto de querellas que no conducen a ninguna salida positiva: divergencias patronal-sindicato; divergencias autonomía-estado; divergencias agudizadas entre los partidos [...]", un pacto de estado entendido y defendido en una triple dimensión, "Discurso de Clausura de la I Asamblea Provincial de Palencia”, junio de 1985, Carpeta 2, AGP.

213 "Estamos avanzando con decisión, honradez y competencia por un duro desierto apuntando con realismo la solución a los problemas que tiene nuestro pueblo", $B D C P, 2$, abril 1984. 
y Municipales eran más un obstáculo en el camino que una meta a conquistar"214, concluyendo, "en política son fundamentales los tiempos".

Las referencias al gobierno del PSOE se centraban en alertar sobre los peligros de la "imposición mecánica" de la mayoría para la propia democracia: "y es que, con los votos y la democracia, ocurre lo que con el agua y las plantas. Que su escasez las seca y su exceso las pudre"215. Junto a la "prepotencia" del gobierno y el desconocimiento de la oferta política del CDS, el suarismo criticaba los “cantos de sirena [de la oposición] que propician la confusión [...] Nos preocupa el juego irresponsable de capitalizar, en beneficio propio las dificultades ajenas". O con otras palabras: "No vamos a sumarnos a quienes pretenden fomentar el desencanto. Conservamos íntegra nuestra fé [sic] en la capacidad de un pueblo para darse a sí mismo el destino que ha elegido".

Generalmente, Suárez proseguía subrayando la importancia transcendental de dotar de coherencia y voluntad de permanencia a un proyecto político de centro reformista y progresista, tradicionalmente frágiles en la Historia de España. Como había demostrado la experiencia transicional, dicho proyecto no podía pivotar exclusivamente sobre una persona: "basta con la descalificación y destrucción de esa persona -y de eso sé yo mucho- para que caiga arrastrado todo el proyecto"216. A continuación, enunciaba, los objetivos y conceptos principales que impulsaban la acción del partido: la promoción y protección de las libertades o la remodelación justa y honesta del modelo económico defendiendo la necesaria reconversión y reindustrialización del país-. En la parte final de su discurso, apelaba a la "profundización ideológica", consciente de que era una de las lagunas más notables del partido.

Las intervenciones realizadas hacia finales de 1984 y 1985 integraron algunos nuevos elementos, de acuerdo con las transformaciones que vivía el partido y el panorama político. Por un lado, respecto a la afiliación de personalidades independientes en el partido $u$ otras operaciones señalaba: "nosotros no cerramos la puerta a nadie [...] lo que no podemos ni estamos dispuestos a hacer es hipotecar el futuro de nuestro proyecto político ni a los intereses de unas minorías, ni a los deseos de determinadas personalidades". Por otra parte, reafirmaba su independencia del PSOE recurrentemente puesta en duda en los medios, "se nos acusa de ser meros satélites del

\footnotetext{
214 "Discurso de Clausura de la I Asamblea Federal de Madrid", julio de 1983, Carpeta 2, AGP.

215 "Discurso de Clausura de la I Asamblea Provincial de Granada", julio de 1983, Carpeta 2, AGP.

${ }^{216}$ Ibid., s.p.
} 
partido del Gobierno". El resto de las intervenciones solía seguir grosso modo la argumentación de los discursos llevados a cabo en los años anteriores sobre los planteamientos ideológicos del partido.

Hay que evitar, a toda costa la pérdida de la ilusión colectiva en la solución de los problemas económicos que nos afectan. Durante la Transición política esa ilusión cristalizó en el consenso, el acuerdo, la transigencia y el pacto de todas las fuerzas políticas, sociales y económicas. Y eso -tan criticado luego- constituyó el activo de mayor valor para la construcción de una democracia pluralista y estable ${ }^{217}$.

En total, Suárez estuvo presente al menos en 36 de las 55 Asambleas Constituyentes Provinciales, Insulares o Federales celebradas en el período 1982-1986 (Anexo VII). Entre enero de 1984 y junio de $1985^{218}$ hizo un total de 41 viajes de partido por el país $^{219}$-incluyendo su intervención en Asambleas Provinciales, que en este período alcanzó las 23-, así como otros 20 actos públicos, parlamentarios o periodísticos -desde conferencias a entrevistas-. En total, según calcula J. L. Garro, jefe de gabinete, empleó más de 150 fines de semana en viajes de partido entre finales de 1982 y las elecciones generales de 1986, la mayor parte de ellos acompañado de un único ayudante generalmente, el propio Garro-, conductor y escoltas. Según confesó Suárez en Lérida: "[recorro España] como un maletilla", para que el partido tuviera futuro más allá de su liderazgo, "porque ya conozco, por propia experiencia, la táctica tan española de 'calumnia' que algo queda"220. Las ruedas de prensa del político abulense centraban la atención de los medios locales y en ellas se entremezclaba la actualidad del CDS, su pasado en la presidencia y su opinión sobre la OTAN o la Operación Roca (Anexo VIII). Como se ve en la tabla inferior, junto a Suárez, Caso y Rodríguez Sahagún fueron los miembros más activos del partido en este período tanto a nivel de organización como de proyección externa. En un segundo nivel, debemos resaltar a Rafael Calvo

\footnotetext{
217 “'Discurso de Clausura en la I Asamblea de Palencia", junio de 1985, Carpeta 2, AGP.

${ }^{218}$ Excluyendo el mes de abril de 1984 del que no disponemos de información sistemática.

${ }^{219}$ Hemos dado en llamar "viaje del partido" a la visita a una capital de provincia que podía durar todo el fin de semana y solía incluir: comida/cena coloquio, reunión con militantes locales/inauguración sede/reunión gestora, recorrido por otras localidades y ruedas de prensa. Para ejemplificar esta idea desarrollamos a continuación la visita a La Coruña del domingo 04 de mayo de 1985, donde acudía desde Lugo tras clausurar la I Asamblea Provincial la jornada anterior: "el programa de la visita que hoy realizará a La Coruña Adolfo Suárez se iniciará por la mañana en la localidad de Cariño, donde tendrá una charla-coloquio; a continuación visitará Moeche, para trasladarse seguidamente a Neda, para participar en una comida-coloquio con los militantes y simpatizantes del CDS en "Casa Paco". Por la tarde, en el Instituto Masculino de Ferrol está prevista otra charla-coloquio, para visitar a continuación Pontedeume y Miño. Finalizará la jornada en La Coruña en donde está programada una cena-coloquio en el Hotel Riazor", $L V G, 04$ de mayo de 1985.

${ }^{220}$ Segre, 09 de abril de 1984.
} 
Ortega (Castilla y León), Javier Soto (actividades de formación) y Fernando Castedo (particularmente activo en la formación del partido en Galicia:

Tabla 16: Actividades de los miembros del Comité Nacional entre enero de 1984 y junio de 1985.

\begin{tabular}{|l|l|l|l|}
\hline \multicolumn{1}{|c|}{ Nombre } & Actos partido $^{\mathbf{2 2 1}}$ & Asamblea $^{\mathbf{2 2} 2}$ & Otros \\
\hline Adolfo Suárez & 18 (Presidente Nacional) & 23 & 19 \\
\hline J. R. Caso & 35 (Secretario General) & 13 & 9 \\
\hline A. Rodríguez Sahagún & 18 (Diputado Nacional) & 6 & 21 \\
\hline R. Calvo Ortega & 5 (CDS-Castilla y León) & 4 & 11 \\
\hline Fernando Castedo & 19 (CDS-Galicia) & 5 & 14 \\
\hline A. Rebollo & 3 (CDS-Asturias) & - & 5 \\
\hline J. L. Glez. Quirós & 1 (CDS-Madrid) & 2 & 1 \\
\hline M. A. Eced & - & 1 & - \\
\hline L. Morso & 3 (CDS-Madrid) & 2 & - \\
\hline Fco. Villodres & 1 (CDS-Andalucía) & - & - \\
\hline F. Ysart & 3 & - & 2 \\
\hline A. Cádiz & - (CDS-Madrid) & 2 & - \\
\hline L. Buil & 1 (CDS-Aragón) & 1 & 3 \\
\hline J. A. Escudero & - & 3 & - \\
\hline G. Harguindey & - & 2 & - \\
\hline E. Pujalte & 3 (CDS-Valencia) & 2 & - \\
\hline M. Jiménez de Parga & 2 (CDS-Cataluña) & 1 & 4 \\
\hline C. Revilla & 2 (Área sectorial) & 1 & 1 \\
\hline J. Soto & 2 (Área sectorial) & 3 & 4 \\
\hline J. M. Viana & - (CDS-País Vasco) & - & 1 \\
\hline A. Marco Tabar & - (CDS-País Vasco) & - & 1 \\
\hline M. de Sárraga & - (CDS-Lérida) & - & - \\
\hline J. V. Cebrián & - & - & - \\
\hline
\end{tabular}

Elaboración propia a partir de la documentación de la Carpeta 1, AGP 223 .

En este período, la dirección del partido había acudido a un total de 14 inauguraciones de sedes en localidades como Sevilla, Valladolid, Málaga, Zaragoza, Vigo o Palma de Mallorca. Del mismo modo, se habían constituido numerosos comités locales y comarcales, con especial intensidad en Canarias, Castilla y León, Asturias, Madrid y la Comunidad Valenciana. En mayo de 1985, este era el balance del Comité Nacional sobre el grado de implantación del partido:

La infraestructura de partido, maquinaria electoral y militancia ha crecido y sigue creciendo de modo satisfactorio, aunque con gran diferencia de unas provincias a otras. Se han celebrado gran número de Asambleas provinciales y regionales $\mathrm{y}$, aunque con un cierto retraso, en plazo breve estarán la totalidad de las mismas y elegidos los órganos

\footnotetext{
${ }^{221}$ No se incluyen en ningún caso las reuniones del Comité Nacional. Se ha incluido a Carlos Revilla, quien no era miembro del Comité Nacional en ese momento.

${ }^{222}$ Constituyentes, anuales o de elección de compromisarios. Asambleas provinciales, insulares o federales.

${ }^{223}$ Datos recogidos en la documentación “Actividades. Miembros Comité Nacional” de Carpeta 2, AGP. Se ha usado exclusivamente esta información para poder llevar a cabo un análisis comparativo -lo que no implica, y más en acciones de este tipo, en ocasiones difíciles de definir- una absoluta exhaustividad.
} 
provinciales del Partido. Paralelamente, en gran número de provincias existen constituidos cierto número de comités locales ${ }^{224}$.

Particularmente negativa se consideraba la situación en Andalucía, Extremadura ${ }^{225}$ y Cataluña. En junio de 1986, se habían formalizado los órganos de gobierno federales del partido de Andalucía, Galicia -ambos en el marco de potenciación del partido previo a comicios autonómicos-, Canarias y Castilla y León ${ }^{226}$. En el resto de casos hubo que esperar a la III Legislatura, funcionando hasta su constitución definitiva con reuniones periódicas de Gestoras compuestas, al menos, por los presidentes y secretarios provinciales.

En lo que respecta a la formación de cuadros y militancia el balance era negativo a nivel nacional. La escasez de medios, la dificultad para celebrar convenciones o asambleas estatales había hecho imposible el seguimiento de los programas y cursos de formación establecidos, “es aquí, donde el cumplimiento del plan de actuación arroja un saldo negativo, y debemos, por ello, prestarle especial atención" 227 . Se publicó un Boletín, cuya edición tuvo que ser reemprendida hasta en cuatro ocasiones ${ }^{228}$, se organizaron algunas Jornadas Culturales ${ }^{229}$ o ciclos de $\operatorname{conferencias~monográficos~}^{230}$ y se intentó participar en eventos sociales de mayor repercusión:

Demostremos que tenemos un mayor rigor profesional, administrativo, político, que el partido socialista y por tanto que, estando en posiciones digamos de centro izquierda, progresista, tenemos una mayor capacitación técnica y [...] merecemos ese voto ${ }^{231}$.

\footnotetext{
${ }^{224}$ Comité Nacional del CDS: "Plan de Actuación 1985", 13 de mayo de 1985, Carpeta 2, AGP.

${ }^{225}$ En julio de 1984 en el resumen de actividades de miembros del CN todavía se podía leer: "J. R. Caso, L. Morso, [quien desde el I Congreso de UCD se había encargado de la coordinación del partido en Extremadura] Badajoz, 17 de julio de 1984. Cena. Grupo de personas interesadas espacio centro". Una época en la que se había iniciado en otras comunidades la celebración de las Asambleas Provinciales y en Badajoz no se contaba todavía con núcleos sólidos de suaristas, Carpeta 1, AGP, y Entrevista con Laura Morso. 11 de febrero de 2015.

${ }^{226}$ Sin contar los órganos de federación uniprovinciales como Madrid, Baleares, Asturias, Cantabria, La Rioja y Murcia. En Murcia se vivieron episodios de división que pusieron en riesgo la viabilidad del partido en esta etapa.

${ }^{227}$ Comité Nacional del CDS: "Plan de Actuación 1985", 13 de mayo de 1985, Carpeta 2, AGP.

${ }^{228}$ Se inició en noviembre de 1982 y tras un período de inactividad y siempre bajo la dirección de Alfonso Íñiguez se retomó en enero de 1984 con, en principio, periodicidad mensual, posteriormente en junio de 1985 y finalmente, en noviembre de ese mismo año, teniendo continuidad hasta 1991.

${ }^{229}$ Como las I Jornadas socioculturales en Talavera de la Reina coordinadas por Javier Soto que contaron con conferencias de Rodríguez Sahagún sobre "Economía y empresa", "Libertad de expresión en la España de hoy" con Fernando Castedo y "El centrismo político: presente y futuro" a cargo de Caso, en: "Actividades. Miembros del CN", Carpeta 1, AGP.

${ }^{230}$ Economía y Pequeña y Mediana Empresa (Rodríguez Sahagún, Rebollo, 1984), el Espacio de Centro (Caso, 1984), Administración Pública (Soto, 1985), Sistema de partidos (Morodo, 1985), Ciclos de Conferencias, prensa, radio y TVE, etc.

${ }^{231}$ Interview undertaken by Richard Gunther, in 1983 (june), AR.
} 
Un ejemplo fueron las jornadas celebradas por la Gestora del CDS en Castilla-La Mancha en Belmonte donde, contando con la presencia de Suárez, se analizaron aspectos de legislación municipal bajo la dirección de Javier Soto, responsable del área de administración local del partido ${ }^{232}$. Junto a militantes del CDS, se intentó atraer en este tipo de jornadas a políticos que tras el fin de UCD habían integrado listas de independientes -"no veían claro todavía que pasaba en el centro"- y quisieran continuar en política: "si nosotros a nuestros concejales damos un buen asentamiento, y ven que funciona esto, creemos que muchos independientes pueden pedir incorporarse al CDS y nosotros creemos que damos una buena [imagen] [...] en el terreno municipal” ${ }^{\text {"233 }}$. En cierto modo, el CDS buscaba constituir un partido de cuadros altamente tecnificados y cualificados, cuya capacidad de gestión técnica, marcara la diferencia con el resto de partidos.

Con el fin de ilustrar mejor este proceso de institucionalización, consideramos necesario abordar con un poco más de detenimiento los principales rasgos del CDS en una provincia concreta - sin dejar de hacer mención, cuando sea necesario, a otros territorios-. Hemos escogido la provincia de Zaragoza por haber constituido uno de los procesos más acelerados de implantación y por contar, desde 1983, con representación autonómica.

En Zaragoza, el núcleo del nuevo partido lo formó José Luis Merino Hernández, consejero de la Diputación General de Aragón (1981-1982) y cuyas discrepancias en el proceso de desarrollo autonómico llevado a cabo por UCD durante los gobiernos de Calvo-Sotelo le condujeron a abandonar el partido junto a otros políticos centristas como José María Lasierra, José Antonio Escudero - cabeza de lista para el Congreso en 1982-, L. Oro, A. Romero, etc ${ }^{234}$. La Asamblea Provincial Constituyente se celebró tempranamente, en torno a diciembre de $1983^{235}$. El primer Presidente Provincial fue José Luis Merino Hernández y el Secretario Ejecutivo José María Lasierra; las

\footnotetext{
${ }^{232}$ ABC, 28 de marzo de 1984.

${ }^{233}$ Interview undertaken by Richard Gunther, in 1983 (june), AR. Otro ejemplo de este tipo de iniciativas, llevadas a cabo a nivel regional y provincial fue el encuentro de Adolfo Suárez con alcaldes y concejales independientes en Valencia 16 y 17 de febrero de 1984, en Carpeta 2, AGP.

${ }^{234}$ José Luis Merino había sido Vicepresidente de la Diputación Provincial de Zaragoza, de 1979 a 1981 y Consejero de la Diputación General de Aragón, de 1981 a 1982 con UCD. Sobre este período véase, MERINO HERNÁNDEZ, José Luis: "Los partidos...", pp. 117-137; DE MIGUEL, Rafael: "Centro Democrático y Social en los ayuntamientos" en VV.AA.: Memorias de los partidos: crónica..., pp. 138149.

${ }^{235}$ Según la documentación del gabinete de presidencia de Suárez antes del 21 de diciembre de 1983 y en cualquier caso, posterior a las elecciones de mayo, s.t., Carpeta 1, AGP.
} 
reuniones de la Ejecutiva Provincial se celebraban mensualmente. En total, de los 15 miembros de la ejecutiva provincial, 8 habían pertenecido a UCD, caso de los anteriores y 2 eran alcaldes electos desde 1983. Por lo tanto, era parte de la clase política ucedista protagonista en el proceso de Transición en Zaragoza quién había puesto en pie el nuevo partido de Suárez y se encargaba de su dirección - este hecho repercutía favorablemente en el grado de cohesión y subsiguiente implantación del partido-. Desde el punto de vista sociológico, en su mayoría ejercían profesiones liberales o actividades empresariales. En nuestro análisis del Comité Ejecutivo encontramos los siguientes desempeños: notario, veterinario (2), catedrático, profesor, comercial, industrial hostelero, inspector de trabajo, agricultor, industrial, abogado, empresario, profesor de instituto, profesor adjunto de derecho del trabajo y médico ${ }^{236}$.

A raíz de las elecciones municipales de 1983, se consiguieron en la provincia de Zaragoza: 44 concejales, 9 alcaldes y 12 tenientes alcaldes ${ }^{237}$. A pesar de ser una de las provincias donde mejores resultados había obtenido, su presencia todavía era irregular en el territorio. Tenía militancia o representación en 27 de algo más de 200 municipios, concentrándose en el entorno de la ciudad de Zaragoza y la zona de Calatayud.

Junto a los órganos de gobierno provinciales, en noviembre de 1983 estaban constituidas cinco áreas de trabajo sectorial que ponen de manifiesto la prioridad absoluta de la implantación del partido en esta primera fase: Organización, Formación, Información, Finanzas y Relaciones con la Provincia. Las actividades fundamentales del Comité Ejecutivo Provincial (CEJ) y las secretarías ejecutivas consistían en mejorar la infraestructura local y provincial y la captación de militancia. Durante aquel mes, se constituyó un grupo de apoyo parlamentario formado por militantes -con reuniones semanales- y se había dado forma a un boletín de información mensual ${ }^{238}$.

Al margen del CEJ de Zaragoza, a nivel regional existía una Gestora del CDSAragón aunque de funcionamiento bastante irregular. En la Gestora estaban representadas las tres provincias a partes iguales, en razón de cuatro miembros cada una. Se impulsó un modelo de organización propio para las juventudes del partido y se creó en enero de 1984 la gestora local de Zaragoza -con diez miembros- y cuyos objetivos fundamentales eran: el aumento de la militancia y su organización en distritos

\footnotetext{
236 “Centro Democrático y Social. Zaragoza”, s.f., Carpeta, 2, AGP.

${ }^{237}$ De los 65, 46 eran agricultores y su edad media era ligeramente superior a los 45 años, AMINHAP.

${ }^{238}$ En diciembre, se creó el Comité de Conflictos del Partido, encargado de proponer al CEJ las medidas disciplinarias pertinentes.
} 
o barrios y sobre todo, el seguimiento de la actividad municipal -el alcalde de Zaragoza era R. Sainz de Varanda (PSOE) ${ }^{239}$. Zaragoza se podía considerar uno de los "éxitos" del CDS en cuanto a implantación y desarrollo territorial.

Como conclusión, el estado del partido en 1985 era aun con todo positivo. Los frutos conseguidos se consideraban "quizás superiores a los que pudimos prever -dadas las dificultades que hemos pasado y que todavía pasamos- y se deben principalmente a que estamos transmitiendo una imagen de seriedad y de rigor". Los retos de cara a las elecciones legislativas de 1986 y al II Congreso Nacional previsto para finales de 1985 (y pospuesto hasta 1986) pasaban por seguir trabajando en dos grandes líneas: "Implantación" y "Pensamiento", destacando como síntesis de ambos ejes la celebración de la I Convención Nacional en mayo de 1985.

Si hasta ahora nos hemos centrado en la "implantación" territorial y los resultados electorales del partido desde 1982, a continuación abordaremos cómo se tradujo el "pensamiento" e ideología del CDS en los posicionamientos políticos defendidos durante la II Legislatura.

${ }^{239}$ Boletín Informativo CDS-Aragón [BICDS-A], 1, noviembre 1983, BICDS-A, 3, enero 1984 y BICDSA, 4, febrero 1984 . 


\section{Capítulo 4:}

\section{EI CDS en la vida política española durante la II Legislatura (1982- 1986)}

El período comprendido entre 1982 y 1986 constituyó la primera legislatura con mayoría absoluta del PSOE en el Congreso de los Diputados. El ejecutivo socialista, liderado por Felipe González, contó entonces con una inmejorable coyuntura para llevar a cabo su labor de gobierno beneficiándose no sólo de la nueva correlación de fuerzas parlamentarias sino también de la recuperación económica internacional, particularmente perceptible desde los años 1984 y 1985.

Siguiendo a Pere Ysàs, podemos agrupar en tres grandes bloques las medidas desarrolladas por los gobiernos socialistas durante este período ${ }^{1}$. Por un lado, es preciso constatar las nuevas orientaciones, transformaciones y cambios puestos en marcha por los gobiernos socialistas en política social, la cual constituyó “el ámbito donde la acción gubernamental más se acercó a las expectativas generadas", agriamente discutida por los conservadores (caso de la LODE) ${ }^{2}$. En segundo lugar, ha sido habitual subrayar las continuidades con los ejecutivos de UCD en política antiterrorista, autonómica y económica ${ }^{3}$, ante las críticas de otros sectores de izquierda, sindicatos y movimientos sociales (reconversión industrial o Ley Antiterrorista) ${ }^{4}$. Finalmente, abordaremos los aspectos relativos a la política de Seguridad y Defensa (OTAN y relaciones con Estados

\footnotetext{
${ }^{1}$ Algunas de las obras fundamentales para el estudio de este período son: POWELL, Charles T.: España en democracia, 1975-2000, Barcelona, Plaza \& Janes, 2001; SOTO CARMONA, Álvaro: Transición y cambio en España, Madrid, Alianza Editorial 2005; RUIZ, David: La España democrática (1975-2000): política y sociedad, Madrid, Síntesis, 2002; MARTÍNEZ, Jesús A. (coord.): Historia de España. Siglo XX: 1939-1996, Madrid, Cátedra, 1999; TUSELL, Javier (coord.): Historia de España. T. XLII, La transición a la democracia y el reinado de Juan Carlos I, Madrid Colección Menéndez Espasa Calpe, 2003; SOTO CARMONA, Álvaro y MATEOS LÓPEZ, Abdón (eds.): Historia de la época socialista, Madrid, Sílex, 2013. Destacar el número monográfico de la revista Ayer a cargo de Pere Ysàs: "Dossier. La Época Socialista: política y sociedad (1982-1996)", Ayer, 84, 2011.

${ }^{2}$ YSÀS, Pere: “Cambio y continuidades: tres lustros de gobiernos socialistas”, Ayer, 84, 2011, p. 27.

${ }^{3}$ Ibid.

4 Nuestro recorrido va a pulsar los tres cleavages básicos para comprender los mecanismos de la sociología electoral en España: el de clase (a través de los posicionamientos socio-económicos), el religioso (aborto, educación) y el nacional o regional (desarrollo autonómico). Si bien, como han señalado numerosos autores los dos primeros, aún existentes, se encontraban "minimizados" desde la Transición, y era el tercero la "escisión diferencial" del comportamiento electoral español, tal y como señala RUIZ CONTRERAS, Marta: La imagen de los partidos políticos, Madrid, CIS, 2007, pp. 36-44.
} 
Unidos); epígrafe que será tratado en el capítulo 5. Podemos decir que en conjunto, bajo los gobiernos del PSOE se acentuó la labor reformista iniciada por UCD años antes, sin asumir excesivos riesgos y en consecuencia, generando algunas contradicciones de carácter ideológico dentro del socialismo español ${ }^{5}$. En el presente epígrafe comenzaremos por el análisis, en sus términos más generales, de la actitud del CDS frente a los ejecutivos socialistas - como partido minoritario de oposición-y lo haremos, teniendo como hilo conductor las intervenciones de Adolfo Suárez en los Debates sobre el Estado de la Nación.

\section{1. El CDS y el gobierno socialista: los Debates sobre el Estado de la Nación}

La actividad del CDS durante la II Legislatura (1982-1986) estuvo relegada a un ámbito absolutamente secundario en el curso de la vida política española. En ocasiones, muchos de sus posicionamientos ni siquiera trascendían en los medios. Como señala Caso, a nivel nacional, la historia del partido en estos años estuvo básicamente sustentada por la intensa actividad parlamentaria de Rodríguez Sahagún ${ }^{6}$ y las escasas intervenciones en el Congreso de Suárez, principalmente, a propósito del Debate sobre el Estado de la Nación tal y como se ve en la tabla inferior:

Tabla 17: Intervenciones en el Congreso de Adolfo Suárez en la II Legislatura?

\begin{tabular}{|l|l|}
\hline Fecha & Motivo \\
\hline Noviembre de 1982 & Debate de investidura del Presidente de Gobierno: Felipe González \\
\hline Septiembre de 1983 & Debate sobre el Estado de la Nación \\
\hline Octubre de 1984 & Debate sobre el Estado de la Nación \\
\hline Junio de 1985 & Autorización para la adhesión de España a las CEE \\
\hline Octubre de 1985 & Debate sobre el Estado de la Nación \\
\hline Febrero de 1986 & Debate sobre política de paz y seguridad (referéndum OTAN) \\
\hline
\end{tabular}

Elaboración propia.

\footnotetext{
${ }^{5}$ SOTO CARMONA, Álvaro: Transición ..., p. 200.

6 "Era empezar de nuevo. Después de haber estado en lo más alto de la política española, tenían que comenzar desde abajo. '-Yo, que había estado toda mi vida acostumbrado a valerme de secretarias, [...] que me ayudaran en mis tareas, durante cuatro años tuve que hacérmelo todo' [...] Consiguió el récord de enmiendas presentadas y admitidas [...] Sahagún recuerda que en aquellos años tuvo que hacer en el Congreso de los Diputados de todo: botones, secretario, diputado, portavoz...”, en DEL RÍO LÓPEZ, Ángel: Agustín Rodríguez Sahagún, Grupo Libro 88, Madrid, 1991, pp. 114-5.

${ }^{7}$ Intitulado en ese curso parlamentario: "Debate sobre la comunicación del Gobierno formulada a los efectos de lo establecido en los artículos 196 y 197 del Reglamento". A propósito de la asistencia al Parlamento de los líderes centristas, comentaba Fernando Jáuregui: "Los huecos en el Grupo Centrista (empezando por el ex presidente Leopoldo Calvo-Sotelo) son también mayoritarios y crónicos, lo mismo que en el Grupo Mixto (Adolfo Suárez parece continuar su periplo latinoamericano y Agustín Rodríguez Sahagún tampoco había hecho ayer acto de presencia hasta media tarde)" en "Fraga, el oso y el escaño", El País, 17 de noviembre de 1983.
} 
La primera intervención parlamentaria de Adolfo Suárez en la II Legislatura, después de su voto favorable a la investidura de Felipe González, no llegó hasta el 21 de septiembre de 1983. Desde comienzos de ese año, el CDS se había distanciado públicamente de la gestión socialista en dos aspectos bastante significativos: el proyecto de ley de despenalización del aborto y el decreto-ley de expropiación de RUMASA ${ }^{8}$. También, se habían vertido fuertes críticas al uso partidista de TVE ${ }^{9}$. Sin embargo, como hiciera a lo largo de la legislatura, había marcado distancias con la oposición comandada por AP -considerada "catastrofista" y "obstruccionista"-, sin apoyar los recursos al Tribunal Constitucional, apelando a un desarrollo legislativo consensuado del que el mejor ejemplo fue su posición ante la LODE- y orientando su discurso a alertar sobre los peligros del bipartidismo y la subsiguiente bipolarización ${ }^{10}$. Junto a los planteamientos ideológicos del CDS, hay que tener en cuenta la experiencia política de sus líderes, comenzando por Suárez, para entender un discurso por lo general bastante prudente sobre las medidas del Gobierno.

El CDS, -representado por Rodríguez Sahagún-, se abstuvo en la votación de los Presupuestos Generales del Estado “provisionales” recogidos en la Ley 5/1983, de 29 de junio, de medidas urgentes en materia presupuestaria, financiera y tributaria, convalidación del Real Decreto-Ley 24/1982, de 29 de diciembre de 1982. Meses después, Rodríguez Sahagún retiró su enmienda de devolución presentada a los presupuestos de "resignación" de 1983, anunciando su abstención y consiguiendo la aceptación de diversas enmiendas parciales. En octubre de ese mismo año, de cara a la aprobación de los PGE de 1984, se mantuvo una enmienda de devolución aduciendo

\footnotetext{
${ }^{8}$ Distanciamiento reflejado en el "Boletín" de febrero de 1983, OICDS, 3, 1986.

${ }^{9}$ El uso político de la TV estatal como "máquina de propaganda" fue una constante desde el inicio de la democracia en España: "governing parties have routinely supplemented these [medios] [...] by turning the state televisión network, RTVE, into a propaganda machine. In the 1970's, Suárez (in the late Franco years director-general of RTVE) and the UCD did this. These efforts were, however, suurpassed by those of González and the PSOE in the 1980's, who were widely criticized for their cynical exploitation of power". HOLLIDAY, Ian: "Building a Parties State in a New Democracy" en WEBB, Paul, FARREL, David y HOLLIDAY, Ian: Political parties in advanced industrial democracies, N. York, Oxford University Press, 2003 p. 269. Sobre el papel de la TV en la Transición pueden verse dos excelentes estudios en PALACIOS, Manuel: La televisión durante la Transición española, Madrid, Cátedra, 2012 y MARTÍN JIMÉNEZ, Virginia: Televisión española y la transición democrática: La comunicación política del cambio (1976-1979), Valladolid, UVA, 2013.

${ }^{10}$ En este caso, la prudencia de Suárez no era seguida por su electorado que según el CIS consideraba en un 33\% que el gobierno respeta poco o nada la Constitución mostrándose "casi tan beligerante como los de AP a la hora de valorar este aspecto de la actuación socialista”, El País, 05 de diciembre de 1983.
} 
que eran contradictorios dentro "del planteamiento de ajuste a medio y largo plazo para la adecuación del aparato productivo y la necesaria reasignación de recursos"11.

En vísperas del primer Debate sobre el Estado de la Nación de la democracia española, el Comité Nacional del CDS identificaba "tres grandes líneas de preocupación" respecto a la política socialista: "la peligrosidad de la política internacional en su conjunto, la arriesgada confianza en el "tirón" americano como factor impulsor de la Economía nacional y el exceso de arbitrariedades y menoscabos en el terreno de las libertades públicas" ${ }^{\prime 2}$.

Críticas, que no obstante, no significaban una absoluta disparidad de criterio con el Gobierno, al menos en lo que respecta a puntos básicos como el grueso de la política económica -a pesar de las críticas-, la política exterior y la lucha antiterrorista.

En el primer Debate de la democracia Suárez efectuó un discurso sobrio, y en el que tuvieron un particular protagonismo el análisis de las Fuerzas Armadas y su propuesta de Pacto de Estado, aspectos que retomaban los principios básicos del Manifiesto centrista -supremacía del poder civil y consenso- ${ }^{13}$. En primer lugar, aludió a los riesgos existentes para la consolidación de la monarquía parlamentaria y la modernización económica, política y social de España, apostando por el fomento de las libertades -“muy especialmente, la libertad de expresión”- y de los hábitos democráticos, "desterrar las inercias históricas que conducen a esa terrible simplificación de dividir a los españoles en buenos y malos, en función de su ideología”. En segundo lugar y de forma prolija, denunció algunas actitudes existentes en el seno de las Fuerzas Armadas "buscando, directa o indirectamente, una autonomía para la institución militar y una cierta capacidad para influir en el mundo de la política interior o exterior de España", subrayando que su única misión era la "de defender la soberanía nacional [...] [que] reside en el pueblo y, por tanto, en sus legítimos representantes" 14 . En este sentido, animaba al Gobierno a profundizar en su reforma de las FAS que debía servir para poner fin a la “deformación que una tradición histórica de

\footnotetext{
${ }^{11}$ DSCD, Sesión Plenaria, 07 de octubre de 1983, n 67, p. 3145; El País, 10 de junio de 1983.

${ }^{12}$ CONTRERAS, Lorenzo: "Los síndromes de una política”, $A B C, 14$ de septiembre de 1983.

13 "Adolfo Suárez pide un amplio pacto social y político", El País, 22 de septiembre de 1983; "Las FAS no son jueces de la evolución política”, $A B C, 22$ de septiembre de 1983.

${ }^{14}$ La semana previa a este Debate estuvo marcada por la destitución del Capitán General de la VII Región Militar tras unas controvertidas declaraciones favorables al 23-F en el semanario Interviú. La decidida actuación del ejecutivo había sido respaldada por la mayoría de los partidos -el CDS había mostrado su "satisfacción"-, véase, "Todos salvo Fraga aplauden la decisión", El Noticiero Universal, 17 de septiembre de 1983.
} 
pronunciamientos militares ha causado en determinados sectores de nuestras Fuerzas Armadas"15. En tercer lugar, apelaba a la consecución de un gran pacto de fuerzas políticas y sociales -Pacto de Estado- capaz de afrontar los desafíos existentes en economía, terrorismo, desarrollo autonómico y política exterior, sin haber observado todavía manifestaciones de la supuesta voluntad negociadora del gobierno ${ }^{16}$. En síntesis, en los apenas siete minutos de intervención de los que dispuso, Suárez renovaba la confianza depositada en el proyecto de modernización socialista. En su réplica, Felipe González se limitó a agradecer la las palabras de Suárez "en su contenido y en su forma" y reivindicar la predisposición abierta y dialogante del gobierno ${ }^{17}$.

La oferta de pacto realizada por Suárez suponía el núcleo y el eje de su intervención y recibió algún comentario elogioso en los medios de comunicación que entrevieron en sus palabras rescoldos de la etapa del "consenso" transicional: "Adolfo Suárez repitió desde la oposición ideas parecidas a las que formulaba cuando ocupaba la presidencia del Gobierno, lo que habla en favor de él"18. En $A B C$, José María Fernández Rúa aprovechaba la intervención de Suárez para señalar: "el ex presidente sugirió que el Gobierno se enfrente a los problemas con firmeza, decisión y autoridad sin desoír el pacto social que ha ofrecido Manuel Fraga" ${ }^{\prime 19}$. Carlos Santos en Diario 16 se refirió a "la línea institucional que mantiene desde que fundó el CDS". En el mismo periódico, J. L. Gutiérrez también tildaba las palabras de Suárez como de "intervención de Estado, acaso excesivamente abstracta, pero de altura, elogiada por el propio presidente [...] remanso de concordia, sensatez y buenos alimentos" ${ }^{\text {,20. }}$.

La amistosa cortesía entre González y Suárez, no por previsible, dejó de suscitar ironías y alusiones sobre un supuesto "entreguismo" político del abulense. García Candau en El País escribía: "Suárez brindó a Felipe González un apoyo casi tan explícito como el del portavoz del Grupo Socialista, Javier Sáenz de Cosculluela, que

\footnotetext{
15 Suárez era el líder "con mayor sensibilidad militar" y entrevía "claras alusiones a las debilidades y deficiencias de Narciso Serra en la política de nombramientos", aludidas explícitamente por Suárez en su intervención, en GUTIÉRREZ, José Luis: “Los pesos pesados”, Diario 16, 22 de septiembre de 1983.

${ }^{16}$ DSCD, Sesión Plenaria, 21 de septiembre, no 56, p. 2691 y ss.

${ }^{17}$ No hubo réplica por parte de Suárez, ibid., p. 2697.

${ }^{18}$ Editorial: "Después del tedio", El País, 22 de septiembre de 1983. Sin embargo, la petición de diálogo de Adolfo Suárez, en la que el CDS se ofrecía como un interlocutor más en esta búsqueda de soluciones a los desafíos estructurales del gobierno, "no se podía, ni debía equiparar, matizaba en sus conclusiones, [a] una vuelta al consenso", DSCD, Sesión Plenaria, 21 de septiembre de 1983, n 56, p. 2693.

${ }^{19} A B C, 22$ de septiembre de 1983. En el editorial de Diario 16, cobraba protagonismo la figura de Miquel Roca, "Don Manuel y don Miguel”, Diario 16, 22 de septiembre de 1983.

${ }^{20}$ GUTIÉRREZ, José Luis: "Los pesos pesados", Diario 16, 22 de septiembre de 1983.
} 
cerró el debate" ${ }^{, 21}$. Jaime Campmany desde $A B C$ constataba una nueva indefinición en la trayectoria política de Suárez: "no está en el Gobierno [...] y se integra en la oposición, pero no está en la oposición [...] ¿en dónde demontre está este muchacho? Habría que buscar urgentemente para don Adolfo Suárez un escaño especial en el limbo parlamentario",22.

Precisamente, a finales de 1983, los esfuerzos del CDS se encaminaron a contrarrestar, lo que se consideraba una intensa "campaña de desprestigio" y en la que los principales rumores vertidos sobre el partido suarista versaban sobre su dependencia financiera del PSOE. Al margen de esta hipótesis -como veremos, la más extendida en la época- no era extraño encontrar referencias a su próxima desaparición, su vinculación con Ruiz-Mateos o la relación de personas de su entorno en el llamado caso de los videomarcadores ${ }^{23}$. En noviembre y diciembre de aquel año las encuestas del CIS otorgaban una intención de voto directo al CDS de sólo un $1 \%$ y la valoración de Suárez se encontraba entre las más bajas de su serie histórica $(3,81 \text { y 4,32 respectivamente })^{24}$. Las manifestaciones efectuadas por el Secretario General del partido en diciembre de 1983, a propósito de la inauguración de la nueva sede nacional en la Calle Jorge Juan de Madrid reflejaban este estado de ánimo: "ha tenido un efecto importante ante los medios de comunicación: ha conseguido acallar la constante rumorología indeseada sobre la desaparición de nuestro Partido"25.

En este contexto, a comienzos del año 1984, el CDS se desmarcó nuevamente de tres proyectos de ley de notable envergadura: la Ley Orgánica de Libertad Sindical $(\mathrm{LOLS})^{26}$, la Ley Orgánica de Régimen Electoral General (LOREG) ${ }^{27}$ y la Ley de Bases

\footnotetext{
${ }^{21}$ GARCÍA CANDAU: "Los nacionalistas y Santiago Carrillo criticaron duramente al gobierno por su política autonómica y social", El País, 22 de septiembre de 1983.

${ }^{22}$ CAMPMANY, Jaime: "Comer palabras", $A B C, 24$ de septiembre de 1983.

${ }^{23}$ CONTRERAS, Emilio: Suárez..., p. 315 y ss. No fueron los únicos: el financiero catalán Pedro Baret acusaba en su libro "Mi verdad y algo más", presentado a comienzos de 1984 a Suárez de haber usado fraudulentamente, una década atrás, fondos de "ENTURSA", La Voz de Galicia, 10 de febrero de 1984. Poco después, fue objeto de rumores la relación de sus bienes patrimoniales "antes y después" de ejercer la presidencia del gobierno, véase, ORTIZ FERNÁNDEZ, Celestino: "El centro-derecha y el sexo de los ángeles", ABC Sevilla, 08 de mayo de 1984.

${ }_{24}$ Tabla1: Evolución de la intención de voto en "La evolución de la intención de voto y otros indicadores políticos: 1983-1986", Revista de Investigaciones Sociológicas (REIS), 35, 1986, pp. 276.

${ }^{25}$ CASO GARCÍA, José Ramón: "Carta del Secretario General”, BDCP, CDS, 1, enero 1984. Acuerdo del Comité Nacional del 07 de diciembre de 1983, RPP, Acta Notarial, nº 233, José Roán Martínez, 13 de febrero de 1984.

${ }^{26}$ Al igual que el resto de grupos de la oposición, Rodríguez Sahagún y Suárez González votaron en contra en la Votación plenaria del día 17 de mayo de 1984 sobre el Proyecto de Ley de Libertad Sindical (votación final de conjunto del proyecto de ley).

${ }^{27}$ Rodríguez Sahagún y Suárez González estuvieron ausentes en la Votación plenaria del día 19 de abril de 1985 del Proyecto de Ley Orgánica de Régimen Electoral General (votación de totalidad). Las
} 
del Régimen Local ${ }^{28}$. Sin embargo, su postura ni siquiera llegaba a los medios y sólo con dificultades, lograba transmitirse entre sus afiliados.

El Debate sobre el Estado de la Nación de 1984, celebrado los días 23, 24 y 25 de octubre, estuvo marcado por la reciente asunción, por parte de Felipe González, de la continuidad de España en la OTAN. Para Rodríguez Sahagún la intervención del Presidente del Gobierno era "triunfalista" y había dejado deliberadamente en un segundo plano aspectos decisivos como los económicos, mientras que Fraga, por su parte, proseguía manifestándose de forma "catastrofista" 29 . Tras un nuevo año de ausencia y silencio en lo que respecta a la vida política nacional, Adolfo Suárez reaparecía en una cita, por otra parte, obligada: “[en Suárez] está depositadas las esperanzas de sus partidarios para que al menos la opinión pública no olvide que éste sigue en la política" ${ }^{30}$.

Suárez caracterizó su intervención como "reflexiva" y comenzó enunciando la pregunta formulada por el Presidente del Gobierno el día anterior: "España está hoy mejor o peor que hace dos años" ${ }^{31}$. La respuesta de Suárez hizo referencia a una sensación de pérdida de la ilusión colectiva en lo que era una mezcla de indiferencia-de unos- y crispación -de otros- $-^{32}$. Reiteró, a continuación, la necesidad de establecer un pacto de Estado que constituyera un "marco de seguridad" de cara a las grandes decisiones nacionales, observando posturas positivas en este sentido -de las minorías- y un "foso de incomunicación" entre los dos grandes partidos políticos:

mayores críticas desde el CDS radicaban en la discriminación respecto a sus oportunidades de presentarse ante el electorado", $A B C, 08$ de octubre de 1984.

${ }^{28}$ Rodríguez Sahagún presentó un texto alternativo -rechazado- a la Ley de Bases del Régimen Local planteada por el Ejecutivo en primera instancia, DSDC, Sesión Plenaria, 14 de junio de 1984, $n^{\circ} 136$. Para el CDS esta ley era un retroceso incluso, si se partía de las propias tesis del PSOE defendidas en las elecciones municipales de 1983. Se tachaba de "reacción socialista" y se consideraba insuficiente en relación a una concepción avanzada de la Administración Local y el desarrollo de los cinco principios básicos que debían regir según la Constitución este nivel de poder territorial: "regionalizada", "autónoma", democrática", "suficiente económicamente" y "moderna", en SOTO CARMONA, Javier: “"El cambio' en la administración local”, Boletín de Difusión Cultural, 2, abril 1984.

${ }^{29}$ ABC, 24 de octubre de 1984. El CDS votó en contra de las reprobaciones ministeriales planteadas por el Grupo Popular, DSCD, Sesión Plenaria, 25 de octubre de 1984, n 159, p. 7142. El miembro del CDS, F. Ysart, comentaba: "Fraga es tal vez demasiado de todo, excesivo, como para permitir que bajo su manto crezca y se vertebre una organización política más moderna y atrayente de la derecha española. Está claro que ésta es la asignatura pendiente del cambio democrático...", en "Fraga excesivo", El Noticiero Universal, 22 de febrero de 1985; YSART, Federico: "Derecha sin sitio", El Noticiero Universal, 01 de mayo de 1985.

${ }^{30} A B C, 24$ de octubre de 1984.

${ }^{31}$ DSCD, Sesión Plenaria, 25 de octubre de 1984, $\mathrm{n}^{\circ} 159$, p. 7153.

${ }^{32}$ Ibid. 
La consolidación de nuestra democracia necesita que ningún tema de Estado -repito- sea resuelto por el Gobierno unilateralmente, de forma irreversible, y necesita también que los partidos de la oposición no provoquemos, en ningún caso, el desprestigio del sistema ni caigamos en la tentación de alargar los defectos históricos que podamos tener como pueblo, y que entre todos debemos corregir, aunque su permanencia pudiera servir para proporcionarnos pequeños resultados electorales ${ }^{33}$.

Los mayores déficits de la obra política socialista se encontraban en materia económica, especialmente, en la irresolución del problema del paro, "uno de los escasos, pero firmes y profundos, reproches" ${ }^{34}$. Para ello, recogía brevemente las líneas maestras desarrolladas por Rodríguez Sahagún en materia económica resaltando el papel que debía jugar en la misma el sector privado y particularmente, las PYMES ${ }^{35}$. A continuación y dentro de su dialéctica habitual, Suárez contrastaba la consagración teórica de las "libertades" en el Estado de Derecho con las dificultades existentes para su realización práctica. Dichas dificultades eran de dos tipos, de carácter material -"la garantía de un mínimo vital suficiente"- y legal -“acción constante contra la pobreza, la ignorancia, la indefensión y el abuso"- ${ }^{36}$.

En sentido contrario, valoró positivamente y sin ambigüedades los éxitos de los gobiernos socialistas contra el terrorismo: "el Gobierno ha conseguido evidentes resultados [...], al obtener, junto con la eficacia de las Fuerzas de Seguridad, la cooperación de las autoridades políticas y policiales de Francia"37. Y en esta línea se refirió a las negociaciones con la CEE, "[que estaban] en el buen camino" y podían instalar definitivamente a España en la "modernidad". En relación al conjunto de la política exterior, Suárez subrayaba los pasos dados en Iberoamérica y Europa para detenerse en la cuestión de la OTAN - aspecto que había centrado el Debate desde la

\footnotetext{
${ }^{33}$ Ibid. Un aspecto básico de esta sensación era la política autonómica, que exigía de un "acuerdo básico" -se entiende, roto desde la LOAPA-, y ello no sólo a propósito de la gestión de los gobiernos territoriales sino porque este desarrollo "constituye la vertebración fundamental de la democracia", ibid., p. 7154.

${ }^{34} A B C, 26$ de octubre de 1984.

${ }^{35}$ En este sentido iban encaminadas la mayor parte de las mociones planteadas por el CDS en el curso del Debate, de las cuales, las tres últimas fueron aprobadas: "encaminadas a la reducción de los niveles de desempleo como problema más grave que tiene la sociedad española. En segundo lugar, sobre el tema de la juventud especialmente castigada por el paro y a la que se debe atender muy especialmente facilitando su formación. La tercera moción insta al Gobierno para que envíe a esta Cámara un plan global de apoyo a la pequeña y mediana empresa. Finalmente, a través de la cuarta resolución el CDS muestra su postura favorable a un acuerdo amplio de todas las fuerzas políticas para hacer frente a todos los problemas más importantes que tiene planteados nuestra sociedad, especialmente de cara a la defensa de los intereses nacionales de España en el exterior”, DSCD, Sesión Plenaria, 25 de octubre de 1984, n 159, pp. 7142 y 7177 y ss.

${ }^{36}$ Ibid., p. 7154.

${ }^{37}$ Resaltando la importancia de una acción política mediante el consenso y el diálogo de todas las fuerzas políticas parlamentarias vascas conduzca a la privación del apoyo popular del que gozaba el terrorismo, DSCD, Sesión Plenaria, 25 de octubre de 1984, n 159, p. 7154.
} 
primera intervención de González-. Fue en el encuadre de la continuidad o no en la Alianza Atlántica, donde el discurso de Suárez resultó más revelador. Recordó su etapa de gobierno y cómo había pospuesto por razones "de política interior y exterior", la integración de España y al producirse la integración: "manifesté mi discrepancia personal por el procedimiento seguido y voté [...] por disciplina". No obstante, en 1984 la situación para Suárez era diferente: "es mucho más difícil salirse [...] que decidir si se entra o no". Al sopesar los argumentos en pro de la continuidad consideraba que España defendía los mismos valores que el resto de democracias integradas en la alianza, pero tampoco podía obviar la preocupación por la "excesiva militarización del mundo" y las limitaciones que podía ejercer la OTAN sobre España en sus relaciones bilaterales con, por ejemplo, Iberoamérica, concluyendo: “este es un tema en el que conviene distinguir muy claramente lo que nos gustaría hacer, lo que debemos hacer y lo que podemos hacer" 38 . Consideraba ineludible un debate público en el Parlamento sobre este asunto con el fin de alcanzar el máximo consenso político al respecto y sólo a continuación, previa consulta al "pueblo español”, actuar en consecuencia. Sus últimas palabras, volvían a poner de relieve la "ambigua" e indescifrable relación de Suárez con la entrada de España en la OTAN: "por encima de mis propias opiniones personales -las que fueren-, en la búsqueda de ese consenso no seré jamás un obstáculo [...] anuncio que subordinaré mi decisión a los frutos de ese consenso" ${ }^{\text {,3 }}$. Culminó su intervención, al igual que en otras ocasiones, instando al Gobierno a dar los pasos necesarios para conseguir ese gran acuerdo de Estado capaz de encauzar los grandes desafíos del país (economía, terrorismo, autonomías y política exterior).

En su respuesta, Felipe González agradeció el tono empleado por Suárez -“que une a su condición de parlamentario su condición de ex Presidente de Gobierno" 40 - y expuso su disposición al acuerdo en los cuatro grandes bloques desarrollados por Suárez. En su turno de réplica, Suárez se congratuló al contemplar como su apelación al consenso centraba la atención política y dedicó sus últimas palabras a la cuestión económica: "seguir caminando con el acuerdo de todos -porque va más allá de una legislatura-, en el logro de una modernización industrial española"41.

\footnotetext{
${ }^{38}$ Ibid., p. 7155.

${ }^{39}$ Ibid.

${ }^{40}$ Ibid.

${ }^{41}$ Ibid., p. 7156. Para $A B C$, la intervención de Suárez fue "serena y constructiva", "carente de crítica", destacándose en su titular: "Suárez apoyó la necesidad de alcanzar un consenso sobre cuestiones de Estado", $A B C$, 26 de octubre de 1984. Sus columnistas políticos se mostraron, como es habitual, más
} 
Conviene indicar que aunque la "voz" de Suárez en los medios era inaudible en el día a día de la política nacional, -despertaban un interés mucho mayor sus esporádicos comentarios sobre el 23-F o su dimisión-, en algunas decisiones particularmente controvertidas y que no contaban con la aquiescencia de los dos grandes partidos no era extraño apelar, en caso de que fuera conveniente, a su opinión.

Sucedió a propósito de la reforma del Consejo General del Poder Judicial (CGPJ) o, sin éxito, en el escándalo de financiación del PSOE (caso Flick) ${ }^{42}$. La decisión del gobierno de elegir íntegramente en las Cortes a los miembros del CGPJ fue objeto de intensos debates a comienzos de $1985^{43}$. Esta reforma partía de una enmienda de José María Bandrés (EE) y tuvo el visto bueno del PSOE que veía una oportunidad para contrarrestar las posiciones conservadoras que de facto copaban la judicatura. Contó con el apoyo de PNV, PCE, CDS y EE y fue acusada por la derecha de constituir un instrumento para la politización de la justicia -aunque posteriormente, varió su opinión44. En este caso, El País recogió el testimonio de Suárez en el transcurso de un acto del partido en Mallorca en el que rechazaba que esta ley vulnerase la independencia o ideologización de la justicia: "si admitimos que el pueblo español participa en las tarea

críticos, Urbano lo consideró una "anécdota" y en otra ocasión señaló: "Adolfo se ha enfundado en su albornoz de fundador de la democracia [...] y no golpea" en URBANO, Pilar: "Felipe, maniatado", $A B C$, 29 de octubre de 1984 e ÍD.: "La reprobación", $A B C, 26$ de octubre de 1984. Campmany lo definía como "la batalla de flores con capullitos de alhelí" en CAMPMANY, Jaime: "Histriones y resuellos", $A B C, 27$ de octubre de 1984. En El País, Jáuregui hablaba de la "concordia y cortesía" entre González y Suárez, desgranando sus palabras en torno a la OTAN, sin duda, las que más atención concentraron, El País, 26 de octubre de 1984. Diario 16 destacaba la subordinación del abulense al PSOE en editorial: "Balance de un debate", Diario 16, 26 de octubre de 1984. Finalmente, "Suárez, por un Pacto de Estado", El Noticiero Universal, 26 de octubre de 1984.

${ }^{42}$ En relación, por ejemplo, al caso Flick a raíz de la formación de la Comisión de Investigación parlamentaria, El País en su editorial resaltó la posibilidad de que la presidencia de la misma por parte de, entre otras personalidades, Suárez o Calvo-Sotelo "aseguraría la neutralidad y objetividad de los trabajos" en "La financiación de los partidos", El País, 15 de noviembre de 1984. Suárez no se pronunció sobre el escándalo de financiación, según apuntó: "los partidos políticos ya estamos en la cola de la general estimación de los ciudadanos por sus instituciones y no conviene perseverar en el naufragio", ESPADA, A.: "Suárez preocupado por la política de ascensos y destinos de Serra", El Noticiero Universal, 30 de noviembre de 1984. El CDS no formó parte de la Comisión de Investigación para la Financiación de Partidos Políticos abierta en el Congreso en noviembre de 1984, al acudir Santiago Carrillo, como portavoz del Grupo Mixto (GM). En las conclusiones y votos particulares de la deliberación del dictamen de dicha Comisión tuvo lugar en el Congreso el día 28 de febrero de 1985 y siguiendo a El País el CDS suscribió, junto al resto de representantes del GM, las ocho conclusiones presentadas sobre el Caso Flick en las que se afirmaba la falsedad de las declaraciones de P. Struck, la recepción de 2,7 millones de marcos por parte del PSOE a través de la Fundación Ebert y "que las declaraciones del Presidente [en su intervención del 14 de noviembre] no habían sido del todo ciertas". Las dos últimas conclusiones se dirigieron contra la negativa labor, que a su juicio, desempeñaban las fundaciones alemanas en España, DÍEZ, Anabel: "Las minorías coinciden en que el presidente no dijo toda la verdad", El País, 01 de marzo de 1985.

${ }^{43}$ El País, 16 de marzo de 1985.

${ }^{44}$ Solo el PNV votó en contra por chocar con las competencias fijadas por el Estatuto de Guernica y el PCE se abstuvo. 
nacionales directamente a través de sus representantes y admitimos que la justicia emana del pueblo [...] es evidente que la vinculación de los miembros del CGPJ debe ser clara" $" 45$.

A partir de 1985, Suárez comenzó a presentarse ante los medios como alternativa de gobierno para 1990 y a proferir una frase, que con el tiempo se iba a convertir en una coletilla habitual de sus ruedas de prensa: "inevitablemente volveré a ser presidente del Gobierno" ${ }^{\text {46 }}$. De forma paralela, se intensificaron las críticas a lo que se consideraba prepotencia del Gobierno, al uso propagandístico de la TV o la "amenaza" a la libertad de expresión: "en España "empieza a haber miedo de opinar libremente" señalaba en el plan anual del partido elaborado en 1985: "CDS alternativa de Gobierno" es el mensaje que, más o menos lejano en el tiempo, se intuye por el electorado" ${ }^{48}$. Sin embargo, no por ello, se debían variar las líneas maestras de su “oposición” al gobierno: “demostrando con su comportamiento y su conducta, esa nítida independencia al servicio de sus ideales, sin abandonar el talante de moderación y diálogo, pero con vocación inextinguible de transformar y mejorar la sociedad"49.

El Debate celebrado en 1985, entre los días 15 y 17 de octubre y previo a las elecciones generales de 1986, expuso con mayor visibilidad el carácter bifronte del discurso centrista. Por un lado, el distanciamiento existente entre el Gobierno y el partido suarista se hizo perceptible. Se criticaban "la arrogancia" socialista, su control sobre la sociedad civil $^{50}$, la política económica ${ }^{51}$ y las tensiones generadas por el aún no convocado referéndum de la OTAN. Sin embargo, como ha señalado Fuentes Aragonés

\footnotetext{
45 EFE: "Suárez favorable a la elección parlamentaria del Consejo General del Poder Judicial”, El País, 16 de marzo de 1985. Sin embargo, el CDS se abstuvo, junto con el resto del Grupo Mixto, en la votación en la que fueron electos los miembros del CGPJ, al haber sido consensuado dicho proceso únicamente entre el Grupo Popular y el Grupo Parlamentario Socialista, El País, 02 de octubre de 1985 y ABC, 03 de octubre de 1985. Según Jiménez de Parga, el apoyo de Suárez se debió a la promesa, incumplida, del Ministro de Justicia de incluir un consejero propuesto por el CDS, JIMÉNEZ DE PARGA, Manuel: Vivir es arriesgarse..., pp. 318-9.

${ }^{46}$ El País, 29 de octubre de 1985; JÁUREGUI, Fernando: "Optimismo en público, prudencia en privado", El País, 17 de junio de 1985; CONTRERAS, Lorenzo: "Suárez opta por ser la alternativa", $A B C, 18$ de junio de 1985.

47 Jornadas de Acción Electoral del CDS, $A B C$, 13 de abril de 1986. O la implacabilidad de las acciones gubernamentales: "han bastado dos años de mayoría parlamentaria absoluta y, sobre todo, de falta de sensibilidad a la hora de administrar sus efectos para volver a encontrar conocidas sensaciones de antaño”, YSART, Federico: “Años después”, El Noticiero Universal, 08 de enero de 1985.

${ }^{48}$ Comité Nacional CDS: "Plan de Actuación 1985", 13 de mayo de 1985, Carpeta 2, AGP.

49 Ibid.

${ }^{50}$ Un buen ejemplo de la posición -y valores- que defendía el CDS puede verse en el artículo del simpatizante centrista y ex ministro, GARCÍA AÑOVEROS Jaime: "Pluralismo social", $A B C, 25$ de octubre de 1984.

${ }^{51}$ El CDS había rechazado los Presupuestos Generales para el año 1985, con una enmienda a la totalidad, $A B C, 09$ de noviembre de 1984 .
} 
sus intervenciones seguían sin corresponder a las "de un dirigente opositor", prosiguiendo el tono institucional y constitucionalista que lo había caracterizado desde la fundación del $\operatorname{CDS}^{52}$. Apenas se profundizó en la "crisis de gobierno" de julio de 1985 y ni siquiera hubo ningún tipo de acusación cuando Felipe González decidió hacer uso del yate Azor para un crucero durante el verano del $85^{, 53}$.

Suárez comenzó su intervención matizando el entusiasmo exhibido por Felipe González después de la firma del Tratado de Adhesión de España a la CEE ya que no implicaba la asimilación automática de todos los valores y principios democráticos que el país todavía necesitaba. Y como hiciera en 1984, aludió a algunas inquietantes tendencias sociales - como la apatía o la escasa valoración de los "partidos políticos"- y al enorme salto existente entre los avances legislativos dados en el proceso de conquista y afirmación de las libertades y una plasmación real acosada por la injusta distribución de la renta, del patrimonio, de la educación, etc. Todo ello exigía una "atención preferente a los sectores más débiles". Su tesis sobre la "igualdad de oportunidades" le condujo nuevamente a defender un "mínimo" material para todos los ciudadanos -era necesario que "el poder público corrija las desigualdades de partida" - y a criticar implícitamente la primacía de las políticas monetaristas neoliberales: "creo que es muy difícil aceptar un mensaje de resignación en virtud de una discutible, por lo menos, ortodoxia económica" ${ }^{\text {54 }}$. Para atenuar el reparto inequitativo de los costes de la crisis, era necesario un gran pacto de Estado tal y como -y citaba por primera vez el nombre del partido- había solicitado el CDS, capaz de diseñar una estrategia global de lucha contra el paro (con particular incidencia en las capas juveniles) y una política expansiva: "una actitud más beligerante de la inversión pública y [...] un marco adecuado de planificación estratégica que evitara la caída de la inversión",55.

En referencia al desarrollo y la consolidación del estado autonómico, el gobierno no debía trasmitir la imagen de que "partiendo de un modo centralista, hace concesiones a

\footnotetext{
${ }^{52}$ FUENTES ARAGONÉS, Juan Francisco: Adolfo Suárez ..., p. 462.

53 Alfonso Iñíguez (CDS) señaló que "no había que dar[lo] excesiva importancia", $A B C, 13$ de agosto de 1985. Según una encuesta realizada por ODEC-UNITEC S.A., aparecida en Diario 16 al $47 \%$ le parecía bien (entre los votantes de UCD/CDS ascendía al 61\%), El Noticiero Universal, 23 de noviembre de 1985.

54 "El ajuste practicado ha recaído sobre los sectores más débiles de la sociedad, lo que, unido a una fiscalidad en la que cada año aumentan los impuestos indirectos más que los directos, contribuye a producir cada vez mayores desigualdades”, DSCD, Sesión Plenaria, 16 de octubre de 1985, n 238, p. 10707. La llegada de Morodo propició un rechazo explícito de los principios neoliberales de la llamada "revolución conservadora”, MORODO, Raúl: “América, América”, El País, 12 de octubre de 1985.

${ }^{55}$ Concediendo, por otra parte, cada vez más importancia a las pequeñas y medianas empresas, Ibid.
} 
las autonomías por exigencia constitucional. Lo que la Constitución exige no son concesiones, sino un nuevo modelo de Estado" "56. Al hablar de la CEE, trasladaba algunas de las claves descritas anteriormente respecto de la política española: evitar la polarización existente -"haciendo el esfuerzo de objetivar los problemas que existen en el mundo, por encima de las ideologías"- e insistía otra vez en la "obligación moral [...] de hacer compatible las economías de mercado con una acción estatal solidaria, que reduzca las desigualdades y los desequilibrios estructurales" ${ }^{~} 57$. En relación a Latinoamérica se debía fomentar el diálogo interamericano, apoyar los proyectos de democratización y cambio social, la defensa de los derechos humanos y buscar soluciones a la crisis centroamericana y el problema de la deuda. Respecto a la OTAN se limitó a manifestar -en vista del próximo debate parlamentario- su postura favorable para la celebración del "referéndum". En la parte final de su discurso, resumía su actitud a lo largo de largo de la Legislatura con las siguientes palabras:

Por último, señor Presidente, me parece que nunca he dejado de reconocer los aciertos concretos que ha logrado la Administración socialista; incluso, algunos han criticado mucho más de lo razonable esta actitud de prudencia. Sé que no es fácil entender que la experiencia dota de una singular capacidad para comprender las dificultades, incluso los errores ajenos. He creído que esa era mi responsabilidad, y así seguiré actuando ${ }^{58}$.

La contestación de Felipe González celebraba la concordancia en política autonómica y política exterior (Europa, Latinoamérica y el Mediterráneo, ratificando la necesidad de celebración del referéndum sobre la OTAN), si bien discrepaba de la visión económica de Suárez y su idea de "justicia social", alertando de las contradicciones y en última instancia, del electoralismo de sus palabras y sus planteamientos contradictorios: aumento de la inversión y descenso del déficit, facilidades a la inversión privada y descenso de la inflación, etc. Sobre la profundización de los comportamientos democráticos se preguntaba, ¿acaso no eran la LODE, la LRU o la LOLS la materialización legislativa para fomentar el ejercicio democrático en el seno de la vida pública (educativa y sindical en este caso)?

En su réplica, Suárez volvió a defender el desarrollo de una política económica de corte, grosso modo, socialdemócrata: “cuando existe una enorme cantidad de recursos

\footnotetext{
56 Ibid., p. 10708. Por el contrario, en la I Convención Nacional del partido dedicada al Estado de las Autonomías se ponía el énfasis en la iniciativa del Estado, instando al "sosiego" a las Comunidades Autónomas -en las que por otra parte, no tenía apenas tenía representación-, OICDS, 0, 1985 (noviembre), p. 8.

${ }^{57}$ DSCD, Sesión Plenaria, 16 de octubre de 1985, nº 238, p. 10708.

${ }^{58}$ Ibid.
} 
ociosos y una infrautilización de la capacidad productiva, se puede y se debe hacer una estimulación de la demanda interna, sin que eso provoque ninguna clase de desequilibrios añadidos". Afirmación que fue contestada con un "ni hablar" por parte del economista y miembro del Partido Liberal Schwartz Girón" ${ }^{\text {"59. }}$.

La intervención de Suárez - aunque bastante similar a la llevada a cabo un año antesrecibió en esta ocasión las críticas tanto de la prensa conservadora como progresista ${ }^{60}$. En el primer caso, se aludía a sus planteamientos en política exterior y económica: “contra la moderación del Gobierno en el delicadísimo terreno de la estrategia, el señor Suárez vino a reiterar su posición contraria a la OTAN y se alineó con los sectores pacifistas al recordar la necesidad y obligatoriedad del referéndum prometido"61. La crónica de su intervención se titulaba: "Suárez pidió una mejor redistribución de la riqueza y una economía expansiva"62; tono social que para El País era "de corte populista y apelando con reiteración a los parados y marginados" ${ }^{\text {"6 }}$. En relación a la OTAN, se limitaba a subrayar su postura favorable al referéndum ${ }^{64}$. En $Y a$ se tildaba su discurso de "netamente electoralista", -“no juzgamos aquí al señor Suárez, sino que nos limitamos a señalar la real naturaleza de su discurso"-, y sustentado por el "estatismo económico, las plenas reivindicaciones autonómicas y el referéndum sobre la OTAN"65. Finalmente, para Diario 16, Miquel Roca fue el gran protagonista de la jornada como auténtico representante del centro político; Suárez, por su parte, "desbordó claramente al Gobierno [...] por la izquierda", planteando una intervención ante todo electoralista:

\footnotetext{
59 A lo que improvisó Suárez: "Bueno, yo lo creo así, señor Schwartz. Es lógico que usted discrepe", ibid., p. 10729.

${ }^{60}$ Por su parte El Noticiero Universal tituló: “Suárez no hay estrategia global contra el paro", 17 de octubre de 1985.

${ }^{61}$ Editorial: "Navegar al pairo", $A B C, 17$ de octubre de 1985.

${ }^{62} \mathrm{ABC}, 17$ de octubre de 1985.

63 El País, 17 de octubre de 1985. Nuevamente, Rodríguez Sahagún consideró "regresivos" los Presupuestos Generales del Estado presentados por el gobierno al no atender la lucha contra el paro desde la reactivación de la inversión productiva, defendiendo una enmienda a la totalidad, El País, 28 de octubre de 1985.

${ }^{64}$ En declaraciones realizadas durante el verano de 1985, Suárez valoraba positivamente la política exterior y la lucha contra el terrorismo del PSOE y criticaba, por excesivamente conservadora, la política económica socialista, $A B C$, 09 de agosto de 1985. "[Adolfo Suárez] Yo sólo me aliaría políticamente con Felipe González en condiciones de anormalidad”, El País, 18 de noviembre de 1985. "[J. R. Caso] Como toda gestión, tiene claroscuros. Puntos positivos y puntos negativos. Los positivos se sitúan, sobre todo, en el terreno de la Educación y el ingreso de España en la CEE. Mientras que lo más negativo, es el abandono de las prioridades de la lucha contra el desempleo y por una sociedad más justa", El País, 29 de octubre de 1985.

${ }^{65}$ Editorial: "La oposición de las minorías", $Y a, 17$ de octubre de 1985.
} 
"un nuevo tono que hay que juzgar más como una estrategia que como un planteamiento político de fondo"

De acuerdo, con lo prescrito en el Plan de Actuación (85') del CDS las intervenciones de Suárez eran quizá la principal herramienta para lograr la "homogeneidad e identificación en la especificidad del mensaje" centrista. Un mensaje que se debía construir sobre cuatro ejes y que a la altura de 1985 se consideraba "perfectamente transmitido". Efectivamente, cada uno de esos ejes había sido pulsado por Suárez a lo largo de sus tres principales intervenciones parlamentarias:

Eje 1. (Pacto de Estado -necesaria colaboración de todos para solventar la crisis); eje 2 (Progreso-modernidad-innovación...); eje 3 (libertades-solidaridad) y eje 4 (Constituciónsentido del Estado Autonómico ${ }^{67}$.

\section{2. La actividad parlamentaria: desarrollo autonómico y economía}

A continuación, vamos a recorrer las iniciativas del gobierno, que como ha subrayado Pere Ysás, evidenciaron mayores continuidades con los ejecutivos precedentes y suscitaron la abierta oposición de amplios sectores sociales y políticos a la izquierda del PSOE. Nos referimos a la política de seguridad y defensa, la política autonómica, las medidas en materia antiterrorista y el ámbito de la política económica ${ }^{68}$; aspecto este último que centrará nuestra atención y en el que resultará fundamental el análisis de dos medidas legislativas: la expropiación de RUMASA y la reconversión industrial.

Las reformas militares y la política de ascensos llevadas a cabo por el PSOE, junto a esporádicas y desafortunadas declaraciones de algunos altos cargos del Ejército centraron la actualidad de las Fuerzas Armadas durante la II Legislatura, período en el que se fue diluyendo definitivamente el temor a un nuevo golpe de estado, al menos, entre la opinión pública ${ }^{69}$. Apenas una semana después de las elecciones de octubre de 1982 un atentado de ETA-m contra el general del ejército de Tierra Lago Román provocó unas ambiguas declaraciones de Fraga que fueron interpretadas por parte de la

\footnotetext{
${ }^{66}$ Editorial: "Y el centro se erigió en oposición", Diario 16, 17 de octubre de 1985.

${ }^{67}$ Comité Nacional CDS: "Plan de Actuación 1985", 13 de mayo de 1985, Carpeta 2, AGP.

${ }^{68}$ Posponemos para un epígrafe posterior la Política de Seguridad y Defensa, aspecto que abordaremos a propósito de la celebración del Referéndum de la OTAN.

${ }^{69}$ Sobre las últimas intentonas puede verse una síntesis en JÁUREGUI, Fernando: Historia vivida de España: de Franco a Podemos, s. 1., Almuzara, 2015, pp. 268-271.
} 
prensa como una justificación de la intentona golpista del $27-\mathrm{O}^{70}$. Una vez más, el CDS tuvo la oportunidad de poner de manifiesto las implicaciones del concepto de "supremacía del poder civil" y a la vez, subrayar las distancias que lo separaban del tremendista discurso de la derecha española. Rodríguez Sahagún en un artículo publicado en El País, titulado "Me niego a comprender", señalaba:

Si no hubiera toda una secuencia anterior de concomitancias e identidades entre golpismo y terrorismo, estos dos últimos sucesos a que nos referimos dejarían suficientemente explícita esta similitud, no sólo en lo criminal, sino en lo antidemocrático [...] Ni el primero [el terrorismo] puede justificarse, como falazmente lo hace ETA en sus comunicados, en la potencial amenaza que implica el segundo [el golpismo]; ni éste, en la provocación que para el Estado y los miembros de las Fuerzas Armadas implican las acciones de aquélla, como argumentan algunos de sus comprensivos valedores.

Desde el CDS se respaldó al gobierno al destituir fulminantemente al Capitán General de la VII Región Militar quien en la revista Interviu había justificado las razones del golpe del $23-\mathrm{F}^{71}$ o en el caso de M. Álvarez Zalba, quien había comentado las deficiencias defensivas de Ceuta y Melilla y criticado el pacto libio-marroquí ${ }^{72}$. Precisamente, en su primera aparición televisiva desde 1982, Suárez alertó sobre la incompatibilidad del ejercicio de la política con la pertenencia a las Fuerzas Armadas señalando que algunos militares "por su esquema de valores, creen tener la exclusividad del patriotismo" -momento en el que volvió a insistir en que su dimisión no estaba motivada por la presión del rey o de las FAS- ${ }^{73}$. Las palabras de Suárez tuvieron lugar en el programa La Clave titulado "A la democracia desde la dictadura" y emitido el 4 de mayo de 1984.

\footnotetext{
70 “'Yo no entiendo el golpismo. Lo que quiero decir es que mientras haya terrorismo habrá otras muchas tentaciones. Y eso lo comprende cualquiera', dijo ayer el jefe de la oposición parlamentaria y presidente de Alianza Popular, Manuel Fraga, en una entrevista concedida a Radio Nacional de España. Fraga matizaba así sus palabras en la última reunión de la Diputación Permanente del Congreso, ratificadas recientemente al comentar, tras el asesinato del general Lago Román, que había que 'entender' a los golpistas", El País, 09 de noviembre de 1982.

${ }^{71}$ Según J. R. Caso no formaban parte de un hecho aislado: "desde el principio del verano e incluso antes desató El Alcázar una campaña en favor del indulto a los condenados en el 23-F”, en "Todos, salvo Fraga, aplauden la decisión", El Noticiero Universal, 17 de septiembre de 1983.

72 "CDS: destitución acertada" en $A B C, 01$ de noviembre de 1984. Sobre estas destituciones, véase, JÁUREGUI, Fernando y MENÉNDEZ, Miguel Ángel.: Lo que nos queda de Franco, Madrid, Temas de Hoy, 1995, p. 222.

${ }^{73}$ El País, 05 de mayo de 1984. Como invitados al coloquio estuvieron: Mario Soares, primer ministro de Portugal, Alejandro Agustín Lanusse, ex presidente de Argentina, Adolfo Suárez, Euclides Acevedo, líder de la Revolución de Paraguay, Abderrahán Bouabid, ministro de Estado marroquí, y Antonin Liehm, ex líder de la Primavera de Praga", ABC Sevilla, 04 de mayo de 1984.
} 
Con ocasión del cuarto aniversario del 23-F reiteró su criterio desfavorable a conceder un indulto a los implicados en la intentona golpista, en lo que supuso siempre, una destacada divergencia de criterio con la derecha aliancista ${ }^{74}$.

Es posible afirmar, que las opiniones de Adolfo Suárez sobre cualquier aspecto relacionado con los "militares" fueron las más ampliamente recogidas y comentadas en la prensa en este período de aparente inactividad en la vida política nacional normalmente, relacionadas periodísticamente con el episodio de su dimisión y el 23-F75 . En el programa anteriormente citado de La Clave y en el que se visionó el clásico de Elia Kazan ;Viva Zapata! (1952), la primera pregunta de los telespectadores fue dirigida a Adolfo Suárez y, no es extraño, inquiría sobre las presiones militares sufridas por el ex presidente:

P. [J. L. Moreno] - Un espectador pregunta si a usted los militares le trataban como a Zapata en la película y le imponían lo que tenía que hacer. R. [A. Suárez] - En modo alguno, y lo digo en honor de los militares [...] y porque tampoco lo hubiera aceptado yo [...] ninguno lo intentó ${ }^{76}$.

Uno de los grandes proyectos de ley iniciados inmediatamente después del Debate sobre el Estado de la Nación de 1983 fue la reforma militar, con el objetivo primordial de: "eliminar las ambigüedades que el gobierno de UCD había introducido en la ley orgánica de 1980, al objeto de que las FAS quedasen claramente subordinadas al Poder

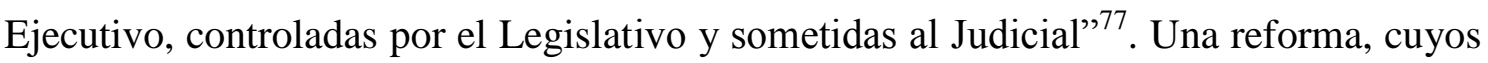
principios, concordaban notablemente con la llamada "supremacía del poder civil" defendida por el CDS.

Aunque la nueva Ley de Defensa Nacional fue apoyada por los suaristas, su tramitación puso de manifiesto, una vez más, la trascendencia de la dicotomía entre los poderes civil y militar en la formación del CDS. Suárez la veía ante todo como una necesidad histórica en la que era prioritario reformar las "enseñanzas" de las academias militares y llevar a cabo una acción firme sobre la política de ascensos para que las FAS

\footnotetext{
${ }^{74}$ El País, 23 de febrero y 22 de noviembre de 1985. "Fraga, favorable al indulto a los condenados por el 23-F", lo que desde el CDS, en palabras de Manuel Gallent fue calificado como "intolerable e insostenible" [...] "[el indulto] ya se concedió en su día, porque se les fijó la pena más leve posible y los que están en prisión tienen un trato excepcional", El País, 22 de febrero de 1986.

${ }^{75}$ Estos episodios centraban la atención en sus visitas a las distintas provincias españoles a propósito de la celebración de actos del partido, véase Anexo IX sobre Titulares en Prensa Local.

${ }^{76}$ La Clave, RTVE, 04 de mayo de 1984.

${ }^{77}$ Ley orgánica 1/84 de 5 de enero, de reforma ley orgánica 6/1980, de 1 de julio, por la que se regulan los Criterios Básicos de la Defensa Nacional y la Organización Militar, BOE, $n^{\circ}$ 6/1984. Véase, PUELL DE LA VILLA, Fernando: "La política de seguridad y defensa", en SOTO CARMONA, Álvaro y MATEOS LÓPEZ, Abdón (eds.): Historia ..., pp. 43-64.
} 
"cumplan con la alta misión que la Constitución les encomienda"78. Merece la pena destacar que Adolfo Suárez fue uno de los diputados que votó en contra de las enmiendas introducidas por AP en el Senado y aceptadas por el PSOE, una de las cuales establecía que la "cúpula castrense" pasaba de "informar" al Presidente de Gobierno y al Ministro de Defensa, a informar y asesorar a los anteriores y al Rey ${ }^{79}$. Para Lorenzo Contreras, “este último extremo es el de mayor interés. Porque el Monarca, asesorado, y no meramente informado, por la 'cúpula' militar responde con mayor plenitud al contenido de su condición de depositario del mando supremo castrense" ${ }^{\text {" } 80}$. La política de ascensos -especialmente al generalato- fue objeto de fuertes críticas por parte de Suárez durante la campaña gallega de 1985 y las generales de $1986^{81}$.

Poco antes de concluir la II Legislatura, Rodríguez Sahagún estaba en condiciones de afirmar en una mesa redonda celebrada durante el I Congreso Iberoamericano de Sociología Militar en Madrid que "con excepción de comportamientos minoritarios”, las Fuerzas Armadas habían acatado la voluntad popular y adquirido una actitud de "neutralidad expectante”. Para Rodríguez Sahagún había cuatro causas: la fórmula de Transición, el papel del rey, la modernización de las Fuerzas Armadas y la unión en el Ejército, concluyendo: "hay que evitar tanto la tentación del militarismo como la del antimilitarismo" $" 82$.

En relación a la Ley de Fuerzas y Cuerpos de Seguridad del Estado (LFCSE) promulgada en marzo de $1986^{83}$, el CDS se mostró particularmente crítico. De acuerdo con Javier Soto, miembro del Comité Nacional, la ley socialista no se adecuaba a una idea de la Policía propia de una democracia avanzada, no desarrollaba todas las potencialidades del articulado constitucional y no respondía a una concepción progresista y moderna de la sociedad. Argumentaba que la LFCSE no favorecía la

\footnotetext{
${ }^{78}$ El País, 03 de octubre de 1983.

${ }^{79}$ Nos referimos a la votación de las enmiendas del Senado del Proyecto de Ley Orgánica por el que se modifica la Ley Orgánica 6/1980 por la que se regulan los criterios básicos de la Defensa Nacional y la Organización Militar de 27 de diciembre de 1983 y en concreto a la Enmienda nº del Grupo Popular referida al apartado $1^{\circ}$ del artículo $9^{\circ}$ de dicho proyecto de ley y defendida el 15 de diciembre de 1983. En la votación final de conjunto, una vez incorporadas las enmiendas del Senado y celebrada unas horas después aunque estaban ausentes tanto Suárez como Rodríguez Sahagún, éstos habían votado favorablemente en la votación plenaria celebrada el 30 de noviembre de 1983, relativa al conjunto de la ley.

${ }^{80}$ Este autor señalaba también una alerta de Suárez sobre la política de ascensos socialista, Lorenzo Contreras: "Reforma militar y elecciones", $A B C, 29$ de diciembre de 1983; CONTRERAS, Lorenzo: "El gobierno que viene", $A B C, 25$ de mayo de 1986.

${ }_{82}^{81}$ El País, 11 de noviembre de 1985.

${ }^{82}$ Acompañado de Liber Seregni, Vasco Lourenço, G. Galeote y el salvadoreño Alonso Manjano, El País, 17de septiembre de 1985 .

${ }^{83}$ BOE, 14 de marzo de 1986, no 63.
} 
normalidad, en calidad de ciudadanos, de los cuerpos policiales "en la medida que prohíbe el ejercicio de los derechos sindicales básicos a todo el colectivo policial, sin distinción"; en segundo lugar, no respetaba la noción de civilidad manteniendo "el régimen militar estricto" de la Guardia Civil y "respecto del resto [...] los califica aconstitucionalmente con el término de "Instituto Armado de carácter civil", sospechosa percha para una fáctica militarización"; en tercer lugar, no promovía la variedad de las instituciones policiales sin dejar prácticamente margen competencial a las CC.AA. y los Ayuntamientos, “imponiéndolas, incluso, a todos el empleo de las 'armas' ¿porque no pueden existir policías no 'armados'?"; finalmente, se aludía a la merma del principio de especificidad y especialidad al no poder ejercer plenamente los derechos sindicales. Concluía Javier Soto parafraseando a una fuente policial anónima: “es una Ley de realización posible sin necesidad de que existiera la Constitución de 1978"84.

En relación al desarrollo autonómico, los años centrales de la década de los 80' sirvieron para comenzar a poner en marcha los distintos órganos de gobierno territoriales e iniciar los mecanismos de transferencia competencial. En este contexto, se observa la prioridad que otorgó el CDS al proceso de estructuración territorial del Estado -como logro colectivo de la Transición-, siendo el objeto de análisis monográfico escogido para su I Convención Nacional, convocada en Madrid a comienzos de marzo de 1985 y dedicada a la elaboración de un "Libro Verde sobre el Estado de las Autonomías". El CDS declaraba irrenunciables los principios fundamentales del consenso constitucional: indisolubilidad de la nación, indivisibilidad de la patria, derechos de las nacionalidades y regiones ${ }^{85}$, solidaridad interregional y principio de autonomía en la gestión ${ }^{86}$. Por ello, las líneas maestras para el desarrollo y consolidación de estos principios pasaban por: la resolución de la "tensión centroperiferia", la oposición frontal a cualquier tipo de revisión constitucional "sean de represión o de progresión federalista" ${ }^{\text {87 }}$, la elaboración de los estatutos de Ceuta y Melilla y la urgente necesidad de orientar el Fondo de Compensación Interterritorial a la

\footnotetext{
${ }^{84}$ Este documento fue el marco base para la elaboración del programa electoral en este punto, en el que se prometía una "revisión" de dicha ley, SOTO, Javier: "Sobre el Proyecto de Ley de Fuerzas y Cuerpos de Seguridad del Estado", 1986, CDS, Carpeta 2, AGP; CDS: El Valor del Centro. Programa electoral, 1986, CDS, pp. 108-109, Archivo Antonio Garrosa (AAG). Rodríguez Sahagún indicó en la tribuna parlamentaria: "Yo creo, con sinceridad, que si respeta la Constitución se queda muy corta, en lo mínimos", DSCD, Sesión Plenaria, 05 de diciembre de 1985, nº 258, p. 11682.

${ }_{85}$ Terminología que "supone el reconocimiento, convenido y formalizado constitucionalmente de la identidad profunda de España", OICDS, 0, 1985 (noviembre), p. 8.

${ }^{86}$ Siguiendo así textualmente el Artículo 137 y 138 del Título VIII y el Artículo $2^{\circ}$ del Título Preliminar de la Constitución.

${ }^{87}$ OICDS, 0, 1985 (noviembre), p. 8.
} 
reducción de los desequilibrios regionales. En este exhaustivo análisis del modelo autonómico se concluía la triple necesidad que había dado origen al mismo en el contexto de la Transición: histórica -reconocimiento de las nacionalidades y regiones que componen España-, política -descentralización de las estructuras de poder democráticas-y funcional -modernización del Estado-.

La atención preferencial que el CDS y el propio Adolfo Suárez depositaron en la elaboración de un discurso autonomista contrastaba con las escasas responsabilidades del partido en la política autonómica española durante esta época (1983-1987). En la contienda electoral de mayo de 1983 el CDS había obtenido un diputado autonómico en Aragón, dos en Castilla y León y seis en Canarias. Únicamente, en esta última región, el CDS mantuvo cierta visibilidad basada en el liderazgo en las islas de Gran Canaria y de Tenerife de Lorenzo Olarte y Fernando Fernández, respectivamente, quienes defendieron un programa basado en la demanda de un "pacto" canario que consolidase la Comunidad, permitiese una paulatina y pausada asunción de competencias y llevase a cabo una reforma de los cabildos insulares ${ }^{88}$.

En lo que respecta a la lucha antiterrorista, el apoyo del CDS al gobierno se mantuvo sin fisuras durante toda la década tanto a nivel autonómico ${ }^{89}$, como nacional ${ }^{90}$. El principal matiz aportado por el CDS demandaba la necesidad de gestar un gran pacto con "las fuerzas políticas de Euskadi [...] el Gobierno central y el Gobierno de Euskadi [...] para evitar cualquier apoyo social [del terrorismo]"91. Asimismo, el partido de

\footnotetext{
${ }^{88}$ Véase, BAEZ GARCÍA, Alberto Javier: Una historia de Coalición Canaria. Una historia de Coalición Canaria: creación y evolución de una fuerza política nacionalista (1993-2010), Las Palmas, Idea, 2014.

${ }^{89}$ Caso del apoyo al plan ZEN (Zona Especial Norte) del Gobierno del PSOE fuertemente criticado por los grupos nacionalistas y que establecía el futuro marco de actuación de las Fuerzas de Seguridad en el P. Vasco. En opinión de un diputado del CDS: "se han agotado las medidas políticas en relación con ETA, porque ETA no tiene ninguna relación con el desarrollo estatutario", Diario de sesiones del Parlamento Vasco, Debate y resolución definitiva con referencia a la Proposición no de Ley, formulada por el Grupo Parlamentario Euskadiko Ezkerra sobre 'El Plan ZEN', 06 de octubre de 1983, $\mathrm{n}^{\circ}$ 34. Disponible en http://www.legebiltzarra.eus/fichas/c_298_int.html Fecha de consulta: 11 de marzo de 2014; "El Parlamento vasco, con los votos en contra del PSE-PSOE, AP y CDS, aprobó ayer una proposición no de ley en la que se considera inoportuno el Plan ZEN como instrumento para luchar contra el terrorismo...", $A B C, 08$ de octubre de 1983.

${ }^{90}$ En una sesión en el Congreso dedicada al debate sobre política antiterrorista, Agustín Rodríguez Sahagún, diputado centrista, exigía una "política verdaderamente de Estado que suscriban todas las fuerzas políticas y sociales, sin que nadie, porque nadie tiene fórmulas mágicas, pueda hacer una utilización partidista ni electoralista de estos problemas", $D S C D$, Sesión Plenaria, 03 de noviembre de 1983, nº 69, p. 3207.

${ }^{91}$ CDS: El valor del Centro. Programa electoral, 1986, p. 112, AAG. Nótese la diferencia con la CP: "apertura de conversaciones con las fuerzas políticas democráticas del nacionalismo vasco para intentar una puesta en común de esfuerzos y medios de lucha antiterrorista", Programa de Gobierno. Coalición Popular, 1986, p. 17. Disponible en http://www.pp.es/sites/default/files/documentos/114720090908161128.pdf Fecha de consulta: 10 de diciembre de 2014.
} 
Suárez se limitó a una ligera crítica de la nueva legislación antiterrorista por incompatibilidades con el Estado de Derecho e imprecisiones técnicas ${ }^{92}$, sin exigir en ningún caso su derogación o apoyar recursos de inconstitucionalidad como postulaban Izquierda Unida o los partidos de ámbito vasco ${ }^{93}$.

En materia económica, el PSOE llevó a cabo, lo que Joaquín Estefanía, ha denominado el "segundo ajuste de la democracia" -tras la firma de Los Pactos de la Moncloa en 1977-. Por un lado, el llamado Programa económico a medio plazo elaborado por el equipo del Ministro de Economía y Hacienda, Miguel Boyer, orientó las medidas a tomar en materia fiscal y monetaria hacia la contención del déficit público, la reversión del saldo negativo en la Balanza de Pagos y la reducción de la inflación. Suponían en síntesis, medidas de saneamiento económico ${ }^{94}$. De forma complementaria, el Ministerio de Industria, con Carlos Solchaga al frente, diseñó el Libro Blanco sobre Reindustrialización para actuar sobre los sectores industriales más afectados por la crisis económica internacional y lograr: "disminuir su endeudamiento, reducir capacidad y mano de obra excedentaria y abordar nuevas inversiones"95. La política industrial, acompañada por una progresiva liberalización de la economía, desembocó en fuertes conflictos sociales, particularmente intensos en la reestructuración del sector siderúrgico y naval ${ }^{96}$. Las medidas de los gobiernos del PSOE desconcertaron a buena parte de la izquierda española y dejaron sin argumentos a una oposición conservadora, que sólo en momentos puntuales pudo presentar auténticas alternativas programáticas. Una de estas situaciones se vivió a propósito de la expropiación de RUMASA.

\footnotetext{
${ }^{92}$ Votación de Totalidad de la Ley Orgánica contra Bandas Armadas y Elementos Terroristas, 27 de septiembre de 1984, en la que Rodríguez Sahagún y Suárez González estuvieron ausentes. El día 20 de junio, en la Comisión Constitucional del Congreso, Rodríguez Sahagún -a propósito de la defensa de una serie de enmiendas parciales- sostenía: "nosotros hemos presentado numerosas enmiendas a este proyecto de Ley porque consideramos que el proyecto presentado por el Gobierno en su conjunto que ha tenido una mejora sustancial en los trabajos de Ponencia, es una mala y precipitada refundación del Real Decreto Ley $311 / 1979$ de 26 de enero, sobre protección de la seguridad ciudadana y de la Ley Orgánica 11/1980, de I de diciembre, sobre los supuestos previstos en el artículo 55.2 de la Constitución", DSCD. Comisión Constitucional, 20 de junio de 1984, nº 191, p. 5910.

93 "Grandes temas ausentes en la campaña", Diario 16, 17 de febrero de 1986; "el Tribunal Constitucional ha invalidado cuatro apartados de la ley antiterrorista, aprobada por las Cortes el 5 de diciembre de 1984 con los votos del PSOE y de Coalición Popular y recurrida a principios de 1985 por los Parlamentos vasco y catalán", El País, 18 de diciembre de 1987.

${ }^{94}$ En expresión de SOTO CARMONA, Álvaro: "El conflicto como respuesta social, pero también política" en MATEOS, Abdón y SOTO CARMONA, Álvaro (eds.): Historia ..., pp. 191-248.

${ }_{95}$ ESTEFANÍA, Joaquín: "El segundo ajuste económico de la democracia" en MATEOS, Abdón y SOTO CARMONA, Álvaro (eds.): Historia ..., p. 142.

${ }^{96}$ SOTO CARMONA, Álvaro: "El conflicto...".
} 
Quizá, la ley que más polémica generó en la II Legislatura fue el Real Decreto-Ley 2/1983 de expropiación de RUMASA del día 23 de febrero de $1983^{97}$; proceso en el que el CDS jugó un papel secundario, aunque singular. Siguiendo los trabajos de Ernesto Ekaizer, la relación entre el CDS y RUMASA se fundamentaba, al menos, en dos pilares. Por un lado, Alejandro Rebollo, dirigente nacional del CDS y Presidente Federal del CDS-Asturias ${ }^{98}$, era desde principios de año -gracias a la mediación de Antonio Navalón ${ }^{99}$ - miembro del equipo de abogados de Ruiz-Mateos y al parecer principal artífice de la rueda de prensa convocada por el empresario jerezano que desató la intervención del gobierno ${ }^{100}$. En segundo lugar, Suárez se reunió con Felipe González en la Moncloa el 21 de enero de 1983 para buscar una salida negociada al conflicto, haciendo uso de la información transmitida por Rebollo en el Comité Nacional ${ }^{101}$, y dando lugar, con el paso del tiempo, a numerosos rumores sobre posibles chantajes y sobornos, los cuales fueron aireados por el propio Ruiz-Mateos a lo largo de su proceso judicial y desmentidos por parte de los dirigentes centristas ${ }^{102}$. Además, el CDS había sido el partido que más financiación recibió por parte del holding en las elecciones de 1982.

En relación a la actuación del gobierno, el CDS criticó el Real Decreto-Ley de Expropiación con el argumento, defendido en el Pleno del Congreso por Rodríguez Sahagún, de que aunque existieran las condiciones objetivas para dicha intervención, lo

\footnotetext{
${ }^{97}$ Real Decreto-Ley 2/1983, de 23 de febrero, de expropiación por razones de utilidad pública e interés social de los Bancos y otras Sociedades que componen el Grupo Ruiz Mateos Sociedad Anónima (RUMASA).

98 “Alejandro Rebollo: 49 años. Abogado, dirigente de Unión de Centro Democrático, más tarde del CDS, fue presidente de RENFE hasta enero de 1982. En esas fechas fue propuesto por Navalón a Ruiz Mateos para reforzar el equipo de asesores del presidente de Rumasa", EKAIZER, Ernesto: José María Ruiz Mateos, el último magnate, Barcelona, Plaza \& Janés, 1985, p. 16. A. Rebollo recomendó la presencia de Fernando Castedo, también dirigente del CDS, en el equipo de abogados, ibid ..., p. 416.

${ }^{99}$ Sobre el papel de Antonio Navalón, vínculo entre el mundo de la política, el empresariado y la banca, y su relación con Adolfo Suárez a lo largo de la década de los 80', véase, MORÁN, Gregorio: Ambición...; GARCÍA ABAD, José: Una tragedia...; HERRERO, Luis: Los que le llamábamos Adolfo, Madrid, La Esfera de los Libros, 2007.

${ }^{100}$ Encargados de organizar la rueda de prensa que desató finalmente la intervención del holding por el Gobierno, GARCÍA ABAD, José: Una tragedia ..., p. 239.

${ }^{101}$ EKAIZER, Ernesto: "La expropiación del miedo" en JULIÁ DÍAZ, Santos, PRADERA, Javier y JULIÁ DÍAZ, Santos (eds.): Memoria ..., pp. 558 y ss.; GUINDAL, Mariano: El declive de los dioses: los secretos de la Transición económica española desvelados por un testigo de excepción, Barcelona, Planeta, 2011.

${ }^{102}$ EKAIZER, Ernesto: José María ..., p. 611. Según Luis Herrero, Ruiz Mateos intentó utilizar a Suárez para defenderse ante Felipe González de la expropiación, lo que dio lugar a muchos rumores sobre maletines, pagos irregulares, etc. HERRERO, Luis: Los que le llamábamos..., p. 247. Durante los meses siguientes, los dirigentes centristas debieron desmentir periódicamente sus supuestos contactos con RUMASA, como la gestión de la situación del holding por parte de Suárez como presidente a la financiación del partido, que según J. R. Caso se reducía a ocho créditos de 25 millones de pesetas, $A B C$, 23 de abril de 1983.
} 
que en principio no se ponía en duda ${ }^{103}$, el procedimiento seguido era "inconstitucional" por vulnerar el Estado de Derecho y por existir fórmulas alternativas para la “intervención”-en lugar de expropiación- (artículo 128.2 de la CE) ${ }^{104}$. El CDS, junto al Grupo Popular y Minoría Catalana, votó en contra de la ratificación del decreto-ley gubernativo y ninguno de sus representantes acudió a la votación del proyecto de ley posterior, debatido en el Congreso el 10 de mayo de $1983^{105}$. Junto a los aspectos legales, el CDS recelaba de una medida que se interpretaba como atentatoria contra los principios de una economía de mercado: "creo que RUMASA y sus efectos a largo plazo [la intervención] es tremendamente perjudicial para la inversión en España"106. Jiménez de Parga, catedrático de derecho constitucional y miembro de la ejecutiva del CDS, indicaba que no sólo era un defecto de forma, sino de contenido, al "verse afectados derechos cívicos"107. La posterior convalidación por parte del Tribunal Constitucional del decreto-ley no fue objeto de interpretaciones políticas por el CDS -al igual que el resto de sentencias a propósito de recursos de inconstitucionalidad de AP-. Sus portavoces se limitaron a advertir la necesidad de "no politizar sus decisiones, que por [ser] la última palabra, son ley"108.

Si la expropiación de RUMASA suscitó la oposición de los partidos y medios de comunicación conservadores, la "reconversión industrial" generó una fuerte contestación social en la clase trabajadora a lo largo de todo el territorio nacional y especialmente en aquellos sectores que se vieron azotados por el desempleo y una merma considerable de su capacidad productiva, caso de la industria naval o de la siderurgia. El CDS, durante la campaña del 82', no había tenido reparos en subrayar la necesidad de llevar a cabo una profunda -y naturalmente, impopular- reconversión de los sectores más fustigados por la larga crisis económica iniciada en los años 70', sin

\footnotetext{
103 "Si los hechos son tal como los cuenta el Ministro -y a mí no me consta que así sea, y creo que el señor Ministro se habrá asegurado de que así son-, creo que justifican sobradamente, y creo que constituyen razones objetivas sobradas para, una intervención del Estado", DSCD, 1 de marzo de 1983, ${ }^{\circ}$ 15 , p. 622.

${ }_{104}$ Adolfo Suárez en el mismo sentido declaró: “a nosotros el argumento de inconstitucionalidad nos sigue pesando a la hora de emitir nuestro voto y en función de esta circunstancia no podemos apoyar el decreto [...] [aunque] me han abrumado los datos [...] Yo creo que posiblemente la intervención y el Fondo de Garantía", LAFORA, Victoria: "Ruiz-Mateos-Al Capone", Diario 16, 02 de marzo de 1983.

${ }^{105}$ Votación Plenaria del día 02 de marzo de 1983 de convalidación del Real Decreto-Ley 2/1983 de 23 de febrero de expropiación... Votación Plenaria del día 10 de mayo de 1983 del Proyecto de Ley sobre la expropiación...

${ }^{106}$ Interview undertaken by Richard Gunther, 1983 (june), AR.

${ }^{107}$ El País, 25 de febrero de 1983.

${ }^{108}$ El País, 10 de diciembre de 1983.
} 
olvidar, una complementaria y sustitutiva política de inversiones en ramas tecnológicas e innovadoras que permitiera la reestructuración del tejido industrial ${ }^{109}$.

Los principios que impulsaban la reconversión industrial eran ampliamente compartidos por el CDS. Las transformaciones sociales vividas en las últimas décadas y la nueva división internacional del trabajo implicaban necesariamente la renovación del aparato productivo lo que en España pasaba por "liberar los fondos necesarios y evitar seguir enterrando recursos públicos en sectores de dudosa viabilidad" ${ }^{\text {"110 }}$. Se hablaba incluso de una "reconversión permanente" para hacer frente no sólo a la crisis energética, sino también a los desafíos que iba a exigir la rápida evolución tecnológica ${ }^{111}$.

De acuerdo con el modelo propuesto por el CDS, el papel de la administración -para no generar un trasvase exagerado y descontrolado entre la empresa pública-privadadebía limitarse a tres sectores, los más duramente castigados por la crisis mundial y la nueva competencia internacional: el siderúrgico, el naval y el textil. La "reconversión" de cada uno de estos sectores se debía llevar a cabo a su vez, mediante un proceso de "reestructuración selectiva", es decir, a nivel de empresas concretas y estableciendo un reparto equitativo de los costes (accionistas, trabajadores, acreedores, financiadores y Estado). El principio de reconversión selectiva había sido, para Rodríguez Sahagún, el impulsor de la reestructuración industrial impulsada entre 1978 y 1980, es decir, bajo los gobiernos de Suárez.

La segunda fuente de discrepancia radicaba en la promulgación de una ley o un “decreto-ley" para llevar a cabo la "reconversión", ya que implicaba una generalización excesiva y sobre todo manifestaba cierta inclinación a esquivar la vía de la negociación ${ }^{112}$. En tercer lugar, la ausencia de una política de reindustrialización había

\footnotetext{
${ }^{109}$ El punto de vista más ampliamente aceptado en la historiografía y testimonios de la época sostiene que la actitud de los gobiernos de Suárez en política industrial había estado subordinada a la necesidad de consenso político -desde junio de 1977 hasta finales de 1980 se ha considerado habitualmente como la primera fase en el proceso de reestructuración industrial-, ESTEFANÍA, Joaquín: "El segundo ajuste..."; MARÍN ARCE, José María: "La fase dura de la reconversión industrial: 1983-1986", Historia del Presente, 8, 2006, pp. 61-101; IGLESIAS, María Antonia: La memoria recuperada, Madrid, Aguilar, 2003, pp. 813-816.

${ }^{110}$ RODRÍGUEZ SAHAGÚN, Agustín: "Reconversión industrial”, El País, 11 de febrero de 1984.

111 RODRÍGUEZ SAHAGÚN, Agustín: "Reindustrialización” y "Reconversión industrial”, BDCP, 2 , abril 1984, pp. 9-12. Estos principios habían sido defendidos en el Parlamento durante la convalidación del Real Decreto-Ley 8/1983 de 30 de noviembre de Reconversión y Reindustrialización, DSCD, Sesión Plenaria, 27 de diciembre de 1983, no 89, p. 4269 y ss.

112 "Hay un segundo punto que a mí me parece fundamental. Yo creo que la reconversión no puede ser, en ningún caso, fruto de la decisión de un Gobierno, ni de éste ni de ningún otro", DSCD, Sesión Plenaria,
} 
centrado las argumentaciones de Rodríguez Sahagún en uno de los debates sobre la "reconversión" industrial llevado a cabo en el Congreso ${ }^{113}$; una política que debía ser paralela al desmantelamiento de los sectores en crisis. En resumen, los motivos por los que el CDS no apoyó la convalidación del Real Decreto-Ley 8/1983 de Reconversión y Reindustrialización fueron los siguientes: no abordaba la reindustrialización, esquivaba el necesario consenso y no atendía las necesidades específicas de las distintas empresas $^{114}$.

A propósito de los conflictos que surgieron a raíz de la puesta en marcha de la reconversión, como sucedió en Sagunto, el CDS se limitó a resaltar las contradicciones del proyecto socialista: "es un problema de coherencia interna del Gobierno. Desde un punto de vista técnico, la propuesta de Carlos Solchaga es correcta; desde un punto de vista política es muy difícil"115. Por ejemplo en Andalucía, la Junta Regional del CDS reunida en mayo de 1984 concluía: "CDS es consciente de que hay que hacer esta reconversión [del sector naval] cuanto antes pero por su trascendencia social-dice la nota informativa- debe hacerse buscando el acuerdo de los afectados y [ser] paralelo a una reindustrialización" "116. De "puertas adentro" las coincidencias entre los planteamientos de los ministros económicos socialistas y los deseos de los dirigentes centristas eran sustancialmente mayores:

Nosotros en este momentos [1983] suscribimos un alto porcentaje del programa de partido socialista, y de hecho ahora nos parece que nos resulta un poco incoherente intentar atacar [...] Las actuaciones del ministro Boyer o del ministro Solchaga son

27 de diciembre de 1983, nº 89, p. 4270. En la tramitación del Proyecto de Ley posterior, Rodríguez Sahagún se opuso -junto a los diputados del PCE- a que las centrales sindicales contrarias a los planes de reconversión fueran excluidas de las respectivas comisiones de control y de seguimiento, propuesta que contaba con el consenso del GS y GP, El País, 23 de mayo de 1984. Rodríguez Sahagún se expresaba en estos términos: "miren ustedes, señorías, en este momento retiraba todas las enmiendas [...] solamente con que ustedes tomaran conciencia del enorme error político que están cometiendo [quiebra del diálogo social y escalada de la contestación]”, DSCD, Sesión Plenaria, 22 de mayo de 1984, no 125, p. 5685.

${ }^{113}$ La postura de Rodríguez Sahagún le llevó a presentar una "enmienda" al propio título de la ley: "Señor Presidente, señorías, brevemente voy a tratar de defender mi primera enmienda, que es una enmienda al título. Como ustedes saben, el proyecto del Gobierno lo llama: Ley de Reconversión y de Reindustrialización, y mi enmienda pretende que el título quede reducido a su primera parte, es decir, Ley, pura y simplemente, de Reconversión”, DSCD, Sesión Plenaria, 18 de mayo de 1984, n 124, p. 5664.

${ }^{114}$ Tampoco era coherente con el modelo de estado autonómico, al no hacer a estas instituciones partícipes del proceso de toma de decisiones, y finalmente, no tenía en cuenta ni al cooperativismo empresarial, ni a la pequeña y mediana empresa, DSCD, Sesión Plenaria, 27 de diciembre de 1983, nº 89, pp. 4270-1. En la Votación Plenaria del día 27 de diciembre de 1983 de convalidación del Real Decreto Ley 8/1983 de Reconversión y reindustrialización tanto Rodríguez Sahagún como Suárez estuvieron ausentes, aunque habían anunciado en el pleno su abstención, DSCD, Sesión Plenaria, 27 de diciembre de $1983, \mathrm{n}^{\circ} 89$, p. 4269.

${ }^{115} A B C, 08$ de julio de 1983.

${ }^{116}$ ABC Sevilla, 16 de mayo de 1984. 
completamente asumibles por CDS. Es más, yo creo que son actuaciones claras de partido social demócrata [en oposición al "socialismo"] [las reformas, la reconversión industrial, planteadas por ambos] podría estarla haciendo perfectamente desde $\operatorname{CDS}^{117}$.

Uno de los problemas, como señalaba otro destacado líder centrista, era que la unilateralidad de los gobiernos socialistas iba a impedir dar continuidad a un proceso de este tipo: “el problema y que así lo señalábamos en el programa electoral, es que una reindustrialización comporta despejar incógnitas a largo plazo, es decir, fijar horizontes de 8,10 o 12 años. Y eso no lo puede comprometer ningún gobierno solo"118.

La política económica socialista, inequívocamente moderada y reformista, concordaba en sus objetivos finales con las preocupaciones de los grupos a los que aspiraba a representar el CDS -directivos, profesionales liberales, altos cargos de la administración y pequeños y medianos empresarios-, es decir, avanzar en el proceso de "modernización" socioeconómica del país y en último término, la tan ansiada, convergencia con Europa.

Desde una perspectiva más amplia, la política económica del CDS fue plasmada en El País por el propio Rodríguez Sahagún en dos extensos artículos: uno relativo al análisis de datos macroeconómicos y otro centrado en la política de empleo ${ }^{119}$. El denominador común de ambos era el alegato en favor de un gran pacto de Estado entre las fuerzas políticas y sociales, para superar la crisis y lograr la tan ansiada modernización de las estructuras socio-económicas nacionales. En el primero de esos artículos, Rodríguez Sahagún sintetizaba en dos, los posibles caminos a seguir por la economía española. La primera vía se centraría en la contención de la inflación, manteniendo niveles de crecimiento bajos y posponiendo la lucha contra el desempleo. El segundo camino partiría de la "utilización intensiva del potencial de desarrollo existente", aprovechando la coyuntura internacional favorable y el bajo precio del crudo:

Apoyándose en un sólido pacto social que permita una adecuada política de rentas y una moderación del consumo público y privado, de forma que se pueda desacelerar la importación y liberar capacidad de producción en los sectores no infrautilizados para

\footnotetext{
117 Interview undertaken by Richard Gunther, in 1983 (june), AR. En materia financiera, Calvo Ortega aseguraba que Boyer estaba aplicando la reforma tributaria de UCD, $A B C, 22$ de enero de 1985.

${ }_{118}$ Interview undertaken by Richard Gunther, in 1983 (june), AR.

119 RODRÍGUEZ SAHAGÚN, Agustín: "La nueva política económica a medio plazo", El País, 13 de junio de 1983; ÍD.: “Un pacto para el empleo”, El País, 19 de mayo de 1983.
} 
atender al reto exportador, así como aumentar la formación bruta de capital fijo hasta cifras superiores al $25 \%$ del PIB $^{120}$.

Para Rodríguez Sahagún, mientras la primera alternativa evidenciaba una mayor dependencia de la economía norteamericana, la segunda hipótesis permitía abordar el grave problema del desempleo y utilizar decisivamente todos los recursos económicos nacionales, si bien, exigía en sus primeras fases de un alto grado de compromiso y de sacrificio por parte de todos. Esta última, opción defendida por Rodríguez Sahagún, tenía como eje central una política de rentas -control de precios y salarios- y en consecuencia, una política de concertación entre sindicatos, patronal y gobierno ${ }^{121}$, que como señalaba el político centrista "sin abandonar el control de las magnitudes monetarias, se diera cuenta de que no acaban ahí todos los problemas"122.

Las herramientas del CDS para alcanzar la recuperación económica y conseguir hacer de la economía española una economía competitiva eran: la flexibilización laboral, financiera- y la implementación de sectores más aptos "dentro de las dinámicas del actual proceso de reajuste de la economía mundial". Objetivos que se debían abordar en un marco de diálogo y en los que el Estado - de forma directa o indirecta- tenía que jugar un papel trascendental ${ }^{123}$. Entre las medidas concretas defendidas por los centristas se encontraban: el apoyo a las PYMES, la mejor administración de los recursos públicos, el fomento de la inversión -mediante políticas de crédito oficial, medidas fiscales, etc.- , la reforma de la Seguridad Social ${ }^{124}$, una nueva política fiscal ${ }^{125}$ y la revisión del Plan Energético Nacional -necesidad de potenciar fuentes de energía

\footnotetext{
${ }^{120}$ A propósito de la "política monetarista" se pronunció también en el Congreso: "Señor Ministro, yo creo que en este país estamos excesivamente [...] obsesionados con la disciplina monetaria y obsesionados con el control de las magnitudes monetarias. A mí me parece fundamental controlar las magnitudes monetarias, pero que quede bien claro que no se conseguirá una política anti-inflacionista verdaderamente seria si no es con una política de rentas de verdad", DSCD, Sesión Informativa de Comisión: Comparecencia del Ministro de Economía y Hacienda, don Miguel Boyer Salvador, para informar sobre política de su departamento, 18 de febrero de 1983, p. 35. En declaraciones de Suárez en el semanario Tiempo: "se ha seguido una política ortodoxa desde las perspectivas del Fondo monetario Internacional, que considero puede ser válida para países con alto nivel de industrialización, pero no para un país semi-industrializado como España. Esta política económica en nuestro país comporta unos costes sociales muy graves", Tiempo, 28 de octubre de 1985 recogido en VILAR, Sergio: La década sorprendente (1976-1986), Barcelona, Planeta, 1986, p. 179.

${ }^{121}$ Con sarcasmo, J. L. Bernal comentaba: "ni vio que los tanques venían [Rodríguez Sahagún], cuando era ministro de defensa, ni ve ahora que los Pactos de la Moncloa han pasado como posibilidad política", pactos que entre otras cosas, habían servido a la izquierda para alcanzar el poder en 1982 y "descapitalizar" la economía en "Rodríguez Sahagún", $A B C, 15$ de junio de 1983.

${ }^{122}$ RODRÍGUEZ SAHAGÚN, Agustín: "La nueva...", El País, 13 de junio de 1983.

${ }^{123}$ RODRÍGUEZ SAHAGÚN: "Reindustrialización” y "Reconversión Industrial”, $B D C P$, 2, abril 1984.

${ }^{124}$ En la línea de liberar recursos para la inversión y creación de puestos de trabajo, RODRÍGUEZ SAHAGÚN: "Reindustrialización” y "Reconversión Industrial”, $B D C P$, 2, abril 1984.

${ }_{125}$ Basada en la congelación y/o rebaja fiscal y la reforma del IRPF (caso de rentas en ambos cónyuges, mínimo exento, etc.), ibid.
} 
alternativas al petróleo-. Merece la pena destacar, en lo que fue una de las señas de identidad del CDS, la elaboración de un discurso económico en el que los conceptos de "competitividad" o "innovación" ocupaban lugares centrales y que pivotaba sobre la pequeña y mediana empresa como principal agente económico y elemento dinamizador ${ }^{126}$. No resulta extraño que tres de las siete "preguntas orales" formuladas en el Pleno por Rodríguez Sahagún estuvieran enfocadas a problemas específicos de las PYMES -siendo las siete, referentes cuestiones económicas ${ }^{127}$. Una postura, en resumen, que podemos definir como "socio-liberal" aunque era un término apenas usado en la época y en ningún caso, por el CDS.

Rodríguez Sahagún, portavoz del partido en materia económica tanto a efectos parlamentarios como de comunicación social, mantuvo una capacidad de trabajo descomunal y logró compensar con bastante éxito la escasa representación suarista en el Congreso. Fue el diputado no socialista con el mayor número de enmiendas aceptadas en la II Legislatura (véase Anexo IX).

\section{3. Política y cambio social (1982-1986)}

La política social del PSOE tuvo en la Ley Orgánica de Derecho a la Educación (LODE, 1985) y la Ley General de Sanidad (LGS, 1986) sus mayores exponentes. Su puesta en marcha permitió la extensión a prácticamente toda la población de dos de los principales derechos sociales de la contemporaneidad, en lo que era una política de corte netamente socialdemócrata que favorecía los mecanismos de redistribución de rentas mediante la provisión de servicios públicos. Ambas leyes supusieron un salto cualitativo en la construcción del Estado del Bienestar en España y lo hicieron desde una perspectiva universalista -en referencia, al modelo inaugurado por William Beveridge

\footnotetext{
${ }^{126}$ Explícitamente diferenciado del gran capital empresarial o bancario: "El problema de las PYMES es mucho más complejo. Oigan a las PYMES primero, y oigan a todas las PYMES, no sólo a aquellas que están integradas en las grandes patronales, no sólo a aquellas que dicen lo que se les encarga decir; oigan ustedes a todas las PYMES", DSCD, Sesión Informativa de Comisión: Comparecencia del Ministro de Economía y Hacienda, don Miguel Boyer Salvador, para informar sobre política de su departamento, 18 de febrero de 1983, p. 37.

${ }^{127}$ Conjunto de las "preguntas orales" formuladas en el Pleno por Agustín Rodríguez Sahagún en la II Legislatura: Medidas para reducir los altos tipos de interés de la Pequeña y Mediana Empresa (PYME); medidas para lograr la reducción de los costes financieros de la Pequeña y Mediana Empresa (PYME); incidencia de la reducción de los precios del petróleo; medidas para lograr la reducción de los intereses pagados por la Pequeña y Mediana Empresa (PYME); objetivos del cuadro macroeconómico de los Presupuestos Generales del Estado para 1984; paro juvenil; paro por sectores.
} 
en Gran Bretaña-. Sin embargo, este criterio expansivo sería alterado finalmente en algunas de las reformas de la Seguridad Social llevadas a cabo que oscilaron, entre la generalización y la racionalización -ajuste-, arrojando un saldo desigual al término de la Legislatura. En torno al debate, generado en el mundo occidental, sobre la viabilidad del Estado del Bienestar Suárez matizaba sus implicaciones para el caso de España:

Este debate no tiene el mismo significado ni profundidad en términos éticos y políticos en sociedades con baja tasa de desempleo y amplia cobertura [...] que en aquellas otras, como es el caso de España, en que los niveles de prestaciones están aún muy lejos de lo que nos correspondería en función de nuestra Renta Nacional ${ }^{128}$.

Por otro lado, y en relación a los derechos económicos, sociales y culturales, no debemos olvidarnos de la decisiva actuación del PSOE en el ámbito de la sexualidad y de las relaciones socio-familiares, una tendencia cuyo principal referente hasta la fecha había sido la Ley del Divorcio (1981, UCD) y ahora iba a implementarse de manera significativa con la Ley de Despenalización del Aborto (LDA, 1983). De cara a nuestra argumentación y por haber constituido tradicionalmente un destacado cleavage en el sistema de partidos español -aunque con una intensidad mucho menor en esta época129 , comenzaremos nuestro discurso atendiendo a las implicaciones religiosas de la LDA y la LODE, y en última instancia, abordaremos las transformaciones de la política sanitaria y de los mecanismos de protección social. En todos los casos, lo haremos tomando como eje referencial los planteamientos del CDS.

El CDS no era un partido confesional ni tampoco, en palabras de Suárez, podía ser definido como un partido laico ${ }^{130}$. Comenzando por el propio Suárez, la militancia del CDS era mayoritariamente católica y practicante, -véase la Tabla 18-, una tendencia acentuada en sus cuadros dirigentes y en cuyo Comité Nacional, se apuntaba la presencia de antiguos miembros del Opus Dei. Todavía en 1979, Suárez, en su famosa intervención televisiva previa a las elecciones, con un tono tremendista y apelando al electorado más conservador arremetía contra los socialistas acusándoles de defender "el aborto libre" ${ }^{131}$. Por otra parte, la jerarquía eclesiástica, a través del presidente de la

\footnotetext{
${ }^{128}$ SUÁREZ GONZÁLEZ, Adolfo: Horizonte político de España, CDS, 1986, p. 15.

${ }^{129}$ Los cleavages tradicionales del sistema de partidos en España habían sido el de clase, el religioso y el regionalista o nacionalista, véase GUNTHER, Richard, SANI, Giacomo y SHABADA, Goldie: $E l$ sistema de partidos políticos en España. Génesis y evolución, Madrid, CIS, 1986. Un análisis sobre su pérdida de relevancia e impacto desde la transición en REDONDO, Marta, La imagen...

${ }^{130}$ Teletipo EFE, 27 de septiembre de 1982, Gabinete de Información, Caja 323, Dossier CDS, AGCYL.

131 Una intervención que ha sido considerada decisiva, RAMÍREZ, Pedro J.: Así se ganaron las elecciones, Madrid, Ed. Prensa Española, 1979, p. 425. De todas formas, no podemos olvidar la existencia de un borrador relativo a la despenalización del aborto -en vista, a una previsible inclusión en el Anteproyecto del Código Penal de 1979- desarrollado por los Gobiernos de UCD y "frenado" por el
} 
Conferencia Episcopal, V. E. Tarancón, se había identificado mayoritariamente con el proceso de Transición política guiado por Suárez.

Sin embargo, la tramitación de la Ley del Divorcio de Fernández Ordóñez, nombrado ministro de Justicia por Adolfo Suárez, -en sustitución de un proyecto anterior, ideado por el democristiano Íñigo Cavero--, supuso un punto de inflexión en su relación con parte de la jerarquía eclesiástica y el asociacionismo católico que orientó sus ojos hacia los democristianos y Alianza Popular. Todo ello, en medio de la fuerte crisis y división interna del partido centrista:

Tabla 18: Auto-consideración en materia religiosa desde el punto de vista comparativo entre la militancia del CDS y el conjunto de la población española.

\begin{tabular}{|c|c|c|}
\hline $\begin{array}{c}\text { Auto-consideración en } \\
\text { materia religiosa }\end{array}$ & $\begin{array}{c}\text { Porcentaje } \\
\text { Militantes CDS } \\
\mathbf{( 1 9 8 3 )}\end{array}$ & $\begin{array}{c}\text { Porcentaje } \\
\text { Población } \\
\mathbf{( 1 9 8 2 )}\end{array}$ \\
\hline Católicos practicantes & 42 & $35-40$ \\
\hline $\begin{array}{c}\text { Católicos no muy } \\
\text { practicantes }\end{array}$ & - & $25-30$ \\
\hline Católicos no practicantes & 38 & 20 \\
\hline Indiferentes & 7 & 10 \\
\hline Creyentes sin religión & 4 & - \\
\hline No creyentes & 4 & - \\
\hline Muy buenos católicos & 3 & - \\
\hline Creyentes otras religiones & 2 & - \\
\hline
\end{tabular}

Elaboración propia a partir del Boletín de Participación Cultural del CDS, 1, enero 1984 y RUIZ CONTRERAS, Marta: La imagen..., p. 40 y 42.

En relación a la Ley de Despenalización del Aborto $^{132}$, -siguiendo un orden cronológico-, el CDS se declaraba desde su Congreso Constituyente "contrario al aborto", si bien contemplaba la posibilidad de establecer atenuantes o eximentes en base a "circunstancias subjetivas y objetivas relacionadas con la mujer que aborta" y siempre por decisión judicial ${ }^{133}$. No obstante, como recogía Carlos Santos, este tema había sido uno de los más debatidos en la ponencia de sanidad y siete de sus miembros habían votado a favor de una modificación de estos planteamientos ${ }^{134}$.

La postura del CDS era favorable a una modificación del Código Penal introduciendo "una mayor discrecionalidad, en función de las circunstancias", en lugar de la vía de la despenalización planteada en el proyecto del gobierno y rechazada

Ministro de Justicia Íñigo Cavero, véase, BARREIRO PÉREZ-PRADO, Belén: Democracia y conflicto moral: la política del aborto en Italia y en España, Madrid, Ed. Peninsular, 1998, p. 187.

${ }^{132}$ Véase, BARREIRO PÉREZ-PRADO, Belén: Democracia ...,

${ }^{133}$ MELLADO PRADO, Pilar: "Congreso...", p. 233. "Suárez: el CDS no es partidario del aborto", El Noticiero Universal, 21 de septiembre de 1982. Abel Hernández recogía los supuestos de salud de la madre, violación y malformación del feto, $A B C, 13$ de octubre de 1982

${ }^{134}$ Diario 16, 04 de octubre de1982. 
explícitamente mediante un comunicado ${ }^{135}$ : "[CDS y PNV] en el turno de intervenciones coincidieron, con algunas matizaciones, en plantear la sustitución de la despenalización por la ampliación de eximentes y atenuantes en el articulado del Código Penal correspondiente al aborto" ${ }^{\text {"136 }}$. Como demostró la intervención, particularmente confusa, de Rodríguez Sahagún durante la tramitación del proyecto de ley socialista la tendencia del CDS al término medio, al consenso y en ocasiones, la ambigüedad calculada no se podía sostener ante una medida de este tipo.

Rodríguez Sahagún comenzó convirtiendo al proyecto del PSOE en un oxímoron al tildarlo simultáneamente de "insuficiente y excesivo"137. Señalaba que "si no existe realmente la vida humana", se mantenían innecesariamente cláusulas legales de una dureza excesiva; mientras que "si realmente existe la vida humana, y nosotros así lo pensamos", no era el camino más adecuado para respetar las circunstancias de la madre y la vida del feto. Para Rodríguez Sahagún la solución pasaba por otorgar mayor discrecionalidad a los jueces y desarrollar una cadena progresiva de atenuantes y eximentes, junto a programas de educación sexual y medidas sociales de prevención ${ }^{138}$. En esta línea, un alto cargo del CDS se reafirmaba en una entrevista realizada en 1983 al considerar hipócrita la posición del PSOE: "si no hay vida humana [...] en los 3 primeros meses de vida, lo que no cabe es aborto en 3 casos. Cabe aborto en todos los casos"139. El CDS al pronunciarse afirmativamente sobre la existencia de la vida desde el momento de la concepción debía exigir en todos los casos concretos la intervención de un juez, independientemente de que fueran más o menos los eximentes y atenuantes. La posición "de facto" del CDS no distaba mucho de la ley propuesta por el PSOE, y en última instancia era incompatible con la defensa del derecho a la vida del no nacido ${ }^{140}$.

\footnotetext{
${ }^{135}$ El País, 27 de enero de 1983.

${ }^{136}$ Miquel Roca votó a favor del proyecto, HERNÁNDEZ RODRÍGUEZ, Gerardo: El aborto en España: análisis de un proceso socio-político, Madrid, UPCO, 1992, p. 182. Antonio Garrigues, líder del PDL, se había pronunciado por una "regulación" del aborto, El País, 20 de marzo de 1983.

${ }^{137}$ DSCD, 25 de mayo de 1983, n40, p. 1872. Rodríguez Sahagún no participó en el Segundo Debate Parlamentario sobre la LDA que tuvo lugar entre abril y junio de 1985, con posterioridad a la sentencia del Tribunal Constitucional.

${ }^{138}$ Ibid.

${ }^{139}$ Interview undertaken by Richard Gunther, in 1983 (june), AR.

140 "La diferencia respecto al método de la despenalización radica en que cada caso de aborto debe ser examinado por un juez, de forma que si no se ajusta a la ley se abre el sumario correspondiente. Es evidente que este modelo es menos proabortista, pero aun así implica una aceptación de la interrupción voluntaria del embarazo y por tanto, aunque sea compatible con la valoración de la vida en desarrollo no lo es con la defensa de que el no nacido tiene derecho a la vida", BARREIRO PÉREZ-PARDO, Belén: Democracia..., p. 236.
} 
Entre los votantes del CDS, la opinión, aunque dividida, era cercana en términos generales a la del electorado socialista -tabla 19-:

Tabla 19: Actitudes ante el aborto y recuerdo de voto en 1982 (porcentajes).

\begin{tabular}{|l|l|l|l|l|l|l|}
\hline & TOTAL (\% a favor) & PSOE & AP & PCE & CDS & UCD \\
\hline $\begin{array}{l}\text { Indicación terapéutica } \\
\text { (salud física/mental) }\end{array}$ & 62 & 77 & 40 & 88 & 74 & 43 \\
\hline $\begin{array}{l}\text { Indicación terapéutica } \\
\text { (vida) }\end{array}$ & 66 & 80 & 44 & 92 & 78 & 49 \\
\hline Indicación eugenésica & 62 & 77 & 40 & 86 & 63 & 40 \\
\hline Indicación ética & 56 & 71 & 33 & 80 & 59 & 38 \\
\hline Aborto Libre & 24 & 30 & 7 & 65 & 11 & 12 \\
\hline
\end{tabular}

"Estudio no 1.341 (CIS)" recogido en BARREIRO PÉREZ-PARDO, Belén: Democracia ..., p. 196.

La postura oficial del CDS respecto a la $L D A$ pasó rápidamente de una crítica distanciada a su aceptación pasiva. En la votación en el pleno del proyecto de ley, finalmente, no estuvieron presentes ni Adolfo Suárez ni Agustín Rodríguez Sahagún quien abandonó el hemiciclo poco antes de comenzar ${ }^{141}$. Jaime Campmany, desde $A B C$, definía con sorna la posición del CDS, un nuevo síntoma de su subordinación al PSOE: "un partido íntegro, el CDS, o sea, Agustín y [...] don Adolfo Suárez, no comparece, ecléctico entre la Moncloa y Santa Teresa"142.

Con el tiempo, el CDS asumió como un avance legislativo positivo la despenalización del aborto, sin renunciar por ello a la defensa de una interpretación basada en las implicaciones éticas existentes y la libertad de conciencia. El ginecólogo y candidato al senado por el CDS en Barcelona, Santiago Dexeus ${ }^{143}$ defendía en El País esta vía intermedia de aproximación a la problemática del aborto: "la primera falacia que hay que denunciar, [...] es la exigencia de un pronunciamiento a favor o en contra del aborto". Tras recorrer los datos de abortos clandestinos en España, las condiciones socio-económicas del país o la situación de las "madres solteras" ratificaba la necesidad de su despenalización en los supuestos desarrollados por el gobierno, lo que, para el autor, no esquivaba los dilemas éticos que podía plantear para los profesionales: "yo estoy por la legalización, pero no voy a practicar interrupciones [...] La despenalización era una llamada más al respeto entre ciudadanos de diversas tendencias, creencias y

\footnotetext{
${ }^{141}$ SÁNCHEZ, José Antonio: "El Congreso despenaliza el aborto con 48 diputados ausentes", $A B C, 07$ de octubre de 1983 y PRADES, Joaquina: "La ausencia de numerosos diputados facilitó la disciplina de voto de los parlamentarios en la reforma del Código Penal", El País, 07 de octubre de 1983.

${ }^{142} A B C, 09$ de octubre de 1983.

143 Candidato del CDS al Senado por la circunscripción de Barcelona en unas elecciones parciales celebradas para cubrir una vacante en la Cámara Alta el 08 de mayo de 1983.
} 
políticas; siempre que se respete la objeción de conciencia"144. Años después, Rodríguez Sahagún en una entrevista con Santiago Martín para la sección sobre Religión de $A B C$ comentaba:

- ¿Pero la fe no aporta contenidos concretos, como en el caso del aborto?

- Yo no estoy dispuesto a imponer a nadie planos puramente de mi religión, a confundir lo religioso con lo político. En el aborto, es obvio que mi posición legislativa y política deriva del propio convencimiento que yo tengo [...] Pero yo no decido, en cuanto hombre religioso, si la vida humana se da en el embrión o no; para eso consulto al científico. Yo estuve en contra de la ley del Aborto, pero, probablemente, ahora ya no removería ese asunto [...] Tampoco puede la Iglesia estar permanentemente volcada en un aspecto de los problemas sociales -como los referentes a la vida-e ignorar otros ${ }^{145}$.

Como vemos, la posición del CDS en materia religiosa estaba situada en una disyuntiva mucha veces difícil de sostener. Un elocuente testimonio de esta afirmación fue lo sucedido en el Ayuntamiento de Segovia en 1984. A propósito de la puesta en escena de la obra "Teledeum" de Els Joglars la oposición (AP-PDP y CDS), tras las críticas del obispo de la diócesis, forzó la dimisión de la concejala socialista de cultura en el ayuntamiento ${ }^{146}$. La postura del CDS hubo de ser rápidamente matizada en una carta del presidente de la gestora provincial, -Rafael Bernardo Santos-, al periódico local en la que justificaba su decisión por la ausencia de consenso con la que el PSOE había dado luz verde a la representación y finalizaba: "queremos dejar claro que nuestra ideología es de centro progresista y reformista, quiere esto decir que consecuentemente distamos de extremos políticos"

La educación fue el otro gran campo de batalla, junto con el aborto, en el que se escenificaron enfrentamientos y recelos entre la Iglesia y el PSOE ${ }^{148}$. El CDS defendió desde sus orígenes la educación privada de acuerdo con el principio de libertad de enseñanza recogido en la Constitución. Según una encuesta publicada en $A B C$ en abril de 1983, un 63\% de los votantes del CDS se manifestaba a favor de la coexistencia de una educación privada y otra pública y sólo un $27 \%$, favorable al monopolio estatal de

\footnotetext{
${ }^{144}$ El País, 19 de abril de 1985. Un concejal del CDS en Albacete declaraba en 1987: "la despenalización del aborto y el divorcio son dos avances legislativos y, como tales, son un servicio a la sociedad porque se deja libertad de elección al ciudadano. Otra cosa distinta es que las convicciones éticas de cada uno le lleven a mostrarse a favor o en contra", CDS Albacete: Eslabón, 4, mayo-junio 1987. Véase también, un punto de vista más restrictivo, MAYOR ZARAGOZA, Federico: Mañana siempre es tarde, Madrid, Espasa-Calpe, 1987, pp. 105-115.

${ }^{145} A B C, 13$ de marzo de 1988. "[Rodríguez Sahagún] Sí. Soy creyente y además creo que el tener un sentido trascendente de la vida es importante a la hora de dar coherencia a los comportamientos de la persona", Blanco y Negro (ABC), 05 de octubre de 1986.

${ }^{146}$ Este alineamiento fue habitual en las votaciones sobre programación religiosa del Consejo de RTVE, $A B C, 09$ de septiembre de 1982 o 22 de marzo de 1983.

${ }_{147}$ El Adelantado de Segovia, 03 de mayo de 1984.

${ }^{148}$ Véase, IGLESIAS, María Antonia: La memoria ..., pp. 46-50.
} 
la educación $^{149}$. Sin embargo, como había sucedido a propósito de la $L D A$ la posición del CDS se matizaba en un doble sentido.

En líneas generales, la LODE se consideró desde el principio una ley con muchos elementos positivos ${ }^{150}$, respetaba el principio de libertad de enseñanza y recogía el fuerte impulso dado a la educación pública tras los Pactos de la Moncloa. El mayor reparo estribaba en la "discrecionalidad" existente en la ley para la concesión y sobre todo, retirada de las ayudas. También se criticaba la pérdida de control de la gestión del centro privado sujeto a subvención pública ${ }^{151}$, la distritalización de los puestos de enseñanza y la ambigua redacción sobre la libertad de cátedra en la enseñanza primaria y media. Se temía una presumible politización de la enseñanza y los subsiguientes perjuicios en el campo de la libertad educativa:

El CDS preconiza un modelo de escuela pluralista, participativa, innovadora y entramada socialmente. El CDS sostiene que el Estado debe asegurar como uno de sus fines primordiales la existencia de un puesto escolar para todos [...] El CDS, defiende la libertad de enseñanza desde dos modalidades. Primera. Como un instrumento de colaboración con la obligación asumida por el Estado en el aseguramiento de los puestos escolares. Segunda. Como un sector libre que responde al principio general de libertad de empresa. En el primer supuesto procede, con la debida reglamentación, la ayuda a fondos públicos. En el segundo, una vigilancia general del Estado en cuanto a programas y contenidos mínimos sin ayuda económica posible ${ }^{152}$.

Una lectura del modelo educativo que encontraba su justificación en las condiciones sociales y económicas del país: "hoy por hoy [...] el 35 o 40\% de la enseñanza está en manos de la enseñanza privada, y [...] son mayores los costos de hacer centros públicos, claramente hay que ir a la subvención del sector privado [...] Pero los niveles de calidad de la enseñanza pública deben equipararse a la privada subvencionada, en la parte que es subvencionada", postura, según el líder centrista cercana, aunque no idéntica, a la de la ley socialista ${ }^{153}$ y es que el CDS se encontraba lejos de sentirse representado por la

\footnotetext{
${ }^{149} A B C, 17$ de abril de 1983 .

${ }^{150}$ El CDS no presentó ninguna enmienda a la totalidad, sí veinte enmiendas parciales. En el debate de las enmiendas de devolución presentadas por el Grupo Popular, Grupo Centrista y Minoría Vasca en el que no estuvieron presentes ni Suárez y Rodríguez Sahagún, véase, El País, 12 de octubre de 1983. En la votación de conjunto de la Ley de Reforma Universitaria (LRU) de 14 de julio de 1983 estuvieron ausentes tanto Rodríguez Sahagún como Adolfo Suárez y en el programa electoral de 1986 se propuso únicamente su "modificación", CDS: Programa Electoral. El valor del centro. CDS, Madrid, CDS, 1986, p. 66, $A A G$.

${ }^{151}$ Es decir, de los "inspiradores" y "fundadores" en beneficio de la administración y del Consejo Escolar. ${ }^{152}$ Asimismo, defendía la obligatoriedad en el nivel preescolar y medio hasta los 16 (y los 18 años en una segunda fase), y en los niveles superiores instaba a: la supresión de la selectividad - “confesión de desconfianza sobre los niveles anteriores"-, gratuidad y acceso en base al mérito" en HERNÁNDEZ, Abel: "La posición de nuestro partido [LODE]", Boletín Cutural, 1, enero 1984.

${ }^{153}$ Interview undertaken by Richard Gunther, in 1983 (june), AR. En este mismo sentido se expresaba Suárez, El Noticiero Universal, 21 de septiembre de 1982.
} 
LOECE -Ley Orgánica de Estatutos de Centros Escolares-, llevada a cabo por el ministerio de Otero Novas (1980): “el PSOE no debería dejarse vencer por la tentación de torcer hacia la izquierda lo que UCD torció hacia la derecha"154. Respecto a la oposición planteada por la CP se criticaba su nulo interés por la educación pública y la identificación automática entre enseñanza religiosa católica y privada, -dando pábulo a un enfrentamiento visceral ${ }^{155}$, en suma, su incapacidad para "ofrecer una alternativa real de libertad y constitucionalidad"156.

En términos políticos, el CDS alertaba de los peligros de la gestación unilateral y escasas cesiones por parte del PSOE en la tramitación de una ley de este calibre. Una actitud que para los suaristas podía haber transmitido un equívoco mensaje pudiéndose haber interpretado como una medida "contra" el sentimiento católico existente en el país y haber contribuido al descrédito del sistema democrático en cuya consolidación tan determinantemente habían participado, caso de la jerarquía eclesiástica ${ }^{157}$. Una lectura, azuzada por el clima de confrontación social creado por asociaciones católicas educativas (CONCAPA, FERE, etc.) -con el respaldo de la $\mathrm{CP}^{158}$-, así como la evidente raíz marxista -según los centristas ${ }^{159}$ - del proyecto socialista:

Volvíamos a la política de bandazos [...] con independencia de las mejoras relativas que la LODE introducía dentro del sistema educativa respecto al control, subvenciones, igualdad, participación de los padres [...] había un cáncer de partido que era una ley impuesta, no negociada, no consensuada, en algo que en nuestra opinión supera a un período legislativo de un gobierno y afecta [...] al futuro de la nación ${ }^{160}$.

\footnotetext{
${ }^{154}$ HERNÁNDEZ, Abel: "La posición de...". "Se convirtió en punta de lanza de reanimación de un sector muy amplio de clientelas de centro-derecha", con el aprovechamiento de la oposición y en connivencia con la campaña de demolición personal de Suárez, LANZACO, Fernando: "Colaboraciones", $B D C P, 2$, abril 1984.

${ }^{155}$ El CDS rechazó acudir a las manifestaciones contra la LODE en las que estuvieron presentes, a título individual, políticos de AP y PDP. Rodríguez Sahagún declaraba que no veía correcto acudir porque "no deben politizarse actos de este tipo. Para él, se ha producido un avance claro en la educación de nuestro país", $A B C, 17$ de noviembre de 1984.

${ }^{156}$ LANZACO, Fernando: "Colaboraciones...", pp. 6-7.

157 Abel Hernández parafraseaba a Ortega y Gasset y advertía sobre el posible distanciamiento del episcopado más conservador: “¡no es esto, no es esto!” en HERNÁNDEZ, Abel: “La posición...”.

${ }^{158}$ MARÍN ARCE, José María: “Los socialistas en el poder (1982-1996)”, Historia y Política: ideas, procesos y movimientos sociales, 20, 2008, p. 46.

${ }^{159}$ La doctrina educativa del PSOE partía de dos presupuestos básicos: el principio marxista de conquista del Estado y la necesidad de igualdad y modernidad de los ciudadanos ante la educación, "no debe perderse de vista ambos propósitos entrelazados en la LODE y no son susceptibles de una separación nítida más que a efectos puramente metodológicos”, LANZACO, Fernando: “Colaboraciones...”, p. 5.

${ }^{160}$ Interview undertaken by Richard Gunther, in 1986 (june), AR.
} 
Por todo ello, la postura final del CDS ante la LODE fue la de la abstención ${ }^{161}$; no se habían suprimido, en las enmiendas aceptadas, todas las posibilidades implícitas en la ley que podían hacer de ella un arma utilizada partidariamente y en otro sentido, contenía suficientes elementos positivos como para no votar en su contra, ni espolear el uso político de la polémica llevado a cabo por la "derecha". El CDS se alineaba en cierto modo con los sectores más progresistas y menos beligerantes de la Iglesia Católica: "yo creo que los [...espacio en blanco...] de la Iglesia, progresista, de la iglesia post-conciliar, coinciden enormemente con los planteamientos de CDS"162.

La posición del CDS en materia religiosa entroncaba con su lectura sobre la evolución histórica de España. La "cuestión religiosa" había significado una de las principales causas de fractura política y social de la sociedad española desde el XIX. En la reseña de un libro del periodista, escritor y miembro del CDS Abel Hernández sobre las relaciones entre la Iglesia y el PSOE, se señalaba tras constatar el progresivo distanciamiento entre ambos: “¿Dejará de ser, por fin, la “cuestión religiosa” motivo de discordia civil entre los españoles?" ${ }^{163}$ Y aunque entreveía un punto de entendimiento al llamar la atención sobre el alto número de creyentes que militaban en el PSOE o la permeabilidad al cambio en diversos sectores de la iglesia -como los jesuitas, frente a la "resistencia" del Opus Dei- ${ }^{164}$, el mismo autor, a propósito de la tramitación de la LODE lamentaba: "En el campo educativo contienden otra vez, como una fatalidad, las ‘dos Españas' [...] la fundada sospecha de que sea una ley de media España frente a otra media" 165 .

En el otro gran ámbito de la política social, la postura del CDS ante la Ley General de Sanidad estuvo caracterizada por una franca oposición desde el instante de su presentación como proyecto de ley. Durante la defensa de una enmienda de devolución, Rodríguez Sahagún argumentó que aun compartiendo la necesidad de reformar y

\footnotetext{
${ }^{161}$ Votación plenaria final de conjunto del Proyecto de Ley Orgánica Reguladora del Derecho a la Educación del 20 de diciembre de 1983 en la que se abstuvo el diputado del CDS Agustín Rodríguez Sahagún.

${ }^{162}$ En palabras de un líder del CDS al preguntársele sobre la oposición de la Iglesia, como poder fáctico, a los gobiernos de Suárez, Interview undertaken by Richard Gunther, in 1986 (june), AR.

163 "Libros", BDCP, 3, julio 1984, p. 15.

164 Ibid.

165 "Se cuenta de un general actualmente retirado del servicio activo que previno los entusiasmos izquierdistas de un contertulio, con la siguiente frase: 'cuando gobiernen ustedes, no cometan los errores de los gobiernos de izquierda, en la época de la República; procuren en sus medidas de gobierno que la derecha española no se movilice, porque cuando la derecha española se pone en marcha, lo arrasa todo..."”, HERNÁNDEZ, Abel: "La posición...". A raíz de las sentencias del TC sobre la LDA y la LODE, los líderes centristas volvieron a insistir en no hacer un uso político de las mismas -véase, $A B C$, 28 de junio de 1985 o El País, 13 de abril de 1985.
} 
mejorar las prestaciones de la sanidad española la elaboración de este proyecto de ley no había sido una prioridad del PSOE a lo largo de la legislatura y únicamente, se podían rescatar algunos aspectos "positivos, escasos y parciales" ("derechos del paciente", por ejemplo). La LGS era fruto del "voluntarismo" político ${ }^{166}$.

En un análisis interno sobre la Ley General de Sanidad se profundizaba en las deficiencias del proyecto socialista, defendiendo la importancia del sector privado y la participación del colectivo médico en su tramitación. Los errores atribuidos a la $L G S$ eran de cuatro tipos. En el plano formal no definía, ni evaluaba técnicamente el sistema sanitario objeto de aplicación, siendo indeterminado en plazos y afirmaciones. En materia de financiación era regresiva al gravar el empleo y no haber realizado un estudio exhaustivo de los costes ${ }^{167}$. Desde el punto de vista técnico, “desconsideraba" el sector privado sin tener en cuenta la actitud del médico como prescriptor del gasto sanitario. Finalmente, no extendía la cobertura sanitaria de forma igualitaria a todos los ciudadanos, ni territorios. Lo más grave para el CDS radicaba en el hecho de que la $L G S$ no presentara un modelo sanitario determinado y aun valorando positivamente el intento por mejorar la acción sanitaria en el sector público, su más grave defecto lo constituía su amplio "desconocimiento" del principio constitucional de libertad de empresa, de ejercicio profesional y de elección en este sector: "dentro las posibles realizaciones de un sistema mixto al uso". Se concluía enfatizando la necesidad de "encontrar el punto de equilibrio necesario entre las legítimas y lógicas aspiraciones de bienestar de nuestro pueblo y las posibilidades reales de carácter económico de un justo sistema de ingresos y gastos presupuestarios"168. La posición del CDS intentaba mantener un equilibrio entre la garantía de un servicio público generalizado -que no universal ${ }^{169}$ - y la defensa

\footnotetext{
${ }^{166}$ DSCD, Sesión Plenaria, 11 de junio de 1985, nº 215, p. 9863 y ss.

${ }^{167}$ La financiación de la Sanidad, así como de la Seguridad Social, debe medirse en función de su participación porcentual en el PIB y buscarse nuevas vías de ingresos (citándose por ejemplo, el futuro IVA).

168 “Centro Democrático y Social rechaza el Proyecto de Ley General de Sanidad...”, Carpeta 2, AGP. En el Parlamento, Rodríguez Sahagún había señalado defectos similares: no cumplía el mandato constitucional en lo referente al derecho a la sanidad -"no hay en el proyecto ni un solo punto de referencia a si será posible y cuándo, efectivamente esa universalización y la gratuidad [...] demoran sine die"-, no presentaba un modelo definido ni claro, por ejemplo a nivel territorial, no solucionaba la cuestión de la financiación - sujeta a las cotizaciones, "gracias a que hay muchos que, prestando cotizaciones, no hacen uso de dicha Sanidad"-, no ofrecía garantías para la participación ciudadana y no contaba con el apoyo de los médicos, DSCD, Sesión Plenaria, 215, 11 de junio de 1985, p. 9863 y ss.

${ }^{169}$ Con el fin de conciliar la escasez de recursos con la atención sanitaria generalizada interpretaba en el artículo 43 de la Constitución proponiendo una sanidad "financiada por impuestos, abierta a todos los españoles y gratuita hasta un determinado nivel de renta", CDS: El valor del centro..., p. 75, AAG.
} 
de los intereses sociales y corporativos de los sectores más cercanos a su base sociológica e identificados con un sistema de prestaciones mixto ${ }^{170}$.

Por último, las reformas de la Seguridad Social de los gobiernos socialistas tuvieron como objetivo el asentamiento definitivo de la "cara bismarckiana" del proceso de construcción y consolidación del Estado del Bienestar. Sin embargo, con este fin se impulsaron medidas tanto favorables a la generalización de los seguros sociales -caso de la protección por desempleo ${ }^{171}$ - como en un contexto de ajuste económico, a la "racionalización" de los sistemas de protección social -jubilación-, en vista a garantizar su viabilidad ${ }^{172}$. La situación del CDS era bastante compleja; aunque las consecuencias sociales de la política económica socialista y su fracaso en la contención de los niveles de desempleo fueron la punta de lanza de la oposición centrista a lo largo de la II Legislatura, su discurso estaba limitado, tanto por las características sociológicas de sus militantes, como por el carácter eminentemente obrero de la contestación al ejecutivo. Por ejemplo, no se profundizó en los momentos decisivos de la legislatura y naturalmente, no apoyó la Huelga General del 20-J de 1985 convocada por CC.OO. y el PCE. Rodríguez Sahagún indicó que aunque la huelga "no era el camino" respondía a la falta "de sensibilidad social” del gobierno y escasa capacidad de diálogo.

Para Rodríguez Sahagún el texto remitido por el Gobierno constituía un "claro retroceso en los niveles de protección alcanzados" siendo erróneo tanto desde el punto de vista técnico como social ${ }^{173}$. La solución pasaba en primer lugar, por otras medidas, como combatir el fraude y en última instancia llevar a cabo un "debate global”, "para

\footnotetext{
${ }^{170}$ En este sentido, el CDS apoyó, junto al centro-derecha, las manifestaciones contrarias a la LGS, $A B C$, 13 de febrero de 1985.

${ }^{171}$ La extensión de la protección contributiva por desempleo se produjo gracias a Ley 31/1984, de 2 de agosto, sobre protección por desempleo, por la que se modifica el título II de la Ley 51/1980, de 8 de octubre.

${ }^{172}$ Ley de Medidas Urgentes para la Racionalización de la Estructura y de la Acción Protectora de la Seguridad Social (1985). El CDS, representado por Agustín Rodríguez Sahagún se abstuvo en la última votación celebrada el 23 de julio de 1985 -que incorporaba enmiendas de la Cámara Alta-. Lo hizo junto al resto de la oposición y el líder de UGT, Nicolás Redondo. Un documento del CDS se hacía eco de la abstención de Nicolás Redondo en la votación parlamentaria: "valiente, desde el punto de defensa de los trabajadores y merece el mayor respeto", s.a., s.t., (1985), Carpeta 2, AGP. Sobre la crisis entre UGT y el PSOE, desde el punto de vista de un miembro del CDS pueden verse, YSART, Federico: "Crisis Socialista", "Más sobre la crisis", "Extraña semana", "10 de mayo", El Noticiero Universal, 25, 26, 30 de abril y 1 de mayo de 1985 respectivamente; $A B C, 21$ de junio de 1985.

${ }^{173}$ Se señalaban como causas: la incapacidad para resolver el problema del desempleo -desequilibrio cotizantes/pensionistas-, la improvisación, los efectos "depresores" en la economía, la incoherencia con el resto de la política económica española y con la CEE, s.a.: "Resumen intervención Agustín Rodríguez Sahagún", (1985), pp. 1-2, Carpeta 2, AGP. Se tildaba de regresivo e insolidario -discriminando a los futuros pensionistas- y responsabilizaba de haber roto la concertación social, generar una fuerte inseguridad jurídica e iniciar el "desmantelamiento de la Seguridad Social pública”, ibid.
} 
que la sociedad español pueda pronunciarse por las prioridades que desea, ya que en el fondo es un problema de opciones políticas" ${ }^{\prime 174}$.

Un documento de análisis del CDS sobre la "reforma de la Seguridad Social", conocida como "reforma de las pensiones"-, alababa la "valentía [del Gobierno] al afrontarla" por su absoluta necesidad, para matizar a continuación: "no deben prevalecer criterios económicos contra principios de justicia [...] No debe pagarse por los más necesitados los resultados de una política errónea" ${ }^{\text {175 }}$. Para el CDS el problema central era encontrar los mecanismos de financiación adecuados -más aún, en un contexto de transformación debido a la implantación del IVA-, insistiendo en que no debían seguir recayendo sobre "empresarios y trabajadores" los costes de la sanidad y de la protección social $^{176}$. En síntesis, se perseguía un doble objetivo de difícil equilibrio: la liberación de capital para la inversión y generación de puestos de trabajo junto al mantenimiento y ampliación de la protección social por parte del Estado.

\section{4. Centro, izquierda y derecha entre 1982 y 1985}

El espectro electoral, entendido como espacio geométrico en el que se disponen los grupos políticos de derecha a izquierda, o viceversa, había sufrido un vuelco tras las elecciones de $1982^{177}$. La Coalición Popular, liderada por Alianza Popular, ocupaba hegemónicamente el espacio de derecha y centro-derecha tras la disolución de UCD que mantenía un Grupo Parlamentario en el Congreso, a modo de testamento político-. El PSOE, por su parte, copaba el espacio de centro-izquierda e izquierda beneficiado por la crisis de UCD y el PCE respectivamente. El centro, pretendido a izquierda y derecha, era reclamado por el CDS y desde 1983, por la Operación Reformista. Analistas, columnistas y políticos teorizaban sobre los "votos prestados"-de UCD al

\footnotetext{
174 S.a.: "Resumen intervención Agustín Rodríguez Sahagún", (1985), p. 2, Carpeta 2, AGP. Véase también, DSCD, 18 de junio de $1985, \mathrm{n}^{\circ} 218$.

175 "Se está produciendo una degradación permanente de las prestaciones" y se reivindicaban los aumentos "por razones de justicia social" llevados a cabo en 1973 y 1979, s.a., s.t., (1985), Carpeta 2, $A G P$.

${ }^{176}$ La reducción de los costes del empleo - trasladando las cotizaciones a la Seguridad Social, de facto, "impuesto sobre la mano de obra" - a los Presupuestos Generales del Estado había sido defendida en el Parlamento por Rodríguez Sahagún en numerosas ocasiones, quien había ubicado la raíz del problema en los fuertes desequilibrios generados por el modelo de crecimiento tecnocrático durante los años 60', DSCD, Sesión Informativa de Comisión: Comparecencia del Ministro de Economía y Hacienda, don Miguel Boyer Salvador, para informar sobre política de su departamento, 18 de febrero de 1983.

177 "Una realineación partidista de proporciones masivas" en GUNTHER, Richard, SANI, Giacomo y SHABADA, Goldie: El sistema de partidos políticos en España ..., p. 449.
} 
PSOE-, los partidos "afines", el "modelo de sociedad" o la "clarificación" de un sistema de partidos del que todavía, se pensaba en fase de transición y en espera de su configuración definitiva. No parecía existir una "alternativa real" capaz de hacer frente a los espectaculares resultados electorales del PSOE.

La viabilidad del CDS como proyecto político pasaba por ser capaces de mantener una opción de "centro" en el nuevo sistema de partidos español -logrando una efectiva implantación territorial- y de su capacidad para transmitir un mensaje diferenciado. Sin embargo, la estratégica ubicación del CDS en el espectro electoral no sólo le otorgaba $a$ priori una posición privilegiada para garantizar la gobernabilidad de las instituciones anulada de facto por las mayorías socialistas-, sino que lo involucraba en un complejo juego político en el que por las más múltiples causas y circunstancias podía ver diluida su identidad. Por un lado, desde la derecha, AP consideraba imprescindible en su proceso de configuración de una alternativa política al PSOE la inclusión de todos los partidos y grupos del centro-derecha -proceso que había comenzado en 1982 gracias a la coalición con el PDP, partidos regionalistas (UPN, PAR y UV fundamentalmente) y el desembarco de numerosos cargos de UCD (sobre todo a nivel provincial y municipal) - ${ }^{178}$. En este esquema, el CDS se consideraba un "obstáculo" más en la constitución de dicha alternativa ${ }^{179}$. Por otra parte, desde la izquierda, la moderada política del PSOE, evidente en áreas como la económica, la política exterior o el desarrollo autonómico, dificultaba enormemente la elaboración de un discurso progresista diferenciado. Finalmente, la irrupción de la Operación Roca (PRD), en competencia explícita y directa por el espacio del CDS, podía desembocar en la subsunción de los cuadros

\footnotetext{
${ }^{178}$ El horizonte de AP en los años 80 ' fue reeditar una especie de CEDA, una confederación de partidos de centro-derecha para competir contra el PSOE en las elecciones. Este sueño se diluyó definitivamente, tras la campaña del 86' y sobre todo tras la moción de censura de Hernández Mancha de 1987 en la que se abstuvieron PDP y PL, BAÓN, Rogelio, Historia ..., p. 786.

${ }^{179}$ Una sensación permanente y que afloraba a propósito de cada contienda electoral. Veamos algunos ejemplos: "se confirmó claramente el bipartidismo, con fracaso de las 'terceras fuerzas' (fuera de Cataluña y el País Vasco), lo cual no quiere decir que no hicieran daño, pues los menos de cuarenta mil votos que sacó Antonio Garrigues, flamante candidato a alcalde de Madrid, no le hicieron ni concejal, pero sumados a los cerca de sesenta mil de Rosa Posada (candidata de Suárez) que tampoco salió, nos quitaron tres concejales a nosotros, en beneficio del PSOE. La Coalición salió consolidada...", FRAGA, M.: En busca del tiempo..., p. 313. En unas declaraciones, nada habituales, el secretario general del CDS en Asturias "admitía": "Es de destacar que nuestra presencia en Oviedo ha dado la mayoría a la candidatura socialista, pues hemos restado votos a la coalición de AP. No tratamos de pasar factura, pero es un fecho fácilmente constatable, hemos contribuido al cambio en el Ayuntamiento de Oviedo", La Nueva España, 09 de mayo de 1983. Fernando Villagrán a propósito de las elecciones autonómicas vascas en 1984 señalaba: "los estrategas de AP se han planteado unos objetivos más modestos, pero igualmente transcendentales para el futuro de la derecha: en el País Vasco se trata de captar el electorado de centro (si el CDS presenta a Jesús María Viana sería un obstáculo adicional)", $A B C, 23$ de enero de 1984.
} 
suaristas en el seno del proyecto reformista o, en caso de mantener su independencia política, conducir a su definitiva desaparición en la próxima cita electoral.

En el curso de nuestra argumentación, transitaremos desde la izquierda -la relación entre el PSOE y el CDS- a la derecha -señalando el papel del CDS en el complejo proceso de alianzas y pactos en este espacio político-, pivotando siempre sobre los suaristas, en este caso, nuestro "justo medio":

La necesidad de este proyecto [...] se verá nuevamente cuando se produzcan los inevitables enfrentamientos entre la derecha y la izquierda consecuencia de este vacío central que puede convertirse en garganta en la que caigan unos y otros; el papel del centro es convertir esa garganta en llanura por la que transiten los hombres de los dos $\operatorname{polos}^{180}$.

En 1982, el CDS había votado a favor de la investidura de Felipe González junto a los partidos parlamentarios de izquierda, una decisión, que sumada a algunas similitudes programáticas, tenía su raíz en la interpretación de la Historia reciente de España llevada a cabo por Suárez y su entorno. Concebido en cierto modo como una resistencia o reacción a los sectores políticos, económicos y sociales que habían conducido a la destrucción de UCD, el CDS se distanciaba explícitamente de las fuerzas políticas conservadoras (salvo por la existencia del PDL-PRD). Como vimos, fue habitual en la campaña del 82' escuchar, de forma más o menos directa, testimonios de dirigentes centristas analizando las semejanzas entre la oferta electoral -"más todavía, el discurso de investidura"- del PSOE y el programa electoral del CDS:

El programa electoral concreto se parece bastante, de alguna manera también nosotros decimos que el programa electoral del partido socialista ha copiado bastante de nuestras tesis en el 82 [...] la supremacía del poder civil, las relaciones con las fuerzas del estado [...] la nueva industrialización o la reconversión industrial, el pacto de estado que ellos querían transformar en pacto social, es decir, una serie de mensajes se acercaban bastante al nuestro ${ }^{181}$.

El propio Suárez afirmaba que España, en la prosecución de su normalización democrática, necesitaba un gobierno del PSOE que diese un nuevo impulso al proyecto de modernización y reforma iniciado durante la Transición y ralentizado en los últimos gobiernos de $\mathrm{UCD}^{182}$. Un proyecto de "modernización” en el que se insertaba el CDS:

\footnotetext{
${ }^{180}$ Sobre el CDS en Diario de Tarragona, 24 de noviembre de 1982, recogido en BADÍA, Lluis: Opiniones Diarias, Tarragona, Ed. CDS., 1988, pp. 7-8.

${ }^{181}$ Interview undertaken by Richard Gunther, in 1983 (june), AR.

${ }^{182}$ Federico Ysart, miembro del CDS, en un artículo crítico con la gestión socialista la introducía como culminación del proceso transicional: "así consiguieron, o conseguimos, la democracia y, más tarde, instalar un gobierno socialista en Madrid" en "Años después”, El Noticiero Universal, 08 de enero de 1985.
} 
"España necesita gobiernos progresistas en un plazo de catorce años"183. El discurso de Adolfo Suárez respondía, no sólo al cariz progresista que intentó imprimir al $\operatorname{CDS}^{184} \mathrm{o}$ al deseo consciente de desmarcarse de la derecha española, sino que en cierto modo, era una manifestación más de su perfil de "hombre de estado", prácticamente institucional, que como ex presidente iba a desarrollar durante los próximos años y que había logrado materializar, por vez primera, gracias al "Manifiesto Político" del CDS. Al analizar la relación de Adolfo Suárez con el PSOE, el periodista Fernando Ónega escribía hacia 1984:

El objetivo de Suárez cuando hablaba, era no irritar a nadie. Sabía que trabajaba con materiales altamente inflamables. Por eso, de la obligación de la cortesía pasó a hacerse un profesional del respeto. Aún hoy se siente en esa obligación de no irritar. Sólo así se entiende la delicadeza con que se refiere al PSOE, cuando fue este partido y no otro el que dijo en una ejecutiva, "la solución pasa por la caída de Suárez ${ }^{185}$.

Un documento de uso interno fechado en enero de 1983 intentaba ya subrayar las diferencias ideológicas y programáticas entre el CDS y el PSOE: "recientes declaraciones de nuestro Presidente Nacional han concretado más esta definición al afirmar que "el centro progresista es en el fondo un centro izquierda". Una idea que generaba confusión al ser percibido el PSOE "en algunos sectores de opinión” en este espacio y que "obliga al CDS, en un plazo razonable, a establecer diferencias con este partido". Para el autor, que efectúa un análisis de las ponencias aprobadas en los últimos congresos socialistas, las bases ideológicas marxistas y el maximalismo verbal del PSOE - retórica de la lucha de clases, superación del capitalismo, planificación, sociedad socialista- suponían una distancia insalvable entre ambos y aseguraban la viabilidad del CDS como opción diferenciada en el espacio de centro izquierda, "ya que por mucho que pretenda el socialismo ocupar el centro izquierda su visión globalizada de la sociedad, su objetivo último respecto a ella y el procedimiento a seguir por lograrlo le alejan de este espacio político"186. En el mismo sentido, se manifestaba un dirigente centrista en 1983 convencido de que la moderación del PSOE era insostenible para el propio partido socialista y podía desembocar o en su ruptura o un fuerte avance del PCE: “creemos que en el largo plazo [...] ni económicamente, ni socialmente, ni

\footnotetext{
${ }^{183}$ El Norte de Castilla, 19 de febrero de 1983, Caja 224, Gabinete de Información, AGCYL.

184 "El excesivo acercamiento del partido a los socialistas fue criticado ayer por algunos de los asistentes a la reunión de los responsables de las gestoras provincias del Centro Democrático Social con el presidente del partido, Adolfo Suárez", El País, 19 de diciembre de 1982.

185 SINOVA, Justino, (ed.): Historia de la Transición, Madrid, Grupo 16, 1984, p. 454.

186 Documento de PÉREZ GONZÁLEZ, José Antonio: "El CDS como opción diferenciada en el actual sistema de partidos”, enero de 1983, Archivo José Antonio Pérez González [AJAPG].
} 
ideológicamente, la sociedad española está preparada para soportar que un partido socialista llegue tan lejos como un SPD alemán" ${ }^{187}$.

Sin embargo, la contención política del PSOE terminó generando un discurso en el CDS, que a lo largo de toda la Legislatura tuvo por leitmotiv la denuncia de los gobiernos socialistas, precisamente, por no ser capaces o no atreverse a desarrollar algunos aspectos de su programa. Una idea que generó múltiples excesos verbales y electoralistas a lo largo de toda la década: "lo que sí me preocupa, a veces, es pasar al PSOE por la izquierda" $" 188$.

Presionaba en la misma dirección la idea -ampliamente extendida entre las fuerzas conservadoras $^{189}$ - de que Suárez había gobernado, sobre todo desde 1979, para la izquierda con los votos de la derecha y había servido en bandeja el triunfo socialista de $1982^{190}$. Siguiendo con este lugar común, el CDS en su avance por el espacio electoral de centro-izquierda fue objeto de la acusación, mantenida invariablemente a lo largo de toda la legislatura de "ser un apéndice del PSOE", es decir, de depender para su supervivencia de la financiación de los socialistas. Esta idea, que adquirió plena consistencia durante el año 1983, se mantenía gracias a dos argumentos: uno, el oportunismo de Suárez -siempre en la "órbita del poder"- y el interés del PSOE en dividir el espacio de centro-derecha y con ello, las opciones de constituir una alternativa electoralmente viable frente al socialismo. Quizá, la explicación más redonda de esta

\footnotetext{
${ }^{187}$ Interview undertaken by Richard Gunther, in 1986 (june), AR.

${ }^{188}$ El País, 31 de diciembre de 1983. Merece la pena rescatar algunos ejemplos: a propósito del XXX Congreso del PSOE, comentaba Suárez: "me parece evidente que los socialistas se han acercado a mi partido, incluso ya se puede afirmar que se mezclan". Caso: "difícilmente se puede hablar de un partido socialista" tildándolo en otra ocasión de "pragmatismo desideologizado", El País, 17 de diciembre de 1984. "P. [...] ¿cómo ve la manera de gobernar del PSOE? R. En algunos temas nos pasan por la derecha. P. ¿Le han decepcionado? R. Yo creí que los socialistas, que tenían la legitimidad, autoridad moral y legalidad, iban a gobernar de otra manera", entrevista con Adolfo Suárez recogida en la sección revista de prensa de El País, 08 de marzo de 1985. Suárez en Oviedo dijo que él no estaba cerca del PSOE sino el PSOE de sus posiciones, $A B C, 13$ de abril de 1985. "José Ramón Caso: 'La política del Gobierno es liberal-conservadora"', $A B C, 23$ de septiembre de 1985.

189 "Los Gobiernos que yo he presidido no han sido de derechas [Suárez]" $A B C, 08$ de diciembre de 1983. A lo que Umbral comentaba con incredulidad: "toma castaña, mendaña", para añadir: "en todo caso, si los Gobiernos de Suárez hubieran sido tan de derechas, a Suárez no lo hubiese asesinado Bruto" en UMBRAL, Francisco: "Rubempré", El País, 09 de diciembre de 1983. Santiago Carrillo decía de Suárez, al menos él "no nos metió en la OTAN ni llevó a cabo esta reconversión brutal" $A B C, 15$ de diciembre de 1983.

${ }^{190}$ CAMPMANY, Jaime: "Canas y Ojeras", $A B C, 18$ de abril de 1985. Sobre Suárez y su empeño en disputar el espacio de izquierda al PSOE creyendo que tiene a la "derecha cautiva", en URBANO, Pilar: "El monaguillo", $A B C, 05$ de marzo de 1985; CAMPMANY, Jaime: "El regreso", $A B C, 15$ de diciembre de 1983 o "el socialismo tributario de don Adolfo Suárez", ÍD.: "Salir al quite", $A B C, 05$ de mayo de 1984.
} 
teoría la dio Ramón Hermosilla en la Tribuna de $A B C$, quien en base a la hipótesis de que el PSOE perdería cuatro millones de votos razonaba:

El PSOE ha perdido alrededor de cuatro millones de electores: segundo, que de esos cuatro millones, por lo menos uno, se decidía ahora por el conglomerado liberalconservador que acepta a Fraga como líder; y tercero, que el resto, o sea tres millones de votos, se mantiene indeciso [...] Entonces, piensan, no queda otra figura disponible salvo Adolfo Suárez; el cual se prestará al juego seguramente con mucho placer. Ahí está el secreto de la anunciada resurrección política del antiguo presidente del Gobierno... ${ }^{191}$

El primer momento en el que se manifestó con singular fuerza esta idea fue a propósito de la mejoría financiera del CDS a finales de 1983 y la buena sintonía existente entre González y Suárez con motivo de dos viajes institucionales del segundo a Argentina -poco después de la victoria electoral de Alfonsín, en noviembre, y con motivo de su toma de posesión en el mes de diciembre- ${ }^{192}$. Francisco Umbral llamó a esta aparente convergencia de intereses "Operación Rubempré" -en recuerdo del personaje de Balzac-, quien "puede enriquecer con un millón de votos al PSOE” con su "progresismo Cortefiel"193. Desde el PSOE, apenas se prestó atención a estas insinuaciones y con su habitual sorna Guerra comentó: "supongo que le apoyamos desde el año 70 cuando Adolfo Suárez era Secretario General del Movimiento"194. Por contra, uno de los líderes de la CP, Osorio, alimentaba las sospechas: "[Suárez] está manteniendo una postura de 'extraña proclividad y siempre de aceptación de los planteamientos del PSOE",195. Y desde la Operación Reformista, no se descartaba que el CDS fuera usado como "escudo contra Roca"196 - Pero sin duda, fue el periodismo político quien más insistió en las conexiones entre PSOE y CDS. Pilar Urbano sostenía que Suárez "como buen falangista de origen, mientras decide cómo quitarse de encima al CDS, descubre su verdadera esencia socialdemócrata 'mucho más próxima al PSOE, a este PSOE, que a cualquier otra fuerza política",197. El más preciso fue Jaime

\footnotetext{
${ }^{191}$ HERMOSILLA, Ramón: "The underground connection", $A B C, 29$ de septiembre de 1984. Esta idea en OTERO NOVAS: "La alternativa al marxismo (IV)", $A B C, 27$ de septiembre de 1984.

${ }^{192}$ Siguiendo a García Abad "[a Suárez] le dolió mucho que el dirigente socialista no tuviera la delicadeza de agradecérselo [el apoyo en la investidura]. Pasado este momento de amargura, las relaciones con González se recompusieron. Felipe González le encargó ciertas misiones diplomáticas y, cuando Suárez viajaba a Sudamérica por negocios o para apoyar con su prestigio procesos democráticos, informaba al presidente y se ponía a su disposición. En noviembre de 1983 llevó un mensaje de felicitación del presidente de Gobierno español a Raul Alfonsín...", GARCÍA ABAD, J. A.: Una tragedia ..., p. 275.

${ }^{193}$ UMBRAL, Francisco: "Rubempré", El País, 12 de diciembre de 1983. "El centrismo al servicio del socialismo, la venda antes de la herida", ID.: "Suárez", El País, 26 de noviembre de 1983.

${ }^{194} A B C, 03$ de mayo de 1984.

${ }^{195} A B C, 10$ de diciembre de 1984.

${ }^{196}$ PI, Ramón: "Suárez reaparece entre cábalas de 'padrinos”, La Vanguardia, 14 de diciembre de 1983.

${ }^{197}$ URBANO, Pilar: "Roca el socio español”, $A B C, 17$ de noviembre de 1983. La observación contenida en este artículo de P. Urbano ha sido objeto de atención hasta nuestros días y muchos, lo han vinculado al
} 
Campmany quien bautizó, con sarcasmo, el nacimiento de un nuevo personaje político: "Don Felipe Adolfo Suárez y González"198.

La insistencia con la que era objeto Suárez de múltiples acusaciones en la prensa no pasó desapercibida al político abulense quien a finales de 1983 envío en estos términos una carta -no publicada - al director de un rotativo nacional: "a la vuelta del reciente viaje que he efectuado a Argentina, con motivo de la investidura del Presidente Alfonsín, leo con sorpresa e indignación el interesado y sesgado tratamiento que, de mi presencia en el avión que transportaba al Presidente de Gobierno español, se ha pretendido transmitir". Continuaba señalando la "manipulación" o la "presunción gratuita" de la que era objeto, lo que "en cualquier país civilizado es mera cortesía y práctica común", rechazando categóricamente las afirmaciones sobre el apoyo económico del PSOE al CDS o a su persona. Defendía a continuación "la responsabilidad" y el "análisis reflexivo" de su partido, "que lamentablemente no todos los medios de comunicación comparten" y describía sus diferencias con el PSOE, cuya coincidencia básica era "el objetivo fundamental de modernización de España". Finalizaba: "solo un afán bipolarizador, que no compartimos, puede justificar los permanentes intentos de anular la presencia de CDS, anunciando, primero su disolución y ahora su dependencia"199.

Meses después, Suárez envió al director de $A B C$ una carta, con fecha de 5 de junio de 1984, refiriéndose a un artículo del día anterior de P. Urbano en el que se hacía referencia "a tres supuestas conversaciones mantenidas por mí, que considero especulaciones rumorológicas [sic] intolerables" ${ }^{200}$. Dichas conversaciones trataban tres aspectos: con F. González habría hablado sobre el respaldo económico del PSOE a cambio de no mantener alianzas perjudiciales; con M. Roca sobre el apoyo de la CEOEBanca a un intento de reconstruir, unidos, el centro; y con Pujol, se preguntaba la

intento de Suárez de desembarazarse de un complejo de ausencia de legitimidad democrática en sus orígenes políticos, SARASQUETA, Antxón: La agonía del duque, Madrid, Temas de Hoy, 1991, pp. 224-6.

198 "Nacido a la política para vivir y crecer a la sombra del poder, ese partido nuevo pronto se convirtió desde su nacimiento- en una sucursal del Partido Socialista", CAMPMANY, Jaime: "Felipe Adolfo", $A B C, 11$ de diciembre de 1983. La prensa provincial también se hacía eco de estos rumores: "Siguen los rumores sobre la conversión del CDS en un satélite del PSOE", Las Provincias, 25 de noviembre de 1983. "Desmentidos por el CDS. el rumor de un próximo paso de Adolfo Suárez al PSOE", Diario de Ávila, 25 de noviembre de 1983.

${ }^{199}$ El documento no posee más referencias, aunque es contiguo a otro documento enviado a la dirección de $A B C$, que parece por el contenido, también el receptor de esta carta, SUÁREZ GONZÁLEZ, Adolfo: s.t., (1983), Carpeta 3, AGP.

${ }^{200}$ SUÁREZ GONZÁLEZ, Adolfo: s.t., Carpeta 3, AGP. 
autora, ¿era portador de algún mensaje del Gobierno sobre Banca Catalana? ${ }^{201}$ Suárez, en su misiva, asumía su compromiso en defensa de la libertad de expresión: "he demostrado, en demasía, capacidad de encaje para asumir críticas y descalificaciones. Y no quise nunca, y hoy tampoco lo pretendo, transmitir la imagen de que la respuesta puntual a determinados desafueros pueda entenderse como atentado represivo de la libertad"; e indicaba: "constituye un ejercicio peligrosamente maniqueísta [sic] el convertir esa actividad en una acusación permanente a la clase política de carencia de objetivos, ausencia de motivaciones éticas y vaciedad de contenidos"202.

Un segundo motivo de polémica surgió de la supuesta publicidad que desde TVE se hacía en favor del CDS; una hipótesis que nuevamente fue defendida y denunciada desde las filas de $A B C$-en su edición de Madrid o Sevilla-. Las acusaciones nacieron a raíz de una única aparición en $L a C l a v e^{203}$, un análisis sobre información política ${ }^{204}$ y tres reportajes de Informe Semanal. Estos últimos estaban dedicados: al PRD ${ }^{205}$, Suárez y el CDS y a la firma del Tratado de Adhesión a las $\mathrm{CEE}^{206}$. En este último caso, se señalaba:

Del vídeo realizado en el hemiciclo se suprime el "audio", pero, ante el asombro de la audiencia, se le concede "sólo" a don Adolfo Suárez con el que se cierra esa secuencia [...] No se advierte tampoco en "off" que el ex presidente habla (lo que en cualquier caso

\footnotetext{
${ }^{201}$ URBANO, Pilar: “Ajedrez de silencios”, $A B C$, 04 de junio de 1984.

${ }^{202}$ SUÁREZ GONZÁLEZ, Adolfo: s.t., Carpeta 3, AGP.

${ }^{203}$ A propósito de la aparición de Suárez en TVE, FERNÁNDEZ, Celestino: "El centro-derecha y el sexo de los ángeles", $A B C$ Sevilla, 08 de mayo de 1984. Una carta al director de $A B C$, alertaba, tras haber contemplado lo que consideraba "descarada propaganda" de TVE a Adolfo Suárez: "Aviso: votar CDS será votar PSOE”, ABC, 24 de abril de 1984.

${ }^{204}$ Un análisis del rotativo madrileño sobre la presencia de los distintos partidos en los telediarios en mayo de 1985 dejaba las siguientes conclusiones: "Las informaciones procedentes del Gobierno o su partido constituyen, en número, los dos tercios de las noticias facilitadas sobre la vida política nacional: PSOE, 587 noticias y menciones; C. Popular, 130; PCE, 51; PNV, 29; CDS (observen el detalle ¡con dos diputados!) 14; UCD, 11, y ¡EE!, 7" en "Sigue creciendo la presencia gubernamental en los Telediarios", $A B C, 25$ de mayo de 1985.

${ }^{205}$ Desde $A B C$ se denunció la emisión del reportaje de Informe Semanal sobre el Congreso del Partido Reformista Democrático celebrado en diciembre de 1983 y titulado "En busca del centro perdido" y que no perseguía sino destruir cualquier posible unión del centro, $A B C, 04$ de diciembre de 1983.

206 En la sección "Crítica" dedicada a TV y titulada: "¿Documento exclusivo o propaganda electoral? Suárez, en Informe Semanal", se decía: “Adolfo Suárez ha vuelto a Televisión Española por la puerta grande. Los 'Telediarios' del sábado anunciaron a bombo y platillo que Informe Semanal había conseguido 'la primera entrevista en exclusiva' con el ex presidente de Unión de Centro Democrático, político reacio a hacer declaraciones [...] Ante tal despliegue, la audiencia esperaba una entrevista a fondo [...] No fue así, sin embargo. 'Informe semanal' ofreció un amplio reportaje cercano al cuarto de hora de duración, que fue una clara propaganda a un partido político llamado Centro Democrático y Social (CDS). Adolfo Suárez nos brindó a través del monopolio televisivo su nueva imagen de centro izquierda, desde un acto electoral en un pueblo de Castilla-La Mancha (Belmonte del Tajo), que parecía montado para que Televisión encontrara imágenes adecuadas y victoriosas. El ya famoso abrazo de Suárez volvimos a verlo en televisión en primer plano, plano medio y de perfil. Placa conmemorativa, aplausos, mitin, populismo con venta de imagen del CDS", $A B C, 10$ de abril de 1984. "La entrevista a Suárez en TVE provoca quejas de CP”, El Noticiero Universal, 10 de abril de 1984.
} 
estaría justificado) como tal, sino que lo hace en función de su grupo de dos diputados. ¿Por qué? Misterio ${ }^{207}$.

Un tono y una crítica que tenían su correlato en el discurso político de Alianza Popular: "en Asturias, el responsable [TV] era el escritor J. J. Plans, cercano al CDS, en un intento por potenciar la testimonial formación política de Adolfo Suárez [...] Sus informativos son absolutamente oficialistas" ${ }^{208}$.

Esta fuente inagotable de rumores vivió su momento álgido cuando Felipe González, literalmente, calificó a Adolfo Suárez como su sucesor. Tuvo lugar en Montevideo en 1985 durante un encuentro en el Hogar de Ancianos de la colonia española de Uruguay, donde ambos se habían trasladado para asistir a la toma de posesión del presidente colorado Julio Sanguinetti. De acuerdo con la crónica de $A B C$, las palabras de Felipe González fueron las siguientes: "Él y yo lo hemos resuelto todo juntos [...] Habrá un día en que un hombre haya de sucederme. Ese hombre está a mi derecha"209. La frase, demasiado redonda, se trató de enmendar sin éxito el día siguiente: "Suárez puede sucederme: tiene juventud y energía"210.

El incidente fue ampliamente recogido en la prensa española, salvo en El País que ni siquiera glosó la noticia. $A B C$ dedicó dos editoriales y una portada a la polémica ${ }^{211}$. Sergio de Otto en $Y a$ hablaba del "Síndrome de Estocolmo" y criticaba de paso toda la estrategia de oposición del CDS: “en las reglas del juego democrático hay una norma fundamental para todo grupo político que no ostente el poder: acosar hasta el derribo (en las urnas) a la fuerza política gobernante”. Según el autor, el CDS hasta ese momento había practicado el compadreo o el silencio cómplice -caso Flick- ${ }^{212}$. Para J. L. Gutiérrez en Diario 16 era la consecuencia de una peligrosa estrategia del CDS en la que las "caricias" del PSOE podían resultar contraproducentes y anular sus opciones

\footnotetext{
${ }^{207}$ SPECTATOR: "Manipulación parlamentaria, suma y sigue", $A B C, 02$ de julio de 1985.

208 "Centros regionales de TVE: cuna de la desinformación”, Revista Alianza, 22, abril 1986.

${ }^{209} A B C$, 04 de marzo de 1985.

${ }^{210} A B C, 05$ de marzo de 1985.

${ }^{211}$ Editorial: "González-Suárez”, $A B C, 04$ de marzo de 1985. Ocupó íntegramente la portada de $A B C$ con la fotografía de ambos y un amplio resumen en las páginas interiores, "Crece el escándalo a la designación de sucesor por parte de Felipe González [...] Editorial, encuesta e información en páginas interiores", $A B C, 05$ de marzo de 1985. Véase, editorial: "El deseado", $A B C, 05$ de marzo de 1985. Campmany hablaba del "delfín" en "Empellón a la justicia", $A B C, 07$ de marzo de 1985 y días antes había titulado a su artículo, ÍD.: "Don Felipe Adolfo", $A B C$, 05 de marzo de 1985; Ovidio en sus Zigzag lo comparaba con el "tapado", en alusión al proceso de elección presidencial priista y a su nombramiento por el Consejo del Reino, $A B C, 05$ de marzo de 1985. En esta línea Alzaga denunciaba: “'hay “sucesores' en México, no en un sistema democrático", $A B C$, 06 de marzo de 1985. ABC lo llegó a considerar uno de los episodios más relevantes del tercer año de gobierno socialista, $A B C, 01$ de diciembre de 1985.

${ }^{212}$ DE OTTO, Sergio: "Suárez y el síndrome de Estocolmo”, $Y a, 06$ de marzo de 1985.
} 
electorales $^{213}$. Sólo algunos como A. Hernández, militante del CDS, hablaba del afloramiento de la "mala conciencia" en el PSOE por su oposición durante la I Legislatura y de paso, intentar obtener un futuro apoyo de cara a una posible victoria electoral con "mayoría relativa" 214 . En una entrevista realizada aquellos días, el propio Suárez afirmaba: "Ahora que tienen la responsabilidad del Gobierno, los socialistas ven quizá con más objetividad la labor que yo desarrollé desde el 76 al 81. También, posiblemente, valoren los comportamientos que política y personalmente vengo manteniendo desde que dejé de ser presidente" ${ }^{, 15}$. Destacados dirigentes socialistas hicieron durante aquellos días algunas declaraciones disculpando su actitud durante la oposición $^{216}$.

Para los servicios de inteligencia norteamericanos -en documentación recientemente desclasificada-, el CDS estaba inclinado decididamente hacia el centro-izquierda y aspiraba a ser socio de gobierno del PSOE, en caso de que los socialistas perdieran la mayoría absoluta. En un análisis efectuado el 11 de septiembre de 1984 sobre la posibilidad de que se creara una alternativa viable al PSOE en el centro derecha señalaba:

We also are not optimistic that former Prime Minister Suarez can regain command of the center at the head of his new Social Democratic Center Party. Suarez has badly alienated the business community, the Church, and the military, and lacks the money to build an effective party organization. We believe he no longer expects to make a strong comeback soon and is trying to cultivate a place for himself as a junior partner to the Socialists ${ }^{217}$.

\footnotetext{
${ }^{213}$ GUTIÉRREZ, José Luis: "González, Suárez y el abrazo de la muerte", Diario 16, 07 de marzo de 1985. Lorenzo Contreras consideraba que las palabras de F. González eran intencionadas y tenían como objetivo "maltratar la aureola de plena independencia y de luz propia que al ex presidente le interesaba mantener" en "La profecía de Montevideo", $A B C, 06$ de marzo de 1985. "Para privar a la derecha nacional de uno de sus posibles líderes, nada mejor que declararlo como afín incondicional del socialismo", en LÓPEZ SANCHO, Lorenzo: "Hacia la unidad por el Turmix", $A B C$, 05 de marzo de 1985.

${ }^{214}$ HERNÁNDEZ, Abel: "El resplandor de las urnas", Diario 16, 04 de marzo de 1985.

${ }^{215}$ En su explicación de los hechos, Adolfo Suárez comentó: "Se produjo -explicó- en un ambiente muy distendido, cuando el presidente Sanguinetti ofrecía una copa a la colectividad española. La frase de González vino a colación de una declaración matinal de Sanguinetti, quien había dicho que su mayor satisfacción sería, cuando terminara su mandato, el transmitir el poder a la persona elegida por votación popular. González vino a decir lo mismo, refiriéndose a mí. ¿Le traicionó el subconsciente?”, La Voz de Galicia, 04 de mayo de 1985.

216 "[Benegas] fuimos injustos con Suárez; desde una perspectiva global de lo que fue la Transición...", $A B C, 31$ de marzo de 1985. "Solana, dijo que antes de decir lo que en alguna ocasión había dicho de Adolfo Suárez se mordería la lengua", El País, 08 de marzo de 1985.

${ }^{217}$ En un análisis de noviembre 1982, se había señalado ya que el CDS había sido el mejor ejemplo de la futilidad de intentar crear una formación viable en el centro-izquierda independiente del PSOE. "Spain: The New Party System", CIA-RDP83; "Spain: Can the Center-Right Challenge the Socialists", 1984, CIA-RDP85, Archivo CIA. Disponibles en: http://www.cia.gov. Fecha de consulta: 25 de enero de 2017.
} 
Si el CDS en su intento de expansión hacia el espacio de centro-izquierda quedaba envuelto en confusiones ideológicas y rumores de toda índole sobre su cercanía al PSOE, su relación con la derecha y el centro-derecha era aún más compleja e intrincada. La mayoría absoluta del PSOE había dado inicio a un sistema de partidos definido como de "partido dominante" 218 , en el que el liderazgo de la oposición recayó en manos de la Coalición Popular, una oposición sin embargo, con notables dificultades para poder ser considerada como "alternativa real de gobierno" y a una distancia de casi cien diputados del partido gobernante ${ }^{219}$.

La estrategia de oposición de AP, inerme en el Parlamento, se basó en la confrontación directa de las políticas socialistas ${ }^{220}$. Esta actitud se tradujo en el desarrollo de amplias campañas sociales y mediáticas contra los principales proyectos de ley, espoleadas por recursos de inconstitucionalidad y un constante obstruccionismo en las Cortes ( 6 de 27 Leyes Orgánicas fueron recurridas) ${ }^{221}$. Como vemos, en lugar de intentar transformar o corregir su discurso hacia posiciones más moderadas, la CP volcó sus energías en la consecución de la convergencia electoral de todo el espacio de centro y de derecha para esquivar las penalizaciones del sistema electoral y lograr vencer electoralmente al $\mathrm{PSOE}^{222}$. Será precisamente este último, el proceso que analizaremos

\footnotetext{
${ }^{218}$ POWELL, Charles T.: "El principal partido de la oposición y el 'Gobierno largo' del PSOE: de Fraga a Aznar" en MATEOS, Abdón y SOTO CARMONA, Álvaro (eds.): Historia de..., p. 392. Otros han hablado de "bipartidismo imperfecto", YSÀS, Pere: "Cambio y continuidades: tres lustros de gobiernos socialistas", Ayer, 84, 2011, p. 26. "Bipartidismo imperfecto" o un sistema de "partido predominante con tendencia a la polarización", POWELL, Charles T.: España ..., p. 328. En la temprana fecha de 1991, M. Ramírez lo definió como: "multipartidismo limitado y no polarizado con dos opciones fundamentales sobre las que descansa el juego político", RAMÍREZ, Manuel: El sistema de partidos en España (19311990), Centro de Estudios Institucionales, Madrid, Cátedra, 1991, pp. 101 y ss. Pluripartidismo limitado y no polarizado protagonizado por un partido dominante, flanqueado a gran distancia por otras opciones, en AGUILERA DE PRAT, Cesáreo R.: "Balance y transformaciones...", pp. 137-153.

${ }^{219}$ Un hecho ratificado en el ámbito de la politología y la historiografía desde los años 80 ' hasta la actualidad, véase, GUNTHER, Richard, SANI, Giacomo y SHABADA, Goldie: El sistema de partidos políticos en España ..., p. 468; BUSE, Michael: "El sistema de partidos políticos en España: evolución y perspectivas", Revista de Occidente, 54, 1984, p. 109.

${ }^{220}$ Según Powell, quien sigue en este punto la tesis de E. García-Guereta, durante este período AP fue transitando desde posiciones que la convertían en una "fuerza eminentemente ideológica para convertirse en una netamente pragmática", POWELL, Charles T.: "El principal partido de la...", p. 389 y ss; GARCÍA-GUERETA RODRÍGUEZ, Elena: Factores externos e internos de la transformación de los partidos políticos: el caso de AP-PP, Tesis Doctoral, Inst. Juan March de Estudios e Investigaciones, Madrid, 2001.

${ }^{221}$ En palabras de Marín Arce: "un tipo de oposición catastrofista que no respondía a la realidad del país ni a la percepción de una gran parte del electorado", en MARÍN ARCE, José María: "Los socialistas...", p. 46.

222 "El trascurso de tiempo que fue desde las elecciones de 1982 hasta las habidas en 1989, la derecha española vivió una serie de luchas internas que anularon cualquier posibilidad de convertirse en alternativa", SOTO CARMONA, Álvaro: Transición y cambio..., p. 269. "Es innegable, que en la estrategia de Alianza Popular siempre estuvo presente el acercamiento a toda fuerza de centro-derecha", nucleada en torno al concepto de mayoría natural, como señala SÁNCHEZ MEDERO Germán y
} 
a continuación. Un miembro del Gabinete de Presidencia del Consejo General de Castilla y León sumaba las columnas de los votos de UCD y AP-PDP en octubre de 1982. Efectivamente, la cifra obtenida era mayor que los votos socialistas, la hipótesis de la "mayoría natural" seguía viva ${ }^{223}$ :

Tanto AP como los partidos centristas partían de la premisa que el resultado de dichas elecciones había sido tan anómalo como pasajero, fruto de una grave crisis política que había permitido al PSOE recibir el apoyo de varios millones de votantes centristas que no dudarían en serlo de nuevo si se les ofrecía una alternativa atractiva. De este diagnóstico ampliamente compartido surgieron varias estrategias distintas, y eventualmente incompatibles entre sî́24.

Una vez absorbido todo el espacio electoral a su derecha, la construcción de una alternativa exigía atraerse parte del antiguo electorado de $\mathrm{UCD}^{225}$. El primer paso fue la formación de la Coalición Popular integrada por AP, PL, PDP y otras formaciones regionalistas $^{226}$. En los análisis de la $\mathrm{CP}$, todos los grupos de centro, centro-derecha y derecha se consideraban parte de una misma opción política -“afines"- caracterizada por defender el mismo "modelo de sociedad":

Hay, por lo tanto, una línea ideológica que separa verticalmente a la izquierda del centro y la derecha, línea que no existe entre estas dos últimas posiciones; [...] Ante esta posición parecería lo natural que el centro y la derecha enteros hubieran llegado a cierto tipo de pactos. Pero asombrosamente, y a pesar del esfuerzo de muchos, entre los que me cuento, no ha sido así, [...] es indispensable un pacto de no agresión entre las fuerzas afines, y necesariamente llamadas a entenderse ${ }^{227}$.

La constitución de una "alternativa real" de poder era la pieza fundamental para lo que en la prensa de la época se llamaba la "clarificación ideológica" -cuya antítesis era la "sopa de letras"-, síntoma de estabilidad y madurez democrática ${ }^{228}$. En este marco de

SÁNCHEZ MEDERO, Rubén: "PP-CDS. Pactos y alternativas de gobierno de centro-derecha en 1989" en Política y Sociedad, 40-2, 2003, p. 197.

${ }^{223}$ S. a.: "Elecciones generales (28-10-1982) en Castilla y León", Gabinete de Información, 147, Legajo 160, AGCYL.

${ }^{224}$ POWELL, Charles T.: España..., p. 417.

${ }^{225}$ Se llegaba a hablar de la "nostalgia de la función centro", documento de la Coalición Popular: "Documentación entregada en la Comisión de Coordinación de la Coalición", 1985, Caja 12, 45-221, $A G U N / J L A$. El PDP era el engarce más evidente con UCD: "Medio millar de personas, la mayoría antiguos centristas, comienza su acercamiento al PDP", El País, 24 de octubre de 1984. En la primavera de 1983 se celebraron unas jornadas a cargo del PDP con el título: "Jornadas sobre la democracia cristiana y la política de centro", MORAL, Javier: El centro de la derecha...

${ }^{226}$ Junto a los partidos regionalistas: UV, PAR y UPN. La unión se consideraba la pieza básica "para expulsar al PSOE", unión preferente con el electorado "limítrofe" al PSOE, "una división de fuerzas en la zona de centro-derecha, aunque un partido sacara solo 15 ó 20 diputados, significa una división del voto que perjudica a este sector y beneficia al socialismo", documento del PDP: "0006Documento", 1985, p. 1, Caja 11, 45-471, AGUN/JLA.

${ }^{227}$ Documento de José Luis Álvarez: “Un pacto de no agresión”, 1983, p. 1, Caja 11-45-467, AGUN/JLA. 228 "Nosotros no queremos complicar el panorama, sino contribuir decididamente a su clarificación" en ALZAGA, Óscar: "Otra política, otro futuro", ABC, 25 de enero de 1985. 
análisis, el centro per se era un ente ficticio y, tanto sus cuadros dirigentes como su electorado (CDS, PRD) eran susceptibles de ser considerados afines o vecinos, formando todos ellos parte de un espacio común más amplio que agrupaba todo el espectro "no socialista"229. Su existencia sólo se podía explicar por la recalcitrante abundancia de "personalismos" propia de la derecha española ${ }^{230}$.

Al contrario de lo que pudiera suponerse después de la exposición anterior, el CDS apenas revestía importancia en los análisis electorales de la CP y la relación entre ambos se valoró a lo largo de toda la legislatura como una ligera competencia sin credibilidad: "hay mucha evidencia sobre la provisionalidad de la actual oferta política de la derecha. La gente no visualiza a Suárez ni al C.D.S. como una alternativa seria en la reordenación de ese espacio y no le asigna ningún futuro electoral" ${ }^{231}$. Una actitud que llegó a ser objeto de una "reprimenda" pública por parte de $A B C^{232}$. Todo ello,

\footnotetext{
${ }^{229}$ Según Osorio, el gran anhelo de la derecha española desde 1982, como expuso en una rueda de prensa en el II Congreso NNGG de Tarragona, $A B C, 10$ de diciembre de 1984. "La unión, la unión, la unión, es el colacao que ese viejo o niño viejo que es la derecha necesita para hacer músculo electoral en LÓPEZ SANCHO, L.: "Patchwork preelectoral", ABC, 25 de marzo de 1985. "Mi aspiración es unir a la derecha, y yo le llamo derecha a todos los que no son socialistas ni comunistas, es decir, yo le llamo derecha a los que ellos le llaman derecha... a CiU, la antigua UCD... [...] -iVe un pacto con Adolfo Suárez?". "También"” en PALMA, Luisa: "Gerardo Fernández Albor: "Aunque saque mayoría absoluta en Galicia, soy partidario de pactar y unir el centro derecha", $A B C, 19$ de mayo de 1985.

${ }^{230}$ CAMPMANY, Jaime: "Cosecha de ombligos", $A B C, 29$ de marzo de 1983. "Las siete tribus de la derecha española" en RODRÍGUEZ, Pedro: "Las siete tribus", $A B C, 02$ de mayo de 1983. "Los maestros en señalar los matices [de las derechas] fueron los derechistas del centro. Y así les lució el pelo en las elecciones. Don Adolfo Suárez señaló matices, y se quedó a solas con don Agustín", CAMPMANY, Jaime: "Matices y distingos", $A B C, 30$ de septiembre de 1983. "Inútiles batallas personalistas" en TUSELL, Javier: "Dos de cada tres españoles", El País, 01 de junio de 1984; CRESPO, Pedro: "La existencia del centro", $A B C, 09$ de mayo de 1985; ORTIZ FERNÁNDEZ, Celestino: "El centro-derecha y el sexo de los ángeles", ABC Sevilla, 08 de mayo de 1984. Emilio Romero tildaba el pluralismo del centro-derecha de "caricaturesco" que sólo beneficiaba al socialismo en "Un manifiesto y la caricatura", $Y a, 15$ de enero de 1985.

${ }^{231}$ Documento de la Coalición Popular: "Objetivo de la Coalición Popular", 1985, p. 12, Caja 45-218, AGUN/JLA. Incluso, un hipotético análisis que distinguía entre escaños seguros, probables y posibles en una gran coalición de centro-derecha excluía al CDS, documento de la Coalición Popular, "Análisis de la situación política", Caja 12, 45-520, 1985, AGUN/JLA. "Las opciones centristas o bien han muerto o resulta que no han llegado siquiera a nacer. El primero es el caso, por injusto y cruel que parezca, de Adolfo Suárez” en TUSELL, Javier: “¿Ganas de no ganar?”, $A B C$, 12 de julio de 1983. J. A. Segurado en una entrevista en $A B C$ al abordar la posibilidad de establecer una gran coalición desestimaba la opción de Suárez por considerarla "mucho más cerca de la socialdemocracia", $A B C, 20$ de enero de 1985. Con cierta ironía y abogando por una gran coalición de centro derecha Javier Laso afirmaba: "ni uno solo de los grupos que hoy ocupan -nominalmente, al menos-, el centro político, admite en su programa concepciones o procedimientos marxistas. Salvo, quizá, don Adolfo Suárez, que afirma estar a la izquierda del PSOE" en LASO, Javier: "La derecha ahora (III)", ABC, 11 de abril de 1985.

${ }^{232}$ En la sección "Actualidad Gráfica" se respondía a Manuel Fraga por criticar a Roca y Suárez: "un ataque innecesario a Miguel Roca y Adolfo Suárez, de los que dijo que la suma de cero es "cero". Atacar a los afines, según los observadores más ecuánimes, es el mayor error que puede cometer el centro derecha. Es además, el propósito del PSOE, que atiza esos ataques porque el "divide y vencerás"', con el titular: "No atacar a los afines", $A B C, 29$ de abril de 1985.
} 
acentuado gracias al distanciamiento personal entre el líder de AP -así como muchos ex ucedistas de la CP-y Adolfo Suárez.

A pesar de todo, no fueron pocas las voces que intentaron alcanzar una vía de entendimiento entre las fuerzas de centro, centro-derecha y derecha. Una opción que fue defendida por numerosos antiguos miembros de $\mathrm{UCD}^{233}$, instituciones como el Centro de Estudios Comunitarios (CEC) -que agrupaba a democristianos descolgados del PDP-, periodistas o destacados personajes del mundo empresarial o bancario y buscada con notable ímpetu a raíz de la materialización de la Operación Roca en el PRD.

\section{5. La aparición de la Operación Roca}

Desde el mes de noviembre de 1982 apareció formulada en los medios lo que para muchos era una vieja pretensión del catalanismo moderado, esto es, su participación en la gobernabilidad de España ejerciendo como principal impulsor de la modernización general del país y de otra parte, atenuando las dificultades existentes en la integración de Cataluña en el ámbito estatal, un proyecto sin duda emulador del intentado por Francesc Cambó a principios de siglo y muy presente en las elites políticas españolas transicionales $^{234}$. Esta idea, que había sido barajada desde el verano de $1982^{235}$, cobró forma gracias al liderazgo político de M. Roca, quien aportaba la proyección estatal del nacionalismo catalán representado por $\mathrm{CDC}$, a lo que se sumó la anuencia de intereses con el Partido Democrático Liberal (PDL) de Antonio Garrigues Walker ${ }^{236}$. La unión de ambas fuerzas dio como resultado la fundación entre 1983 y 1984 del Partido

\footnotetext{
${ }^{233}$ Nuevamente, el argumento era la inexistencia del centrismo como ideología o necesidad políticoelectoral, como defendía el ex centrista Otero Novas en una serie de artículos titulados "La alternativa española al marxismo" (septiembre de 1984) quien explicaba el voto a UCD-CDS en 1982, en términos de fidelidad "personal" o "institucional" en OTERO NOVAS, J. M.: "La alternativa española al marxismo (III)", $A B C, 23$ de septiembre de 1984.

${ }^{234}$ Véase por ejemplo, su influencia en el pensamiento de CALVO SOTELO, Leopoldo: Pláticas de familia, Madrid, La esfera de los libros, 2003.

${ }_{235}$ Según algunos autores, la aparición del CDS obligó a Miquel Roca a posponer su "operación" reformista, MORAL, Javier: El centro de la derecha, Madrid, Eudema, 1990.

${ }^{236}$ La Operación Roca como fenómeno político, pero también social -en relación a la decisiva participación de las elites económicas- no ha sido aún analizado con profundidad, al margen de su aparición en biografías, memorias u otras obras tangenciales, GARCÍA-LEÓN, Carlos y MARTÍNEZ ECHEVARRÍA, Borja: Antonio Garrigues Walker, Madrid, Península, 2014; GARRIGUES WALKER, Antonio: España, las otras transiciones, Oviedo, Nobel, 2013, pp. 148-154; ANTICH, José: El virrei: ¿es Jordi Pujol un fiel aliado de la corona o un caballo de Troya dentro de la Zarzuela?, Barcelona, Planeta, 1994. Sobre el pensamiento político de Roca, véase la obra -en buena medida, promocional- de PAPELL, Antonio: Conversaciones con Miquel Roca Junyent, Barcelona, Argos Vergara, 1984.
} 
Reformista Democrático (PRD), previa disolución del PDL y su posterior alianza con diversas fuerzas regionalistas. A diferencia de los proyectos de Cambó, el nuevo mapa político generado tras las elecciones de 1982 condicionaba el nacimiento de esta operación no en las "derechas" - copadas por AP-PDP-UL- sino en el "centro" y "centro-derecha", desde una propuesta ideológica interclasista -definida como "liberalismo progresista"- y que se proclamaba abiertamente continuadora de UCD ${ }^{237}$.

Inmediatamente después de las elecciones generales de 1982 fue habitual encontrar en la prensa noticias que hablaban de una posible federación de partidos de centro promovida desde Cataluña en la que se barajaba la inclusión del $\operatorname{CDS}^{238}$. En abril de 1983 Antonio Garrigues Walker, líder del PDL, en compañía de Miquel Roca ${ }^{239}$, tendían por vez primera públicamente su mano a Adolfo Suárez. A pesar de que como vimos habían existido diversos contactos entre Suárez y Pujol relativos a posibles alianzas, -a propósito de las elecciones municipales y en el Parlamento de Cataluña-, el CDS se desmarcó de la Operación Roca ante los medios desde el primer momento ${ }^{240}$. Inmediatamente después de las elecciones autonómicas y municipales de 1983 entre los posibles socios de la Operación Roca y al margen del CDS se encontraban: PDL, CiU, PNV (Arzallus), Coalición Galega, Uniò Mallorquina, Convergencia Canaria, independientes y ex miembros de UCD liderados por J. J. Rosón ${ }^{241}$. La disolución de UCD en febrero de 1983 había dejado sin respaldo político a un gran número de antiguos altos cargos, que sin haber ingresado en AP-PDP-UL, ni en el CDS, veían con interés los pasos dados por Roca en vistas a su promoción nacional ${ }^{242}$ y es que, según Javier Moral, el 90\% de los miembros de los integrante del PRD pertenecieron en algún momento a $\mathrm{UCD}^{243}$.

El caldo de cultivo de la Operación Roca entroncaba con la constatación por parte de numerosos círculos políticos, económicos e intelectuales de la derecha moderada de que

\footnotetext{
${ }^{237}$ La fórmula era recuperar el carácter interclasista de UCD en toda España, tal y como hacía CiU en Cataluña: “¿Hacia un nuevo centro?”, La Vanguardia, 04 de mayo de 1984. Una extensa relación de cargos del PRD y UCD en DÍEZ, Anabel: "La segunda fila de UCD”, El País, 26 de noviembre de 1985. Como veremos, a través de la CEPA se vehiculó el paso de algunos ex ministros centristas hacia el PRD. 238 "La disposición del CDS que lidera Adolfo Suárez ante aquella operación es óptima", en la portada: “CDC y PNV pretenden relanzar el centro" en El Noticiero Universal, 10 de noviembre de 1982.

${ }^{239}$ Presentación del libro de A. Caldés de entrevistas con Garrigues Walker con la presencia de Roca, El País y $A B C, 14$ de abril de 1983.

${ }^{240}$ El País, 02 de febrero de 1983.

${ }^{241}$ De cara a las elecciones generales de 1986 acudieron CiU, CG y PRD -integrándose en las listas de este último, representantes del PRP, UM y CC-.

${ }^{242}$ Una magnífica crónica sobre los miembros de UCD en esta época en JÁUREGUI, Fernando: “Cita de 'barones' ucedistas en la despedida al cónsul Marcelino Oreja”, El País, 30 de noviembre de 1983.

${ }^{243}$ MORAL, Javier: La derecha...
} 
Alianza Popular no era una alternativa plausible al PSOE $^{244}$. Como señala Moral, lentamente "Roca [fue] ganando la fama de ser el deseado" 245 , acrecentando, aún más, su presencia política y mediática fuera de Cataluña ${ }^{246}$. El contraste entre el conservadurismo con dejes autoritarios representado por Fraga y la moderación gubernamental del socialismo parecía abrir nuevamente un espacio a la formación de una plataforma de centro que recogiera parte del ideario y los votos de la antigua UCD. Este estado de ánimo lo recogía en un artículo en El País durante el mes de marzo de 1983, el historiador Carlos Seco Serrano:

El resultado [de la Transición] ha sido la creación de un clima convencional de centro, en el que cabe perfectamente el actual PSOE, pero que resulta evidentemente rebasado hacia la derecha por el aliancismo [...] Hay, sin género de dudas, un gran número de españoles [...] que preferirán quedarse en casa ante que dar su voto a la alternativa de la gran derecha y son ellos los que reclaman un centro político capaz de garantizar la continuidad democrática y el civismo [...] La verdadera refundición de esa idea - de la idea de centroparece ya concretada en una de las personalidades más brillantes que la democracia ha revelado en nuestro Parlamento: me refiero, claro es, al señor Roca Junyent.

Una opción que se revelaba como moderna, progresista, demócrata, liberal, socialdemócrata y pragmática y que concluía el autor: “¿quiénes podrían acompañarle, flanquearle en la tarea de estructura el centro? Lamento -y no acabo de entender- el rechazo de Suárez. Creo que se equivoca plenamente en su actitud"247.

La resistencia de Suárez a concretar un pacto con la Operación Roca generó no poco desconcierto, cuando no abierta incomprensión, y únicamente era bien recibida por algunos intelectuales situados en posiciones progresistas. El escritor J. J. Armas Marcelo veía en Suárez el legítimo representante del centro y señalaba: "no es lógico que el centro [...] esté así: como un marinero escapado del naufragio que se pasea por

\footnotetext{
244 "La solución era articular un nuevo partido reformista que pudiese hacer de bisagra tanto cuando ganara la derecha como cuando ganara la izquierda. Aquella formación sólo podía liderarla un hombre inconfundiblemente comprometido con la democracia como Miquel Roca. El objetivo era recuperar los tres millones de votos que el centro había prestado al PSOE en 1982" en GUINDAL, Mariano: El declive..., p. 278.

${ }^{245}$ GUNTHER, Richard, SHAHAB, Goldie y SANI, Giacomo: El sistema de partidos políticos en España. Génesis y evolución, Madrid, CIS, 1986, p. 138.

${ }^{246}$ Miquel Roca, uno de los padres de la Constitución de 1978, no había perdido desde entonces protagonismo en la vida pública española, como demostró la amplia repercusión de su libro: ROCA i JUNYENT, Miquel: ¿Por qué no? Una propuesta catalana para la modernización del estado, Madrid, Mezquita, 1982. Una breve reflexión muy significativa tanto en lo que a la construcción del estado autonómico se refería como, implícitamente, a la reorganización del centro-derecha.

${ }^{247}$ Extractos de un artículo publicado en El País el 11 de marzo de 1983 y titulado: "El centro posible". Recogido en SECO SERRANO, Carlos: Al correr de los días, pp. 157-160. En la línea de Seco Serrano, CONTRERAS, Lorenzo: "La aventura del nuevo centro", $A B C, 12$ de octubre de 1983. La línea editorial de El País destacaba las posibilidades de los proyectos de Roca, Garrigues, y también Suárez, si Alianza Popular seguía el rumbo de acentuar sus posiciones más autoritarias, editorial: "La oposición", El País, 12 de septiembre de 1983.
} 
las tabernas del primer puerto de salvación que le ofrezca" ${ }^{248}$; por su parte, Francisco Umbral escribía: "Adolfo: sabes que te admiro entrañablemente, pero tú no puedes volver a la política para el capitán/ coartada de unos 'profesionales' que son el corporativismo au pair" 249 .

Otros centristas “independientes” como González Seara, contemplaban los movimientos políticos de aquellos meses con cierto escepticismo: "ramplonería política, la exaltación de una idea sin ideas $[\ldots]$ hacer algo de centro, sin saber lo que ese centro puede ser" ${ }^{250}$. Por último, los sectores más conservadores lo recibían con el temor de una nueva fractura en la consecución de la "mayoría natural”: "más que reinventar el centro hay que centrar la derecha. Los reformistas a fundar conventos"251. Aunque, como reflexionaba Pedro Rodríguez, la situación creaba una extraña paradoja:

Aquí es que se está sometiendo al pueblo español a un chantaje histórico: 'O con nosotros, o con Fraga'. Y a todos los demás, a laminarlos, a destruirlos, a fumigarlos. Pero ya ves: Adolfo Suárez fue, después del Rey, el hombre más ovacionado en los Premios 'Príncipe de Asturias'. Fue casi patético: El Duque, reculó, tímida, humildemente, hacia un pequeño corro, 'desnudo como los hijos de la mar', y allí pronunció la frase del año: 'No es mi misión histórica llevar a Miguel Roca a La Moncloa ${ }^{252}$.

De este modo, en 1983 quedaba inaugurada una nueva "batalla" por el espacio de centro entre los reformistas y el CDS - de acuerdo con la terminología habitualmente usada en la prensa- que al margen de las estrategias desarrolladas desde la derecha (AP) y la izquierda (PSOE) se disputaban, con pretensión de exclusividad, esta etiqueta política $^{253}$. Las elecciones autonómicas del País Vasco y de Cataluña (1984) supusieron el primer escenario donde se iba a dilucidar el futuro del centro, un terreno particularmente propicio para tantear la viabilidad de una posible federación de partidos nacionalistas y regionalistas.

\footnotetext{
248 ARMAS MARCELO, Juan José: "La nueva batalla del centro”, El Heraldo de Aragón, 14 de diciembre de 1983.

${ }^{249}$ UMBRAL, Francisco: "La elipse”, El País, 09 de septiembre de 1984. "La peripecia del nuevo Centro, encima, no cuenta con Suárez -o Suárez no cuenta con ellos-, pues que el Duque anda en más altos ducados de ambición o indiferencia", ÍD.: "El centro", El País, 13 de octubre de 1983.

${ }^{250}$ GONZÁLEZ SEARA, Luis: "El centro y la invención política”, Cambio 16, 01 de abril de 1983.

${ }^{251}$ CAMPMANY, Jaime: "Los reformistas", $A B C, 16$ de octubre de 1983. La Operación Roca era un obstáculo en el proceso de cohesión de la derecha en torno a AP -a modo de una nueva CEDA- y Manuel Fraga, BAÓN, Rogelio: Historia..., p. 490-1 y p. 736.

252 RODRÍGUEZ, Pedro: "El gran chantaje", $A B C, 21$ de octubre de 1984.

${ }^{253}$ Desde comienzos de año existía una Comisión Gestora del PRD trabajando en la gestación del partido, GUTIÉRREZ, José Luis: "El lío reformista", Diario 16, 20 de marzo de 1983. La inscripción del Partido Reformista Democrática en el Registro de Partidos Políticos tuvo lugar el 11 de marzo de 1983 con la representación legal a cargo de Joaquín Satrústegui Fernández. Información disponible en: http://www.servicio.mir.es Fecha de consulta: 14 de marzo de 2015. Si bien celebraron diversas “convenciones" a nivel nacional desde finales de 1983, el I Congreso Nacional tuvo lugar los días 24 y 25 de noviembre de 1984, véase, El País, 26 de noviembre de 1984.
} 
La convocatoria electoral en el País Vasco estaba fijada para el 26 de febrero de 1984. A pesar de la ligera mejoría económica vivida en el CDS desde finales de 1983, el 28 de enero, horas antes de la finalización del plazo para la presentación de listas, el CDS decidía no presentarse a las elecciones en el P. Vasco, comunidad, en la que por otra parte apenas contaban con militancia ni estructura. La decisión corrió a cargo de una comisión integrada por Adolfo Suárez, José Ramón Caso, Alfredo Marco Tabar y Jesús María Viana -quien hubiera sido el candidato a lehendakari- ${ }^{254}$.

Si en el País Vasco la escasa implantación y las bajas previsiones de voto desalentaron al CDS, en Cataluña, donde se estimaba necesario un presupuesto de entre 100-120 millones, Caso señaló como ulterior motivo el fracaso de las negociaciones con CiU para ir en coalición -en cualquier caso, imprescindible, tras la crisis de enero de 1983- y en pleno desarrollo de la Operación Roca ${ }^{255}$. Al igual que hicieron en el País Vasco, el CDS se abstuvo de recomendar el voto para ninguna formación política, previamente se había formado una comisión, en este caso compuesta por Suárez, Caso, Manuel Jiménez de Parga y el líder ilerdense Manuel de Sárraga.

En ambas comunidades, se apreciaba en el CDS una actitud coherente con su distanciamiento del gobierno de Leopoldo Calvo-Sotelo en materia autonómica. Podemos hablar, incluso, de cierta sintonía con los gobiernos autonómicos de CiU y del PNV en esta primera etapa del partido centrista y en la que ambos partidos gobernaban con minoría. En el parlamento vasco, desde 1982, el grupo parlamentario autonómico del CDS, encabezado por Jesús María Viana, fue un aliado habitual del PNV, por ejemplo, en leyes tan polémicas como la referente al himno autonómico o la Ley de Territorios Históricos ${ }^{256}$. La relación entre el PNV y el CDS alcanzó su cénit a comienzos de febrero de 1984 cuando el boletín del PNV -la revista Euzkadi-,

\footnotetext{
${ }^{254}$ PALMA, Luisa: "La buena situación económica del CDS permitirá a Suárez concurrir en el País Vasco y Cataluña", $A B C, 21$ de enero de 1984.

${ }^{255}$ Según un dirigente suarista, en una entrevista en 1986, la oferta de CiU era integrar como independientes a miembros del CDS de Cataluña, Interview undertaken by Richard Gunther, in 1986 (june), AR. Desde 1983, en Cataluña el CDS estaba comandado por una comisión ejecutiva encargado de la promoción del partido y no contaba siquiera con sede en Barcelona. Formaban dicha gestora: A. Castella, S. Dexeus, J. Pujadas, V. L. Balader, J. Ros Hombravella y -como presidente- M. Jiménez de Parga, El Noticiero Universal, 28 de enero de 1985.

${ }^{256}$ Carlos Garaikoetxea narra en sus memorias una anécdota ilustrativa sobre la flexibilidad política de Adolfo Suárez en materia autonómica, "por la mañana del día 9 de octubre [en Ajuria-Enea, 1980] yo le invité a escuchar conmigo el himno vasco Gora ta gora Euskadi (todavía sin oficializar) [...] Cuando la banda estaba en plena interpretación vi cómo llegaba Marcelino Oreja con Martín Villa haciendo gestos de sorpresa y casi desesperación, sin duda porque aquel himno todavía seguía teniendo connotaciones subversivas y, para colmo, estaba siendo escuchado en posición de firme por su presidente, al que seguramente consideraba ignorante de la historia de aquella música", GARAIKOETXEA, Carlos: Euskadi. Memorias políticas: la transición inacabada, Barcelona, Planeta, 2002, p. 136.
} 
homenajeaba a Adolfo Suárez "por su talante abierto y voluntad de comprensión a la hora de abordar la problemática vasca en su exacta dimensión, siempre loable en un político cuyo marco de actuación es el estatal" ${ }^{257}$. Aquel día, Arzalluz entregó al político abulense un bastón - makilla - explicándole, no sin cierto misterio que "esto [...] no tiene nada que ver con las metralletas, es para matar lobos, y tú sabes, presidente, que todavía quedan muchos" y pidiéndole excusas por el desaire cometido por el PNV en su visita al País Vasco durante $1980^{258}$. Pilar Urbano, en $A B C$, comentaba con sorpresa que lo interesante no era sólo el homenaje sino "el deseo de reparar -en flash back- a un presidente del Gobierno de la nación", lo que interpretaba en el contexto de los contactos del centro-derecha promovidos por la Operación Roca ${ }^{259}$. Como recordaba Patxo Unzueta desde El País -sin dejar de subrayar "la adjetivación pro autonomista" como rasgo característico del suarismo- una de las claves podía ser el intento del PNV de atraerse a los votantes de un CDS que ya había confirmado su incomparecencia en las futuras elecciones del Parlamento Vasco ${ }^{260}$. En octubre de 1985, Adolfo Suárez volvió a coincidir con la cúpula peneuvista en Ajuria Enea durante el VI aniversario del Estatuto de Guernica ${ }^{261}$, y no fueron extrañas, en el proceso de escisión del PNV, a raíz del nacimiento de Eusko Alkartasuna (EA) las comparaciones entre Suárez y Garaikoetxea $^{262}$.

\footnotetext{
${ }^{257}$ Acompañada de una entrevista a Adolfo Suárez, en Euzkadi, no 123, 03 de febrero de 1984. Destacado por el CDS, $B D C P, 2$, abril 1984.

258 "Xabier Arzallus pidió perdón a Adolfo Suárez por haber promovido desaires políticos. 'Desde que dejaste la presidencia, para nosotros terminó el cambio', declaró el presidente del Partido Nacionalista Vasco". El Presidente de la Diputación de Vizcaya, que tres años antes se había negado a acudir a la recepción oficial de Suárez dijo: "Presidente, hoy tengo que pedirte perdón", El País, 04 de febrero de 1984. Por su parte, en $A B C$ se titulaba: "El PNV opina que con Adolfo Suárez se vivía mejor", $A B C, 04$ de febrero de 1984.

${ }^{259}$ URBANO, Pilar: "Un brindis y un bastón", $A B C$, 09, febrero, 1984; ÍD.: "Suárez y la almohada", $A B C, 14$ de mayo de 1984. Otros aprovechaban para contraponer la actitud de Suárez con el P. Vasco y Cataluña con el "centralismo" del PSOE como DALMAU, Josep: "L'opressió de Catalunya", $E l$ Noticiero Universal, 31 de marzo de 1984. "Y ahora el señor Pujol la evoca [a UCD] nostálgico y el señor Arzallus condecora a don Adolfo Suárez, cuando lo habían declarado persona 'non grata' en Euskadi", PORCEL, Baltasar: "Persona 'non grata"', La Vanguardia, 12 de abril de 1984.

${ }^{260}$ UNZUETA, Patxo: "Adolfo Suárez, premiado como benefactor del pueblo vasco", El País, 03 de febrero de 1984.

${ }^{261}$ Fotografía de portada de Suárez, Garaikoechea y Ardanza en El Noticiero Universal, 26 de octubre de 1985. "En Catalunya, sólo Tarradellas recordó públicamente la fecha", El Noticiero Universal, 26 de octubre de 1985. Josep Pujadas comparaba el papel que había jugado Trudeau en la resolución del conflicto de Quebec en Canadá con la de Suárez durante la Transición en relación a Euskadi, PUJADAS I DOMINGO, Josep: "Euskadi y Quebec", El Noticiero Universal, 01 de febrero de 1985.

${ }^{262}$ Editorial: "La caída de Garaikoetxea", La Vanguardia, 20 de diciembre de 1984; ÁLVAREZ, Faustino F.: "Garaicoechea, rumbo al norte", $A B C, 16$ de mayo de 1987. J. L. Gutiérrez hablaba de dos trayectorias paralelas desde la firma del Estatuto de Guernica: defenestrados por su partido -con la participación del PSOE-, fundadores contra todo pronóstico de un nuevo partido, progresistas con tintes socialdemócratas, con éxito entre el electorado femenino, en "El Suárez vasco", Diario 16, 05 de abril de 1987. En 1984,
} 
En Cataluña, tanto Miquel Roca como Jordi Pujol no tenían tampoco reparos en reconocer públicamente el valioso e histórico papel jugado por Adolfo Suárez. El primero de ellos dejaba como testimonio: "Suárez fue un buen presidente del Gobierno, que condujo acertadamente la Transición, aunque a veces no se le reconozca este mérito"263. En términos semejantes se expresaba Pujol, quien afirmaba mantener una excelente relación personal con el ex presidente e incluso estuvo presente en la presentación del libro sobre la Transición Quién hizo el cambio, escrito por el miembro del CDS, Federico Ysart ${ }^{264}$. No era extraño oír, en boca de algún dirigente del CDS: "sólo hay tres partidos de centro: $\mathrm{CiU}, \mathrm{PNV}$ y $\mathrm{CDS}^{\text {,265. }}$

El éxito del PNV y CiU en las elecciones autonómicas fue interpretado por el CDS, como la respuesta electoral a la política autonómica iniciada en 1981 (LOAPA), que había favorecido el mantenimiento del discurso político en el eje nacionalista donde ambos partidos tenían "el éxito asegurado"266.

A raíz de estas elecciones, se reavivaron las tesis sobre pactos políticos en el espacio de centro y derecha a nivel nacional. Ignacio Camuñas, líder del Partido de Acción Liberal (PAL) en esos momentos, apostaba por una "amplia operación centrista" que al calor del éxito electoral del PNV y CiU se extendiera a todo el Estado ${ }^{267}$. Ofertas que también aparecían desde la Coalición Popular y particularmente, el PDP: "[los resultados] ponen de relieve la necesidad de transformar la Coalición Popular en una gran coalición, notablemente más centrada y ensanchada sobre bases de diálogo y cooperación con las fuerzas democráticas del centro y la derecha. Una coalición plural en su concepción y flexible [...] una contraoferta atractiva"268. Todas las hipótesis pasaban por "resucitar" $\mathrm{UCD}^{269}$, bien desde el centro o bien desde la derecha. Sin

Campmany describía la relación entre Garaikoetxea y Suárez como un "idilio político en cama elástica [...] entre bucólico y circense" en CAMPMANY, Jaime: "Sorpresa", ABC, 09 de febrero de 1984.

${ }^{263}$ SINOVA, Justino: (ed.): Historia de ..., p. 439.

${ }^{264} A B C, 27$ de junio de 1984. "Pujol: Suárez ha sido el presidente más autonomista", El Noticiero Universal, 10 de abril de 1984. Manifestaciones correspondidas por Suárez, quien se mostraba cauto en pleno escándalo contra los ex directivos de Banca Catalana -incluido Pujol- en los momentos de mayor tensión del proceso "por cuanto podía plantear dificultades institucionales que a nadie convienen", $E l$ País, 10 de junio de 1984.

${ }^{265} A B C, 12$ de mayo de 1984.

${ }^{266}$ Carta del Sec. Gral., Boletín de Difusión Cultural, 2, 01 de abril de 1984. Se llegaba a reconocer incluso en el caso de Cataluña que el voto del CDS había ido a parar a CiU, $A B C, 01$ de mayo de 1984.

267 CAMUÑAS, Ignacio: "Después del 29 de abril: un centro amplio", El País, 07 de mayo de 1984; "Garrigues y Camuñas tratarán de atraer a Suárez a la operación reformista", $A B C, 22$ de febrero de 1984. ${ }^{268}$ ALZAGA, Óscar: "Después de Cataluña", El País, 10 de mayo de 1984.

${ }^{269}$ Utilizando las expresiones empleadas por F. Jáuregui en la edición del domingo de El País, 06 de mayo de 1984. Luisa Palma en $A B C$ lo abordaba desde la posibilidad de coordinación global del centroderecha. 
embargo, el alcance de dicha coalición ${ }^{270}$ y la presencia de Suárez - que simbolizaba “todavía para muchos españoles -incluido el presidente González- buena parte de los éxitos de la transición" ${ }^{\text {271 }}$ - eran dos de las principales incógnitas en este proceso. Las ofertas públicas de participación a Adolfo Suárez por parte de Roca u otros líderes reformistas fueron constantes entre 1983 y 1986.

La fundación definitiva del PRD -noviembre de 1984- y el recrudecimiento de la batalla dialéctica entre reformistas y suaristas llevó a algunos ex ministros de UCD de filiación socialdemócrata y suarista a la formación de la CEPA (Centro de Estudios Políticos Actuales), una fundación que debía ejercer de puente entre ambos ${ }^{272}$. Sus impulsores eran: Juan Antonio García Díez, Carlos Bustelo, Luis González Seara, Rafael Arias-Salgado y, especialmente, Juan José Rosón ${ }^{273}$. El PRD contó con el decisivo apoyo de la línea editorial y de opinión de Diario $16^{274}$.

La presentación oficial de la CEPA se produjo con la publicación de un extenso manifiesto en Diario 16 -titulado: "La lucha por el centro político. (Tres estrategias para unas elecciones generales) ${ }^{, 275}$ - en el que se exponían los argumentos para la formación de una alianza de partidos centristas, capaz de garantizar la estabilidad del sistema de partidos. Se comenzaba con el análisis del punto de partida y lo que se consideraba la "cuestión fundamental", esto es, "como organizar el espacio político no socialista". Describía, a continuación, los errores estratégicos e insuficiencias ideológicas y partidistas de la CP. El CDS era, desde el punto de los firmantes, el poseedor de la legitimidad "histórico-democrática" del centrismo y de él debía partir la iniciativa en este ámbito, que de no ejercer podía verse seriamente perjudicada por la

\footnotetext{
270 "Si un pacto Roca-Suárez es imaginable o, cuando menos, no descartable, y un pacto Roca-Coalición Popular se entiende, un acuerdo entre Suárez, Roca y Fraga-Alzaga, pertenece más al campo de la ciencia ficción". Asimismo se cuestionaba el "silencio" premeditado de Suárez -en prácticamente todos los aspectos de relieve- y se ponía en relación su reticencia al pacto con la supuesta financiación del CDS por parte del PSOE, PALMA, Luisa: "El proyecto de centro hace renacer las esperanzas de los desmarcados de la UCD", $A B C, 20$ de mayo de 1984.

${ }^{271}$ Editorial: "En busca del centro perdido", El País, 15 de mayo de 1984. En ABC, se comentaba a partir de un sondeo del CIS que la Operación Roca sin el CDS "tan sólo parece una propuesta de buena intención”, $A B C, 29$ de julio de 1984.

${ }^{272}$ Con J. J. Rosón, J. L. González Seara, Carlos Bustelo, R. Arias-Salgado y J. A. García Díez como canalizadores, URBANO, Pilar: "El puente está servido", $A B C, 20$ de noviembre de 1984.

${ }^{273}$ Rosón señalaba que dicho acuerdo sería un gesto de "grandeza política” por parte de Suárez, "El centro sólo tiene posibilidades si hay acuerdo entre Adolfo Suárez y Miquel Roca", según Juan José Rosón”, El País, 06 de mayo de 1984; ABC, 14 de septiembre de 1984.

${ }^{274}$ Periódico, de otra parte, decisivo en la campaña de "acoso y derribo" contra Suárez y el fin de UCD desde 1980, véase, DÍAZ HERRERA, José: Pedro J. Ramírez al desnudo, Madrid, Akal, 2009, 116-121.

275 "Primer manifiesto del CEPA", Diario 16, 13 de enero de 1985. La CEPA prosiguió su actividad durante 1985, interviniendo sus miembros en conferencias y actos a lo largo del país o publicando estudios tendentes a la consecución del pacto.
} 
Ley Electoral. Finalmente, el PRD, lanzado como alternativa al socialismo, competía en el espacio de centro con el CDS y mantenía una ambigua y compleja relación con su padrino político: CDC. Los objetivos del CDS y del PRD debían ser evitar tanto la consolidación de un partido hegemónico como la formación de una "gran coalición antisocialista",276.

La pregunta que se planteaba era: ¿cómo transformar el "no sistema de partidos" en un "sistema estable, racional y generador de alternativas"? Se consideraba necesaria la formación de una coalición centrista (CDS-PRD-CDC) con el fin, en 1986, de privar al PSOE de la mayoría absoluta mediante la obtención de un grupo parlamentario significativo y a largo plazo, desembocar en "un centro político organizado" generando un "pluralismo moderado" en el sistema de partidos - tres o cuatro partidos de ámbito nacional, junto a las fuerzas nacionalistas $-{ }^{277}$. Todo ello pasaba por el entendimiento entre Suárez y Roca en un proceso de negociación que estaba encontrando numerosos obstáculos. Por un lado, la iniciativa de Roca y su ofrecimiento a Suárez, parecía infravalorar a quien no sólo representaba históricamente el centrismo en España sino ya había formado una opción política en torno a esta idea -el CDS-, asimismo, la pluralidad del PRD podía desembocar -aunque no necesariamente- en una fuerte inestabilidad. Por otra parte, Suárez debía considerar las limitaciones del CDS -cuyo futuro podía ser el de la "Izquierda Democrática" de J. Ruiz-Giménez que desapareció por "equivocar imagen, ubicación y estrategia" a pesar de la simpatía y el prestigio de su líder y del partido-, además de las dificultades generadas por la Ley Electoral que le obligaban a competir no sólo con el PRD sino con el PNV, CiU, PA o CG. El modelo sobre el que reflexionar, en un futuro, era la UDF -Unión Democrática Francesa-, agrupación de partidos políticos centristas franceses y la experiencia que se quería evitar era la de 1982, en la que una coalición UCD-CDS pudo haber conseguido 30 escaños. Según los firmantes del artículo, la espera de Suárez sólo provocaba el aumento de la

\footnotetext{
276 Cinco eran los argumentos en contra: no se podía unir en base a la "negación de...", excesivo pluralismo interno, problemas de liderazgo, podía desembocar en la reaparición de la extrema-derecha, polarización excesiva y finalmente, en caso de fracasar el espacio no socialista "quedaría arrasado".

${ }^{277}$ Razonablemente podía sacar entre 30 o 40 diputados aprovechando el tirón de Suárez, la habilidad de Roca y el empuje de Cataluña y el nacionalismo catalán en la modernización de España, entrevista con Rafael Arias-Salgado, 09 de marzo de 2015. En este sentido, CEPA publicó un estudio electoral en el que valoraba en 30 diputados la coalición entre PRD-CDS, rebajando a un máximo de 4 diputados por formación, si acudían en separado, El País, 28 de diciembre de 1984.
} 
presión económica y financiera en favor de la entente Fraga-Roca, capaz quizá de ocupar el "espacio centrista" pero incapaz de generar una "política centrista"278.

La propuesta de la CEPA recibió el respaldo explícito de algunos medios y periodistas -cabe destacar Diario $16^{279}$, , pero llama la atención sobre todo, el "singular" consenso existente en el campo del periodismo político en torno a la necesidad "objetiva" de Suárez de establecer un pacto, -como es de imaginar, las argumentaciones y los intereses que las motivaban eran múltiples- ${ }^{280}$. Los rumores y filtraciones sobre negociaciones se siguieron sucediendo hasta el verano de 1985, a la par que las acusaciones del PRD al CDS de connivencia con el PSOE ${ }^{281}$, mientras desde el suarismo se acusaba a los reformistas de ser parte de la "derecha" y constituir una formación "artificial e ingobernable". La CEPA rápidamente se dispersó -sin haber conseguido sus objetivos- y sus miembros desembocaron mayoritariamente en el PRD $^{282}$.

De acuerdo con el testimonio de Rafael Arias-Salgado,-miembro del CEPA y posteriormente, del PRD-, estas negociaciones retomaban una idea nacida en tiempos de UCD, cuando en un momento dado y de manera "no formalizada", Suárez ofreció la vicepresidencia de gobierno a Roca, quien rechazó la sugerencia ${ }^{283}$. Tanto en ese

\footnotetext{
${ }^{278}$ Sobre un pacto patrocinado por el banquero March entre Alzaga y Roca en GARCÍA-LEÓN, Carlos y MARTÍNEZ ECHEVARRÍA, Borja: Antonio..., p. 151. El papel de la CEOE y AP en GUINDAL, Mariano: El declive..., p. 278 y ss.

${ }^{279}$ Concluía así su editorial sobre el Manifiesto: "el germen de una nueva dinámica acaba de sembrarse. Tanto Roca como Suárez tienen importantes argumentos ante ellos sobre los que habrán de meditar. Aunque tampoco hay tanto tiempo...", editorial: "El manifiesto centrista", Diario 16, 14 de enero de 1985; GUTIÉRREZ, José Luis: "González, Suárez y el abrazo de la muerte", Diario 16, 07 de marzo de 1985. Sobre el apoyo de Diario 16 a la Operación Reformista: "decididos a desalojar al PSOE del Gobierno, con la entusiasta colaboración del director de Diario 16, un heterogéneo grupo de políticos de la UCD y de CiU, juristas, abogados, periodistas y otra gente de variado pelaje habían montado una nueva formación política, el Partido Reformista Democrático [...] su objetivo era convertirse en un 'partido bisagra",, DÍAZ HERRERA, José: Pedro J. Ramírez..., pp. 55-6.

${ }^{280}$ Con un cierto tono profético, una nueva vinculación de "azules" y Suárez se presagiaba como la única forma de "rescatar" al político abulense según RODRÍGUEZ, Pedro: "Salvad al duque", $A B C, 25$ de mayo de 1983. La existencia de numerosos partidos proclamándose en el espacio de centro había llevado a Fernando Jáuregui a limitar a dos las alternativas de futuro: "socialismo o coalición de partidos burgueses", El País, 24 de enero de 1984; "el éxito depende por lo demás, en gran parte, de cual sea la actitud de Adolfo Suárez", en el editorial: "El congreso reformista", El País, 25 de noviembre de 1984. "Juntos, esos dos hombres pueden ser mucho más que una bisagra. Pueden ser el paraguas, soportal, de la-calle-del-centro que, hoy por hoy, está sin techumbre", URBANO, Pilar: "Paraguas de centro", $A B C$, 24 de enero de 1984.

${ }^{281}$ Con el significativo título de "Alternativa, no complemento", reivindicaba Ernest Sena, miembro de la ejecutiva del PRD la opción reformista, El País, 19 de junio de 1985.

${ }^{282}$ Finalmente, García Díez y Bustelo ingresaron en el PRD en enero de 1986, señalando como una de las diferencias con el CDS era su "ambigua" postura respecto a la OTAN, El País, 25 de enero de 1986. Arias-Salgado dio su apoyo al PRD ocupando el último puesto en la lista de Madrid en las Elecciones Legislativas.

${ }^{283}$ Entrevista con Rafael Arias-Salgado, 09 de marzo de 2015.
} 
momento, como en la década de los 80 ' se intentó “que Cataluña forme parte esencial de la gobernación de España, que es el mejor camino para resolver la integración del nacionalismo catalán" ${ }^{\text {284 }}$. Para Arias-Salgado si el entendimiento no fructificó, en la negociación directa existente entre ambos, fue debido al desacuerdo sobre quién debía encabezar la operación que Suárez reclamaba para sí, lo que Roca consideraba inviable debido a la fuerte erosión que había sufrido el capital político del abulense ${ }^{285}$.

Roca, sin embargo, ha señalado que ofrecieron el liderazgo de la operación a Suárez -"teníamos claro que sólo había una persona que podía sacar el proyecto adelante"-, quien en un principio mostró su disposición y que finalmente no fraguó como consecuencia de la negativa de Eduard Punset -recientemente, incorporado al CDS- y que podía ver mermado su protagonismo. Fue precisamente el político catalán quien le comunicó a Roca la negativa del CDS. Este último sitúa estos hechos en el año 85,286.

Para José Ramón Caso, -quien no estuvo presente en las reuniones determinantes de la negociación-, el punto de desencuentro fundamental para la coalición de ambas formaciones -en la que se ofreció a Suárez encabezar la lista por Madrid- estribó en la negativa de Suárez a que desapareciese una opción de centro nacional en Cataluña, electorado que para Pujol debía ser cubierto en dicho territorio, en exclusiva, por el nacionalismo catalán $(\mathrm{CiU})$. Es decir, los problemas surgieron no tanto en el acople a la Operación Reformista como en relación a su estructuración en Cataluña (CDC). Una opinión expuesta por Adolfo Suárez en el seno del Comité Nacional y que contó con el respaldo unánime de los líderes del partido -Rodríguez Sahagún, Viana o el propio Caso, entre otros- y el apoyo conjunto de la ejecutiva donde al parecer no fue ni siquiera necesaria una votación formal a este respecto ${ }^{287}$.

Al margen de los problemas de liderazgo que planteaba la Operación Roca la coalición con el CDS fue a priori vista con simpatía por numerosos militantes centristas. No existían diferencias ideológicas sustanciales -ambos ocupaban el mismo "espacio electoral"- y como refiere Caso, buscaban la complicidad de las mismas

\footnotetext{
${ }^{284}$ Sin olvidar, el juego de mayorías subyacente como señalaba Caso en una entrevista en 1985 con Ángel Collado: "un objetivo sano como es el expresado por Pujol de cooperar en el gobierno de la nación española se podría ver como un truco para tener más fuerza en Madrid. Y entonces un objetivo sano, por una estrategia equivocada, se habría frustrado", $A B C$, 01 de febrero de 1985.

${ }^{285}$ Véase, El País, 18 de mayo de 1984 y ABC, 19 de mayo de 1984. Según se publicó en El País fueron al menos dos entrevistas durante 1984, El País, 26 de octubre de 1984.

${ }^{286}$ Miquel Roca lo ha atribuido a la negativa de Eduard Punset, NAVARRO, Julia: Entre Felipe y Aznar: 1982-1996. Temas de Hoy, Madrid 1996, pp. 380-381.

${ }^{287}$ Entrevistas con J. R. Caso, 19 de noviembre de 2014 y 21 de abril de 2016.
} 
estructuras socio-profesionales -básicamente, "cuadros" directivos- que vieron con muy buenos ojos la iniciativa reformista, lo que Lorenzo Contreras llamó: "afinidad real en los entornos respectivos"288. Por último, había que tener en cuenta los réditos electorales -y económicos- de dicha coalición:

Y si hubiéramos ido con la financiación y con la idea de un centro, en vez de pelearnos dos centros, [...] yo sí que estoy convencido que aparte de los 17, 18 que sacó Convergencia, [...] no hubiéramos sacado 19, hubiéramos sacado 30. [...] Una plataforma común de intereses de 60 diputados eso sí que hubiera sido interesante: hubiera cambiado la forma de hacer política en este país [...] las ventajas eran muy superiores a los convenientes ${ }^{289}$.

Sin embargo, las principales reticencias planteadas por el entorno de Suárez al diseño de la Operación Roca calaron en la militancia ${ }^{290}$. Siguiendo el relato ofrecido en 1986 por un dirigente suarista, en primer lugar, el CDS no consideraba al PRD "un partido político" sino "un proyecto de ingeniería electoral". Un proyecto basado -en palabras de otro dirigente centrista- en "fomentar artificialmente" partidos regionalistas; lo que podía tener un relativo éxito a nivel autonómico, pero generaba una estructura de partido, -y en su caso, de poder-, ingobernable. La Operación Roca no se consideraba un proyecto común o coherente ideológicamente, sino una suma de arriba a abajo como UCD-, "una reproducción de las tensiones de las que ya tenemos experiencia muchas personas que estamos en la vida política"291 "una repetición de UCD”"292 o "un producto de marketing político"293. En un documento firmado por el propio Suárez en junio de 1984 defendía este mismo argumento: "Con Miguel Roca he mantenido conversaciones y he puesto de relieve mi discrepancia con su proyecto, desde el más absoluto respeto, en función de mi experiencia reciente [no repetir UCD]. Con el Presidente Pujol mantuve una conversación telefónica, pasadas las elecciones, para hacerle llegar mi sincera felicitación... ${ }^{, 294}$.

\footnotetext{
${ }^{288}$ CONTRERAS, Lorenzo: "El problema del líder", $A B C$, 06 de mayo de 1984.

${ }^{289}$ Entrevista con José Ramón Caso, 19 de noviembre de 2014. Según una encuesta de Emopública S.A. difundida por OTR/PRESS dos coaliciones, una de derechas (CP) y otra de centro (PRD-CDS) "quitarían" la mayoría absoluta al PSOE en DE OTTO, Sergio: "Dos coaliciones de centro y de derecha, quitarían la mayoría al PSOE", Ya, 06 de marzo de 1985.

${ }^{290}$ Por su parte, desde el PRD el ataque más frecuente -conectando con un rumor generalizado- fue el de señalar la connivencia del CDS con el PSOE, "Garrigues: 'El PSOE utiliza a Suárez y Carrillo para dividir"”, $A B C, 27$ de mayo de 1985.

291 "Suárez: el CDS no entra en la Operación Roca", $A B C, 17$ de abril de 1983

${ }^{292}$ El País, 31 de diciembre de 1983. "Un tipo de germen disgregador similar al que acabó con la Unión de Centro Democrático [...] una anacronía", CDS-Federación de Madrid, 0, noviembre 1985.

${ }^{293}$ El País, 28 de enero de 1985.

${ }^{294}$ En una carta fechada el 5 de junio de 1984 dirigida al director de $A B C$, Carpeta 2, AGP.
} 
En palabras de Antonio Garrosa, presidente provincial en Valladolid, Suárez en una reunión mantenida a finales de 1983 en Madrid les manifestó por primera vez sus discrepancias con la Operación Roca ${ }^{295}$. Aunque, en términos electorales podía permitir, incluso, el triunfo electoral, ¿qué pasaría después? Imaginando un supuesto en el que Suárez fuera Presidente de Gobierno y M. Roca vicepresidente, ¿qué sucedería si se produce una destitución ministerial?, ¿no le seguirían los diputados de uno de los partidos coaligados? ¿Cómo se mantendría así la estabilidad gubernamental?: “en una situación de oposición al adversario común puede, al menos teóricamente, mantenerse durante un tiempo [...] pero que, en una hipotética posición de gobierno, resultaría de imposible realización práctica" ${ }^{296}$. Un peligro que se agravaba por las divergencias de intereses de los distintos partidos regionalistas y nacionalistas y las dificultades para concretar una política nacional. Unas tesis que Suárez mantuvo a lo largo de los años, a pesar, recuerda Garrosa, de cierta predisposición inicial y mayoritaria entre la militancia suarista favorable al pacto ${ }^{297}$. Como refiere Abel Cádiz en un primer momento existió un sentimiento de decir, “¿por qué no juntos?”298

De otra parte, el papel de CiU en la política catalana y española había dependido en cierto modo de su relación con UCD. Desde la victoria del PSOE en 1982, desde CiU se plantearon exportar al resto de España un modelo -que se demostró como muy eficaz en 1984 - que les permitiera retener en Cataluña todo el voto de centro -fuera o no españolista- y ser el eje vertebrador de un grupo parlamentario fuerte a nivel nacional afín a sus intereses. En ese momento, según el testimonio de un dirigente suarista, fue cuando se produjo la adhesión de numerosos políticos de UCD -en su mayoría altos cargos de la administración-, necesitados de un liderazgo a nivel nacional. Como se podía leer en el boletín del CDS de la Federación de Madrid: "la ambigüedad de Roca le permite colocar una vela a Dios, en el Parlamento de Madrid y otra al diablo en la tribuna de Manresa"299.

\footnotetext{
${ }^{295}$ Reiteró esta postura en la Asamblea de Portavoces celebrada el 2 de junio de 1984: "la posición de CDS respecto a la operación reformista, que es de respeto pero no de participación, dadas las profundas dudas que existen sobre la auténtica naturaleza del partido político de la Operación Reformista", $C D S$ Federación de Madrid, junio de 1984.

${ }^{296}$ Roca equivocaba la necesidad de un partido federado nacional con la federación de partidos nacionalistas, formulada extraña a las democracias occidentales en "La Operación Roca", CDSFederación de Madrid, 0, noviembre de 1985.

${ }^{297}$ Entrevista con Antonio Garrosa, 31 de julio de 2013.

298 Entrevista con Abel Cádiz, 4 de marzo de 2015.

${ }^{299}$ CDS-Federación de Madrid, 0, noviembre 1985.
} 
Finalmente, en relación a las diferencias ideológicas, éstas eran francamente escasas; por ejemplo, el PRD estaba adscrito al liberalismo progresista ${ }^{300}$, etiqueta que iba a asumir el CDS poco después. Las mayores diferencias estribaban en el papel del Estado y la concepción liberal de la economía, más acentuada en el caso de los miembros de la Operación Roca: "mientras los hombres sean como son [...] por lo menos un estado mínimo es imprescindible”,301. Precisamente, el énfasis liberal del PRD era la seña de identidad del nuevo partido, que como manifestaban recurrentemente sus líderes contaba con el apoyo de la Internacional Liberal "del que no gozan partidos como AP, PDP y CDS"302. Para el CDS, el PRD "en los análisis que nosotros hacemos [...] se nutría de votos de la derecha"303 y en cierto modo, su aparición estimuló la acentuación de su discurso de centro-izquierda.

Aunque el pacto entre Roca y Suárez nunca tuvo lugar, la Operación Roca sirvió para atraer el foco de atención indirectamente hacia el CDS cuya vida en este período sin la concurrencia del PRD hubiera padecido de una mayor indiferencia: "todo el mundo asiste en este momento a una inmóvil ceremonia en la que todas las fuerzas políticas tienen curiosamente puestos sus ojos en Adolfo Suárez" ${ }^{\text {304 }}$. La negativa de Suárez a pactar con la Operación Roca empeoró eso sí y de forma drástica la frágil situación económica del CDS.

Desde 1982, la financiación del partido había dependido de los movimientos de Suárez y particularmente de Rodríguez Sahagún - de quien se decía, había puesto en venta algunas piezas de su colección de arte para financiar el partido ${ }^{305}-$. Ellos se habían encargado de la consecución de créditos, ayudas y donaciones en el mundo empresarial y bancario ${ }^{306}$, a lo que había que sumar, el muy exiguo montante de las

\footnotetext{
${ }^{300}$ Para El País la adscripción al "liberalismo progresista" por parte del PRD era exagerada y en España correspondía a posiciones de izquierda, editorial: "El congreso reformista", El País, 28 de noviembre de 1984.

${ }^{301}$ El País, 13 de noviembre de 1983.

${ }^{302}$ Diario 16, 16 de mayo de 1983, Archivo Linz. Para J. Satrústegui -vicepresidente segundo del PDLera el principal aval del nuevo partido, en SATRÚSTEGUI, Joaquín: "La necesaria operación reformista", El País, 10 de agosto de 1984. En el manifiesto inaugural de la Operación Reformista, el epígrafe introductorio del programa político y económico del PRD era precisamente: "Apoyo internacional al reformismo", PRD: La alternativa reformista, Madrid, PRD, 1985, pp. 27-41.

${ }^{303}$ Interview undertaken by Richard Gunther in 1986 (june), AR.

${ }^{304}$ GUTIÉRREZ, José Luis: "González, Suárez y el abrazo de la muerte", Diario 16, 07 de marzo de 1985.

${ }^{305}$ DEL RÍO, Ángel: Agustín Rodríguez Sahagún, Madrid, Grupo Libro 88, 1991, pp. 66, 77 y 252.

${ }^{306}$ Entrevista con José Ramón Caso, 19 de noviembre de 2014.
} 
cuotas aportadas por la militancia -gestionadas a nivel nacional-, o más aún, de las subvenciones públicas (debido a los bajos resultados obtenidos en 1982 y 1983) ) $^{307}$.

En el otoño de 1983 - un momento de cierta mejoría económica del CDS previo a la inauguración de la sede en la C/Jorge Juan- se abordó el tema de la financiación del partido a nivel provincial con el fin de paliar las deudas que acosaban a las distintas gestoras -I Asamblea de Portavoces- $-{ }^{308}$. Según relata Luis Aznar se asignó una cantidad mensual de 50.000 pesetas para cada provincia y "nos dieron en mano un cheque de 150.000 pesetas a cada presidente provincial" ${ }^{, 309}$. El mantenimiento ordinario y la financiación de las campañas electorales de las organizaciones provinciales se efectuaban desde Madrid y se completaban con los créditos suscritos por los dirigentes territoriales.

Sin embargo, como señalan algunos de los líderes regionales del partido, la situación económica en este período era bastante dramática y la subsistencia, precaria: las reuniones y actividades eran escasas y las instalaciones y recursos en muchas ocasiones respondían a prestaciones personales ${ }^{310}$. Como ejemplo, en una carta del dirigente provincial de Valladolid a Rodríguez Sahagún le indicaba:

En diciembre del 84, cuando teníamos en Valladolid tremendos problemas económicos, me remitiste un talón personal de cien mil pesetas. Venía con una tarjeta manuscrita [...] donde me decías: [...] te mando este talón para que hagas frente a las necesidades más urgentes del Partido en tu Provincia. Si algún día podéis me lo devolvéis, y si no, ¡qué se le va a hacer! $!^{311}$

\footnotetext{
${ }^{307}$ En 1982 le correspondieron 8,3 millones de pesetas, ABC Sevilla, 16 de febrero de 1983.

308 "Según los datos facilitados por Caso, deben 570 millones de pesetas a entidades bancarias, de los que 25 fueron avalados con bienes de Suárez y algún otro alto cargo del partido", $Y a, 09$ de marzo de 1986. En 1985, en la II Asamblea del partido en León, el balance arrojaba un saldo favorable de 61.000 ptas., con unos ingresos mensuales medios de 32.000, una situación que les permitía tener contratada a tiempo parcial a una persona en la sede. Sin embargo, arrastraban una deuda total, desde 1982, de un millón y medio de pesetas en AZNAR, Luis: Haciendo..., p. 138. Sólo en la provincia de Valencia, la deuda se valoraba por la Gestora provincial en torno a dos millones de pesetas en septiembre de 1983 y, un comunicado del "sector crítico" regional estimaba en 400 millones lo que se debía a los bancos de RUMASA, Las Provincias, 21 de septiembre de 1983.

${ }^{309}$ AZNAR, Luis: Haciendo ... En el boletín de Aragón, en un tono humorístico se decía: "Se insiste en el rumor, que procedente de Madrid va a llegar a nuestra sedes; ¡fijaos bien!, iiiDINERO!!!!”, Boletín de Información CDS-Aragón, 1, noviembre 1983.

${ }^{310}$ Entrevistas con Antonio Garrosa, 31 de julio de 2013 y con Manuel de Sárraga, 23 de julio de 2014.

${ }^{311}$ S. f., tarjeta de Antonio Garrosa a Agustín Rodríguez Sahagún, $A A G$.
} 


\section{Capítulo 5:}

\section{El largo año de 1986: OTAN, banca y elecciones}

Si hubiéramos de escoger sólo un año en la historia del CDS, sin duda, fijaríamos nuestra atención en el año 1986, auténtico punto de inflexión en la vida del partido una opinión compartida por la inmensa mayoría de la militancia y cargos del partido.

La importancia de 1986 radica en la singular e inesperada evolución de los acontecimientos. En las elecciones autonómicas de Galicia en diciembre del año anterior, el CDS parecía ver truncada definitivamente cualquier opción política de cara al futuro. Luego, la confusión generada en torno al referéndum de la OTAN, en marzo de 1986, y las dificultades existentes de cara a la financiación del partido, fueron interpretadas por muchos como el evidente corolario de una concatenación de infortunios y desaciertos que invitaban a Adolfo Suárez a poner fin a su aventura política.

Fue uno de los momentos más singulares y emocionantes de la carrera política de, Adolfo Suárez, quien volvía a ocupar, después de cinco largos años, las primeras planas de los periódicos consiguiendo un destacado resultado electoral.

\section{1. Del impasse de los comicios gallegos a la convocatoria de las elecciones generales de 1986}

Las elecciones autonómicas gallegas sirvieron como auténtico banco de pruebas de las elecciones generales de 1986 y supusieron una nueva oportunidad para comprobar la viabilidad electoral de la Operación Roca, -que se presentaba con las siglas de Coalición Galega- y del CDS que esta vez sí, iba a acudir a la cita electoral: "Roca propone la retirada del CDS o el PRD, según quien pierda en Galicia"1.

\footnotetext{
${ }^{1}$ El País, 13 de junio de 1985. La decisión de acudir a las elecciones ocupó la fotografía de portada de algunos medios: "El CDS irá a las elecciones gallegas", El País, 04 de febrero de 1985. Como señalaba el miembro del CDS, MOLDES FONTÁN, Francisco: "Galicia 85, ensayo general”, El País, 21 de agosto
} 
Conscientes de la trascendencia de estas elecciones los suaristas habían iniciado en 1984 un intenso plan de reorganización en un territorio donde apenas poseían infraestructura: "como elemento indispensable para poder concurrir con éxito a las Elecciones al Parlamento Gallego que se celebrarán el otoño de 1.985 y que serán evidentemente un test muy importante para todas las fuerzas políticas"2. Se llevó a cabo la celebración de las cuatro asambleas provinciales, se constituyeron numerosos comités locales, se inauguraron sedes -como la de Vigo o Pontevedra en 1984- y se intensificó el proceso de captación de afiliados (Anexo $\mathrm{X})^{3}$. En todo ello, asumió un papel protagonista la dirección nacional del partido. El propio Adolfo Suárez visitó seis veces la comunidad en apenas ocho meses (octubre de 1984 y junio 1985), estuvo presente en todas las Asambleas Provinciales y recorrió prácticamente la totalidad de los grandes municipios gallegos, acompañado por Fernando Castedo, -quien realizó un total de 14 viajes a Galicia ${ }^{4}$, y su equipo personal a cuyo frente se encontraba José Luis Garro ${ }^{5}$. A finales de 1985, el CDS había alcanzado ya los cerca de mil afiliados en toda la Comunidad $^{6}$. La composición de las candidaturas electorales, en octubre de ese año, daba muestra del trabajo realizado: el número de candidatos afiliados en 1984 y 1985 suponía el 65\% de las listas -incluidos los cabezas de lista por Lugo y La Coruña-. Los antiguos miembros de UCD alcanzaban sólo el 23,33\% del total, siendo su porcentaje más elevado en la provincia de Orense ${ }^{7}$.

Los días 15 y 16 de junio se celebró en Santiago el I Congreso Federal del CDSGalicia en el que se designó Presidente al ex miembro de UCD, José Antonio Arán Trillo y, días después, a Francisco Javier Moldes Fontán como Secretario General. La

de 1985. En la campaña electoral participaron activamente los principales líderes políticos nacionales salvo Felipe González.

${ }^{2}$ Carta del Secretario General, BDCP, 3, julio 1984. ““- ¿Cuál es el reto del partido en estos comicios? [José Ramón Caso] Demostrar un avance que hay una estructura de partido y alcanzar un grupo parlamentario propio", $A B C, 01$ de febrero de 1985.

${ }^{3}$ En total, el CDS contaba con seis sedes en Galicia (Vigo, Pontevedra, Santiago, La Coruña, Lugo y Orense) y casi un centenar de comités locales.

${ }^{4}$ Asimismo, debemos destacar la presencia de Caso, quien realizó hasta doce incursiones en Galicia en este período y Rodríguez Sahagún con cinco. En el caso de la provincia de Lugo fue decisiva la participación del lucense Gerardo Harguindey.

5 Durante estos meses Suárez acudió entre otras localidades a Porriño, Tuy, Vigo, O Grove, Lalín, Santiago de Compostela, Cesures, Miño, Moeche, El Ferrol, Neda, Cariño, Noya, Ribeira, Boiro, Negreira, Noya, Barco de Valdeorras, etc.

${ }^{6} A B C, 15$ de junio de 1985. En septiembre J. R. Caso los cifraba en 800 militantes, $A B C, 23$ de septiembre de 1985 .

${ }^{7}$ Cifras inferiores en cualquier caso a las de los órganos de dirección tal y como reflejan los casos de La Coruña y en menor medida, Pontevedra. En La Coruña, de los 16 miembros del Comité Ejecutivo 7 $(43,75 \%)$ habían pertenecido a partidos políticos previamente (5 a UCD y 2 a UCD/PAD). En Pontevedra, de los 15 miembros del Comité, 5 habían pertenecido a UCD y uno a AP (un total del $40 \%$ ). 
celebración de este acto dio inicio a la preparación de la campaña electoral formándose las comisiones encargadas de la redacción del programa. Las candidaturas fueron proclamadas el 19 de octubre de 1985 en Santiago de Compostela con la presencia de Suárez, Caso y Castedo. José Otero Costa, sacerdote secularizado y especialista en derecho matrimonial, fue elegido candidato del partido a la Xunta, una elección que generó bastante sorpresa entre los medios que subrayaban su desconocimiento entre el electorado y lo improvisado de la decisión.

Tabla 20: Cabezas de lista en las EE.AA. de Galicia (1985).

\begin{tabular}{|c|c|}
\hline Provincia & Cabeza de lista \\
\hline La Coruña & M. Martín Gómez \\
\hline Lugo & A. Carro Páramo \\
\hline Orense & S. Ramos Álvarez \\
\hline Pontevedra & J. Otero Costa (candidato a la presidencia de la Xunta) \\
\hline
\end{tabular}

Elaboración propia a partir de $O I C D S$, 0, noviembre, 1985.

La movilización de tiempo y recursos que había puesto en marcha el CDS de cara a su implantación en Galicia debía hacer frente a un último reto: las escasas opciones electorales que le adjudicaban las distintas encuestas y sondeos electorales (3\% y un único escaño) ${ }^{8}$. Ante las bajas expectativas y como había sucedido en ocasiones anteriores la dirección del CDS anteponía la consolidación del partido a los resultados electorales: "los resultados de las elecciones autonómicas en Galicia van a incidir poco en la marcha del partido en toda España"". El periodista Lorenzo Contreras hablaba del "talante experimental" con el que el CDS había afrontado unas elecciones en principio desfavorables, en las que el objetivo era tener presencia parlamentaria ${ }^{10}$. El presupuesto que se barajaba para la campaña rondaba los 50 millones de pesetas, una cifra considerablemente inferior a la manejada por sus rivales políticos: "ello explica que el partido sólo tenga una valla, y regalada, en Pontevedra"11.

\footnotetext{
${ }^{8}$ Encuesta de SOFEMASA para la CEOE: $3,5 \%$ de voto decidido no discriminado (2\% de voto decidido) y 1 escaño: "posición puramente testimonial y no aporta las dosis de optimismo que se buscaban de cara a las elecciones generales", $A B C, 25$ de agosto de 1985; JÁUREGUI, Fernando: "Optimismo en público, prudencia en privado", El País, 17 de junio de 1986.

${ }^{9}$ El País, 17 de junio de 1985. "Si obtenemos un diputado ya hemos ganado y ello porque en Galicia partimos de la nada", El País, 20 de octubre de 1985.

${ }^{10}$ CONTRERAS, Lorenzo: "Suárez opta por ser la alternativa, $A B C, 18$ de junio de 1985; OICDS, 0, noviembre 1985; PALMA, Luisa: "Suárez se conforma con obtener un solo diputado", $A B C, 12$ de noviembre de 1985.

${ }^{11}$ El País, 18 de noviembre de 1985. En torno a 50 millones también según en El Periódico, 14 de noviembre de 1985. AP: 600 millones en Galicia; PSOE 500; CG 200 y CDS 60 millones en, BURGOS, Antonio: "Detergente electoral", $A B C$, 05 de diciembre de 1985. De acuerdo con El País, 30 millones, en
} 
Suárez presente en la apertura de campaña del partido en Vigo, el 8 de noviembre, se convirtió en el protagonista absoluto ${ }^{12}$. Las elecciones gallegas sirvieron a los suaristas para escenificar la transformación política del ex presidente, quien permaneció durante prácticamente tres semanas en Galicia. Y es que, se desplegó un discurso que presentaba a Suárez como alternativa de gobierno en 1990.

Suárez abarrotaba los pequeños cines y teatros donde tenían lugar los mítines. $\mathrm{Su}$ discurso, austero y libre de descalificaciones personales -aunque crítico, especialmente con la política económica y militar del PSOE- estaba en sintonía con los slogans escogidos para aquella ocasión: "Estamos contigo y contra nadie" y "Recuperar la esperanza". Era el momento de medir electoralmente el carisma y la popularidad de Suárez. En los últimos días de campaña, las encuestas parecían confirmar las mejores esperanzas del CDS: un sondeo encargado por el PSOE le otorgaba dos diputados y una encuesta de ARESCO le aseguraba al menos dos y un máximo de cinco.

El CDS mostró su rechazo a establecer pactos con otras fuerzas políticas -optando por, si fuera el caso, dejar gobernar en minoría como insinuaba su lema de campaña-, mientras era tanteado tanto por el PSOE como la CP quienes hicieron declaraciones favorables a un futuro pacto con el CDS. En la prensa conservadora, se agitaron los rumores, poco antes de la jornada electoral, sobre un supuesto pacto progresista entre PSOE, CG y CDS con el fin de desalojar a la CP del gobierno de la Xunta ${ }^{13}$. El País, por su parte, restaba credibilidad a las opciones centristas: "aunque su entusiasmo y su obstinación resulten ejemplares por muchos conceptos, no parece que Adolfo Suárez, con un candidato improvisado, sin recursos económicos y hostilizado desde todos los flancos, pueda sacar al CDS de su actual marginalidad"14.

Los candidatos gallegos del CDS vertebraron su discurso sobre la base de la necesidad de romper el bipartidismo, la renovación de los estructura social gallega frente al caciquismo-, la regeneración industrial y la mejora de las condiciones de la

El País, 08 de enero de 1986. Por otro lado, hubo reclamaciones - aceptadas-del CDS a la Junta Electoral Central por la distribución de los espacios gratuitos en TVE, $A B C, 08$ y 11 de noviembre de 1985.

12 Para Enrique De Diego: "una de las novedades de esta campaña ha sido la activa participación de Adolfo Suárez", $A B C, 24$ de noviembre de 1985; JÁUREGUI, Fernando: “'Resurrección' de Suárez”, El País, 08 de noviembre de 1985. En una entrevista publicada en El País en plena campaña, el propio Suárez afirmaba: "Se ha producido respecto de mí una nueva credibilidad", en JÁUREGUI, Fernando: "Adolfo Suárez: Yo sólo me aliaría políticamente con Felipe González en condiciones de anormalidad”, El País, 18 de noviembre de 1985.

13 “Pacto secreto del PSOE?” en "Guerra: 'Nos quedamos sin Baviera”, ABC, 22 de noviembre de 1985.

${ }^{14}$ Editorial: "Ensayo general en Galicia”, El País, 10 de noviembre de 1985. 
adhesión a las $\mathrm{CEE}^{15}$. Un tono eminentemente pragmático basado en la eficacia y la gestión: "no nos enfrentamos ni con los que están a nuestra derecha ni a nuestra izquierda, sólo nos enfrentamos con los problemas de Galicia”. El énfasis en el papel de las instituciones públicas, la pequeña y mediana empresa y la necesidad de corregir los desequilibrios sociales y económicos persistentes en la sociedad eran los rasgos diferenciadores de su programa electoral ${ }^{16}$.

Los resultados en Galicia supusieron un nuevo revés para el CDS, y en este caso, muchos lo vieron como la prueba definitiva de su falta de viabilidad nacional. El CDS consiguió un 3,28\% de los votos, contabilizando en total 41.411 papeletas. Desglosado por provincias, y de acuerdo con las previsiones del CDS, los mejores resultados habían sido obtenidos en Pontevedra, donde se quedó a décimas de la consecución de un parlamentario -objetivo, que pareció conseguido a lo largo de la noche electoral-:

Tabla 21: Resultados de las elecciones autonómicas de Galicia (1985).

\begin{tabular}{|l|l|l|}
\hline Provincia & Porcentaje & Diputados \\
\hline CP & $40,89 \%$ & 34 \\
\hline PSOE & $28,67 \%$ & 22 \\
\hline CG & $12,94 \%$ & 11 \\
\hline PSG-EG & $5,67 \%$ & 3 \\
\hline BNG & $4,2 \%$ & 1 \\
\hline CDS & $3,28 \%$ & - \\
\hline
\end{tabular}

Elaboración propia a partir de http://www.historiaelectoral.com/agalicia.html Fecha de consulta: 19 de abril de 2015.

Tabla 22: Resultados del CDS desglosados por provincias (24 de noviembre de 1985).

\begin{tabular}{|l|l|}
\hline Provincia & Porcentaje \\
\hline La Coruña & $2,4 \%$ \\
\hline Pontevedra & $3,7 \%$ \\
\hline Orense & $2,6 \%$ \\
\hline Lugo & $2,4 \%$ \\
\hline Total & 3,28 \\
\hline
\end{tabular}

Elaboración propia a partir de http://www.historiaelectoral.com/agalicia.html Fecha de consulta: 19 de abril de 2015.

Las lecturas de los resultados eran bastante decepcionantes. Los índices de popularidad de Suárez, -en los que aparecía como el segundo político más valorado-, no eran una garantía suficiente para el éxito electoral y los votos obtenidos por Coalición Galega, -que había logrado 11 parlamentarios- cuestionaban, según muchas voces, la estrategia seguida por Suárez. José Sentís en $A B C$ escribía: “[Suárez] puede

\footnotetext{
15 "Nuestra oferta electoral", OICDS, 0, noviembre 1985.

${ }^{16}$ GONZÁLEZ IBÁÑEZ, Juan: "El CDS apuesta por la pequeña empresa ante la reconversión", El País, 22 de noviembre de 1985.
} 
comenzar a meditar sobre si es posible mantener una fuerza política con su sólo impulso personal, con tanto entusiasmo como falta de medios humanos y materiales" ${ }^{\prime 1}$. En línea editorial se insistía en dos ideas: los resultados constataban la existencia de una "mayoría natural” y ésta, sólo podía ser operativa previa concertación de fuerzas en el espacio de centro-derecha ${ }^{18}$. En Diario 16, se certificaba el error estratégico del CDS y el éxito inapelable de la estrategia reformista, apoyados por la línea editorial y de opinión del periódico. J. L. Gutiérrez señalaba: “el ‘once a cero’ (once, CG; cero, CDS) es espectacular y revelador del triunfo del proyecto del liberalismo reformista $\mathrm{y}$ progresista del PRD. Esto tendría que hacer reflexionar a Suárez" ${ }^{19}$. Federico Jiménez Losantos atribuía el fracaso electoral a las dificultades del CDS a la hora de asumir un discurso liberal y moderno:

Tres buenos candidatos -Albor, Marinas y Nogueira-, uno bastante malo -González Laxe-, y otro pésimo, Otero, el 'arcipreste' del duque. [...] el tercermundismo tiene poco que hacer frente a un liberalismo moderado, occidental y europeísta, sobre todo porque parece claro que lo único que obtiene votos frescos contra el centro izquierda del PSOE es un centro derecha moderno pero sin nostalgia izquierdosa. A ver quién se lo explica a Suárez ${ }^{20}$.

Del resultado de las elecciones, se extraía una última lectura en las filas de la oposición. El hecho de que la CP no hubiera conseguido mayoría absoluta ¿era testimonio del fracaso como líder nacional del partido de Fraga? ${ }^{21}$ En ese caso, suponía

\footnotetext{
${ }^{17}$ SENTÍS, J.: "El fin de las elecciones gallegas coincide con la precampaña de las generales", $A B C, 26$ de noviembre de 1985; DÁVILA, Carlos: "Tras los comicios, ya nada será igual", Diario 16, 26 de noviembre de 1985 .

${ }^{18}$ Editorial: "La tercera derrota del PSOE", $A B C, 25$ de noviembre de 1985.

${ }^{19}$ GUTIÉRREZ, José Luis: "Mariñas: 'Fraga ha muerto como alternativa de gobierno en España", Diario 16, 26 de noviembre de 1985. "Resulta curioso cómo el CDS de Adolfo Suárez, entendido como elemento perturbador, no solamente ha sufrido su más escandalosa derrota al no conseguir ni siquiera un solo escaño, sino que ha impedido que Coalición Galega redondeara su resultado y obtuviera un resultado inimaginable", en GUTIÉRREZ, José Luis: "El 'caso Marinas' y la sorpresa de CG”, Diario 16, 26 de noviembre de 1985. Estas opiniones se agudizaron conforme se acercaba la campaña electoral de 1986: "que Suárez, si es que recupera la razón -lo dudo- y un mínimo de sentido de la responsabilidad histórica se una a Roca para salvar las libertades", Diario 16, 23 de mayo de 1986 en JIMÉNEZ LOSANTOS, Federico: Contra el felipismo, Madrid, Temas de Hoy, 1993, 173 y ss. "Suárez ha preferido lamerse las heridas de antaño, vivir el rencor del pasado y preservar su corralito caudillista. Sin ideas, sin estrategias, con los medios que le den para torpedear al PRD" en ÍD.: "Suárez o la mayoría absoluta", Diario 16, 09 de mayo de 1986.

${ }^{20}$ JIMÉNEZ LOSANTOS, Federico: "Fraga y el bebé "coaga", $A B C, 26$ de noviembre de 1985. La mención al tercermundismo fue constante desde el discurso reformista. El último día de la campaña de 1986, Roca "hizo referencia a lo difícil que sería encontrar a 'los amigos' del CDS en Europa, aunque inmediatamente sacó el nombre del dirigente palestino Yasser Arafat como político 'homologable' y en la línea del ex presidente del Gobierno", $A B C, 21$ de junio de 1986.

${ }^{21}$ Editorial: "La derrota de una victoria", El País, 25 de noviembre de 1985.
} 
el primer peldaño de un "reajuste de la derecha" merced a una futura unión de PDP-PL y el PRD y una vez copado el espacio de centro en perjuicio del $\mathrm{CDS}^{22}$.

En el CDS los malos resultados se achacaron a tres factores fundamentales. Como era habitual, se apeló a la escasez de recursos y en privado, se valoró negativamente la elección del candidato escogido para la presidencia de la Xunta ${ }^{23}$. En segundo lugar, se consideró perjudicado por la propia estructura social gallega basada en algunas zonas en redes clientelares y caciquiles y que a través de UCD habían recalado casi íntegramente en Coalición Galega. En la Galicia interior y rural su presencia se consideraba determinante en la orientación del voto: "Coalición Gallega, que se dice que es el socio de los reformistas en la región, quien conozca un poco la realidad y la estructura en la cual se sustenta, que fundamentalmente son los residuos caciquiles de la UCD y muy particularmente en Orense" ${ }^{\text {24 }}$. Coalición Galega -que en 1983 se había presentado bajo las siglas de Partido Galego, Coalición Galega y otras agrupaciones independientescontaba con cerca de mil concejales en la comunidad y sólo en Orense con 67 alcaldes $^{25}$, mientras el CDS tenía un total de dos alcaldes y 18 concejales en toda Galicia.

Tabla 23: Alcaldes y concejales del CDS en Galicia (1983-1987).

\begin{tabular}{|c|c|}
\hline Provincia & ${\text { Cargos municipales electos en } \mathbf{1 9 8 3}^{26}}^{{ }^{6}}$ \\
\hline La Coruña & 1 alcalde y 10 concejales \\
\hline Ourense & 1 alcalde y 6 concejales \\
\hline Lugo & - \\
\hline Pontevedra & 2 concejales \\
\hline
\end{tabular}

Elaboración propia a partir de AMINHAP.

Un dirigente centrista en junio de 1986 describía con detalle la importancia de la representación institucional de Coalición Galega en los comicios autonómicos:

\footnotetext{
${ }^{22}$ Una lectura realizada en el espacio de izquierda, SOLÉ TURÁ, J.: "Hacia un nuevo bipartidismo", El País, 14 de diciembre de 1985. Sobre las negociaciones a este respecto en la derecha española, véase GUINDAL, Mariano: El declive...

${ }^{23}$ El País, 26 de noviembre de 1985; editorial: "La derrota de una victoria", El País, 25 de noviembre de 1985.

${ }^{24}$ Palabras de Caso en una entrevista en $A B C, 01$ de febrero de 1985. La impresión de los suaristas ha sido corroborada por las publicaciones académicas: "el voto conservador en Galicia y la dimensión arcaica desde la perspectiva de la composición de su liderazgo y de sus mecanismos de captación de apoyo social en general y electoral en particular, UCD fue un partido todavía más 'arcaico', refugio de la mayor parte de la clase política tardofranquista" en VILAS NOGUEIRA, José: "Las elecciones autonómicas de Galicia 1981-1990”, Revista de Estudios Políticos, 75, enero-marzo 1992. Véase también, AGUILERA DE PRAT, Cesáreo R.: "Balance y transformaciones...".

${ }^{25}$ El País, 09 de agosto de 1985.

${ }^{26}$ El total de alcaldes y concejales durante el mandato -independientemente de si se hubieran dado de baja o de alta en el partido a lo largo del mismo-.
} 
Galicia es una región que tiene 32 mil núcleos de población. [...] Es decir, las decisiones de la administración doméstica, como el acceso de los caminos a los pueblos o a las aldeas, la luz, el teléfono, el agua, hace que los alcaldes y los concejales sean muy importantes, especialmente importantes en esta comunidad. [...] Mil concejales. Mil hombres repartiendo 100 papeletas cada uno, a lo largo del mes de campaña, donde solamente estos hombres saben, son 100 mil votos ${ }^{27}$.

El CDS era consciente de las particularidades de unas elecciones autonómicas como las gallegas, y de un calendario electoral que en los últimos dos años había sido claramente perjudicial para sus intereses en beneficio de los reformistas: elecciones autonómicas del País Vasco, Cataluña y Galicia. Por ello, la presión de lo que un líder centrista llamaba "el factor G[allego]" requería de una ulterior interpretación: "en el voto del emigrante nosotros triplicamos a Coalición Galega. Por eso el análisis que hicimos de las elecciones gallegas es que, nosotros, en Galicia, a nivel de elecciones [sic] autonómicas, estamos en torno al 3 [y] $1 / 2 \%-4 \%$, pero que a nivel de elecciones generales estamos a nivel del 9\%" ${ }^{28}$. Esta opinión había sido compartida medio año antes desde El País:

Quizá resulte excesiva la euforia de los reformistas de Roca, inclinados a abstraer los factores específicamente gallegos de esos resultados y a olvidar que los llamamientos centristas en otras regiones españolas no contarán con la ayuda de las redes de influencia local de Lugo y Orense. Por esa misma razón, el espectacular naufragio en las elecciones gallegas del CDS - defendido por un inverosímil candidato- no sepulta definitivamente las oportunidades, a escala estatal, de Adolfo Suárez ${ }^{29}$.

Finalmente, se había producido un incremento notable de votos, en relación a los comicios municipales -donde no se presentaron candidaturas en muchas localidades- y a las generales corroborando la tendencia ascendente, que según los sondeos, tenía el partido:

Tabla 24: Porcentaje de votos obtenidos en Galicia en los diferentes comicios.

\begin{tabular}{|l|l|}
\hline Año & Porcentaje \\
\hline 1982 (Generales) & $2,405 \%$ \\
\hline 1983 (Municipales) & $0,9875 \%$ \\
\hline 1985 (Autonómicas) & $3,28 \%$ \\
\hline
\end{tabular}

Elaboración propia a partir de bases de datos electorales.

Aunque dichas comparaciones no lograban obviar la realidad de unas cifras demoledoras ni el innegable éxito de la Operación Roca, a priori su competidor más directo, el CDS mantuvo su decisión de acudir en solitario a las Generales.

\footnotetext{
${ }^{27}$ Interview undertaken by Richard Gunther, in 1986 (june), AR.

28 Ibid.

${ }^{29}$ Editorial: "La resaca de Galicia”, El País, 01 de diciembre de 1985. Véase también: CONTRERAS, Lorenzo: "Tiempo de interpretaciones", $A B C, 27$ de noviembre 1985.
} 
Como hemos visto, los testimonios y también las opiniones de biógrafos, periodistas e historiadores parecen discrepar en un punto fundamental sobre las negociaciones entre Roca y Suárez: si a Suárez se le ofreció o no el liderazgo de la Operación Reformista tal y como dieron a entender tanto Roca como los dirigentes del PRD en la época- ${ }^{30}$.

García-León y Martínez Echevarría sostienen que la candidatura presidencial de Roca ya estaba decidida el día en el que se produjo la última y trascendental reunión entre Suárez, Florentino Pérez y el político convergente. Este encuentro se produjo el día de la proclamación de Roca como candidato - debemos situarlo en la primavera de $1986^{31}$ - y al CDS le ofrecieron la cabeza de lista por Madrid (Suárez) y Ávila (Rodríguez Sahagún) en un momento en el que las hipótesis electorales barajadas por los suaristas contemplaban la consecución de un grupo parlamentario, aunque se había producido un notable descenso de las expectativas ${ }^{32}$. Además, la negociación tenía otro hándicap para el CDS. Pérez había logrado obtener de Rafael Termes el compromiso de que el PRD contaba con el apoyo de la AEB y de que no se prestaría "dinero al CDS" en solitario ${ }^{33}$. La negativa de Suárez a aceptar las condiciones fue tajante y ni siquiera en este nuevo escenario hubo algún de tipo planteamiento favorable a la coalición con el PRD dentro de la ejecutiva suarista ${ }^{34}$.

El espacio político de centro-derecha siguió siendo objeto de intensos debates durante aquellas semanas, en un último intento, promocionado por la prensa conservadora, para construir algún tipo de coalición electoral que evitase la dispersión

\footnotetext{
${ }^{30}$ Desde el punto de vista de Fuentes Aragonés el principal obstáculo fueron las "duras exigencias de Suarez en el reparto de los puestos de las listas", en FUENTES ARAGONÉS, Juan Francisco: Adolfo Suárez..., p. 476. Sin embargo, para Gregorio Morán, quien sitúa el último intento de atracción de Suárez en una reunión en la sede del Banco Popular entre Termes, Roca y el propio Suárez en marzo o abril de 1986, lo que se le ofrecía a Suárez - cabeza de lista por Madrid y a Rodríguez Sahagún, por Ávila- era lo que ya tenía, y además, debía desmantelar el CDS en Cataluña, MORÁN, Gregorio: Historia de una..., p. 574. Para García Abad la Operación Roca buscaba básicamente "absorber" al CDS, GARCÍA ABAD, José: Una tragedia ..., p. 216.

31 "Roca se presentará como candidato a la presidencia del Gobierno [proclamación oficial prevista el 11 de mayo]", El País, 27 de abril de 1986.

${ }^{32}$ En septiembre de 1985, las encuestas de intención de voto directo del CIS otorgaban un 5,4\% al CDS, el mayor porcentaje desde el inicio de la serie (marzo de 1983). A raíz de las elecciones gallegas y hasta mayo de 1986, las previsiones habían vuelto a descender y otorgaban a los centristas entre un 3 y $4 \%$, véase, "Evolución de la intención de voto y otros indicadores políticos, 1983-1986", REIS, 35, 1986, p. 276.

${ }^{33}$ GARCÍA-LEÓN, Carlos y MARTÍNEZ ECHEVARRÍA, Borja: Antonio..., p. 147 y ss.

${ }^{34}$ Entrevistas con J. R. Caso, L. Morso, A. Cádiz entre 2014 y 2015. Por el contrario, según Luis Herrero en una reunión del Comité Nacional del CDS celebrada en marzo de 1986 la mayor parte de la directiva salvo Caso y Chus Viana - "que guardó silencio"- se mostró favorable a la forja de una coalición con el PRD, postura ante la que Suárez amenazó con abandonar la presidencia del partido "para no ser un obstáculo $[\ldots]$ yo no puedo realizar algo con lo que no estoy en absoluto de acuerdo", HERRERO, Luis: Los que le llamábamos..., p. 249.
} 
del voto. Como hemos visto el centro-derecha era un concepto amplio y ambiguo, en relación al cual podían figurar partidos políticos como AP, PDP, PL, PRD, CDS y otros grupos de carácter nacionalista o regionalista, asociaciones profesionales y de electores como la Plataforma Independiente de Rafael Pérez Escolar, instituciones o fundaciones de investigación como el Centro de Estudios Comunitarios o la CEPA y un fantasma político de cuerpo todavía insepulto como era la UCD.

En aquella ocasión, era el triunfo del centro-derecha en Francia el principal acicate y objeto de reflexión ${ }^{35}$. Las opciones eran múltiples, siempre y cuando fueran capaces de hacer frente al socialismo y si no vencer, al menos reequilibrar el arco parlamentario. Las principales divergencias entre las diferentes propuestas radicaban en el liderazgo de las fuerzas políticas conservadoras e iban desde la oposición bipolar liderada por Fraga a la exigencia de fórmulas más flexibles y plurales; en definitiva, oscilaban entre dos interpretaciones en función de si la iniciativa debía partir desde la derecha ${ }^{36}$ o el centroderecha $^{37}$. En cualquier caso, gravitaba la idea de una necesaria colaboración. Una invitación que, sin referencias concretas, mantenía $A B C$ en su edición del 17 de marzo y en cuya portada aparecían reflejados Jacques Chirac, Raymond Barre y Giscard D'Estaing: "la respuesta adecuada [al socialismo]: la comparecencia conjunta en las urnas del centro y de la derecha",38.

\footnotetext{
${ }^{35}$ Para Rodríguez Sahagún únicamente eran testimonio de los errores cometidos por el socialismo y una posibilidad para poner fin a la bipolarización política. En ningún caso, hacía referencia a pactos o posibles en el conjunto de la posición, en RODRÍGUEZ SAHAGÚN, Agustín: "A propósito de las elecciones francesas", $A B C, 28$ de marzo de 1986.

36 "El dilema decisivo no es preguntarse si es más conveniente la unión del centro o la unión de la derecha, sino articular un centro-derecha que conforme la nueva mayoría del futuro Parlamento [...] Al lado de la instancia integradora configurada por Coalición Popular plantan sus tiendas [los vecinos] sin querer formar campamento el PNV y CiU, el PRD y el CDS. [...] Esta situación es antinatural, insatisfactoria para los intereses reales y profundos del centroderecha y sumamente beneficiosa para el socialismo gobernante. Mas no es definitiva. Algún día estos partidos asumirán sus propias responsabilidades, abandonarán su ambigüedad y se decidirán a elegir aliados", en ORTI BORDÁS, Miguel: "La Alternativa amplia", El País, 15 de abril de 1986.

${ }^{37}$ El miembro del CEC, J. A. Ortega Díaz-Ambrona, reflexionaba: "las elecciones generales celebradas en Francia el pasado domingo día 16 de marzo han desalojado al Partido Socialista del Gobierno y han instalado, en su lugar, a la hasta ahora oposición de centro-derecha". Pero, advertía que para aplicar el modelo francés debían cambiar muchas cosas: la oposición no debía pivotar en torno a un único líder, no se debía primar la bipolarización, etc. Cabían dos fórmulas en España: o la unión del centro y parte de la derecha (como sucedió con UCD) o la unión de la derecha y parte del centro (como sucedió con CP)" en ORTEGA DÍAZ-AMBRONA, José Antonio: "El dilema decisivo: ¿Unión del centro o de la derecha?", $A B C, 25$ de marzo de 1985.

${ }^{38}$ Portada y editorial: "Francia, por el cambio", $A B C, 17$ de marzo de 1986
} 
El argumento decisivo era la caracterización de todos estos grupos políticos como partidos afines o vecinos ${ }^{39}$. Con motivo del adelanto de las elecciones, $A B C$, en su editorial, volvía a indicar la necesidad de establecer algún tipo de coordinación, que podía pasar ante la inminencia de la cita electoral, por la búsqueda de soluciones provisionales: "Este cambio no será posible, como tantas veces hemos repetido, sin la coordinación de las fuerzas políticas del centro y de la derecha: coordinación que no significa necesariamente integración"

En esta línea, circuló un estudio sobre las posibles alianzas electorales que de cara al Senado -donde el PSOE era más vulnerable- podía llevar a cabo el centro-derecha. En la elaboración de este análisis se identificaban tres categorías principales: senadores del PSOE, senadores del "centro más derecha" y "posible pérdida de senadores PSOE". Concluía:

Una operación así, puesta en práctica con realismo y generosidad, unilateralmente, sin necesidad de pactos, por Coalición Popular, CDS y PRD, por increíble que pueda a primera vista parecer, conseguiría con certeza matemática y como logro mínimo, que las tres opciones aumentasen el número de senadores que, en el mejor de sus sueños, esperan alcanzar $^{41}$.

Eran pocos, no obstante, los que abiertamente -después de las negativas de Suárez de participar siquiera en la Operación Roca- mencionaban al CDS o al ex presidente y menos aún quienes, como Martín Villa, todavía afirmaban que el abulense "bien podría ser el [líder] del centro derecha"42. Desde 1985, en la línea editorial de $A B C$ se

\footnotetext{
${ }^{39}$ En el I Congreso Nacional Independiente celebrado los días 3 y 4 de mayo de 1986, Rafael Pérez Escolar también hizo un llamamiento a la unión del centro-derecha: "Quienes han asumido por vocación la tarea de representarnos -dijo- no acaban de perfilar estrategias comunes entre afines y no han renunciado definitivamente a los personalismos", $A B C, 05$ de mayo de 1985. "Sé que le molestará que le llame afín a nosotros, pero yo no polemizo con afines" señaló Fraga en Ávila en la campaña electoral de 1986 en referencia a Suárez, en JÁUREGUI, Fernando: "Fraga disputa a Suárez la atención de los electores de Ávila, 'feudo' del ex presidente", El País, 20 de junio de 1986. "Sutil recomendación: el cabeza de lista de CP por Valencia, Ángel Sanchís Perales, ha hecho un singular llamamiento a varios partidos políticos. Les ha pedido que retiren sus candidaturas antes del día 22 , ya que 'tal y como están las previsiones de voto y dado que tanto el CDS, el PRD y Unión Valenciana aspiran a un modelo de sociedad distinto al socialista y básicamente idéntico al que pretendemos en $\mathrm{CP}$, encarezco a todos los partidos afines a que retiren sus listas y pidan el voto para CP"” en CASTELLANOS, Begoña: "Sutil recomendación", $Y a, 19$ de junio de 1986, Archivo Linz.

${ }^{40}$ Editorial: "Ante el 22 de junio", $A B C, 22$ de abril de 1986.

${ }^{41}$ SEGRELLES, Francisco: "Una victoria posible", 26 de mayo de 1986, p. 3, Caja 12, 45-507, $A G U N / J L A$ y $A B C, 27$ de mayo de 1986. Un ejercicio acorde con el lenguaje empleado habitualmente en los medios conservadores: "el centro derecha podría obtener tres escaños, incluyendo en el centro al CDS", "el centro-derecha podría obtener previo acuerdo entre CP y PRD", "si hay un acuerdo", etc., en "Previsiones ante el 22-J", $A B C, 01$ de junio de 1986.

${ }^{42}$ El País, 15 de marzo de 1985; "Martín Villa partidario de que el CDS forme parte de una coalición de centro-derecha", $A B C, 14$ de marzo de 1985.
} 
consideraba su presencia en una convergencia de este tipo como muy improbable ${ }^{43}$ e incluso, la había omitido en los últimos editoriales ${ }^{44}$. El CDS estaba, en palabras de L. Contreras, "dejado de la mano de Dios por su derecha y en peligro cierto de llegar a ser un instrumento del PSOE"45. Aunque no se produjo ni en el espacio de centro, ni de derecha ninguna nueva política de pactos, el recorrido sobre su presencia en la prensa es bastante significativo sobre el pulso político de aquellos días y las líneas de pensamiento dominantes ${ }^{46}$.

\section{2. El referéndum sobre la OTAN}

En marzo de 1986 tuvo lugar el referéndum sobre la permanencia española en la OTAN, un episodio central de la joven democracia española y sobre el que aún hoy en día se siguen vertiendo ríos de tinta.

El PSOE, triunfador en las elecciones de octubre de 1982, lanzó su propuesta de llevar a cabo un referéndum sobre la permanencia o salida del organismo defensivo tal y como Felipe González, todavía en la oposición, había anunciado en la gran convocatoria por la paz, el desarme y la libertad celebrada en la Ciudad Universitaria de Madrid en noviembre de 1981. Gracias a las campañas promovidas desde multitud de organizaciones, sindicatos y partidos de izquierdas, la OTAN se había convertido en un importante centro de atención para la opinión pública y aunque los lemas de campaña, "OTAN, de entrada no" y "Por la paz, la libertad y el desarme" esquivaban un compromiso tajante, a esas alturas el socialismo español era claramente favorable a no entrar en la Alianza Atlántica.

La formulación del llamado Decálogo para la Paz y la Seguridad, en el Debate sobre el Estado de la Nación de 1984, consumó sin embargo un giro radical en los planteamientos geopolíticos del socialismo español, no exento de tensiones internas. Desde este momento, el PSOE se mostraba pública y abiertamente partidario de la

\footnotetext{
43 Portada: "Las elecciones podrían adelantarse a noviembre próximo", $A B C, 10$ de marzo de 1985. Portada: "Entiéndanse ustedes", $A B C, 30$ de abril de 1985.

44 Editorial: "Ante el 22 de junio", $A B C, 22$ de abril de 1986. Portada, acompañado del editorial: "Necesidad de coordinación. Las cifras son tozudas", $A B C, 01$ de junio de 1986.

${ }^{45}$ CONTRERAS, Lorenzo: "La "movida" y algo más", $A B C$, 03 de abril 1986.

46 SANTAMARÍA, Julián: "Las derechas y la mayoría", El País, 14 de junio de 1986.
} 
permanencia de España en la Organización Atlántica ${ }^{47}$. El referéndum prometido y demorado en el tiempo, pasaba a convertirse en una auténtica trampa para el gobierno de Felipe González; ya no era para "salir" sino para "quedarse" y en un momento, en el que precisamente gracias a las campañas llevadas a cabo durante los gobiernos de UCD se había conseguido posicionar en contra a un porcentaje nada desdeñable de la opinión pública $^{48}$.

La adhesión a la OTAN, la celebración del referéndum y en definitiva, la fijación de los objetivos fundamentales de la política exterior española, -con especial atención a las relaciones con EE.UU.-, fueron las claves de un debate no siempre bien delimitado que envolvió a la sociedad española a lo largo de la II Legislatura constitucional. En el caso del CDS, su actitud y sus posicionamientos se vieron condicionados por cuatro factores, en torno a los cuales, vamos a intentar articular nuestra argumentación: el cambio de postura socialista, la división interna, la construcción de un discurso progresista y la figura de Adolfo Suárez.

En su I Congreso (octubre, 1982) el CDS escamoteaba un debate abierto sobre la OTAN, dejando entrever la irreversibilidad del proceso de adhesión y la inexistencia de unanimidad a este respecto. Se exigía únicamente la renegociación de las condiciones de adhesión y se criticaba la forma en la que se había producido la integración, pero al margen de alguna declaración aislada, no se mencionaba la posibilidad de un referéndum ${ }^{49}$.

Sólo después de la fase fundacional y cuando era patente que la promesa del referéndum se había convertido en un serio problema para el Gobierno socialista ${ }^{50}$, los dirigentes suaristas apoyaron la celebración de una consulta ciudadana, postura asumida

\footnotetext{
${ }^{47}$ Asimismo, el PSOE se mostraba partidario de la integración en la Unión Europea Occidental y en el Tratado de No Proliferación Nuclear, véase, PUELL DE LA VILLA, Fernando: "La política de seguridad...", pp. 43-64.

48 Según una encuesta de El País, el 52\% de los españoles estaba en contra frente a un 18,1\% a favor, 20 de octubre de 1981, en ORDÁS, Carlos Ángel: “OTAN de entrada No. El PSOE y el uso político de la integración española en el Pacto Atlántico o cómo hacer de la necesidad virtud (1980-1986)", en NAVAJAS ZUBELDIA, Carlos e ITURRIAGA BARCO, Diego (eds.): España en democracia. Actas del IV Congreso Internacional de Historia de Nuestro Tiempo, Logroño, ULR, 2014, pp. 293-305. Disponible en: https://dialnet.unirioja.es/descarga/articulo/4847684.pdf Fecha de consulta: 14 de marzo de 2015.

49 "Suárez no rechazaría un referéndum sobre la OTAN", El Noticiero Universal, 14 de septiembre de 1982.

50 Desde 1983, se habían producido declaraciones contradictorias de miembros del Gobierno sobre la presencia de España en la Alianza Atlántica, mientras se demoraba sine die la celebración del referéndum, véase, MARTÍNEZ SÁNCHEZ, Juan Antonio: "El referéndum sobre la permanencia de España en la OTAN", UNISCI Discussion papers, 26, mayo 2011. Disponible en: https://revistas.ucm.es /index.php/UNIS/article/viewFile/37825 /36602 Fecha de consulta: 13 de noviembre de 2015.
} 
oficialmente desde el verano de 1984 y que llevó al CDS a participar en la Mesa ProReferéndum $^{51}$. Sobre la orientación del voto, en enero de 1985, la dirección del partido se mostró partidaria de dar "libertad de voto" entre sus militantes - es decir, no orientar su decisión en favor de ninguna de las dos opciones-, al tiempo que se anunciaba una futura concreción de la misma en el marco del II Congreso, el cual se celebró finalmente después de la convocatoria del referéndum:

Si el referéndum se celebrase antes del Congreso del Partido, CDS exigirá información amplia y veraz sobre los pros y los contras, las ventajas y los inconvenientes. El Comité Nacional decidirá si recomienda o no un determinado voto a los militantes del Partido ${ }^{52}$.

Para los líderes centristas, la adhesión, que debía haber contado con un amplio consenso, se había producido por la "puerta de atrás", con un gobierno de mayoría relativa, "poca legitimidad" y en un contexto demasiado excepcional -dimisión, 23-F-. Aun conscientes de las dificultades que podía generar la salida de la OTAN debía buscarse una nueva legitimidad que "enterrase" definitivamente la polémica y advertía que la credibilidad de las instituciones del Estado estaba en riesgo si sus legítimos representantes -el Gobierno del PSOE-, incumplían una "promesa política" que dependía únicamente "de la voluntad [...] del gobierno" "53. Para Raúl Morodo, la "radicalización ideológica" del tema OTAN era consecuencia directa del "error" político de $\mathrm{UCD}^{54}$.

La mejor herramienta para zanjar esta polémica era la celebración de un debate sobre política exterior y un referéndum que, como afirmaba Suárez, debía cumplir las siguientes condiciones: una pregunta clara y un resultado vinculante ${ }^{55}$. Para el Secretario General del CDS, José Ramón Caso, la participación en el referéndum se convirtió en una posición perfectamente asumida por todo el partido ${ }^{56}$.

La principal contradicción que encerraba la postura del CDS radicaba en que, ahora que se había conseguido un amplio consenso sobre la permanencia de España en la

\footnotetext{
${ }^{51}$ Fernando Castedo fue uno de los firmantes en su constitución, $A B C, 17$ de julio de 1984. La primera vez que Suárez aludió al referéndum en un Debate sobre el Estado de la Nación fue precisamente en 1984: "sólo después, como usted señalaba en su propuesta, del consenso posible entre las fuerzas políticas y un debate público que, efectivamente, ha de tener lugar aquí, en el Parlamento, es posible proceder a la consulta al pueblo español y decidir en consecuencia”, DSCD, Sesión Plenaria, 27 de octubre de 1984, $\mathrm{n}^{\circ}$ 159 , p. 7155.

52 "Por qué pedimos el referéndum", $O I C D S, 1$, junio 1985.

${ }^{53}$ Interview undertaken by Richard Gunther, in 1986 (june), AR.

${ }^{54}$ MÁRQUEZ REVIRIEGO, Víctor: Cien españoles y la OTAN, Barcelona, Plaza \& Janés, 1985, pp. 6772.

55 JÁUREGUI, Fernando: "Yo sólo me aliaría políticamente con Felipe González en condiciones de anormalidad", El País, 17 de noviembre de 1985.

${ }^{56}$ Entrevista con José Ramón Caso, 19 de noviembre de 2014.
} 
OTAN entre las principales fuerzas políticas (PSOE-CP) -demanda habitual del CDS desde su fundación-, no lo había sobre la celebración del referéndum. El propio Suárez, en el Debate sobre "la Política de Paz y Seguridad" señalaba:

Creo que hoy existe entre las fuerzas políticas parlamentarias un consenso en torno a la permanencia de España en la Alianza Atlántica, aunque no en torno a la fórmula de integración y, por supuesto, en torno a la celebración del referéndum. El consenso a favor de la permanencia, a mi juicio, es ya un valioso activo que, al menos, obliga a reflexionar seriamente a quienes siempre hemos defendido la necesidad de esos amplios acuerdos de base para consolidar la vida política española, aún a costa de la renuncia a posiciones de Partido. No sé si ese consenso parlamentario está o no acompañado ahora mismo de un consenso popular ${ }^{57}$.

El CDS había logrado acentuar con habilidad y prudencia el cambio de parecer del PSOE en esta materia: "nuestra postura respecto a la OTAN fue intencionadamente

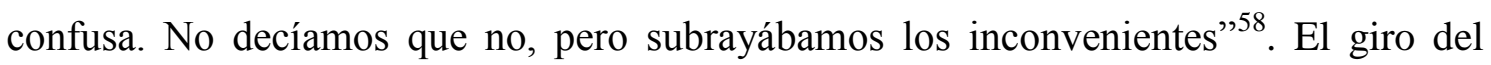
PSOE, desconcertante para parte del electorado socialista, se había visto correspondido con la actitud de la $\mathrm{CP}$, que partidaria de la integración plena en la estructura atlántica y contraria a la celebración del referéndum, defendió una postura aún más equívoca en favor de la abstención. El objetivo era abocar al Gobierno a la convocatoria de elecciones anticipadas ${ }^{59}$.

Si entre los conservadores españoles había un amplio consenso sobre la participación de España en la OTAN, en el caso del CDS, la permanencia era objeto de división entre los dirigentes, la militancia y el electorado. Incluso, la propia dirección del partido desconocía, en un principio, la inclinación mayoritaria. En el boletín nacional de junio de 1985 se anexaba un cuestionario político - para enviar a la dirección de organización del partido- que incluía cuatro preguntas sobre política exterior, de las que, a su vez, dos eran referentes a la OTAN:

24. ¿Cómo se considera usted respecto a la salida de España de la OTAN?

25. A continuación se expresan unas afirmaciones referidas a nuestra permanencia en la OTAN. Indique si está de acuerdo o en desacuerdo con cada una de ellas: aumenta el riesgo de guerra entre los dos bloques, hace más probable un ataque nuclear a España si

\footnotetext{
${ }^{57}$ DSCD, Sesión Plenaria, 05 de febrero de 1986, no 267, p. 12024.

${ }^{58}$ Entrevista (escrita) con Tomás Martín Tamayo, febrero de 2014. En palabras de Rodríguez Sahagún, el CDS era "'la única opción política que puede capitalizar el desgaste del Gobierno socialista' tras el referéndum”, EP: “El CDS en Andalucía”, El País, 23 de marzo de 1986.

${ }^{59} \mathrm{CP}$ : ¿Qué hago yo con la OTAN? Un decálogo para no votar, CP, 1986. Como señala Powell, fue: "el episodio que más dañó el liderazgo de Fraga y la credibilidad de AP”, POWELL, Charles T.: España..., p. 420 .
} 
hay guerra, ayuda a consolidar la democracia en España y afianza el papel internacional de España ${ }^{60}$.

Las respuestas de la primera pregunta arrojaron un saldo favorable a la salida de España de la OTAN -tabla 25-, aunque con una mayoría exigua y reflejando una considerable polarización de las opiniones. Según recuerdan algunos líderes provinciales, era perceptible cierta inclinación hacia el "no" o la abstención entre la militancia $^{61}$ :

Tabla 25: Posicionamiento de la militancia centrista sobre la permanencia o salida de España de la OTAN.

\begin{tabular}{|l|l|}
\hline Posición sobre la salida de España de la OTAN & Porcentaje \\
\hline Muy favorable & 18,4 \\
\hline Bastante a favor & 37,1 \\
\hline Bastante en contra & 31,5 \\
\hline Muy en contra & 8,2 \\
\hline Otros & 4,8 \\
\hline
\end{tabular}

Elaboración propia a partir de $O I C D S, 1$, marzo 1986.

José Antonio Pérez González, militante del CDS en Madrid y defensor del "no" en el referéndum, recuerda cómo se ofreció a realizar algún tipo de actividad sobre la OTAN para el partido. Finalmente se concretó un acto en la sede central en el que participaron Ignacio Camuñas argumentando en favor del "sí” y el propio Pérez González en defensa de la opción contraria, lo que no dejaba de ser una situación insólita ante una decisión de este tipo.

En Fernando Castedo o el recién incorporado Raúl Morodo, no hay una toma de postura explícita en ningún sentido y aunque es perceptible cierto desencanto hacia el papel de la OTAN en el contexto final de la Guerra Fría, sus intervenciones o artículos solían concluir entre interrogantes, agravados por lo que consideraban la falta de definición de una política exterior nacional:

La OTAN, en efecto, no es un fin en sí mismo y sin embargo nos lo han presentado como si lo fuera. ¿Cuál es el diseño de la política exterior que se nos ofrece? ¿Cuáles son los objetivos de nuestra política exterior para el futuro? La respuesta a estas cuestiones permitiría evaluar con nitidez y prescindiendo de otras consideraciones emotivas y oscurecedoras [sic] si la OTAN sirve o no a España en la búsqueda de estos objetivos; si

\footnotetext{
${ }^{60}$ OICDS, 1, junio 1985. Por parte del CDS participaron en la Mesa Nacional Pro-Referéndum Fernando Castedo y Alfonso Íñiguez. Del mismo modo, entre las personalidades e intelectuales que firmaron un documento a favor de la convocatoria de un referéndum vinculante y en términos absolutamente claros estaban Jiménez de Parga o el también miembro del CDS, Eduardo Punset, El País, 06 de agosto de 1986. El propio Rodríguez Sahagún fue uno de los encargados de recoger en el Congreso los más de 200.000 telegramas de la Coordinadora de Comisiones por la Paz y la Libertad, El País, 04 de febrero de 1986.

${ }^{61}$ Entrevistas con Antonio Garrosa, 31 de julio de 2014 y Gerardo Muñoz, 09 de mayo de 2015.
} 
la OTAN constituye o no un instrumento adecuado para el fin que se pretende. La falta de definición de éste hace que aquella pregunta-resumen sea de difícil contestación ${ }^{62}$.

Raúl Morodo, en una serie de entrevistas realizadas por Víctor Márquez Reviriego durante el año 1985, valoraba la opción de la OTAN desde el siguiente punto de vista. La seguridad era un complemento para el desarrollo de la libertad y de la democracia y ésta había sido la doctrina en los inicios del tratado defensivo, que a cambio, para el autor, se había comprometido con la reconstrucción económica europea (Plan Marhsall). Sin embargo, ahora, en el futuro de la OTAN se atisbaban posibles transformaciones:

El peligro está en que tal concepción [...] dé paso a una militarización del pensamiento [...] en otras palabras, que la vieja OTAN regionalizada se transforme, como proponen algunos sectores conservadores americanos, en un dispositivo de planetarización y hegemonismo ${ }^{63}$.

Otros líderes, se mostraban abiertamente favorables a la permanencia. Por ejemplo, Ignacio Camuñas defendía esta postura, precisamente, recurriendo a su pasado en UCD -obsérvese, el contraste con la perspectiva de Suárez-:

Desde el primer momento, esto es, antes del inicio del proceso democrático en nuestro país, y después, como Presidente de la Comisión de Asuntos Exteriores del Congreso [...] he sido siempre partidario de la plena incorporación de nuestro país a las estructuras del mundo occidental. Consejo de Europa, Mercado Común y Alianza Atlántica ${ }^{64}$.

Como líder del PAL se había mostrado más beligerante contra el referéndum: “[al pueblo] lo único que se le ha dicho sobre la OTAN son dos mentiras de gran calibre: en primer lugar que la OTAN es igual a bomba atómica y además que es un pacto de agresión"

De otra parte, el CDS mantuvo siempre un tono muy crítico con la política exterior de EE.UU., cuya raíz, se sumergía tanto en la retórica antiamericana de la Dictadura como en la filiación progresista de parte de los militantes ${ }^{66}$. Esta postura, debido al

\footnotetext{
62 "La ceremonia de la confusión”, $O I C D S, 1$, marzo 1986. Mayor Zaragoza, más ambiguo, abogaba por "una política pacificadora" que "no pacifista", El País, 06 de marzo de 1986.

${ }^{63}$ MÁRQUEZ REVIRIEGO, V.: Cien ... p. 158.

${ }^{64}$ CAMUNANA, I.: "Intereses partidistas", OICDS, 1, marzo 1986. El ex ministro de Hacienda y ocasional articulista en El País, Jaime García Añoveros, en la órbita del CDS, defendía la integración en la OTAN como superación del Tratado Bilateral, vacuna contra tentaciones totalitarias y en definitiva consecuencia inexorable de la situación geográfica de España, país para el que no podría costear una "neutralidad armada", MÁRQUEZ REVIRIEGO, Víctor: Cien..., pp. 87-91 y GARCÍA AÑOVEROS, Jaime: "Por qué voté el ingreso de España en la OTAN y otras cosas más (I, II y III)”, El País, 03, 04 y 05 de diciembre de 1984.

${ }^{65}$ Tiempo de Acción Liberal (Órgano de Información Liberal), 1, febrero 1985.

${ }^{66}$ Un excepcional testigo de esta época, el periodista, J. L. Gutiérrez escribía: "Las críticas no vienen sólo de la izquierda. Una fuerte corriente de antinorteamericanismo, sentimientos que han llegado más allá de la guerra española-americana de 1898, alcanza a la sociedad española, tanto a derechas como a izquierdas. La desaprobación sobre el ataque norteamericano a Libia en abril fue grande en la
} 
papel hegemónico de EE.UU. en el seno de la OTAN, no era obviada en los análisis centristas sobre la organización atlántica. El documento que realizó la Dirección de Organización con el fin de clarificar la postura del partido en este ámbito contaba entre sus conclusiones con la siguiente reflexión:

No aceptamos que países que constituyen la columna vertebral de la OTAN vulneren sistemáticamente los valores que defiende Occidente en áreas extraordinariamente sensibles a nuestra historia como son Centroamérica y el norte de África.

El CDS condenó la intervención del gobierno de Ronald Reagan en Granada, Nicaragua y Libia, y se llevó a cabo una lectura general bastante negativa de la política de bloques: "creemos que se está creando una dinámica peligrosa [tras la invasión de Granada] de incremento de la tensión que parece ir dirigida a demostrar la existencia de una zona de influencia americana en la que los EE.UU. se sienten legitimados para utilizar la fuerza de modo similar a como lo hace la U.R.S.S. en su entorno"67 ${ }^{\text {. De este }}$ modo, la nueva posición del Gobierno socialista se convertía en una oportunidad excepcional para competir electoralmente en el espacio de centro-izquierda sin forzar un discurso que era perfectamente asumido por los cuadros centristas y muy singularmente por Adolfo Suárez.

En las elecciones gallegas de noviembre de 1985 el mensaje sobre la OTAN había sido de no participación en la campaña del referéndum -ni a favor, ni en contra- y algunas declaraciones que podían leerse en ambas direcciones: "no necesariamente ha de primar una política de seguridad en detrimento de una de libertad"68.

En cierto modo, la postura del CDS tenía una estrecha relación con la dimensión política de Adolfo Suárez a mediados de los ochenta. Por un lado, en la mayor parte de los medios seguía apareciendo como quién había obstaculizado y pospuesto la adhesión a la OTAN en beneficio de planteamientos "tercermundistas" y neutralistas. Por otra parte, el papel de mediador que estaba llevando a cabo en los procesos transicionales

conservadora oposición, y en el anterior popular y centrista presidente de Gobierno Adolfo Suárez, que expresó su 'más enérgica condena al ataque'. En comparación el comentario del señor González de que 'no estaba de acuerdo con el método empleado' fue relativamente suave”, GUTIÉRREZ, José Luis: Veinte años no es nada. Textos y pretextos de dos décadas de democracia (1977-1997), Madrid, Espasa, 1997, p. 250.

${ }^{67}$ Entrevista s. t. a Adolfo Suárez, s. f., (1983), Carpeta 2, AGP. "El CDS, que preside Adolfo Suárez, hizo público ayer un comunicado en el que condena el embargo contra Nicaragua decretado por la Administración norteamericana, porque, a su juicio, 'dificulta las condiciones para lograr el desarrollo de los acuerdos de Contadora"”, $A B C, 07$ de mayo de 1985. "Agustín Rodríguez Sahagún, diputado del CDS, criticó con extrema dureza al Gobierno norteamericano por su actitud respecto a Europa. 'Reagan menosprecia a los aliados tratándolos como siervos', dijo", El País, 16 de abril de 1986.

${ }^{68}$ El País, 22 de noviembre de 1985. 
latinoamericanos - donde contaba con un amplio respaldo de las fuerzas democráticas y de la sociedad civil a derecha e izquierda- contrastaba con el intervencionismo norteamericano en esta área geopolítica. En la ponencia sobre Seguridad y Defensa del I Congreso del partido se incluía:

Debe hacerse todo cuanto esté en nuestras manos para afianzar la victoria de la democracia en América. Nuestra experiencia pasada del $23 \mathrm{~F}$, nos ha hecho ver hasta qué punto las fuerzas de la reacción pueden alterar la voluntad de los pueblos que han podido optar por vivir en libertad ${ }^{69}$.

De forma paralela, la convocatoria del referéndum ponía a prueba el papel institucional que Adolfo Suárez jugaba en calidad de ex presidente. Por razones de Estado, ¿debía respaldar al Gobierno en una decisión de este calibre? El caso de Adolfo Suárez probablemente fuera el mejor ejemplo de la división interna del CDS, constituyendo, como comentaba Raúl Morodo, un debate entre la razón (de estado) y el sentimiento $^{70}$.

Si seguimos los comentarios de numerosos columnistas políticos en esta época podemos entrever dos fases a este respecto. Desde 1982, Suárez sostuvo varias conversaciones con González sobre política exterior en las que se compartieron análisis, consejos y recomendaciones. En un segundo momento, y a medida que se acercaba la fecha del referéndum con unos resultados cada vez más reñidos, Felipe González le pidió directamente ayuda, -en forma de declaraciones públicas-, a Adolfo Suárez ${ }^{71}$. En palabras de Suárez a Pilar Urbano en una entrevista concedida con posterioridad al referéndum: "en una conversación [...] en Moncloa, [Felipe González] me sugirió la conveniencia de que yo manifestara en público una posición favorable a la permanencia de España" a lo que se negó en base a dos razones: en su partido (el Comité Nacional) se había decidido dar libertad de voto y una declaración afirmativa implicaba "que nadie hubiera dejado de sospechar que yo era un sicario del Partido Socialista"72.

La polémica se había avivado al filtrarse una visita de funcionarios de Hacienda al ex presidente $^{73}$, admitida por el propio perjudicado, y que algunos medios consideraron

\footnotetext{
${ }^{69}$ OICDS, 1, marzo 1986.

${ }^{70}$ MORODO, Raúl: "El imperio, las dictaduras domésticas y la OTAN", El País, 06 de marzo de 1986

${ }^{71}$ CONTRERAS, Lorenzo: "Llamar a cualquier puerta", $A B C$, 05 de marzo de 1986.

${ }^{72}$ Declaraciones de Adolfo Suárez a Pilar Urbano, s. f., Carpeta 3, AGP.

${ }^{73}$ En la cadena SER el día 16 de mayo de 1986 durante el programa "Pido la Palabra", dirigido por Iñaki Gabilondo.
} 
una auténtica represalia gubernamental ${ }^{74}$. Siguiendo el testimonio de Suárez "fue una tramitación a mi juicio normal" [...] "no puedo poner en relación esa entrevista del presidente, mi negativa a manifestarme a favor del sí, con el requerimiento, qué no fue una inspección porque al final no se hizo una inspección, el requerimiento para [tachado] que aportara una serie de documentaciones"

José Ramón Caso ha indicado como la posición en torno a la OTAN del CDS "libertad de voto"- y la negativa de Suárez a apoyar públicamente la opción del "sí" molestó profundamente "al poder constituido, no sólo el político"; en definitiva, aquellos sectores que consideraban inconveniente y peligrosa la realización del referéndum ${ }^{76}$. Una opinión que apunta a presiones y poderes fácticos tangencialmente citados por Rodríguez Sahagún en su defensa del referéndum: "yo entiendo que el cumplimiento de ese compromiso depende, única y exclusivamente -no se podría aceptar otras cosa, porque entrañaría una limitación de nuestra soberanía- de la voluntad del Gobierno y del Grupo mayoritario que le apoya"77.

Las relaciones entre Felipe González y Adolfo Suárez sufrieron un fuerte revés a partir del referéndum de la OTAN, cuyo síntoma más visible, al parecer, fue la felicitación de Suárez rechazada por el líder socialista, devolviendo a ambos una situación sólo comparable a la vivida en el contexto final de la presidencia de Suárez ${ }^{78}$. De acuerdo con Daniel de Fernando, líder del partido en Castilla y León y la provincia de Ávila, Suárez le comentó en cierta ocasión que "si hubiera dicho que no y hubiera hecho campaña -y lo sabe Felipe-, que era lo que le apetecía: hubiera salido el no”. Al parecer, Suárez se mantuvo al margen debido al perjuicio que hubiera supuesto para los intereses de España en el ámbito internacional la salida de España de la OTAN, optando por apelar en las filas de su partido a la "libertad de voto"79. Laura Morso recuerda que existió cierta división en el Comité Nacional respecto de la decisión a tomar y que

\footnotetext{
${ }^{74}$ Provocó la reacción de algunos medios como $A B C$ : "Es estremecedor lo declarado por Adolfo Suárez sobre la represalia sufrida [inspección de hacienda] por negarse a colaborar con el Gobierno en la campaña del referéndum sobre la OTAN. Cosas de tal jaez, [...] son impropias de un Estado de Derecho", editorial: "Inadmisible", $A B C, 18$ de mayo de 1986.

${ }_{76}^{75}$ Declaraciones de Adolfo Suárez a Pilar Urbano, s/f., Carpeta 3, AGP.

${ }^{76}$ Entrevista con José Ramón Caso, 19 de noviembre de 2014. De acuerdo con J. L. Gutiérrez y Amando de Miguel, los periodistas de El País Javier Pradera y Miguel Ángel Aguilar, el productor de cine, Elías Querejeta y el juez Clemente Auger, entre otros, se entrevistaron con Suárez intentándole persuadir "de que apoyara" el sí en el referéndum, GUTIÉRREZ, J. L. y DE MIGUEL, Amando: La ambición del César, Madrid, Temas de Hoy, 1989, p. 330.

${ }_{77}^{77}$ DSCD, Sesión Plenaria, 05 de febrero de 1986, nº 267, p. 12049.

${ }^{78}$ Véase, HERNÁNDEZ, Abel: Fue Posible la Concordia, Madrid, Espasa, 1996.

${ }^{79}$ Entrevista con Daniel de Fernando, 20 de diciembre de 2013 (Ávila).
} 
"Suárez estaba más a favor del no, que de la abstención”, un posicionamiento que llegó a aparecer en alguna ocasión en la prensa ${ }^{80}$.

Un extenso documento emitido por la Dirección de Organización del CDS dos meses antes del referéndum intentó definir con precisión la posición del partido en relación a la OTAN y la política exterior. El texto ponía una vez más de manifiesto las dificultades del CDS para generar una postura clara al margen de dos líneas rojas infranqueables para los suaristas: la participación en la Plataforma Cívica ${ }^{81}$, favorable a la salida de España de la OTAN, y en el sentido inverso, la integración en las estructuras militares de la OTAN.

Se establecía como punto de partida la necesaria participación de España en la defensa del mundo libre, pero, ¿cómo? Se apostaba por Europa Occidental como comunidad política y se definían dos líneas de actuación privilegiadas: la cuenca mediterránea (el mundo árabe particularmente) y las relaciones transatlánticas “con las naciones de raíz hispana y con los EE.UU.”. A continuación se defendía la soberanía e independencia de la política exterior sin perjuicio de las alianzas defensivas actuales o aquellas "que puedan surgir como convenientes en Europa Occidental en el futuro". Para los suaristas los principios irrenunciables que debían orientar la política exterior nacional eran: la seguridad e independencia de la Patria, la integridad territorial, la soberanía en los espacios marítimos y aéreos, la garantía de nuestros intereses y la defensa del ordenamiento constitucional. El papel de España, una potencia "media" en el contexto internacional, debía limitarse a la optimización de la relación entre mediosobjetivos con el fin de garantizar sus intereses de contribuir a la paz y el entendimiento, frente a los obstáculos constantes que los conflictos entre bloques hacían emerger. Al repasar los últimos acontecimientos se argumentaba así la decisión -o ausencia de

\footnotetext{
${ }^{80}$ Suárez "afirmó que no es partidario de la permanencia de España en la OTAN, aunque el CDS no va a participar en ningún tipo de campaña al respecto", El Norte de Castilla, 08 de junio de 1985. Dos meses después, aparecía en La Reppublica la transcripción de una conversación informal entre un periodista italiano y Suárez: "Sulla Nato, io sono contrario perchè credo utile evitare di rafforzare i blocchi contrapposti. Io sono per l' Occidente ma lo sono anche gli irlandesi che pur partecipando alla Cee non partecipano alla Nato. Nel referendum sulla Nato io sono pronto a tenere la bocca chiusa, a tenermi in disparte a patto che Gonzalez faccia altrettanto", FILO DELLA TORRE, Paolo: "Suarez a Londra a scuola d'inglese ci dice: 'Felipe e' un buon premier'”, La Reppublica, 08 de agosto de 1986. Desmentido por Suárez en una carta al propio periódico tres días después: "il giornalista abbia malinteso le mie risposte su questo e su altri temi, come per esempio la mia posizione ideologica sulla questione del referendum per la Nato [negativo]" en SUÁREZ GONZÁLEZ, Adolfo: "Lettere. Suárez e il re", La Reppublica, 11 de agosto de 1985.

${ }^{81}$ Salvo casos puntuales como el de Asturias donde su Secretario Regional se manifestaba a favor de participar, contra el criterio del Presidente Federal, A. Rebollo, La Nueva España, 01 y 25 de febrero de 1986.
} 
decisiones- del I Congreso: "La decisión de nuestra incorporación nos pareció precipitada. El realismo exigía aceptar ese compromiso del Gobierno”. Se matizaba no obstante que la adhesión no podía suponer un aumento del riesgo nuclear en España ni comprometer las relaciones con "países tradicionalmente amigos"

Ante el futuro, el CDS se comprometía con la defensa de la celebración del referéndum, "ante todo, por una cuestión de dignidad política" y también por la ligera mayoría favorable a la salida, existente entre la militancia. Reivindicaba la autonomía de Europa Occidental y las relaciones exteriores entre países amigos basadas en la "solidaridad" y "no imposición” [...] "Europa Occidental debe tener una política común coordinada con la norteamericana, pero no subordinaba" y desaprobaba duramente la política exterior norteamericana. El informe concluía ratificando su respeto a la decisión de la soberanía nacional expresada en el referéndum y manifestando la necesidad de concretar unos objetivos básicos en política exterior a largo plazo suscritos por todos los partidos.

El 27 de diciembre ningún miembro del CDS estuvo presente en el Congreso de los Diputados durante la presentación y votación de una moción de CiU sobre la permanencia de España en la OTAN. En la siguiente cita parlamentaria, el debate en el Congreso del 4 y 5 de febrero sobre la convocatoria del referéndum, el PSOE contó con el único apoyo del CDS y los diputados del Grupo Mixto ${ }^{83}$. En aquella ocasión fue el propio Suárez quien, junto a Rodríguez Sahagún, defendió la postura del partido ${ }^{84}$.

Suárez manifestó serias reservas sobre la conveniencia de la presencia de España en la OTAN, aunque parapetadas tras los argumentos de que no había existido un debate real sobre el proyecto nacional en política exterior y su desconocimiento de los contenidos del Plan Estratégico Conjunto: "en nuestra actual situación tengo, señoras y señores Diputados, serias dudas sobre las ventajas que nuestra permanencia en la OTAN puedan aportar a la paz y a la distensión en Europa y en el mundo" ${ }^{\text {}}$. Reconocía sin embargo que "la situación actual es más difícil que la que yo debí afrontar [...]

\footnotetext{
82 "CDS y OTAN", enero de 1986, Carpeta 2, AGP.

${ }^{83}$ El País, 06 de febrero de 1986.

${ }^{84}$ Rodríguez Sahagún fijó la posición del partido en el "Debate sobre la autorización parlamentaria para la convocatoria del referéndum", $D S C D$, Sesión Plenaria, 05 de febrero de 1986, $\mathrm{n}^{\circ} 267$. Rodríguez Sahagún manifestó las reticencias del partido al "preámbulo" y el artículo primero del Decreto -es decir, a la formulación de la pregunta y las condiciones de la misma: demasiado complejas y de difícil cumplimiento- y defendió la convocatoria del referéndum en base a dos argumentos -vistos con anterioridad-: salvaguardar la credibilidad de las instituciones y la posibilidad histórica de cerrar, definitivamente, esta polémica, ibid, p. 12049.

${ }^{85}$ Ibid., 12024.
} 
conviene distinguir muy claramente lo que nos gustaría hacer, lo que debemos hacer y lo que podemos hacer" ${ }^{\prime 86}$. Del mismo modo, era innegable el amplio consenso existente entre las fuerzas políticas en favor de la integración -más allá de las posiciones sobre el referéndum o la forma de integración-, un hecho indiscutiblemente positivo tal y como había manifestado en múltiples ocasiones. Concluía por lo tanto, exponiendo las dudas del CDS sobre "las ventajas de la permanencia" y valorando de forma positiva el consenso alcanzado. Aspectos que habían inclinado a la dirección centrista a "dejar a nuestros militantes y simpatizantes [...] libertad de voto".

La réplica de Felipe González intentó desarticular las reticencias de Suárez insistiendo en que la OTAN no había mermado ni las relaciones hispano-árabes, ni hispano-americanas, ni había propiciado un aumento en el gasto armamentístico, y recordaba la existencia de una relación bilateral con EE.UU. de más de treinta años, para por último, afirmar irónicamente: “yo también voy a dejar libertad de voto a todos. Lo que pasa es que quiero que voten en una determinada posición" ${ }^{\text {" }}$. La contrarréplica de Suárez se convirtió en una disertación general sobre aspectos geopolíticos ${ }^{88}$. Para Suárez, la tensión internacional estaba alimentada por tres fracturas, Este-Oeste (militar), Este-Oeste (ideológica) y Norte-Sur (económica) y afrontarlas pasaba por “objetivar los problemas internacionales por encima de las ideologías”. A nivel europeo insistía en la autonomía defensiva de Europa y unas relaciones, "en una segunda línea" con EE.UU. y Canadá, “[creo] con toda sinceridad que no pueden ser capital de Europa ni Washington, ni Moscú". Finalmente, se refugiaba en la ausencia de una decisión en firme de su partido - debido a la posposición del II Congreso- y, con cierto misterio, concluía: "naturalmente eso es lo que impide que le diga a usted ahora qué es lo que voy a votar, aunque supongo que usted lo sospecha, señor Presidente" ${ }^{\text {"9 }}$.

\footnotetext{
${ }^{86} \mathrm{Ibid}$.

${ }^{87}$ Ibid., p. 12026.

${ }^{88}$ Para el profesor Fuentes Aragonés era un testimonio de la importancia que Suárez atribuía a un tema por el que se sentía profundamente atraído, FUENTES ARAGONÉS, Juan Francisco: Adolfo Suárez..., pp. 463-4.

${ }_{89}$ DSCD, Sesión Plenaria, 05 de febrero de 1986, no 267, p. 12027. En su columna, José Luis Gutiérrez escribía: "Adolfo Suárez, con una intervención de mayor habilidad formal que las habituales, no dijo nada revelador ni original, salvo una sorprendente sugerencia: el posible voto negativo a la OTAN en el referéndum. Cuando Felipe González pidió que se pronunciara, Suárez se negó, aunque aseguró que el presidente 'sospecha' cuál podía ser el voto del duque. González temeroso del tirón popular de Suárez, prefirió no averiguarlo y guardó silencio", en GUTIÉRREZ, José Luis: "El ajuste de cuentas”, Diario 16, 06 de febrero de 1986.
} 
En la prensa conservadora se dejó entrever el alejamiento de Suárez de la posición del gobierno, "Suárez expresó sus dudas sobre las ventajas de la OTAN"90. Suárez hacía gala nuevamente de una actitud esquiva y distante: "el presidente del CDS se deslizó entre las aristas del referéndum sin rozarse ni mancharse, con una ambigüedad que empieza a ser endémica" ${ }^{91}$. Con otras palabras, Pilar Cernuda y Berta Fernández en La Vanguardia señalaban: "fue muy cauto en su intervención, sin llegar a definirse" ${ }^{92}$. Para Diario 16: "estilo pausado y desvaído [...] luchó por mantener a su partido en una difícil indefinición. Suárez expuso sus dudas sobre la cuestión, que son un reflejo de las dudas inherente al programa de su partido". Y añadía: "Suárez que en nada se parece al político brillante de otros tiempos, -acaso porque le falta ahora un expreso compromiso-, contribuyó, no obstante, a aumentar el espacio de soledad alrededor del PSOE" "93. La intervención de Adolfo Suárez que evitó recordar el vertiginoso cambio de opinión del PSOE, lo cual por otra parte no deja de ser sorprendente, fue valorada positivamente desde El País ${ }^{94}$; posicionamiento que varió a medida que se acercaba la fecha del referéndum y las encuestas ofrecían un resultado más apretado ${ }^{95}$. La libertad de voto era considerada como "una tontería" ya que acaso, ¿no era un derecho constitucional $?^{96}$, y una vez celebrado el referéndum se criticó que tanto Suárez como Roca habían "renegado de la masa refugiándose en la cómoda indefinición del silencio -siempre ocultadora de la ignorancia o del oportunismo--, justo en los momentos en que su opinión era más que requerida" $"$.

El triunfó del "sí" con un 52,49\% de votos favorables no alteró la estrategia del CDS, que si cabe, y de cara a las elecciones de junio del 86’ y la celebración del II Congreso

\footnotetext{
${ }^{90} A B C$, 06 de febrero de 1986.

91 "Miguel Herrero denunció la manipulación que representa un referéndum-plebiscito", $A B C, 06$ de febrero de 1986. "[Suárez] ha defendido ardientemente la celebración del referéndum, pero sin saber, por lo visto, para qué" en GIL-ROBLES DELGADO, José María: "En busca de la racionalidad (y II)", $A B C$, 19 de febrero de 1986. "Se limitó a ser descriptivo y a situarse en el plano del estadista, más allá del bien y del mal” en CONTRERAS, Lorenzo: "Lástima de tiempo", ABC, 06 de febrero de 1986.

92 CERNUDA, Pilar y FERNÁNDEZ, Berta: "Suárez da libertad de voto a sus seguidores y el PNV declara no haber decidido todavía", La Vanguardia, 06 de febrero de 1986.

${ }^{93}$ Editorial: "Debate OTAN: Las razones de la oposición”, Diario 16, 06 de febrero de 1986.

${ }^{94}$ Editorial: "Demasiado para el cuerpo", El País, 06 de febrero de 1986.

95 Resumiendo la postura de la prensa ante el referéndum se han distinguido tres actitudes: $A B C, Y a, L a$ Vanguardia, Diario 16 estaban en contra de su celebración, mientras El País se posicionaba a favor. Una vez convocado, La Vanguardia y El País fueron quienes con mayor determinación defendieron el "sí", mientras $A B C$ se decantaba por la abstención, MARTÍNEZ SÁNCHEZ, Juan Antonio: "El referéndum sobre...".

${ }^{96}$ Editorial: "El silencio de los líderes", El País, 07 de marzo de 1986.

${ }^{97}$ Editorial: "Quién canta victoria”, El País, 13 de marzo de 1986. Parece plausible que la indefinida posición del CDS contribuyera a la desorientación del electorado y el aumento de la abstención, Equipo de Sociología Electoral: "Sobre la permanencia de España en la OTAN y sus consecuencias para el sistema político", Revista de Estudios Políticos, 52, julio-agosto 1986.
} 
(septiembre, 1986) acentuó su discurso progresista en política exterior. Para los suaristas, la existencia de dos bloques enfrentados ideológicamente y hegemonizados por las grandes potencias "había generado un falso equilibrio para el mantenimiento de la paz, basado en el terror, y [...] originado una carrera de armamentos", considerada un despilfarro y una vía segura hacia el abismo" ${ }^{98}$. En este escenario, Europa quedaba subordinada a los intereses norteamericanos y soviéticos, un posible teatro de operaciones en caso del inicio de un conflicto, a la par que se desatendía la fractura Norte-Sur. En febrero de 1987 y de forma un tanto inesperada, Suárez arrojaba nueva luz sobre el tema de la OTAN. En pleno Debate sobre el Estado de la Nación admitía haber votado la opción del "no" en el referéndum. Confesó: "ahora que no influye no me importa decir cuál fue el mío: voté en contra, soy de los perdedores. (Rumores)"99.

\section{3. Un programa electoral "moderadamente radical" (1986)}

Los dos episodios centrales del ocaso político de Adolfo Suárez, esto es, su dimisión como Presidente de Gobierno y su salida de UCD, eran para los miembros del CDS la última consecuencia de toda una serie de presiones internas y externas cuyo objetivo básico era la neutralización política del centro y de su persona; los poderes fácticos, los sectores privilegiados o la ficción bipartidista se convirtieron desde entonces en expresiones habituales dentro del argot suarista.

El principio de "supremacía del poder civil" reivindicado por el CDS durante su presentación pública y en la campaña del 82' se convirtió quizá, en la referencia más genuina del suarismo. Su imperturbable imagen en el Congreso durante el asalto producido el 23-F constituía la más sólida garantía, en una trayectoria -junto al Teniente Gral. Gutiérrez Mellado- marcada por los desencuentros con los sectores ultras de las Fuerzas Armadas. Para el CDS, el intervencionismo militar, en cualquiera de sus manifestaciones, era un mal endémico de nuestra Historia Contemporánea que debía ser definitivamente erradicado. Y aunque lo desmintiera una y otra vez, para buena parte de la sociedad española estaba íntimamente ligado a su dimisión.

Un ambiente conspirativo que se trasladaba también al contexto de su salida de UCD. Suárez no dudaba en señalar la existencia de grupos e intereses que querían verle

\footnotetext{
${ }^{98}$ CDS: "Ponencia sobre Seguridad, Defensa y Política Militar (II Congreso)", 1986.

${ }^{99}$ DSCD, Sesión Plenaria, 24 de febrero de 1987, nº 31, p. 1766.
} 
"fuera de la política" o cómo él señaló más de una vez "jubilarle" anticipadamente; "poderes fácticos" en los que al margen del Ejército, se citaba a la Banca o la Patronal $^{100}$. El CDS era una respuesta política a la suma de poderes que desde 1980 había maniobrado contra Suárez dentro y fuera de la UCD.

Recordar estos episodios, que en definitiva son parte de la lectura realizada por el suarismo de los acontecimientos sucedidos entre 1981 y 1982, sirve para comprender mejor el éxito del CDS en las elecciones de 1986, en las que la Banca y el Ejército coparon los titulares periodísticos. Si otrora habían formado parte de la nebulosa constelación de los "poderes fácticos" -en los que se puede incluir todo lo relativo a la OTAN y EE.UU.-, ahora su protagonismo respondía a una pregunta básica de marketing electoral: ¿qué le preocupa a la gente? La respuesta era: la "mili” y la hipoteca $^{101}$.

El programa electoral, compuesto gracias al trabajo de diversas comisiones y equipos sectoriales, contó con Rodríguez Sahagún, nuevamente, como eje vertebrador ${ }^{102}$. A continuación, analizaremos este programa electoral del CDS para 1986, comenzando por su programa en materia de Defensa y Política Militar.

La propuesta de reducción del Servicio Militar a tres meses fue la medida electoral de mayor impacto introducida por el CDS en la campaña del $86^{, 103}$. Para Caso suponía proseguir la línea programática de profesionalización de las Fuerzas Armadas defendida desde 1982 y nacía de las experiencias políticas de Suárez y Rodríguez Sahagún en la Presidencia de Gobierno y el Ministerio de Defensa respectivamente. En palabras de Suárez: "es una medida congruente con nuestra política de capacitación de la juventud y profesionalización de nuestras Fuerzas Armadas"104. Una de los objetivos era liberar los excesivos recursos de cuadros profesionales que se dedicaban a gestionar el servicio militar obligatorio durante los 18 meses que duraba -si bien, se había aprobado ya su reducción a doce ${ }^{105}$ - . La propuesta se había discutido con cuadros de las Fuerzas

\footnotetext{
100 Véase, DÍAZ-VARELA, Mar y GUINDAL, Mariano: A la sombra del poder, Barcelona, Tibidabo, 1990.

${ }^{101}$ Véase, FRAILE LAMEYER, Alfredo: Secretos confesables, Barcelona, Península, 2014.

102 Contó por ejemplo, con la colaboración del economista Jorge Planas quien había trabajado con José Luis Sanchís y Miguel Santesmases como asesor de Adolfo Suárez en los inicios de la Transición, SANCHÍS, José Luis: ¿De qué color llevaba Adolfo los calcetines?, Barcelona, Península, 2016. 103 “¿Mili? Tres meses y vale”, Pegatina 2851 C) 2685 F), CRAI Biblioteca Pavellò de la República (UB). 104 "Saldré al paso de cualquier barbaridad que se diga en campaña", El País, 14 de junio de 1986.

${ }^{105}$ El 8 de mayo de 1984 se aprobó en el Congreso la limitación del Servicio Militar a 12 meses gracias al Proyecto de Ley del Servicio Militar en cuya votación final no estuvieron presentes ni Suárez ni Rodríguez Sahagún, quienes tampoco intervinieron durante su tramitación.
} 
Armadas con los que Rodríguez Sahagún mantenía buenas relaciones siendo objeto de debate cuánto tiempo se necesitaba para "la formación elemental en la técnica militar de la población (para el caso de movilización general)". Incluso, se había barajado la opción de la supresión total del Servicio Militar Obligatorio, prevaleciendo la opinión compartida por el PSOE y la mayoría de las formaciones políticas- "de la conveniencia de mantener un breve período de formación según la tradición europea de 'la Nación en armas' para los casos de gran necesidad"106.

Del mismo modo, en el Programa Electoral se había contemplado la posibilidad de realizar una Prestación Social Sustitutoria (PSS) -admitiendo de forma tácita la regulación del derecho de objeción de conciencia y PSS llevado a cabo en $1984^{107}$-, aunque se recordaba en el preámbulo que la Defensa Nacional era una responsabilidad colectiva $^{108}$. La medida del CDS quedaba así:

Se acortará el tiempo de cumplimiento del Servicio Militar hasta un máximo de tres meses facilitando, durante el mismo, la formación profesional especializada en actividades exigidas por la Defensa y se propondrán fórmulas de sustitución de ese servicio al Estado, por otras alternativas de carácter social o de cooperación en el exterior $^{109}$.

Aunque la propuesta del CDS contaba con algunos antecedentes y su puesta en práctica presentaba numerosas dificultades, contribuyó decisivamente a situar en primera plana las demandas de una progresiva y definitiva profesionalización del ejército, como sucedió en las futuras campañas electorales ${ }^{110}$. Desde el punto de vista electoral, y como señalaba un colaborador habitual del partido, "[la propuesta] 'sin estar bien diseñada' había tenido la virtud de calar con facilidad en los sectores juveniles ${ }^{111}$. En la prensa y en el resto de formaciones políticas fue acogida con escepticismo e ironía: "Tiempo de creer: La mili de tres meses. Presentador: Rdo. P. José Ramón Caso,

\footnotetext{
${ }^{106}$ Entrevista (escrita) con J. R. Caso 21 de abril de 2016.

${ }^{107}$ Ni Rodríguez Sahagún, ni Suárez intervinieron en la tramitación de la Ley Reguladora de la Objeción de Conciencia y de la Prestación Social Sustitutoria aprobada el 28 de diciembre de 1984. Asimismo, no participación en la votación plenaria de la totalidad de los artículos orgánicos de dicha ley celebrada el 08 de mayo de 1984.

${ }^{108}$ El CDS, al igual que el resto de partidos, lo vinculó especialmente a su política de juventud aunque no lo hizo así en su programa electoral, $A B C, 17$ de junio de 1986.

${ }^{109} \mathrm{CDS}$ : El Valor del Centro, 1986, CDS, p. 90, AAG.

110 "Desde que, en junio de 1986, el CDS de Adolfo Suárez irrumpió en la campaña con la mili de tres meses como gancho electoral, no ha habido elecciones en las que el reclutamiento obligatorio no haya sido objeto de disputa" en GONZALEZ, Miguel: "La Mili ya no tiene quien la defienda", El País, 11 de febrero de 1996.

${ }^{111}$ PANDO DESPIERTO, Juan: "Perspectiva elecciones 1986", 13-14 de junio de 1986, Carpeta 2, AGP.
} 
N. P. I."112 . El editorial de Diario 16 la definía como "demagógica por inviable"113. La medida del programa suarista generó algunas reacciones también dentro de la cúpula militar. El capitán general de la Región Militar de Levante, Juan Bautista Sánchez de Bilbao comentó: “Querría que Adolfo Suárez me explicara cómo haría él lo de la 'mili' en tres meses" $"$. Sólo Izquierda Unida (IU) planteaba también la reducción del servicio militar, aunque con más cautela en sus compromisos rebajándola: "al mínimo indispensable"

Al margen de esta medida, las propuestas sobre política de Seguridad y Defensa tenían un perfil indiscutiblemente civilista y comprometido con la defensa de las libertades, basándose en una interpretación genuina de la Constitución. Junto a la reducción del servicio militar, el CDS solicitó la eliminación de la "pena de muerte en tiempo de guerra" del Código de Justicia Militar, reivindicó la supresión del carácter militar de la Guardia Civil y abogó por la plena libertad de sindicación para los Cuerpos de Policía ${ }^{116}$.

Siguiendo este perfil progresista, el CDS dedicó un extenso apartado a la ecología casi tres páginas del programa electoral-. El punto de vista centrista buscaba una vía intermedia entre lo que ellos consideraban los extremos "desarrollistas" y los "grupos [ecologistas] radicalizados". Como había sucedido en anteriores ocasiones, los periodistas tenían un motivo más para la incredulidad: “oír hablar a Suárez de la

112 GALLEGO \& REY y FORGES: “23-J. Qué sería esto si Suárez fuera 'Baranda Plus””, Diario 16, 19 de junio de 1986.

113 Editorial: "Un programa socialdemócrata, intervencionista y ambiguo", Diario 16, 09 de junio de 1986.

${ }^{114} A B C$, 03 de julio de 1986. Para algunos autores como J. M. González Quesada, desde el punto de vista militar, un período de duración así era totalmente insuficiente, subrayando como en este proceso de reducción paulatina primaron las argumentaciones referentes a la situación de la juventud y las propuestas electorales a las necesidades objetivas de la defensa o las consideraciones militares en GONZÁLEZ QUESADA, José Miguel: “Adaptación del reclutamiento a la nueva realidad social, militar y estratégica: reformas del servicio militar durante la primera etapa socialista" en V Congreso de la Asociación de Historiadores del Presente: Congreso Internacional Historia de la Época Socialista. España: 1982-1996, UAM-UNED, Madrid, 2011. Disponible en: http://www.historiadelpresente.es/ congresos/historia- de-laepoca-socialista-1982-1996. Fecha de consulta: 24 de mayo de 2015.

${ }^{115}$ Izquierda Unida planteaba en su capítulo II, "Una política alternativa de defensa": "IZQUIERDA UNIDA propondrá la reducción de la duración del servicio militar al mínimo indispensable", en IU: "El compromiso de Izquierda Unida con la sociedad española", 1986, p. 13 Disponible en http://www.izquierdaunida.es. Fecha de consulta: 16 de febrero de 2016. La Mesa de Unidad Comunista (MUC) de Santiago Carrillo propugnaba el "mantenimiento del servicio militar obligatorio a cumplir en la región en origen" y el PRD en su programa electoral barajaba la idea de una reducción del servicio militar, $A B C, 08$ de junio y 20 de mayo de 1986. En el "Programa de Gobierno de Coalición Popular, 1986" se aludía simplemente a la regulación del sistema sustitutorio de prestaciones sociales" y para Fraga se trataba de demagogia electoral: "Fraga defiende las Fuerzas Armadas contra la 'demagogia y las frivolidades"', Ya, 14 de junio de 1986, Archivo Linz.

${ }^{116}$ CENZANO, Arturo: "Los policías prefieren votar al CDS según un sondeo realizado por el SUP", Diario 16, 12 de mayo de 1986, Archivo Linz. 
biosfera" "117. Asimismo, y en la línea del PSOE, incluía apartados dedicados específicamente a la "juventud", "las drogas" y "la igualdad y promoción de la mujer", mientras la CP, optaba por abordar dichos ítems dentro de la etiqueta de "familia" juventud y mujer-y "seguridad" -droga-.

El grueso del programa electoral estaba dedicado a la economía y enfocado a la resolución del problema del "paro" gracias al uso de la concertación social y el diseño de una estrategia de política económica a largo plazo ("planificación flexible") ${ }^{118}$. Si se quería mantener un ritmo de crecimiento sostenido era necesario proceder a aumentar la inversión -pública y privada- y hacer uso de las "bolsas de crecimiento potencial". Respecto al mercado de trabajo, apostaba por introducir nuevos mecanismos de contratación -en función de las necesidades productivas- y flexibilizar el calendario laboral. Se defendía la prioridad del "contrato indefinido" y del valor de los salarios en sus términos reales.

El CDS seguía la línea de las intervenciones de Suárez en los Debates del Estado de la Nación demandando un papel activo del Estado ejecutado dentro de una gran estrategia global consensuada que permitiese asumir los costes y sacrificios de los ajustes estructurales que la economía española demandaba como consecuencia del nuevo contexto económico internacional. Y como había sucedido también a lo largo de la legislatura centraba su atención en las PYMES defendiendo diversas políticas de inversión y de ahorro privado gracias a medidas fiscales y la facilitación del crédito oficial. A diferencia del PRD o de la CP, no se apostaba por la reducción del "sector público" o la privatización de las empresas estatales, apelando textualmente a una "mayor acción del estado en período de crisis":

En la dura lucha política y económica que se plantea en el terreno internacional, las naciones más desarrolladas nos demuestran como la fijación de grandes objetivos nacionales apoyados por los aparatos estatales y la realización de importantes proyectos

\footnotetext{
117 "En la noche del viernes, ante las tres mil personas que abarrotaban el teatro Fleta, de Zaragoza, coincidiendo en el tiempo con el partido Argelia-Brasil -el encanto y la atracción que el líder del CDS ejerce sobre un sector de la ciudadanía, principalmente la femenina, es inocultable- Suárez habló de su nuevo descubrimiento electoral, el llamado 'ramalazo verde', según expresión que le adjudican los periodistas que le acompañan. Oír hablar a Suárez de "la biosfera' le hace momentáneamente semejante a un híbrido de Ramón Tamames y Petra Kelly" en GUTIÉRREZ, José Luis: "Qué verde era mi duque", Diario 16, 08 de junio de 1986, Archivo Linz.

${ }^{118}$ Proponía la creación del Consejo Económico y Social, CDS: El Valor del Centro..., p. 50. Medida contemplada por otros partidos, como el PSOE: Programa 1986/1990. Para seguir avanzando. Por el buen camino, 1986, p. 28. Disponible en http://www.psoe.es/media-content/2015/03/Programa-ElectoralGenerales-1986.pdf. Fecha de consulta 13 de junio de 2015.
} 
de inversión pública, son esenciales para la movilización y mayor aprovechamiento de todas las energías de la sociedad civil ${ }^{119}$.

El talante liberal del CDS tenía su expresión en la crítica, presente a lo largo de todo el programa electoral, al exceso de burocratización, a la politización de la administración, a la escasa eficacia en la gestión de los recursos públicos o la amenaza de las libertades. Sin embargo, no se articulaban propuestas concretas o se defendían posiciones explícitamente ambiguas cuando se hablaba de un modelo de "televisión múltiple" ${ }^{" 120}$. Y es que, la concepción liberal del CDS intentaba, sin decantarse abiertamente por la liberalización, las privatizaciones o la reducción del déficit por la vía del ajuste y racionalización presupuestaria, fomentar la iniciativa privada e individual en un marco de competencia ampliamente regulado; en definitiva, la conciliación de una provisión eficaz y generalizada de servicios públicos de calidad y protagonismo activo del Estado con el impulso e iniciativa del resto de agentes económicos y sociales.

Algunas de las medidas más audaces de los suaristas apostaban por la modificación del sistema de financiación de la Seguridad Social ${ }^{121}$, - una medida dirigida electoralmente a las PYMES-, la supresión de impuestos directos sobre las pensiones y un necesario "saneamiento" de la sanidad, que en virtud de su viabilidad, debía ser totalmente gratuita sólo para las rentas “más débiles”.

La oferta educativa constituyó un marco privilegiado para la defensa de su concepción "meritocrática de la sociedad": igualdad de oportunidades, -educación obligatoria y gratuita hasta los dieciséis años, educación preescolar gratuita o creación de un salario escolar que facilitara la prosecución de los estudios-, valoración del mérito, -en el acceso a los estudios superiores- y modernidad -potenciación de contenidos como "la enseñanza de idiomas extranjeros"-- Respecto a la tradicional polémica entre la educación pública y privada defendía su superación gracias a "una concepción radical de la autonomía escolar”.

\footnotetext{
119 Ibid., p. 40.

${ }^{120}$ Terminología de la que se hizo eco el editorial: "Un programa socialdemócrata, intervencionista y ambiguo", Diario 16, 09 de junio de 1986.

${ }^{121}$ El modelo de financiación de la Seguridad Social se consideraba que repercutía negativamente en la creación de puestos de trabajo y se entendía como un "impuesto sobre la mano de obra". Su cobertura debía ser atendida por los Presupuestos Generales del Estado, "CDS considera un error grave del Gobierno socialista haber desaprovechado la ocasión histórica que ha representado la puesta en marcha del IVA", CDS: El Valor del Centro..., p. 22. La CP, sin proponer un cambio total del modelo, apostaba también por compensar la disminución de las cargas empresariales gracias a la recaudación del IVA, CP: Programa de Gobierno, 1986, pp. 27-28.
} 
El título del apartado referente a la Política Exterior, "La Paz y la defensa de los intereses españoles", enunciaba los dos compromisos básicos del partido en este ámbito. El CDS denunciaba abiertamente los aparatos militares de la política de bloques, "el mayor factor de riesgo que jamás ha afrontado la Humanidad", "falso equilibrio", y buscaba la ruptura de la bipolaridad mediante el refuerzo del protagonismo y de la autonomía de Europa: “como es el caso de la Unión Europea Occidental [UEO] [...] tanto de cara a su actual presencia y actuación en el seno de la OTAN, como para iniciar un camino que permita avanzar hacia la posibilidad algún día de una 'opción específica de seguridad europea"'. En relación a la OTAN, una vez refrendada la incorporación española en los términos planteados, apelaba a la reestructuración de sus relaciones internas en beneficio de un mayor equilibrio entre EE.UU. y el resto de los países aliados, y en lo referente a las relaciones bilaterales hispano-norteamericanas demandaba la reducción de la presencia americana (Zaragoza, Torrejón ${ }^{122}$ ) y denunciaba el Tratado con Washington del que exigía su "revisión"123.

Sobre Iberoamérica abogaba por el respaldo de la CEE a los "proyectos de democratización, cambio social y defensa de los derechos humanos", la dinamización de estrategias de cooperación (Ley de Cooperación, Agencia de Cooperación para el Desarrollo, etc.), el apoyo a las resoluciones del Acta de Contadora de cara a la resolución del conflicto centroamericano y el afrontamiento de la crisis de la deuda externa $^{124}$. En la otra área privilegiada de la política exterior suarista, es decir, el mundo árabe y mediterráneo, aludía "de pasada" al conflicto saharaui "que asegure el buen fin de la descolonización del Sáhara donde nos corresponde una responsabilidad histórica"125 y suscribía "la autodeterminación del pueblo palestino" y el reconocimiento de la OLP como legítimo representante del mismo, sin hacer ninguna

\footnotetext{
${ }^{122}$ Durante la campaña, se hablaba de "cerrar las bases americanas en España", "Plaza Mayor de Madrid. Mitin Final de Campaña”, 20 de junio de 1986, Carpeta 3, AGP.

${ }^{123}$ Es preciso llamar la atención sobre el uso y las connotaciones del verbo "denunciar", como se hizo en el editorial: "Un programa socialdemócrata, intervencionista y ambiguo", Diario 16, 09 de junio de 1986.

${ }^{124}$ Una diferencia cualitativa con el programa de CP, coalición que introducía estos aspectos del siguiente modo: "es preciso, a este fin, abandonar el hispanoamericanismo meramente retórico que desgraciadamente hoy persiste y llenar las grandes palabras de mayor presencia española en el desarrollo iberoamericano. Lamentablemente hoy los intercambios comerciales, culturales y tecnológicos Europa-Iberoamérica, no sólo son insuficientes, sino declinantes y es preciso intensificarlos desde la nueva posición de España en la CEE.", CP: Programa de gobierno, 1986, p. 60. Disponible en: http://www.pp.es/sites/default/files/documentos/1147-20090908161128.pdf Fecha de consulta: 03 de enero de 2015.

${ }^{125}$ Sin apoyar explícitamente la celebración de un referéndum de autodeterminación de acuerdo con las resoluciones internacionales - como recogía el programa del PSOE-, pero sin omitir la referencia a dicho conflicto como sucedía en el caso de CP.
} 
referencia a Israel, país con el que se habían relanzado las relaciones bilaterales apenas unos meses antes ${ }^{126}$.

En el proceso de incorporación a las CEE era preciso superar los llamados "costes de la adhesión" que el CDS achacaba, una vez más, a la realidad socio-económica nacional y a la existencia de "grupos de interés" que habían preferido "la cómoda inmovilidad protegida y la defensa a ultranza de sus intereses particulares al progreso [...] de todos". Por ello, proponía la búsqueda de fórmulas consensuadas que impidieran que "el peso del ajuste necesario" recayera en los sectores más débiles de la sociedad. Por otra parte, era imprescindible la disminución de los desequilibrios interregionales existentes en Europa y es que, sólo así, se podía caminar hacia el objetivo último del proyecto europeo que pasaba por una auténtica "unificación política". Finalmente, constituía un principio irrenunciable de la política exterior española la recuperación de la soberanía española de Gibraltar gracias a la "búsqueda de una solución negociada con Gran Bretaña" 127 .

La "política exterior" había adquirido una relevancia notable gracias al "referéndum". Los debates y posicionamientos habían trascendido a la opinión pública y fueron decisivos de cara a las elecciones generales de 1986. Como ha escrito Fuentes Aragonés, en el caso de Suárez: "la política exterior se le antojaba un terreno propicio para desgastar al Gobierno ante su propio electorado y rentabilizar su experiencia como gobernante que en su día supo mantener una línea independiente ante las grandes potencias occidentales"128. Si el CDS quería atraer a votantes "desencantados" del PSOE, y a la par, marcar distancias con el PRD este era un excelente camino.

De acuerdo con un dirigente del CDS, aunque en un primer momento las líneas maestras de la Operación Roca parecían similares a la de los suaristas, con el paso del tiempo fueron patentes dos grandes diferencias: la política exterior -“"nosotros no somos partidarios de que España sea una potencia militar y no estamos de acuerdo con la guerra de las galaxias"- y la política económica -“con 3 millones de parados es necesario que el estado actúe dentro de un mercado libre, pero que actúe para depegar [sic] incertidumbres, para aclarar horizontes, y sobre todo para que la inversión pública

\footnotetext{
${ }^{126}$ El CDS había apoyado la apertura de relaciones diplomáticas con Israel, DSCD, Sesión Plenaria, 05 de febrero de 1986, nº 19, p. 12026.

${ }^{127}$ CDS: El Valor del Centro..., p. 113 y ss, $A A G$.

${ }^{128}$ FUENTES ARAGONÉS, Juan Francisco: Adolfo Suárez..., p. 463.
} 
sea un motor y un estímulo a la inversión privada"- ${ }^{129}$. En el contexto electoral del 86', el CDS había logrado ser percibido "como un partido situado en el centro exacto del espectro político (en el punto 5,5 de una escala ideológica del 1 al 10), mientras el PRD era considerado como una formación de centro-derecha por el electorado (en el punto 6,2)"130. En opinión del columnista de La Vanguardia, Ramón Pi, realmente, el único partido de centro era el PRD y la ubicación del CDS en este espacio, cuando realmente estaba escorado a la izquierda, era un tic, un reflejo de la etapa de UCD. Acaso, su oferta en materia de defensa, economía o política exterior, ¿se podían considerar de centro ${ }^{131}$

Un último aspecto que creemos necesario destacar del programa electoral centrista insistía en la necesidad de aprobar una nueva Ley Electoral, un punto cuya redacción resultaba deliberadamente vaga y ambigua:

CDS procederá a una reforma de la representación política mediante una nueva Ley Electoral que tienda a reforzar el principio constitucional de igualdad de los españoles ante la Ley Electoral, evitar la preeminencia coyuntural de un partido sobre los demás contra el principio de pluralismo político y asegurar la libre y pacífica concurrencia de los partidos políticos en los procesos electorales.

Aunque el CDS había sido el partido con el mayor coste medio de votos por escaño en 1982, no cuestionó los mecanismos de corrección de la proporcionalidad presentes en el ordenamiento legal -nos referimos a las circunscripciones provinciales y la Ley $d$ 'Hondt ${ }^{132}$, al igual que sucedió durante la tramitación de la LOREG $^{133}$. Según manifestó un dirigente del partido en 1984: “el texto enviado por el Gobierno es

\footnotetext{
${ }^{129} \mathrm{El}$ dirigente suarista lo llegaba a denominar "economía de mercado mixta", Interview undertaken by Richard Gunther, in 1986 (june), AR. En el manifiesto político del PRD editado en 1985 se defendían puntos de vista opuestos. En un contexto de crisis era más necesario, si cabe, "la aplicación flexible e inteligente de los principios económicos del libre mercado [...] durante los años de la bonanza económica muchos países occidentales fomentaron un crecimiento desmesurado del sector público, este sector público es ahora: sobre todo el países europeos uno de los grandes lastres para remontar la crisis". En materia exterior advertía sobre las posiciones "intermedias" en relación a la política de bloques y los "residuos emotivos de tentaciones tercermundistas", vigentes en el PSOE. Defendían el compromiso pleno con el bloque occidental y en consecuencia, una vez aprobada la incorporación a la OTAN en 1981, "propugnamos la plena participación en todas las instancias políticas y militares de esta organización", PRD: La alternativa ..., pp. 69-71.

${ }^{130}$ POWELL, Charles T.: España ..., p. 422.

${ }^{131}$ PI, Ramón: "El sitio de cada cual", La Vanguardia, 24 de mayo de 1986.

${ }^{132}$ El País, 05 de octubre de 1984; TOHARIA, Juan José: "Tras las elecciones: sin apenas novedad en el frente", Cuenta y Razón, 25, 1986.

${ }^{133}$ Nos referimos al Decreto Ley de 18 de marzo sobre Normas Electorales aprobado por el gobierno de Suárez, y en este aspecto convalidado por la Ley Orgánica 5/1985, de 19 de junio, del Régimen Electoral General.
} 
'aceptable' y garantiza el equilibrio adecuado entre representatividad y gobernabilidad"134.

Desde el CDS se criticaba fundamentalmente el socavamiento del principio de igualdad de oportunidades, es decir, el reparto de espacios publicitarios en los medios de comunicación social entre los distintos partidos en función del resultado obtenido en las elecciones precedentes. En el programa electoral era expresado como "preeminencia coyuntural de un partido sobre otros", y Rodríguez Sahagún lo había expuesto con notable claridad en el Congreso un año antes en sintonía con el resto de fuerzas minoritarias:

Lo mismo en cuanto a la igualdad de oportunidades que señala el artículo $9^{\circ}$ de la Constitución. Para los individuos y para los grupos, y también en cuanto a la obligación de los poderes públicos de remover o eliminar cualquier suerte de obstáculos para el ejercicio de esa igualdad ${ }^{135}$.

Para Rodríguez Sahagún, el objetivo de la nueva ley electoral aprobada entre el Grupo Socialista y el Popular era la perpetuación del bipartidismo, aun a costa de aumentar la abstención -lo que beneficiaba a los grandes partidos- y debilitar así la democracia: "insisto en que creo que de lo que se trata es de presentar un menú con dos platos y mucho me temo que al final eso lo que va a conseguir es que el electorado, en gran parte, pierda el apetito y eso no es precisamente bueno"136.

La segunda parte de la propuesta del CDS nos retrotrae al principal problema del partido suarista: la financiación. El CDS denunciaba, sin proponer una alternativa concreta, los mecanismos de financiación de los partidos políticos, lo que Suárez llegó a calificar como "democracia bancaria":

La nueva Ley Electoral, mejorará los mecanismos institucionales de financiación de los partidos políticos para evitar los condicionamientos externos de los grupos de presión nacionales e internacionales en la vida democrática y participativa prevista por la Constitución vigente ${ }^{137}$.

El programa del CDS, en suma, presentaba una oferta electoral con abundantes notas de corte progresista, liberal en su concepción de las libertades y la gestión de los servicios, y socialdemócrata en materia económica. Suárez se había llegado a definir

\footnotetext{
${ }^{134}$ El País, 05 de octubre de 1984.

${ }^{135}$ DSCD, Sesión Plenaria, 18 de abril de 1985, n 199 , p. 9158.

${ }^{136}$ Ibid.

${ }^{137}$ CDS: El Valor..., pp. 95-6.
} 
como un "progresista incómodo"138. Para Manuel Penella, el CDS "basculaba claramente hacia el centro-izquierda" ${ }^{139}$ :

Su intención era ocupar el centro y apoderarse de los votos de los que se habían decepcionado con la actuación del PSOE. Su propuesta más audaz era la reducción del servicio militar a tres meses. En política exterior, ponía el acento en la importancia de Europa, anteponiéndola a los intereses atlánticos. En el plano económico y social, su propuesta era claramente de corte socialdemócrata. Se curaba en salud con respecto a la moda neoliberal indicando que, en último análisis, los Estados Unidos de Reagan no se regían al pie de la letra por sus recetas (en clara alusión al llamado Sistema Pentágono y a las medidas proteccionistas sobre las que se hablaba poco). Suárez apostaba, de manera nítida, por el mantenimiento y la potenciación del Estado de Bienestar ${ }^{140}$.

Para Diario 16, el programa del CDS era "socialdemócrata, intervencionista y ambiguo". Más que un punto intermedio, el texto centrista constituía una suma de actitudes socialdemócratas -“todo el programa rezuma una cierta desconfianza hacia el papel del sector privado en la economía" matizadas "por ciertas declaraciones liberales"- y una oferta "más retórica y ambigua" que "pragmática y concreta"141. La ambigüedad nacía en la propia naturaleza heterogénea e indefinida del partido (OTAN), se concentraba en la política sobre bienestar y era calificada de "etérea" en lo referido a la administración y las instituciones -caso de la nueva ley electoral-. $Y a$ analizaba el programa del CDS, junto al de PRD y $\mathrm{CP}$ en un bloque que denominaba "derecha constitucional" y "de ese centro que en parte votó al socialismo en 1982, pero que parece dispuesto a rectificar su decisión de entonces". En materia económica las diferencias entre el PRD, CP y CDS se consideraban "nimias", manteniendo el CDS "una actitud más populista". Como matiz diferencial se incluía la alusión explícita al principio de libertad de enseñanza y del derecho a la vida en los programas reformista y popular $^{142}$. En $A B C$, se defendía una última propuesta de coordinación del centroderecha -retirando las candidaturas más gravosas para los resultados generales de la oposición conservadora-. En esta ocasión y como sucedió en abril, no contaba con el CDS, partido que no era objeto de ningún análisis por parte del editorial. En El País se dedicaron dos editoriales, uno a propósito del candidato y otro en relación al programa este último junto al PRD-. El programa del CDS compartía con el PRD y la CP reflexiones sobre el "regreso del individuo, la devolución de la iniciativa a la sociedad

\footnotetext{
${ }^{138}$ FUENTES ARAGONÉS, Juan Francisco: Adolfo Suárez ..., p. 463.

139 PENELLA, Manuel: [Tomo II] Los orígenes..., p. 779.

${ }^{140}$ Ibid., p. 826.

141 Editorial: "Un programa socialdemócrata, intervencionista y ambiguo", Diario 16, 09 de junio de 1986.

${ }^{142}$ Editorial: "Elecciones: ni más, ni menos”, Ya, 21 de junio de 1986.
} 
civil, el rechazo del protagonismo multiforme del Estado", que en el suarismo tomaban cuerpo desde un "radicalismo de nuevo cuño", pero que permitían identificarlo dentro de la renovación del discurso liberal. En política económica, se entremezclaban medidas de carácter socialdemócrata junto con otras de "tinte liberal" -flexibilización del mercado de trabajo-, alejado en cualquier caso del "reaganismo" que caracterizaba al PRD. Contemplaba como plausible la reforma del servicio militar y valoraba la defensa de las libertades, de separación de poderes y de transparencia desde una doble perspectiva: "entre quienes ven en Suárez la audacia que falta a los socialistas y quienes responden que muchas de las reformas propugnadas por él ya tuvo ocasión de ponerlas en práctica, y no lo hizo". El centro, o mejor dicho, la experiencia del centrismo en España, protagonizada por políticas y programas flexibles e interclasistas, había caracterizado a UCD y el PSOE; ahora Suárez lo intentaba reconstruir desde un punto de vista geométrico, es decir, "como bisagra de la vida política", y lo hacía con una oferta radical -no exenta de oportunismo- $[\ldots]$ Y por eso mismo se coloca, con enorme habilidad, a la izquierda misma del PSOE si es preciso, con tal de arañarle votos"143.

El País se mostraba más beligerante en el editorial, realizado dos semanas antes, sobre el candidato. Introducía a Suárez de forma polémica y vinculando de manera implícita su dimisión con el 23-F o, peor aún, con una jugada política personal: “aunque nunca estuvieron muy claros los motivos de su dimisión, menos de un mes antes de la intentona del 23-F, parece que se fue entre otras cosas porque sabía que, en caso contrario, sería simplemente apartado de la carrera". El resto del artículo analizaba su trayectoria política enfatizando su pasado dictatorial -"especialista en grandes travesías, en una de ellas, camino de su Damasco particular, descubrió la democracia"- y sintetizando su orientación hacia el centro-izquierda en la siguiente frase: "sus resabios falangistas le enfrentan a la banca y su historial político al militarismo". En el CDS, se ha caracterizado por la ausencia de un discurso ideológico, los silencios -“a veces signo de oportunismo"- y un "sincretismo imposible [a izquierda y derecha]". Sus éxitos políticos se resumían en una concisa afirmación: "en su haber Suárez cuenta con que fue quien desmontó el tinglado de la dictadura". De cara a las elecciones, Suárez se asemejaba a una figura quijotesca, abandonada a su suerte, en suma una mezcla de héroe y loco ${ }^{144}$.

\footnotetext{
${ }^{143}$ Editorial: "El espacio del centro", El País, 17 de junio de 1986.

${ }^{144}$ Editorial: "3. Adolfo Suárez", El País, 03 de junio de 1986.
} 


\section{4. El reto de la campaña del CDS para las elecciones generales de 1986}

La primavera de 1986, inaugurada con la exigua victoria del "sí" en el referéndum de la OTAN, se vivió en un auténtico clima de precampaña electoral. El día 22 de abril, el Vicepresidente de Gobierno Alfonso Guerra confirmaba el adelantamiento de las elecciones generales. Como había venido siendo habitual, la polémica en torno a RTVE era el eje de las críticas de la oposición conservadora al gobierno, secundada en este caso por el conjunto de las fuerzas políticas debido al tratamiento informativo de la campaña sobre el referéndum de la Alianza Atlántica ${ }^{145}$. De otro lado, la izquierda ajena al PSOE trataba de capitalizar el impulso y el protagonismo adquiridos durante la campaña anti-OTAN con la formación de la plataforma política de Izquierda Unida (IU).

De forma un tanto inesperada, las elecciones generales de 1986 iban a suponer el punto de inflexión más determinante en la vida del CDS, gracias a un excelente resultado que aupó a los suaristas como tercera fuerza política nacional. De cara al análisis de la campaña, y una vez desarrollado el programa electoral, abordaremos la gestión de los problemas financieros a los que se enfrentó el partido en los prolegómenos de la misma y la decisiva intervención de Suárez en TVE el día 22 de mayo. A continuación describiremos la gestión y los recursos de la campaña y finalizaremos el presente epígrafe haciendo un recorrido por los principales hitos y polémicas de la misma. Debemos señalar, que las elecciones generales de 1986 coincidieron con las elecciones autonómicas de Andalucía, en las que sin embargo y a diferencia de las primeras, el protagonismo del CDS fue absolutamente marginal.

La situación económica del partido pareció tocar fondo a comienzos de 1986, cuando se dispuso a solicitar los créditos electorales para la campaña de las elecciones legislativas y se topó con el compromiso adquirido entre la patronal bancaria y el $\mathrm{PRD}^{146}$. En ese momento, las expectativas electorales del CDS, de acuerdo con las

\footnotetext{
145 "La Junta Electoral pide a TVE explicaciones sobre la campaña", El País, 27 de marzo de 1986.

${ }^{146}$ Nuevamente, aparecieron en la prensa declaraciones y valoraciones sobre su problemática relación con los poderes financieros: 'no tengo malas relaciones con los Bancos ni pruebas de que haya presiones en mi contra, pero la realidad es que sin financiación no hay posibilidades de que nuestro mensaje, llegue a todos los sitios y algo de esto pasó en Galicia', dice Suárez, que reconoce que en su etapa de presidente de Gobierno acumuló: "muchos odios", $A B C, 19$ de diciembre de 1985. "Los proyectos políticos de Suárez tropiezan con el impedimento de los problemas financieros. En la casa del CDS se palpa el temor de que los banqueros - que nunca sintieron una especial simpatía por Suárez, desde luego menor que por Felipe González- den portazo al duque", $Y a, 09$ de marzo de 1986.
} 
distintas estimaciones manejadas, se movían en torno al $5 \%$ de $\operatorname{los} \operatorname{votos}^{147}$, y se estimaba en mil millones de pesetas el presupuesto necesario para llevar a cabo una “campaña ajustada"148. José Ramón Caso comenta las impresiones que transmitieron en el seno del partido tanto Suárez como Rodríguez Sahagún en aquellas semanas a raíz de sus negociaciones en busca de financiación bancaria: "el dinero es ilimitado si vais con la Operación Reformista, cero si vais solos"149. Normalmente, si los créditos eran concedidos en función de las expectativas electorales, en este caso y como habitualmente denunciaban partidos minoritarios a izquierda y derecha, primaron las motivaciones políticas.

En este contexto, Suárez sometió a discusión en un círculo muy reducido, la posibilidad de disolver el partido antes de las elecciones. El único camino alternativo era plantear una campaña "muy rompedora" y elaborar un discurso "moderadamente radical" que profundizara en el discurso de centro-izquierda, persiguiendo el voto "prestado" al PSOE e intentara aprovechar las turbulencias generadas a propósito del referéndum ${ }^{150}$. Las listas de Madrid, que tenían "un inequívoco valor simbólico" incluían a Carlos Revilla, Miguel Martínez Cuadrado o Raúl Morodo, presencia dirigida claramente a batallar en ese espacio ${ }^{151}$. Si se fracasaba, al menos, debía ser una "honrosa despedida de la política",

El planteamiento suarista consiguió el apoyo de numerosos intelectuales y creativos y supo conectar rápidamente con la opinión pública y los medios de comunicación. Sin embargo, algunas personalidades políticas del partido prefirieron mantenerse en segundo plano durante una campaña difícil e incierta y no ocupar puestos destacados en las listas. El 30 de abril se anunciaba la marcha de Jiménez de Parga del partido por “razones personales” y se señalaba: "[Caso] tampoco ha sido muy explícito sobre la

\footnotetext{
147 Entrevista con J. R. Caso, 19 de noviembre de 2014; OICDS, 0, marzo 1986; Dirección de Organización del CDS, s.f., (Análisis Electorales), Carpeta 3, 1986; "Evolución de la intención...", REIS, 35, 1986.

${ }^{148}$ Ya, 09 de marzo de 1986; ABC, 02 de mayo de 1986; entrevista con J. R. Caso, 19 de noviembre de 2014. Un dirigente nacional afirmaba en junio de 1986 que se calculó en 1.100 millones de pesetas el presupuesto para llevar a cabo las elecciones generales y andaluzas, Interview undertaken by Richard Gunther, in 1986 (june), AR.

${ }^{149}$ Entrevista con J. R. Caso, 19 de noviembre de 2014.

150 "Jornadas de Acción Electoral” clausuradas por Adolfo Suárez, ABC, 13 de abril de 1986.

${ }^{151}$ HERNÁNDEZ, Abel: "El gran mercado del voto. Las listas buscan el centro perdido", Diario 16, 18 de mayo de 1986.

${ }^{152}$ Entrevista con J. R. Caso, 19 de noviembre de 2014.
} 
participación en las elecciones de Eduardo Punset, García Añoveros y Morodo" ${ }^{\text {153 }}$. La preparación de las listas, elaboradas por los comités provinciales, no generó demasiados problemas y en Madrid, salvo circunstancias excepcionales, fueron ratificadas todas las propuestas iniciales. Como recuerda un dirigente provincial: "las expectativas no eran demasiado grandes" ${ }^{\prime 154}$.

Durante el desarrollo de la II Convención Nacional, -en la que tuvo lugar la aprobación del programa electoral ${ }^{155}$, y en el marco de las últimas negociaciones con la banca, la prensa se hizo eco de las nuevas dificultades de los suaristas ${ }^{156}$. Siguiendo al columnista político Lorenzo Contreras:

Dicen fuentes solventes que a don Adolfo se le ha recomendado desde el mundo del dinero no presentarse a las elecciones. El ex presidente se ha revuelto furioso contra la idea. El viejo impulso luchador ha renacido en él, si es que se encontraba apagado. Pero ese impulso no lo es todo, con ser importante. Y a estas alturas el ex presidente no pasa de ser una figura histórica temida y odiada, o las dos cosas a la vez, por el mundo financiero y por el militar ${ }^{157}$.

El 21 de mayo se daba por cerrada la negociación de los créditos electorales y la noche siguiente tenía lugar una entrevista decisiva de Suárez con Mercedes Milá en el programa De jueves a jueves (TVE-1). Fuentes Aragonés desarrolla exhaustiva y fielmente este decisivo episodio en su biografía política de Suárez y afirma que el abulense: "desplegó en ella sus mejores cualidades como animal televisivo"158.

Como ha reconocido Alfredo Fraile, asesor de comunicación de Suárez durante la campaña del 86', la participación en el programa de Mercedes Milá se consideró decisiva desde el primer momento y se preparó minuciosamente durante días ${ }^{159}$.

\footnotetext{
${ }^{153}$ FERNÁNDEZ, Berta: "Jiménez de Parga [miembro del Comité Nacional] se marcha del CDS”, Diario 16, 30 de abril de 1986. Jiménez de Parga en sus memorias lo relacionó con la decisión del Gobierno, tomada el 21 de marzo, de nombrarle Consejero de Estado, en JIMÉNEZ DE PARGA, Manuel: Vivir es arriesgarse...

${ }^{154}$ Entrevistas con J. R. Caso y con A. Garrosa 19 de noviembre de 2014.

${ }^{155}$ El programa se aprobó en durante la II Convención del partido celebrada el fin de semana anterior durante los días 17 y 18 de mayo, $A B C$, 19 de mayo de 1986.

${ }^{156}$ Todavía el 18 de mayo, durante la II Convención Nacional se decía que las negociaciones con los bancos no se habían acabado: "Preguntado sobre si percibe un boicoteo económico a su partido comentó que "el CDS no está siendo valorado suficientemente ni recibiendo un trato equitativo", GONZÁLEZ IBÁÑEZ, Juan: "El CDS propone la denuncia inmediata del convenio España-Estados Unidos", El País, 18 de mayo de 1986.

${ }^{157}$ CONTRERAS, Lorenzo: "El gran solitario", $A B C, 23$ de mayo de 1986.

${ }^{158}$ FUENTES ARAGONÉS, Juan Francisco: Adolfo Suárez ..., p. 466.

${ }^{159}$ El contacto entre Alfredo Fraile y Suárez se produjo gracias a Rafael Ruiz, hombre de confianza de Caso y quien trabajaba en 1985 en la misma empresa que Fraile. A raíz de un encuentro entre Caso, Viana y Fraile se propusieron trasladar al ámbito de la política, los éxitos que el mánager había conseguido en el mundo de la música, FRAILE LAMEYER, Alfredo: Secretos confesables, Barcelona, Península, 2014, pp. 53-4.
} 
Incluso, se logró conocer previamente el guión de la entrevista gracias a una filtración del equipo de redacción, sin que tuvieran constancia de ello ni Mercedes Milá, ni Adolfo Suárez. El objetivo era que Suárez transmitiera la imagen de "alguien cercano, simpático, espontáneo [...] tenía que seducir a Mercedes Milá [...] Había que romperle los esquemas [...] Aleccioné a Adolfo para que fuera moviendo su silla durante la entrevista y cada vez se acercara más a ella [...] has de llegar a agarrarla del brazo" ${ }^{160}$. La entrevista con Milá tuvo, como recuerdan unánimemente las fuentes consultadas, una tremenda importancia en la inmediata campaña electoral y en el ánimo de los miembros del CDS, que apenas veinticuatro horas después presentaban el programa electoral del partido. Prácticamente por vez primera desde su marcha del Gobierno, Suárez vencía la prudencia y distancia propias de un "hombre de estado" en beneficio de las expectativas electorales del CDS, una tensión que no era ignorada por los militantes:

En lo que resta de campaña, el CDS vivirá de las "rentas" de una intervención ya memorable [en Punto y Aparte con M. Campo Vidal], como la que supuso la realizada en el programa "Jueves a Jueves" [...] en un momento decisivo de desconexión entre la praxis habitual del Presidente de no transmitir con regularidad sus inquietudes o esperanzas a los demás por exceso de responsabilidad histórica -ya subsanado, afortunadamente- y los impulsos "dormidos" del pueblo español, que ha visto así galvanizadas sus ilusiones $[\ldots]^{161}$.

El 23 de mayo se presentaba el programa electoral con una considerable atención mediática, y en el que los protagonistas absolutos fueron los contenidos aludidos la noche anterior, en especial, los problemas de financiación del partido. Por primera vez en toda la Legislatura, Suárez lograba concentrar la atención de la opinión pública y lo hacía en un momento crucial. El 24 de mayo los titulares ponían de manifiesto el éxito de la estrategia centrista. El CDS era una "víctima" de los poderes económicos, la "cenicienta" del cuento, hostigada por la "madrastra", es decir, la banca. En El País se podía leer: "La malvada madrastra era Rafael Termes"; en $A B C$ : "Suárez reacciona con dureza ante la "asfixia económica" y como subtítulo: "El PSOE ascendió a responsables

\footnotetext{
${ }^{160}$ Ibid., p. 75.

${ }^{161}$ PANDO DESPIERTO, Juan: "Perspectiva elecciones 1986", 13-14 de junio de 1986, Carpeta 3, AGP. La presencia televisiva de Adolfo Suárez, al margen de los habituales espacios de propaganda electoral, tuvo continuidad en el programa Punto y Aparte de M. Campo Vidal, por el que pasaron todos los candidatos a la Presidencia del Gobierno y la Junta de Andalucía. En las notas para la preparación de las intervenciones de Suárez y ante la pregunta recurrente acerca de su opinión sobre los demás líderes, se marcaba el siguiente principio "desde el respeto a las personas pero política[mente] agresiva": "Felipe: una promesa que se ha empeñado en no ser nunca realidad", "Fraga: una realidad que nunca ha sido prometedora; Roca: un buen nacionalista catalán. Ni es promesa ni es realidad. ¡Cualquiera sabe!”, “A Gerardo y Carrillo que han estado bien, Carrillo te sitúa a la izquierda y Gerardo a la derecha, se puede reconocer su honestidad y su marxismo", en s. a.: "Nota 12 de junio", Carpeta 3, AGP.
} 
del 23-F"162; en la portada de Diario 16: "Iglesias y Suárez atacan a los banqueros por la distribución de créditos"163 y en La Vanguardia: "Adolfo Suárez reitera sus ataques a la banca por los criterios de reparto de los créditos electorales" ${ }^{\text {"64 }}$. La intervención en TVE avivó, por el contrario, las acusaciones de trato de favor del PSOE en perjuicio del PRD, cuyo candidato fue visiblemente "maltratado" en sus apariciones televisivas ${ }^{165}$.

Las consecuencias electorales fueron inmediatas. Subió repentinamente la valoración de Adolfo Suárez y se multiplicó la intención de voto directo del partido -véase tabla 26-. En los datos extraídos de las series del CIS, transcritos a continuación, y que abarcan desde el 15 de mayo hasta el 20 de junio, sobresale especialmente el intervalo entre el 21 y 29 de mayo, el antes y el después de la entrevista con Milá:

Tabla 26: Intención de voto y valoración de Adolfo Suárez en mayo y junio de 1986.

\begin{tabular}{|c|c|c|c|c|c|c|c|c|}
\hline & $15 / 05$ & $21 / 05$ & $29 / 05$ & $05 / 06$ & $09 / 06$ & $13 / 06$ & $17 / 06$ & $20 / 06$ \\
\hline \% de intención de voto directo (CDS) & 5 & 5 & 7 & 6 & 6 & 8 & 10 & 8 \\
\hline Valoración media de Adolfo Suárez & 4,70 & 4,54 & 5,34 & 5,1 & 5,1 & 5,18 & 4,8 & $5^{166}$ \\
\hline
\end{tabular}

Elaboración a partir de "Tabla 1. Evolución de la intención directa de voto y la valoración media de Adolfo Suárez" y "Tabla 17. Evolución de la intención de voto" y "Evolución de la valoración de líderes políticos" en "Evolución de la...", REIS, 35, 1986, pp. 269-340.

La principal fuente de financiación del CDS se redujo a un crédito bancario de cerca de 150 millones -un $10 \%$ de los créditos solicitados ${ }^{167}$-, mientras que el PRD, en su primera campaña electoral barajaba un presupuesto inicial de en torno a 1.200 millones, habiendo conseguido en torno a 800 millones en préstamos ${ }^{168}$. En cualquier caso, señalaba un dirigente nacional del CDS que esa era "la cifra máxima oficial permitida", "pero cualquier persona que tenga una mínima experiencia [...] le saldrá una cuenta del orden de cuatro veces superior al máximo permitido" ${ }^{\prime 69}$. Las cifras estimadas para el PSOE y AP eran de 2.651 y 1.924 millones respectivamente -véase Tabla 27-:

\footnotetext{
${ }^{162}$ Este era el subtítulo de dicha crónica en $A B C$ en la que se relataba el: "El ejército es otro poder fáctico sobre el que Suárez tiene también proyectos para reducir su presencia en la vida pública", en J. M. Z.: "Suárez reacciona con dureza ante la 'asfixia económica", $A B C, 24$ de mayo de 1985.

163 La crónica interior de Victoria Lafora llevaba por título: "Suárez: "Vivimos una democracia parlamentaria y me niego a admitir una democracia bancaria"”, Diario 16, 24 de mayo de 1986.

${ }_{165}^{164}$ La Vanguardia, 24 de mayo de 1986.

${ }^{165}$ Al margen de la entrevista de Milá y como vimos en epígrafes anteriores era una acusación habitual. Poco antes de dicho episodio escribía A. Papell: "no tiene financiación, por lo que sólo podrían ser paliados en virtud de vergonzantes operaciones indirectas urgidas desde el poder", en PAPELL, Antonio: "Suárez, en la encrucijada", Diario de Navarra, 11 de mayo de 1986.

166 Adolfo Suárez era el segundo líder mejor valorado en las encuestas, sólo por detrás de Felipe González.

${ }^{167}$ Interview undertaken by Richard Gunther in 1986 (june), AR.

${ }^{168}$ POWELL, Charles T.: España..., p. 423.

${ }^{169}$ Interview undertaken by Richard Gunther in 1986 (june), AR.
} 
Tabla 27: "Gastos e ingresos en la campaña electoral de 1986".

\begin{tabular}{|c|c|c|c|c|c|}
\hline & PSOE & AP/PP & CDS & PCE/IU & Media $^{170}$ \\
\hline Gastos & 2651 & 1924 & 153 & 428 & 935,7 \\
\hline Ingresos $^{171}$ & 1843 & 811 & 111 & 186 & 544 \\
\hline \% Ingresos Estado & 86 & 91 & 100 & 77 & 72,2 \\
\hline \% Ingresos Partido & 14 & 6 & 0 & 23 & 273 \\
\hline
\end{tabular}

Elaboración a partir de VAN BIEZEN, Ingrid: "Party financing in new democracies Spain and Portugal", Party politics, 3 (6), julio 2000, pp. 329-42 ${ }^{172}$.

El parco presupuesto centrista le impidió llevar a cabo un mailing en todo el territorio -cuyo coste rondaba los 500 millones $^{173}$ - como hicieron las principales fuerzas políticas. Se debió recurrir a un "mailing selectivo en lo cuantitativo" "174. Según Luis Aznar, presidente del partido en León, “desde Madrid se nos había dicho que nos enviarían ensobrados de papeletas para repartir [...] pero la realidad fue muy distinta, ya que las papeleta no llegaron nunca" ${ }^{175}$. Para un colaborador de presidencia era "el único "agujero" serio, que hubiera permitido recuperar parte de los votos de 1979", mucho más determinante que la escasa cartelería electoral, y sólo en parte compensado por la participación en televisión ${ }^{176}$. De acuerdo con una encuesta del PSOE “el 65\% de los electores llevaban la papeleta de casa" ${ }^{\text {177 }}$. Antonio Garrosa señala como para una provincia como Valladolid el presupuesto de campaña enviado desde Madrid no rebasó las 400.000 pesetas, lo que junto a las aportaciones personales de algunos de los candidatos y los medios particulares empleados, -vehículos, por ejemplo-, fue todo lo empleado para cubrir la campaña ${ }^{178}$. El miembro de AP, Rogelio Baón, ha definido la campaña del CDS como una "campaña modesta"179.

El equipo encargado de preparar la campaña estaba dirigido por Alfredo Fraile y el coordinador de la misma en el CDS fue Chus Viana, quien volvía a ocupar la primera línea del partido -pidió una excedencia en su empresa-, precisamente "cuando algunas

\footnotetext{
${ }^{170}$ Teniendo en cuenta el caso del PNV y CiU.

${ }^{171}$ Excluyendo préstamos bancarios y a posteriori.

172 Traducción del autor.

${ }^{173}$ GARCÍA-LEÓN, Carlos y MARTÍNEZ ECHEVARRÍA, Borja: Antonio...

${ }^{174}$ S.a., s. f., (borrador, campaña, 1986), Carpeta 2, AGP.

175 Por ejemplo, en León la organización provincial consiguió imprimir 5.000 papeletas para repartir en los mítines. Además señala, que a nivel provincial la publicidad electoral se la daban únicamente a un medio de comunicación por provincia, en AZNAR, Luis: Haciendo ..., p. 169.

${ }^{176}$ PANDO DOMÍNGUEZ, Juan: "Perspectivas...", Carpeta 3, AGP.

177 AZNAR, Luis: Haciendo ..., p. 169.

178 Entrevista con Antonio Garrosa, 31 de julio de 2013. En León, comenta Aznar: "Carlos Viloria [miembro del CDS] nos tuvo que hacer un préstamo para no empezar la campaña desahuciados de la sede, y con el alivio de tener unas semanas de respiro por delante", AZNAR, Luis: Haciendo ..., p. 168.

${ }^{179}$ BAÓN, Rogelio: Historia..., p. 661.
} 
figuras $[\ldots]$ se escondían detrás de las puertas para no ser vistos y que no se contara con ellos en las listas del supuesto fracaso" ${ }^{" 180}$. En el equipo de Fraile trabajaban periodistas como Forges (Antonio Fraguas), Raúl del Pozo, Fernando Ónega, Carlos E. Rodríguez (economía), Ramón María Aller, a quienes se unió poco después Pablo Sebastián ${ }^{181}$. El equipo contaba con un sociólogo (Carlos Malo de Molino) y un psiquiatra (Rafael Cruz). Su identidad permaneció oculta a lo largo de la campaña. De acuerdo con Fraile se trabajó durante un mes y medio a tiempo completo y según su testimonio: "no debieron de ganar más de 50.000 pesetas cada uno" ${ }^{\text {"182 }}$. Dentro de este equipo se diseñó el lema de campaña -"El valor del centro"183 - y los dos slogans con más gancho del

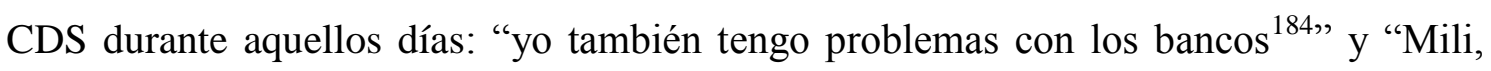
con tres meses basta" 185 . También se diseñaban las intervenciones de los oradores en los mítines del CDS, con quienes procuraban entrevistarse previamente. El recurso a la banca y el servicio militar pulsaban el objetivo fundamental de la campaña: "lanzar a Adolfo Suárez" como aquel que podía resolver los problemas normales de la gente -es decir, el pago de una hipoteca o la realización del servicio militar-. Del mismo modo, se tiño de toques más mediáticos los mítines -al estilo de espectáculos o shows-.

Como sucediera en 1982, Suárez manifestó ciertas reservas iniciales sobre el slogan de campaña -"El valor del centro"- por la evidente relación que guardaba con su actuación durante el $23-\mathrm{F}^{186}$. Las memorias de Fraile exponen perfectamente el doble perfil de Suárez en aquellos momentos, ¿líder de un partido de oposición u hombre de estado?: 'Adolfo, aquí todos te llaman presidente, pero fuera de esta sala ya no lo eres para nadie. Si quieres volver a serlo, tienes que utilizar todo lo que tengas a tu alcance $^{187}$.

En la estrategia de campaña, se identificó al PSOE como principal adversario. Se hablaba tanto de la puesta en peligro de las libertades, la prepotencia, "el riesgo de

\footnotetext{
${ }^{180}$ LAFORA, Victoria: "Los hombres que hicieron posible a Adolfo Suárez multiplicar por diez sus diputados", Diario 16, 26 de junio de 1986.

${ }^{181}$ Jefe de Prensa del CDS, s. a., s. f., (nota de campaña, 1986), Carpeta 2, AGP.

182 FRAILE, Alfredo: Secretos..., p. 64.

183 Slogan que sirvió para generar otras ideas como: "valor seguro", "valor en alza", "valor probado", "dale valor a tu voto".

${ }^{184}$ Slogan ideado por el dirigente del CDS en Extremadura T. Martín Tamayo, Cuestionario escrito de Tomás Martín Tamayo realizado durante febrero de 2014.

${ }^{185}$ Otra célebre frase de campaña fue la de "Guerra al paro".

${ }^{186}$ Fraile había conseguido introducir imágenes del 23-F en el montaje de la entrevista con Mercedes Milá, FRAILE, Alfredo: Secretos...

${ }^{187}$ Ibid., p. 61.
} 
hegemonía", el "clima de miedo" existente en la sociedad como de las "ilusiones rotas" y la frustración generada por la ausencia de un cambio real. En la rueda de prensa posterior a la reunión del Comité Nacional del 28 de abril se declaraba: "restablecer un clima de diálogo en la sociedad, ya que el enorme poder del PSOE ha creado en la sociedad un temor de prepotencia y una sensación de recorte del clima de libertad, para lo que hay que evitar que vuelva a obtener la mayoría absoluta"188.

Junto a este eje, el CDS intentó aprovechar todas las potencialidades políticas de Suárez reivindicando abiertamente sus logros presidenciales como lema de campaña: "el valor del centro". Esta era la gran novedad de la campaña, respecto a 1982. El programa del CDS suponía "seguir la obra aún no concluida que se inició en la transición" a la que ahora sí, se apelaba explícitamente. En expresión de un miembro del Comité Nacional, había que "recuperar la identidad del electorado centrista" "189. Un tríptico publicitario sobre el programa que resumían las razones para votar CDS recordaba:

El único cambio real. Adolfo Suárez fue protagonista del único cambio real que se ha hecho en la España moderna. La democracia, los partidos, la constitución y las autonomías fue obra del centro. Falta el cambio económico, social y cultural que España necesita y solo Suárez puede llevarlo a cabo, sin arrogancias, contando con todos ${ }^{190}$.

Siguiendo los recuerdos de José Luis Garro, -jefe de gabinete de presidencia del CDS-, el plan de apertura de campaña del CDS trató de romper con las fórmulas habituales. Conocidas las enormes reticencias de Adolfo Suárez al acto en sí de la "pegada de carteles" y la subsiguiente y clásica foto "con engrudo y cepillo", en una reunión de los asesores de campaña en la que se encontraban entre otros Fraile, Forges o el propio Garro, se sugirió "sustituir la pegada del clásico cartel por el descubrimiento de una gran valla publicitaria [...] instalada sobre un camión”. El plan era ubicar dicho camión en la Plaza de la Lealtad, “de espaldas a la Bolsa”. A medianoche, Suárez subiría al camión y ante cientos de militantes portando antorchas - a modo de cristianos que han logrado salir de las catacumbas- iniciaría así su intervención: "En la Plaza de la Lealtad/Frente al monumento a la Libertad/De espaldas a la Bolsa/Y en el horizonte el Congreso". La propuesta finalmente se llevó a cabo, aunque se consideró conveniente

\footnotetext{
${ }^{188} A B C, 30$ de abril de 1986. En palabras del experto en marketing y sociología electoral José Luis Sanchís: "la exageración de las características negativas del enemigo puede convertirse en algo habitual y muy práctico", SANCHÍS, José Luis: Elementos básicos para ..., p. 136.

${ }^{189}$ En expresión de un miembro del CN, s. a., 12 de junio de 1986 dirigida a Adolfo Suárez por parte de un miembro del Comité Nacional, Carpeta 3, AGP.

${ }^{190}$ CDS: 15 razones para votar CDS, 1986, Carpeta 3, AGP. En la carta dirigida a los electores se señalaba: "Yo cumplí siempre lo que dije y lo cumpliré una vez más", SUÁREZ GONZÁLEZ, Adolfo: s. t., s. f., (1986), Carpeta 3, $A G P$.
} 
hacer dos pequeñas modificaciones: los militantes no portaron antorchas y se sustituyó la alusión a la Bolsa, "por la más prosaica de "el dinero"”,191.

La campaña de Suárez prosiguió en su localidad natal, Cebreros (Ávila), donde se vivió un ambiente festivo y estuvo acompañado entre otros por Rodríguez Sahagún. Al día siguiente acudió a Segovia, otra provincia donde el suarismo contaba con una sólida presencia. El PSOE, y en menor medida el PRD y la banca, centraban las intervenciones de Suárez. Sin embargo, aquel día la sorpresa llegó de la mano del rotativo El País que por primera vez desde la fundación del partido confirmaba la proyección del CDS como tercera fuerza política: "el CDS de Adolfo Suárez se perfila como ganador de la batalla electoral por el centro" ${ }^{\text {192 }}$. El CDS conseguía un $8 \%$ de los votos y entre 15 y 19 escaños. Asimismo, el 11\% de los encuestados consideraba la opción de Suárez como su favorita de cara a la presidencia. El estudio se había realizado inmediatamente después de la entrevista con Mercedes Milá ${ }^{193}$.

La relación con los medios y la prensa fue objeto de un novedoso tratamiento durante la campaña del 86'. Se empleó un autocar de dos alturas perfectamente equipado que posibilitó una "conexión más directa con la prensa" y en el que se desplazaban Adolfo Suárez, su reducido equipo de apoyo y representantes de los medios. Suárez y los miembros de su gabinete viajaban en la planta inferior, mientras en la zona superior se encontraban los periodistas, a quienes se les entregaba diariamente el programa de actividades previsto -incluidos los horarios de emisión de los partidos de la selección española, en plena celebración del Mundial de Fútbol de 1986- ${ }^{194}$. Muchas veces, las ruedas de prensa o las declaraciones en respuesta a comentarios de otros líderes políticos se realizaban en el mismo trayecto en autobús, optimizando los recursos de

\footnotetext{
${ }^{191}$ Testimonio escrito de José Luis Garro.: "La campaña electoral de 1986”, mayo de 2016.

${ }^{192}$ La mayoría absoluta del PSOE y el ascenso del CDS eran los hechos más relevantes de la encuesta del Instituto Demoscopia realizada para El País, según el editorial: “Un horizonte sin cambios”, El País, 01 de junio de 1986.

193 A la pregunta “¿quién le gustaría a usted que fuese el próximo presidente del Gobierno?”, la preferencia mayoritaria -39\%- fue para Felipe González, seguido a gran distancia por Manuel Fraga (13\%), Adolfo Suárez (11\%) y Miquel Roca (6\%), El País, 01 de junio de 1986; véase, FUENTES ARAGONÉS, Juan Francisco: Adolfo Suárez...

${ }^{194}$ Al margen del autocar y como señala Garro debemos mencionar el equipo conocido como 'Set del Presidente', que iba por delante montando el escenario y los medios técnicos necesarios para la celebración de la cena-coloquio con la que finalizaba cada jornada en la capital de provincia. Como parte del equipo del presidente, se encontraban su jefe de prensa del CDS, Pablo Sebastián, Consuelo Font también responsable de prensa, o el propio Garro.
} 
campaña y permitiendo una interactuación de Suárez con el resto de candidatos, prácticamente en tiempo real ${ }^{195}$.

Alfredo Fraile recuerda en sus memorias otra novedad de la campaña electoral, en este caso relativa al uso de la televisión. El objetivo era sacar el máximo rendimiento de las conexiones en directo que los informativos realizaban diariamente con los distintos mítines "para lanzar los mensajes-fuerza del partido”. El desafío consistía en ¿cómo lograr encajar la frase exacta durante la conexión? La solución pasó por colocar "una tele pequeñita junto a la personas que acompañaba al político" y así saber "en qué momento entraba el Telediario", instante en el que se avisaba al orador sobre la ficha, previamente trabajada, que se quería introducir ${ }^{196}$.

El 2 de junio tuvo lugar un mitin en el Teatro Espronceda de Madrid en el que, junto a Suárez, intervinieron Caso y Revilla, un local abarrotado con algo más de mil personas. Al igual que sucediera los dos días anteriores, las referencias a la banca y a EE.UU. ocuparon los titulares de los medios. El día siguiente, en Barcelona lanzó un tema sobre el que había pasado "de puntillas" durante la Legislatura: las reformas militares de Serra y su política de ascensos. En Sagunto, símbolo de la reconversión industrial, fue recibido por la multitud: "la mayor concentración popular que ha logrado hasta ahora en su campaña electoral. Cerca de 2.000 personas abarrotaron un cine y parte de los alrededores"

En aquella fecha, cambió inesperadamente el tono de la campaña cuando José María Benegas inició un cruce de acusaciones sobre el 23-F, a las que se sumó Guerra quien hizo insinuaciones sobre la conversación que mantuvieron Suárez y Tejero en privado y que fueron respondidas no sin sorna por Suárez ${ }^{198}$. El cambio de actitud del PSOE situaba al CDS en el centro de la campaña como principal receptor de las críticas socialistas -y por ende, rival del partido gubernamental- ${ }^{199}$. Según el socialista J. Feo, director de campaña de F. González:

\footnotetext{
195 Testimonio escrito de José Luis Garro: "Personalidad”, mayo de 2016.

${ }^{196}$ FRAILE, Alfredo: Secretos..., p. 71.

${ }^{197}$ El País, 06 de junio de 1986, Archivo Linz.

198 Siguiendo el borrador de la intervención de Suárez en el mitin del partido en Sevilla: "Señor Guerra con estas cosas no se juega que son muy serias [...] Usted si eso hubiera sido cierto se hubiera muerto de miedo". A continuación, tachado: "Ha dicho que en el 23-F me metieron un Gol. ¿Pero se ha enterado ya Alfonso Guerra de lo que pasó el 23-F? ¿Ya se le ha pasado el miedo?”, s. a., s. f., (mitin-Sevilla), Carpeta 3, AGP.

199 "Suárez trata de forzar un 'cuerpo a cuerpo' con Felipe González", El País, 07 de junio de 1986. "El PSOE introduce en su estrategia el ataque a Suárez”, El País, 10 de junio de 1986.
} 
Durante la campaña, y para nuestra sorpresa, Adolfo Suárez comenzó a atacar al PSOE. El presidente rehusó responderle y el partido sólo decidió hacerlo después de un detenido estudio del comité electoral, cuando ya había transcurrido diez días de campaña electoral, ya que empezaba a mejorar en las encuestas ${ }^{200}$.

Poco a poco, las aguas volvieron a su cauce pero para entonces Suárez había conseguido atraer la atención de la opinión pública e, involuntariamente, recordar uno de los momentos más excepcionales de su carrera ${ }^{201}$.

La primera parte de la campaña había transcurrido favorablemente a los intereses de Suárez, quien el 10 de junio hubo de suspender el viaje a Galicia debido a una ligera afonía -presente durante toda la campaña-, tomando el relevo Rodríguez Sahagún, quien acudió a una cena-coloquio del Club s. XXI. El día 11 Suárez retomó la campaña en Mallorca donde volvió a dirigir sus principales ataques al PSOE retando al partido gubernamental a imitar el slogan usado por UCD en 1979: "UCD cumple". Las encuestas seguían confirmando la tendencia ascendente del CDS, que según la cadena SER se situaba en el $9,3 \%$ de intención de voto ${ }^{202}$. Poco después, un estudio de Demoscopia para El País otorgaba al CDS un $11 \%$ y entre 15 y 29 diputados. El titular del editorial no podía ser más significativo: "El regreso de Suárez"203. En las crónicas de la campaña -C. Valdecantos en El País, F. López Agudín en $A B C$ o V. Lafora para Diario $16^{204}-$, se describía como fórmula del éxito: un exuberante liderazgo personal, una estrategia original, algunos toques populistas y un discurso, en ocasiones deliberadamente demagógico -banca, EE.UU.--

\footnotetext{
${ }^{200}$ FEO, Julio: Aquellos años, Barcelona, Ediciones B, 1993, p. 478. "El criterio benévolo con que se trataba a Suárez al comienzo de la campaña se trocó en estrategia ofensiva contra el Duque, porque el CDS apuntaba en las encuestas como virtual enemigo de la mayoría absoluta. Como Suárez, a propósito de una desatinada alusión de Benegas de que el abulense había dejado el país hecho un caos, dijese que los socialistas en vísperas del golpe de Estado del 23 de febrero de 1981 habían practicado la elegancia social de sentar a su mesa al golpista general Armada [...] La respuesta burlona de Suárez, que no había sido quien había sacado el tema, abundó en la gallarda imagen histórica del abulense [...]" en BAÓN, Rogelio: Historia ..., pp. 670-1.

${ }^{201}$ Lorenzo Contreras y Carlos Seco Serrano salieron -nuevamente- en defensa de Suárez, CONTRERAS, Lorenzo: "El 23-F y el miedo pánico", $A B C$, 09 de junio de 1986 y SECO SERRANO, Carlos: "Ante las urnas", El País, 18 de junio de 1986. También lo hicieron, APOSTÚA, Luis: "Su biografia", Ya, 11 de junio de 1986; JIMÉNEZ LOSANTOS, Federico: "Suárez y Guerra", Diario 16, 09 de junio de 1986; CAMPMANY, Jaime: "Mentira", $A B C$, 09 de junio de 1986.

${ }^{202}$ Según las encuestas-barómetro del Instituto ECO para la Cadena SER a comienzos de mayo los porcentajes en intención de voto al CDS eran del 5,3\% y el tres de junio ya alcanzaban el 8,4\%, $A B C, 12$ de junio de 1986. Un día después, con ironía, escribía Jaime Campmany: "Don Adolfo Suárez es un milagro repetido" en "La Discotheque", $A B C, 13$ de junio de 1986.

${ }^{203}$ Portada: "Suárez e Izquierda Unida mejoran su expectativa de voto y el PSOE baja", El País, 14 de junio de 1986.

${ }^{204}$ Véase, VALDECANTOS, Camilo: "El duque de Suárez busca votos en autobús", El País, 17 de junio de 1986 o LÓPEZ AGUDÍN, Fernando: "Suárez: 'Los socialistas han sido fuertes sólo con los débiles", $A B C, 16$ de junio de 1986 .
} 
Los días finales de campaña, en los cuales recorrió Andalucía, Extremadura y Canarias, estuvieron marcados por el optimismo. En La Vanguardia, una encuesta llevada a cabo por la empresa Line-Staff otorgaba al CDS entre 17 y 28 escaños. La prensa hablaba de la "resurrección" de Suárez ${ }^{205}$. Fernando Ónega, en ese momento miembro del equipo de campaña del CDS, escribía:

Mucha gente se pregunta Sr. Suárez ¿por qué esta resurrección? Bastantes lo atribuyen a aquella noche clamorosa con Mercedes Milá. Pero eso es poco. Aquí se ha creado un ambiente solidario con el castigado por los poderes fácticos. [...] Mártir y rey. Nostalgia de tiempos de mayor libertad y de mayor emoción [...] Y también un curioso complejo de culpa. La sensación colectiva de que todos hemos sido un poco, un mucho injustos con Vd. [...] Y creo que la gente ve algo más todavía. Ve al hombre de pueblo que se llega a Cebreros y dice: yo soy el hijo de la Herminia, y el nieto de la tía Josefa. Como todos ${ }^{206}$.

El éxito del CDS desconcertaba a su derecha -donde se ofrecían pactos postelectorales in extremis- y se apelaba al "voto útil", y a su izquierda, que lo percibía como un "aviso" al PSOE. En todas las localidades superaron las expectativas de asistencia, espoleados por una tendencia al alza. En Las Palmas se consiguió llenar el Insular con más de 10.000 personas: "ya casi al final y con las encuestas a favor, los responsables canarios indicaron la conveniencia de organizar el acto en el Estadio Insular [...] [C. Viana] aceptó el reto de no llenar y fue quien dijo: 'nos la jugamos, pero vale ${ }^{, 207}$. Una experiencia similar se vivió en Valladolid, donde se rebasaron las previsiones en el mitin final de campaña celebrado con la presencia de Suárez el día 20 de junio. El Teatro Calderón, donde tenía lugar el evento, se vio desbordado por la inesperada y gran afluencia de público ${ }^{208}$. El evento organizado para el cierre de campaña en la Plaza Mayor de Madrid constituyó un auténtico mitin-espectáculo, precedido de actuaciones en directo, y conducido por los presentadores de televisión Guillermo Summers e Ignacio Salas. Fue el colofón de la campaña del CDS en la que, en contraste con 1982, había habido más "desparpajo mitinero", "menos prudencia y cautela" y más ambición ${ }^{209}$.

Una última polémica, aunque de menor impacto que la relativa al 23-F, arreció en la prensa durante aquellas últimas jornadas de campaña. Desde el CDS, se denunciaba el

\footnotetext{
${ }^{205}$ Editorial: "Los ciudadanos deciden", El País, 22 de junio de 1986; CRESPO, Pedro: "El misterio de las matrículas", $A B C, 20$ de junio de 1986.

${ }_{206}$ ÓNEGA, Fernando: s. t., 19 de junio de 1986, Carpeta 3, AGP.

${ }^{207}$ LAFORA, Victoria: "Los hombres que hicieron posible a Adolfo Suárez multiplicar por diez sus diputados", Diario 16, 26 de junio de 1986.

${ }^{208}$ Entrevista con A. Garrosa, 31 de julio de 2014.

${ }^{209}$ En expresión de RODRÍGUEZ, Rogelio: "Suárez: 'La única preocupación de Felipe es permanecer en el poder", $Y a, 21$ de junio de 1986.
} 
tratamiento por parte de los medios de comunicación social del estado. Las quejas de Suárez provenían de la supuesta exigencia por parte de EFE del pago de los gastos y desplazamientos de un redactor, a condición del seguimiento de la campaña ${ }^{210}$. Estos comentarios, realizados el día 19 de junio, fueron desmentidos al día siguiente en $E l$ País en una carta del director de la agencia EFE, Ricardo Utrilla ${ }^{211}$, respondida a su vez por Jesús María Viana. El coordinador de campaña del CDS solicitaba el cese del presidente de EFE ya que había pruebas suficientes para demostrar que la agencia, a diferencia de otros medios de comunicación, había demandado sufragar los gastos a costa de los distintos partidos, condición que no fue aceptada por el $\mathrm{CDS}^{212}$.

Un aspecto más delicado aún del tratamiento informativo recibido por el CDS, y que no llegó a trascender a la prensa fueron las denuncias sobre el "acoso a los profesionales de la información" existente tanto en los medios de comunicación estatales como en otras empresas periodísticas. Estas presiones hacían referencia al "enfrentamiento Felipe González-Lorenzo Contreras", y "las limitaciones y presiones" que estaba "recibiendo Pepe Oneto [quien] cada vez que escribe a favor de Adolfo Suárez, le dejan reducida la columna a la mitad, le colocan en la última página, etc." ${ }^{\text {213 }}$. El equipo de Suárez se decantó por aludir sólo puntualmente a ello a lo largo de la campaña ${ }^{214}$. Apenas un mes después, José Oneto que había abandonado un año antes la dirección de Cambio $16^{215}$, demandaba al grupo editorial dirigido por J. Tomás de Salas apelando a la cláusula de conciencia. Entre las razones, se encontraba la estrecha vinculación entre Grupo 16 y la Operación Roca ${ }^{216}$.

En suma, entre la pre-campaña y la campaña electoral Suárez recorrió 15.728 kilómetros para lo que fueron necesarios doce desplazamientos en avión y se dispuso de un autobús preparado por el partido. Como había sucedido en anteriores elecciones, su ausencia en algunas circunscripciones provocaba las iras o el desánimo entre la militancia provincial, una reacción acentuada en un partido de las características del

\footnotetext{
210 "Adolfo Suárez: 'Para mí no hay más adversario que el PSOE"”, $A B C, 20$ de junio de 1986.

${ }^{211}$ Quien se refería en la carta al "duque de Suárez", UTRILLA, Ricardo: "Suárez y la agencia EFE (carta al director)", El País, 21 de junio de 1986.

212 VIANA, Jesús María: “Utrilla y la agencia EFE”, El País, 22 de junio de 1986.

213 "Nota de campaña del 19 de junio de 1986", Carpeta 3, AGP.

${ }^{214}$ Alusión omitida en la intervención en Córdoba, s. a., s. f., (mitin-Córdoba), Carpeta 3, AGP.

${ }^{215}$ DÍAZ HERRERA, José: Pedro J. Ramírez..., p. 193.

216 "José Oneto invoca la cláusula de conciencia en su demanda contra el Grupo 16", El País, 30 de julio de 1986.
} 
$\mathrm{CDS}^{217}$. En cuanto a su participación en los medios tuvo un total de 50 intervenciones en periódicos y revistas y dio 23 ruedas de prensa. En la radio, concedió 12 entrevistas y 4 en televisión -2 en TVE $^{218}$, 1 TV Galicia y 1 TV Canarias ${ }^{219}$-. De acuerdo con un análisis publicado en Diario 16, Suárez fue el penúltimo líder con menor tiempo de apariciones total en TVE y el CDS, el último, en el cómputo de partido ${ }^{220}$. A lo largo de la campaña participó en 25 mítines, en 14 comidas-mitin, 12 cenas-mitin y otras tantas reuniones, inauguraciones o visitas (un total de 11).

Tabla 28 a): Localidades recorridas durante la campaña electoral.

\begin{tabular}{|l|l|}
\hline Localidad & Fecha \\
\hline Madrid & 30 de mayo \\
\hline Ávila & 31 de mayo \\
\hline Segovia y Toledo & 1 de junio \\
\hline Madrid & 2 de junio \\
\hline Barcelona & 3 de junio \\
\hline Madrid y Alicante & 4 de junio \\
\hline Valencia & 5 de junio \\
\hline Zaragoza & 6 de junio \\
\hline País Vasco & 7 de junio \\
\hline Asturias & 8 de junio \\
\hline Galicia (suspendido) & 9 de junio \\
\hline Madrid & 10 de junio \\
\hline Mallorca & 11 de junio \\
\hline Madrid & 12 de junio \\
\hline Madrid & 13 de junio \\
\hline Córdoba y Sevilla & 14 de junio \\
\hline Mérida y Madrid & 15 de junio \\
\hline Madrid & 16 de junio \\
\hline Las Palmas & 17 de junio \\
\hline Tenerife & 18 de junio \\
\hline Madrid & 19 de junio \\
\hline Madrid & 20 de junio \\
\hline
\end{tabular}

Elaboración propia a partir de la documentación en Carpeta 3, AGP.

\footnotetext{
${ }^{217}$ Luis Aznar relata la reacción de la organización leonesa del CDS cuando se confirmó la ausencia de Suárez: "el cabreo en la sede era mayúsculo. Reuniones del comité, protestas de los afiliados que más se estaban entregando a la causa, lloros y lamentos. Todo estaba perdido. Enviamos un telegrama a Jesús Viana, responsable de la campaña en estos términos: "Manifiesto enérgica protesta viajes presidente. Trato vejatorio a León. Recorrido absurdo. Imprescindible presencia. Saludos”, AZNAR, Luis: Haciendo..., p. 170.

${ }^{218}$ Delegó en Fernando Castedo su presencia en el debate de TVE 2 junto a representantes de PSOE, CP y PRD, el 17 de junio, El País, 22 de junio de 1986.

${ }^{219}$ Aparecieron entrevistas en los principales medios nacionales: RNE, 17 de junio de 1986, El País, 14 de junio de 1986; ABC, 19 de junio de 1986 o en $Y a, 20$ de junio de 1986. En El País, se publicó un artículo durante la jornada de reflexión, síntesis del mensaje de campaña, SUÁREZ GONZÁLEZ, Adolfo: "El valor del centro", El País, 21 de junio de 1986.

${ }^{220}$ Diario 16, 22 de junio de 1986.
} 
Tabla 28 b): Espacios electorales del CDS en TVE y RNE.

\begin{tabular}{|l|l|}
\hline TVE & Día 12 y 17 de junio (noche) \\
\hline RNE & Día 13 y 18 de junio (mañana) \\
\hline
\end{tabular}

Elaboración propia a partir de la documentación en Carpeta 3, $A G P^{221}$.

\section{5. El discurso de campaña de Adolfo Suárez: felipismo y Transición}

Las intervenciones de Suárez a lo largo de la campaña obedecieron a un patrón similar, aun alterando el orden, el énfasis o algunos de los puntos desarrollados en función de la localidad o las declaraciones del resto de dirigentes políticos. Los discursos eran preparados por su gabinete $\mathrm{y}$ en última instancia, subrayados $\mathrm{y}$ corregidos por el propio Suárez. El PSOE y Felipe González copaban la práctica totalidad del discurso centrista, que sólo así podía presentarse como alternativa y competir por el electorado de centro-izquierda ${ }^{222}$. Debido a la trascendencia de las elecciones del 86' en el devenir del CDS y en la trayectoria política de Suárez -una vez abandonada la Presidencia de Gobierno- consideramos necesario detenernos en el análisis de sus intervenciones a lo largo de estas semanas y en particular a la construcción del discurso sobre el Gobierno socialista y el PSOE.

Las notas de campaña relativas al PSOE estaban agrupadas en una serie de ítems cuya sola enumeración resulta reveladora sobre la retórica empleada por el suarismo: apego al poder, capacidad, control, engaño, ideología, información, sentido ético, parlamentarismo o convicción ${ }^{223}$. El retroceso de las libertades y desprecio al diálogo eran los ejes de las críticas del CDS al ejecutivo.

Si tomamos como hilo conductor una de las intervenciones de campaña de Suárez observamos los siguientes planteamientos ${ }^{224}$. En primer lugar, se solía hacer un recorrido general por el espacio electoral. El centro político "que sola y exclusivamente pertenece al CDS” debía volver a ocupar el papel que le correspondía en la Historia de

\footnotetext{
${ }^{221}$ Los mismos espacios de los que disponía IU, PRD y MUC.

${ }^{222}$ Durante la campaña, muchos de los discursos fueron preparados por Raúl del Pozo y Fernando Ónega, FRAILE, Alfredo: Secretos...

223 "Notas sobre el PSOE", Carpeta 3, AGP.

${ }^{224}$ Las citas recogidas a continuación están basadas en el texto "Valencia", s. f., (mitin Valencia), Carpeta 3, AGP.
} 
España. La derecha "dividida entre reformistas y conservadores ${ }^{225 \text { " }}$ recibía una menor atención: CP ocupaba un plano absolutamente secundario en los mítines ${ }^{226}$ y el PRD, aunque era ignorado, no dejaba de ser, el "obstáculo a remover", la "conditio sine qua non" para reforzar la posición de centro del $\mathrm{CDS}^{227}$.

Las razones del desgaste electoral del PSOE radicaban en que había defraudado muchas de las ilusiones puestas en 1982. La actitud de Felipe González, otrora esperanzadora y ética había cambiado profundamente: "ya saben que el presidente no siempre dice la verdad", "no cumple lo que promete", "defrauda las esperanzas", "ha preferido mandar, que no gobernar, en favor de las clases más privilegiadas" y "sobre todo [...] ha estado más ocupado en el control y la promoción de su propio partido que en buscar soluciones a los graves problemas de la vida nacional": el paro, la descapitalización de las PYMES o la pérdida de poder adquisitivo de numerosos colectivos -agricultores, pescadores, pensionistas, etc.-. El CDS quería recuperar el electorado centrista y progresista que "tomaron prestado" y que Suárez cifraba en 3,5 millones-.

Felipe González era un político sin programa, "cuando lo ha tenido, no lo ha cumplido", sin ideas -“entró en la vida política con una ideología y ahora está practicando [...] un pragmatismo conservador" ${ }^{228}$-, entrometido en la vida del resto de partidos, “como ya lo hizo con UCD durante la etapa de la transición política española

\footnotetext{
${ }^{225}$ Una nota de campaña del CDS recogía una noticia de $A B C$ que afirmaba que "los programas CP y PRD son idénticos" y "exigía la retirada de algunas candidaturas". "Nota: "El tapado de Fraga es Roca". "La derecha descubre sus cartas -C.P. -PRD" en el documento: "Tres noticias importantes", s. f., Carpeta $3 A G P$.

${ }^{226}$ Por parte de la CP, como ha reconocido J. I. Wert (15 de noviembre de 2002): "En la campaña del 86 había un desconcierto total en AP en el punto de vista del voto útil. Hasta que empezó propiamente la campaña el terror era el PRD, nadie se dio cuenta de lo que estaba pasando con el CDS. Hasta que salieron las primeras encuestas [...] que señalaban que el PRD no era nada y que en cambio el CDS era el competidor relevante [...] En las elecciones de 1986, nosotros [AP-PDP] ni llegamos a hablar del CDS", en LAGO PEÑAS, Ignacio: El voto estratégico en las elecciones generales en España (1977-2000), Madrid, CIS, 2005, pp. 176-7.

${ }^{227}$ En una carta de colaboradores del CDS dirigida al Gabinete de Presidencia se identificaban tres líneas principales de crítica hacia el PRD. Estas tenían que ver con la banca -que había obtenido los "mayores beneficios de su historia"-, con la legitimidad del CDS sobre el espacio de centro y sobre su heterogeneidad, es decir, el "magma" regionalista, nacionalista, de derechas y tecnocrático. El PRD se había convertido en un partido con "más líderes que militantes", en VEGAS, Serafín, PANDO, Juan y GÓMEZ DE SANTAMARÍA, Pedro: s. t., 30 de mayo de 1986, Carpeta 3, AGP.

${ }^{228}$ En Gijón señalaba que "no es que se haya convertido a la socialdemocracia sino que se ha convertido en un Partido Conservador y acentuaba sus críticas en este sentido: "no es que se haya llevado bien con la Banca es que ha cohabitado con ella"; "no es que se haya lleva bien con USA, es que se ha convertido en un súbdito" [...] "Por eso llaman revolucionario a un programa como el nuestro". Y añadía: "estamos recibiendo en todas las sedes el Partido en España adhesiones [...] muchos de ellos que se confiesan votantes frustrados del PSOE”, s. t., s. f., (mitin-Gijón), Carpeta 3, AGP.
} 
que él mismo quiere borrar de nuestra historia". Adolfo Suárez reivindicaba la Transición, durante la cual el PSOE no supo "estar a la altura de las circunstancias",229 y criticaba el intento de F. González de dar a entender que la "historia de España comenzó en 1982" y que se parecía querer "borrar de la memoria de los españoles". Proseguía:

De todas maneras señor González, yo que dirigí la Transición Política Española que usted quiere olvidar o minimizar, me permito incluirle entre las personas que colaboraron en ella, no se preocupe señor González, porque la Transición no la hice yo solo la hicimos todos los españoles, aunque eso sí con el esfuerzo especial y la segura dirección de las mujeres y hombres del centro progresista, que hoy hereda con todos los derechos Centro Democrático y Social.

El siguiente apartado del discurso, llevaba la lucha dialéctica al terreno personal a propósito de un supuesto debate entre ambos, rehuido por González ${ }^{230}$. Todas las referencias a su connivencia con los poderes fácticos y la denegación de créditos al CDS estaban tachados, en su lugar, y en un tono más moderado señalaba: "no me tenga tanto miedo [...] yo soy un hombre respetuoso [...] y yo sabré en un debate político reconocer incluso los aciertos que ha tenido su gobierno; cosa que nunca hizo usted conmigo cuando estaba en la oposición”.

Las intervenciones de los últimos días de campaña recogieron las buenas expectativas electorales que confirmaban al CDS como tercera fuerza política ${ }^{231}$. El CDS, a pesar de los escasos medios económicos, había sido el único partido capaz de poner "nervioso" al PSOE, de amenazar con arrebatarle la mayoría absoluta, "y luego, o a lo mejor al mismo tiempo, quitándole el gobierno", "yo ya le vencí dos veces y ahora le venceré por tercera vez". Alfonso Guerra ${ }^{232}$, el paro o la supuesta necesidad de un gobierno fuerte, argumento defendido desde el PSOE, centraron las referencias de Suárez. A este respecto Suárez criticaba que el último parlamento había sido el menos dialogante y paralelamente, el menos creador de la democracia y en una nota de campaña señalaba: "pero no quiero que siga concediéndome ese honor de ex presidente. Yo quiero sustituirle [...] En las democracias europeas no hay hombres providenciales.

\footnotetext{
229 "Creo que pide mansedumbre [...] FG. Pide paciencia. En la oposición no la tuvo -practica de acoso y derribo- y en el gobierno no ha cumplido [...] FG dice que o la mayoría absoluta o el país es ingobernable", notas escritas en el documento: "Tres noticias importantes", s. f., Carpeta 3, AGP.

${ }^{230}$ Glosado con el término bronca, en el caso del mitin en Valencia, (mitin-Valencia) Carpeta 3, AGP.

${ }^{231}$ En el comentario de una noticia de El País sobre "la victoria del centro" se señalaba: "toda una lección para los banqueros". En el comentario interior: "Jubilar a mi CDS" [subrayado]. 200.000 37\% [aumento de beneficios de la banca], en "Tres noticias importantes", s. f., Carpeta 3, AGP.

232 "A nadie da miedo la persona de Alfonso Guerra pero sí es de temer y lamentar la institución Alfonso Guerra" en "Nota 18 de junio", s. f., Carpeta 3, AGP.
} 
Hasta De Gaulle se fue ${ }^{233}$ ". Sin embargo, y a pesar del tono de campaña, los pasajes más belicosos eran descartados:

Nos han llegado informaciones a C.D.S. de que la guerra sucia de dossiers, de descalificaciones, de calumnias, de montajes televisivos está ya en marcha, que Alfonso Guerra dirige con manu militari la iniciativa política por orden expresa de un Felipe González crispado... ${ }^{234}$

Las alusiones recurrentes al famoso "carnet socialista" eran comentadas de forma superficial y en tono humorístico ${ }^{235}$. Suárez esquivaba las referencias más explícitas y las susceptibles de iniciar una guerra de ida y vuelta: "la presencia abrumadora, digo, de personas que tienen entre sus méritos profesionales el carné de militante [...] y esto nunca ocurrió conmigo, nunca pasó mientras yo fui Presidente"236.

Uno de los colaboradores habituales de presidencia matizaba algunos extremos sobre la idoneidad del discurso centrista. Era necesario contener el exceso de entusiasmo: “resulta engañosa la posibilidad de triunfo al aproximarse 'estadísticamente' a los $20 \mathrm{o}$ 30 diputados [...] Seamos atrevidos pero conscientes". Ya que las intervenciones televisivas habían sido decisivas (Punto y aparte, De Jueves a Jueves) había que cuidar la imagen de los espacios electorales de TVE; el autor consideraba erróneo intentar dar una imagen excesivamente oficial de Suárez en la televisión -en alusión a su pasado presidencial-: "[que] es sólo admitida y valorada positivamente por una parte minoritaria del cuerpo electoral"237. Era interesante aumentar la naturalidad, la espontaneidad y dar mayor agilidad a los discursos. El final de campaña debía insistir en generar escenas un tanto más “inesperadas”, con recorridos por sectores más populistas. El sector servicios, los profesionales urbanos concentraban toda la atención del CDS y era en el campesinado castellano y las zonas más recónditas del país donde se podía conseguir dar el vuelco electoral. Había que ofrecer una imagen más “asequible, intuitiva, popular", ya que aparecía "todavía como la de un hombre que no se

\footnotetext{
233 "Nota 18 de junio", s. f., Carpeta 3, $A G P$.

${ }^{234}$ El papel de Guerra en la campaña del 86' fue especialmente polémico. En El País, el día 24 de julio, se podía leer en su editorial -a raíz de unas duras palabras de González a Iglesias en la investidura-: "se cebó Felipe González con él, quizá olvidando la impresentable actuación de su vicepresidente, Alfonso Guerra, durante la campaña electoral", editorial: "Dos presidentes", El País, 24 de julio de 1986.

${ }^{235}$ Una nota de campaña señalaba "confunde al Partido socialista con el Estado [...] En vez de decir 'fuera de la Iglesia no hay salvación', ha dicho: 'Fuera del PSOE no hay salvación' [...] El mensaje de Felipe González es digno del Concilio de Trento y ya se sabe que después del Concilio de Trento lo que se estabilizó fue la Inquisición", en s. a.: "Nota de campaña", 17 de junio, Carpeta 3, AGP.

${ }^{236}$ S. f., (mitin-Valencia), Carpeta 3, AGP.

${ }^{237}$ Del mismo modo, se consideraba demasiado sobria la imagen elegida para la carteleria (indumentaria, grafismo, enmaquetado), PANDO DESPIERTO, Juan: "Perspectiva elecciones 1986", 13-14 de junio de 1986, Carpeta 2, AGP.
} 
'arremanga la camisa' para descender a la mina o tomarse un bocadillo con el primer turno de la fábrica". Su imagen de "hombre de estado" constituía su mayor capital y a la vez, su principal limitación en términos electorales: "existe una notoria identificación del líder con el reflejo abrumador del poder antes conseguido o impartido, y esto debe ser corregido con urgencia". En otra ocasión señalaba la necesidad de recurrir lo menos posible a los logros de la Transición "que ahora a muy pocos importan"238.

Un análisis de los titulares de las crónicas de campaña, recogidos en los dos principales periódicos de tirada diaria nacional $-A B C$ y $E l$ País-, refleja el notable éxito del CDS a la hora de trasladar los dos grandes ejes de su campaña al electorado. El PSOE y Felipe González concentraban el 30,3\% de las referencias, las referencias a la banca y EE.UU./defensa el 24,24\% y la Transición/23-F el 21,2\%:

\section{Gráfica 3: Análisis de la presencia del CDS en los titulares de prensa durante la campaña (1986).}

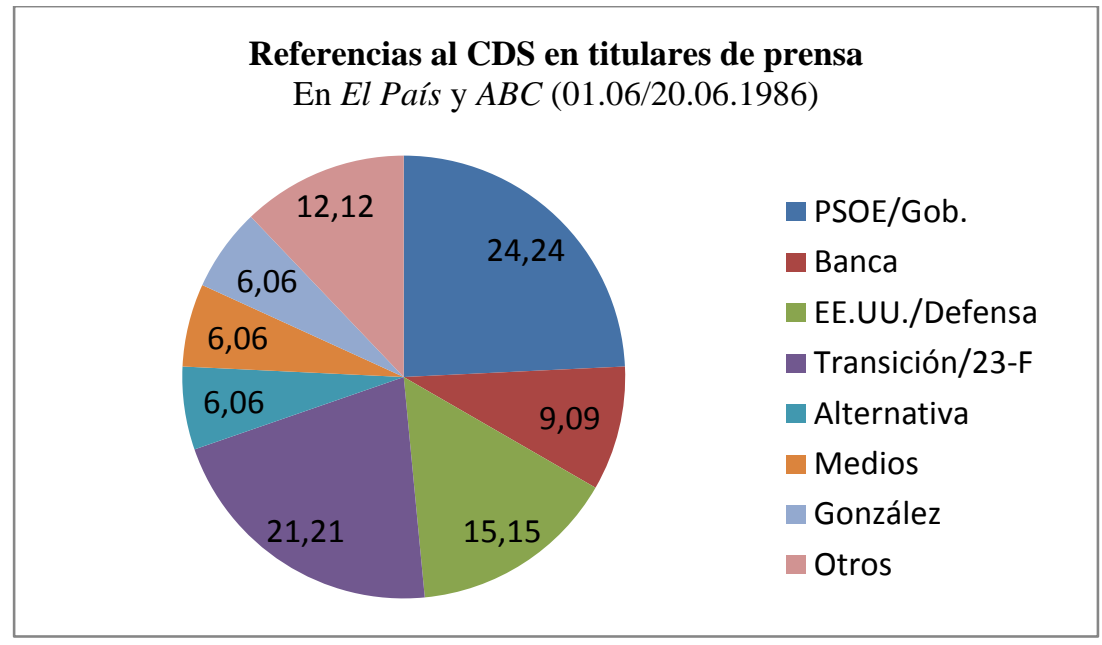

Elaboración propia.

Los ataques del CDS fueron respondidos desde el PSOE en base a tres ideas con las que se intentaba desacreditar la experiencia y credibilidad gubernamental de Suárez -el Duque-. Sus ejecutivos dejaron al país en la bancarrota, lastrado por el terrorismo y ninguneado en Europa ${ }^{239}$. Las notas de campaña de Suárez contraatacaban con las siguientes afirmaciones: "herencia=democracia" y la reivindicación del "ducado", como una concesión por los servicios prestados al país. En el mitin de Sevilla, Suárez señalaba: "nadie en la Historia de España tuvo tanto poder como Felipe González y el

\footnotetext{
238 Ibid.

239 Suárez respondía así a las acusaciones de Alfonso Guerra: “¿Cómo puede consentir que todo un presidente de la nación diga estas barbaridades?", s. a., s. f., (mitin-Sevilla), Carpeta 3, AGP.
} 
líder socialista lo ha despilfarrado". Y sobre las críticas a su etapa en Moncloa se defendía señalando que el hecho de que "discuta nuestra gestión de Gobierno en la transición política, que dicho sea de paso fue excelente, en vez [de] discutir el programa no cumplido del PSOE, porque parece que yo soy el presidente saliente y Felipe el entrante y porque en realidad el saliente es Felipe González y el entrante voy a serlo yo". En el mitin de cierre de campaña en Madrid, Suárez manifestaba: "han querido empañar el histórico proceso de la Transición político que causó el respeto y la admiración del mundo entero".

Las referencias al oportunismo y la retórica electoral de Suárez fueron reemprendidas por el socialista L. Solana en las páginas de Diario $16^{240}$. Comenzaba reconociendo su papel histórico como principal artífice de la transición: "Don Adolfo Suárez fue el instrumento impagable para lograr que el franquismo huérfano aceptase, ciego de humos inteligentes, una democracia que jamás supo a dónde le llevaba. Pero ya está. Muchas, muchas gracias señor duque”. Y a continuación, en lo que era la tesis principal de su artículo, intentaba demostrar cómo ni la izquierda, ni el centro tenían reflejo político alguno en él:

Ahora resulta que busca en buena lid, unos votos [...] ¿Qué votos busca Suárez? [...] A. Los que se creen que izquierdismo es igual a frases. B. Los que se sienten defraudados porque el PSOE no dio la vuelta a la tortilla [...] Los comunistas de clase alta. E. Los que quieren un recitado falangista en libertad y sin pistolas [...] G. Dejo aparte los votantes estéticos. Dice que no es ni de izquierdas, ni de derechas, ni de centro [...] Por cierto, lector, ¿sabía usted que don Adolfo Suárez pertenece al CDS? ${ }^{241}$

En vista del programa electoral, inclinado al centro-izquierda, y el discurso de campaña, centrado en la crítica a la gestión del PSOE y Felipe González, El País llamó la atención sobre la estrategia de Suárez y se preguntaba si las formaciones centristas, ¿no eran "formaciones conservadores de rostro humano"? ${ }^{242}$ El día de la votación, valorando su campaña, se preguntaba si la retórica de campaña de Suárez no había desbordado su propio programa electoral: "intenta combinar fórmulas liberales y socialdemócratas que en el verbalismo electoral se sitúan muchas veces a la izquierda del propio PSOE"243.

\footnotetext{
${ }^{240}$ SOLANA, Luis: "Suárez, el guapo voto útil”, Diario 16, 20 de junio de 1986.

241 Ibid.

${ }^{242}$ Editorial: "El espacio del centro", El País, 17 de junio de 1986.

${ }^{243}$ Editorial: "Los ciudadanos deciden”, El País, 22 de junio de 1986.
} 


\section{6. Las múltiples lecturas de los resultados electorales de 1986}

En el presente epígrafe, prestaremos especial atención al análisis de aquellas cuestiones que, en relación a los resultados electorales, más interés suscitaron en los debates políticos de la época. En primer lugar, y tras una valoración general de los votos y escaños obtenidos, recorreremos a través de las páginas de prensa las características del éxito electoral del CDS. A continuación, nos detendremos en el estudio de los datos y reflexiones aportados por los propios dirigentes centristas; nos referimos a las hipótesis sobre el mantenimiento del centro, la recuperación de los llamados "votos prestados" y las propias expectativas reales del partido, en función de los distintos territorios y circunscripciones.

La noche del 22 de junio, Suárez la pasó en el Hotel Welllington de Madrid, lugar elegido para llevar a cabo el seguimiento de la noche electoral. Cuando accedió al hall junto a Chus Viana fue recibido por los militantes del partido al grito de “ $P$ Presidente, presidente!".

El CDS había logrado pasar de 2 a 19 escaños y alcanzar algo más de 1.800 .000 votos. Unánimemente y a uno y otro lado del espectro político, se subrayó el meritorio éxito del CDS que desde "la nada" se había convertido en el tercer partido nacional: "el milagro del centro"244, "triunfador moral"245, "triunfador de esta convocatoria"246, "Suárez asciende triunfal"247 o "triunfo personal muy meritorio"248. Victoria Lafora sintetizaba el transcurso de la campaña, comenzando por el recuerdo de la entrevista con Milá, con el siguiente titular: "Adolfo Suárez: de la calabaza a la carroza de cristal"249. El éxito del CDS era la antítesis del fracaso reformista: "El PSOE gobernará con mayoría absoluta y Suárez aplasta la alternativa de Roca"250. En las interpretaciones más literarias, se había producido un acto de justicia poética: "el dinero da la felicidad, pero no victorias en las urnas" 251 .

\footnotetext{
${ }^{244}$ Editorial: "El lenguaje de las urnas", Ya, 23 de junio de 1986, Archivo Linz.

245 ÓNEGA, Fernando: "Esto está mejor", Ya, 23 de junio de 1986, Archivo Linz.

${ }^{246}$ Editorial: "Los límites de la mayoría”, El País, 23 de junio de 1986.

${ }^{247}$ USSÍA, Alfonso: "Lo siento", $A B C, 25$ de junio de 1986.

${ }^{248}$ CAMPMANY, Jaime: “Teorías del techo", $A B C, 26$ de junio de 1986.

${ }^{249}$ LAFORA, Victoria: Diario 16, 22 de junio de 1986, Archivo Linz.

${ }^{250}$ Portada en El País, 23 de junio de 1986.

${ }^{251}$ ÓNEGA, Fernando: "Esto está mejor", Ya, 24 de junio de 1986, Archivo Linz.
} 
En términos generales, sin embargo, las elecciones arrojaron notables continuidades respecto a los pasados comicios. El PSOE conseguía 184 diputados y mantenía la mayoría absoluta, aunque el porcentaje de votos obtenidos descendía en más de un $10 \%$. La CP conservaba prácticamente el mismo número de diputados (105), a pesar, de que también registraba un menor número de votos (una bajada del 5,4\%). IU mejoraba los resultados obtenidos por el PCE en 1982 y lograba 7 diputados. De entre los partidos nacionalistas, el PNV perdía dos diputados, y sobre todo, destacaba el éxito de CiU que multiplicaba por dos su número de escaños (18), en lo que constituía un rotundo éxito de la Operación Reformista en Cataluña. De forma paralela, tenía lugar un significativo aumento de la abstención en nueve puntos y un fuerte incremento de HB (5).

La "batalla por el centro", como se había conocido en la prensa el extenso número de movimientos políticos producidos a raíz de la disolución de UCD, había deparado las mayores sorpresas: los excelentes resultados del CDS -que ponía fin a la llamada "travesía del desierto"- y el inapelable fracaso del PRD.

Tabla 29: Resultados electorales al Congreso de los Diputados en 1982 y 1986.

\begin{tabular}{|l|c|l|l|l|l|l|l|l|}
\cline { 2 - 9 } \multicolumn{1}{c|}{} & \multicolumn{9}{c|}{1982} & \multicolumn{3}{c|}{1986} \\
\hline Partidos & $\%$ & Votos & Escaños & Coste $^{252}$ & \% & Votos & Esc. & Coste \\
\hline PSOE & 48,11 & 10.127 .392 & 202 & 50.136 & 44,06 & 8.901 .718 & 184 & 48.379 \\
\hline CP $^{253}$ & 25,70 & 5.408 .959 & 106 & 52.520 & 25,97 & 5.247 .677 & 105 & 49.978 \\
\hline CDS & 2,87 & 604.309 & 2 & 302.147 & 9,22 & 1.861 .712 & 19 & 96.779 \\
\hline PRD & - & - & - & - & 0,96 & 194.538 & 0 & - \\
\hline UCD & 6,77 & 1.425 .093 & 12 & 118.777 & - & - & - & - \\
\hline PCE/IU & 4,11 & 772.726 & 4 & 211.780 & 4,63 & 935.504 & 7 & 133.643 \\
\hline Abst. & 20,03 & - & - & - & 29,51 & - & - & - \\
\hline
\end{tabular}

Elaboración propia a partir de bases de datos electorales y TOHARIA, Juan José: “Tras las elecciones: ...".

Una valoración global de los resultados nos permite hablar de unas elecciones de continuidad, de "espera" 255 o, como han expresado algunos autores de "continuidad sin

\footnotetext{
252 "Coste medio en votos de cada escaño conseguido" en TOHARIA, Juan José: "Tras las elecciones...". ${ }^{253}$ En 1982: AP-PDP-UV.

${ }^{254}$ Excluyendo los resultados de Coalición Galega y Convergencia i Unió. En el PRD participaban además el Partido Riojano Progresista, Convergencia Canaria y Unió Mallorquina.

${ }^{255}$ MONTERO, José Ramón: "Elecciones y ciclos electorales en España”, Revista de Derecho Político, 25, 1987, pp. 9-34.
} 
consolidación" ${ }^{\text {256 }}$. El (des)equilibrio parlamentario seguía sin cambios y el sistema de partidos parecía estar todavía en vías de consolidación. Una paradoja cuya raíz residía, siguiendo a J. Tusell: “[en] la derecha y en el centro, en donde existía una gran vacío". Una derecha, en palabras de A. Soto Carmona, "incapaz de convertirse en alternativa real" "257. Para Manuel Ramírez todavía quedaba pendiente: "la auto-estructuración de una derecha moderna, sin ataduras con el pasado. No montaraz, dialogante, neocapitalista, de corte europeo. Que aleje para siempre el complejo de llamarse derecha y que juegue siempre dentro del sistema" ${ }^{258}$. De hecho, el CDS, de acuerdo con Charles Powell, parecía encontrarse cerca de lograr su objetivo de convertirse en un "partido bisagra" para desempeñar el papel que el Freie Demokratische Partei (FDP) jugaba en Alemania y ratificaba el fracaso de la tesis de la "mayoría natural" fraguista $^{259}$.

La constatación del fracaso de la estrategia de CP para ampliar su electorado hacia el centro trajo nuevas lecturas sobre el papel político que debía jugar el CDS: "Suárez será hoy un obstáculo insalvable, pero sin duda, circunstancial, para la tarea de construir una alternativa al PSOE" ${ }^{, 60}$. Para el sociólogo Díez Nicolás las soluciones en el espacio de centro-derecha pasaban por dos estrategias alternativas; una, la reconstitución de un centro fuerte junto a una derecha residual: "esta opción exigiría basarse en el CDS de Suárez. Pero, si bien el PRD ha quedado descartado como alternativa centrista al CDS, el PDP parece ahora dispuesto a disputarle el centro al CDS". La otra requería de la fórmula inversa: una derecha fuerte y un centro residual. Esta opción implicaba un cambio de liderazgo y una nueva imagen "que no se enajene a los más conservadores de Coalición Popular, y que permitiera ampliar su oferta hacia el electorado de centro, incluida por supuesto la recuperación del PDP"261 . J. R. Montero identificaba cuatro características de AP desde sus orígenes, que ahora la impedían constituirse en una alternativa al PSOE: “el liderazgo de Fraga, la búsqueda, en ocasiones errática, de un

\footnotetext{
${ }^{256}$ RAMÍREZ, Manuel: El sistema ..., p. 126; DEL CASTILLO, Pilar y SANI, Giacomo: "Las elecciones de 1986: continuidad sin consolidación”, en LINZ, Juan José y MONTERO, José Ramón: Crisis y cambio..., pp. 625-645.

${ }^{257}$ SOTO CARMONA, Álvaro: Transición y cambio en España. 1975-1996, Madrid, Alianza, 2005, p. 269.

${ }^{258}$ RAMÍREZ, Manuel: El sistema ..., p. 129.

${ }^{259}$ POWELL, Charles T.: España ..., p. 423.

${ }^{260}$ MARAÑÓN Y BELTRÁN DE LIS, Gregorio: "Reflexiones post-electorales", El País, 16 de julio de 1986.

${ }^{261}$ DÍEZ NICOLÁS, Juan: “Análisis y consecuencias de las elecciones generales de 1986”, Cuenta y Razón, 25, 1986, pp. 75-86.
} 
espacio ideológico y electoral propio, la persistente búsqueda de coaliciones electorales y la existencia de expectativas "desorbitadas"262.

Una ulterior lectura de los resultados evidenciaba cierto retroceso del bipartidismo, aunque muy lejos de las manifestaciones proferidas desde la prensa o partidos como el CDS o IU: "el grado de concentración del voto en torno a las dos principales opciones ha experimentado un cierto descenso: en 1982, el voto PSOE/CP representaba en conjunto el 73\% del total; en 1986, el 69\%"263. Sin embargo, se resquebrajaba la sensación de inmovilidad en el panorama político español y lo que era más importante para el CDS, iniciaba una tendencia electoral ascendente ${ }^{264}$.

La interpretación de editorialistas y comentaristas políticos prolongó las opiniones y preocupaciones políticas previas a la noche electoral y en las que la estrategia de Suárez había sido considerada en el mejor de los casos una boutade. Lorenzo Contreras había dejado escrito:

Es decir, la pérdida de votos por la izquierda [...] puede quedar paliada para el PSOE gracias a los méritos que Santiago Carrillo sepa acumular. Y la sustracción de votos por el centro puede recibir un efecto análogo gracias a la presencia de Adolfo Suárez [...] Y todo ello a mayor gloria del felipismo rampante. Resulta un poco decepcionante que dos grandes figuras de la transición política -Suárez y Carrillo- cumplen esta vez un papel distorsionador de esta gran empresa consistente en devolver a la política española un equilibrio del que lleva cuatro años careciendo ${ }^{265}$.

La prensa conservadora analizó los resultados desde dos categorías básicas de análisis: PSOE y centro-derecha. En $A B C$, su editorial del 23 de junio centraba su lectura de los resultados de la oposición en la siguiente idea: "Coordinación del centro derecha"266. El proyecto de Suárez, basado en una concepción personalista de la política, había constituido un obstáculo más de cara a la necesaria convergencia del centro-derecha y ahora, debido al éxito electoral, reaparecía entre las preocupaciones del rotativo madrileño: “en una portada de nuestro periódico que tuvo gran repercusión entre los ciudadanos y escaso resultados entre los líderes políticos, se presentaba una mesa de billar con bolas con los nombre de Fraga, Alzaga, Segurado, Suárez, Pujol,

\footnotetext{
262 MONTERO, José Ramón: "Los fracasos políticos y electorales de la derecha española: Alianza Popular 1976-1986", REIS, 39, 1987, pp. 7-43.

${ }^{263}$ TOHARÍA CORTES, Juan José: "Tras las elecciones...”.

264 Con el consiguiente "efecto de arrastre" entre el electorado, LAGO PEÑAS, Ignacio: El voto estratégico..., p. 156.

${ }^{265}$ CONTRERAS, Lorenzo: "Fútbol, gasolina y elecciones", $A B C, 13$ de mayo de 1986.

${ }^{266}$ El CDS con el 9,22\% de los votos había conseguido - perjudicado por un alto coste medio de cada escaño- un 5,4\% de los escaños, siendo después de IU, el partido con una mayor penalización -véase Tabla 29-.
} 
Roca, Arzallus, Uruñuela y partidos regionalistas"267. La percepción del CDS como obstáculo o elemento perturbador se constataba en cualquier crónica o balance de los resultados y daba lugar a redacciones como la siguiente: “el espacio político existente en la autonomía vasca no permite ninguna disgregación. De hecho, los resultados del CDS, con un aumento de treinta y cinco mil votos, son los que han dado dos diputados a Herri Batasuna" ${ }^{268}$. Fraga, desde la tercera de $A B C$, concluía sus reflexiones sobre las elecciones del siguiente modo: "La unión de las fuerzas no socialistas se está logrando en toda Europa; en España, mucho menos, y a la vista están los resultado"269 . Desde las páginas del $Y a$, se transmitía una mayor cautela y no sólo se insistía en la coordinación del centro-derecha, sino en su necesaria moderación y adaptación a los cambios sociales. Sobre el CDS se apuntaba:

Bástenos decir que en este momento no se aprecian síntomas de rectificación y que el señor Suárez, líder del Centro Democrático y Social, que ha sido la revelación de las elecciones, parece más dispuesto a esperar que en 1990 sea capaz de arrastrar por sí solo la gran mayoría, como hizo en 1977. El tiempo dirá si encuentra 'techo' o es capaz de repetir la hazaña de entonces y ésta no es de las que sólo pueden realizarse una vez en la historia... 270

Los análisis de sociólogos y politólogos en uno y otro periódico seguían obstinados en la confirmación de la hipótesis de la "mayoría natural" y se afirmaba que por vez primera, los votos de la categoría del centro-derecha sumaban más que lo del PSOE.

Tabla 30: Análisis de resultados en $A B C$.

\begin{tabular}{|l|l|l|l|l|}
\hline \multicolumn{5}{|c|}{ Comparación de votos PSOE y Centro-Derecha } \\
\hline & 1986 & & 1982 & \\
\hline Partidos & Votos & $\%$ & Votos & $\%$ \\
\hline PSOE & 8.887 .345 & 44,0 & 10.127 .392 & 48,40 \\
\hline
\end{tabular}

\footnotetext{
${ }^{267}$ Editorial: "Coordinación del centro derecha", $A B C, 23$ de junio de 1986. "El otro día soñábamos con exportar socialistas a Francia. ¡Ay, si pudiéramos importar, a cambio, derechistas!”, CRESPO, Pedro: "El azar y la necesidad", $A B C, 10$ de julio de 1986. Celestino Fernández Ortiz subrayaba el carácter "izquierdista" y demagógico de la campaña suarista y exhortaba en sus conclusiones: "Déjense, señores de la derecha, de culparse unos a otros. Y más unión”, en “A esperar”, ABC Sevilla, 26 de junio de 1986.

268 "Coalición Popular en el País Vasco no contempla ningún debilitamiento en esta autonomía”, $A B C, 26$ de junio de 1986.

269 En relación al CDS, volvía a mostrar su perplejidad: “queda por clasificar y evaluar el fenómeno del CDS. Parece más vinculado a la personalidad de su líder que a un espacio ideológico y social determinado. El tiempo dirá, como siempre, lo definitivo sobre sus erráticas actuaciones y propuestas" en FRAGA IRIBARNE, Manuel: "Lo que el viento se llevó", $A B C, 02$ de julio de 1986.

${ }^{270}$ Editorial: "El examen de conciencia de la oposición", $Y a, 25$ de junio de 1986. Con ironía, "yo me alegro de que el PSOE haya obtenido la mayoría absoluta, para fastidiar y porque me parece necesario. Y para continuar una labor de Gobierno con resultados estables y duraderos. Y para demostrar que no somos Francia", RICO-GODOY, Carmen: "Mayoría absoluta, nada menos", Ya, 24 de junio de 1986, Archivo Linz.
} 


\begin{tabular}{|l|l|l|l|l|}
\hline Centro y derecha & \\
\hline Otros & 9.001 .421 & 44,6 & 8.820 .721 & 42,60 \\
\hline
\end{tabular}

Elaboración a partir de s.a.: "Los resultados electorales muestran el deseo de estabilidad en la sociedad", $A B C, 24$ de junio de 1986.

Un análisis postelectoral en $Y a$ confirmaba el crecimiento del "centro-derecha" concluyendo: "de haber ido todos juntos, el centro-derecha habría ganado las elecciones". No sin antes matizar: "en cambio, la suma de las opciones de centro y derecha (considerando dentro de ése esquema al CDS, que ahora se autodefine como de centro-izquierda progresista), ha aumentado 557.083 votos populares respecto del

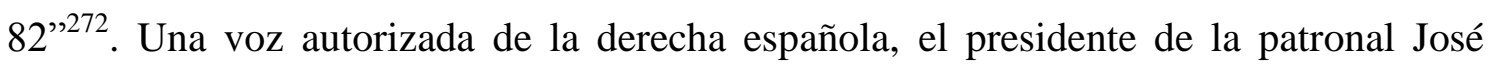
María Cuevas, zanjaba: "lo empresarios no estamos dispuestos a perder el tiempo, mientras la derecha y el centro no se unan se perderá el tiempo"273.

En otro sentido, quienes habían apoyado con mayor ímpetu la Operación Reformista subrayaban la connivencia del CDS y el PSOE entroncando con lo manifestado desde meses antes por los líderes del PRD ${ }^{274}$. Diario 16 glosaba así el éxito suarista:

Con toda evidencia, el PSOE impulsó desde los medios oficiales a este partido, deseoso de que fuera esta opción teóricamente más dócil, y no el otro centrismo, el que recabara la disidencia del PSOE. Sin embargo, una vez puesto en órbita el suarismo, éste ha cobrado hábil autonomía, se ha desmarcado de las pretensiones gubernamentales $[\ldots]^{275}$.

Una idea que era compartida por los principales columnistas políticos del periódico y que se comparaba a lo realizado a la izquierda del PSOE con la escisión comunista de la MUC liderada por Carrillo ${ }^{276}$. Jiménez Losantos, años después, calificó la entrevista de Milá y Adolfo Suárez -entre otros-, como de "entrevistas amaestradas"277.

\footnotetext{
271 "Se incluyen Coalición Popular, PRD, CDS, PNV, CiU, Unidad Valenciana, PAR, UPN, Partido Andalucista y Extremadura Unida", $A B C, 24$ de junio de 1986.

${ }^{272}$ F.L.P.: "La izquierda perdió voto popular y escaños; el centro y la derecha aumentaron", $Y a, 24$ de junio de 1986, Archivo Linz.

${ }_{273}^{273}$ El País, 01 de julio de 1986.

274 "La resistencia de Suárez a participar en una gran alternativa de centro sólo puede entenderse como un servicio prestado al PSOE, al evitarle un considerable adversario electoral" en GONZÁLEZ IBÁÑEZ, Juan: "El reformismo no ha prometido nada a Coalición Popular y no excluye un entendimiento con el PSOE", El País, 14 de julio de 1985.

${ }^{275}$ Editorial: "La mayoría absoluta del PSOE", Diario 16, 24 de junio de 1986; editorial: "El resurgir de Suárez", Diario 16, 26 de junio de 1986.

${ }^{276}$ JIMÉNEZ LOSANTOS, Federico: "El enigma del duque o el monstruo de Guerrastein", Cambio 16, 23 de junio de 1986 en JIMÉNEZ LOSANTOS, Federico: Contra el..., p. 181 y ss.; GUTIÉRREZ, José Luis: "Santiago Carrillo dio la mayoría al PSOE", Diario 16, 23 de junio de 1986, "Adolfo Suárez: ahí está...", Diario 16, 24 de junio de 1986, "Carrillo, el esquirol de Guerra", Diario 16, 24 de junio de 1986; "La hora de la verdad", Diario 16, 22 de junio de 1986, Archivo Linz. En sus memorias, Jordi Pujol también ha aludido al trato de favor del PSOE al CDS, PUJOL, Jordi: Memorias. Tiempo de construir, Barcelona, Destino, 2009, p. 151.

277 JIMÉNEZ LOSANTOS, Federico: “Amarillismo felipista”, $A B C$, 22 de noviembre de 1992.
} 
Asimismo, Diario 16 subrayaba el aviso que las presentes elecciones habían supuesto para el PSOE. En su portada del día 24 de junio profundizaba en esta idea con el titular: "Leguina reconoce que el CDS ha crecido a costa del PSOE"278. También para El País, el resultado debía servir de lección para los dirigentes socialistas: “[...] los socialistas podrán seguir gobernando con comodidad, pero al tiempo no tendrán otro remedio que cambiar el signo de su política, especialmente en lo que se refiere a las autonomías y al uso de las libertades - uno de los caballos de batalla de Suárez durante la campaña [...]-”. En cualquier caso, el CDS no constituía una opción política seria. Su voto era una suma de electores desilusionados con el PSOE y nostálgicos del liderazgo de Suárez: "ha debido pesar más el desapego hacia los otros y la fe en la energía política de su figura emblemática en la transición, y ante el 23-F, que la atención a los concretos términos de su programa" ${ }^{279}$. Como señalaron pocos meses después los politólogos Giacomo Sani y Pilar del Castillo, la estrategia del CDS había pasado por "una vigorosa campaña casi enteramente basada en su atractivo electoral" ${ }^{280}$.

El éxito del CDS era la "gran sorpresa" y la principal novedad de las elecciones. El periodista Luis Herrero ha calificado a Suárez como el "triunfador moral" de aquella noche ${ }^{281}$. Pero, ¿qué significaban los resultados del CDS? Para muchos, las cifras del CDS no permitían hablar de la "recuperación del centro", acaso de su continuidad respecto a las elecciones de $1982^{282}$. Los resultados, ligeramente inferiores a la suma de los votantes de UCD y los del CDS en 1982 obligaban a pensar que en todo caso se había producido un "mantenimiento" de la opción de centro, a la par que una incapacidad de los conservadores para atraerse el electorado centrista. En este sentido, ¿suponía el éxito del CDS la última consecuencia del terremoto electoral iniciado en 1982? En la siguiente tabla comparamos la suma de los votos de CDS y UCD en 1982 con la conseguida por el CDS y la Operación Reformista (PRD/CG) -formados en su mayoría por ex militantes de UCD y partidos fundados a raíz de la desintegración

\footnotetext{
${ }^{278}$ Diario 16, 24 de junio de 1986.

${ }^{279}$ Editorial: "Los límites de la mayoría", El País, 24 de junio de 1986.

${ }^{280}$ RAMÍREZ, Manuel: El sistema..., p. 126; DEL CASTILLO, Pilar y SANI, Giacomo: "Las elecciones de 1986: continuidad sin consolidación", en LINZ, Juan José, y MONTERO, José Ramón: Crisis y cambio..., 1986, pp. 625-645.

${ }^{281}$ HERRERO, Luis: Los que le llamábamos..., 253.

${ }^{282}$ Una hipótesis defendida desde el PSOE y la CP, véanse las declaraciones de Alfonso Guerra, $A B C, 23$ de junio de 1986; $A B C, 24$ de junio de 1986; TOHARIA, Juan José: “Tras las elecciones...". En opinión de Javier Tusell: "el CDS (Centro Democrático y Social) de Adolfo Suárez pasó de dos a 19 escaños, pero este éxito era un tanto ficticio porque quedaba por debajo de la suma de los votos de UCD y CDS en la elección decisiva de 1982", en LYNCH, John (dir): Historia de España (vol. 6. Época Contemporánea, 1808-2004), Barcelona, Crítica, 2007, p. 789.
} 
centrista-. El resultado en ambos casos es prácticamente semejante, salvo en el número de diputados debido a la mayor concentración del voto en el segundo caso:

Tabla 31: Los votos de "centro" en 1982 y $1986^{283}$.

\begin{tabular}{|l|l|l|l|l|l|l|}
\cline { 2 - 7 } \multicolumn{1}{c|}{} & \multicolumn{3}{c|}{1982} & \multicolumn{4}{c|}{1986} \\
\hline Partido & Votos & $\%$ & Diputados & Votos & $\%$ & Diputados \\
\hline UCD & 1.425 .000 & 6,77 & 12 & (PRD, CG) 273.000 & 1,33 & 1 (CG) \\
\hline CDS & 604.000 & 2,87 & 2 & 1.861 .000 & 9,22 & 19 \\
\hline Total & 2.029 .000 & 9,64 & 14 & 2.134 .000 & 10,55 & 20 \\
\hline
\end{tabular}

Elaboración propia a partir de http://www.historiaelectoral.com Fecha de consulta: 28 de junio de 2015.

El CDS analizó los resultados la noche del 4 de julio en el seno del Comité Nacional. En la posterior rueda de prensa, en la que no estuvo presente Suárez desatando nuevamente las referencias a su "mutismo" y sus periódicos silencios, se manejaron unas cifra que implicaban hipótesis sustancialmente diferentes a la expuesta con anterioridad. El Secretario General del CDS consideraba que el trasvase de votos se había producido del siguiente modo:

\section{Gráfica 4: Voto del CDS en 1986 según recuerdo de voto en 1982}

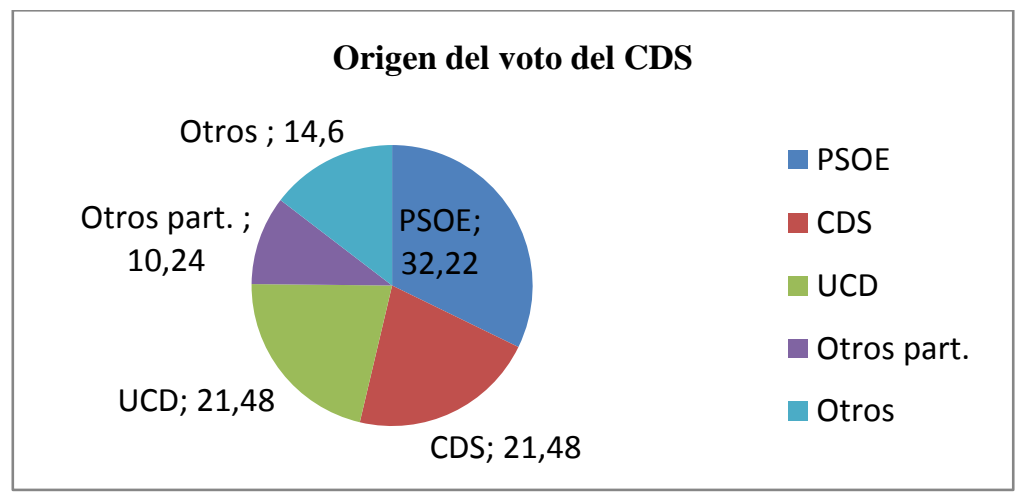

Elaboración propia a partir de El País y Diario 16, 06 de julio de 1986.

Tabla 32: Origen del voto de CDS en 1986.

\begin{tabular}{|c|c|c|c|c|}
\hline & & \multicolumn{2}{|c|}{$\mathrm{N}^{\mathrm{o}}$ de votos } & \\
\hline Partido & $\begin{array}{l}\text { Total } \\
\text { (1982) }\end{array}$ & $\begin{array}{l}\text { Votos transferidos } \\
\text { al CDS en } 1986\end{array}$ & $\begin{array}{c}\% \text { de votos } \\
\text { transferidos al CDS }\end{array}$ & $\begin{array}{l}\text { \% de votos totales } \\
\text { del CDS en } 1986\end{array}$ \\
\hline PSOE & 10.127 .000 & 600.000 & 5,92 & 32,22 \\
\hline CDS & 604.000 & 400.000 & 66,22 & 21,48 \\
\hline
\end{tabular}

\footnotetext{
${ }^{283}$ Se ha decidido excluir en el análisis los resultados de CiU, que como dijimos al principio del epígrafe multiplicó por dos el número de diputados, y aun participando de la Operación Roca era un partido con unas características netamente diferenciadas de los citados (el PRD incluía a su vez al PRP, CC y UM).
} 


\begin{tabular}{|c|c|c|c|c|}
\hline UCD & 1.425 .000 & 400.000 & 28,07 & 21,48 \\
\hline Otros partidos $^{284}$ & 8.893 .000 & 200.000 & 2,24 & 10,24 \\
\hline Otros (abstención...) & - & 200.000 & - & 14,60 \\
\hline
\end{tabular}

Elaboración propia a partir de El País y Diario 16, 06 de julio de 1986 y a partir de bases de datos electorales.

Desde noviembre de 1983 a mayo de 1986, entre un 0 y un $3 \%$ de los votantes socialistas apostaban por el CDS. Las cinco encuestas llevadas a cabo entre el 5 y el 20 de junio otorgaban un porcentaje medio del 5,8\%, prácticamente semejante al 5,92\% estimado por el CDS con posterioridad a la celebración de los comicios (600.000 votos) y una cifra que aunque quizá pueda resultar exagerada parece confirmar al PSOE como la principal fuente de votos de los suaristas en 1986, por encima incluso en términos absolutos de UCD -véase tabla $32-{ }^{285}$. El interés de la transferencia de voto del PSOE al CDS reside en un concepto constantemente agitado por la oposición y estudiado por analistas electorales y politólogos en la época: los "votos prestados" del PSOE (a costa de UCD y el PCE principalmente).

De acuerdo con los análisis electorales existentes y centrándonos en el caso de UCD, J. R. Montero consideraba que entre un $16 \%$ y un $27 \%$ del electorado de UCD en 1979 votó al PSOE en 1982. Otros estudios como el de Pilar Brabo y Carmen Ortiz, en El País, barajaban la cifra de 1.300.000 votos transferidos de UCD al PSOE (el 27,6\% del total de votos perdidos por UCD, casi cinco millones) $)^{286}, 1.200 .000$, de acuerdo con el realizado por Giacomo Sani pocos años después ${ }^{287}$ o 1.700 .000 según políticos como el ex ucedista Jiménez Blanco ${ }^{288}$. Si diéramos por válida la cifra de 600.000 votos transferidos desde el PSOE al CDS en 1986 el porcentaje de recuperación de los llamados "votos prestados" debemos situarlo en un intervalo de entre el 35,45\% y el $59,82 \%$-tabla $33-$.

\footnotetext{
${ }^{284}$ Del total de votos válidos en 1982, menos UCD, CDS y PSOE.

${ }^{285}$ Tabla 15: "Evolución de la intención de voto, según recuerdo de voto. Personas que votaron al PSOE en 1982", "Evolución...", REIS, 35, 1986, p. 306. En cualquier caso, indicativo del alto índice de votos transferidos desde el PSOE hacia el CDS resulta el hecho de que el 3,6\% del total de votantes socialistas en 1986, habían considerado la opción de votar al CDS, -frente a un 0,9\% a IU y un 1,1\% CP-, en las elecciones de 1986, RAMIRO FERNÁNDEZ, Luis: Cambios y adaptación en la izquierda: La evolución del Partido Comunista de España y de Izquierda Unida (1986-2000), Madrid, CIS, 2004.

${ }^{286}$ BRABO, Pilar y ORTIZ, Carmen: "Reportaje: La delimitación del centrismo político En busca del centro perdido. La difícil recogida de los votos que UCD perdió en 1982”, El País, 25 de noviembre de 1985.

${ }^{287}$ SANI, Giacomo: "Los desplazamientos del electorado. Anatomía del cambio", en LINZ, Juan José y MONTERO, José Ramón: Crisis y cambio..., p. 16.

${ }^{288}$ JIMÉNEZ BLANCO, José: Los votos prestados del PSOE, 21 de marzo de 1983.
} 
El principal interés de estos datos reside en una reflexión que merece la pena anticipar ahora, aunque sea someramente. Si el CDS aspiraba a convertirse en alternativa de gobierno en 1990; en julio de 1986 ¿dónde se encontraba su futuro crecimiento potencial?, ¿en el centro-izquierda donde había tenido un éxito notable pero los márgenes de ganancia habían disminuido casi a la mitad?, ¿o en el centro-derecha donde se encontraba el $60 \%$ del antiguo electorado de UCD - ¿votos prestados?- con el que precisamente había logrado vencer dos veces a Felipe González -afirmación esta última incluida en los mítines de campaña de $1986-{ }^{289}$ ?

Tabla 33: Los "votos prestados".

\begin{tabular}{|c|c|c|c|c|}
\hline & \multicolumn{2}{|c|}{$\begin{array}{c}\text { Votantes de UCD en 1979 que } \\
\text { votaron al PSOE en 1982 }\end{array}$} & \multicolumn{2}{|c|}{$\begin{array}{c}\text { Votos "recuperados" por } \\
\text { el CDS en } 1986^{290}\end{array}$} \\
\hline Supuestos (J. R. Montero) & $\%$ & $\begin{array}{c}\text { Número total } \\
\text { de votos }\end{array}$ & $\%$ & $\begin{array}{c}\text { Número total } \\
\text { de votos }\end{array}$ \\
\hline Mínimo & $16 \%$ & 1.002 .974 & $59,82 \%$ & 600.000 \\
\hline Máximo & $27 \%$ & 1.692 .520 & $35,45 \%$ & 600.000 \\
\hline
\end{tabular}

Elaboración propia.

Si partimos de los análisis electorales llevados a cabo por el CDS, los resultados lograban superar los objetivos marcados por el partido a comienzo de la Legislatura y que pasaban, fundamentalmente, por la consecución de Grupo Parlamentario (GP). En febrero de 1983 -los “Objetivos Electorales por circunscripción” y los “Objetivos por militante"- fijaban en 15 los escaños claves -requisito para la formación de GP_291. Para conseguirlos, se debían lograr 1.821 .689 votos $(8,68 \%)$, es decir, 100 por cada militante (cuya cifra en 1986 debía alcanzar los 18.217) ${ }^{292}$. El Comité Nacional en su "Plan de Actuación-84" mantenía estas cifras calculando un mínimo del 8,69\% y 15

\footnotetext{
${ }^{289}$ En torno a tres millones de votos en GONZÁLEZ, Juan Jesús y BOUZA, Fermín: Las razones del voto en la España democrática, Madrid, Los libros de la catarata, 2009, p. 78. Véase también, BRABO, Pilar y ORTIZ, Carmen: "Reportaje: La delimitación del centrismo político En busca del centro perdido. La difícil recogida de los votos que UCD perdió en 1982", El País, 25 de noviembre de 1985; aproximadamente, constituían unos tres millones de votos, SANI, Giacomo: "Los desplazamientos del electorado. Anatomía del cambio", en LINZ, Juan José y MONTERO, José Ramón: Crisis y cambio..., p. 16.

${ }^{290}$ Votos recuperados: es decir, votos que en 1979 fueron de UCD, en 1982 del PSOE y en 1986 del CDS. La cifra refiere al porcentaje de éstos que habiendo votado a UCD en 1979 y al PSOE en 1982 votaron al CDS en 1986.

${ }^{291}$ Según el artículo 23.1 del Reglamento del Congreso, 10 de febrero de 1982.

${ }^{292}$ Interview undertaken by Richard Gunther, in 1986 (june), AR; "1986. Objetivo cumplido", OICDS, 2 , 1986. En septiembre de 1986, el CDS contaba con 14.480 militantes, por debajo de los objetivos señalados, "Líneas de acción política", CDS, 1991.
} 
escaños y un máximo de diputados de 31 , objetivo que se consideraba conseguido en mayo de $1985^{293}$.

Las estimaciones realizadas por la dirección de Organización del CDS, desglosadas en cada una de las distintas circunscripciones, mantenían estos márgenes (entre 14 y 31). Resulta interesante comprobar las vinculaciones entre la estrategia de campaña, los análisis del CDS sobre el "coste" de cada uno de los escaños en votos, -tamaño de las circunscripciones, orientación política, etc.-, y como resultado de lo anterior, las expectativas de éxito en cada una de las provincias (véase, desglose en Anexo XI).

A nivel de CC.AA. se superaron los objetivos electorales previstos (fijados con un valor medio de en torno al 8-10\% de los votos) al menos en 10 de ellas (véase, anexo XII $)^{294}$. El CDS concentraba la mayor parte de sus diputados, un 52,63\%, en tres territorios: Castilla y León, Canarias y Madrid. Galicia y la C. Valenciana contaban con un 10,5\% cada una, y el resto, con un diputado, correspondía a Asturias, Aragón y Cataluña. En Cantabria, Extremadura, Murcia, Baleares, Castilla-La Mancha, Extremadura y las ciudades autónomas de Ceuta y Melilla no se consiguió representación.

La estrategia de campaña del CDS había podido tejer con habilidad un discurso en dos direcciones. Por un lado, había logrado ofrecer una imagen escorada hacia el centroizquierda y que había dado sus frutos no sólo entre las clases medias urbanas, profesionales liberales y trabajadores del sector servicios ${ }^{295}$, sino también en algunas zonas industrializadas (Madrid, Barcelona, Valladolid o Valencia) en las que el desgaste socialista había sido particularmente fuerte. Desde el CDS este electorado, en principio imprevisto, recibió el nombre de "nuevo perfil". Para J. J. Linz, el CDS, en 1986, parecía haber conseguido articular "una opción de centro-izquierda", en competencia

\footnotetext{
293 Comité Nacional CDS: "Plan de Actuación 1985", 13 de mayo de 1985, Carpeta 2, AGP. La relación en 1982 había sido de 1 a 90 según el análisis electoral de BRABO, Pilar y ORTIZ, Carmen: "La militancia de los partidos políticos”, El País, 14 de octubre de 1984.

${ }^{294}$ No disponemos de datos en 5 CC.AA. y en Andalucía y Galicia no se alcanzaron los objetivos, OICDS, 2, julio, 1986.

${ }^{295}$ El dirigente socialista J. Almunia ha comentado: “en esas elecciones emerge el CDS de Suárez, que nos acaba de descolocar, por ejemplo con el tema del servicio militar. Nosotros teníamos a una parte del electorado quemado con la OTAN; el electorado sindical estaba un poco magullado, pero también es cierto que esos votantes son más fieles... Al currante no le iban a decir que votase al PP o a Suárez por castigo por el tema de la OTAN o por la reconversión industrial. Pero todos los sectores urbanos, los jóvenes, los intelectuales, las clases medias, los profesionales, empiezan a fallarnos", IGLESIAS, María Antonia: La memoria ..., pp. 175-6.
} 
directa con el PSOE y espacio donde se concentraba el $45 \%$ del electorado ${ }^{296}$. En las encuestas del CIS en 1986, el CDS obtenía una posición de 5,5 cuando cuatro años antes había obtenido una puntuación media del $5,7^{297}$.

Al ser la tercera o cuarta fuerza política, según las circunscripciones, el CDS salía beneficiado en las provincias con mayor número de escaños en disputa (Madrid, Barcelona, Valencia o Sevilla) y donde el coste de cada uno de ellos en términos porcentuales era menor. Precisamente, estas provincias presentaban actitudes políticas mayoritariamente orientadas a la izquierda. En siete de las circunscripciones consideradas de "izquierdas o progresistas" existían altas probabilidades de obtención de escaños.

En relación a los sectores más conservadores del electorado suarista -votantes de UCD en 1982-, el CDS había defendido la imagen más institucional de Adolfo Suárez y que aportaba como principal argumento sus logros al frente del gobierno durante la Transición. A diferencia del caso anterior y aunque eran más las provincias conservadoras donde el CDS tenía mayores expectativas (9), al exigir un mayor porcentaje en la repartición de escaños, y ser el número de estos en juego considerablemente menor al grupo anterior, presentaban en conjunto, menos opciones de ganancia para los suaristas.

De acuerdo con estas estimaciones, las provincias donde se daba por seguro la obtención de escaño eran: Madrid, Valencia, Ávila, Tenerife, Las Palmas, Asturias, Cantabria, Zaragoza, Barcelona, Segovia y Baleares. En un siguiente escalón se encontraban, Pontevedra, La Coruña, Zamora, Valladolid, Burgos, Salamanca, Álava y Navarra $^{298}$.

El CDS consiguió un total de 19 diputados; si tenemos en cuenta que CP mantuvo prácticamente inalterado los escaños conseguidos en 1982, las principales transferencias se produjeron entre el PSOE-CDS y UCD-CDS. El CDS había arrebatado escaños al PSOE en Madrid (3 de los 5 obtenidos), Valladolid, Salamanca, Zaragoza, Tenerife, Asturias y Valencia. En La Coruña y Pontevedra pasó a sus manos el escaño adjudicado

\footnotetext{
${ }^{296}$ LINZ, J. J.: "Consideraciones finales" en LINZ, Juan José, y MONTERO, José Ramón: Crisis y cambio..., 1986, p. 647. En una escala 1-10, el 45\% del electorado se auto-posicionaba en el nivel 4 o 5, MONTERO, José Ramón: "Sobre las preferencias electorales en España: fragmentación y polarización (1977-1993)" en DEL CASTILLO, Pilar (eds.): Comportamiento político...

297 Ibid.

298 "Elecciones generales [Mapa]", Carpeta 1, AGP.
} 
en 1982 a UCD. El resto de diputados los obtuvo en Alicante, Las Palmas (2), Barcelona, Ávila, -donde fue el partido más votado-, y en Segovia, circunscripción esta última donde lo había conseguido a costa de la CP. En muchas circunscripciones estuvieron cerca de lograr aún una mayor representación: en Baleares por ejemplo, se quedaron a 350 votos. Fue el único caso, donde de acuerdo con los resultados obtenidos hubiera conseguido un nuevo escaño una hipotética coalición entre el PRD y el $\operatorname{CDS}^{299}$. En el Senado, el CDS consiguió tres de los cuatro senadores en disputa en la provincia de Ávila.

Cabe destacar, a modo de conclusión, el espectacular ascenso electoral del CDS en 1986 tanto en número de votos como de escaños y sin embargo, el sólido mantenimiento por parte del PSOE de la mayoría absoluta.

Finalmente, debemos valorar brevemente las elecciones autonómicas andaluzas celebradas también el 22 de junio de 1986. La coincidencia de ambas fechas benefició al CDS, que pudo solapar ambas campañas, en unos comicios en los que no tenía en principio asegurada su presencia por la escasa implantación del partido en buena parte del territorio andaluz y donde otro fracaso electoral -como el acaecido en Galicia en noviembre- podía suponer el golpe definitivo para el partido ${ }^{300}$. En Andalucía de cara a las generales, el objetivo era alcanzar el 7\% y los 238.000 votos, lográndose un 5,61\% (189.640); un resultado sensiblemente superior al obtenido en las elecciones autonómicas donde se vio perjudicado por el "voto útil" logrando el 3,22\% de los votos $(109.628)^{301}$. La escasa implantación del partido había hecho más atractiva para el electorado, según los suaristas, la opción de IU o el PA, partidos con fuerte presencia en Andalucía; un fenómeno de "escisión" del voto por razones de utilidad entre las elecciones generales y autonómicas ${ }^{302}$. El CDS presentó como candidato al cordobés y ex ucedista, Antonio José Delgado de Jesús ${ }^{303}$.

\footnotetext{
${ }^{299}$ DEL CASTILLO, Pilar y SANI, Giacomo: "Las elecciones de 1986: continuidad sin consolidación”, en LINZ, J. J., y MONTERO, José Ramón: Crisis y cambio ..., 1986, pp. 639-40.

${ }^{300}$ Véase, JÁUREGUI, Fernando: "El CDS se plantea no participar en las elecciones andaluzas", El País, 19 de marzo de 1986.

${ }^{301}$ OICDS, 2, julio 1986.

${ }^{302}$ MONTERO, José Ramón: "Voto nacional y voto autonómico: la escisión del voto en las Elecciones de 1986 en Andalucía", REIS, 42, 1988, pp. 177-194.

${ }^{303}$ Presidente Federal del partido en Andalucía y Presidente Provincial en Córdoba. Diputado por UCD en 1977 y antiguo miembro del Partido Social-Liberal de Andalucía liderado por M. Clavero Arévalo, HERAS, Raúl: Enciclopedia política y atlas electoral de la democracia española, Madrid, Temas de Hoy, 1997.
} 

PARTE 2:

APOGEO Y AGONÍA DEL CDS: OPOSICIÓN, PACTOS Y OCASO POLÍTICO DE ADOLFO SUÁREZ (1986-1991) 



\title{
Capítulo 6:
}

\section{EI CDS en la cumbre: una oposición que busca ser alternativa}

\author{
"Adolfo, vuelve; \\ nos rendimos"
}

A raíz de las elecciones de 1986, se inicia una nueva etapa en la trayectoria del CDS. De acuerdo con el Plan Estratégico, desarrollado en 1983, el suarismo entraba en una nueva fase cuya finalización se fijaba hacia 1990 con la celebración de las siguientes elecciones generales. El CDS debía llegar a ser en ese momento alternativa de Gobierno $^{2}$. Según una expresión usada por el propio partido: "el triunfo de CDS es el triunfo de la perseverancia en la consecución de unos objetivos, del mantenimiento de una estrategia en el tiempo, a pesar de los reveses a corto plazo"3.

De acuerdo con documentación manejada por el CDS en las semanas previas al 22J, la importancia de la consecución de un grupo parlamentario residía en que otorgaba la posibilidad de "ir aposentándonos en la memoria colectiva del pueblo español, como la alternativa seria, coherente y honrada". Aumentar su protagonismo político pasaba por saber aprovechar la debilidad de la Coalición Popular, "su descomposición [postelectoral] les va a impedir aún más ser oposición", y alejarse de los maximalismos, de la "furia ciega", del "espectáculo de circo romano" que había caracterizado la política aliancista.

De otra parte, para el CDS, el PSOE era un "partido de aluvión”, que se mantenía unido por la ingente acumulación de cargos institucionales que había conseguido en las elecciones generales, autonómicas y municipales. De acuerdo con los centristas: "si se estropea el pesebre, el PSOE puede acabar disgregándose [...] pesebre que puede limitar una oposición eficaz que utilice todos sus recursos". Y de nuevo, se enarbolaba

\footnotetext{
${ }^{1}$ TUSELL, Javier: "Adolfo, vuelve; nos rendimos [recorte de prensa]", Eslabón, CDS Albacete, 3, marzo-abril 1987.

${ }^{2}$ En base al testimonio de un dirigente centrista: Interview undertaken by Richard Gunther (june 1986), $A R$.

${ }^{3}$ CASO GARCÍA, José Ramón: “Como debe ser”, OICDS, 2, julio 1986.
} 
una teoría sostenida desde 1983 una vez constatada la voluntad reformista y moderada del PSOE: "sus tensiones estructurales son muy fuertes sobre todo por la izquierda".

En los siguientes cuatro años, la acentuación de la prepotencia y unilateralidad del Ejecutivo podía generar las primeras grietas del proyecto socialista: "8 años de dictadura democrática van a ser demasiados para el pueblo español. Hay que ir preparando y ofreciendo una verdadera alternativa ${ }^{4}$. A Adolfo Suárez se le va a echar de menos [...]”. Se concluía: "unos escaños más es lo de menos, lo importante es el año $90 ”$.

Por otro lado, la recién inaugurada tendencia de voto ascendente debía permitir terminar el proceso de implantación y estructuración del partido a lo largo de todo el territorio. Siguiendo el documento anterior: “oposición asentada sobre un partido, CDS, en cuya estructuración hay que seguir trabajando desde la fuerza del grupo parlamentario",

Esta introducción, que es la introducción del suarismo a la etapa que ahora comenzamos, nos permite enunciar los ejes sobre los que construiremos nuestro discurso en los siguientes epígrafes: el trabajo del Grupo Parlamentario, las relaciones con el resto de la oposición, los posicionamientos frente al Gobierno y la construcción del CDS. La transformación de su protagonismo político en el ejercicio de la oposición parlamentaria y la revalidación de sus resultados en las elecciones autonómicas y municipales de 1987 se vio acompañada de la desmembración de la Coalición Popular y el inicio de una larga crisis en la derecha conservadora que duró prácticamente toda la Legislatura. A priori, ante el alborozo de unos y la estupefacción de otros, se estaba generando la "tormenta perfecta" para la irrupción del CDS como alternativa de cara a 1990. Suárez volvía a la primera página de la actualidad política.

\section{1. EI Grupo Parlamentario del CDS (1986-1989)}

Lo que significaba la consecución de un Grupo Parlamentario para el CDS se puede comprender mejor recordando, aunque sea brevemente, lo sucedido la legislatura anterior. El denodado esfuerzo de Agustín Rodríguez Sahagún como portavoz y la

\footnotetext{
${ }^{4}$ Subrayado en el original.

${ }^{5}$ S. a.: Objetivo campaña 86, s. f. (03 de junio de 1986), Carpeta 1, AGP.
} 
actitud, entre simbólica e institucional, de Adolfo Suárez habían supuesto la totalidad de la labor parlamentaria del partido, a la que debemos sumar, ya fuera del Congreso, las ruedas de prensa concedidas por el portavoz y Secretario General, José Ramón Caso. Los posicionamientos del partido en materia económica, militar, internacional, educativa o sanitaria se reducían a estas manifestaciones y cada una de ellas recibía, apenas, un comentario marginal en los medios de comunicación. Ahora, como señalaba El País, "el relanzamiento político de Adolfo Suárez producido en las legislativas de junio tendrá que revalidarse [...] en los inmediatos debates parlamentarios"6.

El Grupo Parlamentario del CDS ocupó las bancadas del Congreso situadas entre los grupos vasco y catalán en "los primeros escaños del centro, justo al lado del pasillo que les separa del lado derecho e inmediatamente detrás del banco azul destinado a los ministros" ". Caso fue nombrado vicepresidente cuarto de la Cámara, Rodríguez Sahagún ejerció como portavoz y Suárez siguió reservando sus intervenciones a aquellas ocasiones en las que interviniera el Presidente del Gobierno ${ }^{8}$.

Tabla 34: Intervenciones en el Congreso de los Diputados de Adolfo Suárez durante la III Legislatura.

\begin{tabular}{|l|l|}
\hline Julio de 1986 & Debate de investidura del Presidente de Gobierno: Felipe González \\
\hline Febrero de 1987 & Debate sobre el Estado de la Nación \\
\hline Marzo de 1987 & Debate de Moción de Censura (por alusiones) \\
\hline Febrero de 1988 & Debate sobre el Estado de la Nación \\
\hline Diciembre de 1988 & Comparecencia del Gobierno ante el Pleno a propósito del 14-D \\
\hline Febrero de 1989 & Debate sobre el Estado de la Nación \\
\hline
\end{tabular}

Elaboración propia.

A comienzos de julio, los recién electos parlamentarios centristas fueron convocados a una reunión en la sede del partido en la Calle Jorge Juan. Allí se debatió la denominación del nombre del Grupo Parlamentario, -en la que se barajó la idea de GP Centrista, en recuerdo de UCD-, escogiéndose finalmente el de GP CDS. En aquella jornada, se llevó a cabo la distribución de los parlamentarios en comisiones en función de su preparación y especialización profesional -el CDS tenía derecho, en ese momento, a dos miembros en cada comisión, (véase, Anexo XIV)-.

\footnotetext{
${ }^{6}$ Editorial: “Ante el nuevo curso político”, El País, 01 de septiembre de 1986.

7 DÍEZ, Anabel: "El CDS y la ruptura en Coalición Popular acapararon la atención en la sesión constitutiva del Congreso", El País, 16 de julio de 1986 y "Distribución de escaños parlamentarios", Documento del Congreso de los Diputados, $A A G$.

${ }^{8}$ El País, 24 de junio de 1986. El portavoz adjunto era León Buil Giral, ABC, 17 de julio de 1986.
} 
Como apoyo al Grupo Parlamentario, se crearon en torno a una veintena de equipos dedicados a las diferentes áreas sectoriales, coordinados y dirigidos por el jefe de gabinete de Adolfo Suárez, José Luis Garro, desde una oficina cercana al propio Congreso. Estos grupos a su vez recogían las distintas sugerencias provenientes de la militancia: enmiendas a los proyectos de ley, iniciativas parlamentarias, etc ${ }^{9}$. Los Grupos Parlamentarios del CDS en el Congreso y en el Senado sufrieron numerosas variaciones a lo largo de la Legislatura incorporando a antiguos miembros del PDPDemocracia Cristiana y del PL, a medida que se producía la desintegración de la Coalición Popular -Anexo XV- y con particular intensidad en dos momentos: la integración del CDS en la ILP (febrero de 1988) y del Partido Liberal y Democracia Cristiana en el PP (enero de 1989).

Tabla 35: Los diputados electos del CDS en julio de 1986.

\begin{tabular}{|c|c|c|c|c|c|}
\hline Nombre & Provincia & Profesión & Cargo CDS & Edad & $\begin{array}{l}\text { Militancia Partidos } \\
\text { Políticos (1977-...) }\end{array}$ \\
\hline Adolfo Suárez & Madrid & Abogado & Presidente & 53 & UCD \\
\hline $\begin{array}{l}\text { Agustín } \\
\text { Rodríguez } \\
\text { Sahagún }\end{array}$ & Ávila & $\begin{array}{l}\text { Doctor en Ciencias } \\
\text { Económicas y } \\
\text { Empresariales y en } \\
\text { Derecho }\end{array}$ & $\begin{array}{l}\text { Comité } \\
\text { Nacional }\end{array}$ & 54 & UCD \\
\hline $\begin{array}{l}\text { José } \quad \text { Ramón } \\
\text { Caso García }^{10}\end{array}$ & Madrid & $\begin{array}{l}\text { Licenciado en } \\
\text { Derecho y Ciencias } \\
\text { Empresariales }\end{array}$ & $\begin{array}{l}\text { Secretario } \\
\text { General }\end{array}$ & 39 & UCD \\
\hline $\begin{array}{l}\text { Rafael Martínez } \\
\text { Campillo }\end{array}$ & Alicante & $\begin{array}{ll}\text { Abogado } & y \\
\text { funcionario } & \end{array}$ & $\begin{array}{l}\text { Presidente } \\
\text { Provincial } \\
\text { Alicante }\end{array}$ & 33 & UCD \\
\hline $\begin{array}{l}\text { Juan Castaño } \\
\text { Casanueva }\end{array}$ & Salamanca & $\begin{array}{l}\text { Agricultor } \\
\text { ganadero }\end{array}$ & -11 & 42 & UCD \\
\hline $\begin{array}{l}\text { Francisco } \\
\text { Moldes Fontán }\end{array}$ & Pontevedra & $\begin{array}{l}\text { Profesor de } \\
\text { Instituto }\end{array}$ & $\begin{array}{l}\text { Presidente } \\
\text { Provincial } \\
\text { Pontevedra }\end{array}$ & 37 & - \\
\hline $\begin{array}{l}\text { Carlos Revilla } \\
\text { Rodríguez }\end{array}$ & Madrid & $\begin{array}{l}\text { Médico. } \\
\text { Neurofisiólogo }\end{array}$ & $\begin{array}{l}\text { Presidente de } \\
\text { la Federación } \\
\text { del CDS- } \\
\text { Madrid }\end{array}$ & 53 & PSOE \\
\hline $\begin{array}{l}\text { Alejandro } \\
\text { Rebollo }\end{array}$ & Asturias & Abogado & $\begin{array}{l}\text { Comité } \\
\text { Nacional y } \\
\text { Presidente de } \\
\text { la Federación } \\
\text { CDS-Asturias }\end{array}$ & 52 & UCD \\
\hline León Buil Giral & Zaragoza & Abogado & $\begin{array}{l}\text { Comité } \\
\text { Nacional }\end{array}$ & 51 & UCD \\
\hline $\begin{array}{l}\text { José Antonio } \\
\text { López Arranz }\end{array}$ & Segovia & Médico & - & 45 & UCD \\
\hline Antonio Garrosa & Valladolid & Doctor en Filosofía & Presidente & 40 & - \\
\hline
\end{tabular}

\footnotetext{
${ }^{9}$ Entrevista con José Luis Garro, 06 de mayo de 2015.

${ }^{10}$ Causó baja el 30 de junio de 1989 para integrarse en el Parlamento Europeo. Fue sustituido por Laura Morso Pérez.

${ }^{11}$ Alcalde de Aldehuela de la Bóveda (Salamanca).
} 


\begin{tabular}{|c|c|c|c|c|c|}
\hline & & $\begin{array}{l}\text { y Letras. Ingeniero } \\
\text { Técnico Industrial } \\
\text { y Profesor de } \\
\text { Universidad }\end{array}$ & $\begin{array}{l}\text { Provincial } \\
\text { Valladolid }\end{array}$ & & \\
\hline $\begin{array}{l}\text { Antonio } \\
\text { Fernández } \\
\text { Teixidó }^{12} \\
\end{array}$ & Barcelona & Titular Mercantil & $\begin{array}{l}\text { Presidente } \\
\text { Provincial } \\
\text { Barcelona }\end{array}$ & 34 & Izquierda extraparl. \\
\hline $\begin{array}{l}\text { Joaquín Abril } \\
\text { Martorell }\end{array}$ & Valencia & $\begin{array}{l}\text { Ingeniero } \\
\text { Aeronáutico }\end{array}$ & $\begin{array}{l}\text { Comité } \\
\text { Nacional }\end{array}$ & 58 & $\mathrm{UCD}$ \\
\hline $\begin{array}{l}\text { Miguel Martínez } \\
\text { Cuadrado }\end{array}$ & Madrid & $\begin{array}{l}\text { Catedrático de } \\
\text { Derecho Político y } \\
\text { Profesor Asociado } \\
\text { de la Universidad } \\
\text { de La Sorbonne }\end{array}$ & - & 51 & $\mathrm{PSI}^{13}$ \\
\hline $\begin{array}{l}\text { Lorenzo Díaz } \\
\text { Aguilar }\end{array}$ & Las Palmas & Médico & - & 56 & - \\
\hline $\begin{array}{l}\text { José Antonio } \\
\text { Santos Miñón }\end{array}$ & Las Palmas & Abogado & - & 47 & UCD \\
\hline $\begin{array}{l}\text { José María } \\
\text { Riobóo } \\
\text { Almanzor }\end{array}$ & Coruña & $\begin{array}{ll}\text { Profesor Titular } & \text { de } \\
\text { Estadística en } & \text { la } \\
\text { Universidad } & \text { de } \\
\text { Santiago } & \text { de } \\
\text { Compostela } & \\
\end{array}$ & - & 35 & - \\
\hline $\begin{array}{l}\text { Pablo Hurtado } \\
\text { Samper }^{14}\end{array}$ & Tenerife & Abogado & - & 47 & $\begin{array}{l}\text { PPC (Partido del País } \\
\text { Canario) }\end{array}$ \\
\hline Federico Ysart & Madrid & $\begin{array}{lr}\text { Licenciado } & \text { en } \\
\text { Ciencias de } & \text { la } \\
\text { Comunicación } & \text { y } \\
\text { Periodismo } & \\
\end{array}$ & $\begin{array}{l}\text { Comité } \\
\text { Nacional }\end{array}$ & 44 & UCD \\
\hline
\end{tabular}

Elaboración propia a partir de $O I C D S, 2$, julio de 1986

Tabla 36: Los senadores electos del CDS en julio de 1986.

\begin{tabular}{|l|l|l|l|l|l|}
\hline Nombre & Provincia & Profesión & Cargo CDS & Edad & $\begin{array}{l}\text { Militancia Partidos } \\
\text { Políticos (1977-...) }\end{array}$ \\
\hline $\begin{array}{l}\text { Alberto Dorrego } \\
\text { (Senado) }\end{array}$ & Ávila & Pediatra & $\begin{array}{l}\text { Presidente } \\
\text { Provincial } \\
\text { Ávila }\end{array}$ & 54 & $\begin{array}{l}\text { UCD } \\
\text { Popular) }\end{array}$ \\
\hline $\begin{array}{l}\text { Celso Rodríguez } \\
\text { Legido (Senado) }\end{array}$ & Ávila & $\begin{array}{l}\text { Ingeniero Técnico } \\
\text { Agrícola }\end{array}$ & - & 37 & - \\
\hline $\begin{array}{l}\text { Tirso Tomás } \\
\text { González } \\
\text { (Senado) }\end{array}$ & Ávila & Industrial maderero & $-{ }^{15}$ & 60 & UCD \\
\hline
\end{tabular}

Elaboración propia a partir de $O I C D S, 2$, julio de 1986

Muchos de los parlamentarios centristas eran auténticos desconocidos entre la clase política. De un total de 22, 13 habían estado en UCD, 6 no contaban con experiencia

\footnotetext{
${ }^{12}$ Causó baja el 14 de junio de 1988 para integrarse en el Parlamento Autonómico de Cataluña. Fue sustituido por Jorge Juan Mataix Hidalgo.

${ }^{13}$ DÍAZ, Elías: “Autobiografía intelectual”, Anthropos, junio 62, 1986, p. 23. Participó en la reunión que dio origen "oficioso", a partir del "grupo tiernista" [Tierno Galván], al PSI/PSP en RUBIO RUBIO, Amalia: Un partido en la oposición. El Partido Socialista Popular, Tesis Doctoral, Universidad Complutense de Madrid, p. 164. En la primera mitad de la década de los 80' se le vinculó con el PDL, Diario 16, 21 de febrero de 1988.

${ }^{14}$ Se integró en el Grupo Mixto el 11 de abril de 1989.

${ }^{15}$ Alcalde de Arenas de San Pedro y Diputado Provincial.
} 
política previa y el resto habían militado en otras formaciones -aunque sólo uno de ellos había ejercido cargos relevantes- ${ }^{16}$. Un análisis sociológico de los parlamentarios nos revela la importancia del segmento de jóvenes profesionales urbanos (Madrid, Comunidad Valenciana, Galicia) relacionados con el mundo de la empresa, la educación o la medicina. Del cómputo total de profesiones nos encontramos con: 3 relacionados con el mundo de la empresa, 6 abogados, 3 médicos, 1 agricultor-ganadero, 4 profesores de universidad o instituto, 2 ingenieros, 1 periodista y 1 titular mercantil. La media de edad aproximada era de 45 años $^{17}$. Finalmente, si tenemos en cuenta los cargos desempeñados en el seno del partido, entre los diputados se encontraban el Presidente del Partido, el Secretario General, cinco vocales del Comité Nacional, cinco presidentes provinciales, dos presidentes de federación y ocho parlamentarios sin responsabilidades de relieve. En resumen, los parlamentarios del CDS constituían en su mayoría un grupo joven, con profesiones liberales y con cierta experiencia política previa, aunque de segundo nivel -véanse tablas 35 y 36-. Un grupo que llamaba la atención a algunos columnistas que como Carlos Dávila se preguntaban:

¿Por qué se negaron Camuñas, Mayor, Añoveros, Sánchez de León, Rafael Calvo, Jiménez de Parga? Creo que por esto: porque el 13 de mayo ni siquiera ellos, consorcios de Adolfo Suárez en el CDS, apostaban un chavo por la suerte electoral del ex presidente $^{18}$.

El CDS, como había anunciado desde la campaña, mudó completamente su actitud respecto a los cursos políticos precedentes. Durante aquel mes de julio, votó en contra de la investidura de González y arrancó el período estival presionando al ejecutivo por un escándalo en Alicante sobre la concesión de administraciones de lotería ${ }^{19}$.

Este salto cualitativo en el ejercicio de la oposición tuvo su primer efecto en el debate de investidura, celebrado el 22 de julio de 1986, en el que Adolfo Suárez ${ }^{20}$. Comenzó su intervención haciendo un balance de la gestión gubernamental desde 1982, marcada por un enorme apoyo popular y político y una coyuntura económica

\footnotetext{
${ }^{16}$ Carlos Revilla había sido Presidente de la Diputación Provincial de Madrid entre 1979 y 1981 por el PSOE.

${ }^{17}$ No llegaba a los cuarenta años si no se computaban los diputados del CDS en la II Legislatura -Suárez y Rodríguez Sahagún-, ni la candidatura al Senado por Ávila

${ }^{18}$ DÁVILA, Carlos: "El centro, para Suárez", Diario 16, 22 de junio de 1986.

${ }^{19}$ El País, 21 de julio de 1986.

${ }^{20}$ El CDS parecía pasar de este modo de un modelo ideal de oposición cercano a la "Gran Consociación", en términos de Arend Lijphart, y que evitase el desgarro de la sociedad gracias a grandes acuerdos sobre el texto constitucional y la política exterior, a como señala Gianfranco Pasquino, una oposición más combativa "que prepara la alternancia", PASQUINO, Gianfranco: "La oposición", Madrid, Alianza Editorial, pp. 39-79.
} 
inmejorable que contó "hasta con el apoyo de una Providencia que se mostró generosa con los españoles a la hora de favorecer unas excelentes cosechas que colaboraron al crecimiento y a una evolución moderada de la tasa de inflación (Rumores) ${ }^{21}$. No se discutía tanto el proyecto de cambio y de modernización -que seguía pospuesto y que no se atisbaba en el discurso de González- como el modo de gobierno. En una doble orientación, socialdemócrata en lo económico y liberal en su concepción del ejercicio de los derechos, advertía que no se estaba haciendo frente a las injusticias, ni al desempleo, en beneficio de una supuesta "estabilidad", y reclamaba un mayor protagonismo de la sociedad "dinámica, abierta y participativa".

Nuevamente, Suárez apeló a un aumento de la inversión productiva, y de forma paralela, señaló que la disciplina del gasto público exigía un pacto entre el Estado y las CC.AA. y un esfuerzo solidario y concertado. La crítica a la forma en la que el PSOE había liderado el país fue respondida con rumores y risas en la bancada socialista -ante lo que comentó, si era posible, escuchar "sin ninguna clase de gestos" a todos los parlamentarios-: "al fin y al cabo, y lo sabemos todos, el Gobierno está al servicio de los españoles y no los españoles al servicio del Gobierno"22.

En materia autonómica Suárez percibía un notable retroceso, identificando la estructura del nuevo estado con la "descentralización administrativa", al tiempo que consideraba acuciante la resolución de la política de financiación territorial y sus desequilibrios. Señalaba:

Para consolidar el nuevo Estado autonómico -lo he reiterado muchas veces- es imprescindible asumir el hecho autonómico y culminar un auténtico proceso de división horizontal del poder político, que obliga a unos modos y maneras de gobernar diferentes y en permanente contacto con los presidentes de las Comunidades Autónomas ${ }^{23}$.

A continuación, Suárez hizo referencia a la situación en la que se encontraban las libertades en España. No sólo había inseguridad ciudadana, sino que existía un franco retroceso en el ejercicio de los derechos fundamentales, e hizo -quizá recordando los meses precedentes-, una mención especial de la libertad de expresión, "porque en ella los medios de comunicación públicos y privados tienen anclada la responsabilidad, en

\footnotetext{
${ }^{21}$ DSCD, Sesión Plenaria, 23 de julio de 1986, nº 3, p. 54.

${ }^{22}$ Ibid., p. 55. Comentario acompañado de una frase que según El País generó bastante sorna entre los escaños socialistas fue: "la sociedad no se cambia por decretos, sino por un proceso de liderazgo social", El País, 24 de julio de 1986.

${ }^{23}$ DSCD, Sesión Plenaria, 23 de julio de 1986, nº 3, p. 55.
} 
cierta manera compartida con esta Cámara, de vigilar la integridad del proceso democrático, la gestión del Gobierno y el estricto cumplimiento de la Constitución"24.

En el ámbito de la política exterior, volvió a insistir en la necesidad de dar un mayor peso específico a Europa en el seno de la OTAN, y aprovechó para denunciar la existencia del acuerdo bilateral defensivo con EE.UU. Valoraba positivamente el camino iniciado en Europa, un acicate a la modernización del país, y lamentaba, la ausencia de proyectos concretos hacia Iberoamérica y el Mediterráneo.

Criticó con firmeza la apelación de González a la estabilidad, preguntándose si acaso se refería a continuismo y anunció una actitud vigilante sobre la actuación del Gobierno por posibles perjuicios en materia de libertades, indicando que la confianza puesta en el ejecutivo hacía cuatro años se había visto defraudada y por ello iban a dar su voto negativo. Suárez finalizaba ofreciendo su apoyo al Gobierno contra el terrorismo y reivindicaba, con el fin de que dejase de ser usado como objeto de lucha partidista, la creación de una Comisión Parlamentaria para desarrollar un Plan Global con tal fin; la única fórmula de Pacto de Estado o amplio consenso defendida por Suárez en aquella ocasión.

La intervención de Suárez fue mal recibida entre las filas gubernamentales, siendo "abucheado" antes y después de la misma ${ }^{25}$. En los turnos de réplica, las intervenciones de Felipe González y Adolfo Suárez se enzarzaron en algunas polémicas personales más relacionadas con la Transición que con la recién inaugurada III Legislatura. Felipe González respondió con ironía a algunas de las principales acusaciones de Suárez, jugó con la ambigüedad del CDS en su posición sobre las relaciones con EE.UU., y respecto a la pretensiones hegemónicas socialistas señaló: "Nunca la he entendido, créame, como 107 años de Gobierno, nunca, jamás (Risas.)"26 . A ambos aspectos respondió con pausa y serenidad Suárez en su dúplica, quien defendió tajantemente la desaparición de las bases y la firma de un acuerdo de Amistad y Cooperación. Incluso, hizo una insinuación sobre el uso indebido por parte de la aviación norteamericana de la Base de Rota

\footnotetext{
24 Ibid.

${ }^{25}$ Véase en SARASQUETA, Antxón: El abuso del Estado, Barcelona, Plaza \& Janés, 1986.

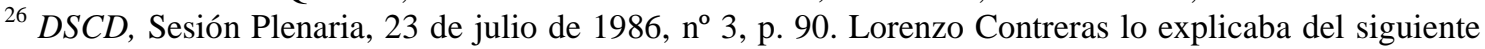
modo: "cuando Adolfo Suárez, muy razonablemente, preguntó si la insistencia conceptual de Felipe González, en "aquello de los Gobiernos estables sacraliza peligrosamente una palabra que puede implicar en el fondo interés por abandonar el proyecto de cambio [...] Don Tancredo no lo dudó. Recordó con su memoria fértil y su prontitud de reflejos" en, "Don Tancredo", $A B C, 24$ de julio de 1986.
} 
durante el ataque a Libia en abril -desmentido a continuación por González- ${ }^{27}$. La Transición -por ejemplo, la ausencia de un debate de investidura en $1979^{28}$ - o el supuesto intercambio de roles "izquierda-derecha" ocuparon el resto de las intervenciones de los dos líderes.

Quizá, el aspecto donde más certera resultó la réplica de González fue al valorar la repetida afirmación de Suárez: "cuando vuelva a ser presidente". Comentaba el Presidente de Gobierno: “desde luego, voy a defender que el Partido Socialista gane elecciones, y digo el Partido Socialista, después quién sea Presidente me parece secundario. Yo, políticamente, creo más en un proyecto político que en la adaptación de un partido a un proyecto personal, pero es perfectamente legítimo (Rumores.)"29.

En la prensa, se subrayaba el compromiso de Suárez con la defensa de las libertades y la dureza de sus críticas, a pesar de las formas, siempre sosegadas y medidas del abulense. El País titulaba: "Suárez dice que vigilará al Gobierno para evitar abusos de poder"30. Para Lorenzo Contreras, Suárez estuvo “duro" con González centrándose en "cuestiones de fondo" 31 y para Diario 16 se inauguraba un nuevo tono:

Adolfo Suárez, por su parte, inicio la andadura parlamentaria en un tono crítico, más comedido que en la campaña electoral y con propuestas más realistas y moderadas. Ofreció también un pacto sobre el terrorismo, sugiriendo medidas apreciables con verdadero contenido político [...] [reclamó] protagonismo para la sociedad y anunció una dura batalla en favor de la vigencia de las libertades reales ${ }^{32}$.

El periodista parlamentario J. A. Sentís valoraba la intervención de Suárez como de "poco crispada y dirigida más a los hábitos y actitudes (la arrogancia) del Gobierno socialista que a sus programas", en un discurso en el que "parecía pasar por la izquierda" a González en "política social, exterior y autonómica"33. Ramón Pi en La Vanguardia señalaba: "el líder del CDS pronunció una alocución al estilo antiguo, bastante celebrada por otras minorías" 34 . López Sancho, indescifrable, la definía como una: "crítica precisa en el estilo ascéticamente no oratorio de Suárez, que prefiere la

\footnotetext{
${ }^{27}$ DSCD, Sesión Plenaria, 23 de julio de 1986, n 3, pp. 96-110.

28 "Yo no celebré ningún debate de investidura en el año 1979, y fue un gran error por mi parte, que pagué. El primer debate lo celebró el Presidente Calvo-Sotelo. Con esto quiero dejar las cosas en su sitio", DSCD, Sesión Plenaria, 23 de julio de 1986, nº 3, p. 96.

${ }^{29}$ Ibid.

${ }^{30}$ El País, 30 de mayo de 1986.

${ }^{31}$ CONTRERAS, Lorenzo: "Don Tancredo", $A B C, 24$ de julio de 1986.

${ }^{32}$ Editorial: "Las minorías despertaron al Parlamento", Diario 16, 24 de julio 1986.

${ }^{33}$ SENTIÍS, José A.: "La oposición está dispuesta a colaborar con el Gobierno sobre los problemas de Estado", $A B C, 24$ de julio de 1986.

${ }^{34}$ PI, Ramón: "Las minorías", La Vanguardia, 24 de julio de 1986.
} 
precisión de las cuartillas a los caracoleos de la improvisación oral"35. El editorial de $A B C$ señalaba que la propuesta de Suárez para la creación de una comisión parlamentaria con el fin de abordar el problema del terrorismo -entre otras cosas"apenas" podía "considerarse que rebasara el nivel de la anécdota"36.

\section{2. EI CDS y la crisis de la derecha española (1986-1987)}

Las elecciones de 1986, en las que el CDS alcanzó casi dos millones de votos y 19 diputados, supusieron un punto de inflexión en la historia política española. Si en el período comprendido entre 1982 y 1986 podemos hablar de una pluralidad de intentos por reconstruir el centro-derecha; a partir de 1986, la fragilidad y posterior consolidación de Alianza Popular va a generar un proceso de convergencia en este espacio, cuyas discontinuidades van a estar en buena medida relacionadas por un lado con los resultados del CDS y por otro, con su política de pactos: "el extraordinario crecimiento del CDS, que empieza a señorear el espacio del centro, es una importante razón añadida al desconcierto de los estrategas de la recomposición de las fuerzas del centro-derecha en España",37.

A continuación, vamos a analizar el impacto de la crisis de AP en el espectro ideológico de centro-derecha, es decir, en su relación con un CDS, que había sido ignorado prácticamente hasta la misma noche electoral. Los acontecimientos parecían presagiar profundas realineaciones políticas: ruptura de la CP por el PDP (junio, 1986), fracaso en las elecciones autonómicas del País Vasco (noviembre, 1986), dimisión de Fraga (diciembre, 1986), integración del PL en el Grupo Mixto (diciembre, 1986), celebración del Congreso Extraordinario de AP (enero, 1987) y finalmente, moción de censura de Hernández Mancha (marzo, 1987).

Los resultados de 1986 propiciaron el primer intento serio y cabe añadir, infructuoso, de AP en su búsqueda de un entendimiento entre Manuel Fraga y Adolfo Suárez, alejados en lo político y en lo personal desde los albores de la Transición: "Fraga:

\footnotetext{
${ }^{35}$ LÓPEZ SANCHO, Lorenzo: "Suárez, al Norte; Fraga al Sur", $A B C, 26$ de julio de 1986.

${ }^{36} A B C$ elogiaba la concreción de Manuel Fraga en su intervención y glosaba su oferta de pacto de Estado (exterior, social, déficit y educación), en el editorial: "La investidura", $A B C, 24$ de julio de 1986.

${ }^{37}$ HERNÁNDEZ, Abel: "Las tribulaciones de la derecha", Diario 16, 24 de junio de 1986. Este mismo autor en septiembre escribía: "La crisis de la derecha [...] no ha hecho más que empezar" en "La descomposición de la derecha", Diario 16, 08 de septiembre de 1986.
} 
'Entre Adolfo Suárez y yo tiene que haber un acuerdo"”38. A raíz de los comicios, los líderes de la derecha manifestaron con rotundidad y notable asiduidad la absoluta necesidad de un acercamiento de este tipo. Para García Tizón: "tanto en el Partido Liberal como el PDP y AP hay que hacer una renovación en profundidad y de ahí debe salir una nueva fuerza, incluyendo al PRD y al CDS, y esto de aquí a final de año",39 y en palabras del líder del PL, José Antonio Segurado: "sería un escándalo que a las elecciones municipales concurriesen cuatro listas de centro-derecha" ${ }^{\natural 4}$. Fraga describió un panorama demoledor en la derecha española transida por: "formaciones nacionalistas de este o aquel particularismo [...] los falsos centrismos que terminan como alguna famosa operación super-fracasada [¿PRD?], los individualismos tenaces [¿CDS?] o las

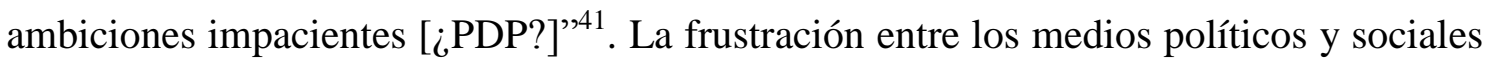
conservadores era considerable: “¿qué había hecho la derecha para recuperar el poder el 22 de junio? Nada. ¿Qué hizo la derecha para demostrar que era mejor oposición que la izquierda y que allí donde gobernaba [...] lo hacía mejor que los socialistas? Nada"42. El CDS mantuvo invariable su intención de acudir en solitario a las elecciones autonómicas del País Vasco y a las municipales y autonómicas de 1987, como veremos, una decisión constantemente polemizada. En el curso de una entrevista en $A B C$ realizada por el periodista Álvaro Santamarina a Chus Viana se producía el siguiente diálogo:

\footnotetext{
${ }^{38}$ Portada de Diario 16, 28 de agosto de 1986. Un informe de Carlos Argos abordaba junto a dos de los más cercanos colaboradores de Suárez (José Luis Graullera y Eduardo Navarro) un replanteamiento de las relaciones con el CDS, en PENELLA, Manuel: Los orígenes y la evolución del Partido Popular (Vol. I), Salamanca, Caja Duero, 2005, p. 848. Ortega Díaz-Ambrona ha hecho un excelente recorrido sobre la rivalidad política entre Suárez y Fraga durante el Gobierno de Carlos Arias Navarro. Concluye al respecto: "de hecho la rivalidad continuará desde Alianza Popular (AP) y Fraga criticará con saña al Gobierno Suárez y no parará hasta hundir a Unión de Centro Democrático (UCD)" en ORTEGA DÍAZAMBRONA, José Antonio: Memorial de Transiciones (1939-1978), Barcelona, Galaxia Gutenberg, 2015, p. 562.

${ }^{39}$ ABC, 26 de junio de 1986. Partidarios de esta tesis, en el seno de AP eran: Osorio y Verstrynge. Mostraban una mayor oposición los sectores más conservadores y los seguidores de Herrero de Miñón, PENELLA, Manuel: Los orígenes y la evolución ..., p. 848. Como señalaba el editorial de $A B C$ para "la estabilidad de la democracia" era necesaria "la consolidación de un gran partido en el centro-derecha, que agrupe a las diversas corrientes conservadoras y liberales [...] [que defienda] los legítimos intereses de la burguesía" y a los problemas internos y externos de Alianza Popular contraponía la lección aprendida por Adolfo Suárez quien "endurecido por la amarga experiencia ha comprendido la necesidad ineludible de hacer partido: esto es, de tejer una amplia red de realidades tangibles -militantes, oficinas, teléfonos, máquinas de escribir-, porque esa y no otra es la base para el funcionamiento de un partido", editorial: "Partidos estables", $A B C, 29$ de julio de 1986.

${ }^{40} A B C, 10$ de octubre de 1986.

${ }^{41} A B C, 14$ de octubre de 1986. El líder de la patronal, J. M. Cuevas, lamentaba en estas fechas, nuevamente, la desunión del centro-derecha y no veía "grandes diferencias ideológicas en el espectro de centro y derecha", $A B C, 08$ de noviembre de 1986. El diputado aliancista José María Aznar lo tildó de "lamentable espectáculo", $A B C, 27$ de noviembre de 1986.

${ }^{42}$ SARASQUETA, Antxón: El abuso..., p. 25 y ss.
} 
[P.] - Pero usted tiene que reconocer la atomización de quienes se enfrentan al partido en el Poder. Que en la política española hay y ha habido siempre demasiadas "cabezas de ratón”, demasiados líderes liliputienses. ¿Por qué no unirse? ¿Por qué no vencer y luego repartir papeles en la representación escénica de nuestra política? - [R.] De ninguna manera. No, no. Eso sería una especia de cruzada, y las cruzadas pasaron de moda. Nosotros no somos anti-socialistas, ni anticomunistas, ni antinada. Nosotros tenemos un proyecto político que es el que vamos a llevar adelante, por muy "cabeza de ratón" que usted considere $[\ldots]^{43}$.

El PDP, recién desligado de la Coalición Popular, achacaba al tremendismo y la imagen autoritaria de Manuel Fraga el fracaso electoral del 86' y alertaba sobre la desatención del espacio de centro practicada por AP. Las elecciones del 22 de junio habían confirmado lo que desde el PDP, en un extenso documento elaborado por la dirección del partido justificando su decisión de romper el pacto con Fraga, llamaban la "impermeabilización electoral de la CP [techo]"44.

Siguiendo las citas de algunos líderes democristianos reunidos en la Ejecutiva del partido tras las elecciones y recogidas por el ex miembro de UCD José Luis Álvarez, se percibe una notable desorientación. Una vez desembarazados de AP se enfrentaban a una "situación muy mala, no se dejó crecer un centro capaz de pactar, el CDS puede pactar con la izquierda" ${ }^{\text {- }}$, y sin la referencia del PRD: ¿qué hacer? García-Margallo apuntaba: "alianza de centro [...] Solos no vamos a ninguna parte, pacto con el centro, ¿dónde?”. Ahora, los interrogantes miraban hacia el CDS: “atención al CDS [L. Peral]”, “evolución del CDS [S. Carro]”, etc.

El PDP, con una credibilidad seriamente dañada, intentó abanderar una opción de centro y moderada, prolongando una estrategia que había sido insinuada antes de las elecciones. De acuerdo con El País: "las cuentas de la lechera [junto al PRD] incluían la posterior atracción hacia dicho grupo de los nacionalistas vascos y catalanes [...] lo que a su vez convertiría el invento en polo de atracción para el centrismo residual de Suárez"46. En su nueva andadura y con las expectativas rotas, el PDP defendió sus

\footnotetext{
43 SANTAMARINA, Á.: "Jesús María Viana: un aspirante a lendakari”, Blanco \& Negro (ABC), 19 de octubre de 1986.

44 Documento detallado sobre las "imputaciones" realizadas al PDP y las subsiguientes "contraargumentaciones” de los democristianos, ÁLVAREZ, José Luis: “0025Documento”, Caja 11, 45-490, 28 de julio de 1986, p. 4, AGUN/JLA.

${ }^{45}$ Citas de los líderes democristianos acerca durante una reunión de la ejecutiva del PDP poco después de las elecciones del 86' en un documento de José Luis Álvarez: “0031Documento”, Caja 11, 45-496, 1986, pp. 1-5, AGUN/JLA.

"Suárez había "pagado con la soledad" su negativa a asociarse a la CP y a cambio había logrado "acreditar una marca propia. En ello consiste la ventaja que el ex presidente del Gobierno lleva a su competidor en la tarea de construir una alternativa desde el centro". Alzaga estaba desacreditado; él había
} 
argumentos, como la plena identificación ideológica de su partido en el mundo occidental. Y al igual que sucediera con las críticas del PRD al CDS, señalaba: "la sociedad podrá contrastar entre un centrismo amorfo, como el del CDS, poco homologable con los partidos europeos y bastante más parecido a ciertas fuerzas políticas de América Latina" ${ }^{\text {47 }}$. De este modo, el PDP se proclamaba como el único representante del centro, frente a la deriva "izquierdista" del CDS y el absoluto fracaso del reformismo. Se volvía a escenificar así, aunque con menor fuerza, una nueva batalla por el centro ${ }^{48}$. El III Congreso del PDP, celebrado en diciembre de 1986, enarbolaba el lema: "El centro de todos"49. La contraposición entre el PDP y el CDS ofrecía a los democristianos algunas ventajas comparativas: contaba con numerosa representación institucional $^{50}$ y podía presumir de pedigrí ucedista -ambos se reivindicaban sucesores de UCD y querían volver a revivir el sistema de partidos de 1977-82-; sin embargo, a diferencia del CDS o la Operación Roca no tenía un liderazgo consolidado -la popularidad de Alzaga era mínima- y su último giro discursivo era difícil de justificar:

sido el primer responsable, "principal dinamitero", de la ruptura del centro y el primero en ceder a la llamada de Fraga, editorial: "Alzaga despide al barquero", El País, 01 de julio de 1986.

${ }^{47}$ Entrevista a Alzaga recogida en la sección "Revista de prensa", El País, 14 de julio de 1986. Otros ejemplos: en expresión de Luis de Grandes el CDS carecía de una "ideología definida" en "El PDP se presentará como 'centro puro' frente al izquierdismo del CDS”, $A B C, 20$ de diciembre de 1986; "[Contexto: elecciones europeas de 1987] Esto va a permitir comprobar que fuerzas políticas entroncan con grupos europeos o cuáles van a tener que ir a los No Inscritos", dijo Alzaga", El País, 12 de abril de 1987. Sobre el complejo proceso de integración del PDP en la Internacional Democristiana, véase, BARBERÀ ARESTÉ, Óscar: Alianzas políticas, relaciones de poder y cambio organizativo: el caso de Unió Democrática de Catalunya, 1978-2003, Madrid, CIS, 2011, p. 149.

48 JÁUREGUI, Fernando: "La recomposición de los restos de UCD" y "Democristianos y suaristas pugnan por ser 'el tercer partido', El País, 04 de septiembre de 1986; ÍD.: "El espacio de Suárez, como objetivo", El País, 21 de diciembre de 1986. Según Sarasqueta, en los informes de trabajo del PDP se había "sucumbido" a la idea de que en España existía una mayoría de centro-izquierda, en SARASQUETA, Antxón.: Abuso... En la revista del CDS albaceteño Eslabón se señalaba: "El PDP seguirá los mismos pasos que siguió el P. Reformista, en su día; con su gran poder de financiación, llegará a todos los rincones de nuestra geografía...", en Eslabón, 1, enero 1987. Quizá el episodio más relevante de la rivalidad entre ambos partidos se vivió a propósito de un cruce de acusaciones en las páginas del $\mathrm{Ya}$ entre Pilar Urbano - quien acusaba al CDS de connivencia con el PSOE- y José Ramón Caso quien llegaba a señalar: "son muchas las personas que, del mismo modo que Pilar Urbano percibe 'indicios de buena sintonía de CDS con el PSOE', me han manifestado que perciben un fuerte aroma a incienso democristiano", CASO, J. R.: "CDS, Suárez y TVE [Carta al director]" y "Política del CDS [Carta al director]", $Y a, 12$ y 09 de septiembre de 1986; URBANO, Pilar: "La hora de Óscar y Adolfo", "CDS: negar por no callar” y “A Caso, ¡ni Caso! [Carta al director]”, Ya, 07, 10 y 13 de septiembre de 1986.

49 El País, 20 de diciembre de 1986. J. Arenas defendía que el PDP era "la voz del centro en el Parlamento andaluz", ABC Sevilla, 21 de noviembre de 1986. Desde 1986, la lucha por el centro entraba en un nuevo escenario: “Aragón es el Centro", Lema del V Congreso del PAR, $A B C$, 03 de noviembre de 1986. Paralelamente, algunos escindidos de AP liderados por Jorge Verstrynge fundaban Renovación Democrática, un partido definido como "moderado, laico, de centro, pragmático y europeo". Verstrynge propugnaba una coalición centrista con el PDP y el CDS, y calificaba de "error histórico" la "voladura de UCD", ABC Sevilla, 07 de marzo de 1987 y "Verstrynge: "Adolfo Suárez es el representante del centro", $A B C, 17$ de marzo de 1987.

5021 diputados, 11 senadores, 123 alcaldes, 4.230 concejales y 60 parlamentarios autonómicos. Sus afiliados superaban en número a los del CDS. 
"el problema de la injusticia [social] es el principal que tenemos que resolver" ${ }^{\text {" }}$. Con ironía, el ex ministro de UCD González Seara escribía:

El partido democristiano se ha separado de Alianza Popular en busca de un supuesto espacio de centro que la Providencia parece haberles reservado. Es posible que la estrella de Oriente en esta ocasión no les alumbre bien la tierra prometida. En toda Europa, hoy, la Democracia Cristiana es la derecha ${ }^{52}$.

En el otoño de 1986 se celebraron elecciones autonómicas en el País Vasco. La situación de crisis vivida en la derecha, contrastaba con el momento de euforia reinante en el suarismo que en septiembre había organizado su II Congreso. La candidatura a la lehendakaritza estaba encabezada por el recién elegido Secretario General del CDS: Jesús María Viana. En la campaña electoral participó intensamente Suárez quien acompañó a los candidatos desde el día 18 de noviembre hasta la celebración de los comicios el 30 de dicho mes. Por fin, Suárez inauguraba una campaña con plenitud de medios -se pudo llevar a cabo el mailing electoral-y en la que los resultados lo podían convertir en "árbitro" del futuro político de la región ${ }^{53}$. El CDS apelaba a la vigencia y las posibilidades del Estatuto para el desarrollo autonómico, apostaba por un gobierno de colaboración entre fuerzas nacionalistas y no nacionalistas y se mostraba abierto a favorecer la gobernabilidad del País Vasco: “el CDS sólo negará su apoyo a un Gobierno vasco que esté exclusivamente integrado por partidos nacionalistas o estatales" $" 54$.

Suárez en sus intervenciones recordaba haber satisfecho las principales reivindicaciones políticas del País Vasco - "libertad, amnistía y Estatuto de Autonomía"- y haber devuelto los conciertos económicos ${ }^{55}$. El consenso y el diálogo, herederos de la Transición, eran el capital que el CDS ofrecía para el futuro del País Vascoy la resolución de los múltiples problemas de la región: "Vamos a centrarnos" (slogan de campaña). El CDS podía ejercer un valioso papel para el "entendimiento

\footnotetext{
${ }^{51}$ El País, 21 de diciembre de 1986.

52 GONZÁLEZ SEARA, Luis: La década..., p. 11. José Ramón Caso en una entrevista con Ángel Collado había comentado un año antes: “- $[\mathrm{P}]$ ¿El PDP no es un partido de centro? -[R] No se lo creen ni ellos; no hay más que repasar las declaraciones de sus líderes en el verano del ochenta y dos. Decían que el centro había muerto, que era una entelequia", $A B C, 01$ de febrero de 1985

${ }^{53}$ En la ciudad de Bilbao el CDS contaba con un concejal, el ex socialista Rogelio Bueno Padilla (elegido nuevamente concejal en 1987). En 1983 había obtenido dos concejales electos en la provincia de Álava, AMINHAP.

${ }^{54}$ El País, 28 de noviembre de 1986.

${ }^{55}$ El País, 29 de noviembre de 1986.
} 
interpartidario [fuerzas estatales y nacionalistas]" económico y de paz exigen de todos los vascos un esfuerzo colectivo instrumentado en un pacto político: el Pacto de Euskadi" ${ }^{57}$. Como sucediera en anteriores ocasiones, las declaraciones de los miembros del CDS y particularmente de Suárez sobre los márgenes y límites del proceso autonómico generaban cierta confusión y desconcierto, máxime, cuando el abulense presentaba como aval su gestión presidencial. En el transcurso de una rueda de prensa en Bilbao señaló:

Entiendo [...] que el Estatuto de Guernica no es un punto de llegada sino que permite la posibilidad de que competencias que el Estado tiene en exclusiva, puedan ser delegadas a los gobiernos autonómicos. En esa profundización se puede hallar el camino a unas cotas muy amplias de autogobierno, que garanticen la cooperación eficaz entre los poderes autónomos y el Gobierno del Estado ${ }^{58}$.

La respuesta de $A B C$, único periódico de gran tirada que se hizo eco de las palabras de Suárez, fue tajante. Señalaba: "posiblemente al calor de la campaña electoral [...] el presidente del CDS ha dicho algo en Vitoria [sic] sobre el Estatuto de Guernica que, si se descuida, le adelanta a Herri Batasuna en la subasta del secesionismo". Para el editorial, definir el Estatuto como "punto de partida y no de llegada" era "reconducir el problema al kilómetro cero". Suárez había carecido, en este caso, de sensibilidad en un aspecto fundamental "y esas bromas no caben en la Constitución"59.

Los resultados arrojaron un panorama complejo para el futuro político del País Vasco. El voto, muy dividido, impedía la formación de gobiernos en solitario. El País y $A B C$ coincidieron en mostrar su preocupación por los resultados electorales y la existencia de un mapa político muy fraccionado. El PNV (17 diputados) fue el partido

\footnotetext{
${ }^{56}$ En relación al fenómeno de la violencia terrorista, llama la atención el extenso recorrido histórico rastreando los orígenes y condicionantes del surgimiento de ETA y las propias contradicciones en que se hallaba la organización y su apoyo político-social en democracia (en base a los estudios del sociólogo alemán Peter Waldmann), Programa Electoral del Centro Democrático y Social. País Vasco, noviembre 1986, CDS, 1986, p. 10 y ss.

${ }^{57}$ Un acuerdo para la Ley de Territorios Históricos, un acuerdo social (economía), educativo y "diálogo" para evitar el derramamiento de más sangre. Señala, "muchos de nosotros" colaboramos en la Constitución-Estatuto, "para nosotros el diálogo político es un arma irrenunciable para combatir la violencia. Propugnamos la búsqueda de acuerdos entre todas las fuerzas políticas de Euskadi y entre el Gobierno central y el Gobierno vasco", ibid., pp. 6-8.

58 "Suárez, partidario de ampliar el autogobierno y eliminar recelos entre las administraciones", El Correo Español-El Pueblo Vasco [ECEPV], 21 de noviembre de 1986. En el programa electoral se tildaba de "cicatera" la política autonómica implementada y en sentido contrario se afirmaba: "denunciamos las posturas independentistas [...] queremos contribuir honestamente a planteamientos realistas que sin eliminar la realización propia de Euskadi a través de la optimización del Estatuto, eviten frustraciones innecesarias y antagonismos", Programa Electoral..., p. 7.

59 Editorial: "Punto de llegada", $A B C, 21$ de noviembre de 1986. En aquellas elecciones, $A B C$ recomendaba el voto para CP y el PSOE con el fin de preservar "la unidad de la Patria española" y evitar la penalización electoral, editorial: "El voto útil en el País Vasco", $A B C$, 28 de noviembre de 1986.
} 
con más votos mientras el PSE-PSOE obtuvo el mayor número de escaños (19), irrumpía Eusko Alkartasuna (13) - a raíz de la ruptura de Carlos Garaikoetxea con el PNV-y se producía el fuerte ascenso de Herri Batasuna $(13)^{60}$. El CDS que obtenía dos escaños por Álava, Alfredo Marco Tabar y Jesús María Viana -ambos antiguos dirigentes regionales de UCD- ${ }^{61}$, era para muchos el partido más idóneo para ejercer de mediador entre el PSOE y el PNV en un futuro gobierno de coalición -desde dentro o fuera del mismo- ${ }^{62}$. Finalmente, el pacto de gobierno entre PSE-PSOE y PNV y la elección de José Antonio Ardanza contó con el apoyo, que no participación, del $\operatorname{CDS}^{63}$.

En aquellas elecciones, AP, aunque en parte atribuyera sus malos resultados al CDS, no podía obviar lo que constituía un patente fracaso de la estrategia aliancista ${ }^{64}$. El 1 de diciembre Manuel Fraga dimitía como Presidente de Alianza Popular y agudizaba una crisis cuyos efectos podían superar las peores expectativas ${ }^{65}$.

Una de las voces más destacadas de la derecha española, como el líder de la Plataforma Independiente, Rafael Pérez Escolar, emitió un duro diagnóstico sobre un problema que consideraba de carácter estructural: "el permanente despropósito del centro-derecha". Según el autor, el descenso de AP y el "regocijo" del "indefinido" CDS en sus "magníficos resultados" eran una manifestación de la lamentable situación de la llamada alternativa -“obstinados [AP y CDS] en negar que dicen lo mismo a la misma gente, se pusieran de acuerdo"-. La solución pasaba por suprimir el viejo sentido "patrimonial de la política", los personalismos, etc. ${ }^{66}$

La situación se agravó si cabe apenas unos días después con el desgajamiento de la frágil coalición del Partido Liberal. Una vez más, las elucubraciones sobre el futuro del

\footnotetext{
${ }^{60}$ Editorial: "Un panorama preocupante", El País, 02 de diciembre de 1986; editorial: "Preocupante resultados", $A B C, 02$ de diciembre de 1986. Euskadiko Ezkerra (EE) obtenía 9 diputados y AP, 2.

${ }^{61}$ Tras el repentino fallecimiento de Jesús María Viana en febrero de 1987 fue sustituido por Carlos Sainz de Angulo, antiguo miembro de UCD en Álava.

62 COPA, Vicente: "Primera posibilidad: PSE-PSOE, PNV y CDS", ECEPV, 06 de diciembre de 1986. "En este supuesto la balanza final entre CP y CDS se inclinaría en favor de este último partido, que, además de tener una concepción ideológica no contrapuesta al PNV...”, ABC, 07 de diciembre de 1986.

${ }^{63}$ La elección como lendakari de J. A. Ardanza contó con los votos a favor de PNV, PSE y CDS, El País, 27 de febrero de 1987. En las votaciones de los miembros de la Presidencia y Mesa del Parlamento, el CDS se alineó con el PNV y la CP y Marco Tabar logró la elección como Secretario Segundo de la misma, $A B C, 07$ de enero de 1986.

64 "El CDS le restará votos a CP [...] para saber eso no hace falta estudiar matemáticas superiores", $A B C$, 18 de noviembre de 1986.

65 “La caníbal vida política española devoró a Suárez, devoró a Carrillo y devora a Fraga, en un alarde de irresponsabilidad y de insensatez. ¿A quién le tocará ahora? Yo creo que nadie sobra y todos hacemos falta, pero esto es algo que se resisten a entender y a admitir los españoles", en CELA, Camilo José: "En la marcha de Fraga", El País, 03 de diciembre de 1986.

${ }^{66}$ PÉREZ ESCOLAR, Rafael: "Un clamor nacional”, $A B C, 03$ de diciembre de 1986.
} 
centro-derecha pasaban por constatar la insostenibilidad -teórica y práctica- de proyectos políticos independientes "centristas" a nivel estatal. Muñoz Alonso se valía de la metáfora del "síndrome de Penélope" para caracterizar a unas fuerzas políticas “dinamiteras", presas del "cerrilismo" y atomizadas, algunas de ellas alimentadas por la creencia en un centro per se, como si pudiera constituir una ideología: "causa estupor por eso oír hablar de 'centrismo radical', como hacen por aquí algunos miembros del CDS" ${ }^{67}$. Las opciones para el centro derecha eran dos: un gran partido amplio y flexible o una coalición de grupos "lealmente decididos a mantener su cohesión y a no inventarse diferencias insalvables" ${ }^{\prime 68}$. Aquel día, el editorial y la portada de $A B C$ estaban dedicados a la reconstitución del espacio de centro-derecha: "No dividir"69. De la viabilidad como opción política y electoral del centro-derecha dependía "el de la propia democracia española". Se necesitaba una opción capaz de "alternar en el ejercicio del poder" y así, reflejar la pluralidad social e ideológica del país.

En las reuniones de la ejecutiva democristiana de estas semanas, se traslucían a la perfección las frustraciones políticas de la derecha española focalizadas en la persona de Adolfo Suárez. En primer lugar, los acontecimientos del otoño-elecciones vascas y dimisión de Fraga- eran una excelente excusa para iniciar el proceso de moderación de temas y discursos, es decir, de seguir avanzando hacia el "centro" ${ }^{70}$. En segundo lugar, se había constatado la "imposibilidad de reconstituir la UCD [a raíz del fracaso del PRD]". Un hecho, que a pesar de todo, seguía resultando atractivo, acaso como perspectiva, y daba pie regularmente a formulaciones o iniciativas más o menos plausibles $^{71}$. Finalmente, eran perceptibles las inmensas dificultades para lograr un

\footnotetext{
${ }^{67}$ Para el autor, el centro era un estilo, una forma de hacer política: "como escribe Bourricaud [sociólogo francés] a propósito de los centristas franceses: 'La pretensión de los moderados reposa sobre una convicción: es siempre la sociedad quien tiene razón frente al Gobierno'. Por eso es sorprendente el estatismo y el intervencionismo 'social' de que hacen gala muchos 'centristas' españoles", MUÑOZ ALONSO, Alejandro: "El síndrome de Penélope", $A B C, 11$ diciembre de 1986. El catedrático de derecho administrativo y desde 1989, diputado del Partido Popular, Gaspar Ariño Ortiz, enfatizaba que el futuro de la oposición no podía pasar por una reedición de UCD y para ejemplo estaba lo que había sucedido con el PRD. El futuro se debía encauzar alrededor de la propuesta liberal-conservadora representada por AP y no del "aventurerismo tercermundista de esa especia de Alan García español que es Adolfo Suárez en su actual versión", ARIÑO ORTIZ, Gaspar: "La derecha sin Fraga”, ABC, 11 de diciembre de 1982.

${ }^{68}$ Ibid.; "Martín Villa propone la unión de partidos de centro-derecha", $A B C, 12$ de enero de 1987.

${ }^{69}$ Editorial: "No dividir", $A B C, 11$ de diciembre de 1986;

70 Véase, CONTRERAS, Lorenzo: "Don Óscar", $A B C, 24$ de diciembre de 1986 y "En torno a don Oscar", $A B C, 28$ de diciembre de 1986. Sobre el papel de Alzaga en la "voladura del centro", Ussía señalaba: "ya le están haciendo carantoñas a Adolfo Suárez. En su éxtasis chapucero no se aperciben de que el bien parecido duque abulense puede ser todo menos tonto y olvidadizo", USSÍA, Alfonso: "El milagro", $A B C, 27$ de diciembre de 1986.

${ }^{71}$ Como el intento de creación de un foro de intercambio de ideas entre los diversos partidos del centro político cuyo objetivo era, una vez más, comprobar si las diferencias existentes respondían a meros
} 
entendimiento con un CDS en alza considerado como un "punto fijo con el que no se puede contar" y que, como constataba Martín Villa, condicionaba el resto de pactos en el centro-derecha. Las opiniones de Alzaga eran aún más explícitas: "la madre del cordero es el CDS -sin él, no hay alternativa-" ${ }^{, 72}$. No es casual, que en una obra publicada en 1987 y escrita por Fernando Jáuregui sobre la situación de la derecha española, uno de los capítulos comience con la siguiente frase de Manuel Fraga: "el gran culpable de que no fructificase la llamada mayoría natural fue Adolfo Suárez"73. Se tenía la sensación de que desde los tiempos de UCD Suárez se interponía consciente o inconscientemente, pero siempre con denodado empeño, en la "inevitable" unificación y consolidación del espacio de centro-derecha. Un dirigente de AP en Jaén manifestaba un año después este sentimiento a propósito de un pacto del CDS con el PSOE en el Ayuntamiento de La Carolina con una frase demasiado redonda para un acontecimiento decididamente secundario: "el partido de Suárez, traidor sistemático del centroderecha" 74 .

Para Arias-Salgado, quien había solicitado ya su ingreso en el CDS, la crisis de AP era el reflejo de una pregunta: "si en España el conservadurismo puede vertebrar una fuerza política hegemónica que sea alternativa" ${ }^{25}$. Tras recorrer las limitaciones de la ley electoral y de la concepción de los partidos políticos -como meras maquinarias electorales-, Arias-Salgado identificaba algunos problemas estructurales en "las derechas": la adscripción al término "conservadurismo" -un vocablo sin aceptación en Europa, salvo en Gran Bretaña y distante de la síntesis liberal, democristiana y socialdemócrata, es decir, reformista de $\mathrm{UCD}^{76}$-, la "identificación consciente o inconsciente entre derecha y dictadura", "pensar que podría imponer de manera incondicional su hegemonía en el ámbito no socialista y, sin pérdida de su identidad derechista" obtener el triunfo electoral ${ }^{77}$, su ligazón a "intereses particulares [CEOE]" y a un discurso anacrónico -“túnel del tiempo"-. Concluía Arias-Salgado como, en un

personalismos o eran realmente insalvables, En un documento de Gaspar Barros de Lis: “0038Documento", 27 de enero de 1987, Caja 10, 38-892, AGUN, Fondo Personal J. Barros de Lis Gaspar.

72 ÁLVAREZ, José Luis: “0045Documento”, (diciembre) 1986, Caja 11, 45-498, 1-5, AGUN/JLA.

73 JÁUREGUI, Fernando: La derecha después de Fraga, Madrid, El País-Aguilar, 1987, p. 28 y ss. Otra obra de esta época que ejemplifica cuales eran las "sensaciones" de la derecha española, DE LA CIERVA, Ricardo: La derecha sin remedio, Barcelona, Plaza \& Janés, 1987.

74 "El voto del CDS entregó al PSOE la alcaldía de La Carolina”, ABC Sevilla, 14 de julio de 1988.

75 ARIAS-SALGADO, Rafael: "Los errores de la derecha”, El País, 13 de diciembre de 1986.

76 "El reformismo de tenor socialdemócrata entonces dominante en Europa", ibid.

${ }^{77}$ Esta premisa estuvo en la base de la "liquidación de UCD" en 1982 y se basaba en la "suposición" de la inutilidad o inexistencia del centro, ibid. 
país donde el electorado se auto-ubicaba mayoritariamente en el centro, el PSOE ya "había verificado su mutación" y UCD fue la oportunidad perdida para hacerlo en el área del centro-derecha "porque fue tolerada más que voluntariamente aceptada por las fuerzas reales de la derecha"78.

En enero de 1987 se celebró el VII Congreso de AP, único en su historia en el que se presentaron dos candidatos a la presidencia del partido: Antonio Hernández Mancha y Miguel Herrero de Miñón ${ }^{79}$. Uno de los contendientes, Herrero de Miñón, rechazaba la disolución de AP y la fundación de una reedición de la CEDA, pero se mostraba inexorablemente partidario de la integración del centro-derecha y el acuerdo con "partidos afines" para las "coaliciones pre o postelectorales" $"$.

La situación era paradójica. El CDS rechazaba su inclusión en el espacio de centroderecha adscribiéndose al centro-progresista, mientras el resto de partidos lo seguían considerando una fuerza necesaria para constituir la gran alternativa al socialismo. Una visión que para Suárez era fruto de la "patología de la simplificación que se produjo en las elecciones del 82",81. Las manifestaciones de esta situación rozaban en ocasiones el esperpento. El 14 de diciembre, la edición dominical de $A B C$ dedicó varias páginas a modo de foro de debate a la "La recomposición del centro-derecha". Expresaron sus opiniones Osorio, Roca, Hernández Mancha, Segurado, Oreja, Verstrynge, Ruiz Gallardón, García Agudín, Luis de Grandes, CDS y PNV. Lo extraño del caso, es que en la columna del CDS no figuraban declaraciones y se indicaba: "los principales dirigentes del CDS rechazan la ubicación en el espacio de 'centro-derecha",82.

Alfonso Osorio entreveía dos causas de desunión: los "particularismos", "partidismos" y por otro lado, los complejos a asumir su posición en el espectro

\footnotetext{
${ }^{78}$ Ibid.

79 El vencedor fue Antonio Hernández Mancha que se convirtió en el nuevo Presidente de Alianza Popular, siendo elegido Arturo García Tizón, Secretario General.

${ }^{80}$ HERRERO DE MIÑÓN, Miguel: "Por la unidad", $A B C, 27$ de enero de 1987.

${ }^{81}$ Diario 16, 26 de marzo de 1987.

82 S. N.: "Centristas y conservadores debaten la creación de una alternativa al PSOE", $A B C, 14$ de diciembre de 1986. De nuevo, el 28 de diciembre de 1986 ABC dedicaba su editorial y portada a abordar la cuestión del centro político. Como era habitual, hacía un llamamiento a ambos "a superar personalismos" y sumarse "a la coordinación del centro derecha", se servía de una cita del político francés Raymond Barré para atestiguar la inexistencia del centro político y apuntaba: "pero estando donde estamos, habrá que empezar por reconocer la enorme diferencia que existe hoy entre un partido democristiano de cuadros, como es el del señor Alzaga y otro de ideología confusa pero de capacidad electoral probada, como es el CDS del señor Suárez", editorial: "El problema del centro", $A B C, 28$ de diciembre de 1986. En la portada, Mingote dibujaba a Suárez y Alzaga arrinconados entre dos enormes rocas que lentamente los dejaban sin espacio. Una representaba al PSOE y otra AP, hacia la primera miraba Suárez y hacia la segunda, Alzaga, MINGOTE: "Los centristas", ABC, 28 de diciembre de 1986.
} 
ideológico, a denominarse "derecha". Unos apelaban a la regeneración, otros al neoliberalismo, los de más allá a "planteamientos populistas":

Pero si a un hombre corriente se le pregunta quiénes son los políticos de la derecha no hay duda sobre quiénes, desde Fraga a Suárez, quedarán incluidos en la lista. Para este hombre medio es inútil que se denominen conservadores, liberal-conservadores, liberales, centristas, progresistas, populistas, reformistas o sociales; para ese hombre medio, mal que le pese a alguno, son la 'derecha'. Ahí, al negar ser lo que son o lo que los demás creen que son, comienza su tragedia política ${ }^{83}$.

Y la paradoja se magnificaba si cabe, al columbrar las posibilidades del CDS para constituirse en "alternativa" por méritos propios y ajenos: "el único ganador de su enfrentamiento [en el seno de AP] (aparte, naturalmente, del Partido Socialista) será Adolfo Suárez”. Pero, ¿cuáles eran las opciones reales del CDS? ${ }^{84}$

\section{3. El Debate sobre el Estado de la Nación de 1987 y la Moción de Censura de Hernández Mancha.}

El camino sin retorno en que parecía haber entrado la derecha corría parejo al resurgimiento de Adolfo Suárez, que volvía a navegar con el viento a favor más de un lustro después. La sensación de que existía una posibilidad no muy descabellada de que Suárez asumiera, mediante una u otra fórmula, el liderazgo de la oposición recorría los mentideros políticos y periodísticos, mientras se repetía, como si de un mantra se tratase: "Suárez: 'Es inevitable que vuelva a ser presidente del Gobierno en 1990",85. Sin embargo, Suárez se aferraba a la estrategia defendida desde 1982, en apariencia indiferente ante las transformaciones y equívocas decisiones de los populares (moción de censura de Hernández Mancha) ${ }^{86}$. En otras ocasiones, eran las contradicciones de su proyecto político las que afloraban al intentar hacer frente a los síntomas de flaqueza del Gobierno (1988).

\footnotetext{
${ }^{83}$ OSORIO, Alfonso: "La reconstrucción de la derecha (I)", $A B C, 29$ de enero de 1987. "Me parece cuanto menos difícil encontrar otro período de la historia de la democracia de nuestro país en el que, cual sucede actualmente, la mayoría de líderes políticos de ideología no socialista muestre tan tozudo empeño atomizador en difusa y confusa constelación de partidos", PONT MESTRES, Magín: "Frustración de millones de votos", $A B C$, 05 de febrero de 1987.

${ }^{84}$ Para Seco Serrano, el mayor hándicap era la inexistencia, todavía, de un programa de gobierno alternativo del CDS: "La alternativa posible", El País, 02 de febrero de 1987.

${ }^{85}$ Con el que se titulaba una entrevista recogida en la edición dominical de $A B C, 04$ de enero de 1987.

${ }^{86}$ Circulaban encuestas en las que hasta un $22 \%$ de los votantes de AP consideraban que el CDS iba a obtener mejores resultados que los conservadores (Sigma Dos, publicada en Actualidad Económica) en USSÍA, Alfonso: "Congreso de AP", $A B C, 24$ de enero de 1987.
} 
La intervención de Suárez en el primer Debate sobre el Estado de la Nación de la legislatura en el mes de febrero de 1987 y en plena crisis de la derecha había producido un inusual interés. Suárez comenzó su intervención, con el fin de contrastar aún más sus críticas al Ejecutivo, recordando sus anteriores intervenciones -en las que no había tenido reparos en reconocer los logros de los gobiernos socialistas-. A continuación, realizaba una descripción de los comportamientos del Presidente de Gobierno: cada vez más aislado, más alejado de la realidad. Y se remitía a episodios de su pasado, para dar más consistencia a sus argumentos: "recuerdo el día, señor González, en que usted mismo en esta tribuna, y no sin razón, me aconsejaba: señor Suárez, salga de la Moncloa, baje a la calle y escuche sus preocupaciones. Pues permítame, señor González, que hoy le devuelva el consejo (Risas)" ${ }^{\text {\$7 }}$.

Tras referirse textualmente a la posibilidad de que el PSOE se convirtiera en “instrumento de dominación” y de la existencia del "miedo del poder", pasó a desgranar sectorialmente las políticas socialistas. En materia económica, defendía los estímulos públicos y la mejora de la competitividad del sector privado como herramientas para la reducción de los niveles de desempleo ${ }^{88}$. Tildó la situación de la justicia de "ineficaz" y "lenta" al igual que la sanidad; respecto a la reforma de la administración señalaba: "sospecho que ustedes han puesto en marcha lo que con benignidad podíamos denominar como una dinámica de ocupación política, de la que se desvía una

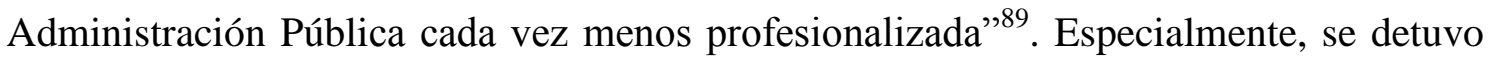
en el terreno de la educación -inmersa en fuertes movilizaciones estudiantilesrecordando la propuesta electoral destinada a aumentar el presupuesto nacional en educación hasta un $6 \%$ del PIB $^{90}$.

Quedaron en un segundo plano cuestiones de estado como la Política Exterior, momento que aprovechó para "confesar" que había votado en contra de la permanencia de España en la OTAN en el referéndum de $1986^{91}$. Por vez primera desde su dimisión,

\footnotetext{
${ }^{87}$ DSCD, Sesión Plenaria, 24 de febrero de 1987, $\mathrm{n}^{\text {o }}$ 31, p. 1763.

${ }^{88} \mathrm{Y}$ dirigía un ataque al sistema financiero español: "cuando los crédito cuestan, en el mejor de los supuestos, ocho puntos o más de lo que se puede percibir por los depósitos, no parece que la banca esté desempeñando con efícacia esa función”, ibid.

${ }^{89}$ Ibid., p. 1764.

90 Abordó las causas de los fracasos en las reformas de los servicios públicos y valoró brevemente los sucesos acaecidos en Melilla -conflicto generado a raíz de la aplicación de la Ley de Extranjería (1985)-

${ }^{91}$ De acuerdo con Pablo Sebastián, le valió unas duras declaraciones de H.D.Genscher, lo que para el autor significaba dos cosas: la importancia creciente de Suárez y el temor a "su no sumisión a Washington" en "Fernando Morán en el embrollo diplomático", $A B C, 12$ de abril de 1987.
} 
Suárez no abordaba la idea de pacto de Estado en una intervención en el Congreso optando por buscar la confrontación dialéctica directa con Felipe González y concluía reivindicando el papel del Parlamento, cuyo prestigio iba en paralelo al del sistema democrático.

El turno de réplica se convirtió en una comparación sin cortapisas entre ambos, en la que Suárez llegó a afirmar: "Señor Presidente, ha dicho que hasta que no llegó el Gobierno socialista no hubo Defensor del Pueblo. ¿Me puede permitir que le diga que hasta que yo no fui Presidente del Gobierno, no comenzaron las libertades en España? (Rumores. Aplausos)”. Suárez finalizó con un exagerado desquite:

[Suárez] ¡Me hubiera encantado tener el equipo que tiene usted! Los tendré en su día porque, le repito, le ganaré en el 90. Gracias. (Rumores. Risas.) El señor PRESIDENTE: Tiene la palabra el señor Presidente del Gobierno. El señor PRESIDENTE DEL GOBIERNO (González Márquez): Señor Suárez, lo primero que quiero decirle es que no pierda las esperanzas, en ningún caso ${ }^{92}$.

Las valoraciones del debate en la prensa amortiguaron el "supuesto" impacto de la intervención de Adolfo Suárez, quien hubo de compartir protagonismo con los fuertes reproches del Secretario General de AP -García Tizón- al Gobierno y una nueva demostración de la pericia parlamentaria de Miquel Roca ${ }^{93}$. En cualquier caso, el resurgir de Adolfo Suárez y la crisis de la CP aumentaba para muchos la distancia entre Gobierno y oposición; en opinión de $A B C$ : "Las tres réplicas de ayer al Presidente fueron parlamentariamente muy pobres"94. Para Diario 16, González había recuperado su mejor tono parlamentario y le dedicaba su titular de portada ${ }^{95}$. Sobre Adolfo Suárez subrayaba la progresiva recuperación de su liderazgo: "un tanto desfigurado en anteriores intervenciones. Su crítica al Gobierno socialista fue más contundente, sin

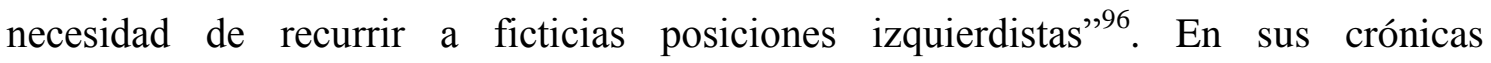

\footnotetext{
${ }^{92}$ DSCD, Sesión Plenaria, 24 de febrero de 1987, nº 31, pp. 1783-4.

93 CONTRERAS, Lorenzo: "Sin especial novedad", La Vanguardia, 25 de febrero de 1987. En comparación con las acusaciones cruzadas que hubo con García Tizón, "el forcejeo dialéctico con Adolfo Suárez fue de guante blanco, y ambos se prodigaron guiños propios de quienes conocen los resortes del poder. Suárez utilizó la técnica de comparar su mandato con el del actual presidente y se atribuyó el mérito de haber llevado la libertad a España", El País, 25 de febrero de 1987.

${ }^{94}$ Editorial: "Socialdemocracia en el PSOE", $A B C, 25$ de febrero de 1987. Suárez apenas recibió un comentario en el editorial de La Vanguardia: "El parlamento y la calle", La Vanguardia, 25 de febrero de 1987.

${ }^{95}$ González transmitió un tono "de avezado gobernante occidental seguro de sí mismo, con constantes referencias a Europa y la mirada puesta en 1982", en el editorial: "González recupera la iniciativa", Diario 16, 25 de febrero de 1987.

96 "Suárez apareció más entonado y firme que otras veces. Acaso, porque se haya decidido, de una vez a hacer realmente oposición" y reservó "sus tics populistas" para el tema de economía y política exterior, ibid.
} 
parlamentarias para $A B C$, José Antonio Sánchez había percibido también este cambio de tercio del discurso suarista y resaltaba los "ataques de un sorprendente Adolfo Suárez"97. Más escéptico se mostraba El País, para quien Suárez había desaprovechado una buena “oportunidad” para capitanear, -al menos simbólicamente-, a la oposición 98 .

La reacción inmediata al nuevo protagonismo de Suárez - que para algunos líderes populares se evidenció en el Debate sobre el Estado de la Nación de $1987^{99}$-, fue la presentación de una moción de censura a cargo del nuevo presidente de AP y en un futuro, posible candidato a la Presidencia del Gobierno: Hernández Mancha -quien en esa legislatura no ejercía como diputado-. El CDS acordó, tras la reunión del Comité Nacional del 24 de marzo que Suárez permaneciese en un segundo plano. Rodríguez Sahagún, en una breve intervención, iba a ser el encargado de definir la posición centrista $^{100}$. Así, se intentaba no reforzar el protagonismo de AP que pretendía consolidar su nuevo liderazgo frente al resurgimiento de Suárez: "la evidente intención de cortocircuitar el protagonismo de otros liderazgos políticos como los de Adolfo Suárez y Óscar Alzaga no podrá pasar desapercibida en esta maniobra"101.

Rodríguez Sahagún intervino en la segunda jornada del debate de la moción de censura. El día anterior, el resto de grupos parlamentarios, especialmente los representantes del PNV, EE e IU, criticaron con vehemencia el programa de gobierno defendido por Hernández Mancha ${ }^{102}$. Junto a los fuertes reproches de El País ${ }^{103}$, se sumó una sensación de amargura en $A B C$, que lamentaba nuevamente la situación de la oposición -aunque alguno de sus periodistas no le dejase de atribuir "valentía de torero"104-:

Ha sido una ocasión perdida por el conjunto de las fuerzas no socialistas y, al propio tiempo, casi un fárrago parlamentario, en la medida que careció, hasta ahora, del atractivo y la brillantez que se esperaba. En la moción de censura debió estar presente el necesario

\footnotetext{
${ }^{97}$ SÁNCHEZ, José Antonio: "Lo que no es el estado de la nación”, $A B C, 25$ de octubre de 1987.

${ }^{98}$ Editorial: "La nación y González", El País, 25 de febrero de1987.

${ }^{99}$ BAÓN, Rogelio: Historia...

${ }^{100}$ El País, 26 de marzo de 1987.

${ }^{101}$ Editorial: "Salto a la fama", El País, 24 de marzo de 1987.

${ }^{102}$ El País, 27 de marzo de 1987. Lorenzo Contreras dejaba entrever como el CDS había sentido que le estaban pisando el terreno en el que se había conseguido un progresivo y gradual desgaste del felipismo, CONTRERAS, Lorenzo: "Censura y derechos de autor", $A B C, 27$ de marzo de 19871.

${ }^{103}$ Editorial: "El candidato se examina...", El País, 27 de marzo de 1987. Diario 16 prorrogaba esa sensación de "reválida" del candidato aliancista, aunque con un tono más amable y cercano a sus propuestas en su editorial: "este es un primer examen de Hernández Mancha. Si lo aprueba, habrán dado un paso adelante él y su programa. Pero está lejos de poder ganar, todavía, la oposición” en "El opositor Hernández Mancha”, Diario 16, 27 de marzo de 1987.

${ }^{104}$ En expresión de José Antonio Sánchez, $A B C, 28$ de marzo de 1987.
} 
espíritu de colaboración y de convergencia en las respuestas al partido gobernante. El encastillamiento en posiciones cuya legitimidad nadie podrá discutir, tiene, como el debate hasta ahora demostró, un coste de oportunidad política muy alto ${ }^{105}$.

La intervención de Rodríguez Sahagún se centró en rebatir los supuestos argumentos políticos existentes para llevar a cabo la moción. El Gobierno había sido ampliamente censurado apenas unas semanas antes, durante el Debate sobre el Estado de la Nación, lo que permitía inferir que esta moción únicamente servía para la presentación parlamentaria del senador Hernández Mancha, la explotación del contexto electoral elecciones municipales y autonómicas de junio de 1987- y el intento de perpetuación de esquemas bipartidistas. Exponía su desacuerdo con el programa de Gobierno presentado, liberal-conservador y con una política económica similar a la del Gobierno, "no creo que la derecha conservadora asuma, en el fondo, el juicio de valor de que el

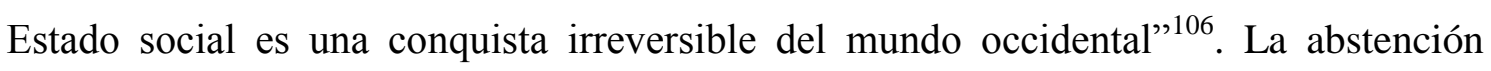
quería significar su distanciamiento tanto con la gestión gubernamental como con los ejes políticos defendidos por el candidato.

Hernández Mancha en su réplica comenzó aludiendo a la presencia de un "nuncius" o "vocero", en lugar del Presidente del CDS, a quien dirigió su intervención. En plena pugna por el liderazgo de la oposición señalaba que "no sólo se ejerce la oposición criticando, sino ofreciendo alternativas" y programas, lo que aprovechó para polemizar sobre la postura de los suaristas en cuestiones de defensa -servicio militar- y "política exterior": "me gustaría que esa tercera vía que encarna el Duque de Suárez se plasmase por escrito, con claridad y sin contradicciones"107. Al final de su intervención, Hernández Mancha glosó unos versos, que atribuía a Santa Teresa de Ávila, y de los que se servía para responder a la indiferencia mostrada por Suárez: “¿Qué tengo yo que mi enemistad procuras? ¿Qué interés te sigue, Adolfo mío, que a mi puerta, cubierto de rocío, pasas la noches del invierno oscuro?"108. Las referencias de Hernández Mancha provocaron la intervención "por alusiones" de Adolfo Suárez, quien gracias a la rápida reacción del profesor de literatura en la Universidad de Valladolid y diputado del CDS, Antonio Garrosa, pudo responder:

Simplemente mencionar al señor Hernández Mancha que si todo su planteamiento de soluciones y de coherencia se cifra en la cita final que ha hecho, diciendo que

\footnotetext{
${ }^{105}$ Editorial: "Balance gris", $A B C, 28$ de marzo de 1987.

${ }^{106}$ DSCD, Sesión Plenaria, 27 de marzo de 1987, no 39, p. 2298.

${ }^{107}$ Ibid., p. 2299.

${ }^{108}$ Ibid., p. 2300.
} 
parafraseaba a mi paisana Santa Teresa de Jesús, me parece que se ha equivocado, porque se refería a Lope de Vega. (Rumores) ${ }^{109}$.

La decisión de no intervenir en el debate por parte de Suárez fue criticada a derecha e izquierda, y se vinculó con sus tradicionales silencios y habitual rechazo hacia la confrontación parlamentaria: "unos líderes de partidos en la oposición con vocación de alternativa de Gobierno, como es don Adolfo Suárez, que no tiene nada que decir en esa confrontación, y que sólo interviene por alusiones". Ni siquiera su intervención, "mal y a destiempo" en palabras de Pablo Sebastián, consiguió los aplausos de los medios ${ }^{110}$.

Poco se pudo concluir de una moción de censura, que sirvió más para mostrar las carencias del candidato y la soledad política de los populares que las grietas del Gobierno: "la reciente historia parlamentaria europea no es muy pródiga en casos como éste, en que el censurante logra salir bastante peor parado que el propio censurado" ${ }^{\prime 11}$.

Tabla 37: Posición de los partidos políticos parlamentarios ante la Moción de Censura.

\begin{tabular}{|l|l|}
\hline A favor & AP, UV \\
\hline Abstención & CDS, PL, PDP, CiU, PAR, No adscritos, \\
\hline En contra & PSOE, PNV, EE, IU, AIC \\
\hline
\end{tabular}

Elaboración propia a partir de información hemerográfica.

La actitud de Suárez generaba numerosos interrogantes entre los medios periodísticos y políticos. El CDS mantenía su estrategia en solitario, desplegada sobre el horizonte de 1990, a pesar del desarme político de la derecha. Suárez multiplicaba su presencia en los medios a la par que acentuaba sus críticas contra el Gobierno, mejoraba en los índices de popularidad y en los sondeos y comenzaba a contar con la simpatía de la línea editorial de Diario $16^{112}$. Santiago Carrillo, quien solía opinar sobre la

\footnotetext{
${ }^{109}$ Ibid., p. 2301; la atribución a Antonio Garrosa, en FUENTES ARAGONÉS, J. F.: Adolfo Suárez... y Entrevista con Antonio Garrosa, 31 de julio de 2013. La contestación de Suárez fue ampliamente celebrada entre los centristas y ocupó las portadas de sus boletines, Eslabón, 2, marzo-abril 1987.

${ }^{110}$ CAMPMANY, Jaime: "Jaula de grillos", $A B C, 28$ de marzo de 1987; SEBASTIÁN, Pablo: "Aspirante peleón y el duque de Guerra", $A B C, 29$ de marzo de 1987; SEBASTIÁN, Pablo: "Aspirante peleón y el duque de Guerra", $A B C, 29$ de marzo de 1987.

${ }^{111}$ POWELL, Charles T.: España ..., p. 502; MAGONE, José María: Contemporary Spanish Politics, Routledge, N. York, 2009. Soto Carmona ha concluido: "La gestión de Hernández Mancha estuvo presidida por los fracasos", en SOTO CARMONA, Álvaro: Transición ..., p. 271. "Su actuación... en un debate televisivo con Felipe González fue calificada de lamentable", MUNIESA, Bernat: La España..., p. 206.

${ }^{112}$ Entrevista de J. L. Gutiérrez y editorial, justo el día del inicio del debate parlamentario sobre la moción de censura: "El optimismo de Adolfo Suárez", Diario 16, 26 de marzo de 1987. Portada: "El ganador en la sombra", Cambio 16 [recorte de prensa] en Eslabón, CDS-Albacete, 3, marzo-abril 1987. Otras manifestaciones: PRECIADO, Nativel: "Por fin habla Suárez", Tiempo, s. f. recogida en Eslabón, 3, mayo 1987. CONTRERAS, Lorenzo: "El progreso de Suárez", $A B C, 09$ de abril de 1987.
} 
trayectoria del abulense, expresaba una idea que ahora sí, flotaba en el aire: "Carrillo: 'Tras la marcha de Fraga, Suárez es la figura del centro-derecha",113:

Tabla 38: Valoración política de Adolfo Suárez (1986-1987).

\begin{tabular}{|r|r|r|r|r|r|r|r|}
\hline Junio & Julio & Septiembre & Octubre & Febrero & Marzo & Abril \\
1986 & 1986 & 1986 & 1986 & 1987 & 1987 & $\begin{array}{r}\text { Mayo } \\
1987\end{array}$ \\
\hline 5,18 & 5,24 & 4,95 & 5,32 & 5,09 & 5,07 & 5,62 & 5,27 \\
\hline
\end{tabular}

Elaboración propia a partir de la encuesta del CIS, Conocimiento y escala de valoración (0-10) de la actuación política de Adolfo Suárez (nacional) (Código: A501010130).

Para los suaristas, el debate había supuesto un nuevo episodio en el relanzamiento de Adolfo Suárez como alternativa al PSOE, una opinión que lejos de ser una mera impresión subjetiva parecía confirmarse por sucesivos movimientos políticos ${ }^{114}$. Según recuerda José Ramón Caso en ese momento se propuso a Suárez encabezar la candidatura del CDS para las elecciones europeas. De acuerdo con Caso:

Esas elecciones se celebran teniendo todo el país como circunscripción única, con lo que desaparece de hecho el elemento corrector que introdujo la ley D'Hondt [...] esas elecciones no tienen consecuencias para el Gobierno de la nación y los ciudadanos no votan con el condicionante del voto útil, por lo que ambas circunstancias unidas a la recuperada popularidad de Adolfo Suárez en las elecciones generales del año anterior, creaban las condiciones favorables para que él pudiera recoger los votos de los ciudadanos descontentos con la izquierda y la derecha ${ }^{115}$.

Ni Suárez estaba muy convencido de la idea, ni la oposición permitió dicha posibilidad. AP, PSOE y MC realizaron una modificación de la ley electoral que exigía como requisito de cara al encabezamiento de listas el abandono previo de su escaño en el Congreso ${ }^{116}$ en medio de un considerable revuelo periodístico y la indignación centrista: "Enmienda intolerable de la minoría catalana [...] Esta enmienda nos hace un daño evidente y reduce nuestras posibilidades de representación europea"117. El País

\footnotetext{
${ }^{113}$ ABC Sevilla, 22 de diciembre de 1986.

114 "Suárez, ni mentarlo": "Los socialistas tienen la consigna de referirse cuanto menos mejor a Adolfo Suárez o el CDS en sus declaraciones públicas. En el Gobierno sucede lo mismo”, Eslabón, 2, febrero 1987.

115 CONTRERAS, Emilio: Suárez..., p. 331.

${ }^{116}$ En portada: “AP se unió a los socialistas para frustrar los deseos de Suárez de encabezar la lista a las elecciones europeas", El País, 19 de marzo de 1987.

117 OICDS, 5, mayo de 1987. Finalmente, merced a la incorporación de unas enmiendas del Senado al Proyecto de Ley de Reforma de la Ley Electoral General para la Reforma de las Elecciones al Parlamento Europeo de 01 de abril de 1987 se omitió esta cláusula, aunque se siguió exigiendo, en caso de obtención del escaño europeo, el abandono obligatorio - a no ser que renunciase a dicho acta- del cargo en Madrid. En palabras de J. R. Caso: "Han pretendido tender una trampa; se creen muy inteligentes. Si algún líder nacional quiere correr el riesgo de presentarse a las elecciones al Parlamento Europeo, se le introduce en un dilema: o bien pierde el escaño nacional, con lo cual se le priva de estar aquí y poder debatir las grandes cuestiones nacionales, o renuncia antes de la proclamación [...] entonces, será el electorado quien estimará si se incurre en un fraude ante ellos", DSCD, Sesión Plenaria, 01 de abril de 1987, n 42, p. 2494.
} 
criticaba la táctica del Gobierno y los conservadores con un elocuente editorial: "Que viene Suárez"118.

\section{4. Las elecciones autonómicas, municipales y europeas de 1987.}

Las contienda electoral de 1987 era una excelente oportunidad para el CDS en muchos sentidos. Le permitirían alcanzar representación institucional y de este modo poner en marcha una implantación más equilibrada en todo el territorio. Su papel en los consistorios, -desde la oposición-, era el escaparate perfecto para la nueva forma de ejercer la política preconizada por los suaristas, favoreciendo el diálogo y privilegiando soluciones pragmáticas: "[el dirigente del CDS en Navarra, Pablo García Tellechea] recordó $[. .$.$] que el CDS era un partido de gente de sentido común" { }^{119}$. Javier Soto hablaba de un programa "realista, posible y riguroso"120. En ambos casos, se trataba de poner en la práctica sus críticas a la prepotencia socialista y al catastrofismo de los conservadores y de resultas, reducir los niveles de confrontación ideológica que había generado la irrupción del bipartidismo. Todo ello, con el objetivo último de lograr presentar al partido y a su líder como alternativa de gobierno en 1990. Las encuestas parecían confirmar que la estrategia del CDS era algo más que el "cuento de la lechera".

Esta estrategia, de acuerdo con el estudio encargado a la empresa publicitaria de la campaña, se basó en concebir las Elecciones como "antesala" de las Generales pivotando sobre dos grandes ideas: "gran poder de atracción del líder y vigencia del espacio político ocupado". Lo que conllevaba que: "el grado de aceptación de la propuesta del CDS estará más en el planteamiento de esquemas políticos susceptibles de quebrar el 'statu quo' pretendidamente bipartidista, que en la capacidad de resolución de los problemas locales del ciudadano sin que, obviamente, se margine este aspecto" ${ }^{121}$. En relación a las expectativas electorales, se reconocía la victoria del PSOE aunque con

\footnotetext{
${ }^{118}$ Portada en El País: "Socialistas y AP se unen para evitar que Suárez se presente a las elecciones europeas", 19 de marzo de 1987. "Los grupos políticos conceden una importancia marginal a esta consulta, y todos los propósitos de varias formaciones presentes en el arco parlamentario se concentran en el estúpido esfuerzo de cortar el camino a Adolfo Suárez para bajar a esta arena electoral. A la voz de que viene el duque, el partido del Gobierno no ha tenido escrúpulos en apoyarse en el nacionalismo catalán y la derecha conservadora para muñir unas normas...", en el editorial: "Que viene Suárez", El País, 20 de marzo de 1987

${ }^{119}$ La Voz de la Ribera, 11 de abril de 1987.

${ }^{120}$ Intervención en el Club Liberal, $A B C, 14$ de mayo de 1987.

${ }^{121}$ A cargo de la empresa de marketing electoral INTERALAS: "Presentación CDS", marzo 1987, Carpeta 1, AGP.
} 
un descenso en el número de votantes: "quizá la máxima expectación de las municipales sea cuántos votos rescatará de los prestados al PSOE en 1982"122. "AP en solitario", y "sin Fraga", era "un enigma" que intentaría ofrecer una imagen renovada y se podría aprovechar de su "sólida implantación”, pero señalaba el análisis: "no alcanzará el número de sufragios de 1983 si el CDS lo hace bien”.

Las bazas del CDS eran: "la titularidad del espacio político de centro", "la fuerza de la figura de su líder y "la ideología diferenciada de la socialista". El CDS además se beneficiaba del efecto ascendente -arrastre- iniciado en 1986 y de la probada incapacidad de las coaliciones conservadoras para poner fin a la hegemonía del PSOE. Aspectos que contrarrestaban dos grandes hándicaps: una implantación débil y un programa "tildado de ambiguo". Sobre Suárez se señalaba:

Es objetivamente reconocido como el artífice de la Transición. Valiente, hábil, excelente estratega, conecta cada vez mejor con el pueblo. Se le atribuye categoría política más que suficiente para competir con el PSOE y su líder. Suárez no tiene que demostrar nada. La gente entiende que en estas elecciones será el principal enemigo del PSOE. El más temido.

El partido llegaba a las elecciones con muy buenas perspectivas en términos electorales. Si damos pábulo a las encuestas recogidas por la revista Tiempo y en diversos boletines del partido, el CDS seguía recuperando votantes de otros partidos, particularmente del PSOE, a la par que aumentaba en intención de voto:

Tabla 39: Procedencia del posible voto al CDS en 1987.

\begin{tabular}{|l|l|l|}
\hline Partido votado en 1986 & Emopública & DYM \\
\hline PSOE & 16,8 & 24 \\
\hline CP & 7,4 & 13,3 \\
\hline CDS & 54,7 & 46,7 \\
\hline No votó & 10,7 & 10,7 \\
\hline Otros & 10,4 & 5,3 \\
\hline
\end{tabular}

Elaboración propia a partir de $O I C D S, 5$, mayo 1987.

Tabla 40: Intención de voto al CDS en 1987.

\begin{tabular}{|l|l|l|}
\hline Intención de voto & Emopública & DYM \\
\hline Intención General de Voto & $7,9$ [AP: 8,$7 ;$ PSOE: 24,2$]$ & $6,3$ [AP: 6,$8 ;$ PSOE: 28,1$]$ \\
\hline Intención Directa de Voto & $14,3$ [AP: 25,$7 ;$ PSOE: 37,8$]$ & 13,8 [AP: 20,$2 ;$ PSOE: 41,6] \\
\hline
\end{tabular}

Elaboración propia a partir de encuestas de Emopública/DYM, Eslabón, 3, marzo-abril 1987.

Incluso, en una encuesta llevada a cabo por la revista Actualidad Económica, por primera vez desde su dimisión, superaba a Felipe González en popularidad (media entre

${ }^{122}$ Ibid. 
el índice de conocimiento y de aceptación) por 0,02 puntos $(4,72 \text { frente a } 4,70)^{123}$. El electorado "objetivo" del CDS se agrupaba en cinco bloques: los votantes del CDS en 1986, "los auténticamente incondicionales", los votantes de la CP que votaron UCD en 1977 y 1979, “el voto conservador respetable, responsable y nunca nostálgico”, los votantes del PSOE, "no cualificados", "profesionales del voto al poder", antiguos votantes de UCD en 1977 y 1979 y finalmente, “jóvenes que votan por primera vez". Para estos segmentos del electorado el CDS estaba "evidentemente en alza" y Suárez había "recuperado el prestigio perdido". Con medios suficientes, se señalaba, el CDS podía "enfrentarse con garantías al PSOE y en el peor de los casos crear una oposición más eficiente que la actual" ${ }^{\prime 24}$.

En marzo se confirmó la candidatura de Rodríguez Sahagún para la alcaldía a la ciudad de Madrid $^{125}$, tras descartarse la posibilidad de que hubiera sido el mismo Suárez quien la encabezase; una opción no tan descabellada y que se había barajado también para el relanzamiento político de Manuel Fraga -la Operación Chirac- ${ }^{126}$. En relación a las listas en el resto de localidades: "los comités locales hacían la propuesta de sus candidaturas al Comité Regional y el Regional elevaba su propuesta al Nacional para las

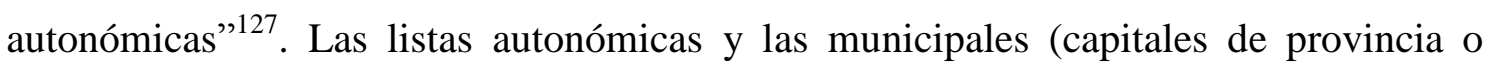
grandes localidades) eran convalidadas en Madrid ${ }^{128}$. Las distintas listas, así como el programa electoral, fueron presentándose a lo largo del mes de mayo por toda la geografía nacional y de nuevo, sirvió de excusa para intensificar la institucionalización del partido, en este caso a nivel federal. Sucedía así en comunidades como Cataluña, donde de acuerdo con el gerente de la campaña y dirigente del CDS en esta Comunidad Autónoma, Xavier Latorre, en 1986 cuando entró en el partido: "no hay implantación,

\footnotetext{
${ }^{123}$ OICDS, 5, mayo 1987.

${ }^{124}$ INTERALAS: "Presentación CDS", marzo 1987, Carpeta 1, AGP.

${ }^{125}$ El 14 de marzo de 1987, se dio por confirmada la noticia en la prensa, que fue revalidada el 08 de abril por la Federación del CDS-Madrid.

126 CONTRERAS, Lorenzo: "Suárez 'alcaldable' posible", $A B C, 04$ de diciembre 1986 y "La larga marcha hacia el futuro", $A B C$, 05 de diciembre de 1986. La idea, según Carlos Abella, partía de Mario Conde, un extremo puesto en duda por FUENTES ARAGONÉS, Juan Francisco.: Adolfo Suárez..., p. 475. Sobre la Operación Chirac, VERSTRYNGE, Jorge: Memorias de un maldito, Barcelona, Grijalbo, 1999, p. 182. De otra parte, la candidatura de Suárez a la Alcaldía de Madrid, como señalaba El País, hubiera podido servir "al objeto de justificar su imagen en los carteles electorales y su activa campaña", El País, 10 de abril de 1987.

${ }^{127}$ Cuestionario escrito con Tomás Martín Tamayo, febrero de 2014.

128 Sólo en la Isla de Gomera se formó una coalición electoral con otro partido, la Agrupación Independiente de La Gomera (AIG), BAEZ GARCÍA, Alberto Javier: Una historia de Coalición Canaria...
} 
no hay afiliación, no hay nada" ${ }^{29}$. Un territorio donde el CDS seguía siendo absolutamente secundario: no participaba en los debates políticos ni era seguido por los medios de comunicación.

Los últimos detalles de la campaña se concretaron en la segunda quincena de abril tabla 41-. El slogan de campaña del CDS fue "El Centro Avanza", dando continuidad a los magníficos resultados de un año antes y acompañándose por la expresión: “Ten Confianza". Se decidió "siguiendo instrucciones de Adolfo Suárez" emplear la tipografía, gráfica y fotografía más similares a "lo realizado durante las últimas elecciones". La imagen de Suárez, una vez más, debía encontrar ese punto intermedio entre la experiencia y la capacidad del Presidente de Gobierno durante la Transición y la juventud y cercanía de un partido dinámico y original: "no deberá tener los brazos cruzados ni arrugas en la chaqueta" ${ }^{" 130}$. El presupuesto en esta ocasión rondaba los mil millones de peseta ${ }^{131}$. El principal contratiempo de cara a la financiación y publicidad de la campaña residía en que "las subvenciones y los espacios oficiales de propaganda se adjudicarán en función de los votos obtenidos en 1983 y no en las Legislativas del 86, como pretende el partido"132. El peso de la campaña recaía, como es lógico, en Madrid cuyo presupuesto asignado en publicidad electoral prácticamente duplicaba al total, en este aspecto, destinado a las elecciones europeas ${ }^{133}$.

Tabla 41: Tiempos y organización de la campaña.

\begin{tabular}{|l|c|}
\hline Fecha & Evento \\
\hline 21 abril & Comentarios de bocetos definitivos con José Ramón Caso. \\
\hline 22 abril (mañana) & $\begin{array}{r}\text { Reunión de Florencio Barranco [Interalas] con miembros del CDS para el cierre de } \\
\text { las condiciones económicas y preparación de contrato. }\end{array}$ \\
\hline 22 abril (tarde) & Sesión fotos de Adolfo Suárez y de Agustín Rodríguez Sahagún. \\
\hline 24 abril & Posible rueda prensa de presentación de campaña. \\
\hline 24 abril & $\begin{array}{r}\text { Artes finales de vallas [...] y prensa, diario de precampaña de A. S. y A. R. S. } \\
\text { (incluido cuerpo de texto a recibir del cliente el día 23). }\end{array}$ \\
\hline 21,22 y 23 abril & Grabación de cambios en jingles (cuñas) que debían estar realizados el día 24. \\
\hline 23 abril & $\begin{array}{c}\text { Organización de la campaña en provincias y coordinación con las oficinas de } \\
\text { Interalas. }\end{array}$ \\
\hline
\end{tabular}

\footnotetext{
${ }^{129}$ Precisamente, alcanzar una mayor compenetración e ilusión entre los afiliados -es decir, un mayor sentimiento de partido, al margen del liderazgo de Suárez-, era uno de los objetivos de campaña, INTERALAS: "Presentación CDS", marzo 1987, Carpeta 1, AGP.

${ }^{130}$ INTERALAS: "Valla 3 x 8 precampaña", 20 de abril de 1987, Carpeta 1, AGP.

${ }^{131}$ El gasto de campaña rondaba una cifra oficial de 800 millones y un gasto total estimado de 1.500 millones, Tiempo, 01 de mayo de 1987. En $A B C$, y desde un punto de vista comparativo se aportaban los siguientes datos: 2.500-PSOE, 1.000-AP, 800-CDS, 600-PDP y 500-IU, ABC, 03 de mayo de 1987.

${ }^{132}$ LAFORA, V.: "Caso: 'Si hubiera elecciones seríamos el segundo partido y el PSOE perdería la mayoría absoluta", Diario 16, 22 de marzo de 1987.

${ }^{133}$ Ibid.
} 
Elaboración propia a partir de documentación existente en $A G P$ e información hemerográfica.

El programa marco del CDS para las elecciones municipales y autonómicas se estructuraba en torno a dos bloques. En primer lugar, se articulaban los principios políticos generales que debían regir la política municipal y autonómica y a continuación, se identificaban y analizaban los cuatro grandes problemas existentes a nivel nacional, susceptibles de ser abordados desde estos niveles de la administración: paro, droga, marginación/pobreza e inseguridad ciudadana ${ }^{135}$. Finalmente, se fijaba un marco programático -valores y propuestas- en los tres escalones administrativos: ayuntamientos, diputaciones y autonomías.

En esta ocasión y como hemos indicado anteriormente, el CDS subrayaba el "sesgo político" de estas elecciones, no sólo por las instituciones en juego, sino por el particular "momento electoral". Para el CDS las diferentes administraciones municipales y autonómicas constituían la "infraestructura" desde la que el PSOE aspiraba a "perpetuar" su hegemonía y fueron la plataforma a partir de la cual habían logrado el éxito de 1982. De este modo, estas elecciones debían contribuir a dar continuidad al proceso que reequilibrase "la titularidad del poder político en España, hoy concentrado en exceso en una sola formación política". Era el momento de comenzar a vertebrar una "mayoría social" que en torno al CDS generase una alternativa progresista y reformista. Para el CDS era prioritario devolver el sentido institucional a las administraciones territoriales, en un camino iniciado por Suárez y revertido desde 1982 por el PSOE en una "gradual contrarreforma legislativa" que había reducido al mínimo la participación democrática, y los instrumentos de control, incrementado la burocracia, desprofesionalizado la administración ("libre designación", "relaciones clientelares"), etc. Dar "marcha atrás" a este paulatino deterioro equivalía a aumentar la "participación democrática" -ciudadana y política, el diálogo

\footnotetext{
${ }^{134}$ Un total de 40.000 candidatos (unas 3.500 candidaturas), que cubrían el 90\% de los municipios/80\% del electorado, El País, 05 de mayo de 1987 y ABC, 07 de mayo de 1987.

135 "Programa marco para las elecciones autonómicas y locales de junio 1987", CDS, 1987, MAST. En cuanto a los programas electorales, estos seguían este esquema básico en las distintas localidades y autonomías con variaciones en cuanto a la introducción -visiones históricas, balances, etc.- o lo anexos finales. Véase por ejemplo: "El Centro Avanza. Programa Electoral para el Ayuntamiento de Madrid", CDS, 1987; "El Centro Avanzar. Programa Electoral para la Comunidad de Madrid", CDS, 1987, MAST.
} 
interinstitucional y entre las fuerzas políticas-, "suficiencia y rigor económicos" y "solidaridad"136.

En relación a las propuestas y los valores que debían guiar las políticas de las administraciones territoriales las propuestas del CDS traslucían un perfil liberal basado en la mejora de la gestión y la simplificación o facilitación de las relaciones con la ciudadanía (unificación de impuestos, de licencias de obra, etc.) ${ }^{137}$. La modernización y el progreso de las estructuras sociales y políticas se debía conseguir a partir de dos valores complementarios: libertad y bienestar.

La campaña se iniciaba la medianoche del 21 de mayo, en un día marcado por la dimisión y definitiva retirada de la política del máximo dirigente del PDP, Óscar Alzaga. En las siguientes semanas Suárez recorrió el país, -tablas 42 y 43-, respaldando a los distintos candidatos locales y autonómicos y acompañado del candidato a eurodiputado Eduard Punset: "el tratamiento mediático era mucho mayor que en 1986. La campaña era una flota de autobuses, en uno de sus pisos viajaba Suárez con un equipo de 20 periodistas" $" 138$. Los mítines discurrieron en espacios amplios (pabellones, plazas de toros e incluso estadios de fútbol). Los mensajes publicitarios diseñados para la campaña fueron encaminados, gracias a una alta notoriedad mediática, a tratar de quebrar el "equilibrio bipartidista", conseguir la inequívoca y exclusiva identificación del CDS como grupo político en el espacio de centro y poner de manifiesto la capacidad de gestión y gobierno de los centristas. La "idea clave" para transmitir la noción de alternativa derivaba de la incapacidad de la "derecha" para conseguirlo; sólo desde el “centro" era posible derrotar al PSOE, cuyos "puntos negros" debían ser denunciados a lo largo de toda la campaña ${ }^{139}$.

\footnotetext{
${ }^{136}$ Se contemplaba la fijación de un "mínimo de participación directa de las Entidades Locales en los ingresos del Estado" a través de leyes presupuestarias, participación que debía alcanzar en diez años el $30 \%$ y la clarificación y facilitación del crédito local y del ámbito tributario. De particular importancia, era el deseo de mejorar el control del Tribunal de Cuentas y la justicia ordinaria a la contabilidad municipal. Y la "limitación drástica del sistema de adjudicaciones directas", la moderación del gasto, "sometiendo en particular a revisión las remuneraciones de los cargos públicos" y el aumento de la "transparencia y publicidad", p. 11.

${ }^{137}$ Una de las medidas propugnaba el uso gratuito por parte de jubilados y estudiantes de los transportes públicos en días laborables. Como ha reconocido Alfredo Fraile: "algunas propuestas como la gratuidad del transporte público para jubilados y estudiantes eran un poco demagógicas..." FRAILE, Alfredo: Secretos..., p. 79.

${ }^{138}$ Ibid.

${ }^{139}$ INTERALAS: "Presentación CDS”, marzo de 1987, Carpeta 1, AGP.
} 
Tabla 42: Viajes de precampaña de Adolfo Suárez.

\begin{tabular}{|l|l|}
\hline Provincia & Fecha \\
\hline Cáceres & 13 mayo \\
\hline Badajoz & 14 mayo \\
\hline Pontevedra y La Coruña & 16 mayo \\
\hline Lugo y Orense & 17 mayo \\
\hline Málaga & 19 mayo \\
\hline Sevilla y Cádiz & 20 mayo \\
\hline Córdoba & 21 mayo \\
\hline
\end{tabular}

Elaboración propia a partir de Carpeta 1, AGP.

Tabla 43: Viajes de campaña de Adolfo Suárez.

\begin{tabular}{|l|l|}
\hline Provincia & Fecha \\
\hline Salamanca, Zamora y León & 23 mayo \\
\hline Palencia & 24 mayo \\
\hline Madrid & 25 mayo \\
\hline Valencia y Alicante & 26 mayo \\
\hline Murcia, Albacete y Cuenca & 27 mayo \\
\hline Baleares & 28 mayo \\
\hline Barcelona & 29 mayo \\
\hline Asturias y Cantabria & 30 y 31 mayo \\
\hline Madrid (descanso) & 1 junio \\
\hline Guadalajara, Zaragoza & 2 junio \\
\hline Navarra, Burgos, Logroño & 3 junio \\
\hline Tenerife & 4 junio \\
\hline Tenerife y Las Palmas & 5 junio \\
\hline Segovia & 6 junio \\
\hline Valladolid y Ávila & 7 junio \\
\hline Madrid & 8 junio \\
\hline
\end{tabular}

Elaboración propia a partir de Carpeta 1, AGP.

Al igual que en otras ocasiones, los cronistas que acompañaron a Suárez a lo largo de aquellas semanas describieron la puesta en escena del CDS como de "corte populista", en la que los mensajes viraban con rapidez de izquierda a derecha y viceversa y el mayor interés residía en los posibles pactos postelectorales del partido ${ }^{140}$. En todo momento, el CDS manifestó su intención de acudir en solitario a las urnas, y desde mayo de 1987, adoptó oficialmente la postura, de dejar gobernar a la lista más votada. Ejercería, en suma, un "arbitraje” vigilante:

Por la inmensa llanura, a trote lento, se divisa y llega un conocido jinete sobre su cabalgadura. Adolfo Suárez se llama. El ex presidente del Gobierno y líder del CDS, con un pelotón de hombres dispuestos para la guerra, controla el acceso a no pocas alcaldías y gobiernos autónomos. Más retador que nunca. Más convencido que nadie. Suárez reclama, medio en broma, lo que un día fue suyo: el contrato de inquilino en el Palacio de la Moncloa $^{141}$.

\footnotetext{
${ }^{140}$ GRIJELMO, Álex: "Suárez insiste en que él cabalga en solitario”, El País, 09 de junio de 1987.
}

${ }^{141}$ Eslabón, 4, mayo 1987. 
En general, fue una campaña deslucida, gris, especialmente en comparación con el tremendo éxito que en 1986 había tenido la propuesta suarista. Lorenzo Contreras o Pablo Sebastián entreveían un exceso de triunfalismo, una campaña sin fuerza y llena de generalidades: "lleva moreno de lámpara de cuarzo, ha cambiado las pegatinas por suculentos cheques de quinientos millones, se pavonea como alcalde de Madrid, candidato para Europa y campeón de campeones [...] ¿Qué le pasa a Suárez?"142. Había resultado una campaña excesivamente influenciada por la política nacional, casi una especie de "primarias" para las Generales, en las que la ausencia de ideas y las descalificaciones fueron la tónica dominante ${ }^{143}$.

El modo de gobierno del PSOE y las referencias al ejecutivo constituyeron el eje orientador de la campaña suarista. El CDS criticaba las pretensiones hegemónicas de los socialistas y la irrealización de sus promesas de cambio, reivindicando el éxito en la Transición: "Guerra sabe bien que el único cambio que se ha hecho en España lo ha

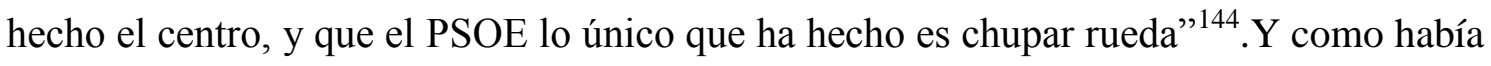
sucedido en 1986, intentaba marcar distancias con AP, -“con Morán discrepo, de Fraga me protejo"-145, partido en el que Fraga había vuelto a manifestar la "necesidad" de pactar con el CDS para configurar la futura alternativa por la "propia naturaleza de las cosas $[\ldots]$ buscarla solos está contra la lógica en estos momentos"146. En una entrevista concedida por Suárez en Chile a la corresponsal de $A B C$, M. A. Bulnes, señalaba:

- ¿Comparte usted el temor de que el PSOE se convierta en una especie de PRI mejicano o de partido único? - No. Me parecería una crítica excesiva. Otra cosa muy diferente es que el PSOE pretenda ser un partido hegemónico durante mucho tiempo [...] ¿Considera la posibilidad de llegar a alguna convergencia con otras fuerzas políticas? -

\footnotetext{
142 SEBASTIÁN, Pablo: "Don Adolfo, Don Manolo y Don Felipe", ABC, 24 de mayo de 1987; CONTRERAS, Lorenzo: "Triunfalismo y verdades", $A B C, 13$ de mayo de 1987.

${ }^{143}$ Editorial: "La eleccion triangular", El País, 09 de junio de 1987.

${ }^{144}$ El País, 18 de mayo de 1987. El CDS editó una serie de pegatinas tituladas “¿Qué hace el gobierno? ¡Para que se enteren!” en las que denunciaba las retribuciones de los cargos autonómicos y locales socialistas, el problema del paro o la subida de los precios en alimentación, Archivo PR-UB.

${ }^{145}$ En expresión de Eduard Punset, GRIJELMO, Álex: "Suárez insiste en que él cabalga en solitario", El País, 09 de junio de 1987.

${ }^{146} A B C, 07$ de junio de 1987. Hubo coaliciones entre el PDP y el PL (Galicia -Coalición Progresista Galega- y Navarra -Unión Demócrata Foral-), AP y PL en Baleares y PL con otras fuerzas en Canarias (Unión Canaria de Centro). En Castilla y León, la dimisión de sus cargos del candidato del PDP, Martín Villa, provocó su sustitución por el presidente de la Diputación de Segovia, Rafael de las Heras. En el transcurso de una entrevista con Martín Villa: “- ¿Le ha hecho alguna oferta el CDS? -No, y no sólo no creo que me la hagan sino que no es verdad que yo haya intentado contactos", $A B C, 02$ de mayo de 1987. Renovación Democrática de Verstrynge dijo que apoyaría al CDS, El País, 17 de mayo de 1987.
} 
Nosotros tenemos una absoluta independencia frente a toda clase de poderes. Nos inspira una concepción radical... 147

En el PSOE, como indicaba El País, se trataron de esquivar las referencias directas al CDS al que genéricamente catalogaban como "la derecha"148 e incluso, se difundió el rumor de un supuesto pacto entre el CDS y AP, con el respaldo de la CEOE. La actitud del PSOE hacia el CDS mostraba para muchos la preocupación real del socialismo y confirmaba la "estrella ascendente" de Suárez ${ }^{149}$. Las filtraciones de las guías de campaña socialista incidían en la idea de considerar, como sus principales adversarios políticos, a IU y CDS. En el caso del CDS y según recogían los medios se debía insistir:

Es un partido al servicio de una persona, su único valor es Adolfo Suárez, que intentará tapar con su manto a todos los candidatos. Los candidatos socialistas no deben replicar nunca a Suárez, la confrontación debe ser con los candidatos del CDS, llamar la atención sobre sus carencias y evidentes limitaciones, sacándoles del discurso genérico para meterles en el de la gestión [inexperiencia]. Hay que poner de relieve su derechismo y su carácter intercambiable con $\mathrm{AP}^{150}$.

Desde AP, emergía un doble discurso. Por un lado, se intentaba mantener la oferta de pacto, imprescindible para evitar la formación de gobiernos socialistas - desde Fraga a Ruiz Gallardón o Aznar ${ }^{151}$, mientras de otra parte, se criticaba la ausencia de definición ideológica y el excesivo personalismo de los suaristas, en un intento por frenar su expansión electoral ${ }^{152}$. En opinión de Manuel Fraga: "la diferencia entre Adolfo Suárez y yo es que yo lucho porque España sea una nación importante y él sólo lucha porque Adolfo Suárez sea un hombre importante" ${ }^{\# 3}$. O, en palabras del dirigente

\footnotetext{
${ }^{147}$ BULNES, M. A.: "Suárez: 'Es inevitable que vuelva a ser presidente del Gobierno en 1990”, $A B C, 04$ de enero de 1986.

${ }^{148}$ DÍEZ, Anabel: "El PSOE proclamará en campaña que el voto al CDS es una opción de derecha", $E l$ País, 22 de mayo de 1987. Por ejemplo, se aludió al pasado de los miembros de las candidaturas del CDS, denunciando que eran representantes de la "derecha pura y dura de siempre", en CARBAJO, Juan Antonio: "Leguina pide que se desenmascare a los del CDS con pasado franquista", El País, 30 de mayo de 1987; "Barranco afirmó que las listas de AP y CDS son intercambiables", El País, 29 de mayo de 1987, etc.

${ }^{149}$ El País, 04 de junio de 1987. Esta idea en SEBASTIÁN, Pablo: "Tres damas y el gobierno de los pobres", $A B C, 07$ de junio de 1987.

${ }^{150} A B C, 24$ de mayo de 1987. "Cuando el perfil del candidato del CDS lo permita, poner de relieve su derechismo", $Y a, 04$ de junio de 1987.

${ }^{151} A B C, 29$ de mayo, 05 de junio o 18 de mayo de 1987.

${ }^{152}$ F. Álvarez Cascos le acusaba de estar disfrazado de "tardo-falangismo", de pasar de estar al servicio de Carrero Blanco al "servicio de la progresía", $A B C, 22$ de marzo de 1987; "AP recrudece sus críticas al CDS", El País, 08 de abril de 1987; "González Estéfani: 'No descarto una coalición post-electoral”", $A B C, 03$ de junio de 1987; "[Hernández Mancha] Que el electorado 'castigue' 'operaciones personales", $A B C, 11$ de junio de 1987. Puntos de vista generalizados entre todos los partidos: "usted cree, por ejemplo que la derecha es por igual el CDS y AP? - [F. Morán] Son dos versiones. El CDS no presenta su programa. Está centrado en la imagen de Suárez y es muy difícil discutir con una imagen, con una mera fotografía", recogido en una entrevista a Fernando Morán en $A B C$, 01 de junio de 1987.

${ }^{153}$ Entrevista a Manuel Fraga en $A B C, 05$ de junio de 1987.
} 
del PDP, Javier Rupérez: "No hay fuerza política europea que merezca el nombre de tal que pueda permanecer sin ideas, sin programas y sin equipos o que consista únicamente en el respeto al líder" ${ }^{\prime 54}$. Para Penella, después de lo sucedido en el PL, PDP y PRD: "el CDS era el único partido de centro a tener en cuenta" 155 , un CDS en evidente expansión, en el que como señala Martín Tamayo, fue en aquel período "una organización muy activa y concienciada, superando en los medios de comunicación con nuestra presencia a $\mathrm{CP}{ }^{\prime 156}$.

La frágil situación de la supuesta alternativa liberal-conservadora y el fracaso absoluto de la operación reformista provocaron que las cada vez más afiladas críticas suaristas a la gestión del PSOE fueran paulatinamente transformando la opinión de periodistas y medios. Suárez se había convertido en el más certero azote de la hegemonía socialista ${ }^{157}$. En este caso, los principales medios críticos con el Gobierno (Diario 16, $A B C, Y a$ ) respaldaron el voto a cualquier opción que fuera en perjuicio de la mayoría socialista; era el momento, como concluía $Y a$ en su editorial, de "la esperada reacción contra [la] hegemonía"158. Su columnista más afamada, Pilar Urbano, hacía un balance similar -"No hay voto inútil"- e incluso presentaba los resultados de un estudio de Francisco Segrelles que señalaba que si la CP hubiera ido fraccionada en dos bloques al Ayto. de Madrid se hubieran sacado los mismos concejales: “de haberse hecho así, el elector habría podido votar más a conciencia, con más libertad y hasta con más eficacia [...] Votar AP, CDS, PDP, IU o cualquier fuerza regionalista, se traduce rigurosamente en "no votar PSOE", 159. Y afirmaba que era el CDS -“nostalgia de una libertad sin miedos al poder político"- y la nueva presencia de Suárez quienes más habían contribuido a "perturbar" al PSOE. $A B C$ defendía un voto capaz de impedir el "predominio hegemónico" de un partido y de cara al futuro inmediato, advertía que la constitución de una alternativa dependía inevitablemente de la convergencia de AP, CDS y CiU: “[portada] de salir robustecidas en las urnas, podrían constituirse en

\footnotetext{
${ }^{154}$ Entrevista a Javier Rupérez en $A B C$, 04 de junio de 1987.

${ }^{155}$ PENELLA, Manuel: Historia..., p. 956.

${ }^{156}$ Cuestionario escrito con Tomás Martín Tamayo, febrero de 2014.

${ }^{157}$ OVIDIO: "Marx, hervido [Zigzags]", $A B C, 18$ de marzo de 1987; CAMPMANY, Jaime: "El bla bla bla de don Felipe", $A B C, 16$ de marzo de 1987 o "Los sofistas", $A B C$, 07 de abril de 1987. En la revista del CDS en Albacete, Eslabón, se destacaba no sólo el mayor seguimiento mediático, sino la mejor percepción del partido por parte de los medios de cara a estas elecciones, $\mathrm{n}^{\circ} 3$.

${ }^{158}$ Editorial: "Al filo de la media noche", $Y a, 11$ de junio de 1987. Las elecciones se planteaban como un "juicio sobre la actual situación política" entre el Gobierno y la definitiva clarificación de la oposición, editorial: "Las elecciones de hoy", $Y a, 10$ de junio de 1987 y "Cuando se acercan las elecciones", $Y a, 31$ de mayo de 1987.

${ }^{159}$ URBANO, Pilar: "No hay voto inútil", $Y a, 10$ de junio de 1987.
} 
alternativa del PSOE en las generales de 1990"160. En su línea editorial, Diario 16 sin decantarse por ninguna opción parecía defender una opción más allá del bipartidismo y capaz de terminar con las mayorías absolutas del PSOE:

Tres horas antes de que se iniciara la jornada de reflexión, la televisión pública ofrecía el último ejemplo lamentable de su acción distorsionadora: los telespectadores pudieron contemplar las intervenciones de sólo dos líderes, el del PSOE y el de AP, como si sólo existieran dos partidos en España y no fuera este país precisamente un ejemplo de multiplicidad. La petición de Adolfo Suárez, oportunista pero legítima de un espacio en TVE para replicar a Felipe González... ${ }^{161}$

De acuerdo con las encuestas que fueron saliendo durante la campaña, las perspectivas se volvían si cabe más halagüeñas: "el CDS, único partido que ha progresado durante la campaña”. En las elecciones al Parlamento Europeo pasaba de una intención de voto del 10,8\% (según el sondeo realizado el 8 de mayo) a un 11-13\% y de 6/8 a 7/9 eurodiputados ${ }^{162}$. El País confirmaba la "estrella ascendente" del CDS y lo consideraba “juez de la situación” en Madrid -donde podía ser segunda fuerza política-, Castilla y León, Comunidad Valenciana y Asturias y le permitía conseguir uno de sus objetivos fundamentales: la consecución de grupo parlamentario en el Senado -merced a los futuros senadores autonómicos- ${ }^{163}$. En Europa, la cifra ascendía a 9/10 eurodiputados, ratificándose el "crecimiento sustancial del CDS [...] posición privilegiada para llevar a cabo pactos de gobierno en muchas alcaldías y autonomías". Y a la hora de valorar la política de pactos, destapaba las enormes posibilidades de un CDS, que con AP, podría obtener la mayoría absoluta desplazando al PSOE en diversos territorios ${ }^{164}$. Concluía: "O sea, que los socialistas tienen motivos para estar nerviosos" $" 165$.

\footnotetext{
${ }^{160}$ Editorial: "Empieza la campaña", $A B C, 22$ de mayo de 1987. Portada con la fotografía de Hernández Mancha, Pujol y Suárez: "Comienza la carrera hacia las urnas", $A B C, 22$ de mayo de 1987. Con ironía, López Sancho especulaba sobre quién sería el siguiente líder de la derecha en caer: "la derecha española, como Salomé, dedica su danza ritual a que Herodes le ponga en bandeja la cabeza del Bautista. Y el oficio de profeta va por turnos [Suárez, Roca, Fraga, Alzaga]" en "Suspense y decapitaciones", $A B C, 24$ de mayo de 1987.

${ }^{161}$ Editorial: "Ante las elecciones de mañana”, Diario 16, 09 de junio de 1987. El periódico se proclamaba ni afín al gobierno ni "altavoz" de la oposición.

${ }_{162}$ Diario 16, 04 de junio de 1987.

163 "El PSOE pierde el control mayoritario de las grandes ciudades", El País, 04 de junio de 1987.

${ }^{164}$ Ibid.

${ }^{165}$ Editorial: "Sondea que algo queda", El País, 04 de junio de 1987.
} 


\section{5. Los resultados electorales de 1987: presencia institucional y política de pactos}

Los resultados supusieron "un notable avance" del CDS, un logro, que como ha señalado Fuentes Aragonés confirmaba "la línea ascendente" iniciada en 1986 y abría una "promesa de poder territorial que se desprendía del éxito alcanzado en autonomías y ayuntamientos claves", especialmente, en Madrid ${ }^{166}$. Un salto cuantitativo de enormes proporciones en su representación institucional que multiplicaba por tres su número de alcaldes, prácticamente por cuatro los concejales y por diez los diputados autonómicos tabla 44-:

Tabla 44: Evolución de la representación institucional y autonómica del CDS (19831987).

\begin{tabular}{|l|l|l|}
\hline & $\mathbf{1 9 8 3}$ & $\mathbf{1 9 8 7}$ \\
\hline Diputados autonómicos & 9 & 105 \\
\hline Diputados provinciales & 16 & 113 \\
\hline Alcaldes & 217 & 681 \\
\hline Concejales & 1339 & 5143 \\
\hline
\end{tabular}

Elaboración propia a partir de “Datos anexos al Informe de Gestión [III Congreso, 1990]”, Líneas de Acción Política, CDS, 1991, pp. 14-25.

La representación era muy significativa en comunidades como Castilla y León, Madrid y Canarias. Aunque como señalaban algunos periodistas, suponía reforzar las dos velocidades de crecimiento del partido existentes desde el inicio - "el Duque, pues, está sólidamente implantado en media España [...] [y] prácticamente no existe en la otra mitad"167-, era un excelente punto de apoyo para la definitiva implantación territorial del partido en aquellos territorios en los que había tenido una presencia menor (Extremadura, Murcia, Castilla-La Mancha o Andalucía) -tabla 45-:

Tabla 45: Representación institucional y autonómica del CDS (datos de 1989).

\begin{tabular}{|l|l|l|l|l|}
\hline & Concejales & Alcaldes & $\begin{array}{l}\text { Diputados } \\
\text { Provinciales }\end{array}$ & $\begin{array}{l}\text { Diputados } \\
\text { Autonómicos }\end{array}$ \\
\hline Andalucía & 568 & 27 & 7 & - \\
\hline Aragón & 296 & 53 & 6 & 6 \\
\hline Asturias & 137 & 5 & $\cdot[$ no existe] & 8 \\
\hline Baleares & 62 & 4 & $\cdot$ & 5 \\
\hline Canarias & 184 & 11 & 23 & 14 \\
\hline Cantabria & 66 & 7 & $\cdot$ & 3 \\
\hline Castilla y León & 1798 & 406 & 37 & 18 \\
\hline Castilla-La Mancha & 514 & 58 & 3 & 4 \\
\hline
\end{tabular}

\footnotetext{
${ }^{166}$ FUENTES ARAGONÉS, Juan Francisco: Adolfo Suárez..., p. 473; POWELL, C. T.: España..., p. 503.

${ }^{167}$ ALTABLE, Juan: "El plan de Suárez para ser alternativa", Cambio 16, 07 de marzo de 1988, MAST.
} 


\begin{tabular}{|l|l|l|l|l|}
\hline Cataluña & 72 & 5 & - & 3 \\
\hline Extremadura & 386 & 36 & 3 & 8 \\
\hline Galicia & 279 & 10 & 1 & - \\
\hline Madrid & 222 & 21 & $\cdot$ & 17 \\
\hline Murcia & 72 & 3 & $\cdot$ & 3 \\
\hline Navarra & 35 & 4 & $\cdot$ & 4 \\
\hline La Rioja & 58 & 9 & $\cdot$ & 4 \\
\hline País Vasco & 8 & - & 1 & 2 \\
\hline Com. Valenciana & 394 & 25 & 7 & 10 \\
\hline Ceuta & 2 & - & - & - \\
\hline Melilla & 1 & - & - & - \\
\hline TOTAL & 5154 & 684 & 88 & $109^{168}$ \\
\hline
\end{tabular}

Elaboración propia a partir de "Datos anexos al Informe de Gestión [III Congreso, 1990]”, Líneas de Acción Política, CDS, 1991, pp. 14-25.

Si bien, era cierto que los suaristas habían levantado más expectación de la que finalmente depararon las urnas, no había que minusvalorar la importancia de los resultados. De acuerdo con los resultados obtenidos en 1986, el CDS podía convertirse en la llave de la gobernabilidad en 23 ciudades. Estas previsiones se cumplieron en el $60,86 \%$ de los casos, un porcentaje al que debemos sumar siete capitales no contempladas en este análisis:

Tabla 46: Trasposición de los resultados en las elecciones generales de 1986 a las elecciones autonómicas y municipales de 1987.

\begin{tabular}{|l|l|}
\hline $\begin{array}{l}\text { "Llave de gobierno" de acuerdo con los } \\
\text { resultados del 22-J (1986) }\end{array}$ & $\begin{array}{l}\text { De acuerdo con los resultados } \\
\text { del 10-J (1987) }\end{array}$ \\
\hline Ávila & Sí \\
\hline Burgos & No \\
\hline Ciudad Real & No \\
\hline Cuenca & No \\
\hline Guadalajara & Sí \\
\hline Huesca & Sí \\
\hline León & Sí \\
\hline Logroño & Sí \\
\hline Madrid & Sí \\
\hline Melilla & No \\
\hline Murcia & Sí \\
\hline Oviedo & Sí \\
\hline Palencia & No \\
\hline Las Palmas & Sí \\
\hline Pontevedra & No \\
\hline Salamanca & Sí \\
\hline Santander & No \\
\hline Valladolid & Sí \\
\hline Zamora & Sí \\
\hline Segovia & Sí \\
\hline Soria & Sí \\
\hline Teruel & No \\
\hline Toledo & Sí \\
\hline
\end{tabular}
${ }^{168}$ En 1988, ingresaron en el CDS 3 diputados autonómicos andaluces provenientes de la CP: Fernández
Jurado, Gonzalo Raúl y Hernández Caire, $A B C$ Sevilla, 03 de febrero de 1989. 
Otros casos en los que el CDS tuvo la llave de la "gobernabilidad" en 1987 Jaén, Castellón, Orense Lugo, Zaragoza, Palma de Mallorca, Tarragona, Cáceres, Valencia.

Elaboración propia a partir de $O I C D S, 3,1986$.

El CDS había logrado convertirse en el "árbitro político" de numerosos lugares y como recogía en su editorial Diario $16^{169}$, permitía a Suárez aspirar a "plantarle cara" a González en las próximas elecciones, y es que como decía Abel Hernández en Diario 16, tenía esta vez "el as de corazones en la manga" $"$.

Sin embargo, para otros se estaban mezclando dos cosas distintas: una era el voto de castigo al PSOE y otra la apuesta por el CDS. Según Antonio Burgos, en $A B C$, esto significaba: “en 1982 no se votó por el PSOE, sino contra la Ucedé, que era una cosa muy distinta. Por las mismas, que Suárez no se crea ahora que se ha votado centrismo. Se ha votado contra los socialistas..."171. En El País, su editorial hacía un balance bastante gris de los resultados y alertaba sobre las contradicciones estratégicas de los suaristas:

La lenta recomposición del centro político se confirma, pero todo indica que el partido de Suárez ha subido bastante menos de lo que las encuestas, optimistamente, prometían. Difícilmente se le puede considerar todavía, por lo mismo, como una alternativa de poder. $\mathrm{Su}$ vocación de partido bisagra le obliga a un complicado equilibrio. Por una parte, debe marcar continuamente distancias con los socialistas a fin de afirmar su identidad, pero -si desea acreditar su imagen como partido progresista- esta identidad sólo se cumpliría, por el momento, como eventual aliado de los socialistas y en oposición frontal a la derecha tradicional ${ }^{172}$.

Si la izquierda reflexionaba sobre la pérdida de la hegemonía, la derecha vislumbraba por fin la posibilidad de cambiar el signo político de la gobernación de algunos ayuntamientos y comunidades. Para el editorial de $A B C$, se encontraban a las puertas de iniciar -por fin- el proceso de coordinación de una futura alternativa al socialismo:

Si se quiere constituir una auténtica alternativa al PSOE. Son muchas las ciudades en las que esa coordinación de fuerzas arrebataría ya el poder a los socialistas [...] Estamos todavía en plena transición: no hay partidos lo bastante consolidados ni equidad suficiente en el juego democrático, especialmente en el terreno de la televisión, la propaganda y las asignaciones de dinero público adjudicadas a los partidos. Nuestra democracia es todavía

\footnotetext{
${ }^{169}$ Editorial: "Fuerte castigo al PSOE", Diario 16, 12 de junio de 1987. Amando de Miguel vislumbraba el nacimiento del "pentapartido" a la española [PSOE, AP, CDS, IU y nacionalistas], "Nos han quitado un PSOE de encima", Diario 16, 12 de junio de 1987

${ }^{170}$ HERNÁNDEZ, Abel: "El as de corazones", Diario 16, 15 de junio de 1987.

${ }^{171}$ BURGOS, Antonio: "La lista más odiada", $A B C, 01$ de julio de 1987. En esta línea URBANO, Pilar: "El PSOE pierde poder", $Y a, 11$ de junio de 1987.

${ }^{172}$ Editorial: “¿El inicio de la pendiente?”, El País, 11 de junio de 1987.
} 
incipiente, frágil y contradictoria. Es una larga etapa que España debe atravesar sin dejarse tentar por la aventura ${ }^{173}$.

El 12 de junio, $A B C$ publicaba en portada una foto de Suárez, a toda página y de cuerpo entero acompañada de un gran titular: "El mundo político pendiente de Suárez". Suárez era el "árbitro de la situación” y tenía "el deber moral de hacer viable el funcionamiento de la democracia" ${ } 174$. La tenacidad antisocialista de $A B C$ le llevaba a modificar sustancialmente su discurso sobre el CDS: "frente a los que certificaron la defunción de Adolfo Suárez, este periódico, lo mantuvo vivo y le prestó permanente atención por considerarle un político indispensable en el funcionamiento de la democracia ${ }^{175}$ ". Se entendía que el CDS no podía establecer "pactos" de acuerdo con lo mantenido a lo largo de la campaña, pero sí podía facilitar acuerdos que impidieran la gobernación socialista. El CDS, aunque mantuvo en todo momento, la decisión general de dejar gobernar a las listas más votadas, demoró intencionadamente una última postura oficial -el día límite para la constitución de las Corporaciones Municipales era el 30 de junio- y abrió la posibilidad a pactos puntuales, fundamentalmente a su derecha ${ }^{176}$, -el Comité Nacional no se había reunido desde el 29 de abril, para la preparación de la campaña- ${ }^{177}$. Existían cuatro factores que lo condicionaban en una dirección u otra. En favor de posibles acuerdos, presionaban parte de los cargos electos, y desde un punto de vista estratégico la posibilidad de conseguir la Alcaldía de Madrid $^{178}$. En contra sin embargo, era necesario valorar las consecuencias de significarse a un lado u otro del espectro político -especialmente, después del largo recorrido realizado por el partido hasta 1987- y la opción futura de poder llevar a cabo mociones de censura.

A medida que pasaban los días, la presión de los sectores más conservadores se agudizó insistiendo en la obligación moral y democrática de Adolfo Suárez de salir de su indeterminación y "asumir una enorme responsabilidad en la que se juega él mismo

\footnotetext{
${ }^{173}$ Editorial: "Duro castigo al partido socialista", $A B C, 11$ de junio de 1987.

${ }^{174}$ FUENTES ARAGONÉS, Juan Francisco: Adolfo Suárez..., p. 473. El día 11 de junio la portada de $A B C$ estaba dedicada a José Luis Álvarez del Manzano y Agustín Rodríguez Sahagún quienes podían arrebatar el ayuntamiento de Madrid a los socialistas, $A B C, 11$ de junio de 1987.

${ }^{175}$ Sección “Actualidad gráfica” de $A B C, 12$ de junio de 1987.

${ }^{176}$ Véase, RODRÍGUEZ SAHAGÚN, Agustín: “Cambiar los modos de gobernar”, Diario 16, 21 de junio de 1987.

${ }^{177}$ El País, 19 de junio de 1987.

178 "La LOREG promulgada en 1985 extiende la posibilidad de interponer la moción de censura a los ayuntamientos" en el período 1987-1991 en MÁRQUEZ CRUZ, Guillermo: "Veinte años de democracia local en España: elecciones, producción de gobierno, moción de censura y elite política (1979-1999)", Revista de Estudios Políticos (Nueva Época), 106, octubre-diciembre 1999, p. 326.
} 
su propio futuro" ${ }^{179}$. Los argumentos favorables al pacto esgrimidos desde AP o medios afines eran múltiples. El principal aludía al triunfo de facto del "centro-derecha": "el pueblo de Madrid se ha manifestado ya, y no en la calle sino en las urnas [...] y ha decidido que quiere un alcalde de centro-derecha" ${ }^{" 180}$. Otros se encargaban de subrayar los beneficios electorales que para el CDS podían deparar los pactos con AP: "si el CDS, en fuer de su imagen izquierdista dejara gobernar al PSOE, permitiría a AP ir creciendo y a la par certificar que el CDS no es alternativa"181. Muñoz Alonso subrayaba las limitaciones del CDS, -electorales, ideológicas-, para a continuación aludir a la necesaria coordinación del centro-derecha -al igual que había sucedido en Francia-: "no está escrito que el PSOE tenga conseguida la victoria de antemano salvo que, por anticipado, se la regalen sus adversarios" ${ }^{\text {182 }}$. José Luis Álvarez se remontaba como antecedente al pacto de izquierdas entre el PSOE y el PCE y las antiguas militancias compartidas (en UCD) ${ }^{183}$. Argumento aducido por Pedro J. Ramírez, quien comenzaba su defensa del pacto entre CDS-AP señalando:

Precisamente, lo que los españoles más admiraron del Adolfo Suárez de entonces fue su capacidad de 'pacto' [...] ¿Y es de este mismo hombre de quien ahora se dice que puede perder sus señas de identidad por llegar a un acuerdo para hacer gobernables una veintena de Ayuntamientos y media docena de autonomías? ${ }^{184}$

La posición del "partido bisagra por excelencia" era compleja ${ }^{185}$. Su eje parecía estar inclinado "necesariamente" hacia la derecha, y sin embargo, no terminaba de permitir: "la anhelada unión del centro derecha [...] Suárez no se plegaba al guión que pretendían

\footnotetext{
${ }^{179}$ Editorial: "Adolfo Suárez", $A B C, 16$ de junio de 1987. La portada mostraba un dibujo en el que en medio de Hernández Mancha y González tirando de una soga se encontraba Suárez reflexionando. El pensamiento que adjudican a Suárez, no era precisamente una lisonja hacia el abulense: "lo malo de ser un ideólogo es que nunca sabe uno cuál es el lado más práctico". En páginas interiores: "hay accionistas que en determinadas sociedades reciben beneficios superiores a su puro derecho contable, a cambio de alcanzar el pequeño final indispensable para evitar el descontrol de la empresa", editorial: "Generosidad de AP", $A B C, 16$ de junio de 1987. Asimismo, se publicaron cartas al director en la que los lectores se preguntaban "ies esto ideología?", “¿a qué juega Suárez?”, $A B C, 10$ de julio de 1987. Los fotomontajes realizados en las portadas de Época, en las que Suárez apareció ocasionalmente en portada antes y después de las elecciones, son realmente elocuentes de este clima político: "Análisis de la promesa de Suárez: La 'mili' de tres meses [en la imagen aparecía Suárez con uniforme y saludo militar]", Época, 27 de abril de 1987; "Suárez, árbitro [en la imagen aparecía Suárez con uniforme arbitral]", Época, 08 de junio de 1987; "El voto 'ambiguo'. Suárez juega a dos paños", Época, 06 de julio de 1987; "Votar Suárez es votar socialismo [Hernández Mancha]”, Época, 13 de julio de 1987.

180 "Y en este espacio político ha optado mayoritariamente por José María Álvarez del Manzano", RUIZ GALLARDÓN, José María: "La responsabilidad del 10-J", Diario 16, 21 de junio de 1987.

${ }^{181}$ JIMÉNEZ LOSANTOS, Federico: "La campaña del 89' ha comenzado", Diario 16, 12 de junio de 1987; ÍD.: “¿Alternativa o PSOE-bis?, Diario 16, 16 de junio de 1987.

${ }^{182}$ MUÑOZ ALONSO, Alejandro: "El fin de un mito", $A B C, 12$ de junio de 1987.

${ }^{183}$ ALVAREZ, José Luis en Diario 16, 14 de junio de 1987; LÓPEZ SANCHO, Lorenzo: "Chiringuitos chiringuiteados", $A B C, 13$ de junio de 1987.

${ }^{184}$ RAMÍREZ, Pedro J.: "Volver al 77'”, Diario 16, 14 de junio de 1987.

${ }^{185}$ MORÁN, Gregorio: Ambición..., p. 579
} 
imponerle" ${ }^{\prime 186}$. Un guión, muy visible en las páginas de $A B C$, donde la misma acción del CDS -abstención-, era leída en términos muy diferentes según sus consecuencias: "El aliancista Cañellas es elegido presidente en Baleares" o "El CDS permitirá que haya alcalde socialista en Oviedo"

El CDS defendió la abstención optando por dejar gobernar a las mayorías minoritarias, sin entrar en los gobiernos municipales y autonómicos -salvo que los propios representantes centristas fueran mayoría-. Para el periodista Luis Herrero, la causa de la actitud del CDS, "inspirada por Suárez", eran encuestas del CIS que identificaban una mayoría de centro-izquierda entre el electorado suarista: "el presidente del CDS ya sabía de antemano, a través de un amplio sondeo elaborado por la secretaría general de su partido, que los simpatizantes del CDS eran 'mayoritariamente partidarios de una colaboración crítica con el partido del Gobierno""188. El centrista Raúl Morodo justificaba la conveniencia de no hacer pactos globales con AP o el PSOE con el fin de salvaguardar la identidad del partido, ya que podrían "confundir más que clarificar". Según José Ramón Caso la decisión, tomada en la dirección nacional, intentaba salvaguardar la imagen que había permitido al partido alcanzar la posición de "tercera fuerza política". Se trataba de evitar la acusación de "cómplices" o "satélites" de la derecha o de la izquierda, inevitable, si hubiera habido un posicionamiento en uno $\mathrm{u}$ otro sentido. Por otro lado, y no menos importante, la mayor parte de los cargos electos suaristas eran "novatos" en el mundo de la política, y resultaba muy comprometida, sin ninguna experiencia previa, ni siquiera en la oposición, otorgarles en un contexto de enorme fragilidad responsabilidades de gobierno ${ }^{189}$. Desde el CDS se hablaba de “oposición constructiva" o "gobierno desde la oposición”, conceptos que ahora más que nunca tenían validez en la escena política española ${ }^{190}$. En palabras de Daniel de Fernando en el pleno de constitución del Gobierno castellano y leonés:

Nada más reafirmarnos en nuestra abstención por las razones expuestas. Insistir en que en los grandes temas de estado buscaremos el consenso de toda la Cámara; del gobierno

\footnotetext{
${ }^{186}$ Las negociaciones corrieron a cargo de J. R. Caso y A. García Tizón, en PENELLA, Manuel: Historia ..., p. 957.

${ }^{187}$ Titulares aparecidos los días 17 y 18 de julio de 1987 respectivamente.

${ }^{188}$ HERRERO, Luis: "Suárez ataca en silencio", Época, s. f. (1987), MAST.

${ }^{189}$ Era una decisión nacional, tal y como corroboran líderes nacionales, como Caso o regionales como Daniel de Fernando, entrevista con J. R. Caso, 19 de noviembre de 2014 y entrevista con Daniel de Fernando 19 de diciembre de 2013.

190 "Sin sufrir el desgaste propio de las labores de gobierno (policy-driven)", SÁNCHEZ MEDERO, Rubén y SÁNCHEZ MEDERO, Gema: "PP-CDS. Pactos y alternativas de gobierno de centro-derecha en 1989”, Política y Sociedad, 40-2, 2003, p. 197.
} 
diario que ejerza el señor Aznar y su equipo haremos un control crítico y efectivo desde esta Cámara ${ }^{191}$.

Si realizamos un análisis cuantitativo, siguiendo los trabajos de Gema y Rubén Sánchez Medero ${ }^{192}$, obtenemos las siguientes posibilidades a priori para el CDS de cara a la participación en gobierno de coalición -tabla 47 a) -.

Debido a que la posibilidad de un pacto PSOE+CDS no fue barajada en ningún caso por ninguna de las partes, resulta más interesante seguir las consecuencias de las decisiones del CDS en relación a la primera de las posibilidades (AP+CDS). La decisión del CDS de abstenerse en las votaciones impidió la formación de mayorías absolutas en el espacio de centro-derecha en instituciones locales (capitales de provincia) y autonómicas en el $61 \%$ de los casos analizados, permitiéndolo en el 38,70\% de los mismos - destacando los casos de Castilla y León, La Rioja, Baleares y Aragón-:

Tabla 47 a): Participación en gobiernos municipales y autonómicos si se hubieran producido pactos globales.

\begin{tabular}{|l|l|l|}
\hline Partidos & Capitales de provincia & Comunidades Autónomas \\
\hline AP + CDS & 22 & 8 \\
\hline PSOE + CDS & 33 & 12 \\
\hline
\end{tabular}

Elaboración propia a partir de SÁNCHEZ MEDERO, Rubén y SÁNCHEZ MEDERO, Gema: "PPCDS..."

Tabla 47 b): Consecuencias desde el punto de vista de la formación de mayorías de centro-derecha de la política de pactos del CDS y transposición de los resultados de 1986.

\begin{tabular}{|l|l|}
\hline $\begin{array}{l}\text { Un acuerdo global con AP hubiera generado } \\
\text { mayorías absolutas de centro-derecha en: }\end{array}$ & $\begin{array}{l}\text { Abstención/Voto en blanco/Voto a } \\
\text { su candidato (CDS) }\end{array}$ \\
\hline Castilla y León & Facilitó I93 $^{13}$ \\
\hline Madrid & Impidió \\
\hline Baleares (AP-UM) & Facilitó \\
\hline La Rioja (AP-PRP) & Facilitó \\
\hline Navarra (UPN-UDF-AP) & Impidió \\
\hline Aragón (PAR-AP) & Facilitó \\
\hline Jaén & Impidió \\
\hline Huesca (AP-PAR) & Impidió \\
\hline Zaragoza (PAR-AP) & Impidió \\
\hline Guadalajara & Impidió \\
\hline Logroño & Impidió \\
\hline Palma de Mallorca (AP-UV) & Impidió \\
\hline Cáceres & Impidió \\
\hline Santander & Facilitó \\
\hline
\end{tabular}

${ }^{191}$ Diario de Sesiones de las Cortes de Castilla y León, Sesión Plenaria, 21 de julio de 1987, nº 3/2.

192 SÁNCHEZ MEDERO, Rubén y SÁNCHEZ MEDERO, Gema: “PP-CDS. Pactos...”, p. 197.

${ }^{193}$ Facilitó: por constituir AP la lista más votada y tener mayoría relativa (un pacto PSOE-CDS hubiera podido arrebatar las alcaldías). Impidió: por no ser AP la lista más votada y sólo poder alcanzar mediante un pacto con el CDS -y en su caso, otras fuerzas de centro-derecha-, el gobierno municipal con mayoría absoluta. 


\begin{tabular}{|l|l|}
\hline Toledo & Facilitó \\
\hline Murcia & Impidió \\
\hline Valencia (AP-UV) & Impidió \\
\hline Valladolid & Impidió \\
\hline Salamanca & Facilitó \\
\hline Soria & Facilitó \\
\hline Zamora & Facilitó \\
\hline Tarragona (CiU-AP) & Impidió \\
\hline Madrid & Impidió \\
\hline Oviedo & Impidió \\
\hline Castellón & Impidió \\
\hline Ourense & Facilitó \\
\hline Ciudad Real & (Otros) \\
\hline Teruel & (Otros) \\
\hline León & (Otros) (“Pacto Cívico") $)^{194}$ \\
\hline Lugo & (Otros) \\
\hline Las Palmas & CDS \\
\hline Segovia & CDS \\
\hline Canarias & CDS \\
\hline
\end{tabular}

Elaboración propia a partir de Diario 16, 12 de junio de 1987, recogido por SÁNCHEZ MEDERO.

Aunque podemos concluir que "si alguien se benefició de la falta de acuerdo entre el CDS y AP fue el PSOE"195, no estaba en juego únicamente la gobernabilidad municipal sino, por un lado, el relanzamiento del CDS como alternativa y, por otro, la definitiva estructuración del centro-derecha. En este sentido, el caso de Navarra fue paradigmático. El CDS, junto con el resto de la oposición votó en contra de la nominación del candidato del PSOE, Gabriel Urralburu -“vetado" por los dirigentes suaristas en Navarra, antes de las elecciones-, pero no apoyó la candidatura del líder de Unión del Pueblo Navarro (UPN), Juan Cruz Allí, absteniéndose en las votaciones. Lo que le valió la fuerte reprobación de $A B C$ que reprodujo en portada unas duras y malintencionadas palabras del líder de Unión Demócrata Foral de Navarra: "Del Burgo acusa a Suárez de favorecer a HB"196.

\footnotetext{
${ }^{194}$ Debido a las particulares circunstancias políticas de la ciudad de León a raíz de la candidatura independiente del alcalde Juan Morano se produjo un pacto entre AP, PSOE y CDS, AZNAR, Manuel: Haciendo... Una situación parecida se vivió en la provincia de Burgos donde un pacto entre el PSOE, CDS y dos diputados de AP -opuestos a la estrategia de Solución Independiente y del alcalde de la capital J. M. Peña-, otorgó al diputado de AP J.L. Montes la Presidencia entre 1987 y 1989, ESCOLAR, Ignacio y ESTEBAN, J. A.: "Las amistades sustanciosas", El País, 20 de mayo de 1992.

195 "El PSOE, beneficiado por el apoyo general a las listas más votadas", $A B C, 01$ de julio de 1987; "El PSOE mantendrá las alcaldías en la mayor parte de las capitales gracias a IU y el CDS", Diario 16, 28 de junio de 1987; "El PSOE deberá pactar su gestión con el centro y la derecha", El País, 01 de julio de 1987.

${ }^{196}$ Portada en $A B C, 25$ de agosto de 1987 y editorial: "Se equivoca Suárez", $A B C, 12$ de agosto de 1987. "El CDS calificó ayer de 'calumniosas' las acusaciones del presidente de UDF, Del Burgo", Diario 16, 26 de agosto de 1987. "Sólo el funambulismo del CDS ha venido a complicar lo que estaba claro [el apoyo mayoritario al centro-derecha]" en el editorial: "Los reyes en Navarra", $A B C, 09$ de febrero de 1988. Finalmente fue elegido presidente autonómico Gabriel Urralburu en cuarta y última votación por mayoría simple.
} 
Por otra parte, la negociación de la "abstención" no estuvo exenta de contrapartidas para el CDS, como sucedió con la presidencia de las asambleas autonómicas o el nombramiento de senadores autonómicos, generando situaciones bastante complejas, caso de Baleares donde la abstención del CDS permitió la gobernación de AP-UM:

En Baleares, el caso fue todavía más rocambolesco, la presidencia de la cámara la ejerció Unió Mallorquina [UM], gracias al acuerdo que estableció AP y CDS, por el cual, UM apoyó al líder regional del CDS, Francisco Quetglás, para su designación como senador autonómico, además de concederle la vicepresidencia de la Mesa. Pero este acuerdo, no dejó de lado a los socialistas, ya que el CDS a su vez, garantizó al PSOE su apoyo a la hora de conformar las Comisiones Parlamentarias ${ }^{197}$.

El CDS consiguió la Presidencia de las Asambleas Autonómicas de las CC.AA. de Aragón, Madrid y Castilla y León y un total de cuatro senadores autonómicos -a los que se añadieron dos más a lo largo de la Legislatura-, lo que permitió formar en el mes de octubre de 1987 Grupo Parlamentario en la Cámara Alta. En el caso de Castilla y León la Presidencia de la Cámara recayó en Carlos Sánchez-Reyes, quien aceptó el ejercicio de este cargo con la condición de "no tener 'obediencia' de voto; prerrogativa de la que se valió en mayo de 1989 -durante la negociación de los Pactos de Madrid-al respaldar una solicitud de comparecencia de José María Aznar solicitada por el PSOE ${ }^{198}$.

Tabla 48: Presidencias de las Asambleas Autonómicas (CDS) y Senadores Autonómicos.

\begin{tabular}{|l|l|}
\hline \multicolumn{1}{|c|}{ Comunidad Autónoma } & \multicolumn{1}{|c|}{ Presidente de la Cámara Autonómica } \\
\hline Castilla y León & Carlos Sánchez-Reyes \\
\hline Aragón & Juan Bautista Montserrat Mesanza \\
\hline Madrid & Rosa Posada Chapado \\
\hline La Rioja Comunidad Autónoma & Manuel Fernández Ilarraza ${ }^{199}$ \\
\hline & $\begin{array}{c}\text { Senadores del CDS de designación autonómica } \\
\text { a lo largo de la Legislatura }\end{array}$ \\
\hline Castilla y León & José Luis Sagredo (1987) y Luis Aznar (1989) \\
\hline Madrid & Fernando Castedo (1987) \\
\hline Navarra & Juan José Otamendi (1987) \\
\hline
\end{tabular}

${ }^{197}$ SÁNCHEZ MEDERO, Rubén y SÁNCHEZ MEDERO, Gema: “PP-CDS. Pactos...”, p. 197.

198 Decano "electo" del Colegio de Economistas y máximo dirigente del OCU desde 1981. Vecino abulense y conocido de Suárez en su juventud, militó en movimientos de oposición al franquismo. Tras recuperar relaciones paulatinamente desde finales de los 70', recibió la invitación de sumarse al proyecto suarista en el verano de 1982 -como segundo al Congreso por Madrid-. Finalmente, y tras abandonar sus responsabilidades en la sociedad civil se afilió al partido hacia 1985, donde terminó aceptando la candidatura a la Presidencia de la Junta en 1987 - un puesto que finalmente declinó Rafael Calvo Ortega, como ha señalado el líder regional Daniel de Fernando-, entrevista con Carlos Sánchez-Reyes, 03 de junio de 2015. Una visión completa de este pacto, así como el documento íntegro en AZNAR, Luis: Haciendo memoria...

${ }^{199}$ Cesó el 11 de julio de 1988 cuando dos de los cuatro diputados del CDS pasaron al Grupo Mixto y en diciembre de 1989 ingresaron en el PRP. En enero de 1990, una moción de censura otorgó la presidencia de La Rioja al PSOE con apoyo del PRP e independientes. Los dos diputados que permanecían en el CDS se ausentaron de la Asamblea en señal de protesta contra el transfuguismo. Disponible en: http://www.historiaelectoral.com/arioja.html Fecha de consulta: 10 de enero de 2016. 


\begin{tabular}{|l|l|}
\hline Islas Baleares & Francisco Quetglás (1987) \\
\hline Comunidad Valenciana & Manuel Martínez Sospedra (1988) \\
\hline
\end{tabular}

Elaboración propia.

En otras Comunidades, donde el CDS no era decisivo para la obtención de mayorías absolutas debido a las amplias mayorías del PSOE o en su defecto por la posibilidad de establecer un pacto entre PSOE e IU, el CDS mantuvo su política de abstención -o bien, votó a su candidato--

En la Comunidad Autónoma de Canarias, las ciudades de Las Palmas y Segovia, la Diputación Provincial de Valladolid (Ovidio Fernández Carnero), el CDS consiguió la máxima representación institucional merced a acuerdos con el centro-derecha. En Canarias, Fernando Fernández se hizo con la Presidencia, hasta que dimitiera en 1988 a raíz de su derrota en una moción de confianza, dando paso a Lorenzo Olarte. En Ávila, el CDS logró la mayoría absoluta y la Presidencia de la Diputación Provincial (Daniel de Fernando). En Lanzarote, el CDS también consiguió la Presidencia del Cabildo Insular (Nicolás de Paiz Pereyra) ${ }^{200}$. En los casos anteriormente citados de Valladolid, Las Palmas y Segovia se produjeron relevos a lo largo de la Legislatura. Ovidio Fernández abandonó el CDS y posteriormente dimitió como Presidente de la Diputación (1990). En Las Palmas, un “tránsfuga” del CDS - primo del alcalde-, posibilitó una moción de censura del PSOE e ICU. Finalmente en Segovia, Luciano Sánchez Creus fue expulsado del partido y relevado de la alcaldía por J. A. Perteguer (CDS).

Tabla 49: Gobiernos municipales y autonómicos del CDS (1987-1991).

\begin{tabular}{|l|l|l|}
\hline Lugar & Nombre (Presidente/Alcalde) & Acuerdos \\
\hline Canarias & Fernando Fernández & CDS-AP-AIC-AHI ${ }^{201}$ \\
\hline Segovia & Luciano Sánchez Creus & CDS-AP-PDP \\
\hline Las Palmas & José-Vicente León & CDS-AP \\
\hline Ávila & Antonio Encinar Núñez & CDS \\
\hline
\end{tabular}

Elaboración propia.

\footnotetext{
${ }^{200}$ Asimismo, logró cuatro vicepresidencias de Diputaciones (Ávila, Valladolid, Zaragoza y Teruel) y tres de Cabildos (Lanzarote), AMINHAP.

${ }^{201}$ En el caso de Canarias el CDS conseguía la Presidencia Autonómica, la Vicepresidencia y tres consejerías. Véase: "Pacto de Legislatura entre CDS, AIC, AP y AHI. 22 de julio de 1987". Disponible en http://www.ub.edu/OGC/Canarias_1987.pdf. Fecha de consulta: 11 de marzo de 2015. Las claves del acuerdo fueron: "la denominada Ley de Aguas en las que se respetarían los derechos de sus propietarios y la señalada Ley de Cabildos ya que desde ATI-AIC se pretendía dar mayores competencias a los cabildos insulares en detrimento de Gobierno autónomo", BAEZ GARCÍA, Alberto Javier: Una historia de Coalición Canaria ..., pp. 44-5.
} 
La posición del CDS, como recuerdan algunos de los principales dirigentes territoriales fue asumida sin mayores reparos por todos los cuadros del partido ${ }^{202}$. Señala Caso que el problema se planteó inmediatamente después, es decir, en la gestión del papel de "bisagra", sometido al "tironeo" de derecha e izquierda:

A regañadientes lo aceptan tanto PSOE como PP, y desde el día siguiente, ellos con estructura de poder o con sus estructuras sociales amigas comienzan a trabajar por alterar ese escenario [...] sobre todo presionando a niveles locales intentando conseguirse el favor de diputados provinciales, de concejales, bien desde la prensa local, bien desde parcelas de poder. Todo ${ }^{203}$.

En un Boletín provincial del partido de enero de 1988 se podía leer: "[los cargos electos] han de querer y poder resistir las TENTACIONES DE PODER, aunque sea en forma parcial y condicionada"204. Siguiendo a Caso:

La presión que están recibiendo nuestros compañeros en las instituciones es obvia que la percibimos porque empiezan a venirse [a la sede central] [...] Todo el mundo tiene un caso excepcional $[\ldots]$ en [su] provincia, en [su] ciudad: desde denuncias de prácticas de malgobierno, presiones sociales, presión política, etc. [...] Y ahí seguimos resistiendo, nacionalmente, ese empujón que empiezas a notar que viene de todos los lados ${ }^{205}$.

Asimismo, el vertiginoso aumento de la militancia, como vimos anteriormente, no siempre respondía a las mismas motivaciones que habían movilizado a muchos de los miembros del CDS en la etapa anterior, ahora en muchos casos, atraídos por el éxito y las halagüeñas perspectivas políticas de los suaristas. Se acentuó la crítica interna y se extendió un nuevo perfil de militante con un grado de compromiso menor. En cierto modo, muchos eran del CDS "como podía[n] ser de otra cosa"206.

En esas fechas, la Secretaría General se vio obligada a establecer un "decálogo" sobre los criterios de actuación por parte de los Comités Provinciales en relación a los pactos postelectorales. Los dos primeros puntos ratificaban la decisión de no alcanzar pactos globales, aunque y como había sucedido en junio de 1987 “consideraba la posibilidad de llegar a acuerdos concretos en algunas provincias o Comunidades":

\footnotetext{
202 Entrevista con Gerardo Muñoz, 09 de mayo de 2015.

203 "No todos los que le acompañan [a Suárez] en la aventura centrista se resignan a respetar con plenitud los intereses del jefe, ya que palpan la proximidad del poder, incluso en grado superior al que les correspondería en estricta proporcionalidad" en CONTRERAS, Lorenzo: "El acuerdo de Madrid", $A B C$, 19 de junio de 1987.

${ }^{204}$ Informativo de Guadalajara (CDS), 1, enero 1988.

${ }^{205}$ Entrevista con José Ramón Caso, 19 de noviembre de 2014.

${ }^{206}$ Entrevista con Xavier Latorre, 14 de julio de 2014. DÍEZ, Anabel: “Adolfo Suárez reúne en secreto a 200 dirigentes regionales para analizar el fracaso electoral del CDS”, El País, 02 de julio de 1989.
} 
CDS está dispuesto a buscar acuerdos que faciliten la gobernabilidad en algunas Comunidades y Ayuntamientos en los que la pluralidad de fuerzas políticas presentes hacen difícil que un solo partido asuma la responsabilidad de gobernar ${ }^{207}$.

En dicho documento se informaba de las reuniones celebradas entre el Secretario General del CDS con sus homólogos de AP y el PSOE para dar respuesta a los "problemas de gobernabilidad". Si el PSOE compartía el criterio de gobierno de "la lista más votada" -aunque le había hecho ofertas de gobierno concretas al partido suarista, ofreciéndole incluso la presidencia del Gobierno autonómico balear-, AP había mantenido en todo momento su "oferta" de "pacto global". El sexto punto del “decálogo" enunciaba la postura del CDS: "ha manifestado a ambas fuerzas políticas que considera como su objetivo primordial [que las instituciones] [...] se gobiernen con mayor transparencia, control y participación”. Con este objetivo había reiterado la necesidad de formar "Comisiones de Vigilancia de la Contratación" y "Comisiones de Gobierno" en todos los municipios, un compromiso que, con otras fórmulas, quería trasladar también a las Comunidades Autónomas ${ }^{208}$.

\section{6. EI Grupo Parlamentario CDS en la oposición: líneas de actuación y principales debates políticos}

Durante la III Legislatura (1986-1989), el PSOE no sólo pudo seguir ejerciendo el poder con mayoría absoluta, sino que la oposición conservadora atravesó años de gran inestabilidad presa de las incertidumbres de un proyecto asediado por problemas internos y externos. La ausencia de una alternativa real agravaba el "distanciamiento del Parlamento como espacio de debate" y acentuaba la hegemonía del PSOE en los distintos niveles de la administración y las instituciones ${ }^{209}$. La expansión económica sin precedentes en la época democrática- y el generalizado optimismo de un país que inauguraba su presencia en la CEE y esperaba ya en el horizonte de 1992 -V Centenario del Descubrimiento de América- dos acontecimientos de magnitud mundial (las Olimpiadas de Barcelona y la Expo de Sevilla) reforzaron aún más la fortaleza del Gobierno.

\footnotetext{
207 "Decálogo del Secretario General sobre pactos electorales", CDS Ciudad-Real, 0, enero 1988.

208 La creación de "Comisiones de Vigilancia a la Contratación" fue exigida en por los grupos municipales del CDS en la oposición. Un caso paradigmático fue el de Burgos, ayuntamiento que se iba a ver salpicado por un caso de corrupción, véase, CHOMÓN, José María y CALVO IBÁÑEZ, Miguel: El jefe: el caso de la construcción, Burgos, s. e., 1994.
}

${ }^{209}$ MUNIESA, Bernat: La España Lampedusiana ..., p. 204. 
Sin embargo, la inmejorable coyuntura para la gobernación del país no se vio acompañada de un viraje en la política social y económica -definitivamente postergado- y desembocó en un conflicto abierto con las fuerzas sindicales, incluida UGT, consumando un cambio de orientación en el sindicato socialista perceptible desde 1985:

En una situación de claro crecimiento económico, que se venía produciendo desde 1986, los sindicatos decidieron pasar a la ofensiva y reclamar del gobierno un giro social, consistente en incrementar el empleo, en una justa distribución de las rentas y en mayores prestaciones sociales $^{210}$.

Como ha escrito Pere Ysás: "se ha señalado con frecuencia que la verdadera oposición al gobierno socialista fue ejercida en esos años por los sindicatos"211. El cénit de este proceso tuvo lugar con la convocatoria de Huelga General, respaldada por las dos grandes centrales sindicales (UGT-CC.OO.) el 14 de diciembre de 1988 (14-D). Junto a las demandas de los trabajadores, otros colectivos como el de los estudiantes mostraron su disconformidad con las políticas socialistas con huelgas, paros y $\operatorname{protestas}^{212}$. Se cumplían sólo en parte las hipótesis de la dirección suarista: las fuertes contradicciones generadas por las políticas reformistas y moderadas del PSOE encontraron un fuerte rechazo social pero, ¿iban a tener consecuencias políticas?

En esta legislatura, las reivindicaciones sociales y laborales sustituyeron a la política exterior como punta de lanza del debate político, materia, en la que la renovación del convenio con EE.UU. y las condiciones de integración de España en la Alianza Atlántica fueron los aspectos de mayor relevancia pública. Finalmente, la lucha contra ETA entró en una nueva fase marcada, como señala Florencio Domínguez, por el fuerte rechazo ciudadano -tras el atentado de Hipercor-, la colaboración francesa, los acuerdos políticos entre las fuerzas democráticas y debemos añadir, el fin de la "guerra sucia" y la irrupción del caso de los GAL ${ }^{213}$.

Gracias a los resultados del 22-J, el CDS contaba con diputados para elaborar y discutir las políticas gubernamentales, ofreciendo propuestas programáticas alternativas, en todas las áreas y comisiones de trabajo. Su labor parlamentaria se desplegó en varias

\footnotetext{
${ }^{210}$ MARÍN ARCE, J. M.: "Los socialistas en...”, p. 59.

${ }^{211}$ YSÀS, Pere: "Cambio y continuidades: tres lustros de gobiernos socialistas", Ayer, 84, 2011, p. 39.

${ }^{212}$ SOTO CARMONA, Álvaro: Transición..., p. 213.

${ }^{213}$ Pacto de Madrid, Ajuria Enea y Acuerdo por la Paz y la Tolerancia de Navarra (1987-1988). Estos tres aspectos constituyeron, junto a la acción policial, las claves de la lucha contra ETA en la etapa democrática, DOMÍNGUEZ IRIBARREN, Florencio: "El enfrentamiento de ETA con la democracia" en ELORZA, Antonio: Historia de ETA, Madrid, Temas de Hoy, 2000, pp. 277-421.
} 
líneas de actuación y si en algo destacó el CDS a lo largo de esta legislatura fue en su intento de dotar al Parlamento de un protagonismo del que había carecido durante el cuatrienio precedente e impedir la monopolización de la oposición en manos de AP, ofreciendo una vía intermedia entre los socialistas y los conservadores, junto con otras minorías como la Agrupación Democristiana y Liberal, las formaciones nacionalistas o IU:

La consolidación del CDS, con su grupo parlamentario propio, y el correlativo aumento en el número de enmiendas que presentó convierten a este partido en el de mayores coincidencias con Alianza Popular, mientras que la Minoría Catalana y [...] Vasca tienden a alejarse de la derecha aliancista [...] Destaca también que el CDS sea el segundo partido en coincidencias para todos (a excepción del PP, que, como acabamos de exponer, lo sitúa en primer lugar). Parece así que el CDS cumple una función de puente -inexistente en la primera legislatura socialista - entre el partido de la derecha y los nacionalistas, a la vez que puede coincidir con el grupo comunista (13 enmiendas sobre 26 presentadas por el CDS) ${ }^{214}$.

No se trataba tanto de una estrategia reactiva, de oposición frontal al Ejecutivo, sino de la denuncia de las limitaciones del poder legislativo, del ejercicio de control al Gobierno y del desarrollo de propuestas de fuerte impacto mediático y contenido simbólico, algunas de ellas de carácter transversal desde el punto de vista del espectro ideológico izquierda-derecha ${ }^{215}$. De forma paralela, se criticó lo que parte de la oposición llamaba falta de "sensibilidad social" del Gobierno, recogiendo y aprovechando la inercia generada por los sindicatos en su pugna con el Gobierno y que llegó a su cénit el 14-D (1988). En definitiva, el CDS intentaba trascender con constancia y originalidad las limitaciones a las que se veía abocado, como señalaba José Ramón Caso, por el control gubernamental del Parlamento y la $\mathrm{TV}^{216}$.

En su actuación en el Congreso de los Diputados, el CDS hizo intentos por aglutinar a las minorías parlamentarias en un frente común, que mejorase desde el punto de vista funcional la capacidad de estas a la hora de ejercer presión en el Parlamento ${ }^{217}$. Aunque tal iniciativa no prosperó y recibió críticas por parte de algunas de las minorías, la oposición aliancista y el gobierno, evidenció la ruptura entre las fuerzas principales

\footnotetext{
${ }^{214}$ CAPO GIOL, Jordi: “Oposición y minorías...", pp. 107-108.

215 "Recuperación del Parlamento como centro de la vida política", contenido del Manifiesto Electoral de 1989, CDS, 1989.

${ }^{216}$ En un artículo de J. R. Caso en El País en respuesta a las palabra de Jordi Solé Turá que unos días antes había señalado que "más allá del Gobierno" sólo existían "líderes silenciosos" en CASO GARCÍA, J. R.: "El doble espejismo socialista", El País, 24 de noviembre de 1987 y SOLÉ TURÁ, Jordi: "Del desierto del centro al desierto de la derecha", El País, 15 de noviembre de 1987.

${ }^{217}$ Reunión celebrada el 27 de enero de 1987, El País, 28 de enero de 1988; ARIAS-SALGADO, Rafael: “¿Un parlamento anémico?”, El País, 11 de febrero de 1987.
} 
(PSOE-AP) y el resto de partidos ${ }^{218}$. Las denuncias sobre la incapacidad del Parlamento para ejercer labores de control a la acción gubernamental arreciaron cuando PSOE, AP y CiU decidieron aprobar, sin el consenso de restos de fuerzas la Reforma del Reglamento del Congreso en 1988. Por ejemplo, el CDS reclamaba, en vano, la posibilidad de crear Comisiones de Investigación sin el respaldo necesario de la mayoría de la Cámara ${ }^{219}$. Como señalaba Suárez en el Debate sobre el Estado de la Nación de 1987: "si en el Parlamento [...] la función de control es difícil de realizar, me parece que estamos contribuyendo todos a que en la opinión pública el Parlamento no tenga el prestigio que necesita" 220 .

Las discrepancias entre los distintos partidos no impidieron la consecución de un consenso básico y unánime en un aspecto clave del funcionamiento institucional: la necesaria regulación de la financiación pública y privada de los partidos políticos -Ley Orgánica de Financiación de Partidos Politicos de 1987, en cuya comisión de estudio participó José Ramón Caso ${ }^{221}$-. Durante su tramitación el CDS volvió a insistir, como hiciera a propósito de la LOREG, en el perjuicio que generaba la ley al principio de igualdad de oportunidades ${ }^{222}$.

Su actitud "vigilante" se extendió a algunos abusos del Estado de Derecho como la utilización de los datos estadísticos (INE, CIS) por parte del Gobierno -el CDS defendió una proposición no de ley para que el Instituto Nacional de Estadística (INE) dependiese del parlamento "que contó con el respaldo unánime del resto de los

\footnotetext{
218 "No sólo la derecha: es el conjunto de las fuerzas políticas el que irresponsablemente amenaza con arruinar en España el sistema de equilibrios que predomina en España", editorial: "Poder y oposición", $A B C, 30$ de enero de 1987.

${ }^{219}$ El CDS en la Junta de Portavoces exigía que la Constitución de comisiones se pudiera solicitar bien por tres grupos parlamentarios o el $20 \%$ de la Cámara, MARTÍNEZ DE VEGA, José Antonio: "El acuerdo para revitalizar el Parlamento, una operación de imagen", OICDS, 10, febrero 1988. En la siguiente legislatura José Ramón Caso que participó en la Comisión de Reglamento y presentó un anteproyecto de reforma en 1993 desarrolló una enmienda ( ${ }^{\circ}$ 17) al art. 58.1. del Reglamento, en este sentido, GUDE FERNÁNDEZ, Ana: Las Comisiones Parlamentarias de Investigación, Santiago de Compostela, USC, 2000, p. 173.

${ }^{220}$ DSCD, Sesión Plenaria, 24 de febrero de 1987, n 31, p. 1767.

${ }^{221} \mathrm{Al}$ margen de la subsanación del vacío legal existente, la ley sirvió para aminorar las enormes deudas contraídas por los partidos mediante un aumento muy significativo de la financiación pública -se incorporó por ejemplo, la financiación ordinaria anual-, GALIACHO, Juan Luis y BERBELL, Carlos: Filesa. Las tramas del dinero negro en la política, Madrid, Temas de Hoy, 1995, pp. 200-201.

${ }^{222}$ Aunque durante su tramitación IU y CDS criticaron la distribución de subvenciones estatales en función del $\mathrm{n}^{\circ}$ de escaños por ir en perjuicio de la "igualdad de oportunidades" fue una ley ampliamente respaldada por todas las fuerzas políticas, El País, 21 de noviembre de 1986 o ABC, 05 de diciembre de 1986.
} 
grupos"223 - . De forma paralela, y en sintonía con el resto de fuerzas de la oposición, se solicitó la creación de numerosas comisiones de control y de seguimiento de las distintas políticas sectoriales ${ }^{224}$.

Inmediatamente después de las elecciones de 1986, el CDS impulsó una medida que pretendía reafirmar el compromiso del partido con el desarrollo completo del texto constitucional. En julio, el CDS presentó una proposición de ley para regular el Secreto Profesional y la Cláusula de Conciencia del Periodista ${ }^{225}$ en un momento, de plena actualidad mediática ${ }^{226}$; una medida, defendida por Federico Ysart, que fue finalmente rechazada a pesar de los aplausos que recibió en los medios u organizaciones como la Asociación de Prensa ${ }^{227}$. Manuel Fraga recogió en su diario: "la mayoría socialista (olvidando que había sido propuesta suya en el debate constitucional) rechaza una proposición de ley del CDS para regular la cláusula de conciencia..."228.

\footnotetext{
223 "La respuesta del Ejecutivo a la pregunta planteada por un diputado del Centro Democrático y Social (CDS) argumenta que "esta información primaria está sometida al secreto estadístico". La única regulación del secreto estadístico se deriva de la ley de 31 de diciembre de 1945, cuyo artículo $11 \ldots$.. en el editorial: "El privilegio del secreto", El País, 09 de diciembre de 1987. Véase, Proposición no de Ley relativa a la Dependencia Parlamentaria del Instituto Nacional de Estadística, en DSCD, Serie D. Actos de control, nº 101, 12 de septiembre de 1987, p. 4702. En relación al uso de los medios de comunicación, el CDS, junto al PP e IU denunciaron el canal de televisión promovido por el ex director de TVE, J. M. Calviño (Canal 10), FERNÁNDEZ, Isabel y SANTANA, Fernando: Estado y medios de comunicación en la España democrática, Madrid, Alianza Editorial, 2000, p. 333.

${ }^{224}$ Instó a la creación de Comisiones para el estudio de las causas del sistema educativo y científico técnico (Proposición no de ley de 29 de diciembre de 1987), para la revisión de la política de "dirección, organización y gestión de los centros sanitarios" (Moción del 22 de septiembre de 1988), para la elaboración de un informe sobre la situación de los principales servicios públicos (Moción del 22 de septiembre de 1988), sobre el estado de la administración de Justicia (Moción del 16 de septiembre de 1987) y se planteó impulsar una comisión de seguimiento de la presidencia europea de Felipe González en HERRERO, Luis: "Suárez garbanzo negro del centro-derecha", Época, 01 de noviembre de 1988.

${ }^{225}$ Proposición de Ley de desarrollo del Artículo 20.1 de la Constitución en relación con el Secreto Profesional y la Cláusula de Conciencia del Periodista, presentada el 28 de julio de 1986 y rechazada. Una proposición similar fue presentada por el CDS el 28 de febrero de 1989, con el mismo resultado. Ambas, implicaban la posibilidad de "negarse a revelar la identidad del autor o autores de la información recibida" y "negarse a colaborar en la confección de informaciones contrarias a sus convicciones", $E l$ País, 29 de julio de 1986.

${ }^{226}$ La medida se llevó a cabo mientras tenía lugar el procesamiento de los directores de EFE y EP por difundir información sobre un supuesto miembro de ETA basándose en fuentes policiales. El País, aunque apoyaba la medida del CDS, consideraba suficiente una modificación de la ley de enjuiciamiento criminal y de la legislación laboral, editorial: "El secreto de la conciencia", El País, 25 de julio de 1986. ${ }^{227} A B C$, 30 de julio de 1986.

${ }^{228}$ FRAGA, M.: En busca del..., p. 454. El PSOE señaló que estaba de acuerdo pero que se iniciaría una tramitación similar poco después. En pleno debate sobre el papel del Parlamento y los mecanismos de control al Ejecutivo por parte de la oposición, El País advertía sobre el abuso de la "iniciativa legislativa" por parte del Gobierno "porque prepotencia política es, aunque sea constitucional, utilizar la iniciativa legislativa a remolque de la de la oposición, en los casos que en que a ésta se le ocurre presentar una proposición de ley sobre un determinado asunto en el marco del Parlamento", editorial: "La iniciativa legislativa", El País, 16 de febrero de 1987
} 
En otros aspectos, como la profundización de las libertades individuales defendió posiciones progresistas ${ }^{229}$. Ejemplo de ello, fue la tramitación del derecho a la reproducción asistida -Ley de 22 de noviembre de 1988 sobre Técnicas de Reproducción Asistida ${ }^{230}$ - Las intervenciones del diputado centrista Carlos Revilla dejaban traslucir su apuesta por un discurso científico y aséptico, frente al cariz excesivamente ambiguo y en ocasiones ideologizado que estaba tomando el debate: "en nuestra opinión, se trata casi sólo de regular unas técnicas médico quirúrgicas que los avances científicos han hecho posibles y poca cosa más, salvo las consecuencias civiles"231. Se defendía una norma "fundamentalmente permisiva" 232 y progresista en su ámbito de aplicación que incluyera a "la mujer sola [soltera]"233. En relación a las políticas de igualdad, a propósito de la aprobación del Decreto-Ley de 22 de febrero por el que se regulaba el acceso de la mujer a las Fuerzas Armadas y que contó con el apoyo de los diputados centristas, León Buil Giral se manifestaba partidario de la "estricta igualdad" ${ }^{234}$, frente a las críticas de la oposición conservadora. En sentido contrario, mostraba su rechazo a la ampliación a un cuarto supuesto, de carácter económico-social, la posibilidad de interrupción voluntaria del embarazo defendida en una proposición de ley por Izquierda Unida ${ }^{235}$.

La pérdida de "sensibilidad social" del Gobierno fue objeto de una constante crítica por parte del GP CDS que se opuso frontalmente a su política económica -presentando una enmienda a la totalidad a todos los Presupuestos Generales de la Legislatura ${ }^{236}$-. A finales del 87', el propio Suárez en una reunión del grupo parlamentario apelaba al

\footnotetext{
${ }^{229}$ En lo referente al ámbito de algunas libertades públicas resulta elocuente la distancia entre el CDS y $\mathrm{AP}$ en el tono empleado en el debate de la proposición no de Ley, respaldada por el primero, en que se instó al Gobierno a la destrucción de todas las fichas que por homosexualidad masculina o femenina o cualquier otro antecedente policial por idéntica causa, obraran en poder de la policía, presentada por la Agrupación IU-EC, véase, DSCD, Comisión de Justicia e Interior, 03 de noviembre de 1987, nº 189, pp. 6917-8.

${ }^{230}$ Esta Proposición de Ley entroncaba con los resultados del trabajo de una Comisión formada para el estudio de estas técnicas de fecundación a raíz de una iniciativa del CDS-PNV en la II Legislatura. El CDS votó a favor, junto con la totalidad de grupos políticos, de la toma en consideración de la Proposición de Ley del GP Socialista y se posicionó en contra de la enmienda de totalidad y texto alternativo presentado por el Grupo Popular y el Grupo Vasco, que a juicio de Carlos Revilla, quebraban la búsqueda necesaria de consenso en una medida -y demanda- social de este tipo.

${ }^{231}$ DSCD, Sesión Plenaria, 14 de abril de 1988, no 101, p. 6299.

${ }^{232}$ DSCD, Comisión de Política Social y Empleo, 17 de mayo de 1988, no 285, p. 9795.

${ }^{233}$ El carácter del texto excesivamente largo, restrictivo y de difícil interpretación motivó el voto negativo del CDS, DSCD, Sesión Plenaria, 20 de octubre de 1988, n 141, p. 8237.

${ }^{234}$ Aunque, concordaba plenamente con los posicionamientos centristas, el CDS se abstuvo debido a la no aceptación de los parlamentarios socialistas de desarrollar este decreto-ley posteriormente como proyecto de ley, DSCD, 10 de marzo de $1988, \mathrm{n}^{\circ} 82$.

${ }_{235}$ Intervención de Carlos Revilla, DSCD, Sesión Plenaria, 22 de abril de 1987, no 42, pp. 2541-2.

${ }^{236}$ En expresión del propio Rodríguez Sahagún, Ya, 14 de abril de 1987.
} 
"contenido social" de las intervenciones, y consideraba "comprensible la actitud de las centrales sindicales, que durante años [habían] realizado muchos sacrificios sin haber encontrado una política social que les compense" ${ }^{\text {,237. }}$

En el primer debate en el Pleno de los Presupuestos Generales del Estado para 1987, Rodríguez Sahagún defendió la devolución de los mismos por el fracaso de la política gubernamental (paro o inflación), debido al "escaso incremento de la inversión pública" y "los excesivos niveles de gastos consuntivos" $"$ " Al año siguiente, la intervención de Rodríguez Sahagún acentuó si cabe el tono social al exigir la extensión del subsidio de desempleo, la elevación del salario de los funcionarios, el aumento de las pensiones y las partidas presupuestarias de investigación, sanidad, justicia, sanidad, infraestructuras de transporte y comunicaciones ${ }^{239}$. De cara a estos presupuestos, aunque el representante del CDS no pudo obviar los buenos datos macroeconómicos -aumento de la inversión, reducción de la inflación ${ }^{240}$, no dejó de advertir las consecuencias del elevado desempleo en la sociedad española, un aspecto que exigía su resolución gracias a "un esfuerzo solidario" ejercitado a través del pacto o la concertación. Al igual que Suárez en sus intervenciones había reclamado la fórmula del pacto para la consolidación democrática, Rodríguez Sahagún recordaba el valor de la concertación socio-económica y su institucionalización ${ }^{241}$ :

Peor aún: tal y como se han presentado los acontecimientos, estos presupuestos podrían pasar a ser recordados en el futuro como un elemento de quiebra en el proceso de concertación social. Es ésta una cuestión que no quiero obviar, porque la concertación social ha sido en nuestro país una conquista histórica de la democracia. Fue la concertación social la que permitió abordar la crisis. No hay nada que pueda sustituir al diálogo con los interlocutores sociales. Las leyes económicas no son leyes físicas, no actúan en un laboratorio, sino en una compleja realidad social ${ }^{242}$.

\footnotetext{
${ }^{237}$ OICDS, 7, octubre de 1987.

${ }^{238}$ DSCD, Serie A. Proyectos de Ley, 27 de octubre de 1986, nº 8-4, p. 543.

${ }^{239}$ Las reflexiones en el seno del CDS sobre el futuro del Estado del Bienestar se articulaban en la búsqueda de una vía intermedia - "alternativa progresista"- consciente de la crisis del paradigma nacido después de la II GM y de las "penosas" limitaciones éticas y políticas de la respuesta monetarista y tecnocrática articulada desde los años 80', "Ponencia sobre Política Social. II Congreso", CDS, 1986.

${ }^{240}$ Entre los votantes del CDS se encontraba, en diciembre de 1988, el porcentaje más alto que sostenía una valoración positiva de la economía (29\%), El País, 23 de abril de 1989.

${ }^{241}$ A raíz del conflicto laboral de Reinosa y las multitudinarias manifestaciones estudiantiles de finales de 1986 y comienzos de 1987, el GP CDS presentó una Interpelación Urgente sobre los propósitos del Ejecutivo en relación con las iniciativas que se deben adoptar para recuperar el necesario clima de diálogo social, DSCD, Serie D. Actos de control, 28 de mayo de 1987, $\mathrm{n}^{\circ}$ 80. En 1988, el CDS presentó una Proposición no de Ley para la remisión a la Cámara del Proyecto de Ley de creación, composición y funciones del Consejo Económico y Social, DSCD, Serie D. Actos de Control, 03 de noviembre de 1988, $\mathrm{n}^{\circ} 242$.

${ }^{242}$ DSCD, Sesión Plenaria, 26 de octubre de 1987, nº 68, p. 4074.
} 
En el debate de Presupuestos para el curso económico de 1989, se mantuvieron los mismos argumentos que en años anteriores, si bien, defendidos en esta ocasión con la intervención, bastante más irónica y barroca, del antiguo diputado de CD José María Lasuén, encargado desde su llegada al CDS del área de economía. Lasuén tachó de “electoralistas" y "antisociales" los presupuestos del $\operatorname{PSOE}^{243}$.

La política socio-liberal del PSOE desdibujaba los flecos más liberales del discurso económico del CDS -tendentes a una mayor flexibilización en materia fiscal ${ }^{244}$ y laboral $^{245}$ o hacia la defensa de la iniciativa privada como eficaz herramienta para complementar la actuación del estado en la provisión de servicios públicos ${ }^{246}-$.

El protagonismo de las fuerzas sindicales - que marcaron la agenda política durante buena parte de la Legislatura-, condicionaron la actitud de los suaristas y las líneas maestras de su discurso opositor, más persistente en sus contenidos sociales -véase, tablas 35 y 36-; aspecto al que se añadía una fuerte inercia estatista entre los hombres más cercanos a Suárez. Con el fin de ejemplificar estas afirmaciones merece la pena detenernos en la tramitación del Proyecto de Ley sobre Televisión Privada (1988), por sus implicaciones, posiblemente la medida legislativa más relevante de toda la Legislatura, y quizá también, la más decepcionante: "establecía fuertes limitaciones en

\footnotetext{
${ }^{243}$ DSCD, Sesión Plenaria, 25 de octubre de 1988, $\mathrm{n}^{\circ}$ 142, pp. 8275-9. Una intervención que recibió las felicitaciones del editorial de $A B C$, por haber sido capaz de desmontar en el debate la retórica del Gobierno sobre la desastrosa situación heredada, utilizando para titularlo, una expresión empleada por el propio Lasuén a propósito del "triunfalismo" gubernamental, editorial: "Falsa euforia", $A B C, 27$ de octubre de 1988.

${ }^{244}$ Una medida defendida por el CDS desde su fundación -contenida también, en el programa electoral de la CP-, era la posibilidad de realizar la tributación del IRPF de forma individual, y no como sucedió hasta 1988 en base, obligatoriamente, a la unidad familiar: "El CDS interpela al Gobierno sobre la tributación de los matrimonios", El País, 06 de diciembre de 1988. Finalmente fue aprobada con modificaciones la Proposición no de ley por la que se insta al Gobierno a elaborar un Proyecto de Ley que modifique las normas del Impuesto sobre la Renta de las Personas para que los Cónyuges puedan realizar la declaración por separado, DSCD, Serie D. Actos de control, 01 de diciembre de 1988, nº 256, p. 12777. Tras la sentencia del Tribunal Constitucional 45/1989, de 20 de febrero, que declaró, "entre otras cosas, inconstitucional la obligación de que los integrantes de una unidad familiar tributasen conjuntamente", el Gobierno desarrolló la Ley 20/1989, de 28 de julio, de adaptación del Impuesto sobre la Renta de las Personas Físicas en ZÁRATE MARCO, Anabel: "La relación entre la tributación de diferentes unidades impositivas: una constante en el IRPF (1979-1999)", Información Comercial Española: Revista de Economía, $\mathrm{n}^{\circ}$ 791, abril-mayo, 2001, p. 165. Disponible en: http://www.revistasice.info/ cachepdf/ICE_791_153-174_3FED94F90CF403FE695F13EB63D347C5.pdf Fecha de consulta: 10 de marzo de 2016.

${ }^{245}$ Conclusiones de la ponencia sobre "Política Económica. II Congreso", CDS, 1986.

${ }^{246}$ Por ejemplo, en uno de los puntos incluidos en la moción presentada por el CDS sobre el correcto funcionamiento de los servicios públicos instaba a la redacción de un "Plan de Autopistas", alternativo al "Plan de autovías" argumentando: "en respuesta a las demandas ciudadanas actuales, a la necesidad de generar empleo, a la urgencia de disminuir el alto déficit de infraestructuras viarias y asimismo, a aumentar la seguridad en las carreteras españolas", $D S C D$, Serie D. Actos de control, 30 de septiembre de $1988, n^{\circ} 227$, p. 11853.
} 
la propiedad de las sociedades que optaran a la concesión, distanciándose notablemente de la práctica seguida en otros países europeos" ${ }^{247}$. La oposición de centro-derecha la calificaba como "intervencionista" y criticaba su concepción como "servicio público" en perjuicio de la iniciativa propia de la sociedad civil ${ }^{248}$. En este sentido, junto a las deficiencias técnicas o la invasión de competencias autonómicas/locales, el diputado del CDS Federico Ysart calificó al marco creado por la ley como "oligopolio controlado" 249 , y en palabras de Suárez: "creo que, si estuviéramos en el poder, haríamos un proyecto que permitiera la generación de empresas de televisión sin ningún tipo de restricciones. Como en la prensa o en la radio..."250. Sin embargo, el CDS se abstuvo de recurrir al Tribunal Constitucional la ley -como hizo el Grupo Popular y la Generalitat- y -en una postura compartida por las fuerzas de izquierda y centroizquierda (IU, EE y PSOE)-, defendió una concepción de la TV (emisoras privadas o públicas) como "servicio público" cuya titularidad última correspondiese al Estado ${ }^{251}$.

En política exterior, la nueva legislatura trajo dos grandes temas de debate, inexorablemente entrelazados: la renovación del convenio bilateral con EE.UU. y el supuesto incumplimiento de alguna de las cláusulas suscritas en el referéndum sobre la permanencia en la OTAN.

Como venía sucediendo desde 1982, desde el CDS se apelaba a la distensión y el desarme multilateral, la defensa de los derechos humanos, el arreglo pacífico de los conflictos en el marco de la ONU y la búsqueda de un orden económico internacional

\footnotetext{
${ }^{247}$ FERNÁNDEZ, Isabel y SANTANA, Fernando: Estado y medios...

${ }^{248}$ Ibid., pp. 326-7.

${ }^{249}$ DSCD, Sesión Plenaria, 14 de abril de 1988, no 101, pp. 6270-1. Idénticas críticas fueron expuestos con motivo de la tramitación de la Ley de Ordenación de las Telecomunicaciones, que para los suaristas incrementaba los "controles estatales" sobre la "radiodifusión privada" e iba en perjuicio de las competencias autonómicas, El País, 22 de octubre de 1987 y "El CDS defiende la Libertad de la Televisión", OICDS, 9, diciembre 1987.

250 Diario 16, 26 de marzo de 1987. En el caso de Suárez, nuevamente hubo comentarios sobre el conflicto en el seno de UCD relativo a la regulación de la televisión privada en 1981 y 1982, que contó con la oposición de suaristas y socialdemócratas, véase, FERNÁNDEZ, Isabel y SANTANA, Fernando: Estado y medios..., p. 136 y ss.

${ }^{251}$ En un boletín regional, el CDS defendía respecto al futuro modelo de "televisión privada" la búsqueda un pacto de estado y tras analizar cuatro modelos de televisión privadas existentes en el mundo -Estados Unidos, Italia, México y Gran Bretaña- se decantaba por este último en el que a través de un Consorcio el Estado poseía el $51 \%$ de la participación y las empresas privadas competían por los espacios televisivos. Concluía el texto señalando: "en definitiva, hay que lograr un modelo que cuente con las suficientes garantías para controlar esa futura televisión que no está al alcance de todos, por las tensiones políticas y económicas que existen en nuestro país, y por la tremenda inversión que ello supone de miles de millones [...] Este Gobierno lo que pretende es conceder las emisoras privadas a los tres grupos poderosos que dominan la prensa nacional [...] Y hay que decirlo a las claras, aunque a muchos les duela: defendemos ante todo una TV pública”, Boletín Federación de Madrid, En la campaña electoral, Suárez defendía abiertamente la llegada de la TV privada, Carpeta 3, AGP.
} 
más justo. La polarización global había "generado un falso equilibrio para el mantenimiento de la paz, basado en el terror, y ha originado una carrera de armamentos" 252 . Un conflicto en el que Europa quedaba subordinada a los intereses norteamericanos y soviéticos (Europa del Este) y era "susceptible" de ser teatro de operaciones en caso del inicio de un conflicto.

Entroncando con el discurso desarrollado antes de 1986, para el CDS la renovación de las relaciones bilaterales era una excelente oportunidad para establecer un nuevo tipo de vinculación basada en aspectos económicos o culturales, y en la que los aspectos militares -si los hubiere- debían inscribirse en el marco de los acuerdos multilaterales prescritos: "a nuestro modo de ver, nuestra contribución a la OTAN no requiere, en ningún modo, la permanencia de ninguna de las bases de utilización conjunta, ni siquiera la de Rota"253. Agustín Rodríguez Sahagún llegaba a decir: "en España no se dan las razones históricas ni económicas que concurren en otros países europeos para justificar la existencia de las bases. España es retaguardia y no frontera, y las bases en su origen contribuyeron a consolidar un régimen totalitario" 254 . La opacidad en las negociaciones del Convenio y en la elaboración del memorándum sobre la permanencia de España en la OTAN alimentaban por otra parte las críticas y reticencias de amplios sectores de la oposición política ${ }^{255}$, y de una sociedad española, recelosa de la actuación de la administración Reagan en el "tablero internacional" 256 . Sin embargo, el discurso del CDS, aunque crítico, seguía sometido a las mismas ambigüedades y limitaciones que con ocasión del referéndum de la OTAN. Un columnista político escribía a propósito de la marcha contra las bases y por la paz celebrada el 25 de octubre de 1987:

El CDS astutamente no ha querido participar. Se limitará, seguramente, en los próximos meses a exigir que el Gobierno cumpla lo acordado en el referéndum, que es lo suficientemente ambiguo como para poder criticar su resultado: si se van de Torrejón, por quedarse en Rota, y si se van de Rota, por quedarse en Torrejón ${ }^{257}$.

\footnotetext{
252 "Ponencia de Seguridad, Defensa y Política Militar. II Congreso", CDS, 1986, pp. 1-2.

${ }^{253}$ DSCD, Sesión Plenaria, 24 de febrero de 1987, n 31, p. 1764. En la Comunidad de Madrid, el CDS votó a favor de una moción de IU favorable al desmantelamiento de la base de Torrejón "subrayando que más que de banderas era un problema de seguridad", $A B C, 23$ de octubre de 1987. En Aragón, ya en 1990, votó en el mismo sentido para la supresión de la base de Zaragoza, ABC, 04 de diciembre de 1990.

${ }^{254}$ El País, 17 de noviembre de 1987. Fue precisamente uno de los argumentos del embajador Máximo Cajal en la negociación sobre la renovación del convenio, 1986, POWELL, C. T.: El amigo americano. España y Estados Unidos: de la dictadura a la democracia, Barcelona, Tusquets, 2010, p. 625.

255 "El Congreso mantendrá en secreto los debates sobre OTAN y bases", $A B C, 21$ de junio de 1988.

256 VIÑAS, Ángel: En las garras del águila: los pactos con Estados Unidos, de Francisco Franco a Felipe González (19451995), Barcelona, Crítica, 2003, p. 482.

257 JIMÉNEZ LOSANTOS, Federico: “Gobierno manifestante”, ABC, 25 de octubre de 1987.
} 
Las negociaciones entre EE.UU. y el Gobierno de España concluyeron el 1 de diciembre de 1988 con la firma de un nuevo Convenio, que aunque había logrado una "reducción sustancial" de las tropas estadounidenses, no había conseguido esquivar otras polémicas como las implicadas en la renuncia del ejecutivo a "preguntar" acerca del contenido de los buques de guerra norteamericanos en el Mediterráneo y que posibilitó, de facto, el despliegue de armas nucleares ${ }^{258}$. El CDS se abstuvo en su ratificación parlamentaria tildando esta cláusula de "vergonzante" -a la que presentó una enmienda-, exigiendo una duración del Convenio menor (de 8 a 5 años) debido al clima de distensión geopolítico existente y poniendo en duda, en definitiva, el cumplimiento de las condiciones del referéndum: "el Convenio entre Estados Unidos y España puede utilizarse en contra de las condiciones del referéndum OTAN"259.

También, el CDS mostró alguna reserva en la forma en la que se había llevado a cabo el proceso de integración en la UEO - no se aseguraba reciprocidad en las relaciones defensivas- y se abstuvo en la votación del Protocolo de Adhesión en la Comisión de Exteriores del Congreso ${ }^{260}$. Críticas que no impidieron la convalidación de la integración española en el Pleno del Congreso el 27 de abril con el voto a favor de los suaristas.

Finalmente, debemos abordar las decisivas transformaciones de las que fue objeto la política antiterrorista en este período: la apertura de contactos y conversaciones con ETA, la convergencia de todas las fuerzas democráticas en amplios pactos y la irrupción del caso de los GAL. Siguiendo una vía iniciada desde la Transición, el Gobierno del PSOE entabló conversaciones con el grupo terrorista en varios momentos de la III Legislatura; contactos interrumpidos en febrero de 1988 y en marzo de 1989 por las

\footnotetext{
${ }^{258}$ GARCÍA CANTALAPIEDRA, David: “España, Estados Unidos y las Relaciones Transatlánticas” en PEREIRA, Juan Carlos (ed.): La política exterior de España. De 1800 hasta hoy, Barcelona, Ariel, 2010, p. 447. Especialmente polémico, como manifestó Caso en una Conferencia en el Club s. XXI, era lo relacionado con la no nuclearización de España y la no incorporación española a la estructura militar de la OTAN, El País, 15 de marzo de 1988. La derogación de esta cláusula fue exigida en las Elecciones de 1989, Manifiesto Electoral, CDS, 1989, p. 96.

${ }^{259}$ Titular de la crónica parlamentaria en OICDS, 20, abril 1989. La enmienda del CDS (art. 12.2) referida a la necesaria aprobación del Parlamento sobre uso de bases, territorio o espacio aéreo español en caso de guerra fue aceptada por el Ministro de Exteriores, Fernández Ordóñez, durante el debate de ratificación. Sobre las votación parlamentaria, véase, El País, 10 de marzo de 1989.

${ }^{260}$ DSCD, Comisión de Exteriores, 18 de abril de 1989, nº 443, p. 14721.
} 
pretensiones políticas de ETA y la sucesión de atentados de la banda terrorista ${ }^{261}$. Desde el CDS, el respaldo a las decisiones, iniciativas y criterios del Gobierno fue absoluto $^{262}$.

La apertura de conversaciones - con el objeto de lograr el cese de la violencia y siempre en el marco de la Constitución y el Estatuto de Guernica- era una opción que "supuestamente" Suárez consideró en al menos tres ocasiones -con subsiguientes desmentidos o matizaciones-a lo largo de la década ${ }^{263}$. Particularmente polémicas fueron sus palabras en el verano de 1986, cuya importancia queda bien reflejada en la siguiente información de $A B C$, rotativo que le dedicaba la sección La figura del día:

El ex presidente del Gobierno y dirigente del CDS, Adolfo Suárez, ha matizado sus declaraciones sobre la negociación con ETA. Suárez habla ahora del diálogo con fuerzas políticas en una línea de ambigüedad muy a lo Carlos Garaicoechea. Suárez tiene la suficiente experiencia política y la suficiente visión de Estado para comprender la irresponsabilidad política que representan algunas de sus medias palabras, en cuestión de tanta transcendencia como el terrorismo. Su populismo y sus intereses de partido no le pueden llevar a frivolidades de tanto calibre ${ }^{264}$.

En una rueda de prensa en octubre de 1987 y en plena gestación del primer gran pacto contra el terrorismo, el propio Suárez reivindicó sus declaraciones del año anterior: "el Presidente recordó que ya en el verano de 1985 [sic] manifestó su apoyo al diálogo con ETA, ‘con la incomprensión entonces del presidente del Gobierno', y

\footnotetext{
${ }^{261}$ Hubo una tercera ronda de encuentros en Santo Domingo en 1990, GONZÁLEZ CALLEJA, Eduardo: "Entre la normalización institucional y la 'guerra sucia", en MATEOS LÓPEZ, Abdón y SOTO CARMONA, Álvaro: Historia de la época ..., pp. 78-9.

${ }^{262}$ Actitud que no suponía en cualquier caso la negociación política o la aceptación de los chantajes del grupo terrorista, por ejemplo, en enero de 1988, en relación la oferta de ETA de llevar a cabo una "tregua" a cambio de negociación política Suárez señaló: "en modo alguno se pueden realizar negociaciones políticas con una banda terrorista [...] no es asumible el planteamiento de la alternativa KAS”, OICDS, 10, febrero 1988.

${ }^{263}$ Como vimos en páginas anteriores, la primera vez fue durante la campaña electoral municipal en Vitoria en 1983, El País, 06 y 07 de mayo de 1983. Una segunda ocasión se produjo a raíz de unas manifestaciones en este sentido de Xabier Arzalluz durante el verano de 1986: “Adolfo Suárez, presidente del Centro Democrático y Social, declaró ayer, preguntado sobre la posibilidad de iniciar una negociación con ETA, que le parece 'lógico' que, 'si existe una oportunidad de diálogo, en el marco de la Constitución y del Estatuto de Guernica, esa oportunidad se aproveche", en "Suárez e Izquierda Unida a favor de dialogar con ETA", El País, 05 de agosto de 1986.

${ }^{264} A B C, 07$ de agosto de 1986. "En medios políticos y militares se ha subrayado la firmeza del presidente del Gobierno al reiterar, como informábamos ayer, que jamás negociará con la banda terrorista de ultraizquierda ETA. Frente a actitudes como la del presidente del PNV, Javier Arzallus, que el domingo se mostraba propicio a la negociación entre el Gobierno y los etarras, o la del presidente del CDS, Adolfo Suárez que, aunque ha recogido velas, todavía afirma como posible el diálogo con ETA" en el editorial: "Felipe González tiene razón", $A B C, 07$ de agosto de 1986. En esta línea de defensa de la política antiterrorista del ejecutivo, aún a expensas de los intentos de las iniciativas de la oposición (CDS, IU y EE), editorial, "Firmeza de Barrionuevo", ABC, 18 de septiembre de 1986.
} 
comentó que la frontera de este tipo de contactos debe estar en el marco constitucional"265.

Como en otras ocasiones, las declaraciones de Suárez sobre la conveniencia o no de profundizar en esta estrategia eran objeto de una particular atención, sobre todo por el Gobierno socialista. No es extraño que en octubre de 1987 y febrero de 1989, Felipe González mantuviera con Adolfo Suárez el primero de los contactos con los líderes de la oposición a propósito de los nuevos pasos a dar en política antiterrorista. En palabras de José Barrionuevo, Ministro de Interior:

El ex presidente del Gobierno Adolfo Suárez, entonces presidente del CDS, reconoció en una intervención pública en Lérida que "la política del Gobierno socialista en relación a la lucha contra el terrorismo es más efectiva que la desarrollada por UCD" cuando él mismo presidía el Gobierno. La generosidad y el valor cívico del posicionamiento del presidente Suárez eran un aval merecedor de todo nuestro reconocimiento ${ }^{266}$.

Los pactos de Madrid y Ajuria Enea, en noviembre de 1987 y enero de 1988 respectivamente, supusieron la concreción de un gran acuerdo inter-partidario con el objetivo inmediato de excluir "la política antiterrorista de la contienda partidista y el debate parlamentario"267; un pacto reivindicado por el CDS desde 1982 y enunciado explícitamente por Suárez en el debate de investidura de $1986^{268}$.

La participación del CDS en este consenso se tradujo, no sólo en la firma de los pactos y un apoyo a las iniciativas del ejecutivo, sino en un rechazo a las propuestas unilaterales que a derecha e izquierda intentaban introducir modificaciones normativas. El CDS se mantuvo al margen de medidas como las defendidas por Alianza Popular que apostaban por el endurecimiento de las penas a los acusados de terrorismo ${ }^{269}$ o

\footnotetext{
265 OICDS, 7, octubre 1987. "Abogó por una política de pacificación del País Vasco que permita poner sobre la mesa de diálogo todo lo que tenga cabida en la Constitución, porque 'se llame negociación o diálogo, no debe haber más viudas ni huérfanos por el terrorismo"”, Ya, 04 de octubre de 1987. En cualquier caso, el CDS apoyó sin reservas las diversas iniciativas del Gobierno respecto al mantenimiento o no de sus contactos con ETA, El País, 15 de diciembre de 1987.

${ }^{266}$ BARRIONUEVO, José: 2001 días en interior, Barcelona, Zeta, 1997, p. 442.

${ }^{267}$ GONZÁLEZ CALLEJA, Eduardo: “Entre la normalización institucional...”, pp. 77.

${ }^{268}$ OICDS, 7, octubre 1987.

269 Por ejemplo, en el caso de la proposición de ley del Grupo de Coalición Popular relativa a la modificación de la Ley Orgánica 8/1984 de 26 de diciembre, contra la Actuación de Bandas Armadas y Elementos Terroristas y desarrollo del Artículo 55.2 de la Constitución, que ampliaba el marco legal para la lucha contra el entorno social de ETA $-D S C D$, Serie B. Proposiciones de Ley, 15 de septiembre de 1986, n 9-, José Ramón Caso anunciaba su voto negativo "en contra de todas estas proposiciones" fundamentalmente por su carácter unilateral, sin mostrarse contrario a considerar futuras modificaciones legales o jurídicas, DSCD, Sesión Plenaria, 04 de marzo de 1988, no 34, p. 1942. En la siguiente Legislatura, el CDS votó en contra, por romper el acuerdo en materia de lucha antiterrorista, de "una proposición de ley del Grupo Popular para que el Gobierno enviase antes de un mes un proyecto que establezca el cumplimiento íntegro de las condenas a los miembros de bandas terroristas", El País, 21 de
} 
propugnaban una acción decidida del ejecutivo conducente a la ilegalización de Herri Batasuna, expresando a este último respecto, que "no va a invadir unas competencias que la Constitución reserva en exclusiva a los jueces y tribunales" ${ }^{\text {270; }}$; en sentido contrario, rechazaba los argumentos de IU o EE a propósito de la derogación y posterior inclusión en el marco de la justicia ordinaria de algunos de los presupuestos de la Ley Antiterrorista $^{271}$.

Los éxitos políticos y policiales de la lucha antiterrorista sufrieron un fuerte revés con la aparición del caso de los GAL, que gracias al procesamiento del comisario José Amedo y el inspector Michel Domínguez y la investigación de, entre otros, Diario 16, adquirió el rango de un "escándalo político" de enormes dimensiones ${ }^{272}$. Las sucesivas revelaciones de magistrados y periodistas salpicaban a altos cargos del Ministerio del Interior y las Fuerzas de Seguridad, llamaban la atención sobre el uso de los llamados "fondos reservados" y en definitiva, llegaron a comprometer la propia credibilidad y legitimidad del Estado en su lucha contra el terrorismo, y muy particularmente a los gobiernos socialistas - con una fortísima intensidad en los años centrales de la década de los $90^{\prime}-$.

febrero de 1990. Fernando Castedo exponía dudas sobre su eficacia y especialmente, su idoneidad: “¿No abrimos así cualitativamente, que no cuantitativamente, señorías, la posibilidad de que nos hablen, por supuesto aquellos a quienes les interesa, de la aplicación de un estatuto de preso político y traten de extraer de ello todas sus consecuencias, incluso con invocación de la Convención de Ginebra? Nosotros creemos que sí, que corremos ese grave riesgo. [...] Pues bien, no entendemos que, vigente el espíritu de aquel amplio acuerdo, una fuerza política haya traído a esta Cámara esta proposición no de ley sin previa consulta a las demás. No se aviene, desde luego, esta actitud con el espíritu cooperativo de aquel pacto; ello conviene advertirlo", DSCD, Sesión Plenaria, 20 de febrero de 1990, n 17, pp. 616-7. No obstante, la sensibilidad de los militantes del CDS no era unánime en estos aspectos. Una de las escasas mociones presentadas en el II Congreso, por parte de los delegados ceutíes solicitaba "adoptar también medidas judiciales de máximo rigor" contra los terroristas, y en su caso, la aplicación de la "pena de muerte", Diario 16, 14 de septiembre de 1986.

${ }^{270}$ Intervención de León Buil Giral a propósito de la interpelación urgente de Coalición Popular: ¿Qué propósitos de política general tiene el Gobierno respecto a la ilegalización de Herri Batasuna? en $D S C D$, Sesión Plenaria,16 de marzo de 1988, nº 94, p. 5944. En febrero de 1989 hubo una nueva polémica a nivel nacional, a propósito a de una moción presentada por UDF en la que se instaba a aprobar una declaración institucional por el Parlamento de Navarra rechazando la posibilidad de llevar a cabo un referéndum en Navarra sobre su integración en el País Vasco y que fue rechazada con los votos del CDS, PSOE-PSN, EE y EA. Para el CDS, que no apoyaba una consulta de este tipo -el CDS navarro presentó una enmienda contraria a esta iniciativa en el II Congreso, Diario 16, 13 de septiembre de 1986-, esta medida resquebrajaba el marco de consenso interpartidario -Acuerdo por la Paz y la Tolerancia del Parlamento de Navarra-, alcanzado meses antes. Véase, editorial: "Navarra, innegociable", $A B C, 24$ de febrero de 1989.

${ }^{271}$ DSCD, Sesión Plenaria, 11 de febrero de 1988, p. 5324; véase, BARRIONUEVO, José: $2001 \ldots$

${ }^{272}$ Como señala González Calleja, el caso de los GAL, sin obviar las responsabilidades penales derivadas del mismo, se convirtió por su tratamiento mediático, político y social en un "escándalo político", que desde 1987, y especialmente, en su última legislatura ejerció como uno de los principales caballos de batalla contra los gobiernos socialistas, GONZÁLEZ CALLEJA, Eduardo: "Entre la normalización institucional..." 
En nuestro período de análisis, el caso GAL ocupó un segundo plano y aunque fue aumentando paulatinamente su importancia, nunca se convirtió en el objeto preferente de las críticas suaristas. Unas declaraciones de Suárez efectuadas en 1987, en el curso de una Convención del Partido Demócrata (Atlanta, EE.UU.), ponían de manifiesto lo espinoso del asunto: "Siendo presidente, jamás habría aprobado las acciones del GAL" ${ }^{273}$. Aunque apostilló que sus palabras no implicaban la asunción de que Felipe González o el Gobierno socialista estaban implicados inevitablemente desató una polémica en la que fue acusado de irresponsabilidad ${ }^{274} \mathrm{y}$, en el peor de los casos, como hizo Felipe González, se le recordaron algunos episodios de la Transición: "No quiero jugar al ping-pong con Adolfo Suárez sobre los GAL; me parece bien lo que dice: yo tampoco hubiera autorizado el Batallón Vasco Español"275. El CDS se limitó a desarrollar algunas iniciativas de control parlamentario con el fin de recabar información sobre los "fondos reservados", el caso Amedo y sus implicaciones entre las Fuerzas de Seguridad del Estado ${ }^{276}$. Para algunos, la prudencia del CDS hundía sus raíces en la propia Transición:

Quien más se juega en el envite son las fuerzas del centro y la derecha. CDS y PNV necesitan disipar la especie de que el recuerdo del Batallón Vasco Español y la sordina puesta por el Gobierno euskaldún de coalición al escándalo de la Ertzantza están distrayéndoles del caso $^{277}$.

\footnotetext{
${ }^{273}$ Portada de Diario 16, 20 de julio de 1988. En su crónica para El País, Francisco Basterra señalaba que Suárez, en cualquier caso, "se mostró prudente y poco agresivo", El País, 18 de julio de 1988. No fueron habituales las declaraciones de Suárez sobre este extremo, en el curso de una entrevista con Victoria Lafora: “- ¿Cuándo Felipe González dice que jura por su honor que el Gobierno no está detrás del GAL, lo cree? - Acepto la palabra del Presidente del Gobierno, aunque el GAL no es una cuestión de honor. En segundo lugar, acepto esa afirmación porque la hace el Presidente del Gobierno, pero habrá que aceptar también las consecuencias que de esa afirmación se deriven si se demuestra lo contrario", Diario 16, 22 de octubre de 1988.

${ }^{274}$ Ovidio en sus zigzags comentaba que la afirmación de Suárez rebasaba los márgenes democráticos al inculpar sin resolución judicial al Gobierno: "El asunto GAL no es el más idóneo para bordar encajes políticos superficiales", "Límites", $A B C, 21$ de julio de 1988.

${ }^{275}$ El País, 07 de agosto de 1988.

${ }^{276}$ Votó a favor, junto al resto de minorías, a la proposición no de ley presentada por el Grupo Mixto Agrupación Democristiana sobre aplicación de los fondos reservados en la que se solicitaba la creación de una comisión de investigación para analizar la naturaleza, control y gestión que tienen o han de tener dichos gastos y sobre su posible uso por los funcionarios del Estado Amedo y Domínguez. Buil Giral defendió la existencia de un "control político" sobre los "fondos reservados", DSCD, Serie D. Actos de control, 12 de septiembre de 1988, no 215 y DSCD, Sesión Plenaria, no 154, 29 de noviembre de 1988, p. 925. Poco después, IU solicitó la creación de una Comisión Parlamentaria de Investigación sobre los GAL que recibió el apoyo del CDS, PNV, CiU, DC, EE y EA, mientras AP se abstuvo y el PSOE votó en contra, El País, 19 de octubre de 1988.

${ }^{277}$ Extracto de un artículo relativo a los GAL titulado: "Lo que está en juego en el caso "Amedo", Diario 16, 04 de septiembre de 1988 en RAMÍREZ, P. J.: España sin proyecto, Madrid, Akal, 1993, p. 150. Como ha señalado el periodista P. Woodsworth llama la atención, desde un punto de vista comparativo, la extensa investigación sobre los GAL y el hecho de que "jamás hubo una investigación similar a propósito de la relación del gobierno e Suárez de la UCD, y de las fuerzas de seguridad con la primera guerra sucia”. En 1995 a raíz de una intervención de Felipe González en el Debate sobre el
} 
A modo de resumen, podemos señalar que el ejercicio de la oposición por parte del CDS varió notablemente en esta Legislatura respecto a la anterior ${ }^{278}$. En primer lugar, en términos cuantitativos aumentó considerablemente, como es lógico, la actividad parlamentaria. Si tenemos en cuenta el número de enmiendas presentadas a Proyectos de Ley, se convirtió en el segundo partido de la oposición (18,8\%, frente a un $4 \%$ en 1982). Cualitativamente, mostró un mayor rechazo a las políticas socialistas presentando enmiendas a la totalidad a 26 proyectos de ley (el 44,8\% de los mismos, siendo este porcentaje de un $8,4 \%$ en 1982). Visto en términos comparativos:

Tabla 50: Enmiendas a la totalidad a Proyectos de Ley del Gobierno del PSOE.

\begin{tabular}{|l|c|c|c|c|}
\hline & \multicolumn{2}{|c|}{ II Legislatura } & \multicolumn{2}{c|}{ III Legislatura } \\
\hline & $\mathrm{n}^{\mathbf{0}}$ & $\%$ & $\mathrm{n}^{\mathbf{o}}$ & $\%$ \\
\hline $\mathrm{AP} / \mathrm{CP} / \mathrm{PP}$ & 71 & 85,5 & 46 & 79,3 \\
\hline $\mathrm{PCE} / \mathrm{IU}$ & 26 & 31,3 & 19 & 32,7 \\
\hline $\mathrm{MC}$ & 26 & 31,3 & 15 & 25,8 \\
\hline $\mathrm{MV}$ & 27 & 32,5 & 15 & 25,8 \\
\hline $\mathrm{UCD}$ & 14 & 16,8 & - & - \\
\hline $\mathrm{CDS}$ & $\mathbf{7}$ & $\mathbf{8 , 4}$ & $\mathbf{2 6}$ & $\mathbf{4 4 , 8}$ \\
\hline $\mathrm{PDP} / \mathrm{dC}$ & - & - & 17 & 29,3 \\
\hline
\end{tabular}

Elaboración a partir de CAPO GIOL, Jordi: “Oposición y minorías en las legislaturas del PSOE”, REIS, 66, 1994.

El CDS concentró a lo largo de esta Legislatura en torno al 10\% y $15 \%$ del total de iniciativas parlamentarias de la oposición relacionadas con el desarrollo legislativo proposiciones de ley- o destinadas a ejercer la función de control del Gobierno proposiciones no de ley, interpelaciones y preguntas-(Anexo XVI).

Tabla 51: Proposiciones de Ley del Grupo Parlamentario CDS (III Legislatura) ${ }^{279}$.

\begin{tabular}{|l|l|}
\hline Situación & $\mathbf{N}^{\mathbf{o}}$ \\
\hline Admitidas a trámite & $16(18)$ \\
\hline Retiradas & $1(1)$ \\
\hline Decaídas & - \\
\hline
\end{tabular}

Estado de la Nación se reabrió este extremo y se habló de la existencia de una grabaciones entre Suárez y miembros del CESID en 1978 que oportunamente interpretadas podían servir para implicar a los gobiernos de UCD - un capítulo más dentro del caso de los papeles de Perote y Mario Conde-. El autor concluye: "la reacción de Suárez en este asunto refleja una lectura igualmente 'pragmática' del concepto de responsabilidad criminal. También para Suárez, las 'razones de Estado' prevalecían claramente sobre los derechos de los individuos a la protección legal y la justicia", WOODWORTH, Paddy: Guerra sucia, manos limpias, Barcelona, Crítica, 2002, pp. 44 y 292. Un supuesto episodio sobre la intermediación de Suárez con el fin de evitar la revelación de los papeles del CESID -sobre la "guerra sucia"-sucedió con la llegada al poder de Aznar en 1996. Al parecer, Suárez, a raíz de una conversación con F. González, medió para evitar el nombramiento de Rafael Arias-Salgado como ministro de defensa, quien estaba dispuesto a hacer pública dicha documentación, ARZALLUS, Xabier: Así fue, Foca, Madrid, 2005, pp. 451-2 y QUINTANS, Rebeca: Juan Carlos I. La biografía en silencios, Madrid, Akal, 2016.

278 Para la actividad parlamentaria en el Senado nos remitimos al Anexo XVII.

${ }^{279}$ Entre paréntesis las presentadas junto a otras formaciones parlamentarias. 


\begin{tabular}{|l|l|}
\hline Rechazadas & 11 \\
\hline Caducadas & 3 \\
\hline $\begin{array}{l}\text { Aprobadas } \\
\text { modificaciones }\end{array}$ & $1(1)$ \\
\hline $\begin{array}{l}\text { Aprobadas con } \\
\text { modificaciones }\end{array}$ & 1 \\
\hline
\end{tabular}

Elaboración propia a partir de GONZALO, Manuel y PAESA, María (eds.): Memoria de la III Legislatura (1986-1989), Madrid, Congreso de los Diputados, 1990, p. 145 y ss. Se ha contrastado con la base de datos online del congreso.

Tabla 52: Proposiciones de Ley del Grupo Parlamentario CDS (III Legislatura) en relación al resto de Grupos de la oposición ${ }^{280}$.

\begin{tabular}{|l|l|l|}
\hline Situación & $\begin{array}{l}\text { Porcentaje sobre el } \\
\text { total de la oposición }\end{array}$ & $\begin{array}{l}\text { Posición en el cómputo de GP de la oposición } \\
\text { y grupos con más proposiciones }\end{array}$ \\
\hline $\begin{array}{l}\text { Admitidas a } \\
\text { trámite }\end{array}$ & 11,51 & $4^{\circ}$ (GCP, GM-AIU-IC, GM-ADC). \\
\hline $\begin{array}{l}\text { Aprobadas con/sin } \\
\text { modificaciones }\end{array}$ & 14,25 & $\begin{array}{l}3^{\circ} \text { (GCP, GS). El mismo número que GM, GM- } \\
\text { AIU-IC y GMC. }\end{array}$ \\
\hline
\end{tabular}

GONZALO, Manuel y PAESA, María (eds.): Memoria de la III Legislatura (1986-1989), Madrid, Congreso de los Diputados, 1990, p. 145 y ss. Se ha contrastado con la base de datos online del congreso.

Un análisis temático de las Proposiciones de Ley resulta enormemente revelador sobre las prioridades políticas del CDS. La mayor parte de ellas hacían referencia a la modificación del Código Penal en un doble sentido: su actualización ${ }^{281}$ y su reforma, en un sentido progresista $(8)^{282}$. El resto aludían a la regulación de los derechos a la cláusula de conciencia y el secreto profesional entre los periodistas (2), cuestiones laborales (2), medio ambiente (2), fiscalidad empresarial y modificación de la Ley Electoral $^{283}$.

En términos porcentuales, si tenemos en cuenta tanto las Proposiciones de Ley, como las no de Ley destaca junto al área de Justicia e Interior (19,44), el de Industria, Obras Públicas y Servicios (12,5\%), el de Política Social y Empleo (12,5\%) y en un segundo escalón cuestiones relativas a la Defensa, Economía y Medio Ambiente $(6,94 \%)$; porcentajes que se mantienen, en el análisis referido a las interpelaciones (ordinarias y urgentes) en el que cuestiones de Política Social y Empleo alcanzan un $35,71 \%$, mientras las relativas a Justicia e Interior (relacionadas con la exigencia de

\footnotetext{
${ }^{280}$ GCP: Grupo Coalición Popular. GM-AIU-IC: Grupo Mixto Asociación Izquierda Unida Iniciativa per Catalunya. GM-ADC Grupo Mixto Asociación Democracia Cristiana. GMC: Grupo Minoría Catalana. GS: Grupo Socialista.

${ }^{281}$ Nos referimos a la regulación del "delito informático" y de la "seguridad del tráfico".

${ }^{282}$ Sobre la "pena de privación del derecho de sufragio,", la "regulación del delito de desacato", penas alternativas a la prisión, la concesión del indulto y "relativa a la responsabilidad patrimonial del Estado por el funcionamiento de la Administración de Justicia".

${ }^{283}$ Con el fin de contemplar la "moción de censura" en los cabildos insulares, mediante la modificación del artículo 201 de la Ley Orgánica 9/1985, de Régimen Electoral General, DSCD, Proposición de Ley, $n^{\circ} 153-1,23$ de junio de 1989.
} 
transparencia al Gobierno) llegan al 17,85\%, mientras en tercer lugar, se sitúan el área de Economía (14,28\%):

\section{Tabla 53: Agrupación temática del conjunto de Proposiciones de Ley y no de Ley del GP CDS (III Legislatura).}

\begin{tabular}{|c|c|c|c|c|}
\hline Materia & PL & PNDL & Porcentaje & Observaciones \\
\hline $\begin{array}{l}\text { Agricultura, } \\
\text { Ganadería y Pesca }\end{array}$ & - & 3 & 4 & - Tasas, ley de montes. \\
\hline Asuntos Exteriores & - & 2 & 2,7 & - Apartheid. \\
\hline Constitucional & 2 & 1 & 4 & - Declaración de conciencia y secreto profesional. \\
\hline Defensa & - & 5 & 6,7 & - Cabañeros, enseñanzas militares. \\
\hline $\begin{array}{l}\text { Economía, } \\
\text { Comercio } \\
\text { Hacienda }\end{array}$ & 1 & 4 & 6,7 & $\begin{array}{l}\text { - Fiscalidad empresas. } \\
\text { - Turismo, comercio, fiscalidad (IRPF). }\end{array}$ \\
\hline $\begin{array}{l}\text { Educación } \quad \mathrm{y} \\
\text { Cultura }\end{array}$ & - & 3 & 4 & - Enseñanzas musicales, Universidades. \\
\hline $\begin{array}{lr}\text { Industria, } & \text { Obras } \\
\text { Públicas } & \mathrm{y} \\
\text { Servicios } & \end{array}$ & - & 9 & 12,2 & $\begin{array}{llll}\text { Urbanismo, infraestructuras } & \text { viarias } & \mathrm{e} \\
\text { hidrográficas. } & & & \end{array}$ \\
\hline Justicia e Interior & 11 & 5 & 21,6 & $\begin{array}{l}\text { - Reforma del Código Penal. Reforma Ley } \\
\text { Electoral. } \\
\text { - Transparencia (INE), síndrome tóxico, } \\
\text { retribuciones salariales, simplificación de las } \\
\text { nomas de los procesos matrimoniales. } \\
\text { - Partidos políticos. }\end{array}$ \\
\hline $\begin{array}{lll}\text { Política } & \text { Social } \\
\text { Empleo } & & \end{array}$ & 1 & 8 & 12,2 & $\begin{array}{l}\text { - Trabajo. } \\
\text { - Concertación, diálogo social y desempleo. } \\
\text { - Lucha contra la droga. Familia. }\end{array}$ \\
\hline Presupuestos & - & 3 & 4 & - Control presupuestario en la administración \\
\hline Medio Ambiente & 2 & 3 & 6,7 & - Conservación y defensa. \\
\hline $\begin{array}{l}\text { Régimen de las } \\
\text { Administraciones } \\
\text { Públicas }\end{array}$ & & 1 & 1,3 & - Canarias. \\
\hline $\begin{array}{l}\text { Mixta para las } \\
\text { Comunidades } \\
\text { Europeas }\end{array}$ & - & 3 & 4 & - Adaptación al Marco Comunitario. \\
\hline $\begin{array}{l}\text { Mixta para la } \\
\text { Investigación }\end{array}$ & - & 1 & 1,3 & - Potenciación de la investigación. \\
\hline Otras & - & 6 & 8,1 & - Emergencias y ayudas. \\
\hline
\end{tabular}

Elaboración propia a partir de GONZALO, Manuel y PAESA, María (eds.): Memoria ..., p. 192 y ss.

Tabla 54: Agrupación temática del conjunto de Interpelaciones (Ordinarias y Urgentes) del GPCDS, (III Legislatura).

\begin{tabular}{|l|l|l|l|l|}
\hline Materia & IO & IU & Porcentaje & Principales temas \\
\hline $\begin{array}{l}\text { Agricultura, } \\
\text { Ganadería y Pesca }\end{array}$ & 1 & 2 & 10,71 & $\begin{array}{l}\text { - Aprovechamiento de aguas. } \\
\text { - Ganadería. Cereales. }\end{array}$ \\
\hline Asuntos Exteriores & 1 & - & 3,57 & - SME. \\
\hline Constitucional & - & - & - & - \\
\hline Defensa & - & - & - & - \\
\hline $\begin{array}{l}\text { Economía, Comercio } \\
\text { y Hacienda }\end{array}$ & 2 & 2 & 14,28 & $\begin{array}{l}\text { - IRPF. Precios del petróleo. } \\
-\quad \text { Administración financiera. Corrección de } \\
\text { desequilibrios interregionales. }\end{array}$ \\
\hline Educación y Cultura & 1 & 1 & 7,14 & $\begin{array}{l}\text { - Universidades sociales. } \\
\text { - Huelgas profesorado. }\end{array}$ \\
\hline Industria, Obras & - & 2 & 7,14 & - Correos y Teléfonos. Red vial: "puntos negros". \\
\hline
\end{tabular}




\begin{tabular}{|c|c|c|c|c|}
\hline Públicas y Servicios & & & & \\
\hline Justicia e Interior & - & 5 & 17,85 & $\begin{array}{l}\text { - Servicio público de justica. Transparencia y control } \\
\text { (INE, caso El Nani). Fuerzas de Seguridad. Datos } \\
\text { del CIS. }\end{array}$ \\
\hline $\begin{array}{lll}\text { Política } & \text { Social } & \text { y } \\
\text { Empleo } & & \end{array}$ & 5 & 5 & 35,71 & $\begin{array}{l}\text { - Servicios Públicos. Política social regresiva. } \\
\text { Desempleo. Diálogo social. Política de rentas. } \\
\text { Atención/urgencia sanitaria. Familias. }\end{array}$ \\
\hline Presupuestos & - & - & - & - \\
\hline Medio Ambiente & - & - & - & - \\
\hline $\begin{array}{l}\text { Régimen de las } \\
\text { Administraciones } \\
\text { Públicas }\end{array}$ & - & - & - & - \\
\hline $\begin{array}{l}\text { Mixta para las } \\
\text { Comunidades } \\
\text { Europeas }\end{array}$ & - & - & - & - \\
\hline $\begin{array}{l}\text { Mixta para la } \\
\text { Investigación }\end{array}$ & - & - & - & - \\
\hline $\begin{array}{lll}\text { Estatuto de } & \text { los } \\
\text { Diputados } & & \\
\end{array}$ & - & 1 & 3,57 & - Materias clasificadas. \\
\hline Otras & - & - & - & - \\
\hline
\end{tabular}

Elaboración propia a partir de GONZALO, Manuel y PAESA, María (eds.): Memoria ..., p. 211 y ss. 



\title{
Capítulo 7:
}

\section{Reestructuración y renovación en el CDS: organización e ideología}

\author{
"La izquierda no detenta, como pretende, \\ el monopolio de la definición del progresismo"1.
}

El éxito electoral vivido en 1986 a nivel nacional y ratificado en Comunidades Autónomas y Municipios un año después tuvo importantes consecuencias en la vida del partido. La militancia se multiplicó por tres, se completó el proceso -al menos formal-, de implantación en el territorio y se celebró el Congreso Nacional que debía dar continuidad a los resultados cosechados en las urnas.

Junto a este desarrollo cuantitativo, el CDS reformuló sus convicciones ideológicas desde una doble perspectiva, intentando enlazar con el pensamiento político español contemporáneo y en segundo lugar -con unos efectos prácticos mucho más decisivos-, conectando con las grandes familias políticas internacionales, lo que se logró en el caso del "liberalismo". Una etiqueta que los suaristas completaron con el epíteto de "liberalismo progresista". La participación en la política europea y el aumento de poder en los diversos parlamentos nacionales exigían un intento decidido en este sentido. Por último, realizaremos un ejercicio de historia comparada entre el CDS y el Partido Renovador Democrático fundado por el ex presidente de la República de Portugal, Ramlaho Eanes con el objetivo de advertir los paralelismos en el nacimiento de ambos partidos, ambos fundados por quienes habían sido los máximos representantes del estado en sus respectivos países.

De este modo, organización e ideología, militancia y proyección internacional serán los vectores que enmarquen el presente capítulo. Nuestro objetivo es delimitar las transformaciones cuantitativas y cualitativas del partido en la segunda mitad de la década de los ochenta y comienzos de la siguiente, definiendo aquellos rasgos que

\footnotetext{
${ }^{1}$ SUÁREZ GONZÁLEZ, Adolfo: La alternativa de Centro Progresista, CDS, 1989, p. 7.
} 
caracterizaron a la formación centrista y cuando sea el caso, las contradicciones que la acecharon.

\section{1. EI II Congreso del CDS y el crecimiento del partido (1986-1989).}

El II Congreso del CDS se celebró en Barcelona los días 13 y 14 de septiembre de 1986. Ante todo, sirvió para ratificar la buena marcha del partido y se vivió en un clima festivo entre la militancia. Suponía el "congreso de la consolidación”, o como señala Antonio Garrosa de "reafirmación",2, después de un inesperado éxito electoral -incluso se usó el mismo slogan que en la campaña de junio-. Si las palabras más repetidas en los medios fueron las de "trámite", "euforia" o "unanimidad"3, los suaristas se encargaron de recordar -subrayando la importancia del acto- las amarguras vividas desde la fundación del partido: "el triunfo de CDS es el triunfo de la perseverancia"4. El Congreso se convirtió, en definitiva, en una demostración de fuerza del suarismo.

Se presentaba asimismo una excelente ocasión para conseguir una mayor definición del proyecto centrista. Diario 16 lo planteaba abiertamente con un editorial titulado: “CDS: Partido o clientela”. Según el rotativo dirigido por Pedro J. Ramírez, el CDS necesitaba profundizar en su implantación territorial y definirse ideológicamente -en el CDS existían electores y afiliados totalmente contrapuestos entre sí-, en el espacio ubicado a la "derecha del PSOE". En definitiva, tenía que transformar la clientela primigenia en un partido político: "la democracia española necesita que allí [en Barcelona] Suárez acierte". El editorial de El País, tras elogiar la unidad y tesón mantenidos hasta 1986 - en contraposición a otros partidos como el PDP- y corroborar

\footnotetext{
${ }^{2}$ Entrevista con Antonio Garrosa, 31 de julio de 2013.

${ }^{3}$ Expresiones aparecidas en ABC, El País, Diario 16, 14 y 15 de septiembre de1986. Adolfo Suárez concedió una entrevista a José Luis Gutiérrez en Diario 16, 12 de septiembre de 1986.

${ }^{4}$ CASO GARCÍA, José Ramón: "Obstáculos, silencios y soledades", Diario 16, 13 de septiembre de 1986. Véase también: VIANA SANTA CRUZ, Jesús María: "La fuerza de creer"; REVILLA, Carlos: "Consolidar una oferta"; CASTEDO, Fernando: "Objetivo: la unidad"; POSADA, Rosa: "El congreso trabajó"; RODRÍGUEZ SAHAGÚN, Agustín: "La hora del CDS", Diario 16, 13 de septiembre de 1986.

${ }^{5}$ Editorial: "CDS: partido o clientela", Diario 16, 13 de septiembre de 1986. ABC no dedicó ningún editorial a la celebración del II Congreso del CDS. Uno de sus columnistas, Jaime Campmany lo llamó "proyecto personal a largo plazo" en "La purga", $A B C, 18$ de septiembre de 1986. El tratamiento de $E l$ País fue bastante parco y recibió las críticas de algunos lectores sobre la imparcialidad del periódico, quienes señalaban el contraste con la prolija información dedicada al congreso del SPD alemán, LÓPEZ MUÑOZ, Ismael: "La sensibilidad de los lectores pone a prueba a El País", El País, 02 de noviembre de 1986. Diario 16 dedicó un extenso dossier de 8 páginas al CDS el día 15 de septiembre.
} 
el tirón electoral de Suárez subrayaba las dificultades del CDS para constituirse en alternativa; la otra posibilidad era ejercer de bisagra, preferentemente con su izquierda ${ }^{6}$.

El lugar elegido, Barcelona, llamó la atención de muchos. Para la dirección suarista era un "guiño" al desarrollo autonómico del partido y la "distribución horizontal del poder político" así como un refuerzo para la situación del mismo en Cataluña -frente a CiU- ${ }^{7}$. La organización corrió a cargo, al igual que la del I Congreso, de Laura Morso y la Presidencia del mismo quedó en manos de Alejandro Rebollo. El Comité Nacional estuvo acompañado por un total de 992 compromisarios electos en las Asambleas Provinciales del partido en función del número de militantes ${ }^{8}$. A diferencia del I Congreso, en esta ocasión la mayor parte de la militancia no había tenido militancia política previa y el 60\% de los afiliados había ingresado en 1983, 1984 y 1985. Todo ello era sintomático del trabajo realizado durante la "travesía del desierto". La media de edad de los compromisarios era similar a la de los parlamentarios electos -siendo el tramo con mayor porcentaje el comprendido entre 36 y 45 años-. Podemos concluir que el afiliado medio "nunca militó en un partido político y profesionalmente" o eran "titulados superiores" o se dedicaban a "profesiones liberales". El proceso de estructuración del partido lograba, al menos entre sus bases, trascender las circunstancias específicas de su nacimiento, como muestra la tabla inferior:

Tabla 55: La militancia del CDS: I y II Congreso.

\begin{tabular}{|l|l|l|l|l|}
\hline & \multicolumn{2}{|l|}{ I CONGRESO } & \multicolumn{2}{l|}{ II CONGRESO } \\
\hline Compromisarios & 622 & 992 & \multicolumn{2}{l|}{} \\
\hline Hombres/Mujeres & $90,5 \%$ & $9,5 \%$ & $88,4 \%$ & $11,6 \%$ \\
\hline & \multicolumn{2}{|l|}{ Procedencia política } & 565 & $57 \%$ \\
\hline Sin militancia previa & 132 & $21,2 \%$ & 353 & $35,6 \%$ \\
\hline UCD & 485 & $78, \%$ & 74 & $7,4 \%$ \\
\hline Otros partidos & 5 & $0,8 \%$ & \multicolumn{2}{l|}{} \\
\hline & Profesión y estudios & $28,5 \%$ & 332 & $33,5 \%$ \\
\hline Titulados Superiores & 177 & $28 \%$ & 144 & $14,5 \%$ \\
\hline Titulados Medios & 174 & $25,3 \%$ & 16 & $16,2 \%$ \\
\hline Especialistas & 157 & $11,5 \%$ & 330 & $33,3 \%$ \\
\hline Trabajadores manuales & 71 & $2,6 \%$ & 10 & $1 \%$ \\
\hline Amas de casa & 16 & $0,5 \%$ & 4 & $0,4 \%$ \\
\hline Jubilados & 3 & $3,9 \%$ & 11 & $1,1 \%$ \\
\hline Estudiantes & 24 & \multicolumn{2}{l}{} \\
\hline & Afiliación &
\end{tabular}

\footnotetext{
${ }^{6}$ Editorial: “La musculatura de Suárez”, El País, 13 de septiembre de 1986.

${ }^{7}$ OICDS, 3, 1986.

${ }^{8}$ Por ejemplo a Madrid le correspondían 101 compromisarios frente a los 18 de Barcelona, El País y $A B C, 13$ de septiembre de 1986.

9 LAFORA, Victoria: "Mil compromisarios acuden a Barcelona a reforzar el CDS en la tierra de Convergencia", Diario 16, 13 de septiembre de 1986.
} 


\begin{tabular}{|c|c|c|c|c|}
\hline 1982 & 622 & $100 \%$ & 377 & $38 \%$ \\
\hline 1983 & - & - & 198 & $20 \%$ \\
\hline 1984 & - & - & 198 & $20 \%$ \\
\hline 1985 & - & - & 198 & $20 \%$ \\
\hline 1986 & - & - & 20 & $1 \%$ \\
\hline & \multicolumn{4}{|c|}{ Edad } \\
\hline $18-25$ & - & - & 30 & $3 \%$ \\
\hline $26-35$ & - & - & 238 & $24 \%$ \\
\hline $36-45$ & - & - & 476 & $48 \%$ \\
\hline $46-55$ & - & - & 238 & $24 \%$ \\
\hline Más de 56 años & - & - & 10 & $1 \%$ \\
\hline
\end{tabular}

Elaboración propia a partir de $O I C D S, 3$, septiembre 1986.

La jornada del sábado 13 tuvo lugar el Pleno de Apertura con la lectura del informe de gestión del Secretario General, José Ramón Caso, en el que describió las dificultades vividas por el partido hasta las elecciones y las claves del ejercicio de la oposición. El texto fue aprobado con un solo voto en contra ${ }^{10}$.

Por la tarde, se presentaron 11 ponencias, elaboradas con anterioridad a las elecciones generales y que sirvieron de base para el Programa de las mismas, 35 enmiendas y diversas mociones ${ }^{11}$, todas ellas debatidas en sesiones plenarias ${ }^{12}$. No hubo ponencias de estatutos -se suprimieron las “disposiciones transitorias"-13, organización, política o estrategia, sustituyéndose de facto esta última por la exposición del propio Suárez.

Tabla 56: Las ponencias del II Congreso del CDS (1986).

\begin{tabular}{|l|l|}
\hline Título de la Ponencia & Defendida por... \\
\hline Política Territorial & Javier Soto \\
\hline Administraciones y Función Pública & Javier Soto \\
\hline Administración de Justicia & José Luis Merino \\
\hline Educación & Fernando Castedo Álvarez \\
\hline Cultura & Fernando Castedo Álvarez \\
\hline Política Económica & Fernando Castedo Álvarez \\
\hline Política Iberoamericana & Miguel Ángel Escotet \\
\hline
\end{tabular}

\footnotetext{
${ }^{10}$ CASO GARCÍA, José Ramón: "España, como debe ser", $O I C D S$, 3, septiembre 1986; $A B C 14$ de septiembre de 1986.

${ }^{11}$ Quizá las mayores innovaciones se encontraban en el área de justicia: la propuesta de supresión del Ministerio de Justicia y de la Audiencia Nacional, la elección directa del Presidente del CGPJ y sus representantes y el restablecimiento del jurado", II Congreso, Ponencia de Justicia, pp. 5-11.

${ }^{12}$ A diferencia del I Congreso, cuando se trabajó mediante el sistema de comisiones, OICDS, 3, septiembre 1986.

${ }^{13}$ En este sentido cabe decir que una moción sobre juventud defendida por Fernando Castedo permitió la modificación del reglamento en este punto dotando de mayor agilidad a la posibilidad de estructurar la rama juvenil del partido, que ya no tenía que ser "refrendada" ex profeso por la dirección nacional: "las Juventudes de C.D.S. (J. CDS) tendrán autonomía en su funcionamiento, en armonía con las determinaciones de los Estatutos que para las mismas apruebe el Comité Nacional del Partido", Artículo 57, RPP, Registro de entrada $\mathrm{n}^{\mathbf{0}}$ 386, 30 de octubre de 1986, (Acta Notarial, 2073. Francisco. J. López Contreras, 30 de octubre de 1986).
} 


\begin{tabular}{|l|l|}
\hline Sanidad & Carlos Revilla Rodríguez \\
\hline Comunidad Económica Europea & José Emilio Cervera \\
\hline Industria & Joaquín Abril Martorell \\
\hline Agricultura & Joaquín Abril Martorell \\
\hline
\end{tabular}

Elaboración propia a partir de Diario 16, 13 de septiembre de 1986

En la sesión del domingo 14 se produjo la renovación y elección de los órganos del partido, proceso que deparó una de las escasas divergencias existentes durante el Congreso. La elección de la única candidatura presentada para el Comité Nacional contó con 619 votos a favor, 145 en blanco y 54 nulos -descontento que se asoció con la ausencia de representación de algunas federaciones como Andalucía o Baleares, aun cuando el Comité Nacional no era un órgano de representación territorial- ${ }^{14}$. La discrepancia pública más sonora provino de Ignacio Camuñas -recientemente afiliado e “invitado" al Congreso- al parecer por la no inclusión de un representante "liberal" en el mismo, y que recibió la réplica del nuevo Secretario General ${ }^{15}$. El $60 \%$ de los miembros del Comité Nacional repetían en sus cargos y se daba entrada a algunos de los dirigentes territoriales con mejores expectativas electorales -Lorenzo Olarte en Gran Canaria, Manuel Garrido en Cantabria o José Luis Merino Hernández en Aragón-, dirigentes de áreas sectoriales particularmente activos (Carlos Revilla en Sanidad o Javier Soto en Administración Municipal), personas de la máxima confianza del Presidente (su jefe de gabinete, José Luis Garro o quien fuera la Secretaria de Presidencia, Rosa Posada) y el nuevo referente intelectual del partido, Raúl Morodo ${ }^{16}$. Según José Luis Gutiérrez, quien cubrió el evento para Diario 16, las bajas correspondieron a hombres cercanos a Calvo Ortega, entre los que podemos a incluir a José Luis González Quirós o Jesús Merino Delgado (Comisión Nacional de Cuentas), líderes regionales como Francisco Villodres $\mathrm{u}$ otros, progresivamente más desentendidos de las labores del partido como Miguel Ángel Eced ${ }^{17}$. Abel Cádiz, quien también salió del Comité Nacional en 1986, recuerda que aquella decisión de Suárez estaba orientada a la renovación del CDS dando mayor protagonismo a políticos que no

\footnotetext{
${ }^{14}$ Divergencia que sirvió de titular de una de las noticias destacadas en la portada de El País: "El nuevo ejecutivo del CDS cosechó más de 200 votos blancos y nulos", 15 de septiembre de 1986. Para J. L. Gutiérrez suponía "la consagración definitiva del aparato de Madrid" en "Apuntes a un Congreso", Diario 16, 16 de septiembre de 1986.

${ }^{15}$ CHARRO, Ana: "Sólo la férrea disciplina de Suárez mantiene el monolitismo del CDS", El Independiente, 24 de junio de 1988, MAST.

${ }^{16}$ Otro de los nombres que se barajaron fue el de Guadalupe Ruiz-Giménez, quien trabajaba en el Instituto de Cooperación Iberoamericana.

17 “Apuntes a un Congreso”, Diario 16, 16 de septiembre de 1986.
} 
provenían de UCD - caso de Raúl Morodo o Carlos Revilla- ${ }^{18}$. De carácter simbólico fueron los 18 votos en blanco y 7 nulos en la votación del Presidente Nacional, Adolfo Suárez, quien a su vez designó a Jesús María Viana como Secretario General. El nombramiento de Chus Viana suponía una recompensa a la magnífica campaña electoral realizada en junio de la que había sido coordinador, y era el reconocimiento a una profunda amistad que los unía desde el inicio de la Transición: "dicen en el CDS que Chus tiene un nivel de amistad con Adolfo Suárez que le permite el decirle las cosas que muy poca gente se atreve. Se le puede considerar un asesor de primera línea"19. Como señala Xavier Latorre: "[a Adolfo Suárez] igual que le molestaban mucho las infidelidades, [...] agradecía mucho las fidelidades" ${ }^{20}$. En opinión de Daniel de Fernando, Viana "era el hombre que le obligaba a Suárez a estar en el partido", a estar pendiente del día a día de la vida del CDS.

Tabla 57: Variaciones del Comité Nacional y del Comité Nacional de Cuentas en 1986.

\begin{tabular}{|l|l|l|}
\hline Comité Nacional & Altas $^{21}$ & Bajas \\
\hline Continúan & Manuel Garrido Martínez & Abel Cádiz Ruiz \\
\hline Adolfo Suárez (Presidente) & José Luis Garro Carballo & Miguel Ángel Eced Sánchez \\
\hline Jesús María Viana (Secretario General) & José Luis Merino Hernández & José Antonio Escudero López \\
\hline José Ramón Caso García & Raúl Morodo Leoncio & José Luis González Quirós \\
\hline Joaquín Abril Martorell & Lorenzo Olarte Cullén & Alfredo Marco Tabar \\
\hline Alejandro Rebollo Álvarez-Amandi & Rosa Posada Chapado & Francisco Villodres García \\
\hline Manuel de Sárraga Gómez & Carlos Revilla Rodríguez & Manuel Jiménez de Parga ${ }^{22}$ \\
\hline León Buil Giral & Javier Soto Carmona & Emilio Pujalte Clariana ${ }^{23}$ \\
\hline Rafael Calvo Ortega & & \\
\hline Fernando Castedo Álvarez & & \\
\hline Gerardo Harguindey Bonet & & \\
\hline Federico Ysart Alcover & & \\
\hline Laura Morso Pérez & & \\
\hline Agustín Rodríguez Sahagún & & \\
\hline Comisión Nacional de Cuentas & & \\
\hline
\end{tabular}

${ }^{18}$ Entrevista con Abel Cádiz, 4 de marzo de 2015.

19 LAFORA, Victoria: "Los hombres que hicieron posible a Adolfo Suárez multiplicar por diez sus diputados", Diario 16, 26 de septiembre de 1986. La relación entre ambos era muy estrecha y sus familias pasaron juntas algunos períodos vacacionales durante estos años, ABC, 07 de agosto de 1983, El País, 13 de septiembre de 1986, $A B C, 30$ de agosto de 1987, etc.

${ }^{20}$ Recuerda Xavier Latorre este papel jugado por Viana por ejemplo en su insistencia para que Suárez realizara la entrevista con Mercedes Milá en mayo de 1986, Entrevista con Daniel de Fernando, 20 de diciembre de 2013 y Entrevista con Xavier Latorre, 14 de julio de 2014.

21 En los medios se destacó la ausencia de Jaime García Añoveros -quien había renunciado personalmente a la militancia política-, Eduard Punset y Federico Mayor Zaragoza, a quienes según El País: "se les ha castigado porque rehusaron encabezar listas electorales en los comicios", El País, 15 de junio de 1986.

${ }^{22}$ De acuerdo con la crónica de El País, "Jiménez de Parga [...] dimitió en vísperas de las elecciones de junio pasado en disconformidad con la decisión del CDS de presentarse en solitario, lo que, según él, supondría un fracaso. Después de las elecciones, Jiménez de Parga ha enviado una carta a Suárez admitiendo que se había equivocado", El País, 15 de septiembre de 1986.

${ }^{23}$ Dimitió como miembro del Comité Nacional antes del 22-J, El País, 15 de septiembre de 1986. 


\begin{tabular}{|l|l|l|}
\hline Continúan & Altas & Bajas \\
\hline Fernando Alcón Sáez & María Jesús del Río Ramón & Joaquín Borrel Mestre \\
\hline Ignacio Ansoleaga Deusto & Urbano Muela Velasco & Jesús Merino Delgado \\
\hline José Luis Sagredo de Miguel & & \\
\hline
\end{tabular}

Elaboración propia a partir del Registro de Partidos Políticos.

Al cierre del Congreso persistían - para columnistas y editorialistas- los mismos déficits con los que se había inaugurado, condensados, de nuevo de acuerdo con José Luis Gutiérrez, en la ausencia de un debate ideológico y el exacerbado personalismo del partido. Para Carmen Rico-Godoy había tenido lugar más bien "un acto publicitario", "una especie de spot" y Adolfo Suárez era "como los modelos publicitarios, un ser con soluciones eficaces para problemas específicos [...] más atractivo el anuncio que el producto" 24 . Carles Pastor hablaba de "la modorra" de un congreso caracterizado por las unanimidades y la exaltación de la uniformidad ${ }^{25}$. La corresponsal de $A B C$, Luisa Palma, se pronunciaba en los mismos términos al valorar los dos objetivos que habían guiado la renovación de cargos: "la cohesión del equipo alrededor del líder y premiar la fidelidad de los que han consolidado al CDS y acompañaron a Adolfo Suárez en la difícil 'travesía del desierto""26. En el editorial de La Vanguardia -intitulado no sin ingenio, "Adolfo Suárez: regreso al futuro"-, se rebajaban las expectativas generadas en el Congreso sobre las posibilidades existentes en 1990 alertando sobre "lo mucho que al CDS le queda por recorrer para ser, como dicen sus líderes, una organización seria, disciplinada y coherente capaz de constituirse en alternativa"27.

Tras la celebración del II Congreso, se aceleró el proceso de estructuración territorial del partido. El análisis sistemático de la celebración de Asambleas Provinciales y Federales durante los meses de febrero, marzo, abril y mayo de 1987 lo pone de manifiesto. Prácticamente, todos los fines de semana Suárez realizó desplazamientos a las distintas provincias con el fin de respaldar los distintos congresos y actos -véase tabla inferior-. Asimismo, se celebraron reuniones provinciales en Albacete, Alicante, Ávila, Burgos, Castellón, Ciudad Real, Cuenca, Huesca, Jaén, León, Palencia, Salamanca, Segovia, Soria, Toledo, Valencia, Valladolid y Zamora, que contaron con la

\footnotetext{
${ }^{24}$ RICO-GODOY, Carmen: "Adolfo Suárez, la imagen”, Diario 16, 16 de septiembre de 1986. "No parece otra cosa que una reunión de amigos, eufóricos, entusiasmados, una especie de grupo de convencidos desde la fe suarista, casi una secta", GUTIÉRREZ, José Luis: "El duque, como "sexsymbol" político", Diario 16, 14 de septiembre 1986; RIGALT, Carmen: "Suárez y su club de fans", Diario 16, 14 de septiembre de 1986.

${ }^{25}$ PASTOR, Carles: "Jesús María Viana elegido nuevo secretario general del CDS en sustitución de José Ramón Caso", El País, 15 de septiembre de 1986.

${ }^{26} A B C, 15$ de septiembre de 1986.

${ }^{27}$ Editorial: “Adolfo Suárez: regreso al futuro", La Vanguardia, 15 de septiembre de 1986.
} 
presencia de los distintos líderes nacionales: Calvo Ortega (Castilla y León), Manuel Garrido (Burgos), Chus Viana (Alicante 14 de febrero y Salamanca 20 de febrero), etc.

Tabla 58: Presencia de Adolfo Suárez en actos territoriales del partido (febrero-mayo 1987).

\begin{tabular}{|l|l|l|}
\hline Territorio & Asamblea & Fecha (1987) \\
\hline Alicante & Asamblea Provincial (elección Compromisarios) & 21 de febrero \\
\hline Ávila & II Asamblea Provincial & 27 de febrero \\
\hline Cataluña & I Congreso Federal (Barcelona) & 1 marzo \\
\hline Com. Valenciana & I Congreso Federal (Castellón) & $7-8$ marzo \\
\hline Castilla y León & II Congreso Federal & $14-15$ marzo \\
\hline Extremadura & I Congreso Federal (Mérida) & - \\
\hline Canarias & Comité Federal & $16-19$ marzo \\
\hline Cantabria & Comité Federal & 21 marzo \\
\hline Pontevedra & Asamblea Provincial & $28-29$ marzo \\
\hline Álava & I Asamblea Provincial & - \\
\hline Navarra & Convención & 4 abril \\
\hline Zaragoza & Comité Federal & 4 abril \\
\hline Almería & I Asamblea Provincial & 5 abril \\
\hline Ciudad Real & Comité Federal & 11 abril \\
\hline Canarias & Comité Federal & $23-26$ abril \\
\hline Baleares* & Visita Adolfo Suárez y José Ramón Caso & $1-2$ mayo \\
\hline Granada* & - & $9-10$ mayo \\
\hline Gerona, Lérida* & - & $9-10$ mayo \\
\hline La Rioja* & - & - \\
\hline
\end{tabular}

*Sin confirmar. Elaboración propia a partir de Carpeta 2, AGP.

Para el período comprendido entre septiembre de 1986 y enero de 1990, la celebración de Asambleas Provinciales y Federales aceleró el ritmo de implantación respecto al período anterior (Anexo XVIII). En las principales provincias se situó un gerente, que liberado de responsabilidades políticas y otros desempeños laborales, se dedicaba íntegramente al partido de cara a su "organización interna y de su potenciación al exterior" ${ }^{28}$. El objetivo-que estuvo lejos de alcanzarse plenamente- era conseguir un liberado en cada provincia y equipos de apoyo parlamentario y/o municipal ${ }^{29}$.

Sin embargo, el mayor número de militantes y la posibilidad de acceder a cargos institucionales -a raíz de los resultados de 1987- hicieron emerger las primeras divisiones y tensiones públicas en el seno del partido, primero tímidamente y desde los Pactos de Madrid y el III Congreso Nacional de forma acelerada. La balsa de aceite que era el partido hasta 1987 se vio sacudida por lo que no eran sino comportamientos democráticos muy difíciles de integrar: se presentaron varias candidaturas a muchas de las ejecutivas, se produjeron sonadas dimisiones y situaciones de auténtica

${ }^{28}$ Órgano de Información del CDS Aragón, 2, 1987.

${ }^{29}$ OICDS, 14, julio 1988. 
ingobernabilidad en algunos territorios ${ }^{30}$. Por ejemplo, en Madrid la lista encabezada por Carlos Revilla recibió el apoyo de únicamente el $40 \%$ de los compromisarios; el sector más crítico con la dirección del aparato había optado por votar en blanco en lugar de presentar una candidatura alternativa ${ }^{31}$.

Tabla 59: Asambleas y convenciones en el CDS (septiembre de 1986- febrero de 1990).

\begin{tabular}{|c|c|}
\hline Tipo & Observaciones \\
\hline $\begin{array}{l}\text { Asamblea } \\
\text { Federal }\end{array}$ & $\begin{array}{l}\text { Se celebraron un total de } 16 . \\
\text { El I Congreso de Federación de Aragón, Cataluña, Com. Valenciana, Castilla-La Mancha } \\
\text { y Extremadura. } \\
\text { El II Congreso de Federación de Castilla y León, Canarias, La Rioja, Cataluña, Galicia, } \\
\text { Murcia, Cantabria, Asturias, Navarra y Madrid. } \\
\text { El III Congreso de Federación de Canarias. } \\
\text { No celebraron Congresos de Federación: País Vasco. }\end{array}$ \\
\hline $\begin{array}{l}\text { Asamblea } \\
\text { Provincial o } \\
\text { Insular }\end{array}$ & $\begin{array}{l}\text { Previsión de Asambleas de acuerdo con los Estatutos (cada tres años) }{ }^{32} \text {. } \\
\text { La I Asamblea Provincial: } \\
\text { - 1987: Álava, Almería, Ibiza. } \\
\text { - 1988: Gerona. } \\
\text { La II Asamblea Provincial: } \\
\text { - 1986: Hierro, Lanzarote, Tenerife, Tarragona. } \\
\text { - 1987: Fuerteventura, La Palma, Gran Canaria, La Coruña, Ciudad-Real, Castellón, } \\
\text { Granada, León, Lérida, Málaga, Orense, Pontevedra, Toledo, Cuenca, Guadalajara, } \\
\text { Cádiz, Albacete. } \\
\text { - 1988: Badajoz, Cáceres, Ceuta, Jaén, Huesca, Segovia, Salamanca, Teruel, Sevilla. } \\
\text { - 1989: Burgos, Barcelona, Córdoba, Lugo, Palencia, Huelva. } \\
\text { - 1990: Valladolid. } \\
\text { La III Asamblea Provincial: } \\
\text { 1987: Ávila. } \\
\text { 1989: Alicante, Valencia. } \\
\text { 1990: Zaragoza. } \\
\text { Otros: Menorca, Mallorca, Guipúzcoa, Soria, Vizcaya. }\end{array}$ \\
\hline $\begin{array}{l}\text { Convención } \\
\text { Nacional }\end{array}$ & $\begin{array}{l}\text { Convención Nacional sobre El Estado de las Autonomías (III, Barcelona, mayo de 1988). } \\
\text { Convención Nacional para la elaboración del Programa Electoral de las elecciones } \\
\text { generales (IV, Madrid, septiembre de 1989). }\end{array}$ \\
\hline
\end{tabular}

Elaboración propia a partir de Carpeta 2, $A G P$ y fuentes hemerográficas.

A nivel local, el partido logró contar en 1990 con 628 comités locales, 409 gestoras locales y un total de 277 sedes. Una implantación sin embargo, bastante menor que la de otras formaciones políticas. Si lo comparamos con UCD, ésta en la ciudad de Madrid se

\footnotetext{
${ }^{30}$ Los episodios más mediáticos fueron los de Ciudad Real, La Rioja o Baleares, donde las crisis internas se solapaban con la diferencia de criterios de actuación política de unos u otros sectores, según participasen de los órgano de gobierno autonómicos o municipales, véase, Cambio 16, 11 de julio de 1988.

${ }^{31}$ En el acto era totalmente perceptible la división del partido en la Federación de Madrid, entrevista con José Antonio Pérez González, 23 de mayo de 2014.

${ }^{32}$ Análisis realizado a comienzos de 1987 gracias a la documentación en las Carpetas 1 y 2, AGP. Las previsiones sufrieron modificaciones en numerosos casos por la celebración de Congresos Federales o Nacionales -aprovechando esa fecha para la elección de compromisarios-, crisis internas -celebración de Asambleas Extraordinarias o formación de gestoras-, etc. Para el caso de Castilla-La Mancha puede verse Informativo (CDS Guadalajara), 0, noviembre 1987. Las celebradas en Huelva, Granada, Jaén y Cádiz, en ABC Sevilla, 30 de abril de 1989, 05 de junio de 1988, 02 de mayo de 1988 y 09 de noviembre de 1987. En el caso de Zaragoza y Valladolid, El País, 15 de enero de 1990 y ABC, 17 de enero de 1990.
} 
organizaba en 21 distritos, cada uno de ellos con sede propia. En el caso del CDS, la sede madrileña -situada primero cerca de la Plaza de España y posteriormente en la Plaza de Chamberí- era común a toda la Federación -la división distrital era operativa por ejemplo, para las distintas elecciones de compromisarios $^{33}$-. En Barcelona sólo existió un comité local desde junio de 1987, y la ciudad contó con una sede absolutamente provisional hasta las elecciones de junio de $1986^{34}$. En algunas provincias, donde había marcados desequilibrios en cuanto al reparto de población, fue habitual no formar comités locales en las ciudades principales, con el fin de no crear dos órganos de gobierno de composición prácticamente similar y solapados -comité local principal y comité ejecutivo provincial- ${ }^{35}$.

Tabla 60: Agrupaciones locales del CDS (febrero de 1990).

\begin{tabular}{|l|l|l|l|}
\hline & Comités Locales & Gestoras Locales & Sedes Locales \\
\hline Andalucía & 116 & 73 & 38 \\
\hline Aragón & 11 & 17 & 9 \\
\hline Asturias & 20 & 2 & 11 \\
\hline Baleares & 21 & 11 & 5 \\
\hline Canarias & 52 & 1 & 18 \\
\hline Cantabria & 29 & - & 7 \\
\hline C-L & 56 & 9 & 19 \\
\hline CM & 28 & 31 & 8 \\
\hline Cataluña & 47 & 61 & 31 \\
\hline Extremadura & 16 & 102 & 10 \\
\hline Galicia & 82 & 18 & 11 \\
\hline Madrid & 26 & 1 & 20 \\
\hline Murcia & 30 & 3 & 24 \\
\hline Navarra & 8 & 2 & 4 \\
\hline La Rioja & 4 & - & 1 \\
\hline País Vasco & 1 & 6 & 3 \\
\hline C. Valenciana & 81 & 72 & 55 \\
\hline TOTAL & 628 & 409 & 277 \\
\hline
\end{tabular}

Elaboración a partir de CDS: Líneas de Acción Política, CDS, 1991.

La dirección nacional incrementó la periodicidad de sus reuniones, hasta ser prácticamente mensual $^{36}$. A comienzos de 1989 , se trasladó la sede del partido a un palacete ubicado en la C/Marqués del Duero - un gesto que muchos con el paso del

\footnotetext{
${ }^{33}$ Entrevista con José Antonio Pérez González, 23 de mayo de 2014.

${ }^{34}$ Papers (CDS Barcelona), octubre 1987.

${ }^{35}$ Fueron los casos por ejemplo, de Salamanca y Valladolid, entrevista con José Luis Sagredo de Miguel, 04 de junio de 2015. En Valladolid, hacia 1988 había unos 700 afiliados, 450 de los cuales pertenecían a la capital, CDS en Valladolid, 1, febrero-marzo 1988.

36 Algunos medios criticaron la inoperatividad del $\mathrm{CN}$ : ausencia de debate, decisiones tomadas de antemano y reuniones comunicadas con escasas horas de antelación, El Independiente, 10 de octubre de 1987, MAST.
} 
tiempo han considerado "un error tremendo" 37 -. Aunque los medios subrayaron una mayor implicación del Presidente Nacional en las actividades del partido en este período, a nuestro juicio y como hemos intentado demostrar en la primera parte de este trabajo esa percepción tiene más que ver con la escasa relevancia del CDS durante la I Legislatura, que con la propia actitud de Suárez ${ }^{38}$.

En este período también se configuró definitivamente el área sectorial del partido mediante la creación de Secretarías Ejecutivas. En octubre de 1987 quedaban configuradas las siguientes Secretarías:

Tabla 61: Secretarias y áreas de trabajo en el CDS entre 1987 y 1990.

\begin{tabular}{|l|l|}
\hline Secretarías Ejecutivas & \\
\hline Organización & Fernando Alcón \\
\hline Participación Ciudadana y Política Territorial & José Luis Gómez-Calcerrada \\
\hline Estudios y Programas & Manuel Justel \\
\hline Administración y Finanzas ${ }^{39}$ & Antonio del Olmo \\
\hline Prensa & $\begin{array}{l}\text { Juan Roldán } \\
\text { Antonio Fernández Teixidó (octubre, 1989) }\end{array}$ \\
\hline Otras áreas y responsabilidades & \\
\hline Departamento Jurídico & José Antonio Souto Paz \\
\hline Gabinete de Presidencia & $\begin{array}{l}\text { Alfonso Î̃niguez } \\
\text { Rafael Arias-Salgado }\end{array}$ \\
\hline Coordinación del Grupo Parlamentario & José Luis Garro \\
\hline Asesores Política Exterior & $\begin{array}{l}\text { Raúl Morodo } \\
\text { Eduardo Punset }\end{array}$ \\
\hline
\end{tabular}

Elaboración propia a partir de fuentes hemerográficas ${ }^{41}$.

José Luis Gómez-Calcerrada colaboraba de forma ocasional en la elaboración de informes o discursos para la Secretaría Provincial de Ciudad-Real y la Secretaría General. En 1987, a raíz de la iniciativa de José Ramón Caso y el propio Adolfo Suárez

\footnotetext{
${ }^{37}$ Una opinión expresada mayoritariamente por la militancia y dirección del partido que lo percibieron, simbólicamente, como un engrandecimiento innecesario: "un palacio no puede ser la sede de un partido político", entrevistas con miembros del CDS (Laura Morso, Antonio Garrosa, J. L. Gómez-Calcerrada o Xavier Latorre).

${ }^{38}$ CASTAÑOS, Federico: “Adolfo Suárez proyecta abandonar su bufete para 'poner orden' en el CDS", Cinco Días, 10 de octubre de 1987; "Un palacete para el duque", El Independiente, 10 de octubre de 1987.

39 "Que otorga [Adolfo Suárez González, Presidente Nacional] poder a favor de DON ANTONIO DEL OLMO AIRES, mayor de edad, español, casado, Ldo. En Ciencias de la Información, [...] y de DON JOSÉ RAMÓN CASO GARCÍA ]...] para que actuando MANCOMUNADAMENTE en nombre y representación del Partido Político "CENTRO DEMOCRÁTICO Y SOCIAL" (C.D.S.) ejerciten las facultades siguientes [...] Comprar, vender, permutar o por cualquier título adquirir o enajenar bienes de todas las clases [...] Representar al Partido en todos los asuntos y actos administrativos y judiciales, ante toda clase de Autoridades, dependencias y organismo del Estado [...] Solicitar, obtener, tomar y percibir dinero a préstamo de cualesquiera Entidades bancarias [...]", $R P P$, Registro de Entrada no 49, 05 de abril de 1988, (Acta Notarial, 2063. Francisco J. López Contreras, 05 de octubre de 1987).

${ }^{40}$ El País, 09 de septiembre de 1989.

${ }^{41}$ PALMA, Luisa: "El CDS reforma su estructura para mejorar su imagen y sus canales informativos", $A B C, 05$ de octubre de 1987.
} 
decidió incorporarse, con dedicación plena, a la coordinación de la Secretaría de Participación Ciudadana ${ }^{42}$. La labor de la Secretaría era hacer frente al ingente trabajo que les llegaba desde el Grupo Parlamentario, la organización de jornadas y encuentros y la formación de la militancia ${ }^{43}$. Juan Roldán, responsable del área de prensa, había trabajado anteriormente en UCD y el PRD, y según El Independiente, había sido un hombre cercano a Javier Rupérez. Fernando Alcón era amigo íntimo de Adolfo Suárez desde su juventud en Ávila ${ }^{44}$, Manuel Justel había sido capellán en la Moncloa durante la Presidencia de Suárez ${ }^{45}$, y Antonio del Olmo había estado vinculado profesionalmente desde los años 60' a RTVE ${ }^{46}$.

Este proceso de reestructuración sufrió muy pronto un fortísimo revés, al fallecer Chus Viana el día 25 de febrero de 1987 con cuarenta y cuatro años, un durísimo golpe personal para Suárez, inesperado y trágico ${ }^{47}$. Siguiendo de nuevo el testimonio de Daniel de Fernando, este amargo y terrible suceso es fundamental para entender el rápido declive posterior del partido.

José Ramón Caso, quien mejor conocía los entresijos de la organización suarista, volvió a hacerse cargo de la Secretaría General. Las circunstancias contribuyeron a reforzar al solapamiento de funciones en el partido suarista en sus dos áreas principales: la Organización y Grupo Parlamentario ${ }^{48}$. Adolfo Suárez, José Ramón Caso y Agustín Rodríguez Sahagún eran el núcleo del partido.

\footnotetext{
${ }^{42}$ Posteriormente se añadió la "Política Territorial", al existir temas de debate abiertos de nivel nacional de gran relevancia como el Fondo de Compensación Interregional o los estatutos de Ceuta y Melilla.

${ }^{43}$ Entrevista con J. L. Gómez Calcerrada, 10 de junio de 2015.

44 "Los amigos perennes", como llama García Abad a la familia Alcón, GARCÍA ABAD, J. A.: Adolfo Suárez..., p. 193.

${ }_{45}$ HERRERO, Luis: Los que le llamábamos... En El Independiente realizaron una severa crítica de la composición de esta ejecutiva en la que sólo había, lo que consideraban "íntimos" de Suárez, a la que había que añadir la "vicepresidencia de facto" de Rodríguez Sahagún, El Independiente, 10 de octubre de 1987, MAST. El análisis del recién inaugurado rotativo madrileño, dirigido por Pablo Sebastián -jefe de prensa durante la campaña del CDS en 1986-, parecía rescatar la imagen de "círculo interior" -dirección del partido-, desarrollada por Maurice Duverger, que adquiere la faz de un "clan" o "camarilla" que rodea a la jefatura política y constituye: "la clientela de ese jefe [...] [que] monopoliza los puestos de dirección y reviste el carácter de una oligarquía" y está unida por lazos personales, DUVERGER, Maurice: Los partidos políticos, México, FCE, 1992, p. 182.

${ }^{46}$ El País, 06 de noviembre de 1980. Elegido miembro del Consejo de Administración de RTVE por el CDS en 1986 y 1990, OICDS, 29, diciembre 1990.

47 "Consternación en el Partido. Chus mantuvo durante toda su vida un generoso estilo de lealtad y trabajo", OICDS, 5, mayo 1987.

${ }^{48}$ Una relación que en los partidos políticos occidentales era, desde hacía décadas, de subordinación del Grupo Parlamentario al Partido, que controla las listas y diseña la política general, véase, DUVERGER, M.: Los partidos..., p. 211 y ss. En cualquier caso, no esquivaba la aparición de tensiones como se vio a propósito de la evolución de UCD desde 1979 y las preocupaciones de Suárez hacia el Grupo Parlamentario. Sin embargo, a pesar de la concentración de poder en la persona de Suárez -presidente del
} 


\section{2. Militancia, electorado y sociedad}

En 1982, uno de los máximos líderes de AP, Fernando Suárez, definió al CDS como "una 'capillita' del duque de Suárez" ${ }^{49}$ proveniente de forma mayoritaria de UCD -algo más del $50 \%$-. En este apartado debemos profundizar en dos cuestiones, que aunque presentes a lo largo de todo el trabajo resultan de especial interés a la hora de comprender la evolución del CDS. Por un lado, abordaremos la transformación cuantitativa y cualitativa de la militancia, sus motivaciones y sus características sociológicas. En un segundo momento, debemos profundizar en las claves del electorado "centrista". En la siguiente gráfica podemos ver el crecimiento del número de afiliados del CDS desde 1982 y la fecha clave de 1991, año de la dimisión de Adolfo Suárez, y en la tabla posterior, la desfavorable relación, en términos comparativos, con el resto de fuerzas políticas:

Gráfica 5: Evolución de la militancia del CDS entre 1982 y 1991.

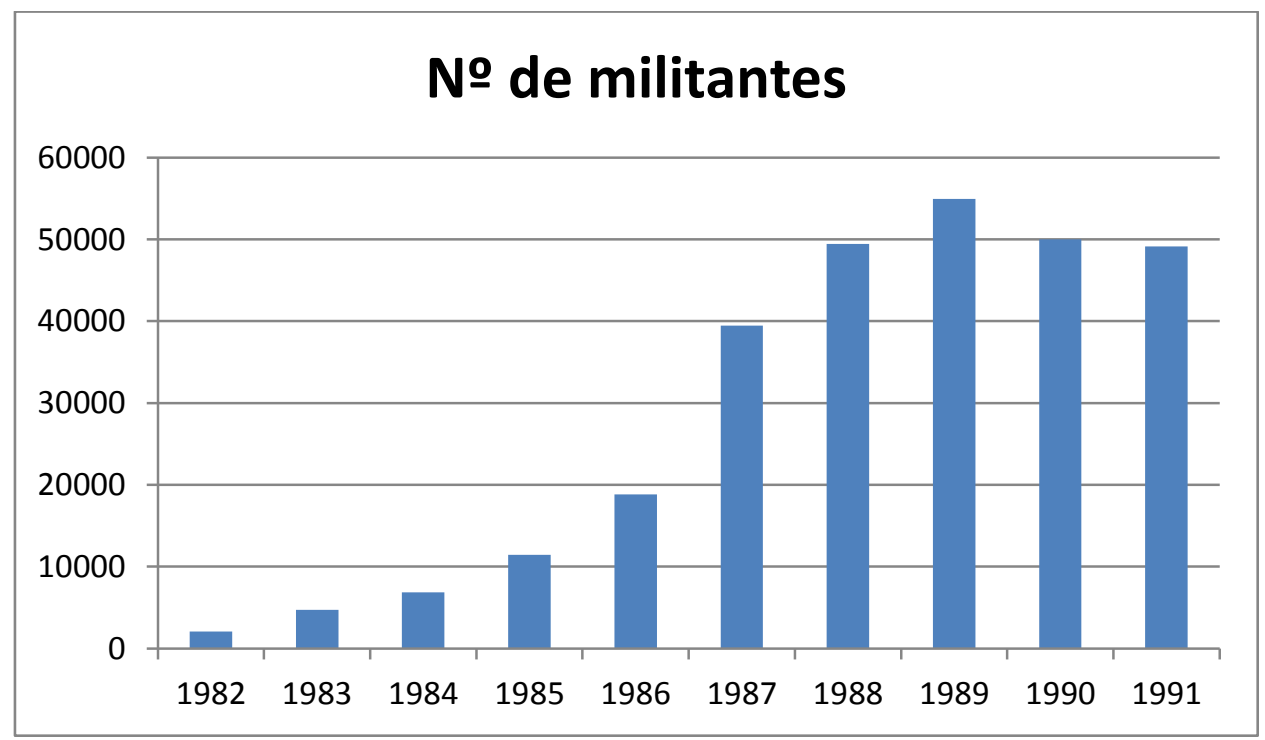

Elaboración propia a partir de CDS: Líneas de Acción ... ${ }^{50}$.

Grupo Parlamentario, art. $2^{\circ}$ de los Estatutos-y su entorno, era imposible ejercer un control absoluto. Aunque el art. $49^{\circ}$ aludía al acatamiento de las resoluciones programáticas y el art. $50^{\circ}$ establecía la obligación de presentar la dimisión si causaran baja del partido, como señalaba un líder nacional: "esto lo tiene el partido socialista también. Lo que pasa es que, claro, a la hora de la verdad, un señor que decide marcharse del CDS y es diputado [...] no hace honor a su compromiso y no pasa nada", interview undertaken by Richard Gunther in 1983 (june), AR.

49 FERNÁNDEZ, Jorge: "Fernando Suárez: 'Mi tesis es que Manuel Fraga tiene que colegiar sus decisiones", Diario 16, 16 de septiembre de 1986.

${ }^{50}$ Los datos para 1990 han sido recogidos en $A B C, 18$ de diciembre de 1990 y El País, 03 de abril de 1991. Según el periodista J. R. Verano, en julio de 1991 el CDS contaba con 49.125 militantes, habiendo 
Tabla 62: Total de afiliados y porcentaje respecto al conjunto del electorado.

\begin{tabular}{|l|l|l|l|l|}
\hline & 1983 & 1985 & 1988 & 1991 \\
\hline PCE & 84.652 & 70.000 & 49.000 & 44.776 \\
\hline PSOE & 145.471 & 165.413 & 213.239 & 309.026 \\
\hline AP & 144.960 & 202.777 & 246.678 & 300.988 \\
\hline CDS & 4.710 & 11.444 & 49.437 & 49.125 \\
\hline \% de afiliados en relación al electorado \\
\hline \multicolumn{5}{|l|}{1985} \\
\hline PCE & 0,24 & 1990 \\
\hline PSOE & 0,53 & 0,16 \\
\hline AP & 0,68 & 0,90 \\
\hline CDS & 0,04 & 0,98 \\
\hline
\end{tabular}

Elaboración propia a partir de BIEZEN, Van: Political parties...

El proceso de tramitación de las afiliaciones se iniciaba a nivel provincial, si bien, debía ser ratificado por la organización del partido en Madrid antes de que el órgano territorial implicado procediese a la creación de la ficha definitiva. El CDS logró duplicar su afiliación poco después de las elecciones 1982, en contra incluso de las suposiciones de la dirección del partido. Un dirigente andaluz comentaba cómo después de las elecciones: "hubo una avalancha de gente que se afilió. En estas últimas elecciones municipales [1983] ha habido otra avalancha de gente que se ha afiliado [...]

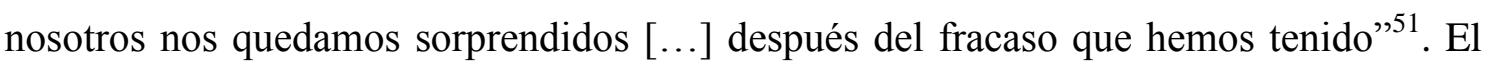
crecimiento en número de afiliados fue continuado, sostenido por el trabajo de la dirección del partido en su despliegue por el territorio. Para muchos, el recuerdo que todavía inspiraba la figura de Suárez era imborrable. Un antiguo miembro de UCD en Barcelona, Xavier Latorre, que se incorporó al partido en 1986 recuerda: "a mí me subyuga una imagen, cuando se presenta y obtiene solo dos diputados: Adolfo Suárez y Agustín Rodríguez Sahagún [...] Aquí a este hombre hay que ayudarle"52.

El aumento de la militancia constituía un objetivo apremiante para la consolidación y estructuración del CDS, más si cabe en un partido presentado ante la opinión pública como un mero apéndice de Adolfo Suárez y su entorno más inmediato. En este contexto se inscribían las campañas de afiliación y planteamientos como el siguiente:

Hay que transmitir la idea de que "estamos vivos y con ganas de guerra". No podemos ofrecer solamente la figura de nuestro Presidente. Necesitamos disponer de una estructura

perdido una medie de 260 afiliados mensuales desde 1989 (54.920), El Independiente, 17 de agosto de 1991.

${ }^{51}$ Interview undertaken by Richard Gunther in 1983 (june), AR.

${ }^{52}$ Entrevista con Xavier Latorre, 14 de julio de 2014. 
de Partido Potente. Aprovechemos los días de vacaciones para "sembrar" nuestras ideas y defender a nuestros líderes ${ }^{53}$.

El gran salto en términos de afiliación se produjo entre el año 1986 y 1987 a raíz de los éxitos electorales en las elecciones generales y las elecciones autonómicas y municipales $^{54}$. El CDS en septiembre de 1986 (II Congreso) sumaba 14.840 afiliados y a finales de 1988 contaba ya con 49.937. En poco más de dos años había multiplicado por más de tres $(3,36)$ su militancia - una variable mayor aún en aquellos territorios donde menor era su implantación en 1986 como las Islas Baleares, Andalucía, Cataluña, Extremadura y Murcia-. En territorios con altos índices de afiliación desde los primeros compases de la formación del partido, como la Comunidad Valenciana $(4,6)$ o Asturias $(4,3)$, y en menor medida, Canarias $(3,5)$, Madrid $(3,3)$ o Castilla y León $(2,9)$, se consiguieron mantener elevadas tasas de crecimiento:

Tabla 63: Distribución regional de la militancia (1986-1989).

\begin{tabular}{|l|l|l|l|l|}
\hline & Sept. 1986 & Abril 1987 & Diciembre 1989 & Múltiplo 1986-9 \\
\hline Andalucía & 1854 & 3645 & 8397 & 4,5 \\
\hline Aragón & 702 & 1095 & 1923 & 2,7 \\
\hline Asturias & 388 & 718 & 1675 & 4,3 \\
\hline Baleares & 175 & 619 & 1174 & 6,7 \\
\hline Canarias & 1186 & 2424 & 4185 & 3,5 \\
\hline Cantabria & 263 & 436 & 774 & 2,9 \\
\hline Castilla y León & 1923 & 3133 & 5554 & 2,9 \\
\hline Castilla-La Mancha & 1192 & 2400 & 3867 & 3,2 \\
\hline Cataluña & 696 & 1102 & 3035 & 4,4 \\
\hline Extremadura & 604 & 1561 & 2638 & 4,4 \\
\hline Galicia & 1430 & 2176 & 4347 & 3 \\
\hline Madrid & 2235 & 3502 & 7361 & 3,3 \\
\hline Murcia & 456 & 935 & 2086 & 4,6 \\
\hline Navarra & 66 & 108 & 243 & 3,7 \\
\hline La Rioja & 79 & 153 & 326 & 4,1 \\
\hline País Vasco & 79 & 173 & 316 & 4 \\
\hline C. Valenciana & 1365 & 3573 & 6775 & 5 \\
\hline Ceuta & 81 & 95 & 107 & 1,3 \\
\hline Melilla & 27 & 47 & 70 & 2,6 \\
\hline Extranjero & 39 & 56 & 67 & 1,7 \\
\hline Total & 14840 & 28054 & 54920 & 3,8 \\
\hline
\end{tabular}

Elaboración propia a partir de CDS: Líneas de Acción...

\footnotetext{
53 “Hacer militantes [...] Te adjunto una 'solicitud de afiliación': “con el fin de que intentes incorporar a nuestro Partido a algún amigo que coincida con nuestras posiciones y objetivos", "Carta del Secretario General”, CDS, BICDS-A, 4, abril 1985. Campañas que, una vez constituidos los órganos de gobierno provinciales, eran ejercidas por éstos. En Zaragoza, su Gestora Local proponía a comienzos de 1984 una campaña de afiliación consistente en lo siguiente: "consiste sencillamente en aportar cada uno tres o cuatro nombres de personas que sepamos pueden recibir una carta del partido con cierta simpatía o, por lo menos, sin desagrado. No sólo convencidos por el CDS que no se han decidido a dar el paso de la afiliación, sino también otros a los que se pudiera llegar a hacer pensar en esa posibilidad o, cuando menos, colaborar con el partido en alguna de sus áreas", BICDS-A, 4, febrero 1984.

${ }^{54} \mathrm{El} \mathrm{45 \%}$ de los compromisarios en el III Congreso se afiliaron entre 1986 y 1987, CDS: Líneas de Acción Política. III Congreso, CDS, 1991.
} 
Como recuerda Gerardo Muñoz, en Alicante, que llegó a ser la segunda provincia con más militantes del CDS, se realizó una intensísima labor de captación de afiliados de cara a las Elecciones de 1987, a lo que se sumó la "avalancha de solicitudes" que se vivió en este período y ante la que las direcciones provinciales debieron poner especial atención. La previsible llegada de "arribistas", pareja al aumento de expectativas de los suaristas, hizo que, como señala Caso, se diera instrucciones a los comités para que fueran "vigilantes" en la aceptación de las diferentes propuestas de afiliación ${ }^{55}$.

Adentrándonos en las características sociológicas de la militancia, la edad nos revela el impacto del perfil progresista del partido, que permitió la incorporación de personas jóvenes y de mediana edad, generalmente de procedencia urbana y sin militancia política previa. El tramo de edad de menores de 25 años alcanzaba el $38 \%$ de la militancia en 1984; un porcentaje que descendía progresivamente en favor de los grupos de edad comprendidos entre los 30 y los 40 años, mayoritarios en 1990.

Hacia 1985 una estimación de la dirección del partido cifraba en el 70\%, los afiliados que no habían estado previamente en otro partido ${ }^{56}$. El análisis de composición de 19 comités provinciales en 1985 -un total de 267 cargos $^{57}$-, parece corroborar esta estimación realizada por la dirección del partido. Un $58 \%$ de la dirección provincial analizada no había militado previamente en política y un $36 \%$ lo había hecho únicamente en $\mathrm{UCD}^{58}$, unos porcentajes sensiblemente más altos que los correspondientes a las bases. Ambos datos: el fuerte peso de los jóvenes entre la militancia centrista y el paulatino descenso de los ex militantes de UCD confirmaba

\footnotetext{
55 Entrevistas con José Ramón Caso, 19 de noviembre de 2014 y Gerardo Muñoz, 09 de mayo de 2015.

56 "La media de edad de los militantes es 34,1 años. El $67 \%$ de los afiliados son hombres y el $33 \%$ mujeres. Es el que tiene menor $n^{\circ}$ de afiliados de los partidos de ámbito estatal", El País, 14 de octubre de 1984. La media de edad a nivel general (datos de PSOE, PCE, CDS y EE) era de 43 años y de 45 entre sus cuadros. En el CDS militaba el 2,6\% de las mujeres (afiliadas a partidos políticos; el 2/3 de las mujeres lo hacía en el centro-derecha). En relación al voto joven se lanzó el siguiente mensaje: "hoy está de moda, está en la 'movida' pertenecer al CDS', $A B C$, 17 de junio de 1985

57 Asturias, Granada, Zaragoza, Madrid, Ávila, Cantabria, Tenerife, El Hierro, Zamora, Lanzarote, Valencia, La Coruña, Alicante, Las Palmas, La Palma, Fuerteventura, Pontevedra, Lérida y Albacete, Carpeta 2, AGP.

${ }^{58}$ El resto habían pertenecido cuatro a partidos de izquierda, cuatro a partidos de derecha integrados en AP y otros cinco habían militado en formaciones marginales de derecha con idearios cercanos a la socialdemocracia: 4 en AP/CP, 2 en el PAD-UCD, 1 en el PCE y UCD, 1 en el PSOE, 1 en Izquierda Democrática-UCD, 1 en ID, 1 en el Partido Social Demócrata, 1 en Reforma Social Española (M. Cantarero del Castillo) y UCD, 1 en el Partido Laborista (Valencia), 1 "Socialdemócrata" y 1 en Unión Regional Valenciana.
} 
que, en lo que se refería a la militancia, los suaristas no fueron los principales beneficiarios de su disolución en $1983^{59}$.

El porcentaje de mujeres en el partido era de un 33\% en 1984, cifra que descendió hasta un $21 \%$ en 1989; un porcentaje que no fue permeable a los órganos de dirección del partido, donde en las ejecutivas provinciales analizadas nos encontramos con un 9,73\% (1985), cifra prácticamente similar a la del Comité Nacional formado en 1986 $(9,52 \%)$ y ligeramente inferior a la del CN nacido del III Congreso que alcanzó el $12,5 \%$.

Tabla 64: Características de los afiliados al CDS (1986-1990).

\begin{tabular}{|l|l|l|c|}
\hline \multicolumn{2}{|l|}{ Tramos de edad y porcentajes (1984) } & \multicolumn{2}{l|}{ Tramos de edad y porcentajes (1990) } \\
\hline Entre 18 y 25 años & 38 & Menores de 26 años & 10 \\
\hline Entre 26 y 35 años & 23 & Entre 26 y 40 años & 47 \\
\hline Entre 36 y 45 años & 21 & Entre 41 y 60 años & 42 \\
\hline Entre 45 y 65 años & 14 & Más de 60 años & 1 \\
\hline Más de 65 años & 4 & - & - \\
\hline Hombres: 67\% / Mujeres: 33\% & Hombres: 79\% / Mujeres: 21\% \\
\hline $\begin{array}{l}\text { Militancia previa en UCD: } \\
\text { Estimada: 70\% }\end{array}$ & $\begin{array}{l}\text { Militancia previa en UCD: } \\
\text { Estimada: - }\end{array}$ \\
\hline
\end{tabular}

Elaboración propia a partir de CDS: Líneas de Acción... y Boletín de Difusión Cultural y Participación, 1, enero 1984.

En cuanto a la profesión desempeñada por la militancia, podemos hablar de la preeminencia de cuadros dirigentes empresariales y profesionales liberales (50\%), frente a un $30 \%$ de empleados y trabajadores asalariados ${ }^{61}$. Debemos incluir finalmente, un reducido porcentaje de estudiantes, amas de casa y jubilados, en torno al $15 \%$.

\footnotetext{
${ }^{59}$ Partido que en 1981-2 llegó a contar con 150.000 afiliados, El País, 06 de mayo de 1984. Aquellos militantes que no abandonaron la política o siguieron como independientes, pasaron a engrosar mayoritariamente las filas de AP, PDP, PRD (o sus múltiples correlatos regionales como Coalición Gallega). En el caso de la CP, las cifras oscilaban entre 12.000/25.000 de los 100.000 militantes con que contaba en 1984, de los que buena parte militaban en el PDP, conformado prácticamente en su totalidad con ex miembros de UCD, lo mismo sucedía con el PRD, cercano a los 4.000 militantes, JÁUREGUI, Fernando: "A la caza del centrista", El País, 27 de marzo de 1984.

${ }^{60}$ El porcentaje se reducía a un 4,52\% en 1982 (I Congreso) y un 6,89\% en 1991 (IV Congreso). Por ejemplo, en el caso del PSOE, para 1988, este porcentaje no alcanzaba el $25 \%$ en el Comité Federal ni en los órganos regionales, El País, 25 de junio de 1988.

${ }^{61}$ El análisis de las profesiones de 17 comités ejecutivos provinciales (1985) nos proporciona porcentajes similares: 53,91\% (industriales, abogados, agricultores/ganaderos, médicos, etc.), 41,01\% (profesores de EGB, funcionarios, comerciales, etc.) y un 5,06\% (amas de casa y estudiantes), Carpeta 2, AGP.
} 
Tabla 65: Características sociológicas de la militancia (1984-1990).

\begin{tabular}{|c|c|c|c|}
\hline & \multicolumn{3}{|c|}{ Porcentaje sobre el total de afiliados } \\
\hline Por estudios/profesiones $^{62}$ & 1984 & 1990 & Media 1984-1990 \\
\hline $\begin{array}{lr}\text { Titulados } & \text { superiores/ } \\
\text { Empresarios, } & \text { profesiones } \\
\text { liberales y similares } & \\
\end{array}$ & 31 & $30^{63}$ & \multirow[t]{2}{*}{51} \\
\hline $\begin{array}{l}\text { Titulados medios/ Directivos y } \\
\text { cuadros medios }\end{array}$ & 19 & 22 & \\
\hline Empleados y vendedores & 22 & 9 & \multirow[t]{3}{*}{33} \\
\hline \multirow[t]{2}{*}{ Trabajadores } & \multirow[t]{2}{*}{12} & Cualificados: 10 & \\
\hline & & No cualificados: 13 & \\
\hline Estudiantes & 9 & \multirow[t]{3}{*}{15} & \multirow[t]{3}{*}{15,5} \\
\hline Amas de casa & 6 & & \\
\hline Jubilados & 1 & & \\
\hline
\end{tabular}

Elaboración propia a partir de CDS: Líneas de Acción... y Boletín de Difusión Cultural y Participación, 1, enero 1984.

La composición sociológica de la militancia suarista contrastaba con la estructura social española de la población activa de la década de los 80’; cuyos datos interpretados comparativamente reflejan proporciones inversas -gráfica 6-.

De acuerdo con estos análisis, las referencias de los medios conservadores que incluían al CDS en el espacio de centro-derecha, y según las expresiones usadas entonces, como un representante más de los intereses de la burguesía (empresariado, profesiones liberales, directivos, etc.) -el CDS no era "en su plataforma social, un partido de izquierda" 64 , eran acertadas:

Gráfica 6: Población activa en España y militancia del CDS (1982-1989) ${ }^{65}$.

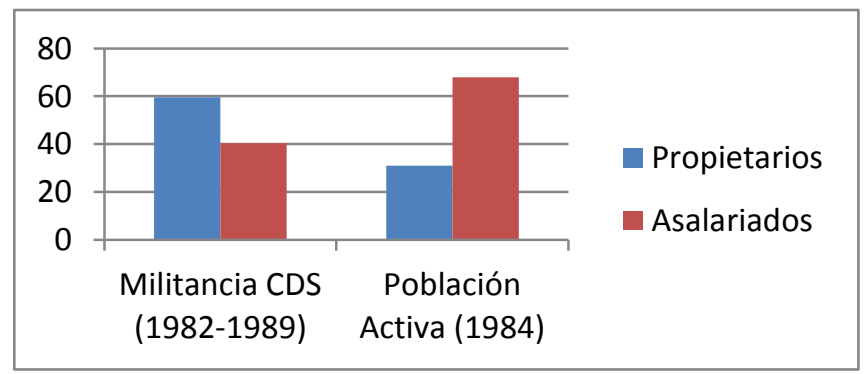

\footnotetext{
${ }^{62}$ La documentación manejada para 1984 hace un desglose en el que entremezcla equívocamente estudios y profesiones, a diferencia de la utilizada para el año 1989. Con el fin de facilitar la lectura, hemos combinado los datos de ambos estudios.

${ }^{63}$ La suma da 101 en el original.

${ }^{64}$ A raíz de unas declaraciones de Rodríguez Sahagún quien señalaba que la crisis de AP es un "problema de la derecha", OVIDIO: "Crisis de la derecha [zigzag]", $A B C, 20$ de noviembre de 1988. El término "burguesía" era empleado en este tipo de argumentaciones tanto por El País como $A B C$ en este período. En las postrimerías de la campaña electoral de 1986, $A B C$ señalaba que era el pequeño y medio comercial/empresario la línea fronteriza entre el PSOE y el resto de grupos que ahora duda entre CDS y AP, en "La gran tentación”, $A B C, 14$ de junio de 1986.

${ }^{65}$ El grupo referente a lo que J. F. Tezanos considera "clases propietarias" incluye a: empresarios agrarios con asalariados, empresarios con asalariados de la industria y los servicios, gerentes y directores,
} 
Terminología y fuente de la gráfica de población activa en: TEZANOS, José Félix.: "Cambio social y modernización en la España actual”, REIS, 28, 1984.

Sin embargo, esta primera lectura, que lleva a cabo una equivalencia automática entre posición socio-profesional e ideología política, debe ser matizada al menos en tres sentidos. En primer lugar, la categoría genérica de "propietarios" incluye, a los trabajadores por cuenta propia y a parte de la categoría de trabajadores de "cuello blanco" (administración pública y servicios); en estos momentos, los elementos más dinámicos de la sociedad -el grueso de las “nuevas clases medias"- ${ }^{66}$ y los grupos más permeables para la movilidad política e ideológica. Sectores en los que el CDS había conseguido tener un arraigo significativo, aunque eso sí, muy débil. Otros grupos como el Partido Popular, reconocían en un informe electoral de manejo interno en una fecha tan tardía como 1989 que los "profesionales liberales" se encontraban todavía "lejos del PP,

En segundo lugar, debemos tener en cuenta el factor generacional. De acuerdo con el testimonio de uno los líderes del partido en Alicante, y posteriormente Presidente Federal en la Comunidad Valenciana, en aquella provincia se daba una situación repetida en otros territorios y aparentemente paradójica. Durante la llamada travesía del desierto, las bajas expectativas del partido suarista favorecieron la renovación de los cuadros dirigentes. Generaciones más jóvenes, inclinadas hacia el centro-izquierda, se hicieron cargo del partido - caso de Alicante $^{68}$-, mientras parte de la militancia, especialmente en las zonas rurales, permanecía identificada sociológicamente con posiciones cercanas a la derecha o el centro-derecha ${ }^{69}$.

Finalmente debemos abordar la caracterización social e ideológica del electorado suarista. Aunque, el CDS apelaba en los distintos manifiestos electorales a las "anchas

profesiones liberales, empresarios sin asalariados y trabajadores independientes, propietarios agrícolas sin asalariados. El segundo bloque, correspondiente a las "clases asalariadas" comprende a: personal administrativo, comercial y técnico, contramaestres y capataces, personal de servicios, obreros especializados, obreros sin especializar y obreros agrícolas. El autor se basa en una Encuesta de Población Activa del INE (1er trimestre de 1984), en TEZANOS, José Félix: "Cambio social y modernización en la España actual", REIS, 28, 1984, p. 43.

66 TEZANOS, José Félix: "España: Estructura y dinámica social" en NAVAJAS ZUBELDIA, Carlos (ed.): Actas del IV Simposio de Historia Actual, Logroño, 17-19 de octubre de 2002, Logroño, Gobierno de la Rioja, Instituto de Estudios Riojanos, 2004, p. 225; FELDMAN, A. S., MENES, J. R. y GARCÍAPRADO N.: "La estructura social y el apoyo partidista en España", REIS, 47, 1989, pp. 7-72.

67 "Bases para el diseño de una estrategia electoral", fechado el primer semestre de 1989, Caja 4, 45-231, AGUN/JLA, p. 16.

${ }^{68}$ La Presidencia Provincial correspondía a Rafael Martínez-Campillo y la Secretaría Provincial al propio Gerardo Muñoz Lorente, Informaciones, 21 de enero de 1986.

${ }^{69}$ Gerardo Muñoz ingresó en el partido en 1984 y no había militado previamente en política. Se convirtió en Secretario de Información e Imagen en el CDS-Alicante. 
capas medias", que comprendían desde el trabajador manual al pequeño y mediano empresario $^{70}$, de puertas para adentro, se distinguían dos grandes grupos diferenciados como objetivos preferenciales de su base electoral-, a los que asignaba los epítetos de "progresista" y "reformista" diferenciados en razón del sexo, la edad, la formación, la religión y la residencia (urbano-rural); grupos que como vimos al analizar los resultados electorales de 1986, conformaron los dos grandes perfiles del electorado suarista en aquellas elecciones:

A) En el segmento progresista de la población electoral: hombres solteros, de 18 a 45 años, con ingresos medios, estudiantes y directivos medios, católicos no practicantes, como mínimo con estudios medios y que viven en áreas metropolitanas.

B) En el segmento reformista de la población electoral: mujeres casadas, mayores de 45 años, con ingresos medios, amas de casa, católicas practicantes, con estudios primarios y que viven en poblaciones menores de 50.000 habitantes $^{71}$.

La síntesis de ambos segmentos de población se producía al apelar de forma genérica a las "clase medias". Rodríguez Sahagún reivindicaba en 1982, en la línea del Manifiesto Político, aquellos sectores sociales alejados de "revoluciones" y de "privilegios" la CEOE o la patronal bancaria, y el mundo del trabajo, vinculado, en su mayor parte, al PSOE y $\mathrm{PCE}^{73}$. Un carácter integrador que le conducía, como señala J. L. Gómez Calcerrada al "interclasismo", por los cargos y la militancia ${ }^{75}$. El éxito del CDS en 1986 había sido concentrar el voto más moderado, alejado de opciones maximalistas en el conjunto del electorado español. El 38\% de los votantes auto-ubicados en el "centro" habían elegido el CDS como opción electoral en 1986 (36\% el PSOE y $22 \%$ CP $)^{76}$.

Las contrapartidas del doble perfil electoral del CDS fueron esencialmente dos. Por un lado, en el momento de mayor éxito electoral se produjo la acentuación de la

\footnotetext{
${ }^{70}$ El valor de centro, CDS, 1986. En el programa para las elecciones autonómicas del País Vasco se hacía un llamamiento a las capas medias, al punto medio entre libertad y solidaridad, CDS: Vamos a centrarnos, CDS, 1988.

${ }^{71}$ Boletín de Difusión Cultural y Participación, 1, enero 1984.

72 RODRÍGUEZ SAHAGÚN, Agustín: "Centro político y Centro Social”, El Noticiero Universal, 15 de septiembre de 1982.

${ }^{73}$ En El País se calificaba al electorado del CDS de "derecha moderada" o "reformismo burgués", editorial: "Un partido para el duque”, El País, 02 de agosto de 1982.

${ }^{74}$ Con una nota de preocupación de lo social, entrevista con José Luis Gómez-Calcerrada, 10 de junio de 2015.

75 "Somos interclasistas", proclamaba el Secretario General del CDS, Jesús María Viana en la campaña electoral del País Vasco, El País, 17 de noviembre de 1987.

${ }^{76} \mathrm{El} 4 \%$ de los votantes de centro-izquierda votaron al CDS en 1986, el 6\% de los de centro-derecha y el $3 \%$ de los de derecha, MONTERO, José Ramón: "Sobre las preferencias..." en DEL CASTILLO, Pilar (eds.): Comportamiento..., p. 5.
} 
indeterminación ideológica de su electorado. Si analizamos las adhesiones políticas de los votantes del CDS en 1986, los datos suaristas arrojaban el balance más elevado en la categoría "ninguna y no respuesta": 45\% (en 1982 había sido de un 20\%) -la media, para PSOE, PCE y AP era de un 26,33\%-. Como ha señalado Aguilera de Prat "los resultados fueron buenos, dado el éxito de una campaña populista centrada en el liderazgo de Suárez cuyo indefinible programa le permite recoger una gran variedad de adhesiones"77. Y no faltaban los clichés, heredados de la Transición y alimentados por columnistas políticos y revistas del corazón sobre el particular "éxito" de Adolfo Suárez entre el electorado femenino más desmovilizado ${ }^{78}$.

Por otro lado, se había generado cierta tensión entre el discurso oficial del partido encarnado en A. Suárez y de corte eminentemente progresista $^{79}-$, y las tendencias ideológicas predominantes entre su electorado que se concentraba en un $31 \%$ en posiciones de derecha o centro-derecha (liberales y demócrata-cristianos especialmente) frente al $22 \%$ identificado con el centro-izquierda o izquierda ${ }^{80}$.

En los últimos días de diciembre de 1988, El País en un editorial en el que definía la actitud del CDS ante el 14-D y las reivindicaciones sociales como de "oportunista" identificaba la escisión -“desgarro interno"- irreconciliable en el electorado de Suárez: “el ya legendario silencio de Suárez no es el fruto de ninguna sutileza estratégica sino más bien de la dificultad de hallar un mensaje que unifique el alma radical y el cuerpo moderado" 81 . En el CDS existía un electorado cercano AP, rural, agrario, conservador, propio de la España interior que votaba a Suárez por simpatía y recuerdo de la Transición. Este electorado suarista convivía con otro grupo, formado por clases medias urbanas desengañadas con los gobiernos socialistas y, de acuerdo con el editorialista de El País, "radicalizadas". Según Raúl Morodo, determinante en la construcción de los

\footnotetext{
${ }^{77}$ AGUILERA DE PRAT, Cesáreo, "Balance y transformaciones...”, p. 149.

${ }^{78}$ Hemos contabilizado su aparición entre 1982 y 1991 en cuatro "encuestas" sobre elegancia e incluso, "preferencia como yerno", recogidas en la revista ;Hola! Fue elegido el "hombre más elegante de España en 1986", véase, ¡Hola!, 09 de septiembre de 1986, 01 de enero de 1987, 29 de diciembre de 1988 y 18 de diciembre de 1989.

${ }^{79}$ Un aspecto que recuerda Laura Morso - a propósito de los viajes en los que acompañaba al Presidente y del que eran plenamente conscientes, entrevista con Laura Morso. 11 de febrero de 2015.

${ }^{80}$ Una diferencia ligeramente inferior a la obtenida en 1982, cuando los votantes de centro-derecha y derecha alcanzaban un $45 \%$, frente a un $34 \%$ adscrito al centro-izquierda.

${ }^{81}$ Editorial: “Amagar y no dar", El País, 27 de diciembre de 1988.
} 
perfiles ideológicos del CDS, esta escisión evocaba el carácter interclasista del partido $^{82}$. Lo explicaba del siguiente modo:

Dicho en otros términos: como partido de centro progresista, el CDS tiene que conjugar y equilibrar un centro-derecha y un centro-izquierda. Posición política que asume legítimamente y que es, entre otras cosas, resultado de un interclasismo social. Hay así contradicción genérica, la que se deriva del sistema global democrático y pluralista, pero no contradicción concreta; la misma coherencia o comprensión coyuntural que tuvieron en su día en las huelgas citadas Melquiades Álvarez y Manuel Azaña: del reformismo liberal al radicalismo democrático ${ }^{83}$.

Esta larga lista de datos y opiniones de difícil cohesión fue una de las causas que impidió al CDS tener éxito en su intento por arraigar en el seno de la sociedad civil, a pesar de los intentos, como la creación de la Secretaría de Participación Ciudadana en 1987 que tenía por fin conectar al partido con los distintos colectivos sociales, y donde tanto el PSOE como el PP tenían sustanciales ventajas comparativas ${ }^{84}$. La escasa presencia institucional del CDS le impedía la irrupción en la administración pública y el sistema funcionarial. Del mismo modo, se encontraba alejado del favor de los medios de comunicación públicos y privados, no se consideraba un partido representativo del mundo de la empresa -a pesar de los intentos de Rodríguez Sahagún ${ }^{85}$-, los sindicatos u otros estratos de la sociedad -como colegios profesionales, universidades, asociaciones de consumidores- $-{ }^{86}$. En un análisis sobre la estructura socio-profesional y el apoyo partidista en las elecciones generales de 1986 publicado en REIS en 1989, se concluía que el CDS carecía "casi por completo de raíces en la estructura socio-profesional" y

\footnotetext{
${ }^{82}$ Aunque el CDS no se definía estatutariamente como "interclasista"-a diferencia de, por ejemplo, Alianza Popular: "Alianza Popular es un Partido democrático, liberal y conservador, reformista e interclasista", Estatutos de Alianza Popular. VII Congreso, 1987.

${ }^{83}$ MORODO, Raúl: “Aquiles y la tortuga”, El País, 11 de enero de 1989.

${ }^{84}$ Seguimos los ítems desglosados por el profesor SORIANO DÍAZ, R. L.: "El dominio de los partidos políticos: partidos y sociedad", Revista de Estudios Políticos (Nueva Época), 105, julio-septiembre 1999, pp. 265-277.

En el marco del asociacionismo de pequeños y medianos empresarios existía afinidad con algunas asociaciones caso de UNIPYME, escindida en 1981 de CEPYME, de la que había sido fundador Rodríguez Sahagún y dirigida por un hombre de su "máxima confianza, González Olivé, El País, 25 de junio de 1981. En el contexto del verano de 1982 se incorporó a las listas electorales del CDS por la circunscripción de Valencia, Cesáreo Fernández, vicepresidente de UNIPYME, El Noticiero Universal, 16 de septiembre de 1982. Una entrevista realizada por la revista de gestión empresarial Futuro a 409 directivos sobre las preferencias de presidente de gobierno daba los siguientes resultados. Felipe González: 17,4\%; Miquel Roca: 16,4\%; Manuel Fraga: 11,2\%; Adolfo Suárez: 8,1\%, ABC, 03 de abril de 1986.

${ }^{86}$ A pesar de algunos casos aparecidos en la prensa, CULLEL, Rosa: "Una candidatura de CDS y PCE se enfrenta a la Junta de los economistas de Madrid", El País, 28 de noviembre de 1985 y El País o "El CDS quiere copar la UCE [Unión de Consumidores de España]", $A B C 01$ de marzo de 1989. Se calculaba que 200 afiliados (de un total de 7.000) en la Com. de Madrid estaban afiliados a UGT en 1988, Tribuna, 02 de mayo de 1988. Un documento del Dpto. de Participación Ciudadana recomendaba la afiliación de la militancia a alguna organización sindical, y el propio Programa 2000 del PSOE llamaba la atención de un acercamiento del CDS al aparato sindical de UGT en $Y a, 27$ de julio de 1989.
} 
apuntaban: "nuestros resultados sugieren, cuando menos, una posición débil para este partido en la política nacional. Y si la interpretación que hemos avanzado antes sobre el significado de los arraigos fuera correcta, este partido podría desaparecer con facilidad" ${ }^{\prime 87}$.

\section{3. Pensamiento e ideología en el CDS (1985-1993)}

La renovación del discurso del CDS se inició en 1985. Ese año, se imprimió un nuevo impulso a las "ideas fuerza" recogidas en el Manifiesto y se emprendió el camino por trayectorias ideológicas hasta ese momento apenas insinuadas. Las específicas circunstancias que habían dado lugar al nacimiento del CDS, que insistimos, tenían que ver con el contexto político concreto en el que se desarrollaron los últimos episodios de la Transición, demandaban una nueva construcción discursiva con la que proyectarse hacia la sociedad. Parecía absolutamente claro que la opción por el "personalismo comunitario" aun siendo bastante elocuente sobre la sensibilidad política de Suárez, había constituido un parche ineficaz de cara a la definición ideológica del partido y la genérica apelación como "constitucionalista” requería de mayores precisiones.

La búsqueda de nuevos perfiles ideológicos abrió dos vías paralelas. Por un lado, hubo un intento por entroncar con alguna de las corrientes de pensamiento político existentes en la Historia de España y por otra parte, se trató de lograr la homologación del partido en el terreno internacional, lo que se consiguió en el seno de una las grandes ideologías contemporáneas: el liberalismo. En ambos procesos desempeñó un papel fundamental, Raúl Morodo, quien había sido la mano derecha de E. Tierno Galván en el PSP y se incorporó al partido avanzada la II Legislatura ${ }^{88}$. A lo largo de las presentes páginas, analizaremos, como a partir de las premisas ideológicas del partido en 1982 surgieron estas dos líneas de trabajo complementarias y nos detendremos en este epígrafe en la primera de ellas, esto es, la perspectiva histórica antes mencionada.

\footnotetext{
${ }^{87}$ FELDMAN, A. S., MENES, J. R. y GARCÍA-PRADO, N.: "La estructura social y el apoyo partidista en España", REIS, 47, 1989, p. 62.

88 "El partido de Suárez representa un centro izquierda, que es donde me siento más cómodamente instalado", El País, 27 de febrero de1985. Su integración en el CDS había sido objeto de rumores desde la fundación del partido y ya había manifestado en numerosas ocasiones la necesidad de fundar una fuerza política de centro-izquierda, MORODO, Raúl: Por una Sociedad Democrática y Progresista, Madrid, Turner, 1982, pp. 21 y 275-6. De gran importancia también en este sentido, fue la incorporación de Eduard Punset, quien tras haber ejercido el Ministerio para las Relaciones con las Comunidades Europeas se presentó a las elecciones de 1982 como independiente por las listas de CiU, $A B C, 18$ de abril de 1985.
} 
El objetivo era superar las acusaciones de oportunismo, indefinición y ambigüedad ${ }^{89}$, verbalizadas por los medios y el resto de partidos como personalismo, caudillismo, populismo, tercermundismo, o en una de sus versiones más elaboradas, espacio donde convivían desde "el franquismo silente al trotskismo irredento" "90, y que en última instancia remitían a la secular polémica iniciada por Maurice Duverger sobre la inexistencia del centro político, mero punto geométrico donde entraban en contacto los moderados de izquierda y de derecha. A pesar de las intenciones eminentemente electoralistas de estas acusaciones, en el seno del CDS nadie ocultaba el reto que suponía elaborar un discurso político propio y coherente que ejerciera de seña de identidad unificadora, máxime cuando según algunos estudios internos la "ideología" estaba relegada al tercer puesto en el orden de motivos de afiliación al partido y las confusiones sobre la misma eran evidentes ${ }^{91}$. En este sentido, un colaborador del Gabinete de Presidencia, en el contexto de la campaña del 86' establecía como una de las líneas de trabajo:

Perfilar el centro. Dimensionar el centro. Las posturas que se transiten sobre la banca, USA, OLP, FF.AA. etc., producen alguna desorientación porque quizá (y a la vez) no se han podido transmitir todavía ejes ideológicos, o no ha llegado a la gente (al menos a la gente que hace opinión) el marco ideológico general del CDS donde poder encuadrar las citadas posiciones sobre temas concretos. Preguntas habituales (más o menos interesadas) siguen siendo: ¿está el CDS a la izquierda del PSOE?; ¿dónde está el CDS?; ¿tiene el CDS una ideología seria, consistente y coherente?; ¿cuál es? Parece entonces necesario dar a conocer cuanto antes una clara síntesis de las líneas principales ${ }^{92}$.

Tabla 66: Tendencias ideológicas de los votantes del CDS entre 1982 y 1986.

\begin{tabular}{|c|c|c|}
\hline & \multicolumn{2}{|c|}{ Porcentajes } \\
\hline Tendencias & $\mathbf{1 9 8 2}$ & $\mathbf{1 9 8 6}$ \\
\hline Franquistas & 2 & 2 \\
\hline Conservadores & 10 & 6 \\
\hline Liberales & 11 & 14 \\
\hline Demócrata-Cristianos & 22 & 14 \\
\hline Socialdemócratas & 34 & 7 \\
\hline Socialistas & - & 1 \\
\hline Comunistas & - & \multicolumn{2}{|c|}{} \\
\hline
\end{tabular}

Elaboración propia a partir de MONTERO, J. R., "Sobre las...", p. 87 y ss.

${ }^{89}$ HALCÓN, Rafael: "El CDS nada en la confusión ideológica, ha renunciado a sus compromisos políticos", El independiente, 10 de octubre de 1987.

90 Expresión del editorial: "Un año en minoría", $A B C, 09$ de junio de 1988; TRILLO-FIGUEROA, Federico: "El populismo suarista", $A B C, 04$ de agosto de 1986. El uso del término indigencia [ideológica] en MUÑOZ-ALONSO, Alejandro: "Desconcierto", $A B C, 09$ de julio de 1988. En la izquierda, se compartía este punto de vista, por ejemplo, la ponencia política del XXXI Congreso del PSOE subrayaba la "ambigüedad ideológica" del CDS, PSOE: "31 Congreso PSOE. Ponencia marco", Madrid, PSOE, 1988 , p. 8. De "coyunturalismo" de izquierdas y derechas lo definía el editorial: "Pocas sorpresas", El País, 28 de mayo de 1989.

${ }^{91}$ HERRERO, Luis: "Suárez ataca en silencio", Época, s. f. (1987), MAST.

${ }^{92}$ S.a., s.f., Carpeta $2, A G P$. 
Desde el punto de vista estratégico, la amalgama ideológica del CDS tenía un reverso inmediato y positivo. El CDS era el partido menos rechazado por el electorado y el que poseía mayores índices de crecimiento potencial ${ }^{93}$. Del mismo modo, no eran injustificados los análisis del CDS sobre la languidez de las ideologías contemporáneas y que afectaban tanto al socialismo como a la derecha conservadora, quienes acrecentaban progresivamente su voracidad hacia el centro político como espacio legitimador $^{94}$. Emergía una nueva política desideologizada, asociada a valores técnicos ${ }^{95}$. Sin embargo, las dificultades para transmitir su mensaje al electorado eran evidentes, y se reproducían por ejemplo, a propósito de cada nueva incorporación en el partido.

Unos eran antiguos barones y ex ministros de UCD "suaristas", que no habían ingresado en el partido en 1982 caso de Enrique Sánchez de León o Jaime García Añoveros ${ }^{96}$. Otros, terminaron ingresando en el CDS tras breves experiencias en otras formaciones como los dirigentes del Partido de Acción Liberal y ex ministros de UCD, Ignacio Camuñas y Federico Mayor Zaragoza, o el ya citado Eduard Punset ${ }^{97}$. Hasta 1987, no se integró en el partido quien fuera uno de los referentes del suarismo durante UCD, Rafael Arias-Salgado, donde desempeñó el cargo de "jefe de gabinete"98. Entre 1987 y 1989, se produjo la llegada de numerosos diputados del PDP como Íñigo Cavero, Félix Pérez Miyares o Modesto Fraile, dándose el caso, de estar el CDS a punto

\footnotetext{
${ }^{93}$ OICDS, 7, octubre de 1987. Mantenía así, muy bajos índices de "preferencias negativas de partido". En las encuestas, sólo el $16 \%$ reconocía que jamás votaría al CDS frente al $15 \%$ en el caso del PSOE, el $52 \%$ para AP y el 55\% del PCE. Desglosado por partidos políticos: el 30\% de los que votaban al PCE afirmaban que nunca concederían su voto al CDS, el 16\% del PSOE y el 14\% de AP. Por su parte, un 85\% de los votantes del CDS jamás concedería su voto al PCE, un 33\% en relación a AP y un $13 \%$ en el caso del PSOE (los datos corresponden al año 1985), MONTERO, José Ramón: "Sobre las preferencias...", pp. 106-7.

${ }_{94}$ MORODO, Raúl: "Mixtificación ladina” y “¿Fin de la ambigüedad fronteriza?”, El País, 21 y 09 de octubre de 1987. El CDS-Pontevedra en un comunicado de 1990 señalaba: "[el centro está] en la modernidad del espacio resultante de la síntesis surgida de la integración de los contrarios que forman el siglo XX", Diario 16, 12 de noviembre de 1990.

${ }^{95}$ Un discurso, que aunque se puede rastrear desde 1982, adquirió su definitiva consistencia en los comicios celebrados en 1989, El País, 07 de agosto de 1989 y 06 de mayo de 1989, etc.

${ }_{96}^{A B C}, 18$ de noviembre de 1984. En el caso de García Añoveros - quien mantenía cierta proyección pública y escribía regularmente en El País- ingresó simplemente por "la amistad" que le unía a Suárez, pero declinando cualquier responsabilidad en el partido, El País, 05 de junio de 1985. García Añoveros, según Mario Conde estaba en el lobby de Antonio Navalón al igual que Adolfo Suárez, CONDE, Mario: Los días de gloria, Madrid, Martínez Roca, 2010, pp. 324, 458 y 492.

${ }^{97} A B C, 22$ de septiembre de 1985.

${ }^{98}$ Como señala el propio Arias-Salgado, su ingreso se produjo no sin algunas dificultades, cabe decir, fruto de esa concepción de la fidelidad tan marcada en Adolfo Suárez, Entrevista con Rafael AriasSalgado, 09 de marzo de 2015.
} 
de controlar la fundación democristiana Humanismo y Democracia ${ }^{99}$. También llegaron parlamentarios del PL -el número dos del partido, Antonio Jiménez Blanco y los diputados Baltasar Zárate, José María Pardo y Ana Yabar- o AP -como José Ramón Lasuén ${ }^{100}$-, junto a representantes de la izquierda política como Ramón Tamames (IUFP), Luis Rufilanchas (UGT y PSOE) o Javier García Núñez (USO y PSP), a quienes había precedido Raúl Morodo en $1985^{101}$. Sobre otros, como Jorge Verstrynge (AP) o Carlos Zayas (PSOE), se rumoreó su posible pase durante meses. Esta "cascada" de nombres sin nexo político alguno sirvió a los medios para subrayar, una vez más, las contradicciones, mezclas imposibles y afanes del proyecto político suarista: "un poco más, un nuevo paso en la integración de políticos variopintos y de vario plumaje y estamos otra vez en la Unión del Pueblo"102. En su descargo, uno de los diputados anteriormente citados, Baltasar de Zárate, indicó: “entiendo que tránsfuga sería aquel político que cambia de ideología en términos absolutos [...] En España el proceso de consolidación de los partidos políticos de centro ha sido muy difícil”103.

Desde 1982 hasta 1990, el CDS se definió en sus documentos oficiales como "progresista y reformista". Si el reformismo era una referencia evidente a la Transición -aspecto del que hemos hablado a propósito del Manifiesto Político-, y al menos sociológicamente, remitía a posiciones más conservadoras, el progresismo invitaba a pensar en el espacio de "centro-izquierda", aunque con unos contenidos bastante vagos, más allá de la defensa explícita de una interpretación "progresista" de la Constitución $^{104}$. Por ejemplo, Daniel de Fernando -dirigente del CDS en Castilla y León-, apunta cómo en algunas comarcas de la provincia de Ávila en las que era muy vivo el recuerdo de la Guerra Civil, recomendaba a Rodríguez Sahagún emplear en

\footnotetext{
99 "El PP, en pugna con el CDS, se hace con la fundación Humanismo y Democracia", $A B C, 17$ de marzo de 1990. Pilar Salarrullana, ex diputada del PDP ingresó en el CDS en 1990, El País, 23 de octubre de 1990.

${ }^{100}$ J. R. Lasuén tomó la decisión a raíz de la intervención parlamentaria de Suárez en el Debate sobre el Estado de la Nación de 1987, BAÓN, Rogelio: Historia..., p. 782.

${ }^{101}$ Se barajaba en 6.000 el número de afiliados que habían militado previamente en partidos de izquierda. Otros fueron Javier de Luján (PSOE), Fernández Palacios (PSP), L. Ortega Monasterio (PSC), J. Ros Hombravella (PSC), Fernández Teixidó (ORT) o el caso de Joaquim Trigo quien estuvo "en la órbita de la Liga Comunista Revolucionaria" y en 1986 era "el director del Fomento de Economía del Trabajo Nacional, la patronal catalana", en TIJERAS, Ramón y FERNÁNDEZ, Antonio: “'Rojos' de toda a vida mandan en el partido de Adolfo Suárez", Tribuna, 02 de mayo de 1988.

${ }^{102}$ CAMPMANY, Jaime: "Las candidatas", 10 de abril de 1989. Véase también: DÁVILA, Carlos: "Los nuevos centristas", Diario 16, 07 de febrero de 1989.

${ }^{103} A B C, 27$ de septiembre de 1987.

104 "Nuestro Manifiesto recalca la posición contraria a cualquier modificación constitucional. [...] Nuestra Constitución es de las más modernas no sólo por la fecha de su promulgación, sino por su concreción y encierra unas potencialidades inmejorables para su desarrollo [Adolfo Suárez]", entrevista recogida en $E l$ País, 08 de agosto de 1982.
} 
lugar del concepto de "centro-izquierda", el de "centro-progresista" al dirigirse en los mítines a simpatizantes y afiliados ${ }^{105}$. Un contraste que no ha pasado desapercibido en otros dirigentes, caso de José Luis Merino, presidente del CDS en Aragón:

Así mucha gente, que había hecho en la época anterior una verdadera «profesión de fe» política hacia la persona de Adolfo Suárez, seguía pensando que UCD y CDS eran lo mismo; el segundo continuador ideológico del primero. Y por ello en algunas elecciones me consta que muchos votantes conservadores (que luego han depositado su confianza electoral en el Partido Popular) votaron al nuevo partido centrista pensando que su voto quedaba en manos de una ideología de derechas, conservadora ${ }^{106}$.

El discurso, progresista y reformista del CDS, iba a incluir hacia 1986 el epíteto de radical. En el cierre del II Congreso, Adolfo Suárez señaló: “el CDS es un pensamiento político que supone tolerancia radical"-_ ${ }^{107}$. Eso sí, para los dirigentes centristas el perfil radical del partido tenía más que ver con el desarrollo de la sociedad civil y la defensa y profundización de los derechos y libertades constitucionales - "radicalismo liberal""108_ que con la estrategia política del famoso Partido Radicale Italiano dirigido por Marco Pannella -con quien existieron no obstante algunos contactos-.

En esta época, la vía intermedia representada por el CDS se dotó de nuevos contenidos adaptándose a las realidades de los años 80': crisis del modelo del Estado del Bienestar, distensión entre bloques, integración en Europa, etc. El término "progresista" ganó peso - en perjuicio de la apelación "reformista"-y se asoció, de la mano del compromiso radical con la defensa de las libertades antes aludido, al de "liberal"109 -liberalismo progresista o social-liberal ${ }^{110}$-, hasta el punto, como veremos, de ingresar en esta Internacional. El ideario del CDS significaba la conjunción de la ética socialdemócrata con la eficacia liberal, dando así respuesta a la nueva correlación de fuerzas globales surgida de las crisis petrolíferas de los 70' desde una postura ideológica transversal y superadora de la defensa unilateral de la intervención pública o

\footnotetext{
${ }^{105}$ Entrevista con Daniel de Fernando, 20 de diciembre de 2013.

${ }^{106}$ MERINO HERNÁNDEZ, José Luis: “Los partidos centristas...”, p. 128.

${ }^{107}$ El término de "centro radical" había sido usado esporádicamente con anterioridad, por ejemplo, por Javier Soto Carmona en una entrevista recogida en $A B C, 06$ de mayo de 1983; Diario 16, 15 de septiembre de 1986.

${ }^{108}$ Según la expresión usada en la Ponencia Política del III Congreso (en el II Congreso, no hubo Ponencia Política), CDS: Ponencias III Congreso Nacional, 1991, p. 277.

${ }^{109}$ Como refleja la literatura programática del partido desde 1986, SUÁREZ GONZÁLEZ, Adolfo: Horizonte político de España, CDS, 1986; ÍD.: Una política de progreso y libertad [Intervención de Adolfo Suárez en el Debate sobre el Estado de la Nación de 1988], CDS, 1988; CASO GARCÍA, José Ramón: Una Sociedad Democrática y Avanzada, CDS, 1988, etc.

110 "Al dotar de contenido al proyecto político del centro señalaba: no me satisface plenamente la etiqueta, pero la que más se aproximaría o sintetizaría mejor el conjunto de principios e ideas que definen al CDS sería -y lo digo para entendernos aquí- la de liberal progresista o la de social-liberal", SUÁREZ GONZÁLEZ, A.: La alternativa..., p. 9.
} 
la iniciativa privada ${ }^{111}$. En cualquier caso, si hubiéramos de escoger una palabra definitoria de lo que supuso el CDS bajo la presidencia de Suárez sería la de "progresista"112.

De forma paralela, el CDS buscó su identidad en la Historia Contemporánea de España. Una empresa, quizá con menor impacto mediático, pero que antecedía a cualquier otra preocupación política. De acuerdo con el propio Adolfo Suárez: "el Centro [UCD o CDS] ha sido y es en primer término una necesidad de nuestra evolución histórica"113. El CDS defendía la forja de una nueva identidad colectiva en torno a los hitos del proceso democratizador y sus valores - una suerte de "patriotismo constitucional" avant la lettre ${ }^{114}$, ante la incapacidad de asumir como propio el pasado reciente -la II República por parte de la derecha, y la Dictadura, por parte de la izquierda-: "una Constitución desde el consenso y para seguir en el consenso" "115. Para Suárez era preciso recordar la serie de obstáculos a la convivencia libre y democrática en España: 1814, 1823, el protagonismo militar durante el régimen isabelino, la I República y la Dictadura de Serrano, el reinado de Alfonso XIII y finalmente, "la II República termina en la Guerra Civil y en el régimen autoritario [...] Durante este largo período de siglo y medio los motines, asonadas, pronunciamientos o golpes de estado se producen con una frecuencia casi diaria"116.

Sólo con la Transición el centro vino a ejercer de herramienta fundamental para consolidar un sistema de libertades. Un consenso, como señalaba Seco Serrano: "tan insólito entre nosotros" y "que sirvió de objeto de rechifla para aquellos que seguían

\footnotetext{
${ }^{111}$ Intervenciones de Ramón Tamames y Eduard Punset en el Club 78', Diario 16, 07 de febrero de 1989.

${ }^{112}$ Para Adolfo Suárez la experiencia del socialismo real, el abandono de los presupuestos marxistas por parte del socialismo democrático europeo y la existencia de un amplio consenso colectivo para la construcción del Estado del Bienestar demostraban que estas políticas iban más allá de cualquier dicotomía ideológica, SUÁREZ GONZÁLEZ, Adolfo: La alternativa ...

${ }^{113}$ Ibid., p. 7.

${ }^{114}$ El término había aparecido en esas fechas en Alemania (1979) y fue popularizado tiempo después por Jürgen Habermas, como nueva fórmula de identidad colectiva basada en el ejercicio de los derechos políticos constitucionales, en VELASCO, Juan Carlos: "Patriotismo constitucional y republicanismo", Claves de la Razón Práctica, 125, 2002, p. 34. Ha tenido bastante influencia en el discurso del PSOE y el centro-izquierda en general, sobre la nación española, véase, NÚÑEZ SEIXAS, Xosé Manoel: "La cuestión nacional en la época socialista: entre la armonización autonómica y el patriotismo constitucional", SOTO CARMONA, Álvaro y MATEOS LÓPEZ, Abdón (eds.): Historia de la ..., pp. 4364; BALLESTER RODRÍGUEZ, Mateo: "Auge y declive del patriotismo constitucional en España", Foro Interno. Anuario de Teoría Política, 14, 2014, pp. 121-134. Disponible en https://revistas.ucm.es/index.php/FOIN Fecha de consulta: 10 de junio de 2016.

${ }^{115}$ Prólogo de Adolfo Suárez a la obra de TAMAMES, Laura y TAMAMES, Ramón: Introducción a la Constitución española, Madrid, Alianza Editorial, 2003, P. 3.

116 "Borrador [de la] Conferencia 'Centro Democrático y Social: un proyecto político necesario"”. Archivador 2, Archivo Eduardo Navarro Álvarez-Jorge Trías Sagnier.
} 
encarnando el maniqueísmo tradicionalmente resuelto (o irresuelto) en una sucesión de guerras civiles" ${ }^{\prime 17}$. De este modo, para los suaristas el centro era ante todo una actitud política, una forma de resolución de los conflictos seculares del país -territoriales, socio-económicos, etc.-, basada en el pacto ${ }^{118}$.Y lo que es más, se apuntalaba sobre la propia experiencia política de sus dirigentes, y en ocasiones sus vivencias personales ${ }^{119}$. Los dos principales referentes del partido, Adolfo Suárez y Agustín Rodríguez Sahagún, eran hijos de republicanos:

Agustín Rodríguez Sahagún y Adolfo Suárez se conocieron en 1976, pero a sus padres les había unido cuarenta años antes una amarga experiencia. Hipólito Suárez era republicano, aunque no tuvo ninguna militancia especial en los años treinta. Al estallar la Guerra Civil fue obligado a trabajar como peón en las obras de pavimentación de la plaza del Mercado Chico de Ávila y, para evitar que las cosas fueran a más, buscó el apoyo del general Martínez Anido [...] En aquella obra coincidió con Tomás Rodríguez [padre de Agustín Rodríguez Sahagún] -tío de Aurelio Delgado [cuñado de Adolfo Suárez]-, que sí había tenido una militancia republicana muy activa por la que fue condenado a muerte. Transcurrido algún tiempo consiguió que se le permutara por la de destierro a Bilbao... ${ }^{120}$

El reajuste del sistema de partidos acaecido en 1982 había alimentado una falsa noción de clarificación política, que bajo la faz del bipartidismo, provocaba un mayor distanciamiento, polarización y posible radicalización política a derecha e izquierda ${ }^{121}$. Por ello, era necesario volver a reproducir el sistema cuatripartito de partidos que había caracterizado a la Transición y tan bien había servido para alcanzar consensos y practicar el diálogo. Este modelo del sistema de partidos se compondría de una derecha conservadora, un centro progresista, una formación socialista y un partido comunista ${ }^{122}$.

\footnotetext{
${ }^{117}$ SECO SERRANO, Carlos: "Ante las urnas", El País, 16 de junio de 1986. Aunque desde una óptica distinta, José Luis Abellán denunciaba el "bipartidismo" artificial y la necesidad una representación política más plural para culminar el proceso de consolidación democrática", "La década democrática", $E l$ País, 12 de junio de 1986.

${ }^{118}$ Una idea apreciable durante todo el período de vida del partido, véase, RODRÍGUEZ SAHAGÚN, Agustín: "El aprendizaje de la democracia", El País, 14 de agosto de 1982; "Ponencia política", V Congreso, CDS, 1992, etc.

${ }^{119}$ El papel que jugó el recuerdo de la Guerra Civil en Adolfo Suárez y en otros líderes de la Transición ha sido analizado por FUENTES ARAGONÉS, Juan Francisco: Adolfo Suárez...

${ }^{120}$ CONTRERAS, Emilio: El acoso y derribo..., p. 319-320. El padre de Rodríguez Sahagún era gran amigo de Claudio Sánchez Albornoz y era militante de Izquierda Republicana. A raíz del fallecimiento del historiador abulense, escribió -Rodríguez Sahagún- unas palabras en $A B C$, 09 de julio de 1984 y DEL RÍO, Ángel: Agustín..., p. 14. En el funeral estuvo, entre otros, Adolfo Suárez, ABC, 16 de julio de 1984. Sobre la formación intelectual de Rodríguez Sahagún, véase, ÍD.: "Gabriel Celaya o el compromiso en verso", El País, 13 de julio de 1990.

${ }^{121}$ Una postura compartida por algunas personalidades, entre las que destacó el historiador SECO SERRANO, Carlos: "La alternativa de centro-izquierda", El País, 08 de mayo de 1985.

${ }^{122}$ Una postura convergente con la expresada por el Partido de Acción Liberal, quien apelaba a un centro "liberal y progresista", Tiempo de Acción Liberal, 1, febrero de 1985. Morodo se decantaba por "un centro progresista -y yo añadiría azañista-", MORODO, Raúl: "Centrar la democracia”, El País, 24 de mayo de 1985.
} 
Y en él, el CDS podía “ocupar el lugar de UCD”"123, aun con unas señas de identidad e ideológicas, como hemos visto, diferenciadas ${ }^{124}$. Un centro, cuyo fondo y sentido histórico, era esa tercera España que algunos debieron asumir trágicamente en el contexto de la Guerra Civil y la Dictadura, muchos de ellos, representantes de lo que Raúl Morodo daba en llamar "neorregeneracionismo":

Regeneracionismo que es revisión y cambio, crítica y búsqueda de nuevas soluciones, pero desde la libertad. Regenerar era, así, modernizar y europeizar: pero, a diferencia de Azaña, que era rusoniano radical, o de Araquistáin, que da el salto del regeneracionismo al socialismo crítico, Madariaga, como Ortega, será un liberal clásico y moderado, aunque no excesivamente demócrata, infatigable defensor de la tolerancia y de la paz ${ }^{125}$.

La nota diferenciada de lo que en general era una actitud compartida por toda una generación -merece la pena traer a colación el término acuñado por Ortega DíazAmbrona de Generación del 78'- fue la reivindicación política y personal de la figura de Manuel Azaña, nuevamente, gracias a la mediación de Raúl Morodo ${ }^{126}$. Para este político e intelectual el neo-azañismo era una de las tres derivaciones del neorregeneracionismo pudiéndose definir como "liberalismo radical":

Vigilancia y profundización de libertades en el sentido de una democracia social avanzada [ecologismo, permisividad social e individual, calidad de vida] [...] redefinición de las funciones del estado: para garantizar el equilibrio libertad-igualdad [...] el asentamiento de nuestra sociedad civil en clave europea y autónoma [distensión] $]^{127}$.

El neo-azañismo defendido por Raúl Morodo en el II Congreso generaba no poco desconcierto e indignación a derecha e izquierda ${ }^{128}$-salvo El País que recogió el guante

\footnotetext{
${ }^{123}$ El País, 12 de noviembre de 1982.

${ }^{124}$ En palabras del líder del CDS en Aragón, Merino Hernández: "el nuevo partido creado por Adolfo Suárez no era el 'sucesor' natural de UCD. Su relevo en el mapa político español, sí; su continuador ideológico, no”, MERINO HERNÁNDEZ, José Luis: “Los partidos centristas...”, p. 129.

${ }^{125}$ MORODO, Raúl: "Madariaga”, El País, 23 de mayo de 1986. Ideas que enlazaban con los estudios sobre pensamiento político del autor, véase, ÍD.: Tierno Galván y otros precursores políticos. Madrid, El País-Aguilar, 1987. En torno a esa idea de "superación" de la Guerra Civil, mediante el análisis de biografías políticas, véase, ÍD.: Siete semblanzas políticas: republicanos, falangistas y monárquicos, Barcelona, Planeta, 2010.

126 "Morodo considera que el CDS practica un modelo político 'neo-azañista", $A B C, 16$ de septiembre de 1986.

${ }^{127}$ MORODO, Raúl: “Azañismo y neo-azañismo”, Diario 16, 19 de septiembre de 1986. Véase también: JÁUREGUI, Fernando: "Adolfo Suárez: 'Yo sólo me aliaría políticamente con Felipe González en condiciones de anormalidad [entrevista]", El País, 18 de noviembre de 1985; MORODO, Raúl: "Novedad y continuidad histórica", El País, 29 de marzo de 1990.

128 “Cuando don Raúl Morodo ha hablado de 'neoazañismo', a algunos nos ha entrado la risa nerviosa. Esto es un desierto de ideas...", CAMPMANY, Jaime: "Desierto de ideas", $A B C, 02$ de octubre de 1986. Abrió una interesante polémica con Jiménez Losantos quien le solicitaba desde su columna en Diario 16, que especificase si se aliaba a aquel Azaña liberal, antitotalitario y desengañado de la Guerra Civil o el centrista "aliado" al PSOE por "odio o incomunicación con la derecha moderada" en "Azaña y Suárez" Diario 16, 17 de septiembre de 1986. Véase también: JIMÉNEZ LOSANTOS, F.: "Morodo y amigos", Diario 16, 22 de septiembre de 1986. En el seno de la izquierda se vivió una polémica, igualmente interesante. Ante las manifestaciones de Rodríguez Sahagún -“si Azaña viviera, militaría en el CDS",
} 
y lo llevó a sus últimas consecuencias ${ }^{129}$-. Azaña era el único ejemplo histórico -aun trágico e inconcluso-, de lo conseguido a raíz de la Transición y la instauración de la Monarquía Constitucional: "la democracia política, la economía de mercado, la autonomía regional, la legislación social avanzada, etc., fueron los pilares fundamentales de su ideario político" ${ }^{\text {130 }}$. Referencias que aunque no llegaron a construir una auténtica matriz ideológica, se constituyeron en una fuente de recurrentes paralelismos. Con evidente intención había escrito Rodríguez Sahagún poco antes de las elecciones de 1986:

A tal objeto [Azaña] fundó un partido, minoritario sin duda, pero que incubó el seguramente mejor proyecto político de entonces para desencadenar la reforma que las estructuras españolas necesitaban de cara a modernizar el país y apuntalar sus instituciones y ponerlo, en fin, a la altura que su pasado merecía y al nivel alcanzado por los demás países del área cultural al que el nuestro pertenece ${ }^{131}$.

Con motivo del $50^{\circ}$ aniversario de la muerte de Manuel Azaña (1990), Raúl Morodo glosaba los diversos homenajes y reconocimientos públicos recordando que su figura tenía el gran mérito de "haber anticipado [...] lo que, a partir de la Constitución de 1978, es una realidad operativa: la institucionalización de un Estado de libertades"132, y haber acometido el intento por resolver los tres conflictos seculares de nuestra Historia: anticlericalismo y clericalismo, república y monarquía -“república, para Azaña es, pues, Democracia"-, y centralismo y autonomismo. Concluía: "muchos que participamos en el CDS, como, en otros tiempos más difíciles, en otros partidos de la oposición democrática al franquismo, nos sentimos herederos de este gran proyecto de democratización de la sociedad española”. Carlos Revilla fue más allá e intentó trazar los paralelismos entre el "azañismo y el suarismo". Revilla certeramente apuntó que ambos intentaron saldar "la deuda" que España tenía "con la Historia": la inacabada

véase, CONTRERAS, Lorenzo: "Triunfalismos y verdades", $A B C, 13$ de mayo de 1987-, Izquierda Republicana, en ese momento en la coalición IU, manifestó su pleno desacuerdo e indebida apropiación de la memoria del político republicano en un comunicado del candidato al Europarlamento por IU, CLEMENTE DE DIEGO, Felipe: "La militancia de Azaña [carta al director]", $A B C, 20$ de mayo de 1987.

${ }^{129}$ El CDS podía desempeñar el papel moderador de los partidos republicanos representantes de la "burguesía urbana democrática [...] [e incluso influir en] la política de los socialistas y, a más largo plazo, forzar a éstos a concluir un pacto de legislatura, con o sin participación en el Ejecutivo, que prepare las condiciones para aspirar a constituirse en auténtica alternativa autónoma de poder", Editorial: "La musculatura de Suárez", El País, 13 de septiembre de 1986.

${ }^{130}$ S. a.: "Perfiles históricos: MANUEL AZAÑA", Boletín del CDS Madrid, 2, enero 1986.

131 En otro momento, "son los mismos axiomas que, mutatis mutandis, especialmente poniendo Monarquía constitucional de corte moderno donde dice República, inspiraron la acción política de la Transición y de los primeros Gobiernos de la democracia", RODRÍGUEZ SAHAGÚN, Agustín: "Azaña hoy", El País, 01 de mayo de 1986.

${ }^{132}$ MORODO, Raúl: “Azaña: cincuenta años después”, OICDS, 29, enero 1990. 
realización del Estado Liberal ${ }^{133}$. Las semejanzas, salvando las distancias, eran múltiples: ambos tenían un proyecto político nacional claro, supusieron intentos por trascender la ruptura de las dos Españas, sus concepciones políticas partían del individuo, compartían preocupaciones sociales, defendían una idea plural de España y demostraron "grandeza de ánimo en los momentos graves y sinceridad" ${ }^{134}$. El sentido histórico del papel del centro, así como los perfiles progresistas del partido acercaron al CDS a la figura de Azaña sobre quién Raúl Morodo se preguntaba: “¿es necesario todavía que descanse en el exilio?" "135 Lejos quedaban de la sensibilidad suarista otros que como Alejandro Lerroux, había abanderado opciones de centro populistas y radicales $^{136}$.

Al margen de la reivindicación de Azaña, en el CDS convergieron políticos que desde distintas tendencias compartieron reflexiones en clave regeneracionista sobre la situación del país, es decir, prestos al diagnóstico de los “males” de España y su posible solución. Una lectura regeneracionista que dio lugar a una interesante bibliografía y una activa participación en foros de pensamiento y debate ${ }^{137}$. En ocasiones, afloró un perfil histórico y político, como el aportado por Raúl Morodo, a partir de su producción investigadora y científica, en la que barruntaba poco antes la caída del Muro y la consolidación de la sociedad postindustrial y la expansión de unos perfiles ideológicos cada vez más laxos e indefinidos entre las grandes tradiciones del pensamiento político occidental. Eduard Punset retomó los viejos debates sobre la ciencia, la innovación y la

\footnotetext{
${ }^{133}$ Recuerda que en 1980, Juan Tomás de Salas durante la presentación de un libro sobre Azaña señaló: "Abstrayendo las enormes diferencias que existen entre ellos, se pude [sic] ver un paralelismo entre la personalización de la República en Azaña y la democracia en Suárez", ibid.

${ }^{134}$ REVILLA RODRÍGUEZ, Carlos: “Azañismo y suarismo", OICDS, 29, enero 1990. En este sentido, se manifestaba Ramón Tamames en El País, 27 de febrero de 1989.

${ }^{135}$ MORODO, Raúl: "La diabolización de Azaña”, El País, 29 de octubre de 1990.

${ }^{136}$ Figura histórica de recuerdo maltrecho en la Historia de España: "punto de referencia del centro político, el Partido Radical desempeñó un papel decisivo en el desarrollo del drama de la Segunda República [...] se sobrevalora el papel y la coherencia de la derecha, mientras que se presta escasa atención, y siempre en tono cáustico, hacia el Partido Radical, considerado un juguete en manos de la contrarrevolución" en TOWNSON, Niguel: La República que no pudo ser, Madrid, Taurus, 2002, pp. 401-8. Las referencias a Lerroux fueron escasas y exógenas, en una ocasión, se instó a Suárez a imitar al Partido Radical pero pactando con la izquierda -FERRERES i PLA, V.: "Carta abierta a Adolfo Suárez", El País, 04 de septiembre de 1982-. En sentido inverso, tras los pactos CDS-PP, Leguina comparaba a Suárez con Lerroux, $A B C, 14$ de junio de 1989. Una última comparación con el "viejo lerrouxismo" fue a propósito de su obstrucción a formar parte de una coalición conservadora: "fue para el centro-derecha español, dicho sea en metáfora populista, como el perro del hortelano, que ni come ni deja comer", TRILLO-FIGUEROA, Federico: "El populismo suarista", $A B C, 04$ de agosto de 1986.

${ }^{137}$ Por ejemplo, tres políticos que fueron miembros del CDS, Punset, Tamames y Suárez - de un total de diecinueve personajes de relieve en la sociedad española-, participaron en la obra colectiva, VV.AA.: Visiones de España. Reflexiones en el camino hacia una España avanzada, Barcelona, Círculo de Lectores, 1987.
} 
tecnología españolas con la vista puesta en Europa y en la idea de "modernización"138, Federico Mayor Zaragoza reflexionaba en 1987 sobre los retos educativos y éticos a los que el ser humano debía hacer frente en el seno de lo que consideraba el "segundo" gran proceso de maquinización y Ramón Tamames o el infatigable José Ramón Lasuén, que también transitaron por el CDS, desarrollaron concienzudos análisis -y recetas- para los males del país, en este caso centrándose en los aspectos económicos ${ }^{139}$.

Sin duda, la fuente de inspiración más notable durante esta época desde un punto de vista simbólico era la idea de "modernización del país". Reconocía Suárez, en su intervención en el Círculo de Lectores de Barcelona en 1986, que después del "cambio" había aparecido una nueva palabra, un símbolo, el de "modernidad" cuyos contenidos eran: "modernización de nuestro sistema productivo; acceso a nuevas tecnologías; homologación occidental y europea de nuestra sociedad, hábitos y costumbres; mayor eficacia de nuestras Administraciones Públicas; incorporación a los foros e instituciones internacionales, etc." ¿Qué era necesario para conseguir esta modernidad? Suárez hablaba de la "solidaridad social" -"garantizar a todos los españoles un mínimo compatible con su dignidad humana"-, el enraizamiento de la democracia "educación"-, el desarrollo científico y tecnológico, unos mayores flujos de información -“televisión múltiple, diarios libres, información transparente sobre las compras del Estado y las oportunidades de subcontratación..."-, la profundización del modelo autonómico de Estado, y finalmente, la adhesión a Europa -es decir, la

\footnotetext{
${ }^{138}$ PUNSET, E.: La España impertinente, Madrid, Espasa-Calpe, 1985, pp. 146-7. ÍD.: “¿Por qué innovan tan poco los españoles?", El País, 16 de noviembre de 1986; ÍD.: "El derecho a que nos dejen vivir en paz", El País, 13 de noviembre de 1987; FIDALGO, Feliciano: "Eduardo Punset. Absolutamente moderno", El País Semanal, 25 de agosto de 1985. En relación a Federico Mayor Zaragoza, ha señalado: "no podemos permanecer imperturbables ante los acontecimientos que caracterizan a nuestros días y sobre todo, ante un futuro que, de no corregirse a tiempo el rumbo actual, se adivina sombrío e inclemente", véase, MAYOR ZARAGOZA, Federico.: Mañana..., p. 19.

${ }^{139}$ Ramón Tamames, ya al margen del CDS, propuso, tras un recorrido de la realidad histórica de España, la renovación económica a nivel nacional poniendo el acento en la disminución del peso del Estado y unas nuevas relaciones con el sistema productivo (empresarial) en el que fue el Premio Espasa de Ensayo de 1993, TAMAMES, Ramón: La España alternativa, Madrid, Espasa, 1993, pp. 117-153. Un análisis similar - en cuanto a su estructura-, realizaba más de una década antes, otro futuro miembro del CDS, Lasuén: "el objeto estricto de este libro es intentar predecir el futuro de España, a través de la evolución probable del mediocratismo [la clase media dirigente], que sigue siendo su gestor, ante la problemática actual, interna y externa”, LASUÉN, José Ramón: La España mediocrática, Barcelona, Planeta, 1979, p. 24. Otro ejemplo, en PUNSET, E.: Una salida de la crisis, Barcelona, Argos Vergara, 1980.

${ }^{140}$ SUÁREZ GONZALEZ, Adolfo: Horizonte político de España, CDS, 1986.
} 
"apertura al exterior"141-. El europeísmo era la llave de la modernización del país, y Europa el espejo en el que se miraba España ${ }^{142}$.

En 1987 se fundaba la Fundación Ciencia, Democracia y Sociedad (CDS) para la "promoción de ideas e iniciativas científicas, culturales y políticas que ofrezcan respuestas válidas para la modernización de España y el mejor asentamiento de sus instituciones democráticas" ${ }^{\text {143 }}$. La modernización de España y la integración en Europa debían ser la llave de la definitiva para la "vertebración" nacional -gracias a la España autonómica- y social -de la mano de la concertación- ${ }^{144}$. Un empeño que debía implicar a toda la nación: "el poder y la oposición, para los trabajadores y los empresarios, para los financieros y los industriales..."145.

\section{4. Un análisis prosopográfico: Dictadura, oposición y UCD}

El presente epígrafe aspira a completar, mediante el análisis de los principales dirigentes de la formación centrista, los perfiles sociológicos desarrollados en los apartados anteriores y que tenían por objeto de estudio al conjunto de la militancia. No obstante, nuestra mirada sigue siendo individual y colectiva, ciñéndonos a la definición más extendida del término prosopografía -“descripción de biografías individuales y colectivas"- en la que son susceptibles de estudio grupos de poder, elites o sagas familiares, y que en este caso, son parte de las elites políticas españolas desde el tardofranquismo hasta los años $80^{146}$. De este modo, a lo largo de las siguientes páginas abordaremos el perfil político, ideológico y profesional de los miembros del Comité Nacional del CDS entre 1982-1991, recorrido en el que integraremos el análisis de

\footnotetext{
${ }^{141}$ Ibid., pp. 29-33.

${ }^{142}$ Europa como punto de llegada a nivel cultural, político y científico, un ideal encarnado en la Generación del 14' -particularmente, en Ortega y Marañón-, NAVARRA ORDUÑO, Andreu: El Regeneracionismo. La continuidad reformista, Madrid, Cátedra, 2014, pp. 229-232; SUANCES MARCOS, Manuel: Historia de la Filosofía Española Contemporánea, Madrid, Síntesis, 2002, p. 306.

143 "La realidad de España es el motivo conductor de esta convocatoria, que se basa en un talento político progresista y que funda su actitud tendida hacia el futuro, es un espíritu generacionalista radical y crítico y en, una clara intención formativa". La Presidencia correspondía a Adolfo Suárez y la Secretaría General a Carlos Revilla, BOE, 25 de febrero de 1986, n 48, p. 7347.

${ }^{144}$ La figura de Ortega y Gasset como principal referente intelectual de la nueva formación suarista, $L a$ Hoja del Lunes, 02 de agosto de 1982; SUÁREZ GONZÁLEZ, Adolfo: "La sensatez política [recorte de prensa]", Eslabón, 3, marzo-abril 1987, etc.

${ }_{145}$ Intervención de Adolfo Suárez, DSCD, Sesión Plenaria, 25 de junio 1985, no 221, pp. 10208-9.

${ }^{146}$ CORTÁZAR, Guillermo: “Oligarquía, élites y prosopografía: tres etapas en la historia de los grupos de poder”, en CARASA SOTO, Pedro (ed.): Elites: Prosopografía contemporánea, Valladolid, Universidad de Valladolid, 1994, p. 37.
} 
quienes ocuparon el primer puesto en las diferentes circunscripciones en las listas del Congreso de $1982^{147}$.

Comenzaremos nuestra descripción a propósito de quienes como Adolfo Suárez ejercieron cargos de responsabilidad política en el Movimiento Nacional o en las máximas instituciones de la dictadura franquista, integrándose poco después en UCD entre los llamados "independientes"; políticos que formaron parte del contingente "reformista" forjado en el seno del régimen ${ }^{148}$. Posteriormente, abordaremos la trayectoria de quienes participaron de forma más o menos activa en movimientos de oposición al franquismo, distinguiendo aquellos que lo hicieron en el seno de la llamada oposición moderada -democristianos, socialdemócratas, liberales, etc.-, y quienes fueron miembros de los grandes partidos de izquierda (PSOE, PCE y PSP). Finalmente, recorreremos las biografías de quienes desempeñaron sus primeras responsabilidades políticas en UCD, proviniendo de la empresa privada o la administración.

Uno de los colaboradores más estrechos de Adolfo Suárez fue el dirigente del CDS canario, Lorenzo Olarte. Olarte ejerció como Presidente de la Mancomunidad Provincial Interinsular de Cabildos de la provincia de Las Palmas y del Cabildo Insular de Gran Canaria en el tardofranquismo resultando elegido Procurador en Cortes por el tercio familiar entre 1974 y 1977, siendo en 1976 miembro de la célebre ponencia que defendió la Ley para la Reforma Política. Poco después fundó Unión Canaria, partido a través del cual recaló en $\mathrm{UCD}^{149}$, donde ejerció diversas responsabilidades, como la Presidencia de AVIACO y particularmente relevante desde nuestro punto de vista, la de Consejero de Presidencia junto a personalidades como Federico Mayor Zaragoza, también futuro miembro del CDS y, como el anterior, Procurador en Cortes durante el final de la Dictadura al ser nombrado Rector de la Universidad de Granada ${ }^{150}$. Un perfil

\footnotetext{
${ }^{147}$ La información ha sido extraída, salvo aquellos casos en los que se especifique, del dossier de fichas de candidatos a las Elecciones de 1982 contenidas en la Carpeta 4, AGP.

${ }^{148}$ Una definición de este grupo, en POWELL, C..: "El reformismo centrista y la transición democrática", Revista Historia y Política, 18, 2007, p. 50.

${ }^{149}$ Podemos citar también a Modesto Fraile Poujade, procurador en Cortes entre 1970 y 1974, alcalde de Cuéllar (1967-1970) y Presidente de la Diputación de Segovia. Hombre cercano a Martín Villa, era director General de Empresas y Actividades Turísticas cuando se integró en UCD (1977). En la III Legislatura, pasó al CDS. Luciano Sánchez Reus, senador por Segovia con UCD, fue alcalde de Segovia en 1975 y procurador en la X Legislatura Franquista, defendiendo la Ley para la Reforma Política. Volvió a ejercer la máxima responsabilidad en la alcaldía segoviana con el CDS entre 1987 y 1989, JÁUREGUI, Fernando y SORIANO, Manuel: La otra historia de UCD, Madrid, Emiliano Escolar, 1980.

150 "Mayor Zaragoza, catedrático de Bioquímica, ejerció como Subsecretario de Educación y Ciencia en el Gobierno formado por Carlos Arias Navarro en 1974 y desde diciembre de 1975 fue designado Presidente de la Comisión de Estudio del Régimen Especial para Cataluña. En 1977 aceptó ir en las listas
} 
parecido presentaba Manuel Ortiz, en 1982 candidato por Sevilla con el CDS y que había llegado a ser subsecretario de despacho de Presidencia de Adolfo Suárez en 1976, a quien conocía desde comienzos de la década de los $60^{, 151}$.

En el caso de Jesús María Viana, aunque sus cargos políticos eran secundarios ocupó desde 1968 la alcaldía de Barrio de Arana (Álava)-, tuvo destacadas responsabilidades en la vida económica y social de la ciudad de Vitoria desempeñando los cargos de Presidente del Círculo Vitoriano y de la Cámara Oficial de Comercio (1976-1979), teniendo en esta época, un destacadísimo papel en la configuración de la UCD del País Vasco y en la negociación del Estatuto de Guernica. El también vitoriano Alfredo Marco Tabar ejerció como Procurador en Cortes entre 1971 y 1977 como representante del tercio familiar por Álava, año en el que recaló en UCD, partido en el que ejerció numerosas responsabilidades: Senador, Alcalde de Vitoria, Consejero del Gobierno Vasco, Parlamentario Autonómico, etc. El industrial de la hostelería Serafín Becerra, catalizador del CDS en Ceuta, fue concejal por el tercio familiar en Ceuta, siendo procurador en Cortes durante casi una década (1967-1976) desde donde posteriormente se incorporó a UCD. En La Rioja dirigió el CDS Manuel Fernández Ilarraza quien había sido concejal del Ayuntamiento de Logroño entre 1972 y 1977, para reincorporarse a la vida pública en 1982 de la mano de la nueva formación suarista.

Otros, como el pacense Fernando Povedano Bustos -cabeza de lista para en el Congreso en 1982-, estuvo vinculado al aparato sindical del régimen. Juan Ríos García -líder del CDS en Melilla- fue también un antiguo dirigente de la obra sindical

\footnotetext{
de UCD como 'independiente', dimitiendo de su escaño al ser nombrado Director General Adjunto de la UNESCO, un año después, para volver en 1981 como Ministro de Educación y Ciencia”, El País, 02 de diciembre de 1981.

151 "Manuel Ortiz Sánchez, hombre de confianza de Adolfo Suárez, con quien le une una buena amistad, cuenta 43 años, es madrileño y licenciado en Derecho por la Universidad de Sevilla. Técnico de Información y Turismo, delegado provincial de dicho departamento en Barcelona durante muchos años, [ocupó] [...] después la subdirección general de Prensa, el Gobierno Civil de Huelva y la Delegación Nacional de Provincias. Procurador en Cortes y consejero nacional, fue profesor de la Escuela Oficial de Periodismo de Barcelona y de la Facultad de Ciencias de la Información de Madrid...", El País, 13 de abril de 1977. Véase también, ORTIZ SÁNCHEZ, Manuel: El bienio prodigioso, Barcelona, Planeta, 2006. Manuel Ortiz, junto a Federico Mayor Zaragoza, integrado en 1985 en el CDS, participó en la Unión del Pueblo Español, la asociación dirigida por Adolfo Suárez en 1975, en RÍO MORILLAS, Miguel Ángel: "La Unión del Pueblo Español (UDPE): los orígenes de la macro-asociación azul de Alianza Popular (AP)", en RUIZ CARNICER, Miguel Ángel (coord.): Falange, las culturas políticas del fascismo en la España de Franco (1936-1975) (CD-ROM), Zaragoza, Instituto Fernando El Católico, 2013, p. 499-514.
} 
melillense, o quien fuera ministro de UCD e ingresara hacia 1988 en el CDS, Félix Pérez Miyares, ocupó cargos en este área en la provincia de Cádiz ${ }^{152}$.

Algunos de los miembros del CDS, por su parte, habían participado significativamente en la oposición antifranquista. Federico Ysart y José Luis González Quirós habían formado parte de ese parlamento de papel, cuyo protagonismo fue decisivo en la evolución política del país. Federico Ysart trabajó en Diario Madrid y Cambio 16. Por su parte, González Quirós fue colaborador del ya citado Diario Madrid y editorialista durante la Transición de Diario 16. En Soria, como cabeza de lista se presentó el célebre columnista del diario $Y a$, Abel Hernández, amigo personal de Adolfo Suárez. Más compleja si cabe fue la trayectoria de uno de los fundadores del partido en Baleares, el periodista Josep Meliá, quien había sido procurador en las Cortes Franquistas por el tercio familiar - posición desde la que mostró muy activo en favor de la apertura-, para fundar poco después un partido nacionalista mallorquín antes de recalar en UCD (1977). Llegó a ocupar el cargo de Portavoz de Gobierno con Adolfo Suárez ${ }^{153}$.

León Buil Giral, diputado con el CDS entre 1986 y 1989, había sido miembro del Grupo Tácito, y fundador en los albores de la Transición del Partido Popular Aragonés, llegando a ser miembro de la ejecutiva del Partido Popular de Pío Cabanillas ${ }^{154}$. Íñigo Cavero, diputado centrista durante la III Legislatura, fue un destacado protagonista de la historia de la democracia cristiana española durante la Dictadura recorriendo sus diversas transformaciones (Democracia-Social-Cristiana/Izquierda Democrática/Partido Popular Demócrata Cristiano ${ }^{155}$ ) hasta su integración final en UCD. Perteneció al Grupo Tácito y fue uno de los participantes del Contubernio de Munich, célebre encuentro de la oposición española al régimen donde también estuvo Antonio de Senillosa integrante de la ejecutiva del Partido Popular en 1977 y cabeza de lista al Congreso por el CDS en 1982, tras un fugaz paso por la Coalición Democrática de Manuel Fraga

\footnotetext{
152 TÉlleZ, Juan José (ed.): 1973-83: Memoria de la Transición Democrática en Cádiz (Colección: Crónica de un sueño, 7), Málaga, C\&T, 2003, p. 15. Juan Ríos fue un miembro destacado del Partido Popular (1977) y posteriormente senador con UCD.

153 PAREJA OLCINA, María: "El periódico Mediterráneo durante la transición española (1975-1982)", Castellón, Universitat Jaume I, 2013, p. 103 y ss.

${ }^{154}$ Fundó el Partido Popular Aragonés en 1976, de corte "socialdemócrata", que se integró en UCD, YSART, Federico: “Un centrista aragonés”, $A B C, 22$ de noviembre de 2013.

${ }_{155}$ Miembro también de la Federación de la Democracia Cristiana -a través de Democracia Cristiana Aragonesa- era José Luis Merino, integrante del Comité Nacional del CDS desde 1990 y máximo dirigente del partido en Aragón.
} 
dentro del partido Acción Ciudadana Liberal-, quien en expresión publicada en El País, era un "personaje inclasificable" 156 . Manuel Jiménez de Parga, catedrático de Derecho Político, había defendido en artículos publicados en La Vanguardia desde los años 60’ la opción de una monarquía democrática, acercándose al entorno del Conde de Barcelona. Fue uno de los firmantes del manifiesto fundacional, junto a Raúl Morodo o los anteriormente citados Antonio de Senillosa e Íñigo Cavero, del movimiento de oposición Unión Española ${ }^{157}$.

Una participación de diferente índole fue la de Agustín Rodríguez Sahagún, proveniente de una familia de significación republicana represaliada, relacionado con intelectuales antifranquistas en el Bilbao de finales de los 50' -a propósito de las tertulias en La Concordia- y quien sólo en los estertores de la Dictadura se vinculó al llamado Grupo Libra - una sociedad de estudios que amparó a personalidades de ideología liberal a cuyo frente se encontraba Joaquín Garrigues Walker-. Durante la Transición, fue uno de los impulsores del asociacionismo empresarial español de la mano de la presidencia de CEPYME y la vicepresidencia de la $\mathrm{CEOE}^{158}$. Más discreta fue la actividad de Alejandro Rebollo Álvarez-Amandi miembro del asociacionismo católico de la mano de PROLESA - caldo de cultivo de posteriores liderazgos políticos centristas- y conocido por ser el encargado de la defensa del histórico miembro del PCE: Julián Grimau ${ }^{159}$. En los albores transicionales, Alejandro Rebollo militó en el Partido Socialdemócrata Asturiano, junto al futuro miembro del CDS, Adolfo Barthe Aza para posteriormente recalar en $\mathrm{UCD}^{160}$. Tanto Rodríguez Sahagún como Rebollo Álvarez-Amandi desempeñaron destacados cargos en UCD y los Gobiernos de Adolfo

\footnotetext{
${ }^{156}$ El País, 28 de febrero de 1994. Véase, BARBA, Donato: La oposición durante el franquismo/1. La democracia cristiana, Madrid, Encuentro, 2001.

157 "Quizá por esta preocupación constante sobre la monarquía que teníamos en el horizonte, al iniciarse la Transición fui considerado por algunos medios de comunicación como uno de los 'tapados del Rey"”, JIMÉNEZ DE PARGA, Manuel: Memorias... p. 177. Véase, ABC, 23 de diciembre de 1990.

${ }^{158}$ Había sido a través del mundo de la cultura y de sus experiencias en Europa, donde había conectado desde los años 50' con escritores y artistas desafectos al régimen, DEL RÍO, Ángel: Agustín...; RODRÍGUEZ SAHAGÚN, Agustín: "Los intelectuales y el poder", El País, 16 de abril de 1984. De acuerdo con el testimonio de Ramón Tamames, podemos advertir cierta evolución en el pensamiento socio-económico de Rodríguez Sahagún quien en los inicios de su carrera política se había caracterizado por la defensa de posiciones liberales a ultranza, TAMAMES, Ramón: Más que unas memorias, Barcelona, RBA, 2013, p. 609.

${ }^{159}$ GONZÁLEZ, Carlos: "De la Dignitatis Humanae a la democracia: la crisis de la Acción Católica y el nacimiento de PROLESA (1965-1978)”, Diacronie, 26, 2016. Disponible en: http://www.diacronie.it Fecha de consulta: 02 de septiembre de 2016. A pesar de su juventud, sólo 28 años, su defensa fue "brillante, sólida" en palabras del corresponsal de Le Monde, J. A. Novais, recogidas en CARVAJAL URQUIJO, Pedro: Julián Grimau: el último muerto de la Guerra Civil, Madrid, Aguilar, 2003, p. 175.

160 Véase, La Nueva España, 14 de julio de 2008. Disponible en: http://www.Ine.es/asturias /2008/07/14/formacion-centro/656310.html Fecha de consulta: 01 de julio de 2016.
} 
Suárez, el primero como Ministro de Industria y Energía (1978-9), de Defensa (197981) y Presidente de UCD (1981), y el segundo como Subsecretario de Transportes y Comunicaciones (1978-80) y Presidente de RENFE (1980-82).

En la Federación Demócrata Cristiana dirigida por Gil Robles, militó Juan $\mathbf{M}^{\mathrm{a}}$ Zubeldia Vicente, poco después asesor de Martín Villa y Arias-Salgado para asuntos del País Vasco, cuando eran ministros de Administración Territorial. Ingresó en UCD en 1978 y en 1982 encabezó las listas al Congreso en Vizcaya. Enrique Galavis, proveniente del ámbito empresarial, había sido miembro del comité político del Partido Popular de Pío Cabanillas antes de recalar en UCD -donde fue diputado nacional y Director General de Prisiones-, para posteriormente, ser cabeza de lista por el CDS en la provincia de Cáceres (1982).

La mayor parte de los integrantes del CDS, como hemos tenido oportunidad de ver, ocuparon puestos de relieve en UCD. En muchos casos, su sólida posición en el organigrama provincial del partido ejerció de impulso para la implantación del CDS. En Zamora, el histórico dirigente de UCD Luis Rodríguez San León, hostelero, funcionario y presidente de diversas asociaciones provinciales se hizo cargo del CDS. Rodríguez San León que fue diputado por UCD se encuadraba dentro del grupo de “independientes”. Junto a él, pasaron al CDS, Jesús Pérez López, quien había militado en el Partido Popular y César Martín Montes definido por Jáuregui y Soriano como “tecnócrata-liberal"161. En Lérida, fue el abogado Manuel de Sárraga, proveniente de CC-UCD -partido del que fue Secretario y Presidente Provincial-, quien estructuró el CDS. De acuerdo con Jáuregui y Soriano, se le podía encuadrar en el grupo de “independientes" o "martinvillista". En Granada, Antonio Iglesias Casado, ingeniero de montes - presidente del Instituto de Conservación de la Naturaleza- y aglutinador de la UCD en la ciudad nazarí como "independiente" fue el impulsor del CDS ${ }^{162}$. En Madrid, quien fuera el Presidente Provincial de UCD, Abel Cádiz, fue el hombre decisivo en la configuración del partido suarista. También en la capital estatal, el antiguo concejal de UCD y secretario adjunto de Política Territorial, Javier Soto Carmona, fue uno de los

\footnotetext{
${ }^{161}$ JÁUREGUI, Fernando y SORIANO, Manuel: La otra... De acuerdo con Rodríguez San León, nunca antes había militado en política: "nada de nada, yo no tenía ni ideología, ni sabía lo que era ser senador ni diputado. Me incorporé a UCD porque era un conglomerado de partidos progresistas. Yo fui 'suarista' siempre", La opinión de Zamora, 14 de marzo de 2014, http://www.laopiniondezamora.es/zamora/2014/ 03/30/franquistas-seguian-dominando-creian-podian/750776.html Fecha de consulta: 06 de julio de 2016. ${ }_{162}$ CASTRO, Eduardo, RAMOS ESPEJO, Antonio y ROMACHO, Francisco: 1973-83. Memoria de la Transición democrática en Granada (Colección: Crónica de un sueño: 3), Málaga, C\&T, 2005.
} 
referentes del CDS. En León, el ex Secretario de UCD, Luis Aznar Fernández coordinó y dirigió a la nueva formación. En Tarragona, el encargado fue el Secretario Provincial de CC-UCD, el abogado Xavier Artal y en Tenerife el interventor y Delegado Fiscal de la Junta de Canarias, Baltasar de Zárate ${ }^{163}$, también, ex militante de UCD. En Cantabria Manuel Garrido, miembro de UCD entre 1979 y 1982, donde había ejercido como Secretario de Política Municipal, fue el máximo dirigente del partido desde 1983 llegando a formar parte del Comité Nacional ${ }^{164}$. En Navarra, el ex teniente alcalde de Pamplona por UCD, Pablo García Tellechea, se convirtió en el líder del CDS navarro, mientras en Burgos, fue clave la actividad de Ricardo García García-Ochoa alcalde de Aranda de Duero con UCD (1979). Otros destacados militantes de UCD, posteriormente en el CDS fueron José Luis Garro -jefe de gabinete de Adolfo Suárez entre 1982 y 1989-, Emilio Pujalte -Director General en el Ministerio de Trabajo (1980) y miembro del Comité Nacional del CDS en 1982-, Guadalupe Ruiz-Giménez -experta en relaciones con el área geopolítica iberoamericana- o José Antonio Escudero -diputado con UCD-.

Debemos analizar, asimismo, el caso de estrechos colaboradores de Adolfo Suárez durante su Presidencia y luego miembros del CDS, como: Josep Coderch - presidente de CC-UCD en Gerona-, Alberto Aza y Rosa Posada, quien presidió su Gabinete de Presidencia y fue candidata de los centristas a la Comunidad Autónoma de Madrid en 1983.

Y es que, numerosos protagonistas del futuro del CDS como José Ramón Caso o Laura Morso, pertenecientes al mundo empresarial y la administración del Estado, tuvieron su primer encuentro con el mundo de la política durante la Presidencia de Adolfo Suárez en $\mathrm{UCD}^{165}$. Desde la administración, se habían incorporado también a UCD Gerardo Harguindey, quien había ejercido numerosas responsabilidades en los cuerpos técnicos del Estado y fue diputado de UCD, el director del INEM Francisco Moure Buorio, o Fernando Lanzaco, quien había sido, entre otros cargos, Delegado Provincial de Educación. Todos ellos se incorporaron al CDS en 1982. Fernando

163 Quien fuera entre 1986 y 1989, diputado del CDS por Alicante y desde 1990, Secretario de Organización, Rafael Martínez-Campillo ingresó en 1977 en UCD llegando a ser Secretario de Política Municipal en Huesca, PANIGUA, Javier y PIQUERAS, J. Antonio (dirs.): Diccionario Biográfico de Políticos Valencianos (1810-2003), Valencia, Institució Alfons el Magnànim, p. 348.

${ }^{164}$ GARRIDO, Aurora (dir.): Diccionario biográfico de los parlamentarios de Cantabria (1902-2002), Santander, Parlamento de Cantabria, 2003, pp. 444-5.

${ }^{165}$ En el caso de Laura Morso tras pasar, sin participar activamente, por el Partido Popular de José María Areilza y Pío Cabanillas, entrevista con Laura Morso, 11 de febrero de 2015. 
Montero, gobernador civil de Toledo e impulsor del partido en la capital manchega, había desempeñado su labor profesional en el Ministerio de Hacienda hasta que recalara en UCD durante la Transición y en 1982 ingresara en el $\operatorname{CDS}^{166}$. Por Valencia, concurría José Miguel Prados Terriente, quien desempeñó diversas responsabilidades en el Ministerio de Trabajo durante la Transición y era técnico de la Administración del Estado $^{167}$. Joaquín Abril Martorell, ingeniero aeronáutico y hermano de Fernando Abril Martorell, había ejercido durante la Transición como presidente de Butano y Enagás ${ }^{168}$. Proveniente del mundo empresarial de las telecomunicaciones y la banca era también el turolense Miguel Ángel Eced, quien antes de integrarse en el CDS ocupaba el cargo de Director General de Correos ${ }^{169}$. En Teruel, desarrollaba su labor profesional vinculada al mundo agrario el senador "independiente" de UCD Antonio Gimeno Lahoz, candidato por el CDS en 1982.

Otros, habían iniciado su participación en la vida política en los efímeros partidos regionalistas, democristianos o socialdemócratas creados entre 1976 y 1977, desde los que recalaron en UCD. Fue el caso del economista y asesor fiscal malagueño Francisco Villodres quien lo hizo en el Partido Socialdemócrata de Fernández Ordóñez (PSD), al igual que el diputado de UCD y futuro líder del CDS en Murcia Enrique Egea ${ }^{170}$ o el sociólogo Paulino González Rodríguez, promotor de grupos socialdemócratas regionales en Galicia y cabeza de lista al Congreso en 1982 por el CDS orensano. José Vicente Cebrián -hermano del periodista José Luis Cebrián- y miembro del primer Comité Nacional del CDS, había formado parte de la ejecutiva del partido socialdemócrata de Fernández Ordóñez $\left(\mathrm{PSD}^{171}\right.$ ) antes de ser un hombre decisivo en la coordinación de UCD en $1977^{172}$, una trayectoria similar a la del suarista Rafael AriasSalgado quien militó en el CDS desde $1987^{173}$. Como "socialdemócrata" se ha definido al

\footnotetext{
166 Véase, Revista de la Diputación Provincial de Toledo, nº 108, noviembre diciembre de 1979. Disponible en http://www.diputoledo.es/global/areas/archivo/revistas/1979_109.pdf. Fecha de consulta 10 de enero de 2015.

${ }^{167}$ El País, 06 de agosto de 1977.

${ }^{168}$ Véase, PANIGUA, Javier y PIQUERAS, J. Antonio (dirs.): Diccionario Biográfico...

${ }^{169}$ En términos profesionales llama la atención el elevado número de profesores de EGB, ejerciendo esta profesión los cabezas de lista al Congreso (1982) de Burgos, Castellón, Cuenca y Guipúzcoa. Sólo en este último caso, podemos confirmar participación política previa como concejal de San Sebastián (Coordinadora Independiente) y miembro de las listas de UCD al Congreso en 1979.

${ }^{170}$ JÁUREGUI, Fernando y SORIANO, Manuel: La otra .., p. 231.

${ }^{171}$ Ibid., p. 55.

172 Véase, ANSON, Rafael: El año mágico de Adolfo Suárez, Madrid, La Esfera de los Libros, 2014.

${ }^{173}$ El País, 03 de febrero de 1977. Sobre la apelación a la socialdemocracia en estos años Díaz Ambrona comenta con ironía: "en el área no socialista el marbete [de socialdemócrata] conservaba enorme potencialidad evolutiva y era tabla de salvación y oscuro objeto de deseo. Evolucionar de "azul" a
} 
diputado de UCD por Almería Alfonso Soler Turmo, desde 1982 destacado miembro del CDS almeriense ${ }^{174}$. En el Partido Gallego Independiente de Meilán Gil participaron el profesor de Derecho, Perfecto Yebra, candidato con el CDS en 1982 y adscrito a la corriente "socialdemócrata" o la profesora de Historia, Nona Inés Vilariño, "regionalistaconservadora" y "relacionada con el Opus Dei”. Ambos habían sido diputados con UCD durante la Transición ${ }^{175}$.

Si en un primer momento (1982), sólo uno de los presidentes de los 16 partidos que formaron la coalición de UCD se integró en el CDS -Lorenzo Olarte (Unión Canaria)-, con el tiempo llegaron a ser destacados militantes del partido suarista: José Ramón Lasuén (líder de la Federación Social Demócrata, diputado entre 1989 y 1993) ${ }^{176}$, Ignacio Camuñas (dirigente del Partido Demócrata Popular) y Enrique Sánchez de León (fundador de Acción Regional Extremeña) ${ }^{177}$. Por su parte en Córdoba promovieron el CDS, dos de los fundadores del Partido Social Liberal de Andalucía (PSLA) y posteriormente diputados de UCD: José Javier Rodríguez Alcaide y Antonio J. Delgado de Jesús ${ }^{178}$.

Rafael Calvo Ortega conoció a Adolfo Suárez cuando éste era Gobernador Civil en Segovia, y de acuerdo con Fernando Jáuregui y Manuel Soriano, estrecharon su relación fruto de los encuentros entre ambos en "un bar propiedad" del padre de Calvo Ortega. Siguiendo a estos autores, la brillante carrera académica de Calvo Ortega y su carácter de "desclasado" en la elite política y social madrileña atrajo la atención de Adolfo Suárez quien le convenció para acudir por las listas de UCD en 1977. Hasta ese momento, según el testimonio de estos autores y de periodistas como Javier Figuero, Calvo Ortega únicamente y de forma puntual, había colaborado con el Partido Socialista

socialdemócrata, por ejemplo, mostraba una enorme ventaja adaptativa, que garantizaba supervivencia tras la brusca glaciación de los Principios del Movimiento. Incluso no siendo "azul", vestía muy bien autoproclamarse miembro de la socialdemocracia", ORTEGA DÍAZ-AMBRONA, José Antonio: Memorial de Transiciones (1939-1978), Barcelona, Galaxia Gutenberg, 2015, pp. 545-6.

${ }^{174}$ JÁUREGUI, Fernando y SORIANO, Manuel: La otra..

175 Ibid.

176 “José Ramón Lasuén, personaje de inteligencia viva y extraordinaria versatilidad fue, a lo largo del tiempo, Víctor de Plata en 1960 por servicios al Sindicato Español Universitario (SEU), miembro de Tácito (1974), progresista y socialdemócrata de oposición poco después, enseguida miembro de Coordinación Democrática (1976), pronto diputado de UCD por Teruel (1977) y luego, diputado de la Aliana Popular de Manuel Fraga (1986), para continuar como disidente de Fraga en el Grupo Mixto y coronar como miembro del Centro Democrático y Social (CDS) de Suárez. ¡Admirable Lasuén! Catedrático de Economía, siempre sabía el remedio para nuestros males con medicinas infalibles, que por desgracia, nunca nos pudo aplicar", ORTEGA DÍAZ-AMBRONA, J. A.: Memorial..., pp. 466-7.

${ }^{177}$ Datos a partir de HUNEEUS, Carlos: La Unión de Centro..., p. 163.

${ }^{178}$ En el que también militó Jaime García Añoveros, véase, JÁUREGUI, Fernando y SORIANO, Manuel: La otra... 
Democrático Español (PSDE) de García López, llegando a coincidir en un mitin con el histórico dirigente socialista José Prat ${ }^{179}$.

Finalmente, debemos mencionar a algunos miembros de la oposición antifranquista de izquierdas que recalaron en el CDS. Proveniente de Izquierda Democrática era Alfonso Moreno de Acevedo, senador por esta formación en la I Legislatura y en 1982, candidato suarista por Badajoz $^{180}$. Raúl Morodo y Miguel Martínez Cuadrado habían sido decisivos en la fundación del Partido Socialista del Interior (PSI-PSP) en los años $60{ }^{181}$. Partido en el que ingresó, no sin polémica, Carmen Díez de Rivera cuando era jefa de gabinete de Adolfo Suárez en mayo de 1977, habiendo militado anteriormente en la USDE de Dionisio Ridruejo ${ }^{182}$. Jaime García Añoveros también se había iniciado en el mundo de la política en el círculo de Dionisio Ridruejo (USDE), para integrarse en UCD en la Transición ${ }^{183}$. Carlos Revilla fue dirigente del PSOE desde los años 60’ y Ramón Tamames y Eduard Punset habían sido destacados militantes del PCE y Antoni Fernández Teixidó había participado en partidos de ideología trostkista ${ }^{184}$.

Merece la pena destacar la innegable importancia y transcendencia del factor abulense en la formación del CDS, provincia de la que eran oriundos muchos de sus dirigentes como el propio Adolfo Suárez, Agustín Rodríguez Sahagún, Laura Morso o Carlos Sánchez-Reyes. Si en ocasiones este origen común sirvió para reforzar relaciones que se estrecharon durante la época de la Transición -como los citados anteriormente-, en otras permitió a Suárez situar a hombres de su máxima confianza en cargos de

\footnotetext{
${ }^{179}$ Ibid., p. 222. Un punto que "nunca ha confesado con claridad" según FIGUERO, Javier: UCD. La empresa..., 74.

${ }^{180}$ Candidato por Badajoz, trágicamente fallecido durante la campaña electoral, $A B C$, 17 de octubre de 1982 y El País, 18 de octubre de 1982.

${ }^{181}$ José Manuel Rey Pichel candidato número uno por La Coruña en 1986 con el CDS fue también un estrecho colaborador de Raúl Morodo. Como ha relatado Eduardo Navarro, el primer encuentro entre Raúl Morodo y Adolfo Suárez se produjo el 03 de agosto de 1976; ambos residían en la zona de madrileña de San Martín de Porres, NAVARRO, Eduardo: Adolfo Suárez..., p. 130.

${ }^{182}$ Carmen Díez de Rivera había militado anteriormente en USDE (el partido liderado por Dionisio Ridruejo) y nunca lo llegó a hacer en UCD, ROMERO, Ana: El triángulo de la Transición, Barcelona, Planeta, 2013, pp. 212-3.

${ }^{183}$ Jaime García Añoveros, ministro de Hacienda y catedrático de Derecho Hacendístico con UCD, estuvo vinculado al CDS, aunque siempre en un segundo plano. Fernando Pérez Royo, amigo y discípulo suyo, ha dejado escrito un interesante dato de su biografía: "aunque nacido en Teruel, pasó la mayor parte de su infancia en Tafalla, junto a su madre, viuda, y su tío, párroco en aquella localidad, a quien Jaime estuvo siempre muy unido y que con el tiempo llegaría a ser el obispo Añoveros, protagonista de un célebre caso de enfrentamiento al poder en los últimos años de la dictadura", en PÉREZ ROYO, Fernando: "Fiel a sí mismo en toda su vida", El País, 16 de marzo de 2000.

${ }^{184}$ José Luis Gómez-Calcerrada y destacado dirigente del CDS desde 1987, ejercía como funcionario del Ministerio de Trabajo y era simpatizante del PCE, hasta poco antes de su ingreso en el CDS, Entrevista con J. L. Gómez-Calcerrada, 10 de junio de 2015.
} 
responsabilidad: Fernando Alcón -Secretario de Organización del CDS entre 1987 y 1990-, Pepe Ferrer -diputado por el CDS entre 1989-1993- o José Luis Sagredo de Miguel -oriundo de Briviesca en Burgos, aunque amigo de juventud de Adolfo Suárez en Ávila, ciudad en la que había recalado por motivos laborales-. Provenientes de UCD y destacados dirigentes del CDS fueron también los abulenses Alberto Dorrego Presidente Provincial del CDS en Ávila- y Daniel de Fernando -Presidente Federal del CDS en Castilla y León-. En la vecina provincia de Segovia, Juan Antonio Perteguer, amigo personal de Adolfo Suárez y Fernando Abril Martorell, ejerció el liderazgo del CDS, adonde recaló desde UCD.

Finalmente otros, como Antonio Garrosa Resina, dirigente provincial del CDS en Valladolid y diputado en la III Legislatura, no habían participado anteriormente en política. Garrosa, ingeniero técnico industrial y profesor no numerario de la Universidad Valladolid. Garrosa señalaba a propósito de su inmersión en el mundo de la política que era la culminación de un camino iniciado en los años 1965-66, “a partir fundamentalmente de la lectura de revistas políticas y de pensamiento de la época, como 'Cuadernos para el Diálogo'”. Una reflexión acompañada de palabras que expresaban el sentir de toda una generación:

Los estudios humanísticos de letras, con su incidencia a través del recuerdo del pasado, sobre los comportamientos del hombre han potenciado aún más el interés por la actividad política, como forma de estar también al servicio del hombre y de la sociedad ${ }^{185}$.

Podemos enmarcar contextualmente, a buena parte de los políticos citados en este recorrido en la generación del 78', como la ha denominado con gran acierto Díaz Ambrona, refiriéndose a aquellos que, nacidos en los 30', llevaron a cabo la obra colectiva de la Transición; una empresa superadora de la secular división que había vivido trágicamente la España Contemporánea. Díaz Ambrona cita entre sus miembros a Adolfo Suárez, Rafael Arias-Salgado y Raúl Morodo ${ }^{186}$. La edad media de los diputados de UCD que se adscribieron al CDS en el verano de 1982 era de 47,5 años.

Aunque el CDS fue el continuador histórico de los valores defendidos por el centro político durante la Transición, la heterogeneidad de UCD y las luchas políticas vividas en su seno nos obligan una vez más, a matizar la relación entre ambos partidos. Por un lado, es innegable que la mayor parte de los políticos del CDS (especialmente en 1982)

\footnotetext{
${ }^{185}$ Valladolid, Carpeta 4, AGP.

${ }^{186}$ ORTEGA DÍAZ-AMBRONA, José Antonio: Memorial..., p. 672 y ss.
} 
provenían de UCD, sin embargo, en su mayoría se correspondían con cargos intermedios o bajos. Sólo desde 1986, a raíz del éxito electoral suarista y paradójicamente, a medida que la presencia de ex militantes de UCD disminuía proporcionalmente se integraron en el CDS un número significativo de antiguos miembros del Comité Ejecutivo de UCD o ex ministros centristas.

De este modo, sólo cinco del total de 35 miembros del Comité Ejecutivo de UCD electo en 1978 se integraron en el CDS en 1982 (Rafael Calvo Ortega, Agustín Rodríguez Sahagún, Jesús María Viana, Enrique Galavis, sin contar a Adolfo Suárez) y únicamente, tres de los 37 del Comité Ejecutivo designado en 1981 (Congreso de Palma), Manuel de Sárraga, Lorenzo Olarte y Jesús María Viana. Con el tiempo, llegaron a formar parte del CDS siete antiguos miembros más ${ }^{187}$. Si nos referimos al conjunto de ministros de los Gobiernos de UCD durante la Transición (52, entre 1977 y 1982), sólo cuatro se integraron en el CDS en 1982 (Adolfo Suárez, Agustín Rodríguez Sahagún, Rafael Calvo Ortega y Manuel Jiménez de Parga) y ocho más ingresaron con posterioridad en el partido (Rafael Arias-Salgado, Ignacio Camuñas, Íñigo Cavero, Jaime García Añoveros, Federico Mayor Zaragoza, Félix Manuel Pérez Miyares, Enrique Sánchez de León y Eduard Punset -pasándose de un 7,7\% a un 23\% del total-). Por último, hemos podido contabilizar como miembros del CDS únicamente a 22 diputados de la Legislatura Constituyente, prácticamente todos, militantes en ese momento de UCD: Jesús María Viana Santa Cruz, Fernando Alcón, Rafael AriasSalgado y Montalvo, León Buil Giral, Daniel de Fernando Alonso, Jaime García Añoveros, José Ramón Lasuén Sancho, Federico Mayor Zaragoza, Helena María Moreno González, Raúl Morodo Leoncio, Enrique Sánchez de León Pérez, Manuel de Sarraga Gómez, Nona Inés Vilariños Salgado, Rafael Calvo Ortega, Alberto Dorrego González, César Augusto Escribano de Gordo, José Antonio Escudero López, José L. Figuerola Cerdán, Gerardo Harguindey Bonet, Antonio Jiménez Blanco, Alfredo Marco Tabar y Luis Rodríguez San León.

Como avanzábamos en la presentación de este epígrafe, el recorrido realizado nos proporciona perfiles excesivamente heterogéneos tanto en cuanto a la trayectoria

\footnotetext{
${ }^{187}$ Del comité formado en 1978: Rafael Arias-Salgado, Ignacio Camuñas, Íñigo Cavero, Antonio Jiménez Blanco y Enrique Sánchez de León. Del comité formado en 1981 debemos citar junto a los ya mencionados: Jiménez Blanco, Cavero, Arias-Salgado, García Añoveros y Pérez Miyares, HUNEEUS, C.: Unión..., pp. 222 y 331.
} 
política como socio-profesional, entre los que sin embargo podemos adelantar algunas conclusiones.

Siguiendo el análisis tripartito de la procedencia política de los miembros de UCD realizado por Carlos Huneeus constatamos el escaso protagonismo de los políticos vinculados al régimen franquista -igual que sucedía en UCD-, en beneficio de los inscritos en la llamada buffer zone, es decir, puestos técnicos sin responsabilidad política directa durante la Dictadura con una significativa presencia de miembros del Opus Dei o relacionados con sus instituciones educativas y socio-profesionales que contribuyeron decisivamente a "neutralizar" las contradicciones entre el franquismo y la oposición. A algunos cabe incluirlos en la llamada "semi-oposición", en el sentido de que, desde dentro del régimen tuvieron actuaciones encaminadas a modificar el sentido del mismo, recalando muchos de ellos en un segundo momento (1976-1977) en grupos democristianos o socialdemócratas. Un ejemplo significativo puede ser la trayectoria de Fernando Castedo, activo miembro del partido suarista hasta su marcha en 1990, quien había estado en el comité político del Partido Popular (1976) antes de dar el salto a UCD y en los últimos años del régimen había ejercido como Secretario General Técnico del Ministerio de Información y Turismo junto al ya citado Pío Cabanillas ${ }^{188}$.

En un segundo escalón, destacan los miembros de la "oposición moderada" vinculados fundamentalmente a la democracia cristiana y por último, merece la pena citar a aquellos que habiendo sido miembros de partidos políticos de izquierda durante la Dictadura recalaron avanzado el tiempo en el CDS. Este último aspecto constituía una nota diferencial respecto a lo que había sido UCD. Sin embargo, y como hemos afirmado a lo largo del presente trabajo, las interpretaciones ideológicas quedaban en un segundo plano en el CDS, siendo el vínculo fundamental del partido suarista una lectura común de lo que había significado la Transición, la Presidencia de Adolfo Suárez y los enfrentamientos internos vividos en $\mathrm{UCD}^{189}$-véase, Anexo XIX-.

\footnotetext{
${ }^{188}$ Con quien fue Subsecretario del Ministerio de Cultura entre 1977 y 1979 y posteriormente Secretario General del Instituto de Cooperación Iberoamericana, así como Director General de RTVE, véase El País, 09 de enero de 1981 y $A B C$, 08 de febrero de 1977.

${ }^{189}$ HUNEEUS, Carlos: La Unión..., pp. 30-31.
} 


\section{5. La Internacional Liberal y Progresista}

Con frecuencia han aparecido a lo largo del texto críticas y acusaciones al CDS en las que se tildaba al partido de ser una fórmula política personalista sin homologación ideológica internacional. Una situación que se repetía con todos y cada uno de sus competidores electorales: el PRD (Internacional Liberal), el PDP/DC (Internacional Democristiana) o el PP (Unión Internacional Demócrata o Internacional Conservadora); una característica especialmente sobredimensionada por aquellos partidos políticos institucional y socialmente menos arraigados en España, caso del PRD o el PDP ${ }^{190}$. No es de extrañar que el principal argumento de la Secretaría General en el Informe de Gestión presentado en 1990 ante el III Congreso (1990) fuera:

[El ingreso en la ILP] ha permitido por un lado, que desaparezca una de las acusaciones que era más frecuente desde nuestra fundación y que causaba notable desasosiego entre muchos de nuestros afiliados y, desde luego, entre los electores, la de la pretendida ambigüedad e indefinición ideológica de nuestro Partido, así como la de nuestra excentricidad ${ }^{191}$.

Si en el epígrafe 7.3. hemos abordado la imbricación ideológica del CDS con la Historia de España, a continuación abordaremos este intento por conectar internacionalmente con alguna de las grandes familias del pensamiento político occidental.

Después del éxito electoral de 1986, el propio Suárez reconocía su deseo de crear una "Internacional de Centro Progresista" con otros partidos europeos -como por ejemplo, el Partido Socialdemócrata del Reino Unido ${ }^{192}$-. Después de constatar la imposibilidad de gestar una operación de este tipo, realmente complicada, los dirigentes del CDS gracias a la mediación de Raúl Morodo, pusieron sus ojos en los sectores más progresistas del liberalismo y contemplaron la posibilidad de integrarse en la Internacional Liberal (IL) -a la que había pertenecido el PRD-. Como señala Caso "en esta etapa [...] el papel de Raúl sobre todo con Adolfo [...] es ir trabando un marco de actuación internacional para el CDS" ${ }^{\prime 193}$.

\footnotetext{
190 "Rupérez: 'Contamos con la ayuda de la DC europea'”, Democracia Cristiana, 0, enero 1988.

${ }^{191}$ CDS: Líneas de acción....

${ }^{192}$ Al que aludía indirectamente en una entrevista con BULNES, M. A.: "Suárez: 'Es inevitable que vuelva a ser presidente del Gobierno en 1990"”, $A B C$, 04 de enero de 1987.

${ }^{193}$ Morodo participaba habitualmente en los seminarios de la Fundación para la Libertad y el Progreso (dirigidos por Antonio Garrigues Walker) y Punset y Mayor Zaragoza habían tenido contactos con Simone Weil -presidenta de los liberales europeos-, HERRERO, Luis: "El CDS descubre su carta oculta.
} 
El día 19 de enero de 1988 saltaba la noticia de que el CDS había solicitado su ingreso en la IL. La decisión, filtrada tras una reunión de la ejecutiva liberal en Londres, antes siquiera de la reunión del Comité Nacional (28 de enero), y la ausencia de comunicación previa a la militancia generó alguna que otra voz crítica en el seno del partido, especialmente en sus sectores más progresistas ${ }^{194}$. Sin duda, el caso más sonado fue el de Carmen Díez de Rivera que abandonó el partido poco después ${ }^{195}$.

La decisión fue tomada por el "aparato" y ratificada en el Comité Nacional, único órgano con competencia para ello ${ }^{196}$. Sin embargo, y a pesar de la ausencia de debate como señala Abel Cádiz "no hubo oposición real en el partido, porque el planteamiento se vendía bien y tenía sentido, pensando en clave europea"197. En relación a la acusación de "derechización”, José Ramón Caso duda de que tuviera algún efecto electoral y subraya que la ILP jamás recomendó ni orientó ningún posicionamiento político ${ }^{198}$; la ILP era una amalgama que incluía "desde partidos muy de derechas a muy de izquierdas"199. Y ante todo suponía un "programa de acción"200:

No es tanto tener una referencia, ponerte un gorro, sino por necesidades [...] Desde nuestra experiencia, y [...] te hablo de la mía particular en UCD, yo tuve contactos orgánicos con la CDU alemana. La potencia en generación de pensamiento [...] de estrategias políticas [...] recursos [...] es muy importante. Ya teníamos la experiencia de que las referencias internacionales aunque sólo sea a efectos de tener aliados, de tener partners que te dan legitimidad en determinados ámbitos [...] es muy importante. Eso lo comprendió a la primera Felipe González. [...] Entonces más que buscando una

Suárez se hace liberal", Época, 01 de febrero de 1988. Contaron a su vez, con el apoyo de Joaquín Satrústegui patrono de la Internacional, MORODO, R.: Siete semblanzas políticas..., pp. 254-6.

194 "[Pregunta al Presidente del CDS-Albacete] ¿A las bases del CDS no les sentará mal que este tema del ingreso en la Internacional Liberal se haya hecho de arriba abajo?", La Verdad [Albacete], 21 de enero de 1988; “Un coqueteo permanente", Diario 16, 24 de enero de 1988. La propia dirección centrista era consciente de ello cuando el Secretario General escribía a la militancia en febrero de 1988 sobre este tema: "en sucesivas publicaciones del Partido, ampliaremos detalles sobre esta información que, sin embargo, he querido que llegue lo más rápidamente a tu conocimiento", OICDS, 10, febrero 1988.

${ }^{195}$ FRAGUAS, Rafael: “[Entrevista] Abandoné el partido de Suárez por coherencia política”, El País, 09 de septiembre de 1988; "Salvando todas las distancias del mundo a favor de lo que había sido el PSP, pensé que podía ser algo similar al partido de Tierno", ROMERO, Ana: El triángulo..., p. 250. En la misma línea, se manifestaba otra ex militante, María Teresa Rodríguez Pérez, "La Internacional Liberal", $A B C, 16$ de septiembre de 1988. La lectura oficial del CDS en CÁDIZ, Abel: "El liberalismo del CDS", El País, 17 de octubre de 1988.

${ }^{196}$ Art. 19.2, g) "Determinar la política del partido en el orden internacional y en relación con los demás partidos españoles y extranjeros". La primera de las Disposiciones Finales de los Estatutos señalaba a su vez: "El Partido podrá adherirse a aquellos organismos de carácter internacional cuyos objetivos sean compatibles con la naturaleza y fines del Partido", Estatutos del CDS, Registro de Partidos Políticos, (MIR), Registro de Entrada n ${ }^{\circ} 170,29$ de julio de 1982.

${ }^{197}$ Entrevista con Abel Cádiz, 4 de marzo de 2015.

${ }^{198}$ Entrevista con José Ramón Caso, 19 de noviembre de 2014.

${ }^{199}$ Entrevista con Abel Cádiz, 4 de marzo de 2015.

${ }^{200}$ OICDS, 10, febrero 1988. 
homologación ideológica estás buscando un partner que te da credibilidad internacional; en países relevantes, [...] [caso del Partido Demócrata en Estados Unidos].

La reacción en los medios y el resto de partidos osciló entre la ironía - "más a la derecha del centro-derecha"201, "neoliberal, o sea del CDS"202 - y la desconfianza "Suárez, ¿liberal?" 203 -. La decisión del CDS recibió el aplauso de Diario 16, un periódico que lo conectaba con la corriente regeneracionista y azañista, "representada en la Institución Libre de Enseñanza" ${ }^{204}$. Justino Sinova realizaba un reportaje sobre la adhesión del CDS recurriendo a la opinión de liberales españoles y al análisis comparado de los textos liberales y suaristas. Concluía, que donde más se alejaba era en sus posiciones económicas - pero que existían actitudes socialdemócratas en la IL- y los mayores puntos de contacto residían en la defensa del pluralismo político, la profundización de las libertades públicas y los derechos humanos o la defensa del Estado de Derecho. Recogía el testimonio de Garrigues Walker para quien la mayor seña liberal de Suárez no había sido otra que la de restaurar la democracia ${ }^{205}$.

Todos convergían no obstante en que había sido una decisión eminentemente práctica. Las razones para la integración en la IL eran acallar las voces que acusaban al CDS de ser un proyecto indefinido ideológicamente y conseguir respaldo en Europa ${ }^{206}$. La importancia de la figura de Suárez a nivel internacional le permitió "imponer" dos condiciones: recomendar la adición del epíteto "Progresista" a la denominación de la Internacional -pasando de IL a ILP-, y el uso del idioma español -para potenciar las relaciones con el área iberoamericana, aspecto que se delegaría en Suárez-. De puertas

\footnotetext{
${ }^{201}$ Para Javier Rupérez (DC) esa era la posición en el espectro ideológico del Grupo Liberal en el Parlamento Europeo, $Y a, 20$ de enero de 1988. Desde el PL, que había solicitado el ingreso se denunció el cambio de "chaqueta" de Suárez y se señalaba que cómo un partido que apostaba por reforzar el gasto público, era contrario a la OTAN, apoyaba proposiciones de IU como la de crear el Consejo Económico y Social podía ser liberal [J. A. Segurado], $A B C, 27$ de marzo de 1988; Celestino Fernández hablaba de la "elasticidad ideológica" de Suárez en "Ahora, liberal", ABC Sevilla, 15 de septiembre de 1988. Incluso se acuñó la expresión: "liberal-suarista", Cambio 16, 01 de febrero de 1988.

${ }^{202}$ LÓPEZ SANCHO, L.: “¿Técnica o política?”, $A B C, 16$ de septiembre de 1988. Campmany señalaba: "A don Adolfo no hay manera de sacarle una definición clara de su posición política [...] Adolfo va a inventar el liberal-felipismo. Está claro. El duque es un individualista de sí mismo" en "Los nuevos liberales", $A B C, 21$ de enero de 1988

${ }^{203}$ Tras recordar su pasado político, desde el Movimiento a su persecución de los liberales en UCD, Enrique de Diego concluía: "pero claro el concepto liberal es hoy confuso y difuso [...] [en España] decir que uno es liberal es definirse como una especie de frívolo sin ideas", Ya, 20 de enero de 1988. "Sus tibiezas [las de Suárez] socialdemócratas y populistas se compadecen muy mal con el calificativo 'liberal' [...] Los fraudes de los políticos comienzan siendo fraudes del lenguaje y acaban siendo abusos del poder", editorial: "El CDS, en la Internacional Liberal", $Y a, 20$ de enero de 1988.

${ }^{204}$ Editorial: "CDS, liberal", Diario 16, 21 de enero de 1988

${ }^{205}$ SINOVA, Justino: ¿Es liberal el partido de Suárez?”, Diario 16, 21 de enero de 1988.

${ }^{206}$ DÍEZ, Anabel: "Cabalgar en compañía", El País, 19 de enero de 1988. En esta línea: ESTEBAN, Esther: "Suárez comenzará su nueva etapa entrevistándose con Genscher", $Y a, 20$ de enero de 1988; "El CDS pide su ingreso en la Internacional Liberal", $Y a, 20$ de enero de 1988.
} 
adentro: ¿era una estrategia para obtener votos del centro-derecha o para atraer a diputados descolgados de la CP?, ¿desvirtuaba su imagen de centro-izquierda? ${ }^{207}$ En la "Carta del Secretario General a los militantes", José Ramón Caso justificaba con las siguientes palabras la adopción de esta decisión:

El CDS se considera próximo, ideológicamente, a recientes declaraciones programáticas de la Internacional Liberal de modo especial a la aprobada en 1981 [Roma]. Por otra parte, el CDS, como Partido de Centro Progresista, considera que la profundización de la democracia pluralista -base política del liberalismo- exige reactualizaciones de la defensa de los derechos civiles, de la política de distensión internacional así como la adaptación a las exigencias sociales del Estado de bienestar ${ }^{208}$.

Siendo conscientes de la enorme diversidad de posturas que aglutinaba en su seno la Internacional Liberal, la lectura de los principios programáticos defendidos en la Proclama Liberal de 1981 (Roma $)^{209}$, la intervención en el XL Congreso de la Internacional Liberal en Ottawa (septiembre de 1987) de J. K. Galbraith ${ }^{210}$ o la interpretación del pensamiento de Ralf Dahrendorf -quizá su máximo exponente ideológico en ese momento-, demuestran que existían puntos de contacto significativos con los programas y manifiestos del CDS. No obstante, como ha dejado escrito Raúl Morodo la apertura de la ILP hacia el centro-izquierda no estuvo exenta de dificultades y resistencias, como las de holandeses y alemanes ${ }^{211}$.

Como señalaba Dahrendorf, todos compartían la "creencia en la primacía de la libertad individual" 212 y principios como el de "igualdad de oportunidades" o la idea de mérito que conectaban con el pensamiento político de Suárez ${ }^{213}$, quien las acompañaba

\footnotetext{
${ }^{207}$ HERRERO, Luis: "El CDS descubre su carta oculta. Suárez se hace liberal”, Época, 01 de febrero de 1988.

${ }^{208}$ CASO GARCÍA, José Ramón: "Carta del Secretario General a la militancia”, OICDS, 10, febrero 1988.

${ }^{209}$ El Manifiesto recogía principios cercanos a los defendidos por el CDS como la crítica a la "carrera armamentística" -aunque en términos más ponderados que los suaristas-, la apelación a lo que se denominaba "economía social de mercado", rechazo a los monopolios "públicos o privados", una aceptación crítica del Estado de Bienestar, etc., en "Nuevo Manifiesto de la Liberal Internacional aprobado en el 34 Congreso Anual Roma, 24-25 septiembre 1981" pp. 27-31 y 39-43, MAST. Para Diario 16, estaba en la línea de Galbraith y lo que llamaba "libertad igualitaria", elementos definitorios de una "sociedad democrática y avanzada", editorial: "CDS, liberal”, Diario 16, 21 de enero de 1988.

${ }^{210}$ GALBRAITH, John Kenneth: El liberalismo hoy, Bogotá, Fundación Friedrich Naumann, s. f., MAST.

${ }^{211}$ MORODO, Raúl: Siete semblanzas políticas..., p. 56.

${ }^{212}$ Ponencia para el Congreso de la ILP de DAHRENDORF, Ralf: "Futuras tareas del liberalismo, una agenda política", Pisa, 1988, MAST.

${ }^{213}$ El principio de "igualdad de oportunidades" fue reivindicado por el "liberalismo progresista" desde la "segunda mitad del siglo XIX [...] cuya idea de una sociedad justa exigía la igualdad en el origen para todos sus miembros, esto es, que todos los ciudadanos en el punto de partida dispusieran de iguales oportunidades para desarrollar sus vidas, sin perjuicio de que, después a lo largo de estas, las diferentes capacidades o esfuerzos [mérito] pudieran llevar a diferencias de renta y riqueza", SEVILLA, José V.: El declive de la socialdemocracia, Barcelona, RBA, 2011, p. 301.
} 
de un acentuado sentido "social" ${ }^{214}$. Se defendía un modelo capaz de combinar al máximo la implementación de oportunidades (estados liberales y conservadores, empresa e iniciativa privada) y a la par generar las condiciones para un "mayor acceso" efectivo a las mismas (empleo y Estado del Bienestar) ${ }^{215}$. Todo ello, en el contexto de la "revolución conservadora" de corte neoliberal cuyos valores no eran íntegramente compartidos por los dirigentes de la Internacional ${ }^{216}$.

Abel Cádiz entendía el liberalismo en términos de "estado óptimo", de eficiencia y de protagonismo de la sociedad civil. En esta línea, se movía el pensamiento de dos destacados miembros del CDS Ros Hombravella y Joaquim Trigo quienes en las páginas de El País argumentaban en favor de la economía libre de mercado -con la salvedad de los servicios públicos básicos-, la defensa del ideal meritocrático -justicia como "retribución al mérito individual-y la reducción del gasto público ${ }^{217}$. José Ramón Caso argumentaba que el debate "Estado-Sociedad", "estatificación-privatización", había que colocarle en otro plano y sin renunciar a las funciones y fines del Estado del Bienestar era necesario perfilar el "Estado posible, es decir, el Estado óptimo". ¿Cómo? A través del aumento de la eficacia -desarrollo tecnológico y mejora de la educación- y creación de un nuevo consenso social. Caso fijaba el marco ideológico del CDS en torno a tres principios, guiados por el pensamiento de John Rawls, en los que el primer deber de la acción política era la búsqueda del marco más amplio posible de libertades. En segundo lugar, éstas debían ser ejercitadas en "igualdad de oportunidades" y

\footnotetext{
${ }^{214}$ Lo social en Suárez ha sido considerado habitualmente como el "poso" de su pasado falangista y lógicamente, referido con desdén a izquierda - por su origen autoritario- y derecha -debido a su resistencia en la configuración de un liberalismo conservador-, véanse los editoriales: "El Gorro liberal", El País, 16 de septiembre de 1986 e ÍD.: "3. Adolfo Suárez", El País, 04 de junio de 1986; URBANO, Pilar: "Roca, el socio español", $A B C, 17$ de noviembre de 1983. La expresión "centro pendiente" en ÍD.: "iSe retira Suárez?", $A B C, 03$ de octubre de 1982; "Suárez se fue de UCD porque tenía que volver al falangismo radical de sus orígenes, a la defensa de la revolución permanente [Luis Marín, candidato del PRD en Andalucía]", $A B C, 17$ de junio de 1986; SOLANA, Luis: "Suárez, el guapo voto útil", Diario 16, 20 de junio de 1986. Una reivindicación desde el CDS de este vínculo, en el militante de las juventudes del partido, "Fernando Márquez, el último 'fan absoluto"', El País, 07 de noviembre de 1987.

${ }^{215}$ Lo que Dahrendorf ha denominado "provisiones" (oportunidad) y "títulos" (acceso a las misas), en un análisis complejo de la realidad social dinamizado por la capacidad de innovación, DAHRENDORF, Ralf: "Futuras tareas del liberalismo...", pp. 12-22, MAST.

${ }^{216}$ En una fecha tan temprana como 1981, se tildaba de "errónea" la asociación entre el libre mercado y "una economía controlada por medios puramente monetarios", en "Nuevo Manifiesto de la Internacional Liberal aprobado en el $34^{\circ}$ Congreso Anual Roma, 24-25 septiembre 1981" p. 40, MAST; DARHENDORF, Ralf: Liberty after socialism, s. e., 1988, pp. 1-2. MAST.

217 "Menor expansión del gato corriente, poda de los gastos superfluos, disminución absoluta de las dotaciones de Defensa, drástica reducción de las subvenciones redundantes a empresas (profesor Lasuén)", HOMBRAVELLA, Ros y TRIGO, Joaquim: "Acabar con el despilfarro inútil”, El País, 24 de febrero de 1988. Sin excluir la reivindicación de F. Hayek, véase, İD.: "¿Qué hacienda pública queremos?", El País, 24 de noviembre de 1986.
} 
finalmente, el conjunto de desigualdades generadas en el seno de la Sociedad debían ser "reducidas o corregidas mediante la intervención directa o indirecta de los poderes públicos" ${ }^{218}$. No es extraño que reflexión sobre el Estado del Bienestar copara un tercio de las reflexiones de Adolfo Suárez en otro de los textos de carácter ideológico editado por el CDS en $1988^{219}$.

El ingreso oficial del CDS en la ILP se produjo en el Congreso de Pisa celebrado el 15 de septiembre de $1988^{220}$. La Presidencia de la ILP corría a cargo de Giovanni Malagodi y Suárez, que realizó el discurso inaugural, fue nombrado vicepresidente para temas Latinoamericanos ${ }^{221}$. De acuerdo con Fernando Jáuregui en su intervención "se esforzó por recalcar la necesidad de ir hacia una sociedad democrática avanzada y por desvincular su idea del liberalismo de la de reducción al mínimo de los poderes del Estado", una opinión compartida por la corresponsal de $A B C$, Luisa Palma ${ }^{222}$. Suárez, si bien criticó con dureza el "control" de los ciudadanos por parte del Estado, justo cuando había aparecido una polémica sobre "escuchas telefónicas" en su propio despacho $^{223}$; realizó una ponderada impugnación de la "mitificación” y apelación acrítica de los dos argumentos más manidos contra la acción estatal: la capacidad integradora de la sociedad civil y la eficacia del mercado regulador. Señalaba, ¿acaso el desempleo, la marginación o la pobreza, no acentúan los efectos disgregadores e impiden la cohesión?, ¿es sostenible la libertad sin la solidaridad? Aunque era necesaria

${ }^{218}$ CASO GARCÍA, José Ramón: Una sociedad democrática y avanzada, CDS, 1988, pp. 7-8. Las semejanzas entre los "principios de justicia” de John Rawls y los enunciados por Caso eran evidentes, más aún si tenemos en cuenta que la intención del filósofo norteamericano era que las instituciones pudieran implementar de forma conjunta "los valores básicos de libertad e igualdad", quizá el mayor "conflicto interno de la tradición del pensamiento democrático", en RAWLS, John: El liberalismo político, Barcelona, Crítica, 1996, pp. 34-5. Al abordar la desigual distribución del ingreso y de la renta y unos fundamentos políticos y éticos igualmente distantes del Estado Mínimo y el Estado Socialista, Mario Bilbao -secretario provincial del CDS en Sevilla-, recurría también a John Rawls, BILBAO, Mario: "La justicia en las teorías políticas", ABC Sevilla, 26 de junio de 1986.

${ }^{219}$ Era necesario reformular el pacto social-liberal, utilizando la expresión de R. Dahrendorf nacido después de la II Guerra Mundial, SUÁREZ GONZÁLEZ, Adolfo: La alternativa ..., pp. 18-26.

${ }^{220}$ En julio, Adolfo Suárez había asistido como invitado a la Convención Nacional del Partido Demócrata celebrada en Atlanta en julio de ese mismo año junto a otros miembros de la Internacional, DÍEZ, Anabel: "Suárez, bautizo liberal en Pisa", El País, 29 de agosto de 1988.

${ }^{221}$ Antonio Garrigues Walker e Ignacio Camuñas habían ocupado una de las veinte vicepresidencias de la IL con anterioridad, como hacía en ese momento, R. Trías Fargas, JÁUREGUI, Fernando: "El líder del CDS, elegido vicepresidente de la Internacional Liberal", El País, 16 de septiembre de 1988; ABC, 20 de septiembre de 1988 .

222 “Adolfo Suárez sorprendió ayer a los delegados del Congreso de la Internacional Liberal, reunidos en Pisa, al hacer una defensa del Estado como 'instrumento de la sociedad', a la vez que criticaba su control sobre el ciudadano, situándose así en lo que se considera la línea más vanguardista del pensamiento liberal", PALMA, Luisa: "Adolfo Suárez critica el 'exceso' burocrático e intervencionista del Estado", $A B C, 16$ de septiembre de 1988.

${ }^{223}$ SERBETO, Enrique: "Suárez desmiente a González asegurando que las escuchas en su despacho no son un montaje", $Y a, 15$ de septiembre de 1988. 
una nueva relación entre el Estado Social o de Bienestar y la sociedad civil, de los excesos burocráticos e intervencionistas del Estado "no se sigue que haya que arrasarlo". Un equilibrio entre libertad y solidaridad que era urgente trasladar al orden de las relaciones internacionales donde nuevamente era vehemente en su condena de la tensión bipolar, con expresiones un tanto sorprendentes en el seno de la IL: "los dirigentes de ambas potencias deben proseguir en el esfuerzo de despojar de ideología sus relaciones internacionales" 224 .

Como señalaron los medios, su intervención generó reacciones “desiguales" entre los asistentes y algún gesto de confusión, no del todo injustificados. Los máximos dirigentes centristas procuraban evitar la adjetivación de "liberal" 225 , que sólo ahora comenzaba a aparecer de forma aislada -"no somos simplemente liberales, sino liberalprogresistas o socialdemócratas" 226 - Entre las causas por las que el CDS se integraba en la ILP relatadas por Suárez en su intervención, lo "liberal", era aludido muy indirectamente: "la defensa de los derechos del hombre [...] [y la idea de] que el principio de libertad vuelva a erigirse en guía que oriente las transformaciones sociales en una dirección liberadora del ser humano y que impulse a todos los pueblos de la tierra a desarrollar su existencia en un marco de solidaridad internacional" ${ }^{\text {227. Raúl }}$ Morodo resaltaba: "CDS se sitúa en el centro progresista de forma inequívoca, y como tal, obtiene un reconocimiento internacional" ${ }^{228}$. Y el propio Caso, había dejado escrito en febrero: "hay una ampliación en la denominación de la Internacional Liberal a los partidos progresistas, por lo que nuestra integración no supone, en ningún caso, una alteración de nuestros planteamientos políticos de Centro Progresista",229.

Por otro lado, la estrategia del CDS colisionaba con los intentos de reestructuración de la derecha española, una vez desgajada de la CP dos de sus grandes familias ideológicas: democristianos y liberales ${ }^{230}$-. Jiménez Losantos reconocía la disposición

\footnotetext{
${ }^{224}$ SUÁREZ GONZÁLEZ, A.: Intervención de A. S. en el Congreso de la I. L., Pisa, septiembre 1988, p. 8, MAST.

${ }^{225}$ Como indicaba $A B C$ en su espacio dedicado a la Figura del día [Adolfo Suárez] "en el que en ningún momento se definió como liberal", $A B C, 16$ de septiembre de 1988.

${ }^{226}$ OICDS, 19, octubre de 1989.

${ }^{227}$ SUÁREZ GONZÁLEZ, A.: Intervención de..., p. 1.

228 "Por principio, todas las Internacionales son clubs abiertos que, desde una identidad común, permiten la diversidad", OICDS, 19, octubre 1989.

${ }^{229}$ CASO GARCÍA, J. R.: "Carta del Secretario General a la militancia”, OICDS, 10, febrero 1988.

${ }^{230}$ Editorial: "La etiqueta liberal", $A B C, 17$ de septiembre de 1988; PLATÓN, Miguel: "Liberales de conveniencia", $Y a, 17$ de septiembre de 1988; MUÑOZ ALONSO, Alejandro: "Buscando una idea desesperadamente", $A B C, 19$ de septiembre de 1988; CAMPMANY, Jaime: "El duque de Pisa", $A B C, 13$
} 
liberal de los gobiernos de Suárez - “autolimitación del poder"- y lo convertía en "inventor del liberalismo molieresco", una especie de liberal sin ser consciente de ello. Pero señalaba, en una defensa de la Escuela Austríaca como única rama legítima del liberalismo: "lo que ya resulta menos tolerable es que algunos intenten predicarnos que hay dos supuestos liberalismos: el conservador [...] y el progresista, que sería el de Galbraith. Y un cuerno. Liberalismo es lo que propugnan Hayek o Von Mises [...] Y Galbraith es antiliberalismo" ${ }^{231}$. Desde la izquierda socialista y medios como El País, la adhesión al liberalismo por parte de Suárez era una buena ocasión para resaltar sus contradicciones ideológicas. Su perfil, más bien intervencionista y estatista, así como las formas en que se había realizado la integración del CDS eran de "escaso talante liberal". Sin embargo, señalaba que contemplado el proceso de transformación ideológica en el PSOE o AP y la ambigüedad del término "liberal" -que lo mismo era usada por Pinochet que por Galbraith-: "entre seguir cultivando el huerto de la melancolía silente y avanzar un paso hacia la definición ideológica, lo segundo es preferible". La estrategia de Suárez -"un encantador de serpientes de corte populista"podía dar sus frutos en el futuro y convertir, finalmente, ese "falangismo de rostro humano que constituyó en un tiempo la ideología de Suárez" en un auténtico partido de centro "con vocación de bisagra"232.

La expectación de la ILP se prolongó gracias a una reunión de la ejecutiva en Madrid con Suárez como anfitrión y su activa participación en el área latinoamericana especialmente, Centroamérica- ${ }^{233}$. Como señala Caso, la inclusión del CDS y Suárez en la ILP no dejó de aportar legitimidad y relevancia a ambos y posibilitó su nombramiento como Presidente el jueves 12 de octubre de 1989 en París ${ }^{234}$, en los prolegómenos de las grandes transformaciones que iba a sufrir el bloque socialista de Europa del Este: "El acontecimiento de nuestro tiempo es la gran crisis del

de septiembre de 1988; “[M. Fraga] Suárez está siempre dispuesto a vestirse de lo que haga falta si ese es el baile que se baila. En un momento se puso la camisa azul, en otro la del centrismo y ahora la de liberal", $A B C, 17$ de septiembre de 1988.

${ }^{231}$ JIMÉNEZ LOSANTOS, Federico: "El Duque de Molière", $A B C, 20$ de septiembre de 1988 e ÍD.: "Equívocos europeístas", $A B C, 07$ de febrero de 1989. La defensa del "Estado Benefactor" en el contexto final de la política de bloques y el auge de la "revolución conservadora", constituye para Federico Quevedo, el punto en "el que se ha centrado el debate en torno al liberalismo o no liberalismo de Adolfo Suárez”, QUEVEDO, F.: Pasión por la libertad. El pensamiento político de Adolfo Suárez, Barcelona, Altera, 2007, p. 237 y ss.

${ }^{232}$ Editorial: "El gorro liberal", El País, 19 de septiembre de 1988.

${ }^{233} A B C, 12$ de febrero de 1989 .

${ }^{234}$ Entrevista con José Ramón Caso, 19 de noviembre de 2014. 
marxismo"235. Como se encargaba de recordar el boletín de información centrista, Suárez era el segundo presidente español tras Salvador de Madariaga, partícipe de su fundación en Oxford en $1947^{236}$.

En su III Congreso, el CDS "para mayor coherencia [con la ILP]” se adscribió al liberalismo progresista, defendiendo un modelo de sociedad "permeable" basado en el mérito $^{237}$. Los tres ejes doctrinarios del partido giraban en torno a la defensa radical de las libertades públicas, la adhesión al Estado social-liberal y a una concepción progresista de la paz y la distensión internacional. De acuerdo con El País: "social porque acepta el estado del bienestar en el que además del mercado cabe la intervención del Estado; liberal porque dicen nutrirse de los principios que parten de la revolución francesa y recogen toda la tradicional liberal española desde Jovellanos a Romanones; el progresismo lo quieren demostrar a través de sus propuestas" 238 .

En julio de 1990, el Comité Ejecutivo de la ILP, nuevamente reunido en Madrid, propuso por unanimidad la reelección de Suárez como Presidente, decisión ratificada en el Congreso de Helsinki de la ILP (octubre, 1990) ${ }^{239}$, una cita -como veremos-, dominada por las reflexiones en torno a la caída del llamado "socialismo real". En aquella jornada Suárez apeló a la defensa de un "humanismo liberal" que no diera la espalda a toda suerte de desigualdades, en un momento propicio para "la formación de un nuevo orden económico internacional [...] una exigencia de la moral y la razón humana"240.Tras su dimisión como Presidente del CDS, Suárez decidió continuar durante unos meses más en la Presidencia de la Internacional Liberal antes de abandonarla definitivamente, decisión que tomó en el Congreso de Lucerna $(1991)^{241}$.

\footnotetext{
${ }^{235} A B C, 13$ de octubre de 1989.

${ }^{236}$ OICDS, 19, octubre de 1989.

${ }^{237}$ Ponencias del III Congreso, CDS, 1991, p. 276. Conferencia de José Ramón Caso en el Club s. XXI: "La vitalidad del liberalismo progresista", El País, 01 de junio de 1990. El CDS se identificaba con el social-liberalismo, doctrina defendida en la práctica -y en la teoría-, por los ministros socialistas de economía, como Carlos Solchaga, IGLESIAS, M. A.: La memoria recuperada ..., p. 97.

${ }^{238}$ El País, 12 de febrero de 1990; Ponencias del III...; V Congreso Nacional del CDS, CDS, diciembre 1992, etc.

${ }^{239}$ El País, 13 de julio de 1990 y 05 de octubre de 1990.

${ }^{240}$ OICDS, 28, noviembre 1990.

${ }^{241}$ Como relata Martín Tamayo, quien le acompañó en su último desplazamiento como Presidente de la ILP, cuestionario escrito de Tomás Martín Tamayo, febrero 2014. Provisionalmente se formó una troika compartida junto al alemán Otto Graf Lambsdorff (FPD) y David Steel (PLD): "Suárez seguirá en la presidencia de la Internacional Liberal", El Mundo, 04 de septiembre de 1991 y "Suárez presentará su dimisión como Presidente del CDS la semana próxima", El País, 24 de octubre de 1991. Véase también: http://www.liberal-international.org/site/In_Memoriam_Adolfo_Suarez.html Fecha de consulta: 20 de julio de 2016.
} 
Aunque la relación de la Internacional Liberal y Progresista con Suárez fue fructífera para ambas partes, quizá sea exagerado identificar ideológicamente a Adolfo Suárez como liberal, al margen de las coincidencias, más bien pragmáticas, existentes. Todavía en 1993, con Suárez fuera de la política se podía leer esta noticia:

El Centro Democrático y Social (CDS) cambiará de nombre en el congreso refundacional previsto para octubre e incluirá en su denominación el término liberal, acompañado de algún otro adjetivo, como social o progresista. El presidente centrista, Rafael Calvo Ortega, admite que ha recibido 'indicaciones, no presiones', de sus socios de la Internacional Liberal en favor de este cambio de nombre ${ }^{242}$.

\section{6. La proyección europea del Centro Democrático y Social}

En 1962, España solicitó, sin éxito, la adhesión al Mercado Común. El rechazo europeo, motivado por el carácter dictatorial del régimen franquista, no impidió la firma de un Acuerdo Preferencial en materia comercial en 1970. En enero de 1976 se reabrieron las conversaciones entre el Consejo de Ministros europeo y el primer gobierno de la Monarquía y tras las elecciones del 15-J de 1977, Suárez solicitó el ingreso en la CEE - ese mismo año España ingresó en el Consejo de Europa y poco después firmó, la Convención Europea de Derechos Humanos-. Sin embargo, a pesar de la determinación europeísta de Suárez y su Ministro de Exteriores, Marcelino Oreja, junto a la labor del recién creado Ministerio para Asuntos Europeos prevalecieron los obstáculos -el giscardazo, Gibraltar, etc.- de cara a una futura adhesión española. No fue hasta los Gobiernos de Leopoldo Calvo-Sotelo y sobre todo, Felipe González cuando las negociaciones cobraron un impulso definitivo ${ }^{243}$.

Al margen de los problemas objetivos - de carácter económico y político- que suponía la entrada de España en la CEE, ha sido habitual subrayar cierta falta de voluntad, acaso desinterés, en la política europea de Suárez ${ }^{244}$. Colaboradores, periodistas e historiadores han aludido con asiduidad a su desconocimiento del inglés y

\footnotetext{
${ }^{242}$ El País, 19 de julio de 1993.

243 PARDO SANZ, Rosa: "La política exterior de España" en TUSELL, Javier: La transición a la democrática y la España de Juan Carlos I. Historia de España Menéndez Pidal. Dirigida por José María Jover Zamora XLII, Madrid, 2003, p. 769.

${ }^{244}$ Lo que Gregorio Morán asocia a una campaña de grupos conservadores dentro y fuera de UCD por “demonizar la política exterior de Suárez", por otra parte, "inclasificable”, MORÁN, G.: Adolfo..., pp. 229-231.
} 
el francés -el "hándicap de los idiomas"245-, su escasa experiencia internacional o al carácter excesivamente técnico de las reuniones para justificar el alejamiento de Suárez de los temas relativos a la CEE: "nunca se movió con soltura por el Viejo Continente, ni mostró especial interés por la política comunitaria” ${ }^{, 246}$. Una visión, que aunque poco a poco está siendo refutada por nuevos trabajos de investigación ${ }^{247}$, fue la mayoritaria en nuestro período de estudio y parece una prolongación injustificada de otro proceso en el que sí existió ambigüedad por parte de Suárez -antes y después de 1981-: la incorporación española a la Alianza Atlántica.

A diferencia de la OTAN, el intento de adhesión a la CEE contaba en España con el respaldo de la mayor parte de fuerzas políticas -incluido el PCE-, y estaba asociado, junto a las transformaciones socio-económicas a valores culturales e identitarios. Europa, mito secular de la contemporaneidad española, constituía el horizonte en el que se lograría la solución de los problemas nacionales y se alcanzaría la efectiva modernización del país ${ }^{248}$.

El Gobierno del PSOE, con la firma del Acta de Adhesión el 12 de junio de 1985, materializaba así un anhelo sentido de forma mayoritaria en la sociedad, que trascendía las diferencias políticas y que ponía punto y final, como se encargaban de subrayar los miembros del CDS al "proceso iniciado con la presentación formal del Presidente Suárez, en 1977, de la Solicitud de Adhesión"249. En el debate parlamentario sobre la adhesión española, no dejan de sorprender las primeras palabras de quien iniciara como presidente de Gobierno los trámites de adhesión, ahora exigua minoría: "brevemente

245 GONZÁLEZ DE VEGA, Javier: Adolfo Suárez: España 1976-1977. El año milagroso, Madrid, Martínez Roca, 2006, p. 154; CALVO-SOTELO, Leopoldo: Memoria ...; CERNUDA, Pilar: El síndrome de la Moncloa, Madrid, Espasa, 2011, p. 28.

${ }^{246}$ POWELL, Charles T.: "Adolfo Suárez. El presidente que se hizo a sí mismo" en BONNIN, Pere y POWELL, Charles T.: Adolfo..., p. 170; ÁLVAREZ-MIRANDA NAVARRO, Berta: El Sur de Europa y la adhesión a la Comunidad: los debates políticos, Madrid, CIS, 1996.

${ }^{247}$ LAFUENTE DEL CANO, Jorge: Leopoldo Calvo-Sotelo y Europa, Tesis Doctoral, UVA, 2015.

248 PARDO SANZ, Rosa: "La política exterior de España" en TUSELL, Javier (coord.) y JOVER ZAMORA José María (dir.): La transición a la democracia y la España de Juan Carlos I. Historia de España Menéndez Pidal. XLII, Madrid, Espasa, 2003, p. 769. De acuerdo con el calendario previsto por Calvo-Sotelo para el ingreso de España en las CEE la adhesión estaba prevista para 1983, año para el que estaban fijadas las elecciones generales, GALLEGO DÍAZ, Soledad y DE LA CUADRA, Bonifacio: Del consenso al desencanto, Madrid, Saltés, 1981, pp. 236-7.

${ }^{249}$ BDCP, 2, abril 1984. Adolfo Suárez y Agustín Rodríguez Sahagún estuvieron presentes y dieron su voto favorable en la votación de conjunto final celebrada el 26 de junio de 1985 de la Ley Orgánica 10/1985 de autorización para la Adhesión de España a las CCEE, aprobada definitivamente el 02 de agosto de 1985. El CDS votó en contra de la enmienda a la totalidad del Grupo Popular, crítico con la concreción de una ley compuesta de un único artículo, más propia, según Herrero de Miñón, del desarrollo plebiscitario que parlamentario, FIDALGO, Luis: "El Congreso rechaza la enmienda contra el tratado de la CEE", El País, 26 de junio de 1985. 
voy a intentar trasladar a la Cámara cuál es la posición de los dos Diputados del CDS, del Grupo Mixto",250.

En aquel debate, Suárez en una breve intervención se mostró respetuoso con el curso de las negociaciones - un discurso que varió en la siguiente legislatura-, absteniéndose de imputar al ejecutivo los "sacrificios" futuros de la sociedad española e incluso, refutando por "indemostrable" el hecho de que cualquier otro grupo de la oposición o ellos mismos lo hubieran hecho mejor. Los principales inconvenientes generados por la apertura al Mercado Común residían en la propia "realidad social y económica de España”. En otro sentido, quizá el aspecto que más preocupaba al líder del CDS era la conciliación de las dos realidades institucionales nuevas para España: la supranacional y europea, con la regional y autonómica; por ello, con el fin de aclarar el futuro marco interinstitucional era necesario llevar a cabo un debate parlamentario ${ }^{251}$.

El consenso en torno a la adhesión a la CEE desincentivó en buena medida el interés de la opinión pública sobre el significado y el papel de España en las instituciones europeas. Un deslucido debate que pivotó, siguiendo el trabajo de Álvarez-Miranda Navarro, en torno a tres grandes ejes: económicas, políticas -régimen político y constitucional- y política exterior ${ }^{252}$. Dichos ejes orientarán nuestro discurso interrelacionándose al ritmo de las distintas transformaciones de la CEE. Concluiremos aludiendo brevemente a la representación europarlamentaria del CDS a lo largo del período comprendido entre 1987 y 1993.

En febrero de 1986, apenas un mes después de la inauguración de la presencia española en Europa, se firmaba en Luxemburgo el Acta Única Europea, que por vez primera modificaba los tratados fundacionales de las CCEE y suponía un paso trascendental en la creación de un espacio económico y social común entre los países miembros. Para el CDS -siguiendo la Ponencia sobre Integración en Europa del II Congreso-, el esfuerzo de adaptación de la economía española al Mercado Común Europeo y la salida de crisis debía ser pareja a la flexibilización de las estructuras

\footnotetext{
${ }^{250}$ DSCD, Sesión Plenaria, 25 de junio de 1985, nº 221, p. 10208.

251 Este discurso fue adquiriendo un tono más crítico en la siguiente legislatura, hablándose de “debilidades e improvisaciones", SUÁREZ GONZÁLEZ, Adolfo: "La salud de la democracia”, Eslabón, 5, agosto-septiembre-octubre 1987 (artículo transcrito de Cambio 16, 26 de octubre de 1987).

${ }^{252}$ Las posiciones, de acuerdo con los análisis de la autora, concordaban con las resoluciones e iniciativas del centro-derecha español (UCD, AP) en aspectos económicos y políticos; convergiendo, como vimos en el epígrafe relativo a la OTAN con el centro-izquierda en materia de política exterior, véase, ÁLVAREZMIRANDA NAVARRO, Berta: El Sur de Europa ..., pp. 224-225 y 283-284.
} 
productivas, financieras o laborales y a la facilitación de los ajustes presupuestarios conducentes a la necesaria estabilidad macroeconómica ${ }^{253}$. Tras una época de crecimiento marcada por la rigidez, la planificación y el intervencionismo -el desarrollismo-, debía producirse una apertura real interna y externa en el marco de un acuerdo o consenso nacional básico ${ }^{254}$. Junto a las transformaciones económicas, debían implementarse -para mejorar la competitividad española en el futuro mercado común, más si cabe, tras su reformulación en el Acta Única Europea- reformas en la política educativa, científica y tecnológica ${ }^{255}$. Un discurso liberal -en la línea del centro-derecha español- que ponía el acento en la expansión de la "oferta" y la contención del gasto:

En España faltan tradicionalmente ciertos servicios básicos, sobran, por el contrario, intervenciones en los ámbitos empresariales y financieros, que se han traducido en una excesiva y a menudo inadecuada distribución del gasto público. La función redistributiva del sistema fiscal debe asegurarse preferentemente mediante el gasto público y no el ingreso, [...] Dentro de las limitaciones inherentes a cualquier sistema redistributivo, es preferible el objetivo de garantizar la igualdad de partida, no la igualdad de resultados ${ }^{256}$.

De forma complementaria, las manifestaciones e intervenciones públicas de algunos de sus miembros ponían el énfasis en la dimensión social y política del proyecto común. Lo que Suárez, en su intervención en el Congreso a propósito de la adhesión llamaba la atención sobre "la libertad y la competencia en la solidaridad" 257 . Apenas un año antes, Raúl Morodo relacionaba la desafección a la construcción de una "Europa de los Mercaderes" con la necesidad de articular una auténtica unión política en clave federalista, un "gran Estado plurinacional y progresista" capaz de desarrollar una política de seguridad autónoma e independiente: "la actual bipolarización mundial no nos interesa como europeos" ${ }^{258}$. En esta línea Suárez había señalado: “estimamos que las Comunidades Europeas son un paso importante en el logro de un objetivo superior,

\footnotetext{
${ }^{253}$ CDS: Ponencia II Congreso Integración Europea, 1986.

${ }^{254}$ Ibid., p. 22.

${ }^{255}$ Ibid., p. 15.

256 Ibid.

${ }^{257}$ DSCD, Sesión Plenaria, 25 de junio de 1985, $\mathrm{n}^{\circ}$ 221, p. 10208. Ambos textos compartían pasajes completos e ideas, aunque expresadas de diferente forma, sirva de ejemplo lo siguiente: "La sociedad española tiene dos objetivos prioritarios: la salida de la crisis económica y la integración satisfactoria en la Comunidad Europea. Ambos pueden obtenerse de manera simultánea si se acepta el aumento de flexibilidad económica que exige el futuro inmediato y si existe una toma de conciencia [...]", CDS: Ponencia..., p. 9. En el caso de Suárez quedaba formulado así: "El esfuerzo que supone nuestra integración en las Comunidades Europeas coincide con el que tenemos que hacer para salir de la crisis económica. La única salida solidaria ante la crisis consiste en el esfuerzo colectivo para la modernización de España en los quince años que restan para terminar este siglo y este milenio”, DSCD, Sesión Plenaria, 25 de junio de $1985, n^{\circ} 221$, p. 10209.

${ }^{258}$ MORODO, Raúl: "Europa a la vista”, El País, 17 de abril de 1986.
} 
cual es una unidad política que permita a Europa desempeñar el protagonismo que histórica, económica y culturalmente le corresponde" 259 .

Las intervenciones de Joaquín Abril Martorell en el Congreso entre 1987 y 1989, con motivo de las comparecencias del Presidente de Gobierno tras las cumbres del Consejo Europeo sintetizaban esta triple dimensión del discurso centrista: liberal, social y defensor de los intereses nacionales. En sus discursos, junto a la demanda de "una política real de cohesión social", llamaba la atención sobre algunos de los efectos perniciosos que tanto para España como para el conjunto europeo podía deparar la Unión Económica y Monetaria, sin olvidar, el papel que debía cumplir Europa en el escenario internacional $^{260}$. A propósito de la Presidencia Española de la CEE, durante el primer semestre de 1989, y la incorporación al Sistema Monetario Europeo, alertó sobre sus consecuencias para la "concertación social" y llamó la atención sobre el truncado anteproyecto de la Carta Comunitaria de Derechos Sociales ${ }^{261}$.

Una destacada presencia en la proyección europea del CDS fue la de Eduard Punset $^{262}$, quien encabezó la candidatura al Europarlamento en 1987, y acompañó en segundo lugar a José Ramón Caso en $1989^{263}$. La campaña de las europeas del 87', relegadas a un segundo plano por las Municipales y Autonómicas y en las que el CDS por fin iba a obtener representación europea ${ }^{264}$, estuvo marcada por la incógnita sobre el lugar que ocuparían los suaristas en la Cámara de Estrasburgo. Su programa subrayaba la defensa de los intereses españoles, tema que concentraba seis de los doce puntos

\footnotetext{
${ }^{259}$ DSCD, Sesión Plenaria, 25 de junio de 1985, no 221, p. 10209. En esta línea, la intervención de Miguel Martínez Cuadrado (CDS) en el debate de ratificación del Acta Única Europea, DSCD, Sesión Plenaria, 02 de octubre de $1986, \mathrm{n}^{\circ} 285$.

260 En 1988, en materia económica desarrolló tres cuestiones: la libre circulación de mercancías -su impacto en la balanza comercial, claramente desfavorable para España ${ }^{260}$, la libre circulación de capitales -su previsible hipertrofia respecto de la economía real- y sobre todo, lo referente a la Unión Económica y Monetaria -la mayor novedad de la cumbre de Hannover de aquel año-. Cerró la intervención esbozando la necesaria participación de Europa en la solución de los conflictos de Sudáfrica, Oriente Próximo - advirtiendo "la "violación de los derechos humanos en los territorios árabes ocupados por Israel"- y sobre todo, Centroamérica, DSCD, Sesión Plenaria, 30 de junio de 1988, nº 129, p. 7608 y SS.

${ }^{261}$ DSCD, Sesión Plenaria, 28 de junio de 1989, nº 204.

262 Debemos señalar el papel de J. Emilio Cervera Cardona, especialmente, en temas de agricultura -la política sectorial decisiva en el marco de la integración-.

${ }^{263}$ Estuvo junto a Adolfo Suárez en una reunión mantenida por éste con Jacques Delors en junio de 1985, en vísperas de la firma del Tratado de Adhesión, El Noticiero Universal, 05 de junio de 1985. Impartió numerosas charlas y conferencias en esta época por todo el país sobre distintos aspectos de la adhesión: $E l$ Ideal de Granada, 08 de julio de 1985; La Voz de Galicia [La Coruña], 08 de junio de 1985, etc.

${ }^{264}$ El CDS reclamó, sin éxito, la modificación de las cuotas representacionales en el Parlamento Europeo adjudicadas en 1985, de acuerdo con las elecciones generales de 1986. Finalmente, no prosperó debido a la convocatoria electoral y la negativa de los distintos grupos a ceder un eurodiputado a los centristas. Martínez Cuadrado fue nombrado miembro de la Asamblea Europea, El País, 26 de enero de 1987.
} 
destacados del programa y cuya redacción todavía recordaba al discurso más "belicoso" del partido: "Seremos una voz firme en la defensa de los intereses españoles, sin someternos a las presiones de grupos poderosos internacionales"265.

Desde el CDS se barajó la posibilidad de formar un Grupo Parlamentario Progresista -junto al PSD británico liderado por David Owen ${ }^{266}$, el PRD de Ramalho Eanes e incluso, el PR de Marco Pannella- ${ }^{267}$, desechada debido a los malos resultados de eanistas y socialdemócratas. Finalmente, los siete diputados electos del CDS se integraron en un Grupo de Coordinación Técnica y Defensa de Grupos y Diputados Independientes, operativo sólo a efectos de "intendencia" con los radicales italianos, el sacerdote progresista belga Jef Ulburhgs y el calvinista holandés Van der Waal, liderado por Punset ${ }^{268}$. Este grupo tuvo una existencia breve, y el CDS volvió rápidamente al Grupo de los no-inscritos.

Tabla 67: Grupos en el Parlamento Europeo del CDS 1987-1989.

\begin{tabular}{|l|l|}
\hline Fechas & Grupo \\
\hline $\begin{array}{l}06 \text { de julio de } 1987 \text { a } 16 \text { de septiembre } \\
\text { de } 1987\end{array}$ & No inscritos. \\
\hline $\begin{array}{l}17 \text { de septiembre de } 1987 \text { a } 17 \text { de } \\
\text { noviembre de } 1987\end{array}$ & $\begin{array}{l}\text { Grupo de Coordinación Técnica y Defensa de los Grupos y } \\
\text { Diputados Independientes }\end{array}$ \\
\hline $\begin{array}{l}18 \text { de noviembre de } 1987 \text { a } 24 \text { de julio } \\
\text { de } 1989\end{array}$ & No inscritos. \\
\hline
\end{tabular}

Elaboración a partir de: http://www.europarl.europa.eu. Fecha de consulta: 13 de agosto de 2014.

De cara a las elecciones europeas de junio de 1989, se decidió la presencia de José Ramón Caso como cabeza de lista. Estas elecciones fueron enfocadas por los principales partidos como unas primarias de las Generales y estuvieron, en el caso de los suaristas, condicionadas por los Pactos de Madrid firmados con el PP en mayo. El CDS presentaba como nudo gordiano de la participación española en Europa el ser capaces de solventar la tensión entre el decidido avance europeísta y "la defensa de los

\footnotetext{
${ }^{265}$ Del resto, tres apelaban a la construcción de una Europa social y solidaria y dos a su papel como impulsor de la paz y la democracia (América Latina), CDS: España en el Centro de Europa [Tríptico resumen del programa para las elecciones europeas del CDS], 1987.

${ }^{266}$ Caso García estuvo en su Congreso, El Noticiero Universal, 10 de septiembre de 1985.

${ }^{267}$ El País, 06 de julio de 1986 y ABC, 02 de octubre de 1986. Adolfo Suárez llegó a hablar de una carta de Marco Pannella expresándole su solidaridad por la "ley liberticida" que le impedía presentarse a las europeas, El País, 19 de mayo de 1987.

${ }^{268}$ CEMBRERO, Ignacio: "El CDS forma grupo en Estrasburgo con los radicales italianos", El País, 17 de septiembre de 1987 y GARRIGÓ, A.: "Punset, Cicciolina y el Parlamento Europeo", ABC, 24 de septiembre de 1987. El circunstancial acercamiento de estos grupos generó alguna que otra sátira política, a propósito de la presencia en el Partido Radical de la actriz de cine erótico Cicciolina, CAMPMANY, Jaime: "Adolfo e Ilona", $A B C, 24$ de noviembre de 1987 o ÍD.: "Ilona y Eduardo", $A B C, 23$ de septiembre de 1987.
} 
grandes intereses nacionales". Éste y no la supuesta confrontación entre una visión progresista y otra conservadora de Europa era el eje a resolver, ahora, como se indicaba en el texto del Programa Electoral con dos retos añadidos: la apertura al Este y la Unión Monetaria $^{269}$. En palabras de Caso:

El día que los socialistas alemanes o franceses defiendan que sus países -Francia y la República Federal de Alemania- deben aportar, en términos absolutos, más que otros al presupuesto comunitario para, por ejemplo, ayudar al desarrollo en Andalucía, Galicia, las Castillas, Canarias o Extremadura, y otras zonas desfavorecidas de Europa, ese día, y sólo ese día, se podrá hablar de que frente al mercado único de Thatcher se encuentra el modelo redistributivo, hoy inexistente y ni siquiera previsto ${ }^{270}$.

Para conseguir cumplir las esperanzas de los españoles en Europa era necesario avanzar en tres líneas: la "realización a escala europea de los valores democráticos [derechos democráticos y libertades civiles", "la construcción de instituciones europeas verdaderamente democráticas y representativas" y la "plena realización" de los valores encarnados por el "Estado Social o el Estado del Bienestar", que exigen políticas redistributivas a nivel europeo ${ }^{271}$. Estos eran los vectores de un programa, que para el periodista de El País, Camilo Valdecantos tenía "ribetes de ensayo", era tremendamente exhaustivo y había depurado sus "perfiles más bruscos" (antiamericanismo, OTAN, etc.) ${ }^{272}$. En esta ocasión, los eurodiputados electos del CDS se integraron en el Grupo Liberal, Demócrata y Reformista del Europarlamento presidido por Giscard d'Estaing. En la votación del presidente del Parlamento Europeo, los miembros del CDS votaron a favor del socialista E. Barón, apoyado también por los eurodiputados del PSOE, PP y EE, a pesar de que su grupo había propuesto otro candidato - Rudiger von Wechmar-:

\footnotetext{
${ }^{269}$ La apertura al Este implicaba la entrada en Europa de los países neutrales, el reforzamiento de relaciones con países centroeuropeos como Hungría, Polonia y Checoslovaquia y el cambio de situación entre las dos Alemanias -nueve meses antes de la caída del Muro, ya que el Programa fue finalizado en febrero de 1989-, CDS: Pas al Centre [Programa elecciones europeas, texto en catalán], 1989, p. 13.

${ }^{270}$ CASO GARCÍA J. R.: "España en Europa: esperanzas y problemas", El País, 14 de junio de 1989. La alusión y el distanciamiento hacia Margaret Thatcher no era casual, máxime cuando Alfonso Guerra había calificado a PP y CDS como "hijos de la Británica", $A B C, 12$ de julio de 1989.

${ }^{271}$ CASO GARCÍA J. R.: "España en Europa: esperanzas y problemas", El País, 14 de junio de 1989.

272 "El programa, pese a la moderación [...] no renuncia del todo al ensueño y al diseñar la política de paz y seguridad el redactor no ha resistido la tentación de señalar que les gustaría 'por utópico que parezca, una renuncia supervisada al arma nuclear", VALDECANTOS, Camilo: "Enfrentados al PSOE por escrito", El País, 07 de junio de 1989.
} 
Tabla 68: Eurodiputados electos del CDS (1987 y 1989).

\begin{tabular}{|l|l|}
\hline Eurodiputados CDS 1987 & \multicolumn{1}{|c|}{ Eurodiputados CDS 1989 $^{274}$} \\
\hline Eduard Punset i Casals & José Ramón Caso García \\
\hline José Emilio Cervera Cardona & José Antonio Escudero (hasta 1991) \\
\hline Raúl Morodo Leoncio & Eduard Punset i Casals (hasta 1991) \\
\hline Carmen Díez de Rivera (hasta 1988) & Rafael Calvo Ortega \\
\hline José Coderch i Planas & Guadalupe Ruiz Giménez Aguilar \\
\hline Federico Mayor Zaragoza & \\
\hline Rafael Calvo Ortega & \\
\hline
\end{tabular}

Elaboración propia a partir de $O I C D S$.

Desde 1989, Suárez decidió participar en los debates parlamentarios sobre las reuniones del Consejo Europeo, exigido por los malos resultados electorales de ese año (europeas y generales) y la presencia en el hemiciclo del Presidente del PP y candidato a Presidente del Gobierno, José María Aznar. El 20 de diciembre de 1989, Suárez se mostró “conciliador” con el Gobierno -en la línea de la intervención del líder de PP, Aznar- y propugnó la "búsqueda de un consenso" para la "defensa de los intereses nacionales en Europa" ${ }^{275}$. Asimismo defendió la implementación de mecanismos presupuestarios que avanzaran en la "cohesión económica y social". Sin embargo, el protagonismo de Aznar ensombreció su intervención, hasta el punto de que su presencia parlamentaria en diciembre de 1990, tras el Consejo Europeo de Roma fue meramente testimonial $^{276}$.

Tabla 69: Participación del CDS en los principales debates parlamentarios sobre Europa.

\begin{tabular}{|l|l|l|}
\hline Debates parlamentarios & Gobierno & CDS y AP/PP \\
\hline Adhesión a las CCEE & $\begin{array}{l}\text { Ministro de Asuntos Exteriores } \\
(25-06-1985)\end{array}$ & $\begin{array}{l}\text { CDS: Adolfo Suárez González } \\
\text { AP: Miguel Herrero de Miñón }\end{array}$ \\
\hline $\begin{array}{l}\text { Ratificación Acta Única Europea } \\
(17-02-1986)\end{array}$ & $\begin{array}{l}\text { Ministro de Asuntos Exteriores } \\
(02-10-1986)\end{array}$ & $\begin{array}{l}\text { CDS: Miguel Martínez Cuadrado } \\
\text { AP: Isabel Ugalde Ruiz de Assin }\end{array}$ \\
\hline $\begin{array}{l}\text { Cumbre del Consejo Europeo de } \\
\text { Copenhague (4 y 5-12-1987) }\end{array}$ & $\begin{array}{l}\text { Comparecencia del Presidente } \\
\text { de Gobierno (09-12-1987) }\end{array}$ & $\begin{array}{l}\text { CDS: Joaquín Abril Martorell } \\
\text { AP: Miguel Herrero de Miñón }\end{array}$ \\
\hline $\begin{array}{l}\text { Cumbre del Consejo Europeo de } \\
\text { Hannover (27 y 28-06-1988) }\end{array}$ & $\begin{array}{l}\text { Comparecencia del Presidente } \\
\text { de Gobierno (30-06-1988) }\end{array}$ & $\begin{array}{l}\text { CDS: Joaquín Abril Martorell } \\
\text { AP: Miguel Herrero de Miñón }\end{array}$ \\
\hline Cumbre del Consejo Europeo de & Comparecencia del Presidente & CDS: Joaquín Abril Martorell \\
\hline
\end{tabular}

${ }^{273}$ Carmen Díez de Rivera en enero de 1989 se integró en el Grupo Europarlamentario Socialista y Federico Mayor Zaragoza debido a su nombramiento como Director de la UNESCO fue sustituido por José Antonio Escudero.

${ }^{274}$ José Antonio Escudero ingresó en el Partido Popular en 1991 y Eduard Punset abandonó el CDS para fundar Foro.

${ }^{275}$ El País, 21 de diciembre de 1989. "Suárez felicitó a González por haber introducido el concepto de ciudadanía europea en la cumbre de Roma", AYLLÓN, Luisa: "La lealtad de Suárez", $A B C, 04$ de enero de 1990

${ }^{276}$ El País, 19 de diciembre de 1990. Suárez no acudió a la comparecencia de Felipe González a raíz del Consejo Europeo en la cumbre de Berlín (junio, 1990).

${ }^{277}$ En diciembre de 1988 se celebró la Cumbre del Consejo Europeo en Rodas. No hubo subsiguiente comparecencia del Presidente de Gobierno. 


\begin{tabular}{|c|c|c|}
\hline 6 у $27-$ & de Gobierno (28-06-1989) & PP: Mig \\
\hline $\begin{array}{l}\text { Cumbre del Consejo Europeo de } \\
\text { Estrasburgo (08 y 09-12-1989) }\end{array}$ & $\begin{array}{l}\text { Comparecencia del Presidente } \\
\text { de Gobierno (20-12-1989) }\end{array}$ & $\begin{array}{l}\text { CDS: Adolfo Suárez González } \\
\text { PP: José María Aznar López }\end{array}$ \\
\hline $\begin{array}{l}\text { Cumbre del Consejo Europeo de } \\
\text { Dublín (25 y 26-06-1990) }\end{array}$ & $\begin{array}{l}\text { Comparecencia del Presidente } \\
\text { del Gobierno }(27-06-1990)\end{array}$ & $\begin{array}{l}\text { CDS: José Ramón Caso García } \\
\text { PP: José María Aznar López }\end{array}$ \\
\hline $\begin{array}{l}\text { Cumbre del Consejo Europeo de } \\
\text { Roma (14 y 15-12-1990) }\end{array}$ & $\begin{array}{l}\text { Comparecencia del Presidente } \\
\text { del Gobierno (18-12-1990) }\end{array}$ & $\begin{array}{l}\text { CDS: Adolfo Suárez González } \\
\text { PP: José María Aznar López }\end{array}$ \\
\hline $\begin{array}{l}\text { Tratado de Maastricht (07-02- } \\
\text { 1992). }\end{array}$ & $\begin{array}{l}\text { Ministro de Asuntos Exteriores } \\
(29-10-1992)\end{array}$ & $\begin{array}{l}\text { CDS: José Ramón Caso } \\
\text { PP: Rodrigo Rato }\end{array}$ \\
\hline
\end{tabular}

Elaboración propia a partir del Diario de Sesiones del Congreso de los Diputados.

A comienzos de los 90', se produjo el gran hito de la convergencia y alineamiento económico de los países de la CEE, el Consejo de Europa de Maastricht (1991 y el Tratado de Maastricht en 1992) que asentaba los pilares de la futura unión monetaria sobre dos ejes: estabilidad macroeconómica y mejora de la competitividad $^{278}$. En vísperas de la firma del Tratado de Maastricht, la posición del CDS respondía a las siguientes líneas maestras:

- Unión Política: solidaridad, democratización -Parlamento Europeo-, política exterior y de seguridad común y mayor eficacia en la toma de decisiones.

- Unión Económica y Monetaria: incremento del Presupuesto Comunitario hasta del 5\% del PIB Europeo (fondo regional, social y agrícola); política de compensación en materia agrícola, acortar los plazos de la unión económica y que "el Banco Central [...] corra a cargo del Parlamento Europeo"279.

La ratificación del Tratado de Maastricht fue rotunda por parte del CDS, votando a favor junto con el resto de fuerzas parlamentarias salvo HB y la mitad de los diputados de $\mathrm{IU}^{280}$. José Ramón Caso señalaba que éste era el debate más importante de la Legislatura y manifestaba un "sí rotundo" al Tratado en el que, por otro lado, era necesario seguir trabajando de cara a solventar algunos "déficits" democráticos, reforzar las políticas de "justicia social, cohesión y solidaridad” y revisar las políticas económicas de convergencia. Pero al margen de cuestiones económicas y sociales, Caso

\footnotetext{
${ }^{278}$ SEVILLA, J.: El declive..., pp. 315-328.

${ }^{279}$ La Unión Monetaria -como había señalado J. R. Lasuén- debía ir acompañada, si quería tener éxito, de una "convergencia fiscal" y finalmente de una "Unión Política", único basamento desde el que poder llevar a cabo la "convergencia social y de corrección de desequilibrios" en el seno de la CEE. El reto, indicaba Joaquín Abril, era que España, que todavía no había alcanzado a los países desarrollados, debía alcanzar su nivel con unas reglas absolutamente distintas para el crecimiento económico a las que habían tenido estos, LASUÉN: "CDS apuesta por la Unión Europea" y ABRIL, Joaquín: "Mercado Único y Evolución de la CE”, OICDS, 30, enero 1991.

${ }^{280}$ Votación plenaria en el Congreso de los Diputados del día 29 de octubre de 1992 para la ratificación por España del Tratado de la Unión Europa del 07 de febrero de 1992.
} 
insistía en una cuestión, recurrente desde 1982, la posibilidad de construir por fin "una defensa común europea", ya que la cesión de soberanía que implicaba Maastricht, generaba las condiciones idóneas para acometer la "gran responsabilidad histórica" de la CEE en favor de la paz $^{281}$, podemos añadir, tras el discreto y desdibujado papel acometido durante la Guerra del Golfo ${ }^{282}$.

\section{7. La consolidación democrática y la aparición de nuevos partidos políticos: el caso del Partido Renovador Democrático de Portugal y del Centro Democrático \\ Social en España}

Os cidadaos perdiam a confiança no regime saído de Abril [...] nace assim, por imperativo democrático inadiável o PRD! $!^{283}$

A comienzos de la década de los 70', cayeron los regímenes dictatoriales de Grecia, Portugal y España. Era el primer instante de un reverdecimiento democrático que iba a alcanzar a lo largo de la siguiente década a Iberoamérica y, finalmente, a raíz de la caída del Muro de Berlín a todo el área geopolítica de Europa del Este. Desde entonces, han sido habituales los análisis comparativos, al albur de la definición de estas tres grandes áreas geopolíticas, y uno de cuyos focos ha centrado su atención en lo que se ha dado en llamar las "transiciones ibéricas" ${ }^{284}$. No es este sin embargo, un episodio de esa “constante histórica”, que identifica Sánchez Cervelló “de mutua interrelación en los procesos políticos vividos en ambos países" durante toda la contemporaneidad ${ }^{285}$; más bien suponen dos relatos sobre las dificultades de ambos países para integrar y aceptar

\footnotetext{
${ }^{281}$ Así, como para el desarrollo de "políticas medioambientales", DSCD, Sesión Plenaria, 29 de octubre de $1992, n^{\circ} 24,11092$.

${ }^{282}$ El papel de Europa en la Guerra de Irak había sido para Morodo, "reducido, si no lamentable" y había servido para confirmar la inexistencia de un proyecto político europeo común. Si la CE había servido para impulsar el bienestar común o abrir un gran mercado económico ahora corría el riesgo de quedar presa de una torre de marfil -"egoísmo colectivo"-, "la guerra brutal debería haber servicio de estímulo para avanzar en la Europa unida y estructurar un nuevo orden planetario más justo, libre y pacífico", MORODO, Raúl: “El Golfo, la reducción europea”, El País, 07 de marzo de 1991.

${ }^{283}$ Discurso de clausura de Ramalho Eanes en la II Convención Nacional del PRD, Discursos: Ramalho Eanes y Herminio Martinho, PRD, 1986, p. 24. Se ha optado, con las anotaciones necesarias, por dejar el texto original en portugués en las diferentes citas originales, N. del A.

${ }^{284}$ Una larga bibliografía inaugurada en 1990 con la publicación de los seminarios Portugal y España en el cambio político (1958-1978) celebrados en el Centro de la UNED en Mérida en 1989 y coordinados por Hipólito de la Torre. Sin afán de exhaustividad, a lo largo de estas décadas destaca entre otras la obra de Josep Sánchez Cervelló (1995), Encarnación Lemus López - una comparativa más amplia, que incluye Chile- (2001) o el reciente monográfico dedicado por la revista AYER, Á. González Fernández (ed.): "Las transiciones ibéricas", Ayer, 99, 2015.

${ }^{285}$ SÁNCHEZ CERVELLÓ, Josep: La revolución portuguesa y su influencia en la transición española (1961-1976), Madrid, Nerea, 1995, p. 258.
} 
políticamente a personajes que se habían convertido en auténticos representantes de su Historia Reciente, catalizadores de los discursos y narrativas de los procesos democratizadores vividos en los años 70'. La creación del CDS (1982) y el PRD (1985) situó a Adolfo Suárez y a Ramalho Eanes a caballo entre la historia y la actualidad política, y a la sociedad ante la posibilidad de juzgar -como electorado- algunos de los rasgos que habían caracterizado los procesos de democratización en ambos países. Un aspecto que ha permanecido en un segundo plano en los análisis históricos y politológicos realizados hasta el momento ${ }^{286}$. Este estudio comparado nos va a ofrecer, en definitiva, una interesante perspectiva de la construcción del discurso "suarista" desde el punto de vista histórico e ideológico.

Después de haber desempeñado las más altas responsabilidades institucionales, Adolfo Suárez y Ramalho Eanes manifestaron su deseo de permanecer en política para hacer efectivos los grandes valores por los que habían luchado recientemente sus países -Democracia, Libertad, Igualdad, Progreso, Justicia, etc.-, como si se tratara de completar una obra inacabada. En la Declaración de Principios del PRD se podía leer “de meras referencias abstractas ou de meros signos ideológicos, em práticas efectivas na actividade do Estado, na vida da empresas e das escolas, no tecido complexo das relações sociais e culturais, 287 .

Merece la pena, aun a riesgo de caer en algunas generalidades, dar unas pinceladas sobre la evolución política portuguesa desde la Revolución de los Claveles comparándolo con el proceso de Transición español- y con especial atención al protagonismo desempeñado en la misma por Ramalho Eanes, debido al escaso conocimiento que de este personaje político ha existido en nuestro país ${ }^{288}$.

Si el detonante del proceso democratizador, lo supuso en Portugal una cruenta y costosa guerra colonial arrastrada desde hacía casi diez años y que desembocó, tras el

\footnotetext{
${ }^{286}$ LISI, M.: Party Change, Recent Democracies and Portugal: Comparative Perspectives, Landham, Lexington, 2015, p. 20.

${ }^{287}$ Declaração de principios, PRD, 1988.

${ }^{288}$ Debemos señalar que, de acuerdo con el testimonio de José Ramón Caso, no existieron otras relaciones entre R. Eanes y A. Suárez que las institucionales desde que éste fue nombrado Presidente de Gobierno. Respecto a la política portuguesa, recuerda Caso: "en 1979/80 siendo presidente de gobierno y de UCD, Adolfo Suárez tuvo una muy buena relación con Sa Carneiro, líder del PSD y de la alianza $\mathrm{AD}[\ldots]$ Esa buena relación [con el PSD, ya que Sa Carneiro falleció en 1980] se recuperó en el parlamento europeo desde 1987 al integrarse en el grupo liberal tanto el PSD portugués como el CDS español. En aquella época como portavoz del CDS retomé la colaboración con Antonio Capucho, portavoz del PSD, y anteriormente secretario general de dicha formación", recogido por el testimonio escrito de José Ramón Caso, 16 de marzo de 2016.
} 
25 de Abril, en un confuso proceso revolucionario, solo reconducido hacia el modelo democrático occidental desde el 25 de Noviembre de 1975 -bajo el mando operacional de Ramalho Eanes y el respaldo de los sectores moderados del Movimiento de las Fuerzas Armadas (MFA), el "Grupo de los nueve"-, en España fue la propia agonía casi podemos decir, biológica-, de la dictadura la que inició un proceso de reforma dirigido por los sectores más aperturistas del régimen, quienes de forma consensuada con las principales fuerzas de oposición lograron la democratización del país. Frente al proceso de ruptura portugués, romántico, anárquico y no exento de tensiones, España inició un camino pausado -en ocasiones, improvisado-, en el que el diálogo ejerció de llave maestra. En Portugal fueron los actores políticos y sociales colectivos los que tomaron protagonismo, destacando sobre todos ellos, el MFA. Todos ellos, respaldados por diversas fuerzas y grupúsculos de izquierda, consiguieron eclipsar los protagonismos de Antonio de Spínola, e incluso, en un primer momento, del emergente líder del socialismo portugués Mario Soares ${ }^{289}$. Sólo después de la estabilización democrática y el fin del proceso revolucionario, el protagonismo de la vida política nacional quedó circunscrito a los grandes liderazgos políticos -y sus más que tumultuosas relaciones personales-: el antes citado Soares, como líder del PS, Álvaro Cunhal -secretario general del PCP-, el recién electo Presidente de la República, el general Ramalho Eanes y finalmente, el representante de las fuerzas conservadoras (PSD), Francisco Sá Carneiro ${ }^{290}$. En España sin embargo, la propia dinámica reformista acentuó desde el primer momento el protagonismo -luego subrayado, quizá en exceso por la historiografía- de las grandes personalidades políticas nacionales: el rey Juan Carlos I, como jefe de Estado, Adolfo Suárez como Presidente del Gobierno desde julio de 1976, Felipe González, al frente del PSOE, y Santiago Carrillo como líder del PCE.

Ramalho Eanes, nacido en Alcains -cerca de la frontera española-, era militar de carrera con una larguísima experiencia en la Guerra Colonial. Cuando se produjo la Revolución de los Claveles, el 25 de abril de 1974, ejercía como oficial superior del ejército en Angola. Hasta ese momento, apenas había tenido algún protagonismo en los movimientos que se estaban gestando en el seno de las FF.AA. contra el régimen, aunque se le consideraba cercano a quien iba a ser el primer presidente portugués tras el

\footnotetext{
${ }^{289}$ SÁNCHEZ CERVELLÓ, Josep: La Revolución de los Claveles, Madrid, Arco Libros, 1997.

${ }^{290}$ Sobre los partidos políticos en Portugal: PS (Partido Socialista), PCP (Partido Comunista Português), CDS (Centro Democrático Social), PPM (Partido Popular Monárquico), PSD (Partido SocialDemocrata) y MDP-CDE (Movimento Democrático Português-Comissões Democráticas Eleitorais).
} 
golpe de estado, Antonio de Spínola. ${ }^{291}$ El miembro del MFA, Vasco Lourenço ha comentado: "uma das primeiras decisões de Spínola foi mandar regressar rapidamente a Portugal os homens do seu grupo. Casos de Firmino Miguel, Ramalho Eanes, Ricardo Durão e outros"292. Militares como Firmino Miguel o Rocha Vieira, con quienes Eanes había estrechado relaciones años antes en la Academia Militar. Tras el 25 de abril, Ramalho Eanes estuvo en la Comisión para los Medios de Comunicación Social y posteriormente ejerció de Presidente del Consejo de Administración de la Radio Televisión Portuguesa (RTP) ${ }^{293}$, cargo del que fue destituido en marzo de 1975 a raíz del Golpe de Estado de las fuerzas contrarrevolucionarias lideradas por el propio Spínola, quien desde septiembre del año anterior había perdido definitivamente el control del proceso de cambio político en favor, del ala más a la izquierda del MFA. Desde este sector se acusó a Eanes de que: "não modificara adequadamente a programação da emissora no dia 11 de Março, o que lhe valeu uma acusação de cumplicidade (pelo menos, de contemporização) com o golpe"294.

La tensión social y política que vivió Portugal durante el verano de 1975, que para algunos condujo al país al borde de la Guerra Civil, determinó la actuación de los sectores moderados del MFA a firmar un documento -"Grupo de los Nueve", al que posteriormente se adhirió Ramalho Eanes-, defendiendo un modelo político socialista y democrático alejado de las postura maximalistas representadas desde el Gobierno por Vasco Gonçalves ${ }^{295}$. Finalmente, el 25 de noviembre un nuevo conato de golpe de estado - esta vez, protagonizado por los grupos de extrema-izquierda- fue abortado por Ramalho Eanes quien se puso al frente de las operaciones militares y puso fin definitivamente al PREC -Proceso Revolucionario en Curso-. A raíz de este éxito militar, Eanes ascendió a general y fue nombrado Jefe del Estado Mayor del Ejército, posición que le sirvió para aglutinar voluntades en el seno del Consejo de la Revolución

\footnotetext{
${ }^{291}$ Participó en la recogida de firmas contra el Congreso dos Combatentes, militares en la órbita de la extrema-derecha que querían la prosecución de la guerra colonial, CRUZEIRO, Maria Manuela y LOURENÇO, Vasco: Do interior da revolução, Coimbra, Áncora, 2009.

292 Ibid., p. 229.

293 Eanes participó en programas de entrenamiento de la OTAN en 1974-5 bajo la dirección de la embajada de EEUU en Portugal y se le asocia con el sector más corporativista del ejército, y en realidad, más numeroso en el inicio del MFA, MAXWELL, Kenneth: The making of portuguese democracy, Cambridge, Cambride University Press, 1997.

${ }^{294}$ VIEIRA PINTO, M.: O General Ramalho Eanes e a história recente de Portugal, Lisboa, Áncora, 2014, p. 163.

${ }^{295}$ Como señala Sánchez Cervello, en este documento redactado por Melo Antunes, "si bien se rechazaba un modelo socialdemócrata de corte occidentalista, la crítica más ácida iba dirigida contra el comunismo político-militar [en el poder]", SÁNCHEZ CERVELLÓ, Josep: La Revolución..., p. 57.
} 
y el MFA siendo nombrado candidato a las presidenciales de 1976 con el respaldo de las principales fuerzas políticas del país (CDS, PSD y PS $)^{296}$.

En 1976, Portugal aprobó la Constitución de la III República. Desde ese momento, el protagonismo se fue trasladando paulatinamente del ámbito militar al civil y a los partidos políticos. Sin embargo, las prerrogativas reservadas al nuevo Presidente de la República, Ramalho Eanes, eran considerables configurando un régimen semipresidencialista con un texto fundamental que mantenía el "socialismo" como aspiración de la nación portuguesa dentro de un estado democrático. El Presidente ejercía de comandante de las Fuerzas Armadas y, junto al Consejo de la Revolución, en el que permanecían muchos de los militares de abril, era garante de la Constitución -y sus conquistas socio-económicas-.

Hasta 1979, la fragilidad de los gobiernos -muchos de ellos de “inspiración presidencial"-, el alejamiento entre el PS y el PCP, así como entre Eanes y Soares marcaron la política nacional. En ese año, la convergencia electoral de las fuerzas políticas conservadoras (Alianza Democrática) provocaron un movimiento de adhesión generalizado en la izquierda del país en torno a Ramalho Eanes que se convirtió en el garante de los logros de abril y al que se sumó el PS y el PCP -aunque no Soares-, consiguiendo su reelección presidencial en 1980. En 1982, sin embargo, con el apoyo del PS, el gobierno de centro-derecha logró limar los poderes presidenciales -“o presidente deixava de poder demitir o governo invocando mera falta de confiança política"297-, así como la influencia de las Fuerzas Armadas en la vida política nacional suprimiendo el Consejo de la Revolución. Con todo, la influencia del Presidente seguía siendo considerable al mantener la capacidad de veto, así como, la posibilidad de disolver la Asamblea de la República, decisión que tomó Eanes en 1983 frente al Gobierno del PSD - que arrastraba una importante pérdida de legitimidad a causa de la crisis económica y el fallecimiento de Sá Carneiro-.

Este movimiento reforzó la posición de Soares, que con el férreo control del PS, llevó a cabo una alianza con el PSD e inauguró el gobierno conocido como del Bloco

296 Para el General Rocha Vieira -determinante en su designación- era necesario legitimar democráticamente lo que había obtenido la legitimidad de la fuerza de las armas (25 de noviembre), ROCHA VIEIRA, Vasco: Todos os portos a que cheguei, Lisboa, Grádiva, 2010, pp. 108-110.

${ }^{297}$ COSTA LOBO Marina y AMORIM NETO, Octavio: “O semipresidencialismo portugués revisitado: uma avaliação do papel do presidente na política nacional, 1976-2006”, en COSTA LOBO Marina y AMORIM NETO, Octavio (eds.): O semipresidencialismo nos países de língua portuguesa, Lisboa, ICS, 2009, p. 31; GONZÁLEZ HERNÁNDEZ, Juan Carlos: Desarrollo político y consolidación democrática en Portugal, Madrid, CIS, 1999, p. 135. 
Central. En este contexto, y ante la imposibilidad constitucional de una nueva reelección, el entorno de Ramalho Eanes relanzó un proyecto político personal, una opción que para el historiador americano K. Maxwell estaba en el aire desde finales de los 70' y que contó con la complicidad del PCP, en lo que era una pieza más en su estrategia de desgaste del PS. ${ }^{298}$ En su último año en la Presidencia de la República era una opción prácticamente decidida y que finalmente vio la luz, como respuesta a la fuerte crisis que padecía el Gobierno y que se fracturó en junio de 1985 (PSD-PS) ${ }^{299}$. El llamado eanismo se estaba fraguando, por un lado, en el contexto de la dialéctica civilmilitar, como defensa del papel de las Fuerzas Armadas y de la Presidencia de la República dentro de las instituciones democráticas, y por otro lado, como "portador de um projecto pessoal", basado en una serie de valores éticos que pretendía condicionar la actuación de las fuerzas políticas tradicionales desde una posição arbitral ${ }^{300}$.

El Partido Renovador Democrático (PRD) fue inspirado por el comité de apoyo electoral a Eanes en 1980 -conocido como ex CNARPE- ${ }^{301}$, miembros de su equipo en el Palacio de Belem -entre otros el Teniente Coronel Lencastre Bernardo o su portavoz Joaquim Letria- y el respaldo más o menos formal de algunos de los más célebres militares de abril y del "Grupo de los Nueve", caso de Ernesto Melo Antunes, Vitor Alves o Pezarat Correia, así como de otros personajes significativos como Adelino Palma Carlos, primer ministro de Portugal después de la Revolución. Su constitución como partido se produjo en la Convención Nacional celebrada en Tomar en julio de 1985. Junto a las antiguas personalidades políticas y militares citadas, se integraron en el PRD miembros relevantes de la sociedad civil, antiguos opositores del salazarismo -

\footnotetext{
${ }^{298}$ El papel del PCP fue determinante al colaborar en el proceso de constitución del partido. Para el PCP (X Congreso), la existencia del PRD confirmaba la hipótesis sobre la existencia de un vasto espacio político y social en el centro-izquierda que permitía la aparición de nuevas formaciones políticas y a la par la defensa de los valores de Abril como recogía en su edición del Avante, 10 de octubre de 1985, $\mathrm{n}^{\circ}$ 615. Siguiendo a Raimundo Narciso (PCP) la formación del PRD era, sobre todo, una forma de desestabilizar al PS, "archienemigo" de los comunistas portugueses, llegando a señalar en 1985 a propósito del éxito electoral eanista: "a "vitória' do PCP por interposto PRD não foi apenas efémera mas também uma vitória de Pirro, como ainda, com o enfranquecimento do PS...", NARCISO, Raimundo: Alvaro Cunhal e a dissidência da Terceira Via, Lisboa, Ambar, 2007, pp. 32-3. Estos hechos fueron objeto de múltiples comentarios en su momento, véase por ejemplo, V. Cunha de Rego: "No fim de contas", Semanario, 29 de diciembre de 1984. Curiosamente, la postura del PCP coincidía con algunas tesis defendidas en la ejecutiva del PCE español por Santiago Carrillo que llamaba a la búsqueda de alianzas y convergencias con, entre otros, Adolfo Suárez, véase, El País, 12 de mayo de 1984 y 28 de abril de 1985.

${ }^{299}$ OLIVEIRA, César: Os anos decisivos: Portugal 1962-1985, un testemunho, Lisboa, Presença, 1993, pp. 306-312.

${ }^{300}$ REIS, A.: "O Partido Socialista no poder e na oposição: da dialéctica com o projecto nacional-militar à dialéctica com o eanismo", en BATISTA COELHO, M. (coord.): Portugal. O sistema política e constitucional 1974-1987, Lisboa, ISCTE, 1989, p. 128 y ss.

${ }^{301}$ Comissão Nacional de Apoio à Reeleição do Presidente Eanes (CNARPE).
} 
Medeiros Ferreira o Mariá de Gloria Padrão-, y políticos descontentos del PSD y el $\mathrm{PS}^{302}$. Eanes desembarcó en el partido una vez abandonaba la presidencia en 1986 y después del éxito en las Elecciones Legislativas de 1985, en las que obtuvieron el 17\% de los votos. En su declaración de principios, el PRD se presentaba a la opinión pública como una respuesta a la profunda crisis que vivía el país:

Crise que não é só económica e financeira, mas que tem a ver também com o modo de funcionamento das instituições, com a credibilidade do Estado, com as relações sociais e humanas, enfim, uma crise geral de valores culturais, políticos, sociais e humanos. Esta dimensão, mais grave e transcendente de crise moral ${ }^{303}$.

Para los eanistas la situación política, tremendamente inestable, padecía las "tendencias de hegemonização do sistema pelos partidos [PS y PSD]”"304, más si cabe, después del fracaso de la estrategia conjunta de socialdemócratas y socialistas -Bloco Central-, la reducción del poder arbitral del Presidente de la República, y la fuerte política de ajuste socio-económica llevada a cabo por los Gobiernos dirigidos por Mario Soares (1983-1985). Como se señalaba en la Declaración de Principios del partido, algunos de los problemas de la democracia portuguesa tenían su origen en el desequilibrio de fuerzas - en favor del Parlamento y en perjuicio de la Presidencia-, ocasionado por la Reforma Constitucional de $1982^{305}$.

La superación de la crisis implicaba renovar las esperanzas y las ilusiones que se despertaron diez años atrás tras el 25 de abril e "que hoje se impoe fazer renascer no coração de todos os Portugueses”306, espíritu de abril al que se apelaba en la Moção de Estratégia del partido y en la que había participado el ex miembro del Consejo de la Revolución y capitán de abril, Ernesto Melo Antunes ${ }^{307}$. En el duodécimo aniversario de la revolución, el semanario del partido editado por el Concelho de Lisboa cerraba su edición con la siguiente proclama: "Nao deixaremos fechar as portas que Abril abriu" ${ }^{\text {308 }}$. Esta idea fue revivida con más intensidad a raíz de la incorporación de Ramalho Eanes como Presidente del Partido en la II Convención Nacional donde los claveles rojos engalanaban el ambiente festivo que se vivía en el Teatro Rivoli de

\footnotetext{
${ }^{302}$ Por ejemplo, Magalhães Mota, quien fuera miembro del PSD y ex ministro del Gobierno. Asimismo, en las Elecciones Presidenciales de 1986, el PRD apoyó la candidatura del antiguo miembro del PS, Salgado Zenha, quien había abandonado el partido por sus desavenencias con M. Soares.

303 Declaração de principios, PRD, Fondo Ernesto Melo Antunes, Caixa 23, Pasta 7, 35.5, Arquivo Torre do Tombo.

304 Ibid.

305 Expuesto en el punto 2.1., Democratização real da sociedade de la Declaração de principios, PRD, 1988.

306 Ibid.

${ }^{307}$ REZOLA, M. I.: Melo Antunes: uma biografia politica, Lisboa, Âncora, 2013, p. 743.

308 "12 anos depois... 25 de abril no Dia a Dia”, Boletim da Concelhia de Lisboa, 1, abril 1986.
} 
Oporto donde tuvo lugar el acto. Nada más comenzar su intervención dedicó un afectuoso saludo a la nutrida representación de la Asociación 25 de Abril presente en la sala -Vasco Lourenço entre otros-, señalando que los militantes del PRD querían contribuir a la "revitalização da democracia, no espírito e com o sentido que o 25 de Abril the imprimiu e que os portgueses repetidamente ratificaram" ${ }^{309}$. En el abrilismo del PRD, no existía tensión alguna con la operación del 25 de Noviembre que puso fin al PREC, todo lo contrario:

Dirigiu em 25 de Novembro de 1975 a operaçãos militares que permitiram a reposição do verdadeiro espírito do 25 de Abril, após o que foi escolhido, pelos seus camaradas, para a chefia do Estado-Maior do Exército [...] Referencia moral e político do PRD, figura catalisadora de uma vontade de mudança e a partir da qual se sedimentou o espírito que deu origen a este partido novo, o General Ramalho Eanes vai agora assumir a liderança deste projecto, garantindo-lhe a credibilidade eleitoral e política que está na razão direta do seu prestigio, em que assenta a Esperança de todos os Portugueses ${ }^{310}$.

El capitán de abril y diputado del PRD, Marques Júnior, resaltó en la tribuna parlamentaria con motivo del XII aniversario el triple significado que entrañaba la vinculación entre la nueva formación y el abrilismo. Personal, pues "que honra maior depois de ter tido a legitimidade revolucionária, ter agora a legitimidade do sufrágio popular para ser um dos representantes do povo português nesta Casa"; partidario, ya que el PRD fue creado para proseguir la acción política de abril, y político, porque de algún modo, se honraba desde la tribuna parlamentario el compromiso de los Militares de Abril con la democracia portuguesa ${ }^{311}$. Eanismo y abrilismo eran los elementos configuradores del nuevo proyecto político.

El final político de Eanes y prácticamente del PRD, tras los malos resultados de las Legislativas de 1987 fue asociado por eanistas y periodistas a auténtico final de ciclo, en que se desvanecían definitivamente las influencias del abrilismo sobre la vida política portuguesa: "se as suas conquistas fundamentais -a liberdade e a democracia-

\footnotetext{
${ }^{309}$ VILELA, A.: "Longo discurso de Eanes marca rota do partido", Diario de Lisboa, 20 de octubre de 1986. En la campaña electoral de 1985, su esposa en una entrevista en Le Point había afirmado que la creación del PRD surgía de la "incapacidade do actual sistema de partidos de responder à esperanças democráticas de Abril", Tempo, 18 de octubre de 1985.

${ }^{310}$ A Renovação, 1, octubre 1986, p. 5. En el XI Aniversario del 25 de Noviembre, Lemos Ferreira, Jefe del Estado Mayor y de las Fuerzas Armas señalaba: "novembro foi o acto final de Abril". Mientras, partidos de izquierda como UDP consideraban "foi un golpe sedicioso de direita", Diário de Lisboa, 25 de noviembre de 1986.

${ }^{311}$ Un discurso aplaudido por el PRD, PSD, PS, MDP-CDE y PCP, Diário da Assembleia da República, I Série, $n^{\circ}$ 61, 26 de abril de 1986, IV Legislatura, p. 2316, disponible en: http://debates.parlamento.pt. Fecha de consulta: 01 de junio de 2016.
} 
não estão por si só em perigo, já não se pode dizer o mesmo das aspirações mais profundas que a ele [25-A] está ligadas"312.

Para el PRD, su salto a la arena política buscar evitar la repetición de "os desvaríos" que habían hecho fracasar la I República ${ }^{313}$. No hacía falta sino mirar en la reciente historia de Portugal y en el "rotativismo" de la Monarquía Constitucional -equivalente al "turnismo" español-: “a I República pretendeu reeditar e que Raul Proença [periodista] avisadamente fustigou, acusando de que 'o que se pretende é matar toda a esperança de renovação [...] aceitar os dois partidos como tendo já em si as condições suficientes de adaptação ao funcionamento político do Pais", ${ }^{\text {,314 }}$. Por ello, a propósito de la monopolización de la vida política del país por parte del PSD y el PS, Eanes señalaba como la actitud del Gobierno y la "ofensiva bipolarizadora em curso" obviaba tanto la situación real del país como la experiencia histórica. En su Moção de estratégia, uno de los objetivos inmediatos planteados por el PRD era "o combate a bipolarização" definida como "a guerra civil gerida políticamente" causa de "uma redução das opções colocada aos Portugueses", un empobrecimiento del juego democrático y una disminución del margen de libertad de los agentes políticos. ${ }^{315}$

Adentrándonos en el terreno de la estrategia de los "renovadores" en el "juego" político, el PRD se creaba en un sistema de partidos aparentemente consolidado. Éste era un sistema "multipartidista", que contaba con dos partidos mayoritarios, PSD y PS, en el centro-derecha y centro-izquierda respectivamente, junto al CDS y PPM en la derecha conservadora y el PCP, aglutinando un porcentaje considerable del voto de izquierdas -en torno al 15\%-. Como hemos señalado antes, el componente ético aportado por Eanes era fundamental en su irrupción política como partido "arbitral". Para Melo Antunes en un documento en el que abordaba la estrategia a seguir en 1985 era esta una característica esencial que debía asegurarse de preservar en sus últimos meses como Presidente de la República:

- O Presidente da República conservará intacto o seu prestigio e a sua autoridade política, não se envolvendo em jogos ou manobras que poderiam facilmente ser classificadas de "politiqueiras" e eticamente reprováveis.

\footnotetext{
312 Palabras de Marques Júnior en CEREJO, J.A.: "Uma derrota totalmente assumida", Diário de Lisboa, 20 de julio de 1987. Véase también, "Da vitoria no 25 de Novembro á derrota a 19 de Julho", Diário de Lisboa, 05 de agosto de 1987.

${ }^{313}$ Diário de Notícias, 18 de junio de 1986.

${ }^{314}$ Discurso de R. Eanes (II Convención Nacional), Discurso H. Martinho. Ramalho Eanes, PRD, 1986, p. 35 .

315 "Uma maniobra estéril que nada tem que ver com a alternancia democrática, antes copia o que havía de pior no rotativismo monárquico", Moções, Com. Org. da Convenção PRD, 1988, p. 7.
} 
- O PR ficaria mais liberto para assumir no futuro, plenamente, as responsabilidades políticas que considerasse mais convenientes. A sua liberdade de acçao política, no futuro, dependerá em grande parte da forma como terminar o seu mandato [motivo por el que se oponía a una hipotética dimisión de la Presidencia $]^{316}$.

En este sentido, el PRD se ofrecía como un elemento de renovación de las viejas formas de hacer política en Portugal -pensado incluso como "movimiento"317, en lugar de "partido"-, y logró proponer medidas muy interesantes desde el punto de vista del funcionamiento institucional: dio libertad de voto a sus diputados -"representantes do povo que os elegeu e não como funcionários do Partido em cujas listas foram eleitos" $" 318$ - y apostó por regular la posibilidad de presentar listas de independientes sin respaldo partidario para las cámara municipales. La periodista Natalia Correia comentaba que aunque nadie esperaba que el PRD fuera el "príncipe" del cuento que despertara a la Bella Durmiente, bastaba con que sacudiera de su letargo a las demás fuerzas políticas ${ }^{319}$. Una nueva forma de concebir la lucha partidaria y el ejercicio de la oposición:

O discurso habitual dos partidos portugueses tende a reduzir-se ao seu posicionamento perante os Governos, com duas opções, e apenas duas -ser a favor ou contra-. Este mau hábito tem subjacente uma ideia que é, ao mesmo tempo, maniqueísta e totalitária: a de que só do nosso lado se encontram os bons, honestos e competentes, sendo os outros, por definição natural, maus, corruptos e incapazes ${ }^{320}$.

La significación política de Adolfo Suárez y Ramalho Eanes, hombres de estado y más bien representantes institucionales de la nación en calidad de ex presidentes permitía al PRD y al CDS ofrecerse como fulcros para el acercamiento entre los principales partidos de izquierda y derecha, es decir, materializarse como partidos bisagra $^{321}$. Lo que en el CDS, por ejemplo, en el eslogan de la campaña electoral de las autonómicas y municipales de 1983 se traducía en "La fuerza del equilibrio", y en el PRD iba un poco más allá, adoptando en su propio logo el símbolo de una balanza de la justicia. En palabras de Herminio Martinho: “coloco desde logo o PRD como partido-

\footnotetext{
316 Aspectos abordados a propósito de la celebración de Elecciones Presidenciales a finales de 1985, Estrategia do PRD, Caixa 23, Pasta 7, 35. 2, Arquivo Torre do Tombo.

${ }^{317}$ El PRD se definía como "partido do projecto", Moçao do Estrategia. Para César Oliveira se presentaba prácticamente como un "antipartido", OLIVEIRA, C.: Os anos...

${ }^{318}$ Declaração de principios, PRD, 1988.

319 "O vagabundo e a Bela Adormecida": Expresso, 03 de agosto de 1985.

${ }^{320}$ Discurso de R. Eanes (II Convención Nacional), Discurso H. Martinho. Ramalho Eanes, PRD, 1986, p. 37. "Sublinhando-se a especificidade da nossa posição e do nosso projecto, o plano diferente em que nos queríamos e queremos, colocar na política, e deque uma das aflorações consiste, no actual quadro político-partidário, em não sermos nem Situação, nem Oposição, no velho sentido de estar sempre a favor o sempre contra, mas sermos, sim Alternativa”, discurso de H. Martinho (secretario general del PRD), ibid., p. 11.

${ }^{321}$ El británico The Times sugería el "parentesco" o "parecido" -kinship- entre ambas formaciones a raíz del éxito electoral del CDS en 1986, The Times, 24 de junio de 1986.
} 
chave de todo o espectro político [...] assim, passámos a ser, como pretendíamos, o fiel da balança do sistema" ${ }^{, 322}$. El semanario Expresso sintetizó ambos símbolos a propósito de la posición clave del CDS tras las elecciones autonómicas y municipales: “Adolfo Suárez o fiel da balança"323.

En términos ideológicos tanto el PRD como el CDS se limitaban a entroncar con la esencia de los proyectos de democratización vividos en ambos países. El PRD se presentaba como un partido de la izquierda democrática, como se había definido el grueso del MFA tanto el 25 de abril, como el 25 de noviembre -mediante el ya citado "Grupo de los Nueve"-. Siguiendo a Ramalho Eanes, el nuevo partido "se orienta pelas ideias e valores que caracterizam a esquerda democrática europeia nos quais se reconhece também, pelo seu melhor, a matriz cultural portuguesa",324, y de acuerdo con Herminio Martinho: "se situa inequivocamente e renovadoramente na área do socialismo democrático e da social-democracia"325. De acuerdo con esta tradición política otorgaba un considerable peso al papel del Estado que debía encargarse de la planificación general de la economía: “O Estado tem a responsabilidade inadiável de definir um modelo estratégico de desenvolvimento para Portugal criando condições para que os sectores privado, público e cooperativo, e as forças do trabalho, postos de lado preconceitos ideológicos geradores de bloqueios [...]". Afirmaba la "primacía" del hombre sobre la economía y las respuestas tecnocráticas y mecanicistas y definía el trabajo, como "valor esencial", en la línea de las fuerzas de izquierda política surgidas a raíz de la Revolución de los Claveles. Por su parte, el CDS se autodenominaba como "Partido de Centro" ${ }^{326}$, en una reivindicación de ese proceso transaccional y negociador que había sintetizado la Unión de Centro Democrático durante la Transición, y aspiraba a proseguir el reformismo progresista de este período.

\footnotetext{
${ }^{322}$ Discurso de H. Martinho (II Convención Nacional PRD), Discurso H. Martinho. Ramalho Eanes, PRD, 1986, p. 7.

${ }^{323}$ Expresso, 13 de junio de 1987.

${ }^{324}$ Discurso de R. Eanes (II Convención Nacional PRD), Discurso H. Martinho. Ramalho Eanes, PRD, 1986, pp. 26-7. Aunque no cabe duda de que en ese momento, Eanes representaba una sensibilidad política de centro-izquierda -como se había puesto de manifiesto con su reelección presidencial en 1980-, en general, la agenda política portuguesa se situaba en el plano teórico, como consecuencia de la Revolución, escorada hacia posiciones de izquierda; hasta el punto, de que el principal partido de centroderecha liberal del país se había dado en llamar Partido Socialdemócrata (PSD) y en su programa fundacional había apostado por la consecución de una sociedad 'socialista libre', véase, GONZÁLEZ HERNÁNDEZ, J. C.: Desarrollo político...

${ }^{325}$ Discurso de H. Martinho (II Convención Nacional PRD), Discurso H. Martinho. Ramalho Eanes, PRD, 1986, p. 6.

${ }^{326}$ Autodefinido con esta expresión en el Manifiesto..., p. 7.
} 
Aunque en un segundo plano, en ambos se adivinaba cierta consciencia del ocaso de las grandes ideologías por la trepidante transformación económica, social y política global. Para el PRD era manifiesto que "as grandes famílias ideológicas internacionais do Socialismo e da Social-Democracia se encontram hoje ultrapassados, denotando os seus quadros mentais e doutrinários evidente usura e erosão". Según Joaquim Letria, miembro de la Comissão Directiva Nacional: "penso que o político, hoje, deve ser fundamentalmente um gestor, eleito pelos accionistas que, no caso, sao os eleitores" ${ }^{\text {327. }}$. Una nueva política desideologizada, asociada a valores técnicos y entendida en términos de eficacia, que se plasmó abiertamente en la campaña de las elecciones europeas del CDS en $1989^{328}$.

Tanto el PRD como el CDS exigían un reparto equitativo de los costes económicos y sociales que exigían la superación de la crisis económica, ${ }^{329}$ en un proceso que debía articularse mediante un amplio proceso de concertación social -“ensaiar novos modos de diálogo entre o poder político e os sindicatos, entre o poder político e os empresários, entre estes e os sindicatos no interior das empresas e outras unidades de produção" 330 -. El objetivo en ambos casos era la "modernización" de las estructuras socio-económicas, plasmación de un anhelo secular en los dos lados de la frontera.

Si nos centramos en el tratamiento mediático del que fueron objeto ambos partidos, ni el PRD, ni el CDS lograron trascender la percepción generalizada, que con más o menos ahínco se encargaron de propagar los medios, esto es, que eran operaciones personalistas creadas fundamentalmente para la satisfacción de las ambiciones personales de sus líderes. El eanismo y el suarismo se constituían así como corrientes que personificaban en Ramalho Eanes y Adolfo Suárez las principales virtudes de sus regímenes políticos con el objetivo de pugnar electoralmente y mantener sus cuotas de poder e influencia.

El PRD nació bajo el patrocinio “interpuesto" de Ramalho Eanes -por ejemplo, mediante la participación de su esposa Manuela Eanes, en la campaña electoral o personas del entorno del Palacio Presidencial de Belém-, ya que a la altura de 1985, ejercía todavía como Presidente de la República. Esta situación provocaba la irritación

\footnotetext{
${ }^{327}$ O Renovador, 2, julio 1987, pp. 8-9.

${ }^{328}$ Un discurso, que aunque se puede rastrear desde 1982, adquirió su definitiva consistencia en los comicios celebrados en 1989: El País, 07 de agosto de 1989, El País, 06 de mayo de 1989, etc.

${ }^{329}$ En el caso del CDS, Manifiesto..., p. 11.

${ }^{330}$ Declaração de principios, PRD, 1988.
} 
de los medios, como el Expresso, el semanario más arraigado en Portugal: "porque é que o PR na esclareceu o país sobre as suas relações com o PRD, deixando a outros o papel de falarem pela sua boca" ${ }^{\text {331 }}$. Hubo incluso quienes criticaron su imparcialidad en el ejercicio de su cargo con el fin de beneficiar al naciente PRD -por ejemplo, en la elección de la fecha de la celebración de las Elecciones Legislativas de 1985- ${ }^{332}$.

Para los sectores más conservadores del país representados por el semanario $O$ $D_{i a b o}{ }^{333}$-dirigido por la periodista Vera Lagoa $^{334}$, considerado prácticamente de "extrema-direita" ${ }^{335}$ - u O Dia, la vuelta de Eanes era una auténtica tragedia política: "[Eanes] vai alimentando o mito de um partido eanista, como dele dependesse a salavação da pátria"336. Un partido que "não tem ideologia, nem coerência estratégica" 337 , marioneta del PCP, financiado irregularmente desde Macao -donde sirvió el propio Eanes-, gracias a su relación con el gobernador Almeida Costa y que incluso había falsificado firmas para poder concurrir en algunos distritos electorales. ${ }^{338}$ Se ponía entredicho así su "capa da seriedad, da anti-corrupção, da anti tudo o que estaba mal nos partidos antigos" 339 . Y con un reproche permanente: "ao criar ao PRD apenas quis salvar o país. Ah! E por que não o salvou durante a sua longa permanência em Belém?” ${ }^{340}$. En 1987, O Diabo celebraba en su portada el fracaso del PRD y con él, el de sus veleidades abrilistas: "Revolução de Julho [fecha de las elecciones] acaba con 'abrilismo",341; una presencia, la de los llamados políticos-militares de abril vista como

\footnotetext{
${ }^{331}$ SARAVIA, J. A.: "Perguntem ao Sr. Presidente", Expresso, 13 de julio de 1985. El editorial de Diario de Noticias señalaba: "À espera de Eanes", 17 de junio de 1985.

${ }^{332}$ En 1985 se publicó y envió a algunos partidos políticos la edición de una demanda contra Eanes por imparcialidad en el ejercicio de su cargo, al apoyar, al PRD, DE SOUSA E MELLO, Henrique: Ramalho Eanes contra a Constituçao, a democracia, a coerencia, o cargo, AGIR, Dezembro 1985.

${ }^{333}$ Las referencia de $O$ Diabo, O Tempo, Expresso y Semánario entre 1984 y 1985 han sido recogidas a partir del dossier elaborado por la Presidencia de la República (Ramalho Eanes) sobre ex CNARPE y PRD depositado en la Biblioteca Nacional de Portugal: "Bibliografía temática, $\mathrm{n}^{\circ}$ 12, 1985. Centro de documentaçao e informaçao. Presidecia da República".

${ }^{334}$ Vera Lagoa (M. A. Pires Falçao) arrastraba un fortísimo enfrentamiento con Ramalho Eanes desde finales de los 70' - O Diabo fue cerrado unos meses entre 1976 y 1977 por instancias gubernativas-. En 1980, le dedicó un opúsculo titulado "Eanes: Nunca mais", Lisboa, Intervenção, 1980.

${ }^{335}$ FIGUEIRA, João: A imprensa portuguesa (1974-2010), Coimbra, Angelus Novus, 2012, p. 29.

336 "Todos foram culpados", O Diabo, 25 de febrero de 1984.

337 JÚDICE, J. M.: "O partido do senhor presidente", O Diabo, 18 de junio de 1985. La tira de humor gráfico de portada de $O$ Diabo representaba al PRD como una banda de bufones con el texto, "Para que serve o PRD", el 21 de octubre de 1986. En O Tempo, rotulaban su I Convención Nacional: "Convenção à procura da ideología", Tempo, 04 de mayo de 1985.

${ }_{338}$ O Diabo, 10 de septiembre de 1985.

339 ALVARENGA, M.: "Batota dos 'renovadores' pode levar Malaquias a cadeia: pela boca more o peixe", $O$ Diabo, 12 de noviembre de 1985.

${ }^{340}$ LAGOA, Vera: "Eanes nunca existiu. Napoleão morreu há 165 anos", O Diabo, 11 de agosto de 1987.

${ }^{341}$ O Diabo, 21 de julio de 1987. Rogeiro, Nuno: "Abril morreu: chegou o futuro", $O$ Diabo, 21 de julio de 1987.
} 
una auténtica amenaza al futuro del país por la derecha lusa: "vultos pouco tranquilizadores de ex conselheiros da revolução e outros militares do MFA [II Convención Nacional PRD]"342.

Semanário, en el que escribían entre otros Marecelo Rebelo de Sousa o Victor Cunha do $\operatorname{Rego}^{343}$, se mostraba crítico con las ambiciones del político de Alcains, la ausencia de ideología y la absoluta dependencia que padecía el nuevo partido: "quando todos os partidos sobrevivem ao desaparecimento dos seus lideres, por muito carismático que o sejam, e impressionante verificar que o novo partido entende que só vale a pena salvar o país se o salvador for o ex presidente de todos nos"344. La abierta defensa de Semanário en favor de la bipolarización política y la alternancia entre PSD y PS le oponía directamente a la estrategia política implementada por Ramalho Eanes ${ }^{345}$, aunque las posibilidades de algún tipo de acuerdo entre el PSD (Cavaco Silva) y el PRD (Ramalho Eanes) fue objeto constante de especulación en toda la prensa lusa durante este período.

No faltaron quienes percibieron en la operación eanista cierto mesianismo: “aos milhares acorrem como quem vai ao culto. Eanes é Deus. D. Manuela sacerdotisa. Martinho o sacristao. Como música sacra, o 'réquiem da clase política actual" ${ }^{\text {346 }}$. Para un corresponsal suizo, como recogía Diario de Noticias, "isto é um culto"347. O manifestaciones más propias de los regímenes personalistas latinoamericanos, lo que permitía a Manuel Vilaverde, tildar de "Manuela Perón" a la esposa de Eanes tras uno de sus mítines ${ }^{348}$.

En el periódico progresista Diario de Lisboa, se valoraban positivamente las posibilidades de regeneración democrática que suponía la aparición de un partido nuevo con un programa de defensa democrática y constitucionalista, sin embargo, todavía, precisaba hacer un esfuerzo de consolidación y clarificación, saliendo de la estrechez que suponía su nada disimulado sebastianismo: "apelar a um homem, seja ele general

\footnotetext{
342 O Día, 18 de octubre de 1986.

343 Expresso y Tempo eran semanarios de centro-derecha, al igual que Semanario, creado en 1983 y partidario de la clarificación política - bipolarización-, tras la experiencia fallida del bloco central, y de la reprivatización en el plano económico, FIGUEIRA, J.: A imprensa ..., p. 113.

344 JÚDICE, J. M.: "O partido tartufo", Semanário, 03 de agosto de 1985.

345 Editorial (CUNHA REGO, Victor): "Bipolarização”, Semanário, 29 de noviembre de 1986; REBELO DE SOUSA, Marcelo: “O reforço das teses das duas hegemonías”, Semanário, 29 de noviembre de 1986. Ambos artículos realizados tras la publicación de unos sondeos electorales en la conmemoración del tercer aniversario del periódico que parecían corroborar sus tesis bipartidistas.

${ }^{346}$ ANTA, M.: "Requiem dos políticos no culto "renovador"”, Semanario, 04 de octubre de 1985.

${ }^{347}$ Diário de Noticias, 18 de junio de 1986.

${ }^{348}$ VILAVERDE, M.: "Manuela Peron", Semanario, 28 de septiembre de 1985.
} 
de quatro estrelas e, no momento, Presidente da República, é uma saída redutora do próprio movimento de opinião e frustrante qualquer que seja a superstiçao sebástica de um heroi-salvador" ${ }^{349}$.

Finalmente, la oposición y los medios subrayaban el carácter errático de su trayectoria política. El conservador $O$ Día describía la carrera política Eanes como un confuso y errático camino: líder inesperado y tardío en el MFA que concitó los apoyos del centro-derecha para su elección presidencial en 1976... y que ahora creaba el PRD para "o perpetuar [perpetuarle]", una especie de "de gaullismo" a la portuguesa ${ }^{350}$.

Adolfo Suárez y Ramalho Eanes parecían incapaces de adaptarse al nuevo papel que la vida política les había deparado y más que como líderes partidarios, seguían actuando como hombres de estado, como ex presidentes. PRD y CDS se consideraban partidos frágiles, sin estructura organizativa, acusados de caudillismo y con una nefasta dirección política. En las semanas previas a las Elecciones Parlamentarias de Portugal de 1987, José Manuel Fernandes valoraba en Expresso: “A anticampanha de Eanes”, “o ex Presidente em vez do candidato" 351 , cuyo carisma era puesto a prueba "fora do Palco Presidencial" ${ }^{352}$. Y en ambos casos, el comienzo del fin se produjo cuando mudaron su "independencia" e "inocencia" política en posicionamientos a izquierda o derecha: “para onde penderá a balança?"353. En el caso del PRD, su iniciativa de promover una moción de censura contra el Gobierno del PSD en abril de 1987, fue el preludio del tremendo "batacazo" electoral de julio de ese mismo año en el que pasó de más de un $17 \%$ de los votos (1985) a menos de un 5\%. Para el CDS, los llamados Pactos de Madrid con el PP (1989) y el posterior giro hacia el PSOE (1990) iniciaron un paulatino descenso electoral que culminó en mayo de 1991, con la celebración de las elecciones autonómicas y municipales en las que perdió prácticamente toda su representación institucional.

Curiosamente, en ambos casos su fin fue parejo a la consolidación de la alternancia bipartidista a la que tanto se habían opuesto. Su presencia atemperó la distancia entre los grandes partidos de derecha (PSD y PP) e izquierda (PS y PSOE) y sobre todo,

\footnotetext{
349 S. A.: "Nasceu en Tomar com a bençao de Eanes", Diario de Lisboa, 15 de junio de 1985. El sebastianismo es un mito nacional y místico portugués basado en el posible retorno del rey Sebastián I, desaparecido en la batalla de Alcazarquivir (s. XVI) y objeto de constante reflexión en la literatura (F. Pessoa) y la búsqueda de los rasgos definitorios de la identidad nacional.

${ }^{350}$ O dia, 20 de otubre de 1986.

${ }^{351}$ Expresso, 04 de julho de 1987.

352 O Dia, 19 de octubre de 1986.

${ }^{353}$ Artículo del mismo título de Joao Mendes en Diario de Lisboa, 07 de octubre de 1985.
} 
facilitó el trasvase de votos entre ambas formaciones: "la aparición del PRD desencadenó una enorme fluidez de voto, iniciando el aprendizaje de la infidelidad electoral por gran parte de los ciudadanos" ${ }^{\prime 354}$.

El PRD (1985) y el CDS (1982), se habían ofrecido ante el electorado como la síntesis de los cambios políticos vividos por sus países. En el primer caso, el abrilismo con su componente político-militar- había encontrado su más firme defensor en Ramalho Eanes, sobre todo, a propósito de la Reforma Constitucional de 1982, que simbólicamente había puesto punto y final al espíritu de abril e inaugurado una nueva fase en la democracia portuguesa. El eanismo, inspirado en posiciones de centroizquierda, encarnaba esta idea en el rictus hierático y el semblante serio del General Eanes. En el caso español, el reformismo de los años centrales de la Transición había encontrado su principal valedor en el programa constitucionalista del CDS y el gesto heroico -y solitario- de Suárez durante el Golpe de Estado del 23-F en defensa de la democracia. Un impulso, canalizado políticamente, mediante lo que se dio en llamar en el seno de UCD como suarismo, distante y combativo con los proyectos democristianos y liberales que en torno al gran partido conservador Alianza Popular abogaban por la "mayoría natural" del centro-derecha español. Debemos advertir finalmente, que sólo el PRD y el CDS fueron capaces de distorsionar, al menos momentáneamente, el proceso de consolidación de sistema de partidos que parecía a presto a estabilizarse tanto en España como en Portugal. De este modo, para suaristas y eanistas, sus respectivos líderes simbolizaban en cierto modo, lo que había significado el proceso de democratización nacional y con este bagaje intentaron materializarse en proyectos políticos al uso y lanzarse al ruedo electoral. Éste ha sido el eje sobre el que hemos vertebrado el presente epígrafe. Como señalaba H. Martinho, mano derecha de Ramalho Eanes, a pesar de todas las injustas acusaciones de las que eran víctimas, nadie en Portugal tenía "mais autoridade moral" que el General, como había demostrado desde el 25 de Noviembre de $1975^{355}$.

\footnotetext{
${ }^{354}$ FREIRE, A.: "Elecciones y comportamiento electoral en Portugal", en BARRETO, Antonio, GÓMEZ FORTES, Braulio y MAGALHAES MOTA, Pedro: Portugal: democracia y sistema político, Madrid, Siglo Veintiuno, 2003, p. 130.

${ }^{355}$ Discursos: Ramalho Eanes y Herminio Martinho, PRD, 1986, p. 6.
} 


\title{
Capítulo 8:
}

\section{Un agitado final de Legislatura (1988-1989)}

\begin{abstract}
"Los de derechas dicen que somos de izquierdas y los de izquierdas aseguran que somos de derechas. Está claro que unos y otros sueñan con ocupar ese espacio político que llaman centro y en el que esperan, a menudo camuflarse para que nadie vea su auténtica manera de ser y lo que pretenden"1.
\end{abstract}

Antonio Garrosa, presidente provincial del partido en Valladolid, recuerda que en marzo de 1989 unas encuestas llevadas a cabo en la capital vallisoletana otorgaban al CDS la primera posición en intención directa de voto ${ }^{2}$. Aunque quizá, estuviera lejos de lograr convertirse en la tan ansiada alternativa hacia 1990, el CDS había logrado significativos avances en todos los comicios electorales posteriores a las generales de 1986: autonómicas del País Vasco (1986) y Cataluña (1988), municipales, autonómicas y europeas de 1987. Encuestas y sondeos sucesivos ratificaban la marcha ascendente del partido que elevaba progresivamente sus índices de aceptación entre el electorado. En abril de 1988, estaba incluso a punto de superar a AP en intención de voto según análisis del CIS. Una pugna, que se mantuvo a lo largo de los meses siguientes en una guerra de datos filtrados por los diferentes periódicos y semanarios.

La evolución del partido desde 1988 hasta 1989 centrará las siguientes páginas. Para ello, comenzaremos analizando el Debate sobre el Estado de la Nación de 1988, posteriormente nos acercaremos a las elecciones autonómicas de Cataluña (1988) y daremos, a propósito de estos comicios, unas pinceladas sobre las líneas maestras de la política autonómica del CDS en su última etapa con representación institucional (19881993). A continuación, abordaremos el papel jugado por el CDS en el clima de contestación sindical al Gobierno culminado con la huelga general del 14-D.

\footnotetext{
${ }^{1}$ Extracto del comunicado del CDS-Pontevedra a raíz del abandono del partido del ex candidato a la Xunta, Jesús Osorio, Diario 16, 12 de noviembre de 1990.

${ }^{2}$ Entrevista con Antonio Garrosa, 21 de agosto de 2013.
} 
Finalmente, la refundación de Alianza Popular, la aparición de Mario Conde y los Pactos de Madrid ocuparán un lugar central en este capítulo, ya que su estudio, nos servirá de llave para explicar el desarrollo de las elecciones europeas y generales de 1989 (programa electoral, campaña y resultados), punto con el que cerraremos el presente capítulo.

\section{1. El Debate sobre el Estado de la Nación de 1988}

El Debate sobre el Estado de la Nación de 1988 se celebró los días 24 y 25 de febrero. Por vez primera, el CDS y concretamente la intervención de Adolfo Suárez concitaron el elogio unánime de la prensa. En un momento en el que no se vislumbraba la resolución de la crisis de AP, el liderazgo de Suárez parecía lo bastante sólido como para ser capaz de aglutinar una alternativa al socialismo.

La intervención de Suárez, siguiendo el orden de la exposición de González, comenzó por abordar la postura del CDS en política exterior, en plena polémica sobre los límites de la aportación defensiva de España a la Alianza Atlántica, la renovación del Convenio con EE.UU., y en consecuencia, el futuro de las bases. En relación a la CEE, señalaba que el consenso no debía obviar el debate y la crítica a algunos puntos, especialmente: "el déficit de nuestra balanza tecnológica y el deterioro estructural de nuestra balanza comercial"3; ; aspecto el primero insoslayable si se quería revertir la pérdida de cuota de mercado nacional. A continuación, valoraba positivamente los acuerdos de Madrid y Vitoria (Ajuria Enea) en materia antiterrorista.

El siguiente escalón lo ocupaba la "inseguridad ciudadana", por entonces, uno de los caballos de batalla de la oposición conservadora contra el Gobierno. Aun reconociendo su imbricación con multitud de causas socio-económicas, esta problemática había contado con una insuficiente respuesta por parte del Estado -desde la formación y dotación de las Fuerzas de Seguridad del Estado a la creación de nuevos organismos de actuación como las “juntas locales de seguridad”-. Una preocupación que extendía al tráfico y consumo de drogas. En relación al desempleo, cuyos niveles superaban la barrera del veinte por ciento, Suárez se preguntaba, si en uno de los mejores años de la

\footnotetext{
${ }^{3} D S C D$, Sesión Plenaria, 24 de febrero de 1988, no 88, p. 5550.
} 
economía española no había conseguido reducirse: “¿qué perspectivas de futuro ofrece el Gobierno a la sociedad española si en el porvenir inmediato las ventas son menos favorables?"4.

Las críticas pasaban, en el siguiente bloque, al intento por parte del PSOE de reproducir la mayoría parlamentaria en todos los niveles del estado y de la sociedad. Uno de sus efectos más perniciosos sucedía en RTVE, cuya política informativa dificultaba enormemente la construcción de una alternativa ${ }^{5}$.

La valoración general sobre la situación del país era amarga. El mal funcionamiento de los servicios públicos y la mala gestión estaba dañando "la idea del Estado del Bienestar, muy necesaria en una sociedad tan injusta como la española", y aún quedaban pendientes cinco grandes reformas de cara a la "modernización" del país: "la educación, la sanidad, la Seguridad Social, la justicia y la función pública"6. La descripción de lo que él consideraba "el colapso" y la "ineficacia" de la provisión de estos servicios públicos fundamentales completaba el resto de la intervención, ocupando prácticamente la mitad de la misma. La educación, dotada insuficientemente, como lo demostraba "la aplicación de la LODE" - una ley en principio "elogiable"-, no lograba superar el lastre de la "masificación" universitaria ni "preparar a nuestra juventud para el mercado común de trabajo de 1992”. La sanidad se encontraba sumida en una situación caótica, presa de la mala gestión, la falta de definición de una política sanitaria y la descoordinación. Pero sin duda, las críticas más profundas se produjeron en el análisis de la Administración pública, presa de una inquietante "politización", pareciendo reproducir las prácticas -sin hacerlo explícito- del funcionariado cesante decimonónico: “¿sería bueno para el país, para el sistema democrático y para la Administración remover no ya los directores generales, sino un gran número de subdirectores generales y directores de servicio, nombrados no pocos de ellos al margen del mérito de la carrera administrativa?", " Los mismos defectos se trasladaban al ámbito de la justicia, donde además, tenían lugar conflictos institucionales... Suárez concluía lamentando la inexistencia de lo que él llamaba un "proceso dinámico de modernización" generado por la falta de independencia del Estado y la Administración respecto del Gobierno, la ausencia de transparencia, rendimiento de cuentas y

\footnotetext{
${ }^{4}$ Ibid.

${ }^{5}$ Aunque la "cultura democrática" encontraba numerosos hándicaps, no le impedía reconocer que la "sistema democrático en sus fundamentos" estaba plenamente afianzado.

${ }^{6}$ Ibid.

${ }^{7}$ Ibid., p .5553.
} 
potenciación de valores de "cultura política democrática" como "la tolerancia, el diálogo, el pluralismo, el control del Poder, la solidaridad y la lucha contra la marginación social y las desigualdades injustas"

Felipe González respondió a la presumible falta de definición del Gobierno en algunos aspectos de política exterior, recordando algunas ausencias de postura del CDS: "a veces la ambigüedad se confunde con una necesidad, que conoce muy bien el portavoz y Presidente del CDS, que es la necesidad de mantener la discreción en todos los procesos de negociación internacional"9. Al contestar a la acusación de "ocupación del Estado" por parte del Gobierno, recordó, y no era la primera vez, los famosos ciento siete años de gobierno de UCD. Este cruce de acusaciones en términos comparativos, terminó cuando Suárez, en un tono agridulce, hizo la que quizá sea una de las referencias más sentidas hacia su propio pasado político. Merece la pena reproducirla extensamente porque refleja bastante bien las contradicciones en que vivía, no sólo Suárez, sino buena parte de la sociedad y la clase política española respecto a la Transición:

Señor González, yo no he lanzado antes ningún guante para un combate dialéctico con usted. Únicamente era por hacer un gesto. Vamos a ver si usted hace también un esfuerzo de comprensión ya que lleva cinco años de Presidente de un Gobierno de mayoría absoluta. ¿Qué pensaría si escuchara durante cinco años en esta Cámara referencias a aquellos cinco años de Gobierno y que nadie saliera a defenderle? Porque la desaparición del partido político -que no fue culpa de usted, aunque también tuvo alguna- (Risas.); la desaparición de aquella fuerza política ha hecho que se repartan entre los diferentes Grupos políticos de esta Cámara muchísimos parlamentarios y no hay nadie que defienda aquella situación. Yo me siento muy orgulloso de haber sido Presidente del Gobierno en aquella época y por eso, cuando no tengo oportunidad de defenderlo de otra manera, digo que a ver si existe tiempo suficiente alguna vez para poder confrontar los éxitos y fracasos - que de todo hubo- en aquella acción de Gobierno y en la actual. Si hoy miro a esta Cámara veo que tengo compañeros de Gobierno de aquella época sentados en todos los ángulos del hemiciclo. (Risas.) Incluso en el Gobierno de la nación. Por tanto, señor González, entenderá que cuando se hacen referencias a la etapa de Gobierno de 1976 a 1981, tenga que acudir naturalmente a alguna fórmula que me permita, debatiendo con quienes quieran, explicarlo con claridad algún día. Eso es todo, no es una película del oeste $^{10}$.

En esta ocasión Suárez se convirtió, según la impresión unánime, en el auténtico líder de la oposición. El largo plazo parecía dar sus frutos. Testimonio de la buena marcha del partido, que tras las elecciones autonómicas y municipales había conseguido una nutrida presencia institucional en todo el país, fue la publicación en una edición de diez mil ejemplares de una conferencia de Suárez bajo el título de: "Una política de

\footnotetext{
${ }^{8}$ Ibid., p. 5555.

${ }^{9}$ Ibid., p. 5564

${ }^{10}$ Ibid., p. 5579.
} 
progreso y libertad" "11. Además, el CDS inauguraba respaldo fuera de las fronteras españolas, tras haber anunciado su integración en la Internacional Liberal.

El País lo valoraba así: "tal vez para ser un buen político no se requieran cualidades excepcionales desde un punto de vista intelectual, cultural o moral. Pero es evidente que algunas cualidades se requieren. Felipe González y Adolfo Suárez las poseen [...] González y Suárez han conseguido parecer Gulliveres en Liliput”. Una situación en la que se confabularon la inexistencia de otras alternativas, la deriva de los populares y la ausencia de los principales líderes políticos del país en el Congreso (Arzalluz, Carrillo, Fraga, Pujol, Hernández Mancha...). Para el editorial de El País, Suárez era "el único político en activo con arrastre suficiente para articular en torno suyo una alternativa capaz de hacer sombra a Felipe González. Su bien construido discurso ha hecho recordar por momentos al mejor de los Suárez posibles, pero cuando ha descendido al cuerpo a cuerpo se le ha visto agarrotado por el recuerdo de glorias pasadas"12. En la portada del periódico dirigido por Pedro J. Ramírez se mostraba el saludo entre González y Suárez justo antes del debate y titulaba: "Suárez culpa al PSOE de que España no sea un país moderno", tomando partido decididamente por el líder del CDS: "las expectativas de que este debate parlamentario sobre el estado de la nación se convirtiera en un mano a mano entre Felipe González y Adolfo Suárez se han cumplido en buena manera". Poco a poco, el editorial del rotativo madrileño elevaba el tono: "El antiguo presidente del Gobierno soltó el brazo y le devolvió al dirigente socialista los directos que éste le lanzó a la mandíbula cuando Suárez estaba en el poder”. Había sido “el discurso parlamentario más convincente del líder centrista, que ha demostrado tablas y ganas de pelea. Puede decirse que ayer presentó su tarjeta como alternativa de Gobierno". Y sobre las estrategias de ambos, señaló como González se había intentado defender con golpes bajos y comparaciones insostenibles:

Intentó comparar la fotografía de estos cinco años en España con la de los cinco años de la transición política [...] a verdad es que no había comparación posible [...] Ha demostrado que hoy está [...] más entero; que tiene más ideas y más pegada que Felipe González. Hace cinco años era al revés ${ }^{13}$.

Dávila, en Diario 16, hablaba de la "resurrección del duelo" entre Suárez y González, aunque seguía lamentando lo que consideraba "desafueros" tercermundistas del abulense. Según $A B C$, más prudente en sus elogios a un político imprevisible,

\footnotetext{
${ }^{11}$ SUÁREZ GONZÁLEZ, Adolfo: Una política de Progreso y Libertad, CDS, 1988.

${ }^{12}$ Editorial: "Un debate más audible”, El País, 26 de febrero de 1988.

${ }^{13}$ Editorial: "Cuerpo a cuerpo Suárez-González", Diario 16, 25 de febrero de 1988.
} 
González había recuperado el tono de buen parlamentario y la oposición había sabido estar en su sitio: “-García Tizón, Suárez, Roca- supieron criticar sin herir, lo cual debe ser saludado como un síntoma de buena salud parlamentaria"14. Para el boletín de información centrista de marzo no había lugar a dudas: "Adolfo Suárez: alternativa a Felipe González" ${ }^{\prime 15}$. Ciertamente, aunque la posibilidad de rebasar electoralmente al PSOE estaba aún muy lejos -a pesar de algunas encuestas $-{ }^{16}$, los márgenes entre AP y el CDS eran realmente estrechos -tabla 70 a) - y se extendía la percepción del CDS como alternativa, -tabla 70 b)-, y de Suárez como futuro líder de la oposición -tabla 70 c)-:

Tabla 70 a): Intención de voto. Comparación AP-CDS.

\begin{tabular}{|l|l|l|l|l|l|l|l|l|l|}
\hline & & $\begin{array}{l}\text { Sept. } \\
1987\end{array}$ & Oct. & Nov. & Dic. & $\begin{array}{l}\text { Enero } \\
1988\end{array}$ & Feb. & Marzo & Abril \\
\hline \multirow{2}{*}{ Intención voto } & AP & 8 & 9 & 10 & 9 & 9 & 7 & 10 & 12 \\
\cline { 2 - 11 } & CDS & 7 & 7 & 11 & 8 & 9 & 6 & 8 & 11 \\
\hline \multirow{2}{*}{$\begin{array}{l}\text { Intención de voto } \\
\text { más simpatía }\end{array}$} & AP & 10 & 10 & 11 & 11 & 10 & 8 & 11 & 14 \\
\cline { 2 - 11 } & CDS & 10 & 8 & 13 & 10 & 12 & 9 & 10 & 13 \\
\hline
\end{tabular}

Elaboración propia a partir del CIS: “Datos de opinión”, REIS, 42, 1988, p. 279.

Tabla 70 b): El CDS como alternativa.

\begin{tabular}{|l|l|l|}
\hline \multicolumn{2}{|c|}{ De aquí a unos años el CDS será la única alternativa real de los socialistas } \\
\hline & Julio 1987 & Abril 1988 \\
\hline Más bien de acuerdo & 26 & 32 \\
\hline Más bien en desacuerdo & 37 & 28 \\
\hline No sabe/no contesta & 35 & 40 \\
\hline
\end{tabular}

Elaboración propia a partir del CIS: “Datos de opinión”, REIS, 42, 1988, p. 253.

Tabla 70 c): El liderazgo de Adolfo Suárez en la oposición.

\begin{tabular}{|c|c|c|c|}
\hline \multicolumn{4}{|c|}{$\begin{array}{c}\text { La experiencia de Gobierno que tiene Adolfo Suárez hace que sea el único líder de la oposición } \\
\text { preparado para gobernar }\end{array}$} \\
\hline & & Julio 1987 & Abril 1988 \\
\hline Más 1 & cuerdo & 31 & 40 \\
\hline Más 1 & esacuerdo & 44 & 29 \\
\hline No $s$ & ntesta & 25 & 31 \\
\hline \multicolumn{4}{|c|}{ En función del recuerdo de voto en 1986 (abril 1988) } \\
\hline & Más bien de acuerdo & Más bien en desacuerdo & No sabe/no contesta \\
\hline AP & 30 & 53 & 17 \\
\hline CDS & 84 & 9 & 6 \\
\hline
\end{tabular}

${ }^{14}$ Editorial: "Después del debate", $A B C, 26$ de febrero de 1988.

${ }^{15}$ OICDS, 10, marzo 1988.

${ }^{16}$ Una encuesta de EMOPÚBLICA encargada por Diario 16 otorgaba al CDS un $17 \%$ en intención de voto gracias al debate y volvía a situar a Suárez $(6,08)$ por encima de González $(5,76)$, en los índices de popularidad, Diario 16, 28 de febrero de 1988. La serie obtenida gracias a las encuestas del CIS realizadas entre julio de 1987 y abril de 1988 situaba a Suárez como el segundo político más valorado aproximadamente a un punto de distancia de Felipe González. En abril de 1988, las encuestas otorgaban: 6,0 (Felipe González) y 5,1 (Adolfo Suárez), CIS: “Datos de opinión”, REIS, 42, 1988, p. 267. 


\begin{tabular}{|l|l|l|l|}
\hline IU & $\mathbf{3 1}$ & 51 & 19 \\
\hline PSOE & $\mathbf{4 4}$ & 28 & 28 \\
\hline PNV & $\mathbf{5 0}$ & 19 & 31 \\
\hline CiU & $\mathbf{4 2}$ & 33 & 25 \\
\hline
\end{tabular}

Elaboración propia a partir del CIS: "Datos de opinión”, REIS, 42, 1988, p. 253.

Únicamente La Vanguardia rebajaba el optimismo centrista y alertaba sobre las sombras de su discurso. Sin dudar de la "gallardía" del abulense, presentándose como aspirante a una futura mayoría absoluta, recordó que la interminable polémica sobre su desempeño presidencial: "lastró lo que hubiera resultado prometedor de concentrarse más en el futuro" ${ }^{17}$. Y lo que es más importante, ¿eran su discurso sobre defensa o política exterior -“resonancia antiamericana”-, sus mejores bazas para la constitución de una alternativa política amplia liberal? La Vanguardia planteaba con precisión dos preguntas: ¿las pretensiones de alternativa del CDS no chocaban con un discurso que debía comenzar a orientarse hacia el electorado de centro-derecha con mayor claridad? $\mathrm{Y}$ en segundo lugar, ¿era un pasado solitario -sin partido, ni instituciones que lo defendieran- crédito suficiente para presentarse como opción de futuro? El CDS seguía su estrategia según el camino trazado, con la vista puesta en 1990. Aunque para algunos, como el ex secretario general de Alianza Popular, Jorge Versrtynge, simplemente no veía "que AP estaba al borde del precipicio y que hubiera podido repetir la operación de 1976-1977 de tener a la derecha "cautiva",18.

\section{2. Las elecciones catalanas de 1988. La política autonómica del CDS (1988-1993)}

El 29 de mayo de 1988 se celebraron las elecciones autonómicas de Cataluña. El candidato designado por el CDS fue Antoni Fernández Teixidó, Presidente Federal del CDS-Cataluña. Junto a él encabezaron las listas Pere Roselló, vinculado al mundo agrario ilerdense y antiguo miembro de CC-UCD que junto a Manuel de Sárraga había forjado el CDS en Lérida, Lluis Badía, también antiguo militante de CC-UCD en el

\footnotetext{
${ }^{17}$ Editorial: "El debate y los problemas pendientes" La Vanguardia, 25 de febrero de 1988.

${ }^{18}$ VERSTRYNGE, J.: Memorias..., p. 291. Una opinión compartida también por José María Aznar quien enmarcando la escena en 1988 señala que "si Adolfo Suárez hubiera querido aprovechar la ocasión en las Cortes, es posible que la historia reciente de España fuera ahora muy distinta", AZNAR, J. M.: Retratos y perfiles: de Fraga a Bush, Barcelona, Planeta, 2005, pp. 62-3. La reconstitución del liderazgo en AP desde el Congreso de Refundación "abortó toda posibilidad de llegada de Suárez como líder renovado del centro-derecha”, en SARASQUETA, Antxón: La agonía..., p. 140. Si pactaba con el PP perdía su eco centro-izquierdista y si no pactaba, la derecha iba a volver a tomar la iniciativa, JIMÉNEZ LOSANTOS, Federico: "La encrucijada ducal", $A B C, 24$ de enero de 1989.
} 
CDS desde 1982 y Pere Lladó, que recaló en la formación en el CDS gerundense en 1985. En general, en Cataluña antes de la constitución del primer Congreso Federal (abril, 1987) el partido apenas poseía medios humanos y técnicos. En el Bulletí d' Informació i Difusió [CDS Cataluña, 1987] se reconocía: “el CDS es un partit que ha emergit a Catalunya des de fa pocs mesos" ${ }^{\prime 19}$. De cara a las Autonómicas y con objeto de relanzar al partido, se produjo la visita de dirigentes nacionales -Adolfo Suárez ${ }^{20}$, José Ramón Caso, Agustín Rodríguez Sahagún o Carlos Sánchez-Reyes-, de cargos electos y se organizaron a contrarreloj actividades de formación -"Escuela de Cuadros", celebrada 24 y 25 de julio en Barcelona ${ }^{21}$, conferencias sobre política autonómica, juventud, etc.--

El objetivo del CDS para las elecciones de 1988 era la consecución de Grupo Parlamentario, como parecían ratificar las primeras encuestas durante la precampaña ${ }^{22}$, aunque las expectativas se redujeron a una cifra de 2 o 3 escaños en los últimos días de campaña $^{23}$. Sin duda, la aparición del CDS y el posible fin de la mayoría absoluta de $\mathrm{CiU}$ eran una de las principales claves de las elecciones ${ }^{24}$.

El recuerdo de la Operación Roca hizo emerger declaraciones sobre el papel del CDS en el futuro nacional y el centro político, que para Jordi Pujol -no así para Miquel Roca-, todavía podía pasar por Suárez ${ }^{25}$, mientras el CDS se mantenía abierto a posibles acuerdos para la gobernabilidad de Cataluña, tanto con CiU como el PSC ${ }^{26}$. Para medios como $A B C$, nuevamente, la contienda se planteaba como una batalla entre el centroderecha y el $\operatorname{PSOE}^{27}$. En cualquier caso, en base a la experiencia de 1987, Jaime Campmany señalaba: "cuando el duque salta, [Fes el salt, slogan de la campaña] luego no hacen saltar a los socialistas. Y para ese viaje no necesitamos alforjas" ${ }^{28}$.

\footnotetext{
${ }^{19}$ Bulletí d'Informació i Difusió, (CDS-Cataluña), 3, mayo 1987.

20 Descrito con detalles en el Boletín Nacional, que incluía una reveladora apreciación: "El Presidente llegó a sorprenderse del alto nivel de militancia y de entusiasmo que respira la región", OICDS, 9, diciembre 1987.

${ }^{21}$ Política Económica, Política Municipal, Organización, Estrategia y Nacional.

22 "Crece el CDS en Cataluña”, Tiempo, 14 de marzo de 1988. Una recopilación de sondeos realizada por el partido, entre enero y abril de 1988, le otorgaba desde 1 a 5 escaños, OICDS, 13, mayo 1988.

${ }^{23}$ El País, 22 de mayo de 1988.

${ }^{24}$ Editorial: "Elecciones en Cataluña", El País, 08 de mayo de 1988.

${ }^{25}$ Editorial: "Dos vías para Convergencia", Periódico de Catalunya, 16 de julio de 1987.

${ }^{26}$ Diario 16, 06 de marzo de 1988.

${ }^{27}$ Con el titular, "En vísperas de la tercera derrota socialista”, comentaba: "AP y CDS, tienen en juego -si no su futuro- si su prestigio nacional", $A B C, 27$ de mayo de 1988

${ }^{28}$ CAMPMANY, Jaime: "El salto de Suárez", ABC, 13 de mayo de 1988.
} 
La campaña, en la que estuvo presente Suárez, fue en general bastante descafeinada, y se dirigió fundamentalmente a criticar la política del Gobierno de Felipe González. El CDS ocupaba una posición absolutamente marginal, frente a la rivalidad CiU-PSC. Como en otras ocasiones, se vertieron duras críticas contra el uso partidario de RTVE y TV-3 durante la campaña. Eso sí, recuerda Xavier Latorre que la campaña ya era sustancialmente distinta de lo acaecido el año anterior. Contó con la implicación absoluta de Adolfo Suárez -“él veía que si no teníamos una implantación en Cataluña no había nada que hacer"-, y del partido -hubo una financiación de más de 400 millones de pesetas- y llegaron más de mil afiliados de toda España para cubrir los puestos de interventores en las mesas electorales.

Los resultados, aunque no le permitían formar un grupo parlamentario, cumplían las expectativas al obtener tres diputados (103.000 votos) y sobre todo mantener la tendencia alcista en un terreno tan complicado como Cataluña: "Objetivo cumplido [...] Mientras las otras fuerzas políticas retroceden, CDS es el único partido en alza" ${ }^{29}$. El CDS obtenía sus mejores resultados a costa del PSOE en el cinturón industrial de Barcelona, a lo que había que sumar "el voto centrista no nacionalista que en 1984 se había refugiado en AP [que perdía casi un tercio de su electorado]" debido a la incomparecencia del CDS. Quizá, como comentaban algunos analistas como Luisa Palma, los resultados fueran más aceptables para el Comité nacional que en la sede de Barcelona, ya que el CDS había quedado como "fuerza testimonial"30. Por su parte, Jordi Pujol, al frente de CiU ratificaba a pesar de un ligero retroceso, la mayoría absoluta conseguida en 1984 en Cataluña.

Las labores parlamentarias del CDS en Cataluña se concentraron en el trabajo de Juan José Toribio y Xavier Latorre que participaron en 12 comisiones cada uno, mientras A. Fernández Teixidó se centraba en los principales debates: presupuestos y política general. Además, existía un grupo de apoyo parlamentario -cuatro o cinco personas- y dos empleados fijos al servicio de los diputados suaristas. En 1989, el CDS se pudo constituir como Agrupación Parlamentaria merced a un pacto con $\mathrm{CiU}$ en la ciudad de Tarragona que desbancó al alcalde socialista, un hecho que se había

\footnotetext{
${ }^{29}$ OICDS, 14, junio-julio 1988.

${ }^{30} A B C, 31$ de junio de 1988. Idéntica postura en el editorial: "Tercera victoria", El País, 30 de mayo de 1988. Lorenzo Contreras subrayaba que el "centro está sólidamente" ocupado por CiU y el CDS no podía crecer más en Cataluña. Para Ignacio Romero de Solís el CDS había surgido "sin la fuerza esperada", respectivamente en CONTRERAS, Lorenzo: "Derrota del españolismo", $A B C, 31$ de mayo de 1988 y ROMERO DE SOLÍS, Ignacio: "Las elecciones catalanas", $A B C, 31$ de mayo de 1988.
} 
convertido en una auténtica necesidad desde el momento en el que los miembros del PCC se escindieron de IC y pasaron a integrarse en el Grupo Mixto compartiendo espacio, gastos y tiempos de intervención. En 1990, Latorre se convirtió en nuevo Presidente Federal (III Congreso) tras la designación como portavoz nacional del partido de Fernández Teixidó. Para Xavier Latorre:

Nosotros hicimos un trabajo parlamentario que visto desde la perspectiva de 20 años, fue un tremendo error. Nosotros teníamos una necesidad de aparecer en los medios de comunicación. Si no apareces en los medios de comunicación, si no tienes presencia en la sociedad, no eres nadie. [...] Nos volcamos de forma extenuante en la tarea parlamentaria y eso fue un error [Xavier Latorre realizó 7.300 preguntas parlamentarias en la Legislatura].

Siguiendo el relato de Latorre, hubiera sido más efectivo, de acuerdo con los medios de que disponían haberse centrado en aquellos mensajes en los que el discurso del CDS estaba más diferenciado y tenía más acogida: medio ambiente, políticas sociales y redimensionamiento de la administración ${ }^{31}$.

En cualquier caso, el CDS creció exponencialmente en este período en Cataluña, llegando a contar con algunos liberados para trabajar en la gestión del partido y una autonomía financiera conseguida gracias a la representación parlamentaria. En términos de militancia:

Tabla 71: Evolución de la militancia catalana (1986-1989).

\begin{tabular}{|l|l|l|l|l|}
\hline & Sept. 1986 & Abril 1987 & Diciembre 1989 & Crecimiento \% \\
\hline Gerona & 72 & 157 & 488 & 6,8 \\
\hline Barcelona & 382 & 770 & 1969 & 5,1 \\
\hline Lérida & 141 & 175 & 262 & 1,8 \\
\hline Tarragona & 101 & 134 & 316 & 3,1 \\
\hline Cataluña & 696 & 1236 & 3035 & 4,4 \\
\hline
\end{tabular}

Elaboración propia a partir de CDS: Líneas de Acción...

Las nuevas responsabilidades políticas del CDS exigieron una redefinición de su postura en materia autonómica que se concretó en la Convención Nacional sobre el Estado de las Autonomías celebrada en Barcelona en 1988 porque "las razones que dieron nacimiento al Estado de las Autonomías deben convertirse ahora en la

\footnotetext{
${ }^{31}$ El CDS propuso, sin éxito y con los votos en contra de CiU la creación de una Consejería de Medio Ambiente.Unos meses después dicha iniciativa fue culminada con éxito por CiU, que negaba así protagonismo al CDS y daba salida a dos problemas de envergadura que habían afectado a la Generalitat relativos a la Gestión de Residuos y las Cuencas Hidrográficas, Entrevista con Xavier Latorre, 14 de julio de 2014.
} 
justificación permanente de su existencia mediante su práctica" ${ }^{32}$. Ahora, la posibilidad de reformas estatutarias para aquellas comunidades que habían transitado por la llamada "vía lenta", iba a centrar buena parte de los debates sobre la cuestión autonómica a finales de la década de los 80 ' y comienzos de la siguiente.

En esta época hubo una breve polémica a raíz de unas manifestaciones del PSC favorables a un debate sobre el estado federal, antes del Debate sobre el Estado de las Autonomías que iba a tener lugar en el senado en diciembre de 1987. Dicha opción fue rechazada por el CDS, desde donde se resaltó el éxito que supuso la aprobación del Estatut de Sau durante la Transición ${ }^{33}$, que lo volvió a reivindicar en el debate de investidura de Jordi Pujol como presidente, solo dos semanas después de la muerte de Josep Tarradellas ${ }^{34}$. El CDS rechazaba modificar el actual modelo de financiación autonómica -"Cataluña al frente, ejemplo de solidaridad"35 - y señalaba que la Comunidad debía recobrar el protagonismo que un día tuvo en la política nacional. El coordinador del Programa Electoral había sido Joaquim Trigo, miembro de la patronal catalana $^{36}$.

En 1988, se cumplía el plazo previsto en la Constitución para que el conjunto de comunidades autónomas pudiesen reformar sus estatutos, y de este modo, ampliar sus competencias, una posibilidad apoyada plenamente por el CDS, tal y como manifestó Adolfo Suárez en el debate de investidura parlamentario de 1989 con el objetivo de que pudieran: "conseguir una equiparación esencial entre todas las comunidades, sin perjuicio de que se respeten sus singularidades"37. En este marco, se consideraba preciso: igualar el techo competencial de todas las CC.AA. (sanidad, educación, trabajo) respetando las diferencias culturales y lingüísticas respectivas, la puesta en vigor de un sistema de financiación basado en el principio de solidaridad interregional, conseguir la

\footnotetext{
${ }^{32}$ OICDS, 13, mayo 1988.

${ }^{33}$ La Vanguardia, 08 de mayo de 1988.

${ }^{34}$ Asimismo, en palabras de su portavoz Fernández Teixidó, asumía como indiscutible "el carácter de Catalunya como nación”, aunque difería - del candidato de CiU-, en el modelo político que se debía colegir de dicha afirmación, OICDS, 14, junio-julio 1988. El CDS se abstuvo en la votación junto con AP. PSC, IC y ERC votaron en contra.

${ }^{35}$ Fes el salt [Programa CDS. Elecciones autonómicas], CDS, 1988, p. 3.

${ }^{36}$ Debats, 1, enero 1988.

${ }^{37}$ DSCD, Sesión Plenaria, 05 de diciembre de 1989, $\mathrm{n}^{\circ}$ 3, p. 89. "El artículo 148 de la Constitución establecía que, pasados cinco años desde la creación de las comunidades autónomas de vía lenta, éstas 'mediante la reforma de sus Estatutos [...] podrían ampliar sucesivamente sus competencias'. En 1988 se cumplió dicho plazo, contado a partir de la aprobación por las Cortes del último Estatuto, el de Castilla y León”, PELAZ LÓPEZ, José-Vidal: El estado de las autonomías: regionalismos y nacionalismos en la historia contemporánea de España, Madrid, Actas, 2002, p. 108.
} 
suficiencia financiera y la corresponsabilidad fiscal, la creación de mecanismos de coordinación entre las CC.AA. y las instituciones europeas o la modificación del Senado para convertirlo en una cámara territorial ${ }^{38}$.

Mediante la reforma estatutaria, la postura del CDS pretendía evitar la delegación de competencias por iniciativa exclusiva del ejecutivo, un planteamiento, que en 1988 guardaba a su vez una estrecha relación con su afianzamiento político y electoral en las CC.AA. de la llamada "vía lenta". Consciente de la necesidad de un gran pacto, no se ocultaba su intención de utilizar el desarrollo autonómico como un arma de desgaste contra el partido en el gobierno, el PSOE:

La naturaleza de estos objetivos demanda un pacto político [...] Corresponde al Gobierno y al partido mayoritario tomar la iniciativa. Si no lo hace, será responsable de las consecuencias que produzca un proceso de reforma estatutaria que, amparado como derecho por la Constitución, debería desarrollarse en un marco global ${ }^{39}$.

Sin embargo, hacia 1989 la estrategia del CDS comenzó a tambalearse: existían muchas dificultades en los gobiernos de coalición -Canarias y Castilla y León-, y se instaló en el partido una sensación de declive irreversible tras las elecciones europeas de junio. En Canarias, si algunas polémicas como la renegociación de su estatus económico y fiscal en la CEE sirvieron para profundizar en un discurso regionalista y lanzar un órdago al gobierno central, la polémica universitaria entre Tenerife y Gran Canaria sumió en una profunda crisis al grupo centrista en función de las rivalidades interinsulares. El 16 de diciembre de 1988, Fernando Fernández, ex presidente de Canarias tras perder una moción de confianza parlamentaria -siendo sustituido por Lorenzo Olarte-, abandonaba el CDS arrastrando en los meses siguientes a buena parte de la militancia centrista en la isla Tenerife donde fue necesario formar una Gestora Provisional $^{40}$. Paradójicamente, habían sido esas mismas rivalidades interinsulares las que habían posibilitado en buena medida el afianzamiento de los suaristas en dicha comunidad $^{41}$.

\footnotetext{
${ }^{38}$ Otros aspectos: la elaboración de los estatutos de Ceuta y Melilla, la asunción de la ejecución de la legislación del estado salvo en cuestiones específicas y la evitación de cualquier duplicidad así como la “dominación” por parte de la Administración Central, OICDS, 13, mayo 1988.

${ }^{39}$ Ibid. "El regionalismo se convertía también en un marco cognitivo de gran eficacia instrumental para ser usado por los partidos políticos situados en la oposición al Gobierno central: el conflicto territorial y el agravio comparativo ofrecían réditos inmediatos y costes prácticamente nulos”, NUÑEZ SEIJAS, Xosé M.: "La cuestión nacional...", p. 113.

40 A comienzos de 1989, Olarte era Presidente del Comité Insular de Gran Canaria y Fernández del de Tenerife, así como Presidente Federal.

${ }^{41}$ El debate sobre el Estatuto de Autonomía de Canarias había generado un intenso debate en el seno de la UCD. Según Baez García: “[UCD] actuó en las islas dividida [...] grancanaria y tinerfeña, diferenciadas internamente, además en corrientes de componentes ideológicos distintos [...] [estos grupos] mantuvieron
} 
La impotencia del CDS para protagonizar los grandes debates políticos nacionales crecía a medida que se consumaba el ascenso del Partido Popular cuya fuerza negociadora con el ejecutivo socialista era muy superior. El CDS quedaba relegado a posicionamientos testimoniales sobre reformas estatutarias a nivel autonómico y estatal, — como sucedió en Castilla y León ${ }^{42}$, Asturias o en el Senado ${ }^{43}$ — o saltaba a primeras planas debido a algunos excesos dialécticos. Sucedió así en pleno debate político sobre el federalismo a finales de 1987, “el Estado de las autonomías va más lejos que un Estado federal” ${ }^{, 4}$, o durante la eclosión independentista en las repúblicas bálticas ${ }^{45}$.

En 1992, ya sin su fundador, con sólo 18 diputados autonómicos, —repartidos entre Aragón, Asturias, Cataluña, y sobre todo, Castilla y León y Canarias-, y al margen de los segundos pactos autonómicos de la democracia ${ }^{46}$, alzó la voz contra la Ley Orgánica de Transferencia de Competencias a las Comunidades del Artículo 143 por vulnerar el "principio de autonomía" de los entes territoriales ${ }^{47}$.

En cualquier caso, la preocupación por la viabilidad de la estructuración territorial de España propuesta en el Estado de las Autonomías fue una constante básica y

entre sí un incesante enfrentamiento, recíproco, y en algunos momentos, [...] llegaron a actuar como dos partidos distintos entre sí y también respecto a Madrid", cuando se produjo el declive del partido a lo largo de 1982, los dirigentes insulares pudieron hacer arraigar con facilidad sus futuras opciones políticas sólo en sus ámbitos territoriales. Lorenzo Olarte, el "hombre de Suárez" en Canarias, se integró en el CDS y con buena parte de la UCD en la provincia de Las Palmas. En Tenerife sin embargo, la dirección del partido a cargo de Galván Bello optó por formar una fuerza regionalista -Agrupación Tinerfeña Independiente (ATI) -, BAEZ GARCÍA, Alberto Javier: Una historia de Coalición Canaria ..., pp. 44-5.

42 "Las Cortes de Castilla y León, a favor de la reforma del estatuto", El País, 26 de mayo de 1988. Hubo, asimismo, posicionamientos en esta línea en otras comunidades: "Los grupos de oposición de las Cortes valencianas pretenden reformar el estatuto de autonomía", El País, 30 de noviembre de1988.

43 "Todos los grupos de la oposición del Senado se mostraron ayer favorables a instar al Gobierno para que permita la reforma de los Estatutos de autonomía de las Comunidades que accedieron al autogobierno por la vía del artículo 143 de la Constitución”, $A B C, 09$ de febrero de 1989.

44 Diario 16, 25 de noviembre de 1987. Tanto Adolfo Suárez como José Ramón Caso se mostraron contrarios a la reforma constitucional que implicaba el diseño de un estado federal aludiendo a las potencialidades del Estado Autonómico. Desde una perspectiva histórica, el centrista Raúl Morodo subrayaba las vinculaciones ideológicas del federalismo y sus posibles consecuencias en el panorama político nacional en "Federalismo español, algunas reflexiones críticas", El País, 22 de septiembre de 1989.

${ }^{45}$ El CDS votó a favor de una proclama sobre el "derecho de autodeterminación" en el Parlamento de Cataluña, aunque matizó que su partido apoya el avance del auto-gobierno de Cataluña, pero "lejos de toda tentación auto-determinista", El País, 14 de diciembre de 1989.

${ }^{46}$ José Ramón Caso señalaba tres razones por las que no los habían suscrito: el desigual proceso de transferencia de competencias, la inexistencia de mecanismo de control del déficit en las autonomías y el hecho de que no se hubieran sacado adelante los estatutos de Ceuta y Melilla, DSCD, Sesión Plenaria, 24 de marzo de 1992, n 175, p. 8621. En el Senado, el CDS presentó dos proposiciones de ley orgánicas para desarrollar los Estatutos de Autonomía de Ceuta y Melilla que no fueron "tomadas en consideración", Boletín Oficial de las Cortes Generales (BOCG), Senado, serie III A, 06 de marzo de $1990, \mathrm{n}^{\circ} 5$.

${ }^{47}$ RUIZ-HUERTA CARBONELL, Alejandro: "Los acuerdos autonómicos de 28 de febrero de 1992: ¿Una alternativa constitucional adecuada?”, Revista de Estudios Políticos, 81, julio-septiembre 1993. 
permanente en la mentalidad política de Suárez. En el ocaso de su vida pública, todavía mostraba su preocupación sobre el futuro del modelo que tanto había contribuido a construir:

Las autonomías constituyen la estructura básica del Estado. Eso no puede discutirse. Ocurre que las reivindicaciones de los nacionalismos, cuando son extremos, tensan la vida política y sobresaltan y disgustan a un buen número de ciudadanos. Hay que acostumbrarse a vivir con los problemas reales, no con los sueños de perfección. La pluralidad de los pueblos que integran España es un dato de la realidad que no se puede controvertir. Pero eso no puede utilizarse como arma política por los nacionalismos. Como no puede utilizarse la realidad de la unidad de España para desconocer la singularidad de nuestros pueblos y su derecho a un autogobierno pleno ${ }^{48}$.

\section{3. El 14-D y la contestación sindical al Gobierno}

Durante la celebración del "X Aniversario de la Constitución", en uno de los seminarios de verano organizados por la Universidad Complutense de Madrid en El Escorial, intervino cerrando el acto Alfonso Guerra. En el turno de preguntas, que en general venían a subrayar o confirmar lo dicho anteriormente por el político sevillano, intervino el miembro del CDS-Madrid, José Antonio Pérez González. El militante centrista sintetizó en su intervención algunas de las críticas vertidas por los suaristas hacia el PSOE durante la III Legislatura, apelando al retroceso sufrido por cuatro puntales del sistema democrático: la participación, la formación, la asunción de principios morales y el control del poder. Curiosamente, recibió el aplauso de un auditorio en principio complaciente con la intervención de Alfonso Guerra y que quizá, estaba esperando una ocasión como ésta a modo de desquite. Pérez González, que hasta ese momento había permanecido relegado en un segundo plano en la Federación Madrid -a la cual, había presentado sin éxito su candidatura en 1983 frente a Carlos Revilla-, fue "rehabilitado" políticamente en el seno del partido recibiendo la felicitación personal de Adolfo Suárez y de todo el Comité Nacional. La noticia fue recogida por los principales medios de comunicación desafectos al Gobierno ${ }^{49}$.

La crítica a la hegemonía socialista y el retroceso en materia de libertades y derechos constituyó la esencia del discurso de oposición del CDS, en marcado contraste con las

\footnotetext{
48 "Nota sobre 20 años de transición. Retos", Dossier 11, Archivador, ENA.

${ }^{49}$ LÓPEZ ALBA, G.: "Salva de pitos a Alfonso Guerra en El Escorial cuando ensalzaba los logros del Gobierno", $A B C, 06$ de agosto de 1988. Véase también, Ya, 16 de agosto de 1988. Basado en entrevista con José Antonio Pérez González, 23 de mayo de 2014.
} 
dificultades que encontraron los suaristas a la hora de posicionarse con los sectores sociales más castigados por las políticas de ajuste económico. En este sentido, el 14-D significó el último envite.

La convocatoria de Huelga General por los sindicatos mayoritarios a raíz de la aprobación del Plan de Empleo Juvenil ponía una vez más a prueba la estrategia del CDS y de Adolfo Suárez en su intento por atraerse parte del electorado socialista, a la par que ponía en evidencia las dificultades de la oposición para articular una contestación política al Gobierno $^{50}$. Y es que, desde la II Legislatura, en temas tan opuestos como la oposición a la OTAN, en el caso de la izquierda, o la LODE y la despenalización del aborto, en el de derecha, la iniciativa parecía corresponder a los actores sociales en lugar de a los partidos políticos ${ }^{51}$.

El 14-D se convirtió rápidamente en un símbolo que sobrepasó las reivindicaciones estrictamente laborales y como ha señalado Redero San Román "no sólo movilizó a los trabajadores sino a la inmensa mayoría de los ciudadanos" ${ }^{\text {"5 }}$. También suponía el definitivo ocaso de la concertación socio-económica -aspecto ya advertido por Rodríguez Sahagún en el Congreso-, es decir, de "los grandes acuerdos sobre la evolución de las rentas" inaugurados durante la Transición ${ }^{53}$.

Desde el primer momento, Sahagún o Caso manifestaron "comprender" las razones de los sindicatos, a los que manifestaban su "solidaridad". Entendían -aunque no respaldaban- la huelga como una "consecuencia de la política antisocial del Gobierno" y la ausencia de diálogo ${ }^{54}$. Caso señaló que "ni recomienda, ni prohíbe" el apoyo a la convocatoria: "respetamos el derecho a la huelga, respaldamos la autonomía de los

\footnotetext{
50 "PCE y CDS quieren adelantar al PSOE por la izquierda [Doble página] $A B C, 16$ de octubre de 1988. Las juventudes del CDS participaron en algunas plataformas de oposición al PEJ, $A B C$, 29de octubre de 1988 y ABC Sevilla, 10 de noviembre de 1988, El País, 27 de noviembre de 1988.

${ }^{51}$ Editorial: "Una huelga política", El País, 14 de noviembre de 1988.

52 REDERO SAN ROMÁN, Manuel: "Los sindicatos en la democracia: de la movilización a la gestión", Historia y Política, 20, julio-diciembre 2008, pp. 145-6.

53 ESPINA, Álvaro: Empleo, democracia y relaciones industriales en España, Madrid, Ministerio de Trabajo y Seguridad Social, 1990, p. 314.

${ }^{54} \mathrm{La}$ "Interpelación urgente sobre el Plan de Empleo Juvenil" presentada por el PNV el 08 de noviembre permitió al CDS fijar su posición al respecto. El diputado del CDS J. M. Rioboo Almanzor criticó el Plan de Empleo por ser más bien de "aprendizaje", no contar los empleados con los mismos derechos laborales que el resto de trabajadores y no estar integrado en un plan de lucha contra el paro más amplio. Lo consideraba un plan de "paro por relevos" que beneficiaba fundamentalmente a la patronal y a la banca se preguntaba si los beneficios empresariales iban a ir destinados a la creación de puestos de empleo fijos- y en última instancia al Gobierno para maquillar las cifras de desempleo. Concluía solicitando la revisión del mismo por el bien de la "sociedad española" y sobre todo de las "clases más perjudicadas", DSCD, Sesión Plenaria, 16 de noviembre de 1988, n 147 , pp. 8639-8640.
} 
sindicatos respecto a la acción política sin criterio" ${ }^{\text {". La }}$. La posición del CDS nuevamente, parecía querer decir más de lo que textualmente defendía y Suárez hizo escasas declaraciones al respecto, defendiendo en todo caso la legitimidad de la convocatoria y criticando la ausencia de diálogo por parte del Gobierno ${ }^{56}$. El CDS se mostraba notablemente más ambiguo que AP, que no dejaba de señalar por ello la responsabilidad del Gobierno y Minoría Catalana (MC), que se había mostrado favorable en todo momento al Plan de Empleo Juvenil. En diciembre, los suaristas votaron a favor de una "proposición" de $\mathrm{MC}$, que con carácter de urgencia intentaba restablecer el diálogo entre Gobierno, empresarios y sindicatos - rechazada en su tramitación por IU y EE- e intentar así desconvocar el paro general ${ }^{57}$. Como remarcó la prensa, el 14-D junto con el PSOE y el centro-derecha, los parlamentarios suaristas hicieron acto de presencia en el Congreso, invitando a sus militantes a "cumplir con su obligación". Para Diario 16, Suárez reproducía la ambigüedad demostrada a propósito del referéndum de la OTAN y glosaba la información al respecto con el antetítulo, "no se ha definido"

El Comité Nacional del CDS se reunió el día 16 de diciembre para valorar las implicaciones del conflicto sindical -oscilando entre reanudar el diálogo y "atender las reivindicaciones sindicales" 59 -, sin embargo, lo que realmente estaba en juego era el liderazgo de la oposición. El 21 de diciembre tuvo lugar la comparecencia del Presidente de Gobierno sobre el desarrollo de la jornada de huelga y la ausencia de Hernández Mancha, quien no ostentaba la condición de diputado, volvió permitir a Adolfo Suárez atraer sobre sí los focos de los medios y ejercer como referente de toda la oposición $^{60}$.

Suárez apuntó en primer lugar, que era la última consecuencia de un estilo de gobernar caracterizado por la ausencia de diálogo y sensibilidad social: "desde hace

\footnotetext{
${ }^{55}$ El País, 27 de noviembre de 1988.

${ }^{56}$ El Independiente, 18 de noviembre de 1989 y El País, 06 de diciembre de 1989, citados en SUÁREZ GONZÁlEZ, A.: "Entre la coherencia y el desgarro", El País, 29 de diciembre de 1989. Aunque la relación con la prensa no fuera muy fluida ni sus apariciones frecuentes, sus "silencios" se convirtieron en un cliché periodístico de uso recurrente, cuando no sistemático, DÁVILA, Carlos: "El inextricable silencio de Suárez", Diario 16, 07 de noviembre de 1988; "Adolfo Suárez, esperando agazapado su oportunidad" en ROMERO DE SOLÍS, I.: "Huelga General Política", ABC Sevilla, 02 de diciembre de 1988, etc.

${ }^{57}$ El País, 01 de diciembre de 1988.

${ }^{58}$ Diario 16, 03 de diciembre de 1988.

59 ABC, 18 de diciembre de 1988. Las reivindicaciones sindicales, junto a medidas para el fomento del diálogo social fueron presentadas en una moción durante el Debate sobre el Estado de la Nación de 1989; moción que fue rechazada, OICDS, 19, marzo 1989.

${ }^{60}$ Comparecencia del Gobierno para informar sobre el desarrollo de la jornada del día 14 de diciembre de 1988, DSCD, Sesión Plenaria, 21 de diciembre de 1988, nº 162.
} 
mucho tiempo viene usted echando un pulso permanente a la sociedad, y el día 14 lo ha perdido"61. En el 14-D convergían las legítimas reivindicaciones sindicales, "para compensar los años de sacrificio que ejemplarmente asumieron entre 1977 y 1985" y una reacción generalizada contra el ejercicio del poder socialista. Las soluciones exigidas por Suárez pasaban por la "retirada" de los Presupuestos Generales y si "no cree en la necesidad de una política social distinta" por la convocatoria de "elecciones generales inmediatas" de la huelga. En la parte final de su intervención, recorrió y suscribió una a una todas las medidas reclamadas por los sindicatos: subidas salariales (funcionariado) y de pensiones para contrarrestar el impacto de la inflación, el criterio en favor de la negociación colectiva por parte de los funcionarios ${ }^{63}$, la equiparación de los niveles mínimos de pensiones con el Salario Mínimo Interprofesional-, la extensión de la cobertura de desempleo y en relación al contrato de empleo juvenil: "[mi Grupo] ha expuesto su opinión sobre la dudosa constitucionalidad y los riesgos que conlleva para la creación de puestos estables el llamado contrato de inserción"

El Presidente de Gobierno, con el fin de subrayar las contradicciones del discurso del CDS y tras resaltar las concordancias entre las demandas de Suárez y las exigidas por los sindicatos indicaba: "Me parece que es interesante que cada uno vaya colocándose en la posición que desea colocarse [...] Es bueno que ese proceso de clarificación parlamentaria se vaya produciendo, porque también se producirá en el conjunto de la sociedad"65. Diversas figuras de la izquierda española intentaron descalificar la actitud de Suárez interpretando sus palabras como electoralistas y oportunistas. Solé Turá ironizaba sobre la "autoproclamación" de Suárez como "líder de los huelguistas",66 más aun cuando había permanecido "mudo" antes del 14-D. En febrero, en el Debate sobre el Estado de la Nación Nicolás Sartorius (IU) manifestó con ironía: "Otros lo hicieron

\footnotetext{
${ }^{61}$ Ibid., p. 9654. Marcaba distancias con los líderes conservadores que habían utilizado con sordina el mismo término para referirse a la huelga: J. A. Segurado la tildaba de "desproporcional" y el portavoz de la DC, J. Rupérez junto al de AP, J. R. Calero, de "desproporcionada".

${ }^{62}$ Ibid., p. 9655.

${ }^{63}$ En la defensa de enmiendas al Proyecto de Ley de órganos de representación, determinación de las condiciones de trabajo y participación del personal al servicio de las administraciones públicas, el CDS ya había aludido a las restricciones en materia de derechos sindicales sobre los funcionarios y había denunciado el perjuicio que suponía para la participación de los sindicatos minoritarios, DSCD, Sesión Plenaria, 05 de marzo de 1987, $\mathrm{n}^{\circ} 35$, pp. 2037-2039.

${ }^{64}$ Los sindicatos exigían: la retirada del PEJ, pensiones dignas, mejoras salariales, más cobertura de desempleo y un cambio en la política económica para atenuar las desigualdades, El País, 13 de noviembre de 1988.

${ }^{65}$ DSCD, Sesión Plenaria, 21 de diciembre de 1988, no 162, p. 9662.

${ }^{66}$ SOLÉ TURÁ, Jordi: “Partidos y sindicatos, después del 14-D”, El País, 30 de enero de 1989.
} 
[pedir la disolución de las Cámaras], precipitadamente, a nuestro juicio, dando a entender que estaban dispuestos a ser generales de una infantería que posiblemente no desea ser mandada por tales generales; mas cada cual con su visión de las cosas" ${ }^{\prime 67}$.

El País dedicaba un duro editorial a lo que consideraba, sempiternas indefiniciones del $\operatorname{CDS}^{68}$, que había hecho igual que durante la OTAN y que se había apuntado al “carro" del éxito del 14-D. Para El País era improbable que obtuviera "réditos electorales" de estas actitudes pragmáticas y oportunistas: “Como todo seductor, Suárez tiene más capacidad para conquistar que para retener los afectos" ${ }^{\prime 69}$. El editorial recibió la contestación del propio Suárez, quien señaló que había sido escrito bajo las órdenes del gobierno, en un polémico artículo publicado en El País y del que se hicieron eco otros medios como $A B C^{70}$. Adolfo Suárez desmentía las acusaciones de El País "silencios", oportunismo- y abogaba por recuperar una iniciativa política de centroizquierda liderada por el CDS para poner fin al intento de monopolización de las instituciones por parte del PSOE ${ }^{71}$. Al debate público se sumaba también Raúl Morodo quien intentaba clarificar la posición del CDS, matizando que más que una identificación total con las demandas de los trabajadores -que por cierto, habían renunciado en su ejercicio del derecho a huelga a cualquier componente utópico o revolucionario-, se pedía una salida negociada, a la que también había sido esquivo el Gobierno.

Desde otra perspectiva, la posición del CDS tampoco era compartida por columnistas y editorialistas conservadores. El líder de la patronal, José María Cuevas, bromeó: "ha salido un nuevo líder de la izquierda en este país. Otra cosa es que los ciudadanos se lo crean"72. Celestino Fernández comentaba: "el que Suárez sea coherente supone ya una incoherencia". De la integración en la Internacional Liberal al 14-D o de la incorporación de Ramón Tamames a la de Íñigo Cavero sólo cabía concluir que la

\footnotetext{
${ }^{67}$ DSCD, Sesión Plenaria, 15 de febrero de 1989, $\mathrm{n}^{\text {o }} 167$, p. 9875.

${ }^{68}$ Una indefinición que consideraba estructural fruto de la división electorado: rural conservador y urbano socialdemócrata y radical, editorial: “Amagar y no dar”, El País, 27 de diciembre de 1988. El Programa Electoral de 1989 del CDS estaba por ejemplo más cerca de las propuestas del PSOE que de los sindicatos, en la línea de generar políticas de desempleo activas - que estimulasen la creación de puestos de trabajo-, en lugar de reforzar directamente las medidas de protección frente al desempleo, Manifiesto Electoral, CDS, 1989, p. 25.

${ }^{69}$ Editorial: “Amagar y no dar”, El País, 27 de diciembre de 1988.

${ }^{70} A B C, 30$ de diciembre de 1988.

${ }^{71}$ SUÁREZ GONZÁLEZ, A.: "Entre la coherencia y el desgarro", El País, 29 de diciembre de 1989.

${ }^{72} A B C, 23$ de diciembre de 1988.
} 
ideología de Suárez era "el suarezismo". Una confusa trayectoria que arrancaba años atrás:

El hombre que un día tuvo la oportunidad de democratizar a España -y lo hizo en grado aceptable- gracias a que un pasado reciente de falangismo y opuseísmo inspiraba confianza a un Consejo del Reino integrado por las familias del extinto sistema de Franco, ha hecho de la oportunidad, de su aprovechamiento, su única norma, sin criterio selectivo $[\ldots]$ oportunista $^{73}$.

Cuando a comienzos de febrero se produjo la ruptura definitiva de las conversaciones entre sindicatos y Gobierno, la actitud del CDS no varió ${ }^{74}$. Apoyaron, junto con AP e IU una iniciativa favorable a la comparecencia y comunicación parlamentaria de los sindicatos $^{75}$, y se abstuvieron en la convalidación del Decreto-Ley de Medidas Sociales de abril con el que se intentó reasignar algunas partidas presupuestarias en favor de los sectores más perjudicados por la crisis - con el apoyo del PSOE, PP, PNV y MC-. Rodríguez Sahagún señalaba que el Decreto-Ley era insuficiente y tardío, además de no haberse hecho ningún esfuerzo en la recuperación del "diálogo social”, que cómo había puesto de manifiesto la reciente historia de nuestra democracia no era incompatible con "la soberanía parlamentaria" " Con ironía, el filósofo Julio Cerón escribía en $A B C$ que existían dos "alianza inevitables", la de la derecha tradicional (PP) con la derecha moderna (PSOE) y la de IU con el $\mathrm{CDS}^{77}$.

El Debate sobre el Estado de la Nación celebrado en febrero de 1989 tuvo como protagonista fundamental los ecos del 14-D. El Presidente del CDS centró su discurso exclusivamente en aspectos socio-económicos y en el modo de gobierno del PSOE. Además, pidió elecciones anticipadas y corroboró el bloqueo de la situación política y social. Los turnos de réplica y contrarréplica desplazaron el debate hacia el terreno personal y de nuevo la mirada se trasladó a los años de la Transición.

Adolfo Suárez definía el "clima político" nacional como "enrarecido y confuso", una "situación" general condicionada fuertemente por la aplicación en exclusividad de

\footnotetext{
73 FERNÁNDEZ ORTIZ, C.: "Oportunidad y oportunismo", ABC Sevilla, 20 de febrero de 1989. Para López Sancho, el CDS esperaba su momento en base a la hipótesis de que los socialistas podían necesitar de un pacto con IU en las próximas elecciones, circunstancia que Suárez aprovecharía para pactar con el PSOE, en "La Parrala, personaje 1989”, $A B C, 10$ de enero de 1989.

74 Editorial: "Más que un fracaso", El País, 08 de febrero de 1989. Suárez en el Congreso del CDSGalicia manifestó que el crecimiento podía ser compatible con cierta "justicia redistributiva", $A B C, 13$ de marzo de 1989.

${ }^{75}$ El País, 17 de febrero de 1989.

${ }^{76}$ Votaron en contra EE, EA e IU, DSCD, Sesión Plenaria, 06 de abril de 1989, no 182, p. 10548.

${ }^{77}$ CERÓN, J.: "El delirio de la autorreferencia (I)", $A B C, 11$ de abril de 1989.
} 
políticas monetaristas, la regresión social, el bloqueo institucional y el deterioro de los servicios públicos, a lo que había que añadir, "un sentimiento creciente de que existe una corrupción generalizada" -sensación injusta, pero en todo caso real-. El 14-D no sólo había sido una contestación de los sindicatos a la política gubernamental, sino que había sido la respuesta general de la sociedad y de la ciudadanía frente a la nefasta situación en la que se encuentra la Administración, por acción u omisión del Gobierno y el fracaso de las reformas educativas y sanitarias. Y en una referencia al boom especulativo que vivía la economía nacional, indicó que el Gobierno no había sabido proteger la utilización del suelo en nombre del interés general ${ }^{78}$.

La visión patrimonialista del Estado de la que hacía gala el PSOE -“no sé si por 107 años"-, su escasa transparencia en el manejo de los Presupuestos o su introducción "en el poder económico y financiero [...] (Rumores)", no coadyuvaban al menos, a la mejora en la percepción de la realidad española. Para terminar, volvía sobre el 14-D y sus efectos a largo plazo, preguntándose qué podía suceder si el Gobierno tenía éxito en su pugna frente a las centrales sindicales, “¿sindicalismo asambleario?”, “¿entramados neocorporativos?", etc. La solución, como había defendido el 21 de diciembre pasaba por una nueva convocatoria electoral: "su proyecto de gobierno creo que está agotado".

Felipe González, en su intervención, contraatacaba señalando que el único objetivo de Suárez, más que el análisis de la situación general del país había sido la demanda de elecciones anticipadas, para a continuación, desactivar comparativamente los argumentos de Suárez: el año con más conflictividad social fue 1979, el único "decreto ley de fijación de rentas salarias y de pensiones" se aprobó en 1978 -a raíz de un fracaso en la concertación con los sindicatos- y la mayor caída de la cobertura de desempleo se produjo en 1980 -Ley Básica de Empleo-. Con sorna, en relación a la falta de control institucional señalaba: "no digo que era difícil conseguir que se sometiera usted a un control parlamentario mediante un debate, difícil no era, era imposible (Risas) ${ }^{, 79}$. Finalmente, insinuaba que en su discurso sobre la regresión social o la pobreza, quizá estaba ahora adoptando las posturas catastrofistas que antaño adoptasen otros [AP].

\footnotetext{
${ }^{78}$ Una de las mociones presentadas en el Debate, sin éxito, fue relativa a la "especulación del suelo". El resto hicieron referencia al diálogo social, al régimen económico-fiscal de Canarias -en el contexto de su adhesión a la CEE- y el desarrollo del Estatuto de RTVE, en favor de la pluralidad y la objetividad, OICDS, 19, marzo 1989.

${ }^{79}$ Comentarios que alcanzaron poco después a Rodríguez Sahagún, DSCD, Sesión Plenaria, 14 de febrero de $1989, n^{\circ} 166$.
} 
La réplica de Suárez comenzaba precisamente poniendo de manifiesto la constante de los últimos años en los debates entre ambos: "el señor González ha mezclado en su intervención, con habilidad, como siempre, el contenido de lo que he dicho hace un momento y la etapa en que yo era Presidente del Gobierno" ${ }^{\text {" }}$. Y las falacias que de este tipo de razonamiento se desprendían pues no se podía comparar la situación económica en ambos períodos, máxime si tenemos en cuenta la crisis petrolífera de 1979 y el descenso, de un día para otro, de la renta real de los españoles en 4 puntos. En la asignación de prioridades, crecimientos y redistribución, se valió de la obra del profesor Enrique Fuentes Quintana para la defensa de sus puntos de vista: "la primera prioridad de mis gobiernos [...] fue atender a los desempleados, la de sus Gobiernos [...] ha sido la de pagar los intereses de la deuda pública”. Más jocoso, con un “ay, madre mía” final, se mostró al considerar el ejercicio de control parlamentario en uno y otro período democrático. La contestación de Felipe González giró en torno al esquema anterior -con referencia al ex ministro y miembro del CDS, Pérez Miyares-, y adquirió el tono de una conversacional informal entre viejos amigos, ahora rivales, en la última intervención de Suárez: "dice usted que yo he cambiado mucho. Yo tengo la sensación de que usted ha cambiado mucho más" ${ }^{\prime 1}$.

En ese momento, abordando la polémica sobre el uso de la TV, Suárez recordó a Felipe González que en 1979 se emitió íntegro su discurso "que le entronizó en la vida política española" en el que dimitía como Secretario General del PSOE y abandonaba el marxismo. Finalmente, Felipe González puso la guinda a un debate cada vez más agrio y enconado que nada tenía que ver ya con el objetivo del evento:

Siempre lo pierde empezar con una frase y terminar con otra. Ha empezado con la frase de que yo soy Secretario General del Partido desde hace catorce años [...] y que usted ha sido Presidente de dos partidos en diez años. Bueno; en doce años Presidente de dos partidos y Secretario General de otro ${ }^{82}$.

Diario 16 destacaba el enfrentamiento entre Felipe González y Adolfo Suárez “escalada de reproches mutuos entre los dos grandes protagonistas de la transición” ${ }^{83}$ - y defendía, en su titular, la estrategia suarista: "González no ofrece ninguna nueva medida

\footnotetext{
${ }^{80}$ Ibid., p. 9847.

${ }^{81}$ Ibid., p. 9851

82 "Estos no son los términos del debate, pero comprenderá usted que tengo que responderle...". Sin éxito, Suárez pidió la palabra una última vez, ibid.

${ }^{83}$ Gallego \& Rey en su viñeta presentaban a Adolfo Suárez y Felipe González en un brindis por los viejos tiempos, que terminaba con el lanzamiento por parte de ambos del champagne a la cara del otro, Diario 16, 15 de febrero de 1989.
} 
y Suárez le dice que su proyecto está agotado" ${ }^{84}$. Para el editorial del periódico liberal, Suárez había sido el ponente más crítico y duro de la oposición y su opción-elecciones anticipadas- era respaldada por Diario $16^{85}$. La dureza del discurso de Suárez fue subrayada también desde $Y a$, donde no se dejaba de hacer mención a la "esgrima personal" con Felipe González "que motivó el interés de los parlamentarios" $"$. El descontento social y el fin de la concertación marcaban para El País los ejes por los que había discurrido un debate, y se sorprendía "por la irrupción" del CDS en el "mismo costado" que IU, es decir, la izquierda social. Si era "dudoso que el CDS" pudiera "ser reconocido como portavoz político del descontento sindical”, lo que consideraba el rotativo madrileño "su radicalización populista", sí podía servir de banderín de enganche para sectores de la burguesía urbana más o menos desencantados y que en ningún caso transferirían su voto a Fraga. La política española parecía desplegarse en torno a tres grandes bloques: un socialismo desplazado hacia el centro, el PP y los regionalistas moderados, y una izquierda "que desborda[ba] las posibilidades de encauzamiento político de Izquierda Unida”. Concluía el editorialista preguntándose qué lugar ocupaba el suarismo: de centro y sin embargo, fulcro de los sindicatos, bisagra y lejano tanto de socialistas como de conservadores ${ }^{87}$. La soledad y lo errático de la estrategia suarista era subrayada también en la portada, en la que se destacaba: “Adolfo Suárez se queda sólo en su propuesta de adelantar las elecciones legislativas" 88 . El editorial de $A B C$ se limitaba a resaltar el acierto de las intervenciones de la oposición, señalando eso sí, que habían tenido "acentos muy diversos [...] perspectivas incluso contrastadas [Miguel Herrero, Adolfo Suárez y Miquel Roca]"89. Sobre la polémica mantenida entre el líder socialista y el centrista, en la sección de $A B C$, “Actualidad gráfica", se titulaba no sin sorna: "Felipe González y Adolfo Suárez, dos vías de evolución",90.

El debate sirvió también para escenificar un cambio de actitud -menos tremendista y más proclive a la cooperación- del nuevo Partido Popular (PP) en relación al PSOE, que el CDS denunció como un supuesto acercamiento entre ambos. Era el primer efecto del

\footnotetext{
${ }^{84}$ Portada, Diario 16, 15 de febrero de 1989.

${ }^{85}$ Editorial: "No se desbloqueó la situación”, Diario 16, 15 de febrero de 1989.

${ }^{86}$ Editorial: "Un debate sin sorpresas", Ya, 15 de febrero de 1989.

${ }^{87}$ Editorial: "Después de la batalla", El País, 18 de febrero de 1989.

${ }^{88}$ Mientras, PP y MC accedían junto al PSOE a la reordenación del gasto social mediante un acuerdo parlamentario, portada, El País, 15 de febrero de 1989.

${ }^{89}$ Editorial: "Retórica de la desilusión", $A B C, 15$ de febrero de 1989.

${ }^{90} \mathrm{ABC}, 16$ de febrero de 1989.
} 
cambio de imagen pretendido tras la refundación de la vieja Alianza Popular en el IX Congreso del partido celebrado en enero de 1989. Poco antes del debate se señalaba en un informe estratégico de uso interno de los populares:

- ¿Existe estrategia para el Debate del Estado de la Nación? Se ha consultado con el CDS y AS? ¿En todo caso, si el portavoz es M. H. qué papel va a jugar M. O.? Lo lógico sería un futuro gobierno CDS/PP/CiU con Suárez, Oreja y Roca con vértices del mismo. ¿Se está en ello? ${ }^{91}$

Curiosamente iba a ser en este contexto, cuando se produjo el primer pacto, desde 1982, entre el CDS y el PP. No obstante, antes de abordar los llamados Pactos de Madrid merece la pena recordar algunas declaraciones que enmarcaron, a izquierda y a derecha esta nueva convergencia política. En diciembre de 1988 y ante los crecientes rumores, Suárez rechazó explícitamente liderar cualquier "alternativa de centro derecha"92. Pocas jornadas después del Debate sobre el Estado de la Nación, The Financial Times -en una noticia recogida por $A B C$ - señalaba: "la gran recompensa para el Partido Popular sería establecer un entendimiento con Suárez, pero hasta hoy no hay signos de ese logro"93.

Por el contrario, como hemos visto, las relaciones entre Felipe González y Adolfo Suárez se habían enfriado notablemente desde el episodio de la OTAN. El propio Suárez en una entrevista con Lucía Méndez ( $E l$ Mundo) señalaba en otoño de 1989 que la última vez que habían hablado había sido en otoño de 1988 -política antiterrorista y política exterior-:

L. M.- Da la impresión de que entre usted y Felipe González existe una relación de amorodio.

A.S.- Yo hablé mucho con él, cuando era presidente del Gobierno, le llamaba con frecuencia a mi despacho. Pero él se ha ido alejando de todas sus ideas sociales y nuestras críticas se han ido acentuando. Felipe encaja mal las críticas y las traslada al terreno personal y al político, hasta el punto que de haber tenido mucha relación en sus primeros años de mandato, hemos pasado a distanciarnos ${ }^{94}$.

\footnotetext{
91 "Bases para el diseño de una estrategia electoral", Fechado el primer semestre de 1989, Caja 4, 45-231, AGUN/JLA, p. 16-17.

${ }^{92}$ SUÁREZ GONZÁLEZ, Adolfo: "Entre la coherencia y el desgarro", El País, 29 de diciembre de 1988.

${ }^{93}$ Definía como "enigmáticas" sus directrices políticas, bastante más cercanas al PSOE y la izquierda desencantada que al PP: "su aspiración sería participar en un Gobierno de coalición con el PSOE", $A B C$, 26 de febrero de 1989.

${ }^{94}$ El Mundo, 27 de octubre de 1989.
} 


\section{4. Entre Mario Conde y la refundación de Alianza Popular}

Las perspectivas de la derecha española durante la III Legislatura fueron, de principio a fin, bastante malas cuando no, directamente nefastas. En 1986, el éxito del CDS había "disparado las alarmas en el seno de la Coalición [Popular]"95. Desde ese momento, el paulatino ascenso de los suaristas en las encuestas y sondeos publicados en la prensa generaba una situación cada vez más insostenible, cuya solución sin embargo no se vislumbraba. Un botón de muestra de la desesperanza con que los supuestos partidos afines o vecinos veían un posible pacto con el CDS era el vano intento del PDP de formar una coalición de centro-derecha, al margen de AP. En febrero de 1987 la ejecutiva democristiana renunciaba a presentar candidaturas en Cataluña -elecciones municipales-. Uno de sus dirigentes razonaba:

No siendo la política el reino de la razón pura, conviene asumir, con realismo las peculiaridades de estructura y conducta del CDS. A partir de aquí entiendo que ante la opinión pública no cabe formular una propuesta positiva de colaboración con el CDS; pero si cabe una política de confrontación y la formulación de un principio general sin el cual el PDP proclama su voluntad de confrontar con otras fuerzas centristas por entender que la conformación de una amplia oferta electoral de centro sólo tiene sentido desde la colaboración y no desde la confrontación ${ }^{96}$.

El repunte en las predicciones electorales del CDS en 1988 inauguró una serie de movimientos, cuya consecuencia a corto plazo, iba a ser un progresivo acercamiento de posturas en el espacio de centro-derecha y pudo decidir la suerte del $\mathrm{CDS}^{97}$. Entre las nuevas hipótesis, rumores y ofertas comenzaba a aparecer la emergente estrella de Mario Conde, quien en 1986 había apoyado al PRD. La prensa subrayaba las coincidencias entre el abulense y el banquero: "Conde ha llegado a la banca como Suárez a la política. Los dos han roto moldes, han sido y son auténticos outsiders" "98 . Al parecer, entre ambos se fraguó la llamada Operación Quijote, lo que para Gregorio Morán era una opa del CDS a AP, diseñada por Mario Conde desde la primavera de 1988 y que gracias a la mediación de Antonio Navalón - a quien ya nos referimos a propósito de la relación entre Suárez y Ruiz Mateos-, había logrado contar con la complicidad de Adolfo Suárez:

\footnotetext{
${ }^{95}$ En expresión de BOUZA, Fermín y GONZÁLEZ, Juan Jesús: Las razones del voto en la España democrática, 1977-2008, Editorial Catarata, Madrid, 2009, p. 83.

96 “QQué hacer en Cataluña?”, Documento de José Luis Álvarez “0010 Documento”, Fechado el 01 de febrero de 1987, Caja 11, 45-475, 1987, AGUN/JLA.

${ }^{97}$ Tiempo, 14 de marzo de 1988.

${ }^{98}$ CASTRO, R. y GARCÍA-ABADILlO, C.: "Operación Quijote: Suárez seduce a Mario Conde", $E l$ Globo, 20 de junio de 1988.
} 
Sólo hay dos líderes que de momento han sobrevivido [...] a la marea socialista: Jordi Pujol en Cataluña y Adolfo Suárez en Madrid. Para la ingeniería política de Mario Conde se trata de unirlos como polo de referencia junto a otras minorías periféricas y dar la batalla de centro-derecha, contemplando las ruinas de Alianza Popular ${ }^{99}$.

La hipótesis de Adolfo Suárez, como líder del centro-derecha ganaba enteros en los medios desde el verano de 1988: "la mayoría de los españoles quiere a Suárez al frente de la oposición"100. Incluso en $A B C$, sus principales comentaristas políticos -Ángel Collado y Luisa Palma-, entreveían alguna posibilidad de unión entre la oposición: "El partido de Suárez duda tomar parte en la operación" [que incluía a AP, DC, PL, CiU y partidos regionalistas $]^{101}$. Según Diario 16 , el $50 \%$ de los votantes del CDS apoyaba una iniciativa de este tipo ${ }^{102}$. Y como reflexionaban los principales líderes conservadores era imposible la constitución de una alternativa al PSOE sin la colaboración del CDS es decir, de todas las fuerzas "no socialistas"103. En ese momento y forzado por unas circunstancias adversas, ¿ofreció Hernández-Mancha a Adolfo Suárez una coalición electoral entre AP y CDS con Suárez como candidato a la Presidencia, y así a su vez, resguardarse del previsible retorno a Manuel Fraga?

Si esta hipótesis fue truncada por el regreso de Fraga a la Presidencia de AP, las relaciones entre Mario Conde y Adolfo Suárez -siguiendo el minucioso trabajo de Fuentes Aragonés- fueron un paso más allá. Conde necesitaba la mediación de Adolfo Suárez con el Banco de España ante la posible fusión que se avecinaba con el Banco Central, y el CDS necesitaba de financiación, que según Conde, Suárez exigió de "manera no oficial", -encuentro de La Salceda (Toledo), 20 y 21 de enero de 1989-. Según el relato de Mario Conde desgranado por Fuentes Aragonés, las entregas se hicieron en febrero y abril de 1989. De este modo, Mario Conde consiguió evitar la fusión bancaria gracias al cambio de actitud del Banco de España y el CDS afrontar sus pagos más urgentes. El escándalo saltó en 1994, cuando "comenzaron los problemas del banquero con la justicia" y los pagos fueron desmentidos públicamente por Suárez ${ }^{104}$. Para Fuentes Aragonés, aunque la existencia de un compromiso entre ambos y la gestión de Suárez ante el Banco de España fuera plausible, quizá lo sean menos las

\footnotetext{
${ }^{99}$ MORÁN, Gregorio: Ambición..., p. 588; GARCÍA ABAD, J. A.: Adolfo Suárez: una..., p. 237.

100 Tiempo, 13 de junio de 1988. O la revista Época: "Suárez, más cerca de la Moncloa", 27 de junio de 1988.

${ }^{101} A B C, 03$ de junio de 1988.

${ }^{102}$ Suplemento dominical de Diario 16, 13 de junio de 1988, MAST.

103 De acuerdo con Alfonso Osorio, ABC Sevilla, 08 de noviembre de 1988. "Ni AP, ni CDS, por sí mismos", constituyen una alternativa, en ÁLVAREZ, José Luis: "El centro-derecha español”, $A B C, 13$ de junio de 1988.

${ }^{104}$ Y también, de forma voluntaria ante los tribunales, El País, 05 de octubre de 1995.
} 
fechas manejadas por Mario Conde sobre la financiación del CDS -que según el testimonio del ex banquero deberían coincidir con una campaña electoral-. Tampoco se puede descartar, "alguna influencia [por parte de ambos] en la defenestración política de Hernández Mancha, como parte de una maniobra para hacerse con el control de AP, paso previo a su fusión con el CDS", una especie de refundación de la oposición de centro-derecha bajo el liderazgo de Suárez y en la que Mario Conde siempre podría, en un futuro, "ejecutar la hipoteca" del nuevo edificio político ${ }^{105}$.

Sin lugar dudas, el acercamiento entre Mario Conde y Adolfo Suárez y su influencia en el devenir del CDS fue vox populi entre la militancia y dirigentes del partido, aunque prácticamente nadie supiera en qué había consistido dicha relación. Al margen de la mejoría en la situación económica del partido, muchos la ponían en relación directa con la firma de los Pactos de Madrid. Merece la pena avanzar algo más en el tiempo, con el fin de esbozar el cuadro completo de las relaciones entre Mario Conde y el CDS.

José Moreira, Presidente del CDS entre 1999 y 2002, momento en el que Mario Conde fue candidato a la Presidencia del Gobierno (2000) avala la versión del ex dirigente de Banesto y confirma que la financiación al CDS se produjo tras la denegación de varios créditos al partido suarista. Precisamente, años después y de acuerdo con Moreira, fueron los propios dirigentes del CDS quienes decidieron ponerse en contacto con Mario Conde -quien se rumoreaba podía fundar un nuevo partido-, debido a los problemas económicos que atravesaba la formación ${ }^{106}$. Para este momento, Adolfo Suárez en un escrito realizado tras la presentación de la candidatura de Mario Conde a propuesta de la dirección de CDS-UC [Unión Centrista], estaba totalmente desvinculado de la iniciativa e incluso del partido fundado en 1982:

D. Adolfo Suárez González quiere dejar constancia de que desde Septiembre de 1991 nada tiene que ver con la actuación de dicho Partido, del que se considera dado de baja, al ordenar, hace años, el no pago de las cuotas [...] lo que según las reglas establecidas, supone la baja automática. En cuanto al hecho en sí que se difunde mi opinión es

\footnotetext{
${ }^{105}$ FUENTES ARAGONÉS, Juan Francisco: Adolfo Suárez..., pp. 475-87. Mario Conde ha señalado que ayudó económicamente a Suárez cuando lo necesitó -mediante el alquiler de locales-, y medió en la recuperación de su imagen pública; por ello, se sintió dolido cuando Suárez negó públicamente dicha financiación, CONDE, Mario: Los días..., pp. 457-461 y pp.728-30. Aunque en un primer momento, ante la Audiencia Nacional, la versión de Mario Conde fue diferente, negando lo ocurrido, EKAIZER, Ernesto: Sed de poder. La verdadera historia de Mario Conde, Barcelona, Espasa, 2012. pp. 141-5.

${ }^{106}$ Entrevista con José Moreira, 21 de mayo de 2015. En el último trimestre de 1993, ante la crisis del Gobierno socialista, y especialmente el agotamiento del proyecto de Felipe González, al parecer Suárez le propuso a Mario Conde que liderara el proyecto del CDS, ya que era patente la necesidad de un proyecto de centro, lo que podría aceptar incluso el PSOE, aunque no el PP, CONDE, Mario: Los días..., pp. 7367.
} 
claramente subjetivo. Sus objetivos son, cuando menos, confusos y susceptibles de las más diversas interpretaciones. Creí que en democracia la claridad es imprescindible. Lamento profundamente que las siglas de un Partido que yo fundé y presidí, sirvan de cobijo para tan sorprendente operación ${ }^{107}$.

De forma paralela, el retorno a la dirección popular de Manuel Fraga a finales de 1988, inauguraba un nuevo ciclo político en la derecha española tras el impasse que había supuesto Hernández Mancha. Dos eran las claves del nuevo proyecto popular: renovación -refundación-y convergencia -integración del PL y del PDP ${ }^{108}$-.

En lo que respecta a la convergencia, desde el CDS siempre se manifestó la voluntad de acudir en solitario a las diferentes convocatorias electorales ${ }^{109}$. Para $E l$ Independiente, la relación del CDS con los afines era de indiferencia hacia DC y PL, esquivo con AP y receloso de los regionalistas, manteniéndose sus mayores puntos de contacto con los nacionalistas ${ }^{110}$. En desafortunada expresión de Luis Herrero, Suárez era "el garbanzo negro del centro-derecha" y la moción de censura en el Ayuntamiento de Madrid, una joya de corona que no acababa de refulgir y más bien parecía, a medida que avanzaba la legislatura, destinada a permanecer apartada en un cajón, optando Suárez "por confirmar su vocación de llanero solitario".

De cara al Congreso de la Refundación y con el objetivo de reforzar esta idea de unión del centroderecha en torno a AP, un análisis estratégico manejado por los dirigentes populares indicaba: "invitación a todos los parlamentarios de centro-derecha del Parlamento español -PL y DC, regionales, CiU, PNV e incluso CDS" ${ }^{111}$. La aparente impasibilidad suarista provocaba la repetición de los juicios que se venían desarrollando desde 1982:

El CDS mantiene su situación de indefinición, y con unas últimas incorporaciones 'contradictorias', buena parte de ellas del PDP e incluso del PL. A. S. genera desconfianza en muchos electores. Exceso de silencio. Falta de fiabilidad programática. ¿Cuadros presentables?

En el entorno de Mayor Oreja, se llegó incluso a barajar un proyecto de coalición conservadora estructurado en torno a los partidos regionalistas (y no AP), en lo que

\footnotetext{
${ }^{107}$ Dossier 15, Archivador 4, ENA.

${ }^{108}$ El País, 15 de marzo de 1989.

${ }^{109}$ Reunión del Comité Nacional del 07 de noviembre de 1988. Aunque El País y ABC sacaban lecturas contrapuestas, PRADES, J.: "Suárez descarta todo pacto preelectoral con la derecha", El País, 09 de noviembre de 1988 y PALMA, Luisa: "Suárez aceptaría el diálogo con Fraga y está dispuesto a pactos poselectorales", $A B C, 09$ de noviembre de 1988.

${ }^{110}$ El Independiente, 24 de junio de 1988, MAST.

111 “0067 Documento", Fechado el 22 de diciembre de 1988, Caja 4, 45-219, 1988, AGUN/JLA, p. 1.
} 
suponía de facto una especie de reedición de la $\mathrm{CEDA}^{112}$, para acudir con garantías a las Europeas de 1989 y quizá inaugurar una vía de convergencia política futura. Como sucedía con anterioridad, el análisis de la situación partía de la frustración a nivel nacional:

Tiene que emerger una fuerza política diferente de AP y CDS. [...] En la construcción de esta alternativa caben dos posiciones. Una posición pasiva que consiste esencialmente en esperar a que las demás piezas de centro-derecha tomen la iniciativa. Que AP y CDS se entienda, que Adolfo Suárez nos llame... Una posición activa en la que la iniciativa corra a cargo de los partidos de ámbito regional [...] porque el CDS en modo alguno va a asumir esta convocatoria, y AP no tiene capacidad de convocatoria alguna ${ }^{113}$.

Precisamente, en noviembre de 1988, saltó a la prensa la petición de Manuel Fraga de una entrevista con Adolfo Suárez, entrevista que se iba a posponer indefinidamente ante el temor del CDS de perder una imagen de independencia sólidamente consolidada $^{114}$. La imposibilidad de un acercamiento a Suárez, las dificultades planteadas por el sistema electoral y la necesidad de mover ficha de cara a las elecciones europeas, hizo que una reunión celebrada por cuatro políticos aliancistas en la Navidad de 1988- autodenominados como "los cuatro hombres buenos"-, concluyese que la única vía a seguir era un proceso de renovación de los populares: "Con el CDS cabe mejorar las relaciones. No obstante, es de momento imposible pensar en pactos preelectorales. Por tanto, lo que puede hacerse ha de partir de la única base real existente, que es Alianza Popular"115. Una nota posterior, previniendo de cualquier experimento, se encargaba de recordar la nefanda experiencia vivida en UCD. Como señalaba Alberto Ruiz Gallardón: "nuestro partido, podrá no ser todo el cuerpo de la alternativa, pero es, sin duda, la columna vertebral alrededor de la cual debe alzarse operativa y eficazmente ese cuerpo" ${ }^{116}$. Columna vertebral renovada con el sutil encaje de antiguos políticos centristas. Siguiendo un informe manejado por AP, anteriormente citado:

Tal resultado puede conseguirse con la incorporación de nuevos grupos y nuevas personas y sobre el entendido, honestamente aceptado, de que se trata de producir un cambio real de imagen y contenidos, y como consecuencia, que esas personas han de

\footnotetext{
112 Algo no del todo infrecuente, véase, CAMPMANY, Jaime: “A por los trescientos", $A B C, 18$ de octubre de 1988.

${ }^{113}$ MAYOR OREJA, J.: “0058Documento”, Fechado en el primer semestre de 1989, Caja 4, 45-210, AGUN/JLA, p. 4.

${ }^{114}$ HERRERO, L.: "El garbanzo negro del centro-derecha”, Época, s.f. [noviembre, 1988, no 193] e ÍD.: "Suárez le da calabazas a Fraga", Época, s. f. [febrero, 1989, no 20].

115 "Reunión de los cuatro 'hombres buenos", Fechado en diciembre de 1988, Caja 4, 45-214, AGUN/JLA, p. 2.

${ }^{116}$ Boletín AP-Madrid, 2, enero 1989.
} 
tener un papel y unas responsabilidades definidas, y no ser absorbidas al poco tiempo por la imagen de la antigua organización [...] La vuelta de Fraga y su lanzamiento de la idea de refundación podía ser la ocasión de transformar AP en un nuevo partido que, cambiando notablemente, pudiera reunir, al fin, a todo el centro-derecha, con excepción del $\operatorname{CDS}^{117}$.

Por ello, era preciso unirse "con las personas de UCD que conserven un prestigio para dar la sensación de que parte de la vieja UCD apoya esta operación y recuperar así los votos aún sin fijar de aquella opción""118. Dicho de otra forma, "el apoyo público de un número elevado de ex parlamentarios de UCD, aunque no ficharan, podía crear un efecto de apoyo de un electorado aún flotante" $" 119$. Una idea, la de atraerse el electorado centrista, repetida con insistencia, conscientes no obstante de los recelos que podía causar en parte del viejo electorado aliancista: "lo que hace falta es conseguir que los esfuerzos de comunicación que dirigimos hacia este colectivo no provoque el rechazo de ésta base sólida de nuestro Partido. Pero no nos equivoquemos [...] son los que hay que convencer por primera vez"120. El candidato para Europa, el ex centrista Marcelino Oreja se ponderaba así, en análisis internos, como "moderado, dialogado, centrado"121.

En enero de 1989, se producía la refundación de Alianza Popular (AP). Durante su IX Congreso, el gran partido de la derecha española cambiaba su denominación por la de Partido Popular (PP) y Manuel Fraga volvía a hacerse con las riendas del grupo.

\section{5. Los Pactos de Madrid (PP-CDS, 1989)}

Profundamente incardinado con el punto anterior, a lo largo de este epígrafe nos proponemos dar una visión de los Pactos de Madrid (PP-CDS) suscritos en la primavera

\footnotetext{
117 “0067 Documento", Fechado el 22 de diciembre de 1988, Caja 4, 45-219, 1988, AGUN/JLA, p. 2.

${ }^{118}$ Ibid., p. 4. En esta época: se integraron en el PP ex dirigentes democristianos de UCD, capitaneados por Javier Rupérez, liberales o personalidades más o menos independientes como Pío Cabanillas.

119 "Razones para la participación", Fechado el 28 de noviembre de 1988, Caja 4, 45-221, 1988, $A G U N / J L A$, p. 3. En un informe del PP de cara a la estrategia en las elecciones europeas se señalaba entre los retos del PP: "Poca penetración en ciertos sectores básicos en los que funcionó bien UCD, la cual, dicho sea de paso, daba una imagen más moderna, refrescante y progresista", "Bases para el diseño de una estrategia electoral", Fechado el primer semestre de 1989, Caja 4, 45-231, AGUN/JLA, p. 5; Una ocupación simbólica del centro que conecta con la usurpación de la Transición: "Por ello más que asistir a una obsesión de posicionamientos geométricos que por otro lado, y dada la sociología electoral española, no nos son favorables, es preciso obsesionarse con la transmisión de capacidad de resolución seria y eficaz de los problemas concretos" [subrayado en el original], "Documento inicial de criterios de estrategia [233]", Fechado el primer semestre de 1989, Caja 4, 45-233, AGUN/JLA, p. 9.

120 "Documento inicial de criterios de estrategia [PP]", Fechado en el primer semestre de 1989, Caja 4, 45-233, AGUN/JLA, p. 5.

${ }^{121}$ Ibid., p. 2.
} 
de 1989 con una particular atención a la visión y recuerdo de los mismos por parte de miembros del CDS. Por ello, en primer lugar y de forma breve completaremos la descripción de los momentos previos al pacto. A continuación, narraremos los principales acontecimientos que se produjeron descendiendo desde las negociaciones a nivel nacional a algunos casos más particulares. Finalmente, abordaremos las consecuencias inmediatas de los mismos a raíz de los resultados en las elecciones europeas de 1989.

La especulación sobre un posible acercamiento entre PP y CDS llegó a tal extremo, que el Comité Nacional de los suaristas remitió en febrero de 1989 una carta a las organizaciones territoriales en la que manifestaba claramente la posibilidad de un pacto post-electoral para hacer frente a la hegemonía socialista pero, en ningún caso preelectoral: "Una coalición preelectoral sesgada hacia la derecha imposibilita ese objetivo. La experiencia electoral comparada demuestra que las listas coaligadas pierden voto por la izquierda y por la derecha, al disminuir la identificación entre partidos y electores" ${ }^{\prime 22}$. El 20 de febrero de 1989, Manuel Fraga enviaba una carta a Adolfo Suárez instándole a ser coherente con la crítica que realizaba al PSOE y que "deberían favorecer, a mi juicio, el que uniéramos esfuerzos [...] De todo ello Madrid, Ayuntamiento y Comunidad, son un ejemplo importante, pero como bien sabes, no el único"123. Suárez mantenía sus reticencias, lo que en irónica expresión de algunos columnistas, le impedía caer en "las menudeces de la política"124. En marzo, periodistas como Luisa Palma afirmaban que Suárez había aceptado mantener un encuentro y estaba dispuesto a hablar de "cooperación política"125.

La actitud del PP, exponiendo públicamente la posibilidad de realizar mociones de censura, había sido prescrita en informes estratégicos de comienzos de año: "liderar los contactos con el CDS y los regionalistas para crear dificultades al PSOE allí donde se halla en minoría (Madrid A./ Madrid, C./Murcia -...)"126. Aunque estaba todavía lejos

\footnotetext{
122 PRIETO, Joaquín: "El CDS prevé la posibilidad de pactos poselectorales "entre fuerzas estables", El País, 04 de febrero de 1989.

123 Texto íntegro reproducido en $A B C, 24$ de febrero de 1989. En $Y a$, se comentaba: "Fraga pensaba ofrecer a Suárez la alcaldía de Madrid para Sahagún", Ya, 28 de febrero de 1989.

124 JIMÉNEZ LOSANTOS, Federico: "De política, ni hablar", $A B C, 25$ de febrero de 1989. Véase también: CAMPMANY, Jaime: "Fraga y el duque", $A B C, 28$ de febrero de 1989; OVIDIO: "Ni hablar de política", $A B C, 01$ de marzo de 1989, etc.

${ }^{125} A B C, 15$ de marzo de 1989.

126 "Bases para el diseño de una estrategia electoral", fechado el primer semestre de 1989, Caja 4, 45-231, $A G U N / J L A$, p. 17.
} 
de ser concreta y estar correctamente analizada - por ejemplo, en el caso de Murcia, fue imposible llevarla a cabo por la situación del Grupo Municipal del Partido Popular-. El día 10 de abril de 1989, un editorial de $A B C$ comentaba el acuerdo sobre política local al que había llegado el PP de alcanzar mociones de censura con el CDS sólo de manera coordinada en pactos globales. Dicho editorial, titulado, "Responsabilidad del CDS", instaba a los suaristas a dar el siguiente paso, atendiendo "los sentimientos" y el "mandato implícito" de su electorado, "nada distante" de los votantes del $\mathrm{PP}^{127}$.

Como señala Caso, la opción de llevar a cabo una serie de pactos "selectivos" fue paulatinamente cobrando más fuerza en el Comité Ejecutivo, siempre con la obsesión de evitar la percepción de derechización y con el objetivo de demostrar que el CDS es un partido "con capacidades de Gobierno". Sin embargo, no se dieron pasos concretos en ningún sentido debido a los riesgos que suponía. En ese momento, se produjo "un suceso desequilibrante" que fue la operación por parte del PSOE de "captura" de conejales y diputados autonómicos en Madrid para garantizarse la mayoría absoluta, anunciándose que dos "concejales del CDS [...] abandona[ba]n la disciplina del CDS" para garantizar la mayoría de Juan Barranco en el Ayuntamiento. Uno de ellos era el miembro del Comité Ejecutivo, Javier Soto, muy activo desde la fundación del partido en trabajos de formación y organización de jornadas y actividades. Obviamente, el PSOE conocía que la probabilidad de una "moción de censura" era un tema recurrente en la ejecutiva suarista pero hasta ese momento no se había tomado ninguna decisión: "la negociación no se abre hasta que se ha producido el intento de fuga de los dos concejales" ${ }^{\prime 28}$.

Efectivamente, el 14 de abril "saltaba la noticia" de que dos concejales del CDS en el Ayuntamiento de Madrid se habían pasado al grupo socialista municipal, alcanzando así, Juan Barranco la mayoría absoluta. Este suceso, como no es de extrañar, generó la indignación en la derecha española. $A B C$ dedicó su portada, su editorial, su sección de actualidad gráfica y un reportaje de cuatro páginas a la noticia: "El PSOE maniobra para engullir al CDS"129. Y ahora sí, se entreveía "la posibilidad de que se produzca una venganza..."130 Al día siguiente, el rotativo monárquico situaba en su portada una fotografía de archivo en la que aparecían Adolfo Suárez y Manuel Fraga y entre ambos,

\footnotetext{
${ }^{127}$ Editorial: "Responsabilidad del CDS", $A B C$, 10 de abril de 1989.

${ }^{128}$ Entrevista con José Ramón Caso, 19 de noviembre de 2014.

${ }^{129}$ Portada de $A B C, 14$ de abril de 1989.

${ }^{130}$ Editorial: "Maniobra del PSOE", $A B C, 14$ de abril de 1989.
} 
Marcelino Oreja "puente" simbólico entre ambas formaciones: "Acercamiento entre el PP y el CDS" $" 131$. El País orientaba su discurso a enfatizar lo que consideraba una crisis interna dentro del CDS y en su editorial quitaba hierro a este episodio, harto habitual en las instituciones y del que los suaristas solían ser habituales protagonistas:

Último episodio de una casi constante serie de fugas de representantes públicos de un partido a otro, en lo que supone, sin duda, un manifiesto fraude a la voluntad expresada por los electores en las urnas. Sin embargo, hay que decir que no es el CDS, el partido que ahora protesta airado por lo que considera una maniobra de acoso, el más cargado de razón para denunciar los hechos ${ }^{132}$.

Para los suaristas, todo ello se había producido necesariamente, con la autorización de Felipe González y constituía un episodio censurable desde todos los puntos de vista, que exigía algún tipo de respuesta. Apenas tres días después repletos de presiones, conversaciones, "reapertura de puertas" y ante el escándalo mediático que se había originado, Martínez Parrondo y Soto Carmona depusieron su actitud. El primero se reintegró a las filas centristas y el segundo abandonó la concejalía.

En ese momento, arrancaron las negociaciones entre el CDS y el PP representados por José Ramón Caso y Federico Trillo respectivamente. En el curso de esas conversaciones se acordó que Rodríguez Sahagún, la figura más emblemática del Ayuntamiento de Madrid, accediera a la alcaldía y por otra parte, que en la Comunidad de Madrid, fuera Alberto Ruiz-Gallardón el futuro Presidente. Asimismo, el PP puso como condición sine qua non, dotar de estabilidad al Gobierno de Castilla y León mediante la entrada del CDS en el Gobierno de la Comunidad. Esos tres puntos fueron los acordados a nivel nacional. El 28 de abril, Suárez, en rueda de prensa anunciaba la celebración de mociones de censura "a corto y largo plazo"133.

Daniel de Fernando, líder del CDS en Castilla y León señala que tuvo al menos tres reuniones con Adolfo Suárez en aquellos días, llegando a ver al ex presidente "fuera de quicio”. Suárez lamentaba: “esto es una faena que me ha hecho Felipe González”. Sin embargo, y a pesar de que el pacto con el PP generó numerosísimos problemas en un CDS castellano-leonés que tenía ya grietas considerables, no hubo imposiciones por

\footnotetext{
${ }^{131}$ Portada de $A B C$. Véase editorial: "Concejales antidemócratas", $A B C, 15$ de abril de 1989; JIMÉNEZ LOSANTOS, Federico: "Mayoría inmoral", $A B C, 15$ de abril de 1989; CAMPMANY, Jaime: "El bisagra", $A B C, 15$ de abril de 1989.

${ }^{132}$ Editorial: “¿Quién defrauda?”, El País, 15 de abril de 1989. Días después Diario 16 señalaba: "nadie está en condiciones de arrojar la primera piedra", editorial: "El 'transfuguismo' de cada día", Diario 16, 18 de abril de 1989.

${ }^{133}$ Portada de El País, 29 de abril de 1989.
} 
parte de la dirección nacional. Por ejemplo, en el caso de Valladolid dicha posibilidad fue barajada por Adolfo Suárez y es que, la suma de concejales de CDS y PP superaba ampliamente al conjunto de las fuerzas de izquierda. Sin embargo, la dirección del partido en la ciudad del Pisuerga se opuso rotundamente y no se llevó a cabo.

El pacto de coalición en Castilla y León se firmó en el domicilio de Federico Trillo, tras una reunión "muy tensa" entre el propio Trillo, José María Aznar, José Ramón Caso y Daniel de Fernando. Se suscribió antes que el Acuerdo de Madrid e incluía el compromiso de seguir con el pacto aunque Aznar abandonara la Presidencia de la Junta.

Para los dirigentes centristas, en ese momento el horizonte político de Aznar era ya nacional y ésta era la única forma de asegurar el control de la Comunidad, hasta ese momento endeble ${ }^{134}$. Recuerda De Fernando, como entre 15 y 20 días antes de precipitarse estos acontecimientos, celebró una reunión con Juan José Laborda (PSOE) barajando la posibilidad de impulsar una moción de censura contra el Gobierno de Aznar, como ya se había planteado en una reunión del Comité Regional del CDS celebrada en Zamora ${ }^{135}$.

El CDS entró finalmente en el gobierno regional del PP ocupando las Consejerías de Medio Ambiente, creada a propuesta de los suaristas, y de Ordenación del Territorio. La primera corrió a cargo de José Luis Sagredo de Miguel, en calidad de vicepresidente segundo, y José María Monforte ocupó la otra. La decisión última de acceder al Gobierno autonómico fue refrendada por el Comité Federal del partido en Castilla y León. La oposición en León, Zamora, Burgos o Soria acentuó una división interna del partido que iba a aflorar en el III Congreso del CDS celebrado en 1990. La disyuntiva se planteaba entre los críticos, sobre el papel defensores de posturas más progresistas y

\footnotetext{
${ }^{134}$ El CDS había votado en contra de los Presupuestos en 1988, El País, 31 de octubre de 1988. Los presupuestos se los habían entregado sólo "dos días antes" para su consulta antes del refrendo parlamentario, Entrevista con Daniel de Fernando, 19 de diciembre de 2013. En palabras de Aznar: "lo prioritario en aquellos momentos era alcanzar acuerdos entre nuestros dos organizaciones, unos acuerdos que nos permitieran alcanzar la Alcaldía y la Presidencia de la Comunidad de Madrid y que estabilizase la situación de Castilla y León", AZNAR LÓPEZ, José María: Retratos y perfiles: de Fraga a Bush, Barcelona, Planeta, p. 63. Acerca de su elección como candidato a la Presidencia, AZNAR LÓPEZ, José María: Memorias I, Barcelona, Planeta, 2012, pp. 150-151.

${ }^{135}$ Entrevista con Daniel de Fernando, 19 de diciembre de 2014. Véase también: AZNAR, Luis: Memorias...; BERZAL DE LA ROSA, Enrique (et al.): 25 años de Castilla y León. Volumen I: Un difícil arranque, una esforzada consolidación, Valladolid, Ed. de Medios de Castilla y León [El Mundo], pp. 125-131.
} 
liderados por Luis Aznar, y los oficialistas ${ }^{136}$. La entrada de los suaristas en el gobierno autonómico y sobre todo, la posterior designación de Jesús Posada como Presidente de la Junta en sustitución de José María Aznar mejoraron, como coinciden los dirigentes regionales suaristas las relaciones entre ambos partidos hasta el final de la legislatura.

Si eso sucedía en Castilla y León, en Madrid Agustín Rodríguez Sahagún se hacía con la alcaldía merced a una moción de censura celebrada el 29 de junio de 1989. De forma paralela, la moción de censura planteada para la Comunidad Autónoma de Madrid y que debía llevar a Alberto Ruiz-Gallardón a la Presidencia terminó en un sonoro fracaso como consecuencia de un caso de transfuguismo en el PP -J. L. Piñeiro ${ }^{137}$-, que levantó una extensísima polémica sobre compra de voluntades. Un acontecimiento, en el que $A B C$ no eximía de cierta responsabilidad a los suaristas:

El margen de confianza que, entonces, decidió abrir el CDS a los socialistas ha sido agotado a golpes de incompetencia y la corrupción rampante, únicos rasgos reconocibles en la gestión socialista. Cuando el CDS pretendió rectificar su ingenuidad inicial, respaldando la candidatura de Ruiz-Gallardón, su decisión resultaría tardía, al mediar la conspiración inmobiliario-socialista, destinada a seducir a un personaje de frágiles $\operatorname{principios}^{138}$.

Entre la militancia suarista existió un fuerte debate sobre el papel que desempeñó Agustín Rodríguez Sahagún en la firma de los Pactos de Madrid. En opinión de José Luis Garro, teniente alcalde del Ayuntamiento de Madrid se extendió en la época una teoría, conocida como "caramelo de Agustín", empleada como agravio hacia el ex ministro centrista. Esta teoría, sostenía 'que el origen del 'Acuerdo por Madrid' con AP, [firmado en mayo de 1989], que se entendió como una derechización del CDS y propició el descenso en las elecciones siguientes, no fue otro que el premio de Adolfo Suárez a la lealtad de su amigo Agustín Rodríguez Sahagún: la Alcaldía de Madrid”. Una visión de los acontecimientos que siempre fue desmentida por el propio Rodríguez Sahagún $^{139}$.

\footnotetext{
${ }^{136}$ Luis Aznar estuvo a punto de ser consejero autonómico pero "por alguna razón, José María Aznar no quería que yo fuese consejero [según le dijo Suárez a L. Aznar]”. De acuerdo con Luis Aznar no sólo era la polémica sobre el escándalo del consejero de economía del PP Pérez Villar, sino la coincidencia de nombres entre ambos, AZNAR, Luis: Memorias..., p. 266.

${ }^{137}$ En su editorial al respecto El País, hacía una breve comparación final con el caso de Ramón Tamames y el CDS, editorial: “Un tal Piñeiro", El País, 21 de mayo de 1989.

${ }_{138}^{138}$ Editorial: “Anticipar las elecciones”, $A B C, 22$ de junio de 1989.

139 La polémica apareció especialmente en el contexto del III Congreso (1990). En este sentido, se entiende la entrevista de URBANO, Pilar: “[Agustín Rodríguez Sahagún] Sigo siendo leal al CDS y a
} 
De acuerdo con José Luis Garro -teniente alcalde de la ciudad de Madrid en este período-, en primer lugar, la decisión de presentar como candidato a Rodríguez Sahagún "fue un simple movimiento estratégico para evitar un bajonazo en la trayectoria de crecimiento y consolidación del CDS" -tras el éxito de 1986-. Sin embargo, "este movimiento no fue tan sencillo en el plano humano":

Agustín Rodríguez Sahagún, ex ministro de Defensa, no había realizado el Servicio Militar, pues tuvo graves problemas de corazón en su juventud y le fueron implantadas entonces cuatro válvulas que el Doctor Carpentier sustituyó en 1974. Las válvulas requerían una nueva sustitución, y el Doctor Carpentier, [...] su mujer [...] y sus seis hijos trataban de atisbar, en la más estricto secreto, una fecha en el calendario existencial de Agustín para su sustitución. La decisión de Adolfo Suárez de que encabezara la candidatura por Madrid en las municipales suponía un contratiempo importante en los cálculos médicos y familiares que Agustín, generosamente, soslayó en absoluto silencio.

Cuando a raíz del "pase" al PSOE de dos concejales del CDS en Madrid, se entablaron negociaciones con el PP para llevar a cabo mociones de censura y:

De nuevo, se le pedía a Agustín Rodríguez Sahagún un esfuerzo que ponía en peligro su vida, y que chocaba frontalmente con el programa que la familia y el Doctor Carpentier tenían en marcha: comenzaba un tratamiento con fármacos preparatorio de la postergada operación de sustitución de válvulas; tratamiento que, por cierto, afectaba notablemente a su aspecto que terminó mostrando un creciente deterioro. Pero esta vez la familia presionó unida y se opuso frontalmente [...] su mujer, se presentó en el despacho de Adolfo Suárez para suplicarle llorando que no le pidiese a Agustín ese esfuerzo. Portaba una carta de Agustín que amenazaba con su dimisión. Suárez contraatacó entonces amenazando también con su dimisión y abandono. Finalmente el asunto se zanjó con la solemne promesa de Suárez de que era el último esfuerzo que le pediría a Agustín. Y lo plasmó en estos términos, por escrito, en el ángulo superior izquierdo de la carta que Rosa portaba.

En este sentido, Daniel de Fernando recuerda como en cierta ocasión acudió a Madrid junto al presidente del partido en Segovia, J. A. Perteguer, invitado por Rodríguez Sahagún para ver los posibles beneficios que, derivados de la capitalidad cultural de Madrid podían recaer en las ciudades más próximas, caso de Ávila o Segovia. Sin embargo, como señala De Fernando: "era una disculpa para enseñarles una carta escrita por él en la que rechazaba a Adolfo Suárez la idea de ser alcalde de Madrid" 140 .

Suárez", Época, enero 1990, Hemeroteca Caixa Tarragona. Véase también la entrevista de ALAMEDA, Sol: "Rodríguez Sahagún", El País Semanal, 23 de junio de 1991.

${ }^{140}$ Entrevista con Daniel de Fernando, 19 de diciembre de 2013. Para Gregorio Morán, la "Operación Madrid" fue iniciativa fundamentalmente de José Ramón Caso y José Ramón Lasuén, en MORÁN, Gregorio: Ambición..., pp. 589-90. "La exigencia de Suárez le hizo candidato al Ayuntamiento de Madrid”, en DEL RíO, Ángel: Agustín Rodríguez Sahagún, Madrid, Grupo 88, p. 119. 
Rodríguez Sahagún desarrolló una febril actividad en el ayuntamiento madrileño, dando un nuevo impulso a la ciudad. Se potenció la movilidad y la seguridad, se impulsó un plan de viviendas de protección oficial, se ejecutaron las obras de grandes pasos y vías subterráneas -Plaza Castilla por ejemplo-, se cerró el perímetro de la M-30 o se aprobó la construcción del Parque Juan Carlos I:

Cumplido su mandato y tras el paréntesis del verano de 1991, Agustín Rodríguez Sahagún partió en el más estricto secreto familiar hacia París, donde fue operado por Carpentier en el hospital Broussais, el 25 de septiembre. El resultado fue exitoso pero complicaciones posteriores [...] provocaron su muerte el 13 de octubre, a los 59 años de edad. Su muerte conmocionó a la clase política española. Fueron múltiples las condolencias y homenajes que recibió, entre ellos el de Adolfo Suárez, compañero de partido en UCD y en CDS, que lamentó 'la pérdida del mejor amigo y compañero que he tenido, ${ }^{141}$.

Los Acuerdos de Madrid agitaron a las corporaciones municipales y las direcciones provinciales de muchos lugares de España y se presentaron mociones de censura en Guadalajara -sin éxito, por la "indisciplina” de un concejal del CDS-, Jaén, Tarragona y Segovia $^{142}$. Estos episodios fueron fenómenos complementarios sucedidos al margen de las negociaciones principales, hasta el punto de que José Ramón Caso, en una reunión con Francisco Álvarez Cascos el CDS decidió poner punto y final a la posibilidad de establecer nuevos acuerdos globales con el PP.

Sin lugar a dudas, desde el PP y medios conservadores nacionales y locales se presionó con denodado esfuerzo al CDS en todas aquellas ciudades donde era posible “desalojar" al PSOE del poder. En ABC, El País y Diario 16 se contemplaban las siguientes posibilidades: Orense, Murcia, Oviedo, Palma de Mallorca, Guadalajara, Valencia -en julio de 1990, el CDS se terminó integrando en el gobierno municipal del PSOE $^{143}$-, Jaén, Valladolid, Castellón -donde existía un pacto de gobierno municipal entre CDS y PSV-PSOE ${ }^{144}$-, Zaragoza, Cáceres y Tarragona. En lo que era un ejercicio de enorme posibilismo, cuando no cínico y absolutamente ajeno a las distintas realidades locales y la gestión municipal, cada periódico, con la complicidad de todos los partidos implicados, analizaba y categorizaba las particulares relaciones inter-

\footnotetext{
${ }^{141}$ Testimonio escrito de José Luis Garro, mayo de 2016. En una entrevista concedida en $A B C$, en julio de 1991, Rodríguez Sahagún lamentaba, como la mayor ausencia de su mandato, no haber podido llevar a cabo la "Ley de Capitalidad", $A B C$, 04 de julio de 1991.

${ }^{142}$ Sólo se contaba con un precedente destacado, el de la Diputación Provincial de Salamanca donde un acuerdo entre PP y CDS había permitido a la suarista Charo Diego alcanzar la Presidencia de la institución salmantina, El País, 26 de octubre de 1988.

${ }^{143}$ ABC, 29 de junio de 1989. Sobre Valencia, El País, 24 y 25 de julio de 1990.

${ }^{144}$ El CDS ocupaba la presidencia de la Comisión de Urbanismo y una tenencia de alcaldía, Diario 16, 29 de abril de 1989.
} 
partidarias en cada una de las distintas localidades con alocuciones del tipo: "a un paso", "muy difícil", "imposible”, etc.

En Tarragona, Segovia y Jaén se culminó con éxito la operación, aunque cada una respondía a pulsiones muy diferentes. En el caso de Tarragona, donde se pactó con CiU y el PP fue una decisión totalmente autónoma que en última instancia correspondió a la dirección federal del partido -"Madrid no intervino nada"- y que respondía a la idea, defendida por Xabier Latorre de que era necesario "tocar poder" -para hacerse más visibles-. El CDS obtuvo una tenencia de alcaldía, una concejalía y logró negociar la figura de la Agrupación Parlamentaria en el órgano autonómico de Gobierno -gracias a CiU-. En Segovia, la situación era delicada para los suaristas, ya que el alcalde Luciano Sánchez Creus había sido suspendido de militancia. Finalmente, en mayo de 1989 se firmó un pacto entre el PP y el CDS -cuando prácticamente parecía cerrado un acuerdo con el PSOE-, que permitió a J. A. Perteguer asumir el bastón de mando municipal. En Jaén, los tres concejales del CDS dieron su voto para que Alfonso Sánchez Herrera (PP) se convirtiera en el alcalde de la ciudad andaluza ${ }^{145}$.

En muchos casos, estos procesos se solaparon con la existencia de diferencias de criterio entre el Grupo Municipal del partido y la Dirección Provincial, como sucedió en Guadalajara, donde hubo de intervenir la dirección nacional -en este caso, en favor del primero- ${ }^{146}$. La moción de censura se frustró debido a la negativa de un concejal centrista a apoyarla. En otros casos, se impuso sin mayores dificultades el criterio mayoritario de las ejecutivas provinciales de rechazar cualquier posibilidad de llevar a cabo una moción de censura al no existir relaciones propicias con los dirigentes populares, ni haber condiciones objetivas -corrupción, bancarrota- para este desenlace $^{147}$. En otras localidades, fue la escisión de concejales hacia el Grupo Mixto tanto de PP como del CDS, la que impidió la materialización de los distintos acuerdos.

La consecuencia inmediata de los acuerdos entre el PP y el CDS fue la afirmación por parte del PSOE de que en el CDS había aflorado su verdadera esencia: "la derecha".

\footnotetext{
${ }^{145}$ En el Ayuntamiento de Ibiza también se produjo una moción de censura del PP y el CDS frente al gobierno municipal del PSOE que otorgó la alcaldía a los populares.

${ }^{146}$ En Guadalajara, la dirección provincial era partidaria frente a la opinión del Grupo Municipal de no llevar a cabo una moción de censura. Finalmente, la dirección provincial fue disuelta por la Secretaría Nacional, (¿Diario 16?), 26 de abril de 1989, MAST.

${ }^{147}$ En una entrevista realizada entre el 08 y el 14 de mayo de 1989 a Rodríguez Bolaños la primera pregunta era: "los últimos datos apuntan a que usted, en breve, tendrá que "limpiar su despacho" s. a., s.t., (¿La Crónica de León?) en "Dossier de Prensa. Pactos PP-CDS” (Presidencia CDS-CyL, Daniel de Fernando).
} 
Una hipótesis sostenida en todo momento -como puede verse en los análisis politológicos de Pilar Brabo ${ }^{148}$, aunque ahora Alfonso Guerra, incisivo, comentara que el CDS, partido satélite, por fin se había "acoplado" a la "nave nodriza"149. En el Bulletí de Campanya (PSC) de las elecciones europeas de 1989 se identificaba en las mismas posiciones - derecha- a CiU, CDS y PP; por ejemplo, en una intervención de J. Solé Turá en un mitin en Manresa (Barcelona) el ex dirigente del PSUC señalaba que se estaba volviendo al molde original, a la UCD, aunque con una diferencia muy importante: "aquesta vegada amb Fraga a dintre"150. En El Socialista, aparecían unas declaraciones de José María Benegas en este sentido: "si las derechas de este país quieren unirse, están en el derecho de hacerlo. Aproximar posiciones entre Fraga Iribarne y Adolfo Suárez para construir el llamado centro-derecha, puede servir para superar la etapa de ambigüedad del CDS"151.

La edición dominical del 7 de mayo de El País titulaba en portada equívocamente: “El PP y el CDS pretenden cerrar esta semana un pacto para dos años". Transmitía la sensación del inicio de un pacto de más largo alcance, y que respondía a relaciones rastreables antes de la "compra" de los dos concejales ${ }^{152}$. Aunque para El País la firma de los acuerdos no convertía necesariamente al CDS en un partido de derechas. Era un acto de utilidad política - la diferenciación de Suárez entre mociones convenientes y posibles no era "creíble" para el periódico madrileño-, desencadenado por la nefasta operación de Barranco - recordando que el CDS había hecho lo mismo con Ramón Tamames- y que convertía al CDS en el FDP español. En definitiva, suponía la convergencia de dos "impaciencias paralelas", la de la refundada AP y la un centrismo que se veía relegado a un segundo o tercer plano bajo el aliento y "la presión de los cruzados de la unidad perdida del centro-derecha, empeñados en hacer una montaña de un bordillo y en convencer de que con tal de apear a los socialistas del poder cualquier combinación, hasta la más descabellada, resultaba aceptable ${ }^{153}$ ". Para Diario 16, estos

\footnotetext{
${ }^{148}$ En 1987, cuando era militante del PSOE analizaba la posición del CDS -"populismo centrista"- como una de las tres líneas de desarrollo de la derecha española, a pesar de sus matices, junto a AP y los regionalistas en BRABO, Pilar: "Las tres nuevas caras de la derecha española", El País, 13 de julio de 1987.

${ }^{149}$ Véase la respuesta de BURGOS, Antonio: "El satélite y la nave", $A B C, 19$ de mayo de 1989.

${ }^{150}$ Bulletí de Campanya PSC: Forts a Europa, 5, 29 de mayo de 1989.

${ }^{151} \mathrm{~S}$. a.: "En las elecciones del 15-J se decidirá el futuro del modelo europeo", El Socialista, 15 de mayo de 1989.

${ }^{152}$ PRIETO, Joaquín: "Un matrimonio por dos años", El País, 07 de mayo de 1989; CONTRERAS, Lorenzo: "Una operación de coyuntura" ABC, 07 de mayo de 1989.

153 "Editorial: "El beneficio de la duda", El País, 30 de junio de 1989". Asimismo, editorial: "Vista a la derecha", El País, 07 de mayo de 1989.
} 
episodios generaban una importante consecuencia para la vida política nacional aunque se desconocían todavía sus "efectos". No cabía duda de que la consecución de la alcaldía con los votos de dos de las minorías municipales era "algo perfectamente normal y acorde con los hábitos de las principales democracias" ${ }^{\prime 154}$.

En $A B C$, era patente una transformación de su discurso político y concretamente, de su visión del grupo centrista. Se criticó el "tratamiento" dispensado por TVE a Adolfo Suárez en aquellas jornadas ${ }^{155}$, y se celebró lo que Muñoz Alonso consideraba la asimilación de España al anhelado modelo francés, aun a pesar de la nueva resistencia de los suaristas a pactar con el PP para las elecciones europeas de junio. En cualquier caso, Suárez daba un paso natural en su camino político: "quiérase o no y a pesar de ciertas piruetas personales, son las naturalmente afines" ${ }^{\text {156 }}$. Además, era un pacto, como señalaba el editorial de $A B C$, de futuro, para construir en su día una "alternativa de gobierno" 157 . Se defendía, como incomparable, el caso de Tamames y el de Piñeiro, ya que el primero no había significado el cambio de color político del Consistorio ${ }^{158}$. Y se recordaban también los pactos entre el PSOE y el PCE en 1979 para desbancar a UCD, lista más votada.

Los fiabilidad electoral de los Pactos fue puesta a prueba inmediatamente después de la firma de los mismos: el 15 de junio de celebraban Elecciones al Parlamento Europeo. El resultado, sin duda, suponía una amarga sorpresa para CDS y PP que retrocedían porcentualmente y perdían, cada uno, dos diputados:

Tabla 72: Evolución de los resultados de los partidos de centro y derecha nacional.

\begin{tabular}{|c|c|c|c|c|}
\hline & \multicolumn{2}{|r|}{1987} & \multicolumn{2}{|r|}{1989} \\
\hline & $\%$ & Eurodiputados & $\%$ & Eurodiputados \\
\hline Centro Democrático y Social & $10,26 \%$ & 7 & 7,15 & 5 \\
\hline Partido Popular & $24,65 \%$ & 17 & 21,41 & 15 \\
\hline Otros (PDP, 1987; AGRM, 1989 a.; FPR, & 0,89 & - & 3,84 & 2 \\
\hline 1989b. ${ }^{159}$ ) & - & - & 0,96 & - \\
\hline
\end{tabular}

Elaboración propia a partir de http://www.historiaelectoral.com/eu1989.html y http://www.historiaelectoral.com/eu1987.html. Consultado el 03 de febrero de 2015.

\footnotetext{
${ }^{154}$ Editorial: Diario 16, "Relevo en Madrid", 30 de junio de 1989.

${ }^{155}$ Sección Actualidad Gráfica, 01 y 03 de mayo de 1989; BURGOS, Antonio: "Los cien días de Solana", $A B C, 01$ de mayo de 1989.Véase también, editorial: "Bochorno en TVE", $A B C, 20$ de junio de 1989.

${ }^{156}$ MUÑOZ ALONSO, Alejandro: "El fin del bisagrismo", $A B C, 01$ de mayo de 1989.

${ }^{157}$ Editorial: "Pacto para la alternativa", $A B C, 09$ de mayo de 1989.

158 OVIDIO, "Debates transfuguistas", $A B C, 20$ de mayo de 1989. En la sección Actualidad gráfica, del día 21 de mayo de 1989, $A B C$ titulaba: "La decisión de Tamames no altera la voluntad democrática mayoritaria, la de Piñeiro sí".

159 PDP: Partido Demócrata Popular; AGRM: Agrupación Ruiz-Mateos; FPR: Federación de Partidos Regionalistas.
} 
El País subrayaba los "estímulos contradictorios" a los que había sido sometido el electorado suarista y constataba, por enésima vez, "la incapacidad del centro-derecha" para forjar una alternativa y materializarla en las urnas ${ }^{160}$. Con ironía Vázquez Montalbán escribía:

No se desanime, don Manuel. Lo de la 'mayoría natural' no era una mala idea, pero partía del error de suponerla un objetivo mesiánico hecho a la medida de su cabeza. No la toque usted más, así es la mayoría natural, y la tiene el PSOE, no usted. [...] Devorador de todo cuanto oliera a carnaza de mayoría natural, se ha tragado hasta al escurridizo Suárez. Ahora, una de dos: o cambia de rollo o a por Ruiz-Mateos ${ }^{161}$.

Una sorpresa también para $A B C$, que con prudencia apuntaba en su editorial: "Sin variaciones" "162. Para $A B C$, los transfuguismos, la corrupción y la irrupción de RuizMateos -“con los votos desviados a Ruiz-Mateos la opción popular hubiera repetido resultados"- habían marcado la cita con las urnas en las elecciones europeas de junio de 1989, mientras se consideraba "preocupante" el resultado del CDS. Llama la atención la candidez con la que en esta contienda se recibió la candidatura de Ruiz-Mateos desde las páginas de $A B C$-salvo excepciones como la de Muñoz Alonso-, quien en el contexto de las Generales sí recibió duras reprimendas del periódico conservador. Darío Valcárcel -en El País- resaltaba lo estéril de la propuesta y la nueva fragmentación que generaba:

El PSOE sabe bien cuál es su único adversario: un acuerdo entre el Partido Popular y los centristas del CDS sería, en el horizonte visible, la única fórmula para desplazarle del Gobierno. Todas las cuñas, interferencias u operaciones que sirvan para romper ese frente son útiles al socialismo ${ }^{163}$.

El agotamiento de Manuel Fraga y el inesperado fracaso de Marcelino Oreja en las Elecciones Europeas de junio de 1989, ¿daban alas a una candidatura conjunta entre PPCDS presidida por Suárez de cara a las Generales? ${ }^{164}$ Todas las especulaciones sobre este punto, antes y después de las elecciones, fueron rápidamente olvidadas. Una de las

\footnotetext{
${ }^{160}$ El CDS debía redefinir su papel político, no mirando a La Moncloa sino al espejo del FDP, Editorial: "El veredicto", El País, 16 de junio de 1989 y editorial, "Lo que había en las urnas españolas", El País, 19 de junio de 1989.

${ }^{161}$ VÁZQUEZ MONTALBÁN, Manuel: “Ahora”, El País, 19 de junio 1989.

${ }^{162}$ Editorial: "Sin variaciones", $A B C, 16$ de junio de 1989.

${ }^{163}$ VALCÁRCEL, Darío: “Quemar el voto”, El País, 19 de junio de 1989.

164 CASTRO, R.: "Fraga y Pujol auparán a Suárez a la Moncloa”, Interviú, 13 de junio de 1989. Otros autores, desde perspectivas opuestas habían alcanzado las mismas conclusiones, SARASQUETA, Antxón: "Tocar poder", El Norte de Castilla, 29 de abril de 1989 ("Dossier de Prensa. Pactos PP-CDS" (Presidencia CDS-CyL, Daniel de Fernando). "Si el CDS quisiera, tal vez una salida sería que Suárez fuera el candidato presidencial de una coalición PP-CDS, pero El Duque, supongo querrá ir sólo", JIMÉNEZ LOSANTOS, Federico: “Sombrío panorama”, $A B C, 17$ de junio de 1989.
} 
decisiones del CDS tras el fracaso electoral fue el alejamiento de los conservadores y el reconocimiento implícito de que los resultados habían sido consecuencia de los pactos.

No cabe duda de que, desde el punto de vista estratégico no habían sido medidos adecuadamente los tiempos -"si hacemos autocrítica es evidente que nos equivocamos en la elección del momento para plantear aquellas mociones de censura"165 - lo que parece confirmar la improvisación con que finalmente se llevaron a cabo los Pactos.

Para el PP, en un análisis de la estrategia electoral del 15-J, las dos ideas que intentaron transmitir al electorado a raíz de la firma de los acuerdos con el CDS no habían sido bien comunicadas: una era la relativa al desgaste del PSOE y otra que éste no era sino el inicio de un futuro acuerdo más amplio: "los acuerdos parciales PP-CDS, que daban pié [sic] a la ilusión de que el PSOE 'se iba a enterar ahora de lo que vale un peine' y de que este no era más que el comienzo de una gran coalicción [sic] en ciernes". Meta que requería, en tan breve plazo de tiempo, de movimientos milimétricos y la articulación de un poderoso respaldo comunicativo -para contrarrestar la contracampaña informativa de RTVE-, aspectos insuficientemente abordados:

Y la delicada operación de los acuerdos PP-CDS, cuyo entronque con la refundación resultase básico para el consejo de futuro con la perspectiva abierta de las elecciones gallegas y de las generales, se trivializó en declaraciones genéricas (hechas aquí y allá, sin orden ni concierto) que ponían de manifiesto la fragilidad de esos acuerdos y sembraban serias dudas sobre la consistencia de los mismos. Visto desde la acera de enfrente y con el PSOE actuando a primera marcha [...] resultaba muy fácil neutralizar la operación ${ }^{166}$.

En cualquier caso, los pactos habían permitido por un lado, generar la sensación en la opinión pública de que el CDS, a pesar de los intentos de construir un centro-progresista con connotaciones radicales, formaba parte del centro-derecha nacional, siendo presentado por el PSOE, como hemos visto, como un satélite de los populares, discurso que contaba con la "complicidad interesada del PP" deseoso de enfocarlo como un acuerdo de futuro ${ }^{167}$. A ello se sumaba el tratamiento informativo de TVE de las mociones de censura y del CDS durante la campaña electoral ${ }^{168}$, denunciado

\footnotetext{
165 Líneas de Acción Política (III Congreso), CDS, 1991.

166 “Consideraciones rápidas sobre la última campaña electoral”, Caja 4,45-241, AGUN/JLA, p. 3.

${ }^{167}$ Según denunciaba José Ramón Caso, El País, 17 de enero de 1990.

168 Para Javier Pradera, si Ruiz-Mateos había sido el "chivo expiatorio" del PP, TVE lo era del CDS. El autor aunque reconocía su control por parte del Gobierno, no lo consideraba un factor determinante y lo achacaba a la indefinición e incapacidad de Suárez, -por su miedo a "las baronías"-, para aprovechar a los próceres de su partido, "El chivo expiatorio", El País, 25 de junio de 1989. Por el contrario, Las críticas a RTVE, llevaron a algunos periodistas conservadores a pedir el abandono del PP y el CDS del
} 
ampliamente por los suaristas, como puso de manifiesto la intervención de Federico Ysart en las Sesiones de Control Parlamentario de RTVE del 30 de mayo, y especialmente, el día 27 de junio, en el que elevó críticas por la "manipulación" informativa ${ }^{169}$ :

Otra gran manipulación, señor Solana [...] hay noticias referidas al Partido Popular o al CDS, da la casualidad que aparecen los logotipos unidos en una esquina. Señor Solana, en contra de los que diga su amigo el señor Guerra, no hay ninguna coalición; hay unos acuerdos concretos (Risas.) entre dos partidos, como ustedes (perdón, ustedes no, el Partido del señor Guerra) los tiene con el Partido Popular en algunos sitios, con Convergencia i Unió en otros, y con el PNV. ¿Por qué no aparece en televisión cada vez que sale el PNV, los logotipos PNV/PSOE? ¿Por qué razón? No confundamos, no confunda el gran manipulador al ciudadano español, que no hay aquí ningún frente ${ }^{170}$.

Sin embargo, los intereses del PP y el CDS eran sustancialmente diferentes. La derechización del CDS se complementaba con la subsiguiente percepción de que la refundación de AP significaba realmente un viraje al centro. Curiosamente, uno de los temores de la dirección del PP era la propia reacción del votante popular más afín a la persona de Fraga, — ahora relevado por Aznar-, debido en parte a la aversión que todavía suscitaba Adolfo Suárez entre parte del electorado: “de cara a las elecciones en que no se puede prever superar al PSOE [...] asentar el electorado tradicional del PP, de manera que no se pensara que estábamos dispuestos a apoyar para Presidente a Suárez"171.

En su defensa de las Mociones de Censura de 1989, la Secretaría General del CDS definía este episodio como la decisión política más "trascendente" del partido desde 1986, la cual había sido motivada por cuatro causas: encuestas sobre la desafección ciudadana a la gestión socialista (en Madrid) -el argumento, como es lógico, más utilizado durante las negociaciones ${ }^{172}$, el incumplimiento por parte del PSOE de facilitar las tareas de control, el acercamiento entre PP-PSOE tras el 14-D -recuérdese

Consejo de Administración, lo que hubiera más peso a sus críticas y restado credibilidad al gobierno, SÁNCHEZ, J. A.: "El consejo de RTVE”, ABC 25 de junio de 1989.

169 “¿Por qué razón los diarios hablados de RNE han tomado posición en más de tres ocasiones frente a los acuerdos PP-CDS para presentar determinadas mociones de censura en algunos ayuntamientos y una Comunidad Autónoma?", pregunta planteada por F. Ysart, DSCD, Comisiones, 30 de mayo de 1989, $\mathrm{n}^{\circ}$ 476, p. 15625.

${ }^{170}$ Federico Ysart había formulado la pregunta: ¿Quién es a su juicio el responsable de la manipulación informativa realizada en beneficio del Gobierno?, DSCD, Comisiones, 27 de junio de 1989, n 494, pp. 16092-3.

${ }^{171}$ ÁLVAREZ, José Luis: “Tipos de oposición”, Caja 4, 45-196, AGUN/JLA, p. 6.

${ }^{172}$ La portada del boletín centrista: "Mociones de censura para frenar la mala gestión socialista en algunas instituciones"; "Con los socialistas se ha producido el mayor fenómeno especulativo de los últimos años", OICDS, 21, mayo 1989. 
el Debate sobre el Estado de la Nación de 1989- y la "agresión" socialista en Madrid que precipitó unos acontecimientos que se estaban sondeando y "debilitó la posición negociadora" del CDS. El balance en conjunto era gris, sobre todo, las consecuencias inmediatas de las mismas -la reacción del PSOE, la complicidad del PP, y el contexto electoral-, y la recepción por parte del electorado suarista, muy sensible ante cualquier tipo de decisión ${ }^{173}$.

Muchos de los dirigentes centristas de entonces, han considerado en perspectiva que los pactos llevados a cabo en la primavera del 89' supusieron un punto de inflexión negativo en la vida del partido, aunque en el momento de su materialización fueron bien vistos por la militancia de base ${ }^{174}$. Daniel de Fernando, Xavier Latorre o José Ramón Caso comparten esta impresión, y aunque éste último reconoce que fue una "estrategia política inteligente por parte de Aznar" no dejaba de responder al sempiterno intento de gestación de "la mayoría natural". Sin embargo, quizá fue Modesto Fraile, recientemente incorporado al partido quien hizo en 1989 la afirmación más elemental y no por ello desacertada: "el término centro-derecha ha inducido a una gran confusión y no se ha podido distinguir entre una opción de centro y una derecha" ${ }^{175}$. Aunque Modesto Fraile achacaba esta malintencionada pirueta lingüística al PSOE, era en el entorno de AP donde mayor rendimiento había tenido su introducción, desplazando a un segundo plano la alternativa "liberal-conservadora" con que se presentaba la Coalición entre 1982 y 1986. Como era habitual en los análisis electorales de $A B C$, poco a poco iban decantándose únicamente dos bloques: el PSOE y el centro-derecha. Un informe del PP, de cara a las elecciones europeas de 1989 lo manifestaba con claridad:

Es preciso cuidar las denominaciones y etiquetas ideológicas. Si el término conservador es limitante e incluso repelente para muchos votantes, el demócrata-cristiano [...] tampoco ayuda mucho [...] Lo idea es construir una alternativa poco recargada ideológicamente que se defina más por posiciones geométricas y de coyuntura que por etiquetas ideológico-históricas. Centro, moderno, moderado. Europeo, progresista,

\footnotetext{
173 Este último argumento merece la pena ser remarcado. Se señalaba que el electorado del CDS a diferencia del socialista o popular no se caracterizaba por ir "en contra de", independientemente de las realizaciones en sí de su partido; lo que le hacía extremadamente más crítico con su propio partido, "Informe de gestión del Secretario General", en Líneas de Acción Política, CDS, 1991.

${ }^{174}$ Según una encuesta interna, publicada por El Mundo, sólo el 4,9\% de los militantes (de un total de quinientos encuestados) tenía una visión negativa de los pactos con el PP, El Mundo, 26 de abril de 1990, MAST.

${ }^{175}$ FERNÁNDEZ, Gregorio: “El CDS pondrá en marcha ‘ya mismo’ la precampaña de los tres próximos comicios", Ya, 09 de julio de 1989, MAST.
} 
popular, con vocablos electoralmente más rentables que conservador, demócrata-cristiana e incluso liberal ${ }^{176}$.

En las elecciones europeas de 1989 el CDS había empeorado contra todo pronóstico los resultados cosechados en 1987 y 1986. El dato es más significativo si cabe debido al sistema electoral empleado en estos comicios, sustancialmente beneficioso para un partido, todavía minoritario, y de escala nacional, como era el CDS. En su descargo, Suárez había llegado a comentar: "Madrid vale más que dos eurodiputados"177.

\section{6. Las elecciones generales de 1989: programa y campaña electoral}

El adelanto de las elecciones generales de 1989, un rumor constante desde finales de 1988, se confirmó poco después de la elecciones europeas. El 1 de septiembre, Felipe González anunció definitivamente la celebración de una nueva convocatoria electoral el 29 de octubre. Y una vez más, superada la euforia vivida en 1986 y 1987 y tras el traspié en las elecciones europeas, las expectativas del CDS eran una incógnita:

Para mí, la interrogación de fondo se refiere a Adolfo Suárez. La caída del CDS el mes pasado ha sido tan general, tan evidente, tan rotunda, que cualquiera apostaría por su hundimiento en los próximos meses. Pero yo he visto a Suárez y al CDS en las últimas elecciones gallegas, cuando surgió con fuerza la "operación Roca", y no hubiera apostado ni un duro por el ex presidente del Gobierno, de modo que hubiera perdido muchísimo dinero $^{178}$.

En este contexto, el CDS intentó con cierta premura perfilar algunos flecos de la estrategia defendida desde su fundación y reequilibrar los sempiternos problemas de organización; con este fin la dirección nacional con la participación de Suárez mantuvo reuniones con más de ochocientos dirigentes territoriales, cuando ya se empezaban a oír, públicamente, algunas voces críticas contra la dirección del partido ${ }^{179}$. Las expectativas de constituirse en alternativa se habían derrumbado definitivamente y el discurso había dado un giro de ciento ochenta grados. Se instaba a dotar de una mayor humildad a las intervenciones públicas, mostrarse favorable a pactos de gobierno e insistir en la

\footnotetext{
176 "Bases para el diseño de una estrategia electoral", Fechado el primer semestre de 1989, Caja 4, 45231, AGUN/JLA, p. 5.

${ }^{177}$ El Independiente, 09 de julio de 1989, MAST.

178 JIMÉNEZ LOSANTOS, Federico: "El tórrido futuro", $A B C, 07$ de julio de 1989.

${ }^{179}$ El País, 29 de julio de 1989; "Eduardo Punset reconoce que los pactos con Fraga y Suárez motivaron el fracaso del CDS”, Ya, 11 de agosto de 1989. José Carlos Blanco ofrecía una visión más maximalista: “Críticos del CDS buscan el relevo de Adolfo Suárez", Tiempo, 11 de julio de 1989, MAST.
} 
necesidad de poner fin a las "mayorías absolutas" $" 180$. Una realidad asumida en las intervenciones de Suárez durante la campaña quien, como señalaba Lucía Méndez en $E l$ Mundo, ya no hablaba de volver a La Moncloa como hiciera en $1986^{181}$. ABC reiteraba su propuesta de coalición electoral entre el PP y el CDS: "favorece al socialismo gobernante la dispersión electoral de las fuerzas del centro y de la derecha [...] El Senado se puede ganar para el centro-derecha. Si se pierde, será culpa de los personalismos y las intransigencias del PP o del CDS o de ambos a la vez" ${ }^{\prime 182}$.

La reaparición pública de Suárez tuvo lugar durante el verano de 1989 para inaugurar el seminario "El centrismo liberal y progresista" celebrado por la Universidad Complutense, en el que expuso algunas de las líneas maestras del programa electoral y avanzó una de las medidas estrella de la campaña: tres meses de mili y "la conversión del servicio militar obligatorio en prestación de carácter voluntario a plazo medio" ${ }^{\text {"183 }}$. El Programa Electoral se aprobó en la Convención Nacional celebrada el 23 de septiembre en la que las medidas más innovadoras fueron:

Generalización del año sabático en la enseñanza, la eliminación de las listas de espera en la asistencia sanitaria, la construcción de 1.500 kilómetros de autopistas y 160.000 viviendas de protección oficial en cuatro años, el salario social para jóvenes que busquen su primer empleo, la creación de 1.000 nuevas plazas para jueces auxiliares y el apoyo a la eliminación en Europa de las armas nucleares ${ }^{184}$.

El programa electoral del CDS para las elecciones generales de 1989, formalmente impecable, pretendía integrar las principales innovaciones defendidas en 1986 y desde

\footnotetext{
${ }^{180}$ DÍEZ, Anabel: "La maldad de la mayoría absoluta”, El País, 07 de agosto de 1989.

${ }^{181}$ En una entrevista publicada por Lucía Méndez, Suárez valoraba la posibilidad de llevar a cabo un gobierno de coalición con Felipe González: "si llaman a nuestra puerta después del día 29, impondríamos condiciones sobre el control de los medios públicos de comunicación, sobre el control parlamentario del Gobierno y sobre la política social”, El Mundo, 27 de octubre de 1989.

182 "El ideal sería la convergencia electoral de todas las fuerzas de centro-derecha para las elecciones generales: PP, CDS, CiU, PNV y partidos regionalistas. Una vez más, esto ya no puede ser, lo que significa una prima para el PSOE. No tenemos demasiada esperanza de que el acuerdo pueda hacerse parcialmente para el Senado. Pero hay que decirlo, y que cada partido afronte su propia responsabilidad ante el electorado", editorial: "Un pacto necesario", $A B C, 15$ de septiembre de 1989. Un estudio que comprendía esta posibilidad en dieciséis provincias, reportaje a doble página de SÁNCHEZ, J. A.: "El centro-derecha puede romper la mayoría socialista en el Senado", $A B C, 15$ de septiembre de 1989 e ÍD.: "El Senado", $A B C, 15$ de septiembre de 1989. Por lo demás, "empieza a verse como sumamente improbable, por no decir imposible, una coalición electoral PP-CDS para llevar a Aznar a la Moncloa", LÓPEZ SANCHO, Lorenzo: "Juegos electorales", $A B C$, 14 de septiembre de 1989.

${ }^{183}$ Manifiesto Electoral 1989, CDS, 1989, p. 107.

${ }^{184}$ El País, 09 de octubre de 1989. Había sido presentado el día 27 de septiembre de 1989 en las principales ciudades del país.
} 
una óptica socio-liberal alcanzar la modernización efectiva de España mediante la consolidación de un "Estado de Bienestar moderno"185.

Para ello, era necesario un aumento general de la renta gracias a la inversión pública y privada, y como paso ulterior, la reducción de los desequilibrios mediante "la mejora de los servicios públicos [que] se debe financiar por la reestructuración del gasto público, mediante la reducción en compras de bienes y servicios, de la carga de intereses de la deuda y las subvenciones" ${ }^{\text {"186 }}$. El CDS era el único partido que hacía una mención al afrontamiento de la "deuda pública" $" 187$.

El programa del CDS en materia económica, ante la persistencia del desempleo a pesar de la dinámica expansiva, era para Diario 16 una "mezcla de la supply-sideeconomics [economía de la oferta] con una renovación del Estado de Bienestar", desplazando el "centro de gravedad de la macro a la microeconomía" " El País también subrayaba esta línea del CDS al citar: "ampliar el equipo productivo, invertir más" ${ }^{189}$. Probablemente, era el programa más decididamente liberal en lo económico del CDS que a su vez proponía, junto con el PP, un sistema de partición "splitting" en el cálculo de la base ponderable del IRPF y la congelación del gasto público en relación al PIB -apostaba eso sí, por mantener la presión físcal aun reformando la estructura impositiva $-{ }^{190}$. En infraestructuras apelaba a la participación del capital privado y la construcción de autopistas ${ }^{191}$.

En política exterior, el CDS también se alejaba de sus postulados más cercanos al centro-izquierda, centrándose en la situación de Gibraltar; aunque seguía demandando una mayor autonomía nacional así como reforzar la utilidad político-social de la CE y señalaba: "la liberación de los recursos dedicados a la defensa y su reasignación a objetivos civiles será una constante de la propuesta de CDS para fijar la posición española"192. Incluía, en una clara alusión a lo que había significado la inclusión en la

\footnotetext{
185 Quizá la nota distintiva de este modelo consistía en que, aun manteniendo el mismo nivel de prestaciones, se procediese a la transferencia de la gestión y titularidad de la provisión de los servicios públicos más ineficaces u onerosos para el Estado hacia el ámbito privado, Manifiesto Electoral 1989, CDS, 1989, pp. 4-8.

${ }^{186}$ El País, 28 de septiembre de 1989.

${ }^{187}$ Editorial: "Impuestos, votar y pagar", Diario 16, 27 de octubre de 1989.

${ }^{188}$ Editorial: "Economía, del auge al ajuste", Diario 16, 26 de octubre de 1989.

${ }^{189}$ MARCOS, Pilar: “Ahora no es el momento”, El País, 16 de octubre de 1989.

${ }^{190}$ El programa económico era obra de José Ramón Lasuén, El País, 30 de octubre de 1989.

${ }^{191}$ Editorial: "Infraestructuras: todos coinciden", Diario 16, 24 de octubre de 1989.

${ }^{192}$ Manifiesto ..., p. 96.
} 
OTAN y el referéndum posterior, una "declaración expresa de que el rumbo exterior de un país no puede ser cambiado bruscamente (a tal fin, habla de la necesidad de consensuar en mayor medida tales políticas)" ${ }^{\text {193 }}$. En defensa, se proponía "modificar el Código Penal Militar para suprimir 'en todos los supuestos' la pena de muerte y reformar la regulación de la objeción de conciencia igualando su prestación temporal con el Servicio Militar"194. Mantenía su compromiso de 1986, en cuanto a la duración de la 'mili', ahora extendido con variaciones al resto de formaciones ${ }^{195}$.

En política interior y en sintonía con partidos tan distantes como IU o el PP, coincidía en la necesidad de revitalizar la sociedad y las instituciones. En concreto, defendía - en lo que había sido un campo de batalla de la Legislatura-, la posibilidad de creación de Comisiones de Investigación a petición de dos grupos parlamentarios. Sin embargo, en cuanto a la reforma de la representación política su modificación de la Ley Electoral se limitaba a exigir el refuerzo del "principio de igualdad" y la "mejora de la proporcionalidad"196. En cuestiones culturales, insistía en atenuar el "dirigismo gubernamental"197.

En materia sanitaria, el programa del CDS era el más "minucioso y elaborado" aunque en líneas generales se asemejaba al de PSOE y PP, manteniendo los conciertos con la sanidad privada, "la libre elección del médico, la creación de la tarjeta individual del enfermo y el teléfono de urgencia", además de aumentar el número de camas hospitalarias, derivando la financiación de la Seguridad Social hacia los Presupuestos Generales del Estado y extendiendo una sanidad pública gratuita generalizada hasta cierto "nivel de renta"198. En cuestiones educativas aludía, al igual que el PP, a la "universidad privada", y no se pronunciaba sobre la selectividad, cuya retirada exigían

\footnotetext{
${ }^{193}$ Editorial: "Una política exterior consensuada y continuista”, Diario 16, 18 de octubre de 1989.

${ }^{194}$ DÍEZ, Anabel: "Los centristas proponen un sistema de protección social para atender a los colectivos marginados", El País, 29 de septiembre de 1989.

195 "Cuando Adolfo Suárez, no demasiado bien avenido con la institución castrense, lanzó su idea de reducir el servicio militar [...] la interpretación inmediata de quienes veían muy lejana esa reforma [...] fue la de considerar la propuesta del líder centrista como un mero ejercicio de demagogia. El tiempo ha demostrado con inesperada rapidez que lo tenido por verde estaba en realidad precozmente maduro", CONTRERAS, Lorenzo: "El CDS fue madrugador", $A B C, 01$ de octubre de 1989. Véase también, JIMÉNEZ LOSANTOS, Federico: "Mili, de entrada no", $A B C$, 22 de septiembre de 1989; LÓPEZ SANCHO, Lorenzo: "Lo que se cantaba en los cuarteles", $A B C, 21$ de septiembre de 1989; CAMPMANY, Jaime: "La pili y la mili", $A B C, 21$ de septiembre de 1989; CEBRIÁN, J. L.: "Reflexiones electorales", El País, 08 de octubre de 1989. "Entre los nueves meses de mili que promete el PSOE, los ocho del PP, los tres del CDS y los cero de IU sólo hay un elemento en común: nadie defiende el sistema actual", El País, 29 de octubre de 1989.

${ }^{196}$ Manifiesto..., p. 76.

${ }^{197}$ Editorial: "Cultura y estado", Diario 16, 25 de octubre de 1989.

${ }^{198}$ Editorial: "Curar la sanidad", Diario 16, 22 de octubre de 1989.
} 
grupos como $\mathrm{IU}^{199}$. Finalmente, merece la pena destacar el intento del CDS por dar un nuevo aire político al discurso ecologista y del medio ambiente ${ }^{200}$.

Para Diario 16, la clave de la campaña era el desvanecimiento ideológico de las fuerzas políticas arrastradas en ocasiones por la "pura demagogia". El episodio paradigmático había sido la generalización de ofertas sobre reducción del servicio militar por parte de todos los partidos políticos. Anabel Díez en El País destacaba, dentro del programa centrista sus políticas sociales, en las que proponía "un sistema de protección para atender a los colectivos marginados” ${ }^{201}$. La propuesta del CDS, que era complementaria a la Seguridad Social, adelantaba la universalización del sistema de pensiones, que cobró forma en la legislación sobre pensiones no contributivas aprobada por el Gobierno del PSOE en 1990 con el apoyo de toda la oposición, salvo IU y MC $\mathrm{MC}^{202}$. Una de sus iniciativas más llamativas era el "salario social" para jóvenes desempleados -criticada por medios liberales como Diario 16-, así como la equiparación de la pensión y el salario mínimos ${ }^{203}$.

La campaña se inició en medio de una fuerte polémica entre el Gobierno y la oposición -PP, IU, CiU y CDS- que suscribió un acuerdo en el Congreso "para la

\footnotetext{
${ }^{199}$ Editorial: "Educación: más ruido que nueces", Diario 16, 23 de octubre de 1989.

200 "Ese día [Suárez] llevaba una chaqueta verde, el mismo tono de buena parte de sus intervenciones. 'Estamos dañando de una forma irreversible el medio ambiente. Nuestra prioridad es apoyar la investigación en temas ecológicos, pero el esfuerzo nacional no es suficiente. Hay que hacer un planteamiento internacional y aplicar la normativa europea: el que contamina paga'. Sobre Anchuras fue rotundo: 'Podemos ganar esa batalla", GARCÍA SANTA CECILIA, Carlos: "Suárez abre nueva estrategia con ataques a González", El País, 18 de octubre de 1989.

${ }^{201}$ DÍEZ, Anabel: "Los centristas proponen un sistema de protección social para atender a los colectivos marginados", El País, 29 de septiembre de 1989. "Sólo los socialistas y el CDS proponen de forma específica incrementar la construcción de centros geriátricos públicos y aumentar el control sobre las residencias de ancianos privadas", URÍA, Lluis: "Pobres, viejos y abandonados", El País, 13 de octubre de 1989.

${ }^{202}$ Manifiesto..., pp. 49-56. En su tramitación parlamentaria Carlos Revilla (CDS) defendió esta ley, que en la práctica desarrollaba constitucionalmente el artículo $41^{\circ}$ y suponía una progresiva equiparación a las políticas sociales europeas, y lo hizo en base a los siguientes argumentos: implicaba el ahorro "en otros sectores del gasto", apostaba porque la redistribución estatal garantizara "una recta mínima [sic] a todos los que por una u otra razón no tengan los recursos para alcanzarla" señalando que su argumento tenía más que ver con "Rawls [...] [o] André Görz que con los del señor Friedman acerca de su impuesto negativo...". Aunque dejaba todavía, sin resolver, el problema de la "atención familiar" o la situación de viudedad, $D S C D$, Sesión Plenaria, 13 de septiembre de 1990, n 54, p. 2574. Un alegato de la progresiva universalización de estos derechos por parte de Carlos Revilla, DSCD, Comisión Política Social y Empleo, 05 de junio de 1990, no 101, p. 3014. En relación a las diversas medidas de "renta mínima de inserción" o "salario social", el CDS tuvo un papel destacado en su tramitación parlamentaria en Extremadura, Aragón y Asturias, en ARRIBA, Ana: "Los procesos de implantación de políticas de rentas mínimas de inserción en España", Unidad de Políticas Comparadas (CSIC), Documento de Trabajo 9909. Disponible en digital.csic.es/bitstream/10261/1559/1/dt-9909.pdf. Fecha de consulta: 11 de noviembre de 2014. Véase también, REVILLA, Carlos: "El CDS y la renta mínima", Documentación Social, 78, 1990, pp. 351-354.

${ }^{203}$ Editorial: "Enseñar a pescar", Diario 16, 11 de octubre de 1989.
} 
defensa del pluralismo político y la objetividad informativa" en TVE intentando supervisar la información emitida, lo que provocó la crítica del PSOE y muchos de los trabajadores del ente público ${ }^{204}$. En cualquier caso, un análisis de las apariciones de Adolfo Suárez durante la campaña le otorgaba, de acuerdo con su presencia parlamentaria la tercera posición, por detrás de Felipe González y José María Aznar ${ }^{205}$.

Como sucediera en 1986, hombres de confianza de Suárez se hicieron cargo de la maquinaria electoral. El director de campaña fue José Ramón Caso ${ }^{206}$, quien a su vez formaba parte del Comité Electoral junto a León Buil, Joaquín Abril, Carlos Revilla, Alejandro Rebollo, Gerardo Harguindey y el propio Adolfo Suárez. Un papel destacado en la elaboración del programa electoral de 1989 correspondió a Rafael Arias-Salgado y Carlos Revilla ${ }^{207}$.

La comunicación externa - con los medios de comunicación- corrió a cargo de Antonio Fernández Teixidó -acompañado por Alfonso Íñiguez en tareas de formación y Ricardo Lenoir como jefe de prensa-, mientras Rafael Martínez Campillo coordinó la comunicación interna del partido -junto a los dirigentes sectoriales Fernando Alcón, José Antonio Souto y J. L. Gómez Calcerrada-. En trabajos técnicos, participaron Eduardo Guerrero y Rafael Ruiz como gerente de campaña y adjunto respectivamente ${ }^{208}$. Coordinando estos trabajos se encontraba el responsable de Acción Electoral, Manuel Justel, profesor de Estadística en la UCM, y encargado de realizar con un equipo de expertos los diversos estudios electorales. El área de prensa estaba

\footnotetext{
${ }^{204}$ El País, 03 de octubre de 1989. La polémica apareció a finales de septiembre y se trasladó al comienzo de la campaña. Idéntico conflicto se vivió a propósito del CIS, cuyos sondeos, a petición de un escrito del Secretario General del CDS a la JEC debían ser puestos a disposición de todos los partidos, ABC Sevilla, 23 de septiembre de 1989 y El País, 07 de octubre de 1989.

${ }^{205}$ Como el resto de líderes, Adolfo Suárez fue entrevistado por RTVE, una entrevista que duró en torno a media hora -frente a los 45 minutos dedicados a José María Aznar, candidato del PP, principal partido de la oposición-. Véase, El País, 29 de octubre de 1989.

${ }^{206}$ Según fuentes del partido: "Caso decide en todas esas áreas [economía de campaña, gerencia, dirección, publicidad, propaganda, creatividad, acción electoral] y lo hace directamente. Antes tenía una labor más de supervisor", LACALLE, Julián: "Los 'tramoyistas' del CDS", Diario 16, 25 de septiembre de 1989.

${ }^{207}$ DUQUE, J. C.: "Harguindey sustituye a Revilla en el CDS de Madrid", Diario 16, 11 de enero de 1989.

${ }^{208}$ La empresa publicitaria contratada para la campaña fue Diagonal. Eduardo Guerrero, "publicista nato que fichó Adolfo Suárez hace varios meses. Trabajó en el grupo de la Cadena SER, siempre en la gerencia publicitaria. Una persona muy competente, que cuenta con la confianza de Suárez y tiene prestigio en los medios publicitarios. Con él trabajan diez expertos en publicidad y propaganda que realizan tareas de contratación, organización, etcétera", Rafael Ruiz también era publicista y había trabajado con el CDS en 1986. Ricardo Lenoir era "periodista con años de profesión. Estuvo en varios gabinetes de prensa ministeriales en la etapa de UCD trabajó en la agencia Colpisa y en su última etapa fue director general de la empresa de imagen relaciones públicas Mediathique, y de José Luis Sanchís [quien coordinase la primera campaña electoral de Adolfo Suárez]", ibid.
} 
completado por quienes desempeñaban ordinariamente estas funciones. Consuelo Fon coordinaba los gabinetes de prensa de los "grupos parlamentarios, tanto a nivel de Cortes Generales como de parlamentos generales”, Begoña Zubieta era responsable de la "imagen y comunicación de los eurodiputados” y Ramón Ongil ejercía como “jefe de prensa del grupo parlamentario del Congreso" ${ }^{, 209}$. Esta vez los medios para la realización de la campaña eran considerables, disponiendo incluso de un avión privado de siete plazas para la misma ${ }^{210}$.

Como vemos, la presencia e importancia de Martínez Campillo y Fernández Teixidó, ambos jóvenes dirigentes regionales del partido, demostraba los intentos de renovación de un "aparato" que por otra parte no sufría fisuras y estaba representado por aquellos que habían acompañado sin reservas a Suárez durante la "travesía del desierto". Uno de los retos de la campaña fue la presentación de las listas, sobre todo, de cara a incluir a muchos de los prestigiosos políticos integrados en el partido a lo largo de la III Legislatura ante las resistencias que en algunas ocasiones mostraron los Comités Provinciales -tabla 73-. En Ávila encabezaban las candidaturas dos amigos personales de Adolfo Suárez, José Alfredo Ferrer (Congreso) y Fernando Alcón (Senado). En Madrid, el propio Adolfo Suárez y José Ramón Caso ocupaban los dos primeros puestos de la lista, junto a Fernando Castedo, Carlos Revilla y Rafael Arias-Salgado. En las provincias más destacadas eran los principales cargos nacionales o territoriales quienes ocupaban las primeras posiciones: A. Fernández Teixidó (Barcelona), J. Abril Martorell (Valencia), L. Buil Giral (Zaragoza), Mario Bilbao (Sevilla), etc.

Tabla 73: Presencia en las listas del CDS de diputados de PDP, PL e IU (1987-1989).

\begin{tabular}{|c|c|c|c|}
\hline Nombre & Candidatura & $\begin{array}{c}\text { Rumores y otras } \\
\text { posibilidades }^{211}\end{array}$ & Electo \\
\hline $\begin{array}{c}\text { Baltasar Zárate Peraza de } \\
\text { Ayala }\end{array}$ & $\begin{array}{c}\text { Sta. Cruz de Tenerife } \\
\left(\text { Congreso } 1^{\circ}\right)\end{array}$ & - & Sí \\
\hline $\begin{array}{c}\text { José Ramón Lasuén } \\
\text { Sancho }\end{array}$ & Murcia $\left(\right.$ Congreso $\left.1^{\circ}\right)$ & Se daba por descartado & No \\
\hline Ana María Yabar Sterling & Madrid (Congreso $\left.6^{\circ}\right)$ & Valencia & - \\
\hline Antonio Jiménez Blanco & - & - & No \\
\hline Íñigo Cavero Lataillade & Burgos $\left(\right.$ Congreso $\left.1^{\circ}\right)$ & - & No \\
\hline Modesto Fraile Poujade & Segovia $\left(\right.$ Congreso $\left.1^{\circ}\right)$ & - & No \\
\hline $\begin{array}{c}\text { José María Pardo } \\
\text { Montero }\end{array}$ & - & - & \\
\hline $\begin{array}{c}\text { Félix Manuel Pérez } \\
\text { Miyares }\end{array}$ & Huelva (Congreso $1^{\mathbf{0}}$ ) & & \\
\hline
\end{tabular}

\footnotetext{
209 Ibid.

${ }^{210}$ El Mundo, 24 de octubre de 1989.

${ }^{211}$ El País, 12 de septiembre de 1989.
} 


\begin{tabular}{|c|c|c|c|}
\hline Ramón Tamames Gómez & - & Sevilla & - \\
\hline $\begin{array}{c}\text { Pilar Salarrullana de } \\
\text { Verda }\end{array}$ & Madrid (Congreso $7^{\circ}$ ) & - & No \\
\hline
\end{tabular}

Elaboración propia a partir de BOE, 30 de septiembre de 1989, n 235, p. 30711 y ss.

La madrugada del 9 al 10 de octubre comenzó, entre incidentes, la campaña electoral. Un grupo de ultraderechistas reventó la pegada de carteles en Madrid en la que participaba Suárez, resultando heridos algunos miembros del CDS. Aunque el episodio generó cierto revuelo mediático -las fotografías fueron publicadas por la revista Panorama-, como señaló el corresponsal de El País Ignacio Carrión no hubo un aprovechamiento electoral del incidente debido a "la actitud de Suárez, ducal, estoica, serena"212. La campaña continuó en Oviedo antes de realizar un traslado a París donde fue elegido Presidente de la ILP. El enviado especial para El País transmitía una imagen quijotesca del líder del CDS, en ocasiones brillante y arrojado, otras prudente y hasta melancólico, una visión compartida en los análisis de Lucía Méndez para El Mundo ${ }^{213}$, ambos sin duda más interesados en abordar la intrincada personalidad del abulense que su proyecto político. Suárez seguía un discurso supeditado a sus antiguas responsabilidades políticas, centrado "en la responsabilidad de la oposición y en la consolidación de una alternativa de gobierno" ${ }^{214}$. Suárez era "el único caso [de entre los grandes líderes nacionales] en que las citas a puntos concretos del programa (26) superan a los ataques (17)"215.

Las intervenciones del Presidente del CDS en los mítines se dividían en tres grandes partes: la recuperación de la "ilusión perdida", "una somera explicación de algunos aspectos de programa [...] y la petición del voto". Nuevamente, a medida que subía el tono de la campaña, aparecieron acusaciones cruzadas sobre algunos episodios de la reciente democracia española que para el PSOE, según Suárez, parecía empezar en $1982^{216}$. El PSOE centró su discurso sobre el CDS en la acusación de ser un "satélite" de la derecha, cuyo pacto podían reeditar, si fuera el caso, tanto en las Generales como en las Autonómicas de Galicia. Por su parte, el PP -que se mostraba abierto a pactos

\footnotetext{
${ }^{212}$ CARRIÓN, Ignacio: "Suárez, su reino no es de este mundo", El País, 24 de octubre de 1989.

213 "A este señor de Cebreros le faltan unos kilos y le sobran unos años para ser como Indiana Jones. Pero lo que son ganas, las tiene todas" en MÉNDEZ, Lucía: "Adolfo Suárez. Indiana Jones, en busca del voto perdido", El Mundo, 24 de octubre de 1989.

${ }^{214}$ El País, 11 de octubre de 1989.

${ }^{215}$ Reportaje: "La batalla por el voto", El País, 29 de octubre de 1989.

${ }^{216}$ Particularmente célebre se hizo su afirmación de que estaban dispuestos a "pagar a precio de oro el kilo de alcalde", El País, 25 de octubre de 1989. Su última intervención televisiva, el 27 de octubre se centró en la crítica al ejercicio del poder socialista, la situación de los servicios públicos y la seguridad social y el medio ambiente.
} 
postelectorales y centró sus ataques sobre el PSOE-, descalificó la opción del CDS como alternativa pidiendo el "voto eficaz" o "útil": "la dispersión del voto de la derecha" solo favorecía al socialismo ${ }^{217}$.

Tabla 74: Campaña electoral de Adolfo Suárez (1989).

\begin{tabular}{|l|l|}
\hline Ciudad & Fecha \\
\hline Madrid & 09 y 10 de octubre \\
\hline Oviedo & 10 de octubre \\
\hline París & 11 y 12 de octubre \\
\hline Madrid (C.A.) & 13 de octubre \\
\hline Palma de Mallorca & 14 de octubre \\
\hline Murcia, Albacete & 15 de octubre \\
\hline Valladolid & 16 de octubre \\
\hline Sevilla & 17 de octubre \\
\hline Zaragoza & 18 de octubre \\
\hline Santander & 20 de octubre \\
\hline Badajoz & 21 de octubre \\
\hline Las Palmas, Santa Cruz de Tenerife & 22 de octubre \\
\hline Málaga & 23 de octubre \\
\hline Valencia & 24 de octubre \\
\hline Barcelona & 26 de octubre \\
\hline Madrid & 27 de octubre \\
\hline
\end{tabular}

Elaboración propia a partir de fuentes hemerográficas.

Los primeros sondeos hechos públicos y realizados durante la precampaña electoral aventuraban un ligero descenso del $\mathrm{CDS}^{218}$. Sin embargo de acuerdo con las diferentes encuestas y sondeos aparecidos mediada la campaña, el CDS parecía ser capaz de frenar la caída en las últimas elecciones europeas y mantenerse en torno a los 18 o 20 escaños, con algo más de un $8 \%$ de los votos: "el CDS se recupera"219. Para los principales medios -El País o Diario 16-, el CDS mantenía sus resultados: "la leve recuperación del CDS $[\ldots]$ retornaría así a la posición de tercera fuerza nacional que parecía disputarle la coalición que encabeza Anguita, es tal vez la novedad más reseñable"220. Sin embargo y a pesar del terreno recuperado, el CDS había "perdido una gran oportunidad de ejercer el arbitraje al que aspira” ${ }^{, 21}$. Las mayores bolsas de voto indeciso se seguían encontrando a ambos lados del CDS: un $8 \%$ (PSOE-CDS) y un 5\% (PP$\mathrm{CDS})^{222}$.

\footnotetext{
${ }^{217} A B C, 29$ de octubre de 1989.

${ }^{218}$ En base a datos del CIS filtrados por el Gobierno, el PSOE y otras fuentes, El País, 05 de octubre de 1989. En esta línea: "IU y PP suben, CDS baja", Tiempo, 11 de septiembre de 1989.

${ }^{219}$ Tiempo, 15 de octubre de 1989.

${ }^{220}$ Editorial: "Temperatura electoral", Diario 16, 22 de octubre de 1989.

${ }^{221}$ Editorial: "Una cierta estabilidad electoral", Diario 16, 22 de octubre de 1989.

${ }^{222}$ El País, 08 de octubre de 1989.
} 
Para El País el electorado del CDS se encontraba desorientado "a derecha e izquierda", por los giros dados los últimos meses ${ }^{223}$. Diario 16, lejos de orientar el voto a los diversos candidatos, se limitaba a indicar la posibilidad de que el PSOE perdiera la mayoría absoluta y subrayar algunas de las limitaciones de la democracia española -ley electoral, partitocracia, etc.- definiendo la campaña como "desangelada y fría". $A B C$, que recogió muy parcamente la campaña del CDS, se hacía eco de sus críticas al PSOE que según el abulense no había puesto ningún empeño en frenar el crecimiento de una abstención, que sólo beneficiaba al partido más votado ${ }^{224}$.

El slogan de la campaña fue Capaces de hacerlo, que aparecía junto a una imagen de Suárez en blanco y negro en mangas de camisa y con corbata, sustancialmente distinta de la empleada en 1986. Ahora, se subrayaba el talante progresista e innovador del partido, que se hizo acompañar en sus mítines por el grupo Objetivo Birmania. Sin embargo, el devenir de la campaña distaba mucho de la celebrada en 1986. Ni las propuestas centristas constituían ya novedades, y ante la indignación del representante del CDS en el Consejo de Administración de RTVE, el ente público canceló una entrevista al abulense concertada en el programa "Entre Paréntesis"225, al que sí había acudido Manuel Fraga -27 de julio-. Fue Suárez sin embargo, quien declinó ser entrevistado por la cadena SER -“Hoy por hoy”-, El País, y Radio Nacional ${ }^{226}$, en un momento, en el que se encontraba en plena recomposición el liderazgo popular: "Aznar, en el segundo puesto de los líderes [políticos]”227.

En relación a la financiación de la campaña, el CDS contó con un presupuesto sustancialmente mayor que en otras ocasiones. De acuerdo con Diario 16 las cifras del PSOE-AP se elevaban entre 1500-2000 millones, el CDS alcanzaba 1000 e IU los $400^{228}$. Aun así, y como muestra de los desequilibrios territoriales en su implantación,

\footnotetext{
${ }^{223}$ Editorial: "Foto fija", El País, 08 de octubre de 1989.

224 Portada: "Suárez: 'La abstención es grave para la democracia'”, $A B C, 23$ de octubre de 1989; COLLADO, Ángel: “La abstención vota al PSOE”, Blanco \& Negro (ABC), 22 de octubre de 1989; "Los partidos de centro-derecha temen que la abstención les pueda perjudicar", $A B C, 29$ de octubre de 1989; Portada de El Mundo: "El PSOE perderá la mayoría absoluta si hay una fuerte participación electoral. Descenso del PP y auge del CDS e IU”, El Mundo, 23 de octubre de 1989.

225 "El CDS protesta por los nuevos 'Entre Paréntesis"”, $A B C, 14$ de septiembre de 1989

${ }^{226}$ El País, 26 y 27 de octubre de 1989.

${ }^{227}$ Con una vloración de 4,4 frente al 4,3 de Adolfo Suárez, El País, 08 de octubre de 1989.

228 Diario 16, editorial: "Derroche electoral", 03 de octubre de 1989. Como anticipo para gastos electorales, el CDS recibió 33 millones, $A B C, 14$ de octubre de 1989. Véase, VAN BIEZEN, Ingrid: "Party financing in new democracies Spain and Portugal", Party politics, 3 (6), julio de 2000, pp. 329-42.
} 
tuvo problemas para cubrir los puestos de interventores en muchos colegios electorales $^{229}$.

${ }^{229}$ PSOE: 80.000 interventores y 10.000 apoderados; PP: 75.000 interventores y 65 o 70.000 apoderados. El CDS 40.000 (entre apoderados e interventores) quitando el País Vasco y Cataluña y 2000 de ellas en Madrid, ÁLVAREZ, María Jose: “Todas las cifras de la jornada electoral”, ABC, 29 de octubre de 1989. 


\section{Capítulo 9:}

\section{El ejercicio de la "oposición” durante la IV Legislatura}

Durante la IV Legislatura, el CDS se alejó paulatinamente del reto que había inspirado su proyecto político durante la etapa inmediatamente precedente y al que no había sido capaz de dar respuesta durante la campaña electoral. Esto es, la puesta en marcha de iniciativas originales, innovadoras y progresistas, y que además fueran capaces de generar un fuerte impacto en la opinión pública.

La incapacidad de profundizar en esta línea y el retroceso electoral orientaron al partido a una infructuosa búsqueda de acercamiento al PSOE, con la pretensión de influir en el Gobierno e iniciar un proceso de regeneración democrática e institucional, y a la par conseguir una mayor visibilidad pública. Una estrategia de difícil aplicación si consideramos que el PSOE de facto, no había perdido la mayoría absoluta en el Congreso después de las elecciones generales de 1989.

El camino emprendido, torpedeado por disidencias internas e inapelables derrotas electorales, debilitó paulatinamente al CDS hasta el punto de provocar la dimisión y abandono del partido de Suárez en 1991 y relegarlo a una posición definitivamente secundaria en el ámbito político. En 1993, con un amargo sabor de boca, el CDS ponía punto y final a más de once años de presencia en las máximas instituciones del Estado. A lo largo de las siguientes páginas, intentaremos desgranar las últimas iniciativas, estrategias y desafíos del CDS en el ejercicio de la oposición política a nivel nacional.

\section{1. Los resultados de las elecciones generales de 1989}

La principal incógnita por desvelar en los comicios del 29-O fue la de saber si el PSOE se iba a alzar finalmente con la mayoría absoluta, una cuestión que arrastró tras de sí una larga polémica debido a la impugnación de los resultados en las 
circunscripciones de Murcia, Pontevedra y Melilla ${ }^{1}$. Finalmente, el PP arrebató al PSOE el diputado electo en Melilla tras la repetición de las elecciones, sin embargo, el acercamiento de las AIC -Agrupaciones Independientes de Canarias-, así como la ausencia de los miembros de HB posibilitó de facto una mayoría absoluta, aunque frágil, a los socialistas.

Entre los medios, $A B C$ destacó los síntomas de desunión, por vez primera desde 1982, en el electorado de izquierda derivando la situación parlamentaria hacia un "multipartidismo atenuado", E igual que sucediera en otras ocasiones llevaba a cabo análisis electorales en base a las categorías de PSOE, Centro-Derecha (incluía al CDS) y Otros $^{3}$, que le permitían apelar a la necesaria alianza de todas las fuerzas políticas a la derecha de los socialistas: "Convergencia nacional" (nacionalistas, regionalistas y un CDS empeñado en la "pasión inútil de ocupar el centro-izquierda" -"quimera progresista"- podían "impedirlo"4). Para El País los resultados consolidaban el liderazgo de Aznar - “al mejorar ligeramente los porcentajes que había logrado su antecesor Manuel Fraga"- y confirmaban el fracaso suarista como consecuencia de los pactos llevados a cabo con el PP, como demostraba el bajón producido en Madrid ${ }^{5}$. El descenso del CDS aunque leve era un elocuente síntoma de una errónea y confusa estrategia:

El descenso del CDS, no siendo tan espectacular como pudo pensarse en junio, refleja, sin embargo, la paulatina pérdida de fe del electorado potencial del centrismo en las virtudes taumatúrgicas de un líder que ha pasado siete años esperando ver pasar ante su puerta el cadáver de su rival. Como estrategia, es poca cosa para llegar a la Moncloa, e incluso para convertirse en complemento necesario algún día de un PSOE más desgastado. Si de secundar las reivindicaciones sindicales se trata, esos electores prefieren a Izquierda

\footnotetext{
${ }^{1}$ Se aprobó por unanimidad en el Congreso la creación de una Comisión de Investigación sobre el Proceso Electoral, DSCD, Sesión Plenaria, 06 de febrero de 1990, n 11 . Un texto pactado entre CDS, PP y CiU, El País, 07 de febrero de 1990.

${ }^{2}$ Editorial: "Las quintas elecciones generales", $A B C, 30$ de octubre de 1989.

3 SÁNCHEZ, J. A.: "De las grandes ciudades [...] sólo en Sevilla logró vencer el PSOE al centroderecha", $A B C, 30$ de octubre de 1989. Un análisis completo en $A B C, 01$ de noviembre de 1989.

4 "La terquedad de los hechos pone de manifiesto que las peculiaridades del sistema de partidos español condenan a las fuerzas del centro-derecha a resignarse al ejercicio crónico de la oposición...", en el editorial: "Convergencia nacional", $A B C, 03$ de noviembre de 1989. La portada con el titular de "La unión hace la fuerza" desarrollaba esta idea mediante el despliegue de las estrategias que dos perros atados por la misma cuerda debían seguir si querían alcanzar su comida -el poder-, $A B C, 03$ de noviembre de 1989. El CDS no poseía identidad política ni espacio electoral más allá del liderazgo de Suárez, MUÑOZ-ALONSO, Alejandro: "Tras las elecciones”, $A B C, 02$ de noviembre de 1989.

5 “El 'baile' de un escaño puso en vilo la mayoría absoluta”, El País, 30 de octubre de 1989.
} 
Unida; si de ser verde, a los verdes de verdad, y si de configurar una alianza antisocialista, a los conservadores de siempre. Ese es el drama de Suárez ${ }^{6}$.

Tabla 75: Los resultados electorales de 1989.

\begin{tabular}{|l|l|l|l|}
\hline Partido & $\mathbf{N}^{\mathbf{o}}$ de votos & Porcentajes & Diputados \\
\hline PSOE & 8.115 .568 & 39,60 & 175 \\
\hline PP & 5.285 .972 & 25,79 & 107 \\
\hline IU & 1.858 .588 & 9,07 & 17 \\
\hline CDS & 1.617 .716 & 7,89 & 14 \\
\hline CiU & 1.032 .243 & 5,04 & 18 \\
\hline
\end{tabular}

Elaboración propia a partid de: http://www.historiaelectoral.com/e1989.html Fecha de consulta: 10 de febrero de 2015 .

Para un medio como El País, la forja de una alternativa viable en la oposición pasaba fundamental -y casi, exclusivamente-, por el Partido Popular. Antonio Elorza, en un análisis de los resultados constataba: "el centro declina irreversiblemente y la derecha trabaja de cara al medio y largo plazo"7. Francisco Bustelo, en esos momentos militante del PASOC ratificaba la renovación de la derecha en una línea europeísta, la ocupación del espacio de centro por un PSOE liberal y el definitivo fracaso suarista ${ }^{8}$.

El CDS había pasado de un 9,22\% en 1986 a un 7,89\% y de 19 a solo 14 diputados. En esta ocasión, el CDS no había logrado ser la lista más votada en ninguna circunscripción, tomando el PP el relevo en el caso de Ávila con un 32,8\% de los votos frente al 31,5\% de los suaristas. Las circunscripciones donde el CDS superaba el $10 \%$ de los votos eran Asturias, las provincias castellano y leonesas de León, Valladolid, Burgos, Segovia, Ávila, Zamora y Salamanca, Madrid (11\%), Murcia, Las Palmas $(24,2 \%$, la segunda fuerza más votada) y Tenerife. En otras, como Badajoz, Alicante, Baleares, Cantabria o La Coruña superaba el 9\%. El CDS obtuvo 14 diputados, en las provincias citadas anteriormente con más escaños en juego, así como en Barcelona $(4,5 \%)$ y Valencia $(6,6 \%)$, -debido al sistema de repartición efectuado por la Ley d'Hondt-, y un senador:

Tabla 76: Los resultados electorales de 1989: parlamentarios.

\begin{tabular}{|l|l|}
\hline Provincia & Parlamentarios \\
\hline Madrid & 4 \\
\hline Las Palmas & 2 \\
\hline Santa Cruz de Tenerife & 1 \\
\hline
\end{tabular}

\footnotetext{
${ }^{6}$ Editorial: "Ganar y perder", El País, 31 de octubre de 1989. En El Mundo, señalaban que en medios cercanos al Gobierno se había producido un "ajuste de cuentas" contra Suárez, El Mundo, 31 de octubre de 1989.

7 ELORZA, Antonio: “¿Vuelve la izquierda?”, El País, 07 de noviembre de 1989.

${ }^{8}$ BUSTELO, Francisco: "Los próximos años”, El País, 08 de noviembre de 1989.
} 


\begin{tabular}{|l|l|}
\hline Ávila & 1 Diputado 1 Senador \\
\hline Asturias & 1 \\
\hline Valencia & 1 \\
\hline Alicante & 1 \\
\hline Murcia & 1 \\
\hline La Coruña & 1 \\
\hline Barcelona & 1 \\
\hline
\end{tabular}

Elaboración propia a partid de: http://www.historiaelectoral.com/e1989.html Fecha de consulta: 10 de febrero de 2015 .

Suárez que compareció pasada la una de la madrugada reconoció la derrota -su poca presencia en los medios, la confusión entre el electorado-, en una comparecencia junto a J. R. Caso y A. Fernández Teixidó. Algunos analistas comenzaban a describir el inicio de su crepúsculo político: "Ya no son edades para errar por los desiertos y el líder centrista, que presentaba ayer una imagen de agotamiento, lo sabe" ${ }^{\text {10 }}$. Opinión compartida por columnistas como Jaime Campmany quien escribía: "El duque es ya casi una estatua ecuestre"11. Como había manifestado a lo largo de la campaña Suárez subrayó su deseo de seguir en política y de volver a presentarse a la Presidencia del CDS. La reunión del Comité Nacional en la que se analizaron los resultados se demoró hasta el 13 de noviembre.

¿Habían sido las mociones de censura, las responsables del descenso electoral? Merece la pena comparar los resultados de las Generales de 1986 con los de 1989 en los territorios más condicionados por la política de pactos entre el PP y el CDS:

Tabla 77: Las mociones de censura y los resultados electorales.

\begin{tabular}{|l|l|l|l|}
\hline & 1989 GENERALES & 1989 EUROPEAS & 1986 GENERALES \\
\hline Madrid (Ciudad) & PP: 39,04\% CDS: 10,64\% & PP: 32, 11\% CDS: $8,74 \%$ & PP: $35,99 \%$ CDS: $13,66 \%$ \\
\hline C. A. Madrid & PP: 34,22\% CDS: 10,99\% & PP: 27,98\% CDS: $9,32 \%$ & PP: $31,97 \%$ CDS: $13,94 \%$ \\
\hline Castilla y León & PP: 40,25\% CDS: $12,75 \%$ & PP: 32,33\% CDS: $13,18 \%$ & PP: $35,82 \%$ CDS: $17,46 \%$ \\
\hline Guadalajara (Ciudad) & PP: 40,45\% CDS: $8,93 \%$ & PP: 34,56\% CDS: $7,87 \%$ & PP: $37,98 \%$ CDS: $12,75 \%$ \\
\hline Jaén $($ Ciudad) & PP 35,19\% CDS 5,79\% & PP: 30,12\% CDS: 4,96\% & PP: $35,71 \%$ CDS: $7,49 \%$ \\
\hline
\end{tabular}

Elaboración propia.

Si atendemos al resultado de las elecciones europeas, celebradas inmediatamente después de los acuerdos entre populares y suaristas, es perceptible la penalización por parte del electorado a ambos partidos. Un voto de castigo que no tuvo su correlato en el

\footnotetext{
${ }^{9}$ Las elecciones al Senado otorgaron en un principio dos senadores al CDS, pero la repetición de las mismas en octubre de 1990 en la localidad de las Mamblas otorgó uno de los escaños al PP.

10 "Suárez reconoce que no ha obtenido los resultados que esperaba", El País, 30 de octubre de 1989.

${ }^{11}$ El empecinamiento de Suárez, que impedía la formación de mayorías en el centro-derecha y sólo aspiraba a hacerse necesario para el PSOE, CAMPMANY, Jaime: "El duque y el retruque", $A B C$, 07 de noviembre de 1989.
} 
caso del Partido Popular en 1989, y sin embargo, pervivió en el CDS en los comicios de octubre desplazando a parte del electorado centrista de 1986 hacia los populares.

En clave interna, muchas voces entre la militancia de base, pero también entre los dirigentes demandaron una presencia más activa y permanente de Suárez ante los medios de comunicación y la opinión pública. En cierto modo, esta demanda enlazaba con los supuestos "silencios" de Suárez y con la sensación de que se comportaba más como ex presidente que como líder de un partido de la oposición ${ }^{12}$. Este cambio de actitud debía ir acompañado de una mayor presencia parlamentaria, intensidad en la organización del partido y una mejora de sus relaciones con los medios de comunicación, lo que Julián Lacalle había llamado la superación del "síndrome de la UCD" -época en el que las filtraciones y deslealtades eran habituales ${ }^{13}-$. Lorenzo Contreras, repasando las diversos ocasos y resurrecciones políticas de Suárez, aunque lo consideraba más bien un "bache subsanable", encontraba la causa en su "ostracismo voluntario" ". Se hablaba ya de una "segunda travesía del desierto"15.

De cara a la estrategia de pactos del partido, el CDS debía reforzar su independencia del Partido Popular (PP) y detener la cascada de mociones de censura que se había producido entre los meses de mayo y junio y que ahora, podía arreciar, como consecuencia de la euforia de los populares, caso por ejemplo de Palma de Mallorca ${ }^{16}$, a pesar de la compleja situación que generaba para Rodríguez Sahagún en el Ayuntamiento de Madrid $^{17}$.

Asimismo, asumió explícitamente sus limitaciones electorales y su papel equilibrador -de bisagra-, como demostró en el primer envite que tuvo lugar tras el 29O, las Elecciones autonómicas de Galicia:

Aunque con vocación de partido mayoritario, CDS de Galicia aspira sobre todo a convertirse en una formación que aglutine a los ciudadanos verdaderamente identificados con su ideario [...] está convencido de que existe un amplio espacio político entre el conservadurismo,

\footnotetext{
${ }^{12}$ DÍEZ, Anabel: "Dirigentes del CDS exigirán a Suárez un cambio de estrategia y mayor distanciamiento de los populares", El País, 02 de noviembre de 1989. Se abstuvieron en una moción de censura presentada por el PP en El Ferrol contra el gobierno municipal socialista, El Correo Español-El Pueblo Vasco, 15 de julio de 1989.

${ }^{13}$ Para lo que se había nombrado a Fernández Teixidó como responsable de comunicación del partido, LACALLE, Julián: “Los 'tramoyistas' del CDS”, Diario 16, 25 de septiembre de 1989.

${ }^{14}$ CONTRERAS, Lorenzo: "El eclipse de Suárez", $A B C, 03$ de noviembre de 1989.

${ }^{15}$ DÍEZ, Anabel: "Dirigentes del CDS...”, El País, 02 de noviembre de 1989.

16 "El CDS no apoyará al PP contra el alcalde socialista de Palma”, ABC, 06 de noviembre de 1989.

${ }^{17}$ Editorial: "Batalla de Madrid", El País, 03 de noviembre de 1989. El CDS hubo de ratificar su voluntad de mantener los pactos con el PP en su reunión del Comité Nacional el 13 de noviembre.
} 
históricamente incapaz de modernizar el Estado, y el intervencionista [...] entiende que en el futuro habrá de corresponderle un papel eminente en la articulación de los equilibrios políticos parlamentarios y, en consecuencia, un rol trascendental en la definición de las directrices de futuro de nuestro país... ${ }^{18}$

Según las encuestas el CDS podía obtener representación y si se repetían los resultados de las elecciones generales podía, incluso, llegar a ejercer esa función de bisagra. La predisposición al pacto del PP con los "afines"19, permitía al PSOE agrupar sus críticas generales a la "derecha" -CDS y PP-. El PSOE en su guía de campaña consideraba al CDS "subsidiario" del PP, único adversario real ${ }^{20}$. El PP, como hiciera en octubre, se limitaba a apelar al voto útil. El editorial de El País señalaba: "sus 36 hipotéticos escaños, sobre un total de 75, bastarían para que Fraga saliese investido presidente con el apoyo o incluso la abstención de los cinco diputados del CDS, que parece abocado a saldar en Galicia la deuda contraída con el PP en Madrid" ${ }^{21}$. Por otra parte, la posición del CDS que en principio permitiría gobernar a la lista más votada era, prácticamente, dejar la presidencia en manos de M. Fraga, aunque cabía la posibilidad de que la suma del PP y el CDS no consiguiera la mayoría absoluta, partido este último que disputaba el espacio de centro con Coalición Galega y Partido Nacionalista Galego. Un sondeo de Demoscopia publicado por El País le otorgaba dos escaños, recién iniciada la campaña ${ }^{22}$. Todas las hipótesis suponían una auténtica encerrona para los centristas:

Si los pronósticos de los sondeos son certeros, el Partido Popular necesitaría del apoyo del CDS para alcanzar la mayoría absoluta [...] que se limitarán a facilitar la gobernabilidad apoyando a la lista más votada o, en su caso, absteniéndose. Pero cabe la posibilidad de que esos escaños centristas no sean suficientes para dar la mayoría a Fraga, mientras que sí lo serían para completar una alternativa formada por los partidos que han gobernado en coalición en estos dos últimos años. En ese caso, ¿cuál sería la opción del CDS? Los votantes tienen derecho a saberlo; pero, si los centristas enseñan sus cartas por anticipado, es posible que pierdan una parte sustancial de sus votos potenciales ${ }^{23}$.

El candidato escogido para la presidencia de la Xunta fue Jesús Osorio quien había ingresado en el CDS en abril de 1987 y ejercía en ese momento labores docentes en la

\footnotetext{
18 "Nuestro partido, 'un novo xeito' en las elecciones autonómicas de Galicia", OICDS, 22, diciembre 1989.

${ }^{19}$ Expresión de Manuel Fraga, $A B C$, 01 de diciembre de 1989.

${ }^{20}$ El País, 29 de noviembre de 1989. El ex diputado centrista por La Coruña José María Rioboo Almanzor se dio de baja ante el previsible pacto del PP con el CDS, El País, 16 de diciembre de 1989.

${ }^{21}$ Editorial: "Lectura gallega", El País, 08 de noviembre de 1989. Véase también, editorial: "El destino del voto", El País, 03 de diciembre de 1989. "De este modo, por acción u omisión del CDS, no se impedirá el acceso de Manuel Fraga a la presidencia de la Comunidad gallega", $A B C, 12$ de diciembre de 1989.

${ }_{22}^{22}$ El País, 10 de diciembre de 1989.

${ }^{23}$ Editorial: "Polarización gallega", El País, 16 de diciembre de 1989.
} 
Cátedra de Bioquímica de la Facultad de Farmacia en Santiago y la dirección del Centro Regional de la UNED en Pontevedra ${ }^{24}$. Suárez participó activamente en la campaña permaneciendo en Galicia desde el día 7 al 17 de diciembre, en la que de nuevo sufrió el ostracismo de la televisión ${ }^{25}$. El discurso suarista se centró en reclamar mayores inversiones por parte del Estado central y, en la línea del resto de partidos, en las políticas sectoriales decisivas para Galicia, fundamentalmente, agricultura y pesca.

Los resultados, en los que salió vencedor Manuel Fraga con mayoría absoluta en número de escaños, agudizaron la mala tendencia del CDS, que permanecía en tierras gallegas como partido extraparlamentario. Adolfo Suárez, que había viajado a Madrid el día antes de los comicios, no volvió a Galicia la noche del escrutinio en la que permaneció junto a los dirigentes autonómicos José Ramón Caso. Poco a poco, el CDS se convertía en una pieza cada vez más marginal del tablero político. Si el 30 de octubre, $A B C$ apenas había dedicado espacio al análisis del CDS, acompañado en la misma página por el Partido Andalucista, ahora, un columnista como Celestino Fernández podía afirmar:

Se ha demostrado que al CDS no le perjudican los pactos con el PP. Mal escapó en las elecciones generales, acusado del supuesto pactismo; peor ha escapado en Galicia jugando al Contra-Fraga. El CDS, a pesar de las simpatías, en mengua, que despierte Adolfo Suárez, poco tiene que hacer. Ni solo ni acompañado [...] Suárez perdió el tren hace tiempo. Y este país camina hacia el bipartidismo, como la mayoría de los países democráticos ${ }^{26}$.

La sucesión de contratiempos electorales -Europeas, Generales y Galicia-, desembocó en la eclosión de sectores del partido descontentos con la dirección nacional y el aparato de muchos territorios ${ }^{27}$; aunque, los procesos de división a menudo tenían orígenes anteriores y diversos - como la rivalidad entre las direcciones provinciales y los grupos municipales o autonómicos, como sucedió en Baleares, La Rioja y Huelva ${ }^{28}$ o

\footnotetext{
${ }^{24}$ El Periódico de Catalunya, 05 de agosto de 1989; ABC, 17 de diciembre de 1989; OICDS, 22, diciembre 1989. Jesús Osorio abandonó poco después el partido, Diario 16, 08 de noviembre de 1990.

${ }^{25}$ En este caso, de la TVG. Por ejemplo, fue el partido con menor cobertura y reparto de tiempos en la apertura de campaña o el único partido, por carecer de representación autonómica, del que no se emitió una entrevista, $A B C$, 06 y 08 de diciembre de 1989.

${ }^{26}$ FERNÁNDEZ, Celestino: "Las elecciones gallegas", ABC Sevilla, 21 de diciembre de 1989.

${ }^{27}$ CONTRERAS, Lorenzo: "El CDS en la encrucijada", $A B C, 12$ de noviembre de 1989; CASADO, Antonio: "Suárez se resigna a no volver a la Moncloa", Tiempo, 13 de noviembre de 1989

${ }_{28}$ Como sucedió en Huelva, donde se produjo la dimisión del Secretario Provincial, Miguel Ángel Velasco, ABC Sevilla, 03 de febrero de 1989. Del mismo tipo fue la división en el CDS riojano donde los dos diputados autonómicos electos se pasaron al Grupo Mixto al desobedecer la disciplina del partido en la votación de los Presupuestos Generales de la Comunidad Autónoma. También se dieron de baja dos concejales del Ayuntamiento de Logroño, véase, La Rioja, 04 de mayo de 1988 y Diario 16, 14 de junio de 1988. En el caso de Baleares se habían conformado dos grupos desde 1987. Uno de ellos en torno a
} 
las discrepancias entre los órganos de gobierno nacionales y territoriales ${ }^{29}-$ y se habían producido episodios muy destacados, como el de la expulsión del partido del alcalde de Segovia L. Sánchez Creus, ahora existía el caldo de cultivo perfecto para su despliegue público y su generalización. Surgía así, en el otoño de 1989, lo que en la prensa se conoció como "los críticos". Si hubiera que buscar una nota común en este grupo era la contestación a lo que se consideraba el "aparato" del partido -personificado en José Ramón Caso- y el déficit de democracia interna en el seno del mismo.

En Madrid, esta corriente estuvo liderada de cara a la comunicación con los medios por Fernando Castedo, y mostraba abiertamente su desafección con la dirección regional del partido, una ruptura perceptible a lo largo de toda la vida de la Federación de Madrid $^{30}$. Asimismo, el diputado autonómico Fernando Lanzaco Bonilla se integró el Grupo Mixto después de la celebración de los comicios regionales.

A la división en el CDS madrileño, le siguieron en cascada episodios similares en Cataluña -Leopoldo Ortega-Monasterio-, Toledo, Murcia, Algeciras, Navarra, Baleares, Cádiz, etc. Un grupo minoritario en Madrid firmaba un manifiesto exigiendo un debate sobre los pactos firmados con el PP, a su entender, origen de los males del partido:

Los autores del documento, que anuncian que lucharán "hasta el final" por defender el derecho a expresar sus opiniones tanto dentro como fuera del partido, recuerdan que los pactos con el Partido Popular se firmaron "con el mayor de los secretismos (...). Los pactos con el PP, además de políticamente erróneos, en nuestra opinión”, insisten los firmantes, "nos sitúa a los militantes de base ante la opinión pública en posición de indefensión; sin saber qué explicar [...]. Los sectores más de derecha del partido caminan

Josep Meliá y el Comité Insular de Mallorca y otro afín a la dirección federal (F. Quetglás) y nacional del partido, así como al grupo municipal de Palma de Mallorca y autonómico. En enero de 1989, fue inhabilitado para ocupar cargos internos en el CDS, Josep Meliá a raíz de un artículo en la prensa local titulado: "El liberal Sitjar y el silencio de los liberales", El Día de Baleares, 04 de octubre de 1988 y 15 de febrero de 1980, Diario 16, 01 de febrero, 21 de marzo y 09 de diciembre de 1988, MAST.

${ }^{29}$ En diciembre de 1988, dimitió en bloque el Comité Ejecutivo Provincial de Vizcaya. La causa inmediata de la decisión había sido la decisión del Comité Nacional de Disciplina de sobreseer tres expedientes de expulsión incoados por el Comité de Disciplina Provincial, El Correo Vasco, 28, 29 y 30 de diciembre de 1988. En Ciudad Real, el Presidente Provincial, Felipe Caballero y dos diputados provinciales se integraron en el PP, Diario 16, 17 de junio de 1988, MAST, y ABC Sevilla, 02 de febrero 1989.

${ }^{30}$ Junto a él, se encontraba José Luis González Quirós, Abel Cádiz o José Antonio Pérez González. En 1988, Carlos Santos señalaba: "Suárez mantiene a ultranza una situación contra natura: el presidente Carlos Revilla sólo cuenta con el apoyo de un 40 por ciento de los militantes, que en su inmensa mayoría consideran a Fernando Castedo como su líder natural. Tal caldo de cultivo alimenta el descontento. Y las contradicciones" en "Suárez, el ermitaño", Cambio 16, 11 de julio de 1988. 
esos días pletóricos de optimismo y fuerza y dicen que la operación beneficia al partido pero el 15 de junio de 1989 el electorado se pronuncia de forma inapelable" ${ }^{\sharp 1}$.

En otros lugares como Murcia, Talavera de la Reina o Algeciras, donde dimitió en bloque el comité local, habían sido discrepancias con la formación de las listas o la forma de llevar la campaña las causantes de la crisis ${ }^{32}$. En Navarra, se pasó al Grupo Mixto el diputado autonómico José Antonio Eder ${ }^{33}$. En comunidades como Castilla y León o la Comunidad Valenciana, las rivalidades interprovinciales -León y Valladolid; Alicante y Valencia ${ }^{34}$ - presentes desde los primeros compases del partido, arreciaron, provocando el posicionamiento y por ende, división del resto de provincias. En estos procesos, el alineamiento con el "aparato" o las acusaciones de "derechización" fueron los argumentos utilizados para respaldar las luchas internas por el poder territorial.

Las declaraciones se sucedieron. Otros líderes nacionales -Eduard Punset, Rafael Calvo Ortega e incluso el propio Castedo- o regionales -Luis Aznar- achacaron públicamente la caída electoral a los Pactos con el PP: "con Fraga, que sigue representando el pasado",35. Otros como Miguel Martínez Cuadrado anticipaban, la que sería la futura estrategia del partido: "el CDS tiene que cambiar radicalmente de estrategia y acercarse al PSOE"36. Finalmente, Arias-Salgado o León Buil hacían hincapié en dinamizar la estructura organizativa del partido -implantación territorial y comunicación interna $-{ }^{37}$.

Como señaló J. R. Caso en su Informe de Gestión ante el III Congreso (Torremolinos), tras un período de éxito y ascenso (1986-1988), el año que ahora pasaba (1989) había supuesto su "calvario electoral".

\footnotetext{
${ }^{31}$ El documento estaba firmado por: Juan Ramon Martínez-Acha, José Ignacio Peregrín, T. Gómez Garrido, Álvaro Martín y Carmen Sartorius, El País, 10 de noviembre de 1989. En la noche electoral, Martínez-Acha exigió democracia interna a Suárez; otros demandaron la dimisión del abulense, ESTEBAN, Esther: "Suárez está acorralado por dirigentes de su partido", Tribuna, 13 de noviembre de 1989.

${ }^{32} A B C, 03$ de noviembre de 1989; Diario 16, 20 de noviembre de 1989.

${ }^{33} A B C, 14$ de diciembre de 1989. En esas fechas, dimitió el Secretario Regional, J. M. Martínez Peñuelas aduciendo razones personales, Diario 16, 27 de noviembre de 1989.

${ }^{34}$ En Murcia, en enero de 1989 se expedientó a la ejecutiva del partido en Cartagena al completo, al celebrar, su Comité Local una asamblea electoral supuestamente irregular, $A B C, 06$ de enero de 1989.

${ }^{35}$ ALTABLE, Juan: "Siete barones inician la revuelta en el CDS", Cambio 16, 27 de noviembre de 1989; ESTEBAN, Esther: "Suárez acorralado...", Tribuna, 13 de noviembre de 1989; HERRERO, Luis: "Jaque a Suárez", Época, s. f. (noviembre de 1989), Hemeroteca Caixa Tarragona.

${ }^{36} \mathrm{Ibid}$.

${ }^{37}$ Ibid.
} 


\section{2. Del Debate de Investidura (1989) al caso "Juan Guerra". Los críticos}

El debate de investidura celebrado en 1989 anticipó un cambio de tercio en el discurso de Adolfo Suárez respecto al Gobierno, que aunque pasó bastante desapercibido, perfilaba las líneas maestras del nuevo papel que iba a jugar el CDS en la IV Legislatura. Una nueva estrategia basada en la búsqueda de acuerdos con el PSOE que dio paso a situaciones muy difíciles de gestionar, como se manifestó a propósito de su actitud frente al caso "Juan Guerra", y acentuó el proceso de fractura y división interna del partido.

La intervención de Suárez en el debate celebrado en diciembre de 1989 comenzó ponderando, a partes iguales las carencias y los aportes realizados por Felipe González, especialmente, su oferta de diálogo y búsqueda de acuerdos -singularmente la institucionalización de las reuniones entre los distintos partidos firmantes de los pactos antiterroristas-. A continuación, indicaba, lo que a su juicio eran los retos apremiantes de la legislatura: la mejora del funcionamiento institucional, de los servicios públicos y la corrección de los graves desequilibrios socio-económicos.

En lo relativo a los mecanismos institucionales, aludió al proceso electoral de octubre, en el que perdieron intensidad los fuertes reproches de la campaña: "afirmamos que no debe repetirse en el futuro una confrontación electoral tan sesgada desde algunas instituciones públicas que controla el Gobierno"38. En segundo lugar, era preciso una reforma del reglamento parlamentario mejorando la "información a los parlamentarios, la agilización de los procedimientos de debates con turnos flexibles" así como "la creación rápida de comisiones de investigación o de órganos de trabajo y seguimiento sin que pueda impedirlo la mayoría [y] mayores posibilidades de control del gasto público". Finalmente, y como venía siendo habitual, la justicia era la gran asignatura pendiente de la Administración española, en la que sin entrar en detalles apostaba por la despolitización del $\mathrm{CGPJ}^{39}$.

A continuación, abordaba la política autonómica. Para Suárez, la IV Legislatura debía servir para cerrar definitivamente el "proceso de construcción" del Estado

\footnotetext{
${ }^{38}$ DSCD, Sesión Plenaria, 05 de diciembre de 1989, $\mathrm{n}^{\circ} 3$.

${ }^{39}$ En el proceso de mejora de la Administración Pública era necesario introducir el "silencio positivo" en la administración, crear una oficina de control presupuestario e implementar una reforma del Tribunal de Cuentas con el fin de erradicar el clientelismo de la función pública, ibid.
} 
Autonómico, es decir, el "reparto del poder político y descentralización administrativa". La referencia a RTVE era el siguiente hito de este recorrido. La reforma del estatuto de RTVE debía pasar por la "desvinculación" de la "influencia directa e inmediata de los partidos políticos" y ampliar la representación de otros sectores sociales. Finalmente, y debido al eco electoral de la propuesta de reducción del servicio militar y el clima de distensión internacional, señalaba la posibilidad de crear una Comisión sobre este particular en el Parlamento. La última parte de su intervención, la dedicaba el abulense a exigir una respuesta rápida y eficaz en la mejora de los servicios públicos como herramienta fundamental para la redistribución real de la renta, tanto a nivel individual como territorial. Exigencias y retos que no eran sino un impulso a la demanda de competitividad que iba a encarar el sistema productivo español a raíz de la entrada en el Mercado Único. Contexto en el que era necesario un nuevo consenso nacional en materia de gasto público.

Cerraba su intervención recordando su intención de votar en contra de la investidura de Felipe González, aunque señalaba: “créame, señor González, si le digo ahora que me alegraría infinitamente y me llenaría de satisfacción poder arrepentirme de la posición que hoy adoptamos, de nuestro no a su investidura" 40 .

El propio Felipe González en su turno de réplica se centró en abordar aquellos puntos de contacto entre ambos, dejando en un segundo plano los desacuerdos. En su intervención se mostró conciliador ante las distintas propuestas del líder del CDS, aun considerándolas improbables o erróneas. Por ejemplo, al comentar la posibilidad de crear una Comisión parlamentaria sobre el Servicio Militar y señalar que debería incluirse como tema de debate en la de Defensa aducía: "si no, permítame que le diga que estudiaríamos a ver si, dentro de eso, se puede crear una especie de subcomisión..."41. En otra ocasión: "ha hecho S. S. algunas propuestas sobre la Administración Pública. Sólo le puedo decir que hay que estudiarlas"42. Las referencias a la Transición, esta vez sí, fueron escasas: “en Radiotelevisión propone modificar un Estatuto cuya paternidad no puedo atribuirme, y me parece razonable la modificación de ese Estatuto. Por tanto, tema a estudiar" ${ }^{\natural 3}$. La réplica de Adolfo Suárez siguió en esa misma orientación subrayando los puntos en contacto entre ambos discursos: "Yo

\footnotetext{
${ }^{40}$ Ibid., p. 91.

${ }^{41}$ Ibid., p. 92.

${ }^{42}$ Ibid., p. 93.

${ }^{43}$ Ibid., p. 94.
} 
aceptaría mejor la última sugerencia que ha hecho, la relativa a que fuera una subcomisión, por ser más limitada..."44 La dúplica de Felipe González señaló el hipotético modelo de referencia para la modificación parlamentaria y los límites de la reforma estatutaria -"la reforma de los Estatutos, como usted plantea, no garantiza que el problema se cierre en esta Legislatura"-. Sus últimas palabras inauguraban un nuevo camino para la legislatura:

Repito que el tono constructivo de su intervención me parece que se corresponde con el esfuerzo que queremos hacer y, por consiguiente, tenemos abierta una vía de diálogo que espero podremos explorar y desarrollar ${ }^{45}$.

Si para $A B C$, Suárez había acogido con "cautela la oferta de diálogo" de González, desde El País, la intervención de Suárez parecía una "oferta de guante blanco" al Ejecutivo recogida por el propio González:

\begin{abstract}
Siete años después, Suárez ha vuelto, tras describir un giro de 360 grados, al punto de partida: el de un partido con vocación de bisagra capaz de apuntalar un Gobierno de centro-izquierda. Pero si entonces tenía sólo tres escaños [sic], que además nadie necesitaba, ahora tiene 14, que pueden resultar imprescindibles a medio plazo para garantizar la gobernabilidad. Las leves objeciones planteadas ayer por Suárez al discurso de González revelan una voluntad de colaboración. Así, la oferta de apertura realizada la víspera halló un destinatario predispuesto. La aceptación genérica de las diferentes propuestas adelantadas por Suárez pueden anunciar, como en Casablanca, "el comienzo de una gran amistad"46.
\end{abstract}

En palabras de Gregorio Morán, "no se apoyó al Gobierno, pero casi" ${ }^{47}$. Esta situación tuvo continuidad a propósito del caso "Juan Guerra". Este incidente había saltado a los medios como consecuencia de la denuncia del portavoz y concejal del CDS de Barbate $^{48}$, Alonso Varo, en enero de 1990. La intensa reacción de la prensa $-E l$ Mundo y $A B C$ - sacudió inmediatamente a la opinión pública española. Para IU, PP o PA, este hecho implicaba la toma en consideración de unas responsabilidades políticas que debían ser dirimidas en el Parlamento. Distinta opinión era la defendida por el CDS, PSOE y PNV para quienes los Tribunales debían ser los únicos encargados de juzgar los hechos: "la actitud de la prensa y la oposición de derecha e izquierda puede dar lugar a

\footnotetext{
${ }^{44}$ Ibid., p. 95.

${ }^{45}$ Ibid., p. 96.

${ }^{46}$ Sin embargo, otorgaba a Aznar la iniciativa en el liderazgo del conjunto de la oposición y le atribuía, al menos, "un esbozo de programa alternativo, inscrito en la lógica del liberalismo conservador y susceptible de servir de referencia para alianzas más amplias", en el editorial: "Las oposiciones", El País, 06 de diciembre de 1989. Sección "Actualidad Gráfica", $A B C, 06$ de diciembre de 1989.

${ }^{47}$ En expresión de MORÁN, Gregorio: Ambición...

${ }^{48}$ En las páginas de $A B C$, desde el 03 de enero de 1990, "el concejal del CDS en el Ayuntamiento de Barbate, Alonso Varo, ha levantado un buen conejo de escándalo", USSÍA, Alfonso: "Tomate en Barbate", $A B C, 07$ de enero de 1990.
} 
la ocurrencia de linchamientos morales"49. Responsabilidades que se redujeron a las explicaciones aportadas por Alfonso Guerra en el Congreso. El CDS, junto a los nacionalistas, aceptó la "versión de Alfonso Guerra al carecer de pruebas para sostener una versión distinta", manteniendo que "las denuncias que se hagan sobre actos ilícitos cometidos por cargos políticos deben sustentarse en pruebas y no en meras sospechas". Se subrayaba además que una de las claves del escándalo era el protagonismo de Alfonso Guerra, distinguido por la virulencia de sus "ataques a los adversarios". Alejandro Rebollo defendió desde el CDS estos argumentos en la tribuna parlamentaria -“traspasaríamos los límites de la justicia, a los que me referí al principio, si aquí y ahora dijéramos que usted miente"-:

¿Es esa la misión de la oposición, atacar, o más bien controlar y construir? El CDS ha pedido cien veces que se llene el vacío legal que existe en nuestro ordenamiento respecto al tráfico de influencias, y el mejor testigo es el 'Diario de Sesiones'; el CDS ha pedido públicamente y desde el primer momento una investigación judicial de las actividades de don Juan Guerra... ${ }^{50}$

La intervención de Alejandro Rebollo fue unánimemente criticada por los medios, especialmente conservadores, y muchos miembros del partido para quienes el CDS hacía dejación de sus responsabilidades en la "oposición" IU, el CDS nunca solicitó formalmente la dimisión del vicepresidente y cuando ésta se produjo -en enero de 1991-, se abstuvo -como miembro de la Diputación Permanentede apoyar la solicitud del PP para convocar un pleno Extraordinario que obligara al

\footnotetext{
${ }^{49}$ JIMÉNEZ SÁNCHEZ, Fernando: Detrás del escándalo político. Opinión pública, dinero y poder en la España del siglo XX, Barcelona, Tusquets, 1995, p. 178. A propósito de la comparecencia pública de Felipe González, Isabel Fernández y $\mathrm{M}^{\mathrm{a}}$ Fernanda Santana han sostenido que "la oposición con la sola excepción del CDS, vio en la comparecencia una operación de imagen" en: Estados y medios de comunicación en la España democrática, Madrid, Alianza, 2000, p. 200. Para Ricardo de la Cierva, A. Rebollo echó "un capote" a Guerra y el día siguiente mucha gente llamó a la sede del partido para pedir la baja, ÍD.: El suicidio..., pp. 161-2.

${ }^{50}$ DSCD, Sesión Plenaria, 01 de febrero de 1990, no 10, pp. 310-11. En el mismo sentido, se pronunció Suárez en el Debate sobre la Moción de Confianza presentada por el Gobierno, apelando a la necesidad de "descrispar la sociedad", DSCD, Sesión Plenaria, 11 de abril de 1990, n 28

51 " [...] Un Adolfo Suárez avanzaba abisagrado (o avinagrado) dando alcance a Carmen Romero con cara de susto", CARRIÓN, Ignacio: "Diente por diente", El País, 02 de febrero de 1990. "Dos partidos políticamente comprados (PNV y Convergencia) y uno vendido (el CDS, que en paz descanse)", JIMÉNEZ LOSANTOS, Federico: "El gobierno se echa al monte", $A B C, 03$ de febrero de 1990. "[Anasagasti y Rebollo] acudieron escandalosamente en socorro del poderoso en apuros", CONTRERAS, Lorenzo: "Después del debate", $A B C, 03$ de febrero de 1990. En el editorial de El País ni siquiera se hacía mención de la intervención de Rebollo y en $A B C$ se señalaba: "Fue triste comprobar cómo los nacionalistas catalanes - con habilidad-, los nacionalistas vascos - con tosquedad - y los centristas con delicuescencia- corrían en auxilio del poder, desenfocando el objeto propio del debate", editorial: "Nadie le creyó", $A B C, 02$ de febrero de 1990. En el contexto del III Congreso, Justino Sinova señalaba que su actitud ante el caso Juan Guerra lastraba su credibilidad liberal-radical, Diario 16, 11 de febrero de 1990.
} 
Presidente de Gobierno a explicar las razones de la misma ${ }^{52}$. El caso Juan Guerra desembocó en la modificación parcial del Código Penal por la que se introdujo la tipificación del delito de tráfico de influencias ${ }^{53}$. En este sentido, el CDS había presentado una proposición de ley en enero de 1990 y había solicitado la ampliación de la figura del cohecho.

Si ante el fracaso electoral, la dirección nacional había apostado por un cambio de estrategia basado en la búsqueda de acuerdos con el PSOE, el sector del partido conocido como "crítico" intentó coordinar sus fuerzas de cara al III Congreso Nacional, cuya celebración se había anunciado para ese mes de febrero de 1990. Los críticos desarrollaron un "manifiesto" precongresual en el que se proponía una transformación estructural del partido -creación de un Consejo Político, máximo órgano doctrinal y programático entre Congresos, compuesto por cien miembros electos con listas abiertas-, la renovación ideológica y un mayor protagonismo político por parte de Suárez $^{54}$. La cena-presentación del sector renovador tuvo lugar el 11 de enero de 1990. El objetivo era presentar listas alternativas de compromisarios en las asambleas provinciales y federales, que se iban a celebrar durante las semanas próximas. En el caso de Madrid, esa lista estuvo encabezada por Abel Cádiz.

En este contexto, apareció un informe de Ignacio Camuñas que con el título de "El futuro del CDS ante su III Congreso Nacional. Memorándum de ideas y propuestas"55 apostaba por el acercamiento al Partido Popular. Camuñas comenzaba recordando su

\footnotetext{
${ }^{52}$ El País, 23 de enero de 1991. En el editorial de $A B C$ se volvió a reprobar la dejación de funciones de centristas y nacionalistas en el "ejercicio de la oposición", en "Desdén", $A B C, 24$ de enero de 1991. "Sólo el CDS acepta la resolución judicial en todos sus términos" en "Escepticismo entre los partidos de la oposición por la exculpación de Guerra", ABC, 05 de abril de 1991.

${ }^{53}$ Proposición de Ley Orgánica por la que se modificaban los artículos 367, 368 y 390 del Código Penal y se introducía en él un nuevo Capítulo acerca del tráfico de influencias, aprobada por práctica unanimidad el 21 de marzo de 1990. J. A. Souto Paz, parlamentario centrista, señaló: "la necesidad de ofrecer una respuesta adecuada por parte de esta Cámara cuando se producen estos hechos, que, aun siendo cuantitativamente limitados, son cualitativamente importantes, en la medida en que se tiende a extrapolar casos aislados de corrupción y se convierten generalizando la excepción en regla general", $D S C D$, Sesión Plenaria, 13 de diciembre de 1990, $\mathrm{n}^{\circ} 76$, p. 3820. El 13 de febrero de 1990, el CDS presentó una moción consecuencia de una interpelación urgente sobre sobre medidas de política general a adoptar por el Gobierno para investigar los asuntos de interés público relacionados con el tráfico de influencias.

${ }^{54}$ Este manifiesto se consideraba una síntesis de dos manifiestos previos, redactados en el entorno de Abel Cádiz y Enrique Sánchez de León. Cabe destacar como en 1989, según publicó El Mundo, se llevó a cabo una encuesta interna en el CDS entre más de quinientos militantes en la que se señalaba como puntos más vulnerables: la inactividad, la falta de democracia interna, la escasa información y el excesivo personalismo (cada uno de estos puntos identificado por poco más de un $10 \%$ de los militantes), $E l$ Mundo, 26 de abril de 1990, MAST.

${ }^{55}$ CAMUNAAS SOLÍS, Ignacio: "El futuro del CDS ante su III Congreso Nacional. Memorándum de ideas y de propuestas", Madrid, 08 de enero de 1990, MAST.
} 
ingreso y participación en el partido entre 1985 y 1986 hasta que, en el II Congreso fuera "amonestado" "públicamente" por la Secretaría General debido a sus críticas tanto a la conformación de la nueva dirección como al soporte doctrinal del partido ${ }^{56}$. Desde entonces, Camuñas, que se definía como liberal con "vocación de hombre de centro", había permanecido como afiliado de base "en silencio" y declaraba expresamente "no haber concertado con ninguno de los grupos o sectores que empiezan a aflorar" ${ }^{\circledR 57}$.

Camuñas comenzaba su análisis de la situación reconociendo la situación de crisis que vivía el partido: en el electorado, la militancia, la estrategia -pactos con el PP y arrepentimiento posterior- y en el discurso político “del líder”. Para encarar estas cuestiones era necesario resolver dos dilemas: " 1 . No se puede mantener un partido con garantías en el futuro si se sigue basando toda la acción y proyección política del CDS en base a la personalidad de Adolfo $\mathrm{Suárez}^{58}$ [... 2. La recurrente pretensión de desbordar por la izquierda al PSOE" aguardar una llamada del PSOE, o la opción defendida por Camuñas: "[jugar] la carta de la alternativa democrática al PSOE, potenciando el centro, para abrir una vía seria y rigurosa de diálogo con las fuerzas de carácter regional, y discutir un programa de cooperación gubernamental con el Partido Popular" ${ }^{\text {"60. }}$.

¿Cómo resolver el "galimatías", el "puzzle de difícil composición” en que se había convertido el CDS? ¿Cómo aunar a los antiguos comunistas, demócrata-cristianos, socialistas, liberales, ecologistas, etc. que militaban en el partido? Era perentorio un gran debate en el seno de los órganos colegiados en lugar de la personalización -entre Caso y Castedo- que se estaba haciendo de la polémica. Concluía el autor:

- El centro seguía existiendo - a pesar de la ocupación que PSOE y PP estaban haciendo de este espacio político- y siendo viable políticamente.

- La creciente interdependencia económica y política global había limitado notablemente "los márgenes de actuación" de todos los gobiernos y formaciones políticas. Se debía profundizar en valores éticos para recuperar la ilusión del electorado.

\footnotetext{
${ }^{56}$ Véase epígrafe 8. 1.

${ }^{57}$ CAMUÑAS SOLÍS, Ignacio: "El futuro...," p. 2.

${ }^{58}$ Máxime, una vez recuperado el liderazgo en AP y descubierto por el electorado que la inevitabilidad de la vuelta de Suárez a la Moncloa "se trataba de un farol", ibid., p. 3.

${ }^{59}$ Subrayado en el original. Ibid., p. 4.

${ }^{60}$ Ibid., p. 6.
} 
- El CDS, como partido minoritario de centro, debía contribuir necesariamente a permitir la articulación de “alternativas”, lo que en la década de los 90' equivalía a concretar acuerdos "con las fuerzas regionales y el Partido Popular"61.

- La estrategia a adoptar debe ser defendida a largo plazo y de forma coherente. "Si el CDS permanece siendo el partido de Suárez, honradamente, pienso que su futuro es incierto. Si Suárez decide sin embargo encabezar el movimiento de institucionalización y apertura del partido, entonces el liderazgo será largo y fructífero" ${ }^{\text {62 }}$.

En este clima de división y de opciones encontradas, se celebraron las elecciones de compromisarios, basadas en criterios de proporcionalidad ${ }^{63}$. En Madrid, la victoria de la candidatura oficial -liderada por J. R. Lasuén, y en la que se encontraban M. Martínez Parrondo o Íñigo Cavero-, obtuvo el 58\% de los votos y 56 compromisarios, frente a los 41 de los "renovadores". El impulso de los “críticos", movimiento que en Madrid estaba cohesionado y había logrado desarrollar un discurso propio, se había extendido a las distintas provincias. Sin embargo, como hemos venido repitiendo, en cada territorio la casuística de la división interna era diferente, solapándose ambos procesos: la polémica en torno a los pactos (Salamanca, Guadalajara), la rivalidad entre ciudades, la contestación a la dirección provincial (Valencia) o incluso, el deseo de representación de las juventudes del partido (Castellón).

En total, se eligió a un $13 \%$ de compromisarios concurrentes en listas "críticas" o "renovadoras", 134 de los mil compromisarios que componían el Congreso ${ }^{64}$. Unos resultados, que aunque reflejaban el clima de descontento que se vivía en el partido, ponían de manifiesto la magnificación por parte de la prensa de la división interna. Como señala Abel Cádiz, los "renovadores" “en el III Congreso no éramos alternativa. No teníamos peso, ni fuerza para ser alternativa. Tampoco teníamos voluntad de ser alternativa, porque en ningún caso cuestionábamos a Suárez. Lo que sí queríamos era cambiar el modelo de trabajo en el partido". De forma desglosada, las listas alternativas obtuvieron los siguientes resultados:

\footnotetext{
${ }^{61}$ Ibid., p. 9.

${ }^{6}$ Ibid. p. 10.

${ }^{63}$ Gracias a un sistema de cocientes que dividía los votos obtenidos por cada una de las listas entre uno, dos, tres, y así sucesivamente, artículo $\mathrm{n}^{\mathrm{o}}$ 11: "Elección de compromisarios", Reglamento de Organización, CDS, 1983, pp. 8-9.

64 "Los críticos del CDS logran el 11 por ciento de los delegados", El Independiente, 27 de enero de 1990.
} 
Tabla 78: Elección de compromisarios por CC.AA. (enero 1990).

\begin{tabular}{|l|l|l|}
\hline Comunidades Autónomas & Oficialistas & Críticos \\
\hline Galicia & 62 & 10 \\
\hline Madrid & 56 & 41 \\
\hline Castilla y León & 98 & 16 \\
\hline Andalucía & 134 & 9 \\
\hline Comunidad Valenciana & 79 & 22 \\
\hline Castilla-La Mancha & 62 & 11 \\
\hline Aragón & 38 & - \\
\hline Murcia & 31 & - \\
\hline Melilla & 9 & - \\
\hline Extremadura & 42 & - \\
\hline Navarra & 8 & - \\
\hline La Rioja & 9 & - \\
\hline Asturias & 26 & - \\
\hline País Vasco & 19 & - \\
\hline Cantabria & 14 & - \\
\hline Cataluña & 28 & 30 (sin elegir) \\
\hline Canarias & 79 & 5 (sin elegir) \\
\hline Baleares & 12 & 17 (sin elegir) \\
\hline Ceuta & - & 6 (sin elegir) \\
\hline
\end{tabular}

Elaboración propia a partir de fuentes hemerográficas

En el caso de la federación castellano y leonesa se agravó la fractura existente entre la dirección regional y algunos líderes provinciales (Zamora, Soria, Palencia y León), encabezados por el Presidente Provincial leonés Luis Aznar. División que se reprodujo en el III Congreso Federal, en el que fue derrotada la candidatura de los críticos ${ }^{65}$.

El 16 de enero el Comité Nacional aprobaba las ponencias sectoriales a debatir en el III Congreso, y que una vez enviadas a los compromisarios podían ser enmendadas hasta la fecha de inicio del mismo (hubo un total de 700, de las que se aceptaron en torno a 300) ${ }^{66}$. La ponencia política, decisiva en este Congreso, fue elaborada por Morodo, Suárez y Caso ${ }^{67}$, en ella se ratificaba el nuevo rumbo ideológico y estratégico: social-liberalismo y "bisagra".

La prensa se convirtió durante las semanas previas en el campo de batalla donde desplegaron sus argumentos unos y otros y de nuevo, las crónicas subrayaron la actitud silente de Suárez, que no concedió una rueda de prensa hasta el día 29 de enero, y lo hizo para salir en defensa de José Ramón Caso, principal blanco de las críticas. Así, Abel Cádiz defendía el proyecto renovador en El Mundo, movimiento que reconocía era anterior "incluso" a "los malos resultados electorales". Señalaba que no nacían fruto de

\footnotetext{
${ }^{65}$ Diario 16, 04 de octubre de 1990 y La crónica de León, 01 de noviembre de 1990, MAST.

${ }^{66}$ Líneas de Acción...

${ }^{67}$ El Independiente, 30 de enero de 1990, MAST.
} 
un complejo edípico irresuelto, "Suárez, como creador del CDS no está en cuestión. Es un líder deseado, pero un líder que alimenta a su criatura con un férreo cordón umbilical que debe ser cortado". Y señalaba la ambivalente actitud del CDS y de su líder en el caso de la OTAN, la ILP, el 14-D, los Pactos de Madrid y ahora "el papelón" en el caso Guerra. Había dos opciones, o repetir la intransigencia del aparato del PCE con los renovadores en 1981 -con las consecuencias que acarreó- o afrontar un nuevo horizonte. En Suárez recaía la responsabilidad ${ }^{68}$. Suárez reconocía tímidamente la crisis por la que pasaba el partido y, aunque sin perder la vocación mayoritaria, apelaba al "gran servicio al país" que significaba contribuir a la gobernabilidad, garantizar transparencia, aportar ideas, etc. ${ }^{69}$. Fernando Castedo apostaba por una mayor implicación y participación de la militancia en la vida del partido, lo que no significaba poner en cuestión el liderazgo de Adolfo Suárez ${ }^{70}$.

No obstante, todos coincidían en que el futuro del CDS estaba en juego y para la prensa, la dirección del partido era incapaz de dar una respuesta satisfactoria. De acuerdo con $A B C$ la actitud de Suárez - "acreedor de una gratitud histórica permanente" - y de su partido se asemejaba a la de "un marinero ebrio", una etapa en la que lo "más notable son las ausencias y lo más elocuente los silencios", plagada de confusión en términos ideológicos ${ }^{71}$. Un par de semanas después del Congreso, Carlos Santos en Diario 16 elegía la elocuente expresión de "Duque del Guadiana" ${ }^{\text {72 }}$. Y en El Mundo, se criticaba que el Congreso se celebrara a puerta cerrada argumentando: "el líder confiere sus cualidades, incluso las peores, a toda la organización"73.

\section{3. EI III Congreso del CDS (Torremolinos, 1990)}

El III Congreso del CDS se celebró entre los días 10 y 11 de febrero de Torremolinos. La actuación del CDS en el caso Juan Guerra, la aparición del sector

\footnotetext{
${ }^{68}$ CÁDIZ, Abel: "La renovación del CDS”, El Mundo, 08 de febrero de 1990, MAST.

${ }^{69}$ SUÁREZ GONZÁLEZ, Adolfo: "El CDS ante su futuro inmediato", Diario 16, 10 de febrero de 1990, MAST.

${ }^{70}$ A pesar de ello, Castedo quedó en un segundo plano en el Congreso. En el caso de Eduard Punset acudió como invitado - evitando así posicionarse de cara a su designación en una de la listas en liza-. Véase, CASTEDO, Fernando: "En el CDS las cosas no van bien”, Diario 16, 10 de febrero de 1990, MAST.

${ }^{71}$ Editorial: "El futuro del CDS", $A B C, 10$ de febrero de 1990.

${ }^{72}$ Cambio 16, 26 de febrero 1990, MAST.

${ }^{73}$ El Mundo, 09 de febrero de 1990, MAST.
} 
crítico y los últimos reveses electorales presagiaban una dinámica congresual muy diferente a la vivida en Barcelona (1986) y Madrid (1982). La dimisión del presidente de la gestora del partido en Torremolinos, en las semanas previas, parecía el anticipo de una auténtica tormenta política ${ }^{74}$.

El presidente del III Congreso fue el propio Alejandro Rebollo, ejerciendo Rosa Posada y Juan Montserrat como vicepresidentes y como secretario, Carlos SánchezReyes. El Congreso aprobó el "Informe de Gestión" del Secretario General con un 70\% de los votos favorables, un informe centrado en la defensa de los "pactos de Madrid" a pesar de su negativas consecuencias inmediatas. Las intervenciones de los "renovadores" -Abel Cádiz o González Quirós- fueron sobrias y sosegadas y las mayores críticas surgieron a raíz de la posición del CDS en el caso Juan Guerra, tema que suscitó la intervención más ácida (Antonio Morillo, Cádiz) ${ }^{75}$. Suárez se vio obligado a intervenir señalando que debía prevalecer el principio de presunción de inocencia y que si hubiera "aprovechado la ocasión para recordarle a Alfonso Guerra todos los insultos y descalificaciones que le ha hecho, la opinión pública quizá habría interpretado que estaba ejerciendo una venganza"76.

El día 11 de febrero se produjo la reelección de Suárez por 769 votos a favor, 157 en blanco y 10 abstenciones. El Comité Nacional, a propuesta de Suárez, contó con un respaldo del $77 \%$ de los compromisarios. El nuevo órgano máximo de gobierno del CDS -ampliado a veinticuatro vocales-, era bastante similar en su composición al de 1986, y seguía formado por el núcleo de líderes más cercano al presidente. Se integraban jóvenes dirigentes que habían asumido un destacado papel parlamentario y colaboraban ya a nivel nacional desde 1989 (Martínez-Campillo o Fernández Teixidó). Otros, eran destacados líderes territoriales (Sánchez Bracho, Martín Tamayo o Egea Ibáñez) que, en comunidades en apariencia más complicadas para los suaristas, como Andalucía, Extremadura o Murcia habían realizado un enorme esfuerzo de implantación. Completaban el grupo, políticos de prestigio como Eduard Punset, José Ramón Lasuén, Guadalupe Ruiz-Giménez y el portavoz del CDS en el Senado, Alberto Dorrego.

\footnotetext{
${ }^{74}$ Diario 16, 07 de enero de 1990, MAST.

75 "El CDS aprobó su informe de gestión pese a la actitud sobre Juan Guerra y los críticos", Diario 16, 11 de febrero de 1990.

${ }^{76}$ El País, 11 de febrero de 1990.
} 
Las bajas eran si cabe más significativas. Fernando Castedo, cabeza visible de los "críticos", abandonaba el Comité Nacional, mientras Javier Soto, protagonista del episodio de abril en el Ayuntamiento de Madrid lo había hecho casi un año antes. Manuel de Sárraga o Manuel Garrido, los hombres claves del suarismo en Lérida y Cantabria, respectivamente, y con una importancia decisiva durante la "travesía del desierto" pasaban ahora a un segundo plano. Por último, José Luis Garro se centraba en su trabajo en el Ayuntamiento de Madrid, como mano derecha de Agustín Rodríguez Sahagún.

Un conocedor del suarismo como Lorenzo Contreras ratificaba que el CDS había cerrado filas en torno "a la vieja guardia",77. Se puede afirmar que la nueva composición del Comité Nacional consumaba la tendencia a la oligarquización de la pequeña elite dirigente -nucleada en torno a Suárez-, en lo que es un fenómeno común de los partidos políticos españoles ${ }^{78}$. Una tendencia ya señalada por Maurice Duverger y que convertía a la dirección de los partidos en una casta, cerrada en sí misma -“círculo interior”- ${ }^{79}$, y que en el caso del CDS sólo se vio resquebrajada tras el abandono de la política por parte de Adolfo Suárez (1991):

Tabla 79: Evolución del Comité Nacional y de la Comisión Nacional de Cuentas (19861990).

\begin{tabular}{|l|l|l|}
\hline \multicolumn{3}{|c|}{ Comité Nacional } \\
\hline Continúan & Altas & Bajas \\
\hline Joaquín Abril Martorell & Alberto Dorrego González & Fernando Castedo Álvarez \\
\hline León Buil Giral & Enrique Egea Ibañez & José Luis Garro Carballo \\
\hline Rafael Calvo Ortega & Antoni Fernández Teixidó & Manuel Garrido Martínez \\
\hline José Ramón Caso García & José Ramón Lasuén Sancho & Javier Soto Carmona \\
\hline Gerardo Harguindey Bonet & Tomás Martín Tamayo & Manuel de Sárraga Gómez \\
\hline José Luis Merino Hernández & Manuel Sánchez Bracho & \\
\hline Raúl Morodo Leoncio & Eduard Punset i Casals & \\
\hline Laura Morso Pérez & Rafael Martínez-Campillo García & \\
\hline Lorenzo Olarte Cullén & Guadalupe Ruiz-Giménez Aguilar & \\
\hline Rosa Posada Chapado & & \\
\hline Alejandro Rebollo Álvarez-Amandi & & \\
\hline Carlos Revilla Rodríguez & & \\
\hline Agustín Rodríguez Sahagún & & \\
\hline Adolfo Suárez González & \multicolumn{2}{|l}{} \\
\hline Federico Ysart Alcover & \multicolumn{2}{|l}{} \\
\hline \multicolumn{2}{|l|}{ Comisión Nacional de Cuentas } & \\
\hline Fernando Alcón Sáez & Antonio Garrosa Resina & Ignacio Ansoleaga Deusto \\
\hline
\end{tabular}

${ }_{77}^{77}$ CONTRERAS, Lorenzo: "Fernando Castedo y el CDS", $A B C, 25$ de abril de 1990.

78 "Spanish parties are highly centralized organizations which have always kept theiir party apparatus under tight control of the national leadership", VAN BIEZEN, I: Political parties..., p. 94.

${ }^{79}$ DUVERGER, M.: Los partidos...

${ }^{80}$ JUSTEL CALABOZO, Manuel y MOSQUERA BAQUERIZA, Juan Carlos [portavoz del CDS en el Ayuntamiento de Orense] [suplentes]. 
Elaboración propia a partir de $R P P$, estatutos (febrero 1990).

El discurso de clausura de Suárez estuvo destinado a explicar las directrices y objetivos del partido en la nueva etapa -"no nos esperan tiempo fáciles"-. Por un lado, había que profundizar, lo hemos dicho ya, en la doctrina social-liberal y progresista del partido $^{81}$. En segundo lugar, era imprescindible mejorar la presencia del CDS en los medios de comunicación, "la democracia es un régimen de opinión pública: ante ella nos presentamos". En tercer lugar, era preciso reforzar la organización del partido ${ }^{82}$, completando la implantación territorial del mismo y con un carácter eminentemente deliberativo. A tal efecto, se creó un órgano de gobierno nuevo: el Consejo de Federación -cesión parcial frente a los críticos $-{ }^{83}$. En cuarto lugar, se intentó explicar la asunción del nuevo papel del CDS como "bisagra" del PSOE - sin duda el punto más polémico y que pasó a ser conocido entre la militancia como "la percha", al parecer en desafortunada expresión de Adolfo Suárez-:

CDS no ha perdido su vocación de partido mayoritario, pero a la vista de los resultados electorales debemos aceptar la realidad actual, la posición y el lugar donde nos ha colocado el pueblo español. Creemos que nuestro Partido es instrumento con el que hay que contar para la modernización del Estado social y democrático de derecho. Creemos que CDS es instrumento necesario para resolver las grandes cuestiones aún pendientes de nuestra convivencia nacional: la consolidación del Parlamento como centro de la vida política en el que se produce el debate y el control eficaz de la acción del Gobierno; el desarrollo de un Poder Judicial independiente y de una Administración de justicia eficiente $[\ldots]$

El momento histórico - caída del Muro de Berlín-actuaba en favor de una opción de centro progresista. Se habían desterrado dogmas, rígidas ideologías y ortodoxias en favor de la democracia, la libertad, de las "sociedades abiertas". En este sentido, el CDS debía saber adaptarse y actuar de forma flexible:

Al fin y al cabo, la misión de cualquier partido político es llevar adelante las ideas, las convicciones del espacio social que aglutina, esto es, influir en la conducción del país precisamente en la dirección deseada, polarizando las aspiraciones de los electores. El poder, cuando se obtiene en democracia, en una sociedad abierta, no es más que un grado superior de influencia social, porque cuando hay verdadera libertad, cuando está plenamente respetada la autonomía de los individuos y de los grupos, ningún poder tiene todos los resortes del futuro en la mano. En consecuencia, cada vez hay que entender más

\footnotetext{
${ }^{81}$ Incorporada a los Estatutos (artículo $1^{\circ}$ ): “el Centro Democrático y Social es un Partido político socialliberal y progresista de ámbito nacional y con organización de federaciones que se corresponden con la estructura autonómica del Estado Español”, RPP, Estatutos CDS (febrero, 1990).

${ }^{82}$ En los estatutos (artículo $5^{\circ}$ y artículo $47^{\circ}$ ) se profundizó en la autonomía de los Comités de Distrito o Comarcales por ejemplo, en cuanto a la tramitación de las fichas de afiliación, ibid.

83 "Discurso de clausura de Adolfo Suárez", Líneas de Acción...
} 
la política como un conjunto de ideas e influencias sociales concurrentes, en el que cada partido aporta su particular tensión, según la implantación, el peso, el prestigio que por sí mismo tiene y que los demás le otorgan ${ }^{84}$.

La "ponencia política" no fue aceptada por los "renovadores", quienes presentaron sin éxito una enmienda a la totalidad de la misma. El acercamiento al PSOE se producía en un momento especialmente delicado "en el que la moral del sistema" se encontraba “en cuestión” y el PSOE ya estaba "tocado por la corrupción" 85 . Para Abel Cádiz, una parte del partido estaba a esas alturas "desalentado". Se había pasado la oportunidad de recuperar lo que fue la UCD y constituir una alternativa de Gobierno.

El único éxito de los renovadores, y en todo caso muy parcial, fue la constitución del ya citado Consejo de Federación que a pesar de ser vinculante para el Comité $\mathrm{Nacional}^{86}$, tenía unas competencias mucho más limitadas que las del Consejo Político propuesto desde este sector: "el Consejo de Federaciones es un órgano de coordinación y planificación de la política autonómica del Partido" ${ }^{\text {87. }}$.

Tabla 80: Consejo de Federación y propuesta del Consejo Político en el CDS (1990).

\begin{tabular}{|l|l|l|}
\hline $\begin{array}{l}\text { Consejo de Federación (propuesta aprobada } \\
\text { por los oficialistas) }\end{array}$ & $\begin{array}{l}\text { Consejo Político (propuesta planteada por los } \\
\text { renovadores) }\end{array}$ \\
\hline $\begin{array}{l}\text { Colegiado: Presidente Nacional, Secretario } \\
\text { General, Secretario General de Juventudes y } \\
\text { Presidentes de Federación, Vocales del Comité } \\
\text { Nacional }\end{array}$ & $\begin{array}{l}\text { Electo mediante listas abiertas: más de cien } \\
\text { miembros }\end{array}$ & \\
\hline Órgano deliberativo & Órgano ejecutivo y de control político del CN \\
\hline Política autonómica & Estrategia política y desarrollo doctrinal \\
\hline
\end{tabular}

Elaboración propia a partir de $Y a, 10$ de febrero de 1990 y $R P P$, Estatutos CDS (febrero, 1990).

En el III Congreso se dio, asimismo, un nuevo impulso a la organización juvenil del partido, constituida de facto en 1986 y formalizada en mayo de $1987^{88}$, inscribiéndose en el Censo de Asociaciones y Organizaciones Juveniles y Entidades de Servicios Prestados a la Juventud (Instituto de la Juventud del Ministerio de Cultura) -

\footnotetext{
${ }^{84} \mathrm{Ibid}$.

${ }^{85}$ Entrevista con Abel Cádiz 4 de marzo de 2015.

${ }^{86}$ El artículo 19.1 referente al Comité Nacional quedaba reformulado así: "el Comité Nacional, determina, desarrolla e impulsa la política del Partido, bajo la dirección del Presidente, dentro del marco de los acuerdos del Congreso, de la Convención Nacional y del Consejo de Federaciones", RPP, Estatutos CDS (febrero, 1990).

${ }^{87}$ Artículo $22^{\circ}$. Asimismo, se creaba la "Convención de Federación", con las mismas atribuciones que la Convención Nacional pero a nivel de Federación, ibid.

88 "Entrevista con Manuel Losada, Secretario Nacional de Juventudes del Partido, OICDS, 10, febrero 1988.
} 
"Juventudes del Centro Democrático y Social SJ-15"89-. Las JCDS contaban con representación (dos delegados) en el Consejo de la Juventud Española ${ }^{90}$. Una semana antes de la celebración del III Congreso se reunían en Madrid, todos los presidentes y secretarios provinciales de juventudes del CDS del país para debatir sobre la estrategia internacional a seguir, así como sobre las ponencias del congreso del partido ${ }^{91}$. Finalmente, en enero de 1991 culminaba este proceso con la celebración del I Congreso Nacional de las Juventudes del $\operatorname{CDS}^{92}$. En todo este período el Secretario General de las Juventudes fue Manuel Alonso Losada, quien calculaba en abril de 1990 en 16.000 el número de afiliados del sector juvenil. La no discriminación a la hora de asignar presupuestos por parte del Gobierno socialista a las asociaciones juveniles, el empleo juvenil, la reducción del servicio militar y la no penalización de la Prestación Social Sustitutoria fueron algunas de las demandas que con más ahínco defendieron las juventudes del partido ${ }^{93}$.

La Secretaría General, a propuesta de Suárez, volvió a recaer en José Ramón Caso, quien obtuvo un voto en blanco en el Comité Nacional. Junto a la nueva Secretaría Ejecutiva del partido en la que se integraban Martínez-Campillo y Fernández Teixidó, el Comité Nacional se dividía en nueve áreas de trabajo correspondientes a los grandes temas de la política nacional.

Tabla 81: La ejecutiva del CDS tras el III Congreso.

\begin{tabular}{|l|l|}
\hline Área & Titular \\
\hline Secretario de Participación y Política Territorial & José Luis Gómez-Calcerrada \\
\hline Secretario de Comunicación y Política Institucional & Antoni Fernández Teixidó \\
\hline Secretario de Economía (Finanzas) & Antonio del Olmo \\
\hline Secretario de Organización & Rafael Martínez-Campillo García \\
\hline
\end{tabular}

Elaboración propia a partir de $Y a, 10$ de febrero de 1990 y $R P P$, Estatutos CDS (febrero, 1990).

Solo El País en su editorial defendía el nuevo posicionamiento del CDS, como estabilizador de mayorías de centro-izquierda: "de las alternativas que quedaban al

\footnotetext{
${ }^{89}$ Documento de salida 000605, 28 de enero de 1988, RPP; “Artículo 57. La Organización Juvenil goza de autonomía funcional, según las determinaciones de los "ESTATUTOS DE LAS JUVENTUDES DEL CDS" aprobadas por el Comité Nacional del Partido", RPP, estatutos (febrero 1990).

${ }^{90}$ Comunicaciones emitidas por el C.J.E. el 16 de noviembre y 17 de diciembre de 1987, RPP.

${ }^{91}$ Las Juventudes del CDS ingresaron en la Federación Internacional de Juventudes Liberales y Radicales (IFLRY) (XI Congreso, Alemania), en el Movimiento de Juventudes Radicales y Liberales de la Comunidad Europea (LYMEC) y como observador en la Federación Latinoamericana de Juventudes Liberales (FEJOL).

${ }^{92}$ Paralelamente se celebraban asambleas juveniles del partido a nivel provincial y federal, OICDS, 30, enero 1991.

${ }_{93}$ Ibid.; OICDS, 31, febrero 1990; Diario 16, 26 de abril de 1990, MAST.

${ }^{94}$ Sin confirmación.
} 
centrismo después de haber amagado en distintas direcciones ésa era la menos mala". Y señalaba a continuación: "puede permitir al CDS convertirse en receptor de ese segmento del voto urbano de quienes desean que el PSOE siga gobernando, pero quisieran que lo hiciera de manera diferente". El editorial se mostraba crítico con los "renovadores", respaldando la decisión tomada por Suárez: "Sin Suárez, el CDS sería un grupúsculo" " Javier Pradera refrendaba esta opinión en un artículo titulado "La meditación de las dos banderas", e incluso avistaba la posibilidad de constitución de algún tipo de fórmula de gobernación multipartidista -a la "italiana"- con CDS, PNV, CiU y el PSOE (desde coaliciones a pactos de legislatura) ${ }^{96}$.

José Luis Gutiérrez en Diario 16 ofrecía la imagen de un Congreso caracterizado por el secretismo -actitud hostil frente a la prensa, imposición, juego sucio del aparato, etc.En definitiva, "un congreso lo que se dice modélico..."97. El editorial de Diario 16 era aún más implacable y tras reconocer las virtudes históricas del abulense subrayaba que su actitud resultaba "sencillamente incomprensible [...] Quiere volver a la Moncloa aunque sea por la puerta de servicio"98. En Cambio 16, Carlos Santos comentaba: "el rumbo zigzagueante de Adolfo Suárez sólo tiene un norte: el poder" 99 . $A B C$ se mostraba igual de contundente, a la par que insistía en subrayar sus servicios a la democracia española, describía a un Suárez víctima del "síndrome de UCD", desconfiado, que quería "hacer del CDS una apoteosis de la mediocridad" y acudía mendicante al $\operatorname{PSOE}^{100}$.

Si tuviéramos que extraer una única conclusión del III Congreso del CDS, deberíamos destacar que por vez primera se producía la contestación y crítica pública de un sector más o menos cohesionado hacia las líneas maestras del partido y que aunque minoritario, se vio favorecido por una amplia repercusión mediática. Como consecuencia, se inició y quizá sea interesante usar esta denominación, un "goteo" de bajas más o menos significativas, que aunque en términos cuantitativos no fueron excesivamente relevantes, sirvieron para dar la impresión en la opinión pública del

\footnotetext{
${ }^{95}$ Editorial: "Onfaloscopia”, El País, 14 de febrero de 1990.

${ }^{96}$ El País, 18 de febrero de 1990. Una visión más crítica -tanto de la crisis interna como de la evolución del partido-, apenas un mes antes en ÍD.: "El turno de las vacas flacas", El País, 14 de enero de 1990, MAST.

97 "La política del 'tampax", y "La incertidumbre”, Diario 16, 11 y 12 de febrero de 1990, MAST.

${ }^{98}$ Editorial: "La chistera de Suárez", Diario 16, 13 de febrero de 1990, MAST.

99 SANTOS, Carlos: "La larga marcha de Adolfo Suárez hasta llegar al PSOE", Cambio 16, 26 de febrero de 1990

${ }^{100}$ Editorial: "Suárez, a los pies del PSOE”, $A B C, 12$ de febrero de 1990.
} 
inicio de un auténtico proceso de descomposición. El primero, y más sonado, fue el abandono del partido por parte del diputado nacional Fernando Castedo -en 1993, ingresó como militante en el PSOE-. En Madrid, Abel Cádiz formaba la Asociación para la Renovación Democrática (ARD) junto a otros diputados autonómicos del partido que pasaron al Grupo Mixto donde fueron particularmente activos (Jesús Arilla, Juan José Arnela o Fernando Lanzaco ${ }^{101}$ ) contando con una destacable presencia entre los concejales de muchas localidades madrileñas. Renovación Democrática pretendía ser una plataforma, para estos políticos, desde la que afrontar los comicios municipales:

[Fines del Partido] [...] contribuir democráticamente a la determinación de la política en la Comunidad de Madrid y en sus municipios y [...] promoviendo su participación en la Comunidad mediante la formulación de programas, la presentación y apoyo de candidatos en las correspondientes elecciones y la realización de todas aquellas actividades necesarias para el cumplimiento de estos fines. Además de estos objetivos esenciales, se propone la consecución de los siguientes objetivos específicos: 1. El fomento en la opinión pública de la cultura propia de una sociedad democrática avanzada en los ámbitos político, económico y social. 2. La mayor participación real de los ciudadanos en las decisiones públicas de su municipio. 3. La promoción de la cooperación entre los pueblos como sistema para la paz. 4. El respeto a la naturaleza, su protección y disfrute racional para ésta y futuras generaciones. RESULTANDO: Que su ámbito territorial de actuación es la Comunidad Autónoma de Madrid ${ }^{102}$.

En el resto de la geografía nacional, unos ochocientos militantes escindidos del CDS se reunieron en mayo con el objeto de intentar crear una federación de partidos regionalistas y radicales de cara a las Elecciones autonómicas y Municipales de $1991^{103}$. En Castilla y León se creó Democracia Regionalista que atrajo a más de ciento cincuenta militantes entre ellos diputados provinciales y el presidente de la Diputación Provincial de Valladolid, Ovidio Fernández. En Canarias, Fernando Fernández y cincuenta militantes fundaban Unidad Canaria antes de recalar en su mayoría en el Partido Popular. La dirección del partido en Barcelona -prácticamente la totalidad del Comité Ejecutivo Provincial- se marchaba del CDS (Armand Ródenas) en mayo, en plena elección de compromisarios para el III Congreso Federal (CDS-Cataluña) fundando Centro Radical ${ }^{104}$. Y en Madrid, el acercamiento al PSOE generaba una difícil

\footnotetext{
${ }^{101}$ La presidenta de la ARD era Ana Rodríguez Ayuso, y el diputado regional Juan José Arnela, ejercía como secretario general. VERANO, J. R.: "Castedo, propuesto líder de los escindidos del CDS", $E l$ Independiente, 27 de mayo de 1990, MAST. El diputado autonómico Javier de Luxán (Madrid) también se pasó al Grupo Mixto.

${ }_{102}$ Acta Notarial de Fundación del Partido Político RDM del día 04 de abril de 1991 ( ${ }^{\circ}$ 1167) en el que figuraban como promotores del partido: Agustín Moyano Sedano, Carolina Aceves López, Ana Rodríguez Ayuso y Pedro Jesús Sánchez Silvan, RPP, Documento ${ }^{\circ} 523$ Registro de salida, 18 de abril de 1991.

${ }_{103} A B C, 05$ de junio de 1990.

${ }^{104}$ ABC, 25 de mayo de 1990 y El Mundo, 04 de junio de 1990, MAST.
} 
situación para Rodríguez Sahagún. Nuevamente se alzaban críticas contra la actitud de Adolfo Suárez. Se decía que apenas "pisaba" la sede del partido y que sólo se reunía con Caso o Fernández Teixidó en su despacho de Antonio Maura. Fuentes del partido lamentaban: "se va a entrevistar con Gorbachov, pero no quiere hablar con los presidentes provinciales" ${ }^{\prime 105}$. Incluso, en la ciudad de Ávila un concejal abandonaba el partido y provocaba la pérdida de la mayoría absoluta del $\mathrm{CDS}^{106}$.

En este proceso, que afectaba a todos los territorios comenzaban a darse dos circunstancias, hasta ahora inéditas. Por primera vez, las críticas, aunque tímidas alcanzaban al propio Adolfo Suárez ${ }^{107}$. Asimismo, muchas de estas bajas no implicaban el abandono de la política, sino que en muchas ocasiones se producía el pase a otro partido, especialmente, el Partido Popular, como sucedió en plena campaña electoral andaluza. En Sevilla, el ex secretario provincial del partido, Mario Bilbao, anunciaba su solicitud de ingreso formal en el $\mathrm{PP}^{108}$. Episodios similares, aunque de menor impacto, se sucedieron en Málaga, Almería y Huelva. Un fenómeno que no afectaba sólo a la militancia, también al electorado. En Melilla, la repetición de los comicios de 1989 condujo a una concentración sin precedentes del voto de las fuerzas del centro y la derecha en el PP y todo ello, en apenas cuatro meses: el CDS pasaba del 8,36\% a un $1,80 \%$ y el PNM (Partido Nacionalista de Melilla), del 7,13\% al 1,70\% ${ }^{109}$.

Una vez más, unas elecciones autonómicas en una comunidad tan complicada como Andalucía se cruzaban en el camino del CDS en el peor momento. El partido, dirigido a nivel regional por Antonio J. Delgado de Jesús, tenía problemas para encontrar un candidato a la Junta, sopesándose, con más ilusión que certeza, el nombre del ex ministro de Hacienda, Jaime García Añoveros -finalmente fue elegido Luis Plaza, ex PDP, que se postuló por Málaga, donde mayor era la representación institucional del

\footnotetext{
${ }^{105}$ El Mundo, 08 de mayo de 1990, MAST.

${ }^{106}$ El País, 18 de febrero de 1990.

${ }^{107}$ ALFARO, Emilio: “Al duque se le caen las almenas", El País, 10 de junio de 1990.

${ }^{108}$ Mario Bilbao había militado en el PCE (1974-1979) y en el CDS desde 1985, ABC Sevilla, 03 de mayo y 02 de junio de 1990.

${ }^{109}$ Resulta interesante volver en este punto la mirada a las páginas de $A B C$ y $E l$ País. En su editorial, $A B C$ constataba la "práctica desaparición" del CDS, "fantasmagoría", ilustrativo "sobre el juicio que merece a sus electores su política", que, de otra parte, consolidaban el liderazgo de José María Aznar, respaldando su "estrategia de oposición moderada y firme" y atribuían "al partido una verosímil dimensión de alternativa al socialismo", "Melilla castiga al PSOE", $A B C, 26$ de marzo de 1990. "Su esfuerzo por fabricarse una biografía de persona moderada, abierta a la modernidad y tolerante en materia de costumbres [...] choca con el hecho de que él se afilió en fecha tan temprana como 1979 a un partido que en aquel momento era cualquier cosa excepto moderado, moderno y tolerante. Pero la voluntad es lo que cuenta, y la de centrar su mensaje parece claramente establecida [sobre Aznar]", editorial: "La hora de Aznar", El País, 28 de marzo de 1990.
} 
CDS- ${ }^{110}$. El previsible fracaso en una región donde todavía, algunos medios recordaban el referéndum de $\mathrm{UCD}^{111}$ no resultaba atractivo para nadie en un partido cada día más dividido por su acercamiento al PSOE, sensaciones que se repitieron en el II Congreso Federal del CDS-Andalucía en marzo de $1990^{112}$. El 3 de junio, la Convención Federal del partido aprobaba el programa electoral y la estrategia de campaña, con la presencia de Adolfo Suárez. El CDS centró su campaña en Málaga y contó con la participación puntual de Adolfo Suárez, quien estuvo en el cierre de campaña el día 22 de junio. En cualquier caso, a nivel mediático el CDS fue irrelevante. $A B C$, en su portada del día de comienzo de la campaña situaba a Aznar y González, mientras en el pie de foto se confirmaba que el CDS no iba a obtener representación según los sondeos ${ }^{113}$. La irrelevancia del CDS se podía constatar también en El País donde no se incluyó una entrevista al candidato suarista Luis Plaza, a diferencia de lo que sucedido con PA, PSOE, PP e IU.

Los resultados fueron muy negativos, alcanzando únicamente un 1,19\% de los votos. El CDS no sólo no conseguía representación sino que obtenía un resultado en el territorio andaluz notablemente inferior al conseguido en las Generales de 1989 (4,22\%) en las autonómicas de 1986 (3,22\%), e incluso al logrado en esta Comunidad en las Generales de 1982 (1,3\%). Ni el referéndum andaluz (1980), ni la actitud ante el caso Juan Guerra, ni la división interna explicaban por sí solos este resultado. Definitivamente, se ponía en cuestión el conjunto de la trayectoria política de los suaristas. El CDS había conseguido poco más de 32.000 votos en un territorio donde contaba, en diciembre de 1989, con más de ocho mil afiliados. El PP tampoco rentabilizaba el batacazo de los centristas e incluso, descendía porcentualmente desde un 23,30\% (1986) a un 22,17\% (1986). El Partido Andalucista, que duplicaba su electorado, y rebasaba el $10 \%$ era el gran beneficiado.

Por vez primera, Adolfo Suárez en rueda de prensa, que ratificaba su intención de no variar el curso del partido, advertía: “el CDS no va a desaparecer de la vida política

\footnotetext{
${ }^{110}$ Desde fuentes del CDS se dijo haber contado con una financiación de 50 millones, El País, 04 de junio de 1990.

${ }^{111}$ El País, 31 de mayo de 1990.

112 Delgado de Jesús fue reelegido presidente federal con un 48,5\% de los votos; aunque no hubo lista alternativa el descontento era patente, especialmente entre la militancia granadina y almeriense, Diario 16 (ed. Andalucía), 26 de marzo de 1990, MAST.

${ }^{113}$ En esta ocasión, el elemento perturbador del espacio de centro-derecha era J. M. Ruiz-Mateos, véase, editorial: "Electores cautivos", $A B C, 07$ de junio de 1990.
} 
española"114. El malagueño El Sol titulaba: "Suárez, otra vez condenado al desierto. Del máximo poder al olvido" $" 115$.

\section{4. El Grupo Parlamentario del CDS durante la IV Legislatura}

Una de las resoluciones estratégicas aprobadas en la Ponencia Política del III Congreso defendía la capacidad del partido de influir, desde sus presupuestos programáticos, en el Gobierno. Aunque no se señalaba explícitamente implicaba un intento de acuerdo con quien era, en ese momento, el partido al frente del Ejecutivo, el PSOE. El Debate de Investidura, la prolongación de los presupuesto del curso anterior, y sobre todo, el caso Juan Guerra fueron los precedentes de esta nueva andadura ${ }^{116}$.

El Grupo Parlamentario del CDS (GP CDS) formado en 1989 tuvo como portavoz a Alejandro Rebollo -Anexos XX y XXI-. En el Senado, el CDS pudo formar grupo gracias a la presencia de senadores de designación autonómica, bajo la dirección de Alberto Dorrego. La predisposición de Adolfo Suárez - presidente del GP CDS, de acuerdo con los estatutos-, a una mayor participación en los trabajos parlamentarios tomó cuerpo al decidir incorporarse a los trabajos de la Comisión Constitucional, la Comisión de Asuntos Exteriores y la Diputación Permanente:

Tabla 82: Intervenciones de Adolfo Suárez en el Congreso de los Diputados durante la IV Legislatura.

\begin{tabular}{|l|l|}
\hline Diciembre de 1989 & Debate de investidura del Presidente de Gobierno: Felipe González \\
\hline Diciembre de 1989 & Comparecencia del Gobierno ante el Pleno: Cumbre del Consejo Europeo \\
\hline Abril de 1990 & Cuestión de Confianza \\
\hline Septiembre de 1990 & Comparecencia del Gobierno ante el Pleno: crisis del Golfo \\
\hline Diciembre de 1990 & Comparecencia del Gobierno ante el Pleno: Cumbre del Consejo Europeo \\
\hline Enero de 1991 & Comunicación del Gobierno: crisis del Golfo \\
\hline Marzo de 1991 & Comparecencia del Gobierno ante el Pleno: crisis del Golfo \\
\hline Marzo de 1991 & Debate sobre el Estado de la Nación \\
\hline
\end{tabular}

Elaboración propia ${ }^{117}$.

\footnotetext{
${ }^{114}$ El País, 26 de junio de 1990. De acuerdo con el análisis efectuado en Diario 16, el voto del CDS había ido a parar a la abstención, Diario 16, 21 de julio de 1990. En $A B C$, se hablaba del voto "cautivo" del socialismo andaluz -subsidio agrícola, promesas de salario social- como las claves de las elecciones, editorial: "Voto cautivo", $A B C, 24$ de junio de 1990.

${ }^{115}$ El Sol, 01 de julio de 1990, MAST.

${ }^{116}$ Apoyado por el CDS en la "Votación plenaria del día 10 de enero de 1990 de convalidación del Real Decreto Ley $7 / 1989$ sobre medidas urgentes en materia presupuestaria, financiera y tributaria".

${ }^{117}$ Según El País estuvo ausente en más del 75\% de las votaciones parlamentarias en editorial: "Mal ejemplo", El País, 07 de noviembre de 1991.
} 
En el seno del Grupo Parlamentario destacó el protagonismo político de Alejandro Rebollo y José Ramón Caso, quien sustituyó al primero en octubre de 1991 como portavoz. Junto a ellos, fueron particularmente activos Rafael Martínez Campillo y José Antonio Souto Paz ${ }^{118}$ :

Tabla 83: Parlamentarios electos del CDS en 1989.

\begin{tabular}{|c|c|c|c|c|c|}
\hline Nombre & Provincia & Profesión & Cargo CDS & Edad & $\begin{array}{l}\text { Militancia } \\
\text { Partidos } \\
\text { Políticos } \\
(1977-. . .)\end{array}$ \\
\hline $\begin{array}{l}\text { Adolfo Suárez } \\
\text { González }\end{array}$ & Madrid & Abogado & Presidente & 56 & UCD \\
\hline $\begin{array}{l}\text { José Ramón } \\
\text { Caso García }\end{array}$ & Madrid & $\begin{array}{l}\text { Licenciado en } \\
\text { Derecho y Ciencias } \\
\text { Empresariales }\end{array}$ & $\begin{array}{l}\text { Secretario } \\
\text { General }\end{array}$ & 42 & UCD \\
\hline $\begin{array}{l}\text { Rafael } \\
\text { Martínez- } \\
\text { Campillo García }\end{array}$ & Alicante & $\begin{array}{l}\text { Abogado } \quad \mathrm{y} \\
\text { funcionario }\end{array}$ & $\begin{array}{l}\text { Presidente } \\
\text { Provincial } \\
\text { Alicante } \\
\text { Comité Nacional } \\
(1990) \text {. } \\
\text { Secretario de } \\
\text { Organización } \\
(1990)\end{array}$ & 36 & UCD \\
\hline $\begin{array}{l}\text { José Ramón } \\
\text { Lasuén Sancho }\end{array}$ & Murcia & $\begin{array}{l}\text { Catedrático } \\
\text { Universitario } \\
\text { (Economía) }\end{array}$ & $\begin{array}{l}\text { Comité Nacional } \\
\text { Presidente } \\
\text { Federación de } \\
\text { Madrid (1990) }\end{array}$ & 57 & $\begin{array}{l}\text { FSD, UCD, } \\
\text { CDE, CP }\end{array}$ \\
\hline $\begin{array}{lr}\text { José } \quad \text { Alfredo } \\
\text { Ferrer Gutiérrez }\end{array}$ & Ávila & Abogado & $\begin{array}{l}\text { Presidente del } \\
\text { CDS en Ávila }\end{array}$ & 42 & UCD \\
\hline $\begin{array}{l}\text { Carlos Revilla } \\
\text { Rodríguez }^{120}\end{array}$ & Madrid & $\begin{array}{l}\text { Médico. } \\
\text { Neurofisiólogo }\end{array}$ & Comité Nacional & 53 & PSOE \\
\hline $\begin{array}{l}\text { Alejandro } \\
\text { Rebollo }\end{array}$ & Asturias & Abogado & $\begin{array}{l}\text { Comité Nacional } \\
\text { y Presidente de la } \\
\text { Federación CDS- } \\
\text { Asturias }\end{array}$ & 55 & UCD \\
\hline $\begin{array}{l}\text { Antonio } \\
\text { Fernández } \\
\text { Teixidó }^{121} \\
\end{array}$ & Barcelona & Titular Mercantil & $\begin{array}{l}\text { Presidente Federal } \\
\text { Cataluña (hasta } \\
1990)\end{array}$ & 37 & $\begin{array}{l}\text { Izquierda } \\
\text { extraparl. }\end{array}$ \\
\hline $\begin{array}{l}\text { Fernando } \\
\text { Castedo } \\
\text { Álvarez }\end{array}$ & Madrid & Abogado & $\begin{array}{l}\text { (Críticos 1989- } \\
\text { 1990) }\end{array}$ & 47 & - \\
\hline $\begin{array}{l}\text { Joaquín Abril } \\
\text { Martorell }\end{array}$ & Valencia & $\begin{array}{l}\text { Ingeniero } \\
\text { Aeronáutico }\end{array}$ & Comité Nacional & 61 & UCD \\
\hline $\begin{array}{l}\text { Lorenzo Díaz } \\
\text { Aguilar }\end{array}$ & Las Palmas & Médico & - & 59 & - \\
\hline $\begin{array}{l}\text { José Antonio } \\
\text { Souto Paz }\end{array}$ & La Coruña & $\begin{array}{l}\text { Catedrático } \\
\text { Universitario }\end{array}$ & $\begin{array}{lr}\text { Director } & \text { del } \\
\text { Departamento } & \text { de } \\
\end{array}$ & 51 & UCD \\
\hline
\end{tabular}

${ }^{118}$ Rebollo, Martínez Campillo y Souto Paz se encontraban entre tres de los catorce principales oradores del Congreso, según el diario El Sol, recogido por OICDS, 30, enero 1991.

${ }^{119}$ Causó baja el 29 de octubre de 1991 siendo sustituido por Laura Morso Pérez.

${ }^{120}$ Causó baja el 05 de mayo de 1992 integrándose en el Grupo Mixto.

${ }^{121}$ Causó baja el 29 de septiembre de 1992 integrándose en el Grupo Mixto.

${ }^{122}$ Causó baja el 24 de abril de 1990 por Rafael Arias-Salgado Montalvo, a su vez, sustituido el 10 de noviembre de 1992 por Manuel Alonso Losada. 


\begin{tabular}{|l|l|l|l|l|l|}
\hline & & (Derecho) & $\begin{array}{l}\text { Asesoría Jurídica } \\
\text { del CDS. }\end{array}$ & \\
\hline $\begin{array}{l}\text { José Antonio } \\
\text { Santos Miñón }\end{array}$ & Las Palmas & Abogado & - & 50 & UCD \\
\hline $\begin{array}{l}\text { Baltasar Zárate } \\
\text { Pérez de Ayala }\end{array}$ & Tenerife & Abogado & - & 45 & UCD, CP \\
\hline $\begin{array}{l}\text { Alberto } \\
\text { Dorrego }\end{array}$ & Ávila & Pediatra & - & 57 & $\begin{array}{l}\text { UCD } \\
\text { (Partido } \\
\text { Popular) }\end{array}$ \\
\hline
\end{tabular}

Elaboración propia a partir de fuentes hemerográficas y http://www.congreso.es

Si realizamos un análisis cuantitativo del conjunto de la IV Legislatura debemos destacar que disminuyó, en términos generales, la actividad parlamentaria de los centristas, tanto en su función legislativa como de control -véase, Anexo XXII-. Asimismo, se produjo una merma del conjunto de "enmiendas a la totalidad" presentadas frente a los proyectos de ley del Gobierno. Si en la III Legislatura, se opuso al $44,8 \%$ de los mismos, este porcentaje se redujo hasta el $30,6 \%$ en la IV Legislatura (un total de 19). Un descenso, aunque menor, apreciable también en los grupos parlamentarios vasco y catalán, frente al aumento producido en el caso de los populares e IU-EC ${ }^{124}$; una consecuencia directa de la política de acercamiento establecida entre el PSOE, CDS, PNV y CiU ${ }^{125}$.

El conjunto de iniciativas parlamentarias presentadas por el CDS pasó de significar entre un $10-15 \%$ del total, a ser en la mayor parte de los casos inferior al $10 \%-$ proposiciones de ley, proposiciones no de ley, interpelaciones ordinarias o preguntas orales (Pleno, Comisión, Director de RTVE)-, e incluso al 5\% -solicitudes de informe, preguntas escritas (Gobierno, RTVE)-. Sólo en el caso de las interpelaciones urgentes, las mociones y la solicitud de comparecencias superaba la barrera del 10\%:

Tabla 84: Proposiciones de Ley del Grupo Parlamentario CDS (IV Legislatura).

\begin{tabular}{|l|l|}
\hline Situación & $\mathbf{N}^{\mathbf{0}}$ \\
\hline Admitidas a trámite & $14(9)$ \\
\hline Retiradas & 1 \\
\hline Decaídas & - \\
\hline Rechazadas & $8(1)$ \\
\hline Caducadas sin & $3(7)$ \\
\hline $\begin{array}{l}\text { Aprobadas } \\
\text { modificaciones }\end{array}$ & - \\
\hline Aprobadas con & 1 \\
\hline
\end{tabular}

\footnotetext{
123 Senador.

${ }^{124}$ El CDS había presentado el $15,2 \%$ de enmiendas sobre el total, frente al 40,8\% del PP y el $24 \%$ de IU. En el caso del CDS en ningún caso fue el único partido en presentar una enmienda a la totalidad a una ley determinada, hecho que sí ocurrió en tres ocasiones en la anterior legislatura, Información recogida en CAPO GIOL, Jordi: "Oposición..."

${ }^{125}$ Ibid.
} 


\begin{tabular}{|l|l|}
\hline modificaciones & \\
\hline Subsumida en otras... & $1(1)$ \\
\hline
\end{tabular}

Elaboración propia a partir de GONZALO, Manuel y PAESA, María (eds.): Memoria de la IV Legislatura..., p. 163 y ss.

Tabla 85: Proposiciones de Ley del Grupo Parlamentario CDS (IV Legislatura) en relación al resto de grupos de la oposición.

\begin{tabular}{|l|l|l|}
\hline Situación & $\begin{array}{l}\text { Porcentaje sobre el } \\
\text { total de la oposición }\end{array}$ & $\begin{array}{l}\text { Posición en el cómputo de } \\
\text { GP de la oposición }\end{array}$ \\
\hline Admitidas a trámite & 7,8 & $5^{\circ}(\mathrm{GP}, \mathrm{GS}, \mathrm{GC}-\mathrm{CiU}, \mathrm{GIU}-\mathrm{IC})$. \\
\hline Aprobadas con/sin modificaciones & 6,4 & $5^{\circ}(\mathrm{GS}, \mathrm{GC}-\mathrm{CiU}, \mathrm{GIU}-\mathrm{IC}, \mathrm{GP})$. \\
\hline
\end{tabular}

Ibid., p. 163 y ss.

Un análisis temático del conjunto de Proposiciones de Ley, centrándonos en aquellas implementadas en solitario, nos permite obtener las siguientes líneas de actuación política preferencial por parte del CDS. Entre las que fueron aprobadas se encuentran la reforma del código penal (artículo 390) -"pena de arresto mayor y multa

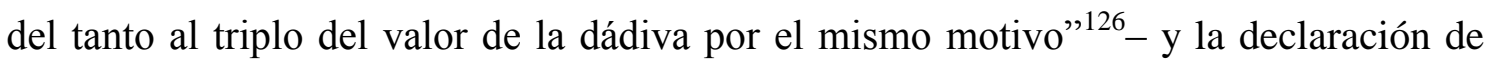
Reserva Natural de las Marismas de Santoña y Noja. Sin éxito, se presentaron dos relativas a la reforma de la Ley Electoral -citadas con anterioridad- , una a propósito del aumento de competencias del CGPJ, la modificación del Código Civil -separación y divorcio $^{127}$-, la reforma del Régimen Urbanístico y la Valoración del Suelo -destinada a impedir la reclasificación urbanística de "los terrenos forestales destruidos y su entorno" 128 -, las desgravaciones de los productos culturales y/o educativos, el desarrollo económico y social del área del Parque Nacional de Doñana, la creación de un estatuto de la pequeña empresa, el establecimiento de una oficina y registro de los "grupos de interés", la modificación del código penal y la Ley Orgánica Penitenciaria en el contexto de los graves incidentes acaecidos en varias prisiones como la del Puerto de Santa María- y finalmente, una proposición de ley, que no se llegó a debatir en el pleno, para integrar la figura del "ama de casa" en el régimen de la Seguridad Social siempre y cuando se solicitara voluntariamente.

\footnotetext{
${ }^{126}$ El País, 09 de febrero de 1990. Fue subsumida junto a proposiciones de otros grupos en la Ley Orgánica, de 22 de marzo de 1991, por la que se modifican los artículos 367, 368 y 390 del Código Penal, introduciéndose en el mismo un nuevo capítulo acerca del tráfico de influencias.

127 "El Grupo CDS presenta hoy una propuesta de reforma legal que consiste fundamentalmente en el establecimiento de la autonomía entre separación y divorcio, siendo el ciudadano quien puede elegir libremente y tener acceso directo tanto a la separación como al divorcio; a la supresión del doble procedimiento para obtener el divorcio y la admisión del divorcio consensual o por mutuo acuerdo, así como del divorcio causal”, DSCD, Sesión Plenaria, 11 de febrero de 1992, nº 161, p. 7909.

${ }^{128}$ DSCD, Sesión Plenaria, 18 de febrero de 1992, $\mathrm{n}^{\circ} 164$, p. 8053.
} 
Si realizamos un análisis porcentual por áreas temáticas de las Proposiciones de Ley y las Proposiciones no de Ley obtenemos los siguientes resultados. El área de "Industria, obra públicas y servicios" presentó los mayores porcentajes (30,5\%), destacando en el conjunto el altísimo número de iniciativas relativas a la Comunidad Valenciana y en concreto, a la provincia de Alicante -gracias a la labor de Rafael Martínez-Campillo-. El siguiente peldaño correspondió a "Justicia y política interior" donde destacaban las distintas medidas encaminadas a la reforma de la Ley Electoral $(22,3 \%)^{129}$. Un tercer escalón lo ocupaban la "Política social y de empleo" y "Medioambiente" (15,3\% respectivamente), ámbitos donde el protagonismo del CDS era perceptible desde la Legislatura precedente. Finalmente, podemos destacar el área de "Economía, comercio y hacienda", cuyo porcentaje alcanzaba el 11,7\% del total. En relación al conjunto de interpelaciones, el primer lugar correspondió a la "Política social y empleo" (31,8\%), seguido de los aspectos relativos a "Agricultura, ganadería y pesca", "Industria, obras públicas y servicios" y el "Régimen de las Administraciones Públicas" con un 13,6\% respectivamente. No cabe duda, que aun expresivos, estos análisis pueden velar la diferente importancia cualitativa entre las diferentes áreas, especialmente, de cara a la proyección mediática del partido.

Tabla 86: Agrupación temática del conjunto de Proposiciones de Ley y no de Ley del GPCDS (IV Legislatura).

\begin{tabular}{|c|c|c|c|c|}
\hline Materia & PL & PNDL & Porcentaje & Observaciones \\
\hline $\begin{array}{l}\text { Agricultura, } \\
\text { Ganadería y Pesca }\end{array}$ & - & 3 & 3,5 & - Sequía. Hortofruticultura. \\
\hline Asuntos Exteriores & - & 4 & 4,7 & $\begin{array}{l}\text { - Guerra del Golfo. Guinea Ecuatorial. Servicio } \\
\text { exterior. El Salvador. Cuba }\end{array}$ \\
\hline Constitucional & - & - & - & - \\
\hline Defensa & 3 & 1 & 4,7 & $\begin{array}{l}\text { - Régimen Personal Militar. Referéndum servicio } \\
\text { militar. }\end{array}$ \\
\hline $\begin{array}{l}\text { Economía, } \\
\text { Comercio } \\
\text { Hacienda }\end{array}$ & 3 & 7 & 11,7 & $\begin{array}{l}\text { - Estatuto Pequeña Empresa. Estatuto del } \\
\text { Contribuyente. Reforma tributaria. Comisión de } \\
\text { control presupuestario. Torres Kio. Ahorro. } \\
\text { Créditos administración. IRPF. }\end{array}$ \\
\hline $\begin{array}{l}\text { Educación } \\
\text { Cultura }\end{array}$ & 1 & 5 & 7 & $\begin{array}{l}\text { - Bienes culturales. Conmemoraciones. Expo } \\
\text { Sevilla. Ley de Patrimonio. }\end{array}$ \\
\hline $\begin{array}{lr}\text { Industria, } & \text { Obras } \\
\text { Públicas } & \mathrm{y} \\
\text { Servicios } & \end{array}$ & 1 & 25 & 30,5 & $\begin{array}{l}\text { - Ley de Contratos. Seguridad en locales } \\
\text { públicos. Turismo. Plan de viviendas. Suelo. } \\
\text { Centrales nucleares. Política hidráulica. Plan } \\
\text { Ferroviario. Infraestructuras. Telefónica. }\end{array}$ \\
\hline Justicia e Interior & 8 & 11 & 22,3 & $\begin{array}{l}\text { - Reforma del Código Penal. Reforma de la Ley } \\
\text { Electoral. Financiación partidos. Registro de } \\
\text { grupos interés. }\end{array}$ \\
\hline Política Social y & 4 & 9 & 15,3 & - Código Civil (familia). Seguridad Social. \\
\hline
\end{tabular}

129 Debemos destacar una proposición de ley orgánica del jurado presentada en el Senado y que finalmente no fue tomada en consideración, BOCG, Senado, serie III A, 27 de febrero de 1990, $\mathrm{n}^{\circ} 3$. 


\begin{tabular}{|c|c|c|c|c|}
\hline Empleo & & & & $\begin{array}{l}\text { Desarrollo zonal. Integración y movilidad. } \\
\text { Sanidad. VIH. Inmigración en España. } \\
\text { Prestaciones desempleo. Regulación sanitarios. } \\
\text { MIR. Salario Social. }\end{array}$ \\
\hline Presupuestos & - & - & - & - \\
\hline Medio Ambiente & 2 & 11 & 15,3 & $\begin{array}{l}\text { - Espacios Naturales. Deforestación. Medio } \\
\text { Ambiente (ONU). Impacto ambiental. Reciclaje. } \\
\text { Vertidos. }\end{array}$ \\
\hline $\begin{array}{l}\text { Régimen de las } \\
\text { Administraciones } \\
\text { Públicas }\end{array}$ & - & 2 & 2,3 & - Canarias. Administración. \\
\hline $\begin{array}{l}\text { Mixta para las } \\
\text { Comunidades } \\
\text { Europeas }\end{array}$ & 1 & 3 & 4,7 & - Adecuación legislativa. \\
\hline $\begin{array}{l}\text { Mixta para la } \\
\text { Investigación }\end{array}$ & - & - & - & - \\
\hline Otras & - & 5 & 5,8 & - Indemnizaciones. Catástrofes. Comparecencia. \\
\hline
\end{tabular}

Elaboración propia a partir de GONZALO, Manuel y PAESA, María (eds.): Memoria de la IV Legislatura ..., p. 192 y ss.

Tabla 87: Agrupación temática del conjunto de Interpelaciones (Ordinarias y Urgentes) del GPCDS, (IV Legislatura).

\begin{tabular}{|c|c|c|c|c|}
\hline Materia & IO & IU & Porcentaje & Principales temas \\
\hline $\begin{array}{l}\text { Agricultura, } \\
\text { Ganadería y Pesca }\end{array}$ & 1 & 2 & 13,6 & - Forestal. Agricultura en Europa. Sequía. \\
\hline Asuntos Exteriores & - & 2 & 9,1 & - Política exterior (defensa y seguridad). Yugoslavia. \\
\hline Constitucional & - & - & - & - \\
\hline Defensa & - & - & - & - \\
\hline $\begin{array}{l}\text { Economía, Comercio } \\
\text { y Hacienda }\end{array}$ & - & 1 & 4,5 & - IRPF. \\
\hline Educación y Cultura & - & - & - & - \\
\hline $\begin{array}{l}\text { Industria, Obras } \\
\text { Públicas y Servicios }\end{array}$ & - & 3 & 13,6 & - Nuclear. Transporte aéreo. Siderurgia. \\
\hline Justicia e Interior & 1 & 1 & 9,1 & - Tráfico de influencias. \\
\hline $\begin{array}{lll}\text { Política } & \text { Social } & \\
\text { Empleo } & & \\
\end{array}$ & - & 7 & 31,8 & $\begin{array}{l}\text { - Tercera edad. Salud mental. Infancia. Desarrollo } \\
\text { zonal. Sanidad. }\end{array}$ \\
\hline Presupuestos & - & - & - & - \\
\hline Medio Ambiente & & - & - & - . \\
\hline $\begin{array}{l}\text { Régimen de las } \\
\text { Administraciones } \\
\text { Públicas }\end{array}$ & - & 3 & 13,6 & - Política municipal. Modernización \\
\hline $\begin{array}{l}\text { Mixta para las } \\
\text { Comunidades } \\
\text { Europeas }\end{array}$ & - & 1 & 4,5 & - Plan de Convergencia. \\
\hline $\begin{array}{l}\text { Mixta para la } \\
\text { Investigación }\end{array}$ & - & - & - & - \\
\hline $\begin{array}{lll}\text { Estatuto } & \text { de } & \text { los } \\
\text { Diputados } & & \\
\end{array}$ & - & - & - & - \\
\hline Otras & - & - & - & - \\
\hline
\end{tabular}

Elaboración propia a partir de GONZALO, Manuel y PAESA, María (eds.): Memoria de la IV Legislatura ..., p. 211 y ss.

Siguiendo a José Luis Gómez-Calcerrada, Secretario General del CDS desde 1992 en su Informe de Gestión de la Secretaría General (V Congreso, 1992), la actuación de los 
parlamentarios del CDS había estado guiada por el objetivo prioritario de proponer una "regeneración institucional". Un proyecto en el que destacaba: la lucha contra la corrupción, la renovación de los sistemas de elección y competencias de instituciones decisivas (Tribunal de Cuentas, CGPJ y Tribunal Constitucional) y la reforma electoral. Si la primera fue puesta en solfa por la propia actuación del CDS en el caso Juan Guerra, las dos siguientes se convirtieron en el auténtico caballo de batalla del partido a lo largo de la siguiente legislatura. De otra parte, la defensa de las libertades, caso paradigmático de la Ley de Seguridad Ciudadana, u otras iniciativas menos mediáticas -“[los proyectos legislativos de] de tratamiento automatizado de datos, telecomunicaciones y régimen jurídico de las Administraciones Públicas"130 - actuó como eje vertebrador de las intervenciones centristas.

\section{5. La experiencia del "bloque constitucional"}

Como vimos al abordar la estrategia política desarrollada por la dirección del partido durante el III Congreso, la mayor o menor proximidad del Grupo Parlamentario del CDS al Gobierno se convirtió en el foco de atención de la Legislatura. En febrero de 1990, una desafortunada expresión de Txiki Benegas inauguró un clima de división política a nivel nacional, sin antecedentes en las anteriores legislaturas socialistas. El Secretario de Organización socialista señaló que su partido pretendía conseguir un 'bloque constitucional' para tratar cuestiones de Estado. Un "bloque" integrado por PSOE, CDS, PNV y CiU. El propio Tixki Benegas criticaba en El Socialista la hostilidad hacia el PSOE proveniente de la "alianza popular-comunista", frente a los "planteamientos razonables" de nacionalistas y suaristas ${ }^{131}$. Una expresión que aunque fue rápidamente rechazada por la dirección centrista, dificultó más aún si cabe la búsqueda del acuerdo con el PSOE ${ }^{132}$.

Las críticas a este acercamiento no se hicieron esperar a uno y otro lado del espectro ideológico: “el CDS está llamado a cumplir el papel que el partido de Carrillo

\footnotetext{
130 "Informe de Gestión de la Secretaría General (V Congreso, 1992)", Documento de José Luis GómezCalcerrada. Respecto a la actividad parlamentaria del CDS en el Senado véase, Anexo XXIII.

${ }^{131}$ BENEGAS, José María: "Ofensiva contra el partido socialista", El Socialista, 15 de febrero de 1990. Véase también: "El PSOE no aceptará la acusación permanente", El Socialista, 28 de febrero de 1990.

${ }^{132}$ Por el propio José Ramón Caso, El País, 16 de febrero de 1990. Miguel Martínez Cuadrado (CDS) lo definió como la posible entrada en una nueva fase política de "pluralismo cooperativo" en "¿A quién representan los partidos políticos", El País, 31 de julio de 1990.
} 
desempeña contra Izquierda Unida: algo políticamente muerto pero que quita escaños valiosísimos a los vivos"133. El editorial de $A B C$ lo valoraba como "una iniciativa espontánea de satelización"134. Para Pablo Castellanos, antiguo dirigente de Izquierda Socialista (PSOE) el episodio era comparable a la "unificación de la Falange"135. Una perspectiva diferente era la defendida por El País, periódico en el que se entendía como una consecuencia lógica del fracaso de la derecha española para concertar una estrategia común con centristas y nacionalistas: "tal vez los jóvenes cachorros de la derecha no han reparado en la posible relación entre la destemplanza de sus críticas indiscriminadas al Gobierno resultante de las urnas y el alejamiento de su campo de los hasta ayer considerados aliados necesarios"136.

En esta nueva dinámica de acercamiento al PSOE, el CDS buscaba la concreción de un acuerdo o compromiso público en algunos de los aspectos sobre los que más se había incidido programática y parlamentariamente en los últimos años ${ }^{137}$. Un acuerdo que no terminaba de llegar fruto de las reticencias socialistas a pesar de la buena disposición de los suaristas. Por ejemplo, el CDS votó a favor de la aprobación parlamentaria de la LOGSE frente al rechazo del PP, y se abstuvo, junto a CiU y PNV en la Cuestión de Confianza presentada por el PSOE en 1991.

En abril de 1990, el PSOE presentaba una Cuestión de Confianza con el objeto de afrontar los importantes retos requeridos por el proceso de integración económica europea y a la par recuperar el crédito interno perdido tras el caso "Juan Guerra". En el debate subsiguiente, Adolfo Suárez se hacía eco de la "voluntad de diálogo anunciada

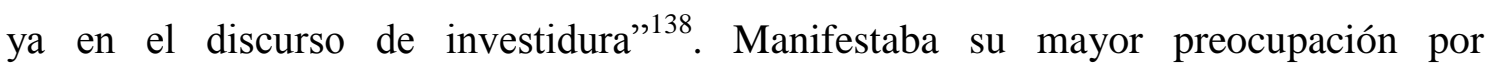
transformar la estructura productiva y los índices macroeconómicos para acercarlos a

\footnotetext{
133 JIMÉNEZ LOSANTOS, Federico: "Debate o entremés", $A B C, 01$ de febrero de 1990; ÍD.: "La falsa crisis del PP", $A B C, 09$ de marzo de 1990. "Ver a Suárez con todo lo que ha sido, haciendo de don Tancredo en la televisión [...] es algo que da ganas de llorar [...] al brindarse al apaño con el PSOE, ¿qué ha conseguido? Primero dejar de ser alternativa y, a continuación, casi dejar de ser", ÍD.: "Aislamiento y envilecimiento", $A B C, 18$ de marzo de 1990; ÍD.: "El bloque prostitucional", $A B C, 22$ de abril 1990.

${ }^{134}$ Editorial: "Bloque constitucional", $A B C, 15$ de febrero de 1990. "La zigzagueante trayectoria del CDS se arruinaría definitivamente en un pacto de esta naturaleza", portada de Mingote y editorial: "Las manzanas de Guerra", $A B C, 28$ de mayo de 1990. No sin humor, López Sancho hablaba de "pequeño contubernio", en "Palabras en juego", $A B C, 15$ de febrero de 1990.

${ }^{135} A B C$, 26 de mayo de 1990. Julio Anguita, irónicamente, lo llamó "honorable sociedad", $A B C, 28$ de septiembre de 1990.

${ }^{136}$ Editorial: "Peronismo en España", El País, 24 de febrero de 1990. "No basta la voluntad de centrar el mensaje para que se disuelva la desconfianza del electorado moderado", en el editorial: "Los hijos de Fraga”, El País, 09 de marzo de 1990.

${ }^{137}$ Llegó a existir el rumor, desmentido por el propio Suárez, de que podía ser nombrado Ministro de Exteriores en un ejecutivo socialista, $A B C, 29$ de mayo de 1990.

${ }^{138}$ Una propuesta defendida por Suárez durante el Debate de Investidura de 1989.
} 
Europa e incidía en la necesidad de reforzar la inversión activando "toda la potencialidad económica de nuestro país"139. Otras medidas eran: la reforma fiscal adecuándola a los modelos europeos-, fomentar el ahorro, mejorar la eficacia del gasto público y favorecer la "concertación social" 140 . Suárez subrayaba la importancia de la "cohesión social" para hacer sostenible y duradero el crecimiento y mostraba su satisfacción por la puesta en marcha del "Consejo Económico y Social" -anunciado aquella misma mañana-.

No obstante, la modernización del país no sólo se conseguía con medidas económicas. Era necesario transformar los valores imperantes en España: una "cultura política autoritaria", la minusvaloración de las profesiones técnicas, "una permanente búsqueda de calidad y de la innovación”, etc. Momento que aprovechaba para mostrar su acuerdo con la LOGSE, recientemente presentada por el Gobierno socialista. Insistió en subrayar la relación entre la "formación profesional" y las enseñanzas universitarias y el "mundo laboral". A continuación, en materia autonómica desgranaba algunas de las ideas defendidas desde 1987:

Establecer un mecanismo de participación estable de las comunidades autónomas en las relaciones con la Comunidad Europea que salvaguarde sus intereses [...sin perjuicio de los nacionales...] Desarrollar un sistema definitivo de financiación de las haciendas territoriales en el que siga produciéndose una descentralización real del gasto público, se asuma un cierto grado de corresponsabilidad fiscal por las comunidades autónomas y se produzca una aplicación más efectiva de la solidaridad interregional $[\ldots]$ aun cuando ha ido muy positivo el reciente Fondo de Compensación Interterritorial ${ }^{141}$.

En este sentido, era muy interesante su propuesta de reforma del Senado, acentuando "su carácter de Cámara de representación territorial", y por otro lado ejerciendo de instancia "para intentar disminuir la conflictividad jurídica que hoy agobia al Tribunal

\footnotetext{
${ }^{139}$ DSCD, Sesión Plenaria, 05 de abril de 1990, nº 28, p. 1071.

${ }^{140}$ En este sentido, el CDS defendió la participación activa de los agentes sociales. Por ejemplo, votó a favor de la ley sobre control sindical de los contratos - medida que encontró la oposición de AP-, $A B C, 06$ de diciembre de 1990.

${ }^{141}$ DSCD, Sesión Plenaria, 11 de abril de 1990, n 28, p. 1072. No deja de llamar la atención, la apelación a Suárez que hizo el diputado de EA J. Azkárraga Rodero al señalar: "Yo estoy seguro de que el ex presidente Suárez (y permítame señor Suárez, que lo comente) convendrá conmigo en que la forma en que se pactó el Estatuto de Autonomía Vasco (y él fue un artífice importante de él, junto con el anterior 'lehendakari' Carlos Garaikoetxea), no es la forma con que se está desarrollando ese texto del Estatuto. Aquí ha existido una degradación...", ibid., p. 1111. Referencia que no pasó por alto Felipe González: "ha sido usted citado, señor Suárez, lo cual es muy malo porque nos pone en una situación difícil respecto del espíritu de la negociación y del acuerdo sobre el Estatuto Vasco [...] podríamos incluso sugerir al señor Suárez que ayudara en esa capacidad de arbitraje cuando se trata de algunos conflictos que pueden estar derivados de una mala interpretación del espíritu estatutario de entonces...", ibid., p. 1116.
} 
Constitucional”142. Como había sucedido en tantas ocasiones, Suárez dedicó el resto de la intervención -prácticamente la mitad- a la política exterior, y en especial a la evolución del Este de Europa, apoyando decididamente la evolución democrática de Polonia, Hungría y Checoslovaquia. En su discurso, Suárez defendía la unificación de las dos Alemanias y llamaba la atención, poniendo de manifiesto una vez más su personal visión de la política internacional, sobre "la negociación de una fórmula singular para que la Alemania del Este no se integre militarmente en el ámbito de la Alianza Atlántica si ello es inaceptable para la Unión Soviética". En relación a la CEE, reiteraba la necesidad de incluir los valores del "estado social o estado del bienestar" en el proceso de unión monetaria, diseñando políticas sociales capaces de incorporar una “dimensión redistributiva"143; un equilibrio social e interterritorial (N-S).

La unificación alemana debía servir, en palabras de Suárez para reflexionar sobre el conjunto europeo. En síntesis la postura de Suárez era conducente a: una mayor unión política y democratización de las instituciones europeas -“reforma del Parlamento [...de cara al...] control democrático del aparato político-administrativo de Bruselas"-, una mayor autonomía europea en materia de seguridad -en el seno de la OTAN y enfatizando, una "reducción del gasto militar"- y un mayor equilibrio económico entre los diferentes países. En relación a los conflictos globales, reclamaba el papel de la Conferencia de Seguridad y Cooperación Europea para la superación de la división E-O, y tomando en consideración "la propuesta de Gorbachov sobre el Mediterráneo", subrayaba la necesidad de implementar una "política de paz y seguridad" en esta área geopolítica en el que se estaba produciendo "una concentración preocupante de armamento convencional y nuclear" ${ }^{\prime 14}$.

Sus últimas palabras retomaban la oferta de diálogo del Gobierno, en lo que debía generar una auténtica "estrategia general" y la unión de todo el país en pos de su "modernización" definitiva. Una opción apoyada por el CDS, pero ante la que la ausencia de "contenidos concretos", sólo quedaba abstenerse.

La pródiga disertación de Suárez sobre temas internacionales y reformas como la del Senado fueron bien acogidas por Felipe González. En relación a la primera señaló: “es

\footnotetext{
142 Ibid.

${ }^{143}$ Ibid., p. 1073.

${ }^{144}$ Ibid., p. 1074.
} 
una descripción bastante convergente con las posiciones que venimos manteniendo"145 Polemizó no obstante sobre sus palabras en relación a la unificación alemana: "no es verdad que se pueda llegar a una política de seguridad si se tiene el permiso de..., para entendernos. No hay, en absoluto, que deslizar el análisis hacia la consideración de si la Unión Soviética puede o no admitirla"146. Un punto que, en el turno de réplica negó explícitamente Suárez, "en ningún momento he planteado que la Unión Soviética tenga un derecho de veto sobre la libertad del pueblo alemán”. Para inmediatamente añadir:

Sabe como yo la enorme importancia que ha tenido en la historia de Europa en los últimos siglos la percepción de amenazas que los diversos países han tenido con mayor o menor fundamento, y eso ha sido especialmente importante en el caso de Rusia y de todos los países vecinos de Alemania, y por eso lo que yo quería señalar esta mañana era la necesidad de diseñar en los foros internacionales en que estamos presentes soluciones que refuercen la percepción de seguridad de todos los países del Este, como de los países del Oeste $^{147}$.

El debate demostraba, desde la línea editorial de El País, que por vez primera en las legislaturas socialistas se había abierto la posibilidad de alcanzar una vía de diálogo entre el Gobierno y la oposición (CDS, PNV y CiU, quienes se abstuvieron en la votación); diálogo que quizá se pudiera concretar en un pacto de legislatura ${ }^{148}$. En $A B C$, se analizaban confrontadas las intervenciones de Felipe González y José María Aznar, y en un segundo plano, se glosaban los discursos de Miquel Roca y especialmente, el muy crítico de Alejandro Rojas Marcos ${ }^{149}$.

Los contactos y negociaciones entre el CDS y el PSOE se prolongaron durante meses, y en ocasiones de forma "extraoficial", tal y como había defendido el propio Suárez en el debate de la moción de confianza recuperando el espíritu de la Transición $^{150}$.

La aparición de una nueva y significativa corriente interna en Madrid -a raíz de la publicación del llamado "Manifiesto de los Cien"-, fue el detonante de un interesante

\footnotetext{
145 Ibid., p. 1098.

${ }^{146}$ Ibid., p. 1099.

${ }^{147}$ Ibid., p. 1108.

${ }^{148}$ Editorial: "El diálogo posible", El País, 06 de abril de 1990 y El País, 07 de abril de 1990.

${ }^{149}$ Editoriales: "El discurso de González", "El discurso de Aznar" y "Otros discursos", ABC, 06 de abril de 1990.

${ }^{150}$ Las críticas desde $A B C$ no se hicieron esperar: "clandestinidad [...] subrepticia atmósfera de reserva [...] Los acuerdo convenidos fuera de las bambalinas parlamentarias y recatados a la opinión pública parecen formar parte de la cultura de la transición y no cabe desconocer que cumplieron, en su momento, una función positivo como instrumento del consenso [...] La concurrencia del CDS es cada vez más una anécdota, pues el partido puede diluirse en cualquier momento", Editorial: "Advertencia a Pujol”, $A B C$, 11 de julio de 1990; MUÑOZ-ALONSO, Alejandro: "Planeta PSOE", ABC, 09 de junio de 1990.
} 
cruce de argumentos entre El País y Adolfo Suárez"151. Para El País, la "zigzagueante trayectoria" del CDS, indeciso entre la "bisagra" y la vocación de "alternativa", había generado una notable confusión y desorientación entre la militancia y el electorado, que después de los últimos sucesos parecían situarlo al borde de la separación ${ }^{152}$. En su contestación en la tribuna de El País, Suárez reconocía "aciertos y errores" en la evolución del partido, pero argumentaba que el editorial había obviado la realidad política española de 1990. El CDS, señalaba Suárez, había nacido con la intención “de [...] profundizar en las libertades públicas y consolidar y perfeccionar las instituciones democráticas recién implantadas [...] [y] contribuir a la configuración en España de un Estado de bienestar moderno y eficaz”. Sin embargo, desde 1982 la aplicación de la "mayoría absoluta" y las rígidas "política de ajuste" habían impedido tanto el acercamiento o diálogo con el PSOE, como la defensa, mediante acuerdos con el Gobierno, de la "sensibilidad social" existente en el CDS. En esta época, tampoco se optó por un pacto político con el PP -simplemente un acuerdo de gestión municipal limitado en el tiempo, aunque el PSOE proclamase que "vuelven las derechas"-, pero del mismo modo no fueron logrados los resultados electorales esperados (1989). Por todo ello, pero sobre todo, como consecuencia de la oferta de diálogo de Felipe González en el discurso de investidura de 1989, el CDS había decidido -según los cauces democráticos internos- variar su estrategia y tratar de colaborar e influir en la gobernación. Esta estrategia necesitaba ante todo, y frente la impaciencia e incomprensión lógica dentro y fuera del partido, tiempo. No se podía concluir que existiera indefinición estratégica o ideológica en el partido ${ }^{153}$.

En materia educativa, se mostró favorable a la reforma del Gobierno Socialista LOGSE $-^{154}$. Para los suaristas la mera existencia de un cambio de ley era absolutamente necesario: “el cambio político justificaría por sí solo la sustitución de la $L G E$ ”. Aunque primaban las coincidencias con el Programa Electoral del CDS, era preciso resaltar alguna diferencia significativa en materia de: calidad de la enseñanza, profesorado, garantías jurídicas de los centros privados y universidades o la supresión de las pruebas

\footnotetext{
${ }^{151}$ Pocos días antes, en plena negociación del Gobierno del PSOE de la Ley de Cabildos con Canarias, presidida por el centrista Lorenzo Olarte, se produjo la crisis del pacto con el PP en las islas al ser sustituidos los dos consejeros populares, El País, 08 de julio de 1990.

${ }^{152}$ Editorial: "Ser o no ser suarista", El País, 11 de julio de 1990.

${ }^{153}$ SUÁREZ GONZÁLEZ, Adolfo: "Reafirmación de la voluntad centrista”, El País, 13 de julio de 1990.

${ }^{154}$ Votación plenaria del día 13 de septiembre de 1990. Votación final de conjunto de la Ley Orgánica de Ordenación General del Sistema Educativo, véase también: SOUTO PAZ, J. A.: "El CDS ante la Reforma Educativa [en 'Los Grupos Parlamentarios. Centro Democrático y Social']', Revista Cuadernos de Pedagogía, 84, septiembre 1990, p. 26 y ss.
} 
de acceso a los estudios superiores ${ }^{155}$. Especialmente crítico, se mostraba el CDS con la indefinición de los medios a emplear para la consecución de dichos objetivos, algo subsanable si se hubiera implementado una Ley de Financiación de la Educación. Al igual que sucediera durante la tramitación de la $L O D E$, el CDS quería ser el punto de encuentro capaz de evitar la polarización social que generaban todas las reformas educativas: "[CDS] se ha preocupado por proponer fórmulas intermedias entre el modelo educativo forzadamente comprensivo y tendente al igualitarismo de la izquierda, y el modelo anticipadamente segregador y falsamente liberal de la derecha”, intentando conjugar libertad e igualdad sin perjuicio de ninguno de los dos polos ${ }^{156}$.

Otros posicionamientos relevantes, en los que el CDS siguió la estela del PSOE fueron su rechazo a la propuesta de reprobación del Ministro de Agricultura, Carlos Romero, planteada por el $\mathrm{PP}^{157}$, el caso Naseiro ${ }^{158}$ o el Caso Sanchís ${ }^{159}$. Una atención particular merece el escándalo de las concesiones a la minería del Consejero Villar en Castilla y León, donde el CDS formaba parte del equipo de Gobierno encabezado por Jesús Posada (PP). Aunque los suaristas no apoyaron la reprobación del consejero, tal y como pedía el PSOE castellano y leonés, sí emitieron un voto particular reconociendo la existencia de anomalías en su tramitación ${ }^{160}$.

En la tramitación de los Presupuestos Generales del Estado de 1990 hubo bastantes convergencias entre la postura del Gobierno y la de los suaristas, hasta el punto de ser el grupo que más enmiendas vio aprobadas durante su debate en el Pleno en el mes de mayo de 1990 -siete de un total de trece- ${ }^{161}$. En el contexto de aprobación de las enmiendas del Senado, José Ramón Lasuén hacía la siguiente valoración:

\footnotetext{
${ }^{155}$ Tales eran los contenidos de las enmiendas presentadas por J. A. Souto Paz, DSCD, Sesión Plenaria, 28 de junio, $\mathrm{n}^{\circ} 48$. El CDS presentó un total de 63 enmiendas en el Congreso y 77 en el Senado, $A B C, 31$ de mayo de 1990 y 17 de julio de 1990. La supresión de las pruebas de acceso a la Universidad era reclamada por las Juventudes del CDS, $A B C, 03$ de julio de 1990.

${ }^{156}$ GÓMEZ-CALCERRADA, José Luis: "La LOGSE, dictamen final”, OICDS, 28, noviembre 1990

${ }^{157} A B C, 13$ de junio de 1990.

${ }^{158}$ Hubo discrepancias sobre cómo abordar parlamentariamente este episodio entre el PP -partidario de abrir una comisión de investigación, una "huida hacia adelante", en palabras de los dirigentes centristasy el CDS partidario de incoar una investigación a través de la Comisión del Estatuto del Diputado [convertida de facto en una comisión permanente de investigación], El País, 20 de mayo de 1990.

${ }^{159}$ El Congreso concedió el suplicatorio del TS sobre Sanchís (PP), con el voto a favor del CDS, "El PSOE y sus aliados dan vía libre al suplicatorio de Sanchís", $A B C$, 09 de noviembre de 1990.

${ }^{160}$ El País, 15 de febrero de 1991. En el País Vasco, los votos de PSE-PSOE, PNV y CDS rechazaron "la petición de crear una ponencia que elaborase un código de conducta de cargos públicos y partidos políticos, propuesta por Eusko Alkartasuna (EA) y apoyada por Euskadizo Ezkerra (EE) y PP”, El País, 01 de junio de 1990.

${ }^{161}$ El País, 25 de mayo de 1990.
} 
Señorías, les hemos dicho que éste es un presupuesto mejor que el del año anterior: hemos votado muchas secciones y títulos a favor del Gobierno. En resumen, después de las enmiendas presentadas por el Senado, nuestra posición es que es un presupuesto que no es suficientemente contractivo para la situación que el país atraviesa, que está creando una situación difícil de tensión entre la política monetaria y la política fiscal, aunque las cifras últimas son bastante mejores de lo que cabía esperar respecto del comercio exterior y, en alguna medida también, respecto de la inflación ${ }^{162}$.

Finalmente, el 8 de octubre de 1990, el CDS suscribía en el Congreso de los Diputados un documento público con el PSOE encaminado a la tramitación parlamentaria de varias reformas. Este documento, aunque no era un "pacto" contenía una serie de medidas a implementar durante lo que restaba de legislatura relativas a: la reforma electoral, el tráfico de influencias y el régimen de incompatibilidades, el Estatuto de RTVE, la política internacional, el Servicio Militar y la Reforma Fiscal. Algunas de las reformas anteriormente citadas podían ir encaminadas a mejorar la visibilidad y las opciones electorales de las minorías parlamentarias, y un éxito en medidas como las relativas al Servicio Militar podía convertirse en una buena carta de presentación frente a los votantes. Unos días después, Suárez confirmaba que no iba a renovar sus acuerdos con el PP. ¿Pretendía el CDS convertirse en el partido indispensable con el que se habría de contar para formar gobierno en 1993, presumiblemente, junto al PSOE?

$A B C$, bajo el epígrafe, "Centro Democrático Socialista", cargó las tintas contra el CDS. No se negaba la importancia del espacio de centro, pero sí que resultaba “censurable [...] la indefinición y la falta de clarificación ideológica y estratégica [...] éste es un nocivo factor de inestabilidad política [...]". Aunque, la previsible absorción del CDS por el PSOE podía "simplificar" de una vez por todas el sistema de partidos español. En El País, se consideraba el pacto desde dos puntos de vista. Si para el PSOE podía ser "un resguardo de eventuales contingencias parlamentarias [tanto en 1993, como en aquellas votaciones en que necesitaba 3/5 de la cámara]", para el CDS era el último paso en un bisagrismo de supervivencia, que por otra parte, el propio Suárez se había encargado de poner en entredicho al afirmar su negativa a pactar con la derecha $^{163}$. El suarista Bernardo Baquedano, Secretario Federal del CDS-Aragón

\footnotetext{
${ }_{162}^{165 C D}$, Sesión Plenaria, 28 de junio de 1990, n 48, p. 2336.

${ }^{163}$ Editorial: "Centro Democrático Socialista", $A B C, 11$ de octubre de 1990 y editorial: "Bisagra de centro", El País, 12 de octubre de 1990. Para Carlos Dávila en Diario 16, equivalía a su renuncia a exigir cualquier tipo de responsabilidad por el "caso Guerra", ÍD.: "El líder centrista "respetará" al vicepresidente del Gobierno", Diario 16, 11 de octubre de 1990.
} 
apelaba al significado político del diálogo durante la Transición como valor intrínseco de los pactos ahora firmados ${ }^{164}$.

Si algunos aspectos, como la categorización penal del "tráfico de influencias" o la política internacional fueron cuestiones transversales a toda la Legislatura, como hemos podido ver, el resto merecen una atención más detallada en este momento. De cara a la reforma electoral se hablaba de "corregir" y "evitar contradicciones" que pudieran degenerar en una situación como la vivida tras el 29-O, de una reducción del gasto, de una "nueva regulación de la moción de censura" -para dotar de estabilidad a las corporaciones- y de una mejor distribución de tiempos y publicidad, más que de una auténtica transformación del sistema de representación prescrito en la ley electoral. Meses antes en El País, José Ramón Caso había insistido en la capacidad del CDS para impulsar la regeneración democrática, lograr un control eficaz de los poderes económicos y políticos y diseñar una auténtica política de igualdad de oportunidades. Un artículo en el que apostaba por una financiación de los partidos políticos fundamentalmente pública ${ }^{165}$.

En relación a las Fuerzas Armadas se señalaban los objetivos de "modernizar y avanzar en la profesionalización de éstas”, aun sin abordar explícitamente una reducción del período de servicio: "ambos partidos mantienen diferencias importantes sobre el modelo y tamaño definitivo que deberán adoptar nuestras Fuerzas Armadas", diferencias que junto a la situación en el Golfo, invitaban a la posposición de cualquier iniciativa. No fue hasta el Debate sobre el Estado de la Nación de 1991, cuando Suárez reiteró su propuesta de reducción del servicio militar y meses después, José Ramón Caso llegó a defender una proposición no de ley para llevar a cabo un referéndum que sirviera para definir finalmente el modelo de Fuerzas Armadas nacional, iniciativa que

\footnotetext{
${ }^{164}$ BAQUEDANO, Bernardo: "El valor de los pactos", Órgano de Información del CDS en la Com. Valenciana, 2, enero 1991.

165 "Que debería ser casi exclusivamente pública materializada básicamente en forma de recursos de comunicación" con el fin de contrarrestar los desequilibrios generados por la financiación privada defendida por "voces [...] del espectro conservador"- y evitar excesivos los gastos electorales y las prácticas corruptas", CASO GARCÍA, José Ramón: "La solidaridad como exigencia democrática", $E l$ País, 29 de junio de 1990 y "Caso defiende que los partidos se financien solo por el estado", El País, 01 de junio de 1990. En el Informe de Gestión presentado por la Secretaría General en 1992 se defendía, en oposición al sistema del mailing, la introducción de una papeleta única o papeleta del Estado que comprendiera todas las candidaturas y cuya impresión y distribución corriera por cuenta de la Administración, Documento de José Luis Gómez-Calcerrada.
} 
fue contestada críticamente dentro del propio grupo centrista por Rafael AriasSalgado ${ }^{166}$.

Las reformas fiscales debían ir encaminadas a potenciar el ahorro, la inversión y la reducción de las cargas impositivas en las rentas más bajas ${ }^{167}$. Finalmente, en relación a la reforma del Estatuto de RTVE, junto a la defensa de la profesionalidad y el pluralismo en los diferentes contenidos y programas del ente público, se reclamaba el "derecho de antena" a las distintas formaciones políticas en función de su representación institucional.

La aprobación de las subvenciones del mailing electoral en febrero de 1991 fue interpretada por muchos como un intento del PSOE por dar aliento al partido de quien podía depender en unos meses la gobernabilidad de múltiples ayuntamientos y comunidades y en dos años, del país. Desde el PP se hablaba de que el objetivo del Gobierno no era otro que "resucitar a un muerto" [al CDS]. Para $A B C$, todas las reformas aprobadas en este período fruto de los acuerdos entre el PSOE y CDS sólo ponían de manifiesto el carácter subordinado de este último: "desfalleciente y fantasmagórica segunda marca", el "servilismo" o una "escueta voluntad de supervivencia asistida"168.

Para el CDS, los acuerdos con el PSOE suponían la confirmación del éxito de la nueva estrategia planteada en el III Congreso. Su capacidad de influir en el Gobierno había mejorado la legislación e impulsado reformas absolutamente necesarias. Se había confirmado la revitalización del diálogo y del consenso -aspecto defendido por Suárez en el Debate de Investidura y la Cuestión de Confianza-, y reformulado, desde la

\footnotetext{
${ }^{166}$ José Ramón Caso defendió un modelo de "ejército profesional” en base a argumentos técnicos -el caso del Reino Unido o EE.UU-, e históricos -citando a numerosos políticos del s. XIX acerca de la injusticia del servicio militar-, DSCD, Sesión Plenaria, 10 de octubre de 1991, no 137, p. 6636 y ss. Sobre la reacción de Rafael Arias-Salgado, véase, El País, 29 de junio de 1991. Recibió asimismo, las críticas de $A B C$ que lo consideraba de "dudosísimo encaje constitucional", en el editorial: "La nueva 'mili", $A B C$, 30 de junio de 1991.

${ }^{167}$ Punto en el que mayor acuerdo hubo entre el CDS y la reforma realizada, como reconocía José Ramón Caso, DSCD, 24 de marzo de $1992, \mathrm{n}^{\circ} 175$, p. 8652.

${ }^{168}$ Editorial: "Necesario consenso electoral", $A B C, 15$ de febrero de 1991; ÍD.: "Se consumó el atropello", $A B C, 26$ de abril de 1990; ÍD.: "1990. La política nacional", $A B C, 02$ de enero de 1991. Véase también: CAMPMANY, Jaime: "La subasta", $A B C, 22$ de febrero de 1991; CONTRERAS, Lorenzo: "Nupcias políticas", 11 de octubre de 1990. Sobre "resucitar a un muerto", $A B C, 28$ de febrero de 1991.
} 
independencia, una nueva forma de ejercer la oposición. Eran en definitiva, acuerdos "entre dos partidos con programas progresistas" $"$.

Sin embargo, la aprobación de la Ley del Servicio Militar (1991) gracias al acuerdo entre PP y PSOE, clausuraba apenas unos meses después de su firma los acuerdos de octubre y ponía rápidamente en evidencia los límites de la estrategia centrista.

El Debate sobre el Estado de la Nación de 1991, en el que fueron aprobadas nueve mociones de los suaristas ${ }^{170}$, supuso la última intervención de Suárez en una cita de esta naturaleza. En aquella ocasión, Suárez describió un panorama político marcado por una intensa situación internacional -la Guerra del Golfo y las transformaciones del Este de Europa-, y defendió su actitud dialogante ante las "numerosas críticas e incomprensiones" de las que había sido objeto en la prensa. Una posición, la del CDS, que era preciso trasladar al terreno político, económico y social con el fin de desarrollar una estrategia conjunta entre partidos, fuerzas sociales y sectores empresariales de cara a la integración en Europa.

En su análisis de la realidad española, identificaba el "desempleo" como el principal obstáculo para alcanzar el nivel de bienestar europeo. Junto a medidas macroeconómicas orientadas a alcanzar estos objetivos, siendo capaces a la vez de contener la inflación, había que seguir invirtiendo en infraestructuras, frenar la especulación del suelo y desarrollar unos servicios públicos más eficientes -sanidad y educación-. Respecto a este último punto, abogaba abiertamente por la externalización de la gestión en una línea política de corte social-liberal: “es conveniente descentralizar su gestión e incrementar la eficacia en su provisión mediante técnica de concierto parcial con la iniciativa privada allí donde la naturaleza del servicio público lo haga posible" ${ }^{, 171}$. En esta ocasión y como consecuencia de la Guerra del Golfo, insistió en la defensa de su modelo de Fuerzas Armadas y señaló que una de las conclusiones "más

\footnotetext{
${ }^{169}$ Editorial: "El significado político de los acuerdos CDS-PSOE”, OICDS, 28, noviembre 1990. En otros medios: VIVES RODRIGUEZ, Francisco (Concejal CDS Ayto. de Elche): "El significado político de los acuerdos CDS-PSOE", Órgano de Información del CDS en la Comunidad Valenciana, 2, enero 1991.

170 De un total de 14. Las mociones aprobaban versaban sobre: concertación social, información parlamentaria sobre las conferencias europeas intergubernamentales, estatutos de autonomía de Ceuta y Melilla, silencio "positivo" en la administración, debate sobre el modelo de FF.AA. y servicio militar, reforma del mercado hipotecario, plan para el impulso de la Formación Profesional y debate parlamentario sobre las drogas, DSCD, Sesión Plenaria, 21 de marzo de 1991, nº 99, pp. 4849-50 y p. 4857.

${ }^{171}$ DSCD, Sesión Plenaria, 20 de marzo de 1991, nº 98, p. 4799.
} 
evidentes [...] ha[bía] sido la indiscutible superioridad de los ejércitos profesionales"172. Además, la nueva situación generada tras el fin de la Guerra Fría exigía una profunda transformación -y reducción- de los modelos defensivos.

Para El País su intervención fue eminentemente económica y tuvo un tono "poco crítico" ${ }^{173}$. En el editorial ni siquiera era mencionado, centrándose en la confirmación, una vez más, de la capacidad de José María Aznar para constituirse como alternativa de gobierno: “Aznar ha dado a su partido una imagen de renovación generacional, y su voluntad de forjar un partido 'centrado, moderado e independiente' se ha traducido en una actitud que combina la crítica a la gestión socialista con la ausencia de la agresividad que asustaba a parte del electorado" ${ }^{\text {174 }}$. $A B C$ situaba en su portada las intervenciones de José María Aznar y Felipe González y tampoco hacía mención de la intervención de Adolfo Suárez en su línea editorial; en páginas interiores subrayaba la intención del líder del CDS de prolongar su cooperación con el PSOE ${ }^{175}$. Quizá lo más interesante estuviera fuera del Parlamento, en la "denuncia" de los diputados centristas al líder del PP, Aznar, acusado de "haberse inspirado" en la intervención de Suárez en 1988 para el Debate sobre el Estado de la Nación, un hecho que evidenciaba el desplazamiento del liderazgo de la oposición hacia la derecha popular y el deseo del PP de presentar ante el electorado un discurso de corte centrista.

Después del verano de 1991, la postura del CDS hacia el PSOE varió significativamente. Más allá de la propia actitud del ejecutivo socialista y la aprobación de leyes, como la referente al servicio militar, que hacían caso omiso a las demandas de los suaristas, la debacle electoral en las elecciones autonómicas y municipales y el cambio de dirección política acaecido tras el IV Congreso del partido marcaron un nuevo punto de inflexión en la historia del CDS.

\footnotetext{
172 Ibid, p. 4800.

${ }^{173}$ El País, 21 de marzo de 1991.

174 "El debate/y 2", El País, 22 de marzo de 1991.

175 Editoriales: "Los gozos y las sombras" y "El autócrata con votos", ABC, 21 y 22 de marzo de 1991.
} 



\section{Capítulo 10:}

\section{El final político de Adolfo Suárez}

A raíz del III Congreso, las vías de agua en el CDS comenzaron a multiplicarse y por primera vez en los casi diez de años de trayectoria del partido, salpicaron directamente a Adolfo Suárez. El portavoz del CDS, Antoni Fernández Teixidó afirmaba en septiembre de 1990 que uno de los problemas del partido era "una cierta ausencia de liderazgo", cuya causa radicaba en la concepción de partido y la relación con los medios de comunicación del propio Suárez "condicionada por el hecho de haber sido presidente del Gobierno y de UCD”" . Un comentario relevante tanto por quién lo hacía, como por lo que había sucedido durante ese verano a raíz del llamado Manifiesto de los 100.

Sea como fuere, las estadísticas del CIS demostraban la fragilidad del liderazgo de Suárez, cuyas cuotas de valoración se hallaban en sus niveles más bajos desde que abandonara la presidencia. Los niveles descendían más allá de la cota mínima alcanzada en noviembre de 1983, de solo 3,81 puntos:

Tabla 88: Valoración de Adolfo Suárez según las encuestas del CIS entre octubre de 1988 y octubre de 1991.

\begin{tabular}{|l|l|l|l|}
\hline Octubre 1988 & Diciembre 1988 & Enero 1989 & Marzo 1989 \\
\hline 5,25 & 4,68 & 4,66 & 4,77 \\
\hline Abril 1989 & Junio 1989 & Julio 1989 & Julio 1989 \\
\hline 4,66 & 3,86 & 3,86 & 3,9 \\
\hline Septiembre 1989 & Febrero 1990 & Marzo 1990 & Julio 1990 \\
\hline 4,41 & 3,82 & 3,76 & 3,4 \\
\hline Octubre 1990 & Diciembre 1990 & Mayo 1991 & Octubre 1991 \\
\hline 3,61 & 3,53 & 3,56 & 3,91 \\
\hline
\end{tabular}

Elaboración propia a partir de las fuentes estadísticas del CIS, Conocimiento y escala de valoración (0-10) de la actuación política de Adolfo Suárez (nacional), Código: (A501010130).

Contestación, división interna y fracasos electorales iban a marcar la trayectoria del partido entre los años 1990 y 1993 determinando el ocaso de su presencia institucional y el abandono de la política activa de quienes fueran el núcleo fundacional del suarismo. En este recorrido, veremos las Elecciones municipales y Autonómicas de 1991, la

\footnotetext{
${ }^{1}$ El País, 17 de septiembre de 1990.
} 
dimisión de Adolfo Suárez - como Presidente del CDS y diputado- y los intentos por reconducir el rumbo del partido en el IV, V y VI Congreso.

\section{1. Las elecciones municipales y autonómicas de 1991}

La celebración de las elecciones municipales y autonómicas de 1991 se convirtió en una auténtica prueba de fuego para el CDS. Si en el plano parlamentario, el mayor escaparate para la política suarista, no se habían conseguido los resultados esperados, en clave interna los síntomas de división acaparaban la atención de los medios proyectando la imagen de un partido profundamente dividido. De ahí, la vital importancia de obtener presencia institucional para ser capaces de transmitir al electorado el decisivo papel que todavía podía jugar el CDS en la gobernabilidad de país.

En junio de 1990, una carta dirigida a Suárez y firmada por cien militantes Manifiesto de los 100 - señalaba abiertamente la errónea estrategia del partido y la ausencia de democracia interna, si bien, en ningún momento ponía en cuestión el liderazgo del abulense. La carta comenzaba criticando la falta de información y de debate entre la militancia en un partido "en el que el silencio" se había convertido en "vida política". Para los autores, el partido se encontraba "en el peor momento desde su nacimiento" y la dirección había tomado por solución el "consabido" "AQUÍ NO PASA NADA".

Esta actitud se había visto acompañado de la renuncia a hacer oposición "dando una sensación de sumisión" al PSOE. Consideraban que una de las razones esgrimidas por Suárez durante el III Congreso, facilitar un supuesto proceso sucesorio abierto en el PSOE que "estaba siendo víctima de una campaña orquestada para dificultarlo", había sido refutada por la propia evolución de los acontecimientos. Además, los socialistas habían vaciado de contenido todas las posibles reformas a acordar. El Estatuto de RTVE no era un objetivo prioritario al existir la TV privada, la reforma del servicio militar se haría de acuerdo con el programa del PSOE y, en relación a la reforma del CGPJ ${ }^{2}$, sólo cabía la opción de cambiar el sistema de elección "que tú [Suárez] apoyaste en su día", preguntándose en último lugar: ¿cuál era el precio a pagar para que la constitución de las comisiones de investigación no dependiesen exclusivamente de la voluntad del

\footnotetext{
${ }^{2}$ Nos remitimos en este punto a la polémica con Jiménez de Parga abordada en el epígrafe 3. 2.
} 
PSOE? Por otro lado, cómo compatibilizar este acercamiento con el propio Programa Electoral de 1989 en el que se afirmaba que la democracia había "retrocedido" bajo los mandatos del PSOE, “¿tanto han cambiado los socialistas, en este tiempo, para poder dar por superados estos análisis? [...] ¿No puede estar justificado el sentimiento de estafa de un sector no desdeñable de nuestro electorado? [subrayado y negrita en el original]".

En segundo lugar, la democracia interna del partido merecía "una cierta reflexión". A propósito, los autores señalaban el caso de la Federación de Madrid elegida en 1987 con sólo un $45 \%$ de los votos y convocada un año y medio después de la fecha correspondiente. Hacía siete años que no se celebraba una "Asamblea Provincial" anual, tal y como prescribían los Estatutos y el Congreso Extraordinario prometido en enero de 1990 iba a ser pospuesto, al menos, hasta comienzos del año siguiente.

Ambas situaciones -estrategia y democracia interna-, motivaban a los autores a recomendar la apertura de debates internos: "es por ello por lo que te rogamos que la expliques a todos aquellos militantes que así lo deseen, dándoles la oportunidad de poder opinar". Seguía: "hace ya muchos años que no se celebran aquellos debates abiertos a la militancia, en los que analizabas la situación política y respondías a las preguntas que te formulaban”, y parafraseaba al propio Suárez quien solía comenzar aquellas intervenciones recordando la epístola de Francisco de Quevedo al Conde Duque de Olivares: “¿Siempre se ha de sentir lo que se dice? ¿Nunca se ha de decir lo que se siente?"3. Finalmente, sus últimas palabras ilustraban la trayectoria de los firmantes de la "carta", junto a Suárez desde los tiempos de UCD, "travesía del desierto" incluida:

No puedes quejarte de nuestra lealtad, tantas veces demostrada. Pero no olvides que la lealtad, que conlleva una exigencia de sinceridad, no basta. Hace falta eficacia y ello depende de ti, porque nuestra disponibilidad es absoluta y sin condiciones en defensa de nuestro proyecto político original [subrayado y negrita en el original].

La carta desembocó en la expulsión de los firmantes, entre los que se encontraban José Antonio Pérez González -principal redactor del texto-, José Luis González Quirós,

\footnotetext{
3 "Manifiesto de los 100”, Archivo José Antonio Pérez González.
} 
José Vicente Cebrián -ambos antiguos miembros del Comité Nacional- o Enrique Sánchez de León -ex ministro de UCD- ${ }^{4}$.

El clima de división existente en el partido, fuertemente aireado por la prensa, obligó en el segundo semestre de 1990 a hacer un último intento por mejorar y revitalizar la estructura interna de los suaristas. Por un lado, se reorganizaron algunos de los comités ejecutivos provinciales, cuyo funcionamiento padecía de cierta falta de actividad y se elaboró un Plan de Acción Municipal y Autonómico con la intención de preparar el futuro terreno electoral. El objetivo era que todos los equipos de gobierno municipal y comités locales desarrollasen iniciativas y propuestas políticas en materia medio ambiental, vivienda y trabajo de cara a las elecciones municipales y autonómicas de 1991. Si Martínez-Campillo, Secretario de Organización, fue el encargado de articular la estrategia a nivel municipal, Fernández Teixidó coordinó un programa similar de cara a las Comunidades Autónomas. Con el objeto de impulsar estas iniciativas Adolfo Suárez inició en septiembre de 1990 una serie de visitas por toda la geografía nacional y que le llevaron a Asturias, País Vasco, Valladolid, Mallorca, Castellón, Santander o Burgos.

De otra parte, de la mano de la Secretaría de Participación Ciudadana, a cuyo frente se encontraba José Luis Gómez-Calcerrada, se intentó subsanar la escasa permeabilidad que tenía el partido entre los sindicatos, asociaciones, movimientos ciudadanos, etc. La estrategia pasaba por crear una red de más de cinco mil agentes sociales "para dar estabilidad al partido y buscar apoyo para las próximas elecciones municipales"5.

Sin embargo, la actividad de los suaristas tenía lugar en un contexto de fuerte endeudamiento, que de acuerdo con el informe anual del Tribunal de Cuentas sobre partidos políticos presentaba una diferencia de más de 940 millones entre lo invertido en las Generales de 1989 y los escasos 100 millones recibidos en concepto de subvención pública. En abril, el Comité Nacional se había visto obligado a aprobar un nuevo

\footnotetext{
${ }^{4}$ La decisión del CDS fue respondida con duros comentarios en la prensa, véase: DÁVILA, Carlos: "Un partido vicario", Diario 16, 08 de julio de 1990. O el editorial: "Ser o no ser suarista", El País, 11 de julio de 1990. Lo que fue recurrido posteriormente por tres de los expulsados y de acuerdo con las sentencias judiciales obligados a ser readmitidos en el CDS, $A B C$, 18 de septiembre de 1991.

${ }^{5}$ La actividad de esta secretaría se concretó en la publicación de al menos cinco números del Informe sobre Participación Ciudadana entre 1990 y 1991 de carácter bimestral y que suponía una reactualización del boletín publicado anteriormente por esta secretaría y titulado: Informe sobre el Estado de las Autonomía.
} 
cambio de sede, trasladándose desde el criticado palacete de la Calle Marqués del Duero a una más económica en la Calle O’Donnell ${ }^{6}$.

En estas circunstancias, el CDS afrontó unas nuevas elecciones en octubre de 1990 en este caso en la Comunidad Autónoma del País Vasco. Ninguna de las encuestas publicadas desde el verano otorgaba escaño alguno al CDS, que presentaba como candidato a lehendakari al miembro del Comité Nacional Alfredo Marco Tabar. Y al igual que sucediera en Andalucía, los análisis preelectorales: “dan por hecho que los votos que tuvo el CDS hace cuatro años serán para el PP"7.

Aunque desde el CDS se insistía en que el auténtico reto había que afrontarlo en 1991, Suárez llegó a Vitoria el día 12 de octubre permaneciendo diez de los quince días de campaña en el País Vasco. Como en otras ocasiones, se mostró partidario de una reedición del gobierno PNV-PSE en el que los suaristas se ofrecían como mediadores. Sin embargo, los resultados confirmaron la tendencia advertida en Andalucía y que les relegaba a un plano extraparlamentario:

Tabla 89: Evolución electoral del CDS en el País Vasco (elecciones municipales y autonómicas).

\begin{tabular}{|c|c|c|c|}
\hline $\mathbf{1 9 8 3}$ (Municip.) & $\mathbf{1 9 8 4}$ (Autonóm.) & $\mathbf{1 9 8 6}$ (Autonóm.) & $\mathbf{1 9 9 0}$ (Autonóm.) \\
\hline $0,5 \%$ de votos & No se presentó & $3,52 \%$ de votos & $0,65 \%$ de votos \\
\hline
\end{tabular}

Elaboración a partir de información disponible en http://www.historiaelectoral. com/aeuzkadi.html; http://www.historiaelectoral.com/ percenteuz.html Fecha de consulta: 15 de julio de 2016.

La otra cara de la moneda era el éxito del PP que lograba formar grupo parlamentario y acrecentaba su imagen de "partido centrado y centrista" al ser capaz de atraer los votos del $\mathrm{CDS}^{8}$. En los medios se vaticinaba el final del ciclo político de Adolfo Suárez, como le había sucedido a otro protagonista de la Transición, quien fuera su principal interlocutor en las negociaciones del Estatuto de Guernica: Carlos Garaikoetxea. Si en el caso del CDS, se asociaban los resultados a los pactos con el PSOE, en el de EA, $A B C$ no perdía la oportunidad de recordar del siguiente modo aquel episodio histórico: “Carlos Garaicoechea está considerado como un político mediocre, vanidoso y con una

\footnotetext{
6 “J. R. CASO, EN CALIDAD DE SECRETARIO GENERAL DEL PARTIDO, CERTIFICA, que de acuerdo con lo dispuesto en el artículo 3 de los Estatutos del Partido, el Comité Nacional, en su Sesión del día 2 de Abril de 1990, procedió a variar el domicilio social de la Sede del Partido a la Calle O'Donnell, n $191^{\circ}$ Planta, 28009 - Madrid”, Dirección General de Política Interior, RPP, Registro de Salida n 527, 19 de abril de 1991.

${ }^{7}$ Entrevista de Ángel Collado a José María Aznar en $A B C, 26$ de agosto de 1990.

${ }^{8} A B C, 29$ de octubre de 1990. "El CDS desaparece estrepitosamente no ya del Parlamento, sino del paisaje político", editorial: "La victoria del PNV", $A B C, 29$ de octubre de 1990.
} 
ambición desmesurada, producto del fácil encumbramiento que consiguió por decisión de Adolfo Suárez, el cual quería repetir en el País Vasco lo que hizo con Tarradellas"9.

No cabe duda de que los pactos entre el CDS y el Partido Popular habían permitido a los populares proyectarse con mayor intensidad hacia el centro. Una empresa en la que contó con la cobertura de medios tan destacados como $A B C$ cuya lectura de los pactos de 1989 se fue haciendo cada vez más áspera, proyectándose sobre la gestión del Ayuntamiento de Madrid -aunque no así sobre su alcalde, Rodríguez Sahagún-. Para $A B C$, sólo las negligencias de los concejales suaristas impedían la correcta gobernación municipal.

En el caso del ayuntamiento madrileño, la firma del Acuerdo de Madrid había otorgado al CDS la alcaldía, una tenencia de alcaldía y cinco concejalías, mientras el PP ocupó el resto de tenencias de alcaldía (tres) y seis concejalías. Una vez pasada la inicial satisfacción del éxito conseguido, en el que siempre el tándem Sahagún-Manzano eran los protagonistas ${ }^{10}$, la balanza no tardó en desequilibrarse del lado de los populares y su futuro candidato, Álvarez del Manzano, a quien se denominaba: "alcalde moral de la Villa y Corte"11. En 1990, surgieron los primeros conflictos, una vez confirmado el cambio de orientación política del CDS. Las reprimendas en el rotativo conservador alcanzaron al concejal de circulación Larraz $^{12}$, al concejal de seguridad Fernando Bocanegra (CDS) -en su conflicto con el presidente de la Junta del distrito centro (Ángel Matanzo, PP)- ${ }^{13}$ e incluso al propio Rodríguez Sahagún ${ }^{14}$. Una ofensiva acentuada desde febrero de $1990^{15}$. En ese momento, aparecieron rumores sobre un

\footnotetext{
${ }^{9}$ ABC, 30 de octubre de 1990.

10 "Sahagún: cien días en el ayuntamiento", $A B C, 08$ de octubre de 1989; JIMÉNEZ LOSANTOS, Federico: "Un ayuntamiento que funciona", $A B C, 22$ de septiembre de 1989.

${ }^{11}$ USSÍA, Alfonso: "La perla del duque", $A B C, 14$ de octubre de 1990.

12 "Larraz, error tras error", $A B C, 26$ de mayo de 1990; "El caso de Larraz", $A B C, 26$ de diciembre de 1990. "La imprevisión municipal provocó ayer un interminable atasco en la avenida de América", $A B C$, 25 de marzo de 1990. "Del borde de Medel [el bordillo de la Calle Serrano, fuertemente criticado desde $A B C$; Medel había sido concejal del PSOE] a la incompetencia de Larraz", $A B C, 17$ de marzo de 1990.

13 "El concejal Bocanegra abre frentes conflictivos por todos los sectores [reportaje a doble página]", $A B C, 10$ de octubre de 1990. En los zig-zags de Ovidio, $A B C, 15$ de octubre de 1990.

14 "Rodríguez Sahagún y Ana Tutor [subdelegada del Gobierno] responsables de la ocupación de la Plaza Tudescos", $A B C, 19$ de octubre de 1990; DE NAVASCUÉS, César: "El Ayuntamiento sigue acumulando error tras error con los 'okupas"”, $A B C, 26$ de marzo de 1991. "Carlos Martínez (CDS) pretende negociar hoy con los asaltantes", $A B C, 25$ de marzo de 199; "Martínez y Bocanegra (CDS), responsables del primer gran triunfo del movimiento Okupa", $A B C, 27$ de marzo de 1991. Otro punto conflictivo era el plan de viviendas de alquiler deseado por Rodríguez Sahagún que para el PP suponía un intento de acercamiento al electorado de "izquierdas"”, $A B C, 11$ de marzo de 1991.

${ }^{15}$ En su editorial de 12 de julio de 1990, se señalaba: "aquel acuerdo de tan magros y efímeros resultados, no fue el mero pacto de conveniencia de la dirección de unos partidos, sino la traducción de una intensa demanda social [...] Si ahora los pactos se ven en peligro es por la mendicante aproximación del CDS a
} 
posible pacto PSOE-CDS que incluyera a la alcaldía de Madrid tras las elecciones municipales de 1991, y sobre todo desde octubre de 1990, cuando Adolfo Suárez anunció que el CDS no iba a renovar los pactos con el PP -lo que se consideró un “desaire” del CDS a Rodríguez Sahagún- ${ }^{16}$. En este contexto se produjo la dimisión del concejal centrista Fernando López-Amor, quien ingresó tiempo después en el Partido Popular. Para $A B C$, el ex miembro del CDS denunciaba así la connivencia entre socialistas y suaristas ${ }^{17}$. En marzo de 1991, declaraciones y reportajes subrayaban la próxima desaparición del CDS y la desbandada a izquierda y derecha de los ediles centristas. Un buen ejemplo del tono con el que se abordaba el papel de los "suaristas" en el Ayuntamiento es el de la siguiente entrevista concedida por Álvarez del Manzano a $A B C$ :

- ¿No cree usted que en estos momentos, más que en los sindicatos, el obstáculo para emprender privatizaciones está en el CDS?

- Con dos años de gobierno que son prácticamente de transición, hemos entendido que no podíamos abordar profundas reformas que, efectivamente podían ocasionarnos problemas dentro del propio equipo de gobierno ${ }^{18}$.

Los sondeos publicados durante los meses finales de 1990 alertaban sobre un fuerte descenso electoral del CDS, no sólo en comunidades menos propicias como el País Vasco o Andalucía, sino en el conjunto de España y apenas restaban seis meses para la celebración de las elecciones autonómicas y municipales (mayo de 1991).

La viabilidad futura del CDS pasaba por convertirse, aun a pesar del descenso electoral, en el partido clave para la gobernabilidad política de ayuntamientos y comunidades. Aunque fue habitual hablar, en mentideros políticos y periodísticos de cualquier signo ideológico de "pactos de progreso" entre PSOE y CDS, sería el Comité

los manteles del poder", editorial: “Agonía de unos pactos”, portada, en la que aparecían Suárez y Aznar, de $A B C$ : "El PP, dispuesto a reestudiar el pacto con el CDS", $A B C, 12$ de julio de 1990. Reportaje ese mismo día: "Los pactos PP-CDS en peligro por la crisis canaria".

${ }^{16}$ Portada: "El PP recela de un pacto PSOE-CDS que incluya la alcaldía de Madrid", $A B C, 01$ de julio de 1990. En otra ocasión, aparecían Rodríguez Sahagún y Adolfo Suárez, acompañados de un pie de foto que decía: "[Lo que] ha sido interpretado en medios políticos como el paso definitivo para la absorción de los centristas por el PSOE", $A B C, 11$ de octubre de 1990. Un distanciamiento que era constantemente subrayado por $A B C$, por ejemplo, a propósito de la votación parlamentaria sobre la penalización del consumo de drogas en público, rechazada por socialistas y centristas en la Asamblea de Madrid, $A B C, 08$ de diciembre de 1990. Unos meses antes en el Senado, el CDS se abstuvo ante una proposición de ley similar del GP, $A B C, 21$ de septiembre de 1990. "Consumir drogas en la calle seguirá sin ser sancionado" [Ayuntamiento de Madrid, abstención del CDS], $A B C, 07$ de octubre de 1990. Una situación que provocaba, para $A B C$, el alejamiento entre el CDS y Rodríguez Sahagún, favorable a esta medida, $A B C$, 19 de octubre de 1990.

${ }^{17}$ El País lo explicaba en base a su distanciamiento del resto de concejales del CDS y acercamiento al PP, El País y ABC, 02 de marzo de 1991.

${ }^{18} A B C, 10$ de noviembre de 1990. En marzo de 1991 señaló al hilo de una Conferencia en el club s. XXI: "No tengo ganas de seguir para que la imagen sea de otro", $A B C, 27$ de marzo de 1990. 
Nacional quien decidiera en última instancia qué pactos postelectorales se iban a firmar y con qué fuerzas políticas ${ }^{19}$. En este agitado contexto interno -contestación y limitada revitalización- y externo -bajas expectativas electorales y ascenso del PP-, arrancó la decisiva campaña electoral de 1991. Las elecciones autonómicas y municipales estaban previstas para el día 26 de mayo, a las que el CDS acudía una vez más a la cita con las urnas en solitario ${ }^{20}$.

La noticia más sobresaliente en la antesala electoral fue la renuncia de Agustín Rodríguez Sahagún -junto a otros miembros de su equipo municipal como José Luis Garro y Fernando Bocanegra-, a presentarse como candidato a la Alcaldía de Madrid. Agustín Rodríguez Sahagún apuntó a razones personales y familiares ${ }^{21}$. Muchos medios sin embargo, vieron en este episodio una nueva vía de agua en el partido suarista. El País sin desmentir las razones del propio Rodríguez Sahagún, consideraba que ante todo eran la consecuencia última del despropósito estratégico del CDS y del difícil papel que le había tocado jugar al mantener un pacto con el PP, cuando el partido giraba hacia el PSOE. Una opinión compartida por $A B C$ que, aun teniendo en consideración las razones anteriormente esgrimidas, ponía el foco en el acuerdo entre socialistas y suaristas como desencadenante de dicha decisión ${ }^{22}$. El halago a la gestión política de Rodríguez Sahagún implicaba un rechazo a la estrategia capitaneada por Suárez, y desembocó en el caso de algunos periodistas en una valoración muy negativa del rol desempeñado por el Presidente del partido:

Los primeros rumores apuntan a que podría ser el propio Suárez el candidato centrista al Ayuntamiento de Madrid. Pero Suárez no es un hombre que se caracterice por tomar decisiones valientes en circunstancias especiales. Piensa en él y en su futuro político, y un fracaso en Madrid con él como candidato, supondría no sólo la quiebra del partido, sino su muerte política personal ${ }^{23}$.

\footnotetext{
${ }^{19} A B C, 14$ de mayo de 1991. "Suárez o comunistas: el dilema del PSOE para el 27 de mayo", $A B C, 07$ de abril de 1991. Una visión crítica en MUÑOZ ALONSO, Alejandro: "Patético Suárez", $A B C, 15$ de abril de 1991; CONTRERAS, Lorenzo: "Ni siquiera un apéndice", $A B C, 15$ de abril de 1991. Se comparaba la magnífica gestión de Rodríguez Sahagún, fruto de la colaboración CDS-PP, en contraposición al acercamiento con el PSOE, en ÍD.: "Sahagún, un ejemplo incómodo", $A B C, 20$ de mayo de 1991.

${ }^{20}$ Sólo en Ourense pactó con Centristas de Galicia, El País, 08 de abril de 1991.

${ }^{21}$ Portada de El País, 08 de abril de 1991. Razones de las que también se hacía eco El Mundo, 09 de abril de 1991.

${ }^{22} A B C, 08$ de abril de 1991. Editorial: "Denuncia de un pacto", $A B C, 08$ de abril de 1991. Columnistas como Alfonso Ussía o Lorenzo Contreras pusieron en duda incluso la hipótesis de la enfermedad, USSÍA, Alfonso: "Un buen alcalde", $A B C, 10$ de abril de 1991 y CONTRERAS, Lorenzo: "Los votos personales de Sahagún", $A B C, 09$ de abril de 1991.

${ }^{23}$ DEL RÍO, Ángel: Agustín..., p. 194.
} 
Entre Rodríguez Sahagún y Suárez González, a pesar de una perceptible disparidad de criterios, no se produjo en aquellos días palabra alguna de reproche, en todo caso el recuerdo emotivo de toda una vida política juntos ${ }^{24}$. Al sopesar la soledad política del CDS, Rodríguez Sahagún comentaba: “quizá [la hayamos vivido] cuando hemos tenido que hacer la travesía del desierto [...]. Pero ahí no había una persona sola; al menos éramos dos: Suárez y yo"25.

Después de este episodio, se aprobaron definitivamente todas las listas -capitales de provincia- por parte del Comité Nacional, siendo el elegido para Madrid, José Ramón Lasuén, Presidente de la Federación madrileña. Las candidaturas autonómicas fueron aprobadas por el Comité de Federaciones el 25 de abril de 1991, -en el caso de la Comunidad de Madrid concurrió Carlos Revilla-. La presentación de los programas municipales y autonómicos tuvo lugar los primeros días de mayo.

En el Programa marco para las elecciones municipales (1991), el CDS se definía como "Partido Liberal y Progresista" vertebrado sobre los conceptos de diálogo, eficacia y estabilidad. Se articulaban seis grandes líneas de propuestas: "el gobierno de la ciudad", "los protagonistas de la ciudad", "la vivienda", "medio ambiente y problemas urbanos", "tráfico y transporte" y "la mili y los ayuntamientos"26.

Se apostaba por el fomento de la participación asociativa y vecinal en la vida del municipio, mejorar la transparencia -“comisiones de control y vigilancia de la contratación de obras y personal"- y el impulso de "nuevos modos de gestión"27. Llamaba la atención la propuesta de creación de un "defensor municipal” y allí donde fuere posible un "estatuto del municipio turístico" acorde con sus necesidades. Colectivos como el de los ancianos, los niños o las mujeres copaban buena parte de las medidas específicas de los suaristas, junto a la rehabilitación del patrimonio, la

\footnotetext{
${ }^{24}$ Rodríguez Sahagún no participó en la campaña electoral, limitándose a una aparición en un vídeo en favor de la candidatura de José Ramón Lasuén, ibid., p. 252. Suárez ofreció su versión de lo sucedido en una entrevista en El País y señaló que la decisión tomada era parte de un compromiso adquirido junto a Rodríguez Sahagún y su familia, El País, 23 de mayo de 1991.

${ }^{25}$ DEL RÍO, Ángel: Agustín..., p. 266.

26 "Garantizar la figura de los CONVENIOS DE ACTUACIÓN CONCERTADA como fórmula de colaboración y compromiso entre el Ayuntamiento y ciudadanos, asociaciones, empresas, órganos de la administración, etc., de tal forma que las negociaciones de los representantes municipales impliquen siempre un COMPROMISO MUNICIPAL [que] puede ser exigido incluso ante los tribunales", Programa electoral marco para las elecciones municipales, CDS, 1991, p. 8.

${ }^{27}$ Un programa, en el que evitaba pronunciarse explícitamente, como sí lo había hecho en otras ocasiones, en favor de una mayor gestión de la "iniciativa privada" aspecto por otra parte desarrollado implícitamente a lo largo del mismo (véase, 1983).
} 
promoción cultural y la mejora de la educación. En el campo de la salud, destacaba la atención al problema de la drogadicción y la lucha contra el $\operatorname{SIDA}^{28}$. La seguridad ciudadana -"La tranquilidad en la calle para los protagonistas de la ciudad"- recibía en este programa una atención menor.

En relación a la vivienda, el "gran agujero" del balance social democrático se defendía la búsqueda de una solución intermedia entre el "mercado libre y [...] las propuestas de la izquierda que nos llevan a ghetos de protección oficial" potenciando un modelo que permitiera "aumentar el parque de viviendas protegidas, tanto de compra como de alquiler, a precios asequibles" 29 . En cuanto al medio ambiente, se abogaba por la ampliación de las zonas verdes y el desarrollo de planes forestales urbanos. En este sentido, la medida más simbólica había sido impulsada por Rodríguez Sahagún en el Ayuntamiento de Madrid donde cada recién nacido tuvo un árbol con su nombre ${ }^{30}$.

A propósito del servicio militar, el CDS apostaba por una reducción del mismo hasta llegar "a su completa sustitución por un servicio militar voluntario, bien remunerado e instructivo". Sin embargo el CDS no excluía la movilización general y se manifestaba favorable a apoyar una ley capaz de garantizar "la prestación del servicio militar en caso de grave tensión internacional" -una medida relevante, si tenemos en cuenta el contexto de la Guerra de la Golfo-. Entre las propuestas concretas destinadas al soldado de reemplazo y el objetor de conciencia se encontraban: la asistencia jurídica y psicológica, la subvención del transporte, una dotación económica, etc. Medidas que ya se habían defendido en diversas mociones municipales durante la anterior Legislatura ${ }^{31}$.

De este modo, el programa del CDS se centró en vivienda, medio ambiente, seguridad ciudadana, drogodependencia, reducciones fiscales a las clases medias y

\footnotetext{
${ }^{28}$ El CDS apostaba por la prevención y la reinserción frente una clarificación penal (PP) o la mera eficacia de las sanciones (PSOE e CiU), El País, 26 de mayo de 1991. Algunos militantes defendían incluso posiciones favorables a la legalización -y de esta forma, control estatal- del consumo de drogas. En palabras del miembro del CDS-Alicante, Vicente Nondedeu: "la legalización de la droga sería un mal, de acuerdo, pero un mal menor, y una medida positiva para luchar contra la droga, y contra la delincuencia que ronda todo el tema de la droga", Órgano de Información del CDS en la Com. Valenciana, 2, enero 1991.

${ }^{29}$ Ibid., p. 23. En materia de transportes se pronunciaba en el mismo sentido: "el CDS no acepta la falsa distinción entre el transporte público y privado, pues el problema no se arreglará satisfactoriamente primando a un tipo de transporte sobre otro, sino revisando los esquemas de actividad y movilidad asociada y aceptando una coexistencia racional que ponga a cada uno en su sitio", ibid., p. 27.

${ }^{30} A B C, 15$ de diciembre de 1989 .

31 "Un ayuntamiento de Cantabria suscribe un seguro a 13 jóvenes que se incorporan a la 'mili", a iniciativa del CDS, El País, 02 de marzo de 1990. "El CDS de Valencia pide un seguro de vida para los que hagan la 'mili'", Diario 16, 25 de septiembre de 1989, etc.
} 
medidas municipales sobre el servicio militar ${ }^{32}$. Sin embargo, la capacidad del resto de partidos para adaptar sus propuestas a algunas de las medidas más innovadoras de los suaristas -servicio militar o vivienda- restó fuerza, como sucediera en 1989, a la que había sido la mayor baza electoral de los suaristas: la originalidad. Una sensación, que no era nueva en el CDS. Unos meses antes, el Presidente Federal en Cantabria, Manuel Garrido, escribía:

¿Recordáis cuánta crítica y demagogia tuvimos que aguantar cuando CDS planteó en 1986 la mili de 3 meses? [...] Estamos influyendo en la sociedad, van calando nuestras ideas; las copian, incuso otros Partidos políticos (aunque mal). Sigamos por nuestro camino que vamos bien a pesar de muchas dificultades y zancadillas ${ }^{33}$.

Si nos centramos en el Programa Autonómico del CDS llama la atención el recurso del CDS al concepto de "segunda transición"; una idea que como ha señalado J. A. Castellanos López, aunque fuera popularizado por José María Aznar a mediados de los noventa, había sido empleado desde comienzos de la década con múltiples sentidos. ${ }^{34}$. El CDS recurría a una idea defendida desde 1982 para conectar con lo que se consideraba imprescindible, es decir, un giro social y progresista de las instituciones: "La segunda transición. Con Adolfo Suárez se hizo la democracia política. Ahora, también con él vamos a hacer la democracia social" ${ }^{\prime 35}$. Junto a este punto, el CDS se limitaba a adaptar las medidas propuestas para el ámbito municipal al nivel autonómico. Apostaba por una mayor participación y libertad política, una mejora de la información pública -"no a la propaganda"-, y en relación a la gestión económica defendía la "austeridad" y la "transparencia" -"la contratación de obras, suministros y servicios se realizará con control de todos los grupos políticos" -36 .

En la campaña electoral, el CDS se ofreció como garantía de gobernabilidad política. El slogan usado fue en aquella ocasión: "La fuerza del diálogo". La imagen de Suárez, aunque no se presentaba en ninguna de las listas, fue empleada una vez más como principal reclamo de la campaña junto a los distintos candidatos. A diferencia de otras ocasiones, no hubo polémicas en relación al espacio televisivo concedido a los

\footnotetext{
${ }^{32}$ El Independiente, 30 de abril de 1991, MAST.

${ }^{33}$ GARRIDO, Manuel: "C.D.S. Sí, Boletín del CDS de Cantabria, 1, enero 1991.

${ }^{34}$ Social-económico (Nicolás Redondo), territorial (J. A. Duran i Lleida) y europeísta (Miquel Roca) en CASTELLANOS LÓPEZ, José Antonio: "El mito de la Segunda Transición" en FOLGUERA, Pilar, PEREIRA, Juan Carlos et alii (eds.): Pensar con la Historia desde el siglo XXI, Madrid, UAM, 2015, pp. 3515-3532. Disponible en: https://www.uam.es/ss/Satellite/es/1242675314514/1242687568365/UAM_ Libro_FA/ libro/ PENSAR_CON_LA_HISTORIA_DESDE_EL_SIGLO_XXI.htm Fecha de consulta: 15 de mayo de 2016.

${ }^{35}$ Programa Autonómico (publicidad, C. A. Madrid).

${ }^{36}$ Ibid.
} 
diferentes partidos por TVE. Según algunos análisis realizados sobre la cobertura electoral al CDS, el tratamiento de TVE al CDS fue proporcional a los votos obtenidos en 1989. Los porcentajes de aparición en espacios electorales e informativos fueron ligeramente inferiores a los de Izquierda Unida rondando el $8 \%$ del total ${ }^{37}$. Finalmente, cabe destacar que el presupuesto barajado por el CDS era el más bajo de los cuatro grandes partidos:

Tabla 90: Presupuesto electoral de los cuatro grandes partidos nacionales.

\begin{tabular}{|l|l|}
\hline Partido Político & Cantidad (en millones de pesetas) \\
\hline CDS & $500^{38}$ \\
\hline IU & 700 \\
\hline PSOE & 1300 \\
\hline PP & 1300 \\
\hline
\end{tabular}

Elaboración propia a partir de fuentes hemerográficas.

Una encuesta realizada por El País, publicada el 19 de mayo de 1991, ratificaba los peores pronósticos y dejaba al CDS sin representación institucional en prácticamente la totalidad de grandes municipios y Comunidades Autónomas: "Suárez sufre un duro golpe". Desde el CDS, se insistía en que manejaban encuestas que les permitían extrapolar los resultados de 1989 y que en los datos publicados todavía era preciso contar con un amplio margen de error.

Tabla 91: Viajes de campaña de Adolfo Suárez (fechas aproximadas).

\begin{tabular}{|l|l|}
\hline Madrid/Santander & - \\
\hline Madrid (Comunidad) & 11 de mayo \\
\hline Ciudad Real & 12 de mayo \\
\hline Cáceres & 13 de mayo \\
\hline Mallorca & - \\
\hline Murcia & 16 de mayo \\
\hline Alicante/Valencia & 17 de mayo \\
\hline Zamora/León & 18 de mayo \\
\hline Oviedo/Santander & 19 de mayo \\
\hline Pamplona & 20 de mayo \\
\hline Logroño/Zaragoza & 22 de mayo \\
\hline Tenerife/Las Palmas & 23 de mayo \\
\hline Ávila/Madrid & 24 de mayo \\
\hline
\end{tabular}

Elaboración propia a partir de fuentes hemerográficas.

\footnotetext{
${ }^{37}$ Un $8,44 \%$ entre el 10 y 15 de mayo y un 7,57\% entre el 16 y el 24 del mismo mes. En cuanto al tiempo de aparición de los líderes políticos Suárez ocupó el quinto lugar tras José María Aznar, Felipe González, Alfonso Guerra y Julio Anguita, $A B C, 19$ y 26 de mayo de 1991.

${ }^{38}$ Rebajado a 250 millones, El País, 23 de mayo de 1991.

${ }^{39}$ El mitin final de campaña en el Cine Consulado de Madrid.
} 
Si hay una nota a destacar en el tratamiento informativo de esta campaña fue el carácter absolutamente secundario y anecdótico del CDS. $A B C$ no tuvo un corresponsal para la campaña del CDS, siendo Concha Martín del Pozo, la enviada de El País. En sus crónicas volvía a subrayar de forma reiterada carácter personalista del partido: "los asistentes a los mítines del CDS son pocos, pero todos convencidos y adoradores de Suárez". Un Suárez una vez más caracterizado en base a los estereotipos habituales "la chulería del 'aquí estoy yo' con mezcla de bondad y una sonrisa que arrebata" $-{ }^{40}$.

Durante la campaña, el CDS centró su mensaje en la defensa de la originalidad e independencia de su proyecto político. La guía de campaña del CDS instaba a evitar los ataques a otras fuerzas y subrayar la independencia del partido. Si hizo referencias a los populares fue para recelar de su viraje al centro y en relación a los socialistas para criticar sus prácticas clientelistas -"Un documento del CDS descubre 18 maneras de defraudar al PER" ${ }^{41}$ - y la relación de ambos con los grandes poderes financieros ${ }^{42}$. Por su parte, el PSOE centró sus críticas en el PP, las bajas expectativas del CDS y la posibilidad de futuros pactos postelectorales ${ }^{43}$. Finalmente, el PP prefería presionar directamente sobre el electorado suarista antes que lanzarse a la crítica directa: "no hay más alternativa que el PP o la alianza de socialistas y comunistas"44. Cuando la Transición salió a relucir, se utilizó para situar a Suárez en los estantes de la Historia ${ }^{45}$.

Desde el PSOE y el PP eran conscientes de que el CDS podía ser la llave para el ejercicio del gobierno municipal y autonómico. Precisamente, José Ramón Lasuén defendía el voto suarista con el fin de evitar una radicalización hacia la izquierda del PSOE en caso de que este partido se viera obligado a pactar con el PCE para mantener

\footnotetext{
${ }^{40}$ El País, 23 de mayo de 1991.

${ }^{41}$ El País, 17 de mayo de 1991.

${ }^{42}$ Daniel de Fernando tras una entrevista con una caricatura en El Norte de Castilla en la que salía bastante mal retratado, se quejó públicamente de la misma y señaló que muchas empresas periodísticas estaban en "poder del capital", El Norte de Castilla, 22 y 24 de mayo de 1991.

43 Una perspectiva similar: "otro dato a considerar en esta campaña es la oferta de alianzas postelectorales, en las que el CDS parece decantarse hacia el PSOE -quien evita hacerlo blanco de sus críticas - lo mismo que IU, capaz de apoyar al partido gobernante a fin de evitar el dominio de la derecha, pero rechazando todo pacto global de gobierno. A su vez, el PP cuida especialmente sus relaciones con los partidos regionalistas, posibles socios futuros" en FERNÁNDEZ-MIRANDA CAMPOAMOR, Carmen: “Análisis de las elecciones autonómicas y municipales de 26 de mayo de 1991”, Revista de Derecho Político, 35, 1992, p. 244.

${ }^{44}$ El País, 23 de mayo de 1991.

45 Polémica entre Suárez y Aznar (PP), "[Suárez tras unas declaraciones de Aznar] Aznar no conseguirá nunca entrar en la historia", El País, 24 de mayo de 1991. En un sentido contrario: "Txiki Benegas [PSOE] elogia al Presidente del CDS [...] como promotor del diálogo ahora al igual que en la Transición", El País, 21 de mayo de 1991. Suárez respondió: "a todo el mundo le puede surgir la vena de la sinceridad, pero lo que el CDS necesita no son piropos, sino votos", $A B C, 21$ de mayo de 1991.
} 
su control institucional. Una idea que le servía al político del CDS para extraer una lección de la Historia reciente de España:

Es la tragedia de siempre en este país desde 1812. Todo el siglo XIX y el XX los conservadores y los moderados españoles intentaron dominar y hasta colonizar a los líderes progresistas, a los liberales para mantener el poder. Así, los socialistas sólo podían pactar con los revolucionarios y ya se encargaba el Ejército de cerrarles el paso. Ahora es lo mismo sólo que al revés: se quiere pulverizar a los liberales para que los socialistas no pacten con nosotros, sin darse cuenta de que el PSOE que ahora está en el poder puede pactar con Izquierda Unida sin que el Ejército se inmute ${ }^{46}$.

$A B C$ secundaba la negativa de J. R. Lasuén a pactar en un hipotético caso con IU y aprovechaba para tachar de "confabulación" cualquier posible pacto-postelectoral que no respondiese a la afinidad ideológica de los partidos o la gobernabilidad. Y es que, si el CDS obtenía representación -es decir, si superaba el 5\% de votos y lograba 3 escaños-, el PSOE necesitaba tanto a IU como al CDS para formar gobierno en la alcaldía madrileña:

El candidato a la alcaldía madrileña por el CDS ha introducido un giro en su campaña, abriendo la hipótesis de un entendimiento con el PP, y descartando, en todo caso, y con inequívoca contundencia, la posibilidad de pacto con los comunistas. Es una actitud razonable y, sobre todo, inteligente [...] En cualquier caso, nadie podría llamarse a engaño sobre los acuerdos - prácticamente anunciados- PSOE-CDS, allá donde la suma de ambas formaciones baste para alcanzar la mayoría absoluta. Pero si además de los escaños o concejales del PSOE y del CDS se necesitara los de los comunistas de IU para poder gobernar, está claro que los centristas estarían obligados a retirarse ${ }^{47}$.

En el mismo editorial se confirmaba la consolidación del PP en el espacio de centro, la inviabilidad de los partidos de centro per se -"la capacidad de diálogo es un patrimonio común y compartido de la cultura democrática"-, y menos aún de un partido cuyas insinuaciones reiteradas son para con el "vecino de la izquierda". Por vez primera, el PP se había acercado a las clases medias urbanas y tenía la "voluntad de retomar la herencia abandonada de la desaparecida UCD"48.

\section{2. El punto de inflexión de los resultados electorales de 1991}

Los resultados de las elecciones municipales y autonómicas de 1991 aunque no fueron los peores obtenidos en la trayectoria del partido, suponían en perspectiva un

\footnotetext{
${ }^{46}$ CDS. La Fuerza del diálogo. L'Hospitalet, CDS, 1991.

${ }^{47}$ Editorial: "De pactos y coaliciones", $A B C, 22$ de mayo de 1991.

${ }^{48}$ Editorial: "Votar con realismo", $A B C, 25$ de mayo de 1991
} 
tremendo mazazo para su continuidad: "El PSOE resiste, suben PP e IU y se hunde el CDS $^{״ 4}$. En un análisis electoral de la Universitat Autónoma de Barcelona publicado en El País, señalaban como una de las conclusiones de la campaña que "el poder decisorio que se había atribuido a los centristas para la formación de mayorías electorales [...] no se había materializado en los resultados electorales y era bastante menor de lo que se ha dicho en los primeros momentos"

En Madrid, los suaristas pasaban de ostentar la alcaldía a no contar siquiera con representación, quedando muy lejos del mínimo necesario (5\%), con un 2,9\%. Desglosados los resultados, nuevamente, el CDS obtenía sus mayores porcentajes en Canarias (10,2\%) -donde acudió en coalición con Agrupación Gomera de Independientes (AGI)-, Castilla y León $(8,7 \%)$ y Asturias (6,7\%). Especialmente significativos eran los buenos resultados obtenidos en dos comunidades tradicionalmente más esquivas al voto centrista como Extremadura $(6,7 \%)$ y Murcia $(5,4)$, y en Galicia, donde el pacto con los centristas gallegos les había permitido obtener el 5,9\% de los votos. Si en el País Vasco, Cataluña o Andalucía su fuerza era testimonial (1-2\%) en el resto de las Comunidades Autónomas no conseguía franquear la barrera del 5\%, caso de la Comunidad Valenciana y la Comunidad de Madrid, y con ello la obtención de representación parlamentaria. Pero, ¿dónde había ido a parar el electorado centrista?, y sobre todo, ¿qué había provocado la desafección del electorado?

En el conservador $A B C$, la errática trayectoria del CDS era la principal causante del descenso electoral. El origen se remontaba a la fecha en que se negó a arrebatar el Ayuntamiento y la Comunidad de Madrid al PSOE - “firmó su sentencia de muerte política"51 - y lo que columnistas de la importancia de Lorenzo Contreras consideraban ahora un auténtico "suicidio" 52 . El reverso era la definitiva consolidación de una alternativa de centro-derecha: el PP. Para El País, el ascenso del PP era un éxito parcial consecuencia inmediata de su capacidad para capitalizar la gestión municipal de los últimos cuatro años - caso destacado de Madrid- y sobre todo del fracaso electoral del CDS. En cierto modo, era un avance a expensas de los suaristas quienes

\footnotetext{
${ }^{49}$ En la portada de La Vanguardia. En El País, en el titular de una de las noticias del día se habla del "derrumbe del CDS" y de "pésimos resultados", en el texto de la portada de $A B C$, véase, La Vanguardia, El País y ABC, 27 de mayo de 1991.

${ }^{50}$ El País, 31 de mayo de 1991.

${ }^{51}$ Sección "Actualidad gráfica", "Suárez pagó las contradicciones", $A B C, 28$ de mayo de 1991.

${ }^{52}$ CONTRERAS, Lorenzo: "La consolidación de Aznar", ABC, 28 de mayo de 1991.
} 
paradójicamente desaparecían de las instituciones justo en el momento en el que mayor convergencia política existía en torno al "centro" político ${ }^{53}$.

En este sentido, aunque se reconocía que buena parte de los votos centristas habían ido a parar al PP - había pasado de un $20,94 \%$ a un $25,34 \%$-, no era menos cierto que la suma de PSOE e IU había ascendido ligeramente (en casi dos puntos), viéndose también beneficiado por parte del voto suarista. En cuanto a la considerable representación institucional del PP se había debido no sólo al trasvase de votos, sino a la imposibilidad del CDS de acceder -en muchos casos con porcentajes ligeramente inferiores al 5\%- al reparto de escaños autonómicos y de concejalías ${ }^{54}$. Para Gabriel Camuñas, el PP había recibido el 50\% del voto perdido por Adolfo Suárez -cerca de 600.000 votantes-, mientras que su "política centrista y de acoso al CDS había llevado al otro $50 \%$ de los votantes "perdidos' del CDS a votar por el PSOE"55. Según el análisis del grupo de investigación de la Universitat Autónoma de Barcelona el voto había ido a parar mayoritariamente al PP en algunas comunidades (Madrid, C. Valenciana, Baleares, Navarra, La Rioja y Castilla-La Mancha) y en otras, al PSOE (Canarias, Castilla y León, Asturias, Extremadura), sin olvidar, el peso de la abstención. Para los autores, había influido la opción por el "voto útil", ya que había "permanecido fiel [...] allí donde tenía más influencia” y la equívoca estrategia impulsada desde 1987 estaba detrás del fracaso centrista (abstención en 1987, pacto con el PP en 1989 y con el PSOE en 1990, este último "la enmienda de la enmienda" ${ }^{56}$. Independientemente del número exacto de votos trasvasados y de las causas del descalabro centrista, la clave de estos resultados, como señalan Josep M. Vallés y Jordi Sánchez Picanyol radicaba en que mostraban un nuevo "cambio de tendencia", que apuntalaba el camino hacia el éxito del PP y del ocaso definitivo del $\mathrm{CDS}^{57}$ :

\section{Tabla 92: Votos y porcentajes del CDS en 1987 y 1991 desde un punto de vista comparativo.}

\begin{tabular}{|l|l|l|}
\hline Elecciones 1991 & Votos & Porcentaje \\
\hline PSOE (PSC) & 7.224 .242 & 38,34 \\
\hline PP (UPN, UM) & 4.775 .051 & 25,34 \\
\hline
\end{tabular}

\footnotetext{
${ }^{53}$ Editoriales: "Lo que permanece y lo que puede cambiar" y "26-M, en perspectiva”, El País, 27 y 28 de mayo de 1991.

54 En esta línea, véase la sección "Actualidad Gráfica" de $A B C, 25$ de junio de 1991 y el editorial: “Claroscuro popular”, El País, 01 de junio de 1991.

${ }^{55}$ CAMUÑNS, Gabriel: “La alternativa Aznar”, El País, 05 de junio de 1991.

${ }^{56}$ Publicado en El País, 31 de mayo de 1991.

${ }^{57}$ VALLÉS, Josep María y SÁNCHEZ PICANYOL, Jordi: "Las elecciones municipales en España entre 1979 y 1991: balance provisional” en DEL CASTILLO, Pilar (ed.): Comportamiento ..., p. 372.
} 


\begin{tabular}{|c|c|c|}
\hline IU (IPC, CAA, IC) & 1.579 .097 & 8,38 \\
\hline CDS & 731.331 & 3,93 \\
\hline Elecciones 1987 & |---------------------- & 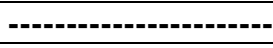 \\
\hline PSOE (PSC) & 7.229 .782 & 37,08 \\
\hline $\mathbf{A P}$ & 4.080 .705 & 20,94 \\
\hline CDS & 1.564 .964 & 9,77 \\
\hline IU (UPV-IC) & 1.904 .984 & 8,03 \\
\hline
\end{tabular}

Elaboración propia a partir de la tabla n 59 y los datos referidos a 1991 en AMINHAP.

Tabla 93: Cargos electos del CDS en 1991 desde un punto de vista comparativo.

\begin{tabular}{|c|c|c|}
\hline & Cargos Electos 1987 & Cargos electos 1991 \\
\hline Diputados Autonómicos ${ }^{58}$ & 105 & 17 \\
\hline Concejales & 5143 & 2935 \\
\hline Alcaldes & 687 & 377 \\
\hline Diputados provinciales/cabildos & 113 & 35 \\
\hline \multirow{2}{*}{ Porcentajes } & Porcentaje 1987 & Porcentaje 1991 \\
\hline & 9,77 & 3,93 \\
\hline
\end{tabular}

Elaboración propia a partir de la tabla n $^{\circ} 59$ y los datos referidos a 1991 en AMINHAP.

En su reunión del 3 de junio, el Comité Nacional apostó por la libertad de actuación de los concejales centristas para firmar pactos con el resto de fuerzas y fijar posiciones en los debates de investidura. Decisión ratificada a nivel autonómico por el Consejo de Federaciones el 8 de junio ${ }^{59}$.

Tabla 94: El CDS en las asambleas autonómicas (1991-1995).

\begin{tabular}{|l|l|l|l|}
\hline CC.AA. & CDS & Gobierno & Votación investidura \\
\hline Canarias & 7 & PSOE-AIC & En contra \\
\hline Castilla y León & 5 & PP & En contra \\
\hline Extremadura & 2 & PSOE & Se ausentan \\
\hline Asturias & 2 & PSOE & - \\
\hline Ceuta & 1 & PFC & - \\
\hline
\end{tabular}

Elaboración propia a partir de la información disponible en http://www.historiaelectoral.com/heauto2.html Fecha de consulta: 10 de marzo de 2016.

El CDS era decisivo para la formación de gobiernos en una comunidad -Canarias-, siete capitales de provincia y cuatro diputaciones provinciales ${ }^{60}$. Su capacidad decisoria se había visto relegada a un segundo plano no sólo por el ascenso del PP, sino por la presencia de los partidos regionalistas como el PAR, PA, EU, PRP, etc.:

\section{Tabla 95: Papel decisorio del CDS en la formación de Gobiernos municipales y autonómicos.}

\begin{tabular}{|l|l|l|}
\hline Institución territorial & Gobierno & Papel del CDS \\
\hline Canarias (C.A.) & PSOE-AIC & Votó en contra de la investidura \\
\hline
\end{tabular}

\footnotetext{
${ }^{58}$ Se han tenido en cuenta los representantes de Ceuta y Melilla.

${ }^{59}$ ABC, 08 de junio de 1991

${ }^{60}$ Hemos considerado aquellos casos en los que la suma de las fuerzas de centro-izquierda e izquierda o centro-derecha y derecha eran insuficientes para la formación de mayorías.
} 


\begin{tabular}{|l|l|l|}
\hline Logroño (Ayuntamiento) & PSOE & $\begin{array}{l}\text { Apoyo de IU y CDS. La concejala del CDS Pilar } \\
\text { Salarrullana participó en la Comisión de Gobierno } \\
\text { como responsable de las áreas de tráfico y medio } \\
\text { ambiente. Teniente de alcalde6 }\end{array}$ \\
\hline Segovia (Ayuntamiento) & PP & $\begin{array}{l}\text { Votó a su candidato. El apoyo de IU al PSOE fue } \\
\text { insuficiente } \text {. El CDS permaneció en la oposición. }\end{array}$ \\
\hline Palencia (Ayuntamiento) & PSOE & $\begin{array}{l}\text { Abstención. El apoyo de la Agrupación Popular } \\
\text { Palentina al PP fue insuficiente. }\end{array}$ \\
\hline Huesca (Ayuntamiento) & PSOE & $\begin{array}{l}\text { Permitió gobernar al PSOE. Empate entre PSOE-IU y } \\
\text { PAR-PP. }\end{array}$ \\
\hline Oviedo (Ayuntamiento) & PP & $\begin{array}{l}\text { Abstención que posibilitó el gobierno del PP. } \\
\text { Consuelo Vallaure, concejala del CDS se integró en el } \\
\text { equipo de gobierno, dimitiendo en 1992 }\end{array}$ \\
\hline Las Palmas (Ayuntamiento) & CDS-PP- & $\begin{array}{l}\text { Pacto con el PP e ICAN } \\
\text { ICAN. }\end{array}$ \\
\hline Salamanca (Ayuntamiento) & PSOE & $\begin{array}{l}\text { Apoyo al Gobierno del PSOE. Carlos Adame (CDS) } \\
\text { fue primer teniente alcalde. Un pacto PP-CDS hubiera } \\
\text { conseguido la alcaldía. }\end{array}$ \\
\hline Salamanca (Diputación Prov.) & Ind.-PSOE- & $\begin{array}{l}\text { José Dávila miembro del PP abandonó su partido y fue } \\
\text { elegido Presidente de la Diputación con el apoyo del } \\
\text { CDS y el PSOE }\end{array}$ \\
\hline Ávila (Diputación Prov.) & CDS-PSOE & $\begin{array}{l}\text { El Presidente de la Diputación Provincial es Alfredo } \\
\text { Barranco (CDS) hasta 1993. Moción de censura del PP } \\
\text { apoyada por un miembro del CDS. }\end{array}$ \\
\hline Valladolid (Diputación Prov.) & PSOE-CDS & $\begin{array}{l}\text { Coalición CDS-PSOE en 1991. Moción de censura del } \\
\text { PP con apoyo del CDS en 1993. }\end{array}$ \\
\hline Orense (Diputación Prov.) & $\begin{array}{l}\text { CdG-CG- } \\
\text { CDS }\end{array}$ & $\begin{array}{l}\text { Coalición centrista con el apoyo del PP. El Presidente } \\
\text { de la Diputación fue J. L. Baltar. }\end{array}$ \\
\hline
\end{tabular}

Elaboración propia a partir de fuentes hemerográficas y http://www.historiaelectoral.com/diputacions 83.html. Fecha de consulta: 15 de julio de 2016.

${ }^{61}$ ABC y El País, 16 de junio de 1991.

${ }^{62}$ El País, 15 de junio de 1991.

${ }_{63}$ Veáse, http://www.Ine.es/asturias/2013/06/17/debi-dejarme-convencer-direccion-cds/1428891.html Fecha de consulta: 10 de julio de 2016.

${ }^{64}$ Sobre este pacto: "Tras las elecciones de 1991, hubo un pacto entre CDS, PP e ICAN, que debían ocupar la alcaldía de forma rotatoria; en primer lugar, fue para León (CDS), y en noviembre de 1992 fue para el independiente José Sintes (uno de los 6 concejales del PP que había pasado al Grupo Mixto), que rompe el pacto un mes más tarde, y gobierna con PSOE y 8 concejales del Grupo Mixto (los 6 que eran del PP, 1 de ICAN y 1 del CDS); en enero de 1993, una sentencia judicial le obligó a dimitir, con lo que el PSOE asumió la alcaldía, con apoyo del Grupo Mixto". Información disponible en http://www.historiaelectoral.com/mlaspalmas.html. Fecha de consulta: 09 de agosto de 2016.

${ }^{65}$ El PP tenía mayoría absoluta en la Diputación Provincial y se eligió al popular Casimiro Hernández para suceder en el cargo a la centrista Rosario Diego. El apoyo de CDS y PSOE al diputado del Partido Popular José Dávila recientemente escindido del mismo desembocó en graves incidentes: "fue entonces cuando uno de los hombres del PP, José Dávila, alcalde de Palacios Rubios, decidió pactar con los 11 diputados del PSOE y el del CDS para hacerse con la presidencia. En el fondo latían las largas y serias desavenencias entre 'populares' y centristas y entre Dávila y Hernández, pero también los criterios encontrados en torno a la organización de 'Salamanca 92'. Cuando el 16 de julio se hizo público el pacto de Dávila con los adversarios políticos del PP en el Palacio de Salinas [...] durante la noche y primeras horas de la mañana del 18 de julio [los seguidores de Hernández] se dedicaron a convocar a alcaldes y concejales para que acudieran a la Diputación a impedir la toma de posesión de Dávila. El séquito de Hernández lo aupó en hombros en plena Plaza Mayor, prendió fuego a determinados periódicos considerados desafectos a su causa, profirió insultos contra sus adversario [al grito de ¡Franco, Franco!] y arremetió contra el líder centrista, José Luis Sagredo, al que dio persecución al grito de 'ése es el culpable, a por él, a matarlo'. Sagredo tuvo que saltar por la ventana y refugiarse en una tienda, donde lo rescató la policía", BERZAL DE LA ROSA, Enrique: "Juan José Lucas inaugura el reinado del Partido Popular", en VV.AA.: 25 años de Castilla y León 1983-1995. (Vol. 1) Un difícil arranque, una esforzada consolidación, Valladolid, El Mundo, 2003, p. 144. 
La política de pactos del CDS, que se dejó a la libre decisión de los distintos comités territoriales, dependió en buena medida de las circunstancias concretas de cada localidad o autonomía y de las relaciones inter-partidarias en dichos territorios. Para $E l$ País, los pactos habían servido fundamentalmente "para reforzar al partido vencedor (pero sin mayoría absoluta) y no para componer otra mayoría alternativa". El editorial cifraba en ocho las excepciones, y en dos los casos que habían posibilitado la designación de alcaldes socialistas (Valladolid y Logroño) ${ }^{66}$. Por su parte, $A B C$ resaltaba el incumplimiento de la "promesa" mantenida durante la campaña de no llegar a acuerdos a tres bandas en los que participaran los miembros de $\mathrm{IU}^{67}$. Su editorial "El CDS, con los comunistas" fue particularmente duro con los centristas. Tras contextualizar las problemáticas generadas habitualmente por las negociaciones y pactos postelectorales, se centraba en el caso del CDS:

Y hay que ocuparse, en fin, de un CDS, en estado de caquexia. Nos alegramos sinceramente por el decoro histórico de Adolfo Suárez, que su alejamiento de las responsabilidades de partido no permita imputarle al espectáculo de desvergüenza y literal traición a sus electores que están proporcionando algunos de sus náufragos. Porque en la situación crepuscular de este partido, la abstención o el apoyo a las listas más votadas hubieran sido las únicas conductas inteligibles y respetables. El apoyo al PP se hubiera correspondido con el sentir de los propios electores centristas, como las urnas han demostrado. El apoyo al PSOE no hubiera podido extrañar tras Torremolinos y la política parlamentaria de los socialistas. Pero confluir con socialistas y comunistas -como en Palencia y en Logroño- imponiendo este maridaje a la voluntad mayoritaria de los electores y desmintiendo promesas solemnes como la de Lasuén, llega más allá de lo que resultaba concebible y tolerable. Ver marchar del bracete a los hijos de Suárez con los nietos de Lenin rebasa todos los márgenes del estupor. También para estos singulares 'centristas' hay que pedir con entusiasmo la Concejalía de basuras ${ }^{68}$.

Por vez primera, en el nuevo mapa político PP y PSOE compartían fronteras en el espacio de centro. Una situación que provocó una última consecuencia: la decisión de Adolfo Suárez de abandonar la Presidencia del CDS después de casi diez años en el ejercicio del cargo.

\footnotetext{
${ }^{66}$ Editorial: "Pactos y coherencia", El País, 20 de junio de 1991.

67 "El CDS se coliga con los comunistas en Valladolid y Logroño", $A B C, 15$ de junio de 1991. La diferente percepción de $A B C$ frente a una u otra posición del CDS quedaba explicitada en titulares publicados en la misma página con evidente intención: "Logroño: CDS e IU votaron al PSOE" y "El PP gobernará en Oviedo", cuando este último episodio había sido posible también gracias a la abstención del CDS, véase, $A B C, 16$ de junio de 1991.

68 "Los españoles parecen mirar con recelo los pactos interpartidistas. Y no les falta razón. Porque, más allá de los discursos sobre gobernabilidad o afinidad, tras las negociaciones para componer gobiernos y corporaciones, se olfatea un tufo de 'piñeirismo', una inmoderada avidez de poltrona. Ningún partido está exento de culpa", editorial: "CDS, con los comunistas", $A B C, 16$ de junio de 1991. Véase también el editorial: "Se impuso la cordura", $A B C, 05$ de julio de 1991. En Actualidad gráfica se preguntaba, con la foto entre otros de Daniel de Fernando: "¿Qué les ha dado el PSOE”, ABC, 07 de julio de 1991
} 


\section{3. La dimisión de Adolfo Suárez como Presidente del CDS}

La noche del 26 de mayo, Adolfo Suárez dimitía como Presidente del CDS. En una rueda de prensa junto a José Ramón Caso, José Ramón Lasuén, Carlos Revilla y Antoni Fernández Teixidó, asumió las consecuencias del fuerte retroceso electoral y señaló que “es lo que debe hacer un líder de un partido con una estructura presidencialista cuando obtiene un varapalo de esta magnitud" ${ }^{\prime 69}$. Sin embargo, anunció su intención de permanecer en la vida política española dentro del Grupo Parlamentario del CDS. En el presente epígrafe, la lectura mediática de su dimisión y las consecuencias inmediatas de la misma constituirán la primera parte de nuestro análisis. En un segundo momento, abordaremos la evolución del partido a propósito de la celebración del IV Congreso Extraordinario.

A pesar de la magnitud de la noticia, su dimisión no constituyó una sorpresa para una opinión publicada que había especulado con esta idea durante prácticamente un año ${ }^{70}$. Las dos publicaciones de mayor impacto aparecieron en El País Semanal, en sendas entrevistas de Sol Alameda a Rodríguez Sahagún y Adolfo Suárez, esta última ocupando la portada del semanario con el significativo titular: "La última caída de Adolfo Suárez. ¿Punto final?”71. En páginas interiores, una fotografía de Adolfo Suárez de plano medio se contraponía con un busto romano clásico representado en la página precedente. Sol Alameda presentaba así su trabajo:

Varias páginas de la historia española llevan estampada su firma, pero el ex presidente Adolfo Suárez insiste en permanecer en la política y no convertirse en un rostro del pasado. Enfrentado a las críticas, los insultos y los malos momentos del CDS, solo, el hombre que llevó a cabo la transición se queja de desagradecimiento ${ }^{72}$.

La entrevista recorría su pasado político con cierta amargura, ante la dureza y la incomprensión con la que había sido tratado en el mundo político y mediático. El cansancio y el desánimo habían hecho mella en el ex Presidente de Gobierno. En palabras de Suárez, lo que "[deseo es] ser juzgado adecuadamente”. Y ante la reflexión

\footnotetext{
${ }^{69}$ El País, 27 de mayo de 1991.

${ }^{70}$ En El País ocupó una de las columnas de la portada, con el titular: "Suárez dimite por el derrumbe del CDS", El País, 27 de mayo de 1991.

${ }^{71}$ ALAMEDA, Sol: “Adolfo Suárez", El País Semanal, 02 de junio de 1991. Poco después se publicó una entrevista de la misma autora a Rodríguez Sahagún en dicho medio: "Rodríguez Sahagún. La fidelidad tiene un precio". En ella, Rodríguez Sahagún manifestaba su deseo de alejarse definitivamente de la política para poder dedicar más tiempo a su familia y aficiones -escribir-, El País Semanal, 23 de junio de 1991.

${ }^{72}$ ALAMEDA, Sol: “Adolfo Suárez”, El País Semanal, 02 de junio de 1991.
} 
de la periodista "seguramente es bastante querido por lo que hizo", respondía Suárez: "tal vez, pero no se dice", para concluir más adelante que "para unos fui un continuista, y para otros, un traidor $[\ldots]$ ¿Es que un político no tiene nervios ni sentimientos como lo demás?”. El decaído estado de ánimo de Adolfo Suárez había sido perceptible por compañeros de partido desde tiempo antes. Como ha recordado Fernando Alcón, amigo íntimo de Adolfo Suárez y Secretario de Organización entre 1987 y 1990:

Todos los días le enviaba con un mensajero un informe de algo más de un folio para tenerlo al día de las incidencias del partido en las provincias. Como pasaba el tiempo y Adolfo Suárez no le hacía ningún comentario sobre el contenido de estos informes, en uno de los muchos fines de semana que los dos matrimonios pasaban juntos, Fernando le preguntó: "¿te pasan los informes que te envío todos los días?". "Sí”, le respondió. "¿Quieres que te los siga enviando?”."No, no me los envíes"73.

En El País y $A B C$, que preveían la definitiva desaparición del partido de Adolfo Suárez, se intentó compensar la aspereza de los juicios políticos vertidos durante los últimos años con el recuerdo de lo que había significado Suárez en la Historia de España. Incluso, el repaso de la trayectoria del ahora "respetable proyecto" político que suponía el CDS, evocaba un camino jalonado por éxitos y fracasos a partes iguales ${ }^{74}$. En La Vanguardia se recurrió a la visión de Le Monde y The New York Times, para valorar el significado histórico de la salida de Adolfo Suárez, otro protagonista más de la Transición que abandonaba la política activa ${ }^{75}$. Las consecuencias de la dimisión de Suárez y el fracaso electoral del CDS fueron fundamentalmente de dos tipos. Por un lado, el partido inició un profundo y agitado proceso de renovación interna, lo que por otro lado, ponía a prueba su capacidad para hacer frente a una inédita y peligrosa eventualidad -la marcha de Adolfo Suárez-. Por otro lado, el espacio político de centro parecía decantarse hacia los dos grandes partidos mayoritarios, con la pujante irrupción del Partido Popular.

De acuerdo con los estatutos, la presidencia del partido recayó en José Ramón Caso, Secretario General y se procedió a la convocatoria inmediata de un Congreso Extraordinario $^{76}$. La dimisión de Adolfo Suárez fue seguida por anuncios similares de destacados líderes nacionales, provinciales y federales, destacando los de:

\footnotetext{
${ }^{73}$ CONTRERAS, Emilio: Suárez..., p. 332.

${ }^{74}$ Noticia en "Nacional" titulada: "Respeto a Suárez", $A B C, 27$ de mayo de 1991. Editorial: "Lo que permanece, lo que puede cambiar" e ÍD.: “Mutis por el centro”, El País, 27 y 29 de mayo de 1991.

${ }^{75}$ Sección "Revista de Prensa", La Vanguardia, 29 de mayo de 1991.

${ }^{76}$ Según el artículo 25.2 el Presidente: "será sustituido provisionalmente por el Secretario General, el cual deberá convocar el Comité Nacional, que se reunirá dentro de los treinta días siguientes, para convocar de
} 
Tabla 96: Anuncios de dimisión tras las elecciones de 1991.

\begin{tabular}{|l|l|}
\hline Nombre & Responsabilidad política \\
\hline Tomás Martín Tamayo & Comité Nacional \\
\hline J. Fernández Palacios & Presidente Provincial Almería \\
\hline Eduard Punset & Comité Nacional. Fundación de Foro \\
\hline Iñigo Cavero & Diputado en la III Legislatura (ingresó poco después en el PP). \\
\hline Federico Ysart & Comité Nacional $^{77}$ \\
\hline Manuel Sánchez Bracho & Comité Nacional $^{78}$ \\
\hline
\end{tabular}

Elaboración propia a partir de fuentes hemerográficas.

En la reunión del Comité Nacional del 4 de julio se plantearon diversas propuestas de reestructuración organizativa y política del partido. Ese mismo mes se celebró una Convención Nacional en la que gracias a una enmienda de la militancia, se incluyó el epíteto de "radical" junto al de "liberal" y "progresista" como una de las señas de identidad del CDS y se aprobó un cambio de actitud -alejamiento- respecto del PSOE $^{79}$. Una Convención sobre la que cayó como una losa el silencio de Suárez, quien para muchos todavía debía ser la cabeza electoral en 1993, aunque sólo el dirigente cántabro Manuel Garrido y Carlos Revilla pidieran abiertamente su vuelta ${ }^{80}$. La prensa insistía en la desorientación de un CDS sin Suárez y la necesidad de renovación del aparato que pasaba inexorablemente por la marcha de José Ramón Caso ${ }^{81}$.

A comienzos de agosto, Antonio Fernández Teixidó forzaba su cese como portavoz del partido, quedando libre para la presentación de sus propuestas alternativas de cara al nuevo congreso. Un estudio realizado entre la militancia sobre la valoración de los distintos líderes del CDS arrojaba unos apretados resultados de cara al sprint final por el

acuerdo con lo previsto en el artículo $16^{\circ}$ de estos Estatutos el Congreso Extraordinario para una nueva elección de Presidente y Comité Nacional. Podrá ser designados compromisarios los que tenían dicha condición en el último Congreso si así lo dispone el Comité Nacional, teniendo en cuenta las circunstancias políticas y las variaciones producidas en la afiliación”, Estatutos (1990), RPP, Registro de entrada $\mathrm{n}^{\circ}$ 168, 29 de junio de 1990, Acta notarial, Francisco J. López Contreras, $\mathrm{n}^{\circ} 1055$.

${ }^{77}$ Foro suponía un intento de superar las vías convencionales de hacer política y ejercer el poder, capaz de hacer frente a los retos interdisciplinares, internacionales y científicos que planteaba el futuro más inmediato. Se acompañaba de la Fundación Foro para la Innovación Social. Entre sus propuestas defendía una reforma de la Ley Electoral, una actuación decidida frente al problema de la drogadicción, una reforma de la administración y del sistema educativo. En cuanto a su estructura política apostaba por el fin de la burocratización interna de los partidos, PUNSET, Eduard: “¿Qué es Foro?”, El País, 15 de octubre de 1991. En otra ocasión, "lo importante no es cambiar de política, sino cambiar la política [...] sólo así podrán los españoles romper el círculo vicioso que ahora les atenaza”, en Foro. Entrevista a Eduardo Punset, Foro, 1994.

${ }^{78}$ ABC, 31 de mayo de 1991.

${ }^{79}$ Diario 16, 14 de julio de 1991, MAST.

${ }^{80}$ Ibid.

81 "En política se puede hacer casi todo menos el ridículo. Y justamente el ridículo es lo que están haciendo los señores Caso, Teixidó, y demás protagonistas del pintoresco espectáculo [...] Porque lo que uno y otro parecen ignorar es la carencia de relevancia y significación que para la opinión pública tienen sus nombres”, editorial: “¿CDS, sin Suárez?”, $A B C, 31$ de julio de 1991. 
control del centrismo. No obstante las supuestas críticas a Adolfo Suárez realizadas en el seno del partido eran, de acuerdo con estos resultados, cuanto menos exageradas:

Tabla 97: Valoración de líderes del CDS (IV Congreso).

\begin{tabular}{|l|c|c|c|c|c|}
\hline Líderes & Adolfo Suárez & Caso García & Alejandro Rebollo & Fernández Teixidó & Arias-Salgado \\
\hline Valoración & 9,1 & 6,45 & 6,13 & 6,21 & 6,06 \\
\hline
\end{tabular}

Elaboración a partir de ECO-Consulting, El Mundo, 27 de septiembre de 1991, MAST.

Durante el verano se perfilaron grosso modo distintas candidaturas para la dirección del CDS que implicaban a su vez diferencias en cuanto al modelo organizativo y la estrategia partidista $^{82}$. En primer lugar se encontraba buena parte de los miembros más veteranos del partido agrupados en torno a José Ramón Caso. En un segundo escalón, el ex portavoz del partido, Fernández Teixidó, quien había conseguido gracias al apoyo de destacados líderes regionales vertebrar una opción alternativa (Plataforma de Renovación). Asimismo, existieron posturas eclécticas como la de Raúl Morodo y liderazgos independientes como el de Rafael Calvo Ortega acompañado de Rafael Arias-Salgado. En estas circunstancias, un sector de los dirigentes territoriales del partido (Plataforma Territorial) intentó tender puentes entre las distintas opciones a la Secretaría General y apostar por un candidato de consenso a la Presidencia (Raúl Morodo, propuesta defendida por Adolfo Suárez). A modo de resumen:

Tabla 98: Corrientes de cara al IV Congreso.

\begin{tabular}{|l|l|l|l|l|l|}
\hline Alternativa & Líderes & Presidencia & $\begin{array}{l}\text { Secretario } \\
\text { General }\end{array}$ & Propuestas & Espacio político \\
\hline Oficialista & $\begin{array}{l}\text { José Ramón } \\
\text { Caso }\end{array}$ & $\begin{array}{l}\text { Raúl } \\
\text { Morodo }^{83}\end{array}$ & $\begin{array}{l}\text { Rosa } \\
\text { Posada }^{84}\end{array}$ & $\begin{array}{l}\text { Afianzamiento de } \\
\text { la Secretaría } \\
\text { General y }\end{array}$ & $\begin{array}{l}\text { Oposición } \\
\text { constructiva al } \\
\text { PSOE. }\end{array}$ \\
\hline
\end{tabular}

\footnotetext{
${ }^{82}$ El País, 31 de mayo de 1991.

83 "Raúl Morodo y la tercera vía”, El Mundo, 11 de agosto de 1991. El CDS debía clarificar su opción ideológica, abandonar el presidencialismo organizativo, evitar convertirse en un "satélite" de los partidos mayoritarios y clarificar la posición de Suárez, quien podía ser todavía el candidato para 1992-3, MORODO, Raúl: "La aporía del CDS”, El País, 24 de septiembre de 1991.

${ }^{84}$ En un primer momento, José Ramón Caso.
} 


\begin{tabular}{|c|c|c|c|c|c|}
\hline & $\begin{array}{l}\text { Otros líderes } \\
\text { Rafael } \\
\text { Martínez- } \\
\text { Campillo, } \\
\text { Alejandro } \\
\text { Rebollo }^{86} \text { o } \\
\text { Carlos Revilla. }\end{array}$ & & & $\begin{array}{l}\text { dirección } \\
\text { colegiada. } \\
\text { Recibe el apoyo } \\
\text { de Adolfo } \\
\text { Suárez }^{85} \text {. }\end{array}$ & $\begin{array}{l}\text { Adolfo Suárez } \\
\text { candidato en } \\
1993 .\end{array}$ \\
\hline \multirow[t]{2}{*}{$\begin{array}{l}\text { Plataforma } \\
\text { de } \\
\text { Renovación }\end{array}$} & $\begin{array}{l}\text { Antoni } \\
\text { Fernández } \\
\text { Teixidó }\end{array}$ & \multirow[t]{2}{*}{$\begin{array}{l}\text { Raúl } \\
\text { Morodo }\end{array}$} & \multirow[t]{2}{*}{$\begin{array}{l}\text { Antoni } \\
\text { Fernández } \\
\text { Teixidó }\end{array}$} & \multirow{2}{*}{$\begin{array}{l}\text { Renovación } \\
\text { simbólica de los } \\
\text { órganos } \\
\text { directivos. } \\
\text { Integra a un sector } \\
\text { de la Plataforma } \\
\text { Territorial. }\end{array}$} & \multirow[t]{2}{*}{$\begin{array}{l}\text { Radicalismo } \\
\text { liberal }\end{array}$} \\
\hline & $\begin{array}{|lr|}\text { Luis } & \text { Aznar } \\
\text { (Castilla } & y \\
\text { León) } & \mathrm{o} \\
\text { Bernardo } & \\
\text { Baquedano } & \\
\text { (Aragón) } & \\
\end{array}$ & & & & \\
\hline \multirow[t]{2}{*}{$\begin{array}{l}\text { Plataforma } \\
\text { Territorial }\end{array}$} & $\begin{array}{l}\text { Líderes } \\
\text { territoriales }\end{array}$ & \multirow[t]{2}{*}{$\begin{array}{l}\text { Raúl } \\
\text { Morodo }\end{array}$} & \multirow{2}{*}{$\begin{array}{l}\text { Rafael } \\
\text { Calvo } \\
\text { Ortega }\end{array}$} & \multirow[b]{2}{*}{$\begin{array}{l}\text { Radicalismo } \\
\text { institucional. } \\
\text { Decisiones } \\
\text { colegiadas y } \\
\text { plurales. } \\
\text { Presidencia más } \\
\text { institucional. } \\
\text { Superador del } \\
\text { conflicto Caso- } \\
\text { Teixidó }{ }^{87} \text {. }\end{array}$} & \multirow{2}{*}{$\begin{array}{l}\text { Equidistancia } \\
\text { entre el PP y el } \\
\text { PSOE. }\end{array}$} \\
\hline & $\begin{array}{l}\text { Gerardo Muñoz, } \\
\text { Manuel Garrido, } \\
\text { etc. }\end{array}$ & & & & \\
\hline \multicolumn{6}{|c|}{ Otros liderazgos $^{88}$} \\
\hline- & $\begin{array}{l}\text { Rafael Calvo } \\
\text { Ortega/Rafael } \\
\text { Arias-Salgado. }\end{array}$ & $\begin{array}{l}\text { Rafael } \\
\text { Calvo } \\
\text { Ortega }\end{array}$ & $\begin{array}{l}\text { Rafael } \\
\text { Arias- } \\
\text { Salgado }\end{array}$ & $\begin{array}{l}\text { Mayor poder de } \\
\text { decisión: órganos } \\
\text { territoriales. } \\
\text { Oposición a Caso } \\
\text { García }^{89} \text {. }\end{array}$ & $\begin{array}{l}\text { Propuestas } \\
\text { moderadas. } \\
\text { Entendimiento } \\
\text { con el PP }\end{array}$ \\
\hline
\end{tabular}

Elaboración propia a partir de fuentes hemerográficas.

La situación del CDS previa al IV Congreso evidenciaba las consecuencias de los malos resultados electorales y una cada vez mayor división interna. Desde 1989, se

\footnotetext{
${ }^{86}$ Había defendido una visión del CDS como instrumento de diálogo, que sin ser alternativa -como era evidente-, contribuyese a la estabilidad política e institucional en REBOLLO ÁLVAREZ-AMANDI, Alejandro: "La viabilidad del centro", El País, 06 de agosto de 1991.

${ }^{85}$ Un rumor existente desde el verano confirmado veinticuatro horas antes del inicio del Congreso, $E l$ País, 04 de agosto 1991.

${ }^{87}$ Entrevista a Gerardo Muñoz en Ya, 12 de agosto de 1991, MAST

${ }^{88}$ José Ramón Lasuén presentó la "Junta Radical" para impedir que el partido se derechizara. En esta línea, Pablo Sebastián, una vez confirmada la ocupación del centro por el PP atisbaba la necesaria posición del CDS en el centro-izquierda, "El sabor del centro", $A B C, 04$ de agosto de 1991; İD.: "El oportunismo de la izquierda española", $A B C$, 01 de septiembre de 1991. Finalmente, merece la pena destacar la posición de manifiesta independencia respecto de todas las corrientes que defendieron las Juventudes del partido.

${ }^{89}$ Ante un partido al borde de la extinción era preciso un cambio radical en el equipo directivo, ARIASSALGADO, Rafael: “¿Qué hacer con el CDS”, El País, 26 de septiembre de 1991.
} 
había producido la baja de al menos cinco mil afiliados - de los cuales, 150 habían sido compromisarios en 1990-, contaba sólo con nueve sedes regionales operativas y 56 provinciales-insulares. En Vizcaya, Tarragona y Guipúzcoa los locales habían echado el cierre. Asimismo, se habían acrecentado las deudas - que superaban los dos mil millones de pesetas- y con ellas, los problemas de financiación.

El anteproyecto de la ponencia política de cara al IV Congreso reconocía una situación deficiente en la administración y gestión de los asuntos cotidianos ${ }^{90}$. Y a todo ello, se añadía el nuevo rol desempeñado por Adolfo Suárez quien anunciaba su deseo de no acudir a la celebración del Congreso, aun manifestando públicamente su apoyo a Raúl Morodo y Rosa Posada. Los intentos de convergencia entre las distintas candidaturas no dieron finalmente sus frutos. En la antesala de la celebración del IV Congreso, los medios aludían a una previsible desaparición del partido, aferrado todavía a una considerable presencia institucional (14 diputados nacionales, un senador, cuatro eurodiputados, dieciocho diputados autonómicos, 423 alcaldes y 2989 concejales) $)^{91}$. Según una encuesta publicada por El Mundo y realizada por ECO Consulting, el $42 \%$ de la militancia consideraba que el partido iba a desaparecer. Para Diario 16, en su editorial del 27 de septiembre, el Congreso era un reguero de luchas personalistas sobre un fondo de indefinición. El CDS había perdido su razón de ser ideológica y política en un espacio de centro copado por los partidos mayoritarios ${ }^{92}$.

\section{4. La celebración del IV Congreso: Adolfo Suárez abandona la política}

El IV Congreso, celebrado en el barrio madrileño de Cantoblanco los días 28 y 29 de septiembre y presidido por la eurodiputada Guadalupe Ruiz-Giménez, se abría con la principal incertidumbre de saber quiénes iban a ocupar los cargos organizativos del

\footnotetext{
${ }^{90}$ VERANO, José Ramón: "La sangría imparable del CDS", El Independiente, 17 de agosto de 1991, MAST, y El País, 29 de septiembre de 1991.

91 "El silencio de Suárez provoca desconcierto y temor ante la desaparición del partido", El Sol, 27 de septiembre de 1991. "El CDS abre mañana su congreso extraordinario bajo el síndrome de extinción", $E l$ País, 27 de septiembre de 1991. "El CDS prepara un congreso que puede ser el de la disolución", Tiempo, 12 de agosto de 1991. "CDS, entre Caso y el ocaso", Blanco y Negro (ABC), 11 de agosto de 1991. En la línea editorial de Ya: "Oscuro porvenir del CDS", Ya, 12 de agosto de 1991. En otros medios se señalaba: "una repetición de los últimos momentos de UCD convertiría los estertores del CDS no ya en dramáticos, sino en patéticos, que es un paso más hacia la hipérbole del sin sentido", editorial: "El drama del CDS", Diario 16, 27 de septiembre de 1991. Datos de representación institucional en: VERANO, J. R.: "La sangría imparable...".

${ }_{92}$ Editorial: “El drama del CDS", Diario 16, 27 de septiembre de 1991.
} 
partido. Los compromisarios debían elegir directamente al Presidente Nacional, el Secretario General y al Comité Nacional -en el que se incluyeron a siete miembros de las listas derrotadas-. Siguiendo una expresión utilizada por destacados miembros del CDS, había dado comienzo el "congreso de la locura".

La primera sorpresa tuvo lugar en el discurso inaugural cuando José Ramón Caso en su presentación del informe de gestión anunciaba su decisión de desistir en sus aspiraciones de mantener la Secretaría General con el objetivo de buscar un candidato de mayor consenso (Rosa Posada). El episodio más estrambótico se vivió al aprobarse una ponencia política realizada por un militante murciano de treinta años ajeno a las corrientes del partido, Jose Muelas, derrotando a la ponencia oficial defendida por el senador Alberto Dorrego ${ }^{93}$. Una ponencia muy autocrítica y con una estrategia radical que ejemplificaba el rechazo de los compromisarios a la dirección. Esta ponencia defendía una mayor participación y autonomía de la militancia en la toma de decisiones -en cuestiones internas- y de cara al exterior el compromiso radical de control de los partidos políticos -corrupción- y de los grupos de presión. Esta tendencia se confirmó en el resultado de las votaciones,

Tabla 99: Resultado de las votaciones a los cargos de dirección en el IV Congreso.

\begin{tabular}{|l|l|l|l|}
\hline & \multicolumn{3}{|c|}{ Candidaturas } \\
\hline & \multicolumn{1}{|c|}{ Oficial } & \multicolumn{1}{c|}{ Rafael Calvo Ortega } & \multicolumn{1}{c|}{ Renovadores } \\
\hline Presidencia & Raúl Morodo & Rafael Calvo Ortega & (Raúl Morodo) \\
\hline & 339 & 445 & - \\
\hline Secretaría General & Rosa Posada & Rafael Arias-Salgado & A. Fernández-Teixidó \\
\hline & 222 & 279 & 290 \\
\hline
\end{tabular}

Elaboración propia a partir de fuentes hemerográficas.

Las votaciones confirmaron lo imprevisible del Congreso, durante las cuales algunos militantes llegaron a abuchear a quienes dijeron hablar en nombre de Suárez. La Presidencia recayó en Rafael Calvo Ortega y la Secretaría General fue a parar a la candidatura rival auspiciada por Fernández-Teixidó, gracias a un acuerdo de última hora entre Calvo Ortega y el grupo de éste. Pocos días después, Calvo Ortega asumía en una entrevista en El País su disposición a presentarse como candidato presidencial en

\footnotetext{
${ }^{93}$ Votación: 247 a favor de José Muelas - presentada como enmienda a la totalidad-, 183 en contra y 102 abstenciones. Estuvo a punto de prosperar otra enmienda a la totalidad relativa a la ponencia de organización, GARCÍA-ATANCE, María Victoria: "Congreso Extraordinario del CDS", Revista de Derecho Político, 34, 1991, p. 273.
} 
$1993^{94}$. Las listas respaldadas por Adolfo Suárez habían sido derrotadas; era el final simbólico del suarismo como tendencia política organizada en España:

[Rafael Calvo Ortega] Si el suarismo ha sido una adscripción política sólo en base a la persona de Suárez, evidentemente el suarismo habría terminado; si lo que se entiende es la adscripción al centro liberal y progresista, el suarismo sólo es una frase con escaso sentido $^{95}$.

El Comité Nacional electo estaba profundamente renovado y de él desaparecían, bien por voluntad por propia o decisión de los compromisarios prácticamente todos los representantes del mismo electos desde 1982 como León Buil Giral, Laura Morso, Federico Ysart, Alejandro Rebollo, Agustín Rodríguez Sahagún y Adolfo Suárez, es decir, quienes habían constituido el núcleo fundacional del partido. De aquel Comité permanecían Rafael Calvo Ortega como Presidente Nacional, José Ramón Caso y Joaquín Abril Martorell. Estos dos últimos, junto a Arias-Salgado, Martínez-Campillo, Gómez-Calcerrada Rosa Posada y Raul Morodo fueron elegidos en las listas abiertas para el Comité Ejecutivo, frente a una mayoría electa en la lista presentada por Fernández Teixidó. Entraban en la Ejecutiva líderes territoriales del partido de primera hora: Luis Aznar (León, acompañado de Ignacio Morán) y Luis Rodríguez San León (Zamora) - destacados miembros de la facción crítica- el dirigente del CDS en la isla de Mallorca desde su fundación (Francisco Quetglás), el impulsor del partido en Tarragona Lluis Badía o el dirigente murciano Luis Fuentes Varela, líder del partido en Lorca desde la época de la travesía del desierto (tercero en la lista al Congreso en 1986). Asimismo, asumían un mayor protagonismo los nuevos liderazgos surgidos tras el proceso de renovación de cargos territorial vivido entre 1990 y 1991, como Teresa Sandoval en Barcelona -quien fue candidata a la Generalitat y Presidenta Federal en 1992-, el Secretario General de las Juventudes del CDS-Cataluña, Santiago J. Castellá Surribas $^{96}$, el concejal del CDS en Zaragoza entre 1987 y 1991 Rafael de Miguel, Arcadio Sarrriugarte -cabeza de lista del CDS en Guipúzcoa en 1989-, Miguel Ángel Ramírez -segundo en la lista del Congreso por Cuenca (1989) -, José-Miguel Saval Pérez - presente en la lista del Senado por Alicante (1989)-, José María Lasierra -uno de los fundadores del CDS en Zaragoza-, los parlamentarios autonómicos de Canarias entre 1987 y 1990, Julio Bonis Álvarez y Luis Hernández Pérez (Consejero de

\footnotetext{
${ }^{94}$ El País, 01 de octubre de 1991.

${ }^{95}$ GONZÁLEZ IBÁÑEZ, Juan: "Me siento con ánimo y firmeza para rivalizar con González", El País, 01 de octubre de 1991.

${ }^{96}$ Teresa Sandoval ingresó en el partido en 1986, La Vanguardia, 27 de enero de 1992 y 07 de septiembre de 1990.
} 
Economía y Consumo) y el ex diputado de la Comunidad Valenciana y antiguo dirigente del partido en Alicante, José Ramón Navarro Nicolau. Completaban la lista Juan Carmona Carmona y Andrés Díaz Pérez, miembros también de la candidatura de Fernández Teixidó.

El nuevo Secretario de Organización era Luis Aznar, Rafael de Miguel pasaba a coordinar la Política Municipal, mientras José Luis Gómez-Calcerrada continuaba como Secretario de Participación Política y Ciudadanía. La vieja guardia del CDS estaba representada por su Grupo Parlamentario, en el que permaneció como portavoz José Ramón Caso y es que 12 de los diputados habían apostado por el tándem MorodoPosada para la dirección, en lo que era un grupo parlamentario cada vez más distante de la dirección del partido. Un distanciamiento, confirmado por Rafael Arias-Salgado, quien en junio se había manifestado públicamente contrario a la petición de un referéndum por parte de José Ramón Caso sobre el futuro del servicio militar ${ }^{97}$, y que ante la imposibilidad de defender, en calidad de vocal de la Comisión de Exteriores, la posición del CDS en el Parlamento relativa a la firma del Tratado de Maastricht se decidió a abandonar definitivamente el escaño ${ }^{98}$. Curiosamente, la Asamblea Nacional electa -órgano que sustituía de facto a la Convención Nacional- estaba controlada también por una mayoría oficialista.

\section{Tabla 100: Evolución del Comité Nacional (1990-1991) y miembros electos del Comité Federal.}

\begin{tabular}{|l|l|l|}
\hline \multicolumn{3}{|c|}{ Comité Nacional } \\
\hline Continúan & Altas & Bajas \\
\hline Rafael Calvo Ortega & $\begin{array}{l}\text { Luis Aznar Fernández (candidatura de } \\
\text { Teixidó, CDS-León) }\end{array}$ & Enrique Egea \\
\hline $\begin{array}{l}\text { José Luis Merino Hernández } \\
\text { (candidatura de Teixidó) }\end{array}$ & $\begin{array}{l}\text { Teresa Sandoval Roig (candidatura de } \\
\text { Teixidó, CDS-Barcelona) }\end{array}$ & José Ramón Lasuén \\
\hline $\begin{array}{l}\text { Antoni Fernández Teixidó } \\
\text { (candidatura de Teixidó) }\end{array}$ & $\begin{array}{l}\text { Francisco Quetglás Rosan (candidatura } \\
\text { de Teixidó, CDS-Baleares) }\end{array}$ & León Buil Giral \\
\hline $\begin{array}{l}\text { Raúl Morodo Leoncio } \\
\text { (candidatura personal) }\end{array}$ & $\begin{array}{l}\text { Rafael de Miguel Jiménez (candidatura } \\
\text { de Teixidó, CDS-Zaragoza) }\end{array}$ & Agustín Rodríguez Sahagún \\
\hline $\begin{array}{l}\text { José Ramón Caso García } \\
\text { (candidatura personal) }\end{array}$ & $\begin{array}{l}\text { Miguel Ángel Jiménez Ramírez } \\
\text { (candidatura de Teixidó, CDS-Cuenca) }\end{array}$ & Alberto Dorrego \\
\hline $\begin{array}{l}\text { Rosa Posada Chapado } \\
\text { (candidatura personal) }\end{array}$ & $\begin{array}{l}\text { Arcadio Sarriurgarte Aldecoai } \\
\text { (candidatura de Teixidó, CDS- } \\
\text { Guipúzcoa) }\end{array}$ & Tomás Martín Tamayo \\
\hline $\begin{array}{l}\text { Rafael Arias-Salgado } \\
\text { Montalvo } \\
\text { (candidatura personal) }\end{array}$ & $\begin{array}{l}\text { José-Miguel Saval Pérez (candidatura de } \\
\text { Teixidó, CDS-Alicante) }\end{array}$ & Manuel Sánchez Bracho \\
\hline $\begin{array}{l}\text { Joaquín Abril Martorell } \\
\text { (candidatura personal) }\end{array}$ & $\begin{array}{l}\text { Luis Rodríguez San León (candidatura } \\
\text { de Teixidó, CDS-Zamora) }\end{array}$ & Eduard Punset i Casals \\
\hline
\end{tabular}

\footnotetext{
${ }^{97}$ El País, 29 de junio de 1991.

${ }^{98}$ Entrevista con Rafael Arias-Salgado, 09 de marzo de 2015.
} 


\begin{tabular}{|c|c|c|c|}
\hline $\begin{array}{l}\text { Rafael Martínez-Campillo } \\
\text { García }\end{array}$ & \multicolumn{2}{|c|}{$\begin{array}{l}\text { Andrés Díaz Pérez (candidatura de } \\
\text { Teixidó) }\end{array}$} & Adolfo Suárez González \\
\hline & \multicolumn{2}{|c|}{$\begin{array}{l}\text { Julio Bonis Álvarez (candidatura de } \\
\text { Teixidó, CDS-Gran Canaria) }\end{array}$} & $\begin{array}{l}\text { Guadalupe Ruiz-Giménez } \\
\text { Aguilar }\end{array}$ \\
\hline & \multicolumn{2}{|c|}{$\begin{array}{l}\text { Luis Hernández Pérez (candidatura de } \\
\text { Teixidó, CDS-Gran Canaria) }\end{array}$} & $\begin{array}{l}\text { Alejandro Rebollo Álvarez- } \\
\text { Amandi }\end{array}$ \\
\hline & \multicolumn{2}{|c|}{$\begin{array}{l}\text { José Ramón Navarro Nicolau } \\
\text { (candidatura de Teixidó, CDS-Valencia) }\end{array}$} & Carlos Revilla Rodríguez \\
\hline & \multicolumn{2}{|c|}{$\begin{array}{l}\text { Santiago José Castella Surribas } \\
\text { (candidatura de Teixidó, CDS- } \\
\text { Tarragona) }\end{array}$} & Federico Ysart Alcover \\
\hline & \multicolumn{2}{|c|}{$\begin{array}{l}\text { José María Lasierra Hasta (candidatura } \\
\text { de Teixidó, CDS-Zaragoza) }\end{array}$} & Lorenzo Olarte Cullén \\
\hline & \multicolumn{2}{|c|}{$\begin{array}{l}\text { Luis Fuentes Valera (candidatura de } \\
\text { Teixidó, CDS-Murcia) }\end{array}$} & Laura Morso Pérez \\
\hline & \multicolumn{2}{|c|}{$\begin{array}{l}\text { Lluis Badía Chancho (candidatura de } \\
\text { Teixidó, CDS-Tarragona) }\end{array}$} & \\
\hline & \multicolumn{2}{|c|}{$\begin{array}{l}\text { Juan Carmona Carmona (candidatura de } \\
\text { Teixidó) }\end{array}$} & \\
\hline & \multicolumn{2}{|c|}{$\begin{array}{l}\text { José Luis Gómez-Calcerrada Gascón } \\
\text { (candidatura personal, CDS-Madrid) }\end{array}$} & \\
\hline & \multicolumn{2}{|c|}{$\begin{array}{l}\text { Ignacio Morán González (candidatura de } \\
\text { Teixidó, CDS-León) }\end{array}$} & \\
\hline \multicolumn{4}{|c|}{ Vocales del Comité Federal (los diez miembros electos por el IV Congreso) } \\
\hline \multicolumn{2}{|c|}{ Carlos Alonso de Velasco } & \multicolumn{2}{|c|}{ CDS-Madrid } \\
\hline \multicolumn{2}{|c|}{ Jorge Luis Varela González } & \multicolumn{2}{|c|}{ CDS-Lugo } \\
\hline \multicolumn{2}{|c|}{ Fernando González Gálvez } & \multicolumn{2}{|c|}{ CDS-Guadalajara } \\
\hline \multicolumn{2}{|c|}{ Lola Bedate Ruiz Zorrilla } & \multicolumn{2}{|c|}{ CDS-Pontevedra } \\
\hline \multicolumn{2}{|c|}{ Antonio Garrosa Resina } & \multicolumn{2}{|c|}{ CDS-Valladolid } \\
\hline \multicolumn{2}{|c|}{ Juan Mulet Estrany } & \multicolumn{2}{|c|}{ CDS-Baleares } \\
\hline \multicolumn{2}{|c|}{ Manuel Cerón Montes } & \multicolumn{2}{|c|}{ CDS-Málaga } \\
\hline \multicolumn{2}{|c|}{ María Esther Hernández Padilla } & \\
\hline \multicolumn{2}{|c|}{ Jesús González González } & \multicolumn{2}{|c|}{ CDS-La Gomera } \\
\hline
\end{tabular}

Elaboración propia a partir de $R P P$, estatutos (febrero 1990).

La nueva estructura organizativa del partido presentaba dos novedades: la pérdida de competencias de la Presidencia Nacional en favor de la Secretaría General y la aparición de nuevos órganos de dirección y fiscalización -la Comisión Permanente, que se debía reunir al menos semanalmente, y la Asamblea Nacional-. A modo de resumen:

Tabla 101: Los órganos de gobierno del CDS tras el IV Congreso.

\begin{tabular}{|l|l|}
\hline $\begin{array}{l}\text { Presidente } \\
\text { Nacional }\end{array}$ & Electo por los compromisarios en el Congreso: sistema mayoritario. \\
\hline Pierde algunas de sus competencias en favor del Secretario General. \\
\hline $\begin{array}{l}\text { Secretario } \\
\text { General }\end{array}$ & $\begin{array}{l}\text { Electo por los compromisarios en el Congreso, integrado en la lista vencedora al Comité } \\
\text { Ejecutivo: sistema mayoritario. }\end{array}$ \\
\hline $\begin{array}{l}\text { Recibe algunas de las competencias del Presidente Nacional como la dirección del Grupo Parlamentario } \\
\text { o la relación con el resto de partidos. }\end{array}$ \\
\hline $\begin{array}{l}\text { Comité } \\
\text { Ejecutivo }\end{array}$ & $\begin{array}{l}\text { Electos por los compromisarios en el Congreso. Sistema mayoritario en el que se } \\
\text { Nacional }\end{array}$ \\
\hline Conserva las competencias un número determinado de plazas en listas abiertas (hasta 7). Total de 27 \\
\hline Comisión & Integrada por el Presidente, el Secretario General, los miembros natos del Comité \\
\hline
\end{tabular}




\begin{tabular}{|l|l|}
\hline Permanente & $\begin{array}{l}\text { Ejecutivo Nacional y un número variable de entre } 5 \text { o } 10 \text { Secretarios Ejecutivos } \\
\text { designados por el propio Comité a propuesta del Secretario General }{ }^{99} \text {. }\end{array}$ \\
\hline $\begin{array}{l}\text { La Comisión Permanente desarrolla la dirección política ordinaria del Partido. Actúa con criterios de } \\
\text { corresponsabilidad y promueve el más estrecho contacto entre la organización interna del Partido y los } \\
\text { representantes de las Instituciones. La Comisión Permanente es políticamente responsable ante el Comité }\end{array}$ \\
$\begin{array}{l}\text { Ejecutivo Nacional. La atribución de tareas específicas a los miembros de la Comisión Permanente } \\
\text { corresponde al Secretaría General. La Comisión Permanente se reunirá cuantas veces sea preciso y, } \\
\text { como mínimo, una vez por semana. }\end{array}$ \\
\hline $\begin{array}{l}\text { Comité } \\
\text { Federal }\end{array}$ & $\begin{array}{l}\text { Integrado por el Presidente, el Secretario General, el Comité Ejecutivo, los Presidentes } \\
\text { por el Congresón, dos Vicesecretarios de Juventudes y diez vocales elegidos directamente }\end{array}$ \\
\hline Conserva las competencias del III Congreso. \\
\hline $\begin{array}{l}\text { Asamblea } \\
\text { Nacional }\end{array}$ & $\begin{array}{l}\text { El Presidente, el Secretario General, los miembros del Comité Ejecutivo Nacional, los } \\
\text { directamente por el Congreso mediante un sistema electoral proporcional puro, pudiendo } \\
\text { al respecto presentarse listas con un mínimo de veinticinco candidatos y el mismo } \\
\text { número de avales, cargos institucionales (Gobierno, parlamentos, alcaldes de capital de } \\
\text { provincia y diez concejales electos por la Conferencia Municipal Nacional) y diez } \\
\text { miembros del Secretariado de Juventudes. }\end{array}$ \\
\hline $\begin{array}{l}\text { Aumenta las } \\
\text { estrategia política, programas electorales, situación económica y financiera, etc. Se reúne con una } \\
\text { periodicidad de cuatro meses. }\end{array}$ \\
\hline
\end{tabular}

Elaboración propia a partir de los Estatutos del IV Congreso.

Otras novedades eran el reconocimiento de la "posibilidad de la existencia en su seno de corrientes internas de opinión, que permitan el trabajo y relación entre personas que, dentro de las líneas programáticas y estratégicas del Partido, puedan estar más sensibilizadas", el endurecimiento del régimen de incompatibilidades impidiendo la simultaneidad de cargos electos en el seno del partido y la aprobación de una cláusula para evitar el transfuguismo en el Grupo Parlamentario, que conminaba a quienes abandonaran el partido a presentar la dimisión ${ }^{100}$. Asimismo, desaparecía el cargo de portavoz.

Se produjeron nuevas y significativas dimisiones en lugares tan destacados como la Comunidad Valenciana encabezadas por su Presidente Federal, Gerardo Muñoz y el Presidente Provincial de Alicante, Rafael Martínez-Campillo -acompañado de toda la Ejecutiva-, en Cataluña, con Xavier Latorre y Peré Lladó al frente, quienes habían sido los máximos responsables del CDS en Barcelona y Gerona o Aragón, protagonizada por el histórico líder suarista, José Luis Merino. En esta última comunidad, también Juan Montserrat y Manuel Plaza, diputados autonómicos entre 1987 y 1991, abandonaban el partido. En Canarias, Lorenzo Olarte anunciaba su intención de crear una nueva formación política canaria junto a los cargos dirigentes del partido en Las Palmas. En

\footnotetext{
${ }^{99}$ Estatutos IV Congreso (septiembre 1991), RPP, Registro de entrada, no 614, 25 de noviembre de 1991.

${ }^{100}$ GARCÍA-ATANCE, María Victoria: "Congreso Extraordinario..."
} 
Castilla y León, Daniel de Fernando y el resto de la ejecutiva manifestaban su disposición de no intentar revalidar su cargos. Líderes como Raúl Morodo, Rosa Posada o Alejandro Rebollo dudaban públicamente de la capacidad de supervivencia del partido. En diciembre de 1991, dimitía José Ramón Lasuén como presidente de la Federación madrileña. Modesto Fraile abandonaba en octubre en partido y políticos como Ramón Tamames, Antonio Jiménez Blanco o Miguel Martínez Cuadrado que se habían vinculado al grupo mediante compromisos personales con Suárez y Rodríguez Sahagún se desligaban definitivamente del proyecto en los meses siguientes, tras intentarse sin éxito la creación de un consejo asesor de intelectuales que sirviera de apoyo a la dirección y les diera algún protagonismo en la nueva etapa política ${ }^{101}$.

El Congreso fue interpretado como el último portazo a Suárez del partido que él fundara en 1982. Luis Carandell titulaba su análisis sobre el IV Congreso, "Hartos de Adolfo", en relación a la votación de la militancia ${ }^{102}$; Anabel Díez y J. J. González Ibáñez en El País hablaban de un "parricidio simbólico"103, en lo que era un ruptura de magnitudes edípicas con el legado de Adolfo Suárez -al rechazar la lista de Raúl Morodo-. Pilar Cernuda expresaba "Adolfo Suárez se llevó un gran revolcón" ${ }^{104}$. Y en Época, Miguel Platón hablaba de "bofetón" a Suárez ${ }^{105}$. El recuerdo de UCD y la incapacidad de Adolfo Suárez para el desempeñar el liderazgo político cotidiano fueron los tópicos recurrentes de aquellas páginas.

El editorial de El País resaltaba las contradicciones internas, dudas y dificultades que iba a hallar el nuevo proyecto político para lograr su consolidación: sin su referente y líder, sin identidad, sin poder institucional, etc ${ }^{106}$. Todo ello, en un congreso desarrollado a tumba abierta, excesivo en ocasiones, y siempre imprevisible. Días después, publicaba su homenaje a Adolfo Suárez. Reconocía la singular trayectoria de un político común, pragmático y en ocasiones contradictorio que había llevado a cabo el proceso de Transición ${ }^{107}$. Un hombre que supo llevar las riendas del mayor cambio político de la Historia de España pero incapaz de desenvolverse en la política

\footnotetext{
${ }^{101}$ El Mundo, 11 de noviembre de 1991.

${ }^{102}$ El Sol, 01 de octubre de 1991.

103 El País, 30 de septiembre de 1991. Una metáfora habitual en aquellas fechas, CASADO, Antonio: "Parricidio político en el Congreso del CDS", Tiempo, 03 de octubre de 1991.

${ }^{104}$ Diario 16, 30 de septiembre de 1991.

105 Época, 07 de octubre de 1991.

106 Editorial: "El legado de Suárez", 30 de septiembre de 1991. En su portada titulaba: "Calvo Ortega presidirá el CDS contra la voluntad de Suárez", El País, 30 de septiembre de 1991.

${ }^{107}$ Editorial: "Elogio del derrotado", 04 de octubre de 1991.
} 
cotidiana $^{108}$. El Independiente en un duro editorial identificaba dos errores fundamentales en el proyecto centrista. Por un lado, intentar revivir el papel jugado por la UCD durante la Transición y respecto a Suárez, "confundir la político con una psicoterapia para tratarse los propios complejos"109. Sólo $A B C$ otorgaba alguna credibilidad al futuro político del partido tras la victoria de los sectores más conservadores del partido de la mano de Rafael Calvo Ortega -“aunque solo sea por la salud democrática interna que ha reflejado [...] hay que abrir un margen de confianza"-. El editorial de Diario 16 cuestionaba la actitud de Suárez, que inmerso en un "pertinaz silencio" y en el intento de controlar "por teléfono" el Congreso había contribuido a un final poco honorable. ¿Era este el final real de la vida política de Suárez? ¿O sucedería igual que en 1981? ${ }^{110}$ Para Pilar Cernuda, también Suárez había sido el único "que no ha[bía] estado a la altura de las circunstancias" en esos días ${ }^{111}$. Y desde el punto de vista de otro destacado periodista, José Luis Gutiérrez, el episodio protagonizado por Suárez había sido, intentando controlar el Congreso "sin atreverse a dar la cara", "uno de los sucesos más bochornosos que se recuerdan". Una línea de interpretación defendida grosso modo por García-Atance:

El hecho de que éste dimitiera en su peor momento, y que no asistiera al Congreso, ni se hubiera pronunciado políticamente en los últimos meses, es muy chocante y difícilmente justificable y más aún que al mismo tiempo trate de orientar el voto de los Congresistas en una dirección ${ }^{112}$.

Después del IV Congreso, llegó un mes de octubre teñido de amargas despedidas. En París, fallecía el ex alcalde de Madrid, Agustín Rodríguez Sahagún, ante el reconocimiento y el sentido homenaje de compañeros de partido, políticos de todo el espectro ideológico y periodistas ${ }^{113}$. Políticamente, Rodríguez Sahagún había sido, de

\footnotetext{
${ }^{108}$ ALONSO DE LOS RÍOS, César: "Suárez en la Historia", El Sol, 27 de septiembre de 1991, MAST. En esta línea, GONZÁLEZ FERRARI, J.: "Habla, mudito", Diario 16, 27 de septiembre de 1991.

${ }^{109}$ Editorial: "El psicodrama del centro", El Independiente, 30 de septiembre de 1991. En términos parecidos se manifestaba Josep Meliá en el mismo medio: "Suárez o la historia de un resentimiento", $E l$ Independiente, 28 de septiembre de 1991.

${ }^{110}$ Editorial: “¿Un CDS sin Suárez?”, Diario 16, 01 de octubre de 1991, MAST.

${ }^{111}$ CERNUDA, Pilar: "La hora del relevo", Diario 16, 01 de octubre de 1991, MAST.

112 GARCÍA-ATANCE, María Victoria: "Congreso Extraordinario...", p. 273.

113 Su fotografía ocupaba la portada de los principales medios nacionales (El País, ABC y $L a$ Vanguardia): "Inesperada muerte de Rodríguez Sahagún", El País, 14 de octubre de 1991 y "Ayer falleció en París el ex alcalde de Madrid, Agustín Rodríguez Sahagún", ABC, 14 de octubre de 1991. En este último medio, acompañado de un intenso y emotivo editorial: "Agustín Rodríguez Sahagún", $A B C$, 14 de octubre de 1991. Véase también el editorial: "Se ha ido un hombre honrado", Diario 16, 14 de octubre de 1991. Editorial acompañado de un sentido homenaje por Gallego \& Rey en su viñeta diaria: "A D. Agustín con nuestro recuerdo"; SARASQUETA, Antxón: "El valor de Agustín", El Norte de Castilla, 15 de octubre de 1991; GARROSA, Antonio: "Nos veremos, Agustín”, El Norte de Castilla, 15 de octubre de 1991, etc.
} 
forma indiscutida, el colaborador más incansable y leal de los que acompañaron a Adolfo Suárez en toda su trayectoria y él fue, gracias a una vasta labor parlamentaria, mediática y financiera, quien mantuvo vivo al partido durante la "travesía del desierto".

Apenas dos semanas después, Adolfo Suárez abandonaba su escaño en el Congreso de los Diputados, pareciendo confirmar en su carta dirigida al Presidente del Congreso, Félix Pons, que no volvería a presentarse como candidato en 1993. Su definitivo abandono de la política recibió una atención secundaria, pues en medios como El País se dio por consumado con su derrota en el IV Congreso. $A B C$ mostró su gratitud al ex Presidente en su edición dominical, de la mano de un editorial en el que reflexionaba en términos elogiosos sobre su contribución a la Historia de España, para ofrecer como contrapunto una opinión entonces generalizada: "son muchos los que creen que Adolfo Suárez debió poner término a su actividad política al dimitir de la Presidencia..." Una trayectoria que arrojaba un amargo final, víctima de un más que "cicatero elogio del mérito"114. El historiador Javier Tusell iba más allá y sin dejar de exigir gratitud a la sociedad española para quien había sido quizá el mejor político español de todos los tiempos apuntaba: "Suárez no ha dejado de equivocarse desde 1979""115. Diario 16, que dedicó dos páginas a la inclusión de artículos sobre el personaje, también exigía un "juicio sereno" para el final político de Suárez quien "no debe irse de la escena cosido por las cicatrices de la pequeña política" ${ }^{\# 16}$. Los reveses electorales, la “insubordinación” del IV Congreso y la inexistencia de un espacio político propio aspecto en el que incidía Ramón Cotarelo ${ }^{117}$ - habían conducido al abulense a tomar una decisión que ahora sí, parecía irreversible.

Su vuelta a la política se consideraba, una vez más, su principal “error: el afán de resurrección", "Suárez entonces perdiendo el norte y 'ahora voy y ahora vengo' y un partido, el suyo, hecho de retazos" ${ }^{\text {118. }}$. Josep Meliá lamentaba el egoísmo político de Suárez, puesto de manifiesto en el $\operatorname{CDS}^{119}$. Santiago Carrillo -al igual que Javier

\footnotetext{
114 Editorial: "La retirada de Suárez", $A B C, 27$ de octubre de 1991. En su sección, actualidad gráfica: "Adolfo Suárez: la dignidad de la retirada de un hombre de Estado", $A B C, 27$ de octubre de 1991.

115 TUSELL, Javier: "Un cargo para Adolfo", Diario 16, 09 de octubre de 1991. Una visión crítica del papel de Suárez en el IV Congreso en ÍD.: "Sinfonía de irresponsabilidad", Diario 16, 06 de octubre de 1991.

${ }^{116}$ Editorial: "El adiós de Adolfo Suárez", Diario 16, 25 de octubre de 1991.

${ }^{117}$ COTARELO, Ramón: "Destino manifiesto", Diario 16, 09 de octubre de 1991.

118 APARICIO, Juan Pedro: “Aventura y naufragio" y ORTIZ, Lourdes: "Kao en la mandíbula" en Diario 16, 09 de octubre de 1991.

${ }^{119}$ MELIÁ, Josep: “El dolor de Suárez”, Diario 16, 09 de octubre de 1991.
} 
Tusell- reclamaba un papel protagonista para Suárez en cuestiones de estado, y desdeñando la crítica a su política de pactos o su gestión partidista se limitaba a comentar: "a mi entender Suárez lleva en su interior una contradicción que puede estar en el origen de sus aparentes vacilaciones: es, en el fondo, un hombre de izquierda al que la historia colocó en la derecha. En ésta no se sintió a gusto y en aquélla no tenía espacio" $" 120$. Finalmente, otros como Ramón Tamames veían una excelente ocasión de cara a la aparición de unas memorias que sirvieran para clarificar algunos de los aspectos más trascendentales de la Historia reciente de España ${ }^{121}$.

El "Plan de Acción de Política" del CDS señalaba que el nuevo papel de Adolfo Suárez, todavía militante centrista, debía ser aprovechar su proyección nacional -a través de la Fundación Ciencia, Democracia y Sociedad, a modo de foro de debate y de creación de ideas-e internacional -como parte de la troika dirigente de la Internacional Liberal-. Sin embargo, desde entonces Adolfo Suárez permaneció alejado definitivamente del CDS y aunque siempre mantuvo su interés y conexiones con el mundo de la política, centró su tiempo en su familia y en el despacho de abogados.

${ }^{120}$ CARRILLO, Santiago: "Hombre de Estado", Diario 16, 09 de octubre de 1991.

121 TAMAMES, Ramón: "Índice para unas memorias", Diario 16, 09 de octubre de 1991. 


\title{
Capítulo 11:
}

\section{La Transición, Adolfo Suárez y el CDS}

\begin{abstract}
"Hay una parte de Adolfo Suárez que se ha transformado en intocable, en función de que se ha convertido en un patrimonio-común [...] talento, astucia, y audacia, hizo la transición política de modo irreversible [...] Hay otra parte de Adolfo Suárez perfectamente sujeta a la crítica y la discrepancia $[\ldots]$ ejerce como político normal en un mercado de votos normal [...] la figura y su tarea pasada ya no están sujetos a esta discusión electoral" .
\end{abstract}

Entre 1982 y 1991, Adolfo Suárez era algo más que Presidente del CDS. Ante todo era el ex Presidente de Gobierno de España durante la Transición. Más allá del estatuto oficial de ex presidente, reconocido en 1983, este desempeño condicionaba decisivamente el nuevo despertar de su carrera política. El recuerdo, o deberíamos decir, los múltiples recuerdos, del "Suárez de la Transición” implicaban a su vez múltiples aproximaciones al mismo susceptibles de diversos usos y tratamientos.

En el primer epígrafe abordaremos el tratamiento mediático de la presidencia de Adolfo Suárez (1976-1981), durante la etapa en la que ejerció de líder del Centro Democrático y Social. Para ello, analizaremos dos de los principales periódicos de la época, -El País y ABC-. El objetivo es desvelar los usos retóricos y argumentativos desplegados en torno a su labor de gobierno y susceptibles de ser utilizados política y electoralmente. Y es que el proyecto político del CDS, permaneció sustentado -y en buena medida, sepultado- por el peso histórico de su período presidencial durante la Transición. Primero, sucedió así a lo largo de toda la década de los 80' y posteriormente se manifestó en los estudios históricos, en la investigación periodística y en las memorias de los protagonistas.

En un segundo apartado intentaremos desentrañar y sintetizar el discurso de su propio partido, el CDS, y de Adolfo Suárez sobre su gestión presidencial. Como matiz diferencial, prestaremos una especial atención a los posicionamientos de los suaristas sobre los hechos más significativos de la Historia Contemporánea de España (II

\footnotetext{
${ }^{1}$ APOSTÚA, Luis: "Su biografia”, Ya, 11 de junio de 1986
} 
República, Dictadura y Transición). El principal objetivo es bucear en el papel que jugó el CDS en la construcción de las incipientes políticas de la memoria. En un segundo momento, abordaremos la capacidad de los suaristas para hacer efectivo el capital político heredado de la Transición, un aspecto transversal en el presente trabajo y que consideramos necesario sintetizar en sus rasgos principales.

A continuación, seguiremos la pista de Adolfo Suárez en Iberoamérica y Europa del Este, dando a conocer internacionalmente el proceso de Transición y contribuyendo a la extensión de este paradigma interpretativo en los procesos de cambio político ${ }^{2}$. Nuevamente, su condición de líder de un pequeño partido de la oposición, el Centro Democrático y Social, influyó en el desarrollo de estos contactos y condicionó la capacidad de transmisión de su discurso.

\section{1. Visión mediática del Suárez de la Transición.}

A lo largo de las siguientes páginas nos centraremos en las referencias al papel concreto de Adolfo Suárez en la Transición existentes en El País, y por otra parte, en $A B C$, a lo largo de la década de los 80'; correspondiéndose grosso modo, con la óptica de una sensibilidad ideológica de centro-izquierda -cercana al Gobierno-, y con la oposición conservadora, respectivamente ${ }^{3}$. En este recorrido prestaremos especial atención, en cada uno de estos medios, a cuatro aspectos que nos parecen singularmente reveladores: la llegada del PSOE al poder, cuestiones de política exterior, las consecuencias del éxito electoral del CDS a raíz de las elecciones de 1986 y por último, el final político de Adolfo Suárez en 1991. Intercalaremos en nuestro recorrido, algunos testimonios de sus colaboradores que nos permitirán comprender mejor la relación de Adolfo Suárez con los medios y la "opinión pública” en su conjunto.

Para comenzar, consideramos necesario sintetizar la interpretación que ambos periódicos llevaron a cabo durante la década de la dimisión de Suárez y el final de

\footnotetext{
${ }^{2}$ Labor en el que no ha sido un caso aislado, aunque sí uno de los pioneros: "los políticos españoles de la época suelen presentarse en el extranjero con el orgullo de la obra bien hecha y numerosos políticos de otros países en transición [...] se han referido con frecuencia a la experiencia española y han buscado inspiración en ella" en COLOMER, Josep M.: La transición a la democracia: el modelo español, Barcelona, Anagrama, 1998, p. 9.

${ }^{3}$ Sobre posicionamiento político y discurso periodístico, véase, SÁNCHEZ GARCÍA, Francisco José: Pragmática de los titulares de políticos, Madrid, Visor, 2010, pp. 69-89; PINILLA, Alfonso: La transición... pp. 95-103.
} 
UCD. El editorial, cronistas y columnistas de El País subrayaban la responsabilidad de los líderes centristas en su dimisión auspiciados por la "derecha" nacional -"la voladura del centro"- ${ }^{4}$; mientras $A B C$ ponía el acento en la responsabilidad de Suárez en el fin del partido, quien a su vez había sido víctima de las intrigas del $\mathrm{PSOE}^{5}$. Si los "suaristas" hablaban de la derechización de la UCD y las presiones externas ${ }^{6}$, antiguos líderes de UCD en las filas de otros partidos contraatacaban con el supuesto "giro" a la izquierda de Suárez ${ }^{7}$. En su número 25.000, $A B C$ hacía un recorrido histórico en el que subrayaba el intento de Suárez por "arrebatar banderas al Socialismo" y en consecuencia "abrirle el sendero y alfombrárselo de flores. Muchos piensan que el centrismo era una derecha que no se atrevía a decir su nombre" ${ }^{\text {}}$. El relato sobre la dimisión de Suárez resulta especialmente interesante para comprender la propia evolución política del país durante los gobiernos socialistas, especialmente, la evolución del espacio de centro-derecha y su final convergencia en torno al Partido Popular.

Siguiendo a Gregorio Morán, la "versión oficial” de que Suárez dimitió, fundamentalmente, como consecuencia de la "táctica de acoso y derribo a la que le sometió [especialmente] el PSOE” se consolidó gracias a las declaraciones del propio Suárez para el suplemento de El Mundo sobre la Transición en 1995, año en el que tenían lugar dos procesos paralelos: la recuperación de la figura de Suárez y la fuerte campaña mediática contra los gobiernos socialistas ${ }^{9}$. Sin embargo, a lo largo de la década de los 80', las declaraciones de Suárez sobre su dimisión eran sustancialmente distintas y achacaba sobre todo su decisión a la pérdida de apoyo de su propio partido

\footnotetext{
${ }^{4}$ Editorial: "Las espadas en alto", El País, 02 de agosto de 1982; BASSETS, Lluís: "Como coexistir sin pactar", El País, 20 de febrero de 1988; PRADES, Joaquina: "La autodestrucción de UCD un proceso que podría haber ideado Kafka", El País, 30 de octubre de 1982; UMBRAL, Francisco: "La neoderecha", El País, 17 de enero de 1983; VICENT, Manuel: "El rayo de Óscar Alzaga", El País, 05 de noviembre de 1983.

${ }^{5}$ LÓPEZ SANCHO, Lorenzo: "Historia Medieval", $A B C, 21$ de febrero de 1983; "Centrífugas, ¿huyeron de la quema o provocaron el incendio?", $A B C, 31$ de diciembre de 1982; CONTRERAS, Lorenzo: "La teoría del saco", $A B C, 05$ de julio de 1983.

${ }^{6}$ Desde el Manifiesto Político a YSART, Federico: "Voluntad política y liderazgo", El País, 12 de septiembre de 1982. Sobre el papel de la "mayoría natural" y los "neoconservadores", DE SENILLOSA, Antonio: "Un plan más ambicioso", El País, 19 de diciembre de 1982.

${ }^{7}$ Durante la I Convención del PDP, Alzaga señalaba: "puestos a gobernar, tras las elecciones generales de 1979, pronto se vio claro que el programa electoral no era compartido por muchos dirigentes y parlamentarios centristas. En consecuencia, buena parte del programa ha permanecido inédito [...] ciertos dirigentes [en relación a la OTAN o el Estatuto de Centros Docentes] han optado por el hipereeclecticismo [...] por la "improvisación permanente", PDP: Una política joven y europea ..., p. 14. Véase, el testimonio de J. Aizpún (UPN) en una entrevista con Carmen García Romero, $A B C$, 28 de julio de 1990.

8 "1982", ABC, 12 de noviembre de1985.

${ }^{9}$ Véase, BERMEJO, Fernando y LORENZO, Javier (eds.): Historia de la Democracia. La Aventura de la libertad (1975-1995), Madrid, El Mundo, 1995, p. 225 y ss.
} 
en el Congreso. Sirva de ejemplo el extracto de una entrevista realizada por J. L. Gutiérrez en septiembre de 1982:

La mayor importancia en esa operación ["de acoso y derribo"] la tuvo el Partido Socialista. Pero para mí, lo más decisivo no fue que los socialistas participasen en la operación. Quien decidió el resultado fue mi propio partido. El "acoso y derribo" encontró fervientes partidarios en UCD y muy principalmente en el seno del grupo parlamentario $^{10}$.

O en otra ocasión:

El pueblo español había constituido la democracia y el Estado de las Autonomías para "vivirlo" no para una mera proclamación formal. Es evidente que los sectores conservadores del centrismo encontraron en algunas fuerzas económicas y tradicionales del país un apoyo decisivo y, desde él, colaboraron, consciente o inconscientemente, en la operación de "acoso y derribo" que, contra el Presidente del Gobierno protagonizó el $\mathrm{PSOE}^{11}$.

Si prevaleció una idea más o menos constante a lo largo de la década, tanto en la izquierda como la derecha fue la de valorar la fundación del nuevo partido como un descabellado intento de Suárez por vengar una "afrenta", como si la creación del CDS fuera un episodio de "resentimiento" $"$. La actitud de Suárez zigzagueaba entre la habilidad y el oportunismo -lo que caracterizó Emilio Romero como el "trashumante" ${ }^{-}$, y si para unos -los sectores conservadores-, había desembocado en una "derecha" avergonzada o acomplejada, para otros se había teñido de falso progresismo o populismo. A finales de 1985 y ante la escalada de descalificaciones de que eran víctimas tanto el CDS como Adolfo Suárez, apenas un solitario artículo de Rodríguez Sahagún se atrevió a destacar la importancia histórica de su líder. El título no podía ser más elocuente: "Destruir a Suárez""14.

A partir del arrollador triunfo socialista en 1982, -encarnado en la figura de Felipe González-, y el magro resultado electoral del CDS que con dos diputados consiguió un papel meramente testimonial en la vida política española, en $A B C$ fue habitual recordar la presidencia de Adolfo Suárez desde un punto de vista comparativo. Suárez era el modelo desde el que subrayar los aciertos y, especialmente, los "errores" de los

\footnotetext{
${ }^{10}$ Diario 16, 26 de septiembre de 1982

${ }^{11}$ SUÁREZ GONZÁLEZ, Adolfo: Horizonte político de España, CDS, 1986, p. 22. Rodríguez Sahagún, a propósito de la dimisión de Suárez escribió: "la hartura moral que experimentó con todos estos comportamientos [UCD-PSOE], es lo que llevó a Suarez a su dimisión", RODRÍGUEZ SAHAGUN, Agustín: "Pretextos de un intento, razones de un fracaso", El País, 23 de febrero de 1991.

12 "Está en su triste derecho" SOLANA, Luis: "Suárez, el guapo voto útil", Diario 16, 20 de junio de 1986 o CAMPMANY, Jaime: “¡Fraga sí; Fraga no!”, $A B C, 03$ de diciembre de 1986.

13 "Adolfo no reparaba en las creencias [disputas: azules/tecnócratas] sólo en los caminos". ROMERO, Emilio: Retratos de época, Barcelona, Plaza \& Janés, 1985, p. 154.

${ }^{14}$ RODRÍGUEZ SAHAGÚN, Agustín: "Destruir a Suárez", El País, 07 de noviembre de 1985.
} 
ejecutivos de Felipe González. De forma muchas veces humorística e irónica, se preludiaba el declinar felipista en función del de Suárez, en lo que no era sino un recurso argumentativo y retórico de "falacia de asociación". Al hilo de este discurso, los temas que aparecían con más asiduidad se correspondían con los más polémicos de los gobiernos Suárez, en especial, su actitud presidencial (síndrome de la Moncloa, opacidad, ambición, "los cuñados") $)^{15}$. De entre los columnistas de $A B C$, destacaba en esta labor Jaime Campmany quien una y otra vez recurría a los clichés más negativos construidos sobre el político abulense ${ }^{16}$. Cualquier motivo servía de pretexto para la comparación:

En sus años de Gobierno, el signo característico de don Felipe González es el zig-zag: contra los empresarios y a favor del capitalismo; por la defensa de los débiles pero con recorte de las pensiones; contra la OTAN y a favor de la OTAN [...] Este tejer y destejer - que también caracterizó la etapa final de Adolfo Suárez- desemboca en la inanidad y en la insignificancia... ${ }^{17}$

Un aspecto que suscitó un sinfín de comparaciones fue el de la política internacional. Pedro Rodríguez recordaba ocasionalmente, todavía con sarcasmo, el llamado síndrome-cuello-de-botella-estrecho-de-Ormuz que caracterizó buena parte de la política exterior suarista ${ }^{18}$. En otro tono, M. Blanco Tobío, desde la sección de internacional, se encargó de subrayar las coincidencias entre González y Suárez; ambos anteponían su proyección internacional a las gestiones de la política interna ${ }^{19}$. El llamado "tercermundismo" suarista estaba tan presente en la opinión pública que la

\footnotetext{
15 En la prensa de la época, RODRÍGUEZ, Pedro: "El síndrome de la Moncloa", $A B C, 19$ de junio de 1983; URBANO, Pilar: "La soledad", $A B C, 19$ de julio de 1984. "Llegó un momento que entre Lito y Fernando el Caótico tenían a Adolfo Suárez como enjaulado" en CAMPMANY, Jaime: "Los cuñados", $A B C, 12$ de junio de 1986; USSÍA, Alfonso: "El cuñadísimo", $A B C, 14$ de septiembre de 1989; BURGOS, Antonio: "Cuñados”, $A B C, 10$ de febrero de 1989; FERNÁNDEZ, Celestino: "¿Ortodoxia socialista?", $A B C$ Sevilla, 09 de febrero de 1987; CRESPO, Pedro: "Los silencios del Presidente", $A B C$, 06 de agosto de1984; CRIS, Miguel: "Quién Será", ABC, 08 de enero de 1987; CONTRERAS, Lorenzo: "Opacidades", $A B C, 05$ de noviembre de 1987. etc. Véase, CERNUDA, Pilar: El síndrome de la Moncloa, Madrid, Espasa, 2011.

${ }^{16}$ Comparaciones acerca de la ambición entre Suárez y el PSOE en CAMPMANY, Jaime: "La escoba detrás de la puerta", $A B C, 09$ de marzo de 1985; ÍD.: "La salud del socialismo", $A B C, 23$ de noviembre de 1983; ÍD.: "La herencia", $A B C, 19$ de septiembre de 1984; ÍD.: "Don Felipe Adolfo", ÍD.: $A B C, 05$ de marzo de 1985; ÍD.: "Queimadas", $A B C, 14$ de noviembre de 1985; ÍD.: "La cama redonda", $A B C, 02$ de noviembre de 1984, etc.

${ }^{17}$ Editorial: "Felipe González: la política del zigzag", $A B C$, 02 de junio de 1985. Otro punto habitual de comparación, particularmente en $A B C$, era el recuerdo de la oposición realizada por los socialistas particularmente, los usos de Alfonso Guerra-, desde 1979. Más que un desagravio hacia Adolfo Suárez, servía para amortiguar la estrategia de oposición aliancista o poner de manifiesto las contradicciones del PSOE.

${ }^{18}$ RODRÍGUEZ, Pedro: "La Colgadura”, $A B C$, 05 de junio de 1984; "Suárez empezó a agonizar cuando abrazo a Arafat" en ÍD.: "La carpeta de Ciriaco", $A B C$, 18 de marzo 1984. Un editorial de $A B C$ en 1991, a propósito de las gestiones del ejecutivo en la Guerra del Golfo, apostillaba que esa fue la principal causa de la caída de Suárez, Editorial: "Síndrome de Ormuz", ABC, 03 de marzo de 1991.

${ }^{19}$ Por ejemplo, BLANCO TOBÍO, Manuel: "Debate en la oscuridad", $A B C, 14$ de junio de 1983.
} 
primera portada dedicada a Adolfo Suárez desde las elecciones de 1982 por $A B C$ incluyó la fotografía de su famoso abrazo con Arafat en $1979^{20}$. A propósito del interés del Gobierno socialista en el seguimiento del conflicto de Oriente Próximo en 1991:

Adolfo Suárez perdió el liderazgo, no tanto por su mala conciencia de "derechas" o por gestos, más o menos estrambóticos, como el abrazo a Yasser Arafat, sino por creer que su misión como gobernante en España era solucionar el problema del Estrecho de Ormuz. El sentido de la incapacidad para resolver lo propio... ${ }^{21}$

Otra faceta del Gobierno de Suárez de ingrato recuerdo en las páginas del rotativo monárquico fue la gestión de TVE por parte del futuro miembro del CDS, Fernando Castedo o su incapacidad para atajar la situación en el País Vasco. A propósito de la posibilidad de que el terrorista de ETA, Juan Carlos Yoldi, pudiera acudir al Parlamento Vasco en 1987, su editorial intentando exculpar de responsabilidad a José Barrionuevo se explayaba en su análisis del pasado del siguiente modo:

La falta de coraje de los posfranquistas, el apresuramiento ovejil por ceder en casi todo, la adulación reiterada del adversario y la política de parches revelaba el verdadero fondo de la cuestión: después de una larga dictadura, España padecía la falta de convicciones, la miseria ideológica, el oportunismo de muchos de sus gobernantes de la Transición ${ }^{22}$.

A raíz del sorprendente éxito electoral del CDS en 1986, que logró 19 diputados, así como el estancamiento de AP, el discurso de $A B C$, en líneas generales, se centró en identificar al CDS como el principal obstáculo existente en el proceso de estructuración de una alternativa de centro-derecha ${ }^{23}$. Todo ello era interpretado como una prueba más de posibilismo y personalismo político de Suárez que escondía, a su vez, un profundo vacío intelectual e ideológico, aspecto también recordado a izquierda y a derecha: "Don Adolfo Suárez no escribió ningún libro para explicar su idea de la democracia, y albergo dudas de que haya leído alguno acerca del mismo asunto" 24 .

Si los pactos de Madrid entre PP-CDS, en la primavera de 1989, vinieron a materializar para $A B C$ una esperanza postergada desde años atrás y abrieron la puerta al reconocimiento explícito del papel jugado por Suárez en la Transición, el repentino giro hacia el PSOE promovido por Suárez en el III Congreso del CDS en Torremolinos,

\footnotetext{
${ }^{20}$ A propósito de la reunión de Felipe González con el presidente del Congreso Judío Mundial, $A B C, 18$ de noviembre de 1983.

${ }^{21}$ Editorial: "Síndrome de Ormuz", $A B C, 03$ de marzo de 1991.

${ }^{22}$ Editorial: "Adónde hemos llegado", $A B C, 27$ de febrero de 1987.

${ }^{23}$ Para Manuel Fraga, "el gran culpable de que no fructificase la llamada mayoría natural fue Adolfo Suárez”, JÁUREGUI, Fernando: La derecha después de Fraga, Madrid, El País, 1987, p. 28.

${ }^{24}$ CAMPMANY, Jaime: "Verstrynge", $A B C, 13$ de octubre de 1988; "Virgínea biblioteca ducal" en ÍD.: "Poemas de escaño", $A B C, 21$ de diciembre 1987. "Luego resultó que no había leído ni la Constitución", ÍD.: "Cambiar de imagen", $A B C$, 08 de abril de 1985; OVIDIO: "Humanistas", $A B C, 01$ de abril de 1987; AYALA, Javier: "El Parlamento Económico", $A B C, 24$ de noviembre de 1983
} 
reintrodujo un tono crítico, sin embargo atemperado por una sensación cada vez más generalizada: la consciente necesidad de valorar adecuadamente los logros políticos de Suárez como Presidente, deslindándolo de su actividad posterior.

Desde 1982, en El País se trazó una línea en una trayectoria contraria, menos intensa, y en la que, en todo caso, se intentaron acentuar las diferencias entre Felipe González y Adolfo Suárez. No había ninguna necesidad de hablar de Adolfo Suárez ni de presentar algún tipo de paralelismo, máxime cuando desde el PSOE se preconizaba la idea de "cambio" 25 . En caso de existir alguna referencia, la llegada a la presidencia de Felipe González debía construirse desde su inicio de forma antitética a lo que había supuesto la última legislatura suarista. Fernando Jáuregui señalaba a comienzos de diciembre de 1982: 'Los 'hombres del presidente' no quieren ser 'fontaneros' de la Moncloa" ${ }^{26}$. En cualquier caso y de un modo más genérico, las comparaciones entre el período de Gobierno de UCD y el del PSOE eran claramente desfavorables hacia los primeros, hasta el punto de existir, como señaló Calvo-Sotelo la "costumbre de agraviar a UCD, 27 .

A pesar de esta tendencia, el interés por Adolfo Suárez y lo que había supuesto en la Historia de España se reactivaba, siempre de forma puntual, precisamente en aquellos momentos en los que "el Duque" llevaba a cabo vistosas actuaciones, -en el ámbito internacional-, en defensa de la democracia e iba consiguiendo una imagen progresista próxima a los postulados del centro-izquierda. Después de un primer escepticismo, el rechazo a integrarse en la "derecha disfrazada" de Miquel Roca y su protagonismo político en Hispanoamérica apuntalaron las bases de ulteriores reflexiones sobre el papel de Suárez en la Transición que provocó la admiración de algunos intelectuales de izquierdas y para quienes la caída política de Suárez había sido ejecutada desde su derecha. El episodio de su expulsión de Uruguay por la dictadura militar en el verano de 1984 marcó el cénit de este proceso. M. Vázquez Montalbán escribía:

La expulsión del Uruguay de Adolfo Suárez replantea el caso de este singular político [...] ¿O acaso democratizó España porque se lo pidió el Rey y de igual manera habría cumplido la orden de declarar la guerra a Malta o prohibir los Sanfermines? [...] La

\footnotetext{
${ }^{25}$ Uno de los primeros intentos sistemáticos de interpretar la Transición desde la izquierda se llevó a cabo en la revista Sistema, en un monográfico sobre la Transición, Sistema, 68 (1985), en el que Adolfo Suárez tiene reservado un muy discreto protagonismo.

${ }^{26}$ JÁUREGUI, Fernando: "Los hombres del presidente no quieren ser fontaneros", El País, 06 de diciembre de 1982.

${ }^{27}$ En una carta al director: "La legislatura más larga", CALVO-SOTELO, Leopoldo, El País, 24 de abril de 1986.
} 
primavera ha venido yo no sé cómo ha sido [...] sigue siendo un misterio el proceso psicológico de Adolfo Suárez ${ }^{28}$.

J. J. Armas Marcelo recuerda una cena en el verano de 1984 en la que estuvo presente Suárez junto a algunos de los intelectuales hispanos más prestigiosos del momento como Juan Benet, Jorge Edwards, José Hierro, Daniel Sueiro o Blanca Andreu en un episodio que ha sido glosado por algunos de los biógrafos del abulense, como Gregorio Morán. Siguiendo a Armas Marcelo: "se trataba de acercar a Suárez a lo imposible, a ciertos ámbitos más o menos culturales e intelectuales de los que había estado completamente al margen durante los años de su controvertido mandato presidencial" 29 . En el curso de aquella charla, en el que el interés de los asistentes se centró en temas como el de las autonomías, Juan Benet espetó a Adolfo Suárez: “Adolfo me da la impresión de que no sólo has solventado problemas de la democracia española, sino que estás llamado a provocarle otros problemas futuros a esa misma democracia"30.

Sin embargo, a partir de 1986, la actitud de columnistas y editorialistas de El País respecto al CDS se endureció. Los resultados electorales de los centristas les convirtieron en una amenaza electoral capaz de atraerse numerosos votos desencantados con el "cambio" socialista, por lo que incidió en minimizar el protagonismo histórico de Suárez. Para la izquierda el pedigrí democrático de Suárez era fruto de una "revelación”, del azar o del siempre presente "posibilismo político" que generaba la perpetuación de una forma de hacer política heredera del franquismo ${ }^{31}$. A fin de cuentas, Suárez había tenido ya una oportunidad para hacer lo que ahora prometía desde su nueva alternativa política:

En su haber Suárez cuenta con que fue quien desmontó el tinglado de la dictadura. En su debe, su incapacidad para mantener en orden a su propio partido [...] Sus aseveraciones de que él gobernaba mejor que los de ahora cabe ponerlas en entredicho si uno mira el

\footnotetext{
${ }^{28}$ VÁZQUEZ MONTALBÁN, Manuel: "El Duque", El País, 30 de agosto de 1984; ÍD.: “Otra carta”, El país, 28 de julio de 1986. En esta línea, editorial: "Ex presidente non grato", El País, 22 de agosto de 1984; UMBRAL, Francisco: "La elipse”, El País, 09 de septiembre de 1984; ÍD.: "Suárez", El País, 26 de noviembre de 1983; ÍD.: "Rubempré" 09 de diciembre de 1983, etc. Véase también, RODRÍGUEZ, Pedro: "El oso y el duque", $A B C, 20$ de noviembre de 1983; BENET, Juan: "El corro de la patata", El País, 30 de enero de 1985. O su visita a Julio Cerón, "mito" de la izquierda resistente a la dictadura", junto al que declaró: "soy ceronista", $A B C, 18$ de julio de 1985.

${ }^{29}$ ARMAS MARCELO, Juan José: Los años que fuimos Marilyn, Madrid, Espasa-Calpe, 1995, p. 90 y ss.

${ }^{30}$ Ibid., p. 97-8. Véase también, MORÁN, Gregorio: Ambición...

31 "Don Adolfo Suárez fue el instrumento impagable para lograr que el franquismo huérfano aceptase [...] Pero ya está. Muchas, muchas gracias señor duque", SOLANA, Luis: "Suárez, el guapo voto útil", $Y a, 20$ de junio de 1986. "Camino de su Damasco particular, descubrió la democracia, y a ella se entregó en cuerpo y alma. Enarbolando la fe del converso", Editorial: "3. Adolfo Suárez [Los candidatos]”, El País, 3 de junio de 1986. "La política de Sahagún en el Ayuntamiento es la de Suárez en la Historia", UMBRAL, Francisco: "Rodríguez Sahagún”, El País, 12 de diciembre de 1987; ÍD.: "El español y el voto", El País, 06 de junio de 1986.
} 
naufragio posterior del 23-F y el descalabro de UCD. Sus promesas electorales pierden peso específico en alguien que ha gobernado todavía recientemente. Pero, a pesar de todo, en la campaña, la figura de Adolfo Suárez tiende a reencarnar a Don Quijote ${ }^{32}$.

Asimismo, los sucesivos posicionamientos y decisiones políticas de Adolfo Suárez, -su discurso de centro-izquierda, el ingreso en la Internacional Liberal, su política de pactos-, aumentaban las dificultades para elaborar un discurso definido sobre su papel histórico y en especial, sus convicciones ideológicas. Ante lo que Francisco Umbral consideraba un descarado "doble juego" frente al PSOE en la política municipal madrileña por parte de los concejales suaristas señalaba que el CDS era "la ambigüedad cristalizada" liderado por el "falangista demócrata [Suárez]" y el "capitalista/populista [Sahagún]"33. Después de haber llevado a cabo su pacto con el PP en 1989, autores como J. M. Guelbenzuno o M. Vázquez Montalbán insistían en la dificultad existente para mantener un grato recuerdo -"lo ideal en casos parecidos -señalaba el escritor barcelonés- es asumir funciones de embajador especial, escribir unas memorias y apuntarse a una causa ejemplar"-, mientras siguiera en la lucha partidaria:

Hoy nadie discute a Adolfo Suárez su valor en la historia reciente de nuestro país y, más que probablemente, en la futura; lo que no obsta para que algunos pensemos que su afán de volver es justamente lo que está erosionando esa imagen, porque ha puesto demasiado en evidencia su lado débil ${ }^{34}$.

La convergencia entre las posturas de $A B C$ y $E l$ País se produjo al abordar el final político de Suárez; la llave que abrió la posibilidad de nuevas valoraciones, que iban a llegar definitivamente a mediados de los 90’. Una idea que expresó con crudeza Carlos Dávila, para quien Suárez debía haber abandonado la política cuando dimitió: "no tiene derecho a burlarse de su historia" ${ }^{\text {35 }}$. Desde una postura ideológica opuesta aunque una conclusión convergente, Gregorio Morán escribía que cuando ingresó en el CDS “se convirtió en el ejemplar más vulgar de oportunista de cuantos representaba la nata de la clase política de la transición [...] hay hombres que no saben morir a tiempo, y en política eso es un crimen" ${ }^{\text {36. }}$

\footnotetext{
${ }^{32}$ Editorial: “3. Adolfo Suárez [Los candidatos]”, El País, 3 de junio de 1986.

${ }^{33}$ UMBRAL, Francisco: "Rodríguez Sahagún", El País, 12 de diciembre de 1987.

${ }^{34}$ GUELBENZU, José María: "La historia o la cotidianidad", El País, 11 de septiembre de 1989. "Si le salen bien las cosas y vuelve a la Moncloa, que se prepare: no habrá piedad para el osado resucitado. Y si no llega a la Moncloa y queda en la cuneta con el culo malherido, los buitres no le van a respetar ni la sonrisa. La mejor sonrisa de toda la historia de España fotografiada", VÁZQUEZ MONTALBÁN, Manuel: "El duque", El País, 15 de mayo de 1989.

35 "Un partido vicario", Diario 16, 08 de julio de 1990. Véase también, esta idea de un "sí" a Suárez, y un "no" al CDS, ÍD.: "Tras las comicios, ya nada será igual", Diario 16, 26 de noviembre de 1985.

${ }^{36}$ MORÁN, Gregorio: El precio de la transición, Barcelona, Planeta, 1991, pp. 182-3.
} 
En el aire planeaba un reconocimiento, siempre demorado y en ocasiones esbozado, como sucedía en esporádicas alusiones a su intervención en el $23-\mathrm{F}^{37}$, pero postergado precisamente por la prolongación, -“residual" ${ }^{\text {_ }}$, de un protagonismo político cuyo momento histórico había finalizado diez años antes: “el papel de Adolfo Suárez en la historia contemporánea de España en absoluto podrá ser cuestionado por este poco brillante colofón" ${ }^{39}$. El País exaltaba la figura de Suárez subrayando que su mayor éxito político fue precisamente, con su reforma, "abrir paso al gobierno de los partidarios de la ruptura" $" 40$. En $A B C$, Mingote sintetizaba en una viñeta: "A Adolfo Suárez: la democracia agradecida" ${ }^{"}$. El francés Le Monde había señalado esta complementariedad entre "derrota" y "agradecimiento" para los mal comprendidos políticos de la Transición: "et si la vie politique espagnole a maintenant un tel tonus, on le doit largement au perdant d' aujord'hui" "42. La interpretación de autores como H. M. Enzensberger, esbozada en aquella época a propósito de las transformaciones del Este de Europa y asentada sobre la base de que las dificultades en la asimilación histórica de personajes como Suárez residían en la pertenencia de los mismos al régimen que precisamente habían desmantelado, aunque sugerente, iba a demostrarse incapaz de explicar por completo el caso del político abulense $\mathrm{e}^{43}$.

Una vez recogidas estas impresiones, es necesario dar unas pinceladas de aquellos autores que a través de las páginas de estos periódicos esbozaron a lo largo de esta década un discurso, regular y constante, evocador y nostálgico, del proyecto político

\footnotetext{
${ }^{37}$ Editorial: "Centro Democrático Socialista", $A B C, 11$ de octubre de 1990. Actitud ambivalente evocada ocasionalmente con anterioridad en la línea editorial de El País: "La etiqueta liberal", El País, 19 de septiembre de 1988 o ÍD.: "Las espadas en alto", El País, 02 de agosto de 1982. O perceptible en diversos columnistas, "no quisiera que mi crítica se quedara en una simple descalificación personal, que ni su figura ni sus servicios a España y a la libertad merecen" en JIMÉNEZ LOSANTOS, Federico: "Suárez, contra reloj", $A B C, 24$ de diciembre de 1988 u OVIDIO: "Ni hablar de política", $A B C, 01$ de marzo de 1989. A propósito de unas declaraciones de Matilde Fernández, Ministra de Asuntos Sociales, en las que "tachaba" de "cobarde" a Adolfo Suárez, $A B C$ salió resueltamente en defensa del abulense en su sección de Actualidad Gráfica, $A B C, 13$ de febrero de 1989. “Adolfo Suárez, símbolo de valor personal e hidalguía política el 23-F”, $A B C, 23$ de febrero de 1991.

${ }^{38}$ Editorial: “¿CDS sin Suárez?”, $A B C, 28$ de septiembre de 1991.

${ }^{39}$ Editorial: "Lo que permanece, lo que puede cambiar", El País, 27 de mayo de 1991.

40 Editorial: "Mutis por el centro" El País, 29 de mayo de 1991. Se publicaron cartas al director de agradecimiento a la figura de Suárez, El País, 14 de junio de 1991.

${ }^{41} A B C, 29$ de mayo de 1991.

42 "La sortie de Suárez", Le Monde, 28 de mayo de 1991.

${ }^{43}$ Propia de los "héroes de la retirada": "España no le ha perdonado hasta el presente. A los ojos de sus antiguos camaradas, él fue un traidor; a los ojos de aquellos para quienes había abierto el camino, fue un oportunista [...] Una cosa y sólo una cosa tiene garantizada el héroe de la retirada, la ingratitud de la patria", ENZESNBERGER, Hans Magnus: "El héroe de la retirada", El País, 26 de diciembre de 1989. Citado por CERCAS, Javier: Anatomía...
} 
que había representado Adolfo Suárez: Lorenzo Contreras y el filósofo Julián Marías ${ }^{44}$, para $A B C$, y el historiador Carlos Seco Serrano colaborador ocasional de El País ${ }^{45}$. Carlos Seco Serrano apelaba a la necesidad histórica en España de un proyecto de centro político que evitase la polarización política de la sociedad: "sustituyendo la confrontación armada por el pacto" "46. En agosto de 1982, su defensa del legado y gestión de Adolfo Suárez le llevó a una polémica abierta con Emilio Romero $(Y a)^{47}$. Julián Marías halagaba la transformación política llevada a cabo por Suárez, especialmente, por la época de libertad que significó la Transición y el papel desempeñado por la $\mathrm{UCD}^{48}$. Las columnas políticas de Lorenzo Contreras arroparon desde el comienzo al proyecto político suarista y defendió la época de la Transición como el periodo de mayores libertades - deterioradas desde la llegada al poder del PSOE-, si bien, no pudo eludir cierto desencanto final ante los errores de Suárez al frente del partido ${ }^{49}$.

Para poder entender esta dualidad, hay que distinguir a lo largo de toda esta década por un lado, los duros artículos de muchos creadores de opinión, con el recuerdo, sin duda más benévolo de la sociedad española. Siguiendo a Rafael Arias-Salgado, jefe de su gabinete desde 1987, acompañar a Suárez por "capitales de provincia, pueblos grandes [...] era un espectáculo", la gente salía a la calle, a verle, a darle la mano, a aplaudirle ${ }^{50}$ :

Todo ese tipo de crítica de columnista, especialmente, y de editoriales, tarda mucho en llegar a la gente, $[\ldots]$ [y es que] coincidiendo con esas críticas feroces, acompañarle a cualquier sitio era un espectáculo [...] curiosamente no se dedicaba a esto, y debiera haberse dedicado a mi juicio mucho más, había una empatía con determinadas capas populares [...] él tenía un enorme recelo hacia las oligarquías, tanto las culturales como las económicas y sin embargo, tenía en cambio una enorme empatía con lo que podríamos llamar clases medias populares.

\footnotetext{
${ }^{44}$ Véase: MARÍAS, Julián: Memorias 3. Una vida presente, Madrid, Alianza Editorial, 1988, pp. 57-9.

45 Asimismo, miembros del CDS como Raúl Morodo, Jaime García Añoveros, Eduardo Punset, J. Ros Hombravella, Rafael Arias-Salgado, José Ramón Caso o Agustín Rodríguez Sahagún escribían ocasionalmente en El País, este último, también en $A B C$.

${ }^{46}$ SECO SERRANO Carlos: "La alternativa de centro", El País, 08 de mayo de 1985.

${ }^{47}$ Recibió cartas al director en apoyo de Seco Serrano los días 19, 22 y 27 de agosto de 1982 firmadas por Alfonso Moreno de Acevedo, Luis Otaday y José Costa Font.

${ }^{48}$ MARÍAS, Julián: "Comprender la política”, $A B C$, 07 de septiembre de 1986.

${ }^{49}$ CONTRERAS, Lorenzo: "La inundación", $A B C$, 04 de febrero de 1987; ÍD.: "Revilla, Sahagún y el CDS", $A B C, 01$ de abril de 1991; ÍD: "Los desaires de Gorbachov", $A B C, 29$ de octubre de 1990.

${ }^{50}$ Señala David Ruiz: "acabaría con el paso del tiempo suscitando una selectiva memoria de honestidad que contrastaría con la imagen oportunista de la mayoría de los barones que sólo Suárez fugazmente aglutinó. Un dato éste que avalarían sin cesar las encuestas realizadas, sobre todo después de que el país contemplara por televisión la gallarda actitud que Adolfo Suárez mostró en las Cortes [23-F]", ÍD.: La España democrática (1975-2000), Madrid, Síntesis, pp. 198-9.
} 
Un ejemplo de este entusiasmo, lo constituye la siguiente anécdota narrada por José Luis Garro, jefe del gabinete de presidencia durante la "travesía del desierto", sucedida en una cena-coloquio en Huelva que:

Se había organizado en un gran polideportivo que durante todo el día acogía actividades de gran número de deportes. En la cancha del polideportivo, profusamente iluminada, se montaron las sillas, mesas, manteles, etc. para unos seiscientos comensales que habían pagado su ticket; el entorno eran las gradas que se preveían vacías y en total oscuridad. Pero cuando se tuvo conocimiento de esa cena-coloquio con Suárez, miles de deportistas del centro, se sentaron y permanecieron en las gradas para presenciar la cena-mitin o cena-coloquio. No se les podía echar porque estaban en su perfecto derecho a sentarse y hacer uso de las gradas de su polideportivo. Fernando Jáuregui era uno de los periodistas que seguían aquel día la campaña, y testigo de la patética situación [...] un acto con dos planos: los que comían, Adolfo Suárez y sus seguidores en la cancha iluminada, unas seiscientas personas, y los que no comían y sólo miraban (pues no habían pagado y su presencia ni se había previsto) sentados en la penumbra de las gradas, que terminaron siendo más de dos mil. Se pensó convertir la cena formal y servida en un cóctel para todos, pero no tenía sentido, los comensales habían pagado rigurosamente su cena. Al final, solución improvisada: se tiró una línea de audio hasta lo más alto de las gradas del polideportivo, donde se situó Adolfo Suárez. Desde aquella atalaya, Suárez se dirigió a todos, a los que no cenaban y a los que cenaron ajenos a los momentos de crisis que habíamos vivido. Habíamos salvado la situación, decía yo satisfecho. A lo que Suárez con paciente resignación contestó: "Sí, vosotros, todos, cenando ahí felizmente, y yo en todo lo alto como si fuese un showman" [negrita en el original].

Una última frase de la que desprende una sensación recordada por otros de sus colaboradores a propósito de estos "baños de masas" a lo largo de la geografía española. Según Rafael Arias-Salgado, ese tipo de actos le aburrían tanto que apunta "[yo] conseguí que lo hiciera muy pocas veces". Como recuerda Daniel de Fernando, dirigente del CDS en Ávila y Castilla y León cuando llegaba a Ávila, donde el reconocimiento era prácticamente unánime y los encuentros multitudinarios, había "que sacarlo a la calle", soliéndose mostrar más bien esquivo.

La empatía con la gente anteriormente mencionada parece evocar esa "capacidad de seducción", "magnetismo" con la que tanto se ha caracterizado su figura. Sobre este punto, subraya José Luis Garro:

Se ha resaltado hasta la saciedad su magnetismo y capacidad de seducción en la corta distancia. Pero nadie ha sabido o querido explicar que no era una impostura, una simple técnica mejor o peor aprendida, que dominase para seducir o atraer a su interlocutor a las posiciones que él defendía. No era un truco de magia. No era la técnica mil veces ensayada que puede aplicar un mago o un prestidigitador que domina la escena. Se trataba de algo natural y distinto.

Incluso, como señala José Luis Garro, en su relación con los medios existía en el trato personal mucho afecto y cordialidad: 
La relación de los periodistas con Adolfo Suárez era fluida, y éste gozaba de un sincero aprecio entre todos ellos. Periodistas como Fernando Jáuregui, Carlos Santos, Victoria Lafora, Luis Herrero, Pilar Urbano, Miguel Ángel Aguilar, le habían seguido antaño en sus apariciones en campañas cuando era el Presidente del Gobierno. Después vino la etapa final de acoso y derribo que terminó con su dimisión. Y ahora, todos ellos, le manifestaban un reconocimiento y afecto creciente que coincidía con el que le dispensaban desde todos los frentes y desde todos los medios.

Si había un punto de fricción eran las entrevistas. Señala Garro, "era conocida su aversión inicial a conceder entrevistas".

A veces, ya aceptada y comprometida, su celebración se retrasaba reiteradamente sin una fácil explicación. [Inocencio] Amores, su secretario particular en la oficina de Antonio Maura, tuvo que lidiar a diario con los tira y afloja que le generaba este tema. Yo fui testigo y sufrí los estertores de una entrevista con reflejo en portada que había concedido a Pilar Urbano para la revista Época. La entrevista estaba concedida y formalmente comprometida. Faltaba fijar fecha y hora concretas. La Dirección de la Revista Época había tirado ya la portada que -Pilar Urbano me había dicho- hacía referencia a la entrevista contenida en su interior; pero la entrevista a Adolfo Suárez seguía sin celebrarse. La situación era angustiosa. Pilar me mostraba estar al borde de un ataque de nervios, con la portada ya tirada y la entrevista pendiente de celebración. Nuestra conversación era dramática, y yo trataba de presionar al Presidente trasladándole la presión que Pilar Urbano me transmitía. Por fin se consiguió, Adolfo Suárez fijó la fecha, la entrevista se celebró y la tensión se disipó. Pero para nuestra sorpresa, cuando la revista salió a la calle: ¡Cielos!, la tan traída y llevada portada era un fotomontaje de dos futbolistas y un árbitro vestido de negro en el centro con la cabeza de Adolfo Suárez. Recuerdo los comentarios críticos a semejante portada. Durante unos días no supe bajo qué esconderme.

Una personalidad que J. L. Garro, mano derecha del Presidente del CDS durante los viajes realizados en la "travesía del desierto" completa con un fuerte sentido de la disciplina, un fino sentido del humor y la ironía, y un temperamento sosegado y extremadamente respetuoso.

Junto a todos estos factores, como señalan los miembros del CDS anteriormente citados, hay otro punto a tener en cuenta. Suárez antepuso su concepción y defensa del Estado al desarrollo inmediato y electoralista del partido; una actitud que por otro lado, quizá pudo ir en perjuicio de la propia consolidación del partido y que en manos de los medios se tradujo exclusivamente en el tópico sobre los "silencios" y la "ambigüedad" del abulense. De acuerdo con José Luis Garro:

Decía Adolfo Suárez, lo repitió en cientos de ocasiones y por tanto, muchos recordarán haberlo oído: "A veces se me propone que tome una decisión alegando que se trata de una Cuestión de Estado. Y yo entonces me pregunto: ¿Me beneficia a mí? ¿Beneficia a mis intereses? ¿Beneficia a mi Partido? Si la respuesta es Sí, entonces, no se trata de una Cuestión de Estado",51.

\footnotetext{
${ }^{51}$ Testimonio escrito de José Luis Garro, mayo de 2016, Entrevista con Rafael Arias-Salgado, 09 de marzo de 2015 y Entrevista con Daniel de Fernando, 20 de diciembre de 2013.
} 
Todo ello nos permite comprender la ambivalencia de periodistas y editorialistas en sus crónicas, siempre dispuestos aún entre críticas a reconocer su determinante papel en la democratización de España y cómo, muchos de estos comentarios periodísticos de los años 80' respondían fundamentalmente a las exigencias del discurso políticoelectoralista, estaban basadas en estereotipos y eran herederas de una inercia generalizada desde los últimos años de la Transición. Un dirigente socialista, como Gregorio Peces Barba, lamentaba en un artículo publicado en $A B C$ en el año 1988 las ofensas, "la difamación", sufrida a lo largo de la Historia de España de políticos de diverso signo que en la época bien podían ser Suárez, Fraga, Abril Martorell, González o Guerra ${ }^{52}$. En 1986, Suárez afirmaba que aunque el país no había sido injusto con él, no había sido "bien tratado por algunos sectores de los poderes fácticos"

Podemos afirmar que entre 1982 y 1991, a través de las páginas de ABC y El País, no se intentó formular un juicio sobre Adolfo Suárez que lo integrase de forma coherente con las posturas mantenidas acerca de la Transición, -asimismo, la inmediatez temporal había impedido iniciar siquiera el subsiguiente proceso de decantación histórica, en el sentido de la configuración de un discurso historiográfico-. La mayor parte de las referencias eran asistemáticas, breves y aisladas ${ }^{54}$; Adolfo Suárez no ocupaba un lugar destacado en las reflexiones globales sobre la Transición que a propósito de aniversarios o sucesos destacados esbozaban ambos periódicos. La figura de Juan Carlos I ocupaba el lugar central ${ }^{55}$. Los medios de comunicación y los partidos mayoritarios se limitaron a hacer un uso retórico con velada intencionalidad política de los diversos aspectos relativos al protagonismo de Suárez en la Transición. En consecuencia, la mayoría de las alusiones a su etapa presidencial dependían de la

\footnotetext{
52 PECES BARBA, Gregorio: "Una luz en la barricada", $A B C, 26$ de diciembre de 1988. Josep Tarradellas reconocía años antes que los españoles "han sido injustos con Suárez", SINOVA, Justino, (ed.): Historia de la Transición, Madrid, Grupo 16, 1984, p. 439.

${ }_{53}^{53}$ ABC Sevilla, 18 de mayo 1986.

${ }^{54}$ Salvo Diario 16 (1984), las principales cabeceras españolas realizaron compendios monográficos sobre la Transición tiempo después, El País (1996), El Mundo (1995), etc.

${ }^{55}$ Por ejemplo, los editoriales: "La constitución y el Rey", El País, 06 de diciembre de 1985, "Diez años después", El País, 20 de noviembre de 1985 o "El general Franco a diez años de su muerte", $A B C, 20$ de noviembre de 1985; SHMIDT, Helmut: "Una suerte para España", El País, 27 de febrero de 1986. Antonio Burgos escribía: "tiempo [la Transición] de habilidad profunda de Adolfo Suárez y de inspiración patria que nunca agradeceremos como es debido a Su Majestad... un oasis de libertades entre una dictadura y una hegemonía democrática", "El régimen", $A B C, 07$ de abril de 1986. Asimismo es significativa la ausencia de aniversarios en sus editoriales como: el 3 de julio de 1976 o, especialmente, el 15 de junio de 1977, tanto en El País como ABC. En relación al 15-J, se celebró en La Moncloa el veinte aniversario en 1997 con la presencia de los cuatro ex presidentes. En 1985, buena parte de la plana mayor de UCD celebró el VIII Aniversario, aunque sin la presencia ni de socialistas, ni comunistas, ni tampoco los militantes del CDS, El País, 15 de junio de 1985.
} 
situación política del CDS y se solían enfatizar con el recurso a la crítica personal. De esta forma, se contribuyó a caracterizar negativamente diversos aspectos de su presidencia y de su persona, en un proceso de construcción mediática determinado por el uso político subsiguiente. En el programa de TVE "Primera Fila", todavía en 1990, se utilizaban las siguientes palabras para comenzar una entrevista a Adolfo Suárez:

[Presentador, Antonio Martín Benítez] [...]- Usted ganó las primeras elecciones democráticas de esta etapa [...] por lo tanto es usted una figura que ya está en la historia de nuestro país y tiene una parte de actualidad, ¿le molesta que le identifiquen mucho esa primera parte?"

[Adolfo Suárez] -No, yo creo, en todo caso me satisface... ${ }^{56}$

La popularidad que le había rodeado durante buena parte de la Transición se había difuminado en parte por la intensa crítica a la que fue sometido $y$, salvo en los momentos de mayor éxito político del CDS, no se iba a recuperar hasta bien entrados los años 90' de la mano de multitud de homenajes y reconocimientos y una vez hubo abandonado la política activa:

Tabla 102: Principales homenajes.

\begin{tabular}{|c|c|}
\hline Homenaje & Fecha \\
\hline Premio Blanquerna & Enero 1995 \\
\hline Premio de Convivencia Manuel Broseta & Enero 1995 \\
\hline Premio del Año de una popular publicación ${ }^{57}$ & Abril 1995 \\
\hline Emisión de "Memoria de la Transición. Adolfo Suárez". Victoria Prego & Noviembre 1995 \\
\hline Orden del Águila Azteca (México) & Febrero 1996 \\
\hline Medalla de Honor de la Univ. Carlos III & Abril 1996 \\
\hline Doctor Honoris Causa de la Universidad Complutense de Madrid & Julio 1996 \\
\hline Premio Príncipe de Asturias de la Concordia & Noviembre 1996 \\
\hline Homenaje en Barcelona & Diciembre 1996 \\
\hline Medalla de Oro de Castilla y León & Marzo 1997 \\
\hline Premio de "Política Nacional" de Cambio 16 & Marzo 1997 \\
\hline Medalla del Orden Nacional al Mérito en el Grado de Comendador (Paraguay) & Abril 1997 \\
\hline Académico de Honor de la Academia de las Ciencias y las Artes de Televisión & Abril 1997 \\
\hline Medalla de Oro del Spanish Institute de Nueva York & Diciembre 1997 \\
\hline Doctor Honoris Causa de la Universidad de La Coruña & Diciembre 1997 \\
\hline Doctor Honoris Causa de la Universidad Politécnica de Madrid & Marzo 1998 \\
\hline Medalla de Oro de Madrid & Noviembre $1998^{58}$ \\
\hline Premio Convivencia de Ceuta & Mayo 1999 \\
\hline Máxima distinción de la Cruz Roja & Mayo 1999 \\
\hline Premio Convivencia Fundación Pro-Derechos Humanos Miguel Ángel Blanco & Julio 2000 \\
\hline Premio Valores Humanos del Grupo Correo-Prensa Española & Abril 2002 \\
\hline
\end{tabular}

Elaboración propia a partir de la revista iHola! (1995-2002).

\footnotetext{
56“Primera Fila" (1990), Archivo Histórico de RTVE. Disponible en: (http://www.rtve.es/alacarta/videos/personajes-en-el-archivo-de-rtve/entrevista-adolfo-suarez-primerafila-1990/699235/). Fecha de consulta: 10 de abril de 2014.

${ }_{57}^{57}$ Recogido por su hija Sonsoles Suárez, Hola, 20 de abril de 1995.

${ }^{58}$ El Pleno Municipal de Madrid concedió por unanimidad al cardenal V. E. Tarancón y al Rey la medalla de la ciudad, $A B C, 27$ de noviembre de 1987 y $A B C, 23$ de noviembre de 1988.
} 
Cabe señalar como, en este proceso de recuperación de la memoria del ex Presidente de Gobierno, los miembros del CDS, muchos de ellos junto a Adolfo Suárez desde su entrada en la Presidencia de Gobierno, se vieron relegados a un papel secundario. El PP, que se había proclamado heredero de UCD y del centro político, y desde 1991 comenzaba a gobernar en numerosos ayuntamientos y regiones, hizo un notable esfuerzo por protagonizar esta recuperación del pasado.

Recuerda Daniel de Fernando que la condición que puso Adolfo Suárez de cara a la recepción de la Medalla de Oro de las Cortes de Castilla y León -en la Legislatura comprendida entre 1991-1995- se basó en que fuera a propuesta unánime de la cámara, es decir, de todos los grupos parlamentarios. Dicho acto, se celebró en el Monasterio de Nuestra Señora de Prado de Valladolid y en él, el Partido Popular, al frente de la autonomía castellano y leonesa asumió el papel protagonista. Lo mismo sucedió durante la conmemoración en la apertura de las Cortes de Castilla y León y la aprobación del Estatuto de Autonomía o el homenaje a Agustín Rodríguez Sahagún organizado por el Ayuntamiento de Madrid en 2011; actos celebrados bajo la dirección del Partido Popular, que ensombrecieron el papel de otros protagonistas políticos de estos acontecimientos, caso de los miembros del $\mathrm{CDS}^{59}$. De forma similar, unos años antes se había apelado al propio Adolfo Suárez a propósito de la integración del CDS en el PP. El Secretario General de los centristas, José Moreira, al elogiar la actuación de su última Presidenta Nacional del CDS subrayaba: "[el esfuerzo por mantener] la ilusión de los militantes del Partido, llevando las ideas del centrismo Político, que representaba el CDS, desde su fundación por Adolfo Suárez, al que, desde aquí le dedico esta mención especial, pues sé que él refrendaría esta decisión de integración de CDS en otro Partido Centrista, que en este caso, es el PP"60.

\footnotetext{
${ }^{59}$ Entrevistas con Daniel de Fernando, José Luis Sagredo de Miguel y Antonio Garrosa, entre julio de 2013 y mayo de 2015.

${ }^{60}$ Discurso de José Moreira de integración del CDS en el Partido Popular, 2005, Documentación de José Moreira.
} 


\section{2. La mirada en el espejo: la Transición vista desde el CDS}

Si otros dicen lo que han conseguido, ¿por qué no puedo yo poner de manifiesto lo que hice cuando era presidente de

Gobierno? [Adolfo Suárez] ${ }^{61}$.

A partir de la propia concepción de Adolfo Suárez de la Transición y su experiencia en UCD se construyeron las líneas maestras del CDS. La reflexión de Adolfo Suárez y sus colaboradores en torno a su época presidencial, -reflejada en artículos, manifiestos y boletines-, sirvió para forjar el marco ideológico y organizativo sobre el que edificar su nuevo proyecto político:

Tabla 103: Principales artículos o conferencias de Adolfo Suárez sobre la Transición (1982-1991).

\begin{tabular}{|l|l|l|}
\hline Publicación Tipo & Fecha \\
\hline $\begin{array}{l}\text { Historia de la Transición de } \\
\text { Diario 16 }\end{array}$ & Artículo & 1984 \\
\hline $\begin{array}{l}\text { Anatomía de un cambio de } \\
\text { régimen (José Oneto) }\end{array}$ & Prólogo 1984 \\
\hline Fundación Ortega y Gasset & $\begin{array}{l}\text { Entrevistas sobre la Transición con los } \\
\text { principales protagonistas }\end{array}$ & Mayo 1984. \\
\hline Revista de Occidente (n' 54) & $\begin{array}{l}\text { Entrevista de Charles Powell a Adolfo } \\
\text { Suárez }\end{array}$ & Noviembre 1984. \\
\hline $\begin{array}{l}\text { Universidad Internacional } \\
\text { Menéndez Pelayo }\end{array}$ & $\begin{array}{l}\text { Seminario sobre la Prensa en la } \\
\text { Transición y el nuevo orden informativo }\end{array}$ & Julio 1984 \\
\hline Cuenta y Razón & 1988 \\
\hline Universidad de Cádiz & Jrtículo & Sin confirmar (1989). \\
\hline EFE. 50' Aniversario & Prólogo & Marzo 1990 63. \\
\hline
\end{tabular}

Elaboración propia ${ }^{\mathbf{6 4}}$.

La presencia y reiteración de todo aquello que tenía que ver con la Transición era perceptible en las ruedas de prensa o entrevistas, bien fueran a nivel local o nacional. José Luis Garro apunta, como durante sus viajes con el Presidente entre 1982 y 1986, era frecuente en todos los pueblos y ciudades donde se detenían que Adolfo Suárez explicara pacientemente una y otra vez los motivos que condujeron a su dimisión. En ocasiones, la asociación de ideas entre Adolfo Suárez y la Transición llegaba a impedir

\footnotetext{
${ }^{61}$ Una de las frases de la campaña electoral, $A B C, 15$ de mayo de 1991.

${ }^{62}$ Elogió su presión en favor de la apertura política, El País, 06 de julio de 1984.

${ }^{63} A B C, 02$ de marzo de 1990.

${ }^{64}$ Cabe señalar que junto a Historia 16, la revista Sistema y la Revista de Occidente realizaron monográficos sobre este aspecto. De acuerdo con Gregorio Morán, el primer "cronista oficial" de la Transición fue el periodista Joaquín Bardavío con numerosas publicaciones desde finales de los 70', MORÁN, Gregorio: El Precio de la..., p. 99 y ss. Destacar la obra del miembro del Comité Nacional del CDS, Federico Ysart: ¿Quién hizo el cambio?, Barcelona, Argos Vergara, 1984. En 1986, Sergio Vilar que también había participado de la fundación del partido en Barcelona en 1982, publicaba, La década sorprendente 1976-1986, Barcelona, Planeta, 1986.
} 
transmitir con claridad la existencia de un nuevo proyecto político. En Galicia, José Moreira recuerda cómo unas señoras en una comarca del interior se extrañaron al verle durante la campaña de las autonómicas de 1985 preguntándose: ¿no había dimitido?, ¿no estaba en UCD? ${ }^{65}$

En sus análisis de la Transición, Suárez se refirió a esta etapa como el período histórico que iba desde 1976 a 1978, en el que destacaban ante todo tres hechos: la Ley para la Reforma Política, las elecciones del 15 de junio de 1977 y la Constitución -en la que era clave la estructuración autonómica de España- ${ }^{66}$. Esta esquematización concordaba perfectamente con la lectura política de la Transición que realizó el CDS, trasladada al plano ideológico por su Manifiesto Político de 1982 y en el que se postularon dos líneas fundamentales: superación de la división secular de España mediante la búsqueda del pacto -a la "polarización" se contraponía el ideal de "reconciliación" plasmado durante la Transición ${ }^{67}-$, y, una vez cumplimentadas las reformas políticas durante la Transición, finalización de la transformación económica y social (iniciada con medidas como la Reforma Fiscal). En un mitin electoral celebrado en la campaña de 1986, se podía leer entre las notas del líder centrista:

Felipe González hace de la realidad la apropiación indebida necesaria para suscitar otra vez el mito de las dos Españas: La España buena y la España mala, la España del progreso y la España de la reacción [...] Al desconocer el pluralismo real de la sociedad política y tratar de encuadrar la realidad en sólo dos términos, borrando el centro ${ }^{68}$.

Resulta interesante subrayar cómo, en el Manifiesto Político, se usó la primera persona del plural para referirse a los logros de la Transición en un momento en el que todavía existía UCD u otros partidos, como el PDP (Partido Demócrata Popular), el PAD (Partido de Acción Democrática) o el PDL (Partido Demócrata Liberal), creados en buena medida a partir de escisiones del bloque centrista. El CDS, en expresión usada

\footnotetext{
${ }^{65}$ Entrevista con José Moreira, 21 de mayo de 2015.

${ }^{66}$ Como publicaba en el no 1000 de Cambio 16 en 1991, SUÁREZ GONZÁLEZ, Adolfo: "La transición española”, Cambio 16, 2193 (abril 2014).

${ }^{67}$ Como recordó el propio Suárez en numerosas ocasiones; una de ellas, tan significativa como el fallecimiento de La Pasionaria. Fue el propio Suárez quien acudió a mostrar sus condolencias, al igual que Rodríguez Sahagún -alcalde de Madrid- y señaló: "sella el término de una vida en la que es indiscutible su amor a España, su fidelidad a sus ideales y la valentía con la que los defendió[su retorno a España, dijo Suárez] representa uno de los símbolos que proyectan lo que pretendió la transición democrática: la reconciliación entre todos los españoles en un intento democrático de convivencia”, $E l$ País, 13 de noviembre de 1989. El Secretario General en Asturias del CDS, Ángel Maldonado, había acudido tres años antes a la fiesta homenaje que el PCE de Asturias dedicó a La Pasionaria. Junto a él, y la plana mayor del PCE se encontraban miembros de CC.OO., USO, PSOE y UGT, La Nueva España, 03 de diciembre de 1985.

${ }^{68}$ Nota 18 de julio, $A G P$.
} 
por José María Carrascal en 1989, se había convertido en el "intérprete de la Transición"

El CDS aspiraba a recoger en su plenitud los valores que habían simbolizado la Transición, -consenso, tolerancia y respeto-, para favorecer la convivencia como valor supremo. Las posibles deficiencias del texto constitucional se subordinaban al carácter consensuado del mismo, en una actitud que trasladaron a su forma de ejercer la oposición política -por ejemplo, en la necesidad de una gran ley educativa apoyada por los dos principales partidos-. La recuperación de estos valores era la clave, como pusieron de manifiesto a lo largo de toda la década, para la consolidación definitiva de las instituciones democráticas. En expresión de Rodríguez Sahagún, Adolfo Suárez y el CDS tenían la "legitimidad" para recoger a todo el electorado de centro progresista que "respaldó la Transición",70.

Su apelación genérica al Pacto de Estado en materia económica, antiterrorista, política exterior o autonómica ${ }^{71}$, y su insistencia en la necesaria concertación social -en el contexto previo al 14-D-, en definitiva la reivindicación del diálogo y la búsqueda de acuerdos como herramientas políticas, constituían la mayor herencia política mantenida en el discurso suarista desde la época transicional. Durante el año 1990, en el que se produjo el acercamiento del CDS al PSOE, Adolfo Suárez instaba al desbloqueo político con este argumento final:

Y por último, y desde mi experiencia, señor Presidente, de mi experiencia como expresidente, le sugiero que, además de los contactos que se mantengan en esta Cámara, en el Parlamento, en las Comisiones correspondientes, no renuncie a los encuentros informales bilaterales. Usted y algunos otros parlamentarios ilustres de esta Cámara saben qué útiles fueron en otros momentos de nuestra historia reciente esos contactos para resolver problemas que parecían entonces insalvables, como la elaboración de la Constitución y de los primeros estatutos de autonomía. ${ }^{72}$

Los propios dirigentes socialistas reconocieron a propósito de la política de pactos antiterrorista las virtudes que suponía el haber ejercido previamente cargos de la máxima responsabilidad durante la Transición: “[Benegas] afirmó que quizás el hecho de que los responsables del CDS hayan gobernado con UCD en tiempos de gran dureza

\footnotetext{
${ }^{69}$ Según el autor, una de las conclusiones que se extraía de la situación política de España de la lectura de dos libros: La ambición del césar, obra de J. L. Gutiérrez y Amando de Miguel y De Fraga a Fraga, firmada por Carlos Dávila.

${ }^{70}$ ABC Sevilla, 25 de agosto de 1989.

${ }^{71}$ En ocasiones, se defendía explícitamente desde el CDS, la reedición de los "Pactos de la Moncloa" sobre uno u otro aspecto, "El CDS propone un 'Pacto de la Moncloa' para la Radiotelevisión pública y el 'reparto de las televisiones", El País, 06 de septiembre de 1988.

${ }^{72}$ DSCD, Sesión Plenaria, 05 de abril de 1990, nº 28, p. 1108.
} 
terrorista explique su actitud actual y el que haya sido posible 'avanzar rápidamente en la idea de un pacto de Estado",73.

De otra parte, el recuerdo de la UCD, cuya compleja relación ya hemos visto a propósito del CDS, era generalmente esquivado por el conjunto de la derecha que recordaba no sin pesadumbre los personalismos, las injerencias socialistas y el proyecto truncado de "mayoría natural"74 . Sólo el PRD, y desde 1989, el PP -cuando comenzó su ofensiva sobre el espacio de centro-, recuperaron abiertamente su legado. Por el contrario, Rodríguez Sahagún, a propósito de la presencia de Calvo-Sotelo y Marcelino Oreja en una convención del PRD señalaba: “con Adolfo Suárez está la UCD que hizo posible el cambio político y que quiere protagonizar el cambio social, mientras que con Miguel Roca están los que hicieron la [...] LOAPA y contribuyeron a derechizar UCD" "75. Los "restos de UCD" o la "operación UCD" constituyeron en cualquier caso un objeto habitual de comentarios y especulaciones a lo largo de toda la década.

Con el fin de completar nuestro viaje de ida y vuelta entre la realidad política y personal de Adolfo Suárez durante la década de los 80' y su inmediato pasado político, debemos abordar tres aspectos, que aunque puntuales, no era extraño que aparecieran con intensidad en las primeras páginas de los periódicos. Nos referimos a: su trayectoria durante la Dictadura franquista, la relación entre el Rey y Adolfo Suárez y la "supuesta" conexión entre su dimisión y el 23-F.

Las referencias al pasado franquista y falangista de Adolfo Suárez durante esta etapa no fueron especialmente intensas ni en la prensa, ni en la dialéctica política. Sin embargo, aunque fueron episodios secundarios, jugaron su papel en los editoriales y artículos de opinión de los distintos medios de izquierda o derecha -cuando se quería subrayar bien su imprevisibilidad o su oportunismo-, y en la dialéctica electoral del

\footnotetext{
${ }^{73}$ El País, 09 de septiembre de 1987.

${ }^{74}$ En el contexto de crisis de Alianza Popular (diciembre 1986) se podía leer: "UCD se derrumbó cuando empezaron a buscar escapatorias colaterales sus líderes más preocupados por garantizar su propio futuro político", editorial: "No dividir", $A B C, 11$ de diciembre de 1986. "El recuerdo de UCD ha planeado en estos días con su oscura sombra sobre la crisis de la derecha" en ÍD.: "Mayoría de edad para AP", $A B C$, 05 de diciembre de 1986. Incluso, Suárez comentó en varias ocasiones que a Manuel Fraga le estaba ocurriendo lo mismo que a él, El País y ABC, 20 de diciembre de 1986.

${ }^{75} A B C, 21$ de mayo de 1986. En el mismo sentido se pronunciaba el militante del CDS, ROS HOMBRAVELlA, Jacinto: "Reformismo: ¿de qué?", El País, 24 de mayo de 1986. En una frase de Roca, recogida por Antxón Sarasqueta: "Suárez es el pasado, yo soy el futuro", SARASQUETA, Antxón: El abuso..., p. 196-7. “¿Es el PRD el heredero legítimo de UCD?” preguntaba Luisa Palma al candidato reformista a la Junta de Andalucía en $A B C, 11$ de abril de 1986.
} 
PSOE. Por ejemplo, a raíz de su negativa a firmar un acuerdo global con AP tras las Autonómicas y Municipales de 1987, Manuel Barrios en ABC Sevilla escribía:

A mí lo que me asombra no es que el duque de Suárez traduzca a la práctica lo que es diametralmente opuesto a sus palabras, sino que aún haya en España tantos desmemoriados que, ingenuamente y de buena fe, crean en aquel que puede prometer y promete, pero casi nunca cumple. A mí, desde luego, ante cualquier declaración del ex ministro general del Movimiento, me ha bastado siempre recordar su papel ante un 28 de febrero [referéndum de Andalucía]... ${ }^{76}$

Rara vez se concretó este discurso en episodios concretos. Apenas podemos citar la pequeña polémica con Manuel Fraga, durante la presentación del segundo tomo de sus memorias, durante la cual atribuyó a Suárez la responsabilidad de los sucesos de Vitoria y Montejurra (1976), episodios que sucedieron cuando el líder aliancista se encontraba en el extranjero ${ }^{77}$. Adolfo Suárez no intentó velar o restar importancia a su pasado político durante la Dictadura. A propósito de una visita a Segovia, en plena campaña electoral de 1982, Suárez "se anticipó a cualquier insinuación [de la prensa local y nacional], recordando que no sólo fue gobernador civil, sino también Jefe Provincial del Movimiento"78 y en otra ocasión, defendió que jamás había traicionado al Movimiento pues la reforma del mismo se hizo siempre desde la "legalidad vigente"79. Cuatro años después, en Chile, al ser preguntado acerca de si su pasado político durante el franquismo le había pesado después: "no he ocultado jamás mi curriculum y mis adversarios más fuertes sacan este tema a colación. Sí que fue un obstáculo al comienzo de mi gestión como Presidente [...] porque durante mucho tiempo no tuve credibilidad" ${ }^{\prime 80}$. De otra parte, cuando era atacado con este argumento por los líderes socialistas no tenía empacho en afirmar que si él había ido del Movimiento a la libertad, otros estaban transitando desde "la libertad hacia el Movimiento" 81 ".

Se ha hablado mucho del distanciamiento entre el Rey y Adolfo Suárez en esta época, un tema presente en todos los mentideros políticos. Según Abel Hernández, periodista, amigo de Adolfo Suárez y candidato al Congreso por el CDS en la provincia de Soria, una de las condiciones que puso el Rey para otorgar el ducado a Adolfo Suárez, tras una "negociación durísima”, fue su retirada de la política activa, condición

\footnotetext{
${ }^{76}$ BARRIOS, Manuel: "Páginas de ayer”, ABC Sevilla, 23 de julio de 1987.

${ }^{77}$ La respuesta de Suárez en El País, 24 de septiembre de 1988.

${ }^{78}$ El País, 15 de octubre de 1982

${ }^{79} A B C, 01$ de junio de 1985.

${ }^{80}$ ABC Sevilla, 12 de diciembre de 1986.

${ }^{81}$ En la campaña de las europeas de 1989 en la que tras los pactos con el PP, estos cruces de acusaciones fueron más que frecuentes -junto a las de 1986, ABC y El País, 05 de junio de 1989. Polémica con Díaz Ambrona (UCD) en el verano de 1982 en $A B C, 11$ y 13 de agosto de 1982.
} 
que "Suárez aceptó [...] sin ánimo de cumplirla" 82 . La ruptura entre ambos, al menos políticamente, se produjo con la fundación del $\operatorname{CDS}^{83}$. Y durante un tiempo su relación se redujo a poco más que las tradicionales felicitaciones en los correspondientes $\operatorname{aniversarios}^{84}$.

Un editorial de $A B C$ publicado en 1983 reavivó la polémica. El texto se afanaba en subrayar las buenas relaciones entre el Rey y Felipe González, y lo hacía comparándolo con los Presidentes de Gobierno anteriores, lo que suscitó la inmediata reacción de Adolfo Suárez en un artículo en el propio medio: "no esperaba de un periódico, bajo tu dirección, una descalificación de esa naturaleza". Lamentaba la actitud del medio y le invitaba a rectificar su opinión; en lo que era una reivindicación personal: "por lo que a mí respecta fui designado por el Rey, a propuesta del Consejo del Reino, en 1976 y más tarde, en dos ocasiones consecutivas en 1977 y 1979, por el sufragio del pueblo". Insistía en que "los que se declaran sólo partidarios de la Corona, acaban haciendo de la Corona un partido más, excluyendo de su defensa y respeto -que nos incumbe a todosa las distintas opciones políticas y a sus electores". En su artículo se mostraba particularmente duro: "el desprecio o la injuria a quienes encarnaron en sucesivas etapas del Poder ejecutivo, daña gravemente, a mi juicio, la propia democracia" ${ }^{\$ 2}$.

En agosto de 1985, la prensa italiana publicó una polémica noticia a raíz de una conversación informal entre Suárez y un periodista de La Reppublica en el descanso de un curso de inglés al que asistían en Londres -que ya vimos a propósito de la OTAN-. Paolo Filo della Torre transcribía unas palabras de Suárez en las que éste reconocía la obra del soberano en el proceso de democratización aunque se considerase "republicano":

Credo che la Spagna democratica sia ormai un dato di fatto. Ritengo di avere agito saggiamente quando, ottenuto l' incarico dal Re, mi sono premurato di impegnare nel gioco democratico tutte le forze politiche del paese. La stabilizzazione è continuata e

\footnotetext{
${ }^{82}$ HERNÁNDEZ, Abel: Suárez y el Rey, Madrid, Espasa, 2009, p. 183.

${ }^{83} \mathrm{Ibid}$, p. 188. Sin duda, su última y más polémica manifestación ha sido la obra de la periodista Pilar Urbano (2014) quien sitúa el contexto de su dimisión y el 23-F como la primera gran manifestación de esta ruptura de relaciones, véase, URBANO, Pilar: La gran desmemoria: lo que Suárez olvidó y el Rey prefiere no recordar, Barcelona, Planeta, 2014.

${ }^{84}$ Sobre este punto, comentaba Pilar Cernuda en 1983 a propósito de la recepción en el Palacio Real con motivo de la onomástica del Rey: "no fue Adolfo Suárez, por razones que no se conocen, pero sí estaba Leopoldo Calvo Sotelo...", La Vanguardia, 26 de junio de 1983. Sí acudieron, por ejemplo, en 1985 junto a toda la familia Suárez, ocasión en la que Amparo Illana fue condecorada con la Banda de la Orden su Majestad Isabel la Católica junto a Pilar Ibáñez Martín, $A B C, 25$ de junio de 1985.

85 SUÁREZ GONZÁLEZ, Adolfo: "Servir a la Corona", $A B C, 04$ de agosto de 1983. En defensa de Suárez, apareció también una carta al director de GONZÁLEZ BELDA, J. A.: "El rey y el presidente", $A B C, 21$ de julio de 1983.
} 
continua. E' importante riconoscere l' opera del sovrano anche se io sono repubblicano e resterò tale. E' la democratizzazione dell' esercito che deve continuare ${ }^{86}$.

El subsiguiente desmentido de Suárez llegó tres días después, desdiciendo que se hubiera producido algún tipo de entrevista, sólo una conversación informal mientras tomaban un café. Se había referido al carácter más bien republicano del país en las décadas precedentes como consecuencia del régimen anterior -una posición que él también compartía-, pero que hoy en día era mayoritariamente monárquico:

Il giornalista italiano mi pose diverse domande sulla situazione spagnola e, tra l' altro, sulla monarchia. Nella conversazione sottolineai l' importanza della corona e della figura del re Juan Carlos nel processo di democratizzazione della Spagna e precisai che un paese, che nella sua grande maggioranza non era affatto monarchico ma fortemente repubblicano nel regime precedente -ed anch' io ero allora republicano- si era trasformato in un paese nel quale noi spagnoli in grande maggioranza difendiamo la monarchia parlamentare. d' altronde evidente che io lavoro per la monarchia da più di venti anni, come ben sa il re ${ }^{87}$.

A pesar de estos episodios agitados por la prensa, Adolfo Suárez siempre defendió en público su compromiso con la Monarquía Parlamentaria y su servicio a la Corona. En relación a su dimisión, insistió, y en esto no hubo pie a malentendidos por parte del político abulense durante todos estos años, en que no hubo presiones del rey ni del estamento militar. Señalando que por supuesto, si hubiera tenido conocimiento previo del Golpe jamás hubiera dimitido -como difundió por ejemplo, Josep Tarradellas-. Desde el verano de 1981, se había extendido el rumor de una supuesta reunión el día 22 de enero, junto al Rey y cuatro capitanes generales, en la que aprovechando la ausencia momentánea del monarca, le "forzaron" a dimitir. Un trabajo de investigación de J. L. Barbería y J. Prieto publicado en 1991 negaba rotundamente este extremo, aunque hacía público el contenido del documento de los servicios de información del Estado sobre las “operaciones militares en marcha", fechado en noviembre de $1980^{88}$.

Suárez se mostró contrario al indulto a los golpistas del 23-F y sólo en 1988 varió esta posición al menos en el caso de Armada ${ }^{89}$. Sobre el intento de magnicidio de La

\footnotetext{
${ }^{86}$ FILO DELLA TORRE, Paolo: "Suarez a Londra a scuola d'inglese ci dice: 'Felipe e un buon premier", La Reppublica, 08 de agosto de 1986.

${ }^{87}$ SUÁREZ GONZÁLEZ, Adolfo: "Lettere. Suárez e il re", La Reppublica, 11 de agosto de 1985.

${ }^{88}$ Solo un día después de que se hiciera público el intento de golpe de estado de La Coruña (1985), $E l$ País publicó esta noticia fruto del trabajo de los citados periodistas: "El Gobierno Suárez conocía cuatro tramas previas al 23-F", El País, 18 de febrero de 1991.

89 "Suárez opinó que, según su conocimiento de los hechos en aquella fecha, los planes de Armada 'eran muy diferentes' a los del resto de los condenados y podrían 'haber estado dentro de la Constitución'. Según Suárez, en el caso de Armada se dan todos los supuestos necesarios para la concesión del indulto: edad, enfermedad, arrepentimiento y acatamiento de la Constitución", véase, El País 16 de septiembre y 24 de diciembre de 1988.
} 
Coruña contra las vidas del Rey y el Presidente del Gobierno manifestó su extrañeza cuando se desveló el episodio- por el hecho de que "una vez abortado el intento por los servicios de inteligencia, no se haya procesado a ninguno de los implicados" ${ }^{\prime 90}$.

Los militares o el Rey eran la punta de lanza de rumores que se acrecentaban ante el hermetismo de Suárez. Y es que, la posposición indefinida de sus "memorias" y desde los noventa, el misterio que ha rodeado a su archivo personal, ha contribuido a alimentar múltiples teorías sobre algunos episodios de su trayectoria política. El propio Suárez declaró en una ocasión: "ya que hay documentos que tengo que valorar si es conveniente o no revelar en el presente político español"91.

Finalmente, debemos intentar valorar en su conjunto las dificultades con las que tropezó Adolfo Suárez -y el CDS-, para rentabilizar el extraordinario capital político heredado de la Transición. Tras su nombramiento como Duque por parte del Rey Juan Carlos I en 1981, recordar los primeros reconocimientos públicos a su figura provoca cuanto menos sorpresa: revista Euzkadi (PNV, 1984) y villa de Belmonte (placa en una plaza de la localidad $)^{92}$.

Las causas de esta situación transcendían las escasas posibilidades mediáticas y políticas que podía tener un partido secundario a nivel nacional como era el CDS. En primer lugar, Adolfo Suárez, para los militantes del CDS, fue ante todo "el presidente" y él, se veía así mismo, como un hombre de estado. No sólo era un político en la oposición, ostentaba un papel institucional ${ }^{93}$. Aquellos hechos que despertaban un reconocimiento social mayoritario, no eran susceptibles para Suárez, precisamente por la dimensión institucional que representaban, de ser utilizados electoralmente; así sucedió con la imagen del 23-F en la campaña electoral de 1982. Por otra parte, el desgaste lógico que supone toda gestión política había generado una fuerte corriente de opinión contraria a los gobiernos de Suárez, especialmente incisiva en su última etapa. La intensidad de las críticas prolongaron, como vimos en el epígrafe anterior,

\footnotetext{
${ }^{90}$ Diario 16, 27 de febrero de 1991, MAST.

${ }^{91} A B C, 23$ de agosto 1984. En 1983, llegó a afirmar que podían publicarse en dos años y que ya había comenzado la reordenación de su archivo si bien señaló que su divulgación podía ser "desestabilizadora", ABC, 03 de mayo de 1983; El País, 30 de septiembre, 03 de octubre de y 21 de noviembre de 1983. En 1985, definitivamente decidió posponer su publicación para "un tiempo más tranquilo", $A B C, 03$ de febrero de 1985.

${ }^{92}$ Donde ni siquiera tenía concejales el CDS, $A B C, 28$ de marzo de 1984.

${ }^{93}$ En enero de 1988, un lapsus de Suárez, a propósito de su entrevista con el líder nicaragüense Daniel Ortega en Madrid sobre el proceso de paz en Centroamérica, provocó el regocijo de los presentes, ROIG, E.: "Suárez afirmó: 'Mi Gobierno apoya el proceso de paz””, El País, 28 de enero de 1988.
} 
comentarios y crónicas especialmente ácidas en editorialistas y columnistas a lo largo de toda la década ${ }^{94}$.

De este modo, el desgaste generado por su gestión al frente del Gobierno y la percepción institucional que Adolfo Suárez tenía de su presidencia impidieron al partido centrista recurrir con eficacia a la Transición, como valor político y electoral y los intentos de Rodríguez Sahagún y el propio Suárez resultaban a menudo contraproducentes $^{95}$, hasta el punto de que Nativel Preciado llegó a preguntarle en una ocasión: "hay una actitud suya que nadie acaba de entender. ¿Por qué no ha explotado más electoralmente sus éxitos en la transición? ¿Por qué se resiste a hablar de su pasado inmediato?"96. Las intervenciones parlamentarias de Suárez ejemplifican como el recuerdo de su etapa presidencial era sobre todo usado por los demás partidos como un depósito de contraargumentos con los que anular sus propuestas: "Señor Suárez, yo respeto a las minorías, las he respetado siempre, tanto las he respetado que hasta ahora [...] no ha habido un debate de investidura [en alusión a 1979]"97. Parece plausible, como ha recordado un destacado miembro del partido en Madrid, la existencia de recomendaciones expresas de no usar su pasado presidencial como tema de disputa en los Debates Sobre el Estado de la Nación ${ }^{98}$.

Adolfo Suárez se quejaba de la "soledad" en la que se encontraba la Transición y de la compleja situación política y económica en la que se vio obligado a asumir la presidencia y no era extraño que reprochara al PSOE su prepotencia al querer "borrar la transición o ponerla en 1982" "99. En el debate de Presupuestos Generales de 1988, Rodríguez Sahagún señalaba a Carlos Solchaga: “yo podría también -tengo cantidad de citas de cuando usted estaba en la oposición-, referirme al pasado, pero yo creo que

\footnotetext{
${ }^{94}$ Fue emblemático el caso de Andalucía, como consecuencia del referéndum de febrero de 1980. El secretario general Jesús María Viana, todavía comentaba en 1987 que "el error de Suárez en el referéndum de la autonomía andaluza no puede suponer su suicidio político en Andalucía", ARENZANA, J. M.: "Viana: El CDS no quiere independientes vistosos en sus listas municipales", ABC Sevilla, 18 de enero de 1987 o ROMERO DE SOLÍS, Ignacio: "Nueves años después (I)", ABC Sevilla, 01 de marzo de 1989.

${ }^{95}$ En el caso de Rodríguez Sahagún a propósito de los debates de los Presupuestos Generales del Estado en 1983, 1984 y 1985, como por ejemplo en DSCD, Sesión Plenaria, 27 de diciembre de 1983, nº 89, p. 4270.

${ }^{96}$ En otra ocasión: "[Nativel Preciado reproduciendo las palabras de un experto en marketing electoral norteamericano] Con el vídeo del 23-F yo hubiera hecho presidente de los Estados Unidos a Adolfo Suárez en dos meses" o "está usted respondiendo todo el tiempo como un estadista. ¿Qué pretende demostrar", PRECIADO, Nativel: “Adolfo Suárez", Tiempo, 23 de noviembre de 1987.

${ }^{97}$ DSCD, Sesión Plenaria, 23 de julio de 1986, nº 3, p. 90.

${ }^{98}$ Entrevista con José Antonio Pérez González, 23 de mayo de 2014.

${ }^{99}$ Mitin electoral en Guadalajara, $A B C, 03$ de junio de 1987 o entrevista con Faustino F. Álvarez, en $A B C$, 05 de junio de 1987. Véase, MORÁN, Gregorio: El precio de la ..., p. 30.
} 
sería bueno que dejara usted ya de mirar al pasado, porque los ojos los tiene en la frente y no en la nunca, señor Ministro" ${ }^{" 100}$. En ocasiones, los debates rayaban en lo absurdo y la tenacidad de los socialistas lograba implicar a parlamentarios como Miguel Martínez Cuadrado, quien ni siquiera había militado en $\mathrm{UCD}^{101}$.

Cuando se apelaba a la Transición en contextos electorales o debates parlamentarios de cierta intensidad política era palpable el doble filo que ejercía el recuerdo. En el Congreso, estos aspectos salieron únicamente a relucir cuando el CDS pudo haberse convertido en una alternativa de gobierno, entre 1986-1989, y normalmente, era el PSOE quien llevaba la iniciativa. Precisamente, en aquellas ocasiones en las que el CDS no constituía una amenaza política y era evidente su buena sintonía con el Gobierno, como en $1984^{102}$, 1990 o 1991, apenas se pasó de soslayo sobre la Transición y casi siempre con un tono medido, agradecido y anecdótico tanto por parte de González como de Suárez.

El CDS al proclamarse heredero del reformismo suarista y asumirlo como base ideológica lo introducía permanentemente en la contienda política y de este modo, lo hacía indefendible públicamente tanto para la derecha como la izquierda. Asimismo, su uso como recurso electoral estaba condicionado por su posición relativamente secundaria en el panorama político, así como la percepción institucional del propio Suárez y el vívido recuerdo, por parte de la sociedad, de su época de gobierno.

\section{3. El peso de la Historia: II República, Dictadura y Transición}

Si el espíritu de la Transición y UCD seguían vivos en el CDS y en el recuerdo de comentaristas y analistas políticos, no debemos olvidar aquellos episodios y conflictos irresueltos de la Transición -en parte, como consecuencia del modelo reformista y transaccional que inspiró el proceso- y que fueron objeto de desarrollos legislativos

\footnotetext{
${ }^{100}$ DSCD, Sesión Plenaria, 28 de octubre de 1986, nº 12, p. 465.

${ }^{101}$ DSCD, Sesión Plenaria, 22 de mayo de 1987, $\mathrm{n}^{\circ}$ 50. Véase la polémica entre Federico Ysart (CDS) y José V. Beviá a propósito del mayor o menor protagonismo de unos y otros en la tramitación de la Constitución, DSCD, Sesión Plenaria, 28 de febrero de 1989, nº 171, p. 10022.

102 “Comienzo lógicamente por agradecer el tono medido de las palabras del señor Suárez quien, sin duda, ha puesto de manifiesto que une a su condición de parlamentario su condición de ex Presidente de Gobierno", DSCD, Sesión plenaria, 25 de octubre de 1984, nº 159, p. 7155.
} 
durante los gobiernos socialistas ${ }^{103}$. En esta mirada al pasado, que comprende episodios históricos que van desde la II República hasta la Transición, seguiremos la obra de la profesora Josefina Cuesta Bustillo y nos centraremos en aspectos legales, en el "calendario democrático" -conmemoraciones, homenajes y aniversarios-, y finalmente, en la "recuperación memorial [...] de espacios y tiempos"104.

Los parlamentarios suaristas suscribieron el proyecto de ley del gobierno de rehabilitación de los militares de la Unión Militar Democrática (UMD), abriendo incluso el debate sobre la situación de otros militares que hubieran sufrido igualmente algún tipo de represión. Desde el principio de la II Legislatura, habían mostrado su intención de apoyar una proposición de ley de Izquierda Unida en este sentido, finalmente retirada ${ }^{105}$. En relación a la ampliación de las leyes de amnistía, el CDS apoyó las medidas que desde el Gobierno y la oposición intentaron extender los supuestos o las indemnizaciones de quienes fueron víctima de la represión. Para Rafael Arias-Salgado, diputado del CDS, era necesario cerrar un tema que se estaba prolongando desde hacía demasiado tiempo, se traslucía en sus palabras el temor a que estos debates pudieran servir para polarizar aún más la sociedad ${ }^{106}$.

Tabla 104: Leyes, posicionamientos y contenidos (memoria).

\begin{tabular}{|l|l|l|}
\hline Ley & Posicionamientos partidos estatales & Contenido \\
\hline $\begin{array}{l}\text { Ley de 24 de } \\
\text { diciembre de 1986, } \\
\text { número 24/1986 }\end{array}$ & $\begin{array}{l}\text { PSOE, CDS e IU a favor. } \\
\text { AP abstención }{ }^{107} .\end{array}$ & $\begin{array}{l}\text { Rehabilitación de los militares } \\
\text { profesionales (UMD). }\end{array}$ \\
\hline $\begin{array}{l}\text { Proposición de Ley } \\
\text { de IU (1988) }\end{array}$ & $\begin{array}{l}\text { IU y CDS a favor. } \\
\text { PSOE en contra. } \\
\text { PP se abstuvo. }\end{array}$ & $\begin{array}{l}\text { Indemnizaciones a presos políticos ya } \\
\text { beneficiados por la Ley de Amnistía de } \\
1977^{108} \text {. }\end{array}$ \\
\hline $\begin{array}{l}\text { Disposición } \\
\text { adicional 18 a la }\end{array}$ & $\begin{array}{l}\text { PSOE y CDS a favor. } \\
\text { PP en contra. }\end{array}$ & $\begin{array}{l}\text { Derecho a indemnización -a la persona } \\
\text { o al cónyuge supérstite- a quienes }\end{array}$ \\
\hline
\end{tabular}

\footnotetext{
${ }^{103}$ Debemos señalar, que en la II Legislatura apenas hemos encontrado posicionamientos del CDS sobre algunas medidas: ni en la prensa, ni en el Diario de Sesiones. Sobre la Ley Sindical de Patrimonio Acumulado: el CDS no presentó enmiendas, ni participó en los debates en comisión el 26 y 27 de noviembre de 1985 y el 05 de noviembre y 19 de diciembre en el Pleno (1985), tampoco participó en las votaciones. Idéntica situación nos encontramos ante la Ley de reconocimiento de derechos y servicios prestados a quienes durante la guerra civil formaron parte de las Fuerzas Armadas, Fuerzas de Orden Público y Cuerpo de Carabineros de la República (Ley 37/1984, de 22 de octubre).

${ }^{104}$ Algunas de las categorías usadas por la profesora Josefina Cuesta Bustillo en su análisis de la memoria durante la etapa democrática. En el aspecto legislativo, no obstante, iremos un poco más allá de la legislación únicamente referida a la amnistía, analizada sistemáticamente en la obra, CUESTA BUSTILLO, Josefina: La odisea de la memoria. Historia de la Memoria en España. Siglo XX, Madrid, Alianza, 2008, pp. 377-417.

105 "Satisfacción en CDS e izquierda Unida y prudencia en Coalición Popular", El País, 01 de noviembre de 1986.

${ }^{106}$ DSCD, Sesión Plenaria, 25 de septiembre de 1990, $\mathrm{n}^{\circ} 58$.

${ }^{107}$ En las votaciones efectuadas el 04 de diciembre al Proyecto de Ley, AP se abstuvo, El País, 05 de diciembre de 1986.

${ }^{108} A B C$, 08 de junio de 1988.
} 


\begin{tabular}{|l|l|l|}
\hline $\begin{array}{l}\text { Ley 29 de junio de } \\
1990 \text { número 4/1990 } \\
\text { (PGE) }\end{array}$ & IU-IC abstención. & $\begin{array}{l}\text { sufrieron prisión durante un mínimo de } \\
\text { tres años por supuestos contemplados } \\
\text { en la Ley de Amnistía (mayores de 65 } \\
\text { años el 21-12-1990) }\end{array}$ \\
\hline $\begin{array}{l}\text { Proposición de Ley } \\
\text { de IU }\end{array}$ & $\begin{array}{l}\text { Apoyo de toda la oposición. } \\
\text { Rechazada por el PSOE. }\end{array}$ & $\begin{array}{l}\text { Ampliación de los supuestos para } \\
\text { indemnizaciones a presos políticos ya } \\
\text { beneficiados por la Ley de Amnistía de } \\
1977 .\end{array}$ \\
\hline
\end{tabular}

Elaboración propia a partir de CUESTA BUSTILLO, J.: La odisea ..., DSCD y fuentes hemerográficas.

En otras ocasiones, aunque las iniciativas parlamentarias no afectaban directamente a episodios sucedidos durante la Dictadura, provocaban de forma tangencial el recuerdo de la misma. Esto se puso de manifiesto con la proposición de ley del diputado del Grupo Mixto y miembro del Partido Liberal, José Manuel Paredes, instando a la supresión y sustitución de la figura del "gobernador civil”. Quien fuera vicepresidente del PL, Antonio Jiménez Blanco, en las filas del CDS, apoyó la iniciativa y no sustrajo en su argumentación la evocación política de su papel no muy afortunado durante "el régimen anterior" o en épocas pretéritas, como la Restauración ${ }^{110}$. De un gran valor simbólico fue la pregunta formulada por el diputado centrista Antonio Garrosa en 1988 acerca de la posibilidad de repatriar "los restos mortales de don Antonio Machado", o al menos, dignificar su enterramiento en Collioure, en avanzado estado de abandono ${ }^{111}$.

Si las iniciativas anteriores, guardaban una estrecha con la "memoria" histórica reciente, en otras ocasiones, era la propia gestión política de UCD la que era objeto de investigación. Significativo fue el hecho de que sólo el PSOE, Democracia Cristiana formado casi exclusivamente por miembros de UCD- y el CDS impidieran el envío de un cuestionario a todos los altos cargos públicos existentes desde 1977 relativo a su patrimonio, en pleno debate sobre la corruptibilidad de los poderes públicos. Esta medida defendida en las filas de AP e IU, finalmente no cuajó ${ }^{112}$.

La retirada de los símbolos de la Dictadura o el reconocimiento de los actores políticos y sociales protagonistas de la II República fueron políticas apenas esbozadas

\footnotetext{
${ }^{109}$ Votación plenaria del día 18 de mayo de 1990 sobre las Disposiciones Adicionales $18^{\circ}$ y $19^{\circ}$ al Texto de Presupuestos Generales del Estado.

${ }^{110}$ Una argumentación, no obstante, cuyo pilar fundamental era la dificultad de armonizar dicha figura con la construcción del estado autonómico -como se reflejó en el Programa electoral para las elecciones autonómicas de 1991-. La medida fue rechazada por el PSOE y AP, DSCD, Sesión Plenaria, 21 de junio de 1988, n 124, pp. 7348-9.

${ }^{111}$ DSCD, Iniciativas Serie-D, número 220, 19 de septiembre de 1988.

${ }^{112}$ Portada de El País. Se señalaba: "con ello se pretendía neutralizar a los partidos que, como el CDS, la Democracia Cristiana y sectores de AP, contaban en sus filas con antiguos altos cargos de los Gobiernos de UCD”, editorial: "Tráfico de influencias", El País, 17 de junio de 1988. Véase, CONTRERAS, Lorenzo: "El frenazo", $A B C, 12$ de abril de 1988.
} 
en esta etapa y de las que disponemos escasas referencias. En Pamplona, el CDS aprobó junto a PSOE, HB y EA un Plan Especial del Ayuntamiento que implicaba la retirada del busto y la placa que el general Sanjurjo conservaba en la ciudad ${ }^{113}$. Por su parte, el Parlament de Cataluña aprobó una proposición no de ley en la que tachaba de "simulacro", el "consejo de guerra" de Lluis Companys. La "iniquidad" de la condena fue respaldada por PSC, CiU, ERC, IC, Mixto y CDS. A propósito de Manuel Azaña, de quien hemos hablado en epígrafes precedentes, en Madrid la Vía Borde de Hortaleza de la M-40 pasó a denominarse Avenida de Manuel Azaña en 1990. Se conmemoraba el cincuenta aniversario de su fallecimiento y Agustín Rodríguez Sahagún era el Alcalde de la Villa; un homenaje no exento de fricciones en el seno del Grupo Municipal (CDSPP) ${ }^{114}$. En 1992, el CDS presentó una Proposición no de Ley por la que se instaba, mediante la Ley de Patrimonio Histórico, a "asegurar la conservación y el uso público de los documentos particulares del General Franco, así como a seleccionar aquellos bienes muebles del mismo que merezcan la consideración de bienes de interés cultural" ${ }^{\prime 15}$.

En relación a los homenajes, sin duda, el momento más destacado tuvo lugar a propósito del X Aniversario de la Constitución (1988). Acontecimiento en el que como ha señalado Cuesta Bustillo al enumerar los artículos y dossieres que se hicieron a tal efecto, "el papel del Rey quedaba de relieve" "116 y una vez más, la presencia de Suárez no estuvo exenta de polémica. Relegado al cuarto lugar en los actos protocolarios de recepción de la Medalla al Mérito Institucional -tras los presidentes de las cámaras-, su participación en el acto permaneció en el aire hasta escasas horas antes de su inicio ${ }^{117}$. El CDS protestó abiertamente por la "cicatería socialista" y el propio Suárez señaló que acudía únicamente "por respeto a la Corona". En plena batalla política con el PSOE, la crónica del boletín suarista describía así aquel episodio: “[Suárez] recibió una calurosa

\footnotetext{
${ }^{113}$ Diario de Navarra, 24 de mayo de 1988.

114 “Azaña divide al gobierno que preside Rodríguez Sahagún”, ABC, 27 de abril de 1990.

${ }^{115}$ GONZALO, Manuel y PAESA, María (eds.): Memoria de la IV Legislatura...

${ }^{116}$ CUESTA BUSTILLO, Josefina: La odisea ..., p. 412. Más expeditivo se ha mostrado Gregorio Morán quien ha señalado: "la muerte política de estas tres figuras [Torcuato Fernández-Miranda, Santiago Carrillo y Adolfo Suárez] dejó el camino expedito a la consideración de que el Rey Juan Carlos era el único y excelso protagonista, aquel que por principio había estado a la altura de las circunstancias", ÍD.: El precio..., p. 27. Adolfo Suárez que nunca escatimó elogios a la Corona y a su contribución en el proceso de democratización, ha recordado que la Monarquía no efectuó la Transición sino que se convirtió en un imprescindible punto de apoyo, véase, nº00 de Cambio 16 (1991) reproducido en SUÁREZ GONZÁLEZ, Adolfo: "La transición española", Cambio 16, 7 de abril 2014 (nº 2193).

117 “Adolfo Suárez ha decidido no asistir a esa parte de la conmemoración”, El País, 07 de diciembre de 1988. Lo que subvertía el ordenamiento general de precedencias del Estado establecido en 1983, El País, 05 de agosto de 1983.
} 
ovación de los presentes, como desagravio y en reconocimiento a esa gran obra que fue la transición española" $" 118$.

Con motivo de este homenaje, Suárez, junto con otros protagonistas de la transición, plasmó su visión de los últimos diez años de Historia de España en la revista Cuenta y Razón, una mirada que aunque feliz, no ocultaba cierta amargura: "se está desnaturalizando el debate político y olvidando el impulso reformador que hizo posible la Transición" porque "la Constitución es válida, pero se ha devaluado el consenso" $" 119$.

Un año antes, a propósito del décimo aniversario de la llegada de la democracia, Adolfo Suárez, en un artículo publicado en la prensa, presentaba un balance general con algunos claroscuros, que aunque secundarios, no dejaban de ser significativos. Comenzaba elogiando el logro de tres realidades incontestables: la monarquía parlamentaria, el Estado de las Autonomías y la adhesión a la CEE. Y aunque constataba la buena salud de la legitimidad democrática -reconocimiento de los derechos humanos y expresión de la voluntad popular-, no valoraba igual su eficacia social, es decir, la capacidad del sistema para impulsar "la vertebración y el protagonismo de la sociedad" y manifestar "de manera normal e institucionalizada para la realización de esos derechos". Nuevamente, la solución pasaba por volver al diálogo y el acuerdo inter-partidario ${ }^{120}$.

\section{4. Exportando la Transición: la proyección internacional de Adolfo Suárez}

(1982-1991)

La transformación de los regímenes dictatoriales en democracias ha sido en las últimas décadas uno los principales focos de atracción académica en el campo de las

\footnotetext{
${ }^{118}$ Portada de $O I C D S, 17$, diciembre 1988. "Suárez: 'El Gobierno ha querido restar protagonismo a mi persona'", Diario 16, 08 de diciembre de 1988. En el reportaje emitido aquellas fechas por Documentos $T V$ Suárez rehusó participar. Según su versión le avisaron tardíamente de que había habido un cambio de guión y "le pidieron que hablara de las presiones que recibió por parte del Ejército y de la jerarquía eclesiástica [...alegando....] que eso no era lo acordado y se negó”, El País, 06 de diciembre de 1988.

${ }^{119}$ CUESTA BUSTILLO, Josefina: La odisea..., p. 412; El País, 16 de marzo de 1989. Véase, SUÁREZ GONZÁLEZ, Aadolfo: "Consideraciones sobre la transición española”, Cuenta y Razón, 41, 1988, pp. 13-22 y SUÁREZ GONZÁLEZ, Adolfo: "Vigencia de la Constitución”, $A B C, 06$ de diciembre de 1988.

${ }^{120}$ Refiriéndose a la recuperación del Parlamento, la modernización e independencia del poder judicial, la reforma de la administración, la mejora del sistema educativo y sanitario, el ajuste funcional y financiero del Estado de las Autonomías, la disminución del desempleo, el cumplimiento del referéndum de la OTAN y la mejora de las condiciones en la CEE, SUÁREZ GONZÁLEZ, Adolfo: "La salud de la democracia", Eslabón, 5, agosto-septiembre-octubre 1987 (artículo transcrito de Cambio 16, 26 de octubre de 1987).
} 
Ciencias Sociales" ${ }^{121}$. El concepto de "tercera ola"122, -al hilo de los procesos de democratización de Europa del Sur, Iberoamérica y Europa del Este-, significó el acelerador de un sinfín de estudios politológicos, comparativos, sociológicos e incluso, prescriptivos en las últimos años del siglo XX. La rápida instauración, expansión y divulgación teórica del paradigma transitivo, en general, y de la Transición española, en particular, se insertaba en el contexto de búsqueda de nuevas fórmulas de legitimación política tras el ocaso de la Guerra Fría y no ha sido ajeno a motivaciones fuertemente ideologizadas. ${ }^{123}$ En relación con este marco global, uno de los tópicos más extendidos en los análisis relativos a la Transición en España ha consistido en sostener su carácter “modélico”, e incluso, “exportable”, resaltando su carácter consensuado y pacífico ${ }^{124}$.

El área geopolítica en el que Suárez ejerció su, por definirlo de alguna manera, "activismo pro-democrático" fue Iberoamérica y en bastante menor medida, Europa del Este. En el primer caso, el declinar de las dictaduras militares y el advenimiento de los regímenes pluripartidistas durante la década de los años 80’ permitió a Adolfo Suárez asumir un papel protagonista en las relaciones entre España y el ámbito iberoamericano $^{125}$; protagonismo asentado sobre la popularidad a ambas orillas del Atlántico que había conseguido durante su etapa como jefe de gobierno.

\footnotetext{
${ }^{121}$ Sobre el uso que daremos a la palabra "transición", "es obligado recordar que buena parte de la literatura transicionológica [...] agrega a ésta un destino final de deseable consecución: la democracia. Hablamos entonces, en un sentido más restringido y a menudo problemático, de 'transiciones a la democracia”, TAIBO, Carlos: Las transiciones en la Europa central y oriental. ¿Copias de papel carbón?, Madrid, Los Libros de Catarata, 1998, p. 21.

${ }_{122}$ Algunos de los estudios más representativos, HUNTINGTON, Samuel: La Tercera Ola, Barcelona, Paidós Ibérica, 1998; O’DONNELL, Guillermo, SCHMITTER, Philippe C. y WHITEHEAD, Laurence (comps.): Transiciones desde un gobierno autoritario (I, II y III), Buenos Aires, Paidós, 1988.

123 "La fortuna de la experiencia histórica de la Transición española fue el haber permitido teorizar un modelo alternativo - pacífico, rápido y reformista- de acceso a la democracia a partir de dictaduras y regímenes autoritarios, válido para la coyuntura histórica de emergencia del capitalismo global", PÉREZ SERRANO, Julio: "La Transición a la democracia como modelo analítico para la historia del presente: un balance crítico" en QUIROSA-CHEYROUZE, Rafael (coord.): La Transición a la democracia, Madrid, Biblioteca Nueva, 2007, p. 67.

124 "La democracia española -y la Transición que la había hecho posible- era cada vez más valorada en todo el mundo, que parecía dispuesto a mostrarla como ejemplo a seguir por todos los países que pudieran y quisieran salir en paz de una etapa autocrática y caminar hacia un régimen de libertades", en NAVARRO, Eduardo: La sombra ..., p. 294. ORTIZ HERAS, Manuel: "Historiografía de la Transición", VI Jornadas de Castilla-La Mancha sobre Investigación en Archivos, Guadalajara, 2003. Disponible en: https://www.uclm.es/ab/humanidades/seft/pdf/textos Fecha de consulta: 11 de marzo de 2014. Esta perspectiva ha contado con un fuerte respaldo político, institucional y mediático, que se ha esforzado en generar una visión idealizada del proceso de Transición, PÉREZ SERRANO, Julio: "La Transición..." Véase también, CHAPUT, Marie-Claude y PÉREZ SERRANO, Julio (eds.): La transición española. Nuevos enfoques para un viejo debate, Madrid, Biblioteca Nueva, 2015.

${ }^{125}$ Una visión general en MALAMUD, Carlos: América Latina. Siglo XX: La búsqueda de la democracia, Madrid, Ed. Síntesis, 2003; ANDERLE, Adam y GIRÓN, José (eds.): Estudios sobre transiciones democráticas en América Latina, Oviedo, Universidad de Oviedo, 1997.
} 
Recorreremos las intervenciones más mediáticas de Adolfo Suárez en Iberoamérica, analizando por un lado, el discurso del propio Adolfo Suárez y el CDS, y por otra parte, algunas de las lecturas de la opinión pública iberoamericana y española. Para ello, abordaremos su papel en Argentina (1983), Uruguay (1984), Chile (1986 y 1988) y Nicaragua $(1989)^{126}$. Una época en la que no era extraño encontrar en la prensa comparaciones, cuando no anhelos del "modelo" o "factor" Adolfo Suárez: "El semanario El Pueblo -órgano oficial del Partido Revolucionario Febrerista- publicaba el pasado día 7 de mayo, en su columna de comentario internacional, un artículo titulado 'En el Paraguay se espera que surja un Adolfo Suárez"'127. Sobre Turquía, Blanco Tobío escribía: "Turgut Ozal está haciendo en su país un papel bastante parecido al de Adolfo Suárez en el nuestro..."

La escasa presencia que obtuvo el CDS en el parlamento, con sólo dos diputados en las elecciones de octubre de 1982, y una considerable marginación mediática, obligaron a Adolfo Suárez a poner en práctica una nueva estrategia de comunicación política basada en: "alternar su presencia en la política española con ausencias dosificadas del país para asegurarse una presencia internacional con eco en los m[edios] de c[omunicación] s[ocial] españoles" ${ }^{\prime 29}$. En la prensa internacional, las referencias a la fundación del nuevo partido fueron anecdóticas. Para Time, Suárez buscaba ejercer de apoyo en un futuro gobierno con una austera campaña basada únicamente en su persona en la que defendía posiciones socialdemócratas en lo económico y un duro discurso contra cualquier tentativa de involución militar $^{130}$, lo que para el semanario marxista Rouge tenía por objetivo ir preparando un futuro acuerdo de gobierno con el $\mathrm{PSOE}^{131}$. El semanario francés L'Express comentaba, como la creación del CDS cerraba el círculo-boucle est bouclée- en el proceso de desintegración de $\mathrm{UCD}^{132}$.

\footnotetext{
${ }^{126}$ En Iberoamérica llevó a cabo, al menos, doce viajes en este período, y sólo uno, a Europa del Este.

${ }^{127}$ MARTÍN PALLÍN, José Antonio: "La transición a la democracia única”, El País, 21 de julio de 1986. A propósito de Brasil, GUZZANTI, Paolo: "Il gigante Brasile prova la libertá", La Reppublica, 16 de noviembre de 1986. En relación al papel de P. Aylwin en Chile, BLANCO TOBÍO, Manuel: "Democracia cautiva", $A B C, 17$ de diciembre de 1989.

${ }^{128}$ BLANCO TOBÍO, Manuel: “Ozal sigue”, $A B C, 29$ de marzo de 1989.

${ }^{129}$ Documento del Archivo de José Luis Sanchís, colaborador de Adolfo Suárez, citado por FUENTES ARAGONÉS, Juan Francisco: Adolfo Suárez: la historia que no se contó, Barcelona, Planeta, 2011, p. 457.

${ }^{130}$ NIELSEN, John: “Spain's Socialists On The Move”, Time, 25 de octubre de 1982.

${ }^{131}$ PICQUET, Christian: "Les socialists face à leur succès", Rouge, no 1036, octubre-noviembre 1982.

${ }^{132}$ L'Express, 29 de octubre de 1982.
} 
Tras una primera aproximación, no muy exitosa, al mundo académico norteamericano en mayo de $1983^{133}$, Adolfo Suárez tuvo la oportunidad de volver la vista a Iberoamérica, área en el que se estaban comenzando a dar las circunstancias idóneas para su despliegue político: no había barreras lingüísticas ${ }^{134}$, disfrutaba de una gran popularidad y además, se comenzaban a vivir procesos políticos susceptibles de ser comparables al que él había protagonizado en España. Se daba la circunstancia de que Iberoamérica constituía también el ámbito de proyección internacional de su despacho de $\operatorname{abogados}^{135}$.

En noviembre de 1983, Adolfo Suárez se trasladó a Argentina para entrevistarse con el recién electo presidente Raúl Alfonsín, al parecer como portador de un mensaje privado de Felipe González. Adolfo Suárez era el primer líder internacional en acudir al país tras las elecciones de otoño de 1983. Suárez aparecía como el estandarte de la nueva legitimidad democrática contraída: "[tengo la] convicción profunda [...] que el proceso histórico que se abre en la Argentina es un proceso histórico trascendente, no sólo para la Argentina, sino para todo el mundo libre"136. Pero a la hora de abordar las claves del futuro proceso evitaba la concreción: “el objetivo es el mismo [soberanía popular y modernización] [...] Las diferencias son importantes [...] partimos de hechos distintos" $" 137$.

Desde el CDS, se valoraba positivamente la estrategia de su presidente para recobrar la centralidad mediática, "sus viajes a Hispanoamérica, y particularmente a Argentina [...] han contribuido poderosamente a que los analistas políticos empiecen a destacar

\footnotetext{
133 Ibid., p. 457.

${ }^{134}$ Hándicap argüido por su sucesor en el ejecutivo Leopoldo Calvo-Sotelo: “¡Cuánta mayor satisfacción la que obtenía Suárez de sus viajes a Hispanoamérica, sin intérpretes, sin intereses contrarios que discutir y vencer, donde le basta para el éxito con dejarse llevar por el prestigio que había ganado en España y por la retórica de las cordialidades!", CALVO-SOTELO, Leopoldo: Memoria viva de la Transición, Barcelona, Plaza \& Janés, 1990, p. 126.

${ }^{135}$ Durante estos años Adolfo Suárez estuvo "dedicado a su oficina de abogados y a establecer contactos con políticos latinoamericanos", en Hoy (Chile), 30 de junio de 1986. Emilio Romero más crudo escribía: "el duque de Suárez cultiva ahora la América hispana en sus personajes democráticos; tiene un bufete de influencias para los negocios internacionales [...] Políticamente, humanamente, es un extraterrestre. Su destino perpetuo es el de trashumante", en ROMERO, Emilio: Retratos de ..., pp. 174-6. "Yo me ocupé de establecer contactos con los principales despachos de abogados de Madrid -recuerda José Luis Graullera, con los que llegué a un principio de acuerdo para ofrecerles nuestros servicios en Iberoamérica. Pero ese proyecto se desvaneció desde el momento en que Adolfo decidió lanzarse de nuevo a la arena política", CONTRERAS, Emilio: Suárez..., p. 315.

${ }^{136}$ Portada y noticia principal en La Nación (Argentina), 10 de noviembre de 1983.

${ }^{137}$ Volvemos a encontrar reflexiones sobre la situación política española y sus posibles paralelismos con la futura situación argentina en La Nación (Argentina), 11 de noviembre de 1983. Iba a volver a Argentina: "Suárez y Fraga acompañarán al presidente del Gobierno en la toma de posesión de Alfonsín", El País, 27 de noviembre de 1983.
} 
que el centro pasa necesariamente por Adolfo Suárez y el CDS"138. Una visión que enlazaba con la actitud distendida y pródiga en entrevistas de un Adolfo Suárez que, desacreditado ante la opinión pública española, buscaba la complicidad de los líderes iberoamericanos $^{139}$.

La presencia de Adolfo Suárez en Iberoamérica no tardó en repetirse. En julio de 1984, tuvo lugar un encuentro sobre la Transición española en Montevideo, organizado por el Instituto de Cooperación Iberoamericana, durante el cual se anunció la asesoría de Adolfo Suárez al grupo de abogados encargados de la defensa del líder del Partido Blanco/Nacional y opositor a la dictadura militar, Wilson Ferreira Aldunate, encarcelado tras su regreso a Uruguay. El 20 de agosto, Adolfo Suárez acudía a Uruguay a dar su apoyo a Ferreira Aldunate, en un acto, que dentro de la dinámica del cambio de régimen uruguayo suponía un fuerte respaldo a la estrategia de este líder político, en ese momento "proscrito" por la dictadura ${ }^{140}$. A pesar de que a su llegada a la Convención del Partido Nacional Adolfo Suárez declaró, en relación a los rumores sobre la irritación de los militares por su presencia en el país que procuraba "separar lo profesional de lo político" "141, sus comentarios en favor de la constitución de regímenes democráticos supusieron finalmente su expulsión del país ${ }^{142}$.

Este suceso volvió a convertir a Adolfo Suárez en un fenómeno mediático tanto en España como en Uruguay, donde una multitud ciudadana lo escoltó entre aplausos y cánticos camino del aeropuerto, entremezclándose el rechazo a la dictadura militar junto con el reconocimiento del ex presidente de España. La presencia de Adolfo Suárez implicaba, de forma inevitable, la búsqueda de paralelismos políticos. Precisamente, la entrevista que la revista Jaque logró realizar a Suárez, antes de su partida, llevaba por título: "La transición requiere audacia". Nuevamente, sin embargo, los paralelismos

\footnotetext{
${ }^{138}$ Carta del secretario general centrista a la militancia en, CASO GARCÍA, José Ramón: "Carta del secretario general", Boletín de Difusión Cultural, 1, 1984, Madrid.

${ }^{139}$ Como así retrataban las crónicas de Martín Prieto, véase, El País, noviembre de 1983.

${ }^{140}$ Suárez en una entrevista en Jaque subrayaba: "ese fue uno de mis aciertos: evitar que nadie quedara proscripto. De ahí [...] la legalización que hice en España del Partido Comunista", en el semanario vinculado al político del Partido Colorado, Manuel Flores Silva, Jaque (Uruguay), 24 de agosto de 1985; disponible en: http://biblioteca.periodicas.edu.uy/collections/show/20. Fecha de consulta: 10 de mayo de 2015. La estrategia de Ferreira Aldunate, que había decidido marginalizar al Partido Nacional en el llamado "Pacto del Club Naval", era un pulso al gobierno militar, NAGY, M.: "La caída de la dictadura y el nuevo sistema político en Uruguay” en ANDERLE, Adam y GIRÓN, José: Estudios... pp. 291-315.

141 “Adolfo Suárez, expulsado de Uruguay (actualidad gráfica)", $A B C, 21$ de agosto de 1984.

${ }^{142}$ Periódicos uruguayos como El Día, Opinar -dirigido por un líder del Partido Colorado, "Suárez no es tirabombas, ni vino a exaltar a nuestros tirabombas autóctonos. Suárez es un político particularmente ecuánime, tranquilo y sensato"- y El Telégrafo la tacharon de arbitraria, según recogieron $A B C, 22$ de agosto de 1984 y El Noticiero Universal, 26 de agosto de 1984.
} 
eran esquivados explícitamente por Adolfo Suárez, quién no obstante no dudaba en detallar en profundidad su papel en el surgimiento de la democracia en España, enfatizando su protagonismo personal, "por la operación política que diseñé y dirigí por aquel entonces"143. A su vuelta a Madrid, estuvieron presentes un buen número de exiliados uruguayos (del Frente Amplio y del Partido Nacional) así como los principales líderes del CDS. ${ }^{144}$ En la prensa española, junto a un reconocimiento unánime y general -"los dictadores le han hecho el máximo honor que puede recibir un demócrata: considerarlo peligroso para la dictadura" ${ }^{145}$ - el gesto de Suárez recibió interpretaciones diversas. Si desde la izquierda, se elogió sin reservas la actuación de Suárez, los sectores más conservadores anhelaron un gesto similar ante las dictaduras de izquierdas, y en todo el panorama político nacional, se subrayaban los réditos electorales de su expulsión, para la mayoría, el principal motor de su visita. Ricardo de la Cierva se preguntaba:

Es un nuevo capítulo arrebatador y apasionante de su singular biografía que como diría Malraux toma cada vez más visos de antibiografía [...] no sé si seguirá cumpliendo el efecto moral de ciertos editoriales empeñados en elogiar como aplicación directa de las teorías de Gramsci a los políticos de la derecha, cuando se convierten al más ardoroso y emocionante de los izquierdismos [...] el nuevo descubrimiento de América, por el ex presidente Suárez, ¿no será también obra de un equipo y no solamente de un genio? ${ }^{146}$

Poco antes del episodio uruguayo y de forma muchos menos espectacular, Paraguay, bajo la férrea dictadura de A. Stroessner había prohibido la intervención de Gutiérrez Mellado y Adolfo Suárez en un ciclo de conferencias ${ }^{147}$.

De puertas adentro, los gestos de Suárez permitían relanzar la imagen de un partido y generar un poderoso caudal de atracción política: “CDS considera que España tiene una enorme potencialidad moral y cultural, que viene dado por su lengua, historia y pacífica

\footnotetext{
143 “Adolfo Suárez es para los uruguayos el padre de la transición española. ¿Qué lecciones puede dejar de esa experiencia extraordinaria? [...] Usted está intentando llevarme a los problemas internos del país. Pero yo sigo con España”, Jaque (Uruguay), 24 de agosto de 1984.

${ }^{144} A B C, 24$ de agosto de 1984.

145 Editorial: "Un hombre peligroso", El Noticiero Universal, 22 de agosto de 1984. Editorial: "Ex presidente "non grato"', El País, 22 de agosto de 1984. En el caso de $A B C$ destacándole como "figura del día": "postura digna en defensa de las libertades [...] ejemplo a seguir en la transición pacífica hacia un sistema de libertades", en $A B C, 22$ de agosto de 1984. Editorial: "El difícil camino de Iberoamérica hacia la democracia", $Y a, 23$ de agosto de 1984. Asimismo, PDP, PCE y PSOE emitieron comunicados en favor de Suárez.

${ }^{146}$ DE LA CIERVA, Ricardo: "La felicidad de Suárez", Ya 24 de agosto de 1984. Véase también, "La expulsión de Suárez abre una polémica entre AP y CDS", El Noticiero Universal, 25 de agosto de 1984; "Fraga acusa a Suárez de buscar publicidad con s visita a Uruguay", Ya, 25 de agosto de 1984. Reclamando un gesto similar ante las "dictaduras de izquierda", en el editorial: "Una expulsión dictatorial", $A B C, 22$ de agosto de 1984.

${ }^{147}$ La Vanguardia, 11 de julio de 1984.
} 
transición democrática que puede convertir en influencia y liderazgo en la política mundial"148.

A finales de la década de los 80', el papel de Adolfo Suárez en las relaciones internacionales adquirió una nueva dimensión gracias a su nombramiento como vicepresidente (septiembre de 1988) y posteriormente presidente (septiembre de 1989) de la Internacional Liberal y Progresista; asimismo, iba a contar con un fuerte respaldo político a nivel nacional, debido al éxito electoral del CDS en 1986, convertido entonces en tercera fuerza política y amenazando el incipiente bipartidismo entre PSOE y AP. Se produjo en este período un exponencial aumento de sus "visitas" a Iberoamérica, normalmente, a propósito del reforzamiento de lazos con partidos afines al liberalismo al que se sumó a finales de la década, un ámbito geopolítico nuevo, el de Europa del Este.

En Europa la prensa glosó con interés el nuevo protagonismo político de Suárez, subrayando su renacimiento gracias a un partido creado de la nada. La Reppublica publicaba en su portada: "E adesso Gonzalez dovrá affrontare la stella Suarez"149 . El día 21 de junio se subrayaba el protagonismo de Adolfo Suárez durante la campaña con un amplio reportaje titulado: "Un Duca per "matar' a Felipe" 150 . El portugués Diario de Notícias publicaba una fotografía de Suárez ejerciendo el voto en sus páginas interiores. En su editorial subrayaba que si el PSOE había virado del socialismo a un ligero escoramiento a la izquierda, el CDS aspiraba a ejercer de referencia simétrica en el centro-derecha. Parecía confirmarse la preferencia del electorado español por el espacio de centro ${ }^{151}$. El francés L'Express perfilaba un Suárez "sans complexe", abierto desde el centro hacia la izquierda, lo que para el corresponsal de The New York Times, Edward Schumacher, constituía un discurso "populist, anti-American" que le había hecho ganar enteros en las últimos días de campaña ${ }^{152}$. Para Time el éxito de Suárez se basaba en el afecto que conservaba para muchos españoles: "for his role in the transition"153.

\footnotetext{
${ }^{148}$ El valor del centro, CDS, 1986, p. 120.

149 Artículo de Paolo Guzzanti. En páginas interiores: "Il balzo del centro di Suárez è la novità delle elezioni espagnole", La Reppublica, 24 de junio de 1986.

${ }^{150}$ Artículo de Paolo Guzzanti, La Reppublica, 21 de junio de 1986. Días antes, se barajaba como posible un gobierno de coalición, o al menos un entendimiento, entre el PSOE y el CDS, La Reppublica, 19 de junio de 1986.

${ }^{151}$ Editorial: “A vitória que se esperaba”, Diario de Notícias, 23 de junio de 1986.

152 SCHUMACHER, Edward: “Spanis Socialists' Majority at Stake in Voting Today", The New York Times, 22 de junio de 1986.

${ }^{153}$ PHILLIPS, B. J.: "Toward victory”, Time, 23 de junio de 1986.
} 
En diciembre de 1986, Adolfo Suárez acudió junto con Leopoldo Torres (PSOE) y Óscar Alzaga (PDP) a Chile para entablar contacto con algunos políticos opositores a la dictadura de Pinochet y participar en las jornadas de la Fundación Frei "Consenso y Transición a la Democracia: la experiencia de España"154 . Como señalaba El País, "los paralelos y diferencias con la transición española [marcaron] la visita" ${ }^{155}$. Las charlas y entrevistas de Adolfo Suárez durante su estancia seguían el mismo patrón, subrayando los sucesos acaecidos en España como "ejemplo" de lo que podía ser un caso de democratización en base a dos polos, consenso y no revisión del pasado. ${ }^{156}$ Sin embargo, la actitud de Adolfo Suárez distaba en cierto modo de su experiencia previa en Uruguay o Argentina desarrollada en un ambiente si cabe decirlo, más espontáneo, reflejado tanto en los actos, como en las opiniones-.

En relación a la dictadura chilena era coherente con el posicionamiento político de su partido, que marcaba así distancias con la derecha representada por Alianza Popular. En el contexto de la celebración de una jornada cívica contra la dictadura chilena, el CDS en su Congreso Nacional había aprobado una moción apoyando una "vía pacífica hacia la democracia" y mostrando su repulsa ante "los trece años de feroz dictadura que sufre el pueblo de Chile, desde que el general Pinochet abortara salvajemente el Gobierno constitucional y legítimo de Salvador Allende" ${ }^{157}$. En esta dialéctica de enfrentamiento entre AP y el CDS, medios como $A B C$ criticaron nuevamente la parcialidad de la actitud de Adolfo Suárez, demandando su visita a Cuba o Nicaragua, ${ }^{158}$ e incluso, los columnistas más beligerantes pusieron sobre el tapete los aspectos menos encomiables del cambio de régimen español: "suponemos que ha debido hacer hincapié en la necesidad de partir de donde él partió, de una fuerte posición en la situación anterior. Esa, y no otra, es la enseñanza que con más legitimidad puede impartir"159.

Cuando en septiembre de 1988 en Pisa se produjo la integración del Centro Democrático y Social en la Internacional Liberal y Progresista, el discurso de ingreso de Adolfo Suárez hizo hincapié en los vínculos entre la ideología liberal-progresista y la

\footnotetext{
${ }^{154}$ Visita ampliamente recogida en el libro de LEMUS, Encarnación: En Hamelin... La Transición española más allá de la frontera, Oviedo, Septem, 2001, pp. 129-134.

${ }^{155}$ MÉDANO, M.: "Suárez pide en Chile la unidad contra Pinochet”, El País, 12 de diciembre de 1986.

${ }^{156}$ Con el fin de no incomodar a las Fuerzas Armadas, ni al empresariado y asegurar la "vía pacífica" a la democracia, como expone Encarnación LEMUS: En Hamelin... p. 131.

${ }^{157}$ Moción presentada en el II Congreso del CDS, el 14 de septiembre de 1986, en Boletín CDS Madrid, 3, Madrid, 1986.

158 "Denunciar a medias (editorial)", $A B C, 04$ de enero de 1987.

${ }^{159}$ FERNÁNDEZ, Celestino: "Tres, en Chile", ABC Sevilla, 18 de diciembre de 1986.
} 
Transición exponiendo lo que no dejaba de ser el guión para una vía pacífica a la democracia y que remitía a su visión de lo sucedido en España: "las primeras y más urgentes medidas fueron la amnistía, la implantación de los Derechos humanos, la legalización de todos los partidos políticos y la celebración de elecciones generales libres $[. .$.$] predestinadas a elaborar una Constitución" { }^{\text {160 }}$. No por casualidad dedicó los últimos párrafos de aquel discurso al mundo latinoamericano ${ }^{161}$.

Aquel congreso supuso además el nombramiento de Adolfo Suárez como vicepresidente y responsable de todo lo relativo a Iberoamérica de la ILP: "la primera tarea de Suárez [...] será encabezar la representación que viajará el 1 de octubre a Chile [celebración de un referéndum sobre la continuidad de Pinochet al frente del Estado]"162. Las conclusiones de la ponencia sobre la situación en Chile, -cuya comisión estaba comandada precisamente por el centrista y ex PSP, Raúl Morodo-, marcaron la pauta a seguir: apoyo del "no" en el plebiscito y salvaguarda de la libertad y transparencia en el mismo. ${ }^{163}$ En España, los sectores más conservadores subrayaron nuevamente el carácter electoralista de la estrategia de Adolfo Suárez aunque no pudieron dejar de alabar su disposición, "dando la cara por las urnas"164, y admitir, junto con periódicos como El País, la considerable brecha ideológica existente entre Alianza Popular y el Centro Democrático y Social. ${ }^{165}$ En Chile, la presencia de Adolfo Suárez, como parte de una delegación de personalidades internacionales y partidario del "no", fue vista por la dictadura de Pinochet como una amenaza. A su llegada, miembros de la organización fascista "Tradición, Familia y Propiedad" lo recibieron entre abucheos y gritos de "traidor" y "Kerenski"166. La prensa oficial consideró a las delegaciones internacionales injerencias externas y en el caso de Adolfo Suárez trató de

\footnotetext{
160 "Intervención de Adolfo Suárez, presidente del Centro Democrático y Social en la Internacional Liberal", Pisa, 15 a 18 de septiembre de 1988, MAST.

${ }^{161}$ Ibid., p. 9.

162 JÁUREGUI, Fernando: "El líder del CDS, elegido vicepresidente de la Internacional Liberal", El País, 16 de septiembre de 1988.

163 "International Resolution IX. Chile", en Liberal International Congress, 15-18 septiembre de 1988, MAST.

164 JIMÉNEZ LOSANTOS, Federico: “AP ya ha perdido en Chile”, ABC, 06 de octubre de 1988.

165 "Alianza Popular volvía a poner de manifiesto las dificultades de la derecha española para limar su imagen autoritaria, -días antes, el senador aliancista Juan de Arespacochaga había defendido públicamente a Pinochet-," en PENELLA, Manuel: Los orígenes..., pp. 1033-1034; "Chile ante su destino (editorial)", El Pais, 04 de octubre de 1988.

${ }^{166}$ COMAS, J.: "Adolfo Suárez, abucheado por ultraderechistas", El País, 04 de octubre de 1988. Un término ya usado durante la Transición por la extrema derecha, como en el Alcázar, en RODRÍGUEZ JIMÉNEZ, José Luis: Reaccionarios y golpistas: la extrema derecha en España: del tardofranquismo a la consolidación de la democracia, 1967-1982, Madrid, CSIC, 1994, p. 276.
} 
desacreditarle, ${ }^{167}$ paradójicamente, recordando su pasado dictatorial: "el novísimo vicepresidente de la 'Internacional Liberal' no ha sido ciertamente muy fiel a sus ideas políticas. Más bien veleidoso según los españoles, [...] abrazó el franquismo, y [...] Falange española, tildada de 'fascista' por la izquierda y centro izquierda" ${ }^{\text {"168 }}$.

La siguiente actuación relevante de Adolfo Suárez en el ámbito internacional tuvo lugar en Centroamérica, -Guatemala, Nicaragua, Costa Rica y República Dominicana-, donde intentaba promocionar políticamente a los partidos de la ILP, con el elocuente argumento de que: "el centrismo es una fórmula adecuada para que renazca o crezca la libertad y se permita la consecución o el fortalecimiento de una democracia [en una referencia directa a UCD]" ${ }^{\text {169 }}$. Precisamente su protagonismo histórico le permitía entrar en contacto con los líderes más importantes del área, como sucedió en Nicaragua con Daniel Ortega. ${ }^{170}$ En aquella entrevista, Adolfo Suárez valoró positivamente los pasos dados hacia la apertura por el régimen sandinista, recomendó la concurrencia de todos los partidos a la cita electoral prevista para 1990 y en su tono habitual dejó caer que "si él fuera Jefe de Estado brindaría una amnistía general para conciliar los intereses de la oposición, aclarando sí, que ésta no era una recomendación para el Presidente Ortega sino una opinión muy particular" ${ }^{171}$. Si la derecha española volvió a incidir en la parcialidad de Adolfo Suárez en su trato con los distintos regímenes iberoamericanos ${ }^{172}$, la prensa oficial nicaragüense extrajo sus propias lecciones a propósito de la legitimidad de la próxima convocatoria electoral:

Hoy que el político español nos visita, nos parece oportuno recordar que entre los mayores méritos de Suárez está el HABERLE QUITADO EL MIEDO A LA DEMOCRACIA a más de uno de los dirigentes de los principales partidos españoles. [...] A nadie va a asombrar pues, que las reformas lleguen al impulso del gobierno y que las elecciones se realicen con los que no tengan miedo a la democracia ${ }^{173}$.

\footnotetext{
167 “Intromisión extranjera (editorial)", La Tercera (Chile), 03 de octubre de 1988.

168 “Adolfo Suárez: de franquista a liberal”, La Tercera (Chile), 02 de octubre de 1988.

169 "Embajador de España agasajó al líder centrista Adolfo Suárez”, La Hora (Guatemala), 04 de abril de 1989.

${ }^{170}$ Adolfo Suárez había acudido a apoyar al líder liberal Virgilio Godoy, miembro de una oposición bastante dividida en la que existió una cierta pugna por entrar en contacto directo con Suárez y por ende, obtener una mayor legitimación, véase, Nuevo Diario (Nicaragua), 30 de abril de 1989.

${ }^{171}$ Nuevo Diario (Nicaragua), 02 de abril de 1989. Sobre el contexto político nicaragüense, MALAMUD, C.: América Latina ... pp. 133-144.

${ }^{172}$ Véase, $A B C, 24$ de abril de 1989.

173 AGUIRRE, Danilo: "Don Adolfo Suárez y un paralelo con España (editorial)", Nuevo Diario (Nicaragua), 30 de marzo de 1989. En esta línea, en el caso de Guatemala: "su visita a nuestro país fue ampliamente aceptada ya que aportó valiosos conocimientos a la problemática de la naciente democracia guatemalteca", La Hora (Guatemala), 04 de abril de 1989.
} 
En palabras de Carlos Rodríguez Braun, Suárez se había convertido en Iberoamérica en "el profeta del nuevo régimen desde las entrañas del antiguo" ${ }^{174}$. Uno de sus últimos viajes, todavía como presidente del CDS, tuvo lugar a Cuba en el verano de 1991. Episodio recordado por Raúl Morodo en sus memorias, quien certifica las buenas relaciones entre Fidel Castro y Adolfo Suárez y que tuvo un escasísimo impacto en los medios, que lo reseñaron como: "Suárez viaja a Cuba para pedir a Castro cambios democráticos"175. Un viaje en el que al parecer Suárez confesó a Morodo que su padre había residido durante un período de su vida en Cuba ${ }^{176}$. En una de las escasas declaraciones de Suárez sobre su relación con Castro había declarado en 1985:

Suárez se refirió por una alusión del preguntante, a sus relaciones con Fidel Castro: Yo me siento con Castro estupendamente y le estoy muy agradecido por servicios que me ha prestado a mí, a España y que algún día se sabrán. También es verdad que me manda cada veinte días una caja de cohíbas y le estoy agradecido por ello; otros dejaron de mandarme las cajas cuando dejé la presidencia del Gobierno, hay que decir que Castro es más coherente que ellos ${ }^{177}$.

A comienzos de la década de los 90', poco antes de abandonar, tanto a nivel nacional como internacional, la política activa, la voz de Adolfo Suárez pudo escucharse en Europa del Este, unos episodios que precisan de una breve contextualización ${ }^{178}$.

La invasión soviética de Afganistán y el triunfo en las presidenciales de R. Reagan provocaron el súbito recrudecimiento de una Guerra Fría que parecía haberse ralentizado gracias a los acercamientos entre R. Nixon/G. Ford y L. Brezhnev. El CDS, alejado de los postulados defendidos por Reagan, no entendía el conflicto internacional sólo en términos axiológicos o políticos, sino esencialmente como una deriva absurda y apocalíptica, "falso equilibrio [...] [que] precipita al mundo inevitablemente hacia el abismo de la autodestrucción"179. Su discurso, aunque nunca explícitamente "neutralista", se basaba en la distensión militar, la imperiosa necesidad de poner fin a la política bipolar y la necesidad de dotar a Europa de una mayor autonomía política y militar. Como miembro del Interaction Council -organización internacional de ex presidentes-, Suárez señaló textualmente: "los foros internacionales diseñados en 1945 tienen una efectividad muy relativa [...] la lucha contra el subdesarrollo es inseparable

\footnotetext{
${ }^{174}$ RODRÍGUEZ BRAUN, Carlos: "El Bautista”, Diario 16, 14 de octubre de 1991.

${ }^{175}$ El País, 09 de julio de 1991.

${ }^{176}$ MORODO, Raúl: Atando cabos..., p. 50.

177 Asamblea del CDS en Navarra, Diario de Navarra, 01 de junio de 1985.

${ }^{178}$ Abandonó su escaño en el Congreso de los Diputados, así como la presidencia del CDS, en 1991, año en el que pasó a formar parte de una troika en la presidencia de la Internacional Liberal.

${ }_{179}$ Comunicación sobre Seguridad, Defensa Nacional y Política Militar (II Congreso), CDS, Madrid, 1986.
} 
de la voluntad de desarme" ${ }^{\text {180 }}$. En general, su actitud crítica con el imperialismo norteamericano (y por supuesto, soviético) conectaba con buena parte de la sociedad española ya que como señala Ángel Viñas: "no hay que olvidar que en los años de la Administración Reagan ciertas actuaciones de Washington en el tablero internacional alimentaron el difuso sentimiento antiamericano de grandes sectores de la sociedad"181.

El nuevo clima de acercamiento entre EE.UU. y la URSS, inaugurado con la llegada de M. Gorbachov al poder y el cambio de postura de Reagan, fue acogido con un entusiasmo generalizado en la sociedad europea, del que el CDS no fue una excepción: "las conversaciones de desarme han estado estancadas durante muchos años. Han coincidido dos destacadas personalidades, Reagan y Gorbachov [...] De esa cooperación y comprensión mutua se puede derivar nuestra esperanza de supervivencia" ${ }^{\text {182 }}$. Los nuevos liderazgos, el fracaso económico del modelo comunista y las transformaciones subsiguientes que se habían originado en el seno de las instituciones soviéticas debían servir a su vez para apuntalar una nueva política de la CEE basada en la "apertura al Este”, especialmente dirigida a los países centroeuropeos.

La caída del Muro de Berlín en el otoño de 1989 desencadenó los últimos episodios de la Guerra Fría, abriendo la puerta al fin de las dictaduras comunistas del Este de Europa. De forma paralela al declive de su actividad política en España, debido al fuerte retroceso electoral de 1989, Adolfo Suárez fue refugiándose cada vez más en la política internacional; una vez más, el modelo de transición española era muy valorado en los procesos de cambio político, en este caso europeos: participó en la campaña electoral húngara apoyando al candidato del partido liberal Alianza de Demócratas Libres, pronunció un vibrante discurso de clausura en el Congreso de Helsinki de la ILP, e incluso, se barajó la posibilidad de concertar una entrevista con Gorbachov ${ }^{183}$. La Transición volvía a ejercer un poderoso influjo internacional ${ }^{184}$.

\footnotetext{
${ }^{180}$ El Noticiero Universal, 17 de enero de 1985.

${ }^{181}$ VIÑAS, Ángel: En las garras del águila: Los pactos con Estados Unidos, de Francisco Franco a Felipe González (1945-1995), Barcelona, Crítica, 2003, p. 453.

${ }^{182}$ CASO GARCÍA, José Ramón: Una sociedad ..., p. 27. Véase también, FONTANA LÁZARO, Josep: Por el bien del imperio: una historia del mundo desde 1945, Barcelona, Pasado y Presente, 2011, pp. 549-50.

${ }^{183}$ TERTSCH, Hermann: "Budapest acusa a Bucarest”, El País, 24 de marzo de 1990.

${ }^{184}$ Según comentaba en la prensa el diputado centrista Martínez Cuadrado, "la Constitución española de 1978 ha sido estudiada y ha servido de orientación a la Unión Soviética para efectuar la transición de un régimen autoritario a otro de pluralidad política [...] aseguró que su afirmación está basada en el testimonio de altos funcionarios de aquel país, quienes le confirmaron que habían analizado la Carta Magna española", Diario 16, 20 de marzo de 1989.
} 
Para Adolfo Suárez -en una línea de opinión cercana a Ralf Dahrendorf- las "transiciones" de Europa del Este constituían ante todo un motivo de celebración por la recuperación de las libertades democráticas: “el cambio de Europa Central y Oriental hacia la democracia liberal constituye un proceso revolucionario del que no existen precedentes en la historia contemporánea" ${ }^{\text {185 }}$. Sin embargo, su apoyo a los procesos democratizadores de Europa del Este ${ }^{186}$, no implicaba necesariamente la asunción de todos los presupuestos del neoliberalismo económico representado por el FMI, siendo preciso legislar "contra los excesos y los abusos que puede producir la liberalización de la economía",187.

El estallido de la Guerra del Golfo puso de manifiesto los retos a los que se enfrentaban las nuevas relaciones internacionales después de la caída del Muro. Resulta sorprendente ver como Oriente Medio iba a ser el principal foco de inestabilidad y desequilibrios desde los años 90' tal y como había predicho Adolfo Suárez diez años antes. En una de sus últimas intervenciones en el Congreso, volvió a incidir en que junto a la celebración de una Conferencia de Paz sobre Oriente Medio al finalizar el conflicto, era necesario otorgar la posibilidad al pueblo palestino de ejercer su derecho de autodeterminación junto a Israel porque "o las resoluciones de la ONU tienen todas el mismo valor [...] o no volverá a ser posible convocar a la comunidad internacional"188.

Las reflexiones de Adolfo Suárez sobre el orden internacional posterior a la Guerra Fría mantuvieron un tono, ciertamente pesimista, tanto por los nuevos desequilibrios y hegemonías como por la creciente desigualdad. En primer lugar, consideraba ineludible poner límites a la industria armamentística, subrayando la responsabilidad fundamental

\footnotetext{
185 "Suplemento: Discurso de Clausura de Adolfo Suárez en el Congreso de la I.L.P.", OICDS, 28, noviembre 1990; DAHRENDORF, Ralf: "Un aire nuevo para Europa", OICDS, 19, diciembre 1989.

${ }^{186}$ El CDS condenó enérgicamente el golpe de estado de 1991 o la intervención del Ejército Soviético en Lituania, OICDS, 30, enero 1991.

${ }^{187}$ OICDS, 28, noviembre 1990. En este sentido, E. Punset, eurodiputado del CDS y presidente de la Delegación del Parlamento Europeo para Polonia escribía: "me caben pocas dudas de que el tránsito de una economía intervenida a una economía de mercado constituye una experiencia tan compleja y sin precedentes que, desde un punto de vista estrictamente técnico, no tiene solución a menos que concurran dos factores básicos: una luz intensa que ilumine el proceso de ajuste para saber en cada momento lo que está ocurriendo y una red de seguridad susceptible de neutralizar las distorsiones que generan los propios mecanismos de corrección”, PUNSET, Eduard: "El reto de Europa Central", El País, 30 de abril de 1990. ${ }^{188}$ DSCD, Sesión Plenaria, 18 de enero de 1991, no 81, p. 4035. El CDS apoyaba el envío de tropas al Golfo con el fin de llevar a cabo el "bloqueo" a Irak, aunque el inicio de las hostilidades, orientó su postura hacia el retorno de las mismas El País, 17 de septiembre y 19 de enero de 1991. Para Lorenzo Contreras, se encontraban en un punto intermedio entre el pacifismo, crítico con el doble rasero de la comunidad internacional, y el compromiso con los aliados, "Debate en Blanco y Negro", $A B C, 20$ de enero de 1991.
} 
de Occidente como principal exportador ${ }^{189}$. En segundo lugar, era preciso redefinir las relaciones del mundo occidental con el islam; el empleo de la fuerza podía originar "secuelas de terrorismo y enfrentamiento". En tercer lugar, la CEE había tenido una actuación, cuanto menos, secundaria en el episodio bélico del Golfo, precisamente cuando debido al proceso de disolución del Pacto de Varsovia se habían dado unas circunstancias históricas inmejorables para dar un paso al frente en el proceso de integración europea, incluso, desde el punto de vista de la seguridad y la defensa ${ }^{190}$.

El final de la Guerra Fría no era susceptible de una lectura eufórica y victoriosa, y mucho menos, se podía hablar de una nueva armonía global. La tensión E-O era ahora reemplazada por el abismo social, económico y político que suponía la brecha N-S. El slogan del "fin de la historia" y el llamado triunfo de la democracia y la libertad eran un adorno teórico innecesario en un mundo "en el que las 225 personas más ricas poseen tanto como el $72 \%$ de la Humanidad". El fin del totalitarismo comunista, pensaba Suárez, no podía usarse como excusa para soslayar el componente igualitario y solidario de nuestras democracias, en definitiva, sociales y pluralistas ${ }^{191}$.

\footnotetext{
${ }^{189}$ Las interpelaciones del CDS a lo largo de las legislaturas precedentes sobre casos de ventas de armas al gobierno, habían sido realmente numerosas.

${ }^{190}$ SUÁREZ GONZÁLEZ, Adolfo: "Reflexiones para después de una guerra", El País, 03 de marzo de 1991.

${ }^{191}$ Conferencia "Liberalismo y democracia" prevista para el 08 de marzo de 1991, Archivador 1, Dossier 2, AJTS/ENA.
} 

EPÍLOGO:

EL CDS DESPUÉS DE ADOLFO SUÁREZ 

Tras el Congreso Extraordinario celebrado en Madrid en septiembre de 1991, tomó las riendas del CDS Rafael Calvo Ortega acompañado en la Secretaría General por Antoni Fernández Teixidó. Las deudas, el alejamiento del Grupo Parlamentario y la progresiva desafección de la militancia constituían los principales retos a los que tuvo que enfrentarse la nueva dirección, a la par que se debía hacer frente a las diferentes citas electorales. Aunque sin duda, como acertadamente ha señalado un dirigente centrista: "lo definitivo fue cuando Adolfo Suárez presentó su dimisión como presidente del partido, apartándose de la dirección del mismo. Era un partido de corte personalista y perder a nuestro mejor valor nos precipitó hacia la desaparición"”.

Poco después de asumir la Presidencia del CDS en 1991, Rafael Calvo Ortega declaraba que el "bloque constitucional" era "un mal recuerdo"2. El propio Caso hacía una lectura bastante negativa de la colaboración centrista con el PSOE: "nuestro esfuerzo ha sido inútil -dijo-, y por ello hemos perdido la confianza"3. El radicalismo liberal del CDS fue el "banderín de enganche" de la nueva estrategia. Como ha señalado el investigador Jordi Capo Giol, el cambio de estrategia se produjo a partir del verano de 1991: "es de destacar que el acceso a la dirección de Calvo Ortega supuso un incremento de la misma actividad opositora (¿o simplemente de actividad?) en comparación al primer período de la legislatura"4. Sin embargo, esta mayor presencia no se correspondió con su visibilidad en los medios, siendo un partido absolutamente secundario en las grandes citas y debates políticos.

En octubre de 1991, Alejandro Rebollo abandonaba el cargo de portavoz siendo sustituido por José Ramón Caso, frente a la candidatura planteada por Rafael AriasSalgado. En estos momentos, la descoordinación entre el partido y el Grupo Parlamentario era evidente. José Ramón Caso, fuertemente criticado por numerosos sectores del partido, ejerció entre 1992 y 1993 como representante del CDS en los grandes debates celebrados en el Congreso como el Debate sobre el Estado de la Nación celebrado en marzo de 1992.

José Ramón Caso dedicó el comienzo de su intervención a una vehemente defensa de las instituciones parlamentarias y democráticas, que a su juicio, estaban en riesgo como

\footnotetext{
${ }^{1}$ Cuestionario escrito de Tomás Martín Tamayo realizado durante febrero de 2014.

${ }^{2}$ Diario 16, 16 de noviembre de 1991, MAST.

${ }^{3} A B C, 19$ de agosto de 1991.

${ }^{4}$ CAPO GIOL, Jordi: “Oposición y minorías...”, p. 100.
} 
consecuencia de los casos de corrupción y la subsiguiente retórica demagógica. De cara a su argumentación, se sirvió de una extensa cita de Manuel Azaña: "que los enemigos de la libertad no vengan a mortificarnos el tímpano con declamaciones antiparlamentarias" Hobbes y Maquiavelo, y una síntesis de la posición del CDS -que podía servir al conjunto de la historia del partido-:

Señorías, la posición de nuestro Grupo Centrista es clara. Sin utopías ilusorias, nosotros creemos que una sociedad moderna sólo lo es si está fundada en una ética de los valores y si la acción de los gobernantes se dirige a la realización de esos valores de la libertad, la justicia y la solidaridad, y todo ello dentro de un marco democrático de equilibrio de poderes, respeto del derecho, transparencia y control ${ }^{6}$.

Y daba un paso más en su razonamiento al advertir:

Nos preocupa, por tanto, mucho a los centristas que ante los problemas y ante las críticas, la respuesta sea a veces negar las evidencias; pero nos preocupa tanto o más que los errores del Gobierno y el uso de la demagogia en la lucha partidaria acaben beneficiando sólo a movimientos de tipo fascista otra vez emergentes en el mundo occidental.

Como parte de esta lucha contra la corrupción, José Ramón Caso apelaba a la reforma de cuatro instituciones: el sistema electoral ${ }^{7}$, el Parlamento -facilitar la creación de comisiones de investigación y la creación de una Oficina de Control Presupuestaria ${ }^{8}$ , Justicia -aumento de medios humanos y administrativos- y el Tribunal Constitucional $^{9}$. Una regeneración ética, en suma, enmarcada dentro del gran proyecto colectivo europeo que se inauguraba con la plena inserción en el mercado común: cómo hacer converger en este sentido, las esperanzas de mejoras inmediatas en el bienestar con los inmediatos ajustes de sectores tan relevantes como la agricultura, la ganadería o la minería. Era necesario negociar y dialogar con los sindicatos representativos, sin

\footnotetext{
${ }^{5} D S C D, 24$ de marzo de 1992, $\mathrm{n}^{\circ} 175$, p. 8617.

${ }^{6}$ Ibid., p. 8618.

${ }^{7}$ En una Proposición de Ley, debatida en el pleno el 17 de marzo de 1992, propuso la modificación de la Ley Electoral (1985) en tres sentidos: "control de la financiación de los partidos en las campañas", por ejemplo, mediante la intervención del Tribunal de Cuentas durante la campaña -y no cuatro meses después, como disponía la ley-, declaración pública del presupuesto de campaña ante la JEC y finalmente aumentar -en términos pecuniarios- las sanciones. La proposición fue rechazada por el PSOE y contó con la abstención de PP y CiU y el apoyo de IU, DSCD, Sesión Plenaria, 17 de marzo de 1992, n 173, pp. 8462 y ss. El 25 de noviembre de 1992 se constituyó, como consecuencia de una Proposición de Ley presentada por el CDS una Ponencia para el estudio de la reforma de los gastos electorales, en este triple sentido, PAESA, María y MANUEL Gonzalo (eds.): Memoria de la IV ..., p. 78.

${ }^{8}$ Se presentó una iniciativa parlamentaria en este sentido -que contó únicamente con el apoyo del PP-, DSCD, Sesión Plenaria, 06 de junio de 1992, nº 195, p. 9579.

${ }^{9}$ Sobre el que se preguntaba: "¿Qué daño no se estará causando al prestigio de dicha institución cuando los dos partidos principales de esta Cámara boicotean su renovación, y por tanto su funcionamiento normal, mientras discuten si la televisión pública es más o menos partidista?", $D S C D, 24$ de marzo de 1992, n $^{\circ} 175$, p. 8618.
} 
obviar el desarrollo de una ley de huelga, que evitara su excesiva multiplicación. A continuación y enumerando algunos de los principales retos sociales, alertaba una vez más sobre la especulación del suelo de la periferia urbana:

Es indispensable que el plan del Gobierno se acompañe con ayudas financieras a los ayuntamientos para que expropien, como previene la Ley del Suelo, suelo rústico a precios asequibles para que se puedan construir y comprar viviendas que atiendan a satisfacer esa necesidad primaria de tantos españoles ${ }^{10}$.

La puesta en marcha de un Plan Hidrológico Nacional y la protección medioambiental completaban esta larga enumeración de las principales preocupaciones de la ciudadanía, que terminaba con las obligadas referencias a la educación y la sanidad -sobre todo, en relación a la sostenibilidad del gasto-. En los siguientes minutos, profundizó en la necesaria convergencia con Europa mediante un aumento del empleo y de la inversión -favoreciendo el ahorro- y pugnando por los fondos de cohesión social en Bruselas. Concluía destacando las divergencias del CDS en materia autonómica -segundos pactos autonómicos- y en su concepción de las Fuerzas Armadas con el Gobierno ${ }^{11}$.

La distancia entre el Gobierno y el PSOE era a esas alturas considerable. El CDS se opuso a los Presupuestos Generales presentados por el Gobierno para los ejercicios económicos de 1992 y $1993^{12}$. Estos últimos, elaborados en un contexto de recesión económica suponían un ajuste presupuestario que no fue secundado por el CDS, que apelaba a una reducción aún mayor del gasto - para controlar la inflación- pero también a un reparto más equitativo del existente. Era imprescindible la reedición consenso vivido durante la crisis del petróleo o la entrada en el Mercado Común ${ }^{13}$. En el contexto previo a la celebración del IV Congreso (1991) suscribió una proposición no de ley para exigir comparecencias mensuales de Felipe González - que contó con el apoyo de toda la oposición, menos $\mathrm{CiU}^{14}$ - y manifestó su rechazo a la Ley de Seguridad Ciudadana.

\footnotetext{
${ }^{10}$ Ibid. p. 8620.

${ }^{11}$ Como había sucedido en 1991 con Adolfo Suárez, El País y ABC relegaron a un lugar muy secundario su análisis de la intervención de José Ramón Caso. En el primer caso, se llamaba la atención sobre su alerta a los peligros que se cernían sobre la democracia y se consideraba la posición de los centristas cercana a la del Gobierno. En el segundo caso, Ángel Collado comentaba: "[Caso] eludió criticar al Gobierno y valoró positivamente algunas de las propuestas aprobadas”. Véase, ABC y El País, 26 de marzo de 1992.

${ }^{12}$ Enmienda a la totalidad al Proyecto de Ley de Presupuestos Generales del Estado de 1992, DSCD, 21 de octubre de 1991, Serie A- Proyectos de Ley, no 63-4, p. 354.

${ }^{13}$ Enmienda a la totalidad al Proyecto de Ley de Presupuestos Generales del Estado de 1993, DSCD, 19 de octubre de 1992, Serie A- Proyectos de Ley, n 104-3, p. 341-342.

${ }^{14}$ El País, 12 de septiembre de 1991.
} 
Se presentó una enmienda a la totalidad a dicha ley y, en particular se criticó su artículo 21 que autorizaba a las fuerzas de orden público "para la entrada y registro en domicilio por delito flagrante" ${ }^{\natural 2}$. Solo en el proceso de reformas económicas impulsado por el Gobierno de cara a la integración en Europa, existió coincidencia de posturas. Sucedió así a propósito del llamado "Pacto de Competitividad" presentado por el Ministro de Economía, Carlos Solchaga, y que suponía de facto un amplio abanico de medidas liberalizadoras.

En otro orden de cosas, la apuesta del CDS por la profundización de algunas de las libertades sancionadas en la Constitución prosiguió durante la presente legislatura aun con una intensidad notablemente menor. Debemos destacar la presentación de una proposición de ley en el Senado para la abolición del Código Penal Militar de la pena de muerte $^{16}$ y la apuesta por la formación de una comisión de expertos sobre la reforma sanitaria -“Informe Abril"-17.

En marzo de 1992, tuvieron lugar elecciones autonómicas en Cataluña. El CDS, cuya candidatura estaba encabezada por Teresa Sandoval, perdió la representación que había conseguido cuatro años antes y no logró rebasar el $1 \%$ de los votos $(0,91 \%)$. La consecuencia inmediata fue la dimisión de Antoni Fernández Teixidó, quien apenas un año después recalaba en CiU. En una votación celebrada el 28 de marzo en el seno del Comité Nacional Fernández Teixido sólo conseguía el apoyo de 2/3 del mismo, frente a

\footnotetext{
${ }^{15}$ El CDS votó en contra al conjunto de la Ley Orgánica de Protección de la Seguridad Ciudadana, 14 de noviembre de 1991, y durante su refrendo definitivo tras el pase por el Senado el 13 de febrero de 1992. En palabras de García Añoveros: "con una ley así en nuestro corpus legal, seremos, camellos o no camellos, menos libres que antes. Y más inseguros. No sé si tendremos más seguridad ciudadana; sí sé que tendremos menos seguridad jurídica, y mayores razones para temer al poder; es decir, a la autoridad", ÍD.: "Carta abierta al Ministro del Interior", El País, 01 de noviembre de 1991. Véase también, ÍD.: "Derechos y libertades inexpugnables" El País, 20 de junio de 1991.

16 "Para el CDS, la Constitución permite la pena de muerte en caso de guerra, pero no obliga a mantenerla", $A B C, 06$ de enero de 1990. Asimismo, el CDS e IU votaron en contra del proyecto de reserva del Gobierno socialista al "Segundo protocolo Facultativo del Pacto Internacional de Derechos Civiles y Políticos destinado a abolir la pena de muerte [Nueva York, 15 de diciembre de 1989]", DSCD, Sesión Plenaria, 29 de noviembre de 1990, nº 73, p. 3651 y ss.

17 Proposición no de Ley por la que se insta al Gobierno a la constitución de una Comisión [extraparlamentaria] para la revisión del Sistema Nacional de Salud y las tendencias de su entorno en el momento actual y cara al futuro, defendida en el Pleno por Carlos Revilla, quien en su argumentación instaba a trascender la dialéctica privada-publica desde la óptica de una mejora de la gestión y la eficiencia en la provisión de las prestaciones sanitarias, las cuales constituían una conquista irrenunciable del Estado Social, DSCD, 13 de febrero de 1990, n ${ }^{\circ}$ 14, p. 487. Una defensa argumentada del necesario "chequeo técnico" -que no ideológico- del futuro de la sanidad española en REVILLA RODRÍGUEZ, Carlos: "Un gran paso adelante", El País, 10 de septiembre de 1990. Cabe señalar que Carlos Revilla se desvinculó de las conclusiones del Informe Abril a propósito de la Comparecencia del Ministro de Sanidad y la Comisión de Análisis y Evaluación del Sistema Sanitario en una intervención en la que ensalzó las virtudes del modelo canadiense -íntegra financiación pública y provisión universal, junto a plena gestión privada-, $D S C D$, Sesión Plenaria, 26 de septiembre de 1991, no 134, pp. 6451-6452.
} 
tres votos favorables a aceptar su dimisión, una abstención y cuatro en blanco -tanto Calvo Ortega, como Fernández Teixidó no votaron- ${ }^{18}$. Le apoyaron personas cercanas a Suárez como Raúl Morodo o Alberto Dorrego, aunque contaba con la oposición de José Ramón Caso y de la línea más crítica del partido -Rafael Arias-Salgado o Tomás Martín Tamayo- ${ }^{19}$. El partido estaba de facto dividido entre el Grupo Parlamentario junto a la Asamblea Nacional-, y el Comité Ejecutivo Nacional. La labor mediadora de Calvo Ortega resultó en este caso insuficiente.

El sucesor de Fernández Teixidó fue José Luis Gómez-Calcerrada, particularmente activo en el partido desde 1987. Para Gómez-Calcerrada, su nombramiento por la Asamblea Nacional fue fruto de un acuerdo, explícito o no, entre Rafael Calvo-Ortega y José Ramón Caso ${ }^{20}$. Carlos Revilla, Luis Aznar, Raúl Morodo y otros dirigentes se mostraron muy críticos con la decisión. La labor inmediata de la nueva secretaría pasaba por la celebración de un nuevo Congreso, que se demoró hasta diciembre de ese año. Apenas tres meses antes, la federación del partido en Canarias, junto con la madrileña y castellano y leonesa la más decisiva en la historia del partido, abandonaba el CDS prácticamente por unanimidad $^{21}$.

El V Congreso se celebró los días 12 y 13 de diciembre de 1992 en el Palacio de Exposiciones y Congresos de Madrid. El acto comenzó con la lectura del informe de gestión por parte del Secretario General, J. L. Gómez-Calcerrada ${ }^{22}$. El político manchego perfilaba un futuro no exento de claroscuros para el partido. En primer lugar,

\footnotetext{
18 DÍEZ, Anabel: "Fernández Teixidó ratifica su dimisión al no recibir apoyo de los críticos del CDS, El País, 29 de marzo de 1992.

${ }^{19}$ El Presidente del partido en León se daba de baja, El País, 21 de marzo de 1992.

${ }^{20}$ Entrevista con J. L. Gómez-Calcerrada, 10 de junio de 2015.

${ }^{21}$ Desde la dimisión de Fernando Fernández y su ingreso en el PP en diciembre de 1990, el partido vivía una fuerte crisis sobre todo en la isla de Tenerife. De cara a las municipales de 1991, había intentado pactar con grupos de independientes algunas de las listas a ayuntamientos y cabildos. En el contexto de crisis interna y de rechazo del CDS canario al pacto con el PSOE, Olarte planteó desde el IV Congreso una nueva relación bilateral entre la Federación CDS-Canarias y Madrid, basada en una mayor “autonomía". En enero de 1992, tuvo lugar el V Congreso Regional en el que Lorenzo Olarte sucedió a Jesús Morales como Presidente del Comité Federal y se aprobó una nueva denominación: "Centro Democrático Canario-CDS". Sin embargo, la imposibilidad de estructurar una vía autónoma organización y estrategia- y a la vez asociada al CDS en cuestiones de política nacional desembocó en la formación de un partido nacionalista que se iba a formar en torno a la militancia gran canaria -con la oposición de los centristas tinerfeños-. Finalmente, en el VI Congreso Federal (junio de 1992) triunfaron las tesis de Olarte proclives a la escisión y la adopción del nacionalismo. Una postura que contaba con una larga tradición en las asociaciones políticas insulares canarias agrupadas en torno a las AIC, BAEZ GARCÍA, Alberto Javier: Una historia de Coalición Canaria ..., pp. 79-83.

${ }^{22}$ El informe estaba dividido en tres grandes apartados: Superación de la crisis, objetivos, realizaciones y preparar el futuro, Informe de Gestión Política del Secretario General (José Luis Gómez-Calcerrada) ante el V Congreso Nacional del CDS, Madrid, diciembre de 1992.
} 
identificaba las "inercias ambientales" adversas y los "comportamientos internos" que habían ejercido de hándicaps para el impulso renovador. Obstáculos que arrastraban la herencia de los pactos firmados en 1989:

Mal explicados y peor entendidos. El hecho de tener como interlocutores de pactos y acuerdos a partidos de la derecha y de la izquierda, algo que es consustancial a nuestra posición centrista pero que cuesta entender en España, generó una imagen de ambigüedad e indefinición que caló en una parte muy importante del electorado. Si a esto unimos la fuerte e interesada campaña de desprestigio de las dos grandes fuerzas nacionales: socialistas y conservadores, que veían en nuestro Partido una real amenaza a su continuidad en un caso y a su crecimiento en el otro, tenemos las principales causas origen de nuestros problemas ${ }^{23}$.

Sin embargo, según Gómez-Calcerrada el partido había sabido reaccionar, superar su crisis interna y en lugar de desaparecer, como muchos auguraban, resistir gracias a su fuerza en las instituciones. En este último año, los objetivos habían sido tres: "revitalizar las estructuras del Partido, devolver la confianza a los militantes y recuperar simpatías electorales perdidas" ${ }^{24}$; un último aspecto que fue el más amargamente valorado: no habían conseguido una "tradición de identificación electoral" y sus acciones eran juzgadas con "mayor severidad" que en el resto de partidos - de ahí, ese permanente impulso de reinvención-. El tratamiento de los medios de comunicación se revelaba como una de las claves para comprender la evolución del partido:

Recordad por un momento la hostilidad con que éramos tratados por los grandes medios nacionales de comunicación hace tan sólo unos meses. No es que ahora suscitemos simpatías desmedidas, todavía no, pero llegará el día, sino que lo que se aprecia es un tratamiento respetuoso, escaso pero respetuoso [...] El problema es que todavía no hemos conseguido vencer el círculo vicioso con la política informativa de los últimos años.

Pero de puertas adentro, el partido tampoco había sido incapaz de ofrecer una "unidad de criterio" en lo fundamental. Había habido voces críticas, cuando no destructivas y narcisistas:

Dicho esto, me veo obligado a hacer una pequeña apostilla y es que lamentablemente han fallado algunos prohombres del partido, personas que le debían casi todo lo que son en política al C.D.S. Aunque tal vez no haya venido mal su huida, porque ahora sabemos quiénes estaban aquí por interés y quiénes por convicción. Ahora sabemos que al socaire de la argumentación de que el partido había perdido el rumbo, lo que había detrás era la excusa para buscar refugio y colocación en otras opciones políticas -eso sí casi siempre con el escaño a cuesta- ${ }^{25}$.

\footnotetext{
23 Ibid.

${ }^{24}$ Indicaba que en los últimos cuatro meses habían sido más las altas que las bajas en el partido.

25 “Todos mis compañeros están legitimados para decirnos a Adolfo y a mí que nos equivocamos firmando los pactos, y yo tengo toda la legitimidad para decirles a ello que no fueron resistentes a las
} 
Reflexiones que daban paso al elogio de quien había sido el político centrista más maltratado, dentro y fuera del partido, desde la firma de los pactos en 1989:

Y por último, rendir un sentido tributo de admiración a la persona que con acierto y errores ha demostrado por encima de cualquier otra consideración su lealtad al proyecto, no siempre reconocida. El sigue aquí y otros están dando tumbos, mendigando un lugar al sol, me refiero a nuestro Portavoz en el Congreso, José Ramón Caso.

Gómez-Calcerrada reclamaba desde una perspectiva histórica el espacio de centro como lugar de consenso y a la vez, absolutamente independiente. Sin embargo, era necesario un mayor realismo político y -aunque no lo verbalizara de manera explícitarenunciar a la vocación mayoritaria que había originado tanta confusión entre la militancia y el electorado anteriormente: "El C.D.S. no puede ser un Partido "atrapalotodo", si lo pretendiera (ya lo intentó en el pasado) seguramente perdería la última oportunidad de conectar con una parte, de dimensiones variables pero cualitativamente significativa, del electorado".

Concluía Gómez-Calcerrada anunciando su intención de presentarse nuevamente a la Secretaría General del partido. El V Congreso ratificó en la Presidencia a Calvo-Ortega y a Gómez-Calcerrada en la Secretaría General con un $70 \%$ de los votos y en mayo de 1993, se corroboraba la candidatura a la Presidencia del Gobierno de Rafael Calvo Ortega.

La campaña del CDS para las elecciones generales de 1993 estuvo protagonizada, paradójicamente, por la ausencia de Adolfo Suárez, dedicado en exclusiva a estar con su familia -su hija Mariam había iniciado su tratamiento contra el cáncer en Estados Unidos-, y cuyo nombre, no obstante, fue invocado a lo largo de todo el espectro ideológico con evidentes intenciones electoralistas:

Desde allí expresaba ayer, en Diario 16 y El Mundo, que sólo pide paz y que no se le acose. Se extrañaba de que su nombre hubiera aparecido en la campaña electoral -PSOE, PP y CDS luchan ahora por heredar su terreno político- y negaba conocer las ofertas de las que ha hablado Felipe González (quien aseguró haberle propuesto un cargo institucional que el ex presidente había rechazado ${ }^{26}$.

presiones, para mantener el partido en pie”, Entrevista con José Ramón Caso, 19 de noviembre de 2014. En este sentido, Gómez-Calcerrada manifestaba: "Rendir también homenaje a nuestros tres diputados canarios. José Antonio Santos Miñón, Lorenzo Díaz y Baltasar de Zárate que han sabido soportar todo tipo de presiones, que han permanecido fieles al proyecto y no como otros que se fueron a dormir defendiendo un proyecto nacional y se levantaron con un proyecto nacionalista-radical insularista", Informe de Gestión...

${ }^{26}$ GONZÁLEZ IBÁÑEZ, Juan: "El gran ausente”, El País, 08 de mayo de 1991. 
Si desde el PSOE se le ofrecían supuestamente, cargos de relieve a nivel institucional y había recuperado la fluidez que tuviera durante la II Legislatura en su relación con Felipe González ${ }^{27}$, desde el PP José María Aznar invocaba su nombre: "Voté a Suárez en 1977 [...] Políticamente me sentí muy identificado con la política de Suárez, con la primera etapa de Suárez, pero yo le debo mucho a Manuel Fraga" ${ }^{28}$. El CDS, cuyo lema elegido en un momento de enorme crispación política fue "Ahora más que nunca el centro es necesario", recordaba que Adolfo Suárez seguía siendo militante de los centristas.

Las candidaturas centristas reflejaron la renovación del partido, en el que sólo repetían ocho cabezas de lista al Congreso: Alejandro Rebollo (Asturias), Macario Herrera (Cáceres), Antonio José Delgado (Córdoba), Eduardo Herrero (Gerona), Bernardo Baquedano (Huesca), Juan José Otamendi (Navarra), Santos Miñon (Las Palmas) y José Manuel Calzado Puertas (Melilla). En Madrid, Rafael Calvo Ortega y José Luis Gómez-Calcerrada encabezaban las listas acompañados por la eurodiputada Guadalupe Ruiz-Giménez y en quinta posición quien fuera parlamentario en el Congreso, José Antonio Souto Paz. José Ramón Caso acudía como número uno por la provincia de Ávila ${ }^{29}$. Por otra parte y como si se hubiera retrocedido un lustro reaparecían antiguos problemas: problemas de financiación, denuncias a la Junta Electoral Central por la discriminación realizada desde TVE, aunque también por parte de nuevos medios como Antena 3, y dimisiones (José Varela, Presidente Federal del CDS-Cataluña $)^{30}$.

El Programa Electoral identificaba como prioridad política la lucha contra el desempleo mediante una transformación del modelo de crecimiento económico sostenido por un gran acuerdo inter-partidario. Se volvía a insistir, como sucediera en otras propuestas electorales, en un aumento de la inversión directa del Estado como

\footnotetext{
${ }^{27}$ Hasta el punto algo exagerado de que el periodista Graciano Palomo le considerase hacia 1993 como el "principal asesor-confidente" de Felipe González en estos años, PALOMO, Graciano: La tierra ..., p. 758.

${ }^{28}$ Entrevista en ESTEFANÍA, Joaquín: "No me identifico con la derecha clásica española", El País, 03 de junio de 1993.

${ }^{29}$ BOE, 11 de mayo de $1993, \mathrm{n}^{\circ} 112$ y BOE, 30 de septiembre de 1989, no 235.

30 "El secretario general del CDS y número dos de este partido por Madrid, José Luis Gómez Calcerrada, denunció ayer en Zamora 'el boicoteo que a este partido se le está haciendo desde determinados poderes fácticos de este país' y el intento de poner los votos de centro al servicio de la derecha conservadora de siempre. Calcerrada, que no concretó a qué poderes fácticos se refería, explicó que sólo le ha sido concedido al CDS un 10\% de los 250 millones de pesetas que habían solicitado a determinados bancos para financiar la campaña”, El País, 30 de mayo de 1993. Véase también, El País, 02 de junio de 1990.
} 
estímulo de la economía acompañado de una potenciación de la inversión privada rebajas fiscales, modificación de la financiación de la Seguridad Social, apoyo a las PYMES-, etc. Junto a estas medidas de carácter económico, el CDS insistía en la necesaria "regeneración" política y social del país. En buena medida, el Programa Electoral mantenía las señas de identidad del partido centrista ${ }^{31}$.

Los resultados de las elecciones generales de 1993 confirmaron las expectativas más pesimistas y el CDS, después de once años $-\mathrm{y}$ de forma definitiva-, desaparecía de las máximas instituciones del Estado a pesar de ser el quinto partido más votado (414.740 votos y 1,76\%). En Madrid se quedaba con 93.347 votos y un 2,99\%, sólo por una centésima y algo más de trescientos votos fuera del reparto escaños que le hubiera otorgado al menos un diputado. Sin apenas haber podido ejercer un papel decisivo en la gobernabilidad del país -salvo en algunos gobiernos autonómicos y municipales-, el CDS daba un paso atrás en la vida política española, siendo su lugar ocupado por los partidos regionalistas y a nivel estatal por los grandes partidos nacionalistas. José Luis Merino, dirigente aragonés de los centristas, lo ha explicado así:

Siempre he pensado que la ideología y sobre todo la estrategia del CDS no fue bien entendida por los españoles. En un país todavía muy polarizado entre derechas e izquierdas la aparición de un partido de centro radical y progresista no era bien recibido. Creo, incluso, que la gente votaba más por razón de sus líderes -especialmente Adolfo Suárez- que atendiendo a sus principios ideológicos. Y desde luego nunca fue entendida la estrategia post-electoral del partido, al menos en Aragón: no se podía entender que mientras los concejales centristas del Ayuntamiento de Zaragoza daban su apoyo al partido en mayoría relativa que era el PSOE, los diputados autonómicos dejásemos gobernar, con nuestra abstención, a una pseudo-coalición conservadora formada por el PAR y el PP, que entre ambos habían obtenido mayor número de escaños que el PSOE. Ese papel de equilibrio político, tan frecuente en países occidentales, en España, y en particular en Aragón, no era entendido. Como es bien sabido la desaparición de un partido 'intermedio' como era el CDS en España ha determinado, entre otras cosas, que los sucesivos gobiernos de la Nación -y tanto PSOE como PP-, sin mayorías absolutas, hayan tenido que apoyarse necesariamente en los partidos nacionalistas, especialmente en el catalán $\mathrm{CiU}^{32}$.

En esta situación se llegó al VI Congreso Extraordinario del CDS, celebrado el 16 y 17 de julio de 1993 en Madrid, y en el que se planteó abiertamente -contando con el apoyo de J. R. Caso, León Buil y Alejandro Rebollo entre otros-, la disolución del partido. Una propuesta rechazada mayoritariamente por los 661 compromisarios con un $66 \%$ de los votos, en la que sin embargo se denunciaron numerosas irregularidades -

\footnotetext{
31 "Programa Electoral 1993", CDS, 1993, Documentación de Jaime Hernando (CDS-Soria).

32 MERINO HERNÁNDEZ, José Luis: "Los partidos centristas en la formación de la Comunidad Autónoma de Aragón" en VV.AA.: Memorias de los partidos...”, pp. 133.
} 
como consecuencia de la votación a mano alzada en la que pudo haber militantes no acreditados como compromisarios, tal y como denunció el dirigente andaluz, Antonio Delgado de Jesús ${ }^{33}$ - . Gómez-Calcerrada, que anunció su dimisión y apostó por la disolución, señalaba que la marginación mediática, la ratificación del bipartidismo y los propios errores del partido habían alejado definitivamente al CDS del electorado, dejando al partido en una suerte de "esquizofrenia política". Las organizaciones provinciales se hallaban divididas: unas apostaban por la disolución y otras por la continuidad. Rafael Calvo Ortega o Martínez Cuadrado, que jugaron la carta de la continuidad, aportaban como principales razones: el apoyo de la Internacional Liberal, la existencia de una bolsa electoral proclive a una opción de centro argumentaban su decisión y los más de tres mil cargos electos, en su mayoría concejales y alcaldes, elegidos en las listas centristas. De este VI Congreso salió la promesa de refundación del partido a cargo de una gestora dirigida por el propio Rafael Calvo Ortega.

Paralelamente, el espacio del CDS era cada vez más estrecho, presionado a izquierda y derecha por PSOE y PP. Por ejemplo, se desveló una oferta del PP rechazada mayoritariamente por los líderes del partido como Rafael Calvo Ortega o J. L. Gómez Calcerrada para acudir en coalición a las elecciones ${ }^{34}$. El futuro de los miembros del CDS basculó entre tres opciones: el abandono de la política, el pase al Partido Popular o, en menor medida, al PSOE. Episodios todos ellos, producidos ante la perplejidad de la militancia: "No podemos decir nosotros lo mismo de ti, que lo que tú dices de nuestro Presidente Nacional [...] ¿nos ha pedido usted [Fermín Artagoitia] y el Sr. Pascual Durá opinión a los simples militantes sobre que pensamos de pasarse ustedes a otras formaciones políticas?"35

Si atendemos al análisis del futuro político de los miembros del Comité Nacional del CDS entre 1982 y 1991, el resultado fue el siguiente:

Tabla 105: Destino político de los miembros del Comité Nacional del CDS (1982-1991) en la década de los 90'.

\begin{tabular}{|l|l|l|}
\hline $\begin{array}{l}\text { Miembros Comité Nacional } \\
\text { 1982-1991 }\end{array}$ & CDS & PP-PSOE \\
\hline Adolfo Suárez & Abandona el CDS en la década de los 90’ & Ninguno. \\
\hline
\end{tabular}

\footnotetext{
${ }^{33}$ ABC Sevilla, 19 de julio de 1993.

${ }^{34} A B C, 18$ de julio de 1993.

${ }^{35}$ VIDAL COPOVI, Joquín (Presidente Local CDS Rafelguaraf): "A Fermín Artagoitia", Órgano de Información y Opinión del Centro Democrático y Social de la Comunidad Valenciana, 2, enero 1991.
} 


\begin{tabular}{|c|c|c|}
\hline Jesús María Viana & Fallecimiento en 1987 & Ninguno. \\
\hline José Ramón Caso García & $\begin{array}{l}\text { Abandona el CDS tras la dimisión de } \\
\text { Adolfo Suárez y el VI Congreso. }\end{array}$ & $\begin{array}{l}\text { Considerado más cercano al } \\
\text { PSOE. Ninguno. }\end{array}$ \\
\hline Joaquín Abril Martorell & $\begin{array}{l}\text { Abandona el CDS tras la dimisión de } \\
\text { Adolfo Suárez y el VI Congreso. }\end{array}$ & PP. \\
\hline $\begin{array}{l}\text { Alejandro Rebollo Álvarez- } \\
\text { Amandi }\end{array}$ & $\begin{array}{l}\text { Abandona el CDS tras la dimisión de } \\
\text { Adolfo Suárez y el VI Congreso. }\end{array}$ & $\begin{array}{l}\text { Considerado más cercano al } \\
\text { PSOE. Ninguno. }\end{array}$ \\
\hline Manuel de Sárraga Gómez & $\begin{array}{l}\text { Abandona el CDS tras la dimisión de } \\
\text { Adolfo Suárez. }\end{array}$ & Ninguno. \\
\hline León Buil Giral & $\begin{array}{l}\text { Abandona el CDS tras la dimisión de } \\
\text { Adolfo Suárez y el VI Congreso. }\end{array}$ & Ninguno. \\
\hline Rafael Calvo Ortega & Presidente del CDS 1992-1998 & Ninguno. \\
\hline Fernando Castedo Álvarez & Abandona el CDS en 1990 & PSOE (1993) \\
\hline Gerardo Harguindey Bonet & $\begin{array}{l}\text { Abandona el CDS tras la dimisión de } \\
\text { Adolfo Suárez. }\end{array}$ & $\begin{array}{l}\text { Considerado en la órbita del } \\
\text { PP. }\end{array}$ \\
\hline Federico Ysart Alcover & Abandona el CDS en 1991. & $\begin{array}{l}\text { Considerado en la órbita del } \\
\text { PP. }\end{array}$ \\
\hline Laura Morso Pérez & $\begin{array}{l}\text { Abandona el CDS tras la dimisión de } \\
\text { Adolfo Suárez y el VI Congreso. }\end{array}$ & Ninguno. \\
\hline Agustín Rodríguez Sahagún & Fallecimiento en 1991 & Ninguno. \\
\hline Javier Soto Carmona & Abandona el CDS en 1987 & Ninguno. \\
\hline Manuel Garrido Martínez & $\begin{array}{l}\text { Abandona el CDS tras la dimisión de } \\
\text { Adolfo Suárez y el VI Congreso. }\end{array}$ & $\begin{array}{l}\text { Diputado en la Asamblea de } \\
\text { Cantabria en las listas del } \\
\text { PSOE como independiente } \\
(1995-1999) \text {. }\end{array}$ \\
\hline José Luis Garro Carballo & Abandona el CDS hacia 1991 & Ninguno. \\
\hline José Luis Merino Hernández & $\begin{array}{l}\text { Abandona el CDS tras la dimisión de } \\
\text { Adolfo Suárez. }\end{array}$ & Ninguno. \\
\hline Raúl Morodo Leoncio & - & Ninguno. \\
\hline Lorenzo Olarte Cullén & Abandona el CDS en 1992. & $\begin{array}{l}\text { Unión Canaria (1992). } \\
\text { Coalición Canaria. }\end{array}$ \\
\hline Rosa Posada Chapado & Abandona el CDS en 1992. & PP (1994). \\
\hline Carlos Revilla Rodríguez & Abandona el CDS en 1991. & Ninguno. \\
\hline Abel Cádiz Ruiz & - & - \\
\hline Miguel Ángel Eced Sánchez & Desvinculado desde finales de los $80^{\prime}$ & - \\
\hline José Antonio Escudero López & Abandona el CDS en 1991 & PP (1992). \\
\hline José Luis González Quirós & Abandona el CDS en 1990 & $\begin{array}{l}\text { PP. } \\
\text { VOX (2013, Presidente } \\
\text { Nacional })^{36} \text {. }\end{array}$ \\
\hline Alfredo Marco Tabar & - & PP (1995) \\
\hline Francisco Villodres García & Abandona el CDS hacia finales de los $80^{\prime}$ & - \\
\hline Manuel Jiménez de Parga & Abandona el CDS en 1986 & - \\
\hline Emilio Pujalte Clariana & - & - \\
\hline Alberto Dorrego González & Presidente del CDS entre 1998-1999 & Ninguno. \\
\hline Enrique Egea Ibañez & - & - \\
\hline Antoni Fernández Teixidó & Abandona el CDS en 1992 & $\mathrm{CiU}(1993)$. \\
\hline José Ramón Lasuén Sancho & Abandona el CDS en 1992 & Ninguno. \\
\hline José Vicente Cebrián & - & - \\
\hline Tomás Martín Tamayo & Abandona el CDS hacia 1992 & $\begin{array}{l}\text { Convergencia Regional } \\
\text { Extremeña (1992-3). } \\
\text { PP (2003-200?) }\end{array}$ \\
\hline Manuel Sánchez Bracho & Abandona el CDS hacia 1992 & PP (1993). \\
\hline Eduard Punset i Casals & Abandona el CDS en 1991 & Foro (1992). \\
\hline $\begin{array}{l}\text { Rafael Martínez-Campillo } \\
\text { García }\end{array}$ & $\begin{array}{l}\text { Abandona el CDS tras la dimisión de } \\
\text { Suárez y el VI Congreso }\end{array}$ & $\begin{array}{l}\text { Considerado en la órbita del } \\
\text { PSOE. Ninguno. }\end{array}$ \\
\hline Guadalupe Ruiz-Giménez & Alejada del partido desde 1993 & Ninguno. \\
\hline
\end{tabular}

\footnotetext{
${ }^{36}$ Partido en el que también participa el ex miembro del CDS y UCD, Ignacio Camuñas.
} 
Aguilar

Elaboración propia a partir de MENÉNDEZ, Miguel Ángel: “Los últimos del CDS”, Interviú, 1994, no 962, (localización: Hemeroteca Caixa-Tarragona).

Retirados de la política, amén de los mencionados, cabe citar a amigos íntimos de Adolfo Suárez como Fernando Alcón, José Luis Sagredo de Miguel o José Ferrer. También desvinculados de la política figuraban los canarios Lorenzo Díaz Aguilar, Santos Miñón, el sevillano Jaime García Añoveros o el malagueño Perfecto Yebra. Cabe señalar el caso de José Luis Gómez-Calcerrada, clave en la vida interna del CDS entre 1987 y 1992, año a partir del cual recibió ofertas para ingresar tanto en el PP como en el PSOE desestimando ambas.

Otros miembros del CDS decidieron permanecer activos en el partido junto a Rafael Calvo Ortega caso de Charo Diego (Salamanca) o José Moreira (Madrid). En otras ocasiones, como fue la opción de Daniel de Fernando en Ávila o Luis Rodríguez San León en Zamora, prosiguieron su actividad política con nuevas fórmulas para amparar a la numerosa representación política "residual" del CDS en sus respectivas provincias. En el caso del primero, puso en marcha junto a José María Monforte la Agrupación Independiente de Ávila para las Elecciones de $1995^{37}$.

Sin embargo, el grueso de políticos centristas que decidieron permanecer en política ingresaron en el PP. Entre otros podemos citar a Joaquín Álvarez de Toledo (CDSMadrid, área económica), Domingo González (ex diputado autonómico canario), Juan Castaño (ex diputado por Salamanca), Fernando Fernández (ex Presidente de Canarias), Fernando López Amor (ex concejal en Madrid), Luis Aznar (máximo dirigente del partido en León), Fermín Artagoitia (CDS-Valencia), Alejandro Font de Mora (candidato autonómico en Valencia en 1991), César Díez Solís e Inocencio Mayoral Sánchez (ex diputados autonómicos extremeños), el ex diputado provincial de Badajoz, Mariano Barbero, Mario Bilbao y Adolfo Lama (dirigentes del partido en Sevilla), Dionisio Ramos (secretario de las juventudes), Jesús Merino Delgado (miembro de la primera Comisión Nacional de Cuentas).

Una de las consecuencias de los resultados electorales de 1990, 1991 y 1992 había sido el llamamiento generalizado de los líderes del Partido Popular para que se integraran en el partido los militantes del CDS. El razonable éxito de una estrategia

\footnotetext{
${ }^{37}$ BERZAL DE LA ROSA, E. (et al.): 25 años de Castilla y León. Volumen I: Un difícil arranque..., p. 136.
} 
desplegada con intensidad en esta época responde, desde nuestro punto de vista a dos factores. Por un lado, la transformación gestual y simbólica del Partido Popular que abandonaba la retórica más conservadora desplegada durante los años 80 ' bajo la Presidencia de Manuel Fraga -como vimos paradigmáticamente a propósito de la II Legislatura-. Por otro lado, las opciones de "salida" hacia el PP para los miembros del CDS, usando la terminología empleada por Jonathan Hopkin en su análisis de UCD, resultaban una posibilidad más favorable de cara a la continuidad de sus trayectorias políticas que la permanencia en el partido fundado por Adolfo Suárez.

El Partido Popular inició su intento por representar políticamente lo que había significado la UCD desde finales de la década de los 80', proyecto escenificado con singular fuerza en el X Congreso del partido: "Centrados con la libertad" (marzo, 1990). Como señalaba el periodista Luis R. Aizpeolea, el PP se había lanzado "a una campaña de gestos para ocupar el centro" 38 . En apenas dos años, recibió la adhesión de antiguos ministros centristas como Jaime Lamo de Espinosa, Luis Gámir o José-Pedro Pérez Llorca y el elogio de políticos tan destacados como Leopoldo Calvo-Sotelo ${ }^{39}$. Se comenzó a eludir el término centro-derecha -en el que meses antes se había incluido al CDS-, intentándose emplear con exclusividad la idea del centro. En una entrevista en El País, Aznar señalaba: "voy a ser rompedor con el proyecto de centrar el PP"40. Y en sus memorias define así estos objetivos: "quería que el PP se convirtiera en el depositario del legado histórico de la UCD, y por tanto, de Suárez"41.

Para la politóloga Lucía Medina, el viraje al centro del PP culminó en 1996, momento en el que se produjo definitivamente el desplazamiento de la media ideológica de sus votantes y la distribución de sus posicionamientos políticos hacia el centro en la escala izquierda-derecha ${ }^{42}$. De acuerdo con los profesores González Cuevas y Feliciano Montero tres fueron las claves de este proceso de transformación: "reivindicó la experiencia ucedista, el Estado de las Autonomías y la realidad 'plural' de la nación española"43. Abundaron en esta época notorias similitudes retóricas entre el CDS y el

\footnotetext{
38 "El PP se lanza a una campaña de gestos para ocupar el centro", El País, 21 de octubre de 1991.

${ }^{39}$ El País, 10 de junio de 1991.

${ }^{40}$ El País, 31 de marzo de 1991. Véase el editorial: "Tres pasos al centro", El País, 08 de abril de 1991.

${ }^{41}$ AZNAR LÓPEZ, José María: Memorias..., pp. 161-162.

${ }^{42}$ En la legislatura 1993-1996 el 17\% de sus votantes se ubicaban en el centro en MEDINA, Lucía: Izquierda y derecha en España: un estudio longitudinal comparado, Madrid, CIS, 1996, pp. 129-130.

${ }^{43}$ GONZÁLEZ CUEVAS, Pedro C. y MONTERO, Feliciano: "Los conservadores españoles en el siglo XX” en MORALES MOYA, Arturo (Coord.): Las claves de la España del siglo XX. Vol. 4: Ideologías y movimientos políticos, Madrid, Sociedad Estatal España Nuevo Milenio, 2001, p. 60. Para el profesor
} 
PP. Por ejemplo, se defendió el proyecto de "democracia avanzada", hubo alusiones a Azaña, y se reivindicaron los epítetos de "reformista" y "progresista" 44.

En esta ofensiva, el CDS acusó al Partido Popular de presionar, de la mano de ofertas de ingreso, sobre su militancia y cargos electos de forma sistemática, así como de llevar a cabo un viraje meramente propagandístico hacia el centro. Una de las voces más críticas durante este período con el Partido Popular, el Secretario General del CDS José Ramón Caso, recibió una dura, áspera y tenaz contestación en las páginas de $A B C$ durante los años 1990 y $1991^{45}$.

Poco a poco, miembros relevantes del CDS pasaron a las filas populares, caso de Arias-Salgado, Íñigo Cavero o José Luis González Quirós, quien fuera miembro del primer Comité Ejecutivo:

Somos el centro político: se repetía hasta el paroxismo, con ocasión y sin ella, tal y como había ordenado José María Aznar. La idea del "gana el centro" surgió de las calderas de Arturo Moreno, que para entonces ya había sido liberado por Ángel Corcóstegui en la empresa Comelta y trabajaba directamente para Aznar desde un despacho de la fundación FAES. Igual que la idea del himno "Por fin" cuyo autor, Joaquín Torres, es amigo de Rodríguez [...] González Quirós [director de la revista de Cuadernos de Pensamiento Político] y Carlos Fernández Conde, dos antiguos colaboradores de Adolfo Suárez en UCD, participan activamente en la idea ${ }^{46}$.

González Cuevas fue Aznar el líder que mejor conectó con los postulados de Francis Fukuyama sobre el triunfo de la economía de mercado y la democracia liberal, ÍD.: El Pensamiento político de la derecha en el siglo XX, Madrid, Tecnos, 2005, p. 244.

${ }^{44}$ Conferencia pronunciada el 12 de noviembre de 1990 por Álvarez Cascos en el Club Siglo XXI, véase también, CASO GARCÍA, José Ramón: "Una sociedad democrática y avanzada", CDS, 1988. Este concepto, que aparece en el preámbulo constitucional es una invitación sugerente aunque inconcreta a una mayor participación ciudadana en la toma de decisiones políticas, RUBIO CARRACEDO, José: "Democracia y legitimación del poder en Rousseau", Revista de Estudios Políticos (Nueva época), 58, 1987, pp. 215-252.

45 "José Ramón Caso superó de forma brillante, a Martín Toval [PSOE] en la defensa del Gobierno", SÁNCHEZ, José Antonio: "La crisis", $A B C, 27$ de enero de 1991. "El secretario general del CDS ha demostrado, una vez más que no siempre es fácil ser inteligente. No de otro modo cabe interpretar sus inefables declaraciones" en "Baja", $A B C, 03$ de febrero de 1991. En junio de 1990, estuvo también en "baja" al advertir del riesgo de desnaturalización del liberalismo por parte del conservadurismo, $A B C, 03$ de junio de 1990 -véase, CASO GARCÍA, José Ramón: "La solidaridad como exigencia democrática", $E l$ País, 29 de junio de 1990-; OVIDIO: "Extraña acusación”, ABC, 26 de diciembre de 1990. También el día 6 de enero Caso ocupó la sección de "En baja", por atribuir al PP la responsabilidad de la marcha de los militantes centristas al partido de Aznar: "Cada uno es libre de decir las tonterías que quiera", $A B C$, 06 de enero de 1991. Véase también, $A B C, 20$ de enero de 1991 o CAMPMANY, Jaime: "Otros 40 años", $A B C, 18$ de marzo de 1991. A propósito del referéndum sobre el servicio militar, "En baja", $A B C, 07$ de julio de 1991.

${ }_{46}$ PALOMO, Graciano: La tierra prometida, Madrid, Vergara, 1996, p. 28. "El 13 de mayo de 1992 se fundó la FAES para crear un cuerpo doctrinal permanente. Para ello, se ha rodeado de 'gente ilustre', y tienen 'desván propio' antiguos UCD como: A. Fontán, J. P. Pérez Llorca, M. Oreja, J. Lamo de Espinosa, F. C. Sainz de Robles. El factótum es M. A. Cortés y el director Alfredo Timerman del Olmo", ibid. pp. 33-4 y pp. 431-3; GONZÁLEZ IBÁÑEZ, Juan: "Ex ministros de UCD colaborarán en el programa del PP”, El País, 02 de septiembre de 1991. 
Íñigo Cavero afiliado al Partido Popular en el verano de 1991, se preguntaba en la revista Tiempo sobre el porqué del fracaso de los partidos de centro político a pesar de corresponder con el espacio en el que se posicionaba mayoritariamente el electorado. Siguiendo los análisis teóricos de Giovanni Sartori o Maurice Duverger concluía cuatro razones: la legislación electoral, el avance de PP y PSOE hacia dicho espacio político, la competencia de partidos nacionalistas o regionalistas y la dificultad para desarrollar un perfil propio o centrista; una situación en la que emergía de forma renovadora el Partido Popular. Lo explicaba con las siguientes palabras:

Concluiremos con la afirmación que la actual situación política española abre, ante la crisis del CDS, mayores posibilidades al PP para incidir con éxito sobre el espacio electoral del centro, si continúa la línea estratégica que promueve José María Aznar y mayores dificultades para el PSOE [...] al tener que acudir al apoyo político de Izquierda Unida para mantener posiciones municipales y autonómicas, y evitar la erosión que por su izquierda le pueda producir la coalición que lidera Anguita. El moderado votante centrista puede rechazar los excesivos condicionamientos que al PSOE le va a ir imponiendo Izquierda Unida ${ }^{47}$.

Rafael Arias-Salgado, jefe de gabinete de Adolfo Suárez durante la IV Legislatura, y desde 1993 miembro del Partido Popular, valora del siguiente modo la relación entre ambos partidos. El CDS representaba fundamentalmente dos ideas: la capitalización del liderazgo de Adolfo Suárez y la colmatación de una organización político socio-liberal capaz de "tirar" de una derecha española estancada en algo menos del $25 \%$ de los votos desde 1982. ¿Cómo? Mediante el desarrollo del modelo europeo, y lo que en el Partido Popular pasaba necesariamente por la idea de "centrar el partido". Recuerda AriasSalgado, partícipe decisivo en el programa electoral de 1996 junto a Cristóbal Montoro y José María Michavila algunas de las "ideas fuerza" que defendió y aportó en aquel grupo de trabajo: "pasar del inter-gubernamentalismo a la defensa de la integración europea [...] europeísmo" y el abandono de la retórica de la sociedad de bienestar y asunción como modelo del Estado del Bienestar -modelo inequívocamente europeo, aunque variasen los modos de gestión-. España, al igual que los países europeos, debía consolidar un estado de derecho basado en la democracia representativa, el funcionamiento de la economía de mercado y la forja de un estado social y la defensa de la libertad de crítica y el método empírico ${ }^{48}$.

En el caso del PSOE, los ejemplos fueron menos numerosos, al margen de Carmen Díez de Rivera podemos citar al líder del partido en Mallorca, Francisco Quetglás

\footnotetext{
${ }^{47}$ CAVERO, Íñigo: "El volátil espacio político de centro", Tiempo, 12 de agosto de 1991.

${ }^{48}$ Entrevista con Rafael Arias-Salgado, 09 marzo de 2015.
} 
(diputado electo en el Parlamento Balear en las listas del PSOE como independiente en 1995), el ex diputado regional murciano Ángel González Hernández o el ex Presidente Federal en la Comunidad Valenciano Gerardo Muñoz ${ }^{49}$. Otros representantes históricos del partido como José Ramón Caso se limitaron a admitir públicamente una mayor sintonía con los posicionamientos socialistas (PSOE) $)^{50}$.

Merece la pena mencionar tres casos, que por distantes, nos hablan de la flexibilidad ideológica del partido centrista. Por un lado, Carlos Sánchez-Reyes, presidente del parlamento regional castellano y leonés con el CDS fue incluido recientemente en las listas de Podemos de cara a las elecciones generales (2015) y el ex ministro Federico Mayor Zaragoza se ha convertido en una voz de las voces críticas de nuestro país con el proceso de globalización económica; por otro lado, el máximo responsable de las Juventudes del CDS durante la década de los años 90', Juan Pina, es en la actualidad máximo responsable del Partido Libertario defensor de una mínima intervención del Estado en todos los ámbitos de la vida económica y social, mientras Ignacio Camuñas y José Luis González Quirós han encabezado la formación conservadora VOX.

El análisis realizado del destino político de los miembros más relevantes del CDS, que hemos abordado de forma sistemática sólo en el caso del Comité Nacional nos ha desvelado como la permeabilidad del CDS al PP tuvo lugar fundamentalmente entre los cargos bajos e intermedios del partido, siendo el destino mayoritario de la militancia que optó por proseguir su carrera política. Mientras, el núcleo del fundacional del partido -José Ramón Caso, Alejandro Rebollo, León Buil o Laura Morso- rechazó respaldar esta operación, desvinculándose definitivamente de la política a raíz de la crisis producida en el CDS entre 1991 y 1993.

Podemos afirmar que el grueso de los integrantes del CDS que permaneció en el partido dejó de participar activamente desde el VI Congreso (1993), momento en el que

\footnotetext{
49 Sobre las trayectorias políticas anteriormente descritas véase, MENÉNDEZ, Miguel Ángel: "Los últimos del CDS", Interviú, 1994, $\mathrm{n}^{\circ}$ 962, Hemeroteca Caixa-Tarragona; PANIGUA, Javier y PIQUERAS, Josep A.: Diccionario Biográfico de Políticos Valencianos, Valencia, Institució Alfons el Mágnanim, 2006; BARRIOS, María Bernarda: Diccionario Biográfico de Diputados Canarios, Madrid, Congreso de los Diputados, 2003; GARRIDO, Aurora: Diccionario Biográfico de los Parlamentarios de Cantabria (1902-2002), Santander, Parlamento de Cantabria, 2003; HERAS, Raúl: Enciclopedia política y Atlas Electoral de la democracia española, Madrid, Temas de Hoy, 1997; PELAZ LÓPEZ, José-Vidal, PÉREZ LÓPEZ, Pablo y CLAVERO ARÉVALO, Mariano: Castilla y León en democracia. Partidos, elecciones y personal político (1977-2007), Madrid, Temas de Hoy, 1997. En el caso de los diputados extremeños véase, http://www.asambleaex.es Fecha de consulta: 10 de junio de 2014.

${ }^{50} A B C, 02$ de julio de 1993.
} 
el partido contaba con cerca de 40.000 afiliados, aunque muchos mantuvieron su militancia en los años siguientes. El 18 de enero de 1994 se inscribía en el Registro Unión Centrista, partido que celebraba su I Congreso en Octubre y en el que fue nombrado Presidente Fernando J. García Fructuoso - cabeza de lista al Congreso por Barcelona con el CDS en 1993- y Secretario General, Rafael Calvo González. En 1998, y tras haber acudido a distintos comicios en coalición, se aprobaba la fusión del CDS y UC, siendo presidente del primero Alberto Dorrego y quedando como máxima dirigente María Teresa Gómez Limón.

En 1999, el CDS-Unión Centrista rondaba los 10.000 afiliados ${ }^{51}$. La proclamación de Mario Conde como candidato a la Presidencia en el año 2000, supuso otra avalancha de bajas. Pocos se reconocían ya en el partido en el partido que fundara Adolfo Suárez en $1982^{52}$. En el año 2005, el CDS, sin apenas fondos, se integró en el Partido Popular, bajo la Presidencia de María Teresa Gómez-Limón y con José Moreira como Secretario General. El acuerdo, negociado entre Ángel Acebes y José Moreira -del que únicamente disponemos el discurso de integración pronunciado por el propio Moreira- respetó los cargos orgánicos del CDS, que se integraron en los comités ejecutivos del PP tras la ratificación "de la propuesta que la Dirección Nacional formulaba en el orden del día de su ONCE Congreso Nacional", celebrado el 26 de noviembre ${ }^{53}$. Este fue el último acto del CDS fundado por Adolfo Suárez en 1982.

\footnotetext{
${ }^{51}$ Datos de afiliación, El País, 10 de agosto de 1993 y 24 de septiembre de 1999.

${ }^{52}$ No existe constancia de la protocolización de los acuerdos -estatutos o nombramientos- en el Registro de Partidos del Ministerio del Interior del V, VI y VII Congreso dentro de la carpeta 560 (CENTRO DEMOCRATICO y SOCIAL (CDS), julio de 1982 hasta abril de 2004). La última comunicación notarial es el nombramiento de José Luis Gómez-Calcerrada. Posteriormente, la información se reinicia a propósito de la coalición entre Foro y CDS. Todavía en 1994, la documentación del Registro de Partidos para cuestiones estatutarias seguía remitiendo al IV Congreso. En 1998 "[Alberto Dorrego, Presidente del CDS] autoriza la cesión en el uso al Partido Unión Centrista (UC), de los signos identificativos de CDS, como logotipo, las siglas y denominaciones regionales, la banda sonora y cualquier otro que en derecho pueda entenderse, sin restricción alguna y para todo uso a título oneroso", en $R P P$, Registro de Entrada, $\mathrm{n}^{\circ}$ 630, 16 de diciembre de 1998, Acta Notarial de Miguel Ángel García-Ramos, no 4153.

${ }^{53}$ Discurso de José Moreira de integración en el Partido Popular, 2005, Documentación de José Moreira.
} 

CONCLUSIONES 

“Adolfo Suárez será permanentemente, una polémica figura para los aficionados o los profesionales de la Historia, en estas postrimerías del siglo XX. Luego se serenarán las cosas, y a lo mejor en el otro siglo le glorifican ${ }^{1}$.

La aguda y descarnada observación de Emilio Romero, realizada de 1985 no estaba desencaminada, aunque los acontecimientos se adelantaron algo más de lo que el autor de estas líneas preveía. A lo largo de la presente tesis doctoral y de acuerdo con los objetivos planteados, hemos recorrido la trayectoria política de Adolfo Suárez entre 1982 y 1991 y junto a él, el sinuoso camino del partido que fundara y dirigiera en este período, el Centro Democrático y Social. A la par, nos hemos sumergido en el análisis del "centro" como realidad política, y su desenvolvimiento en el proceso de reordenación del sistema de partidos vivido en España durante los años 80' a propósito del hundimiento de UCD. En última instancia, hemos pretendido aportar algunas claves para abordar las reflexiones que hicieron acerca del papel de Adolfo Suárez sus contemporáneos, singularmente, desde los medios de comunicación y la política. Comprender las circunstancias del nacimiento del Centro Democrático y Social, su peripecia electoral durante una década y la actitud en ocasiones resuelta, otras errática, de su líder, Adolfo Suárez, ha implicado el conocimiento exhaustivo de la vida política española durante esta etapa.

Con el fin de desplegar las conclusiones de nuestro trabajo, trazaremos dos grandes líneas argumentativas que nos permitirán valorar, con una nueva luz, las hipótesis planteadas en la introducción. De un lado, abordaremos la noción de centro político y su concreción ideológica y programática en el Centro Democrático y Social. Veremos las principales lecturas acerca de la consistencia ideológica del CDS por parte de los medios de comunicación y del resto de fuerzas políticas, e intentaremos, prestando especial atención a la política exterior, autonómica y económica, desgranar los planteamientos del partido de Adolfo Suárez. En segundo lugar, desarrollaremos el papel jugado por Adolfo Suárez en la Presidencia del CDS y las consecuencias del mismo desde el punto de vista estratégico y organizativo. Reflexiones que nos llevarán en última instancia a evocar los múltiples perfiles que adquirió su pasado presidencial tanto dentro del propio CDS como en los medios de comunicación.

\footnotetext{
${ }^{1}$ ROMERO, Emilio: Retratos..., p. 151.
} 
El CDS intentó trasladar el esquema de valores defendido durante la Transición a la realidad del sistema de partidos español de los años $80^{\prime}$, en una etapa en el que no resultaba evidente todavía el carácter reformista del PSOE, ni se adivinaba el aggiornamiento de la derecha conservadora. El CDS se ofrecía así como elemento de consenso, diálogo y moderación, un puente entre AP y PSOE, defensor de los grandes pactos de Estado, por ejemplo, en materia educativa, económica o exterior. Este carácter, en un primer momento limitado a las escasas intervenciones públicas de los miembros del partido y más bien testimonial, se tradujo desde 1987 en la posibilidad de ejercer de "facilitador" de mayorías parlamentarias en las distintas instituciones. Como había hecho el FDP alemán, el CDS pudo ser un partido bisagra inclinado alternativa o simultáneamente a izquierda y derecha; un papel en el que fue relevado desde 1991 por los partidos regionalistas y nacionalistas tras los precipitados pactos con el PP de 1989 y el posterior giro de 1990 hacia el PSOE.

Desde el CDS, lamentaban que su política de acuerdos homologable a la de otros partidos socio-liberales y progresistas europeos no hubiera sido comprendida. De una parte, los errores estratégicos de los centristas y de otra, la crítica implacable bien de su derechización, bien de su alianza con el poder socialista, que medios de comunicación y el conjunto de las fuerzas políticas ejercieron por igual, imposibilitó el éxito de esta fórmula.

En cualquier caso, nuestro intento por caracterizar programática e ideológicamente el centro ha resultado cuanto menos complejo y el juego de adscripción de etiquetas se ha mostrado infructuoso, cuando no, frustrante. Siguiendo, las categorizaciones empleadas en la época podemos concluir lo siguiente. En primer lugar, ha sido perceptible la presión de los medios de comunicación más conservadores favoreciendo el uso genérico del término centro-derecha para alentar la formación de grandes coaliciones a la derecha del PSOE y allanar el trasvase de electores desde el CDS a AP; mientras que por otro, desde la izquierda, se servían de esta categoría para descalificar las pretensiones progresistas del partido de Adolfo Suárez y acolchar una previsible pérdida de votos del PSOE. En segundo lugar, fue habitual el uso de apelativos con evidente afán descalificador por columnistas, editorialistas y políticos para referirse a la supuesta indefinición y demagogia del partido "suarista". Paradójicamente, algunos de los términos empleados, como la etiqueta de "populismo", eran al menos tan imprecisos como la realidad que se pretendía denunciar. En este sentido fue patente sin embargo, la 
atracción electoral que suscitaba la vaga alusión "suarista" a los "poderes fácticos", sustitución sui generis de la clásica dicotomía pueblo-elites. En un escrito elaborado junto a su secretario personal Eduardo Navarro en los últimos años de su vida pública todavía se manifestaba en estos términos al abordar la crisis de legitimidad de los partidos políticos:

En nuestra sociedad han surgido nuevos Poderes "de hecho". La antigua referencia al Ejército o la Iglesia no es ya válida. Al menos no lo es, con la intensidad y la fuerza con que hace 20 años se predicaba. Esos nuevos poderes son hoy el dinero y los medios de comunicación. [...] este es un fenómeno que se da en todos los países [...] Esta libertad [...irrenunciable...] no es una patente de corso para la manipulación ${ }^{2}$.

Podemos afirmar que el CDS careció de un cuerpo doctrinal coherente y cohesionado que fuera garantía de estabilidad. Creemos que la causa se halla en el carácter esencialmente histórico y no doctrinal o filosófico con el que se dotó la noción de "centro" político en España desde su constitución por UCD, su fuerte personalización en el Adolfo Suárez del bienio 1976-1978 y los acontecimientos finales de la Transición. Personalismo comunitario, progresismo, social-liberalismo o liberalismo progresista fueron parches ante una realidad cuya denominación más acertada, por adecuarse perfectamente a la experiencia política de la Transición, fue la de centro reformista. Remitiéndonos a los valores que lo caracterizaban debemos mencionar su tendencia al diálogo y al pacto y la defensa del ideal meritocrático y la igualdad de oportunidades.

No obstante, debe ser tenido en cuenta que la ambigüedad ideológica del CDS participaba de un contexto, cuya tendencia primordial era hacia la laxitud y la flexibilidad. Buen ejemplo de ello, fueron la renovación del comunismo en torno a Izquierda Unida, el salto desde el conservadurismo liberal al centrismo reformista por parte del Partido Popular o la brecha abierta entre los contenidos programáticos del PSOE y unas políticas, que en lo económico, y una vez abandonado el socialismo marxista, pasaron rápidamente de la socialdemocracia al socio-liberalismo, hasta el punto de haber sido definido como un "partido burgués de centro"3.

\footnotetext{
2 "Nota sobre 20 años de transición. Retos", Dossier 11, Archivador 3, Archivo J. Trías-Sagnier y Eduardo Navarro Álvarez.

${ }^{3}$ YSÁS, P. y MOLINERO, C.: Historia de España siglo XX: 1939-1996, Madrid, Cátedra, 1999, p. 317. Quien fuera analista socio-político de cabecera del CDS, Ralf Darhendorf, afirmaba en una ponencia de cara al Congreso de la ILP: "los partidos socialistas están evolucionando hacia algo muy distinto para lo que no hay nombre adecuado", DAHRENDORF, Ralf: "Futuras tareas del liberalismo, una agenda política", Pisa, 1988, MAST.
} 
En cierto modo, todo ello contribuyó a acentuar las contradicciones ideológicas presentes en el propio Suárez, reticente a ser etiquetado como "conservador" y que quiso relanzar su carrera política en el espacio de centro progresista, es decir, ligeramente inclinado hacia la izquierda; una tendencia, cuyo origen bebía de su propia experiencia personal -“chusquero de la política”- y que era espoleada por la crítica, más o menos fácil, a algunas decisiones socialistas difícilmente encuadrables en el imaginario político de la izquierda.

Si nos remitimos al análisis de los contenidos programáticos, el protagonismo de partidos caracterizados como de catch-all -o en su caso, partidos-cartel-, dificulta enormemente el deslindamiento de lo que puedan constituir fuegos de artificio electoral y aquello que remita a las fuentes ideológicas y doctrinales. Con el fin de contribuir a la clarificación ideológica del suarismo y percibir las continuidades o discontinuidades en el conjunto de la trayectoria política de Adolfo Suárez debemos descender aún un poco más, y abordar con detenimiento las tres áreas que más interés recibieron por parte del CDS: política exterior, política autonómica y economía.

En relación a la política exterior, la posición del CDS, en numerosas ocasiones titubeante, se incardinaba con la indecisión de Adolfo Suárez ya durante su mandato presidencial; una aceptación a regañadientes de lo que, por otra parte, se veía en amplios sectores de la sociedad como inevitable. Es decir, implicaba la alineación de España no sólo política, económica y cultural con Occidente, sino también militar, con las consecuencias que de ello se derivaban dado el papel hegemónico de EE.UU. en perjuicio de Europa. Baste recordar, la actitud del CDS durante el referéndum sobre la permanencia en la OTAN (1986). Si la "transición exterior" había sido iniciada por Adolfo Suárez desde unos planteamientos muy personales en 1976, su culminación en 1988 -año en el que se concretaba definitivamente la política española de seguridad y defensa- fue acogida con bastante frialdad entre las filas suaristas.

Cabe señalar que quizá sea la faceta relativa a la política exterior, donde Adolfo Suárez escenificó mejor, el papel de hombre de estado distante con el día a día político que tanto gustaba de representar, sobre todo en Iberoamérica, pero también percibiendo con cierta clarividencia los derroteros políticos y económicos del mundo posterior a la caída del Muro de Berlín. Lo que hacía una década se consideraba el "síndrome" del 
Estrecho de Ormuz se había convertido en la cruda realidad, "la última gran intuición política de Adolfo Suárez", como ha dejado escrito el profesor Fuentes Aragonés.

La postura del CDS en materia autonómica constituyó, en líneas generales, una férrea defensa del desarrollo de todas las potencialidades que encerraban la Constitución y los estatutos autonómicos, asumiendo, por ejemplo, una postura crítica con la LOAPA. El objetivo era dotar de una verdadera autonomía decisoria a las comunidades, capaz de complementarse en materia financiera con el reequilibrio de las diferencias regionales existentes. Los congresos monográficos dedicados al análisis del futuro autonómico, en un partido de escasas dimensiones y recursos, son un testimonio de la preocupación central de Adolfo Suárez por la cuestión autonómica. En su mirada retrospectiva sobre la Transición, desarrollada junto a Eduardo Navarro Álvarez, subrayaba: "la Democracia nacía en España con dos aspiraciones inequívocas: Europa y Autonomías"4. En cualquier caso, el papel del CDS fue siempre secundario, y si adquiría relevancia mediática era habitualmente por la autoridad de su líder, Adolfo Suárez. Podemos concluir, que el planteamiento del CDS sobre el desarrollo autonómico fue sostenido sin grandes modificaciones desde sus inicios, cuando apenas contaba con representación, lo que no quiere decir, como hemos intentado resaltar, que sus posicionamientos no se viesen condicionados por la realidad política más inmediata. Una vez más, la apuesta autonómica del CDS estaba enraizada en la labor de los ejecutivos de Adolfo Suárez, durante los cuales se puso en marcha este proceso de descentralización. La coherencia del CDS contrastaba con la evolución del discurso de AP, a medida que aumentaba sus cotas de poder en los diversos gobiernos regionales, $\mathrm{o}$ la posición de un PSOE, sujeto a las responsabilidades de gobierno.

En política económica, el CDS sufrió una considerable evolución. En un primer momento asumió rasgos socialdemócratas, aunque de una forma vaga e imprecisa, para avanzada la década de los $80^{\prime}$ mostrarse partidario de políticas liberales por ejemplo, en la gestión de servicios públicos, sin abandonar nunca la capacidad interventora del Estado y sobre todo el uso de las políticas sociales como factor redistributivo. Un aspecto que debemos destacar, y en cuya visibilidad tuvo un notable éxito el CDS, fue la puesta en marcha de un discurso económico centrado en torno a las PYMES como agente económico primordial, y que entendía la responsabilidad política e institucional,

\footnotetext{
${ }^{4}$ Borrador de una copia para Pte. Conferencia sobre la Transición en el "Dossier 2", Archivador 1, Archivo Eduardo Navarro de Jorge Trías Sagnier.
} 
en términos de eficacia y gestión. Sendas ambas que han recogido fructíferos réditos electorales desde los años 90', sobre todo en el espacio de centro-derecha.

Una vez recorridas las claves ideológicas y programáticas del CDS, debemos reflexionar acerca del papel jugado por Adolfo Suárez al frente del partido. Se ha hablado mucho de su dificultades para ejercer la dirección política ordinaria, aspecto compartido por buena parte de las fuentes orales consultadas, y que nos lleva a subrayar su fracaso a la hora de generar estructuras sólidas que trascendieran su protagonismo recuérdense los IV, V y VI Congresos-. La concepción personalista del poder perceptible en la formación del Comité Nacional durante este período- y la concentración de la toma de decisiones en su persona volvió más vulnerable su liderazgo en el momento en el que descendieron las expectativas electorales; posteriormente, su marcha de la política arrastró inexorablemente al partido. De esta afirmación, podemos colegir el carácter "carismático" del CDS. La categoría, empleada por Angelo Panebianco, concibe a estas formaciones políticas como vehículos de transmisión de un liderazgo, hecho perceptible en el CDS desde su fundación hasta su declive y en las que la presencia del componente carismático transitó en perjuicio de la capacidad de institucionalización -y por ende, supervivencia-, del partido. No obstante, las frecuentes críticas alusivas a la ausencia de democracia interna en el suarismo no deben hacernos olvidar que éste ha sido un déficit común al conjunto de la política española y que en el caso del CDS centraba con particular intensidad los focos de la prensa. Tampoco hay que menospreciar el recuerdo de lo sucedido en UCD y como el cuestionamiento del liderazgo llevó a su crisis. En todo caso, siendo cierto todo lo anterior, resulta evidente la fuerte dependencia, que a todos los niveles, generaba la figura de Adolfo Suárez.

Además, la personalidad de Adolfo Suárez influyó decisivamente en la concepción estratégica del "centro" político encarnado en el CDS. Para Suárez el "centro" no se podía concebir como un totum revolutum equiparable a lo que había supuesto UCD, concepción que le llevó por ejemplo a rechazar el pacto con la Operación Roca. La compleja relación de Adolfo Suárez con la derecha política española, consecuencia tanto de unas convicciones políticas distantes como de la propia experiencia ucedista, le alejaban de cualquier opción de encabezar una coalición alternativa al socialismo. La experiencia histórica nos ha impedido desvelar si la estrategia de Adolfo Suárez pasaba por colaborar con el PSOE, bien desde el Gobierno o de la mano de un Pacto de 
Legislatura en caso de haber obtenido los socialistas una mayoría relativa en 1982 o 1986, una hipótesis por otra parte que resulta absolutamente plausible de acuerdo con las fuentes manejadas. En cualquier caso, la fortaleza de los gobiernos del PSOE forzó a Adolfo Suárez a un juego de bisagras, erróneamente planteado y siempre a remolque de los acontecimientos - pactos con el PP en 1989 y con el PSOE en 1990- que sin respaldo mediático alguno y por ende, carente de canales de comunicación válidos con el electorado tenía escasas posibilidades de triunfar.

Debemos tener en cuenta asimismo, el perfil institucional mantenido por Adolfo Suárez durante este período. Siguiendo los testimonios de compañeros de partido, siempre antepuso los intereses del Estado y una visión de estadista a la lucha política partidaria. En este sentido, a lo largo de esta década se caracterizó por mantener una actitud excesivamente cautelosa y esquiva con las cuestiones más polémicas, aunque en ocasiones incluso pareciera ir en perjuicio de los intereses inmediatos del partido. Un perfil que completó con su actuación internacional en Iberoamérica y en menor medida Europa del Este, donde ejerció de representante del proceso transicional español. Una actuación que sin embargo, al enmarcarse dentro de su estrategia de afianzamiento en el panorama político nacional, dificultó su recepción en España donde seguían siendo habituales las críticas.

De este modo, el fracaso en la institucionalización del CDS radicó tanto en factores externos como internos. Por un lado, hemos constatado a través del análisis de la organización del partido, la incapacidad del CDS y el núcleo "suarista" para delegar responsabilidades en el proceso de toma de decisiones y cómo este hecho, fue fatídico a raíz de los descensos electorales. Por otro lado, podemos hablar de una oposición sistemática por parte de los medios de comunicación -que apostaron decididamente por el bipartidismo-, impidiendo a los "suaristas" dotarse de respaldos sólidos en la sociedad.

Estos fracasos, estratégicos y estructurales, no ocultan sin embargo, un notable éxito anterior, puesto habitualmente en solfa. Nos referimos a la creación sin apenas recursos, medios o publicidad de un proyecto político de alcance nacional en poco más de tres años. Acontecimiento de relieve que debemos atribuir al empeño de Adolfo Suárez junto a Agustín Rodríguez Sahagún y José Ramón Caso-, y que se llevó a cabo, sin ningún apoyo mediático o financiero estable -buena muestra de ello, es el acercamiento 
a personajes como José María Ruiz-Mateos o Mario Conde, de gloria efímera en el mundo económico español-.

Finalmente, el análisis de la "opinión publicada" nos ha permitido extraer una visión más global de las dinámicas políticas vividas en España durante esta década. Actualmente, pudiera parecer que el mayor obstáculo en la reivindicación de Adolfo Suárez dentro del panteón democrático español fue su pasado franquista; como consecuencia de la denuncia de los continuismos existentes entre la Dictadura y la Transición se han constituido precisamente buena parte de las posturas críticas y desmitificadoras de este proceso político. Sin embargo, es interesante advertir que fueron las instancias que se encargaron de la recuperación pública de su protagonismo político y que en buena medida han construido la visión "oficial" de la Transición, -medios de comunicación y partidos políticos- las que, como hemos visto, pospusieron indefinidamente este reconocimiento, especialmente, por motivos de competencia electoral. De este modo, el punto de inflexión fundamental en la valoración de la obra de Suárez en la Transición, dependió de su abandono definitivo de la actividad política y particularmente, de la reestructuración del sistema de partidos a la derecha del PSOE.

La paradoja consistía en que la caricaturización de Suárez (ambición, ignorancia, indefinición ideológica, etc.) repercutía indirecta y negativamente en la propia naturaleza y legitimidad del proceso transicional. Sólo así se entiende que el giro producido desde mediados de los 90', -reconocimiento público e institucional de Adolfo Suárez-, haya llegado a ser valorado, en palabras de Javier Tusell como un auténtico proceso de "higiene pública colectiva". El contraste entre el discurso historiográfico y periodístico de las realizaciones políticas de Adolfo Suárez antes y después de 1979, aún hoy perceptible, no se sustenta únicamente en la enorme magnitud del legado de uno y otro período -entiéndanse los años centrales de la Transición, y por otra parte, el 23-F, el fin de UCD y la creación del CDS-, sino que enmascara una constante, sostenida durante casi una década, en la que editorialistas, columnistas, políticos e intelectuales de diversas tendencias se afanaron en desautorizar sistemáticamente todas las decisiones públicas del abulense -por dispares que estas fueran-. Hasta el punto de que, la caricatura de Adolfo Suárez -“el duque”- fue el discurso hegemónico sobre el personaje hasta su abandono de la política. En este

\footnotetext{
${ }^{5}$ TUSELL, J.: "Prólogo" en IGLESIAS, Ma Antonia: La memoria recuperada: lo que nunca han contado Felipe González y los dirigentes socialistas de sus años de gobierno, Madrid, Aguilar, 2003, p. 24.
} 
sentido, las críticas a la existencia o no per se de estrategias políticas centristas o la mayor o menor artificialidad de los proyectos sustentados en liderazgos personales, adquirían una nueva dimensión condicionada por la más inmediata lucha electoral. Las apelaciones a los modelos de sociedad, la clarificación política, el voto cautivo o el voto prestado intentaban dotar de respaldo analítico a lo que, antes que nada, era una parte más y ni siquiera la más determinante, del combate político.

Gracias a las fuentes utilizadas, hemos podido rastrear la evolución de la visión, y posterior ocupación conservadora del centro político, en ese momento capitalizado por el CDS. Desde este punto de vista, se aprecia la invariabilidad y estabilidad de dicha lectura a lo largo de la década y cómo alrededor de la misma fueron pivotando las distintas estrategias conducentes a la construcción de una alternativa al socialismo. De este modo, se llevó a cabo un proceso de uniformización y naturalización de un espacio en origen plural que sucumbió no sólo a la materialización definitiva de afinadas hipótesis políticas, sino básicamente al triunfo de unos intereses concretos sobre otros, consecuencia en buena medida de un desequilibrio en la correlación de fuerzas. La tesis de la mayoría natural estaba recorriendo un tramo más en un camino que se iba a revelar como una profecía auto-cumplida. Precisamente por ello, la supuesta ventaja de Adolfo Suárez, haber vencido dos veces en las elecciones generales y ejercer la presidencia de gobierno en el proceso fundacional de la democracia, la Transición, significó en este momento un aliciente más para lograr su desactivación política posponiendo indefinidamente el reconocimiento explícito a su labor.

Creemos estar en condiciones de afirmar que el CDS encarnó en sus inicios y de forma genuina el significado político, social y económico de la Transición, etapa en la que estaba absolutamente enraizado. Sin embargo, aunque fracasó en su intento de convertirse en una cuña liberal, que sin perder el tono social, ejerciera de bisagra entre la derecha y la izquierda, condicionó decisivamente el futuro de la democracia española. Contribuyó al proceso de renovación del Partido Popular al ser el principal punto de llegada de políticos centristas en el ocaso del CDS, benefició la fluidez del voto entre la izquierda y la derecha y contribuyó decisivamente a redirigir hacia el centro el debate político. Podemos remarcar incluso la audacia y éxito del CDS a la hora de introducir con escasos recursos asuntos determinantes en la agenda pública -por ejemplo, lo relativo al servicio militar-. 
De alguna manera, la presente Tesis Doctoral ha pretendido ofrecer testimonio de una etapa política de la Historia de España en la que Adolfo Suárez, protagonista de la Transición, era el singular punto de contacto entre el pasado histórico del país y las más audaces apuestas de futuro o como fuera definido en la época "el pasado más próximo al futuro"6. En torno a la figura de Adolfo Suárez, se concentraron discursos periodísticos, parlamentarios y electorales de una extrema e inusual densidad, que paradójicamente pasaron a la opinión pública como si de un puñado de "frases hechas" se tratasen. Desandar este camino, reconstruir los hechos históricos decisivos y reinterpretar de forma contextualizada estos testimonios de nuestro pasado reciente han sido nuestros principales objetivos. Por ello, aun tentados de ejercitarnos en las lides de las historia contrafáctica -¿cómo hubiera sido la evolución de la historia política española con el CDS?, ¿qué hubiera ocurrido si el PSOE pierde la mayoría en 1986?, ¿si Adolfo Suárez se hubiera retirado en 1982 de qué forma se hubiera recordado su gestión presidencial?, etc.- creemos prudente no incurrir, al menos por esta vez, en excesos retóricos sobre un pasado, ya de por sí, más que sugerente.

\footnotetext{
${ }^{6}$ PARADA, Luis I.: “Tántalo Suárez”, ABC, 28 de octubre de 1989.
} 
CONCLUSIONS 

'Adolfo Suárez will permanently be, a controversial figure for amateurs or professionals of history, of the latter stages of the twentieth century. Then things will be settled, and perhaps in the next century he will be glorified ${ }^{1}$.

Emilio Romero's sharp and stark observation of 1985 was not misleading, although the events advanced somewhat more than the author of these lines had foreseen. Throughout this doctoral thesis and in accordance with the objectives set out, we have traced the political trajectory of Adolfo Suárez between 1982 and 1991 and next to him, the winding road of the party that he founded and directed in this period, the Democratic and Social Center. At the same time, we have immersed ourselves in the analysis of the "center" as a political reality, and its development in the process of party system reordering lived in Spain during the 1980s, with regard to the collapse of UCD. Ultimately, we have tried to provide some clues to address the reflections some his contemporaries made about the role of Adolfo Suárez, notably from the media and politics. Understanding the foundation of the Democratic and Social Center, its electoral validity for a decade, and the sometimes resolute, sometimes erratic attitude of its leader, Adolfo Suárez, involves a exhaustive knowledge of the Spanish political life during this stage.

In order to unfold the conclusions of our work, we will elaborate on two great argumentative lines that will enable us to assess, with a new light, the hypotheses presented in the introduction. On the one hand, we will approach the notion of political center and its ideological and programmatic concretion in the Democratic and Social Center. We will present the main readings about the ideological consistency of CDS drawn the media and other political forces, and we will try to unravel Adolfo Suárez's party proposals, paying special attention to foreign, autonomic and economic policies. Secondly, we will develop the role played by Adolfo Suárez in the Presidency of CDS and the consequences of the same from the strategic and organizational point of view. Reflections that will ultimately lead us to evoke the multiple profiles acquired by his presidential past both in CDS itself and in the media.

CDS attempted to move the value scheme advocated during the Transition towards the reality of the Spanish party system of the 1980s, at a stage at which the reformist

\footnotetext{
${ }^{1}$ ROMERO, Emilio: Retratos..., p. 151.
} 
character of PSOE had not yet been foreseen, nor was the aggiornamiento of the conservative right . CDS was offered this way as an element of consensus, dialogue and moderation, a bridge between AP and PSOE, as the defender of the major State covenants, for example, about educational, economic or external matters. This character, initially limited to the few public interventions of the members of the party and rather testimonial, has since 1987 been translated into the possibility of exercising as a "facilitator" of parliamentary majorities in the different institutions. As the German FDP had done, CDS might be a party alternatively or simultaneously hinged between left and right; a role in which was relieved since 1991 by the regionalist and nationalist parties after the precipitous pacts with the PP of 1989 and the subsequent turn of 1990 towards PSOE.

The CDS core regretted that their policy of agreements, comparable to that of other European socio-liberal and progressive parties, had not been understood. On the one hand, the strategic errors of the centrists and on the other hand, the relentless criticism either of their drift towards the right (derechización), or either their alliance with power, which the media and the whole of the political forces exercised equally, prevented the success of this formula.

In any case, our attempt to programmatically and ideologically characterize the center has been, to say the least, complex and the labeling game has been unsuccessful, if not frustrating. Following the categorizations used at the time we can conclude the following. In the first place, it is perceptible the pressure of the more conservative media favouring the generic use of the term center-righ to encourage the formation of great coalitions to the right of PSOE and to smooth the transfer of voters from CDS to AP; while on the other hand, from the left, they used this category to disqualify the progressive claims of Adolfo Suárez's party and to cushion a foreseeable loss of votes of PSOE. Secondly, it was customary to use appellations with a clear disqualifying desire by columnists, editorialists and politicians to refer to the supposed indefinition and demagoguery of the "suarista" party. Paradoxically, some of the terms used, such as the label of "populism", were at least as imprecise as the reality that was intended to be denounced. However, during this whole period, the electoral attraction that the vague allusion "suarista" to "factual powers" was evident, sui generis substitution of the classic village-elites dichotomy. In a paper written with his personal secretary, Eduardo 
Navarro, in the last years of his public life he still expressed in these terms when addressing the crisis of legitimacy of political parties:

In our society new powers have emerged "de facto". The old reference to the Army or Church is no longer valid. At least it is not, with the intensity and strength with which 20 years ago was preached. These new powers today are money and the media. [...] this is a phenomenon that occurs in all countries [...] This freedom [...indispensable...] is not a carte blanche for manipulation ${ }^{2}$.

We can say that CDS lacked a coherent and cohesive body of doctrine that guaranteed stability. We believe that the cause lies in the essentially historical and nondoctrinal or philosophical character with which the notion of political "center in Spain has been endowed since its constitution by UCD, its strong personalization in the Adolfo Suárez of the biennium 1976-1978 and the final events of the Transition. Communitarian personalism, progressivism, social liberalism or progressive liberalism were patches to a reality whose most appropriate denomination, to fit perfectly to the political experience of the Transition, was that of a reformist center. Referring to the values that characterized it, it should be mentioned its tendency to dialogue and negotiate and the defense of the meritocratic ideal and equal opportunities.

On the other hand, the ideological ambiguity of the CSD was part of a context whose main tendency was laxity and flexibility. A good example of this was the renewal of communism around the United Left, the leap from liberal conservatism to reformist centrism by the Popular Party or the open gap between PSOE programmatic content and some policies, regarding economics, and once having the Marxist socialism been abandoned, moved rapidly from Social-Democracy to socio-liberalism, to the point of being defined as a "bourgeois center party." 3 .

In a way, all this contributed to accentuate the ideological contradictions that where present in Suárez, reluctant to be labeled as "conservative" and wanting to relaunch his political career in the progressive center space, that is, slightly inclined to the left; A tendency whose origins he drank from his own personal experience - "chusquero de la

\footnotetext{
2 "Nota sobre 20 años de transición. Retos", Dossier 11, Folder 3, Archivo J. Trías-Sagnier y Eduardo Navarro Álvarez.

${ }^{3}$ YSÁS, P. y MOLINERO, C.: Historia de España siglo XX: 1939-1996, Madrid, Cátedra, 1999, p. 317. The socio-political analyst of the DCS head, Ralf Darhendorf claimed at a speech aimed to the run for the ILP Congress: "Socialist parties are evolving towards something very different for what we have no appropiate name", DAHRENDORF, Ralf: "Futuras tareas del liberalismo, una agenda política", Pisa, 1988, MAST.
} 
política" - and which was spurred by criticism, more or less easy, towards some socialist decisions hardly framed in the political imaginary of the left.

If we refer to the analysis of the programmatic content, the protagonism of parties characterized as catch-all -or in their case, billboard-parties-, greatly hinders the delineation of what may constitute electoral fireworks and all what refers to the ideological and doctrinal sources. In order to contribute to the ideological clarification of suarismo and to perceive the continuities or discontinuities in the political trajectory of Adolfo Suárez we must descend still a little more, and to take a close look at the three areas that received the most interest from CDS: foreign policy, autonomic policy and economy.

Regarding foreign policy, the position of CDS, in many occasions hesitant, matched with the indecision of Adolfo Suárez during his term; a reluctant acceptance of what, on the other hand, was seen in broad sectors of society as inevitable. That is to say, it implied not only a political, economic and cultural alignment with the West, but also a military one, with the consequences derived from it, given the hegemonic role of the United States to the detriment of Europe. It is enough to recall the attitude of CDS during the referendum on the permanence of Spain in NATO (1986). If Adolfo Suárez's "external transition" had been initiated from some very personal approaches, its culmination in 1988 - year in which the Spanish security and defense policy finally took shape - was welcomed with rather coldness among the ranks of the Suaristas.

It should be noted that it may be the foreign policy facet, where Adolfo Suárez better staged the role of distant statesman with the political day-to-day that he liked to represent, perceiving with some foresight the political and economic paths of the later world subsequent to the fall of the Berlin Wall. What a decade ago was considered the "syndrome" of the Strait of Hormuz had become the stark reality, "the last great political intuition of Adolfo Suárez," as Professor Fuentes Aragonés left us written.

The position of CDS in autonomic matters was, in general terms, a strong defense of the development of all the potentialities that contained the Constitution and the autonomic statutes, assuming, for example, a critical position with LOAPA. The objective was to provide real autonomy for decision-making in the communities, capable of complementing in financial matters with the rebalancing of existing regional differences. The monographic congresses dedicated to the analysis of the autonomic 
future, in a match of scarce dimensions and resources, are a testimony of the central concern of Adolfo Suárez about the autonomic question. In his retrospective view of the Transition, developed with Eduardo Navarro Álvarez, he emphasized: "Democracy was

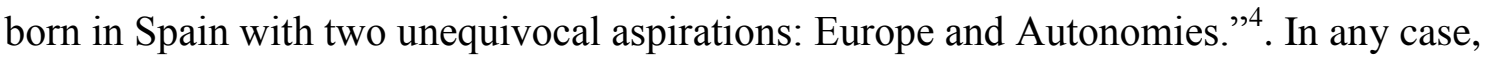
the role of CDS was always secondary, and if it acquired media relevance it was usually by the authority of its leader, Adolfo Suárez. We can conclude that CDS's approach to autonomic development was maintained without major changes from the outset, when it was hardly represented, which does not mean, as we have tried to emphasize, that its positions were not conditioned by the most inmediate political reality. However, the bet of CDS for an autonomic state was rooted in the work of the executives of Adolfo Suárez, during which this process of decentralization was initiated. The coherence of CDS contrasted with the evolution of the PA discourse, as its power levels increased in the various regional governments, or the position of a PSOE, subject to the responsibilities of government.

In economic policy, CDS underwent a considerable evolution. At first it assumed social democratic features, although in a vague and imprecise way,so that in the late 1980s it could show itself supportive of liberal policies, for example, in the management of public services, without ever abandoning the State's capacity to intervene and, above all, the use of social policies as a redistributive factor. One aspect that we must highlight, and thanks to whose visibility CDS achieved a notorious success, was the launching of an economic discourse centered around SMEs as a primary economic agent, which undestood the political and institutional responsibility in terms of effectiveness and Management. Both paths have collected fruitful electoral revenues since the 1990s, especially in the center-right space.

Once we have covered the ideological and programmatic clues of CDS, we must reflect on the role played by Adolfo Suárez as head of the party. Much has been said about Adolfo Suárez's difficulties in exercising the ordinary political leadership, an aspect shared by many of the oral sources consulted, and which leads us to underline his failure to generate solid structures that transcend his protagonism - remember the IV, V and VI Congresses. The personalistic conception of power - perceptible in the formation of the National Committee during this period - and the concentration of the decision-

\footnotetext{
${ }^{4}$ Draft of a copy for Presidente, conference about Spanish Transition, "Dossier 2", Folder 1, Archivo Eduardo Navarro de Jorge Trías Sagnier.
} 
making in his person made his leadership more vulnerable at the moment when the electoral expectations descended; subsequently, his leaving politics dragged inexorably the party. From this statement, we can recognize the "charismatic" character of CDS. The category, used by Angelo Panebianco, conceives these political formations as vehicles of transmission of a leadership, made perceptible in CDS from its founding until its decline and in which the presence of the charismatic component passed to the detriment of the capacity of institutionalization - and hence the survival, of the party. The frequent criticisms alluding the absence of internal democracy should not make us forget that this has been a common deficit in the whole of the Spanish politics, and that in the case of CDS, it focused with particular intensity the focus of the press. It was actually truthful, however, the exisxtence of a strong dependence, which at all levels generated the figure of Adolfo Suárez.

In addition, the personality of Adolfo Suárez decisively influenced the strategic conception of the political "center" embodied in CDS. For Suárez the "center" could not be conceived as a totum revolutum comparable to what UCD had assumed, a conception that led him, for example, to reject the pact with Operation Roca. Adolfo Suárez's complex relationship with the Spanish political right, as a result of both distant political convictions and his own ucedist experience, kept him away from any option of leading an alternative coalition to socialism. Historical experience has prevented us from revealing if Adolfo Suárez's strategy was to collaborate with PSOE, either from the Government or from the Pact of Legislature in case the Socialists obtained a relative majority in 1982 or 1986, a hypothesis which seems absolutely plausible according to the sources handled. In any case, the strength of the governments of PSOE forced Adolfo Suárez to play the hinges, erroneously raised and always awaiting events to happen - covenats with PP in 1989 and with PSOE in 1990 - which without any media support and therefore, lacking valid channels of communication with the electorate had little chances of success.

We must also take into account the institutional profile maintained by Adolfo Suárez during this period. Following the testimonies of party partners, he always put the interests of the State and a statesman's vision of the party political struggle. In this sense, throughout this decade he was characterized by maintaining an excessively cautious and elusive attitude with the most controversial issues, although at times even appear to go towards the detriment of the immediate interests of the party. A profile that 
he completed with his international performance in Latin America and to a lesser extent Eastern Europe, where he served as representative of the Spanish transitional process. An action that, however, as part of its strategy of strengthening the national political scene, made it difficult to receive it in Spain, where criticism was still common.

In this way, the failure to institutionalize CDS was based on both external and internal factors. On the one hand, we have verified through the analysis of the organization of the party, the inability of CDS and the nucleus "suarista" to delegate responsibilities in the decision-making process and how this fact was fateful due to the electoral declines. On the other hand, we can speak of a systematic opposition on the part of the mass media - that bet decisively for the bipartisanship -, preventing the "Suaristas" endow themselves with solid backups in the society.

These failures, strategic and structural, however, do not hide a notable earlier success, usually placed in solfa. We refer to the creation almost without resources, means or publicity of a political project of national scope in little more than three years. An outstanding event that we must attribute to the efforts of Adolfo Suárez - along with Agustín Rodríguez Sahagún and José Ramón Caso -, and that was carried out, without any stable media or financial support - a good example of this, is the approach to characters like JM Ruiz-Mateos or Mario Conde, of ephemeral glory in the Spanish economic world.

Finally, the analysis of "published opinion" has allowed us to extract a more global view of the political dynamics experienced in Spain during this decade. At the present time, it may seem that the greatest obstacle in Adolfo Suárez's claim within the Spanish democratic pantheon was his Francoist past; as a consequence of the complaint of the continuisms between the Dictatorship and the Transition, a large part of the critical and demystifying positions of this political process have been constituted. However, it is interesting to note that it was the instances that were responsible for the public recovery of their political role and that to a large extent have constituted the "official" vision of the Transition, -media and political parties- which, as we have mentioned, have indefinitely postponed this recognition, especially with respect to the electoral competition. This way, the fundamental turning point depended on the definitive abandonment of the political activity by Adolfo Suárez and in particular, the restructuring of the party system to the right of PSOE. 
The paradox was that the caricaturization of Suárez (ambition, ignorance, ideological indefinition, etc.) had an indirect and negative impact on the very nature and legitimacy of the transitional process. Only this way can it be understood that the turnaround since the mid-1990s, -of the public and institutional recognition of Adolfo Suárez-, has been valued, in the words of Javier Tusell, as an authentic process of "collective public hygiene" ${ }^{~}$. The contrast between the historiographic and journalistic discourse of Adolfo Suárez's political achievements before and after 1979, still perceptible today, is not only based on the enormous magnitude of the legacy of the two periods - the central years of the Transition, and on the other hand, 23-F, the end of UCD and the creation of CDS -, but masks a constant,for almost a decade sustained, in which editorialists, columnists, politicians and intellectuals of various tendencies worked to systematically disavow all the public decisions of Suárez - however disparate they were. To the point that, the caricature of Adolfo Suárez - "the duke" - was the hegemonic discourse on the character until his abandonment of politics. In this sense, criticisms of the existence or nonexistence per se of centrist political strategies or the greater or lesser artificiality of projects based on personal leadership, would acquire a new dimension conditioned by the most immediate electoral struggle Appeals to the models of society, political clarification, captive vote or lent vote tried to provide analytical support to what was, first of all, a part more and not even the most decisive part of the political struggle.

Thanks to the sources used, we have been able to trace the evolution of the vision, and subsequent conservative occupation of the political center, at that time capitalized by the CSD. From this point of view, we can see the invariability and stability of this reading throughout the decade and how around the same were pivoting the different strategies leading to the construction of an alternative. In this way, a process of uniformization and naturalization of a space with a plural origin was carried out, which succumbed not only to the definitive materialization of refined political hypotheses, but basically to the triumph of concrete interests over others, a consequence largely due to an imbalance in the correlation of forces. The thesis of the natural majority was travelling a further stretch on a road that was to be revealed as a self-fulfilling prophecy. Precisely because of this, Adolfo Suárez's alleged advantage, having twice won the general elections and exercising the presidency of government in the founding process

\footnotetext{
${ }^{5}$ TUSELL, J.: "Prólogo" in IGLESIAS, Ma Antonia: La memoria recuperada: lo que nunca han contado Felipe González y los dirigentes socialistas de sus años de gobierno, Madrid, Aguilar, 2003, p. 24.
} 
of democracy, the Transition, meant at this moment an additional incentive to achieve his political deactivation by postponing indefinitely The explicit recognition of his work.

We believe we are in the position to affirm that the CSD represented in its beginnings and in a genuine way the political, social and economic significance of the Transition, at a stage in which it was absolutely ingrained. Nevertheless, although it failed in its attempt to become a liberal wedge, without losing its social tone, it exercised a hinge between the right and the left, decisively conditioning the future of the Spanish democracy. It contributed to the process of renewal of the Popular Party as it being the main point of arrival of centrist politicians in the decline of CDS, it benefited the fluidity of the vote between left and right and contributed decisively to redirect the political debate to the center. We can even highlight the audacity and success of the CSD when it comes to introducing, with scarce resources, key issues on the public agenda - for example, matters regarding the military service.

In a way, the present Doctoral Thesis has tried to offer testimony of a political stage of the History of Spain in which Adolfo Suárez, protagonist of the Transition, was the singular point of contact between the historical past of the country and the most audacious bets of Future or as defined at the time "the past closest to the future". 6 . Around the figure of Adolfo Suárez, journalistic, parliamentary and electoral discourses were concentrated of an extreme and unusual density, that paradoxically passed to the public opinion as if they were merely a handful of "already-made phrases". To retrace this path, to reconstruct the decisive historical facts and to reinterpret in a contextualized way these testimonies of our recent past have been our main objectives. For this reason, even tempted to walk through the boundaries of counterfactual history - what would have been the evolution of Spanish political history with CDS? Had Adolfo Suárez retired in 1982 in what way his presidential administration would have been remembered? , etc. - we believe it prudent not to incur, at least for this time, in rhetorical excesses about a past, already in itself, more than suggestive.

\footnotetext{
${ }^{6}$ PARADA, Luis I.: “Tántalo Suárez", ABC, 28th, October, 1989.
} 

TABLAS, GRÁFICAS Y ANEXOS 



\section{Tablas}

Tabla 1: a): Diputados y senadores electos en la provincia de Zamora (1977); b): Diputados y senadores electos en la provincia de Zamora (1979); c): Diputados y senadores electos en la provincia de Zamora (1982).

Tabla 2: Tendencias políticas en los principales partidos (auto-posicionamiento en tendencias ideológicas) (1982).

Tabla 3: a): Tendencias políticas en los principales partidos (auto-posicionamiento en el continuum izquierda-derecha) (1982); b): Tendencias políticas en los principales partidos (auto-posicionamiento en tendencias ideológicas) (1982).

Tabla 4: Los miembros del Comité Nacional en las listas electorales.

Tabla 5: Recorrido de campaña de Adolfo Suárez (1982).

Tabla 6: a): Diputados conseguidos por el CDS (nombre y circunscripción) en las elecciones generales de 1982; b): Porcentajes obtenidos por el CDS en las diferentes circunscripciones electorales en las elecciones al Congreso de los Diputados.

Tabla 7: Conocimiento y escala de valoración (0-10) de la actuación política de Adolfo Suárez.

Tabla 8: Valoración media de Adolfo Suárez en las distintas provincias castellano y leonesas en diciembre de 1982.

Tabla 9: Reuniones del Comité Nacional y principales temas de debate político en el CDS entre las elecciones generales de 1982 y 1986.

Tabla 10: Principales áreas de trabajo sectorial en el CDS durante la II Legislatura.

Tabla 11: Resultados electorales del CDS en las circunscripciones catalanas (1982).

Tabla 12: Desplazamientos de Adolfo Suárez entre diciembre (1982) y abril (1983).

Tabla 13: Viajes de campaña de Adolfo Suárez en las elecciones del 8 de mayo de 1983.

Tabla 14: Porcentaje de votos y diputados/concejales del CDS en los parlamentos autonómicos y las grandes ciudades españoles en las elecciones de 1983.

Tabla 15: Posición del CDS en la formación de gobiernos autonómicos y municipales.

Tabla 16: Actividades de los miembros del Comité Nacional entre enero de 1984 y junio de 1985.

Tabla 17: Intervenciones en el Congreso de los Diputados de Adolfo Suárez durante la II Legislatura.

Tabla 18: Auto-consideración en materia religiosa desde el punto de vista comparativo entre la militancia del CDS y el conjunto de la población española.

Tabla 19: Actitudes ante el aborto y recuerdo de voto en 1982 (porcentajes).

Tabla 20: Cabezas de lista en las EE.AA. de Galicia (1985).

Tabla 21: Resultados de las elecciones autonómicas de Galicia (1985).

Tabla 22: Resultados del CDS desglosados por provincias (24 de noviembre de 1985).

Tabla 23: Alcaldes y concejales del CDS en Galicia (1983-1987).

Tabla 24: Porcentaje de votos obtenidos en Galicia en los diferentes comicios.

Tabla 25: Posicionamiento de la militancia centrista sobre la permanencia/salida de España de la OTAN.

Tabla 26: Intención de voto y valoración de Adolfo Suárez en mayo y junio de 1986.

Tabla 27: "Gastos e ingresos en la campaña electoral de 1986".

Tabla 28: a): Localidades recorridas durante la campaña electoral (1986); b): Espacios electorales del CDS en TVE y RNE.

Tabla 29: Resultados electorales al Congreso de los Diputados en 1982 y 1986.

Tabla 30: Análisis de resultados en $A B C$.

Tabla 31: Los votos de “centro" en 1982 y 1986. 
Tabla 32: Origen del voto de CDS en 1986.

Tabla 33: Los "votos prestados".

Tabla 34: Intervenciones en el Congreso de los Diputados de Adolfo Suárez durante la III Legislatura.

Tabla 35: Los diputados electos del CDS en julio de 1986.

Tabla 36: Los senadores electos del CDS en julio de 1986.

Tabla 37: Posición de los partidos políticos parlamentarios ante la Moción de Censura.

Tabla 38: Valoración política de Adolfo Suárez (1986-1987).

Tabla 39: Procedencia del posible voto al CDS en 1987.

Tabla 40: Intención de voto al CDS en 1987.

Tabla 41: Tiempos y organización de la campaña.

Tabla 42: Viajes de precampaña de Adolfo Suárez.

Tabla 43: Viajes de campaña de Adolfo Suárez.

Tabla 44: Evolución de la representación institucional y autonómica del CDS (1983-1987).

Tabla 45: Representación institucional y autonómica del CDS (datos de 1989).

Tabla 46: Trasposición de los resultados en las elecciones generales de 1986 a las elecciones autonómicas y municipales de 1987.

Tabla 47: a) Participación en gobiernos municipales y autonómicos si se hubieran producido pactos globales; b) Consecuencias desde el punto de vista de la formación de mayorías de centro-derecha de la política de pactos del CDS y transposición de los resultados de 1986.

Tabla 48: Presidencias de las Asambleas Autonómicas (CDS) y Senadores Autonómicos.

Tabla 49: Gobiernos municipales y autonómicos del CDS (1987-1991).

Tabla 50: Enmiendas a la totalidad a Proyectos de Ley del Gobierno del PSOE.

Tabla 51: Proposiciones de Ley del Grupo Parlamentario CDS (III Legislatura).

Tabla 52: Proposiciones de Ley del Grupo Parlamentario CDS (III Legislatura) en relación al resto de Grupos de la oposición.

Tabla 53: Agrupación temática del conjunto de Proposiciones de Ley y no de Ley del GP CDS (III Legislatura).

Tabla 54: Agrupación temática del conjunto de Interpelaciones (Ordinarias y Urgentes) del GPCDS, (III Legislatura).

Tabla 55: La militancia del CDS: I y II Congreso.

Tabla 56: Las ponencias del II Congreso del CDS (1986).

Tabla 57: Variaciones del Comité Nacional y del Comité Nacional de Cuentas en 1986.

Tabla 58: Presencia de Adolfo Suárez en actos territoriales del partido (febrero-mayo 1987).

Tabla 59: Asambleas y convenciones en el CDS (septiembre de 1986- febrero de 1990).

Tabla 60: Agrupaciones locales del CDS (febrero de 1990).

Tabla 61: Secretarias y áreas de trabajo en el CDS entre 1987 y 1990.

Tabla 62: Total de afiliados y porcentaje respecto al conjunto del electorado.

Tabla 63: Distribución regional de la militancia (1986-1989).

Tabla 64: Características de los afiliados al CDS (1986-1990).

Tabla 65: Características sociológicas de la militancia (1984-1990).

Tabla 66: Tendencias ideológicas de los votantes del CDS entre 1982 y 1986.

Tabla 67: Grupos en el Parlamento Europeo del CDS 1987-1989. 
Tabla 68: Eurodiputados electos del CDS (1987 y 1989).

Tabla 69: Participación del CDS en los principales debates parlamentarios sobre Europa.

Tabla 70 a): Intención de voto. Comparación AP-CDS; $b$ ): El CDS como alternativa; $c$ ): El liderazgo de Adolfo Suárez en la oposición.

Tabla 71: Evolución de la militancia catalana (1986-1989).

Tabla 72: Evolución de los resultados de los partidos de centro y derecha nacional.

Tabla 73: Presencia en las listas del CDS de diputados de PDP, PL e IU (1987-1989).

Tabla 74: Campaña electoral de Adolfo Suárez (1989).

Tabla 75: Los resultados electorales de 1989.

Tabla 76: Los resultados electorales de 1989: parlamentarios.

Tabla 77: Las mociones de censura y los resultados electorales.

Tabla 78: Elección de compromisarios por CC.AA. (enero 1990).

Tabla 79: Evolución del Comité Nacional y de la Comisión Nacional de Cuentas (1986-1990).

Tabla 80: Consejo de Federación y propuesta del Consejo Político en el CDS (1990).

Tabla 81: La ejecutiva del CDS tras el III Congreso.

Tabla 82: Intervenciones de Adolfo Suárez en el Congreso de los Diputados durante la IV Legislatura.

Tabla 83: Parlamentarios electos del CDS en 1989.

Tabla 84: Proposiciones de Ley del Grupo Parlamentario CDS (IV Legislatura).

Tabla 85: Proposiciones de Ley del Grupo Parlamentario CDS (IV Legislatura) en relación al resto de grupos de la oposición.

Tabla 86: Agrupación temática del conjunto de Proposiciones de Ley y no de Ley del GPCDS (IV Legislatura).

Tabla 87: Agrupación temática del conjunto de Interpelaciones (Ordinarias y Urgentes) del GPCDS, (IV Legislatura).

Tabla 88: Valoración de Adolfo Suárez según las encuestas del CIS entre octubre de 1988 y octubre de 1991.

Tabla 89: Evolución electoral del CDS en el País Vasco (elecciones municipales y autonómicas).

Tabla 90: Presupuesto electoral de los cuatro grandes partidos nacionales.

Tabla 91: Viajes de campaña de Adolfo Suárez (fechas aproximadas).

Tabla 92: Votos y porcentajes del CDS en 1987 y 1991 desde un punto de vista comparativo.

Tabla 93: Cargos electos del CDS en 1991 desde un punto de vista comparativo.

Tabla 94: El CDS en las asambleas autonómicas (1991-1995).

Tabla 95: Papel decisorio del CDS en la formación de Gobiernos municipales y autonómicos.

Tabla 96: Anuncios de dimisión tras las elecciones de 1991.

Tabla 97: Valoración de líderes del CDS (IV Congreso).

Tabla 98: Corrientes de cara al IV Congreso.

Tabla 99: Resultado de las votaciones a los cargos de dirección en el IV Congreso.

Tabla 100: Evolución del Comité Nacional (1990-1991) y miembros electos del Comité Federal.

Tabla 101: Los órganos de gobierno del CDS tras el IV Congreso.

Tabla 102: Principales homenajes.

Tabla 103: Principales artículos o conferencias de Adolfo Suárez sobre la Transición (1982-1991). 
Adolfo Suárez y el Centro Democrático y Social (1982-1991)

Tabla 104: Leyes, posicionamientos y contenidos (memoria).

Tabla 105: Destino político de los miembros del Comité Nacional del CDS (1982-1991) en la década de los $90^{\prime}$. 


\section{Gráficas}

Gráfica 1: Difusión total de la prensa de información general nacional (1982-1991).

Gráfica 2: Distribución del total de Diputados Provinciales y Consejeros en Cabildos Insulares (19831987).

Gráfica 3: Análisis de la presencia del CDS en los titulares de prensa durante la campaña (1986).

Gráfica 4: Voto del CDS en 1986 según recuerdo de voto en 1982.

Gráfica 5: Evolución de la militancia del CDS entre 1982 y 1991.

Gráfica 6: Población activa en España y militancia del CDS (1982-1989). 


\section{Anexos}

Anexo I: El secretariado de UCD entre marzo de 1981 y enero de 1982.

Anexo II: La “sociedad de mérito” según Adolfo Suárez.

Anexo III: Parlamentarios que se vincularon al CDS en el verano de 1982.

Anexo IV: Movimientos entre UCD y CDS en el verano de 1982.

Anexo V: Diputados autonómicos electos por UCD que se vincularon al CDS en 1982.

Anexo VI: El nacimiento y formación del CDS en Cataluña.

Anexo VII: Presidentes provinciales del CDS (1982-90’).

Anexo VIII: Asambleas Constituyentes Federales, Provinciales e Insulares entre 1982 y 1986 con presencia de Adolfo Suárez.

Anexo IX: Titulares de prensa local: Asambleas Constituyentes del CDS con presencia de Suárez.

Anexo X: Actividad parlamentaria del CDS durante la II Legislatura.

Anexo XI: Las elecciones autonómicas de Galicia como ejemplo de la actividad del partido en el período 1982-1986.

Anexo XII: Estimación de las elecciones generales de 1986.

Anexo XIII: Análisis de voto de las elecciones generales de 1986 por Comunidades Autónomas.

Anexo XIV: Miembros del CDS en los Órganos de Gobierno del Congreso de los Diputados

Anexo XV: Diputados adscritos al GPCDS del Congreso de los Diputados a lo largo de la III Legislatura.

Anexo XVI: Actividad del CDS durante la III Legislatura en el Congreso de los Diputados.

Anexo XVII: Actividad del CDS durante la III Legislatura en el Senado.

Anexo XVIII: Asambleas provinciales o federales celebradas entre finales de 1986 y 1989.

Anexo XIX: Análisis de las trayectorias políticas del Comité Nacional.

Anexo XX: Miembros del CDS en los Órganos de Gobierno del Congreso de los Diputados en la IV Legislatura.

Anexo XXI: Modificaciones del Grupo Parlamentario del Congreso de los Diputados en la IV Legislatura.

Anexo XXII: Conjunto de Iniciativas Parlamentarias del Grupo Parlamentario CDS durante la IV Legislatura.

Anexo XXIII: Órganos de Gobierno y actividad legislativa en el Senado (CDS), IV Legislatura 19891993. 


\section{Anexo I}

El secretariado de UCD entre marzo de 1981 y enero de 1982

\begin{tabular}{|l|l|l|}
\hline Cargo $^{1}$ & Nombre & CDS \\
\hline Presidencia & Agustín Rodríguez Sahagún & Sí $^{2}$ \\
\hline Secretario General & Rafael Calvo Ortega & Sí $^{3}$ \\
\hline Gabinete de Comunicación & Enrique de Blas & No \\
\hline Acción Social & Gerardo Harguindey & Sí \\
\hline Coordinación & L. Alberto Salazar Simpson & No \\
\hline Emigración & José Luis González Quirós & Sí \\
\hline Formación, Educación y Cultura & José Antonio Escudero & Sí \\
\hline Juventudes & Arcadio Domínguez & No \\
\hline Información & Juan Díez Nicolás & No $^{4}$ \\
\hline Organización & José Ramón Caso & Sí $^{5}$ \\
\hline Política Territorial & Juan Manuel Reol Tejada & No \\
\hline Relaciones Internacionales & Javier Rupérez & No $^{6}$ \\
\hline Relaciones Económicas & Blas Camacho Zancada & No $^{6}$ \\
\hline
\end{tabular}

Elaboración propia a partir del Archivo Histórico Provincial de Soria. Guía Funcional del Secretariado Ejecutivo Nacional, Secretaria Información, junio 1981, Caja 3304.

\footnotetext{
${ }^{1}$ Fueron elegidos en marzo de 1981: Caso, Camacho, Escudero, Salazar Simpson y Díez Nicolás, $A B C$, 08 de marzo de 1981 y El País, 10 de marzo de 1981. Fueron sustituidos en enero de 1982 por el nuevo secretariado del partido dirigido por Íñigo Cavero: Salazar Simpson, Díez Nicolás, Caso García, Escudero, González Quirós y Harguindey Bonet, en SORIANO, Manuel: "UCD elige un secretariado de origen democristiano", Diario 16, 15 de enero de 1981 [sic, 1982], Archivo Linz.

${ }^{2}$ Fernando Lanzaco Bonilla (director de gabinete), $\mathrm{n}^{\mathbf{0}} 1$ del CDS por Albacete en las elecciones generales de 1982.

3 Jesús Merino Delgado (gabinete político), $\mathrm{n}^{\circ} 2$ del CDS al Senado por Segovia en las elecciones generales de 1982 .

${ }^{4}$ Miembro y promotor de la Fundación Para el Progreso y la Democracia, HUNEEUS, C.: La Unión..., p. 351.

${ }^{5}$ En este departamento trabajaron también los responsables del gabinete de presidencia de Adolfo Suárez desde 1982: José Luis Garro, María Antonia Alenyar y Alfonso Íniguez, Guía Funcional del Secretariado Ejecutivo Nacional, Secretaria Información, junio 1981, Caja 3304, Archivo Histórico Provincial de Soria,

${ }^{6}$ Cedió a Adolfo Suárez, tras su dimisión, el primer lugar de trabajo en la Calle Génova, "de los pocos que se acordó de Suárez", hasta la definitiva ubicación en el despacho de la Calle Antonio Maura n4. entrevista con Aurelio Delgado, diciembre de 2014.
} 


\begin{abstract}
Anexo II
La "sociedad de mérito" según Adolfo Suárez

“Tenemos que profundizar de verdad y a fondo en las verdades que decimos [...] sentir La libertad, la igualdad, la justicia, la solidaridad, y yo, con mi experiencia como presidente de gobierno y cinco años como ex presidente, pero perteneciendo a muchos foros internacionales pues me da la impresión de que el mundo occidental proclamamos mucho esas palabras pero muy pocas veces profundizamos en ellas. Yo, sí me permiten digo lo que creo que hoy España está empeñada [...] que esas realidades se traduzcan en realidades perceptibles por los ciudadanos. Yo soy de los cree sinceramente que la palabra igualdad es una afirmación en la que se dice que todos nacemos iguales y es verdad, pero que cada segundo que transcurre desde el nacimiento nos va haciendo más desiguales, que no es lo mismo nacer en mi pueblo de Cebreros, que es el ejemplo que pongo siempre donde el impacto cultural mayor que he recibido en los primeros años de la infancia ha sido el pasodoble tocado por la banda municipal que el impacto cultural que se recibe en una ciudad universitaria donde [...] desde el momento que se nace [recibes] un impacto cultural de primera magnitud, que le va haciendo al hombre mucho más libre y que le va capacitando realmente al hombre para vivir en libertad [...] Y que por eso el estado tiene que ayudar a todo ser humano por el mero hecho de nacer [hacia] un principio de igualdad de oportunidades en educación, cultura, vivienda y trabajo que le permita enfrentarse al futuro en condiciones de igualdad y que permita consolidar una sociedad que yo llamo de mérito en la que esfuerzo, el trabajo, el sacrificio y la abnegación sea lo que permita ascender a los puestos más altos de la sociedad. Una sociedad más permeable. Pero que permita también caer de los más altos a los más bajos si deja uno de esforzarse, de trabajar, etc ${ }^{1,}$.
\end{abstract}

\footnotetext{
${ }^{1}$ Intervención de Adolfo Suárez en una mesa redonda en CIEPLAN (Corporación De Estudios para Latinoamérica), Chile, diciembre de 1986. Disponible en: http://www.youtube.com/ watch?v=fvIHGR9s44I Fecha de consulta: 10 de mayo de 2015.
} 
Anexo III

Parlamentarios que se vincularon al CDS en el verano de 1982

\begin{tabular}{|c|c|c|c|}
\hline NOMBRE & CIRCUNSCRIPCIÓN & $\begin{array}{l}\text { BAJA DE } \\
\text { UCD }^{1} \\
\end{array}$ & $\begin{array}{l}\text { CANDIDATURA EN } \\
1982\end{array}$ \\
\hline Adolfo Suárez González & Madrid & $28 / 07 / 1982$ & $1^{\circ}$ Madrid Congreso \\
\hline Agustín Rodríguez Sahagún & Vizcaya & 29/07/1982 & $1^{\circ}$ Ávila Congreso \\
\hline León Buil Giral & Huesca & $31 / 07 / 1982$ & $1^{\circ}$ Huesca Congreso \\
\hline Jesús Pérez López & Zamora & $03 / 08 / 1982$ & $2^{\circ}$ Zamora Congreso \\
\hline César Martín Montes & Zamora & 03/08/1982 & No se presentó \\
\hline Lorenzo Olarte Cullén & Las Palmas & $03 / 08 / 1982$ & $1^{\circ}$ Las Palmas Congreso \\
\hline José J. Rodríguez Alcaide & Córdoba & $03 / 08 / 1982$ & $1^{\circ}$ Córdoba Congreso \\
\hline Femando Alcón Sáez & Ávila & $07 / 08 / 1982$ & $2^{\circ}$ Ávila Congreso \\
\hline Perfecto Yebra Martul-Ortega & La Coruña & $13 / 08 / 1982$ & $2^{\circ}$ La Coruña Congreso \\
\hline Jaume Barnola Serra & Lérida & $16 / 08 / 1982$ & $1^{\circ}$ Lérida Senado \\
\hline José María Mesa Parra & Barcelona & $16 / 08 / 1982$ & $3^{\circ}$ Barcelona Congreso \\
\hline Manuel de Sárraga Gómez & Lérida & $19 / 08 / 1982$ & $1^{\circ}$ Lérida Congreso \\
\hline Josep Pujadas Domingo & Barcelona & $17 / 08 / 1982$ & $2^{\circ}$ Barcelona Congreso \\
\hline Rafael Calvo Ortega & Asturias & 19/08/1982 & $2^{\circ}$ Madrid Congreso \\
\hline Antonio José Delgado de Jesús & Córdoba & $24 / 08 / 1982$ & $2^{\circ}$ Córdoba Congreso \\
\hline Alfonso Soler Turmo & Almería & $03 / 09 / 1982$ & $1^{\circ}$ Almería Senado \\
\hline Antonio de Senillosa Cros & Barcelona (CD) & $03 / 09 / 1982$ & $1^{\circ}$ Barcelona Congreso \\
\hline J. María Sanjuán Bordá & Navarra & Agosto-Sept. & $2^{\circ}$ Navarra Congreso \\
\hline Jesús María Viana & Álava & $30 / 07 / 1982^{2}$ & $3^{\circ}$ Madrid \\
\hline \multicolumn{4}{|c|}{ Otros casos } \\
\hline Ángel Cristóbal Montes & Zaragoza (PSOE) & - & $\begin{array}{l}2^{\circ} \text { o } 3^{\circ} \text { CDS Ayto. } \\
\text { Zaragoza } 1983 \text { (Independ.) }\end{array}$ \\
\hline
\end{tabular}

Elaboración propia a partir de fuentes hemerográficas

Senadores vinculados al CDS en agosto de 1982

\begin{tabular}{|l|l|l|l|}
\hline NOMBRE & CIRCUNSCRIPCIÓN & BAJA DE UCD & CANDIDATURA EN 1982 \\
\hline Luis Rodríguez San León & Zamora & $29 / 07 / 1982$ & $1^{\circ}$ Zamora Congreso \\
\hline Francisco Villodres García & Málaga & $09 / 08 / 1982$ & $1^{\mathbf{0}}$ Málaga Congreso \\
\hline Antonio Gimeno Lahoz & Teruel & $20 / 08 / 1982$ & $1^{\mathbf{o}}$ Teruel Senado \\
\hline Serafín Becerra Lago & Ceuta & $22 / 08 / 1982$ & $1^{\circ}$ Ceuta Congreso \\
\hline
\end{tabular}

Elaboración propia a partir de fuentes hemerográficas

\footnotetext{
${ }^{1}$ Fechas aproximadas a partir de la prensa en la que se recoge su emisión de la carta de dimisión a la dirección de Unión de Centro Democrático. Hay que tener en cuenta que la fecha de cese del cargo oficial fue el 31 de agosto de 1982. Todos ellos permanecieron hasta el final en el Grupo Parlamentario Centrista o en su defecto en el de Coalición Democrática, caso de Antonio de Senillosa.

${ }^{2}$ Había renunciado a su escaño en 1980.
} 


\section{Anexo IV}

Movimientos entre UCD y CDS en el verano de 1982

\section{Principales cargos directivos del gobierno de UCD que recalan en el CDS (agosto-septiembre, 1982)}

\begin{tabular}{|l|l|}
\hline Nombre & Cargo \\
\hline Jorge Fernández Díaz & Gobernador Civil de Barcelona \\
\hline Manuel del Hoyo & Gobernador Civil de Burgos \\
\hline Joaquín Borrell & Gobernador Civil de Pontevedra \\
\hline Fernando Montero & Gobernador Civil de Toledo \\
\hline José María Sieira & Gobernador Civil de Granada \\
\hline José Vicente Cebrián & Director General de Industria \\
\hline Alejandro Rebollo & Director General de RENFE \\
\hline José Antonio Escudero & Consejo de Administración de RTVE \\
\hline Antonio del Olmo & Consejo de Administración de RTVE \\
\hline Emilio Pujalte & Secretario General del Ente Público RTVE \\
\hline Enrique Galavis & UCD. Director de Instituciones Penitenciarias \\
\hline Joaquín Abril Martorell & Presidente de ENAGÁS \\
\hline Fernández Felgueroso & Presidente de HUNOSA \\
\hline
\end{tabular}

Elaboración propia a partir de fuentes hemerográficas

Políticos y personalidades públicas relacionadas con el CDS en el verano de $1982^{2}$

\begin{tabular}{|l|l|}
\hline Nombre & Pertenencia o vinculación política \\
\hline Manuel Gutiérrez Mellado & $\begin{array}{l}\text { Ex ministro de UCD (protagonismo Transición y 23-F). Retirado de la } \\
\text { política. }\end{array}$ \\
\hline Francisco Laína & $\begin{array}{l}\text { UCD (protagonismo 23-F). Director General de la Seguridad del } \\
\text { Estado. }\end{array}$ \\
\hline Enrique Fuentes Quintana & $\begin{array}{l}\text { UCD (protagonismo Transición). Profesor universitario y Director } \\
\text { General de FIES. }\end{array}$ \\
\hline Carlos Bustelo & $\begin{array}{l}\text { Ex ministro de UCD. Director del INI. Impulsor del "Club de los } \\
1000 ”\end{array}$ \\
\hline Luis González Seara & $\begin{array}{l}\text { Ex ministro de UCD. Dirigente del PAD. Promotor de la Fundación } \\
\text { para el Progreso y la Democracia e impulsor del "Club de los 1000”. }\end{array}$ \\
\hline Santiago Rodríguez Miranda & UCD. Ministro de Trabajo. \\
\hline Félix Pérez Miyares & Ex ministro de UCD. Delegado del Gobierno en Andalucía. \\
\hline Ramón Tamames & Ex PCE. Promotor de la Fundación para el Progreso y la Democracia. \\
\hline Raúl Morodo & $\begin{array}{l}\text { Ex PSP. Rector UIMP. Fundación para el Progreso y la Democracia e } \\
\text { impulsor del “Club de los 1000”,3. }\end{array}$ \\
\hline Federico Mayor Zaragoza & UCD. Ministro de Educación y Ciencia. \\
\hline José Ignacio de Mesa & UCD. Alcalde de Toledo. Vicepresidente de la FEM. \\
\hline Manuel Fombuena & UCD. Diputado. \\
\hline Jaime García Añoveros & UCD. Ministro de Hacienda. \\
\hline Manuel Clavero Arévalo & Ex ministro de UCD. Dirigente de UA. \\
\hline
\end{tabular}

Elaboración propia a partir de fuentes hemerográficas

\footnotetext{
${ }^{1}$ La fecha tope para la dimisión de dichos cargos, inelegibles electoralmente, era el 07 de septiembre, $E l$ País, 01 de septiembre de 1982.

${ }^{2}$ Finalmente no incorporados al partido, al menos en ese momento.

${ }^{3}$ Nuevamente, a propósito de las elecciones municipales de 1983, El Noticiero Universal, 21 de enero de 1983.
} 
Anexo V

Diputados autonómicos electos por UCD que se vincularon al CDS en $1982^{1}$

\begin{tabular}{|c|c|c|c|}
\hline NOMBRE & C.A. & $\begin{array}{l}\text { BAJA DE UCD/ } \\
\text { ALTA CDS }\end{array}$ & OTROS \\
\hline $\begin{array}{l}\text { Eugenio Cabrera } \\
\text { Montelongo }\end{array}$ & Canarias & $\begin{array}{l}\text { Agosto/Sept. } \\
1982\end{array}$ & Parlamento Provisional de Canarias hasta 1983 \\
\hline $\begin{array}{l}\text { Domingo González } \\
\text { Arroyo }\end{array}$ & Canarias & $\begin{array}{l}\text { Agosto/Sept. } \\
1982\end{array}$ & Parlamento Provisional de Canarias hasta 1983 \\
\hline $\begin{array}{l}\text { Jesús Morales } \\
\text { Morales }\end{array}$ & Canarias & $\begin{array}{l}\text { Agosto/Sept. } \\
1982\end{array}$ & $\begin{array}{l}\text { Secretario primero en el Parlamento Provisional } \\
\text { de Canarias hasta } 1983\end{array}$ \\
\hline $\begin{array}{l}\text { Santiago Guillén } \\
\text { Fernández }\end{array}$ & Cataluña & $\begin{array}{l}\text { Agosto/Sept. } \\
1982 \text { (Baja del } \\
\text { CDS en enero de } \\
\text { 1983). }\end{array}$ & $\begin{array}{l}\text { Baja del Grupo Centrista el } 01 \text { de septiembre de } \\
\text { 1982, pasando a diputado no adscrito. }\end{array}$ \\
\hline $\begin{array}{l}\text { Pere Roselló i } \\
\text { Esteban }\end{array}$ & Cataluña & $\begin{array}{l}\text { Agosto/Sept. } \\
1982\end{array}$ & $\begin{array}{l}\text { Baja del Grupo Centrista el } 01 \text { de septiembre de } \\
\text { 1982, pasando a diputado no adscrito. Se integra } \\
\text { en el Grupo Mixto el } 11 \text { de julio de } 1983 \text { hasta el } \\
\text { final de la Legislatura. }\end{array}$ \\
\hline Joan Besa i Esteve & Cataluña & $\begin{array}{l}\text { Agosto/Sept. } \\
1982 \text { (Baja del } \\
\text { CDS en enero de } \\
\text { 1983). }\end{array}$ & $\begin{array}{l}\text { Baja del Grupo Centrista el } 01 \text { de septiembre de } \\
\text { 1982, pasando a diputado no adscrito. Se integra } \\
\text { en el Grupo Mixto el } 11 \text { de julio de } 1983 \text { hasta el } \\
\text { final de la Legislatura. }\end{array}$ \\
\hline $\begin{array}{l}\text { Joan Manuel } \\
\text { Margaleff i Miralles }\end{array}$ & Cataluña & $\begin{array}{l}\text { Agosto/Sept. } \\
1982\end{array}$ & $\begin{array}{l}\text { Baja del Grupo Centrista el } 01 \text { de septiembre de } \\
\text { 1982, pasando a diputado no adscrito. Se integra } \\
\text { en el Grupo Mixto el } 11 \text { de julio de } 1983 \text { hasta el } \\
\text { final de la Legislatura. }\end{array}$ \\
\hline $\begin{array}{l}\text { Josep Mesegué i } \\
\text { Utgé }\end{array}$ & Cataluña & $\begin{array}{l}\text { Agosto/Sept. } \\
1982\end{array}$ & $\begin{array}{l}\text { Baja del Grupo Centrista el } 01 \text { de septiembre de } \\
\text { 1982, pasando a diputado no adscrito. Se integra } \\
\text { en el Grupo Mixto el } 11 \text { de julio de } 1983 \text { hasta el } \\
\text { final de la Legislatura. }\end{array}$ \\
\hline $\begin{array}{l}\text { Francesc-Xavier } \\
\text { Puig i Andreu }\end{array}$ & Cataluña & $\begin{array}{l}\text { Agosto/Sept. } \\
1982\end{array}$ & $\begin{array}{l}\text { Baja del Grupo Centrista el } 01 \text { de septiembre de } \\
\text { 1982, pasando a diputado no adscrito. Se integra } \\
\text { en el Grupo Mixto el } 11 \text { de julio de } 1983 \text { hasta el } \\
\text { final de la Legislatura. }\end{array}$ \\
\hline $\begin{array}{l}\text { Ramon Vinyals i } \\
\text { Soler (No adscrito } \\
\text { desde 1981. Electo } \\
\text { en la lista de ERC) }\end{array}$ & Cataluña & $\begin{array}{l}\text { Agosto/Sept. } \\
1982\end{array}$ & $\begin{array}{l}\text { En el Grupo Parlamentario de Esquerra } \\
\text { Republicana hasta el } 03 \text { de febrero de } 1981 . \\
\text { Posteriormente diputado no adscrito hasta el } 11 \text { de } \\
\text { julio de } 1983 \text { cuando se integra en el Grupo } \\
\text { Mixto. }\end{array}$ \\
\hline $\begin{array}{l}\text { Albert Planasdemunt } \\
\text { i Gubern }\end{array}$ & Cataluña & $\begin{array}{l}\text { Agosto/Sept. } \\
1982\end{array}$ & $\begin{array}{l}\text { Baja del Grupo Centrista el } 01 \text { de septiembre de } \\
\text { 1982, pasando a diputado no adscrito. Se integra }\end{array}$ \\
\hline
\end{tabular}

\footnotetext{
${ }^{1}$ Para el caso de Canarias la información, salvo mención expresa, ha sido extraída de DE LAS HERAS, Raúl: Enciclopedia politica y atlas electoral de la democracia española”, Madrid, Temas de Hoy, 1997; El País, 05 de diciembre de 1982 y ABC 22 de diciembre de 1982. Para el caso de Cataluña se ha consultado http://www.parlament.cat. Para País Vasco, se ha manejado, $A B C, 20$ de agosto de 1982 y http://www.legebiltzarra.eus/portal/web/eusko-legebiltzarra En Andalucía, se ha manejado, http://www.parlamento deandalucia.es Respecto al caso de Asturias, Cantabria y Galicia se han consultado respectivamente http://www.biblioteca.parlamento-cantabria.es, http://www.jpga.es http://www.es.parlamentodegalicia.es El caso de los diputados navarros fue seguido en las páginas de $E l$ País y $A B C$. La división en la UCD de Navarra se remontaban a la polémica por el asunto "FASA" y la Asamblea Provincial de 1981, BERMEJO GARDE, Moisés y DÍEZ LAGO, Pablo: Crónica del parlamento de Navarra: 1979-1989, Navarra, Parlamento de Navarra, 1990. En el caso de los diputados del CDS navarros Cigudosa, Esparza, Muruzábal, Sagredo y Esquisábel se pidió su cese parlamentario por parte de UCD en Navarra, Diario de Navarra, 12 de enero de 1983. Esta medida fue declarada ilegal por el Tribunal Constitucional en 1984, ABC, 01 de marzo de 1983. Véase también, El País, 30 de mayo de 1985. Las páginas webs referidas anteriormente fueron consultadas a lo largo del año 2015.
} 


\begin{tabular}{|c|c|c|c|}
\hline & & & $\begin{array}{l}\text { en el Grupo Mixto el } 11 \text { de julio de } 1983 \text { hasta el } \\
\text { final de la Legislatura. }\end{array}$ \\
\hline $\begin{array}{l}\text { Jesús Ma Viana Santa } \\
\text { Cruz }\end{array}$ & Euskadi & $\begin{array}{l}\text { Agosto/Sept. } \\
1982\end{array}$ & $\begin{array}{l}\text { Parlamentario del Grupo Centristas Vascos (31- } \\
\text { 03-1980/25-05-1983) } \\
\text { Parlamentario del Grupo Centro Democrático y } \\
\text { Social (25-05-1983/19-01-1984) }\end{array}$ \\
\hline Alfredo Marco Tabar & Euskadi & $\begin{array}{l}\text { Agosto/Sept. } \\
1982\end{array}$ & $\begin{array}{l}\text { Parlamentario del Grupo Centristas Vascos (31- } \\
\text { 03-1980/25-05-1983) } \\
\text { Parlamentario del Grupo Centro Democrático y } \\
\text { Social (25-05-1983/19-01-1984) }\end{array}$ \\
\hline Carlos Saiz Angulo & Euskadi & $\begin{array}{l}\text { Agosto/Sept. } \\
1982\end{array}$ & $\begin{array}{l}\text { Parlamentario del Grupo Centristas Vascos (31- } \\
\text { 03-1980/25-05-1983) } \\
\text { Parlamentario del Grupo Centro Democrático y } \\
\text { Social (25-05-1983/19-01-1984) }\end{array}$ \\
\hline Pablo López Heredia & Euskadi & $\begin{array}{l}\text { Agosto/Sept. } \\
1982\end{array}$ & $\begin{array}{l}\text { Parlamentario del Grupo Centristas Vascos (31- } \\
\text { 03-1980/13-01-1983) }\end{array}$ \\
\hline $\begin{array}{l}\text { Jesús García de } \\
\text { Miguel Martínez }\end{array}$ & Euskadi & $\begin{array}{l}\text { Agosto/Sept. } \\
1982\end{array}$ & $\begin{array}{l}\text { Parlamentario del Grupo Centristas Vascos (07- } \\
\text { 02-1983/25-05-1983) } \\
\text { Sustituye a Pablo López de Heredia Quintana } \\
\text { Parlamentario del Grupo Centro Democrático y } \\
\text { Social (25-05-1983/19-01-1984) }\end{array}$ \\
\hline $\begin{array}{l}\text { Antonio José Iglesias } \\
\text { Casado }\end{array}$ & Andalucía & $\begin{array}{l}\text { Agosto/Sept. } \\
1982\end{array}$ & $\begin{array}{l}\text { Diputado autonómico del Parlamento de } \\
\text { Andalucía 1982-1986. }\end{array}$ \\
\hline Adolfo Barthe Aza & Asturias & $\begin{array}{l}\text { Agosto/Sept. } \\
1982\end{array}$ & $\begin{array}{l}\text { Legislatura Provisional 1982-1983. Causó baja en } \\
\text { el Grupo UCD y se integró en el Grupo Mixto el } \\
13 \text { de enero de } 1983\end{array}$ \\
\hline Rafael Calvo Ortega & Asturias & $\begin{array}{l}\text { Agosto/Sept. } \\
1982\end{array}$ & $\begin{array}{l}\text { Legislatura Provisional 06-03-1982 hasta el 28- } \\
\text { 10-1982 (por su condición de diputado nacional). }\end{array}$ \\
\hline $\begin{array}{l}\text { María Consuelo } \\
\text { Marcos Vallaure }\end{array}$ & Asturias & $\begin{array}{l}\text { Agosto/Sept. } \\
1982\end{array}$ & $\begin{array}{l}\text { Legislatura Provisional 06-03-1982 hasta el } 28- \\
\text { 10-1982 (electa según la proporción de los grupos } \\
\text { políticos representados). }\end{array}$ \\
\hline $\begin{array}{l}\text { Manuel Esquisavel } \\
\text { Miranda }\end{array}$ & Navarra & $\begin{array}{l}\text { Agosto/Sept. } \\
1982\end{array}$ & $\begin{array}{l}\text { Adscrito al GP CDS } \\
\text { Destituido el 06-02-1983 }\end{array}$ \\
\hline $\begin{array}{l}\text { Jesús Muruzábal } \\
\text { Arregui }\end{array}$ & Navarra & $\begin{array}{l}\text { Agosto/Sept. } \\
1982\end{array}$ & $\begin{array}{l}\text { Adscrito al GP CDS } \\
\text { Destituido el 06-02-1983 }\end{array}$ \\
\hline $\begin{array}{l}\text { José Joaquín Sagredo } \\
\text { Sagredo }\end{array}$ & Navarra & $\begin{array}{l}\text { Agosto/Sept. } \\
1982\end{array}$ & $\begin{array}{l}\text { Adscrito al GP CDS } \\
\text { Destituido el 06-02-1983 }\end{array}$ \\
\hline $\begin{array}{l}\text { José María Esparza } \\
\text { Echevarría }\end{array}$ & Navarra & $\begin{array}{l}\text { Agosto/Sept. } \\
1982\end{array}$ & $\begin{array}{l}\text { Adscrito al GP CDS } \\
\text { Destituido el 06-02-1983 }\end{array}$ \\
\hline $\begin{array}{l}\text { Ángel Lasunción } \\
\text { Goñi }\end{array}$ & Navarra & $\begin{array}{l}\text { Finales de marzo } \\
\text { de 1982; Mayo } \\
1985 \text {. }\end{array}$ & Adscrito al GP CDS \\
\hline $\begin{array}{l}\text { Emilio Cigudosa } \\
\text { Mazo }\end{array}$ & Navarra & $\begin{array}{l}\text { Agosto/Sept. } \\
1982\end{array}$ & $\begin{array}{l}\text { Adscrito al GP CDS } \\
\text { Destituido el 06-02-1983 }\end{array}$ \\
\hline $\begin{array}{l}\text { Gerardo González } \\
\text { Martín }\end{array}$ & Galicia & $\begin{array}{l}\text { Agosto/Sept. } \\
1982\end{array}$ & $\begin{array}{l}\text { Pasó a GP Mixto el 08-10-1982 } \\
\text { Pasó a GP Independente el 09-09-1983 }\end{array}$ \\
\hline $\begin{array}{l}\text { José Manuel } \\
\text { Hernández } \\
\text { Hernández }\end{array}$ & $\begin{array}{l}\text { Castilla y } \\
\text { León }\end{array}$ & $\begin{array}{l}\text { Agosto/Sept. } \\
1982\end{array}$ & $\begin{array}{l}\text { Miembro del Consejo General de Castilla y León } \\
\text { de octubre de } 1982 \text { a mayo } 1983 \text {. }\end{array}$ \\
\hline Daniel de Fernando & $\begin{array}{l}\text { Castilla y } \\
\text { León }\end{array}$ & $\begin{array}{l}\text { Agosto/Sept. } \\
1982\end{array}$ & $\begin{array}{l}\text { Miembro del Consejo General de Castilla y León } \\
\text { de octubre de } 1982 \text { a mayo } 1983 \text {. }\end{array}$ \\
\hline Luis Silió Fernández & Cantabria & & Marzo de 1982 a mayo de 1983. \\
\hline $\begin{array}{l}\text { Antonio Bernó } \\
\text { Castanedo }\end{array}$ & Cantabria & - & Marzo de 1982 a mayo de 1983. \\
\hline $\begin{array}{l}\text { Jesús Merino } \\
\text { Delgado }\end{array}$ & Aragón & - & $\begin{array}{l}\text { Consejero de la Diputación General de Aragón } \\
\text { 1981-1982. }\end{array}$ \\
\hline- & Murcia & - & - \\
\hline - & Madrid & - & - \\
\hline- & Baleares & - & - \\
\hline
\end{tabular}


Darío Díez Miguel

\begin{tabular}{|l|l|l|l|}
\hline- & La Rioja & - & Fundación del Partido Riojano Progresista \\
\hline- & $\begin{array}{l}\text { Extremadu } \\
\text { ra }\end{array}$ & - & - \\
\hline- & $\begin{array}{l}\text { Castilla La } \\
\text { Mancha }\end{array}$ & - & - \\
\hline
\end{tabular}

Elaboración propia 
Anexo VI

El nacimiento y formación del CDS en Cataluña

Pasos constitutivos del CDS en Cataluña 1982-1983

\begin{tabular}{|c|c|c|c|}
\hline Tipología & Lugar y fecha & $\begin{array}{l}\text { CDS- } \\
\text { Nacional }\end{array}$ & CDS-Cataluña \\
\hline $\begin{array}{l}\text { Reunión } \\
\text { informal }\end{array}$ & $\begin{array}{l}\text { Despacho privado de Adolfo Suárez } \\
\text { de Calle Maura en Madrid } \\
04 / 08 / 1982\end{array}$ & $\begin{array}{l}\text { Adolfo Suárez } \\
\text { y } \\
\text { Agustín } \\
\text { Rodríguez } \\
\text { Sahagún }\end{array}$ & $\begin{array}{l}\text { Josep Pujadas i Domingo, } \\
\text { José María Mesa Parra, } \\
\text { Manuel de Sárraga, Jaume } \\
\text { Barnola, Pere Roselló y } \\
\text { Santiago Guillén }\end{array}$ \\
\hline $\begin{array}{l}\text { Reunión } \\
\text { informal }\end{array}$ & $\begin{array}{l}\text { Céntrico Hotel de Barcelona } \\
\text { 05/08/1982 y 06/08/1982 }\end{array}$ & $\begin{array}{l}\text { Chus Viana y } \\
\text { Agustín } \\
\text { Rodríguez } \\
\text { Sahagún }\end{array}$ & $\begin{array}{l}\text { Cincuenta miembros de } \\
\text { CC-UCD de la corriente } \\
\text { "suarista" }\end{array}$ \\
\hline $\begin{array}{l}\text { Constitución } \\
\text { del Grupo } \\
\text { Promotor del } \\
\text { CDS en } \\
\text { Barcelona }\end{array}$ & $\begin{array}{l}\text { Despacho de Josep Sánchez Llibre } \\
\text { en Barcelona 16/08/1982 }\end{array}$ & - & $\begin{array}{l}\text { Josep Pujadas i Domingo y } \\
\text { compuesto por José María } \\
\text { Valón, Josep Sánchez } \\
\text { Llibre, José María Mesa } \\
\text { Parra, Santiago Guillén, } \\
\text { Lluís Puyó y Xavier Martí. }\end{array}$ \\
\hline $\begin{array}{l}\text { Reunión } \\
\text { informal }\end{array}$ & Madrid 19/08/1982 & $\begin{array}{l}\text { Adolfo Suárez } \\
\text { Agustín } \\
\text { Rodríguez } \\
\text { Sahagún y } \\
\text { Gerardo } \\
\text { Harguindey } \\
\end{array}$ & $\begin{array}{l}\text { Grupo Promotor del CDS } \\
\text { en Barcelona }\end{array}$ \\
\hline $\begin{array}{l}\text { Presentación } \\
\text { pública del } \\
\text { CDS en } \\
\text { Cataluña }\end{array}$ & Hotel de Barcelona 30/08/1982 & - & - \\
\hline $\begin{array}{l}\text { Constitución de } \\
\text { las Comisiones } \\
\text { Gestoras } \\
\text { Provinciales }\end{array}$ & $\begin{array}{l}\text { Entre finales de agosto y el } \\
09 / 09 / 1982^{1}\end{array}$ & $\begin{array}{l}\text { Líderes } \\
\text { nacionales }\end{array}$ & Líderes provinciales \\
\hline $\begin{array}{l}\text { Creación de la } \\
\text { Gestora de } \\
\text { Cataluña }\end{array}$ & Finales de 1982 y enero de 1983. & - & $\begin{array}{l}\text { Líderes provinciales y } \\
\text { autonómicos }\end{array}$ \\
\hline $\begin{array}{l}\text { Crisis de la } \\
\text { Gestora de } \\
\text { Cataluña y de la } \\
\text { Gestora de } \\
\text { Barcelona } \\
\end{array}$ & 29 у 30/01/1983 & $\begin{array}{l}\text { Adolfo Suárez } \\
\text { y J. R. Caso }\end{array}$ & $\begin{array}{l}\text { Ceses y dimisión posterior } \\
\text { de: Santi Guillén, J. M. } \\
\text { Valón, J. M. Mesa Parra, } \\
\text { etc. }\end{array}$ \\
\hline
\end{tabular}

Elaboración propia a partir de fuentes hemerográficas

\footnotetext{
${ }^{1}$ Gabinete de información. Caja 243. Informe Diario n³17, Ya, 09 de septiembre de 1982, AGCYL. El paso de los grupos promotores a las Comisiones Gestoras Provinciales tuvo lugar entre la última semana de agosto y la primera de septiembre.
} 
Principales cargos de CC-UCD que se integraron en el CDS.

\begin{tabular}{|c|c|c|c|c|c|c|}
\hline Nombre & Provincia & $\begin{array}{l}\text { Responsabili } \\
\text { dades en CC- } \\
\text { UCD }^{2}\end{array}$ & $\begin{array}{l}\text { Cargo } \\
\text { institucional }\end{array}$ & \begin{tabular}{l}
\multicolumn{3}{l}{ Responsabilidades } \\
en el CDS hasta \\
enero de 1983
\end{tabular} & $\begin{array}{l}\text { Baja } \\
\text { de } \\
\text { CDS }\end{array}$ & $\begin{array}{l}\text { Elecciones } \\
1982^{3}\end{array}$ \\
\hline $\begin{array}{l}\text { Jaume } \\
\text { Barnola } \\
\text { Serra }\end{array}$ & Lérida & $\begin{array}{l}\text { Vicepresident } \\
\text { e de CC-UCD } \\
\text { y miembro del } \\
\text { Comité } \\
\text { Ejecutivo }\end{array}$ & $\begin{array}{l}\text { Diputado } \\
\text { nacional }\end{array}$ & - & - & $\begin{array}{l}1^{\circ} \text { Senado } \\
\text { Lérida }\end{array}$ \\
\hline $\begin{array}{l}\text { José María } \\
\text { Mesa } \\
\text { Parra } \\
\end{array}$ & Barcelona & $\begin{array}{l}\text { Miembro del } \\
\text { Comité } \\
\text { Ejecutivo }\end{array}$ & $\begin{array}{l}\text { Diputado } \\
\text { nacional }\end{array}$ & $\begin{array}{l}\text { Miembro de la } \\
\text { gestora autonómica }\end{array}$ & $\begin{array}{l}\text { Enero } \\
1983\end{array}$ & $\begin{array}{l}3^{\circ} \\
\text { Congreso } \\
\text { Barcelona } \\
\end{array}$ \\
\hline $\begin{array}{l}\text { Manuel de } \\
\text { Sárraga } \\
\text { Gómez }\end{array}$ & Lérida & $\begin{array}{l}\text { Presidente de } \\
\text { CC-UCD en } \\
\text { Lérida y } \\
\text { miembro del } \\
\text { Comité } \\
\text { Ejecutivo }\end{array}$ & $\begin{array}{l}\text { Diputado } \\
\text { nacional }\end{array}$ & $\begin{array}{l}\text { Miembro del Comité } \\
\text { Nacional y de la } \\
\text { gestora autonómica }\end{array}$ & - & $\begin{array}{l}1^{\circ} \\
\text { Congreso } \\
\text { Lérida }\end{array}$ \\
\hline $\begin{array}{l}\text { Josep } \\
\text { Pujadas i } \\
\text { Domingo }\end{array}$ & Barcelona & $\begin{array}{l}\text { Presidente de } \\
\text { CC-UCD en } \\
\text { Barcelona y } \\
\text { miembro del } \\
\text { Comité } \\
\text { Ejecutivo }\end{array}$ & $\begin{array}{l}\text { Diputado } \\
\text { nacional }\end{array}$ & $\begin{array}{l}\text { Presidente de la } \\
\text { Gestora Provincial de } \\
\text { Barcelona y de la } \\
\text { gestora autonómica }\end{array}$ & - & $\begin{array}{l}2^{\circ} \\
\text { Congreso } \\
\text { Barcelona }\end{array}$ \\
\hline $\begin{array}{l}\text { Josep } \\
\text { Sánchez } \\
\text { Llibre }\end{array}$ & Barcelona & $\begin{array}{l}\text { Secretario } \\
\text { provincial de } \\
\text { CC-UCD en } \\
\text { Barcelona }\end{array}$ & - & $\begin{array}{l}\text { Miembro de la } \\
\text { Gestora de Barcelona }\end{array}$ & $\begin{array}{l}\text { Enero } \\
1983\end{array}$ & $\begin{array}{l}5^{\circ} \\
\text { Congreso } \\
\text { Barcelona }\end{array}$ \\
\hline $\begin{array}{l}\text { Pere } \\
\text { Roselló }\end{array}$ & Lérida & $\begin{array}{l}\text { Presidente del } \\
\text { Comité Local } \\
\text { de CC-UCD } \\
\text { de Lérida y } \\
\text { miembro del } \\
\text { Comité } \\
\text { Ejecutivo }\end{array}$ & $\begin{array}{l}\text { Diputado } \\
\text { autonómico }\end{array}$ & $\begin{array}{l}\text { Presidente de la } \\
\text { Gestora Provincial de } \\
\text { Lérida y miembro de } \\
\text { la gestora autonómica }\end{array}$ & - & - \\
\hline $\begin{array}{l}\text { Joan } \\
\text { Manuel } \\
\text { Margaleff } \\
\text { i Miralles } \\
\end{array}$ & Tarragona & $\begin{array}{l}\text { Miembro del } \\
\text { Comité } \\
\text { Ejecutivo }\end{array}$ & $\begin{array}{l}\text { Diputado } \\
\text { autonómico }\end{array}$ & $\begin{array}{l}\text { Miembro de la } \\
\text { Gestora de Tarragona } \\
\text { y miembro de la } \\
\text { gestora autonómica }\end{array}$ & - & $\begin{array}{l}2^{\circ} \\
\text { Congreso } \\
\text { Tarragona }\end{array}$ \\
\hline $\begin{array}{l}\text { Albert } \\
\text { Planasdem } \\
\text { unt }\end{array}$ & Gerona & $\begin{array}{l}\text { Miembro del } \\
\text { Comité } \\
\text { Ejecutivo }\end{array}$ & $\begin{array}{l}\text { Diputado } \\
\text { autonómico }\end{array}$ & $\begin{array}{l}\text { Presidente de la } \\
\text { Gestora de Gerona y } \\
\text { miembro de la } \\
\text { Gestora de Catalunya }\end{array}$ & - & $\begin{array}{l}1^{\circ} \text { Senado } \\
\text { Gerona }\end{array}$ \\
\hline $\begin{array}{l}\text { Santiago } \\
\text { Guillén }\end{array}$ & Barcelona & $\begin{array}{l}\text { Miembro del } \\
\text { Comité } \\
\text { Ejecutivo }\end{array}$ & $\begin{array}{l}\text { Diputado } \\
\text { autonómico }\end{array}$ & $\begin{array}{l}\text { Portavoz del CDS en } \\
\text { el Parlamento de } \\
\text { Catalunya y miembro } \\
\text { de la Gestora de } \\
\text { Barcelona y de la } \\
\text { gestora autonómica }\end{array}$ & $\begin{array}{l}\text { Enero } \\
1983\end{array}$ & - \\
\hline $\begin{array}{l}\text { Joan Besa } \\
\text { i Esteve }\end{array}$ & Lérida & - & $\begin{array}{l}\text { Diputado } \\
\text { autonómico }\end{array}$ & - & $\begin{array}{l}\text { Febrero } \\
1983\end{array}$ & - \\
\hline
\end{tabular}

\footnotetext{
2 Salvo indicación expresa o justificación a lo largo del epígrafe los datos han sido extraídos de $L a$ Vanguardia, 31 de enero de 1982 y del documento Càrrecs parlamentaris $i$ biografies dels diputats $i$ diputades Composició dels grups parlamentaris, disponible en http://www.parlament.cat Fecha de consulta de 10 de julio de 2013. En total, podemos afirmar que al menos 14 de un total de 35 miembros del Comité Ejecutivo de CC-UCD, constituido en enero de 1982 pasaron al CDS.

${ }^{3}$ BOE, 02 de octubre de 1982, no 236.
} 


\begin{tabular}{|c|c|c|c|c|c|c|}
\hline & & & & & $\begin{array}{l}\text { (Junio, } \\
\text { AP) }\end{array}$ & \\
\hline $\begin{array}{l}\text { Josep } \\
\text { Mesegué i } \\
\text { Utgé }\end{array}$ & Lérida & $\begin{array}{l}\text { Cargos } \\
\text { provinciales }\end{array}$ & $\begin{array}{l}\text { Diputado } \\
\text { autonómico }\end{array}$ & - & - & - \\
\hline $\begin{array}{l}\text { Francesc- } \\
\text { Xavier } \\
\text { Puig i } \\
\text { Andreu }\end{array}$ & Lérida & $\begin{array}{l}\text { Miembro del } \\
\text { Comité } \\
\text { Ejecutivo }\end{array}$ & $\begin{array}{l}\text { Diputado } \\
\text { autonómico }\end{array}$ & $\begin{array}{l}\text { Miembro de la } \\
\text { gestora autonómica }\end{array}$ & - & - \\
\hline $\begin{array}{l}\text { Julián } \\
\text { Valón }\end{array}$ & Barcelona & $\begin{array}{l}\text { Secretario } \\
\text { General }\end{array}$ & Abogado & $\begin{array}{l}\text { Miembro de la } \\
\text { gestora autonómica }\end{array}$ & $\begin{array}{l}\text { Enero } \\
1983 \\
\end{array}$ & $\begin{array}{l}1^{\circ} \text { Senado } \\
\text { Barcelona }\end{array}$ \\
\hline $\begin{array}{l}\text { Josep } \\
\text { Coderch }\end{array}$ & Gerona & $\begin{array}{l}\text { Presidente de } \\
\text { CC-UCD en } \\
\text { Gerona }\end{array}$ & $\begin{array}{l}\text { Ex } \\
\text { gobernador } \\
\text { Civil de } \\
\text { Barcelona }\end{array}$ & - & $\begin{array}{l}\text { Otras } \\
\text { dedicac } \\
\text { iones }\end{array}$ & $\begin{array}{l}1^{\circ} \\
\text { Congreso } \\
\text { Gerona }\end{array}$ \\
\hline $\begin{array}{l}\text { Martí M. } \\
\text { Díaz } \\
\text { Lloret }\end{array}$ & Gerona & $\begin{array}{l}\text { Secretario } \\
\text { Provincial de } \\
\text { CC-UCD en } \\
\text { Gerona y } \\
\text { miembro del } \\
\text { Comité } \\
\text { Ejecutivo. }\end{array}$ & $\begin{array}{l}\text { Concejal } \\
\text { Ayuntamient } \\
\text { o de Gerona }\end{array}$ & $\begin{array}{l}\text { Miembro de la } \\
\text { gestora autonómica }\end{array}$ & - & \\
\hline $\begin{array}{l}\text { Josep } \\
\text { María } \\
\text { Oller }\end{array}$ & Tarragona & $\begin{array}{l}\text { Presidente } \\
\text { Provincial de } \\
\text { CC-UCD en } \\
\text { Tarragona } \\
\end{array}$ & - & - & - & $\begin{array}{l}10^{\mathrm{a}} \\
\text { Congreso } \\
\text { Tarragona }\end{array}$ \\
\hline $\begin{array}{l}\text { Xavier } \\
\text { Artal }\end{array}$ & Tarragona & $\begin{array}{l}\text { Presidente } \\
\text { Local y ex } \\
\text { Secretario } \\
\text { Provincial de } \\
\text { CC-UCD en } \\
\text { Tarragona y } \\
\text { miembro del } \\
\text { Comité } \\
\text { Ejecutivo }\end{array}$ & - & $\begin{array}{l}\text { Presidente de la } \\
\text { Gestora de Tarragona } \\
\text { y miembro de la } \\
\text { gestora autonómica }\end{array}$ & - & $\begin{array}{l}1^{\circ} \\
\text { Congreso } \\
\text { Tarragona }\end{array}$ \\
\hline $\begin{array}{l}\text { Lluis } \\
\text { Badía }\end{array}$ & Tarragona & $\begin{array}{l}\text { Presidente en } \\
\text { funciones y } \\
\text { secretario } \\
\text { provincial de } \\
\text { CC-UCD } \\
\text { Tarragona } \\
\end{array}$ & - & - & - & - \\
\hline $\begin{array}{l}\text { Juan } \\
\text { Martín } \\
\text { Toribio }\end{array}$ & Barcelona & $\begin{array}{l}\text { Comité } \\
\text { Ejecutivo CC- } \\
\text { UCD por } \\
\text { Barcelona }\end{array}$ & - & $\begin{array}{l}\text { Miembro de la } \\
\text { gestora autonómica }\end{array}$ & - & $\begin{array}{l}2^{\mathrm{a}} \text { Senado } \\
\text { Barcelona }\end{array}$ \\
\hline $\begin{array}{l}\text { Lluis Puyó } \\
\text { Pérez }\end{array}$ & Barcelona & $\begin{array}{l}\text { Miembro } \\
\text { Comité } \\
\text { Ejecutivo } \\
\text { Barcelona }\end{array}$ & - & - & - & $\begin{array}{l}6^{\circ} \\
\text { Congreso } \\
\text { Barcelona }\end{array}$ \\
\hline $\begin{array}{l}\text { Jorge } \\
\text { Fernández } \\
\text { Díaz }\end{array}$ & Barcelona & CC-UCD & $\begin{array}{l}\text { Gobernador } \\
\text { Civil }\end{array}$ & - & \begin{tabular}{|l} 
Enero/ \\
Febrero \\
de \\
1983 \\
(AP) \\
\end{tabular} & $\begin{array}{l}4^{\circ} \\
\text { Congreso } \\
\text { Barcelona }\end{array}$ \\
\hline $\begin{array}{l}\text { Manuel } \\
\text { Jiménez } \\
\text { de Parga }\end{array}$ & Barcelona & $\begin{array}{l}\text { CC-UCD (sin } \\
\text { actividad } \\
\text { política) }\end{array}$ & $\begin{array}{l}\text { Ex diputado } \\
\text { nacional }\end{array}$ & Comité Nacional & $\begin{array}{l}\text { Abril } \\
1986\end{array}$ & $\begin{array}{l}1^{\circ} \\
\text { Congreso } \\
\text { Alicante }\end{array}$ \\
\hline $\begin{array}{l}\text { Jacinto } \\
\text { Saiz } \\
\text { García }\end{array}$ & Gerona & $\begin{array}{l}\text { Ex Secretario } \\
\text { Provincial de } \\
\text { CC-UCD }\end{array}$ & - & $\begin{array}{l}\text { Miembro de la } \\
\text { gestora autonómica }\end{array}$ & - & . \\
\hline
\end{tabular}




\begin{tabular}{|c|c|c|c|c|c|c|}
\hline & & $\begin{array}{l}\text { Gerona; } \\
\text { Comité } \\
\text { Ejecutivo CC- } \\
\text { UCD }\end{array}$ & & & & \\
\hline $\begin{array}{l}\text { Javier } \\
\text { Campoy }\end{array}$ & Barcelona & $\begin{array}{l}\text { Secretario de } \\
\text { Juventudes } \\
\text { CC-UCD }\end{array}$ & - & - & - & $\begin{array}{l}35^{\circ} \\
\text { Congreso } \\
\text { Barcelona }\end{array}$ \\
\hline \multicolumn{7}{|c|}{ Otros cargos representativos del CDS en Cataluña desde el verano de 1982 a comienzos de 1983} \\
\hline $\begin{array}{l}\text { Lluis } \\
\text { Pascual } \\
\text { Estevill }\end{array}$ & Tarragona & - & Abogado. & $\begin{array}{l}\text { Miembro de la } \\
\text { gestora autonómica y } \\
\text { de la Gestora de } \\
\text { Tarragona }\end{array}$ & - & $\begin{array}{l}2^{\circ} \text { Senado } \\
\text { Tarragona }\end{array}$ \\
\hline $\begin{array}{l}\text { Ramón } \\
\text { Vinyals i } \\
\text { Soler }\end{array}$ & Barcelona & $\begin{array}{l}\text { Tesorero de } \\
\text { ERC hasta } \\
1980 .\end{array}$ & $\begin{array}{l}\text { Diputado } \\
\text { autonómico } \\
\text { (grupo } \\
\text { parlamentari } \\
\text { o no- } \\
\text { adscritos) }\end{array}$ & $\begin{array}{l}\text { Miembro de la } \\
\text { Gestora de Barcelona }\end{array}$ & $\begin{array}{l}\text { Finales } \\
\text { de } \\
1983- \\
1984^{4}\end{array}$ & - \\
\hline $\begin{array}{l}\text { Antonio } \\
\text { de } \\
\text { Senillosa }\end{array}$ & Barcelona & ACL-CD & $\begin{array}{l}\text { Diputado } \\
\text { Nacional } \\
\text { (Grupo } \\
\text { Parlamentari } \\
\text { o CD) }\end{array}$ & - & $\begin{array}{l}\text { Otras } \\
\text { dedicac } \\
\text { iones }\end{array}$ & $\begin{array}{l}1^{\circ} \\
\text { Congreso } \\
\text { Barcelona }\end{array}$ \\
\hline
\end{tabular}

Elaboración propia a partir de fuentes hemerográficas

Composición de las Gestoras Provinciales del CDS en Cataluña (septiembre 1982)

\begin{tabular}{|l|l|}
\hline Provincia & Miembros \\
\hline Barcelona & $\begin{array}{l}\text { Josep Pujadas i Domingo, J. M M Mesa Parra, J. Sánchez Llibre, Juan Collo Majó de Sant } \\
\text { Celoní, Jorge Fernández Díaz, Santiago Guillén Fernández [Barcelona]; Francisco Guillemía } \\
\text { Laseras [de Manresa], Teófilo Hidalgo Talavera [el Prat]; J. Lucas Carrasco, Xavier Martí } \\
\text { Monllor, J. Martí Roibio, Jaume Olivé Ollé [Badalona]; Lluis Puyó Pérez, Juliá Ma Valon } \\
\text { Cunillerra, Enrice Verdet y Ramon Vinyals i Soler. }\end{array}$ \\
\hline Tarragona & $\begin{array}{l}\text { Javier Artal Morillo, Luis Badía Sancho, Joaquín Borrel Mestres, Ramón Calanda Alfonso, } \\
\text { Víctor Cervera, José Fernández Rufí, María Paz Griman, José Lletí Asesi, Juan Manuel } \\
\text { Margalef Miralles, María Teresa Martí Estrada, José Maria Ollé Monte. }\end{array}$ \\
\hline Lérida & $\begin{array}{l}\text { Javier Barnola Serra, Juan Besa Estebe, Jorge Barrus Burbayá, Josep Font Huguet, Antonio } \\
\text { Guix Rivelles, José Mesegué Utgé, José Mora Cacigán, Javier Puig Andreu, Pedro Roselló } \\
\text { Esteban y Manuel de Sárraga Gómez. }\end{array}$ \\
\hline Gerona & $\begin{array}{l}\text { J. Coderch Planas, Martína Manuel Diez Lloret, Francisco Hortal Burgues, Guillermo Mateu } \\
\text { Coll, Albert Planasdemunt Gubert, Jaime Ramón i Soler, Jacinto Saiz y Jacinto Romero. }\end{array}$ \\
\hline
\end{tabular}

Elaboración propia a partir de El Noticiero Universal, 10 de septiembre de 1982.

\footnotetext{
${ }^{4}$ En las elecciones autonómicas catalanas de 1984 se presentó por el PSDC, como primero de lista por Barcelona. Cartel Electoral depósito CEDOC de la UAB: "Dóna la sorpresa... : vota diferent : Ramon Viñals i Soler : vota Socialdemòcrata / Partit Social Demòcrata de Catalunya", Universitat Autònoma de Barcelona. Biblioteca de Comunicació i Hemeroteca General. CEDOC, 1984. Imagen disponible en http://www.uab.cat Consultado el 09 de noviembre de 2013.
} 


\section{Anexo VII}

Presidentes provinciales e insulares del CDS (1982-90') ${ }^{1}$

\begin{tabular}{|c|c|c|c|c|}
\hline Provincia & $\begin{array}{l}1982 \\
\text { (Portavoz) }\end{array}$ & $\begin{array}{l}1982-1986 \\
\text { (Portavoz y/o } \\
\text { Presidente) }\end{array}$ & $\begin{array}{l}\text { 1987-1990 } \\
\text { (Presidente) }\end{array}$ & $1991-\ldots{ }^{3}$ \\
\hline Albacete & $\begin{array}{l}\text { - Alejandro } \\
\text { Baldueza }\end{array}$ & $\begin{array}{l}\text { - Alejandro } \\
\text { Baldueza }\end{array}$ & $\begin{array}{l}\text { - Alejandro } \\
\text { Baldueza }\end{array}$ & $\begin{array}{l}\text { Dimisión como Presidente CDS } \\
\text { CLM y CDS-Albacete (1990). }\end{array}$ \\
\hline Alicante & $\begin{array}{l}\text { - Mariano } \\
\text { Rodríguez } \\
\text { Cerdá }\end{array}$ & $\begin{array}{l}\text { - Pedro Tomás } \\
\text { (1984) } \\
\text { - Rafael } \\
\text { Martínez } \\
\text { Campillo } \\
\text { (1986) }\end{array}$ & $\begin{array}{l}\text { - Rafael } \\
\text { Martínez- } \\
\text { Campillo }\end{array}$ & $\begin{array}{l}\text { Dimisión de la Ejecutiva Provincial } \\
\text { con Rafael Martínez Campillo al } \\
\text { frente tras el IV Congreso. }\end{array}$ \\
\hline Álava & $\begin{array}{l}\text { - Alfredo } \\
\text { Marco Tabar }\end{array}$ & $\begin{array}{l}\text { - Alfredo } \\
\text { Marco Tabar }\end{array}$ & $\begin{array}{l}\text { - Alfredo Marco } \\
\text { Tabar }\end{array}$ & $\begin{array}{l}\text { Ingresó en el PP en la década de } \\
\text { los } 90^{, 4} \text {. }\end{array}$ \\
\hline Almería $^{5}$ & $\begin{array}{l}\text { - Alfonso } \\
\text { Soler Turmo }\end{array}$ & $\begin{array}{l}\text { - Alfonso Soler } \\
\text { Turmo }\end{array}$ & $\begin{array}{l}\text { - Joaquín } \\
\text { Fernández } \\
\text { Palacios }\end{array}$ & $\begin{array}{l}\text { Joaquín Fernández, quien había } \\
\text { militado en el PSP, dimitió tras los } \\
\text { resultados electorales de } 1991^{6}\end{array}$ \\
\hline Asturias & $\begin{array}{l}\text { - Alejandro } \\
\text { Rebollo }\end{array}$ & $\begin{array}{l}\text { - Alejandro } \\
\text { Rebollo }\end{array}$ & $\begin{array}{l}\text { - Alejandro } \\
\text { Rebollo } \\
\text { - Alfonso } \\
\text { Román(1990) }\end{array}$ & $\begin{array}{l}\text { Alejandro Rebollo abandona la } \\
\text { actividad del partido en el VI } \\
\text { Congreso (1993). } \\
\text { Alfonso Román se integra en el PP } \\
\text { en la década de los } 90^{\prime} \text {. }\end{array}$ \\
\hline Ávila & $\begin{array}{l}\text { - Fernando } \\
\text { Alcón Sáez }\end{array}$ & $\begin{array}{l}\text { - Alberto } \\
\text { Dorrego }\end{array}$ & $\begin{array}{l}\text { - Alberto } \\
\text { Dorrego } \\
\text { - José Alfredo } \\
\text { Ferrer }(1989)^{7} \\
\end{array}$ & $\begin{array}{l}\text { Fernando Alcón: desvinculado de } \\
\text { la actividad política. } \\
\text { Alberto Dorrego (presidente del } \\
\text { CDS entre } 1998 \text { y 1999). }\end{array}$ \\
\hline Badajoz & $\begin{array}{l}\text { - Fernando } \\
\text { Povedano de } \\
\text { Bustos }\end{array}$ & $\begin{array}{l}\text { - Tomás } \\
\text { Martín } \\
\text { Tamayo }\end{array}$ & $\begin{array}{l}\text { - Tomás Martín } \\
\text { Tamayo } \\
\text { - Macario } \\
\text { Herrera }(1991)^{8}\end{array}$ & $\begin{array}{l}\text { Tomás Martín Tamayo fundó en } \\
1992 \text { Convergencia Regionalista } \\
\text { Extremeña. Fue diputado por las } \\
\text { listas del Partido Popular en la } \\
\text { Junta de Extremadura. }\end{array}$ \\
\hline $\begin{array}{l}\text { Baleares } \\
\text { (Ibiza) }\end{array}$ & - & $\begin{array}{l}\text { - Juan Vereda } \\
\text { Escandell }\end{array}$ & - & - \\
\hline $\begin{array}{l}\text { Baleares } \\
\text { (Mallorca) }\end{array}$ & $\begin{array}{l}\text { - Francisco } \\
\text { Quetglás } \\
\text { Rosanes }\end{array}$ & - & $\begin{array}{l}\text { - López Obrador } \\
\text { (1988) }\end{array}$ & $\begin{array}{l}\text { Francisco Quetglás apoyó la } \\
\text { disolución en 1993. Ingresó en el } \\
\text { PSOE. }\end{array}$ \\
\hline $\begin{array}{l}\text { Baleares } \\
\text { (Menorca) }\end{array}$ & - & - Carlos Ricci & $\begin{array}{l}\text { - J. J. Quetglás } \\
\text { (1988) }\end{array}$ & $\begin{array}{l}\text { Carlos Ricci abandonó el CDS en } \\
1988 \text { y encabezó en } 1991 \text { las listas } \\
\text { de Unió Progresista de Menorca9 }\end{array}$ \\
\hline
\end{tabular}

\footnotetext{
${ }^{1}$ La información de los dos primeros apartados procede en buena medida de $A G P$. Se ha omitido la información relativa a la trayectoria política previa, debido a la escasez de fuentes de las que disponemos y ser un aspecto que hemos abordado sistemáticamente en el epígrafe 7. 4.

${ }^{2}$ La información ha sido obtenida con fuentes hemerográficas coetáneas a los hechos cuya referencia se ha omitido, abordándose únicamente aquella de carácter diferente.

${ }^{3}$ Ha sido decisiva la información procedente de MENÉNDEZ, Miguel Ángel: "Los últimos del CDS", Interviú, 1994, n 962, Hemeroteca Caixa-Tarragona.

${ }^{4}$ CRESPO, Txema: "El político se retira”, El País, 22 de abril de 2007.

5 FERNÁNDEZ AMADOR, Mónica: El poder municipal en Almería durante la transición a la democracia, Tesis Doctoral, Univ. de Almería, 2013, pp. 416-7.

${ }^{6}$ ABC Sevilla, 29 de mayo de 1991.

${ }^{7}$ Información disponible en la ficha de diputado disponible en el repositorio online del Congreso de los Diputados.

${ }^{8}$ ¿D16?, 03 de febrero de 1991, MAST.
} 


\begin{tabular}{|c|c|c|c|c|}
\hline Burgos & $\begin{array}{l}\text { - Francisco } \\
\text { Reyes }\end{array}$ & $\begin{array}{l}\text { - Ricardo } \\
\text { García García- } \\
\text { Ochoa }\end{array}$ & $\begin{array}{l}\text { - Ricardo García } \\
\text { García-Ochoa }\end{array}$ & - \\
\hline Barcelona & $\begin{array}{l}\text { - Josep } \\
\text { Pujadas }\end{array}$ & $\begin{array}{l}\text { - Manuel } \\
\text { Jiménez de } \\
\text { Parga }\end{array}$ & $\begin{array}{l}\text { - Antonio } \\
\text { Fernández- } \\
\text { Teixidó } \\
\text { Armand Ródena } \\
(-)\end{array}$ & $\begin{array}{l}\text { Antonio Fernández Teixidó fue } \\
\text { Secretario General del CDS (1991- } \\
\text { 1992). Ingresó en CiU en } 1996 .\end{array}$ \\
\hline Cáceres & $\begin{array}{l}\text { - Jesús } \\
\text { Sánchez } \\
\text { Baviano }\end{array}$ & $\begin{array}{l}- \text { Carlos } \\
\text { Villamor } \\
\text { Maquieira } \\
(1985)\end{array}$ & $\begin{array}{l}\text { - Carlos } \\
\text { Villamor } \\
\text { Maquieira }\end{array}$ & - \\
\hline Cádiz & $\begin{array}{l}\text { - José Antonio } \\
\text { Muñoz } \\
\text { Vázquez }\end{array}$ & $\begin{array}{l}\text { - Antonio } \\
\text { Morillo Crespo } \\
\text { (1985) }\end{array}$ & $\begin{array}{l}\text { - Antonio } \\
\text { Morillo Crespo }\end{array}$ & - \\
\hline $\begin{array}{l}\text { Fuerteventura } \\
\text { (Canarias) }\end{array}$ & - & $\begin{array}{l}\text { Domingo } \\
\text { Rodríguez } \\
\text { Calero }\end{array}$ & - & - \\
\hline $\begin{array}{l}\text { Lanzarote } \\
\text { (Canarias) }\end{array}$ & - & $\begin{array}{l}\text { Jesús Morales } \\
\text { Morales } \\
\text { (1983) } \\
\end{array}$ & - & - \\
\hline $\begin{array}{l}\text { Las Palmas } \\
\text { (Canarias) }\end{array}$ & $\begin{array}{l}\text { - Lorenzo } \\
\text { Olarte }\end{array}$ & $\begin{array}{l}\text { - José Antonio } \\
\text { Santos Miñón } \\
\text { (1984) }\end{array}$ & - & $\begin{array}{l}\text { José Antonio Santos Miñón } \\
\text { abandonó la actividad política. } \\
\text { Lorenzo Olarte, en } 1992 \text { fundó } \\
\text { Centro Canario Independiente a } \\
\text { partir del CDS-Canarias -que se } \\
\text { integró en Coalición Canaria-. }\end{array}$ \\
\hline $\begin{array}{l}\text { Tenerife } \\
\text { (Canarias) }\end{array}$ & $\begin{array}{l}\text { - Antonio } \\
\text { Jiménez } \\
\text { García }\end{array}$ & $\begin{array}{l}\text { - Fernando } \\
\text { Fernández } \\
\text { Martín (1983) }\end{array}$ & - & $\begin{array}{l}\text { Fernando Fernández Martín, quien } \\
\text { había militado en el PAD y el } \\
\text { sindicato UGT }{ }^{10} \text {, ingresó en el PP } \\
\text { (1990). }\end{array}$ \\
\hline $\begin{array}{l}\text { Hierro } \\
\text { (Canarias) }\end{array}$ & $\begin{array}{l}\text { - Antonio } \\
\text { Jiménez } \\
\text { García }\end{array}$ & $\begin{array}{l}\text { - Manuela } \\
\text { Padrón } \\
\text { Hernández } \\
(1983)\end{array}$ & - & - \\
\hline $\begin{array}{l}\text { La Palma } \\
\text { (Canarias) }\end{array}$ & $\begin{array}{l}\text { - Antonio } \\
\text { Jiménez } \\
\text { García }\end{array}$ & $\begin{array}{l}\text { - Manuel A. } \\
\text { Yanes } \\
\text { Camacho } \\
(1984)\end{array}$ & - & - \\
\hline Cantabria & $\begin{array}{l}\text { - Federico } \\
\text { Ysart }\end{array}$ & $\begin{array}{l}\text { - Manuel } \\
\text { Garrido (1983) }\end{array}$ & $\begin{array}{l}\text { - Manuel } \\
\text { Garrido } \\
\text { Martínez }\end{array}$ & $\begin{array}{l}\text { Manuel Garrido abandonó el } \\
\text { partido tras el VI Congreso. } \\
\text { Diputado por el PSOE, como } \\
\text { indepndiente, en el Parlamento } \\
\text { cántabro (1995). } \\
\text { Federico Ysart: se dedicó a la } \\
\text { actividad privada, políticamente en } \\
\text { la "órbita del PP" }(1994) \text { ". }\end{array}$ \\
\hline Castellón & $\begin{array}{l}\text { - Ángel } \\
\text { Solsona } \\
\text { Montón }\end{array}$ & $\begin{array}{l}\text { - Pedro } \\
\text { Gozalbo } \\
\text { Herrero (desde } \\
1983 \text { ) }\end{array}$ & $\begin{array}{l}\text { - Pedro Gozalbo } \\
\text { Herrero }\end{array}$ & - \\
\hline Ceuta & - José Luis & - Antonio & - Antonio & Antonio Vázquez Sarmiento (2004, \\
\hline
\end{tabular}

\footnotetext{
${ }^{9}$ De acuerdo con la candidatura a las elecciones autonómicas publicadas en el Butlletí Oficial de la Comunitat Autònoma de les Illes Balears, 30 de abril de 1991, $\mathrm{n}^{\circ}$ 55, p. 3453. Disponible en: http://www.boib.caib.es Fecha de consulta: 10 de marzo de 2016.

${ }^{10} \mathrm{Ya}$, 04 de agosto de 1987.

${ }^{11}$ MENÉNDEZ, Miguel Ángel: "Los últimos del CDS", Interviú, 1994, nº 962, Hemeroteca CaixaTarragona.
} 


\begin{tabular}{|c|c|c|c|c|}
\hline & Chaves Torcal & $\begin{array}{l}\text { Vázquez } \\
\text { Sarmiento }\end{array}$ & $\begin{array}{l}\text { Vázquez } \\
\text { Sarmiento }\end{array}$ & listas PSPC) $^{12}$ \\
\hline Ciudad Real & $\begin{array}{l}\text { - Felipe } \\
\text { Caballero }\end{array}$ & $\begin{array}{l}\text { - Felipe } \\
\text { Caballero } \\
\text { Naranjo }\end{array}$ & $\begin{array}{l}\text { - Felipe } \\
\text { Caballero } \\
\text { Naranjo (hasta } \\
\text { 1988) } \\
-\end{array}$ & $\begin{array}{l}\text { Felipe Caballero Naranjo } \\
\text { vinculó al PP en } 1989^{13} \text {. }\end{array}$ \\
\hline Córdoba & $\begin{array}{l}\text { - Antonio J. } \\
\text { Delgado de } \\
\text { Jesús }\end{array}$ & $\begin{array}{l}\text { - Antonio J. } \\
\text { Delgado de } \\
\text { Jesús }\end{array}$ & $\begin{array}{l}\text { - Antonio J. } \\
\text { Delgado de } \\
\text { Jesús }\end{array}$ & - \\
\hline La Coruña & $\begin{array}{l}\text { - Perfecto } \\
\text { Yebra }\end{array}$ & $\begin{array}{l}\text { - J. A. Arán } \\
\text { Trillo }\end{array}$ & - J. A. Trillo & - \\
\hline Cuenca & $\begin{array}{l}\text { - José Tovar } \\
\text { Jiménez }\end{array}$ & $\begin{array}{l}\text { - Benedicto } \\
\text { Torre Teresa }\end{array}$ & $\begin{array}{l}\text { - Benedicto } \\
\text { Torre Teresa }\end{array}$ & - \\
\hline Gerona & $\begin{array}{l}\text { - Alberto } \\
\text { Planasdemunt }\end{array}$ & $\begin{array}{l}\text { - Jacinto Sainz } \\
\text { García (1986) }\end{array}$ & $\begin{array}{l}\text { - Jacinto Sainz } \\
\text { García }\end{array}$ & - \\
\hline Granada & $\begin{array}{l}\text { - Juan de Dios } \\
\text { Luque Durán }\end{array}$ & $\begin{array}{l}\text { - Antonio } \\
\text { Iglesias } \\
\text { Casado }\end{array}$ & $\begin{array}{l}\text { - Ramiro Pérez } \\
\text { de la Blanca }\end{array}$ & $\begin{array}{l}\text { Ramiro Pérez de la } \\
\text { abandonó la presidencia } \\
\text { actividad política en } 1991 .\end{array}$ \\
\hline Guadalajara & $\begin{array}{l}\text { - José Luis } \\
\text { Muñoz Ibáñez }\end{array}$ & $\begin{array}{l}\text { - Francisco } \\
\text { Ruiz del } \\
\text { Castillo }\end{array}$ & \begin{tabular}{|l} 
- Francisco Ruiz \\
del Castillo \\
(1989) \\
- Lucio \\
Cabrerizo \\
(1989) \\
- Enrique \\
Sánchez \\
Goyanes (-) \\
\end{tabular} & - \\
\hline Guipúzcoa & $\begin{array}{l}\text { - Martín } \\
\text { Mendaza } \\
\text { Zabala }\end{array}$ & $\begin{array}{l}\text { - Martín } \\
\text { Mendaza } \\
\text { Zabala }\end{array}$ & $\begin{array}{l}\text { - Martín } \\
\text { Mendaza Zabala }\end{array}$ & - \\
\hline Huelva & $\begin{array}{l}\text { - Francisco J. } \\
\text { Rodríguez } \\
\text { Batllori }\end{array}$ & $\begin{array}{l}\text { - Juan José } \\
\text { Domínguez } \\
\text { (desde 1985) }\end{array}$ & $\begin{array}{l}\text { - Juan José } \\
\text { Domínguez } \\
(1990)\end{array}$ & - \\
\hline Huesca & $\begin{array}{l}\text { - Bernardo } \\
\text { Baquedano }\end{array}$ & $\begin{array}{l}\text { - Bernardo } \\
\text { Baquedano }\end{array}$ & $\begin{array}{l}\text { - Bernardo } \\
\text { Baquedano }\end{array}$ & - \\
\hline Jaén & $\begin{array}{l}\text { - Luis Peña } \\
\text { Gallardo }\end{array}$ & $\begin{array}{l}\text { - José Visedo } \\
\text { Navarro } \\
\text { (1985) }\end{array}$ & $\begin{array}{l}\text { - José Visedo } \\
\text { Navarro }\end{array}$ & - \\
\hline León & $\begin{array}{l}\text { - Luis Aznar } \\
\text { Fernández }\end{array}$ & $\begin{array}{l}\text { - Luis Aznar } \\
\text { Fernández }\end{array}$ & $\begin{array}{l}\text { - Luis Aznar } \\
\text { Fernández }\end{array}$ & $\begin{array}{l}\text { Luis Aznar ingresó en el Partido } \\
\text { Popular a mediados de los 90'. }\end{array}$ \\
\hline Lérida & $\begin{array}{l}\text { - Manuel de } \\
\text { Sárraga } \\
\text { Gómez } \\
\end{array}$ & $\begin{array}{l}\text { - Manuel de } \\
\text { Sárraga } \\
\text { Gómez }\end{array}$ & $\begin{array}{l}\text { - Manuel de } \\
\text { Sárraga Gómez }\end{array}$ & $\begin{array}{l}\text { Abandonó la política con la marcha } \\
\text { de Adolfo Suárez. }\end{array}$ \\
\hline Lugo & $\begin{array}{l}\text { - Jesús Villela } \\
\text { García }\end{array}$ & - César Garrote & $\begin{array}{l}\text { - Ramón Díaz } \\
\text { López }\end{array}$ & - \\
\hline Madrid & $\begin{array}{l}\text { - Carlos } \\
\text { Revilla } \\
\text { Rodríguez }\end{array}$ & $\begin{array}{l}\text { - Carlos } \\
\text { Revilla } \\
\text { Rodríguez }\end{array}$ & $\begin{array}{l}\text { - Gerardo } \\
\text { Harguindey } \\
\text { Bonet (desde } \\
\text { 1989) } \\
\text { - José Ramón } \\
\text { Lasuén (desde } \\
\text { 1990) } \\
\end{array}$ & $\begin{array}{l}\text { Carlos Revilla abandonó el partido } \\
\text { en } 1991 \text { tras el IV Congreso. } \\
\text { José Ramón Lasuén abandonó la } \\
\text { actividad política en } 1993 \text {. } \\
\text { Gerardo Harguindey dedicado a la } \\
\text { actividad profesional desde } 1991 . \\
\text { Se le consideró "cercano al PP"14. }\end{array}$ \\
\hline
\end{tabular}

${ }^{12}$ De acuerdo con las candidaturas electorales publicadas en el Boletín Oficial Ciudad de Ceuta, 11 de febrero de 2003, $n^{\circ} 2$ (extr.). Disponible en: www.ceuta.es/ceuta/bocce. Fecha de consulta: 26 de junio de 2016.

${ }^{13}$ ABC Sevilla, 02 de febrero de 1989. 


\begin{tabular}{|c|c|c|c|c|}
\hline Málaga & $\begin{array}{l}\text { - Francisco } \\
\text { Villodres }\end{array}$ & $\begin{array}{l}\text { - Francisco } \\
\text { Villodres } \\
\text { - Manuel } \\
\text { Rodríguez } \\
\text { Domínguez } \\
(1985)\end{array}$ & $\begin{array}{l}\text { - Manuel } \\
\text { Sánchez Bracho } \\
(1987)\end{array}$ & $\begin{array}{l}\text { Manuel Sánchez Bracho se integró } \\
\text { en el PP en } 1993 .\end{array}$ \\
\hline Melilla & $\begin{array}{l}\text { - Juan Ríos } \\
\text { García }\end{array}$ & $\begin{array}{l}\text { - Juan Carlos } \\
\text { Romero (-) }\end{array}$ & $\begin{array}{l}\text { - José Manuel } \\
\text { Calzado Puertas } \\
(1988)\end{array}$ & $\begin{array}{l}\text { José Manuel Calzado Puertas se } \\
\text { integró en el PP. }\end{array}$ \\
\hline Murcia & $\begin{array}{l}\text { - Bartolomé } \\
\text { Montoro }\end{array}$ & $\begin{array}{l}\text { - Mariano } \\
\text { Pelegrín } \\
\text { Muelas (1985) }\end{array}$ & $\begin{array}{l}\text { - Mariano } \\
\text { Pelegrín Muelas } \\
\text { - Enrique Egea } \\
\text { Ibáñez (1987) }\end{array}$ & - \\
\hline Navarra & $\begin{array}{l}\text { - Pablo García } \\
\text { Tellechea }\end{array}$ & $\begin{array}{l}\text { - Pablo García } \\
\text { Tellechea }\end{array}$ & $\begin{array}{l}\text { - Pablo García } \\
\text { Tellechea }\end{array}$ & Abandonó la política hacia $1991^{15}$ \\
\hline Orense & $\begin{array}{l}\text { - Paulino } \\
\text { González } \\
\text { Rodríguez } \\
\end{array}$ & $\begin{array}{l}\text { - Senén Ramos } \\
\text { Álvarez (1984) }\end{array}$ & $\begin{array}{l}\text { - Senén Ramos } \\
\text { Álvarez }\end{array}$ & - \\
\hline Palencia & $\begin{array}{l}\text { - José Antonio } \\
\text { Martínez }\end{array}$ & $\begin{array}{l}\text { - Godofredo } \\
\text { Martín } \\
\text { González }\end{array}$ & $\begin{array}{l}\text { - Godofredo } \\
\text { Martín González }\end{array}$ & - \\
\hline Pontevedra & $\begin{array}{l}\text { - Gerardo } \\
\text { González }\end{array}$ & $\begin{array}{l}\text { - Francisco } \\
\text { Moldes Fontán } \\
(-)\end{array}$ & $\begin{array}{l}\text { - Francisco } \\
\text { Moldes Fontán }\end{array}$ & $\begin{array}{l}\text { Abandonó la política a comienzos } \\
\text { de los } 90 \text { ' }\end{array}$ \\
\hline La Rioja & $\begin{array}{l}\text { - Manuel M. } \\
\text { Fernández } \\
\text { Ilarraza } \\
\end{array}$ & $\begin{array}{l}\text { - Manuel M. } \\
\text { Fernández } \\
\text { Ilarraza }\end{array}$ & $\begin{array}{l}\text { - Manuel M. } \\
\text { Fernández } \\
\text { Ilarraza } \\
\end{array}$ & $\begin{array}{l}\text { Abandonó la presidencia del CDS- } \\
\text { La Rioja y la política en } 1995^{16}\end{array}$ \\
\hline Salamanca & $\begin{array}{l}\text { - José Luis } \\
\text { Sagredo de } \\
\text { Miguel }\end{array}$ & $\begin{array}{l}\text { - José Luis } \\
\text { Sagredo de } \\
\text { Miguel }\end{array}$ & $\begin{array}{l}\text { - José Luis } \\
\text { Sagredo de } \\
\text { Miguel }\end{array}$ & $\begin{array}{l}\text { Abandonó la política activa a } \\
\text { mediados de los 90' (procurador } \\
\text { autonómico en Castilla y León } \\
\text { hasta 1995). }\end{array}$ \\
\hline Segovia & $\begin{array}{l}\text { - Rafael } \\
\text { Bernardo } \\
\text { Santos } \\
\end{array}$ & $\begin{array}{l}\text { - Juan Antonio } \\
\text { Perteguer Rey } \\
(1985)\end{array}$ & $\begin{array}{l}\text { - Juan Antonio } \\
\text { Perteguer Rey } \\
\text { (1985) }\end{array}$ & $\begin{array}{l}\text { J. A. Perteguer Rey se desvincula } \\
\text { del partido en } 1993 \text {. }\end{array}$ \\
\hline Sevilla & - Manuel Ortiz & $\begin{array}{l}\text { - Salvador } \\
\text { Valdenebro y } \\
\text { García de } \\
\text { Polavieja } \\
\text { (1983) }\end{array}$ & $\begin{array}{l}\text { - Adolfo Lama } \\
\text { Cotelo }\end{array}$ & $\begin{array}{l}\text { El comité provincial en bloque se } \\
\text { integró en el PP (A. Lama Cotelo y } \\
\text { M. Bilbao) (1991) }\end{array}$ \\
\hline Soria & $\begin{array}{l}\text { - Carlos de } \\
\text { Santiago } \\
\text { Bartolomé }\end{array}$ & $\begin{array}{l}\text { - César Antón } \\
\text { Merino (1986) }\end{array}$ & $\begin{array}{l}\text { - José Antonio } \\
\text { Villanueva } \\
\text { (hasta 1990) }\end{array}$ & - \\
\hline Tarragona & - Lluis Badía & - Lluis Badía - & - Lluis Badía & $\begin{array}{l}\text { Lluis Badía se integra en CDC a } \\
\text { mediados de los 90'. }\end{array}$ \\
\hline Teruel & $\begin{array}{l}\text { - Miguel } \\
\text { Ángel Eced } \\
\text { Sánchez }\end{array}$ & $\begin{array}{l}\text { - Antonio } \\
\text { Gimeno Lahoz }\end{array}$ & - & $\begin{array}{l}\text { Miguel Ángel Eced Sánchez } \\
\text { desvinculado desde finales de los } \\
\text { 80'. }\end{array}$ \\
\hline Toledo & $\begin{array}{l}\text { - Fernando } \\
\text { Montero }\end{array}$ & $\begin{array}{l}\text { - María } \\
\text { Dolores Calvo }\end{array}$ & $\begin{array}{l}\text { - Agustín } \\
\text { Velasco (1987- }\end{array}$ & - \\
\hline
\end{tabular}

${ }^{14}$ MENÉNDEZ, Miguel Ángel: "Los últimos del CDS”, Interviú, 1994, no 962, Hemeroteca CaixaTarragona.

15 Diario de Navarra, 24 de enero de 2016. Disponible en: http://www.diariodenavarra.es/noticias/navarra/pamplona_comarca/2016/01/24/ahora_ideologia_importa nte_debatir_ideas_391075_1002.html Fecha de consulta: 19 de julio de 2016.

${ }^{16}$ La Rioja, 28 de junio de 2010. Disponible en: http://www.larioja.com/v/20100628/riojalogrono/vocacion-lealtad-ciudadania-20100628.html Fecha de consulta: 19 de julio de 2016. Había sido reelegido en 1994 en el II Congreso Federal del CDS-La Rioja, FERNÁNDEZ FERRERO, Miguel Ángel: Procesos electorales: elecciones autonómicas y municipales en La Rioja 1979-1995, Logroño, Universidad de la Rioja, 1997, p. 205. 


\begin{tabular}{|c|c|c|c|c|}
\hline & $\begin{array}{l}\text { Casado de } \\
\text { Amezúa }\end{array}$ & Cirujano (-) & 1990) & \\
\hline Valencia & $\begin{array}{l}\text { - Emilio } \\
\text { Pujalte }\end{array}$ & $\begin{array}{l}\text { José L. Boado } \\
\text { Martínez } \\
(1983)\end{array}$ & $\begin{array}{l}\text { José L. Boado } \\
\text { Martínez (1990) }\end{array}$ & $\begin{array}{l}\text { José Luis Boado abandonó el } \\
\text { partido hacia } 1991 .\end{array}$ \\
\hline Valladolid & $\begin{array}{l}\text { - Francisco } \\
\text { Rodríguez }\end{array}$ & $\begin{array}{l}\text { - Antonio } \\
\text { Garrosa Resina } \\
(1983)\end{array}$ & $\begin{array}{l}\text { - Antonio } \\
\text { Garrosa Resina }\end{array}$ & $\begin{array}{l}\text { Antonio Garrosa se desvinculó del } \\
\text { partido en } 1993 \text { y abandonó la } \\
\text { actividad política. }\end{array}$ \\
\hline Vizcaya & $\begin{array}{l}\text { - Iñaki } \\
\text { Ansoleaga } \\
\text { Deusto }\end{array}$ & $\begin{array}{l}\text { - Iñaki } \\
\text { Ansoleaga } \\
\text { Deusto }\end{array}$ & $\begin{array}{l}\text { - Iñaki } \\
\text { Ansoleaga } \\
\text { Deusto (1988) } \\
\end{array}$ & $\begin{array}{l}\text { Iñaki Ansoleaga Deusto dimitió en } \\
1988 .\end{array}$ \\
\hline Zamora & $\begin{array}{l}\text { Luis } \\
\text { Rodríguez San } \\
\text { León }\end{array}$ & $\begin{array}{l}\text { - Luis } \\
\text { Rodríguez San } \\
\text { León }\end{array}$ & $\begin{array}{l}\text { - Luis Rodríguez } \\
\text { San León }\end{array}$ & $\begin{array}{l}\text { Luis Rodríguez } \quad \text { San } \text { León } \\
\text { abandona el partido en } 1999 . \\
\text { Funda Centro } \\
\text { Democrático (2013) }\end{array}$ \\
\hline Zaragoza & $\begin{array}{l}\text { - José Luis } \\
\text { Merino } \\
\text { Hernández }\end{array}$ & $\begin{array}{l}\text { - José Luis } \\
\text { Merino } \\
\text { Hernández }\end{array}$ & $\begin{array}{l}\text { - José Luis } \\
\text { Merino } \\
\text { Hernández } \\
\end{array}$ & - \\
\hline
\end{tabular}

Elaboración propia 


\section{Anexo VIII}

\section{Asambleas Constituyentes Federales, Provinciales e Insulares entre 1982 y 1986 con presencia de Adolfo Suárez ${ }^{I}$}

\begin{tabular}{|l|l|}
\hline Provincia/Isla/CC.AA. & Fecha $^{2}$ \\
\hline La Palma & 25 de febrero de $1983^{3}$ \\
\hline Granada & 07 de julio de $1983^{4}$ \\
\hline Madrid & 14 de julio de $1983 ; 25$ de junio de $1984^{5}$ \\
\hline Cantabria & 03 de octubre de $1983^{6}$ \\
\hline Ávila & 19 de noviembre de $1983^{7}$ \\
\hline Zamora & 25 de noviembre de $1983^{8}$ \\
\hline La Coruña & 10 de febrero de 1984 \\
\hline Alicante & 17 de febrero de $1984^{9}$ \\
\hline Albacete & 02 de marzo de 1984 \\
\hline Pontevedra & 26 de mayo de 1984 \\
\hline León & 06 de junio de $1984^{10}$ \\
\hline Toledo & 06 de julio de $1984^{11}$ \\
\hline Canarias & $15-6$ de junio de 1984 \\
\hline Orense & 22 de octubre de 1984 \\
\hline Ciudad Real & 03 de noviembre de 1984 \\
\hline Tarragona & 30 de noviembre de 1984 \\
\hline Málaga & 14 de diciembre de 1984 \\
\hline Cuenca & 25 de enero de 1985 \\
\hline Huesca & 22 de febrero de 1985 \\
\hline Mallorca & 17 de marzo de 1985 \\
\hline Guadalajara & 22 de marzo de 1985 \\
\hline Jaén & Marzo/mayo de $1985^{12}$ \\
\hline Salamanca & 17 de mayo de 1985 \\
\hline Segovia & 18 de mayo de $1985^{13}$ \\
\hline La Rioja & 01 de junio de 1985 \\
\hline Navarra & 01 de junio de 1985 \\
\hline Valladolid & 07 de junio de 1985 \\
\hline Palencia & 08 de junio de 1985 \\
\hline &
\end{tabular}

\footnotetext{
${ }^{1}$ No excluye la asistencia de otros líderes nacionales. Elaboración propia a partir de Documento Carpeta $2 \mathrm{~s} / \mathrm{t}$ : mapa con fecha entre junio y julio de 1984 momento de constitución de la última asamblea en Las Palmas, junio de 1984. Documento Carpeta 1 "Actividades líderes del Comité Nacional (1984-1985)". Carpeta 1 y 2, AJLG, ABC y El País.

${ }^{2}$ Fecha de inauguración/clausura de la Asamblea Provincial o Federal.

${ }^{3}$ En la Asamblea informativa anual del año siguiente acudió José Ramón Caso, 25 de febrero de 1984.

${ }^{4}$ En la Asamblea informativa anual del año siguiente acudió J. R Caso, 26 de octubre de 1984.

${ }^{5}$ En la Asamblea informativa anual del año siguiente acudió J. R Caso, en junio de 1984.

${ }^{6}$ En la Asamblea informativa anual del año siguiente acudió J. R Caso, 02 de diciembre de 1984.

${ }^{7}$ En la Asamblea informativa anual del año siguiente acudió Suárez, en mayo de 1985.

${ }^{8}$ En la Asamblea informativa anual del año siguiente acudió Rodríguez Sahagún, en mayo de 1985.

${ }^{9}$ En la Asamblea informativa anual del año siguiente acudió J. R. Caso, 24 de febrero de 1985.

${ }^{10}$ En la Asamblea informativa anual del año siguiente acudió Rodríguez Sahagún, 22 de junio de 1985.

${ }^{11}$ En la Asamblea informativa anual del año siguiente acudió J. R. Caso 22 de junio de 1985 (Talavera de la Reina).

12 Ideal, 26 de marzo de 2014. Disponible en: http://www.ideal.es/jaen/v/20140326/jaen/presidentelibreta-piturda-20140326.html Fecha de consulta: 25 de mayo de 2015.

${ }^{13}$ Contó con la presencia de 5 miembros del Comité Nacional, una cifra realmente alta, que demuestra la importancia de Segovia para el CDS y la vida política de Suárez: Rafael Calvo Ortega, José Luis González Quirós, Gerardo Harguindey, José Antonio Escudero y J. R. Caso. Por establecer una comparación, en la Asamblea Provincial de Madrid del día 27 de junio el C. Nacional estuvo representado por 6 miembros.
} 
Adolfo Suárez y el Centro Democrático y Social (1982-1991)

\begin{tabular}{|l|l|}
\hline Galicia & 16 de junio de 1985 \\
\hline Cáceres & 21 de junio de 1985 \\
\hline Badajoz & 22 de junio de 1985 \\
\hline Huelva & 28 de junio de 1985 \\
\hline Barcelona & 23 de abril de 1986 \\
\hline Andalucía & 25 de mayo de 1986 \\
\hline
\end{tabular}

Elaboración propia 


\section{Anexo IX}

Titulares de prensa local: Asambleas Constituyentes del CDS con presencia de Suárez.

\begin{tabular}{|c|c|c|c|c|}
\hline Periódico & Titulares & Tema & Ubicación & Fecha \\
\hline \multirow[t]{3}{*}{$\begin{array}{l}\text { Diario de } \\
\text { Navarra }\end{array}$} & $\begin{array}{l}\text { Adolfo Suárez criticó las coaliciones } \\
\text { de partidos como alternativa al PSOE }\end{array}$ & Operación Roca & Interior & $\begin{array}{l}\text { 01 de junio de } \\
1985\end{array}$ \\
\hline & $\begin{array}{l}\text { [Frase destacada en el texto] } \\
\text { Coaliciones }\end{array}$ & Operación Roca & Ídem & Ídem \\
\hline & $\begin{array}{l}\text { [Frase destacada en el texto] Fraude } \\
\text { en la administración }\end{array}$ & PSOE & Ídem & Ídem \\
\hline $\begin{array}{l}\text { El Diario } \\
\text { Montañés } \\
\text { [Cantabria] }\end{array}$ & $\begin{array}{l}\text { Suárez, especialmente preocupado por } \\
\text { el tema militar }\end{array}$ & $23-\mathrm{F}$ & Interior & $\begin{array}{l}\text { 03 de octubre } \\
\text { de } 1983\end{array}$ \\
\hline \multirow[t]{6}{*}{$\begin{array}{l}\text { Diario de } \\
\text { Tarragona }\end{array}$} & $\begin{array}{l}\text { Celebrar nuevas elecciones alternativa } \\
\text { al referéndum }\end{array}$ & OTAN & $\begin{array}{l}\text { Portada } \\
\text { (principal) }\end{array}$ & $\begin{array}{l}01 \text { de } \\
\text { diciembre de } \\
1984\end{array}$ \\
\hline & $\begin{array}{l}\text { "En } 1986 \text { podemos conseguir } 15 \\
\text { escaños en el Congreso"; "Suárez: } \\
\text { "Quiero que me aplaudan menos y } \\
\text { que me voten más"; "Sigue siendo un } \\
\text { centro de atracción". }\end{array}$ & $\begin{array}{l}\text { CDS; Adolfo } \\
\text { Suárez }{ }^{1}\end{array}$ & Interior & Ídem \\
\hline & $\begin{array}{l}\text { [Frase destacada en el texto] "Yo he } \\
\text { sido presidente..." }\end{array}$ & Adolfo Suárez & Ídem & Ídem \\
\hline & $\begin{array}{l}\text { [Frase destacada en el texto] } \\
\text { Referéndum o disolución }\end{array}$ & OTAN & Ídem & Ídem \\
\hline & $\begin{array}{l}\text { [Frase destacada en el texto] } \\
\text { Acercamientos al CDS } \\
\end{array}$ & CDS & Ídem & Ídem \\
\hline & $\begin{array}{l}\text { [Antetítulo] Entrevista con el ex } \\
\text { presidente Adolfo Suárez }\end{array}$ & Adolfo Suárez & Ídem & Ídem \\
\hline \multirow[t]{3}{*}{$\begin{array}{l}\text { Diario de } \\
\text { Teruel }\end{array}$} & $\begin{array}{l}\text { El Duque Adolfo Suárez en nuestra } \\
\text { ciudad }\end{array}$ & Adolfo Suárez & $\begin{array}{l}\text { Portada } \\
\text { (secundaria) }\end{array}$ & $\begin{array}{l}13 \text { de julio de } \\
1985\end{array}$ \\
\hline & $\begin{array}{lll}\text { Las segundas partes pueden } & \text { ser } \\
\text { mejores si aprovechamos } & \text { las } \\
\text { experiencias y errores } & \\
\end{array}$ & Operación Roca & Interior & Ídem \\
\hline & $\begin{array}{l}\text { [Frase destacada en el texto] } \\
\text { Operación de Centro Progresista }\end{array}$ & CDS & Ídem & Ídem \\
\hline \multirow[t]{2}{*}{$\begin{array}{l}\text { El Ideal de } \\
\text { Granada }\end{array}$} & $\begin{array}{l}\text { Creo fundamentalmente en el Estado } \\
\text { de las Autonomías }\end{array}$ & LOAPA & Interior & $\begin{array}{l}08 \text { de julio de } \\
1983\end{array}$ \\
\hline & $\begin{array}{l}\text { [Antetítulo] Adolfo Suárez durante su } \\
\text { estancia en Granada }\end{array}$ & Adolfo Suárez & Ídem & Ídem \\
\hline \multirow{5}{*}{$\begin{array}{l}\text { La Voz de } \\
\text { Galicia [La } \\
\text { Coruña] }\end{array}$} & $\begin{array}{l}\text { Adolfo Suárez anunció en La Coruña } \\
\text { una querella criminal contra Baret }\end{array}$ & Adolfo Suárez & Interior & $\begin{array}{l}\text { 11 de febrero } \\
\text { de } 1984\end{array}$ \\
\hline & [Frase destacada en el texto] Querella & Adolfo Suárez & Ídem & Ídem \\
\hline & $\begin{array}{l}\text { [Frase destacada en el texto] } \\
\text { Reconversión }\end{array}$ & Economía & Ídem & Ídem \\
\hline & $\begin{array}{l}\text { [Frase destacada en el texto] Visita a } \\
\text { Cesura }\end{array}$ & Adolfo Suárez & Ídem & Ídem \\
\hline & $\begin{array}{l}\text { [Antetítulo] Arán Trillo presidente } \\
\text { provincial }\end{array}$ & $\mathrm{CDS}$ & Ídem & Ídem \\
\hline \multirow[t]{2}{*}{$\begin{array}{l}\text { La Voz de } \\
\text { Galicia } \\
\text { [Pontevedra] }\end{array}$} & $\begin{array}{l}\text { Suárez dice que el CDS se "volcará" } \\
\text { en las elecciones autonómicas }\end{array}$ & $\mathrm{CDS}$ & Interior & $\begin{array}{l}27 \text { de mayo de } \\
1984\end{array}$ \\
\hline & $\begin{array}{l}\text { [Antetítulo] Descarta cualquier } \\
\text { acuerdo con el Partido Reformista }\end{array}$ & Operación Roca & Ídem & Ídem \\
\hline La Voz de & Adolfo Suárez insistió en que el CDS & Operación Roca & Interior & 04 de mayo de \\
\hline
\end{tabular}

\footnotetext{
${ }^{1}$ La categoría Adolfo Suárez se refiere a "personaje político" y/o "ex presidente".
} 


\begin{tabular}{|c|c|c|c|c|}
\hline \multirow{3}{*}{$\begin{array}{l}\text { Galicia } \\
\text { [Lugo] }\end{array}$} & irá solo a las elecciones & & & 1985 \\
\hline & $\begin{array}{l}\text { [Antetítulo] Inició ayer en Lugo su } \\
\text { visita política a Galicia }\end{array}$ & CDS & Ídem & Ídem \\
\hline & $\begin{array}{l}\text { [Frase destacada en el texto] } \\
\text { Alternativa de poder; no hay lugar al } \\
\text { desaliento; elección de la ejecutiva; } \\
\text { visita a la provincia coruñesa }\end{array}$ & CDS & Ídem & $\begin{array}{l}22 \text { de } \\
\text { septiembre de } \\
1984\end{array}$ \\
\hline $\begin{array}{l}\text { La Voz de } \\
\text { Galicia } \\
\text { [Orense] }\end{array}$ & $\begin{array}{l}\text { Adolfo Suárez dice en Orense que ni } \\
\text { pacta ni teme a Franqueira }\end{array}$ & Operación Roca & Interior & Ídem \\
\hline \multirow{7}{*}{$\begin{array}{l}\text { El Norte de } \\
\text { Castilla } \\
\text { [Valladolid] }\end{array}$} & El CDS ya puede sobrevivir sin mí & CDS & Interior & $\begin{array}{l}08 \text { de junio de } \\
1985\end{array}$ \\
\hline & $\begin{array}{l}\text { [Frase destacada en el texto] "Mil } \\
\text { militantes expulsados"; "No nos gusta } \\
\text { la OTAN"; "No debe haber indultos } \\
\text { sobre el 23-f". }\end{array}$ & $\begin{array}{l}\text { CDS; OTAN; } \\
23-\mathrm{F}\end{array}$ & Ídem & Ídem \\
\hline & $\begin{array}{l}\text { Garrosa Resina, nuevo presidente } \\
\text { provincial del CDS }\end{array}$ & CDS & Interior & Ídem \\
\hline & $\begin{array}{l}\text { El presidente nacional clausuró ayer la } \\
\text { asamblea provincial, de la que salió su } \\
\text { nueva ejecutiva }\end{array}$ & CDS & Antetítulo & Ídem \\
\hline & $\begin{array}{l}\text { Palencia: "Suárez dice que prestará } \\
\text { especial atención a Castilla y León, } \\
\text { tras la encuesta de la Junta" }\end{array}$ & CDS & Ídem & $\begin{array}{l}09 \text { de junio de } \\
1986\end{array}$ \\
\hline & $\begin{array}{l}\text { [Frase destacada en el texto] Escasa } \\
\text { asistencia }\end{array}$ & CDS & Ídem & Ídem \\
\hline & $\begin{array}{l}\text { [Antetítulo] Cerca del } 50 \text { por ciento de } \\
\text { los delegados ausentes del Congreso } \\
\text { Provincial }\end{array}$ & CDS & Ídem & Ídem \\
\hline \multirow[t]{5}{*}{$\begin{array}{l}\text { Segre } \\
\text { [Lérida] }\end{array}$} & $\begin{array}{l}\text { Suárez admite no caer bien a los } \\
\text { militares }\end{array}$ & $23-\mathrm{F}$ & $\begin{array}{l}\begin{array}{l}\text { Portada } \\
\text { (secundaria) }\end{array} \\
\end{array}$ & $\begin{array}{l}06 \text { de abril de } \\
1984\end{array}$ \\
\hline & $\begin{array}{l}\text { Suárez: "reto a cualquier militar a que } \\
\text { pruebe haber ejercido presión sobre } \\
\text { mí" }\end{array}$ & $23-\mathrm{F}$ & Interior & Ídem \\
\hline & $\begin{array}{l}\text { [Frase destacada en el texto] No } \\
\text { conozco el Partido Reformista }\end{array}$ & Operación Roca & Ídem & Ídem \\
\hline & $\begin{array}{l}\text { Homenaje a los parlamentarios del } \\
\text { CDS }\end{array}$ & CDS & Interior & Ídem \\
\hline & $\begin{array}{l}\text { [Antetítulo]El ex presidente participó } \\
\text { en el homenaje a los parlamentarios } \\
\text { del CDS }\end{array}$ & CDS & Ídem & Ídem \\
\hline \multirow[t]{6}{*}{$\begin{array}{l}\text { Diario de } \\
\text { Mallorca }\end{array}$} & $\begin{array}{l}\text { Suárez descarta en Palma una alianza } \\
\text { con Roca }\end{array}$ & Operación Roca & $\begin{array}{l}\text { Portada } \\
\text { (secundaria) }\end{array}$ & $\begin{array}{l}16 \text { de marzo de } \\
1985\end{array}$ \\
\hline & $\begin{array}{l}\text { Suárez resaltó ayer las diferencias } \\
\text { entre el CDS y el Partido Reformista } \\
\text { de Miquel Roca }\end{array}$ & Operación Roca & Interior & Ídem \\
\hline & $\begin{array}{l}\text { [Antetítulo] Un importante personaje } \\
\text { político. El ex jefe de Gobierno } \\
\text { presidió ayer en Palma varios actos } \\
\text { del Centro Democrático y Social }\end{array}$ & CDS & Ídem & Ídem \\
\hline & $\begin{array}{l}\text { [Frase destacada en el texto] Volvió a } \\
\text { repetir su tesis sobre la necesidad de } \\
\text { un "pacto de Estado" }\end{array}$ & Pactos & Ídem & Ídem \\
\hline & $\begin{array}{l}\text { Xisco Quetglás elegido presidente del } \\
\text { CDS en Mallorca }\end{array}$ & CDS & Interior & Ídem \\
\hline & $\begin{array}{l}\text { [Frase destacada en el texto] Exceso } \\
\text { de verbalimos }\end{array}$ & - & Ídem & Ídem \\
\hline
\end{tabular}




\begin{tabular}{|c|c|c|c|c|}
\hline $\begin{array}{l}\text { Información } \\
\text { [Alicante] }\end{array}$ & $\begin{array}{l}\text { Adolfo Suárez propone unos nuevos } \\
\text { "pactos de la Moncloa" }\end{array}$ & Economía & Portada & $\begin{array}{l}18 \text { de febrero } \\
\text { de } 1984\end{array}$ \\
\hline & $\begin{array}{l}\text { Adolfo Suárez quiere una reedición de } \\
\text { los pactos de la Moncloa }\end{array}$ & Pactos & Interior & Ídem \\
\hline & $\begin{array}{l}\text { [Antetítulo] Ayer asistió a la } \\
\text { Asamblea Constituyente del CDS }\end{array}$ & CDS & Ídem & Ídem \\
\hline \multirow[t]{12}{*}{$\begin{array}{l}\text { Diario de } \\
\text { Avisos } \\
\text { [Tenerife] }\end{array}$} & $\begin{array}{l}\text { El CDS no urgirá al Gobierno un } \\
\text { referéndum sobre la OTAN }\end{array}$ & OTAN & Interior & $\begin{array}{l}03 \text { de } \\
\text { diciembre de } \\
1983\end{array}$ \\
\hline & La prensa no es toreable & Prensa & Interior & Ídem \\
\hline & $\begin{array}{l}\text { [Antetítulo] Adolfo Suárez a Diario de } \\
\text { Avisos }\end{array}$ & Adolfo Suárez & Ídem & Ídem \\
\hline & $\begin{array}{l}\text { No expropié RUMASA porque no se } \\
\text { daban las condiciones para ello }\end{array}$ & RUMASA & Portada & Ídem \\
\hline & $\begin{array}{l}\text { [Antetítulo] Adolfo Suárez el político } \\
\text { que nunca muere, a Diario de Avisos }\end{array}$ & Adolfo Suárez & Ídem & Ídem \\
\hline & $\begin{array}{l}\text { Si la historia se repite no volvería a } \\
\text { crear un partido como UCD }\end{array}$ & Operación Roca & Interior & Ídem \\
\hline & $\begin{array}{l}\text { [Frase destacada en el texto] El CDS } \\
\text { está para hacer más moderada a la } \\
\text { derecha y más tolerable a la izquierda }\end{array}$ & - & Ídem & Ídem \\
\hline & $\begin{array}{l}\text { [Frase destacada en el texto] } \\
\text { RUMASA expropiación }\end{array}$ & RUMASA & Ídem & Ídem \\
\hline & $\begin{array}{l}\text { [Frase destacada en el texto] } \\
\text { Especificidades canarias }\end{array}$ & - & Ídem & Ídem \\
\hline & $\begin{array}{l}\text { [Frase destacada en el texto] Hogar } \\
\text { dulce hogar }\end{array}$ & - & Ídem & Ídem \\
\hline & $\begin{array}{l}\text { [Frase destacada en el texto] Suárez y } \\
\text { los militares }\end{array}$ & $23-\mathrm{F}$ & Ídem & Ídem \\
\hline & $\begin{array}{l}\text { Roca ha optado por crear } \\
\text { regionalismos incluso donde no } \\
\text { existen }\end{array}$ & Operación Roca & Interior & $\begin{array}{l}13 \text { de junio de } \\
1984\end{array}$ \\
\hline \multirow[t]{5}{*}{$\begin{array}{l}\text { El Periódico } \\
\text { de Huesca }\end{array}$} & $\begin{array}{l}\text { Suárez presidió en Huesca la I } \\
\text { Asamblea Provincial del partido }\end{array}$ & CDS & Portada & $\begin{array}{l}23 \text { de febrero } \\
\text { de } 1985\end{array}$ \\
\hline & $\begin{array}{l}\text { [Antetítulo] El líder centrista se } \\
\text { mostró optimista con las perspectivas } \\
\text { electorales de su partido }\end{array}$ & CDS & Ídem & Ídem \\
\hline & $\begin{array}{l}\text { Adolfo Suárez presidió ayer en } \\
\text { Huesca la I Asamblea Provincial de su } \\
\text { partido }\end{array}$ & CDS & Interior & Ídem \\
\hline & $\begin{array}{l}\text { [Frase destacada en el texto] No hay } \\
\text { ningún tipo de "agujero"; "El 23-F"; }\end{array}$ & UCD; 23-F. & Ídem & Ídem \\
\hline & $\begin{array}{l}\text { [Antetítulo] "El 23-F es una fecha a } \\
\text { olvidar y, paradójicamente, a tener } \\
\text { presente", dijo el presidente del CDS }\end{array}$ & $23-\mathrm{F}$ & Ídem & Ídem \\
\hline \multirow[t]{3}{*}{$A B C$ Sevilla } & $\begin{array}{l}\text { Delgado de Jesús, elegido presidente } \\
\text { de la Federación Andaluza del CDS }\end{array}$ & CDS & Interior & $\begin{array}{l}26 \text { de mayo de } \\
1986\end{array}$ \\
\hline & $\begin{array}{l}\text { Suárez: “Algunos pagarían por } \\
\text { hacerme callar" }\end{array}$ & Adolfo Suárez & Interior & Ídem \\
\hline & $\begin{array}{l}\text { [Frase destacada en el texto] } \\
\text { Asamblea Provincial }\end{array}$ & CDS & Ídem & Ídem \\
\hline
\end{tabular}

Elaboración propia 
Anexo X

Actividad parlamentaria del CDS durante la II Legislatura ${ }^{1}$

\section{Grupo parlamentario del $\operatorname{CDS}^{2}$}

\begin{tabular}{|c|c|c|c|}
\hline Nombre & Grupo & Militancia política previa & Circunscripción \\
\hline Adolfo Suárez González & Mixto & FET-JONS; UDPE; UCD & Madrid \\
\hline Agustín Rodríguez Sahagún & Mixto & UCD & Ávila \\
\hline
\end{tabular}

Elaboración propia

Miembros del CDS en los Órganos de Gobierno del Congreso de los Diputados II Legislatura

- Vocal de la Diputación Permanente desde el 12/12/1982 al 15/07/1986

- Portavoz Titular de la Junta de Portavoces desde el 23/11/1982 al 23/04/1986

- Vocal de la Comisión de Economía, Comercio y Hacienda desde el 02/12/1982 al 23/04/1986

- Vocal de la Comisión de Presupuestos desde el 02/12/1982 al 23/04/1986

- Vocal de la Comisión de Control Parlamentario sobre RTVE desde el 19/10/1983 al 23/04/1986

-Vocal de la Comisión de Estudio de la fecundación "in vitro" e inseminación artificial desde el 29/05/1985 al 10/04/1986

- Vocal de la Comisión Especial de Estudio situación de la Agencia "EFE" desde el 11/12/1985 al 23/04/1986

\begin{tabular}{|c|}
\hline Adolfo Suárez González \\
\hline - Vocal de la Comisión de Asuntos Exteriores desde el 02/12/1982 al 23/04/1986 \\
\hline
\end{tabular}

Iniciativas Parlamentarias de los miembros del CDS dentro del G. Mixto durante la II Legislatura desglosadas por diputados 3

\begin{tabular}{|l|l|l|l|l|}
\hline & $\begin{array}{l}\text { Preguntas } \\
\text { Orales en } \\
\text { el Pleno }\end{array}$ & $\begin{array}{l}\text { Preguntas al } \\
\text { Gobierno con } \\
\text { respuesta escrita }\end{array}$ & $\begin{array}{l}\text { Preguntas } \\
\text { al Director } \\
\text { de RTVE }\end{array}$ & $\begin{array}{l}\text { Ponencias en Proposiciones } \\
\text { de Ley, Proyectos de Ley, } \\
\text { Reales Decretos y Otros }\end{array}$ \\
\hline $\begin{array}{l}\text { RODRÍGUEZ } \\
\text { SAHAGÚN, Agustín }\end{array}$ & 7 & 20 & 20 & 27 \\
\hline $\begin{array}{l}\text { SUÁREZ } \\
\text { GONZÁLEZ, Adolfo }\end{array}$ & - & $1^{4}$ & - & - \\
\hline
\end{tabular}

\footnotetext{
${ }^{1}$ Elaboración propia a partir de GONZALO, Manuel y BLANCO, Ricardo: Memoria de la II Legislatura 1982-1986), Madrid, Congreso de los Diputados, 1987.

${ }^{2}$ A lo largo del año 1985, se vincula al CDS, Manuel Gallent en el Grupo Mixto desde el 28 de diciembre de 1984, procedente de la Coalición Popular.

${ }^{3}$ No hubo "Preguntas orales en Comisión", ni "Solicitudes de Informes".

${ }^{4}$ Referente a: "Infraestructura portuaria del archipiélago canario".
} 


\section{Anexo XI}

Las elecciones autonómicas de Galicia como ejemplo de la actividad del partido en el período 19821986

Candidatos del CDS a las elecciones autonómicas de Galicia ${ }^{1}$

\begin{tabular}{|c|c|}
\hline Categorías & Porcentajes \\
\hline \multirow[t]{8}{*}{ Año de afiliación } & 1982: $10---11.11 \%$ \\
\hline & 1983: $21----23,33 \%$ \\
\hline & 1984: 22 ---- 24,44\% \\
\hline & 1985: 37 --- 41,11\% \\
\hline & Cabezas de lista: \\
\hline & 1982: $25 \%$ \\
\hline & $1983: 25 \%$ \\
\hline & 1985: $50 \%$ \\
\hline Hombres/Mujeres & $75 \% / 25 \%$ \\
\hline \multirow{2}{*}{$\begin{array}{l}\text { Con militancia política previa /sin militancia } \\
\text { política previa }\end{array}$} & $30 \% / 70 \%$ \\
\hline & $\begin{array}{l}21: \mathrm{UCD}-77,77 \% \\
2: \mathrm{AP}-7,40 \% \\
\text { 2: PCE - 7,40\% } \\
\text { 1: PSOE - 3,70\% } \\
1: \text { UGT }-3,70 \%\end{array}$ \\
\hline Profesiones & $\begin{array}{l}\text { Titulados superiores: } 17,28 \% \\
\text { Industriales: } 25,92 \% \\
\text { Funcionarios: } 17,28 \% \\
\text { Empleados: } 23,45 \% \\
\text { Obreros: } 11,11 \% \\
\text { Estudiantes: } 2,47 \% \\
\text { Otros: } 2,47\end{array}$ \\
\hline
\end{tabular}

Elaboración propia

Actividad líderes nacionales del CDS en Galicia (1984-1985) ${ }^{2}$

\begin{tabular}{|l|c|c|}
\hline & $\begin{array}{c}\text { Implantación } \\
\mathbf{1 9 8 4} \text { (Marzo)- 1985 (Sept.) })^{\mathbf{3}}\end{array}$ & $\begin{array}{c}\text { Pre y Campaña } \\
\mathbf{1 9 8 5} \text { (Oct.-Nov.) }\end{array}$ \\
\hline Adolfo Suárez & 6 & 25 \\
\hline J. R. Caso & 12 & 7 \\
\hline A. Rodríguez Sahagún & 5 & 6 \\
\hline F. Castedo & 14 & 6 \\
\hline A. Rebollo & - & 2 \\
\hline R. Calvo Ortega & - & 1 \\
\hline M. Jiménez Parga & - & 5 \\
\hline L. Morso & - & 18 \\
\hline F. Ysart & - & 2 \\
\hline G. Harguindey & 2 & 5 \\
\hline
\end{tabular}

${ }^{1}$ OICDS, 0, noviembre 1985; AGP.

2 AGP. Cabe destacar que Adolfo Suárez estuvo presente en las cuatro asambleas provinciales constituyentes y en el Congreso Federal.

${ }^{3}$ Viajes a Galicia (de uno, dos o tres días de duración).

${ }^{4}$ Días de campaña en Galicia. 
Adolfo Suárez y el Centro Democrático y Social (1982-1991)

\begin{tabular}{|l|c|c|}
\hline J. M. Viana & - & 2 \\
\hline E. Punset & - & 7 \\
\hline F. Mayor Zarag. & - & 2 \\
\hline R. Morodo & - & 7 \\
\hline I. Camuñas & - & 6 \\
\hline
\end{tabular}

Elaboración propia 


\section{Anexo XII \\ Estimaciones elecciones generales de $1986^{1}$ \\ Clasificación general de las circunscripciones}

\begin{tabular}{|c|c|}
\hline \multicolumn{2}{|c|}{$\begin{array}{l}\text { A partir del análisis del coste de votos por escaño -en las distintas circunscripciones- y teniendo en } \\
\text { cuenta los resultados obtenidos por CDS, UCD y PSOE en } 1982 \text { se clasificaron en cuatro categorías las } \\
\text { circunscripciones electorales en función de las posibilidades de obtener un escaño }\end{array}$} \\
\hline Categoría & Provincias \\
\hline $\mathrm{C}$ & GERONA, GUIPÚZCOA, VIZCAYA \\
\hline $\mathrm{B}$ & $\begin{array}{l}\text { ALAVA, ALBACETE, ALMERÍA, BADAJOZ, BURGOS, CANTABRIA, CASTELLÓN, } \\
\text { CEUTA, CIUDAD-REAL, CORUÑA, CUENCA, GRANADA, GUADALAJARA, } \\
\text { HUELVA, JAÉN, LA RIOJA, LUGO, LÉRIDA, MÁLAGA, MELILLA, MURCIA, } \\
\text { NAVARRA ORENSE, PALENCIA, PONTEVEDRA, SALAMANCA, SEGOVIA, } \\
\text { TARRAGONA, TERUEL, TOLEDO }\end{array}$ \\
\hline $\mathrm{B} / \mathrm{A}$ & $\begin{array}{l}\text { ALICANTE, BALEARES, CÁDIZ, CÁCERES, CÓRDOBA, HUESCA, LEÓN, SEVILLA, } \\
\text { TENERIFE, VALLADOLID, ZAMORA, ZARAGOZA }\end{array}$ \\
\hline A & STURIAS, ÁVILA, BARCELONA, LAS PALMAS, MADRID, VALENCIA \\
\hline
\end{tabular}

Elaboración propia

Clasificación según la estimación de escaños y de actitudes políticas

\begin{tabular}{|c|c|c|}
\hline Categoría & Clasificación ideológica & Provincias \\
\hline \multirow[t]{3}{*}{ A } & Conservadoras & LAS PALMAS, ÁVILA \\
\hline & Progresistas y nacionalistas & BARCELONA \\
\hline & Izquierdas & ASTURIAS, MADRID, VALENCIA \\
\hline \multirow[t]{3}{*}{$\mathrm{B} / \mathrm{A}$} & Conservadoras & $\begin{array}{l}\text { VALLADOLID, TENERIFE, ZAMORA, HUESCA, } \\
\text { LEÓN, BALEARES, CÁCERES }\end{array}$ \\
\hline & Progresistas y nacionalistas & ALICANTE \\
\hline & Izquierdas & ZARAGOZA, CÓRDOBA, CÁDIZ, SEVILLA \\
\hline \multirow[t]{3}{*}{ B } & Conservadoras & $\begin{array}{l}\text { BURGOS, CANTABRIA, CIUDAD-REAL, CORUÑA, } \\
\text { CUENCA, GUADALAJARA, LA RIOJA, LUGO, } \\
\text { NAVARRA ORENSE, PALENCIA, PONTEVEDRA, } \\
\text { SALAMANCA, SEGOVIA, TARRAGONA, TERUEL, } \\
\text { TOLEDO }\end{array}$ \\
\hline & Progresistas y nacionalistas & $\begin{array}{lll}\text { ALAVA, CASTELLÓN, } & \text { ALMERÍA, LÉRIDA, } \\
\text { BADAJOZ, CIUDAD REAL } & & \\
\end{array}$ \\
\hline & Izquierdas & $\begin{array}{l}\text { ALBACETE , MURCIA, MÁLAGA, GRANADA, } \\
\text { HUELVA, JAÉN }\end{array}$ \\
\hline \multirow[t]{3}{*}{$\mathrm{C}$} & Conservadoras & - \\
\hline & Progresistas y nacionalistas & GUIPÚZCOA, VIZCAYA, GERONA \\
\hline & Izquierdas & - \\
\hline
\end{tabular}

Elaboración propia

Estimación de escaños según la actitud política

\begin{tabular}{|l|l|l|}
\hline Ideología & Escaños posibles & Provincias \\
\hline Conservadoras & 9 & $\begin{array}{l}\text { Ávila, Cuenca, Guadalajara, Palencia, Segovia, Soria, Huesca, } \\
\text { Teruel, Burgos, Rioja, Salamanca, Zamora, Cantabria, Cáceres, } \\
\text { León, Lugo, Orense, Navarra, Toledo, Valladolid, Baleares, }\end{array}$ \\
\hline
\end{tabular}

\footnotetext{
${ }^{1}$ Dirección de Organización, s.t., "Estimación de la actitud política", "Estimación de comparación de escalas", Estimación de la conversión del \% de votos totales conseguidos en España a escala a nivel nacional", "Estimación del \% de votos por el que se obtiene un escaño con una probabilidad del 92\%", s.f., Carpeta 3, $A G P$.
} 


\begin{tabular}{|l|l|l|}
\hline & & Tenerife, Las Palmas, Pontevedra, Coruña \\
\hline Progresistas & 1 & Almería, Castellón, Ciudad Real, Badajoz, Alicante, \\
\hline Nacionalistas & 1 & $\begin{array}{l}\text { Lérida, Álava, Gerona, Tarragona, Vizcaya, Barcelona, } \\
\text { Guipúzcoa }\end{array}$ \\
\hline Izquierdas & 8 & $\begin{array}{l}\text { Albacete, Huelva, Jaén, Córdoba, Granada, Zaragoza, Murcia, } \\
\text { Asturias, Cádiz, Málaga, Sevilla, Valencia, Madrid }\end{array}$ \\
\hline
\end{tabular}

Elaboración propia

\section{Cuadro-resumen}

\begin{tabular}{|l|l|l|l|l|l|l|}
\hline Escaños & Circunscripciones & Conservadores & Progresistas & Izquierdas & Coste \% & Margen \\
\hline 1 & - & - & - & - & 33 & \\
\hline 3 & 8 & $\begin{array}{l}\text { Ávila, Cuenca, } \\
\text { Guadalajara, } \\
\text { Palencia, } \\
\text { Segovia, Soria, } \\
\text { Huesca, Teruel }\end{array}$ & - & - & 19 & $1 / 2$ \\
\hline 4 & 6 & $\begin{array}{l}\text { Burgos, Rioja, } \\
\text { Salamanca, } \\
\text { Zamora }\end{array}$ & Lérida & Albacete & 16 & $0 / 1$ \\
\hline 5 & 15 & $\begin{array}{l}\text { Cantabria, } \\
\text { Cáceres, León, } \\
\text { Lugo, Orense, } \\
\text { Navarra, } \\
\text { Toledo, } \\
\text { Valladolid }\end{array}$ & $\begin{array}{l}\text { Almería, } \\
\text { Castellón, } \\
\text { Ciudad Real, } \\
\text { Álava, } \\
\text { Gerona, } \\
\text { Tarragona }\end{array}$ & Huelva & 13 & $0 / 3$ \\
\hline 6 & 4 & $\begin{array}{l}\text { Baleares, } \\
\text { Tenerife }\end{array}$ & $\begin{array}{l}\text { Badajoz } \\
\text { Laén }\end{array}$ & Jaén & 11 & $1 / 4$ \\
\hline 7 & 4 & Las Palmas & Guipúzcoa & $\begin{array}{l}\text { Córdoba, } \\
\text { Granada }\end{array}$ & 10 & $1 / 3$ \\
\hline 8 & 3 & Pontevedra & - & $\begin{array}{l}\text { Zaragoza, } \\
\text { Murcia }\end{array}$ & 9 & $2 / 3$ \\
\hline 9 & 4 & Coruña & - & $\begin{array}{l}\text { Asturias, } \\
\text { Cádiz, } \\
\text { Málaga }\end{array}$ & 8 & $2 / 4$ \\
\hline 10 & 2 & - & - & 7,5 & $0 / 2$ \\
\hline 12 & 1 & 1 & - & - & Alicante, \\
Vizcaya & - & Sevilla & 6,7 & $1 / 1$ \\
\hline 33 & 2 & - & Barcelona & Madrid & 2,6 & $1 / 1$ \\
\hline & & - & & $5 / 7$ \\
\hline
\end{tabular}

Elaboración propia

\section{Escaños obtenidos}

\begin{tabular}{|l|l|l|l|}
\hline Categoría & Escaños & Provincias & \\
\hline A & 11 & $\begin{array}{l}\text { ASTURIAS, ÁVILA, BARCELONA, VALENCIA, MADRID (5), LAS } \\
\text { PALMAS (2) }\end{array}$ \\
\hline B/A & 4 & VALLADOLID, ZARAGOZA, ALICANTE, TENERIFE & \\
\hline B & 4 & CORUÑA, PONTEVEDRA, SALAMANCA, SEGOVIA & \\
\hline C & - & - & \\
\hline
\end{tabular}

Elaboración propia 
Anexo XIII

Análisis de voto de las elecciones generales de 1986 por Comunidades Autónomas

\begin{tabular}{|c|c|c|c|c|}
\hline & $\begin{array}{l}\begin{array}{l}\text { Resultados } \\
\text { diputados }\left(\mathbf{n}^{\circ}\right)\end{array} \\
\end{array}$ & Objetivos \% & $\begin{array}{l}\text { Aumento 1982- } \\
86 \text { ' en \% }\end{array}$ & Otros \\
\hline Andalucía & 5,61 & 7 & 318,4 & $\begin{array}{l}\text { El CDS se quedó a } 9.000 \text { votos de } \\
\text { un escaño en Almería y } 15.000 \text { en } \\
\text { Cádiz }\end{array}$ \\
\hline Aragón & 11,2 (1 por Zaragoza) & 10 & 138,2 & - \\
\hline Asturias & $13,20(1)$ & - & 185,3 & $\begin{array}{l}\text { Implantación fuerte en Oviedo, } \\
\text { Avilés y Gijón }\end{array}$ \\
\hline Baleares & 11,33 & 10 & 99,7 & A 350 votos de un escaño \\
\hline Canarias & $\begin{array}{l}16,89 \text { ( } 1 \text { por Tenerife } y \\
2 \text { por Las Palmas) }\end{array}$ & 15 & 249,7 & $\begin{array}{l}\text { Un escaño más de los previstos en } \\
\text { Las Palmas }\end{array}$ \\
\hline Cantabria & 12,95 & 10 & 143,7 & A 5.300 votos de un escaño \\
\hline $\begin{array}{ll}\text { Castilla } & \text { y } \\
\text { León } & \end{array}$ & $\begin{array}{l}\text { 17,48 (1 por Segovia, } \\
\text { Ávila, Salamanca y } \\
\text { Valladolid) }\end{array}$ & 12 & 208 & $\begin{array}{l}\text { Primera fuerza política en Ávila } \\
\text { donde se han conseguido tres } \\
\text { senadores }\end{array}$ \\
\hline $\begin{array}{l}\text { Castilla-La } \\
\text { Mancha }\end{array}$ & 9,73 & -1 & 360,5 & - \\
\hline Cataluña & 4,12 (1 Barcelona) & - & 88,25 & $\begin{array}{l}\text { Supera en Barcelona a PSUC y } \\
\text { ERC }\end{array}$ \\
\hline Extremadura & 8,06 & 7 & 407,3 & $\begin{array}{l}\text { La CC.AA. donde más se creció en } \\
\text { relación a } 1982\end{array}$ \\
\hline Galicia & $\begin{array}{l}8,57 \text { (1 por Pontevedra } \\
\text { y La Coruña) }\end{array}$ & 9 & 250,597 & $\begin{array}{l}\text { La moral de derrota en CG y sus } \\
\text { cuantiosas deudas electorales } \\
\text { posibilita un rápido crecimiento en } \\
\text { la estructura municipal del partido }\end{array}$ \\
\hline Madrid & $14,09(5)$ & 10 & 346,1 & $\begin{array}{l}\text { El PSOE sufrió un retroceso del } \\
26,9 \% \text { (388.400). "Especialmente } \\
\text { significativo teniendo en cuenta que } \\
\text { es la circunscripción donde ha } \\
\text { concurrido Felipe González. Si esta } \\
\text { tasa de desgaste hubiera sido la } \\
\text { media nacional, el PSOE sólo } \\
\text { habría conseguido } 7.400 .000 \text { votos }\end{array}$ \\
\hline Murcia & 8,34 & 7 & 346,1 & $\begin{array}{l}\text { Con un } 9,8 \% \text { se hubiera conseguido } \\
\text { un escaño }\end{array}$ \\
\hline Navarra & 9,54 & - & 108,5 & $\begin{array}{l}\text { Con } 12.000 \text { votos más se hubiera } \\
\text { conseguido escaño }\end{array}$ \\
\hline País Vasco & 9,54 & - & 146,9 & $\begin{array}{l}\text { Consolidar presencia municipal en } \\
\text { Bilbao y Vitoria. Se relaciona con } \\
\text { la crisis interna del PNV }\end{array}$ \\
\hline La Rioja & 10,07 & 10 & 159,9 & - \\
\hline $\begin{array}{l}\text { C. } \\
\text { Valenciana }\end{array}$ & $\begin{array}{l}8,78(1 \text { por Valencia y } \\
\text { Alicante })\end{array}$ & - & 228,3 & $\begin{array}{l}\text { Muestra con claridad el trasvase de } \\
\text { votos del PSOE al CDS }\end{array}$ \\
\hline
\end{tabular}

Elaboración propia a partir de Boletín del CDS, 2, julio de 1986.

\footnotetext{
${ }^{1}$ Se alude a que se han conseguido los objetivos del plan.
} 


\section{Anexo XIV}

\section{Miembros del CDS en los Órganos de Gobierno del Congreso de los Diputados ${ }^{I}$}

\begin{tabular}{|c|c|c|}
\hline Órgano & Nombre & Cargo \\
\hline Mesa de la Cámara & José Ramón Caso García & ${\text { Vicepresidente } 4^{\mathbf{o}}}$ \\
\hline
\end{tabular}

\begin{tabular}{|c|c|c|c|}
\hline \multicolumn{2}{|c|}{ Órgano } & Nombre & Fecha de alta y baja \\
\hline \multicolumn{2}{|c|}{ Junta de Portavoces } & & \\
\hline \multicolumn{2}{|c|}{ Titulares } & Agustín Rodríguez Sahagún & $21-07-1986 / 30-06-1989$ \\
\cline { 2 - 4 } & & León Buil Giral & $30-06-1989 / 21-11-1989$ \\
\hline & Suplentes & León Buil Giral & $21-07-1986 / 30-06-1989$ \\
\hline
\end{tabular}

\begin{tabular}{|c|c|c|}
\hline Órgano & Nombre & Fecha de alta y baja ${ }^{2}$ \\
\hline \multicolumn{3}{|l|}{ Diputación Permanente } \\
\hline \multirow[t]{6}{*}{ Titulares } & Agustín Rodríguez Sahagún & $28-07-1986 / 21-11-1989$ \\
\hline & Adolfo Suárez González & 28-07-1986/21-11-1989 \\
\hline & José Ramón Caso & 27-04-1988/21-11-1989 \\
\hline & Modesto Fraile Poujade & 07-02-1989/01-09-1989 \\
\hline & Ramón Tamames Gómez & 07-02-1989/01-09-1989 \\
\hline & Joaquín Abril Martorell & \\
\hline & León Buil Giral & 28-07-1986/01-09-1989 \\
\hline & José Ramón Caso García & $28-07-1986 / 27-04-1988$ \\
\hline & $\begin{array}{c}\text { Alejandro Rebollo Álvarez- } \\
\text { Amandi }\end{array}$ & 27-04-1988/21-11-1989 \\
\hline & Carlos Revilla Rodríguez & 01-09-1989/21-11-1989 \\
\hline
\end{tabular}

\begin{tabular}{|c|c|c|}
\hline Órgano & Nombre & Fecha de alta y baja \\
\hline \multicolumn{3}{|l|}{ Diputación Permanente } \\
\hline Titulares & Agustín Rodríguez Sahagún & 28-07-1986/21-11-1989 \\
\hline & Adolfo Suárez González & $28-07-1986 / 21-11-1989$ \\
\hline & José Ramón Caso & 27-04-1988/21-11-1989 \\
\hline & Modesto Fraile Poujade & 07-02-1989/01-09-1989 \\
\hline & Ramón Tamames Gómez & 07-02-1989/01-09-1989 \\
\hline \multirow[t]{5}{*}{\begin{tabular}{l|r} 
& Suplentes \\
\cline { 2 - 2 }
\end{tabular}} & Joaquín Abril Martorell & \\
\hline & León Buil Giral & 28-07-1986/01-09-1989 \\
\hline & José Ramón Caso García & $28-07-1986 / 27-04-1988$ \\
\hline & $\begin{array}{c}\text { Alejandro Rebollo Álvarez- } \\
\text { Amandi }\end{array}$ & 27-04-1988/21-11-1989 \\
\hline & Carlos Revilla Rodríguez & 01-09-1989/21-11-1989 \\
\hline
\end{tabular}

\begin{tabular}{|c|c|}
\hline \multicolumn{2}{|c|}{ Comisión de Agricultura, Ganadería y Pesca } \\
\hline Juan Castaño Casanueva & - \\
\hline Lorenzo Díaz Aguilar & - \\
\hline Francisco Moldes Fontán & $29-09-1987 / 14-03-1989$ \\
\hline Ramón Tamames Gómez & $31-03-1989 / \ldots$ \\
\hline
\end{tabular}

\section{Comisión de Asuntos Exteriores}

\footnotetext{
${ }^{1}$ Basado en GONZALO, Manuel y PAESA, María (eds.): Memoria de la III Legislatura (1986-1989), Congreso de los Diputados, Madrid, 1990, pp. 61-111.

${ }^{2}$ En aquellos casos en que el Diputado no comenzó la Legislatura en el GP CDS se ha tenido en cuenta la fecha de alta en dicho grupo.
} 


\begin{tabular}{|c|c|}
\hline Joaquín Abril Martorell & - \\
\hline Agustín Rodríguez Sahagún & $29-09-1987 / \ldots$ \\
\hline Adolfo Suárez González & - \\
\hline
\end{tabular}

\begin{tabular}{|c|c|}
\hline \multicolumn{2}{|c|}{ Comisión de Asuntos Exteriores } \\
\hline Miguel Martínez Cuadrado (Secretario Segundo) & - \\
\hline José Ramón Caso & - \\
\hline Agustín Rodríguez Sahagún & - \\
\hline
\end{tabular}

\begin{tabular}{|c|c|}
\hline \multicolumn{2}{|c|}{ Comisión de Defensa } \\
\hline Joaquín Abril Martorell & $29-09-1987 / 22-02-1989$ \\
\hline León Buil Giral & $08-05-1989 / \ldots$ \\
\hline José Ramón Caso & $\ldots .30-06-1989$ \\
\hline Íñigo Cavero & $07-02-1989 / 30-06-1989$ \\
\hline Pablo Hurtado Samper & $\ldots .08-05-1989$ \\
\hline
\end{tabular}

\begin{tabular}{|c|c|}
\hline \multicolumn{2}{|c|}{ Comisión de Economía, Comercio y Hacienda } \\
\hline Joaquín Abril Martorell & - \\
\hline José Ramón Lasuén Sancho & $06-10-1987$ \\
\hline José María Rioboo Almanzor & - \\
\hline
\end{tabular}

\begin{tabular}{|c|c|}
\hline \multicolumn{2}{|c|}{ Comisión de Educación y Cultura } \\
\hline Antonio Garrosa y Resina & - \\
\hline Miguel Martínez Cuadrado & $01-02-1987 / \ldots$ \\
\hline Francisco J. Moldes Fontán & \\
\hline
\end{tabular}

\begin{tabular}{|c|c|}
\hline \multicolumn{2}{|c|}{ Comisión de Industria, Obras Públicas y Servicios } \\
\hline Antonio Garrosa y Resina & - \\
\hline Rafael Martínez Campillo & - \\
\hline Jorge Mataix Hidalgo & $24-01-1989 / \ldots$ \\
\hline Alejandro Rebollo Álvarez-Amandi & - \\
\hline
\end{tabular}

\begin{tabular}{|c|c|}
\hline \multicolumn{2}{|c|}{ Comisión de Justicia e Interior } \\
\hline León Buil Giral & - \\
\hline José Ramón Caso García & $\ldots / 22-02-1989$ \\
\hline Pablo Hurtado Samper & $01-10-1987 / 12-08-1989$ \\
\hline Alejandro Rebollo Álvarez-Amandi & - \\
\hline José María Pardo Montero & $07-02-1989 / 22-11-1989$ \\
\hline
\end{tabular}

\begin{tabular}{|c|c|}
\hline \multicolumn{2}{|c|}{ Comisión de Política Social y Empleo } \\
\hline Carlos Revilla Rodríguez (Secretario Segundo) & - \\
\hline Antonio Fernández Teixidó & $\ldots .14-06-1988$ \\
\hline José Antonio López Arranz & $01-10-1987 / 28-02-1989$ \\
\hline Félix Manuel Pérez Miyares & $07-02-1989 / \ldots$ \\
\hline Ana Yabar Sterling & $24-01-1989 / \ldots$ \\
\hline
\end{tabular}

\begin{tabular}{|c|c|}
\hline \multicolumn{2}{|c|}{ Comisión de Presupuestos } \\
\hline Antonio Garrosa Resina (Secretario Segundo) & - \\
\hline José María Rioboo Alamanzor & - \\
\hline Ramón Tamames Gómez & $07-02-1989 / 14-03-1989$ \\
\hline
\end{tabular}




\begin{tabular}{|c|c|}
\hline \multicolumn{2}{|c|}{ Comisión de Régimen de las Administraciones Públicas } \\
\hline $\begin{array}{c}\text { Rafael Martínez Campillo (Vicepresidente } \\
\text { Segundo) }\end{array}$ & - \\
\hline José Antonio Santos Miñón & - \\
\hline Baltasar Zárate Pérez de Ayala & $29-09-1987 / \ldots$ \\
\hline
\end{tabular}

\begin{tabular}{|c|c|}
\hline \multicolumn{2}{|c|}{ Comisión de Control Parlamentario de RTVE } \\
\hline José Antonio López Arranz (Secretario Segundo) & - \\
\hline Antonio Garrosa Resina & $01-10-1987 / \ldots$ \\
\hline Federico Ysart Alcover & - \\
\hline
\end{tabular}

\begin{tabular}{|c|c|}
\hline \multicolumn{2}{|c|}{ Comisión del Defensor del Pueblo } \\
\hline José Antonio López Arranz & $\ldots / 16-01-1989$ \\
\hline Jorge Mataix Hidalgo & $16-01-1989 / \ldots$ \\
\hline Francisco J. Moldes Fontán & - \\
\hline José Antonio Santos Miñón & $29-09-1987 / \ldots$ \\
\hline
\end{tabular}

\section{Comisión Mixta para las Relaciones con el Tribunal de Cuentas}

Alejandro Rebollo Álvarez-Amandi José Luis Sagredo de Miguel

\begin{tabular}{|c|c}
- & Diputado \\
\hline 27-10-1987/12-11-1987 & Senador \\
\hline $05-02-1987 / 27-04-1988$ &
\end{tabular}

\begin{tabular}{|c|c|c|}
\hline \multicolumn{3}{|c|}{ Comisión Mixta para las Comunidades Europeas } \\
\hline Miguel Martínez Cuadrado (Secretario Segundo) & - & Diputado \\
\hline Celso Rodríguez Legido & $\ldots / 11-11-1987$ (Mixto) & Senador \\
& $04-11-1988 / \ldots$ (CDS) & \\
\hline Federico Ysart Alcover & - & \\
\hline
\end{tabular}

\begin{tabular}{|c|c|c|}
\hline \multicolumn{3}{|c|}{ Comisión Mixta de Investigación Científica y Desarrollo Tecnológico } \\
\hline Carlos Revilla Rodríguez (Secretario Segundo) & - & Diputado \\
\hline Antonio Valverde Ortega & $27-10-1987 / \ldots$ & Senador \\
\hline
\end{tabular}

\begin{tabular}{|l|l|}
\hline \multicolumn{2}{|c|}{ Comisión Estatuto de los Diputados } \\
\hline Carlos Revilla Rodríguez (Secretario Segundo) & - \\
\hline
\end{tabular}

\begin{tabular}{|c|c|}
\hline \multicolumn{2}{|c|}{ Comisión de Peticiones } \\
\hline Antonio Fernández Teixidó (Secretario) & - \\
\hline Ana Yabar Sterling (Secretario) & - \\
\hline
\end{tabular}

\begin{tabular}{|c|c|}
\hline \multicolumn{2}{|c|}{ Comisión de Reglamento } \\
\hline José Ramón Caso (Vicepresidente Cuarto) & - \\
\hline León Buil Giral & $\ldots / 16-01-1989$ \\
\hline Modesto Fraile Poujade & $07-02-1989 / \ldots$ \\
\hline Alejandro Rebollo Álvarez-Amandi & $01-10-1987 / 22-02-1989$ \\
\hline Agustín Rodríguez Sahagún & - \\
\hline
\end{tabular}


Comisión de Investigación: sobre incompatibilidades y tráfico de influencias

Alejandro Rebollo Álvarez-Amandi (Secretario)

Comisión de Estudio: sobre la situación de las sectas en España

Antonio Garrosa Resina (Secretario)

Comisión de Estudio y Desarrollo de la Cooperación entre España y Guinea Ecuatorial

Joaquín Abril Martorell (Secretario)

Comisión Mixta para la Igualdad de Oportunidades de la Mujer

\begin{tabular}{|c|c|c|}
\hline Francisco Quetglás Rosales & $27-07-1989 / \ldots$ & Diputado \\
\hline José Luis Sagredo de Miguel & $\ldots / 01-06-1989$ & Senador \\
\hline Carlos Revilla Rodríguez & - & Senador \\
\hline
\end{tabular}

\section{Comisión de Estudio: sobre la situación de las Administraciones Públicas en España ${ }^{3}$}

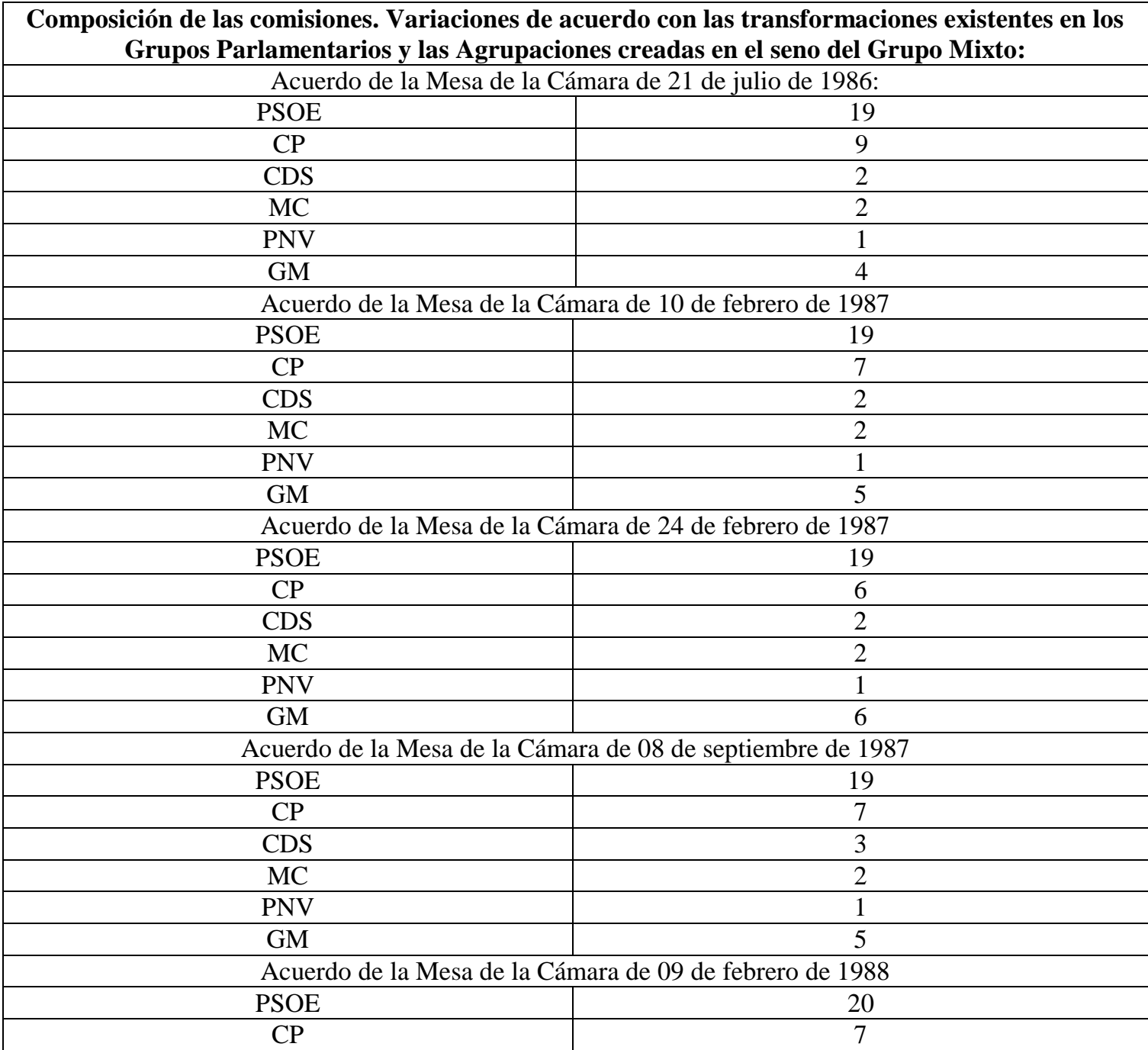

\footnotetext{
3 “Creada por resolución del Pleno de la Cámara de 25 de febrero de 1988, no llegó a constituirse”, p. 109
} 


\begin{tabular}{|c|c|}
\hline CDS & 2 \\
\hline MC & 2 \\
\hline PNV & 1 \\
\hline GM & 6 \\
\hline Acuerdo de la Mesa de la Cámara de 07 de febrero de 1989 \\
\hline PSOE & 20 \\
\hline CP & 10 \\
\hline CDS & 3 \\
\hline MC & 2 \\
\hline PNV & 1 \\
\hline GM & 3 \\
\hline Acuerdo de la Mesa de la Cámara de 16 de febrero de 1989 \\
\hline PSOE & 19 \\
\hline CP & 9 \\
\hline CDS & 3 \\
\hline MC & 2 \\
\hline PNV & 1 \\
\hline GM & 1 \\
\hline
\end{tabular}

\begin{tabular}{|}
$\mid \begin{array}{c}\text { Acuerdo de las Mesas del Congreso de los Diputados y del Senado en reunión conjunta de 20 de } \\
\text { febrero de 1989, que establece la composición de las Comisiones Mixtas }\end{array}$ \\
\begin{tabular}{|c|c|c|}
\hline \multicolumn{2}{|c|}{ Comisión de Comunidades Europeas y Comisión de Estudio para la Igualdad de Oportunidades } \\
de la Mujer
\end{tabular} \\
\hline Partido & Diputados & Senadores \\
\hline PSOE & 6 & 4 \\
\hline CP & 4 & 2 \\
\hline CDS & 1 & 1 \\
\hline MC & 1 & 1 \\
\hline PNV & 1 & 1 \\
\hline GM & 1 & 1 \\
\hline IU-IC & 1 & - \\
\hline \multicolumn{3}{|c|}{ Comisión de Investigación Científica y Desarrollo Tecnológico } \\
\hline Partido & Diputados & Senadores \\
\hline PSOE & 11 & 9 \\
\hline CP & 6 & 3 \\
\hline CDS & 1 & 1 \\
\hline MC & 1 & 1 \\
\hline PNV & 1 & 1 \\
\hline GM & 1 & 1 \\
\hline IU-IC & 1 & - \\
\hline \multicolumn{3}{|c|}{} & Comisión para las relaciones con el Tribunal de Cuentas \\
\hline Partido & Diputados & Senadores \\
\hline PSOE & 11 & 9 \\
\hline CP & 5 & 4 \\
\hline CDS & 2 & 1 \\
\hline MC & 1 & 1 \\
\hline PNV & 1 & 1 \\
\hline GM & 1 & 1 \\
\hline IU-IC & 1 & - \\
\hline \multicolumn{2}{|c|}{} & \\
\hline
\end{tabular}

La composición de las Ponencias. Variaciones a lo largo de la Legislatura.

\begin{tabular}{|c|c|}
\hline \multicolumn{2}{|c|}{ Resolución de la Presidencia de 23 de septiembre de 1986 } \\
\hline PSOE & 3 \\
\hline CP & 2 \\
\hline CDS & 1 \\
\hline
\end{tabular}




\begin{tabular}{|c|c|}
\hline MC & 1 \\
\hline PNV & 1 \\
\hline GM & 3 \\
\hline Resolución de la Presidencia de 16 de febrero de 1989 \\
\hline PSOE & 3 \\
\hline CP & 2 \\
\hline CDS & 1 \\
\hline MC & 1 \\
\hline PNV & 1 \\
\hline GM & 2 \\
\hline
\end{tabular}




\section{Anexo XV}

Diputados adscritos al GPCDS del Congreso de los Diputados a lo largo de la III Legislatura

\begin{tabular}{|c|c|c|c|}
\hline \multicolumn{2}{|c|}{ GRUPO PARLAMENTARIO CONGRESO CDS (Altas) } \\
\hline Nombre & Fecha alta GP CDS & Electo & Militancia política previa \\
\hline Baltasar Zárate Peraza de Ayala & $10-02-1987$ & CP (PL) & UCD; CDS; PL \\
\hline José Ramón Lasuén Sancho & $08-09-1987$ & CP (AP) & Tácito; FSI; UCD; AP ${ }^{1}$ \\
\hline Ana María Yabar Sterling & $02-02-1988$ & CP (PL) & PL \\
\hline Antonio Jiménez Blanco & $02-02-1988$ & CP (PL) & PDP; UCD, PL \\
\hline Jorge Juan Mataix Hidalgo & $14-06-1988$ & Sustitución & - \\
\hline Íñigo Cavero Lataillade & $07-02-1989$ & CP (PDP) & Tácito; DC; ID; PPDC; UCD; \\
\hline Modesto Fraile Poujade & $07-02-1989$ & CP (PDP) & FEDISA $;$ UCD; PDP \\
\hline José María Pardo Montero & $07-02-1989$ & CP (PL) & UCD; PL; CGP \\
\hline Félix Manuel Pérez Miyares & $07-02-1989$ & CP (PDP) & UCD; PDP \\
\hline Ramón Tamames Gómez & $07-02-1989$ & IU (FP) & PCE; FP \\
\hline Laura Morso Pérez & $10-07-1989$ & Sustitución & UCD \\
\hline
\end{tabular}

Elaboración propia a partir de fuentes hemerográficas y GONZALO, Manuel y PAESA, María (eds.): Memoria de la III... Esta información se completa con la aportada en texto en el epígrafe 6.1.

\footnotetext{
1 Integrado en las listas de AP iba como "independiente", $Y a, 04$ de agosto de 1987.

2 "Biografía de Íñigo Cavero", $A B C, 25$ de diciembre de 2002.

${ }^{3}$ Durante la Dictadura Franquista fue Presidente de la Diputación Provincial de Segovia (1970-1974).

Sobre su pertenencia a FEDISA, FIGUERO, Javier: La otra ..., p. 38.
} 


\section{Anexo XVI}

Actividad del CDS durante la III Legislatura en el Congreso de los Diputados

Conjunto de Iniciativas Parlamentarias del Grupo Parlamentario CDS durante la III Legislatura

\begin{tabular}{|c|c|c|c|c|c|c|c|c|c|c|}
\hline & $\begin{array}{l}\text { Present } \\
\text { adas }\end{array}$ & $\begin{array}{l}\text { Admitidas } \\
\text { a trámite }\end{array}$ & Inadmitidas & Retiradas & Decaídas & Rechazadas & Caducadas & $\begin{array}{l}\text { Aprobadas con } \\
\text { modificaciones }\end{array}$ & $\begin{array}{l}\text { Aprobadas sin } \\
\text { modificacione } \\
\mathrm{S}\end{array}$ & $\begin{array}{l}\text { Convertidas }{ }^{1} / \mathrm{D} \\
\text { ebatidas }{ }^{2} / \text { Conte } \\
\text { stadas }^{3} / \text { Celebra } \\
\text { das }^{4}\end{array}$ \\
\hline Proposiciones de Ley & $16(2)$ & $16(2)$ & - & $1(1)^{5}$ & - & 11 & 3 & $(1)^{6}$ & $1^{7}$ & - \\
\hline $\begin{array}{l}\text { Proposiciones no de } \\
\text { Ley ante el Pleno }\end{array}$ & $18^{8}$ & 16 & - & 7 & - & 4 & 1 & 4 & - & - \\
\hline $\begin{array}{l}\text { Proposiciones no de } \\
\text { Ley para debatir en } \\
\text { Comisión }\end{array}$ & 39 & 37 & - & 4 & - & 20 & - & 5 & 2 & - \\
\hline $\begin{array}{l}\text { Interpelaciones } \\
\text { Ordinarias }\end{array}$ & 10 & 10 & - & 3 & - & - & 1 & - & - & 6 \\
\hline $\begin{array}{l}\text { Interpelaciones } \\
\text { Urgentes }\end{array}$ & 19 & 16 & 3 & - & - & - & - & - & - & 16 \\
\hline Mociones $^{9}$ & 14 & 14 & - & - & - & 12 & - & 1 & 1 & - \\
\hline Preguntas con & 190 & 185 & 5 & 15 & 26 & - & - & - & - & 144 \\
\hline
\end{tabular}

${ }^{1}$ En pregunta oral/escrita en el caso de las interpelaciones.

${ }^{2}$ En el caso de las interpelaciones urgentes.

${ }^{3}$ En el caso de las preguntas orales/escritas.

${ }_{5}^{4}$ Solicitudes de comparecencia.

${ }^{5}$ Una de ellas presentada junto a GM-APDP

${ }^{6}$ La única proposición de Ley del CDS aprobada fue: "Ley1/1988 de 14 de enero, por la que se modifica la Ley de 18 de junio de 1870 , estableciendo reglas para el ejercicio de la gracia de indulto".

${ }^{7}$ Presentada por GS, GCP, GCDS, GM-AIU-IC, GM-APDP y GM. Se incluyen, por la decisiva importancia de esta función legislativa, las presentadas, ya salvo que sea el GCDS, "primer firmante", son computadas aparte en el resto de iniciativas.

${ }^{8}$ Se admitieron dos proposiciones más del CDS para su debate en Pleno, pero finalmente pasaron a debate en Pleno, y otra más, viceversa. Así como una más en comisión, pero no pasó a su debate en el Pleno.

${ }^{9}$ Consecuencia de interpelaciones urgentes. 


\begin{tabular}{|c|c|c|c|c|c|c|c|c|c|c|}
\hline $\begin{array}{l}\text { respuesta oral en el } \\
\text { pleno }\end{array}$ & & & & & & & & & & \\
\hline $\begin{array}{l}\text { Preguntas orales al } \\
\text { Gobierno en Comisión }\end{array}$ & 313 & 310 & 3 & 7 & - & - & 3 & - & - & 98 \\
\hline $\begin{array}{l}\text { Preguntas orales al } \\
\text { Director del Ente } \\
\text { Público RTVE }\end{array}$ & 69 & 63 & 6 & - & 16 & - & - & - & - & 47 \\
\hline $\begin{array}{l}\text { Preguntas orales al } \\
\text { Consejo de Admon. de } \\
\text { RTVE }\end{array}$ & 8 & 8 & - & - & - & - & - & - & - & $178^{11}$ \\
\hline $\begin{array}{l}\text { Preguntas al Gobierno } \\
\text { con respuesta escrita }\end{array}$ & 1248 & 1241 & 7 & 7 & - & - & 135 & - & - & 1099 \\
\hline Solicitudes de informe & 201 & 193 & 8 & - & - & - & - & - & - & - \\
\hline $\begin{array}{l}\text { Comparecencias del } \\
\text { Gobierno ante el Pleno }\end{array}$ & 2 & 1 & 1 & - & - & 1 & - & - & - & - \\
\hline $\begin{array}{l}\text { Comparecencias del } \\
\text { Gobierno en Comisión }\end{array}$ & 373 & 372 & 1 & 38 & 3 & 7 & 19 & - & - & $296^{12}$ \\
\hline
\end{tabular}

Elaboración propia a partir de GONZALO, Manuel y PAESA, María (eds.): Memoria de la III...

Iniciativas Parlamentarias del GPCDS durante la III Legislatura en el conjunto de la oposición ${ }^{13}$

\begin{tabular}{|l|l|l|l|}
\hline & Situación & $\begin{array}{l}\text { Porcentaje sobre el } \\
\text { total de la oposición }\end{array}$ & Posición en el cómputo de GP de la oposición \\
\hline Proposiciones de Ley & Admitidas a trámite & 11,51 & $4^{\circ}$ (GCP, GMAIU-IC, GMADC). \\
\cline { 2 - 4 } & $\begin{array}{l}\text { Aprobadas con/sin } \\
\text { modificaciones }\end{array}$ & 14,25 & $3^{\circ}$ (GCP, GS) \\
\hline $\begin{array}{l}\text { Proposiciones no de Ley } \\
\text { para debatir en }\end{array}$ & Admitidas a trámite & 11,37 & $4^{\circ}$ (GCP, GMADC y GMAIU-IC). \\
\cline { 2 - 4 } Aprobadas con/sin & 14,86 & $5^{\circ}$ (GM, GMAIC-IC, GMC, GCP) \\
\hline
\end{tabular}

${ }^{10}$ A diferencia del resto de los mecanismos de control gubernamental las preguntas orales o escritas se presentan de forma individual.

11166 fueron contestados por la administración del Estado, 5 por la autonómica y 7 por otras entidades.

${ }^{12}$ Debemos añadir 19 no celebradas.

${ }^{13}$ Iniciativas en solitario. 


\begin{tabular}{|c|c|c|c|}
\hline Comisión/ante el Plano & modificaciones & & \\
\hline \multirow[t]{2}{*}{ Interpelaciones Ordinarias } & Admitidas a trámite & 25 & $2^{\circ}(\mathrm{GCP})$. El mismo número que GMADC. \\
\hline & Convertidas & 27,2 & $3^{\circ}$ GCP y GMADC \\
\hline Interpelaciones Urgentes & Admitidas a trámite & 10,73 & $3^{\circ}$ (GCP, GMADC). El mismo número que GMC. \\
\hline \multirow{2}{*}{ Mociones $^{14}$} & Admitidas a trámite & 13,72 & $3^{\circ}$ (GCP, GMADC). \\
\hline & $\begin{array}{l}\text { Aprobadas con/sin } \\
\text { modificaciones }\end{array}$ & 8,69 & $\begin{array}{l}3^{\circ} \text { (GCP y GMADC). El mismo número que GMAIU-IC, } \\
\text { GM y GMC. }\end{array}$ \\
\hline \multirow{2}{*}{$\begin{array}{l}\text { Preguntas orales al } \\
\text { Gobierno en Comisión }\end{array}$} & Admitidas a trámite & 19,91 & $2^{\circ}(\mathrm{GCP})$ \\
\hline & Contestadas & 22,19 & $2^{\circ}(\mathrm{GCP})$ \\
\hline \multirow{2}{*}{$\begin{array}{l}\text { Preguntas orales al director } \\
\text { del ente público de RTVE }\end{array}$} & Admitidas a trámite & 9,47 & $3^{\circ}(\mathrm{GCP}, \mathrm{GS})$ \\
\hline & Contestadas & 9,95 & $3^{\circ}(\mathrm{GCP}, \mathrm{GS})$ \\
\hline $\begin{array}{l}\text { Preguntas al Gobierno con } \\
\text { respuesta escrita }\end{array}$ & Contestadas & 6,12 & $3^{\circ}(\mathrm{GCP}, \mathrm{GMADC})$ \\
\hline \multirow[t]{2}{*}{ Solicitudes de informe $^{15}$} & Admitidos a trámite & 10,34 & $2^{\circ}(\mathrm{GCP})$ \\
\hline & Contestados & 14,25 & $2^{\circ}(\mathrm{GCP})$ \\
\hline \multirow{2}{*}{$\begin{array}{l}\text { Comparecencia del } \\
\text { Gobierno ante el Pleno }\end{array}$} & Admitidos a trámite & 5,26 & $3^{\circ}($ Gobierno, GCP $)$ \\
\hline & Celebrados & - & - \\
\hline \multirow{2}{*}{$\begin{array}{l}\text { Comparecencia del } \\
\text { Gobierno en Comisión }\end{array}$} & Admitidos a trámite & 17,11 & $3^{\circ}(\mathrm{GCP}, \mathrm{GMADC})$ \\
\hline & Celebrados & 17,98 & $3^{\circ}(\mathrm{GCP}, \mathrm{GMADC})$ \\
\hline
\end{tabular}

\footnotetext{
${ }^{14}$ Consecuencia de interpelaciones urgentes

${ }^{15}$ Se tiene en cuenta el total de los mismos, referentes tanto a la Administración del Estado, la administración autonómica, y otras entidades.
} 
Iniciativas Parlamentarias del GPCDS durante la III Legislatura desglosadas por diputados ${ }^{16}$

\begin{tabular}{|c|c|c|c|c|c|c|}
\hline & $\begin{array}{l}\text { Preguntas } \\
\text { Orales en } \\
\text { el Pleno }\end{array}$ & $\begin{array}{l}\text { Preguntas } \\
\text { Orales en } \\
\text { Comisión }\end{array}$ & $\begin{array}{l}\text { Preguntas al } \\
\text { Gobierno con } \\
\text { respuesta escrita }\end{array}$ & $\begin{array}{l}\text { Preguntas al } \\
\text { Director de RTVE } \\
\text { /Consejo de } \\
\text { Administración } \\
\text { /Ente de RTVE con } \\
\text { respuesta escrita } \\
\end{array}$ & $\begin{array}{l}\text { Solicitud de informes a la } \\
\text { administración del Estado } \\
\text { /Comunidades autónomas } \\
\text { /Otras entidades }\end{array}$ & $\begin{array}{l}\text { Ponencias en } \\
\text { Proposiciones de Ley, } \\
\text { Proyectos de Ley, Reales } \\
\text { Decretos y Otros }\end{array}$ \\
\hline ABRIL MARTORELL, Joaquín & 4 & 11 & 1 & - & & 1 \\
\hline BUIL GIRAL, León & 2 & 48 & 340 & [1] & $60(9)^{17}[1]^{18}$ & 15 \\
\hline CASO GARCÍA José Ramón & 6 & 12 & 4 & - & 5 & 8 \\
\hline CASTAÑO CASANOVA, Juan & 10 & 5 & 12 & 2 & 3 & 2 \\
\hline CAVERO LATAILLADE, Íñigo & 2 & 7 & 1 & - & - & 3 \\
\hline DÍAZ AGUILAR, Lorenzo & 3 & 4 & 42 & - & - & - \\
\hline FERNÁNDEZ TEIXIDÓ, Antonio & 7 & 2 & 60 & {$[1]$} & - & 2 \\
\hline FRAILE POUJADE, Modesto & 2 & 7 & 4 & - & - & - \\
\hline GARROSA RESINA, Antonio & 12 & 11 & 52 & $8(1)[2]$ & 7 & 6 \\
\hline HURTADO SAMPER, Pablo & 9 & 4 & 20 & - & - & 3 \\
\hline JIMÉNEZ BLANCO, Antonio & 1 & - & - & - & - & 4 \\
\hline LASUÉN SANCHO, José Ramón & - & 30 & - & - & - & 4 \\
\hline LÓPEZ ARRANZ, José Antonio & - & - & - & - & - & - \\
\hline MARTÍNEZ CUADRADO, Miguel & 6 & 3 & 13 & - & 3 & 1 \\
\hline MARTÍNEZ-CAMPILLO GARCÍA, Rafael & 20 & 39 & 46 & - & $18[1]$ & 8 \\
\hline MATAIX HIDALGO, Jorge Juan & 7 & 9 & 14 & - & 11 & - \\
\hline MOLDES FONTÁN, Francisco J. & 12 & 18 & 50 & - & 8 & - \\
\hline MORSO PÉREZ, Laura & - & - & - & 1 & - & - \\
\hline PARDO MONTERO, José María & - & - & - & - & - & - \\
\hline PÉREZ MIYARES, Félix Manuel & - & - & 1 & - & - & - \\
\hline REBOLLO ÁLVAREZ-AMANDI, Alejandro & 10 & 4 & 14 & - & - & 7 \\
\hline
\end{tabular}

\footnotetext{
${ }^{16}$ En el caso de los diputados inscritos a lo largo de la Legislatura al GCDS o dados de baja sólo se han tenido en cuenta las intervenciones realizadas con dicho grupo. Asimismo, sólo se han contabilizado aquellas tramitadas. Por ello, se ha contrastado la información con la base de datos online del Congreso y los datos finales desglosados pueden no coincidir con los totales estadísticos.

${ }^{17}$ Comunidades Autónomas.

${ }^{18}$ Otras entidades.
} 


\begin{tabular}{|c|c|c|c|c|c|c|}
\hline REVILLA RODRÍGUEZ, Carlos & 15 & 23 & 59 & - & 1 & 4 \\
\hline RIOBOO ALMANZOR, José María & 12 & 14 & 96 & - & 48 & 17 \\
\hline RODRÍGUEZ SAHAGÚN, Agustín & 1 & 44 & 59 & 4 & $15[2]$ & - \\
\hline SANTOS MIÑÓN, José Antonio & 9 & 7 & 265 & - & 2 & 1 \\
\hline SUÁREZ GONZÁLEZ, Adolfo & - & - & - & - & - & - \\
\hline TAMAMES GÓMEZ, Ramón & 5 & - & - & - & - & - \\
\hline YABAR STERLING, Ana María & - & 1 & - & - & 1 & 6 \\
\hline YSART ALCOVER, Federico & 4 & - & - & $54(7)$ & & 2 \\
\hline ZÁRATE PERAZA DE AYALA, Baltasar & 17 & 12 & 68 & - & 2 & 5 \\
\hline
\end{tabular}

Iniciativas Parlamentarias del GPCDS durante la III Legislatura en el conjunto de la oposición ${ }^{19}$

\begin{tabular}{|c|c|c|c|}
\hline & Situación & $\begin{array}{l}\text { Porcentaje sobre el } \\
\text { total de la oposición }\end{array}$ & Posición en el cómputo de GP de la oposición \\
\hline \multirow[t]{2}{*}{ Proposiciones de Ley } & Admitidas a trámite & 11,51 & $4^{\circ}$ (GCP, GMAIU-IC, GMADC). \\
\hline & $\begin{array}{l}\text { Aprobadas con/sin } \\
\text { modificaciones }\end{array}$ & 14,25 & $3^{\circ}(\mathrm{GCP}, \mathrm{GS})$ \\
\hline \multirow{2}{*}{$\begin{array}{l}\text { Proposiciones no de Ley } \\
\text { para debatir en } \\
\text { Comisión/ante el Plano }\end{array}$} & Admitidas a trámite & 11,37 & $4^{\circ}$ (GCP, GMADC y GMAIU-IC). \\
\hline & $\begin{array}{l}\text { Aprobadas con/sin } \\
\text { modificaciones }\end{array}$ & 14,86 & $5^{\circ}$ (GM, GMAIC-IC, GMC, GCP) \\
\hline \multirow[t]{2}{*}{ Interpelaciones Ordinarias } & Admitidas a trámite & 25 & $2^{\circ}(\mathrm{GCP})$. El mismo número que GMADC. \\
\hline & Convertidas & 27,2 & $3^{\circ}$ GCP y GMADC \\
\hline \multirow{2}{*}{ Interpelaciones Urgentes } & Admitidas a trámite & 10,73 & $3^{\circ}$ (GCP, GMADC). El mismo número que GMC. \\
\hline & Convertidas & 13,91 & $3^{\circ}$ (GCP y GMADC). \\
\hline \multirow[t]{2}{*}{ Mociones $^{20}$} & Admitidas a trámite & 13,72 & $3^{\circ}$ (GCP, GMADC). \\
\hline & $\begin{array}{l}\text { Aprobadas con/sin } \\
\text { modificaciones }\end{array}$ & 8,69 & $\begin{array}{l}3^{\circ} \text { (GCP y GMADC). El mismo número que GMAIU-IC, } \\
\text { GM y GMC. }\end{array}$ \\
\hline \multirow{2}{*}{$\begin{array}{l}\text { Preguntas con respuesta } \\
\text { oral en el Pleno }\end{array}$} & Admitidas a trámite & 12,83 & $2^{\circ}(\mathrm{GCP})$ \\
\hline & Contestadas & 13,27 & $2^{\circ}(\mathrm{GCP})$ \\
\hline
\end{tabular}

${ }^{19}$ Iniciativas en solitario.

${ }^{20}$ Consecuencia de interpelaciones urgentes 


\begin{tabular}{|c|c|c|c|}
\hline \multirow{2}{*}{$\begin{array}{l}\text { Preguntas orales al } \\
\text { Gobierno en Comisión }\end{array}$} & Admitidas a trámite & 19,91 & $2^{\circ}(\mathrm{GCP})$ \\
\hline & Contestadas & 22,19 & $2^{\circ}(\mathrm{GCP})$ \\
\hline \multirow{2}{*}{$\begin{array}{l}\text { Preguntas orales al director } \\
\text { del ente público de RTVE }\end{array}$} & Admitidas a trámite & 9,47 & $3^{\circ}(\mathrm{GCP}, \mathrm{GS})$ \\
\hline & Contestadas & 9,95 & $3^{\circ}(\mathrm{GCP}, \mathrm{GS})$ \\
\hline \multirow{2}{*}{$\begin{array}{l}\text { Preguntas orales al } \\
\text { Consejo de Administración } \\
\text { de RTVE }\end{array}$} & Admitidas a trámite & 24,24 & $2^{\circ}$ (GMAPL) \\
\hline & Contestadas & 30,76 & $2^{\circ}$ (GMAPL) \\
\hline \multirow{2}{*}{$\begin{array}{l}\text { Preguntas al Gobierno con } \\
\text { respuesta escrita }\end{array}$} & Admitidas a trámite & 6,41 & $3^{\circ}$ (GCP, GMADC) \\
\hline & Contestadas & 6,12 & $3^{\circ}(\mathrm{GCP}, \mathrm{GMADC})$ \\
\hline \multirow[t]{2}{*}{ Solicitudes de informe $^{21}$} & Admitidos a trámite & 10,34 & $2^{\circ}(\mathrm{GCP})$ \\
\hline & Contestados & 14,25 & $2^{\circ}(\mathrm{GCP})$ \\
\hline \multirow{2}{*}{$\begin{array}{l}\text { Comparecencia del } \\
\text { Gobierno ante el Pleno }\end{array}$} & Admitidos a trámite & 5,26 & $3^{\circ}$ (Gobierno, GCP) \\
\hline & Celebrados & - & - \\
\hline \multirow{2}{*}{$\begin{array}{l}\text { Comparecencia del } \\
\text { Gobierno en Comisión }\end{array}$} & Admitidos a trámite & 17,11 & $3^{\circ}$ (GCP, GMADC) \\
\hline & Celebrados & 17,98 & $3^{\circ}$ (GCP, GMADC) \\
\hline
\end{tabular}

Iniciativas Parlamentarias del GPCDS durante la III Legislatura desglosadas por diputados ${ }^{22}$

\begin{tabular}{|c|c|c|c|c|c|c|}
\hline & $\begin{array}{l}\text { Preguntas } \\
\text { Orales en } \\
\text { el Pleno }\end{array}$ & $\begin{array}{l}\text { Preguntas } \\
\text { Orales en } \\
\text { Comisión }\end{array}$ & $\begin{array}{l}\text { Preguntas al } \\
\text { Gobierno con } \\
\text { respuesta escrita }\end{array}$ & $\begin{array}{l}\text { Preguntas al } \\
\text { Director de RTVE } \\
\text { /Consejo de } \\
\text { Administración } \\
\text { /Ente de RTVE con } \\
\text { respuesta escrita } \\
\end{array}$ & $\begin{array}{l}\text { Solicitud de informes a la } \\
\text { administración del Estado } \\
\text { /Comunidades autónomas } \\
\text { /Otras entidades }\end{array}$ & $\begin{array}{l}\text { Ponencias en } \\
\text { Proposiciones de Ley, } \\
\text { Proyectos de Ley, Reales } \\
\text { Decretos y Otros }\end{array}$ \\
\hline ABRIL MARTORELL, Joaquín & 4 & 11 & 1 & - & & 1 \\
\hline BUIL GIRAL, León & 2 & 48 & 340 & {$[1]$} & $60(9)^{23}[1]^{24}$ & 15 \\
\hline
\end{tabular}

${ }^{21}$ Se tiene en cuenta el total de los mismos, referentes tanto a la Administración del Estado, la administración autonómica, y otras entidades.

${ }^{22}$ En el caso de los diputados inscritos a lo largo de la Legislatura al GCDS o dados de baja sólo se han tenido en cuenta las intervenciones realizadas con dicho grupo. Asimismo, sólo se han contabilizado aquellas tramitadas. Por ello, se ha contrastado la información con la base de datos online del Congreso y los datos finales desglosados pueden no coincidir con los totales estadísticos.

${ }^{23}$ Comunidades Autónomas.

${ }^{24}$ Otras entidades. 


\begin{tabular}{|c|c|c|c|c|c|c|}
\hline CASO GARCÍA José Ramón & 6 & 12 & 4 & - & 5 & 8 \\
\hline CASTAÑO CASANOVA, Juan & 10 & 5 & 12 & 2 & 3 & 2 \\
\hline CAVERO LATAILLADE, Íñigo & 2 & 7 & 1 & - & - & 3 \\
\hline DÍAZ AGUILAR, Lorenzo & 3 & 4 & 42 & - & - & - \\
\hline FERNÁNDEZ TEIXIDÓ, Antonio & 7 & 2 & 60 & [1] & - & 2 \\
\hline FRAILE POUJADE, Modesto & 2 & 7 & 4 & - & - & - \\
\hline GARROSA RESINA, Antonio & 12 & 11 & 52 & $8(1)[2]$ & 7 & 6 \\
\hline HURTADO SAMPER, Pablo & 9 & 4 & 20 & - & - & 3 \\
\hline JIMÉNEZ BLANCO, Antonio & 1 & - & - & - & - & 4 \\
\hline LASUÉN SANCHO, José Ramón & - & 30 & - & - & - & 4 \\
\hline LÓPEZ ARRANZ, José Antonio & - & - & - & - & - & - \\
\hline MARTÍNEZ CUADRADO, Miguel & 6 & 3 & 13 & - & 3 & 1 \\
\hline MARTÍNEZ-CAMPILLO GARCÍA, Rafael & 20 & 39 & 46 & - & $18[1]$ & 8 \\
\hline MATAIX HIDALGO, Jorge Juan & 7 & 9 & 14 & - & 11 & - \\
\hline MOLDES FONTÁN, Francisco J. & 12 & 18 & 50 & - & 8 & - \\
\hline MORSO PÉREZ, Laura & - & - & - & 1 & - & - \\
\hline PARDO MONTERO, José María & - & - & - & - & - & - \\
\hline PÉREZ MIYARES, Félix Manuel & - & - & 1 & - & - & - \\
\hline REBOLLO ÁLVAREZ-AMANDI, Alejandro & 10 & 4 & 14 & - & - & 7 \\
\hline REVILLA RODRÍGUEZ, Carlos & 15 & 23 & 59 & - & 1 & 4 \\
\hline RIOBOO ALMANZOR, José María & 12 & 14 & 96 & - & 48 & 17 \\
\hline RODRÍGUEZ SAHAGÚN, Agustín & 1 & 44 & 59 & 4 & $15[2]$ & - \\
\hline SANTOS MIÑÓN, José Antonio & 9 & 7 & 265 & - & 2 & 1 \\
\hline SUÁREZ GONZÁLEZ, Adolfo & - & - & - & - & - & - \\
\hline TAMAMES GÓMEZ, Ramón & 5 & - & - & - & - & - \\
\hline YABAR STERLING, Ana María & - & 1 & - & - & 1 & 6 \\
\hline YSART ALCOVER, Federico & 4 & - & - & $54(7)$ & & 2 \\
\hline ZÁRATE PERAZA DE AYALA, Baltasar & 17 & 12 & 68 & - & 2 & 5 \\
\hline
\end{tabular}




\section{Anexo XVII}

Actividad del CDS durante la III Legislatura en el Senado ${ }^{1}$

Órganos de Gobierno y actividad legislativa en el Senado (CDS) (1986-1989) ${ }^{2}$

\begin{tabular}{|c|c|}
\hline \multicolumn{2}{|c|}{ Portavoz del Grupo Mixto en el Senado } \\
\hline Alberto Dorrego González & $06-10-1986 / 22-10-1987$ \\
\hline Portavoz del Grupo Centro Democrático y Social \\
\hline Alberto Dorrego González & $22-10-1987 / \ldots{ }^{3}$ \\
\hline Miembros de la Diputación Permanente \\
\hline Alberto Dorrego González (titular) & $22-12-1988 / \ldots$ \\
\hline Antonio Valverde Ortega (suplente) & $22-12-1988 / \ldots$ \\
\hline & \\
\hline
\end{tabular}

\begin{tabular}{|c|c|}
\hline \multicolumn{2}{|c|}{ Comisiones } \\
\hline \multicolumn{2}{|c|}{ Comisión de Asuntos Exteriores } \\
\hline Alberto Dorrego González & $27-10-1987 / \ldots$ \\
\hline \multicolumn{2}{|c|}{ Comisión de Autonomías y Organización y Administración Territorial } \\
\hline Fernando Castedo Álvarez & $27-10-1987 / 06-02-1989$ \\
\hline Manuel Martínez Sospedra & $06-02-1989 / \ldots$ \\
\hline \multicolumn{2}{|c|}{ Constitución } \\
\hline Fernando Castedo Álvarez & $27-10-1987 / 09-02-1989$ \\
\hline Manuel Martínez Sospedra & $09-02-1989 / \ldots$ \\
\hline \multicolumn{2}{|c|}{ Defensa } \\
\hline Tirso Tomás González & $11-11-1987 / 06-02-1989$ \\
\hline Manuel Martínez Sospedra & $06-02-1989 / \ldots$ \\
\hline \multicolumn{2}{|c|}{ Economía y Hacienda } \\
\hline JoséLuis Sagredo de Miguel & $27-10-1987 / 12-04-1988$ \\
\hline Fernando Chueca Aguinaga & $12-04-1988 / 24-05-1989$ \\
\hline Francisco Quetglás Rosanes & $24-05-1989 / \ldots$ \\
\hline \multicolumn{2}{|c|}{ Educación, Universidades, Investigación y Cultura } \\
\hline Antonio Valverde Ortega & $20-10-1987 / \ldots$ \\
\hline \multicolumn{2}{|c|}{ Industria y Energía, Comercio y Turismo } \\
\hline Tirso Tomás González & 27-10-1987/06-02-1989 \\
\hline Ángel Hernández Benito & $06-02-1989 / \ldots$ \\
\hline \multicolumn{2}{|c|}{ Justicia } \\
\hline Juan José Otamendi Rodríguez -Bethencourt & $27-10-1987 / \ldots{ }^{5}$ \\
\hline Fernando Chueca Goitia & $24-05-1989 / \ldots$ \\
\hline \multicolumn{2}{|c|}{$\begin{array}{c}\text { Obras Públicas, Ordenación del Territorio y Medio Ambiente, Urbanismo, Transportes y } \\
\text { Comunicaciones }\end{array}$} \\
\hline Francisco Quetglás Rosanes & $27-10-1987 / 27-04-1988$ \\
\hline Ángel Hernández Benito & 27-04-1988/26-07-1989 \\
\hline Luis Aznar Fernández & $26-07-1989 / \ldots$ \\
\hline \multicolumn{2}{|c|}{ Presidencia del Gobierno e Interior } \\
\hline Tirso Tomás González & $17-09-1986 / \ldots$ \\
\hline
\end{tabular}

\footnotetext{
${ }^{1}$ S. a.: Memoria de la III Legislatura del Senado, Madrid, Secretaría General del Senado, 1990.

${ }^{2}$ No se ha tenido la presencia de Gerardo Mesa Noda y José Miguel Galván Bello quienes únicamente estuvieron en el Grupo del CDS en el Senado con la finalidad de facilitar la constitución del mismo, entre el 20 y 22 de octubre de 1987. En el caso de Senadores inicialmente en otros Grupos Parlamentarios o partidos políticos se han tenido en cuenta únicamente los períodos en los que ejercieron sus cargos como miembros del GPCDS.

${ }^{3}$ El 02 de septiembre de 1989 finalizó la Legislatura. El portavoz adjunto fue José Luis Sagredo de Miguel.

${ }^{4}$ Tras su reorganización el 23 de diciembre de 1988.

${ }^{5}$ Con la excepción del período comprendido entre el 24 de mayo y 27 de julio de 1989.
} 


\begin{tabular}{|c|c|}
\hline Juan José Otamendi Rodríguez -Bethencourt & $27-10-1987 / 24-05-1989$ \\
\hline Manuel Martínez Sospedra & $24-05-1989 / \ldots$ \\
\hline \multicolumn{2}{|c|}{ Presupuestos } \\
\hline Alberto Dorrego González & $16-09-1986 / \ldots$ \\
\hline Francisco Quetglás Rosanes & $20-10-1987 / 03-11-1988$ \\
\hline Fernando Chueca Aguinaga & $03-11-1988 / \ldots$ \\
\hline \multicolumn{2}{|c|}{ Sanidad y Seguridad Social $^{6}$} \\
\hline Alberto Dorrego González & $17-09-1986 / \ldots$ \\
\hline \multicolumn{2}{|c|}{ Trabajo } \\
\hline Celso Rodríguez Legido & $20-10-1987 / 27-07-1989$ \\
\hline Ángel Hernández Benito & $27-07-1989 / \ldots$ \\
\hline \multicolumn{2}{|c|}{ Peticiones } \\
\hline Celso Rodríguez Legido & $16-09-1986 / \ldots$ \\
\hline Ángel Hernández Benito & $27-07-1989 / \ldots$ \\
\hline \multicolumn{2}{|c|}{ Reglamento } \\
\hline Juan José Otamendi Rodríguez -Bethencourt & 27-10-1987/01-03-1988 \\
\hline Alberto Dorrego González & $01-03-1988 / \ldots$ \\
\hline \multicolumn{2}{|c|}{ Suplicatorios } \\
\hline Fernando Chueca Aguinaga & $27-10-1987 / 29-03-1988$ \\
\hline \multicolumn{2}{|c|}{ Incompatibilidades } \\
\hline Alberto Dorrego González & $16-07-1986 / \ldots$ \\
\hline Fernando Chueca Aguinaga & 27-04-1988/27-07-1988 \\
\hline Francisco Quetglás Rosanes & $27-10-1987 / \ldots 7$ \\
\hline
\end{tabular}

\begin{tabular}{|c|c|}
\hline \multicolumn{2}{|c|}{ Comisiones no legislativas } \\
\hline Relaciones con el Defensor del Pueblo y de los Derechos Humanos \\
\hline Fernando Castedo Álvarez & $10-11-1987 / 27-04-1988$ \\
\hline Comisión de seguimiento del Fondo de Compensación Interterritorial \\
\hline José Luis Sagredo de Miguel & $27-10-1987 / 05-06-1989$ \\
\hline Luis Aznar Fernández & $27-07-1989 / \ldots$ \\
\hline
\end{tabular}

\begin{tabular}{|c|c|}
\hline \multicolumn{2}{|c|}{ Comisiones de investigación o no especiales $^{\mathbf{8}}$} \\
\hline \multicolumn{2}{|c|}{ Comisión Especial de Investigación sobre Incendios Forestales } \\
\hline Tirso Tomás González & $27-10-1987 / \ldots$ \\
\hline $\begin{array}{c}\text { Comisión Especial de Investigación de la violencia en los espectáculos deportivos, con especial } \\
\text { referencia al fútbol }\end{array}$ \\
\hline \multicolumn{2}{|c|}{ Antonio Valverde Ortega } \\
\hline
\end{tabular}

\footnotetext{
${ }^{6}$ En esta Comisión se formó una Ponencia sobre el tratamiento y reinserción de toxicómanos y alcohólicos en la que participó Alberto Dorrego González (CDS).

${ }^{7}$ Salvo el período comprendido entre el 27 de abril de 1988 y el 27 de julio de 1989.

${ }^{8}$ Las comisiones mixtas se incluyen en los anexos relativos al Congreso de los Diputados.
} 
Grupo Parlamentario del CDS en el Senado: constitución y variaciones ${ }^{9}$

\begin{tabular}{|c|c|c|c|c|c|}
\hline Nombre & Circunscripción & Profesión & $\begin{array}{c}\text { Militancia política } \\
\text { previa }\end{array}$ & Designación & Fechas \\
\hline $\begin{array}{c}\text { Alberto M. } \\
\text { Dorrego } \\
\text { González } \\
\text { (Portavoz) }\end{array}$ & Ávila & Médico & UCD (Partido Popular) & Electo & $\begin{array}{c}15-07-1986 / \\
20-11- \\
1989^{10}\end{array}$ \\
\hline $\begin{array}{l}\text { Tomás } \\
\text { González } \\
\text { Tirso }\end{array}$ & Ávila & $\begin{array}{l}\text { Industrial } \\
\text { Maderero }\end{array}$ & UCD & Electo & $\begin{array}{l}15-07-1986 / \\
02-09-1989\end{array}$ \\
\hline $\begin{array}{l}\text { Luis Aznar } \\
\text { Fernández }\end{array}$ & $\begin{array}{l}\text { Castilla-León } \\
\text { (León) }\end{array}$ & Funcionario & UCD & Autonómico & $\begin{array}{c}20-06-1989 / \\
02-09-1989 \\
\end{array}$ \\
\hline $\begin{array}{l}\text { Fernando } \\
\text { Castedo } \\
\text { Álvarez }\end{array}$ & Com. Madrid & Abogado & - & Autonómico & $\begin{array}{l}08-10-1987 / \\
02-09-1989\end{array}$ \\
\hline $\begin{array}{c}\text { Celso } \\
\text { Rodríguez } \\
\text { Legido }\end{array}$ & Ávila & $\begin{array}{c}\text { Ingeniero Téc. } \\
\text { Agrícola }\end{array}$ & - & Electo & $\begin{array}{l}15-07-1986 / \\
02-09-1989\end{array}$ \\
\hline $\begin{array}{l}\text { José Luis } \\
\text { Sagredo de } \\
\text { Miguel }\end{array}$ & $\begin{array}{l}\text { Castilla-León } \\
\text { (Salamanca) }\end{array}$ & Abogado & - & Autonómico & $\begin{array}{l}30-07-1987 / \\
31-05-1989\end{array}$ \\
\hline $\begin{array}{l}\text { Francisco } \\
\text { Quetglás } \\
\text { Rosanes }\end{array}$ & Islas Baleares & Funcionario & - & Autonómico & $\begin{array}{l}28-07-1987 / \\
20-10-1987\end{array}$ \\
\hline $\begin{array}{c}\text { Juan José } \\
\text { Otamendi } \\
\text { Rodríguez- } \\
\text { Bethencourt }\end{array}$ & Navarra & Abogado & - & Autonómico & $\begin{array}{l}08-10-1987 / \\
02-09-1987\end{array}$ \\
\hline $\begin{array}{c}\text { Manuel } \\
\text { Martínez } \\
\text { Sospedra } \\
\end{array}$ & $\begin{array}{l}\text { Comunidad } \\
\text { Valenciana } \\
\text { (Valencia) } \\
\end{array}$ & $\begin{array}{l}\text { Profesor de } \\
\text { Universidad }\end{array}$ & - & Autonómico & $\begin{array}{l}22-11-1988 / \\
02-09-1989\end{array}$ \\
\hline $\begin{array}{c}\text { Ángel } \\
\text { Hernández } \\
\text { Benito }\end{array}$ & Zamora & $\begin{array}{l}\text { Profesor de } \\
\text { EGB }\end{array}$ & Partido Liberal (CP) & Otros partidos & $\begin{array}{l}29-03-1988 / \\
02-09-1989\end{array}$ \\
\hline $\begin{array}{l}\text { Antonio } \\
\text { Valverde } \\
\text { Ortega }\end{array}$ & Burgos & $\begin{array}{c}\text { Profesor de } \\
\text { Enseñanza } \\
\text { Media }\end{array}$ & $\begin{array}{l}\text { Partido Demócrata } \\
\text { Popular (CP) }\end{array}$ & Otros partidos & $\begin{array}{c}20-10-1987 / \\
20-11- \\
1989^{11}\end{array}$ \\
\hline $\begin{array}{l}\text { Fernando } \\
\text { Chueca } \\
\text { Aguinaga }\end{array}$ & Toledo & Economista & Partido Liberal (CP) & Otros partidos & $\begin{array}{l}29-03-1988 / \\
02-09-1989\end{array}$ \\
\hline \multicolumn{6}{|c|}{ Acuerdos y participación en el GPCDS para facilitar la formación del grupo } \\
\hline $\begin{array}{c}\text { Gerardo } \\
\text { Mesa Noda }\end{array}$ & Fuerteventura & Administrativo & Asamblea Majorera & Otros partidos & $\begin{array}{c}20-10-1987 / \\
22-10- \\
1987^{12}\end{array}$ \\
\hline $\begin{array}{l}\text { José Miguel } \\
\text { Galván Bello }\end{array}$ & Tenerife & Ingeniero & $\begin{array}{c}\text { UCD, Agrupación } \\
\text { Tinerfeña } \\
\text { Independiente (AIC) }\end{array}$ & Otros partidos & $\begin{array}{c}20-10-1987 / \\
22-10- \\
1987^{13}\end{array}$ \\
\hline
\end{tabular}

9 En el Grupo Mixto: 15-07-1986/20-10-1987. Se formó gracias al nombramiento de senadores autonómicos tras las elecciones municipales y Autonómicas de 1987.

${ }^{10}$ Miembro de la Diputación Permanente del Senado.

${ }^{11}$ Miembro suplente de la Diputación Permanente del Senado.

12 Acuerdo para la formación del Grupo Parlamentario del CDS en el Senado.

${ }^{13}$ Acuerdo para la formación del Grupo Parlamentario del CDS en el Senado. 


\section{Ponencias en Proyectos de Ley}

\begin{tabular}{|c|c|}
\hline Nombre & $\begin{array}{c}\text { Ponencias (proyectos y } \\
\text { proposiciones de ley) }\end{array}$ \\
\hline Alberto M. Dorrego González (Portavoz) & - \\
\hline Tomás González Tirso & - \\
\hline Luis Aznar Fernández & - \\
\hline Fernando Castedo Álvarez & - \\
\hline Celso Rodríguez Legido & - \\
\hline José Luis Sagredo de Miguel & - \\
\hline Francisco Quetglás Rosanes & 3 \\
\hline Manuel Martínez Sospedra & 6 \\
\hline Ángel Hernández Benito & - \\
\hline Antonio Valverde Ortega & - \\
\hline Fernando Chueca Aguinaga & - \\
\hline
\end{tabular}

Proposiciones de Ley iniciadas en el Senado ${ }^{14}$

\begin{tabular}{|c|c|}
\hline CP & 10 \\
\hline CiU & 4 \\
\hline PSOE & 2 \\
\hline DC-Mixto & 2 \\
\hline CDS & 11 \\
\hline Grupo Mixto & 1 \\
\hline
\end{tabular}

\section{Resumen actos de control}

\begin{tabular}{|c|c|c|c|}
\hline Tipo & CDS & Total & Observaciones \\
\hline Preguntas Orales (pleno y comisión) & 116 & 273 & El CDS es el $2^{\circ}$ por detrás de CP \\
\hline Preguntas Escritas & 72 & 5711 & $\begin{array}{c}\text { El CDS es el } 6^{\circ} \text { por detrás de CP, } \\
\text { ADC, Mixto, PL y CiU }\end{array}$ \\
\hline Interpelaciones & 49 & 261 & $\begin{array}{c}\text { El CDS es el } 3^{\circ} \text { por detrás de } \mathrm{CP} \text { y } \\
\text { Mixto }\end{array}$ \\
\hline Mociones & 14 & 104 & $\begin{array}{c}\text { El CDS es el } 3^{\circ} \text { por detrás de CP y } \\
\text { Mixto. Igual que DC. }\end{array}$ \\
\hline
\end{tabular}

${ }^{14}$ Proposición de Ley Orgánica por la que se modifica el artículo 14.4 del Código Civil; Proposición de Ley modificndo la Disposición Adicional decimoquinta de la Ley de Medidas para al reforma de la Función Pública 


\section{Anexo XVIII}

Asambleas provinciales o federales celebradas entre finales de 1986 y 1989

\begin{tabular}{|c|c|c|}
\hline Provincia/ C.A. & Asamblea & Fecha \\
\hline Albacete & II Asamblea Provincial & - \\
\hline Alicante & - & - \\
\hline Castilla y León & II Congreso Federal (León) & Marzo de 1987 \\
\hline Canarias & II Congreso Federal (Tenerife) & Abril de 1987 \\
\hline Álava & I Asamblea Provincial & Marzo de 1987 \\
\hline Almería & I Asamblea Provincial & Abril de 1987 \\
\hline Asturias & III Congreso Federal & Julio de 1988 \\
\hline Ávila & III Asamblea Provincial & Febrero de 1987 \\
\hline Extremadura & I Congreso Federal (Mérida) & Marzo de 1987 \\
\hline Badajoz & II Asamblea Provincial & Junio de 1988 \\
\hline Baleares (Ibiza) & I Asamblea Insular & Mayo de 1987 \\
\hline Baleares (Mallorca) & - & - \\
\hline Baleares (Menorca) & - & - \\
\hline Burgos & II Asamblea Provincial & Marzo de 1989 \\
\hline Cataluña & I Congreso Federal (Platja d'Aro) & Marzo de 1987 \\
\hline Barcelona & II Asamblea Provincial & Abril de 1989 \\
\hline Cáceres & II Asamblea Provincial & Junio de 1988 \\
\hline Cádiz & II Asamblea Provincial & Noviembre de 1988 \\
\hline Fuerteventura & II Asamblea Insular & Febrero de 1987 \\
\hline Hierro & II Asamblea Insular & Diciembre de 1986 \\
\hline Lanzarote & II Asamblea Insular & Diciembre de 1986 \\
\hline La Palma & II Asamblea Insular & Febrero de 1987 \\
\hline Las Palmas & II Asamblea Insular & Febrero de 1987 \\
\hline Tenerife & II Asamblea Insular & Diciembre de 1986 \\
\hline Cantabria & II Congreso Federal & Octubre de 1986 \\
\hline Comunidad Valenciana & I Congreso Federal (Castellón) & Marzo de 1988 \\
\hline Castellón & II Asamblea Provincial & Febrero de 1987 \\
\hline Ceuta & II Asamblea & Verano de 1988 \\
\hline Ciudad Real & II Asamblea & Noviembre de 1987 \\
\hline Castilla La Mancha & I Congreso Federal & Abril de 1987 \\
\hline Córdoba & II Asamblea Provincial & Abril de 1989 \\
\hline La Coruña & II Asamblea Provincial & Febrero de 1987 \\
\hline Cuenca & II Asamblea Provincial & Enero de 1988 \\
\hline Gerona & I Asamblea Provincial & Diciembre de 1988 \\
\hline Granada & II Asamblea Provincial & Febrero/marzo de 1987 \\
\hline Guadalajara & II Asamblea Provincial & Enero de 1989 \\
\hline Guipúzcoa & - & - \\
\hline Huelva & II Asamblea Provincial & Junio de 1988 \\
\hline Huesca & II Asamblea Provincial & Febrero de 1988 \\
\hline Jaén & II Asamblea Provincial & Marzo de 1988 \\
\hline León & II Asamblea Provincial & Junio de 1987 \\
\hline Lérida & II Asamblea Provincial & Abril de 1987 \\
\hline Lugo & II Asamblea Provincial & Abril de 1989 \\
\hline Madrid & II Congreso Federal & - \\
\hline Málaga & II Asamblea Provincial & Diciembre de 1987 \\
\hline Melilla & I Asamblea & Abril de 1987 \\
\hline Murcia & II Congreso Federal & Mayo de 1988 \\
\hline Navarra & II Congreso Federal & Junio de 1988 \\
\hline Orense & II Asamblea Provincial & Septiembre de 1987 \\
\hline Palencia & II Asamblea Provincial & Abril de 1989 \\
\hline Pontevedra & II Asamblea Provincial & Marzo de 1987 \\
\hline
\end{tabular}




\begin{tabular}{|l|l|l|}
\hline La Rioja & II Congreso Federal & Junio de 1988 \\
\hline Salamanca & II Asamblea Provincial & Mayo 1988 \\
\hline Segovia & II Asamblea Provincial & Mayo de 1988 \\
\hline Sevilla & II Asamblea Provincial & - \\
\hline Soria & - & - \\
\hline Tarragona & II Asamblea Provincial & Diciembre de 1986 \\
\hline Teruel & II Asamblea Provincial & Julio de 1988 \\
\hline Toledo & II Asamblea Provincial & Julio de 1987 \\
\hline Valencia & II Asamblea Provincial & Abril de 1989 \\
\hline Valladolid & II Asamblea Provincial & Junio de 1988 \\
\hline Vizcaya & - & - \\
\hline Zamora & II Asamblea Provincial & Noviembre de 1986 \\
\hline Zaragoza & II o III Asamblea Provincial & Diciembre de 1985 \\
\hline Aragón & I Congreso Federal & Marzo de 1987 \\
\hline
\end{tabular}

Elaboración propia a partir de fuentes hemerográficas y AGP. 


\section{Anexo XIX}

Análisis de las trayectorias políticas del Comité Nacional

\begin{tabular}{|c|c|c|c|c|}
\hline Comité & Trayectoria polític & & & \\
\hline Nombre & $\begin{array}{l}\text { Dictadura/ } \\
\text { oposición }\end{array}$ & $\begin{array}{l}\text { Partidos 1976- } \\
1977\end{array}$ & $\begin{array}{l}\text { UCD (máxima } \\
\text { responsabilidad) }\end{array}$ & Profesión \\
\hline Adolfo Suárez & Régimen & $\begin{array}{l}\text { UDPE - Grupo de } \\
\text { Independientes } \\
\text { (Cortes) }\end{array}$ & Presidente & Abogado \\
\hline León Buil Giral & $\begin{array}{l}\text { Oposición } \\
\text { democristiana } \\
\text { (Tácito) }\end{array}$ & $\begin{array}{l}\text { PPA } \\
\text { PP }\end{array}$ & Diputado & Jurista \\
\hline $\begin{array}{l}\text { Alejandro } \\
\text { Rebollo }\end{array}$ & $\begin{array}{l}\text { Buffer zone - } \\
\text { PROLESA }\end{array}$ & - & $\begin{array}{l}\text { Direcciones } \\
\text { generales } \quad \text { y } \\
\text { subsecretarías }\end{array}$ & Abogado \\
\hline $\begin{array}{l}\text { José } \quad \text { Ramón } \\
\text { Caso }\end{array}$ & - & - & $\begin{array}{l}\text { Dirección } \\
\text { general/ } \\
\text { Secretario } \\
\text { Organización } \\
\end{array}$ & Empresa \\
\hline $\begin{array}{l}\text { Agustín } \\
\text { Rodríguez } \\
\text { Sahagún }\end{array}$ & $\begin{array}{l}\text { Buffer zone - } \\
\text { Grupo Libra }\end{array}$ & - & $\begin{array}{l}\text { Ministro/ } \\
\text { Presidente }\end{array}$ & Empresa \\
\hline Federico Ysart & Buffer zone ${ }^{I}$ & - & Diputado & Periodista \\
\hline $\begin{array}{ll}\text { José } & \text { Luis } \\
\text { González } & \\
\text { Quirós } & \\
\end{array}$ & - & - & Cargos orgánicos & $\begin{array}{l}\text { Periodista } \\
\text { Filósofo }\end{array}$ \\
\hline $\begin{array}{ll}\text { Rafael } & \text { Calvo } \\
\text { Ortega } & \end{array}$ & Buffer zone & $\begin{array}{l}\text { Partido Social } \\
\text { Democrático } \\
\text { (García López) }\end{array}$ & $\begin{array}{l}\text { Ministro/ } \\
\text { Secretario } \\
\text { General }\end{array}$ & Catedrático \\
\hline Abel Cádiz & - & - & $\begin{array}{l}\text { Presidente UCD- } \\
\text { Madrid }\end{array}$ & Marketing/Empresa \\
\hline $\begin{array}{ll}\text { Jesús } & \text { María } \\
\text { Viana } & \\
\end{array}$ & Buffer zone & - & $\begin{array}{l}\text { Consejero País } \\
\text { Vasco }\end{array}$ & Empresa \\
\hline $\begin{array}{ll}\text { Joaquín } & \text { Abril } \\
\text { Martorell } & \end{array}$ & - & - & $\begin{array}{l}\text { Presidencia de } \\
\text { empresas } \\
\text { públicas }\end{array}$ & Ingeniero \\
\hline $\begin{array}{l}\text { Manuel de } \\
\text { Sárraga Gómez }\end{array}$ & - & - & $\begin{array}{l}\text { Diputado } \\
\text { (Independientes) }\end{array}$ & Abogado \\
\hline $\begin{array}{l}\text { Fernando } \\
\text { Castedo } \\
\text { Álvarez } \\
\end{array}$ & Buffer zone & $\mathrm{PP}$ & Director RTVE & Abogado \\
\hline $\begin{array}{l}\text { Manuel } \\
\text { Jiménez de } \\
\text { Parga }\end{array}$ & Oposición (UE) & - & Ministro & Catedrático \\
\hline $\begin{array}{l}\text { Miguel Ángel } \\
\text { Eced }\end{array}$ & - & - & Director General & Empresa \\
\hline $\begin{array}{l}\text { José Antonio } \\
\text { Escudero }\end{array}$ & - & - & Diputado & Catedrático \\
\hline $\begin{array}{l}\text { Alfredo Marco } \\
\text { Tabar }\end{array}$ & Régimen & - & UCD & Abogado \\
\hline $\begin{array}{l}\text { José } \quad \text { Vicente } \\
\text { Cebrián }\end{array}$ & - & PSDE & $\begin{array}{l}\text { Coordinador } \\
\text { UCD (1977) }\end{array}$ & - \\
\hline Laura Morso & Buffer zone & $\mathrm{PP}$ & Subsecretaría & Administración \\
\hline
\end{tabular}

\footnotetext{
${ }^{1}$ Para Carlos Huneeus, medios como Cambio 16, en los que trabajó Federico Ysart, puede ser vista "como el mejor ejemplo de los intereses de los individuos situados en esta zona [buffer zone]", HUNEEUS, Carlos: La Unión..., p. 31.
} 


\begin{tabular}{|c|c|c|c|c|}
\hline $\begin{array}{l}\text { Gerardo } \\
\text { Harguindey }\end{array}$ & Buffer zone & - & Senador & Administración \\
\hline Javier Soto & - & - & Concejal Madrid & Administración \\
\hline Emilio Pujalte & - & - & Director General & - \\
\hline $\begin{array}{l}\text { Francisco } \\
\text { Villodres }\end{array}$ & - & PSDE & Senador & Asesor Fiscal \\
\hline Carlos Revilla & Oposición - PSOE & PSOE & - & Médico \\
\hline Raúl Morodo & Oposición - PSP & PSP & - & Catedrático \\
\hline José Luis Garro & - & - & Cargos orgánicos & - \\
\hline Manuel Garrido & - & - & Cargos orgánicos & Ingeniero Industrial \\
\hline Lorenzo Olarte & Régimen & $\begin{array}{l}\text { Procurador Cortes } \\
\text { (Independientes) } \\
\text { Unión Canaria }\end{array}$ & $\begin{array}{ll}\text { Consejero } & \text { de } \\
\text { Presidencia } & \end{array}$ & Abogado \\
\hline $\begin{array}{ll}\text { José } & \text { Luis } \\
\text { Merino } & \end{array}$ & Buffer zone & $\begin{array}{l}\text { Federación de la } \\
\text { Democracia } \\
\text { Cristiana }\end{array}$ & $\begin{array}{l}\text { Consejero } \\
\text { Aragón }\end{array}$ & Notario \\
\hline Rosa Posada & - & - & $\begin{array}{lr}\text { Asesora } & \text { y } \\
\text { Directora } & \text { del } \\
\text { Gabinete Político } \\
\text { del Presidente del } \\
\text { Gobierno Adolfo } \\
\text { Suárez }\end{array}$ & Abogada \\
\hline $\begin{array}{l}\text { Alberto } \\
\text { Dorrego }\end{array}$ & - & - & Senador & Médico \\
\hline Enrique Egea & - & PSDE & Diputado & Catedrático \\
\hline $\begin{array}{l}\text { Antoni } \\
\text { Fernández } \\
\text { Teixidó } \\
\end{array}$ & - & $\begin{array}{l}\text { Organización } \\
\text { Revolucionaria del } \\
\text { Trabajo }\end{array}$ & - & Titulado Mercantil \\
\hline $\begin{array}{l}\text { José } \quad \text { Ramón } \\
\text { Lasuén }\end{array}$ & Buffer zone & $\begin{array}{l}\text { Federación Social } \\
\text { Demócrata }\end{array}$ & $\begin{array}{l}\begin{array}{l}\text { Diputado } \\
\text { (expulsado en } \\
1978)\end{array} \\
\end{array}$ & Catedrático \\
\hline Tomás Martín & - & - & $\begin{array}{l}\text { Consejero } \\
\text { Extremadura }\end{array}$ & Maestro \\
\hline $\begin{array}{l}\text { Rafael } \\
\text { Martínez- } \\
\text { Campillo } \\
\end{array}$ & - & - & Cargos orgánicos & $\begin{array}{l}\text { Abogado/ } \\
\text { Administración }\end{array}$ \\
\hline Eduard Punset & Oposición - PCE & - & Ministro & Empresa \\
\hline $\begin{array}{l}\text { Guadalupe } \\
\text { Ruiz-Giménez }\end{array}$ & - & - & Cargos orgánicos & - \\
\hline $\begin{array}{l}\text { Manuel } \\
\text { Sánchez }\end{array}$ & 2 & - & - & Maestro \\
\hline
\end{tabular}

Elaboración propia a partir de información aportada en el epígrafe 7.4.

\footnotetext{
${ }^{2}$ Concejal en el Ayuntamiento de Estepona desde 1974 e integrante de Democracia Cristiana Andaluza, posteriormente en UCD, véase, El País, 28 de marzo de 1986.
} 


\section{Anexo XX}

Miembros del CDS en los Órganos de Gobierno del Congreso de los Diputados en la IV Legislatura ${ }^{1}$

\begin{tabular}{|c|c|c|}
\hline Órgano & Nombre & Fecha de alta y baja \\
\hline \multicolumn{3}{|l|}{ Junta de Portavoces } \\
\hline Titulares & José Ramón Caso García & 05-10-1991/13-04-1993 \\
\hline & Alejandro Rebollo Álvarez-Amandi & $30-11-1989 / 15-10-1991$ \\
\hline Suplentes & Rafael Martínez-Campillo García & 19-05-1992/13-04-1993 \\
\hline & Carlos Revilla Rodríguez & $30-11-1989 / 19-05-1992$ \\
\hline & José Antonio Souto Paz & 19-05-1992/13-04-1993 \\
\hline
\end{tabular}

\begin{tabular}{|c|c|c|}
\hline Órgano & Nombre & Fecha de alta y baja ${ }^{2}$ \\
\hline \multicolumn{3}{|l|}{ Diputación Permanente } \\
\hline \begin{tabular}{l|l} 
& Titulares \\
\end{tabular} & José Ramón Caso García & 26-11-1991/29-06-1993 \\
\hline & Adolfo Suárez González & 21-12-1989/29-10-1991 \\
\hline & Alejandro Rebollo Álvarez-Amandi & $\begin{array}{l}26-12-1989 / 26-11-1991 \\
26-05-1992 / 29-06-1993\end{array}$ \\
\hline & Antonio Fernández Teixidó & 07-02-1989/01-09-1989 \\
\hline Suplentes & Joaquín Abril Martorell & \\
\hline & León Buil Giral & 28-07-1986/01-09-1989 \\
\hline & José Ramón Caso García & $28-07-1986 / 27-04-1988$ \\
\hline & Alejandro Rebollo Álvarez-Amandi & 27-04-1988/21-11-1989 \\
\hline & Carlos Revilla Rodríguez & 01-09-1989/21-11-1989 \\
\hline
\end{tabular}

\begin{tabular}{|c|c|}
\hline \multicolumn{2}{|c|}{ Comisión de Agricultura, Ganadería y Pesca } \\
\hline José Alfredo Ferrer Gutiérrez & - \\
\hline Lorenzo Díaz Aguilar & - \\
\hline
\end{tabular}

\begin{tabular}{|c|c|}
\hline \multicolumn{2}{|c|}{ Comisión de Asuntos Exteriores } \\
\hline Rafael Arias-Salgado Montalvo & $26-11-1991 / 10-11-1992$ \\
\hline José Ramón Caso García & $13-10-1992 / \ldots$ \\
\hline Antonio Fernández Teixidó & $26-11-1991 / 29-09-1992$ \\
\hline Alejandro Rebollo Álvarez-Amandi & $17-11-1992 / \ldots$ \\
\hline Adolfo Suárez González & $\ldots . / 29-10-1991$ \\
\hline
\end{tabular}

\begin{tabular}{|c|c|}
\hline \multicolumn{2}{|c|}{ Comisión Constitucional } \\
\hline José Ramón Caso García & $26-11-1991 / \ldots$ \\
\hline Antonio Fernández Teixidó & $26-11-1991 / 29-09-1992$ \\
\hline Alejandro Rebollo Álvarez-Amandi & $\ldots . / 26-11-1991$ \\
\hline José Antonio Souto Paz & $17-11-1992 / \ldots$ \\
\hline Adolfo Suárez González & $\ldots . / 29-10-1991$ \\
\hline
\end{tabular}

\begin{tabular}{|c|c|}
\hline \multicolumn{2}{|c|}{ Comisión de Defensa } \\
\hline Manuel Alonso Losada & $17-11-1992 / \ldots$ \\
\hline José Ramón Caso García & $\ldots / 17-11-1992$ \\
\hline José Antonio Santos Miñón & - \\
\hline
\end{tabular}

\footnotetext{
${ }^{1}$ Elaborado a partir de GONZALO, Manuel y PAESA, María (eds.): Memoria de la IV Legislatura (1989-1993), Congreso de los Diputados, Madrid, 1995.

${ }^{2}$ En aquellos casos en que el Diputado no comenzó la Legislatura en el GP CDS se ha tenido en cuenta la fecha de alta en dicho grupo.
} 


\begin{tabular}{|c|c|}
\hline \multicolumn{2}{|c|}{ Comisión de Economía, Comercio y Hacienda } \\
\hline Joaquín Abril Martorell & - \\
\hline José Ramón Lasuén Sancho & $13-03-1990 / \ldots$ \\
\hline Baltasar Zárate Pérez de Ayala & $\ldots .13-03-1990$ \\
\hline
\end{tabular}

\begin{tabular}{|c|c|}
\hline \multicolumn{2}{|c|}{ Comisión de Educación y Cultura } \\
\hline Manuel Alonso Losada & $17-11-1992 / \ldots$ \\
\hline Rafael Arias-Salgado Montalvo & $16-04-1991 / 10-11-1992$ \\
\hline Fernando Castedo Álvarez & $\ldots .24-04-1990$ \\
\hline José Antonio Souto Paz & - \\
\hline
\end{tabular}

\begin{tabular}{|c|c|}
\hline \multicolumn{2}{|c|}{ Comisión de Industria, Obras Públicas y Servicios } \\
\hline Rafael Martínez-Campillo García & - \\
\hline Alejandro Rebollo Álvarez-Amandi & $26-11-1991 / \ldots$ \\
\hline José Antonio Santos Miñón & $\ldots .26-11-1991$ \\
\hline
\end{tabular}

\begin{tabular}{|c|c|}
\hline \multicolumn{2}{|c|}{ Comisión de Justicia e Interior } \\
\hline Fernando Castedo Álvarez & $\ldots / 24-04-1990$ \\
\hline José Antonio Santos Miñón & $12-06-1990 / \ldots$ \\
\hline José Antonio Souto Paz & - \\
\hline
\end{tabular}

\begin{tabular}{|c|c|}
\hline \multicolumn{2}{|c|}{ Comisión de Política Social y Empleo } \\
\hline Lorenzo Díaz Aguilar & $02-06-1992 / \ldots$ \\
\hline Antonio Fernández Teixidó & $\ldots . / 26-11-1991$ \\
\hline Laura Morso Pérez & $26-11-1991 / \ldots$ \\
\hline Carlos Revilla Rodríguez & $26-05-1991 / 05-05-1992$ \\
\hline
\end{tabular}

\begin{tabular}{|c|c|}
\hline \multicolumn{2}{|c|}{ Comisión de Presupuestos } \\
\hline Joaquín Abril Martorell & - \\
\hline José Ramón Lasuén Sancho & $13-03-1990 / \ldots$ \\
\hline Baltasar Zárate Pérez de Ayala & $13-03-1990 / \ldots$ \\
\hline
\end{tabular}

\begin{tabular}{|c|c|}
\hline \multicolumn{2}{|c|}{ Comisión de Régimen de las Administraciones Públicas } \\
\hline José Alfredo Ferrer Gutiérrez & - \\
\hline Baltasar Zárate Pérez de Ayala & - \\
\hline
\end{tabular}

\begin{tabular}{|c|c|}
\hline \multicolumn{2}{|c|}{ Comisión de Control Parlamentario de RTVE } \\
\hline Antonio Fernández Teixidó & $21-12-1989 / 21-11-1991$ \\
\hline Laura Morso Pérez & $21-11-1991 / \ldots$ \\
\hline Baltasar Zárate Pérez de Ayala & $21-12-1989 \ldots$ \\
\hline
\end{tabular}

\begin{tabular}{|c|c|}
\hline \multicolumn{2}{|c|}{ Comisión del Defensor del Pueblo } \\
\hline Antonio Fernández Teixidó & $\ldots / 21-11-1991$ \\
\hline Alejandro Rebollo Álvarez-Amandi & $21-11-1991 / \ldots$ \\
\hline José Antonio Santos Miñón & - \\
\hline
\end{tabular}

\section{Comisión Mixta de relaciones con el Defensor del Pueblo}


Comisión Mixta para las relaciones con el Tribunal de Cuentas Baltasar Zárate Pérez de Ayala

\begin{tabular}{|c|c|c|}
\hline \multicolumn{3}{|c|}{ Comisión Mixta para las Comunidades Europeas } \\
\hline Joaquín Abril Martorell & - & Diputado \\
\hline Franciso Quetglás Rosanes & $\ldots / 03-07-1991$ & Senador \\
\hline
\end{tabular}

\begin{tabular}{|c|c|c|}
\hline \multicolumn{2}{|c|}{ Comisión Mixta de Investigación Científica y Desarrollo Tecnológico } \\
\hline Joaquín Abril Martorell & - & Diputado \\
\hline Franciso Quetglás Rosanes & $\ldots . / 03-07-1991$ & Senador \\
\hline
\end{tabular}

\begin{tabular}{|c|c|}
\hline \multicolumn{2}{|c|}{ Comisión Estatuto de los Diputados } \\
\hline Carlos Revilla Rodríguez & $01 / 12 / 1989 / 05-12-1992$ \\
\hline José Antonio Souto Paz & $12-05-1992 / \ldots$ \\
\hline
\end{tabular}

\begin{tabular}{|l|l|}
\hline \multicolumn{2}{|c|}{ Comisión de Peticiones } \\
\hline Carlos Revilla Rodríguez & $21-12-1989 / 05-05-1992$ \\
\hline
\end{tabular}

\begin{tabular}{|c|c|}
\hline \multicolumn{2}{|c|}{ Comisión de Reglamento } \\
\hline José Ramón Caso & $21-12-1989 / \ldots$ \\
\hline Alejandro Rebollo Álvarez-Amandi & $21-12-1989 /$ \\
\hline
\end{tabular}

\section{Comisión de Investigación: Irregularidades proceso electoral del 29-O}

José Antonio Souto Paz

15-03-1990/...

\begin{tabular}{|l|c|}
\hline \multicolumn{2}{|c|}{ Comisión de Investigación: RENFE } \\
\hline Rafael Martínez-Campillo García & $27-12-1991 / \ldots$ \\
\hline
\end{tabular}

\begin{tabular}{|c|c|c|}
\hline \multicolumn{3}{|c|}{ Comisión Mixta: Estudio del problema de la droga } \\
\hline Carlos Revilla Rodríguez & $\ldots / 05-05-1992$ & Senador \\
\hline Juan José Otamendi Rodríguez-Bethencourt & $\ldots . / 08-07-1991$ & Senador \\
\hline
\end{tabular}

\begin{tabular}{|c|c|c|}
\hline \multicolumn{3}{|c|}{ Comisión Mixta: Derechos de la Mujer } \\
\hline José Alfredo Ferrer Gutiérrez & - & Diputado \\
\hline Francisco Quetglás Rosanes & $\ldots / 03-07-1991$ & Senador \\
\hline
\end{tabular}

Composición de las comisiones. Variaciones de acuerdo con las transformaciones existentes en los Grupos Parlamentarios y las Agrupaciones creadas en el seno del Grupo Mixto:

\begin{tabular}{|c|c|}
\hline \multicolumn{2}{|c|}{ Acuerdo de la Mesa de la Cámara de 20 de septiembre de 1989: } \\
\hline PSOE & 19 \\
\hline PP & 9 \\
\hline CDS & 2 \\
\hline CiU & 2 \\
\hline IU-IC & 2 \\
\hline PNV & 1 \\
\hline
\end{tabular}




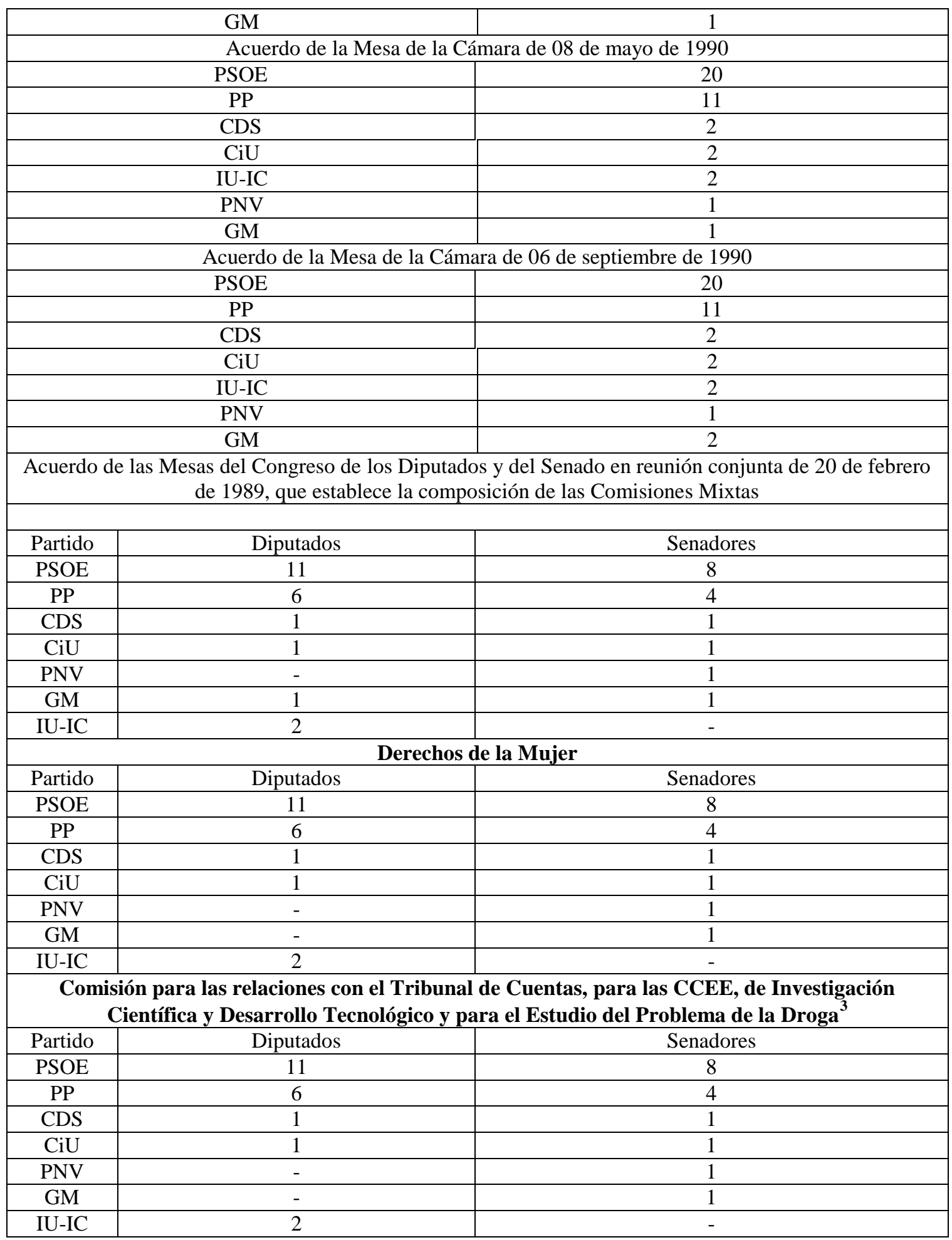

\footnotetext{
${ }^{3}$ El acuerdo de las Mesas del Congreso de los Diputados y del Senado del día 24 de septiembre de 1990 ratifica esta composición, agregando un diputado por el Grupo Mixto, al que se añade un diputado del GPNV en la Resolución de las Mesas del Congreso y del Senado de 08 de abril de 1991.
} 
La composición de las Ponencias. Variaciones a lo largo de la Legislatura.

\begin{tabular}{|c|c|}
\hline \multicolumn{2}{|c|}{ Acuerdo del día 19 de diciembre de 1989 } \\
\hline PSOE & 3 \\
\hline CP & 2 \\
\hline CDS & 1 \\
\hline CiU & 1 \\
\hline PNV & 1 \\
\hline IU-EC & 1 \\
\hline GM & 1 \\
\hline
\end{tabular}




\section{Anexo XXI}

Modificaciones del Grupo Parlamentario del Congreso de los Diputados en la IV Legislatura ${ }^{1}$

Altas a lo largo de la IV Legislatura en el GPCDS

\begin{tabular}{|c|c|c|}
\hline \multicolumn{2}{|c|}{ GRUPO PARLAMENTARIO CONGRESO CDS (Altas) } \\
\hline Nombre & Fecha alta GP CDS & Sustituto de... \\
\hline Rafael Arias-Salgado Montalvo & $24-04-1990$ & Fernando Castedo Álvarez \\
\hline Manuel Alonso Losada & $10-11-1992$ & Rafael Arias-Salgado Montalvo \\
\hline Laura Morso Pérez & $29-10-1991$ & Adolfo Suárez González \\
\hline
\end{tabular}

Bajas a lo largo de la IV Legislatura en el GPCDS

\begin{tabular}{|c|c|c|}
\hline \multicolumn{3}{|c|}{ GRUPO PARLAMENTARIO CONGRESO CDS (Bajas) } \\
\hline Nombre & Fecha baja GP CDS & Fin de Legislatura $^{\mathbf{2}}$ \\
\hline Fernando Castedo Álvarez & $24-04-1990$ & Abandona el escaño. Ingresa en el PSOE hacia 1993 \\
\hline Adolfo Suárez González & $29-10-1991$ & Abandona el escaño. \\
\hline Carlos Revilla Rodríguez & $05-05-1992$ & Se integra en el Grupo Mixto. \\
\hline Rafael Arias-Salgado Montalvo & $10-11-1992$ & Abandona el escaño. Ingresa en el PP hacia 1993 \\
\hline Antoni Fernández Teixidó & $29-09-1992$ & Se integra en el Grupo Mixto. Ingresa en CDC hacia 1993 \\
\hline
\end{tabular}

\footnotetext{
${ }^{1}$ Elaborado a partir de GONZALO, Manuel y PAESA, María (eds.): Memoria de la IV...

2 Basado en MENÉNDEZ, Miguel Ángel: “Los últimos del CDS”, Interviú, 03 de octubre de 1994.
} 


\section{Anexo XXII}

\section{Conjunto de Iniciativas Parlamentarias del Grupo Parlamentario CDS durante la IV Legislatura ${ }^{1}$}

\begin{tabular}{|c|c|c|c|c|c|c|c|c|c|c|}
\hline & Presentadas & $\begin{array}{l}\text { Admitidas } \\
\text { a trámite }\end{array}$ & Inadmitidas & Retiradas & Decaídas & Rechazadas & Caducadas & $\begin{array}{l}\text { Aprobadas con } \\
\text { modificaciones }\end{array}$ & $\begin{array}{l}\text { Aprobadas sin } \\
\text { modificacione } \\
\mathrm{S}\end{array}$ & $\begin{array}{l}\text { Convertidas }{ }^{2} / \mathrm{D} \\
\text { ebatidas }^{3} / \text { Conte } \\
\text { stadas }{ }^{4} / \text { Celebra } \\
\text { das }^{5}\end{array}$ \\
\hline $\begin{array}{l}\text { Proposiciones de } \\
\text { Ley }\end{array}$ & $14(9)$ & $14(9)$ & - & 1 & - & $8(1)$ & $3(7)$ & 1 & - & $1(1)^{7}$ \\
\hline $\begin{array}{l}\text { Proposiciones no } \\
\text { de Ley ante el } \\
\text { Pleno }\end{array}$ & $34(8)$ & $33(8)$ & - & 7 & - & 9 & $3(3)$ & 2 & $7(5)$ & - \\
\hline $\begin{array}{l}\text { Proposiciones no } \\
\text { de Ley para } \\
\text { debatir en } \\
\text { Comisión }\end{array}$ & $43(2)$ & $39(2)$ & $2^{8}$ & 4 & 2 & 13 & 5 & 11 & $2(2)$ & - \\
\hline $\begin{array}{l}\text { Interpelaciones } \\
\text { Ordinarias }\end{array}$ & 2 & 2 & - & - & - & - & - & - & - & 2 \\
\hline $\begin{array}{l}\text { Interpelaciones } \\
\text { Urgentes }\end{array}$ & 22 & 21 & 1 & - & - & - & - & - & - & 4 \\
\hline
\end{tabular}

${ }^{1}$ Se ha seguido el trabajo de Manuel Gonzalo y María Paesa en la obtención de los datos parciales y totales. En el caso de las "Proposiciones de Ley" ha sido contrastado con la información disponible en http://www.congreso.es

${ }^{2}$ En pregunta oral/escrita en el caso de las interpelaciones.

${ }^{3}$ En el caso de las interpelaciones urgentes.

${ }^{4}$ En el caso de las preguntas orales/escritas.

${ }^{5}$ Solicitudes de comparecencia.

${ }^{6}$ Se incluyen, por la decisiva importancia de esta función legislativa, las presentadas junto a GP, GC-CiU, GV-PNV, GIU-IC y GM, a GS, GC-CiU y GV-PNV y GS, GC-

CiU, GV-PNV, GIU-IC y GM. Salvo que sea el GCDS, "primer firmante", son computadas aparte en el resto de iniciativas de acuerdo con la obra de Manuel Gonzalo y

María Paesa, siendo el total de proposiciones de ley de 14.

7 Acumulada con otra iniciativa.

${ }^{8}$ No llegaron a la Mesa. 


\begin{tabular}{|c|c|c|c|c|c|c|c|c|c|c|}
\hline Mociones $^{9}$ & 18 & 18 & - & - & - & 10 & - & 8 & - & - \\
\hline $\begin{array}{l}\text { Preguntas con } \\
\text { respuesta oral en } \\
\text { el pleno }\end{array}$ & 139 & 130 & 9 & 5 & 20 & - & - & - & - & 105 \\
\hline $\begin{array}{l}\text { Preguntas orales } \\
\text { al Gobierno en } \\
\text { Comisión }\end{array}$ & 126 & 124 & 2 & 8 & 4 & - & 8 & - & - & $103^{11}$ \\
\hline $\begin{array}{l}\text { Preguntas orales } \\
\text { al Director del } \\
\text { Ente Público } \\
\text { RTVE }\end{array}$ & 46 & 41 & 5 & 3 & 6 & - & - & - & - & 14 \\
\hline $\begin{array}{l}\text { Preguntas al Ente } \\
\text { Público RTVE } \\
\text { con respuesta } \\
\text { escrita }\end{array}$ & 5 & 5 & - & - & - & - & - & - & - & 5 \\
\hline $\begin{array}{l}\text { Preguntas al } \\
\text { Gobierno con } \\
\text { respuesta escrita }\end{array}$ & 590 & 574 & 16 & 1 & - & - & 86 & - & - & 487 \\
\hline $\begin{array}{l}\text { Solicitudes de } \\
\text { informe }\end{array}$ & 34 & 16 & 18 & - & - & - & 2 & - & - & $5^{12}$ \\
\hline $\begin{array}{l}\text { Comparecencias } \\
\text { del Gobierno } \\
\text { ante el Pleno }\end{array}$ & 1 & - & 1 & - & - & - & - & - & - & - \\
\hline $\begin{array}{l}\text { Comparecencias } \\
\text { del Gobierno en } \\
\text { Comisión }\end{array}$ & 390 & 381 & 9 & 19 & 19 & 73 & 33 & - & |- & $195^{14}$ \\
\hline
\end{tabular}

\footnotetext{
${ }^{9}$ Consecuencia de interpelaciones urgentes

${ }^{10}$ A diferencia del resto de los mecanismos de control gubernamental las preguntas orales o escritas se presentan de forma individual.

${ }^{11}$ Una más fue "acumulada con otra iniciativa".

${ }^{12}$ Correspondientes a la "Administración del Estado".

${ }^{13}$ Debemos añadir: 2 solicitudes caducadas (una presentada junto a IU y otra junto al PNV), 2 celebradas (una junto a CiU y otra junto al PP, CiU, IU, PNV y G. Mixto), 1 convertida en comparecencia del Gobierno en Comisión (junto a IU), 1 rechazada (presentada junto a CiU, PNV, G. Mixto e IU).

${ }^{14}$ Debemos añadir: 24 no celebradas y 18 acumulada con otra iniciativa.
} 
Iniciativas Parlamentarias del GPCDS durante la IV Legislatura en el conjunto de la oposición ${ }^{15}$

\begin{tabular}{|c|c|c|c|}
\hline & Situación & $\begin{array}{l}\text { Porcentaje sobre el } \\
\text { total }\end{array}$ & Posición en el cómputo de GP de la oposición \\
\hline Proposiciones de Ley & $\begin{array}{l}\text { Aprobadas con/sin } \\
\text { modificaciones }\end{array}$ & 6,4 & $5^{\circ}(\mathrm{GS}, \mathrm{GC}-\mathrm{CiU}, \mathrm{GIU}-\mathrm{IC}, \mathrm{GP})$. \\
\hline \multirow{2}{*}{$\begin{array}{l}\text { Proposiciones no de Ley } \\
\text { para debatir en } \\
\text { Comisión/ante el Pleno }\end{array}$} & Admitidas a trámite & 8,6 & $4^{\circ}$ (GP, GIU-IC, GC-CiU). \\
\hline & $\begin{array}{l}\text { Aprobadas con/sin } \\
\text { modificaciones }\end{array}$ & 16,6 & $3^{\circ}$ (GIU-IC, GCP) \\
\hline \multirow[t]{2}{*}{ Interpelaciones Urgentes } & Admitidas a trámite & 11,29 & $3^{\circ}$ (GP, GIU-IC). \\
\hline & Debatidas & 12,58 & $3^{\circ}(\mathrm{GP}, \mathrm{GIU}-\mathrm{IC})$ \\
\hline \multirow[t]{2}{*}{ Mociones $^{17}$} & Admitidas a trámite & 12,41 & $3^{\circ}(\mathrm{GP}, \mathrm{GIU}-\mathrm{IC})$ \\
\hline & $\begin{array}{l}\text { Aprobadas con/sin } \\
\text { modificaciones }\end{array}$ & 22,85 & $3^{\circ}$ (GIU-IC, GP). \\
\hline $\begin{array}{l}\text { Preguntas con respuesta } \\
\text { oral en el Pleno }\end{array}$ & Admitidas a trámite & 6,6 & $5^{\circ}$ (GP, GS, GIU-IC, GC-CiU) \\
\hline \multirow{2}{*}{$\begin{array}{l}\text { Preguntas orales al director } \\
\text { del ente público de RTVE }\end{array}$} & Admitidas a trámite & 5,6 & $5^{\circ}$ (GS, GP, GIU-IC, GM). \\
\hline & Contestadas & 5 & $5^{\circ}(\mathrm{GS}, \mathrm{GP}, \mathrm{GIU}-\mathrm{IC}, \mathrm{GM})$. \\
\hline \multirow{2}{*}{$\begin{array}{l}\text { Preguntas al ente público } \\
\text { de RTVE con respuesta } \\
\text { escrita }\end{array}$} & Admitidas a trámite & 1,4 & $3^{\circ}(\mathrm{GP}, \mathrm{GIU}-\mathrm{IC})$ \\
\hline & Contestadas & 1,4 & $3^{\circ}(\mathrm{GP}, \mathrm{GIU}-\mathrm{IC})$ \\
\hline \multirow{2}{*}{$\begin{array}{l}\text { Preguntas al Gobierno con } \\
\text { respuesta escrita }\end{array}$} & Admitidas a trámite & 3,8 & $4^{\circ}$ (GP, GIU-IC, GM). \\
\hline & Contestadas & 3,4 & $4^{\circ}$ (GP, GIU-IC, GM). \\
\hline Solicitudes de informe ${ }^{18}$ & Admitidos a trámite & 0,3 & $6^{\circ}$ (GP, GIU-IC, GC-CiU, GS, GM). \\
\hline
\end{tabular}

${ }^{15}$ Iniciativas en solitario

${ }^{16}$ Se incluye: "Acumuladas con otra iniciativa".

${ }^{17}$ Consecuencia de interpelaciones urgentes

${ }^{18}$ Se tiene en cuenta el total de los mismos, referentes tanto a la Administración del Estado, la administración autonómica, y otras entidades. 


\begin{tabular}{|l|l|l|l|}
\hline & Contestados & 0,1 & $6^{\circ}$ (GP, GIU-IC, GC-CiU, GS, GM). \\
\hline \multirow{2}{*}{$\begin{array}{l}\text { Comparecencia del } \\
\text { Gobierno ante el Pleno }\end{array}$} & Admitidos a trámite & 1,7 & $\begin{array}{l}5^{\circ} \text { (GP, GIU-IC, GC-CiU, GM). El mismo número que } \\
\text { GS, GC-CiU, GV-PNV y GM. }\end{array}$ \\
\cline { 2 - 4 } & Celebrados & - & - \\
\hline $\begin{array}{l}\text { Comparecencia del } \\
\text { Gobierno en Comisión }\end{array}$ & Admitidos a trámite & 10,65 & $3^{\circ}$ (GP, GIU-IC). \\
\cline { 2 - 4 } & Celebrados & 9,3 & $3^{\circ}$ (GP, GIU-IC). \\
\hline
\end{tabular}

Iniciativas Parlamentarias del GPCDS durante la IV Legislatura desglosadas por diputados ${ }^{19}$

\begin{tabular}{|c|c|c|c|c|c|c|}
\hline & $\begin{array}{l}\text { Preguntas } \\
\text { Orales en } \\
\text { el Pleno }\end{array}$ & $\begin{array}{l}\text { Preguntas } \\
\text { Orales en } \\
\text { Comisión }\end{array}$ & $\begin{array}{l}\text { Preguntas al } \\
\text { Gobierno con } \\
\text { respuesta } \\
\text { escrita }^{20}\end{array}$ & $\begin{array}{l}\text { Preguntas al } \\
\text { Director de RTVE } \\
\text { /Consejo de } \\
\text { Administración } \\
\text { /Ente de RTVE con } \\
\text { respuesta escrita } \\
\end{array}$ & $\begin{array}{l}\text { Solicitud de informes a la } \\
\text { administración del Estado } \\
/(\text { Comunidades } \\
\text { autónomas }) \\
\text { /[Otras entidades ] }\end{array}$ & $\begin{array}{l}\text { Ponencias en } \\
\text { Proposiciones de Ley, } \\
\text { Proyectos de Ley, Reales } \\
\text { Decretos y Otros }\end{array}$ \\
\hline ABRIL MARTORELL, Joaquín & 4 & - & 1 & - & - & 9 \\
\hline ALONSO LOSADA, Manuel & 7 & 14 & 88 & - & 2 & - \\
\hline ARIAS-SALGADO MONTALVO, Rafael & 3 & 1 & - & - & 1 & 4 \\
\hline CASO GARCÍA José Ramón & 4 & 9 & 15 & - & - & 6 \\
\hline CASTEDO ÁLVAREZ, Fernando & - & - & - & - & $-[1]$ & 2 \\
\hline DÍAZ AGUILAR, Lorenzo & 3 & 2 & 7 & - & - & 1 \\
\hline FERNÁNDEZ TEIXIDÓ, Antonio & 4 & 2 & 235 & $14[4]$ & - & 5 \\
\hline FERRER GUTIÉRREZ, José Alfredo & 4 & 2 & 7 & - & - & 3 \\
\hline LASUÉN SÁNCHO, José Ramón & - & - & - & - & - & 19 \\
\hline MARTÍNEZ-CAMPILLO GARCÍA, Rafael & 15 & 23 & 46 & - & $6[2]$ & 14 \\
\hline MORSO PÉREZ, Laura & 1 & - & - & 22 & - & 4 \\
\hline REBOLLO ÁLVAREZ-AMANDI, Alejandro & 17 & 3 & 11 & - & 1 & 13 \\
\hline REVILLA RODRÍGUEZ, Carlos & 16 & 23 & 64 & - & 2 & 6 \\
\hline SANTOS MIÑÓN, José Antonio & 12 & 26 & 52 & $-[1]$ & 1 & 26 \\
\hline SOUTO PAZ, José Antonio & 13 & 9 & 12 & 1 & - & 18 \\
\hline
\end{tabular}

${ }^{19}$ En el caso de los diputados inscritos a lo largo de la Legislatura al GCDS o dados de baja sólo se han tenido en cuenta las intervenciones realizadas con dicho grupo. Asimismo, sólo se han contabilizado aquellas tramitadas.

${ }^{20}$ Debemos añadir una pregunta como CDS. 
SUÁREZ GONZÁLEZ Adolfo

$-$

$-$
$-$ 5 $-$ $-$ 


\section{Anexo XXIII}

Órganos de Gobierno y actividad legislativa en el Senado (CDS) (IV Legislatura 1989-1993)

\begin{tabular}{|c|c|}
\hline \multicolumn{2}{|c|}{ Portavoz del Grupo Centro Democrático y Social } \\
\hline $\begin{array}{c}\text { Alberto Dorrego González } \\
\text { Juan José Otamendi Rodríguez-Bethencourt } \\
\text { (adjunto) }\end{array}$ & $21-11-1989 / 08-07-1991$ \\
\hline \multicolumn{2}{|c|}{ Miembros de la Diputación Permanente } \\
\hline $\begin{array}{c}\text { Alberto Dorrego González (titular) } \\
\text { Juan José Otamendi Rodríguez-Bethencourt }\end{array}$ \\
\hline
\end{tabular}

\begin{tabular}{|c|c|}
\hline \multicolumn{2}{|c|}{ Comisiones } \\
\hline \multicolumn{2}{|c|}{ Comisión de Agricultura y Pesca } \\
\hline Alberto Dorrego González & $20-12-1989 / \ldots$ \\
\hline \multicolumn{2}{|c|}{ Comisión de Asuntos Exteriores } \\
\hline Alberto Dorrego González & 20-12-1989/11-07-1991 \\
\hline \multicolumn{2}{|c|}{ Comisión de Autonomías y Organización y Administración Territorial } \\
\hline Manuel Martínez Sospedra & $20-12-1989 / 11-07-1991$ \\
\hline \multicolumn{2}{|c|}{ Constitución } \\
\hline Manuel Martínez Sospedra & 20-12-1989/11-07-1991 \\
\hline \multicolumn{2}{|c|}{ Defensa } \\
\hline Manuel Martínez Sospedra & 20-12-1989/11-07-1991 \\
\hline \multicolumn{2}{|c|}{ Economía y Hacienda } \\
\hline Luis Aznar Fernández & 20-12-1989/15-04-1991 \\
\hline Francisco Quetglás Rosanes & 15-04-1991/03-07-1991 \\
\hline \multicolumn{2}{|c|}{ Educación, Universidades, Investigación y Cultura } \\
\hline Jesús Morales Morales & $20-12-1989 / 26-06-1990$ \\
\hline Alberto Dorrego González & $26-06-1990 / \ldots$ \\
\hline \multicolumn{2}{|c|}{ Industria y Energía, Comercio y Turismo } \\
\hline Fernando Alcón Sáez & $20-12-1989 / 10-09-1990$ \\
\hline Luis Aznar Fernández & 17-10-1991/11-07-1991 \\
\hline \multicolumn{2}{|c|}{ Justicia } \\
\hline Juan José Otamendi Rodríguez-Bethencourt & 20-12-1989/08-07-1991 \\
\hline \multicolumn{2}{|c|}{$\begin{array}{c}\text { Obras Públicas, Ordenación del Territorio y Medio Ambiente, Urbanismo, Transportes y } \\
\text { Comunicaciones }\end{array}$} \\
\hline Francisco Quetglás Rosanes & 20-12-1989/03-07-1991 \\
\hline \multicolumn{2}{|c|}{ Presidencia del Gobierno e Interior } \\
\hline Juan José Otamendi Rodríguez -Bethencourt & 20-12-1989/08-07-1991 \\
\hline \multicolumn{2}{|c|}{ Presupuestos } \\
\hline Francisco Quetglás Rosanes & 20-12-1989/03-07-1991 \\
\hline \multicolumn{2}{|c|}{ Sanidad y Seguridad Social } \\
\hline Alberto Dorrego González & $20-12-1989 / \ldots$ \\
\hline \multicolumn{2}{|c|}{ Trabajo } \\
\hline Gerardo Harguindey Bonet & 20-12-1989/19-07-1991 \\
\hline \multicolumn{2}{|c|}{ Incompatibilidades } \\
\hline Manuel Martínez Sospedra & $20-12-1989 / 11-07-1991$ \\
\hline \multicolumn{2}{|c|}{ Suplicatorios } \\
\hline Juan José Otamendi Rodríguez -Bethencourt & $20-12-1989 / 08-07-1991$ \\
\hline \multicolumn{2}{|c|}{ Peticiones } \\
\hline
\end{tabular}

\footnotetext{
${ }^{1}$ No se ha tenido la presencia de Gerardo Mesa Noda, Dimas Martín Martín, Juan José Pujana y Emilio Eiroa quienes únicamente estuvieron en el Grupo del CDS en el Senado con la finalidad de facilitar la constitución del mismo en noviembre de 1989. En el caso de Senadores inicialmente en otros Grupos Parlamentarios o partidos políticos se han tenido en cuenta únicamente los períodos en los que ejercieron sus cargos como miembros del GPCDS. Nos hemos basado en VV.AA.: Memoria de la IV Legislatura del Senado (1989-1993), Madrid, Secretaría General del Senado, 1995.
} 


\begin{tabular}{|c|cc|}
\hline Fernando Alcón Sáez & $20-12-1990 / 17-10-1990$ \\
\hline Alberto Dorrego González & \\
\hline & Reglamento \\
\hline Alberto Dorrego González & & $20-12-1989 / \ldots$ \\
\hline
\end{tabular}

\begin{tabular}{|c|c|}
\hline \multicolumn{2}{|c|}{ Comisiones no legislativas } \\
\hline \multicolumn{2}{|c|}{ Comisión de Asuntos Iberoamericanos } \\
\hline Alberto Dorrego González & $20-12-1989 / 16-09-1991$ \\
\hline Relaciones con el Defensor del Pueblo y de los Derechos Humanos \\
\hline Luis Aznar Fernández & $20-12-1989 / 19-07-1991^{2}$ \\
\hline Comisión de seguimiento del Fondo de Compensación Interterritorial \\
\hline Luis Aznar Fernández & $20-12-1989 / 19-07-1991$ \\
\hline Luis Aznar Fernández & $27-07-1989 / \ldots$ \\
\hline
\end{tabular}

\begin{tabular}{|c|c|}
\hline \multicolumn{2}{|c|}{ Comisiones de investigación o no especiales ${ }^{3}$} \\
\hline \multicolumn{2}{|c|}{$\begin{array}{c}\text { Comisión Especial de Investigación de la violencia en los espectáculos deportivos, con especial } \\
\text { referencia al fútbol }\end{array}$} \\
\hline Gerardo Harguindey Bonet & $20-12-1989 / \ldots$ \\
\hline \multicolumn{2}{|c|}{ Comisión Especial de Publicidad } \\
\hline Alberto Dorrego González & $19-06-1992 / \ldots$ \\
\hline \multicolumn{2}{|c|}{$\begin{array}{c}\text { Comisión Especial de Encuesta e Investigación sobre los problemas derivados del uso del } \\
\text { automóvil y de la Seguridad Vial }{ }^{4}\end{array}$} \\
\hline Manuel Martínez Sospedra (Presidente) & $-12-1989 / 26-09-1991$ \\
\hline
\end{tabular}

Grupo Parlamentario del CDS en el Senado. Variaciones.

\begin{tabular}{|c|c|c|c|c|c|}
\hline \multicolumn{7}{|c|}{$\begin{array}{l}\text { GRUPO PARLAMENTARIO SENADO CDS } \\
\text { Comenzó la Legislatura con 11 senadores. Se disolvió el 08 de julio de 1991. } \\
\text { Quedando únicamente: Alberto Dorrego González }\end{array}$} \\
\hline Nombre & Circunscripción & Profesión & $\begin{array}{c}\text { Militancia política } \\
\text { previa }\end{array}$ & Designación & Fechas \\
\hline $\begin{array}{c}\text { Alberto M. } \\
\text { Dorrego } \\
\text { González } \\
\text { (Portavoz) }\end{array}$ & Ávila & Médico & UCD (Partido Popular) & Electo & $\begin{array}{c}\text { En el Grupo } \\
\text { Mixto desde el } \\
11 \text { de julio de } \\
1991\end{array}$ \\
\hline $\begin{array}{c}\text { Fernando } \\
\text { Alcón Sáez }\end{array}$ & Ávila & Industrial & UCD & Electo & $05-12-1989 / 10-$ \\
\hline $\begin{array}{c}\text { Luis Aznar } \\
\text { Fernández }\end{array}$ & $\begin{array}{c}\text { Castilla-León } \\
\text { (León) }\end{array}$ & Funcionario & UCD & Autonómico & $\begin{array}{c}21-11-1990^{5} \\
07-11-\end{array}$ \\
\hline $\begin{array}{c}\text { Gerardo } \\
\text { Harguindey } \\
\text { Bonet }\end{array}$ & \begin{tabular}{c} 
Com. Madrid \\
\hline
\end{tabular} & Funcionario & UCD & Autonómico & $\begin{array}{c}21-11-1989 / 15- \\
07-1991\end{array}$ \\
\hline
\end{tabular}

\footnotetext{
${ }^{2}$ Participó en la Ponencia para el Estudio de la Pobreza y sus consecuencias en España, en el Grupo de Trbajo sobre problemática de la Tercera Edad, en el Grupo de Trabajo sobre el Estudio de Otros Trabajos y en el Grupo de Trabajo sobre el Tratamiento de la Correspondencia y Demandas a la Comisión de Españoles y Extranjeros creados por acuerdo de la Comisión el 28 de junio de 1990.

${ }^{3}$ Las comisiones mixtas se incluyen en los anexos relativos al Congreso de los Diputados.

${ }^{4}$ Cuya creación había sido solicitada por el GPCDS.

${ }^{5}$ Sentencia del Tribunal Constitucional 131/1990 de 16 de julio que obligó a la repetición en la localidad abulense de Mamblas. Previamente había sustituido "al señor Díaz de Mera y García Consuegra, en virtud de Sentencia del Tribunal Superior de Justicia de Castilla y León, de 2 de diciembre de 1989, posteriormente anulada por Sentencia del Tribunal Constitucional 27/1990, de 22 de febrero; alta el 13 de marzo de 1990, en virtud de Sentencia del Tribunal Superior de Justicia de Castilla y León de 28 de febrero de 1990", VV.AA.: Memoria de la IV Legislatura del Senado...
} 


\begin{tabular}{|c|c|c|c|c|c|}
\hline $\begin{array}{l}\text { Francisco } \\
\text { Quetglás } \\
\text { Rosanes }\end{array}$ & Islas Baleares & Funcionario & - & Autonómico & $\begin{array}{c}21-11-1989 / 03- \\
07-1991\end{array}$ \\
\hline $\begin{array}{c}\text { Juan José } \\
\text { Otamendi } \\
\text { Rodríguez- } \\
\text { Bethencourt }\end{array}$ & Navarra & Abogado & - & Autonómico & $\begin{array}{c}\text { 21-11-1989/08- } \\
07-1991\end{array}$ \\
\hline $\begin{array}{c}\text { Manuel } \\
\text { Martínez } \\
\text { Sospedra } \\
\end{array}$ & $\begin{array}{l}\text { Comunidad } \\
\text { Valenciana } \\
\text { (Valencia) }\end{array}$ & $\begin{array}{l}\text { Profesor de } \\
\text { Universidad }\end{array}$ & - & Autonómico & $\begin{array}{c}21-11-1989 / 18- \\
09-1991^{6}\end{array}$ \\
\hline $\begin{array}{l}\text { Jesús } \\
\text { Morales } \\
\text { Morales } \\
\end{array}$ & Canarias & $\begin{array}{l}\text { Profesor de } \\
\text { EGB }\end{array}$ & - & Autonómico & $\begin{array}{c}21-11-1989 / 15- \\
10-1991^{7}\end{array}$ \\
\hline \multicolumn{6}{|c|}{ Acuerdos y participación en el GPCDS para facilitar la formación del grupo } \\
\hline $\begin{array}{c}\text { Gerardo } \\
\text { Mesa Noda } \\
\end{array}$ & Fuerteventura & $\begin{array}{c}\text { Administrati } \\
\text { vo }\end{array}$ & Asamblea Majorera & Otros partidos & $\begin{array}{c}21-11-1989-28- \\
11-1989 \\
\end{array}$ \\
\hline $\begin{array}{c}\text { Juan José } \\
\text { Pujana Arza }\end{array}$ & País Vasco & Abogado & PNV, EA & Otros partidos & $\begin{array}{c}21-11-1989-28- \\
11-1989\end{array}$ \\
\hline $\begin{array}{c}\text { Emilio Eiroa } \\
\text { García }\end{array}$ & Aragón & Abogado & PAR & Otros partidos & $\begin{array}{c}21-11-1989-28- \\
11-1989\end{array}$ \\
\hline $\begin{array}{l}\text { Dimas } \\
\text { Martín } \\
\text { Martín }\end{array}$ & Lanzarote & -- & $\begin{array}{c}\text { PIL (Partido } \\
\text { Independientes de } \\
\text { Lanzarote) }\end{array}$ & Otros partidos & $\begin{array}{c}21-11-1989-01- \\
12-1989\end{array}$ \\
\hline
\end{tabular}

Proposiciones de Ley iniciadas en el Senado:

\begin{tabular}{|c|c|}
\hline CiU & 2 \\
\hline Mixto & 1 \\
\hline CDS & $4^{8}$ \\
\hline Grupo Popular & 5 \\
\hline
\end{tabular}

Resumen actos de control

\begin{tabular}{|c|c|c|c|}
\hline Tipo & CDS & Total & Otros \\
\hline Preguntas Orales (pleno y comisión) & 66 & 1130 & $\begin{array}{c}\mathrm{El} 4^{\circ} \text { por detrás de GCP, GS y } \\
\text { GM. }\end{array}$ \\
\hline Preguntas Escritas & 13 & 11904 & $\begin{array}{l}\text { El CDS es el } 5^{\circ} \text { por detrás de } \\
\text { GP, GM, GS y G CiU. }\end{array}$ \\
\hline Interpelaciones & 59 & 441 & $\begin{array}{c}\text { El CDS es el } 3^{\circ} \text { por detrás de } \\
\text { GP y GM. }\end{array}$ \\
\hline Mociones & 20 & 232 & $\begin{array}{c}\text { El CDS es el } 3^{\circ} \text { por detrás de } \\
\text { GP y GM }{ }^{9} \text {. }\end{array}$ \\
\hline
\end{tabular}

\footnotetext{
${ }^{6}$ Se incorporó al Grupo Mixto entre el 11 de julio de 1991 y el 18 de septiembre de 1991.

${ }^{7}$ Se incorporó al Grupo Mixto entre el 11 de julio de 1991 y el 15 de octubre de 1991.

8 "Proposición de ley para que queda abolida la pena de muerte en el ordenamiento jurídico español, proposición de ley orgánica del jurado, proposición de ley orgánica de Estatuto de Autonomía para Ceuta y proposición de ley orgánica de Estatuto de Autonomía para Melilla.

${ }_{9}^{9}$ Una moción fue presentada por todos los Grupos de manera conjunta.
} 

FUENTES 

Archivos públicos y/o institucionales

Archivo Histórico Provincial de Zamora

Archivo Histórico Provincial de Soria

Archivo del Consejo General de Castilla y León

Archivo Diario 16: MAST-Fundación San Pablo CEU

Archivo General de la Universidad de Navarra

Registro de la Dirección General de Coordinación con las Comunidades Autónomas y las Entidades

Locales del Ministerio de Hacienda y Administraciones Públicas de España)

Registro de Partidos Politicos (Ministerio del Interior de España)

Archivo de Fuentes Orales Richard Gunther (Archivo Linz de la Transición del Centro de Estudios Avanzados en Ciencias Sociales del Instituto Juan March de Estudios e Investigaciones) 
Adolfo Suárez y el Centro Democrático y Social (1982-1991)

\section{Fondos documentales de particulares}

Documentación de Antonio Garrosa Resina

Documentación de José Luis Garro Carballo

Documentación de José Antonio Pérez González

Documentación de Daniel de Fernando

Documentación de José Luis Gómez-Calcerrada

Documentación de José Moreira

Documentación de Jaime Hernando

Archivo Eduardo Navarro-Jorge Trías Sagnier 


\section{Bibliotecas}

Biblioteca Pública de Castilla y León

Biblioteca Pública de Castilla-La Mancha

Biblioteca Pública de Andalucía

Biblioteca Publica de Cantabria

Biblioteca Pública de Asturias

Biblioteca Pública de la Comunidad Valenciana

Biblioteca Pública de Cataluña

Biblioteca Pública de Galicia

CEDOC (Centre Documental de la Comunicació, Universidad Autónoma de Barcelona)

Biblioteca del Pavelló de la República (Universidad de Barcelona)

Instituto Bibliográfico Aragonés 


\section{Hemerotecas}

Hemeroteca Caixa Tarragona

Hemeroteca Municipal de Lisboa

Hemeroteca de la Biblioteca de la Facultad de Ciencias de la Información de la Universidad Autónoma de Barcelona

Hemeroteca de la Biblioteca Nacional de España

Archivo Linz de la Transición del Centro de Estudios Avanzados en Ciencias Sociales del Instituto Juan March de Estudios e Investigaciones (online: http://www.march.es/ceacs/linz/).

El País (online: http://www.elpais.es/archivo)

$A B C$ (online: http://www.hemeroteca.abc.es)

La Vanguardia (online: http://www.lavanguardia.com/hemeroteca)

Archivo Linz de la Transición Española, Madrid: Centro de Estudios Avanzados en Ciencias Sociales, Instituto Juan March de Estudios e Investigaciones, 2006 (online: http://www.march.es/ceacs/biblioteca/proyectos/linz/

Relación completa de los títulos de prensa local o regional empleada en el presente trabajo.

\begin{tabular}{|l|l|}
\hline Galicia & La Voz de Galicia \\
\hline Asturias & La Nueva España \\
\hline Castilla y León & $\begin{array}{l}\text { Crónica de León; El Norte de Castilla; El Adelantado de Segovia; El } \\
\text { Adelanto de Salamanca; Diario de Ávila; Campo Soriano; Diario de } \\
\text { Burgos; El Correo de Zamora; Diario 16 (ed. Burgos) }\end{array}$ \\
\hline Cataluña & $\begin{array}{l}\text { La Vanguardia; El Noticiero Universal; El Periódico de Catalunya; Segre; } \\
\text { Diario Español de Tarragona; Los Sitios }\end{array}$ \\
\hline Canarias & Diario de Avisos; La Provincia \\
\hline Cantabria & Alerta; Diario Montañés \\
\hline Comunidad Valenciana & Las Provincias; Información; Mediterráneo \\
\hline Murcia & La Verdad \\
\hline País Vasco & Deia; El Correo Español del Pueblo Vasco \\
\hline Aragón & El Heraldo; Diario del Alto Aragón; Diario de Teruel \\
\hline Castilla La Mancha & La Verdad \\
\hline Extremadura & Hoy \\
\hline La Rioja & La Rioja \\
\hline Navarra & Diario de Navarra \\
\hline Islas Baleares & Diario de Mallorca; Diario 16 (ed. Baleares). \\
\hline Andalucía & ABC Sevilla; El Sol; El Ideal de Granada; Diario 16 (ed. Andalucía) \\
\hline Ediciones Hoja del Lunes & \\
\hline
\end{tabular}


Publicaciones periódicas del Centro Democrático y Social, 1982-1991.

\begin{tabular}{|c|c|c|c|}
\hline Edición & \multicolumn{2}{|l|}{ Título } & Año \\
\hline \multirow{15}{*}{$\begin{array}{l}\text { CDS } \\
\text { (Madrid) }\end{array}$} & \multicolumn{2}{|l|}{ Manifiesto Político } & 1982 \\
\hline & \multicolumn{2}{|l|}{ España Como Debe Ser } & 1982 \\
\hline & \multicolumn{2}{|c|}{ Programa Marco para las Elecciones Locales } & 1983 \\
\hline & \multirow{2}{*}{\multicolumn{2}{|c|}{ Estatutos-Reglamento de Organización }} & 1983 \\
\hline & & & 1990 \\
\hline & \multicolumn{2}{|l|}{ El Valor del Centro } & 1986 \\
\hline & \multicolumn{2}{|l|}{ Horizonte Político para España } & 1986 \\
\hline & \multicolumn{2}{|l|}{ Ponencias del II Congreso } & 1986 \\
\hline & \multicolumn{2}{|c|}{ Programa Marco para las Elecciones Locales y Autonómicas } & 1987 \\
\hline & \multicolumn{2}{|l|}{ Documento-marco sobre la función pública } & 1987 \\
\hline & \multicolumn{2}{|l|}{ Una Sociedad Democrática y Avanzada } & 1988 \\
\hline & \multicolumn{2}{|c|}{ Centro Democrático y Social en la Internacional Liberal y Progresista } & 1989 \\
\hline & \multicolumn{2}{|c|}{ La Alternativa Progresista } & 1989 \\
\hline & \multicolumn{2}{|l|}{ Manifiesto Electoral } & 1989 \\
\hline & \multicolumn{2}{|l|}{ Líneas de Acción Política (III Congreso) } & 1990 \\
\hline $\begin{array}{l}\text { Ediciones } \\
\text { periódicas }\end{array}$ & Título & Números conservados & Año \\
\hline \multirow[t]{4}{*}{ Nacional } & Boletín de Información & - & $1982-1983$ \\
\hline & $\begin{array}{l}\text { Boletín de Participación y Difusión } \\
\text { Cultural (1984, refundado en 1985) }\end{array}$ & $\begin{array}{l}0,1 \\
1,2,3 \text { (segunda época) }\end{array}$ & $1984-1985$ \\
\hline & $\begin{array}{l}\text { Órgano de Información del Centro y } \\
\text { Democrático y Social }\end{array}$ & $\begin{array}{l}1,2,3,4,5,7,6,8,9,10,11,13, \\
14,18,19,20,21,23,25,26,28, \\
29,30,31 .\end{array}$ & $1986-1991$ \\
\hline & El Centro Avanza & $1,2,3,4,5$ & 1987 \\
\hline Tarragona & Boletín Provincial & 1 & 1983 \\
\hline Zaragoza & Boletín Informativo & $1,3,4$ & $1983-1984$ \\
\hline \multirow[t]{4}{*}{ Madrid } & Boletín Informativo & 1 & 1984 \\
\hline & Boletín Informativo & $1,2,3$ & $1985-1986$ \\
\hline & Órgano Informativo (Alcorcón) & 0,1 & 1987 \\
\hline & Boletín Informativo (PRD) & $1,2,4,5,6$ & \\
\hline Zamora & Boletín Informativo Provincial & - & 1986 \\
\hline Albacete & Eslabón & $1,2,3,4,5,6,7$ & $1987-1988$ \\
\hline Jaén & Eslabón & $1,2,3,4,6$ & $1988-1989$ \\
\hline Valladolid & CDS en Valladolid & 1 & 1988 \\
\hline \multirow[t]{3}{*}{ Cantabria } & Boletín del CDS & 1 & 1991 \\
\hline & $\begin{array}{l}\text { Boletín de Opinión sobre } \\
\text { Participación Ciudadana }\end{array}$ & $1,2,3,5$ & 1990 \\
\hline & Boletín Informativo Aragón & 2 & 1987 \\
\hline \multirow[t]{3}{*}{ Córdoba } & Boletín CDS Cabra & 1 & 1988 \\
\hline & Boletín Córdoba & 1,2 & $1987-1988$ \\
\hline & Boletín Puente Genil & 1 & 1988 \\
\hline \multirow[t]{3}{*}{ Ciudad Real } & $\begin{array}{l}\text { Boletín Informativo Alcázar de San } \\
\text { Juan }\end{array}$ & $1,2,3,4,5$ & $1987-1989$ \\
\hline & Boletín Informativo Miguelturra & $6,9,10$ & $1989-1990$ \\
\hline & Boletín Informativo Provincial & 0 & 1988 \\
\hline \multirow[t]{2}{*}{ Cataluña } & Bulletí d'informació i difusió & $3,4,5$ & $1987-1988$ \\
\hline & Debats. Revista de Orientaciò Política & $0,1,2$ & $1987-1990$ \\
\hline Barcelona & Papers & & 1987 \\
\hline Castellón & Boletín Informativo & 1 & 1990 \\
\hline Granada & Diálogo & 0,1 & 1988-1989 \\
\hline Toledo & Información Ciudadana & 8 & 1989 \\
\hline Guadalajara & $\begin{array}{l}\text { Informativo: Órgano de Difusión } \\
\text { Interna }\end{array}$ & $0,1,2,3$ & $1987-1989$ \\
\hline
\end{tabular}




\section{Fuentes orales}

Relación completa de las entrevistas realizadas en el curso de nuestra investigación (2013-2015).

\begin{tabular}{|c|c|c|c|}
\hline Apellidos, nombre & Cargo & Lugar & Fecha \\
\hline Garrosa Resina, Antonio & Diputado Nacional & $\begin{array}{l}\text { - Fuensaldaña } \\
\text { (Valladolid) }\end{array}$ & $\begin{array}{l}\text { - } 17 \text { de julio de } 2013 \\
-31 \text { de julio de } 2013 \\
-21 \text { de agosto de } 2013\end{array}$ \\
\hline De Fernando, Daniel & Presidente Federal & - Ávila & - 20 de diciembre de 2013 \\
\hline Martín Tamayo, Tomás & Presidente Federal & - [Testimonio escrito] & - Febrero de 2014 \\
\hline $\begin{array}{l}\text { González Quirós, José } \\
\text { Luis }\end{array}$ & Comité Nacional & - Madrid & - 04 de febrero de 2014 \\
\hline $\begin{array}{l}\text { Pérez González, José } \\
\text { Antonio }\end{array}$ & CDS-Madrid & - Madrid & $\begin{array}{l}\text { - } 16 \text { de mayo de } 2014 \\
\text { - } 03 \text { de junio de } 2014\end{array}$ \\
\hline Latorre, Xavier & Presidente Federal & - Barcelona & - 14 de julio de 2014 \\
\hline $\begin{array}{l}\text { De Sárraga Gómez, } \\
\text { Manuel }\end{array}$ & Comité Nacional & - Lérida & - 23 de julio de 2014 \\
\hline Caso, José Ramón & Secretario General & $\begin{array}{l}\text { - Madrid } \\
\text { - [Testimonio escrito] }\end{array}$ & $\begin{array}{l}\text { - } 19 \text { de noviembre de } 2014 \\
\text { - Marzo de } 2016\end{array}$ \\
\hline Delgado Martín, Aurelio & Secretario Personal & $\begin{array}{l}\text { - Ávila } \\
\text { - Valladolid }\end{array}$ & $\begin{array}{l}\text { - } 19 \text { de diciembre de } 2014 \\
-11 \text { de mayo de } 2015\end{array}$ \\
\hline Cádiz, Abel & Comité Nacional & - Madrid & - 04 de marzo de 2015 \\
\hline Morso, Laura & Diputada Nacional & - Madrid & -11 de febrero de 2015 \\
\hline Calvo Ortega, Rafael & Presidente Nacional & - Madrid & -18 de febrero de 2015 \\
\hline Arias-Salgado, Rafael & Diputado Nacional & - Madrid & - 09 de marzo de 2015 \\
\hline Graullera, José Luis & Colaborador personal & - Madrid & -13 de abril de 2015 \\
\hline Lanzaco, Fernando & $\begin{array}{l}\text { Diputado } \\
\text { Autonómico }\end{array}$ & - Madrid & - 16 de abril de 2015 \\
\hline Garro, José Luis & Gabinete Presidencia & $\begin{array}{l}\text { - Madrid } \\
\text { - [Testimonio escrito] }\end{array}$ & $\begin{array}{l}\text { - } 06 \text { de mayo de } 2015 \\
\text { - Mayo de } 2016\end{array}$ \\
\hline Muñoz Lorente, Gerardo & Presidente Federal & $\begin{array}{l}\text { [Entrevista } \\
\text { telefónica] }\end{array}$ & - 09 de mayo de 2015 \\
\hline Moreira, José & Secretario General & - Madrid & -21 de mayo de 2015 \\
\hline Sánchez-Reyes, Carlos & $\begin{array}{l}\text { Presidente Cortes de } \\
\text { Castilla y León }\end{array}$ & - Valladolid & - 03 de junio de 2015 \\
\hline $\begin{array}{l}\text { Sagredo de Miguel, José } \\
\text { Luis }\end{array}$ & $\begin{array}{l}\text { Consejero } \\
\text { Autonómico }\end{array}$ & - Salamanca & - 04 de junio de 2015 \\
\hline $\begin{array}{l}\text { Gómez-Calcerrada, José } \\
\text { Luis }\end{array}$ & Secretario General & - Madrid & - 10 de junio de 2015 \\
\hline
\end{tabular}


BIBLIOGRAFÍA 



\section{Historia de España}

- AGUILAR FERNÁNDEZ, Paloma: Memoria y olvido de la Guerra Civil, Madrid, Alianza, 1996.

- BARBA, Donato: La oposición durante el franquismo/1. La democracia cristiana, Madrid, Encuentro, 2001.

- BERMEJO, Fernando y LORENZO, Javier (eds.): Historia de la Democracia. La Aventura de la libertad (1975-1995), Madrid, El Mundo, 1995.

- CASANOVA, Julián: Historia de España en el siglo XX, Madrid, Ariel, 2009.

- CHAPUT, Marie-Claude y PÉREZ SERRANO, Julio (eds.): La transición española. Nuevos enfoques para un viejo debate, Madrid, Biblioteca Nueva, 2015.

- COMELLAS, José Luis: Historia de España Contemporánea, Madrid, Rialp, 2008.

- CUESTA BUSTILLO, Josefina: La odisea de la memoria. Historia de la Memoria en España. Siglo XX, Madrid, Alianza, 2008.

- DÍAZ GIJON, José Ramón: Historia de la España actual, 1939-2000, autoritarismo y democracia, Madrid, Marcial Pons, 2001.

- FUENTES ARAGONÉS, Juan Francisco: El fin del Antiguo Régimen 1808-1868, Madrid, Síntesis, 2000.

- MARÍN ARCE, José María: “Los socialistas en el poder (1982-1996)”, Historia y Política: ideas, procesos y movimientos sociales, 20, 2008, pp. 43-71.

- MUNIESA, Bernat: La España Lampedusiana: Dictadura y Transición II. La monarquía parlamentaria, Barcelona, UAB, 2005.

- NAVAJAS ZUBELDIA, Carlos (ed.): Actas del III Simposio de Historia Actual. Logroño, 26-28 de octubre de 2000, Logroño, Gobierno de La Rioja, Instituto de Estudios Riojanos, 2002.

- NAVAJAS ZUBELDIA, Carlos e ITURRIAGA BARCO, Diego (eds.): España en democracia. Actas del IV Congreso de Historia de Nuestro Tiempo, Logroño, Universidad de la Rioja, 2014.

- POWELL, Charles T.: España en democracia, 1975-2000, Barcelona, Plaza \& Janes, 2001.

- ÍD.: "El reformismo centrista y la transición democrática", Revista Historia y Política, 18, 2007, pp. 4982.

- PRIETO, Joaquín, JULIÁ DÍAZ, Santos y PRADERA, Javier (eds.): Memoria de la Transición, Madrid, Taurus, 1996.

- SOTO CARMONA, Álvaro: Transición y cambio en España. 1975-1996, Madrid, Alianza, 2005.

- SECO SERRANO, Carlos: "La Transición a la democracia", en DOMÍNGUEZ ORTIZ, Antonio (dir.): Historia de España. Tomo 12. El régimen de Franco y la Transición a la democracia (de 1939 a hoy, Barcelona, Planeta, 1991.

- SOTO CARMONA, Álvaro: La transición a la democracia, España 1975-1982, Madrid, Alianza, 1998.

- SOTO CARMONA, Álvaro y MATEOS LÓPEZ, Abdón (eds.): Historia de la época socialista, Madrid, Sílex, 2013.

- SINOVA, Justino, (ed.): Historia de la Transición, Madrid, Grupo 16, 1984.

- YSÀS, Pere: "Cambio y continuidades: tres lustros de gobiernos socialistas", Ayer, 84, 2011, pp. 23-49.

- TOWNSON, Niguel: La República que no pudo ser, Madrid, Taurus, 2002.

- TUSELL, Javier: La Transición española: la recuperación de las libertades, Madrid, Historia 16, 1997.

\section{Análisis monográficos (nacionalismos, economía, sociedad e instituciones)}

- CAPO GIOL, Jordi: “Oposición y minorías en las legislaturas socialistas”, REIS, 66, 1994, pp. 91-116.

- ELORZA, Antonio: Historia de ETA, Madrid, Temas de Hoy, 2000.

- ESPINA, Álvaro: Empleo, democracia y relaciones industriales en España, Madrid, Ministerio de Trabajo y Seguridad Social, 1990.

- GRANJA, José Luis, BERAMENDI, Justo y ANGUERA, Pere: La España de los nacionalismos y las autonomías, Madrid, Síntesis, 2001.

- GUDE FERNÁNDEZ, Ana: Las Comisiones Parlamentarias de Investigación, Santiago de Compostela, USC, 2000.

- MARTÍNEZ SÁNCHEZ, Juan Antonio: "El referéndum sobre la permanencia de España en la OTAN", UNISCI Discussion papers, 26, mayo 2011. Disponible en: https://revistas.ucm.es /index.php/UNIS/article/viewFile/37825 /36602 Fecha de consulta: 13 de noviembre de 2015.

- PELAZ LÓPEZ, José-Vidal: El estado de las autonomías: regionalismos y nacionalismos en la historia contemporánea de España, Madrid, Actas, 2002.

- REDERO SAN ROMÁN, Manuel: "Los sindicatos en la democracia: de la movilización a la gestión", Historia y Política, 20, julio-diciembre 2008, pp. 129-158.

- REVILLA, Carlos: “El CDS y la renta mínima”, Documentación Social, 78, 1990, pp. 351-354. 
- RUIZ-HUERTA CARBONELL, Alejandro: “Los acuerdos autonómicos de 28 de febrero de 1992: ¿Una alternativa constitucional adecuada?", Revista de Estudios Políticos, 81, julio-septiembre 1993, pp 103128.

- TAMAMES, Laura y TAMAMES, Ramón: Introducción a la Constitución española, Madrid, Alianza Editorial, 2003.

- ZÁRATE MARCO, Anabel: "La relación entre la tributación de diferentes unidades impositivas: una constante en el IRPF (1979-1999)", Información Comercial Española: Revista de Economía, $\mathrm{n}^{\circ}$ 791, abril-mayo, 2001. Disponible en: http://www.revistasice.info/ cachepdf/ICE_791_153174_3FED94F90CF403FE695F13EB63D347C5.pdf Fecha de consulta: 10 de marzo de 2016.

\section{Historia europea, política exterior y relaciones internacionales}

- ÁlVAREZ-MIRANDA NAVARRO, Berta: El Sur de Europa y la adhesión a la Comunidad: los debates políticos, Madrid, CIS, 1996.

- PEREIRA, Juan Carlos (ed.): La política exterior de España. De 1800 hasta hoy, Barcelona, Ariel, 2010.

- POWELL, Charles T.: El amigo americano. España y Estados Unidos: de la dictadura a la democracia, Barcelona, Círculo de Lectores, 2001.

- TAIBO, Carlos: Las transiciones en la Europa central y oriental. ¿Copias de papel carbón?, Madrid, Los Libros de Catarata, 1998.

- VIÑAS, Ángel: En las garras del águila: Los pactos con Estados Unidos, de Francisco Franco a Felipe González (1945-1995), Barcelona, Crítica, 2003.

\section{Historia local y regional}

- BERZAL DE LA ROSA, Enrique (et al.): 25 años de Castilla y León. Volumen I: Un difícil arranque, una esforzada consolidación, Valladolid, Ed. de Medios de Castilla y León, 2008,

- CASTRO, Eduardo, RAMOS ESPEJO, Antonio y ROMACHO, Francisco: 1973-83. Memoria de la Transición democrática en Granada (Colección: Crónica de un sueño: 3), Málaga, C\&T, 2005.

- FERNÁNDEZ AMADOR, Mónica: El poder municipal en Almería durante la transición a la democracia, Tesis Doctoral, Univ. de Almería, 2013.

- FERNÁNDEZ, Pedro Víctor: La transición en León, León, Instituto Leonés de Cultura, 2008.

- PÁEZ RENEDO, Pablo: Del Tardofranquismo a la Democracia en Palencia (1968-1982), Palencia, Diputación de Palencia, 2013.

- PÉREZ LÓPEZ, Pablo y GONZÁleZ CLAVERO, Mariano: La transición en Segovia, Palencia, Cálamo, 2007.

- TÉLLEZ, Juan José: 1973-83: Memoria de la Transición Democrática en Cádiz (Colección: Crónica de un sueño, 7), Málaga, C\&T, 2003.

\section{Adolfo Suárez}

- ABELLA, Carlos: Adolfo Suárez. El hombre clave de la Transición, Madrid, Espasa-Universidad, 2005.

- ÍD.: Adolfo Suárez, Madrid, Espasa-Calpe, 1997.

- BONNIN, Pere y POWELL, Charles: Adolfo Suárez, Barcelona, Ediciones B, 2004

- CAMPO VIDAL, Manuel: Adolfo Suárez: el presidente inesperado de la Transición, Barcelona, RBA, 2012.

- CONTRERAS, Emilio: Suárez. Acoso y derribo, Madrid, La Esfera de los Libros, 2016.

- DE LA CIERVA, Ricardo: El suicidio político de Suárez, Madrid, ARC Editores, 1997.

- FUENTES ARAGONÉS, Francisco: Adolfo Suárez. La historia que no se contó, Barcelona, Planeta, 2011.

- GARCÍA ABAD, José: Adolfo Suárez. Una tragedia griega, Madrid, La esfera de los libros, 2005.

- GONZÁLEZ DE VEGA, Javier: A la sombra de Adolfo Suárez, Barcelona, Plaza \& Janés, 1996

- GUERRERO, Francisco y NAVALÓN, Antonio: Objetivo, Adolfo Suárez: 1980, el año de la agonía, Madrid, Espasa, 1987.

- HERNÁNDEZ, Abel: Suárez y el rey, Madrid, Espasa, 2011.

- HERRERO, Luis: Los que le llamábamos Adolfo, Madrid, La Esfera de los Libros, 2007

- LAVIÑA, Carmen: Recuerdos prestados, Madrid, Laberinto, 2010.

- MELIÁ, Josep: Así cayó Adolfo Suárez, Barcelona, Planeta, 1981.

- MORÁN, Gregorio: Adolfo Suárez. Historia de una ambición, Barcelona, Planeta, 2009. 
- ÍD.: Ambición y destino, Barcelona, Debate, 2009.

- NAVARRO, Eduardo: La Sombra de Adolfo Suárez, Barcelona, Plaza \& Janés, 2014.

- ÓNEGA, Fernando: Puedo prometer y prometo, Barcelona, Mondadori, 2013.

- ONETO, José: Los últimos días de un presidente, Barcelona, Planeta, 1981.

- ORTIZ, Manuel: Adolfo Suárez y el bienio prodigioso, Barcelona, Planeta, 2006;

- PREGO, Victoria: Adolfo Suárez (1976-1981): la apuesta del Rey, s. 1., Unidad Editorial, 2002.

- QUEVEDO, Federico: Pasión por la libertad. El pensamiento político de Adolfo Suárez, Barcelona, Altera, 2007.

- SARASQUETA, Antxón: La agonía del Duque: el enigma de Adolfo Suárez, Madrid, Temas de Hoy, 1991.

- S.A.: Adolfo Suárez o el Valor de la Concordia, s. 1., Círculo de Lectores, 1997.

- SUÁREZ GONZÁLEZ, Adolfo: Fue posible la concordia, Espasa, Madrid, 1996.

- URBANO, Pilar: La gran desmemoria: lo que Suárez olvidó y el Rey prefiere no recordar, Barcelona, Planeta, 2014.

\section{Memorias parlamentarias, diccionarios biográficos y atlas electorales}

- GONZALO, Manuel y BLANCO, Ricardo: Memoria de la II Legislatura 1982-1986), Congreso de los Diputados, Madrid, 1987.

- GONZALO, Manuel y PAESA, María (eds.): Memoria de la III Legislatura (1986-1989), Madrid, Congreso de los Diputados, 1990.

- PAESA, María y MANUEL Gonzalo (eds.): Memoria de la IV Legislatura 1989-1993, Madrid, Congreso, 1995.

- VV.AA.: Memoria de la III Legislatura del Senado, Madrid, Secretaría General del Senado, 1990.

- VV.AA.: Memoria de la IV Legislatura del Senado (1989-1993), Madrid, Secretaría General del Senado, 1995.

- HERAS, Raúl: Enciclopedia política y Atlas Electoral de la democracia española, Madrid, Temas de Hoy, 1997.

- PELAZ LÓPEZ, José-Vidal, PÉREZ LÓPEZ, Pablo y CLAVERO ARÉVALO, Mariano: Castilla y León en democracia. Partidos, elecciones y personal político (1977-2007), Valladolid, Junta de Castilla y León, 2007.

- BERMEJO, Moisés y DÍEZ LAGO, Pablo: Crónica del parlamento de Navarra: 1979-1989, Navarra, Parlamento de Navarra, 1990.

- PANIGUA, Javier y PIQUERAS, J. Antonio (dirs.): Diccionario Biográfico de Políticos Valencianos (1810-2003), Valencia, Institució Alfons el Magnànim, 2003.

- GARRIDO, Aurora (dir.): Diccionario biográfico de los parlamentarios de Cantabria (1902-2002), Santander, Parlamento de Cantabria, 2003.

\section{Ensayo: política, investigación y periodismo}

- BADÍA, Lluis: Opiniones Diarias, Tarragona, Ed. CDS, 1988.

- CARVAJAL URQUIJO, Pedro: Julián Grimau: el último muerto de la Guerra Civil, Madrid, Aguilar, 2003.

- CERCAS, Javier: Anatomía de un instante, Madrid, Debolsillo, 2014.

- CERNUDA, Pilar: El síndrome de la Moncloa, Madrid, Espasa, 2011.

- COTARELO, Ramón: La Conspiración. El golpe de estado difuso, Barcelona, Ediciones B, 1995.

- DE LA CIERVA, Ricardo: La derecha sin remedio, Barcelona, Plaza \& Janés, 1987.

- DÍAZ-VARELA, Mar y GUINDAL, Mariano: A la sombra del poder, Barcelona, Tibidabo, 1990.

- EKAIZER, Ernesto, El último magnate, Barcelona, Plaza \& Janés, 1984.

- GALIACHO, Juan Luis y BERBELL, Carlos: Filesa. Las tramas del dinero negro en la política, Madrid, Temas de Hoy, 1995.

- GARRIGUES WALKER, Antonio: España, las otras transiciones, Oviedo, Nobel, 2013.

- GUINDAL, Mariano: El declive de los dioses, Barcelona, Planeta, 2011.

- GUTIÉRREZ, José Luis: Veinte años no es nada. Textos y pretextos de dos décadas de democracia (1977-1997), Madrid, Espasa, 1997.

- GUTIÉRREZ, José Luis y DE MIGUEL, Amando: La ambición del César, Madrid, Temas de Hoy, 1989.

- JÁUREGUI, Fernando: La derecha después de Fraga, Madrid, El País-Aguilar, 1987.

- JIMÉNEZ LOSANTOS, Federico: Contra el felipismo, Madrid, Temas de Hoy, 1993, 
- LASUÉN SANCHO, José Ramón: La España mediocrática, Barcelona, Planeta, 1979.

- MORAL, Javier: El centro de la derecha, Madrid, Eudema, 1991.

- MORODO, Raúl: Tierno Galván y otros precursores políticos, Madrid, El País, 1987.

- ÍD.: Siete semblanzas políticas: republicanos, falangistas y monárquicos, Barcelona, Planeta, 2010.

- ONETO, José: Anatomía de un cambio de régimen, Barcelona, Plaza \& Janés, 1985.

- PUNSET, Eduard: Una salida de la crisis, Barcelona, Argos Vergara, 1980.

- ÍD.: La España impertinente, Madrid, Espasa-Calpe, 1985.

- RAMÍREZ, Pedro J.: España sin proyecto, Madrid, Akal, 1993.

- ROMERO, Emilio: Retratos de época, Barcelona, Plaza \& Janés, 1985.

- TAMAMES, Ramón: La España alternativa, Madrid, Espasa, 1993.

- WOODWORTH, Paddy: Guerra sucia, manos limpias, Barcelona, Crítica, 2002.

\section{Pensamiento e ideología}

- ÁLVAREZ JUNCO, José y GONZÁLEZ LEANDRI, Ricardo (coord.): El populismo en España y América, Catriel, 1994.

- CASTELlANOS LÓPEZ, José Antonio: “El mito de la Segunda Transición” en FOLGUERA, Pilar, PEREIRA, Juan Carlos et alii (eds.): Pensar con la Historia desde el siglo XXI, Madrid, UAM, 2015, pp. 3515-3532. Disponible en: http://www.uam.es/ss/Satellite/es/1242675314514/1242687568365/UAM_ Libro_FA/ libro/ PENSAR_CON_LA_HISTORIA_DESDE_EL_SIGLO_XXI.htm Fecha de consulta: 15 de mayo de 2016.

- DÍAZ HERNÁNDEZ, Carlos: Mounier: ética y política, Madrid, Editorial: Cuadernos para el Diálogo (Colección Suplementos: $n^{\circ}$ 59), 1975.

- GONZÁLEZ CUEVAS, Pedro C.: El pensamiento político de la derecha española en el siglo XX. De la Restauración al Estado de partidos (1898-2000), Madrid, Tecnos, 2005.

- ÍD.: "Reseña. Pasión por la libertad. El pensamiento político de Adolfo Suárez", El Catoblepas: revista crítica del presente, 76, 2008, disponible en http://www.nodulo.org/ec/2008/n076p16.htm Fecha de consulta: 12 de diciembre de 2012.

- NAVARRA ORDUÑO, Andreu: El Regeneracionismo. La continuidad reformista, Madrid, Cátedra, 2014.

- SEVILLA, José: El declive de la socialdemocracia, Barcelona, RBA, 2011.

- SUANCES MARCOS, Manuel: Historia de la Filosofía Española Contemporánea, Madrid, Síntesis, 2002.

\section{Análisis electoral y sistema de partidos}

- AGUILERA DE PRAT, Cesáreo R.: "Balance y transformaciones del sistema de partidos en España, 1977-1987”, Revista de Investigaciones Sociológicas, 42,1987, pp. 137-154

- BOUZA, Fermín y GONZÁLEZ, Juan Jesús: Las razones del voto en la España democrática, 19772008, Editorial Catarata, Madrid, 2009.

- BOTELlA, Joan "Elementos del sistema de partidos en la Cataluña actual", Papers. Revista de Sociología, 21, 1983, pp. 27-45.

- BUSE, Michael: "El sistema de partidos políticos en España: evolución y perspectivas", Revista de Occidente, 54, 1984, pp. 95-112.

- CACIAGLI, Mario: “España 1982. Las elecciones del Cambio”, Revista Española de investigaciones sociológicas, 28, 1984, pp. 85-118.

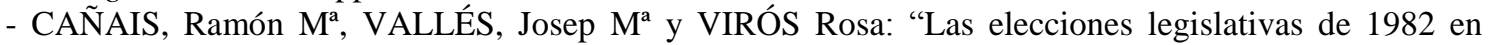
Cataluña", REIS, 28, 1982, pp. 207-222.

- DEL CASTILLO, Pilar (ed.): Comportamiento político y electoral, Madrid, CIS, 1998.

- DÍEZ NICOLÁS, Juan: “Análisis y consecuencias de las elecciones generales de 1986”, Cuenta y Razón, 25, 1986.

- FELDMAN, Arnold S., MENES, Jorge R. y GARCÍA-PRADO Natalia: "La estructura social y el apoyo partidista en España”, REIS, 47, 1989, pp. 7-72.

- FERNÁNDEZ FERRERO, Miguel Ángel: Procesos electorales: elecciones autonómicas y municipales en La Rioja 1979-1995, Logroño, Universidad de la Rioja, 1997.

- GARCÍA ROJAS, José Adrián: "Pactos Electorales y coaliciones en Canarias (1977-2002)", Política y Sociedad, 2 (Volumen 40), 2003, pp. 137-156. Disponible en: http://revistas.ucm.es/index.php/POSO/article /viewFile/POSO0303110137A/23812 Fecha de consulta: 12 de enero de 2015. 
- GUNTHER, Richard, SANI, Giacomo y SHABADA, Goldie: El sistema de partidos políticos en España. Génesis y evolución, Madrid, CIS, 1986.

- GUNTHER, Richard: "Electoral Laws, Party Systems, and Elites: The Case of Spain" en American Political Science Review Vol. 83, 3, september 1989, pp. 11-30.

- MÁRQUEZ CRUZ, Guillermo: "Veinte años de democracia local en España: elecciones, producción de gobierno, moción de censura y elite política (1979-1999)", Revista de Estudios Políticos (Nueva Época), 106, octubre-diciembre 1999, pp. 289-334.

- MONTERO, José Ramón: “Elecciones y ciclos electorales en España”, Revista de Derecho Político, 25, 1987, pp. 9-34.

- ID.: “Los fracasos políticos y electorales de la derecha española: Alianza Popular 1976-1986”, REIS, 39, 1987, pp. 7-44.

- ÍD.: "Voto nacional y voto autonómico: la escisión del voto en las Elecciones de 1986 en Andalucía", REIS, 42, 1988, pp. 177-194.

- LAGO PEÑAS, Ignacio: El voto estratégico en las Elecciones generales en España (1977-2000), Madrid, CIS, 2005.

- LINZ, Juan José y MONTERO, José Ramón (eds.): Crisis y cambio: electores y partidos en la España de los años ochenta, Madrid, Centro de Estudios Constitucionales, 1989.

- PASQUINO, Gianfranco: La oposición, Madrid, Alianza Editorial, 1998.

- RAMÍREZ, Manuel: El sistema de partidos en España (1931-1990), Centro de Estudios Institucionales, Madrid, Cátedra, 1991.

- RENIU, Josep Ma (ed.): Pactar para gobernar. Dinámicas coalicionales en la España multinivel, Valencia, Tirant lo Blanch, 2013.

- SÁNCHEZ MEDERO Germán y SÁNCHEZ MEDERO, Rubén: "PP-CDS. Pactos y alternativas de gobierno de centro-derecha en 1989” en Política y Sociedad, 40-2, 2003.

- SANCHÍS, José Luis: Elementos básicos para una campaña electoral, Madrid, Universidad Complutense, Tesis Doctoral, 2014, p. 141. Disponible en: http://eprints.ucm.es/27652/ 1/T35562.pdf. Fecha de consulta: 10 de marzo de 2016.

- TOHARIA, Juan José: “Tras las elecciones: sin apenas novedad en el frente”, Cuenta y Razón, 25, 1986, pp. 85-90.

- S. a.: "Datos de opinión", REIS, 42, 1988.

- S. a.: "Evolución de la intención de voto y otros indicadores políticos, 1983-1986", REIS, 35, 1986.

- SORIANO DÍAZ, Ramón Luis: "El dominio de los partidos políticos: partidos y sociedad”, Revista de Estudios Políticos (Nueva Época), 105, julio-septiembre 1999, pp. 265-277.

- VAN BIEZEN, Ingrid: Political parties in new democracies party organization in Southern and EastCentral Europe, Hampshire, Palgrave Macmillan, 2003.

-ID.: "Party financing in new democracies Spain and Portugal", Party politics, 3 (6), julio 2000, pp. 329342.

- WERT, José Ignacio: "La campaña electoral de octubre de 1982: el camino del cambio”, REIS, 28, 1984, pp. 63-84.

\section{Ciencias de la Información}

- ALFÉREZ, Antonio: Cuarto poder en España. La prensa desde la ley de Fraga de 1966, Barcelona, Plaza \& Janés, 1986

- BERROCAL, Salomé y RODRÍGUEZ-MARIBONA, Carlos: Análisis básico de la prensa diaria. Manual para aprender a leer periódicos, Madrid, Universitas, 1998.

- BONI, Federico: Teorías de los medios de comunicación, Bellaterra, UAB, 2008

- BAZÁN, Francisco: Análisis crítico de los discursos editoriales de La Vanguardia, El País y Diario 16 durante las elecciones generales (1977, 1979 y 1982) de la transición española (1975-1982), Madrid, Tesis Doctoral, Universidad Complutense, 2014.

- DE FONTCUBERTA, Mar: La noticia. Pistas para percibir el mundo, Barcelona, Paidós, 1993.

- DÍAZ GÜELL, Luis: Periodismo y periodistas de investigación en España, 1975-2000: contribución al cambio político, jurídico, económico y social, Tesis Doctoral, Madrid, UCM, 2003, pp. 34-5. Disponible en: http://www.biblioteca.ucm. Fecha de consulta: 02 de marzo de 2015.

- FERNÁNDEZ, Isabel y SANTANA, Fernando: Estado y medios de comunicación en la España democrática, Madrid, Alianza Editorial, 2000.

- FUENTES ARAGONÉS, Juan Francisco y FERNÁNDEZ SEBASTIÁN, Javier: Historia del periodismo español, Madrid, Síntesis, 1998.

- QUIROSA-CHEYROUZE y MUÑOZ, Rafael (ed.): Prensa y democracia: los medios de comunicación en la Transición, Madrid, Biblioteca Nueva, 2009. 
- RUIZ CONTRERAS, Marta: La imagen de los partidos políticos: el comportamiento electoral en España durante las Elecciones generales de 1993 y 1996, Madrid, CIS, 2007

\section{Memorias}

- ALMUNIA, Joaquín: Memorias políticas, Madrid, Aguilar, 2001.

- ÁLVAREZ DE MIRANDA, Fernando: La España que soñé: recuerdos de un hombre de consenso, Madrid, La Esfera de los Libros, 2013.

- ARMAS MARCELO, J. J.: Los años que fuimos Marilyn, Madrid, Espasa-Calpe, 1995.

- ARZALLUZ, Xabier: Así fue, Foca, Madrid, 2005.

- AZNAR, Luis: Haciendo memoria, León, Ed. Eolas, 2015.

- AZNAR LÓPEZ, José María: Memorias I, Barcelona, Planeta, 2012.

- BARRIONUEVO, José: 2001 días en interior, Barcelona, Zeta, 1997.

- CALVO-SOTELO, Leopoldo: Memoria Viva de la Transición, Barcelona, Plaza \& Janés, Barcelona, 1991.

- CASTELlANO, Pablo: Yo sí me acuerdo: apuntes e historias, Madrid, Temas de Hoy, 1994.

- CONDE, Mario: Los días de gloria, Madrid, Martínez Roca, 2010.

- FEO, Julio: Aquellos años, Barcelona, Ediciones B, 1993.

- FRAGA, Manuel: En busca del tiempo servido, Barcelona, Planeta, 1988.

- FRAILE LAMEYER, Alfredo: Secretos confesables, Barcelona, Península, 2014.

- GARAIKOETXEA, Carlos: Memorias políticas: Euskadi, la transición inacabada, Barcelona, Planeta, 2002.

- GUERRA, Alfonso: Dejando atrás los vientos: memorias (1982-1991), Pozuelo de Alarcón, Espasa, 2006.

- HERRERO DE MIÑÓN, Miguel, Memorias de estío, Madrid, Temas de Hoy, 1993.

- JÁUREGUI, Fernando: Historia vivida de España: de Franco a Podemos, s. 1., Almuzara, 2015

- JIMÉNEZ DE PARGA, Manuel: Vivir es arriesgarse: memoria de lo pasado y de lo estudiado, Barcelona, Planeta, 2008.

- LÓPEZ DE CELIS, María Ángeles: Los presidentes en zapatillas, Madrid, Espasa, 2010.

- MORODO, Raúl: Atando cabos: memorias de un conspirador moderado [Tomo I], Madrid, Taurus, 2001.

- OREJA, Marcelino: Memoria y esperanza: relatos de una vida, Madrid, La Esfera de los Libros, 2011.

- ORTEGA DÍAZ-AMBRONA, José Antonio: Memorial de Transiciones (1939-1978), Barcelona, Galaxia Gutenberg, 2015.

- PUJOL, Jordi: Memorias politicas: 1980-1993. Tiempo de construir, Barcelona, Destino, 2009.

- TAMAMES, Ramón: Más que unas memorias, Barcelona, RBA, 2013.

- VERSTRYNGE, Jorge: Memorias de un maldito, Barcelona, Grijalbo, 1999.

\section{Entrevistas y biografías}

- AZNAR, José María: Retratos y perfiles: de Fraga a Bush, Barcelona, Planeta, 2005.

- BURNS MARAÑÓN, Tomás: Conversaciones sobre la derecha, Barcelona, Plaza \& Janés, 1997.

- DEL RÍO, Ángel: Agustín Rodríguez Sahagún, Madrid, Grupo Libro 88, 1991.

- DÍAZ HERRERA, José: Pedro J. Ramírez al desnudo, Madrid, Akal, 2009

- GARCÍA-LEÓN, Carlos y MARTÍNEZ ECHEVARRÍA, Borja: Antonio Garrigues Walker, Madrid, Península, 2014.

- GONZÁLEZ MARTÍNEZ, Carlos: Salvador Sánchez-Terán. Una biografía política, Tesis Doctoral, Universidad de Valladolid, 2014.

- IGLESIAS, María Antonia: La memoria recuperada, Madrid, Aguilar, 2003.

- LAMELAS, Antonio: La Transición en abril: Una biografía política de Fernando Abril Martorell, Madrid, Ariel, 2004.

- MÁRQUEZ REVIRIEGO, Víctor: Cien españoles y la OTAN, Barcelona, Plaza \& Janés, 1985.

- NAVARRO, Julia: Entre Felipe y Aznar: 1982-1996. Temas de Hoy, Madrid 1996.

- ROMERO, Ana: El triángulo de la Transición, Barcelona, Planeta, 2013.

- SEBASTIÁN, Isabel: Mayor Oreja : una victoria frente al miedo, Madrid, La Esfera de los Libros, 2001. 


\section{UCD y CDS}

- ALONSO CASTRILLO, Silvia: apuesta del centro: una historia de UCD, Madrid, Alianza Editorial, 1996.

- CHAMORRO, Eduardo, Viaje al Centro de UCD, Barcelona, Planeta, 1981.

- FERNÁNDEZ AMADOR, Mónica y QUIROSA-CHEYROUZE Y MUÑOZ, Rafael: "La creación del Centro Democrático y Social en 1982" en QUIROSA-CHEYROUZE Y MUÑOZ, Rafael, (ed.): Los partidos en la Transición, Madrid, Biblioteca Nueva, 2013, pp. 201-219.

- FIGUERO, Javier: UCD. La empresa que creó Adolfo Suárez, Madrid, Grijalbo, 1981.

- GARCÍA-ATANCE, María Victoria: "Congreso Extraordinario del CDS", Revista de Derecho Político, 34, 1991, pp. 273-280.

- ÍD.: "III Congreso Nacional del Centro Democrático y Social", Revista de Derecho Político, 32, 1991, pp. 249-256.

- GASCÓ ESCUDERO, Patricia: UCD-Valencia. Estrategias y grupos de poder político, Valencia, Universidad de Valencia, 2011.

- HOPKIN, Jonathan Richard: El partido de la transición. Ascenso y caída de la Unión de Centro Democrático. Madrid, Acento, 2000.

- HUNEEUS, Carlos: La Unión de Centro Democrático y la Transición a la Democracia en España, Madrid, CIS, 1985.

- JÁUREGUI, Fernando y SORIANO, Manuel: La otra historia de UCD, Madrid, Emiliano Escolar, 1980.

- MELlADO PRADO, Pilar: "Congreso Constituyente del Centro Democrático y Social", Revista de Derecho Político, 16, invierno 1982-1983, pp. 229-236.

- QUIROSA-CHEYROUZE y MUÑOZ, Rafael: "El Centro Democrático y Social. Auge y caída de un proyecto político (1982-1996)" en MATEOS LÓPEZ, Abdón y SOTO CARMONA, Álvaro (dirs.), Historia de la época socialista: 1982-1996, Ed. Sílex, 2013, pp. 405-430.

- RUIZ DÍEZ, Manuel: Formación y desarrollo de un partido en la Transición, Trabajo Fin de Máster, Universidad de Zaragoza, 2013.

\section{Otros partidos políticos}

- BAÓN, Rogelio: Historia del Partido Popular: del Franquismo a la Refundación, Madrid, Ibersaf, 2001.

- BARBERÀ ARESTÉ, Óscar: Alianzas políticas, relaciones de poder y cambio organizativo: el caso de Unió Democrática de Catalunya: 1978-2003, Madrid, CIS, 2011.

- GARCÍA-GUERETA RODRÍGUEZ, Elena: Factores externos e internos de la transformación de los partidos políticos: el caso de AP-PP, Tesis Doctoral, Instituto Juan March de Estudios e Investigaciones, Madrid, 2001.

- PAD: Partido de Acción Democrática. Congreso Constituyente, Madrid, PAD, 1982.

- PDP: Una política joven y europea. Primer Congreso Nacional del Partido Demócrata Popular, Madrid, 1982.

- DEL RÍO MORILLAS, Miguel Ángel: "La Unión del Pueblo Español (UDPE): los orígenes de la macro-asociación azul de Alianza Popular (AP)", en RUIZ CARNICER, Miguel Ángel (coord.): Falange, las culturas políticas del fascismo en la España de Franco (1936-1975) (CD-ROM), Zaragoza, Instituto Fernando El Católico, 2013, p. 499-514.

- PENELlA, Manuel: [Tomo II] Los orígenes y la evolución del Partido Popular: una historia de AP, Salamanca, Caja Duero, 2005.

- RAMIRO FERNÁNDEZ, Luis: Cambios y adaptación en la izquierda: La evolución del Partido Comunista de España y de Izquierda Unida (1986-2000), Madrid, CIS, 2004.

- RUBIO, Amalia: Un partido en la oposición. El Partido Socialista Popular, Tesis Doctoral, Universidad Complutense de Madrid, 1995.

\section{Teoría y metodología}

- ARÓSTEGUI, Julio: Historia vivida. Sobre la Historia del Presente, Madrid, Alianza Editorial, 2004.

- CARASA SOTO, Pedro (ed.): Elites: Prosopografía contemporánea, Valladolid, Universidad de Valladolid, 1994.

- DUVERGER, Maurice: Los partidos políticos, México, FCE, 1992.

- KROUWEL, André: "Party models", en KATZ, Richard S. y CROTTY, William: Handbook of party politics, SAGE Publications, 2006. 
- MAGONE, José María: Contemporary Spanish Politics, N. Y., Routledge, 2009.

- OLIVER ARAUJO, Joan y CALAFELL FERRÁ, Juan Vicente: Los estatutos de los partidos políticos españoles, Madrid, CEPC, 2007.

- PANEBIANCO, Angelo: Los partidos políticos, Madrid, Alianza Editorial, 1990.

- PEREIRA, Juan Carlos., NUÑEZ, Vanessa y JORGE, David: "Les sources orales pour l'étude de la dimension internationale de la transition espagnole", Revue d'Histoire Diplomatique, 4, 2013.

- WARE, Alan: Partidos Políticos y Sistemas de partidos, Madrid, Istmo, 2000.

- WEBB, Paul, FARREL, David y HALLIDAY, David (eds.): Political parties in advanced industrial democracias, Oxford University Press, N. York, 2003,

\section{Historia Contemporánea de Portugal}

- COSTA LOBO Marina y AMORIM NETO, Octavio: “O semipresidencialismo portugués revisitado: uma avaliação do papel do presidente na política nacional, 1976-2006”, en COSTA LOBO Marina y AMORIM NETO, Octavio (eds.): O semipresidencialismo nos países de língua portuguesa, Lisboa, ICS, 2009.

- CRUZEIRO, Maria Manuela y LOURENÇO, Vasco: Do interior da revolução, Coimbra, Áncora, 2009. - FREIRE, André: "Elecciones y comportamiento electoral en Portugal", en BARRETO, Antonio, GÓMEZ FORTES, Braulio y MAGALHAES MOTA, Pedro: Portugal: democracia y sistema político, Madrid, Siglo Veintiuno, 2003.

- GONZÁlEZ HERNÁNDEZ, Juan Carlos: Desarrollo político y consolidación democrática en Portugal, Madrid, CIS, 1999.

- LISI, Marco: Party Change, Recent Democracies and Portugal: Comparative Perspectives, Landham, Lexington, 2015.

- MAXWELL, Kenneth: The making of portuguese democracy, Cambridge, Cambride University Press, 1997.

- OLIVEIRA, César: Os anos decisivos: Portugal 1962-1985, un testemunho, Lisboa, Presença, 1993.

- REIS, António: “O Partido Socialista no poder e na oposição: da dialéctica com o projecto nacionalmilitar à dialéctica com o eanismo", en BATISTA COELHO, Mario (coord.): Portugal. O sistema política e constitucional 1974-1987, Lisboa, ISCTE, 1989.

- REZOLA, Maria Inácia: Melo Antunes: uma biografia politica, Lisboa, Âncora, 2013.

- ROCHA VIEIRA, Vasco: Todos os portos a que cheguei, Lisboa, Grádiva, 2010.

- SÁNCHEZ CERVELLÓ, Josep: La revolución portuguesa y su influencia en la transición española (1961-1976), Madrid, Nerea, 1995.

- ÍD.: La Revolución de los Claveles, Madrid, Arco Libros, 1997.

- VIEIRA PINTO, Manuel: O General Ramalho Eanes e a história recente de Portugal, Lisboa, Áncora, 2014. 


\section{Webgrafía}

http://www.historiaelectoral.com

http://www.congreso.es

http://www.hemeroteca.abc.es

http://www.elpais.es/archivo

http://www.biblioteca.ucm.es

http://www.dialnet.unirioja.es

http://www.march.es/ceacs/linz/

http://www.lavanguardia.es

http://www.revistasucm.es

http://www.parlament.cat

http://www.debates.parlamento.pt

http://www.legebiltzarra.eus/portal/web/eusko-legebiltzarra

http://www.parlamentodeandalucia.es

http://www.biblioteca.parlamento-cantabria.es

http://www.rtve.es

http://www.diariodenavarra.es

http://www.larioja.com

http://www.laopiniondezamora.es

http://www.nodulo.org

http://www.uab.

http:// www.jpga.es

http://www.lne.es

http://www.biblioteca.periodicas.edu.uy

http://www.diacronie.it

http://www.diputoledo.es

http://www.es.parlamentodegalicia.es

http://www.boe.es

http://www.cia.gov

http://www.ub.edu/web/ub/ca/

http://www.ideal.es

http://www.uam.es

http://www.liberal-international.org

http://www.pp.es

http://www.psoe.es

http://www.historiadelpresente.es

http://www.izquierdaunida.es

http://www.europarl.europa.eu 
